\title{
Menschenrechte und Gerechtigkeit als bleibende Aufgaben
}

Beiträge aus Religion, Theologie, Ethik, Recht und Wirtschaft

\section{Vienna University Press}


Open-Access-Publikation im Sinne der CC-Lizenz BY 4.0

(C) 2020, Vandenhoeck \& Ruprecht $\mathrm{GmbH} \&$ Co. KG, Göttingen ISBN Print: 9783847111658 - ISBN E-Lib: 9783737011655 
Irene Klissenbauer / Franz Gassner /

Petra Steinmair-Pösel /

Peter G. Kirchschläger (Hg.)

\section{Menschenrechte und Gerechtigkeit als bleibende Aufgaben}

Beiträge aus Religion, Theologie, Ethik, Recht und Wirtschaft

Festschrift für Ingeborg G. Gabriel

Mit zwei Abbildungen

V\&R unipress

Vienna University Press 


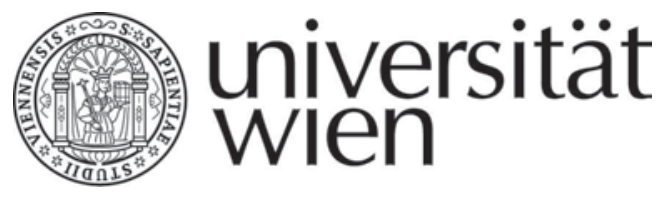

Bibliografische Information der Deutschen Nationalbibliothek

Die Deutsche Nationalbibliothek verzeichnet diese Publikation in der Deutschen Nationalbibliografie; detaillierte bibliografische Daten sind im Internet über https://dnb.de abrufbar.

\section{Veröffentlichungen der Vienna University Press erscheinen bei $V \& R$ unipress.}

Die Beiträge dieses Werks sind peer-reviewed.

(C) 2020, Vandenhoeck \& Ruprecht GmbH \& Co. KG, Theaterstraße 13, D-37073 Göttingen Dieses Werk ist als Open-Access-Publikation im Sinne der Creative-Commons-Lizenz BY International 4.0 („Namensnennung“) unter dem DOI 10.14220/9783737011655 abzurufen. Um eine Kopie dieser Lizenz zu sehen, besuchen Sie https://creativecommons.org/licenses/by/4.0/. Jede Verwertung in anderen als den durch diese Lizenz zugelassenen Fällen bedarf der vorherigen schriftlichen Einwilligung des Verlages.

Vandenhoeck \& Ruprecht Verlage | www.vandenhoeck-ruprecht-verlage.com

ISBN 978-3-7370-1165-5 


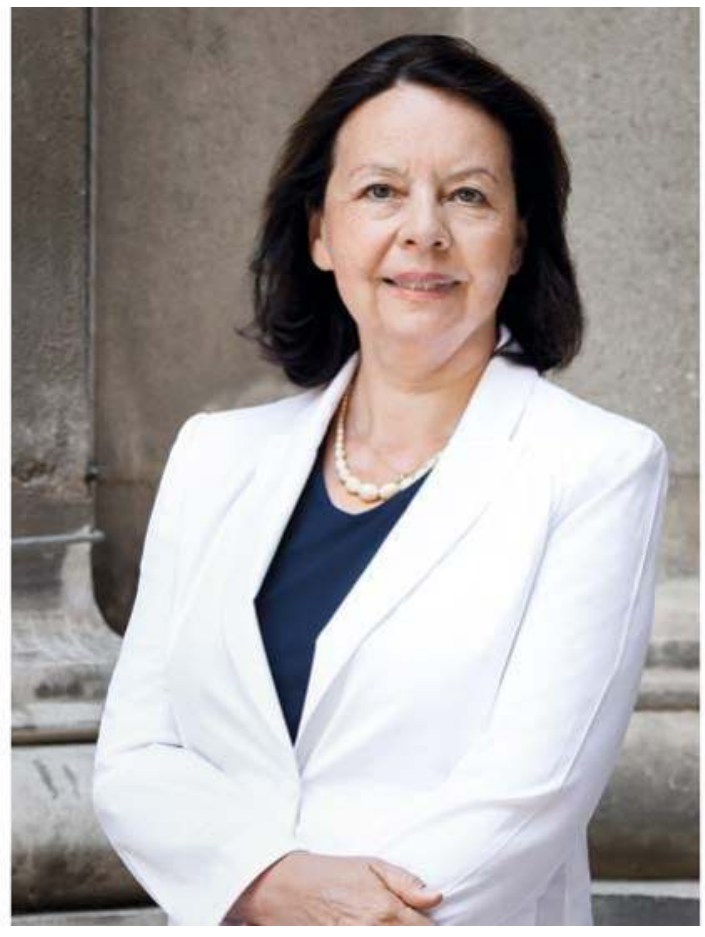

Open-Access-Publikation im Sinne der CC-Lizenz BY 4.0

(c) 2020, Vandenhoeck \& Ruprecht GmbH \& Co. KG, Göttingen

ISBN Print: 9783847111658 - ISBN E-Lib: 9783737011655 
Open-Access-Publikation im Sinne der CC-Lizenz BY 4.0

(C) 2020, Vandenhoeck \& Ruprecht $\mathrm{GmbH} \&$ Co. KG, Göttingen ISBN Print: 9783847111658 - ISBN E-Lib: 9783737011655 


\section{Inhalt}

\section{Grußworte}

Kardinal Dr. Christoph Schönborn (Erzbischof von Wien)

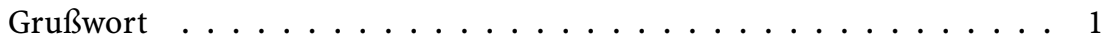

Metropolit Arsenios von Austria und Exarch von Ungarn und

Mitteleuropa

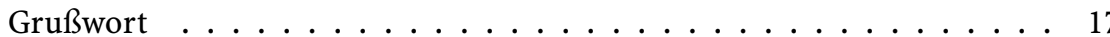

Diözesanbischof em. von Linz Dr. h.c. Maximilian Aichern OSB

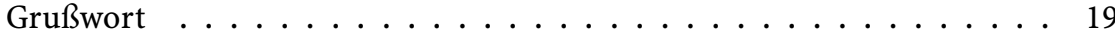

Alexandros K. Papaderos (Mitbegründer und erster Generaldirektor der Orthodoxen Akademie Kretas, Offizial des Ökumenischen Patriarchats) Grußwort: Über den Dialog . . . . . . . . . . . . . . . . . 23

ao. Univ.-Prof. Mag. Dr. Christa Schnabl (Vizerektorin für Studium und Lehre)

Grußwort: Als Quereinsteigerin Brücken bauen . . . . . . . . . . 27

Irene Klissenbauer / Franz Gassner / Petra Steinmair-Pösel / Peter G.

Kirchschläger

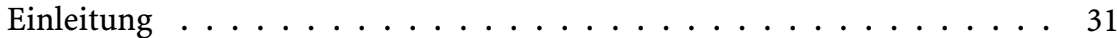

\section{Theologie}

Georg Braulik OSB (Wien)

Der blinde Fleck - das Gebot, den Fremden zu lieben. Zur sozialethischen Forderung von Deuteronomium 10,19 . . . . . . . . 41 
Stanisław Fel (Lublin)

Die Bedeutung empirischer Gerechtigkeitsforschung für die Sozialethik 65

Daniel Bogner (Freiburg)

Macht und Herrschaft - Stiefkinder oder Schlüsselkategorien

theologischer Ethik . . . . . . . . . . . . . . . . . 79

Markus Vogt (München)

Zum Stellenwert theologischer Argumente für die Begründung,

Motivation und Entfaltung der Ethik . . . . . . . . . . . . . . . . 93

Kurt Appel (Wien)

Die Grenze der Grenzen. Christentum, Abrahamitische Religionen,

Zivilgesellschaft und die Neubestimmung des öffentlichen Raums in

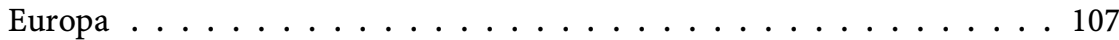

Stefan Tobler (Hermannstadt/Sibiu)

Die Welt als Gottes Innerstes. Die sozialethische Dimension in der mystischen Erfahrung Chiara Lubichs . . . . . . . . . . . . . . 123

Petra Steinmair-Pösel (Innsbruck/Feldkirch)

„Ein Wort, das wir bis zur Erschöpfung wiederholen müssen“. Papst

Franziskus und der Dialog als Weg Christlicher Sozialethik . . . . . . . . 139

\section{Dialog}

Jakob Helmut Deibl (Wien)

Interreligiöser Dialog, öffentlicher Raum und Ästhetik . . . . . . . . 159

Konstantinos Delikostantis (Athen)

Wie sozial ist die Orthodoxe Kirche? . . . . . . . . . . . . . . . . 175

Cezar Marksteiner-Ungureanu (Wien)

"Forgiving one another" (Col. 3,13). Ethical and Theological Reflections on Reconciliation within the Ukrainian Ecclesial Crisis . . . . . . . . . 185

Peter Schipka (Wien)

Der Islam als Thema der Österreichischen Bischofskonferenz. Positionen und Stellungnahmen . . . . . . . . . . . . . . . . 201 
Rüdiger Lohlker (Wien)

Kollektive Ethik und individuelle Ethik: Reflexionen anhand der

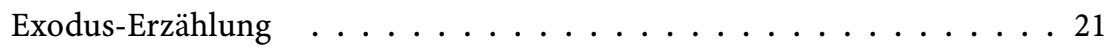

Johann Figl (Wien)

Pazifistische Intentionen neureligiöser Bewegungen. Motive des

„Universalen Sufismus“ angesichts beider Weltkriege . . . . . . . . . 225

Hans Gerald Hödl (Wien)

Demokratie und sakrales Königtum. Zentralmacht und Konsens im

präkolonialen Afrika . . . . . . . . . . . . . . . . 239

\section{Menschenrechte}

Heiner Bielefeldt (Erlangen-Nürnberg)

Menschenrechte und „traditionelle Werte“: Eine hoffnungslos vergiftete

Debatte . . . . . . . . . . . . . . . . . . 265

Marianne Heimbach-Steins (Münster)

Das Recht auf Religions- und Weltanschauungsfreiheit - Kompass

demokratischer Religionspolitik ? . . . . . . . . . . . . . . 279

Stefan Hammer (Wien)

Politische Säkularität heute . . . . . . . . . . . . . . 293

Peter G. Kirchschläger (Luzern)

Liberaler Rechtsstaat - Menschenrechte - Religions- und

Weltanschauungsgemeinschaften .............. 305

Richard Potz (Wien)

Die Pluralität des europäischen Rechtsraums und das Religionsrecht . . . 327

Wolfgang Palaver (Innsbruck)

Religionsfreiheit in Österreich: Ein kritischer Blick . . . . . . . . . . . 345

Manfred Nowak (Wien) / Anna-Maria Steiner (Venedig)

The impact of religion on universal human rights in Brunei's Syariah

Penal Code . . . . . . . . . . . . . . . . . . 359 
Irene Klissenbauer (Wien)

Islamischer Schleier versus Emanzipation? Religions- und

Weltanschauungsfreiheit als Teil der Frauenrechte . . . . . . . . . . . 379

Günter Virt (Wien)

Menschenrechte im Prozess. Erfahrungen im hermeneutischen Zirkel von

Theorie und Praxis . . . . . . . . . . . . . . . . . . 399

Konrad Hilpert (München)

Recht auf reproduktive Autonomie. Sinn und Problematik eines aktuellen menschenrechtlichen Topos . . . . . . . . . . . . . . 413

\section{Politik und Gesellschaft}

Jan-Heiner Tück (Wien)

Kreuzesabnahme. Wie in Wien die religiösen Symbole aus den Hörsälen der katholischen Theologie verschwanden - ein Nachruf . . . . . . . . 431

Johann Pock (Wien)

Grenzen der Pastoral - Pastoral an Schwellen und Grenzen. Thesen für die Zukunft kirchlichen Handelns . . . . . . . . . . . . . . . . . . . . 443

Peter Klasvogt (Dortmund)

Epochenwandel. Auf der Suche nach einer neuen Erzählung

Adrian Loretan (Luzern)

Wie kann das friedliche Zusammenleben freier und gleicher Menschen in einer pluralistischen Gesellschaft dauerhaft gelingen? . . . . . . . . . . 475

Kristina Stoeckl (Innsbruck)

Orthodoxe Theologie und politische Philosophie: Postsäkularität in

Russland . . . . . . . . . . . . . . . . . . . 495

Richard Sturn (Graz)

Soziale Gerechtigkeit und populistische Polarisierung . . . . . . . . . 505

Christian Spieß (Linz)

Neue religiöse Intoleranz und die Abkehr vom Modell des religiösen Pluralismus: Religionspolitische Transformation in Österreich? . . . . . 519 
Linda Hogan (Dublin)

Designing an Ethical Future: Can Artificial Intelligence Help? . . . . . . 533

Ulrich H.J. Körtner (Wien)

Verantwortungsethik in Medizin und Pflege . . . . . . . . . . . 545

Christoph Stückelberger (Genf/Zürich)

Integrität: Die Tugend der Tugenden. Der christliche Beitrag zu einer globalen Tugend für Wirtschaft und Politik . . . . . . . . . . . . . . 559

\section{Wirtschaftsethik}

Kardinal Peter K.A. Turkson (Vatikan/Rom)

Investment within the Framework of the "Environment, Society and

Governance". A Catholic Church Perspective . . . . . . . . . . . . . 577

Leopold Neuhold (Graz)

Wirtschaft - mehr als Wirtschaft: Sozialethische Bemerkungen . . . . 587

Michaela Schaffhauser-Linzatti (Wien)

Tue Gutes und Berichte darüber . . . . . . . . . . . . . . . . . 603

Bernhard Leubolt (Wien) / Magdalena Holztrattner (Wien) / Markus

Schlagnitweit (Wien)

Zur Erneuerung des Sozialstaats: Soziale Innovation und katholische

Soziallehre . . . . . . . . . . . . . . . . . . 623

Klaus Gabriel (Wien)

Das Richtige vor dem Rentablen. Zur Entwicklung und zu den aktuellen

wirtschaftsethischen Herausforderungen der ethisch-nachhaltigen

Geldanlage . . . . . . . . . . . . . . . . 637

Georges Enderle (University of Notre Dame, USA)

Unternehmensverantwortung für weniger Einkommensungleichheit . . . 651

Wilfried Stadler (Wien)

Wirtschaftsordnung - Wertschöpfung - Schöpfungsverantwortung.

Zu den Chancen ökosozialer Ordnungspolitik in der Globalisierung . . . 667

Franz Gassner (Macau, S.A.R. China)

Resources for Future in a Caring Economy . . . . . . . . . . . 683 


\section{Anhang}

Curriculum vitae o. Univ. Prof. MMag. Dr. Ingeborg Gabriel . . . . . 701

Publikationen o. Univ. Prof. MMag. Dr. Ingeborg Gabriel ․ . . . . 703

Zu den AutorInnen . . . . . . . . . . . . . . . 715 


\section{Grußworte}

Open-Access-Publikation im Sinne der CC-Lizenz BY 4.0

(c) 2020, Vandenhoeck \& Ruprecht GmbH \& Co. KG, Göttingen

ISBN Print: 9783847111658 - ISBN E-Lib: 9783737011655 
Open-Access-Publikation im Sinne der CC-Lizenz BY 4.0

(C) 2020, Vandenhoeck \& Ruprecht $\mathrm{GmbH} \&$ Co. KG, Göttingen ISBN Print: 9783847111658 - ISBN E-Lib: 9783737011655 


\section{Kardinal Dr. Christoph Schönborn (Erzbischof von Wien)}

\section{Grußwort}

Wien, am 2. Mai 2019

Es ist mir eine große Freude, Frau Prof. Dr. Ingeborg Gabriel anlässlich ihrer Emeritierung für ihr langjähriges und vielfältiges Wirken als Ordinaria für das Fach Sozialethik an der Universität Wien zu danken. Mehr als 20 Jahre lang hat Frau Prof. Gabriel das Fach Sozialethik entschieden vertreten, dabei wichtige Impulse gesetzt und junge Menschen dazu ermutigt, eine gerechtere Welt- und Gesellschaftsordnung mitzugestalten.

Derzeit erleben wir, dass politische und religiös motivierte Konflikte verstärkt aufflammen. In weiten Teilen der Welt fliehen Menschen vor Verfolgung, Zerstörung und Armut, Menschenrechte werden mit den Füßen getreten. Auch religiöser Fanatismus und Terror nehmen in erschreckendem Ausmaß zu, wie das Attentat von Christchurch oder die Anschläge von Sri Lanka gezeigt haben. Umso wichtiger ist der Beitrag, den die christliche Sozialethik zu einem friedlichen und gelingenden Zusammenleben aller Menschen leisten kann, indem sie den Blick auf die „umfassende Entwicklung des ganzen Menschen und der ganzen Menschheit" (Populorum Progressio 42) richtet.

Ich danke Frau Prof. Gabriel, dass sie mit großer Klarheit und Wachsamkeit aktuelle Krisen und Fehlentwicklungen benannt hat und konsequent für ein Mehr an Solidarität, Gerechtigkeit und Frieden eingetreten ist. Dabei konnte sie ihre einschlägigen Erfahrungen als Ökonomin und Diplomatin für die Sozialethik nutzbar machen. In Lehre und Forschung, aber auch in öffentlichem Wirken und ihrem persönlichen Lebenszeugnis hat sich Frau Prof. Gabriel dafür eingesetzt, Politik, Gesellschaft und Wirtschaft menschengerechter zu gestalten.

Besonders danke ich für Ihr großes ehrenamtliches Engagement als Direktorin von Iustitia et Pax Österreich und als Vizepräsidentin von Iustitia et Pax Europa. Auch im interreligiösen Dialog mit Muslimen, im Schutz religiöser Minderheiten und dem tatkräftigen Einsatz für die Menschenrechte, besonders die Religionsfreiheit, hat Frau Prof. Gabriel als persönliche OSZE-Beauftragte Beachtliches geleistet. 
Die vorliegende Festschrift sei ein Ausdruck des Dankes für das umfassende Wirken von Frau Prof. Gabriel. Ich wünsche ihr noch viele gesunde und erfüllende Jahre!

Mit herzlichen Segenswünschen +Christoph Kardinal Schönborn 


\section{Metropolit Arsenios von Austria und Exarch von Ungarn und Mitteleuropa}

\section{Grußwort}

Wien, am 28. Mai 2019

Mit großer Freude habe ich die Einladung vernommen, ein Grußwort für die Festschrift anlässlich der Emeritierung von Univ.-Prof. Dr. Ingeborg Gabriel zu verfassen. Gerne bin ich dieser Einladung nachgekommen. Kennengelernt habe ich Ingeborg Gabriel bereits vor einigen Jahren durch ihr interkonfessionelles und ökumenisches Engagement, das unter anderem auch einige gemeinsame Projekte hervorbrachte. Neben ihrer klar ökumenischen Perspektive hat mich auch ihr sozialethischer und politischer Einsatz beeindruckt, besonders auch im Bereich des Umweltschutzes, der in der heutigen Zeit notwendiger denn je ist. Für dieses vielfältige Engagement bin ich sehr dankbar.

Nicht selten begegnet man dem Vorwurf, Religion, Glaube und Spiritualität würden zu einer Abgewandtheit von der Welt führen, einer Abkehr vom äußerlichen Tun in eine Welt der Innerlichkeit, einer „Weltflucht“ gewissermaßen. Dem gilt es aus christlicher Sicht gegenüberzustellen - wie auch Ingeborg Gabriel nicht müde wurde zu betonen -, dass christlicher Glaube und das Engagement für eine aktive Mitgestaltung der Welt keine einander entgegengesetzten Pole sind, sondern zutiefst aufeinander angewiesen sein müssen. Christlicher Glaube ohne Einsatz für eine bessere Welt ist undenkbar. In theologischer Sprache ausgedrückt: Auftrag der Christen ist es, „Salz der Erde“ und „Licht für die Welt“ zu sein, ihre „Mission“ ist es, das Reich Gottes schon in ihrem irdischen Leben für ihre Mitmenschen sichtbar werden zu lassen: „wie im Himmel, so auf Erden“, wie uns Christus selbst gelehrt hat.

Gott selbst ist in Jesus Christus Mensch geworden. Die Kirche setzt in der Kraft des Heiligen Geistes dieses ,inkarnatorische Prinzip“ fort, in ihrem Leben, in ihrem Gebet, ihrer Präsenz und ihrem Einsatz in der Welt, vor allem jedoch in ihrer Liturgie, in der Feier der lebenschaffenden Mysterien. Die Feier der Liturgie ist für Christen die überlebensnotwendige Beziehung und Kommunikation Gottes mit den Menschen, sie ist gleichsam die Lebensquelle, aus der der Mensch und auch die ganze Schöpfung lebt und durch das Wirken des Heiligen Geistes beständig erneuert und gewandelt wird. In der Liturgie werden uns die Augen geöffnet und wir sehen die Welt in einem neuen Licht, im Licht der Auferstehung 
und paradoxerweise auch schon im eschatologischen Licht der Wiederkunft Christi. Als Christgläubige leben wir also gleichsam zwischen dem „Jetzt" und dem „Noch nicht“. Beides fällt in der liturgischen Gottesbegegnung zusammen. In ihr geschieht auf mystische, dadurch aber nicht weniger reale Weise eine vom Heiligen Geist gewirkte Erhöhung und Verwandlung - der natürlichen Gaben von Brot und Wein, Symbole der Gott dargebrachten Schöpfung, aber auch der Menschen.

Diese Wandlung kann sich jedoch nicht bloß auf den liturgischen Moment beschränken, denn in diesem Fall wäre der Vorwurf einer Weltflucht durchaus gerechtfertigt. Die in der Liturgie gefeierte und gelebte Gottesbeziehung muss sich fortsetzen, sie muss Gestalt annehmen im Leben der Menschen und es bis in ihr Innerstes durchdringen. Die orthodoxe Tradition kennt hier den Begriff einer „Liturgie nach der Liturgie“, der gerade diesen inneren Zusammenhang zwischen der Liturgie und dem alltäglichen Leben betonen möchte.

Aus der Kraft der lebenschaffenden Quelle, von der wir kosten dürfen, können wir als Christen mit offenen Augen in der Welt, im „Weinstock des Herrn“, unseren Beitrag zum Aufbau des Reiches Gottes leisten.

Mit diesen Gedanken möchte ich Ingeborg Gabriel noch einmal meinen Dank für ihr langjähriges und unermüdliches Wirken sowohl auf universitärer aber auch auf sozialpolitischer Ebene aussprechen und ihr weiterhin viel Kraft und Gottes reichen Segen für ihr Engagement und ihren Einsatz wünschen. 


\section{Diözesanbischof em. von Linz Dr. h.c. Maximilian Aichern OSB}

\section{Grußwort}

Mit der Sozialethikerin, Frau Univ.-Prof. Dr. Ingeborg Gabriel, verbindet mich das sozialethische Engagement und die Suche nach einer authentischen christlichen Sozialbotschaft für die heutigen Menschen.

Die gebürtige Welserin hat ihre Professur in Wien diesen schwerwiegenden Themen gewidmet. Sie war präsent in einer Reihe von Aktivitäten, an denen auch ich in 24 Jahren als Diözesanbischof von Linz und darüber hinaus für die Katholische Kirche in Österreich und die Ökumene beteiligt war. Seit Beginn meiner Tätigkeit als Linzer Diözesanbischof war ich in der österreichischen Bischofskonferenz - auf Initiative des damaligen Vorsitzenden Kardinal König u. a. für soziale Fragen, die Katholische Sozialakademie, für den Dialog mit Sozialpartnern und der Wirtschaft zuständig, ebenso für die Sozialgespräche in Rom und in Brüssel.

Auf Initiative der Katholischen ArbeitnehmerInnenbewegung Österreichs war ich mitverantwortlich für die Erarbeitung des Sozialhirtenbriefes der österreichischen Bischöfe mit einer längeren Vorbereitungsphase und breiter Basis-Diskussion (der dann 1990 erschien), und war an einigen mitteleuropäischen Symposien beteiligt. Mitzuwirken hatte ich auch bei der Basis-Diskussion und der Erstellung des Ökumenischen Sozialwortes Österreichs, welches 2003 herausgegeben wurde. Bei diesen wichtigen kirchlichen und sozialen Beratungen, Begegnungen und Erarbeitungen stand oft der international erfahrene österreichische Sozialethiker Univ.-Prof. P. Dr. Johannes Schasching SJ im Hintergrund, im Vordergrund immer P. Dr. Alois Riedlsperger von der KSÖ, Frau Prof. Dr. Ingeborg Gabriel und weitere Sozialethiker Österreichs und anderer europäischer Länder.

Dieses Engagement verband mich mit Frau Univ.-Prof. Dr. Gabriel und so begegneten wir einander bei nationalen und internationalen Tagungen und waren uns einig, wenn es um die Kontakte mit den politischen Parteien, aber auch mit den Sozialpartnern ging - was wir nach dem österreichischen EUBeitritt besonders auf die europäische Ebene übertrugen. Die Kontakte zu den ArbeitnehmerInnen- und ArbeitgeberInnen-Verbänden, auch mit den öster- 
reichischen Sozial- und WirtschaftsministerInnen, auch den Bundes- und Vizekanzlern, waren selbstverständlich. Ich erinnere mich dabei besonders gerne an die Gespräche mit den früheren österreichischen SozialministerInnen Dallinger, Hesoun, Hostasch, Haubner, Haupt, Buchinger, Hundstorfer, die damals unsere ökumenischen Vorschläge aufgegriffen haben und mithalfen, auf nationaler und auch auf europäischer Ebene eine Sozialverträglichkeitsprüfung bei Gesetzesinitiativen einzuführen. Und wir sprachen darüber hinaus über die Notwendigkeit von Umweltverträglichkeitsprüfungen auf nationaler und der EU-Ebene. Es gelang sogar, diese Anliegen an die Sozial- und UmweltkommissarInnen und die Kommissionspräsidenten der EU heranzutragen. Auch die Idee einer sozialen Mindestsicherung - diese wurde in Österreich 2008 gesetzlich eingeführt - war damals, in den 1990er Jahren, bereits Gesprächsthema unserer ökumenischen Sozialinitiativen in Brüssel und in Österreich. Gesprächsthemen in Österreich und Brüssel waren immer auch die Bereiche der öko-sozialen Marktwirtschaft, der christlichen Soziallehre, die soziale Dimension der Religion überhaupt sowie auch immer der arbeitsfreien Sonn- und Feiertage.

Die Kontakte zu den Sozialpartnern und PolitikerInnen der EU sind mir auch deshalb in Erinnerung, weil sie zwei Anliegen eines sozialen Engagements der heutigen Kirchen verbinden: das Ökumenische und das ebenfalls Grenzen überwindende Europäische im gemeinsamen Handeln. Ich bin überzeugt, dass sich die großen Probleme der sozialen Gerechtigkeit - Hunger, Ernährung und Versorgung der Menschen mit Trinkwasser, Hygiene, Medizin - und der Ökologie und Nachhaltigkeit, nur gemeinsam lösen lassen.

Der heutige neue Nationalismus und die Wirtschaftskriege, die geistige Haltung, immer von einer gegenseitigen Bedrohung auszugehen, oder das Schüren von Feindbildern und Generalverdächtigungen, helfen allesamt nicht weiter, sondern vergrößern die Probleme, die die Welt heute hat. Europa musste in den 1930er- und 1940er Jahren schmerzhaft lernen, dass der verbissene Gegensatz die Menschheit nicht weiterbringt, auch wenn es berechtigte Anliegen, verschiedene Auffassungen und gegensätzliche Bedürfnisse geben mag.

Das nach 1945 neu entstandene Europa hatte vor allem den großen Vorteil, dass sich in vielen Köpfen und Herzen die Überzeugung durchsetzte: „Wir müssen es gemeinsam angehen". Gemeinsam - das bedeutet etwa die europäische Integration, aber auch das Überwinden von Vorurteilen - Antisemitismus, Ausländerfeindlichkeit, Rassendiskriminierung. Diese Erkenntnis ist nicht schlagartig überall gekommen, aber sie griff immer mehr um sich - und dies lässt sich wirklich als geistiger Fortschritt (im besten Sinne) begreifen! Gemeinsam bedeutete für die Kirchen auch und vor allem: die gegenseitige Achtung der christlichen Bekenntnisse. Wir Katholiken nehmen heute das Gute und Wahre bei unseren evangelischen und orthodoxen Schwestern und Brüdern 
anders zur Kenntnis als früher. Sie können uns in manchem Vorbild sein. Wir brauchen sie nicht mehr zu bekämpfen oder zu verdächtigen.

In diesem Sinn sagt das Selbstverständnis der Kirchen - nach 1945 - in einem ökumenischen Geist immer etwas über unsere Gesellschaft aus, die ja auch christliche Wurzeln aufweist. Mir wird das an den sozialen Botschaften des gegenwärtigen Papstes Franziskus besonders deutlich.

Neben meiner Zuständigkeit für soziale Fragen im Auftrag der Österreichischen Bischofskonferenz durfte ich unsere Bischöfe auch als Delegierter bei den Plenarsitzungen der italienischen Bischofskonferenz vertreten - und zwar über Jahrzehnte hin. Mein Dienst als Diözesanbischof und auch dieser besondere Auftrag der österreichischen Bischofskonferenz führte mich oft zu Begegnungen nicht nur mit den über 200 italienischen Diözesan- und Weihbischöfen, sondern auch mit den Päpsten Johannes Paul II., Benedikt XVI. und Franziskus. Insbesondere der derzeitige Papst - das fällt auf - bringt sich nachhaltig mit sozialen Fragen in die Debatten ein.

Papst Franziskus argumentiert, hört aber auch genau zu und geht ernsthaft auf seine Gesprächspartner ein. In seiner Enzyklika Laudato si' bringt er die Notwendigkeit eines vertrauensvollen Dialoges zum Ausdruck: Kirchen, Politik, Wirtschaft und Wissenschaft, aber auch alle Menschen, die von den Nöten unserer Zeit betroffen sind, haben eine gemeinsame Verantwortung wahrzunehmen. Dabei wird die fortgeschrittene Klimakatastrophe, aber auch Verschwendung und Vermüllung (z.B. Plastik) der Erde und des Meeres, Hunger und Vergiftungen und vieles andere immer wieder besprochen.

Papst Franziskus hebt in dieser Enzyklika die gemeinsame Verantwortung aller Menschen, aber auch etwa die ökologischen Initiativen des ökumenischen Patriarchen Bartholomäus von Istanbul hervor. Ohne hier auf die Details einzugehen, möchte ich ein Zitat von Papst Franziskus anfügen, das dieses gemeinsame Herangehen und die gemeinsame Verantwortung mit christlicher Hoffnung und Zuversicht unterlegt: „Der Schöpfer verlässt uns nicht, niemals macht er in seinem Plan der Liebe einen Rückzieher, noch reut es ihn, uns erschaffen zu haben. Die Menschheit besitzt noch die Fähigkeit zusammenzuarbeiten, um unser gemeinsames Haus aufzubauen." (LS 13)

Neben aller Betroffenheit über Unrecht und Zerstörung, und neben dem Bewusstsein von Verantwortung, dass wir Menschen unser Verhalten ändern müssen, braucht es eben auch diese Zuversicht und das Vertrauen, dass es gelingen kann. Wir verkünden in diesen Sorgen auch den Glauben daran, dass diese Welt und unser Dasein Sinn haben, dass hinter ihr eine Idee der Liebe und ein guter Plan Gottes steht, ohne den die Welt nicht entstanden wäre, und auf den wir zurückgreifen dürfen.

Vielleicht ist es heute manchen Menschen, die an einer besseren Welt arbeiten, gar nicht so bewusst, dass diese Zuversicht und das Erkennen eines Sinnes 
wesentliche Bestandteile dafür sind, nicht in Resignation zu flüchten, noch in privaten Konsum und Betäubung, sondern uns mit Offenheit dieser Welt, wie sie tatsächlich ist, auszusetzen.

Was ist das Heilige in dieser Welt? Wo berührt der Wille Gottes unsere Realität, unser gewöhnliches Leben? Wie nehmen wir unsere Verantwortung wahr und werden dadurch zu Geschwistern und Freunden aller Menschen? Diese Fragen lassen sich nicht völlig trennen. Daher gehört es auch zum Leben und Engagement von Frau Univ.-Prof. Dr. Ingeborg Gabriel, in den sozialen Nöten das Angesicht Christi zu entdecken. Für diesen Einsatz und die wissenschaftliche Vertiefung danke ich ihr! 


\section{Alexandros K. Papaderos \\ (Mitbegründer und erster Generaldirektor der Orthodoxen Akademie Kretas, Offizial des Ökumenischen Patriarchats)}

\section{Grußwort: Über den Dialog}

Die Gnade Gottes, die erschienen ist um alle Menschen zu retten (Tit.2,11), hat die Orthodoxe Akademie Kretas während der ersten 50 Jahre ihrer Arbeit (1968-2018) reichlich begleitet. Dies wurde durch das ganze Jahr 2018 verschiedentlich gefeiert; u. a. durch die Ausgabe einer Festschrift unter dem Titel „Diakonie, Dialog, Versöhnung“ in griechischer Sprache. ${ }^{1}$ Seine 638 Seiten haben viele Freunde und Freundinnen mit Beiträgen gefüllt. Texte in nicht griechischer Sprache wurden übersetzt, darunter der Beitrag von o. Univ.-Prof. Mag. Mag. Dr. Ingeborg Gabriel. ${ }^{2}$

Frau Gabriel verdanke ich einen großen Teil all dessen, was mich mit Österreich verbindet. Das Eingangstor für mich war zwar Graz. Wien verdanke ich aber viel mehr. Mein kretischer Landsmann Gregor Larentzakis hat mir das Tor der Katholischen Theologischen Fakultät der Universität Graz geöffnet, welche vorher ihm ein anderes, für die Wissenschaft und die Ökumene wichtiges Tor, geöffnet hatte. Sie hatte ihn in die Gemeinschaft ihrer Professoren aufgenommen und ihm die volle Freiheit gegeben, sowohl für die Fakultät, wie überhaupt für die Katholische Kirche eine Brücke zur Welt der Orthodoxie zu bauen! Von Graz sind die ersten Professoren und Studenten zu uns in die Orthodoxe Akademie (mehrmals) gekommen, in dieser Fakultät habe auch ich reichlich ökumenische Wärme und aufrichtige Freundschaft gefunden. ${ }^{3}$

Das Tor zu Wien öffnete mir zwar die Griechisch-Orthodoxe Metropolis von Österreich schon in der Zeit des verewigten Metropoliten Chrysostomos und

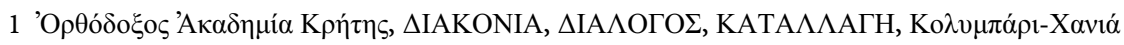
2018.

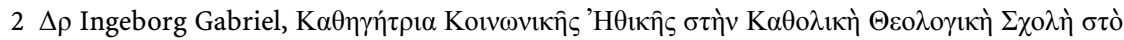

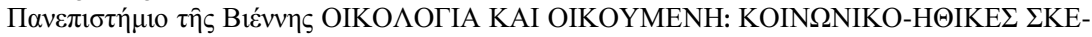

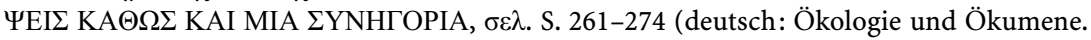
Überlegungen aus der Sicht der Sozialethik).

3 Krönung dieser Beziehungen war die mir zu meinem 60sten Geburtstag gewidmete Festschrift Ökumenisches Forum Nr. 15 mit vielen und interessanten Beiträgen und das Fest zu seiner Übergabe an mich. 
seines Nachfolgers Michael Staikos'. Zu meinen großen Mentoren für Wissenschaft und Ökumene im Bereich Wien und vielem mehr gehört aber Ingeborg Gabriel. Gerne und dankbar denke ich z. B. an die vielen ökumenischen Kontakte, an meine Gespräche in der Morgenfeier des Österreichischen Rundfunks, ökumenische Dialoge im Fernsehen, Bekanntschaft und Freundschaft mit vielen Personen und Institutionen wie die Katholische Theologische Fakultät der Universität Wien, die Stiftung Pro Oriente, und insbesondere natürlich an die Begegnungen mit Katholischen Geistlichen wie dem Weihbischof der Erzdiözese Wien Dr. Helmut Krätzl, Kardinal Christoph Schönborn und seinem Vorgänger Franz Kardinal König, der uns große Freude und Ehre bereitete, als er zu unserer Orthodoxen Akademie in Kreta kam (Mai 1984), begleitet von einer größeren Schar von prominenten Personen. Auch Michael Staikos war dabei. Hier sei notiert, dass Prof. Ingeborg Gabriel die gute Idee einer Widmung zu verdanken ist. $^{4}$

\title{
1. Der Dialog als Hauptaufgabe und Arbeits-Methode einer christlichen Akademie
}

Eine christliche Akademie, welche echten und erfolgreichen Dialog ermöglichen will, hat in den Worten des Heiligen Johannes Chrysostomos in seiner 51. Homilie die Grundvoraussetzungen dafür :

\begin{abstract}
„Die ihr zum Kreuz kommen wollt, lasst die eitlen Bilder hinter euch, löscht Zorn und Wut aus, strebt nicht danach, irgendjemandem Kummer zuzufügen, lasst euch im Kampf nicht zum Mord hinreißen und führt keinen lügnerischen Dialog. Die ihr zum Kreuz kommen wollt, verweilt nicht in Lügen und lasst euch nicht von schamlosen und seelenschädlichen Begierden fesseln, sondern bewahrt mit ganzer Seele die Gebote Gottes. Die ihr zum Kreuz kommen wollt, strebt nach dem Wohl und dem Guten, und lasst euch nicht in Kämpfe und Flüche verwickeln. Die ihr zum Kreuz kommen wollt, sprecht Worte der Wahrheit zu euren Nächsten, verabscheut alle Schande und Lüsternheit und vertreibt die Unzucht. “5
\end{abstract}

Dies sage ich in voller Überzeugung aus der 50jährigen Erfahrung an der Orthodoxen Akademie Kretas. Dabei war die platonische Akademie, der Dialog, das Symposion, das „symphilosofein“ - das zusammen philosophieren - in der Suche nach der Wahrheit, für uns der sichere Wegweiser.

4 „In memory of Michael Staikos (1946-2011) Greek Orthodox Metropolitan of Austria and Exarch of Hungary and Central Europe, who, through his ecumenical spirit, gave great inspiration to this work. “, Ingeborg G. Gabriel / Ulrich H. J. Körtner / Alexandros K. Papaderos (eds.), Trilogy of Social Ethics. Orthodox-Catholic-Protestant, Philadelphia 2012.

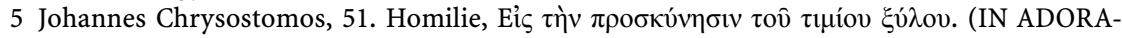
TIONEM VENERANDE CRUCIS), Migne P G 62, S. 748 f. 
Das Programm der Akademie „Lebendige Orthodoxie“, d.h. die Orthodoxe Kirche wie sie heute lebt, mit all ihrem Segen und Heimsuchungen, adressiert an Geistliche und Laien anderer christlicher Traditionen vom Ausland, ermöglicht den ökumenischen Dialog der Wahrheit und der Liebe mit tausenden Brüdern und Schwestern. Ähnliche Erfahrungen haben wir mit dem Programm „Kreta gestern und heute“, welches die Möglichkeit bietet, kulturhistorische und aktuelle europäische und weltpolitische Themen zu besprechen, bzw. traumatische Erinnerungen unter das christliche Licht der Vergebung und der Versöhnung zu stellen.

Eine frohe Rückerinnerung bewegt mich, dieses Grußwort mit dem Epilog einer verwandten Rede zu schließen.

Vor einigen Jahren hat mir die Katholisch-Theologische Fakultät der Universität Wien die große Ehre und Freude gemacht, bei der Feier zum 60. Geburtstag von Frau Prof. Gabriel die Laudatio zu übernehmen. Deren Schlussworte wiederhole ich nun aus ganzem Herzen:

Verehrte, liebe Frau Gabriel,

Konstantinos Kavafis (1863-1933), der griechische Dichter, der in Alexandria, Ägypten, gelebt hat, machte Ithaka zum höchsten Ideal und Ziel menschlichen Strebens. Meine Wünsche möchte ich durch ein paar Verse aus seinem gleichnamigen Gedicht $I \Theta A K H$ zum Ausdruck bringen:

Brichst du auf gen Ithaka, wünsch dir eine lange Fahrt, voller Abenteuer und Erkenntnisse.

Der Sommermorgen möchten viele sein, da du, mit welcher Freude und Zufriedenheit in nie zuvor gesehene Häfen einfährst;

Immer halte Ithaka im Sinn.

Dort anzukommen ist dir vorbestimmt. Doch beeile nur nicht deine Reise.

Besser ist, sie dauere viele Jahre;

Und alt geworden lege auf der Insel an, reich an dem, was du auf deiner Fahrt gewannst,

So Weise, wie du wurdest, in solchem Maße erfahren, wirst du ohnedies verstanden haben, was die Ithakas bedeuten. ${ }^{6}$

CHRONIA POLLA - viele, gesegnete Jahre!

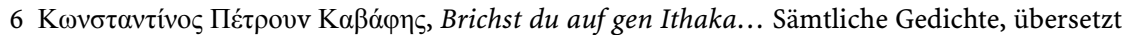
von Wolfgang Josing unter Mitarbeit von Doris Gundert, Köln 1983. 
Open-Access-Publikation im Sinne der CC-Lizenz BY 4.0

(C) 2020, Vandenhoeck \& Ruprecht $\mathrm{GmbH} \&$ Co. KG, Göttingen ISBN Print: 9783847111658 - ISBN E-Lib: 9783737011655 


\author{
ao. Univ.-Prof. Mag. Dr. Christa Schnabl \\ (Vizerektorin für Studium und Lehre)
}

\title{
Grußwort: Als Quereinsteigerin Brücken bauen
}

Die Sozialethik, wenn man sie im Fächerkanon der Katholischen Theologie betrachtet, könnte man als das „Außenministerium“ der Theologie bezeichnen. Sie hat die Aufgabe, das, was das menschliche Handeln aus christlicher Sicht ausmacht, im gesellschaftlichen Kontext zu reflektieren und zu begründen, und nicht zuletzt auch so zu beschreiben, dass es für Menschen, die nicht per se Angehörige der Katholischen Kirche sind, verstehbar und nachvollziehbar wird. Die Grenzen zwischen dem sog. „innen“ und „außen“ sind dabei heute selbstverständlich als durchlässig zu denken. Auch für die Gläubigen selbst geht es darum, sich des eigenen Handelns zu vergewissern und eigene Standpunkte theologisch-ethisch vor dem Hintergrund der diversen gesellschaftlichen Herausforderungen immer wieder neu zu reflektieren. Dies geschieht heute unabweisbar im Dialog mit den großen gesellschaftlichen Gruppierungen und Einrichtungen über Konfessionen, Religionen und Weltanschauungen hinweg. Interdisziplinäre Gesprächskompetenzen sind für diesen Dialog im globalen Kontext unumgänglich. Folglich liegt die Bedeutung der Sozialethik in Fortschreibung ihrer Entstehungssituation im Verlauf des 19. Jahrhunderts darin, als „interdisziplinäres Brückenfach “1 ${ }^{\mathrm{zu}}$ fungieren:

„Da die Gesellschaft heute in eine neue Stufe der Pluralisierung und internationalen Verflechtung eingetreten ist, sind von dem theologischen Fach Sozialethik verstärkte Anstrengungen für interkulturelle und transnationale, aber auch interreligiöse Lernprozesse gefordert, um im Dialog mit Anderen allgemein akzeptanzfähige, zeitgemäße und praktikable Gerechtigkeitsnormen für freiheitliche und soziale Welt- und Gesellschaftsordnungen zu formulieren. ${ }^{“ 2}$

1 Positionspapier der AG Christliche Sozialethik 2018 zur Bedeutung Christlicher Sozialethik für Gesellschaft, Universität, Theologie und Kirche, S. 2, vgl. http://www.christliche-sozial ethik.de/wp-content/uploads/2018/03/Positionspapier-CSW_23.03.2018.pdf (letzter Zugriff: 10.07.2019).

2 Ebd. 
Ingeborg Gabriel brachte als „Quereinsteigerin“ die besten Voraussetzungen für die Herausforderungen dieses Faches mit, als sie 1996 als erste Frau an der Katholisch-theologischen Fakultät der Universität Wien den Ruf auf eine Professur erhält. Vor dem Theologiestudium hat sie ein wirtschaftswissenschaftliches Studium absolviert sowie ein Post-Graduate Studium an der Diplomatischen Akademie in Wien. Auslandsaufenthalte im diplomatischen Dienst in Moskau, Madrid, New York, Nepal und der Mongolei führen ihr biographisch schon früh die verschiedenen Herausforderungen diverser Weltregionen vor Augen. ${ }^{3}$ Sowohl in wissenschaftlicher als auch in praktischer Hinsicht wird mit diesen Voraussetzungen bereits der Duktus für die wichtigsten wissenschaftlichen Schwerpunkte in späterer Zeit vorgegeben. Ingeborg Gabriel widmet sich beispielsweise dem Projekt: Sozialethik aus ökumenischer Perspektive, um die unterschiedlichen innerchristlichen Zugänge zum Diakonischen und Sozialen aus katholischer, orthodoxer und protestantischer Sicht miteinander ins Gespräch zu bringen. Die Perspektive weitet sich jedoch auch auf andere Religionen aus. Wissenschaftlich und praktisch engagiert sich Frau Prof. Gabriel im interreligiösen Dialog. Ich erinnere mich noch sehr bildhaft an Erzählungen über Reisen in den Iran bereits in den 1990er-Jahren, bei denen sie als eine der ganz wenigen weiblichen Delegierten an interreligiösen Gesprächen unter der Federführung von Steyler Missionar Pater Andreas Bsteh SVD ${ }^{4}$ teilgenommen hat. In den letzten Jahren hat sie dieses Engagement zur Organisation einer Summer School im Benediktinerstift Altenburg geführt, bei der jeweils 40-50 Studierende aus diversen Regionen der Welt zusammengekommen sind, um theologische Themen aus christlicher und muslimischer Sicht zu diskutieren.

Ethisches Rückgrat der diversen interreligiösen, interdisziplinären, interkulturellen Brückenschläge sind jedenfalls immer die Menschenrechte. Dazu hat Ingeborg Gabriel regelmäßig publiziert sowie Lehrveranstaltungen abgehalten. Die Menschenrechte bilden Ingeborg Gabriel zufolge den besten Ansatz für eine national, europäisch und international anschlussfähige christliche Sozialethik. Dabei geht es sowohl um die menschenrechtlich durch Abwehrrechte zu garantierenden Freiräume (Religionsfreiheit, Meinungsfreiheit, ...) einerseits, als auch um die Möglichkeit, diese Freiräume z. B. für das christliche Engagement in der Zivilgesellschaft (Stichwort: gesellschaftliche und politische Partizipation) zu nutzen. Zudem erlauben die sozialen Menschenrechte die ganze Bandbreite an sozialen Fragen in der Gesellschaft (Migration, Gesundheit, Bildung, Soziale

3 Vgl. Ingeborg Gabriel, Spannende Zeiten, in: Konrad Hilpert (Hg.), Theologische Ethiker im Spiegel ihrer Biographie. Stationen und Kontexte, Paderborn 2016, S. 165-184.

4 Vgl. Andreas Bsteh, Geschichte eines Dialoges: Dialoginitiativen St. Gabriel an der Jahrtausendwende, Mödling 2013, S. 87-92. 
Sicherheit, Ökonomie, Ökologie und Klimawandel) in den Blick zu nehmen und auch vor dem Hintergrund der globalen Entwicklungen zu reflektieren.

Ingeborg Gabriel hat sich in ihrer über zwanzigjährigen Tätigkeit als Professorin für Sozialethik an der Universität Wien insbesondere diesen Themenbereichen gewidmet und damit das Fach Sozialethik am Standort Wien dahingehend geprägt. 
Open-Access-Publikation im Sinne der CC-Lizenz BY 4.0

(C) 2020, Vandenhoeck \& Ruprecht $\mathrm{GmbH} \&$ Co. KG, Göttingen ISBN Print: 9783847111658 - ISBN E-Lib: 9783737011655 


\section{Irene Klissenbauer / Franz Gassner / \\ Petra Steinmair-Pösel / Peter G. Kirchschläger}

\section{Einleitung}

Menschenrechte und Gerechtigkeit als bleibende Aufgaben - Beiträge aus Religion, Theologie, Ethik, Recht und Wirtschaft - unter diesem Titel steht die Festschrift für Ingeborg G. Gabriel, die anlässlich ihrer Emeritierung Gabriels beeindruckendes Werk und großes Engagement würdigen soll.

Nach dem Studium der Handelswissenschaften und Volkswirtschaftslehre sowie der Geschichte und Germanistik, trat Gabriel in den Dienst der Vereinten Nationen (UNDP), der sie nach New York, Nepal und in die Mongolei führte. Die großen existentiellen Fragen, die Gabriel in ihrer Forschung begleiten, etwa nach den Bedingungen authentischer Entwicklung oder nach der Möglichkeit, unter unmoralischen Bedingungen moralisch zu sein, wurden wesentlich auch von diesen Erfahrungen geprägt. Das Studium der Katholischen Theologie mit einem Schwerpunkt auf alttestamentliche und sozialethische Fragen war so nicht zuletzt auch Ausdruck ihres großen Interesses an grenz- und fächerüberschreitendem Denken.

Nach der Assistenzprofessur und Leitung der Abteilung für Internationale Ethik erhielt Gabriel 1997 den Ruf als Ordinaria der Sozialethik (damals noch Christliche Gesellschaftslehre) an die Universität Wien, wo sie von 1997 bis 2020 Leiterin des Fachbereichs Sozialethik (bis 2016 Institut für Sozialethik) der Katholisch-Theologischen Fakultät war.

Die große gesellschaftliche und kirchenpolitische Bedeutung dieser Berufung zeigt sich auch daran, dass mit ihr zum ersten Mal in der Geschichte der Katholisch-Theologischen Fakultät in Wien (gegr. 1384) eine Frau auf einen theologischen Lehrstuhl berufen wurde.

Einen der wesentlichen Ausgangspunkte der Forschungsarbeit Gabriels bildet die Pastoralkonstitution Gaudium et spes mit ihrer Verpflichtung auf einen Dialog von Kirche und Welt. In all ihren Arbeiten zeigt sich nicht zuletzt aus diesem Grund die für die Sozialethik notwendige Verschränkung von Philosophie, Humanwissenschaften, Sozialwissenschaften, Rechtswissenschaften und theologischer Ethik. Für diese notwendige Brückenfunktion der Sozialethik hat sich die Geehrte unermüdlich in sowohl wissenschaftlicher als auch menschli- 
cher Weise eingesetzt. Die Menschenrechte betont Gabriel dabei als „Rückgrat der internationalen und nationalen Rechtsordnungen“ und besten „Ansatz für eine national, europäisch und international anschlussfähige christliche Sozialethik $^{\text {“1 }}$. Diesen Ansatz theologisch zu vertiefen, ist zu einem ihrer großen Forschungsanliegen geworden.

Die gesellschaftspolitische Relevanz ihrer Arbeit und ihr stetiges Suchen, dem aggiornamento gerecht zu werden, zeigt sich darüber hinaus auch in den zahlreichen Konferenzen zu zentralen sozialethischen Themen, die Gabriel organisierte, sowie in ihrem großen Engagement in interreligiösen und ökumenischen Dialogen.

Gabriels theologische, aber auch internationale und fächerübergreifende Expertise macht sie zu einer gefragten Ansprechpartnerin für Studierende, KollegInnen der Theologie und anderer Fächer, aber auch für VertreterInnen in Gesellschaft, Wirtschaft, Politik, Presse, Radio und Fernsehen. Die Anschlussfähigkeit und Praxisrelevanz ihrer Forschung zeigt sich in den zahlreichen universitären und außeruniversitären Funktionen, von denen hier nur einige genannt seien: Sonderbeauftragte der OSZE im Kampf gegen Rassismus, Xenophobie und Diskriminierung, Direktorin der „Iustitia et pax“-Kommission der Österreichischen Bischofskonferenz, Vizepräsidentin von „Iustitia et pax“Europa und des Vereins der Stiftung Pro Oriente, Wien.

Neben ihrem wissenschaftlichen und gesellschaftspolitischen Engagement ist Gabriel die Lehre und der Austausch mit Studierenden ein großes Anliegen, sodass sie sich als Lehrstuhlinhaberin in unterschiedlichen Projekten, wie etwa dem CEEPUS Austausch-Programm „Ethics and Politics in the European Context" oder der vom österreichischen Wissenschaftsministerium finanzierten Sommeruniversität für christlich-islamischen Dialog (VICISU) im österreichischen Benediktinerstift Altenburg engagierte. Dabei sind es vor allem ihr ehrliches Interesse an den Studierenden und ihren Lebensrealitäten sowie ihre intellektuell anspruchsvollen und stets mit aktuellen Bezügen versehenen Vorträge, die Studierende für theologische Fragen und sozialethische Reflexionen begeistern. Wer die Lehrveranstaltungen von Gabriel kennt, wird so wenig verwundert sein, dass nicht nur Theologinnen und Theologen, sondern auch zunächst fachfremde Studierende ihre wissenschaftlichen Abschlussarbeiten in der Sozialethik angesiedelt haben.

Entsprechend Gabriels vielfältigen Forschungsinteressen werden in diesem ihr gewidmeten Band unterschiedlichste Themenbereiche behandelt. Das sie verbindende Moment ist der Versuch, die Zeichen der Zeit zu lesen und die sozialethisch brennenden Fragen zu diskutieren, wie Menschenrechte und Ge-

1 Ingeborg Gabriel, Spannende Zeiten, in: Konrad Hilpert (Hg.), Theologische Ethiker im Spiegel ihrer Biografie: Stationen und Kontexte, Paderborn 2016, S. 165-184, hier: S. 181. 
rechtigkeit verwirklicht werden können und Zusammenleben in aller Vielfalt gelingen kann. Dabei deutet die Bandbreite der unterschiedlichen Forschungsrichtungen, die im Rahmen der Festschrift zu Wort kommen, nicht nur auf Gabriels zahlreiche Interessen hin, sondern ist charakteristisches Zeichen der Interdisziplinarität der christlichen Sozialethik selbst. Besonders deutlich wird dies etwa angesichts eines der zentralen Forschungsschwerpunkte Ingeborg G. Gabriels, d.i. der Frage nach dem Gelingen der langfristigen Gewährleistung der Menschenrechte.

In einem jüngst erschienenen Beitrag konstatiert Gabriel dabei, dass die Realisierung der Menschenrechte, trotz ihrer völkerrechtlich starken Verankerung, zeitgenössisch wesentlich geschwächt ist. ${ }^{2}$ Im Hintergrund ist, laut Gabriel, auch die Spannung zwischen der rechtlichen Ordnung der Menschenrechte und ihren ethischen Begründungen und Fundierungen in unterschiedlichen Kulturen und Religionen zu sehen. Die hierbei bisher ausstehende aber notwendige noch stärkere Vermittlung, zu der auch das vorliegende Werk einen Beitrag leisten möchte, ist eines der zentralen Anliegen der Arbeit Gabriels. Dabei trägt die Festschrift durch die konfessionelle Vielfalt der AutorInnen ihrer Überzeugung Rechnung, dass dies nur in einer ökumenischen und interreligiösen $\mathrm{Zu}$ sammenarbeit gelingen kann.

Sollen Schritte in Richtung einer größeren Gerechtigkeit für alle Menschen weltweit gesetzt werden, muss die Welt, auch dies zeigt die Forschungsarbeit Ingeborg G. Gabriels deutlich, in all ihrer Komplexität betrachtet werden. Erst ein Blick auf die tieferen Zusammenhänge zwischen Politik, Recht, Ökologie und Wirtschaft erklärt die aktuellen Herausforderungen und nur ein gemeinsam suchendes Gespräch, das auch unterschiedlichen religiösen und nichtreligiösen Weltanschauungen Platz einräumt, ermöglicht die Verwirklichung von Gerechtigkeit, die jedoch als niemals endgültig gesicherte betrachtet werden kann. Auch deshalb versteht sich die Festschrift als nicht abgeschlossenes Gespräch über die Realisierung von Gerechtigkeit.

1. Der erste Teil widmet sich aus theologischer Perspektive Fragen der Gerechtigkeit und aktuellen Herausforderungen, wobei zunächst Georg Braulik den Umgang mit Fremden und die Bedeutung und Umsetzung der sozialethischen Forderung von Deuteronomium 10,19 behandelt.

Stanislaw Fel widmet sich der Relevanz und den verschiedenen Formen empirischer Gerechtigkeitsforschung für und in der Sozialethik.

2 Vgl. den Beitrag zu Menschenrechten, Demokratie, Nationalstaat und Supranationalität in: Ingeborg Gabriel, Ethik des Politischen. Grundlagen - Prinzipien - Konkretionen, Echter 2020 (im Erscheinen). 
Daniel Bogner betrachtet den bisher im theologisch-ethischen Diskurs nur wenig reflektierten Themenkreis von Macht und Herrschaft und fragt nach den Chancen, die seine stärkere Integration mit sich bringen würde. Jegliche Spaltung von Orthodoxie and Orthopraxie abwehrend, entspringt eine Christliche Ethik aus dem Inneren des Glaubens.

Markus Vogt betont die Bedeutung einer ökumenisch, interreligiös, interkulturell und interdisziplinär eingebundenen Sozialethik und die gesellschaftliche Brisanz der Frage nach dem Stellenwert theologischer Argumente für die Begründung, Motivation und Entfaltung der Ethik.

Kurt Appel thematisiert das Verhältnis von Religion und Zivilgesellschaft in Europa sowie die Bedeutung öffentlicher Räume und die Chancen eines neuen Zueinander von Christentum, Judentum, Islam und säkularer Welt in Europa.

Stefan Tobler widmet sich der sozialethischen Dimension in der mystischen Erfahrung Chiara Lubichs.

Petra Steinmair-Pösel reflektiert nach einer Darstellung des dialogischen Elements in Gabriels Arbeit den Dialogbegriff in den Enzykliken, nachsynodalen Lehrschreiben und sozialethisch relevanten Texten von Papst Franziskus. Die darin zum Ausdruck gebrachte Bedeutung des Dialogs für die Arbeit von Ingeborg G. Gabriel bildet die Brücke zum zweiten, dem Dialog gewidmeten Teil des Bandes:

2. Mit Blick auf Gabriels vielfältiges Engagement im ökumenischen und interreligiösen Bereich erörtert dieser die Frage nach gelingendem Zusammenleben. Diesen Teil beginnend thematisiert Jakob Helmut Deibl die Rolle des interreligiösen Dialogs als theologische Öffnung einer religiösen Tradition einerseits, sowie als Beitrag zur Gestaltung des öffentlichen Raumes andererseits.

Konstantinos Delikostantis analysiert mit Blick auf eine orthodoxe Sozialethik das spezifische Verhältnis von Liturgie und Diakonie in der Orthodoxie.

Cezar Marksteiner-Ungureanu fragt aus theologischer und ethischer Perspektive nach der Möglichkeit einer Versöhnung der orthodoxen Kirchen und damit nach einer Lösung der ekklesialen Krise in der Ukraine.

Peter Schipka analysiert in seiner Funktion als Generalsekretär der österreichischen Bischofskonferenz ausgewählte Stellungnahmen der Bischofskonferenz zu rechtlichen Regelungen, die den Islam in Österreich betreffen.

Rüdiger Lohlker widmet sich der Verhältnisbestimmung von Exodus und Hidschra aus einer religionswissenschaftlichen Perspektive.

Johann Figl blickt auf pazifistische Intentionen neureligiöser Bewegungen, wobei er im Besonderen auf die Botschaft Hazrat Inayat Khans und der von ihm gegründeten Bewegung eingeht.

Hans Gerald Hödl beleuchtet eine philosophische Diskussion um eine afrikanische Form der Demokratie. Eine kritische Analyse zeigt jedoch, dass eine 
idealisierende Konstruktion einer panafrikanischen politischen Identität der historischen Vielfalt afrikanischer Gesellschaften und deren politischer Realität nicht gerecht wird.

3. Die Mitte des Bandes, sozusagen sein „Rückgrat“ bildend, ist dem wissenschaftlichen und praktischen Einsatz von Gabriel im menschenrechtlichen Diskurs gewidmet, indem vielfältige Herausforderungen allgemeiner ebenso wie spezieller Natur aus sowohl theologischer als auch juristischer Perspektive thematisiert werden.

Heiner Bielefeldt fragt nach dem Verhältnis von modernen Menschenrechten und unterschiedlichen Formen eines traditionellen, religiös eingebetteten Ethos, wobei er im Besonderen auf die UN-Resolution über „traditional values“ eingeht.

Marianne Heimbach-Steins widmet sich den humanisierenden Potenzialen des religiösen Freiheitsrechts in einer Demokratie und plädiert dafür, dieses als Kompass und Zukunftsressource der Religionspolitik zu nutzen.

Stefan Hammer thematisiert das Konzept der politischen Säkularität und fragt, ob und inwiefern ihr angesichts der zunehmenden Pluralisierung und Diversifizierung des Religiösen heute noch ein eigenständiger normativer Stellenwert zukommen kann. Eine Möglichkeit dafür sieht er im Anschluss an Toleranz als politische Tugend.

Peter G. Kirchschläger reflektiert die Anwendung der Menschenrechte im Verhältnis zwischen Staat und Religions- und Weltanschauungsgemeinschaften und mögliche Interventionspflichten von Seiten des Staates in diesen Gemeinschaften.

Richard Potz skizziert den hohen Komplexitätsgrad des europäischen Rechtsraums und analysiert in diesem Zusammenhang kritisch die Tendenz der Entwicklung von Schwerpunkten in einem immer sichtbarer werdenden europäischen Religionsrecht und deren Folgen.

Wolfgang Palaver analysiert die Umsetzung der Religionsfreiheit in Österreich und problematisiert diese mit besonderem Blick auf das Alevitentum und seine (Nicht-)Anerkennung.

Manfred Nowak und Anna-Maria Steiner analysieren die Problematik der (Wieder-)Einführung religiöser Rechte am Beispiel des Einflusses von Religion auf die Menschenrechte im Sharia Strafgesetzbuch in Brunei.

Irene Klissenbauer stellt aus sozialethischer Perspektive Überlegungen hinsichtlich des Verhältnisses von Frauenrechten und Religions- und Weltanschauungsfreiheit am Beispiel des islamischen Schleiers an.

Günter Virt beschreibt seine persönlichen Erfahrungen im Engagement für Menschenrechte, vor allem mit Blick auf die Verhandlungsprozesse bei der Verabschiedung von Menschenrechtsdokumenten. 
Konrad Hilpert widmet sich dem Recht auf reproduktive Autonomie als menschenrechtlichem Topos und seinen ethischen Grenzen sowie der Frage nach seiner rechtssystematischen Zuordnung.

4. Den für Gabriel stets zentralen Fragen nach den Herausforderungen und Chancen gesellschaftlicher Pluralität und damit nach politischen Gestaltungsmöglichkeiten widmet sich der vierte Teil des Bandes. Die AutorInnen thematisieren dabei sowohl grundlegende Fragen und Analysen der gegenwärtigen politischen Situation und einer angemessenen Reaktion hierauf von Seiten der Theologie als auch zukünftige Herausforderungen, die sich abzeichnende Entwicklungen mit sich bringen. Den vierten Teil eröffnend reflektiert Jan-Heiner Tück die Bedeutung des Kreuzes als religiöses Symbol und die verpassten Chancen anlässlich seiner Abnahme in den Hörsälen der katholischen Theologie in Wien.

Johann Pock untersucht das Phänomen der Grenze mit Blick auf konkrete gegenwärtige Grenzfälle in Gesellschaft, Kirche und Pastoral und entwickelt davon ausgehend eine Vision zukünftigen kirchlichen Handelns.

Einer zukünftigen Vision - mit Blick auf die Gesamtgesellschaft - widmet sich auch Peter Klasvogt, der im Anschluss daran die Bedeutung einer neuen Erzählung für Europa und die Weltgesellschaft angesichts der zeitgenössischen epochalen Herausforderungen thematisiert.

Die von ihm darin angesprochene notwendige Kultur der Begegnung beschäftigt auch Adrian Loretan, der in seinem Beitrag die Voraussetzungen einer solchen mit Blick auf die Herausforderungen religiöser Vielfalt für den Rechtsstaat und die Religionsgemeinschaften untersucht.

Kristina Stoeckl widmet sich spezifischen Positionen innerhalb dieser Pluralität und geht in ihrem Beitrag auf das Phänomen der Postsäkularität ein und fokussiert in diesem Zusammenhang im Besonderen auf den russisch-postsäkularen Diskurs.

Richard Sturn thematisiert die Frage nach Paradigmen des Politischen sowie nach den Chancen und Umsetzungsmöglichkeiten sozialer Gerechtigkeit.

Christian Spieß analysiert ausgehend von den Überlegungen Martha Nussbaums zu einer Kulturalisierungstendenz hin zu einer „neuen religiösen Intoleranz" den religionspolitischen Modellwechsel der vergangenen Jahre mit besonderem Fokus auf Österreich.

Einen Blick auf eine nicht allzu ferne Zukunft wirft Linda Hogan, die Entwicklungen und ethische Herausforderungen im Bereich künstlicher Intelligenz (AI) erläutert und fragt, ob und unter welchen Voraussetzungen diese zur Entwicklung einer ethischeren Zukunft beitragen könnte.

Ulrich H.J. Körtner evaluiert den Umgang mit Verantwortung in Medizin- und Pflegeethik. 
Den vierten Teil abschließend und überleitend geht Christoph Stückelberger auf die Bedeutung der Tugenden ein, wobei er besonders für Integrität als christlicher Beitrag einer globalen Tugendethik für Wirtschaft und Politik plädiert.

5. Auf Gabriels umsichtige Analysen wirtschaftsethischer Fragen verweist der fünfte Teil des Bandes, wobei auch hier die Frage der Gerechtigkeit eine zentrale Stellung einnimmt.

Peter Kodwo Appiah Kardinal Turkson thematisiert ethisches Investment und dessen Potenzial für das Wohlergehen der Erde und ihrer BewohnerInnen.

Leopold Neuhold wirft unter Bezugnahme auf Caritas in veritate einen kritischen Blick auf das zeitgenössische Wirtschaftsmodell und betont die Notwendigkeit, Wirtschaft in Perspektiven zu stellen.

Michaela Schaffhauser-Linzatti analysiert aktuelle ökonomische Entwicklungen und entfaltet ethische Unternehmensberichterstattung als ein Instrument zur Förderung nachhaltigen Wirtschaftens und des Gemeinwohles.

Bernhard Leubolt, Magdalena Holztrattner und Markus Schlagnitweit thematisieren aus Perspektive der Katholischen Sozialakademie Österreichs Krisenerscheinungen des Sozialstaats sowie die Möglichkeiten und Grenzen seiner Erneuerung durch soziale Innovation und katholische Soziallehre.

Klaus Gabriel beschreibt die Entwicklung der ethisch-nachhaltigen Geldanlage ebenso wie die unterschiedlichen Motive von Investierenden und benennt aktuelle wirtschaftsethische Herausforderungen.

Georges Enderle fragt nach der Verantwortung von Unternehmen - verstanden als "moralische Akteure“ - für weniger Einkommensungleichheit in wirtschaftlichen Organisationen.

Wilfried Stadler analysiert die Chancen einer ökosozialen Ordnungspolitik angesichts einer globalisierten Ökonomie.

Franz Gassner plädiert mit Blick auf gegenwärtige Entwicklungen und den Klimawandel für die Notwendigkeit einer Ressourcenethik.

Wer Ingeborg G. Gabriel kennt - und dies zeigen auch ihre zahlreichen Projekte, Publikationen und Mitgliedschaften (im Anhang angefügt) - weiß, dass die Emeritierung keinen „Ruhestand“ bedeuten wird. Und so freuen wir uns bereits jetzt auf weitere Forschungsergebnisse, Gespräche und gemeinsame Projekte. Dies, und die Ein- und Ausblicke der vorliegenden Festschrift wollen zeigen, wie sehr das Fach Sozialethik gefordert ist, mitzuhelfen, im "globalen Problemstau“ den Weg zu einer gerechteren und friedlicheren Welt zu bahnen, z. B. in der Suche nach Lösungen der globalen sozialen und ökologischen Fragen, im Ringen um eine Weltordnungspolitik mit globalen Institutionen für Politik, Umwelt, Fi- 
nanzen und Wirtschaft, die dem Leben aller dienen, und im schonenden Umgang mit Ressourcen durch nachhaltigere Lebensstile.

„Die sich rasch global wirtschaftlich und technisch vernetzende und zugleich sozial, politisch, kulturell und religiös fragmentierte Welt auf der politischen Systemebene als auch auf der gesellschaftlichen Ebene zu integrieren, ist eine gewaltige, bisher kaum in Angriff genommene Aufgabe, wie im Übrigen auch die sozialwissenschaftliche und sozialethische Reflexion der Globalisierungsprozesse. ${ }^{\text {“3 }}$

Neben dem Dank an alle Mitwirkenden, gebührt großer Dank all jenen Personen und Institutionen, die uns aufgrund ihrer langjährigen guten Beziehung mit Ingeborg G. Gabriel großzügige Zuschüsse für die Drucklegung haben zukommen lassen, namentlich Abtpräses Mag. Christian Haidinger, Erster Vorsitzender der Superiorenkonferenz Österreichs, P. Anton Fencz SVD, Rektor des Missionshauses St. Gabriel, P. Mag. Stephan Dähler SVD, Provinzial der Mitteleuropäischen Provinz ECP der Steyler Missionare, sowie Bischof em. Dr. h.c. Maximilian Aichern OSB und der Katholisch-Theologischen Fakultät der Universität Wien, namentlich Ihrem Dekan Prof. Dr. Johann Pock.

Dank gilt darüber hinaus auch Beate Anger und Dr. Rudolf Kaisler für Ihre wertvolle Unterstützung sowie Oliver Kätsch und Anke Moseberg-Sikora vom Vandenhoeck \& Ruprecht-Verlag für die freundliche Betreuung der Festschrift und deren Aufnahme in das Verlagsprogramm.

Irene Klissenbauer - Franz Gassner Petra Steinmair-Pösel - Peter G. Kirchschläger Wien - Macao - Innsbruck - Luzern, 2020

3 Ingeborg Gabriel, Einleitung, in: Dies. / Ludwig Schwarz (Hg.), Weltordnungspolitik in der Krise: Perspektiven Internationaler Gerechtigkeit, Paderborn 2011, S. 9-30, hier: S. 13. 


\section{Theologie}

Open-Access-Publikation im Sinne der CC-Lizenz BY 4.0

(c) 2020, Vandenhoeck \& Ruprecht GmbH \& Co. KG, Göttingen 
Open-Access-Publikation im Sinne der CC-Lizenz BY 4.0

(C) 2020, Vandenhoeck \& Ruprecht $\mathrm{GmbH} \&$ Co. KG, Göttingen ISBN Print: 9783847111658 - ISBN E-Lib: 9783737011655 


\section{Der blinde Fleck - das Gebot, den Fremden zu lieben. Zur sozialethischen Forderung von Deuteronomium 10,19}

Jonathan Sacks, früher britischer Oberrabbiner, erzählt in seinem Buch Not in God's Name ${ }^{1}$ von Csanad Szegedi, einem der führenden Funktionäre der ultranationalistischen ungarischen Jobbik-Partei. Szegedi entdeckte 2012, dass er Jude war, dass zwar seine Großeltern Auschwitz überlebt hatten, aber die Hälfte seiner Familie dort umgebracht worden war. Parteigenossen verlangten deshalb von ihm, sich öffentlich zu entschuldigen. Denn seine orthodox-jüdischen Vorfahren passten nicht zur rassistisch antijüdischen Ideologie der Partei. Szegedi trat daraufhin aus der Partei aus, ließ sich beschneiden, lernte Hebräisch, ging am Sabbat in die Synagoge und nannte sich fortan David. Heute sehe er seine wichtigste Aufgabe als Politiker in der Verteidigung der Menschenrechte für alle. Sacks meint dazu: „To be cured of potential violence towards the Other, I must be able to imagine myself as the Other. “2 Der Antisemit musste sich erst als Jude finden, um geheilt zu werden. Die Hebräische Bibel, so weiter Sacks, gehe deshalb über das Gebot „liebe deinen Nächsten wie dich selbst“ hinaus, das heißt über ein wechselseitig altruistisches Verhalten innerhalb der eigenen Gruppe des Glaubens, der Kultur, der Schicksalsgemeinschaft, des gleichen politischen Systems. Sie verlange Schwierigeres, nämlich: den Fremden zu lieben. Als Belege dieser Forderung zitiert er: „Einen Fremden sollst du nicht ausnützen oder ausbeuten, denn ihr selbst seid im Land Ägypten Fremde gewesen.“ (Ex 22,20). Und: „Einen Fremden sollst du nicht ausbeuten. Ihr wisst doch, wie einem Fremden zumute ist; denn ihr selbst seid im Land Ägypten Fremde gewesen.“ (Ex 23,9). Wichtig ist:

1 Jonathan Sacks, Not in God's Name. Confronting Religious Violence, London 2016, S. 177-188 („The Stranger“). Ich verdanke die Kenntnis dieses Buches der Jubilarin, die es mir bei einem unserer Gespräche über biblische Theologie schenkte. Prof. Ingeborg Gabriel ist ja promovierte Alttestamentlerin und hat auch als Sozialethikerin die Heilige Schrift stets in ihre Diskurse eingebracht. Dafür und insbesondere für die jahrzehntelange menschliche wie geistliche Freundschaft möchte ich ihr mit diesem kleinen Beitrag danken.

2 Ebd., S. 179. 
„Memory in this sense is role reversal: do not harm the stranger because you were once where he is now. See the world from his perspective because it is where your ancestors stood, and you never ceased to recall and re-enact their stories. Biblical ethics is a prolonged tutorial in role reversal. ${ }^{\text {3 }}$

Der Rabbiner schreibt von der Liebe zum Nächsten und zum Fremden. Angesichts seiner exzellenten Schriftkenntnis verwundert es deshalb, dass er nicht das dem Gebot der Nächstenliebe (Lev 19,18) benachbarte Gebot der Fremdenliebe $(19,34)$ im Buch Levitikus erwähnt oder die Fassung des Deuteronomiums (Dtn 10,19). Diesen Texten möchte ich im Folgenden nachgehen.

\section{Den Fremden lieben heißt: (wie) Gott lieben (Dtn 10,19)}

Im Deuteronomium schließt Mose an seinen Rückblick auf den beinahe gescheiterten Bundesschluss am Gottesberg Horeb (Dtn 9,8-10,11) eine Gebotsparänese an. In ihr werden gewissermaßen die Folgerungen aus der Auflehnung Israels während der Wüstenzeit, seiner Ursünde, dem Abfall zum Goldenen Kalb, und der Vergebung Gottes gezogen. Eine rhetorische Frage (10,12-13) gibt zu Beginn den Ton für alles an, was dann bis zum Ende von Kapitel 11 folgt. Der Sache nach führt sie in die beiden wichtigsten Themen deuteronomischer Paränese ein: Zunächst in das eine Hauptgebot des Gottesbundes, und zwar in mehreren synonymen bzw. komplementären ${ }^{4}$ Formulierungen. Man kann es aber nur erfüllen, wenn man die Gebote Gottes verwirklicht. Deshalb folgt - mit dem Hauptgebot verwoben - die Mahnung zur Gesetzesobservanz. Letztlich dient dann alles dem Glück Israels:

Und nun, Israel, was erbittet JHWH, dein Gott, von dir außer dem einen: dass du JHWH, deinen Gott, fürchtest, indem du auf all seinen Wegen gehst, und dass du ihn liebst und JHWH, deinem Gott, mit ganzem Herzen und mit ganzer Seele dienst; (und das,) indem du die Gebote JHWHs und seine Gesetze bewahrst, auf die ich dich heute verpflichte. Dann wird es dir gut gehen. (Dtn 10,12-13).

An diese Loyalitätsforderung in allen Dimensionen des gesellschaftlichen Lebens, wie sie die Kult- und Sozialordnung der deuteronomischen Tora konkretisiert, schließt ein Lobpreis der universalen Herrschaft Gottes, seiner Hoheit über den Kosmos an (Vers 14). Trotz seiner allumfassenden Überlegenheit wendet sich JHWH nur den Patriarchen zu, die er „ins Herz geschlossen“, geliebt und deren Nachkommen er unter allen Völkern ausgewählt hat (Vers 15). Doch lassen sich Liebe und Erwählung nicht als zwei getrennte

3 Ebd., S. 184.

4 Vgl. Bill T. Arnold, The Love-Fear-Antinomy in Deuteronomy 5-11, in: Vetus Testamentum 61/2011, S. 551-569. 
Handlungen Gottes auf die beiden Gruppen aufteilen, als gelte nur den Vätern die Liebe Gottes und Israel bloß die Erwählung. Der Wortgebrauch ist im Deuteronomium vielmehr systematisiert, 10,15 fasst 4,37 und 7,7-8 zusammen. Demnach gehört auch die Erwählung zum Mysterium der Liebe Gottes, ist wie die Liebe voraussetzungslos und affektgeladen, allerdings mit ihr nicht identisch. Israel soll darauf - vermutlich wegen des Beschneidungsbundes Abrahams, an den man bei den Vätern denkt - mit der Beschneidung seines Herzens antworten; es soll seine Halsstarrigkeit, das heißt: seine widerspenstige und trotzige Gesinnung, aufgeben (Vers 16). Danach wird JHWH, der Gott Israels, nochmals mit hymnischen Superlativen gepriesen, jetzt als gewaltiger Kriegsheld voll numinosen Schreckens und als unbestechlicher Richter (Vers 17). Die meisten dieser Formulierungen haben ihre Vorbilder in der altorientalischen, insbesondere der neuassyrischen Königstitulatur. ${ }^{5}$ „Gottes vorrangige Option“6 aber gilt den gesellschaftlichen Randgruppen in Israel. Als idealer König verhilft er ihnen unbestechlich zu ihrem Recht bzw. versorgt sie mit den zum Leben notwendigen Gütern ${ }^{7}$ :

Er [JHWH, euer Gott,] verschafft Waisen und Witwen ${ }^{8}$ Recht

und liebt den ${ }^{9}$ Fremden $(g \bar{e} r)$, sodass ${ }^{10}$ er ihm Nahrung und Kleidung gibt. (Vers 18).

5 Moshe Weinfeld, Deuteronomy 1-11. A New Translation with Introduction and Commentary, The Anchor Yale Bible Commentaries 5, New York 1991, S. 438. Vgl. auch Ps 24,8; 47,3; 136,2-3.

6 Timo Veijola, Das fünfte Buch Mose (Deuteronomium): Kapitel 1,1-16,17, Das Alte Testament Deutsch 8,1, Göttingen 2004, S. 257.

7 Vgl. z. B. die hymnischen Prädikationen JHWHs als König in Ps 146,7-9, die u.a. in Anlehnung an die deuteronomische Trias der „Fremden, Waisen und Witwen“ formulieren: „JHWH liebt die Gerechten (8b), JHWH beschützt die Fremden, er hilft auf den Waisen und Witwen (9a)“. Vgl. José E. Ramírez Kidd, Alterity and Identity in Israel. The gr in the Old Testament, Beihefte zur Zeitschrift für die alttestamentliche Wissenschaft 283, Berlin 1999, S. 78-79.

8 Als lectio difficilior des Masoretentextes gegen die Septuaginta, die den Fremden in Anpassung an die übliche dreigliedrige Formel einbezieht. Im Unterschied zu dieser Trias fehlt in 10,18 außerdem bei Witwe und Waise wie beim Fremden der Artikel.

9 Im Hebräischen fehlt auch an dieser Stelle wie bei „Waise“ und „Witwe“ der Artikel, weil es sich bei allen drei Bezeichnungen um einen Kollektivsingular handelt. Er lässt sich im Deutschen nicht durch den unbestimmten Artikel wiedergeben, weil dadurch der falsche Eindruck entstehen könnte, es handle sich jeweils um eine einzige Person. Deshalb muss die deutsche Übersetzung an dieser Stelle den Artikel verwenden.

10 Die Infinitivgruppe (lātoet) drückt semantisch eine praktische Konsequenz aus, die sich aus der Haltung der Liebe Gottes zum Fremden ergibt - Oskar Dangl, Methoden im Widerstreit. Sprachwissenschaftliche Zugänge zur deuteronomischen Rede von der Liebe Gottes, Textwissenschaft - Theologie - Hermeneutik - Linguistik -Literaturanalyse - Informatik 6, Tübingen 1993, S. 214. 
Aus diesem Handeln Gottes ergibt sich als assoziativ angeschlossene Forderung an Israel, die an keine bestimmten Umstände gebunden ist und mit seiner Erfahrung motiviert wird:

Auch ihr sollt den Fremden (häggēr $)^{11}$ lieben, denn ihr (selbst) seid Fremde (gērîm) im Land Ägypten gewesen. (Vers 19).

Wer ist mit „dem Fremden“ gemeint? ${ }^{12}$ Ist er ein nicht-israelitischer und nicht-judäischer Immigrant, ${ }^{13}$ wie es nach der kollektiven Geschichtserinnerung im „Credo“ einst Israel in Ägypten war (Dtn 26,5) ${ }^{14}$ ? Oder ist er ein israelitischer Flüchtling aus dem untergegangenen Nordreich, der nun in Juda lebt ${ }^{15}$ ? Oder geht es um jemanden, der keinem fremden Volk zugehört, sondern als Volksgenosse nur gegenüber seinem Aufenthaltsort fremd ist? ${ }^{16}$ Die Antworten di-

11 „Die in den Gesetzen des Deuteronomiums angesprochenen oder dargestellten Personen sind großteilig im Singular genannt. So geht es um den Fremden, der in das Land kommt, oder das ,Du' als Adressat der Gesetze. Hierbei gilt jedoch, dass trotz der singularischen Formulierungen nicht von Identitätsfigurationen, die auf das Individuum zielen, gesprochen werden kann. Indem jeder Israelit als , $\mathrm{Du}^{\prime}$ angesprochen wird und jeder Fremdling der Fremdling ist, entfällt jegliche individuelle Differenzierung zwischen den Vertreterinnen und Vertretern dieser Gruppen. Es handelt sich vielmehr um ein Konzept der ,corporate personality ' oder ,corporate identity. " (Ruth Ebach, Das Fremde und das Eigene. Die Fremdendarstellungen des Deuteronomiums im Kontext israelitischer Identitätskonstruktionen, Beihefte zur Zeitschrift für die alttestamentliche Wissenschaft 471, Berlin-Boston 2014, S. 10). Der Plural „Fremde“ in Vers $19 \mathrm{~b}$ (im Unterschied zum Singular in Vers 19a) ist durch seine grammatikalische Funktion als Prädikatsteil bedingt, der sich nach dem Subjekt „ihr“ richten muss.

12 Zur Forschungsgeschichte s. Mark A. Awabdy, Immigrants and Innovative Law. Deuteronomy's Theological and Social Vision for the $g r$, Forschungen zum Alten Testament II, 67, Tübingen 2014, S. 15-35. Einen Überblick über die wichtigsten Studien zu den Fremden im Alten Testament bietet Ebach, Fremde, S. 2-8.

13 So Awabdi, Immigrants, S. 110-116. Er bestätigt damit die Überlegungen von Siegbert Riecker, Ein Priestervolk für alle Völker. Der Segensauftrag Israels für alle Nationen in der Tora und den Vorderen Propheten, Stuttgarter Biblische Beiträge 59, Stuttgart 2007, S. 309.

14 Israel wird ,in diesem zentralen Bekenntnistext durch eine doppelte Fremdheit gekennzeichnet. Ethnisch führt es sich auf jemanden außerhalb des eigenen Volkes, einen ,Aramäer zurück; lokal auf ein Land außerhalb des eignen, auf Ägypten, in dem es zu einem großen Volk geworden war.“ (Ilse Müllner, „Du selbst bist fremd in Ägypten gewesen!“ [Dtn 10,19]. Das Erste Testament als Migrationsliteratur, in: Annegret Reese-Schnitker / Daniel Bertram / Marcel Franzmann (Hg.), Migration, Flucht und Vertreibung. Theologische Analyse und religionsunterrichtliche Praxis, Religionspädagogik innovativ 23, Stuttgart 2018, S. 39-50, hier: S. 43).

$15 \mathrm{Zu}$ dieser Bevölkerungsschicht s. Israel Finkelstein, Migration of Israelites into Judah after 720 BCE: An Answer and an Update, in: Zeitschrift für alttestamentliche Wissenschaft 127/ 2015, S. 188-206.

16 Dafür plädiert Christoph Bultmann, Der Fremde im antiken Juda. Eine Untersuchung zum sozialen Typenbegriff, ger ${ }^{\text {c }}$ und seinem Bedeutungswandel in der alttestamentlichen Gesetzgebung, Forschungen zur Religion und Literatur des Alten und Neuen Testament 153, Göttingen 1992, S. 22. Zu Dtn 10,18-19 s. Ebd., S. 126-130. Bultmann versteht den gēr als einen „sozialen Typenbegriff“. Seine Fremdheit werde durch sein notwendiges Umher- 
vergieren, unter anderem auch deshalb, weil der soziologische Begriff gèr einen Bedeutungswandel durchgemacht hat ${ }^{17}$ und die Texte unterschiedlich (literar-)historisch verortet werden. ${ }^{18}$ Vielleicht kann man den Fremden ( $\left.g \bar{e} r\right)$ als „resident outsider“ bezeichnen, wobei seine Abkunft offen bleibt und er außerhalb der Gastgesellschaft steht. ${ }^{19}$

Das Begriffsfeld gr/gwr (Fremder / als Fremder wohnen) ist in keinem anderen Buch der Hebräischen Bibel absolut wie prozentual so häufig wie im Deuteronomium belegt. ${ }^{20}$ Der Ausdruck $g \bar{e} r$ findet sich fast ausschließlich in Gesetzestexten. Das könnte darauf deuten, dass es sich um einen „sozialen Typenbegriff“ handelt. ${ }^{21}$ Dabei bleiben aber Herkunft und Geschlecht des Fremden immer unbestimmt, ebenso seine kulturellen Bezüge. Moderne Fragen nach der eigenen Sprache und Kultur wie die nach Legalität und Dauer des Aufenthalts spielen keine Rolle. „Über seine [des Fremden] eigene Gefühlslage, Mentalität, politische oder religiöse Gesinnung wird an keiner Stelle des Deuteronomiums gesprochen. “22

Einzelne seiner Texte lassen ein gewisses Profil „des Fremden“ aus der Sicht derer, die Mose in seinen Abschiedsreden anspricht, erkennen. Dazu gehört zunächst, dass er außerhalb seines Verwandtschaftssystems lebt und kein Bürgerrecht besitzt. Obwohl er in 1,16 als Prozesspartner und in 24,14 als Arbeitskollege auftritt, gehört der Fremde nicht zu den „Brüdern“. Doch wird er nirgends als „Fremder in Israel“ bezeichnet, sondern steht in einem gewissen Naheverhältnis. Er ist - und zwar nur im Deuteronomium (von Ex 20,10, der

wandern aufgrund von Arbeitssuche und seine wirtschaftliche Abhängigkeit von selbständigen Grundbesitzern verursacht. Ihn charakterisiere also sein minderer sozialer Rang, nicht seine nationale Fremdheit. Gegen Bultmann argumentiert Markus Zehnder, Umgang mit Fremden in Israel und Assyrien. Ein Beitrag zur Anthropologie des „Fremden“ im Licht antiker Quellen, Beiträge zur Wissenschaft vom Alten und Neuen Testament 168, Stuttgart 2005, S. 285-86, für die Annahme, „dass sowohl ethnische wie auch religiöse Fremdheit in aller Regel zu den Bedeutungselementen des Nomens gēr gehören." (S. 286).

17 Vgl. Christiana van Houten, The Alien in Israelite Law, The Library of Hebrew Bible/Old Testament Studies 107, Sheffield 1991, S. 164.

18 So untersucht z. B. Ebach, Fremde, S. 31, getrennt „die Darstellungen des Fremden in vorexilischer, exilischer und nachexilischer Zeit“, weil „die Veränderung der Gesellschaftsstruktur von der vorexilischen Mehrheitsgesellschaft über die exilische Minderheitsgesellschaft bis hin zum nachexilischen Kampf um die ,Leitkultur' entscheidend" sei. Sie orientiert sich dabei an verschiedenen redaktionsgeschichtlichen Modellen der modernen Deuteronomiumsforschung (Ebd., S. 26-31). Vgl. aber z.B. Awabdy, Immigrants, S. 110: „We cannot reconstruct from D [Deuteronomy] the precise historical referents of the gè $r$, but we can identify within D the distinct social and religious statuses of the $g \bar{e} r$. "

19 Vgl. Saul M. Olyan, Rites and Rank. Hierarchy in Biblical Representations of Cult, Princeton, NJ 2000, S. 74-81.

20 Ebach, Fremde, S. 41.

21 Bultmann, Fremde, S. 94 u. ö.

22 Ebach, Fremde, S. 47 Anm. 157. 
Parallele zu Dtn 5,14 im Sabbatgebot, abgesehen) - „dein Fremder“ (5,14; 24,14; $29,10 ; 31,12)$. Er gilt als Schutzbürger oder Schutzbefohlener ${ }^{23}$ „in deinem Land innerhalb deiner Stadtbereiche ${ }^{24 \text { “ }}(24,14)$, „hat in deinen/euren Stadtbereichen Wohnrecht“ $(5,14 ; 14,21 ; 31,12)$, „ist inmitten deines Lagers“ $(29,19)$ oder „in deiner Mitte“ $(26,11 ; 28,43)$, also im Inneren eines menschlichen Raumes ${ }^{25}$. Dieses Beziehungsgefüge ist insofern auffällig, als der Fremde weder wie sonst im Alten Orient dem Schutz des Königs unterstellt noch der Versorgung eines einzelnen Patrons zugeordnet wird. Vielmehr erscheint er in das Miteinander der Gesellschaft, des kollektiven „Du“ Israels bzw. des „Ihr“ der einzelnen Israeliten, eingebunden. Er wird sogar Partner des Moab-Bundes $(29,10)$ und soll im Sabbatjahr wie ganz Israel an der erwählten Stätte, dem Tempel von Jerusalem, die Verlesung der Tora mitverfolgen $(31,12)$. Diese Solidarität ist lebensnotwendig. Denn der Fremde verfügt über keinen Bodenbesitz und ist daher in einer Agrarwirtschaft ökonomisch abhängig. Das findet sogar einen festsymbolischen Ausdruck. Nach 26,11 ist nämlich der Fremde anlässlich der Darbringung der Erstlingsfrüchte zusammen mit den ebenfalls grundbesitzlosen Leviten zur Freude über die Güter des Verheißungslandes geladen, und zwar „in deiner“, Israels, „Mitte“, wobei aber, offenbar bewusst, kein geographischer Raum wie Land oder Stadtbereich genannt wird.

Im Zusammenhang der Speisevorschriften wird der Fremde in 14,21a sowohl vom „heiligen Volk“ als vom „Ausländer“ (nokrî) $)^{26}$ geschieden: „Ihr dürft keinerlei Aas essen. Du sollst es dem Fremden, der in euren Stadtbereichen Wohnrecht hat, zum Essen überlassen oder einem Ausländer verkaufen. Denn du bist ein Volk, das JHWH, deinem Gott, heilig ist.“ Einerseits sind also für den Fremden wie für den Ausländer die Speiseverbote außer Kraft gesetzt. Andererseits erscheint gerade beim Umgang mit unreinem Fleisch der Fremde als in gewissem Umfang zur Gesellschaft Israels gehörend, wobei wohl seine finanzielle Bedürftigkeit das Geschenk veranlasst. Dagegen ist der Ausländer „nicht in das eigene Wertesystem integriert" und es braucht auf seine soziale Lage keine Rücksicht genommen zu werden - man darf ihm das Aas verkaufen, das man selbst nicht essen darf. ${ }^{27}$ Im Übrigen wird „der Bruder“, also der israelitische

23 Während „Schutzbürger“ stärker die Zugehörigkeit zur israelitischen Gesellschaft betont, obwohl sich ihre Struktur nicht adäquat als „Bürgertum“ beschreiben lässt, verdeutlicht "Schutzbefohlener" die Aufgabe der Israeliten, wobei dem Begriff aber die Konnotation des Fremden fehlt (Ebach, Fremde, S. 47 Anm. 156).

24 S. dazu Daniel A. Frese, A Land of Gates: Covenant Communities in the Book of Deuteronomy, in: Vetus Testamentum 65/2015, S. 33-52.

25 Ebach, Fremde, S. 144.

26 Sowohl der in den Büchern Exodus bis Numeri belegte Gegenbegriff zum Fremden, der „Einheimische“ ('cezrāh), als auch der vor allem in Levitikus 25 gängige Begriff des „Beisassen" (tôšā $b$ ) fehlen im Deuteronomium.

27 Ebach, Fremde, S. 49f., Zitat 67. 
Vollbürger, wesentlich deutlicher als der Fremde vom „Ausländer, der aus einem fernen Land kommt" $(29,21)$ abgegrenzt: politisch bei der Inthronisation eines Königs (17,15), ökonomisch beim Schuldenerlass (15,3) und beim Zinsnehmen $(23,21)$, wo die international üblichen Handelsbedingungen gelten. Diese Differenzen bedeuten keinen Konflikt, es herrscht keinerlei Ausländerfeindlichkeit. $^{28}$

Nach dieser Skizze des deuteronomischen Sprachgebrauchs kehren wir zurück zu unserem Text. In 10,18 fällt auf, dass der Fremde zwar in unmittelbarer Nachbarschaft zu Waise und Witwe genannt, mit ihnen aber nicht zur Trias der klassischen marginalen Gesellschaftsgruppen zusammengeschlossen wird. ${ }^{29}$ Weil der Fremde erst an letzter Stelle angeführt wird, handelt es sich noch nicht um die deuteronomische Formel „Fremde, Waise und Witwe“. ${ }^{30}$ Sie findet sich beim Informationsaufbau im Lesegefälle des Buches erst in der Sammlung der Einzelgesetze $(14,29 ; 16,11.14 ; 24,[17] .19 .20 .21 ; 26,12.13$; ferner 27,19$) .{ }^{31}$ Den Hintergrund von 10,18 bildet eine für den Alten Orient typische Krisensituation. Frauen, die ihren Mann verloren hatten und allein auf sich selbst gestellt waren, hatten keinen Rechtsbeistand. Waren ihre Kinder noch versorgungsbedürftig, dann waren auch diese in der Gesellschaft besonders gefährdet - ihre Rechte wurden oft nicht respektiert (vgl. 24,17 und 27,19). Anders als Witwen und Waisen wird der Fremde in 10,18 nicht in den Blick genommen, weil er nicht rechtsfähig, sondern weil er mittellos ist. Denn „Brot“ und „Mantel“, die Gott ihm gewährt, stellen das Lebensnotwendige dar (vgl. Jes 3,7; 4,1). Diese Unterscheidung innerhalb der sozialen Randgestalten bedeutet zugleich: Die Liebe JHWHs bezieht sich in Dtn 10,18 nur auf den Fremden. Sie ist im Alten Testament einzigartig. Ebenso einmalig ist es, dass der Fremde in 10,19 das ausschließliche

28 „Der nokrî ist der ganz andere, der sich vom ,Du“ unterscheidet. Seine Stellung unterliegt deshalb nicht den positiven Privilegien innerhalb der solidarischen Brüdergemeinschaft, sie ist aber auch nicht negativ konnotiert." (Ebach, Fremde, S. 66).

29 Vgl. Ramírez Kidd, Alterity, S. 82.

30 Der Doppelausdruck „Waise und Witwe“ steht im Deuteronomium niemals allein, sondern fordert vor sich den „Fremden“. Dagegen ist das Wort „Fremder“ nicht notwendig an „Waise und Witwe" gebunden.

31 Die Belege variieren allerdings, weil z. B. in 16,14 und 26,12 die Leviten mit dem Fremden, der Waise und der Witwe zu einer Tetrade zusammengeschlossen werden. Eine Übersicht bietet Awabdi, Immigrants, S. 117-119. Durch die Konstruktion einer Gesellschaft ohne Arme hat das Deuteronomium dem Fremden, der Waise und der Witwe einen Versorgungsanspruch gesichert - s. Norbert Lohfink, Das deuteronomische Gesetz in der Endgestalt - Entwurf einer Gesellschaft ohne marginale Gruppen, in: Studien zum Deuteronomium und zur deuteronomistischen Literatur III, Stuttgarter Biblische Aufsatzbände 20, Stuttgart 1995, S. 205-218, hier: S. 209-216. Für einen grundlegenden Unterschied zwischen dem altorientalischen und dem biblischen Ethos plädiert zuletzt Georg Braulik, Eine Gesellschaft ohne Arme. Das altorientalische Armenethos und die biblische Vision, in: Tora und Fest. Aufsätze zum Deuteronomium und zur Liturgie, Stuttgarter Biblische Aufsatzbände 69, Stuttgart 2019, S. 13-30. 
Objekt eines positiven Befehls bildet, nämlich ihn zu lieben. Den altorientalischen Zivilisationen fehlt überhaupt jede Aufmerksamkeit für den Fremden.

Anders als bei den zwei Stellen Lev 19,18 und 34, auf die ich später eingehe, gibt es im Deuteronomium keine Entsprechung zu einem Gebot, den „Nächsten“ bzw. ein hilfsbedürftiges Mitglied der eigenen Gesellschaft zu lieben. ${ }^{32}$ „Offensichtlich soll hier [in Dtn 10,19] durch die Nennung des gēr der Höhepunkt dessen bezeichnet werden, was an Liebe auf der zwischenmenschlichen Ebene anzustreben ist, bzw. diejenige Beziehung hervorgehoben werden, in der diese

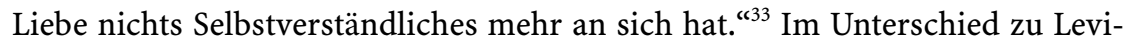
tikus 19 ist für die in Dtn 10,19 Israel befohlenen Liebe zunächst entscheidend, was der Kontext 10,12-11,1 betont, der das Verb „lieben“ 5-mal verwendet $(10,12.15 .18 .19 ; 11,1)^{34}$ : die „Gegenseitigkeit“ der Liebe Israels und der Liebe Gottes. „Lieben“ durchzieht ('āhēb) als Leitverb auch die ganze Perikope 10,12-19, und zwar in den rahmenden Versen 12 und 19 als Forderung an Israel, in den Versen 15 und 18 aber als Erfahrung Gottes. ${ }^{35}$ Somit soll Israel die als unergründliches Geschenk empfangene göttliche Liebe mit seiner Liebe zu Gott und mit der zwischenmenschlichen Liebe zum Fremden beantworten. Angesichts des erst im Neuen Testament zusammengefügten Doppelgebots greift der Text zumindest in der Formulierung weiter aus. An die Stelle des „Nachbarn“ tritt „Fremde“.

Weil in unserer Kultur Liebe als ein spontanes Gefühl angesehen wird, erscheint es widersinnig, sie zu gebieten. Nach unserem Verständnis gehört sie zum Privat- und Intimbereich und existiert getrennt von jeder Verpflichtung. Gefühle gelten außerdem als ethisch irrelevant. ${ }^{36}$ Trotzdem wird die von Dtn 10,19 gebrauchte sprachliche Form der Aufforderung zu „lieben“ ${ }^{\text {“37 }}$ - nur hier übrigens in Pluralgestalt - in der Hebräischen Bibel nur noch in Lev 19,18 und 34 sowie in Dtn 6,5 und 11,1 verwendet. Das sind Spitzentexte alttestamentlicher

32 Ramiréz Kidd, Alterity, S. 81.

33 Zehnder, Umgang mit Fremden, S. 366.

34 In der gesamten Perikope 10,12-11,25 wird „lieben“ ('āhēb) zusätzlich noch in 11,13 und 22, also insgesamt 7-mal, verwendet und dadurch stilistisch als Leitverb unterstrichen. Seine Belege stehen betont jeweils zu Beginn oder am Ende eines Abschnitts.

35 Vgl. Georg Braulik, Die Liebe zwischen Gott und Israel. Zur theologischen Mitte des Buches Deuteronomium, in: Studien zu Buch und Sprache des Deuteronomiums, Stuttgarter Biblische Aufsatzbände 63, Stuttgart 2017, S. 241-259, insbesondere S. 254-256.

36 Vgl. Jacqueline E. Lapsley, Feeling Our Way: Love for God in Deuteronomy, in: The Catholic Biblical Quarterly 65/2003, S. 350-369, besonders S. 365-369. Zur moralischen Bedeutung von Gefühlen aufgrund der modernen Tugendethik sowie der Neurobiologie und Psychologie Ebd., S. 368f. Ferner Martha C. Nussbaum, Politische Emotionen. Warum Liebe für Gerechtigkeit wichtig ist, Berlin 2014.

37 Vgl. Jan Joosten, The Verbal System of Biblical Hebrew. A New Synthesis elaborated on the Basis of Classical Prose, Jerusalem Biblical Studies 10, Jerusalem 2012, S. 298: „The use of WEQATAL expressing obligation is very typical of legal discourse“. Zu Dtn 10,19 s. S. 297. 
Gottesverehrung und Sozialethik. Subjekt all dieser Stellen ist Israel, an das sie als Du des Volksganzen oder als Ihr seiner einzelnen Mitglieder appellieren. Lieben soll Israel entweder Gott (Dtn 6,5; 11,1) oder den Nächsten (Lev 19,18) oder den Fremden (Lev 19,34; Dtn 10,19). Im altorientalischen wie biblischen soziokulturellen Milieu widerspricht ein ethisches Verhalten, das als Liebe gefordert wird, nicht ihrem affektiven Gehalt: „an ongoing personal and emotional relationship undergirds formalized legal expressions of that relationship “. ${ }^{38}$ Das Deuteronomium hat man sogar als ,a program of sensory reform “ bezeichnet, „that seeks to reshape how the self relates to the world by teaching the senses that mediate between them - the eyes, the ears, and the tongue - to act in new ways " 39 Ohne hier zwischen Emotionen und Gefühlen zu unterscheiden, lässt sich die deuteronomische Konzeption von „Lieben“ als eine „Handlungsemotion“ verstehen. ${ }^{40}$

Wie gefühlsbetont schon Gott liebt, illustriert seine Liebe zu Vätern des Volkes: Er hatte sie „ins Herz geschlossen / sich an sie gehängt ( hāǎšq), um sie zu

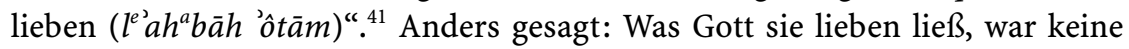

38 Lapsley, Feeling, S. 356. Dagegen spricht Katrin Müller, Lieben ist nicht gleich lieben. Zur kognitiven Konzeption von Liebe im Hebräischen, in: Andreas Wagner (Hg.), Göttliche Körper - göttliche Gefühle. Was leisten anthropomorphe und anthropopathische Götterkonzeptionen im Alten Orient und im Alten Testament, Orbis Biblicus Et Orientalis 270, Fribourg-Göttingen 2014, S. 219-237, hier: S. 229, von einer „Rationalität der Liebe“ im Deuteronomium, bei der es sich im Licht altorientalischer Staatsverträge um „keine emotionale Liebe“, sondern „um eine Loyalitäts- bzw. Dienstverpflichtung“ handle. Zum juristischen Traditionshintergrund der Liebe s. z. B. William L. Moran, The Ancient Near Eastern Background of the Love of God in Deuteronomy, in: Ders., The Most Magic World. Essays on Babylonian and Biblical Literature, ed. by R. S. Hendel, CBQ.MS 35, Washington 2002, S. 170-181. Weiterführend Susan Ackerman, The Personal is Political. Convenantal and Affectionate Love ( $' \bar{A} H \bar{E} B$, 'AHĂBÂ) in the Hebrew Bible, in: Vetus Testamentum 52/2002, S. 437-458. Die jüngste Forschung betont auch die kognitiven Aspekte der Gefühle.

39 Steven Weizmann, Sensory Reform in Deuteronomy, in: David Brakke / Michael L. Satlow / Steven Weizmann (Hg.), Religion and the Self in Antiquity, Bloomington/IN 2005, S. 123139, hier: S. 135 und S. 125.

40 Dorothea Erbele-Küster, Gebotene Liebe. Zur Ethik einer Handlungsemotion im Deuteronomium, in: Manfred Oeming (Hg.), Ahavah. Die Liebe Gottes im Alten Testament, Arbeiten zur Bibel und ihrer Geschichte 55, Leipzig 2018, S. 143-156.

41 Veijola, Deuteronomium, S. 242, übersetzt „in Liebe angehangen“; Eckart Otto, Deuteronomium 1-11. Zweiter Teilband: 4,44-11,32, Herders Theologischer Kommentar zum AT, Freiburg i. Br. 2012, S. 1011, gibt ḥāšaq mit „sein Herz geschenkt“ wieder. Dangl, Methoden, weist darauf hin, dass zwischen dem Substantiv und dem Infinitivus constructus 'a 'a ${ }^{a} b \bar{a} h$ weder morphologisch noch semantisch ein Unterschied besteht (S. 88 Anm. 459). Die semantische Nominalisierung betone auch die Dauerhaftigkeit der Liebe Gottes. Ferner könne $l^{e^{2}} a h^{a} b \bar{a} h$ als Apposition mit JHWH verbunden und semantisch mit ihm identifiziert werden, ohne den finalen Bezug („um zu“) zum Prädikat zu verlieren. Außerdem seien die beiden Appositionsverbindungen "Jahwe, dein Gott“ $(10,14)$ und „Jahwe, lieben“ semantisch gleichwertig und zu einer Isotopie zusammengeschlossen: „Sie beschreiben beide funktional 
Augenblicksempfindung, sondern seine zärtliche Zuneigung und Anhänglichkeit. Diese emotionelle und tatkräftige Liebe galt nach 7,7-8 auch seinem erwählten Volk: „Nicht weil ihr zahlreicher als die anderen Völker wäret, hat euch JHWH ins Herz geschlossen (hāšaq) und ausgewählt; [...]. Weil JHWH euch liebt und weil er auf den Eid achtet, den er euren Väter geschworen hat, deshalb hat euch JHWH mit starker Hand herausgeführt und dich aus dem Sklavenhaus freigekauft, aus der Hand des Pharao, des Königs von Ägypten. “Wenn Gott dann den Fremden liebt, drückt sich das wie bei seiner Liebe zu Israel in praktischen Handlungen aus: er gibt ihm Nahrung und Kleidung $(10,18)$. Eine solch affektive wie effektive Liebe also ist gemeint, wenn Mose im Anschluss an das Verhalten Gottes verlangt, den Fremden zu lieben $(10,19)$. Das heißt zusammenfassend: Trotz der Herkunft der deuteronomischen Liebesprache aus der juristischen Rhetorik altorientalischer Vasallenverträge und ihres rechtlich verbindlichen Charakters ist bei der Erfüllung des Gebots Emotionalität gewünscht und ethisch relevant. Zugleich lässt das vorbildliche Handeln Gottes erkennen, wie Israel den besonders hilfsbedürftigen Fremden praktisch lieben soll: durch Versorgung mit allem, was zum Leben gehört.

Auch die anschließende Begründung von Israels „Bringschuld der Liebe“42 wendet sich an seine Empathie. Sie ist ein Appell an das kollektive Gedächtnis Israels. ${ }^{43}$ Die Formel „denn ihr (selbst) seid Fremde (gērîm) im Land Ägypten gewesen" findet sich in der Hebräischen Bibel 5-mal: Ex 22,20; 23,9; Lev 19,34; 25,23 und Dtn 10,19. Sie ist auf den Pentateuch - genauer: auf seine drei Rechtssammlungen Bundesbuch, Heiligkeitsgesetz und deuteronomische Tora beschränkt. Das Deuteronomium enthält neben 10,19 noch eine Ägypten-Fremde-Motivation in 23,8: „Einen Ägypter sollst du nicht verabscheuen, denn du bist Fremder ( $g \bar{e} r$ ) in seinem Land gewesen. “ Dennoch dominiert beim Blick auf Ägypten im Deuteronomium nicht die Erinnerung an die Fremdlingschaft, sondern an die Sklavenexistenz Israels. ${ }^{44}$ Fünfmal findet sich nämlich auch der Hinweis „dass du in Ägypten Sklave ('ceboed) warst“ (5,15; 15,15; 16,12; 24,18.22). Diese Formel ist für das „Erinnerungsschema“ des Deuteronomiums charakteristisch. ${ }^{45}$ Es wird durch „Denk daran“ eingeleitet. In drei Fällen folgt

gleichbleibend Jahwe [...]. ,Gottsein für ...` und ,Lieben` ist für Jahwe dasselbe.“ (Ebd., S. 91).

42 Vgl. Hermann Spieckermann, Mit der Liebe im Wort. Ein Beitrag zur Theologie des Deuteronomiums, in: Gottes Liebe zu Israel. Studien zur Theologie des Alten Testaments, Forschungen zum Alten Testament 33, Tübingen 2001, S. 157-172, hier: S. 165.

43 Ramiréz Kidd, Alterity, S. 83.

44 Zum Folgenden vgl. Norbert Lohfink, Gibt es eine deuteronomistische Bearbeitung im Bundesbuch, in: Studien zum Deuteronomium und zur deuteronomistischen Literatur III, Stuttgarter Biblische Aufsatzbände 20, Stuttgart 1995, S. 39-64, hier: S. 50-55.

$45 \mathrm{Zu}$ diesem Schema s. Georg Braulik, Geschichtserinnerung und Gotteserkenntnis. Zu zwei Kleinformen im Buch Deuteronomium, in: Studien zu den Methoden der Deuteronomi- 
auf die Reminiszenz „dass du in Ägypten Sklave warst“ eine Bemerkung über die Befreiung aus der Knechtschaft $(5,15 ; 15,15 ; 24,18)$. Aus dieser persönlichen Erfahrung der impliziten Adressaten der Mosereden in Ägypten ergibt sich die Gehorsamsforderung, bestimmte Sozialgebote zu beobachten. ${ }^{46}$ So lautet zum Beispiel 15,15 im Gesetz über die Freilassung eines hebräischen Sklaven oder einer hebräischen Sklavin: „Denk daran: Als du in Ägypten Sklave warst, hat JHWH, dein Gott, dich freigekauft. Darum verpflichte ich dich heute auf dieses Gebot.“ Die Logik dieser Ägypten-Sklave-Motivation entspricht der Grundgestalt des Dekalogs, nämlich dem Sachzusammenhang, der zwischen seinem Prolog und den folgenden Geboten besteht. Sie spiegelt sich in den beiden Teilen der Kleinform: „Jahwe kann fordern, weil er selbst zuvor befreiend gehandelt hat. Ja noch mehr: Jahwes Forderung ist nichts anderes als die Weisung, wie die geschenkte Freiheit bewahrt werden kann, ohne dass wieder Unterdrückung aus ihr wird. “47 Immer ist es die Leidensgeschichte, die durch „Freikauf“ oder „Herausführung“ in eine „Befreiungs-“ bzw. „Erlösungsgeschichte“ aufgehoben wird. Dieses Verhalten seines Gottes soll Israel im jeweils konkret Geforderten nachahmen. Insgesamt sind die beiden Formen der Ägypten-Motivationen im Deuteronomium sieben Mal belegt, was gewiss nicht zufällig ist. Denn die deuteronomische Rhetorik unterstreicht durch Siebenergruppen von Ausdrücken oder Formeln, was theologisch wichtig ist. Wenn aber das Deuteronomium die zwei Ägypten-Motivationen zusammensieht, warum differenziert es dann beim Aufenthalt Israels zwischen dem „Fremden“ und dem „Sklaven“? ${ }^{48}$

Offenbar stehen die beiden soziologischen Kategorien für zwei völlig unterschiedliche Erfahrungen. Beide finden sich im Credo von 26,5-9. Nachdem der Pharao Jakob und seiner Familie ermöglicht hatte, sich als „Fremde“ (gērîm) in Ägypten aufzuhalten (Gen 47,4), „wohnte er dort als Fremder ( $g w r$ ) mit wenigen Leuten und wurde dort zu einem großen, mächtigen und zahlreichen Volk“ (Dtn 26,5). Dieses für die Ägypter nun furchterregende Israel wurde in der anschließenden Periode unterdrückt: „Die Ägypter behandelten uns schlecht,

umsexegese, Stuttgarter Biblische Aufsatzbände 42, Stuttgart 2006, S. 165-183, hier: S. 167175.

46 Im Zusammenhang von 5,15; 15,15; 16,12 ist von Sklaven (und Sklavinnen) die Rede, in 5,15 und 16,12 auch vom Fremden. In 24,18.22 wird sogar nur vom Fremden und nicht vom Sklaven gesprochen. Die Ägypten-Motivation steht somit in Spannung zum Vokabular des Kontexts. Schon diese Beobachtung lässt fragen, warum das Deuteronomium in 10,19 und 23,8 Israel als Fremde(n) bezeichnet (Lohfink, Bearbeitung, S. 51).

47 Lohfink, Bearbeitung, S. 52.

48 Diese Frage, die erstmal von Lohfink, Bearbeitung, S. 50-55, befriedigend beantwortet wurde, hat jetzt Awabdy, Immigrants, S. 142-152, ausführlich behandelt. Obwohl er den Artikel von Lohfink kennt, bezieht er ihn aber nicht in seine Diskussion ein. Dennoch kommt er wie Lohfink zu einer semantischen Unterscheidung zwischen dem Fremden-Ägypten und dem Sklaven-Ägypten im Deuteronomium (vgl. Ebd., S. 162-164). 
machten uns rechtlos und legten uns harte Fronarbeit ('abōdāh) auf." (26,6). Mit Hilfe der beiden hebräischen Wurzeln $g w r$ und $b d$, die sich auch schon in den älteren Erzählungen finden, werden also verschiedene Phasen charakterisiert. Deshalb gilt für die zwei Ägypten-Motivationen im Deuteronomium: „Wenn das Wort 'ceboed steht, ist die leidvolle, wenn das Wort gēr steht, die davor gelegene glückliche Periode in Ägypten im Blick. “49 Die Ägypten-' "eboed-Motivation durfte deshalb nicht in 10,19 ${ }^{50}$ verwendet werden: „Wenn es um Liebe zum gēr, das heißt um Aufnahme des gēr in ein Verhältnis, wie nach Dt 6,5 Israel es zu seinem Gott hat, geht, sollte da in der Motivation an das ägyptische Leid erinnert sein?“51 Anders im Bundesbuch (Ex 20,22-23,33). Es kennt keine ÄgyptenSklaven-Motivation. Deshalb nehmen in Ex 22,20 und 23,9 die beiden Sätze über Israels Fremdlingschaft diese Funktion ein, die sich am Anfang bzw. Schluss der beiden humanitären Gesetzessammlungen Ex 22,20-26 und Ex 23,1-9 finden. Deshalb kann es in Ex 23,9 heißen: „Ihr wisst doch, wie es einem Fremden ( $g \bar{e} r$ ) zumute ist“. Dabei sind nicht Gemeinschaft und Glück, sondern Elend und Bedrängnis gemeint. Unter diesem Gesichtspunkt sieht Dtn 10,19 jedoch den Aufenthalt Israels als „Fremde“ in Ägypten gerade nicht. Er soll vielmehr als ein erfreuliches Erlebnis zur Liebe motivieren. Man darf sich also vom gemeinsamen Wortlaut der Formel „denn ihr (selbst) seid Fremde ( gērîm) im Land Ägypten gewesen " in Bundesbuch und Deuteronomium nicht täuschen lassen - der Begriff „Fremde“ ist unterschiedlich festgelegt und gehört jeweils zu einem anderen Aussagensystem. Das deuteronomische System beurteilt den Ägyptenaufenthalt Israels differenzierter und ist breiter ausgebaut als das des Bundesbuchs. ${ }^{52} \mathrm{Li}$ terargeschichtlich hat es wahrscheinlich die Ägypten-Fremde-Motivation des Bundesbuchs in Anlehnung an den Dekalog durch die Ägypten-Sklave-Motivation ersetzt und dem heilsgeschichtlichen Periodendenken des Credo (Dtn 26,5-6) entsprechend die Ägypten-Fremden-Motivation in Dtn 10,19 und 23,8 neu positiv festgelegt. ${ }^{53}$ Zusammenfassend:

49 Lohfink, Bearbeitung, S. 54.

50 Analoges gilt für 23,8: Ein Ägypter kann deshalb so leicht in die Gemeinde JHWHs aufgenommen werden, weil Israel, als es sich in seinem Land aufhielt, von den Ägyptern als "Fremder" $(g \bar{e} r)$ zugelassen und in ihre Gemeinschaft aufgenommen worden war (Ebd., S. 53).

51 Ebd., S. 54.

52 Vgl. Veijola, Deuteronomium, S. 257-258: „Während die Anspielung auf das ägyptische Sklavendasein auf die aus ihm erfahrene Rettung durch Jahwe zielt und damit an die Dankbarkeit appelliert, beruft sich das Argument des eigenen Fremdenschicksals in Ägypten auf die gegenseitige Solidarität der Menschen, die Ähnliches erfahren haben“.

53 So mit Lohfink, Bearbeitung, S. 54-55; vgl. Awabdy, Immigrants, S. 153-156, und Alexander Kraljic, Deuteronomium 10,12-11,32: Gottes Hauptgebot, der Gehorsam Israels und sein Land. Eine Neuuntersuchung, Österreichische Biblische Studien 49, Frankfurt a. M. 2018, S. 368-369. 
„In the gēr-Egypt formula ... the operative principle is a compound reciprocity: Egypt's kindness to Jacob's family ( $g \bar{e} r$ ) and Jacob's family's status as allochthonous dependents was to be reciprocated by Israel's kindness and empathy toward the gèr residing in Israel (Deut 10:19; 23:8). The 'seboed-Egypt formula with YHWH's redemption of Israel indicates an imitatio dei principle: YHWH redeemed Israel from exploitation in Egypt; therefore Israel must redeem its vulnerable classes from exploitation in Israel $(5: 15 ; 15: 15 ; 24: 18)$. Finally, the 'reboed-Egypt formula without mention of YHWH's redemption signals an inversion principle: toilsome labor to build store cities for Pharaoh to hoard food was to be inverted by Israel's landowners when they give away their food surplus to those who have not earned it $(16: 12 ; 24: 22){ }^{*}{ }^{c 54}$

Abschließend: Wie schon erwähnt folgen in Dtn 10,12-19 Gottes Liebesgeschichte und die Israel gebotene Liebe dicht aufeinander. Israel soll seinen Gott JHWH lieben (Vers 12), der schon zuvor seine Väter geliebt und deren Nachkommen aus freier Liebe erwählt hat (Vers 15). Und es soll den Fremden lieben (Vers 19), letztlich weil und wie Gott ihn liebt (Vers 18). Der Liebeswille Gottes, das Motiv seines Handelns, ist ebenso unergründlich wie unverfügbar. Auch geht er dem Verhalten Israels und seiner Vorfahren stets voraus. Wenn also „Gott Israel im Blick auf die Fremdlinge mit dem hohen Gebot der Nachfolge in seiner eigenen Liebe konfrontiert, fordert er nichts Menschenunmögliches, sondern Widerhall und Widerschein der Liebe, die Israel zuallererst von ihm empfangen hat “ ${ }^{55}$ Dabei gilt: „Wenn Israel den von Jahwe geliebten Fremden liebt, liebt es zugleich seinen Gott. Enger können Gottes- und Fremdenliebe kaum mehr zusammenrücken. “56

Das Gebot der Fremdenliebe steht in einem anderen Rechtskodex des Pentateuchs, dem sogenannten Heiligkeitsgesetz (Levitikus 17-26), auch mit dem Gebot der Nächstenliebe in einem literarischen wie theologischen Naheverhältnis, nämlich im sogenannten „Gemeindekatechismus “57. Die beiden Texte Lev 19,18 und 19,34 dürften Dtn 10,19 bereits vorgegeben gewesen sein, als dieser Vers an Dtn 10,17-18 angefügt wurde. ${ }^{58}$ Im Folgenden vergleiche ich die drei Liebesgebote miteinander.

54 Awabdy, Immigrants, S. 162.

55 Hermann Spieckermann, Die Stimme des Fremden im Alten Testament, in: Gottes Liebe, S. 84-99, hier: S. 88.

56 Braulik, Liebe, S. 256.

57 Erhard S. Gerstenberger, Das 3. Buch Mose Leviticus, Das Alte Testament Deutsch 6, Göttingen 1993, S. 240. Es geht um eine Gemeindebelehrung im Glauben. Der schriftliche „Katechismus“ wurde in der Gottesdienstgemeinschaft verlesen. Sein Grundsatz, die „Heiligkeit im Alltag“, lässt sich nahezu überall verwirklichen (Thomas Hieke, Levitikus. Zweiter Teilband: 16-27, Herders Theologischer Kommentar zum AT, Freiburg i. Br. 2014, S. 709).

58 Ausführlich nachgewiesen durch Kraljic, Deuteronomium, S. 366-371. Weitere Belege dieser Annahme einer nachträglichen Ergänzung finden sich auf S. 366 Anm. 259. Mit der spezifischen Argumentation durch Ramiréz Kidd, Alterity, S. 79-81, setzt sich Kraljic, Deute- 


\section{Den Nächsten und den Fremden lieben heißt: heilig werden (Lev 19,34)}

Nächstenliebe und Fremdenliebe stehen in Levitikus $19^{59}$ unter dem Programmwort: „Heilig sollt ihr sein/werden, ${ }^{60}$ denn heilig (bin) ich, JHWH, euer Gott!“ Diese beiden „Spitzensätze“ formulieren „pointiert und prägnant die zentrale Begründungsfigur des ethischen Konzeptes im Heiligkeitsgesetz “ ${ }^{61}$ Ihre direkte Anrede des „Ihr“ der ganzen israelitischen Gemeinde verdeutlicht, „dass Recht und Ethos im Heiligkeitsgesetz als ein Beziehungsgeschehen verstanden werden “. ${ }^{62}$ Doch wird die Heiligkeit Israels nicht nur durch die Heiligkeit Gottes, sondern abschließend auch durch sein Handeln begründet: „Ich (bin) JHWH, euer Gott, der ich euch aus dem Land Ägypten herausgeführt habe, damit ihr alle meine Satzungen und Rechtsentscheide bewahrt und haltet. Ich (bin) JHWH.“ (Verse 36-37). Die vielfältigen religiösen und sozialen Regelungen innerhalb dieses Rahmens von Heiligungs- und Herausführungsformel, die sie begründen und motivieren, bilden beispielhaft eine „Anleitung zu einem heiligmäßigen Leben“ im Alltag, das „als imitatio dei die Heiligkeit Gottes auf Erden im Verhalten des Volkes repräsentiert“". ${ }^{63}$ Nächsten- und Fremdenliebe stehen dabei gegen Ende der beiden Hauptstücke der Gebote und Verbote aus Kult und Gesellschaft (Verse 3-18 und 20-36); genauer: sie beschließen die apodiktisch formulierten Teilkomplexe dieses Diptychons (Verse 11-18 und 26-32). Die Selbstvorstellungsformel „Ich bin JHWH“ bzw. „Ich bin JHWH, euer Gott“ gliedert die gesamte Komposition in Abschnitte und verleiht ihren Rechtssätzen

ronomium, S. 366-367, kritisch auseinander. Zu vermuteten sozialen Ursachen, die eine Einfügung von Dtn 10,19 erforderlich erscheinen ließen, s. Ebd., S. 410.

59 Die jüngste Exegese von Lev 19,17-18 und 33-34 mit Schwerpunkt auf der Erklärung der Termini "Nächster“ (rēēa), „Mitbürger“ ('āmît), „Fremder“ (gēr) und „Einheimischer“

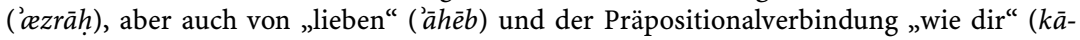
$m o \hat{k} \bar{a}$ ) hat Kengo Akiyama, The Love of Neighbour in Ancient Judaism. The Reception of Leviticus 19:18 in the Hebrew Bible, the Septuagint, The Book of Jubilees, the Dead Sea Scrolls and the New Testament, Ancient Judaism and Early Christianity 105, Leiden-Boston 2018, S. 19-66, vorgelegt.

$60 \mathrm{Zu}$ Syntax und Übersetzung s. Erasmus Gaß, „Heilige sollt ihr werden. Denn heilig bin ich, JHWH, euer Gott." Gott, Mensch und Nächster in Lev 19,11-18, in: Menschliches Handeln und Sprechen im Horizont Gottes. Aufsätze zur biblischen Theologie, Forschungen zum Alten Testament 100, Tübingen 2015, S. 288-323, S. 294. Dabei sorgt Gott selbst bei entsprechendem Verhalten für die Heiligung Israels - „Ich bin JHWH, der euch heiligt“ (20,8; 22,32). Die Heiligkeit Israels ist also nicht mit der Heiligkeit Gottes gleichzusetzen. (Ebd.).

61 Matthias Hopf, Zwischen Sollen und Sein. Einige rechtsanthropologische Überlegungen zum Menschenbild in Lev 19, in: Andreas Wagner / Jürgen van Oorschot (Hg.), Individualität und Selbstreflexion in den Literaturen des Alten Testaments, Veröffentlichungen der Wissenschaftlichen Gesellschaft für Theologie 48, Leipzig 2017, S. 355-372, hier: S. 359.

62 Ebd., S. 360.

63 Hieke, Levitikus, S. 709 und S. 703. 
göttliche Autorität. Die klar abgegrenzten Abschnitte machen deutlich: Nächsten- wie Fremdenliebe dürfen nicht von ihrem Kontext 19,17-18a bzw. 19,33 gelöst werden, obwohl er - wie die Auslegungsgeschichte zeigt - meist ausgeblendet wurde ${ }^{64}$ Diese Isolierung förderte seine Entwicklung zu einem absoluten ethischen Grundsatz.

Die apodiktischen Rechtssätze 19,11-18 definieren ein „erwartbares Solidarverhalten gegenüber dem Nächsten “65. Verboten werden Betrug, Gewalt gegen sozial Schwache, Parteinahme gegen das Recht im Gericht und Hass wie Rache. Die Anweisungen gipfeln in den ethischen Verhaltensregeln und Grundeinstellungen der Verse 17-18, die jede Art von Konflikten zwischen dem „Bruder“, „Mitbürger“ und „Nächsten" betreffen. ${ }^{66}$ Die beiden Verse sind parallel aufgebaut, zweimal werden „Verbot“ - „Abhilfe“ - „Begründung, Motivation“ durchlaufen ${ }^{67}$ :

${ }^{17}$ Du sollst deinen Bruder nicht in deinem Herzen hassen.

Du sollst deinen Mitbürger nachdrücklich zurechtweisen, so dass du seinetwegen keine Schuld auf dich lädst.

${ }^{18} \mathrm{Du}$ sollst dich nicht rächen

und den Angehörigen deines Volkes nichts nachtragen,

so dass ${ }^{68}$ du deinem Nächsten Liebe erweist ( $\left.w^{e^{e}} \bar{a} h a b t \bar{a} l^{e} r \bar{e}^{c a} k \bar{a}\right)$ wie (man) dir (Liebe erweist) $(k \bar{a} m \hat{o} k \bar{a}){ }^{69}$

64 Das betont Adrian Schenker, Das Gebot der Nächstenliebe in seinem Kontext (Lev 19,17-18): Lieben ohne Falschheit, in: Zeitschrift für die alttestamentliche Wissenschaft 124/2012, S. 244-248, hier: S. 244-245.

65 Andreas Ruwe, „Heiligkeitsgesetz“ und „Priesterschrift“. Literaturgeschichtliche und rechtssystematische Untersuchungen zu Leviticus 17,1-26,2, Forschungen zum Alten Testament 26, Tübingen 1999, S. 206.

66 Zum Folgenden s. vor allem Gaß, Heilige, S. 300-314, der die exegetisch unterschiedlich gelösten Probleme des „Liebesgebotes“ in Vers 18 ausführlich und mit überzeugenden Argumenten diskutiert.

67 Jacob Milgrom, Leviticus 17-22, Anchor Bible 3a, New York 2000, S. 1646.

68 Der Satzanschluss ist schwierig zu bestimmen. Die Konjunktion „w“ wird z. B. in der Vulgata, der revidierten Einheitsübersetzung (2016) und der revidierten Lutherbibel (2017) nicht wiedergegeben. Bleibt sie unübersetzt, erscheint das Liebesgebot als von den vorausgehenden Verboten unabhängige Bestimmung oder als deren Zusammenfassung bzw. Begründung. „ $w^{\prime \prime}$ ist polyvalent und wurde bisher verschieden verstanden. Fasst man die Konjunktion wie z.B. die Septuaginta koordinierend („und“) auf, dann bildet das Gebot der Nächstenliebe eine weitere Anweisung in der Reihe von Verhaltensforderungen beim Umgang mit dem Nächsten. Sie kann die vorausgegangenen Verbote aber auch wie in der Zürcher Bibel (2007) adversativ („sondern“) weiterführen und formuliert dann mit dem Liebesgebot ein positives Verhalten. Gibt man die Konjunktion modal („auf diese Weise“) wieder, besteht die Erfüllung der Nächstenliebe im Einhalten der vorausgehenden Verbote. Am meisten spricht für einen konsekutiven Satzanschluss („sodass“). Dann ist die Nächstenliebe die allgemeine Folge des Verzichts auf Hass und Rache - s. dazu Gaß, Heilige, S. 303-304.

69 Nach Gaß, Heilige, S. 314, liegt in 19,18.34 mit kāmôkāä - wörtlich „wie du“ - „vermutlich ein verkürzter Vergleichssatz vor, der das Objekt beider Sätze miteinander vergleicht“. Der 
Ich (bin) JHWH.

Der schuldig gewordene Bruder muss unbedingt auf sein Vergehen angesprochen werden. Stellt man ihn nicht zur Rede, übernimmt man die Verantwortung für sein Verhalten. Nur eine offene Aussprache kann, wenn verborgener Hass aufgestaut ist und sich in einer unangemessenen Reaktion zu entladen droht, eigene Schuld vermeiden. Bleibt die klärende Zurechtweisung aber ergebnislos, darf dies weder zu Rachegelüsten noch zu nachtragendem Groll führen. Wenn die anschließende Konjunktion ( $w$ ) wie oben konsekutiv („sodass“) übersetzt wird, dann ist die Liebe, die man jetzt „dem $\left(l^{l}\right)$ Nächsten $(r \bar{e} \bar{a})^{\text {“ }}$ erweist, die Folge des Gehorsams gegenüber den vorausgehenden Weisungen. Dieser Liebe geht es nicht nur um Emotion, sondern auch um Taten, „um Solidarität, Loyalität und praktische Zuwendung “. ${ }^{70}$ Sie erscheint im Zusammenhang als Erfolg des Verzichts auf Hass, Rache und Zorn und ist daher kein weiteres Gebot, sondern die Zusammenfassung des in den Versen $17-18 \mathrm{a}^{\star}$ geforderten Verhaltens. ${ }^{71}$ Es ist die liebende Zuwendung, die man entweder schon selbst erfahren hat oder die man vom anderen erhofft, die dem Nächsten ebenfalls gewährt werden soll. ${ }^{72}$ Die vergleichende Präpositionalverbindung ( $k \bar{a} m \hat{o} k \bar{a})$ beabsichtigt eine wechsel-

Objektvergleich beschreibt das Vorbild mit „man“ als (gewöhnlich zu ergänzendes) unbestimmtes Subjekt und die Nachahmung durch das „Du“. „Es geht folglich nicht um eine Selbstliebe, sondern um die bereits erfahrene oder in Zukunft erhoffte Liebe, mit der die Aussage des Hauptsatzes verglichen werden soll.“ (Ebd.). Dabei wird auch der Handlungsaspekt der Wendung 'āhēb $l^{e}$ berücksichtigt. Zur Auseinandersetzung mit anderen Auslegungen s. Ebd., S. 309-314. Kurz zu den beiden in der christlichen und jüdischen Auslegungsgeschichte entwickelten Interpretationen - zu der von der Septuaginta vorgegebenen und uns geläufigen Übersetzung „Liebe deinen Nächsten wie dich selbst!“ und der Wiedergabe „Liebe deinen Nächsten, denn er ist wie du!" Die Deutung des kāmôkā als reflexives Adverbiale „wie dich selbst“ und damit die Selbstliebe als Maß der Nächstenliebe scheidet heute definitiv aus - die Präpositionalverbindung kann kein Reflexivverhältnis ausdrücken (Ebd., S. 309-310). Auch die griechische Wiedergabe der Septuaginta mit einem Reflexivpronomen übersetzt den hebräischen Text nicht exakt. Gegen das Verständnis von kāmôk $\bar{a}$ als Attribut zu rēe $\bar{a}$ - der Nächste „der dir gleich ist“, also eine universale Ausweitung der Nächstenliebe wegen der Gleichheit bzw. Gleichbedürftigkeit aller Menschen - spricht inhaltlich, dass der Fremde nicht mit dem Mitbürger gleichgesetzt wird, vor allem aber die zu Vers 18 parallele Aussage in Vers 34, bei der kāmôk $k \bar{a}$ noch das enklitische Personalpronomen in $l \hat{o}$,ihm“ (d.h. dem Fremden) bestimmen müsste (Ebd., S. 311-312). Nach Gaß hat sich noch Akiyama, Love, S. 55-62, zu den beiden Hauptübersetzungen geäußert. Er plädiert für den ,adjectival sense (,who is like yourself) “. Doch scheint er den Artikel von Gaß und dessen Widerlegung dieser Lösung nicht zu kennen.

$70 \mathrm{Gaß}$, Heilige, S. 307.

71 Ebd., S. 304. „In der Rezeption wird sich zeigen, dass im Judentum wie im Christentum das Gebot der Nächstenliebe tatsächlich die ,Summe', Zusammenfassung oder innerer Kern der Gebote Gottes angesehen wird.“ (Hieke, Levitikus, S. 728). Damit erübrigt sich die Diskussion von Kengo Akiyama, How Can Love Be Commanded? On Not Reading Lev 19,17-18 as Law, in: Biblica 98/2017, S. 1-9.

$72 \mathrm{Gaß}$, Heilige, S. 314. 
seitige Praxis der Liebe und somit eine besondere Form der Goldenen Regel, die zum Maßstab des eigenen Verhaltens nimmt, was man selbst vom anderen erfahren möchte. ${ }^{73}$ Angesichts des nahezu synonymen „Bruders“, „Mitbürgers“ und Volksgenossen und der ausschließlich an die Gemeinde gerichteten apodiktischen Verbote (Verse 11-18) meint der „Nächste“ nicht irgendwelche Mitmenschen, sondern die Mitglieder des Gottesvolkes. „Die ,Bruder'-Metapher schafft (...) das Idealbild einer nach dem Vorbild der Familiensolidarität strukturierten Gesellschaft “ ${ }^{74}$ Dabei spricht nichts dafür, den schuldig gewordenen Mitisraeliten als persönlichen Feind und die gebotene Liebe dann als Feindesliebe zu verstehen. ${ }^{75}$ Entscheidend ist, dass die Liebe, die sonst innerhalb einer Großfamilie gilt, auf alle im Volk Gottes ausgeweitet wird. Obwohl also „der Nächste“ nur den nicht-verwandten Israeliten, die Israelitin, nicht aber den „Fremden“ bezeichnet, wird die selbe tätige Solidarität beim Weiterlesen auch für den Fremden gefordert, der im Gottesvolk wohnt. Das Gebot der Fremdenliebe zitiert in 19,34a inmitten eines pluralischen Kontextes das fast gleichlautende, im Singular formulierte Liebesgebot aus Vers 18:

${ }^{33}$ Und wenn bei dir ein Fremder ( $\left.g \bar{e} r\right)$ in eurem Land als Fremder wohnt (jāgûr), sollt ihr ihn nicht unterdrücken.

${ }^{34}$ Wie ein Einheimischer ('azrāhh) unter euch soll euch der Fremde (haggēr) sein, der bei euch als Fremder wohnt (haggār).

Und du sollst ihm Liebe ( $\left.w^{e} \bar{a} h a b t \bar{a} l \hat{o}\right)$ erweisen wie (man) dir (Liebe erweist) $(k \bar{a}-$ $m o ̂ k \bar{a}$ ). Denn ihr seid Fremde (gērîm) im Land Ägypten gewesen.

Ich bin JHWH, euer Gott.

Der im Land Israels wohnende Schutzbürger und die Israeliten, die Fremde im Land Ägypten waren, unterstreichen die Gemeinsamkeit von Fremden und Einheimischem. Zugleich rahmen sie auch das Herzstück des Gesetzes - das Verbot, den Fremden zu unterdrücken, und das damit kontrastierende Gebot, ihn zu lieben. Im Einzelnen: Der im Land ansässige „Fremde“ verfügt über

73 Ebd., S. 317-318. „In Lev 19,18.34 geht es um einen Vergleich der Nächstenliebe nicht mit der Selbst- bzw. Eigenliebe, sondern mit der von anderen Menschen erwarteten Liebe. Was man an tätiger Liebe selbst erhofft, sollte man dem anderen genauso zukommen lassen. Diese Art von Nächstenliebe zeigt sich besonders in der Einhaltung der zuvor genannten Weisungen.“ (Ebd., S. 318).

74 Hieke, Levitikus, S. 729.

75 Vgl. Christoph Nihan, From Priestly Torah to Pentateuch. A Study in the Composition of the Book of Leviticus, Forschungen zum Alten Testament 25, Tübingen 2007, S. 474 Anm. 304. Anders z. B. Gianni Barbiero, L'asino del nemico. Rinucia alla vendetta e amore del nemico nella legislazione dell'Antico Testamento (Es 23,4-5; Dt 22,1-4; Lv 19,17-18), Analecta Biblica 128, Roma 1991, S. 265-296, der seine eingehende Exegese von Lev 19,17-18 überschreibt: „L'amore del nemico“. Nach Ruwe, Heiligkeitsgesetz, S. 205, fungiert das Liebesgebot im Kontext von 19,17-18 ,als ein Feindesliebegebot“. 
keinen Bodenbesitz und ist deshalb im Blick auf Arbeit und Lebensunterhalt von „einem bei euch Geborenen“ abhängig. Wie schon im Bundesbuch (Ex 22,20) erwähnt, besteht für die Israeliten die Versuchung, seine wirtschaftliche Bedürftigkeit auszunützen. Die von Lev 19,34 beanspruchte grundlegende „Gleichwertigkeit ${ }^{\text {“76 }}$ verlangt aber mehr als den Verzicht auf Übervorteilung und Ausbeutung von Abhängigen mit Migrationshintergrund. Der gerechte Umgang wird von der liebenden Zuwendung überholt, die der Fremde mit dem Einheimischen teilen soll. ${ }^{77}$ Das Gesetz erweitert deshalb den Geltungsbereich der Liebe vom Nächsten auf den Fremden, der sich dauerhaft im Land aufhält (Vers 34). Mit der Forderung der Fremdenliebe gewinnt das „alte Familienethos“, nämlich „die Zusammengehörigkeit und gegenseitige Verantwortung von Menschen, die in einer Glaubensgemeinschaft leben“, eine „neue Dimension“ ${ }^{78}$ Sie wird damit, wie Israel seinen Aufenthalt in Ägypten erlebt hat, anthropologisch und heilsgeschichtlich begründet. Nach dem Heiligkeitsgesetz (wie dem Bundesbuch vgl. Ex 22,20b; 23,9b) kennen die Israeliten das Fremdsein mit all seinen rechtlichen, politischen und wirtschaftlichen Diskriminierungen aus ihrer eigenen Geschichte. Sie können sich also nicht nur in die Situation der Fremden in Israel versetzen (vgl. Ex 23,9b), sondern sollen in ihnen auch ihr alter ego erkennen. Darüber hinaus erfüllt die dem Fremden erwiesene Liebe, was Lev 19,2 verlangt: „Heilig sollt ihr sein/werden“! Die abschließende Selbstvorstellungsformel „Ich bin JHWH, euer Gott" ruft diese Heiligkeitsforderung in Erinnerung.

Dtn 10,19 ist ausschließlich positiv formuliert. Von Ausbeutung und Unterdrückung des Fremden wie in Ex 22,20; 23,9 und Lev 19,33 wird nicht mehr gesprochen. ${ }^{79}$ Argumentiert Lev 19,34 bei der Fremdenliebe mit der Goldenen Regel, die zu befolgen Zeichen der Heiligkeit Israels ist, so wird sie in Dtn 10,19 durch die vorgängige Liebe JHWHs zum Fremden (Vers 18) theologisch motiviert. Dadurch „wird die Anthropologie und Ethik der Fremdenliebe so stark

76 Zehnder, Umgang S. 344.

$77 \mathrm{Zu}$ konkreten Auswirkungen dieser Aufhebung des Unterschieds zwischen „im Land Geborenen und Fremden" bei der Neuverteilung des Landes vgl. Ez. 47,22-23, sodass der Fremde auch Land besitzen darf. Diese Tendenz wird jedoch, worauf z. B. Gianni Barbiero, Der Fremde im Bundesbuch und im Heiligkeitsgesetz, in: Studien zu alttestamentlichen Texten, Stuttgarter Biblische Aufsatzbände 34, Stuttgart 2002, S. 221-254, hier: S. 248-249, aufmerksam macht, von der Gesetzgebung des Heiligkeitsgesetzes nicht durchgehalten (s. Lev 25,35-55). Vgl. Zehnder, Umgang, S. 345-348.

78 Gerstenberger, Leviticus, S. 248-249.

79 Literargeschichtlich folgert Benjamin Kilchör, Mosetora und Jahwetora. Das Verhältnis von Deuteronomium 12-26 zu Exodus, Levitikus und Numeri, Beihefte zur Zeitschrift für Altorientalische und Biblische Rechtsgeschichte 21, Wiesbaden 2015, dass „Lev 19,33f. in vollem Umfang von Ex 22,20 und Lev 19,17f. her erklärt“ und „im Programm von Lev 19,2 gelesen werden kann, ohne dass irgendein Rückgriff auf das Deuteronomium anzunehmen ist" (S. 291 und S. 290). 
untermauert, wie es im Alten Testament nur geht “ ${ }^{80}$ Dazu kommt, „dass der Vers mit dem Verweis auf Israels eigene Erfahrung [als Fremde] einen Appell an das kollektive Gedächtnis darstellt. [...] Indem Israel die nach innen gelebte Solidarität auch auf die Fremden ausdehnt, überwindet es seine nationalen Schranken und wird zu einer humanen und geschwisterlichen Gesellschaft. ${ }^{\text {(81 }}$

\section{Ein blinder Fleck?}

Ein Gebot der Fremdenliebe fehlt im Neuen Testament. Das heißt aber nicht, seine Liebesethik würde den Fremden ausklammern. Das gilt nicht einmal für Texte, die weder von Liebe noch vom Fremden ausdrücklich sprechen. Die Agapeethik der synoptischen Jesustradition orientiert sich trotz aller Unterschiede an der Rezeption des alttestamentlichen Liebesgebots. Das Lukasevangelium zitiert nicht nur das Gebot der Nächstenliebe im Rahmen des Doppelgebots, sondern lässt Jesus auf die Frage eines Gesetzeslehrers „Wer ist mein Nächster?" mit der Beispielerzählung vom barmherzigen Samariter antworten. Dieser Samariter ist „das Urbild der Nächstenliebe ${ }^{\text {“82 }}$. Was aber kaum bedacht wird: Der Samariter weiß sich der Tora Israels und mit ihr auch dem Gebot der Fremdenliebe verpflichtet. Er erfüllt es an dem unter die Räuber gefallenen Juden, der für ihn ein von Lev 19,34 gemeinter „Fremder“, nicht aber ein „Ausländer“ ist. Die Anwendung des Gleichnisses liegt dann nicht darin, dass grundsätzlich jeder Mensch der Nächste sein kann, sondern in dem unbedingten Anspruch, dem jeweils Hilfsbedürftigen zum Nächsten zu werden (Lk 10,36-37). Allerdings spricht der Gesetzeskundige beim „Nächsten“ nicht von Liebe, sondern von Barmherzigkeit - er ist derjenige, „der barmherzig an ihm gehandelt hat“ (10,37). Denn „den Samariter kennzeichnet ein Hinsehen, das sich vom Leiden des anderen anrühren lässt und aus der Empathie heraus zur konkreten barmherzigen Zuwendung führt. “83

Bezeichnend für Jesu Gesprächsführung ist, dass der Schriftgelehrte selbst die Antworten auf die Fragen gibt: er zitiert das Doppelgebot der Liebe (Vers 27) und bestimmt die Identität des Nächsten (Vers 37a). Jesus braucht ihn in beiden

80 Thomas Söding, Nächstenliebe. Gottes Gebot als Verheißung und Anspruch, Freiburg i. Br. 2015, S. 70.

81 Kraljic, Deuteronomium, S. 410.

82 Söding, Nächstenliebe, S. 129, in der Überschrift des Kapitels über den barmherzigen Samariter (S. 129-144).

83 Matthias Konradt, Liebesgebot und Christusmimesis. Eine Skizze zur Pluralität neutestamentlicher Agapeethik, in: Gabrielle Oberhänsli-Widmer / Michael Welker (Hg.), Liebe, Jahrbuch für Biblische Theologie 29, Neukirchen-Vluyn 2014, S. 65-98, hier: S. 70-71. Vgl. Shimon Gesundheit, Die „Erfindung“ der Barmherzigkeit im Alten Israel. Biblische und nachbiblische Perspektiven, in: Biblische Zeitschrift 63/2019, S. 289-306. 
Fällen nur mehr zum Handeln aufzufordern (Verse 28 bzw. 37b). Die Liebe ist das Schlüsselwort. Sie ist aber im Samaritergleichnis eigentlich der Not zugeordnet. Weder für Lukas noch für Markus und Matthäus ist die Nächstenliebe eine „universale Liebe“. „In der Sache lässt sich - von dem, was durch die veränderte Zeit und Situation bedingt ist, abgesehen - praktisch kein Unterschied zwischen Altem und Neuem Testament feststellen. So werden auch die leitenden Prinzipien die gleichen sein. Ein Unterschied liegt nur im Sprachgebrauch. Der Gebrauch des Wortes ,Liebe' nimmt zu, auch für Fälle, die man im Alten Testament nicht unter dem Stichwort ,Liebe behandelt hat. ${ }^{\text {“84 }}$ Versteht man jedoch unter dem „Nächsten“ - anders als das Alte (und Neue) Testament - jeden Menschen, ja sieht man diese Nivellierung sogar als für das Christentum charakteristisch an, dann droht dem von Gott besonders geliebten und von der Tora privilegierten Fremden nur allzu leicht die Gefahr, nicht mehr gesehen zu werden. ${ }^{85}$ Sogar die Kurzformel von Gottes- und Nächstenliebe kann dazu verleiten. Deshalb stellt sich für Theologie und Kirche die Frage: Hindert sie ein blinder Fleck daran, unter den Liebesgeboten das Gebot der Fremdenliebe sozialethisch wahrzunehmen $?^{86}$

\section{Quellen}

Ackerman, Susan, The Personal is Political. Convenantal and Affectionate Love ('ĀHĒB, 'AHĂBÂ) in the Hebrew Bible, in: Vetus Testamentum 52/2002, S. 437-458.

Akiyama, Kengo, The Love of Neighbour in Ancient Judaism. The Reception of Leviticus 19:18 in the Hebrew Bible, the Septuagint, The Book of Jubilees, the Dead Sea Scrolls and the New Testament, Ancient Judaism and Early Christianity 105, Leiden-Boston 2018.

84 Norbert Lohfink, Liebe. Das Ethos des Neuen Testaments - erhabener als das des Alten?, in: Unsere großen Wörter. Das Alte Testament zu Themen dieser Jahre, 3.Aufl., Freiburg i. Br. 1985, S. 225-240, hier: S. 236 und S. 237. Vgl. Thomas Söding, Wie weit reicht die Nächstenliebe: Das biblische Konzept in der Diskussion über den Altruismus, in: Evangelische Theologie 77/2017, S. 258-267, hier: S. 262: „Die Nächstenliebe ist eine Ethik auf Sichtweite.“

85 Vgl. z. B. Katharina Westerhorstmann, Das Liebesgebot als Gabe und Auftrag. Moraltheologie im Licht des jüdisch-christlichen Dialogs, Studien zu Judentum und Christentum 29, Paderborn 2014, im Kapitel über „Nächstenliebe ist Menschenliebe“ (S. 387-408). Nur der Abschnitt über „Die Liebe zum Fremden als ,Glaubensgebot‘ in der Beziehung zwischen Gott und Mensch"(S. 338-340) behandelt - vor allem aus der Sicht Martin Bubers - das Gebot der Fremdenliebe, insbesondere in Dtn 10,17-19. Dabei übersetzt Westerhorstmann Vers 19 mit „Liebet den Gast“ (S. 338), obwohl das Deuteronomium den Fremden klar vom Gast unterscheidet. Der jüdische Philosoph Michael Walzer knüpft in Mitgliedschaft und Zugehörigkeit, in: Frank Dietrich (Hg.), Ethik der Migration. Philosophische Schlüsseltexte, stw 2215, Berlin 2017, S. 29-47, hier: S. 32, zwar an die Geschichte vom Samariter an, bleibt aber bei der Diskussion über das Prinzip der gegenseitigen Hilfe bei der Unterscheidung zwischen Mitgliedern einer Gesellschaft und Fremden.

86 Ich danke Norbert Lohfink SJ für die kritische Lektüre des Manuskripts. 
Akiyama, Kengo, How Can Love Be Commanded? On Not Reading Lev 19,17-18 as Law, in: Biblica 98/2017, S. 1-9.

Arnold, Bill T., The Love-Fear-Antinomy in Deuteronomy 5-11, in: Vetus Testamentum 61/2011, S. 551-569.

Awabdy, Mark A., Immigrants and Innovative Law. Deuteronomy's Theological and Social Vision for the gr, Forschungen zum Alten Testament II, 67, Tübingen 2014.

Barbiero, Gianni, L'asino del nemico. Rinucia alla vendetta e amore del nemico nella legislazione dell'Antico Testamento (Es 23,4-5; Dt 22,1-4; Lv 19,17-18), Analecta Biblica 128, Roma 1991.

Barbiero, Gianni, Der Fremde im Bundesbuch und im Heiligkeitsgesetz, in: Studien zu alttestamentlichen Texten, Stuttgarter Biblische Aufsatzbände 34, Stuttgart 2002, S. 221-254.

Braulik, Georg, Eine Gesellschaft ohne Arme. Das altorientalische Armenethos und die biblische Vision, in: Tora und Fest. Aufsätze zum Deuteronomium und zur Liturgie, Stuttgarter Biblische Aufsatzbände 69, Stuttgart 2019, S. 13-30.

Braulik, Georg, Die Liebe zwischen Gott und Israel. Zur theologischen Mitte des Buches Deuteronomium, in: Studien zu Buch und Sprache des Deuteronomiums, Stuttgarter Biblische Aufsatzbände 63, Stuttgart 2017, S. 241-259.

Braulik, Georg, Geschichtserinnerung und Gotteserkenntnis. Zu zwei Kleinformen im Buch Deuteronomium, in: Studien zu den Methoden der Deuteronomiumsexegese, Stuttgarter Biblische Aufsatzbände 42, Stuttgart 2006, S. 165-183.

Bultmann, Christoph, Der Fremde im antiken Juda. Eine Untersuchung zum sozialen Typenbegriff ,ger' und seinem Bedeutungswandel in der alttestamentlichen Gesetzgebung, Forschungen zur Religion und Literatur des Alten und Neuen Testament 153, Göttingen 1992.

Dangl, Oskar, Methoden im Widerstreit. Sprachwissenschaftliche Zugänge zur deuteronomischen Rede von der Liebe Gottes, Textwissenschaft - Theologie - Hermeneutik Linguistik -Literaturanalyse - Informatik 6, Tübingen 1993.

Ebach, Ruth, Das Fremde und das Eigene. Die Fremdendarstellungen des Deuteronomiums im Kontext israelitischer Identitätskonstruktionen, Beihefte zur Zeitschrift für die alttestamentliche Wissenschaft 471, Berlin-Boston 2014.

Erbele-Küster, Dorothea, Gebotene Liebe. Zur Ethik einer Handlungsemotion im Deuteronomium, in: Manfred Oeming (Hg.), Ahavah. Die Liebe Gottes im Alten Testament, Arbeiten zur Bibel und ihrer Geschichte 55, Leipzig 2018, S. 143-156.

Finkelstein, Israel, Migration of Israelites into Judah after 720 BCE: An Answer and an Update, in: Zeitschrift für alttestamentliche Wissenschaft 127/2015, S. 188-206.

Frese, Daniel A., A Land of Gates: Covenant Communities in the Book of Deuteronomy, in: Vetus Testamentum 65/2015, S. 33-52.

Gaß, Erasmus, „Heilige sollt ihr werden. Denn heilig bin ich, JHWH, euer Gott.“ Gott, Mensch und Nächster in Lev 19,11-18, in: Menschliches Handeln und Sprechen im Horizont Gottes. Aufsätze zur biblischen Theologie, Forschungen zum Alten Testament 100, Tübingen 2015, S. 288-323.

Gerstenberger, Erhard S., Das 3. Buch Mose Leviticus, Das Alte Testament Deutsch 6, Göttingen 1993.

Gesundheit, Shimon, Die „Erfindung“ der Barmherzigkeit im Alten Israel. Biblische und nachbiblische Perspektiven, in: Biblische Zeitschrift 63/2019, S. 289-306. 
Hieke, Thomas, Levitikus. Zweiter Teilband: 16-27, Herders Theologischer Kommentar zum AT, Freiburg i. Br. 2014.

Hopf, Matthias, Zwischen Sollen und Sein. Einige rechtsanthropologische Überlegungen zum Menschenbild in Lev 19, in: Andreas Wagner / Jürgen van Oorschot (Hg.), Individualität und Selbstreflexion in den Literaturen des Alten Testaments, Veröffentlichungen der Wissenschaftlichen Gesellschaft für Theologie 48, Leipzig 2017, S. 355372.

Joosten, Jan, The Verbal System of Biblical Hebrew. A New Synthesis elaborated on the Basis of Classical Prose, Jerusalem Biblical Studies 10, Jerusalem 2012.

Kilchör, Benjamin, Mosetora und Jahwetora. Das Verhältnis von Deuteronomium 12-26 zu Exodus, Levitikus und Numeri, Beihefte zur Zeitschrift für Altorientalische und Biblische Rechtsgeschichte 21, Wiesbaden 2015.

Konradt, Matthias, Liebesgebot und Christusmimesis. Eine Skizze zur Pluralität neutestamentlicher Agapeethik, in: Gabrielle Oberhänsli-Widmer / Michael Welker (Hg.), Liebe, Jahrbuch für Biblische Theologie 29, Neukirchen-Vluyn 2014, S. 65-98.

Kraljic, Alexander, Deuteronomium 10,12-11,32: Gottes Hauptgebot, der Gehorsam Israels und sein Land. Eine Neuuntersuchung, Österreichische Biblische Studien 49, Frankfurt a. M. 2018.

Lapsley, Jacqueline E., Feeling Our Way: Love for God in Deuteronomy, in: The Catholic Biblical Quarterly 65/2003, S. 350-369.

Lohfink, Norbert, Das deuteronomische Gesetz in der Endgestalt - Entwurf einer Gesellschaft ohne marginale Gruppen, in: Studien zum Deuteronomium und zur deuteronomistischen Literatur III, Stuttgarter Biblische Aufsatzbände 20, Stuttgart 1995, S. 205-218.

Lohfink, Norbert, Gibt es eine deuteronomistische Bearbeitung im Bundesbuch, in: Studien zum Deuteronomium und zur deuteronomistischen Literatur III, Stuttgarter Biblische Aufsatzbände 20, Stuttgart 1995, S. 39-64.

Lohfink, Norbert, Liebe. Das Ethos des Neuen Testaments - erhabener als das des Alten?, in: Unsere großen Wörter. Das Alte Testament zu Themen dieser Jahre, 3.Aufl., Freiburg i. Br. 1985, S. 225-240.

Milgrom, Jacob, Leviticus 17-22, Anchor Bible 3a, New York 2000.

Moran, William L., The Ancient Near Eastern Background of the Love of God in Deuteronomy, in: Ders., The Most Magic World. Essays on Babylonian and Biblical Literature, ed. by R. S. Hendel, CBQ.MS 35, Washington 2002, S. 170-181.

Müller, Katrin, Lieben ist nicht gleich lieben. Zur kognitiven Konzeption von Liebe im Hebräischen, in: Andreas Wagner (Hg.), Göttliche Körper - göttliche Gefühle. Was leisten anthropomorphe und anthropopathische Götterkonzeptionen im Alten Orient und im Alten Testament, Orbis Biblicus Et Orientalis 270, Fribourg-Göttingen 2014, S. 219-237.

Müllner, Ilse, „Du selbst bist fremd in Ägypten gewesen!“ [Dtn 10,19]. Das Erste Testament als Migrationsliteratur, in: Annegret Reese-Schnitker / Daniel Bertram / Marcel Franzmann (Hg.), Migration, Flucht und Vertreibung. Theologische Analyse und religionsunterrichtliche Praxis, Religionspädagoik innovativ 23, Stuttgart 2018, S. 39-50.

Nihan, Christoph, From Priestly Torah to Pentateuch. A Study in the Composition of the Book of Leviticus, Forschungen zum Alten Testament II, 25, Tübingen 2007. 
Nussbaum, Martha C., Politische Emotionen. Warum Liebe für Gerechtigkeit wichtig ist, Berlin 2014.

Olyan, Saul M., Rites and Rank. Hierarchy in Biblical Representations of Cult, Princeton, NJ 2000.

Otto, Eckart, Deuteronomium 1-11. Zweiter Teilband: 4,44-11,32, Herders Theologischer Kommentar zum AT, Freiburg i. Br. 2012.

Ramírez Kidd, José E., Alterity and Identity in Israel. The gr in the Old Testament, Beihefte zur Zeitschrift für die alttestamentliche Wissenschaft 283, Berlin 1999.

Riecker, Siegbert, Ein Priestervolk für alle Völker. Der Segensauftrag Israels für alle Nationen in der Tora und den Vorderen Propheten, Stuttgarter Biblische Beiträge 59, Stuttgart 2007.

Ruwe, Andreas, „Heiligkeitsgesetz“ und „Priesterschrift“. Literaturgeschichtliche und rechtssystematische Untersuchungen zu Leviticus 17,1-26,2, Forschungen zum Alten Testament 26, Tübingen 1999.

Sacks, Jonathan, Not in God's Name. Confronting Religious Violence, London 2016.

Schenker, Adrian, Das Gebot der Nächstenliebe in seinem Kontext (Lev 19,17-18): Lieben ohne Falschheit, in: Zeitschrift für alttestamentliche Wissenschaft 124/2012, S. 244248.

Söding, Thomas, Wie weit reicht die Nächstenliebe: Das biblische Konzept in der Diskussion über den Altruismus, in: Evangelische Theologie 77/2017, S. 258-267.

Söding, Thomas, Nächstenliebe. Gottes Gebot als Verheißung und Anspruch, Freiburg i. Br. 2015.

Spieckermann, Hermann, Mit der Liebe im Wort. Ein Beitrag zur Theologie des Deuteronomiums, in: Gottes Liebe zu Israel. Studien zur Theologie des Alten Testaments, Forschungen zum Alten Testament 33, Tübingen 2001, S. 157-172.

Spieckermann, Hermann, Die Stimme des Fremden im Alten Testament, in: Gottes Liebe zu Israel. Studien zur Theologie des Alten Testaments, Forschungen zum Alten Testament 33, Tübingen 2001, S. 84-99.

Van Houten, Christiana, The Alien in Israelite Law, The Library of Hebrew Bible/Old Testament Studies 107, Sheffield 1991.

Veijola, Timo, Das fünfte Buch Mose (Deuteronomium): Kapitel 1,1-16,17, Das Alte Testament Deutsch 8,1, Göttingen 2004.

Walzer, Michael, Mitgliedschaft und Zugehörigkeit, in: Frank Dietrich (Hg.), Ethik der Migration. Philosophische Schlüsseltexte, stw 2215, Berlin 2017, S. 29-47.

Weinfeld, Moshe, Deuteronomy 1-11. A New Translation with Introduction and Commentary, The Anchor Yale Bible Commentaries 5, New York 1991.

Weizmann, Steven, Sensory Reform in Deuteronomy, in: David Brakke / Michael L. Satlow / Steven Weizmann (Hg.), Religion and the Self in Antiquity, Bloomington, IN 2005, S. 123-139.

Westerhorstmann, Katharina, Das Liebesgebot als Gabe und Auftrag. Moraltheologie im Licht des jüdisch-christlichen Dialogs, Studien zu Judentum und Christentum 29, Paderborn 2014.

Zehnder, Markus, Umgang mit Fremden in Israel und Assyrien. Ein Beitrag zur Anthropologie des „Fremden“ im Licht antiker Quellen, Beitrage zur Wissenschaft vom Alten und Neuen Testament 168, Stuttgart 2005. 
Open-Access-Publikation im Sinne der CC-Lizenz BY 4.0

(C) 2020, Vandenhoeck \& Ruprecht $\mathrm{GmbH} \&$ Co. KG, Göttingen ISBN Print: 9783847111658 - ISBN E-Lib: 9783737011655 


\section{Die Bedeutung empirischer Gerechtigkeitsforschung für die Sozialethik}

\section{Soziale Gerechtigkeit}

Die Gerechtigkeit ist neben der Freiheit ein tief in der menschlichen Natur verwurzeltes Bedürfnis. Bestätigt wird dies dadurch, dass diese Werte schon seit frühesten Zeiten Gegenstand intellektueller Reflexion sind. Mit der Gerechtigkeit befasste man sich seit Jahrhunderten auf dem Boden normativer Wissenschaften, vor allem der Philosophie und des Rechts. Angestrebt wurde die Herausarbeitung ihrer universalen, allgemein akzeptierten Erfassung. In der Praxis führte dies zur Formulierung ihrer Regeln und der Arten ihrer Anwendung in den verschiedenen sozialen und wirtschaftlichen Lebensbereichen. Es scheint, dass sich die von Aristoteles und von Thomas von Aquin getätigten Feststellungen zum Thema der Gerechtigkeit auf überaus beständige Weise in die intellektuelle Geschichte der Menschheit eingeschrieben haben ${ }^{1}$. Die von ihnen eingeführten Unterscheidungen der Arten der Gerechtigkeit und die Art und Weise ihres Verständnisses stellen bis in die Gegenwart wichtige Bezugspunkte dar. Gewöhnlich werden drei Arten unterschieden: a) die Tauschgerechtigkeit (iustitia commutativa), die den Tausch von Waren, Gütern und Dienstleistungen regelt; als ihr Hauptkriterium gilt die Gleichheit; b) die Verteilungsgerechtigkeit (iustitia distributiva) als Prinzip der Verteilung der ihr unterstehenden Werte; als ihr Grundkriterium gilt die Proportionalität, unter Berücksichtigung des Verdienstes und des Bedürfnisses; c) die legale Gerechtigkeit (iustitia legalis), die sich auf die Proportion der verschiedenartigen Verpflichtungen der Individuen und kleineren Gemeinschaften zugunsten breiterer Gemeinschaften bezieht; auch hier gilt das Kriterium der Proportionalität, und berücksichtigt werden insbesondere der Umfang der Nutzung gemeinsamer Güter und die realen Möglichkeiten des Tragens der Lasten.

1 Witold Morawski, Sprawiedliwość społeczna a transformacja systemowa. Uwagi wstępne, in: Bogdan Cichomski / Wiesława Kozek / Paweł Morawski (Hg.), Sprawiedliwość społeczna. Polska lat dziewięćdziesiątych, Warszawa 2001, S. 7-26, hier: S. 13-14. 
Heute wird zu den bekanntesten philosophischen Erfassungen der Gerechtigkeit die Gerechtigkeitstheorie von John Rawls gezählt ${ }^{2}$. Man kann sich kaum eine dem Thema der Gerechtigkeit gewidmete ernsthafte Abhandlung ohne akzeptierende oder kritische Bezugnahme auf die von ihm formulierten Prinzipien der Gerechtigkeit vorstellen.

In der Neuzeit verlor die Problematik der Gerechtigkeit nicht an Bedeutung. Die Gerechtigkeit wird weiterhin als sozialer Grundwert hochgeschätzt und ist ein wichtiger Gegenstand wissenschaftlicher Forschung. Heute werden jedoch größere Diskrepanzen festgestellt, wie die Gerechtigkeit verstanden wird. Diese Unterschiede betreffen jedoch nicht nur ihr Verständnis, sondern sogar die Existenzberechtigung einiger ihrer Arten. Während die Kategorie der Gerechtigkeit selbst nicht in Frage gestellt wird, hinterfragt zum Beispiel Friedrich A. von Hayek die Existenzberechtigung der sozialen Gerechtigkeit. Hayeks Standpunkt scheint die Konzeption des homo oeconomicus zugrunde zu liegen, die den Menschen als egoistisches Individuum ohne soziale Natur betrachtet. Seiner Ansicht nach "gehört der Ausdruck, soziale Gerechtigkeit' nicht zur Kategorie eines Irrtums, sondern zur Kategorie des Nonsens, so wie der Ausdruck ,moralischer Stein““3. Auch wenn man nicht nur die verbale Form berücksichtigt, in der Hayek seine Meinung zum Ausdruck bringt, kann man darin eine Trennung der Gerechtigkeit von den Werten, die von den Menschen real anerkannt werden, erkennen ${ }^{4}$. Piotr Sztompka zeigt auf überzeugende Weise, dass die Gerechtigkeit „die zwischenmenschlichen Beziehungen betrifft, d.h. die Art der Konstituierung des zwischenmenschlichen Raumes“, was in der Konsequenz bedeutet, dass ,jede Gerechtigkeit immer soziale Gerechtigkeit ist; sie realisiert sich nur in den Beziehungen mit anderen Menschen und hat keinen Sinn in Bezug auf isolierte Individuen“5. In einer ähnlichen, humanistischen Perspektive sieht auch Leszek Kołakowski die soziale Gerechtigkeit. Er schreibt:

„Der Begriff der sozialen Gerechtigkeit ist notwendig, um den Glauben zu rechtfertigen - der mir keineswegs extravagant erscheint -, dass es eine Menschheit gibt, nicht nur Individuen, dass die Menschheit, der Kantischen Tradition gemäß, eine moralische Kategorie ist, und dass die Menschheit gegenüber ihren Mitgliedern und Segmenten Pflichten hat" ${ }^{\text {c6 }}$.

2 John Rawls, A Theory of Justice, Cambridge, Mass. 1971.

3 Friedrich A. von Hayek, Recht, Gesetzgebung und Freiheit, Bd. 2: Die Illusion der sozialen Gerechtigkeit, Landsberg am Lech 1981, S. 112.

4 Siehe die Polemik mit der These von Hayek: Franciszek J. Mazurek, Godność osoby ludzkiej podstawą praw człowieka, Lublin 2001, S. 310.

5 Piotr Sztompka, Sprawiedliwość, in: Małgorzata Bogunia-Borowska (Hg.), Fundamenty dobrego społeczeństwa. Wartości, Kraków, S. 233-250, hier: S. 235-236.

6 Leszek Kołakowski, Moje słuszne poglądy na wszystko, Kraków 1999, S. 216. 
In den modernen Gesellschaften, die sich durch eine alle Subsysteme durchdringende soziale Arbeitsteilung auszeichnen, wird der Gerechtigkeit sehr große Bedeutung beigemessen. Die Arbeitsteilung ist mit der Notwendigkeit der $\mathrm{Zu}$ sammenarbeit, des gegenseitigen Austausches, der Verteilung verschiedenartiger Güter und Dienstleistungen verbunden. Das bedeutet in der Konsequenz eine Verbindung der Mitglieder der Gesellschaft durch ein dichtes Netz gegenseitiger Beziehungen. Bei der Verwirklichung verschiedener Ziele kommt es immer öfter zur Nutzung der Dienste anderer Personen oder Institutionen. Dies betrifft nicht nur den Bereich des Berufslebens oder des Erwerbs von Mitteln und Gerätschaften, die aus offensichtlichen Gründen nicht eigenhändig hergestellt werden können, sondern auch persönlichere Bereiche, die bisher für den Kreis der Familie und nahestehender Personen vorbehalten waren. In den heutigen digitalisierten Gesellschaften basieren diese Beziehungen sehr oft nicht mehr auf persönlichen Kontakten, sondern sie werden mithilfe moderner, gewöhnlich auf die Technologie des Internets gestützter Kommunikationskanäle geknüpft und aufrechterhalten.

Die meisten dieser Tauschbeziehungen werden durch Mechanismen des freien Marktes geregelt, die nicht immer ausreichenden Schutz vor der Ausnutzung bestimmter Teilnehmer dieser Beziehungen durch andere enthalten. Gleichzeitig gewann die Überzeugung von der jeder menschlichen Person zustehenden Würde und in der Konsequenz davon von der grundsätzlichen Gleichheit auf dem Gebiet der jedem Menschen zustehenden Rechte weite Verbreitung. Diese Tatsache bildet eine der Prämissen, die die besondere Sensibilisierung zeitgenössischer Gesellschaften für die Beachtung der Gerechtigkeit erklären, und widerspiegelt sich gleichsam in einem Phänomen, das als „kulturelles Gleichheitspostulat der Moderne" bezeichnet wird. Es gründet sich auf das in der demokratischen Gesellschaft vorhandene Bedürfnis nach Begründung fast jeder ungleichen Behandlung oder ungleichen Verteilung gegenüber einem Mitglied dieser Gesellschaft ${ }^{7}$. Trotz der erwähnten großen Bedeutung der Marktmechanismen geschieht ein beträchtlicher Teil der Verteilung der verschiedenen Güter, Dienstleistungen und geschaffenen Chancen auf der Basis von Entscheidungen der politischen Behörden oder nichtöffentlicher Institutionen mit starken Einflussmöglichkeiten (z. B. internationale Unternehmen), die mehr oder weniger indirekt die Kriterien solcher Verteilungen festlegen. Ähnlich verhält es sich, wenn Einzelnen oder bestimmten sozialen Gruppen Lasten auferlegt werden. Die Gerechtigkeit der erwähnten Kriterien bildet ebenfalls einen Gegenstand aufmerksamer Kontrolle durch die modernen Gesellschaften. Daher erweisen sich die Instrumente zur vielschichtigen Untersuchung des

7 Uwe Schimank, Differenzierung und Integration der modernen Gesellschaft, Wiesbaden 2005, S. 313. 
Phänomens der Gerechtigkeit in den zeitgenössischen Gesellschaften als besonders nützlich und wertvoll.

\section{Das interdisziplinäre Merkmal der Bereichsethiken}

Die Wissenschaftler, die sich mit den Bereichsethiken befassen, wie Wirtschaftsethik, Unternehmensethik, Sozialethik und Politische Ethik, aber auch einige Spezialisten, die eine spezifische Form der Sozial- und Wirtschaftsethik betreiben: die katholische Soziallehre, verbinden in ihren Untersuchungen gewöhnlich zwei Wissenschaftsbereiche (oder sollten sie zumindest berücksichtigen): auf der einen Seite die Ethik und auf der anderen entweder die Ökonomie, das Management, die Politologie oder die Soziologie. Ein solches Betreiben dieser wissenschaftlichen Disziplinen hat mehrere Gründe. Es geht vor allem um den Realismus der vorgeschlagenen Lösungen oder - negativ betrachtet - um Vermeidung des Vorwurfs, die formulierten Standpunkte seien von den sozio-ökonomischen Gegebenheiten losgelöst und die verkündeten Ansichten hätten gewissermaßen utopischen Charakter. Außerdem erfordert die Annahme der vorgeschlagenen Lösungen in der sozio-ökonomischen Lebenspraxis deren Formulierung in einer für die Personen verständlichen Sprache, die die entsprechenden Prärogative für ihre Implementierung besitzen. In demokratischen Gesellschaften bedeutet dies, dass eine entsprechend breite soziale Akzeptanz erreicht werden muss, die eine unerlässliche Bedingung für die Durchführung demokratischer Prozeduren darstellt, welche dann die erwarteten Regelungen nach sich ziehen. Dass eine Berücksichtigung der auf der Grundlage empirischer Untersuchungsergebnisse der Sozialwissenschaften erarbeiteten Feststellungen durch die Sozial- und Wirtschaftsethiker unerlässlich ist, dafür spricht auch die Existenz anerkannter Theorien, die auf der Grundlage des zwischen den moralischen Überzeugungen der Gesellschaft und der Implementierung ethischer Normen bestehenden Zusammenhangs formuliert wurden. Als Beispiel hierfür kann Götz Briefs Theorie der Grenzmoral dienen ${ }^{8}$. Im Falle der katholischen Soziallehre ist das interdisziplinäre Herangehen im Sinne einer Zusammenarbeit mit den Sozialwissenschaften in ihre Methodologie ge-

8 Götz Briefs, Zum Problem der „Grenzmoral“, in: Goetz Briefs, Ausgewählte Schriften, Erster Band: Mensch und Gesellschaft, hrsg. von Heinrich Basilius Streithoven und Rüdiger von Voss, Berlin 1980, S. 51-61. Vgl. Monografische Auffassung dieser Theorie aus der Perspektive der katholischen Soziallehre: Aniela Dylus, Moralność krańcowa jako problem dla katolickiej nauki społecznej, Warszawa 1992. 
radezu „eingeschrieben“ und bildet daher gleichsam ihr Identitätsmerkmal ${ }^{9}$. Dies betrifft insbesondere das erste und das dritte Element der stichwortartig beschriebenen Methodologie: Sehen - Urteilen - Handeln ${ }^{10}$. Die Stichhaltigkeit dieser allgemeinen methodologischen Direktive bestätigte Papst Johannes XXIII. in der Sozialenzyklika Mater et magistra:

„Die Grundsätze der Soziallehre lassen sich gewöhnlich in folgenden drei Schritten verwirklichen: Zunächst muss man den wahren Sachverhalt überhaupt richtig sehen; dann muss man diesen Sachverhalt anhand dieser Grundsätze gewissenhaft bewerten; schließlich muss man feststellen, was man tun kann und muss, um die überlieferten Formen nach Ort und Zeit anzuwenden. Diese drei Schritte lassen sich den drei Worten ausdrücken: sehen, urteilen, handeln ${ }^{\text {“11 }}$.

Besonders auf den oben erwähnten Stufen - der ersten und der dritten - spielen solche Disziplinen auf dem Gebiet der Sozialwissenschaften wie die Soziologie, die Ökonomie und die Politikwissenschaft eine bedeutsame Rolle. Sie erlauben eine professionelle Diagnose einzelner Elemente des weitgefassten sozio-ökonomischen Systems sowie des Systems als Ganzes. Angesichts der ständig zunehmenden Dynamik der sozialen Veränderungen, die von solchen Faktoren wie der Globalisierung und den neuen Kommunikations- und Produktionstechnologien noch beschleunigt werden, ermöglicht die Zusammenarbeit mit diesen Disziplinen eine verhältnismäßig schnelle und präzise Diagnose eventueller neuer sozialer Fragen und deren ethische Beurteilung sowie die Formulierung von Lösungsvorschlägen, die zu einer effektiven Implementierung geeignet sind. Bemerkt werden muss, dass ein solches Herangehen für viele die katholische Soziallehre betreibende Gelehrte charakteristisch ist, die neben ihrer theologischen Ausbildung auch akademische Qualifikationen auf dem Gebiet der Ökonomie, der Soziologie oder der Politikwissenschaft erworben haben. Ein Beispiel gekonnter Verbindung ökonomischer und ethisch-theologischer Kompetenz in der Wissenschaft mit praktischen Erfahrungen im politischen System, die u.a. im Dienste der Vereinten Nationen erworben wurde, bilden die Forschungen und Veröffentlichungen von Frau Professor Ingeborg Gabriel ${ }^{12}$.

9 Franciszek J. Mazurek, Katolicka nauka społeczna - status metodologiczny i główne obszary problemowe, in: Stanisław Fel / Józef Kupny, Katolicka nauka społeczna. Podstawowe zagadnienia z życia społecznego i politycznego, Katowice 2007, S. 11-30, hier: S. 12.

10 Vgl. Joachim Wiemeyer, Keine Freiheit ohne Gerechtigkeit. Christliche Sozialethik angesichts globaler Herausforderungen, Freiburg i. Br. 2015, S. 40-45.

11 Johannes XXIII, Sozialenzyklika Mater et magistra, Nr. 236.

12 Vgl. Ingeborg Gabriel / Peter G. Kirchschläger / Richard Sturn (Hg.), Eine Wirtschaft, die Leben fördert. Wirtschafts- und unternehmensethische Reflexionen im Anschluss an Papst Franziskus, Ostfildern 2017; Ingeborg Gabriel / Petra Steinmair-Pösel (Hg.), Gerechtigkeit in einer endlichen Welt. Ökologie - Wirtschaft - Ethik, 2. Aufl., Ostfildern 2014; Ingeborg Gabriel / Ludwig Schwarz (Hg.), Weltordnungspolitik in der Krise. Perspektiven internationaler Gerechtigkeit, Paderborn 2011. 


\section{Empirische Gerechtigkeitsforschung}

Ein empirisches Herangehen an die Frage der Gerechtigkeit wurde in der Mitte des 20. Jahrhunderts zuerst von den Sozialpsychologen unternommen. Hierbei handelte es sich hauptsächlich um die von George C. Homans und John Stacy Adams veröffentlichten Arbeiten. In den achtziger Jahren des vergangenen Jahrhunderts unternahmen dann auch die Soziologen intensive Untersuchungen zur Gerechtigkeit. Verhältnismäßig schnell bildeten sich mehrere Theorie- und Forschungsansätze heraus. Seit einigen Jahren wird die Soziologie der Gerechtigkeit als etablierte soziologische Subdisziplin anerkannt. Zu ihren bedeutendsten europäischen Vertretern gehört heute Stefan Liebig, ein Soziologe aus Bielefeld.

In den Sozialwissenschaften, vor allem in der Soziologie und Psychologie, werden heute vier Forschungsperspektiven zur Gerechtigkeit unterschieden: die der Einstellungen, die behaviorale (Verhaltensanalyse), die des Diskurses oder die institutionelle ${ }^{13}$. In dem auf Forschung der Einstellungen orientierten Ansatz wird angestrebt, die Arten des Verständnisses der Gerechtigkeit und deren Beurteilung durch die jeweiligen Personen zu analysieren. Dies führt zu Feststellungen, was die Menschen als gerecht ansehen, wodurch das jeweilige Gerechtigkeitsverständnis bedingt ist und wie sich diese individuellen Sichtweisen der Gerechtigkeit in den Überzeugungen und Haltungen der Menschen widerspiegeln. Auf der Grundlage empirischer soziologischer Forschung wurde unter anderem eine Abhängigkeit zwischen dem Typ der in der jeweiligen Gesellschaft dominierenden Beziehungen und dem von dieser Gesellschaft bevorzugten Prinzips der Gerechtigkeit festgestellt. In auf starke soziale Bindungen gegründeten Gesellschaften, die eine einigermaßen homogene Gruppe mit Gemeinschaftscharakter bilden, stellt die Anwendung des Bedarfsprinzips (des Prinzips der Bedarfsgerechtigkeit) eine Voraussetzung für die Anerkennung der Realisierung sozialer Gerechtigkeit dar. Dagegen wird in Gesellschaften, die eine Menge eher locker miteinander verbundener Individuen bilden und in denen sich die Beziehungen hauptsächlich auf Marktmechanismen stützen, das Leistungsprinzip als dominierende Regel sozialer Gerechtigkeit anerkannt ${ }^{14}$.

Im behavioristischen Forschungsansatz konzentriert sich die Aufmerksamkeit des Forschers auf die Feststellung der Verhaltensweisen von Personen in Situationen, wenn sie Ungerechtigkeiten erleben. Diese Forschungsperspektive

13 Stefan Liebig, Soziale Gerechtigkeit - Modelle und Befunde der soziologischen Gerechtigkeitsforschung, in: Monica Budowski / Michael Nollert (Hg.), Soziale Gerechtigkeiten. Differenzen, Zürich 2008, S. 33-63, S. 34-36.

14 Stefan Liebig / Meike May, Dimensionen sozialer Gerechtigkeit, in: Aus Politik und Zeitgeschichte. Beilage zur Wochenzeitung „Das Parlament“ 47/2009 am 16.11.2009, S. 3-8, hier: S. 7. 
wird insbesondere von den Psychologen genutzt. Die Ergebnisse der in den letzten drei Jahrzehnten in verschiedenen Organisationen durchgeführten Untersuchungen erlauben die Feststellung, dass (auch nur subjektiv) wahrgenommene Ungerechtigkeit das berufliche und das sozio-politische Engagement und den Willen zur Anstrengung mindert ${ }^{15}$ sowie $\mathrm{zu}$ einer Erosion des Vertrauens in den Beziehungen zwischen Angestellten und Vorgesetzten führt, ja sich sogar negativ auf den Gesundheitszustand der Mitarbeiter auswirken kann, die sich ungerecht bezahlt fühlen ${ }^{16}$.

Die auf eine Analyse des Diskurses über die Gerechtigkeit ausgerichteten Forschungen wollen feststellen, wie die Gerechtigkeit im öffentlichen Diskurs definiert wird. In dieser Forschungsperspektive besteht das Ziel nicht nur darin, den im öffentlichen Diskurs verwendeten Begriffsapparat kennenzulernen, sondern auch, wie für eine bestimmte Idee der Gerechtigkeit argumentiert wird. Eine bedeutsame Strömung in diesem Herangehen ist die Erforschung der Evolution des Verständnisses von Gerechtigkeit, besonders im Kontext der dynamischen Veränderungen der sozio-ökonomischen Wirklichkeit. Ein reiches Feld für derartige Forschungen bieten die Transformationsprozesse in den Ländern Ostmitteleuropas mit einer starken Dynamik des sich verändernden Verständnisses von Gerechtigkeit ${ }^{17}$. In den Ländern Westeuropas bilden einen solchen Kontext u. a. die tiefgreifenden demographischen Veränderungen, die zu „einer Alterung“ der Gesellschaft führen ${ }^{18}$. Diese Veränderungen sind so weitgehend, dass sie zur Ursache zunehmender neuer sozialer Ungleichheiten werden und Generationskonflikte auslösen können. Nach Ansicht mancher Forscher sind diese Veränderungen (z.B. in Deutschland) bereits von so großer Bedeutung, dass sie eine größere Rolle spielen als die schon über Jahrzehnte fortdauernden Hauptarten der Ungleichheiten, die die Prinzipien der sozialen Gerechtigkeit verletzen ${ }^{19}$. Die Trendforscher prognostizieren sogar, dass in der

15 Holger Lengfeld / Stefan Liebig / Alfredo Märker, Politisches Engagement, Protest und die Bedeutung sozialer Ungerechtigkeit, in: Stefan Liebig / Holger Lengfeld (Hg.), Interdisziplinäre Gerechtigkeitsforschung. Zur Verknüpfung empirischer und normativer Perspektiven, Frankfurt a. M. 2002, S. 243-264.

16 Reinhard Schunck / Carsten Sauer, Peter Valet, Macht Ungerechtigkeit krank? Gesundheitliche Folgen von Einkommens(un)gerechtigkeit, in: WSI Mitteilungen 66/8/2013, S. 553-561.

17 Vgl. Artur Laska, Sprawiedliwość społeczna w dyskursie polskiej zmiany systemowej, Toruń 2011; Max Haller / Bogdan Mach / Heinrich Zwicky, Egalitarismus und Antiegalitarismus zwischen gesellschaftlichen Interessen und kulturellen Leitbildern. Ergebnisse eines internationalen Vergleichs, in: Hans-Peter Müller / Bernd Wegener (Hg.), Soziale Ungleichheit und soziale Gerechtigkeit, Wiesbaden 1995, S. 221-264.

18 Jörg Tremmel, Eine Theorie der Generationengerechtigkeit, Münster 2012.

19 Harald Künemund, Gibt es einen Generationenkonflikt, in: Nils Goldschmidt (Hg.), Generationengerechtigkeit. Ordnungsökonomische Konzepte, Tübingen 2009, S. 11-33, hier: S. 17. 
alternden Gesellschaft die Generationengerechtigkeit in Zukunft eine Schlüsselkategorie bilden wird, welche den Platz der sozialen Gerechtigkeit einnimmt ${ }^{20}$.

Beim institutionalen Forschungsansatz wird versucht, die den gesellschaftlichen Institutionen zugrundeliegenden Prinzipen der Gerechtigkeit festzustellen. Dabei geht es darum, wie in der jeweiligen Institution Entscheidungen über die Verteilung bestimmter Güter gefällt werden, inwieweit man dabei die Überzeugungen von der Gerechtigkeit berücksichtigt und was das letztendliche Ergebnis dieser Aktivitäten ist.

Wenn man die Ergebnisse der mittels dieser Forschungsparadigmen durchgeführten Untersuchungen berücksichtigt, dann kann man erkennen, dass in den heutigen Gesellschaften beim Streben nach Gewährleistung sozialer Gerechtigkeit ein starkes Gewicht auf die Partizipations- und die Chancengerechtigkeit gelegt wird. Dies korrespondiert mit der von Amartya Sen vorgeschlagenen Konzeption der Gerechtigkeit ${ }^{21}$. Dabei geht es hauptsächlich um die Schaffung von Möglichkeiten, damit die einzelnen Personen ihre individuellen Ziele erreichen können. Dass sich die heutigen Gesellschaften für Chancengerechtigkeit aussprechen, gründet auf der Überzeugung, dass die bisherigen Standards sozialer Sicherheit gegenwärtig bereits eine Selbstverständlichkeit darstellen. Dies bedeutet daher keinen Verzicht auf die mit dem Bedarfsprinzip (der Bedarfsgerechtigkeit) verbundenen Anforderungen ${ }^{22}$.

Verallgemeinernd könnte man sagen, dass die Ergebnisse der im Rahmen der hier genannten Forschungsparadigmen durchgeführten empirischen Untersuchungen zu der Schlussfolgerung führen, dass das Vorhandensein von Gerechtigkeit eine Schwellenbedingung für die Bereitschaft der Menschen zur Zusammenarbeit untereinander und in der Konsequenz für ein gutes Funktionieren der Organisationen, der Institutionen und der Gesellschaft als Ganzes darstellt ${ }^{23}$.

\section{Normative versus empirische Gerechtigkeitsforschung - ein Abriss der Diskussionsbereiche}

Die empirischen Sozialwissenschaften streben nicht an, eine Antwort auf die Frage zu finden, was gerecht und was ungerecht ist. Sie wollen lediglich beschreiben und erklären, welche Phänomene als gerecht oder ungerecht wahr-

20 Jörg Tremmel, Generationengerechtigkeit - Versuch einer Definition, in: Handbuch der Generationengerechtigkeit, 2. Aufl., München 2003, S. 27-80, hier: S. 28.

21 Amartya Sen, Inequality Reexamined, Cambridge 1992.

22 Liebig / May, Dimensionen sozialer Gerechtigkeit, S. 8.

23 Karen A. Hegtvedt / Deena Isom, Inequality: A Matter of Justice?, in: Jane D. McLeod / Edward J. Lawler / Michael Schwalbe (Hg.), Handbook of the social psychology of inequality, New York 2014, S. 65-94. 
genommen werden und welches die individuellen, sozialen oder auch historischen Ursachen einer solchen Wahrnehmung dieser Phänomene als gerecht oder ungerecht sind. Sie wollen also die individuellen und/oder sozialen Bedingungen der Genese eines Urteils über die Gerechtigkeit oder ihr Fehlen herausarbeiten. Andererseits streben sie nach einer Erklärung dafür, was für individuelle und soziale Konsequenzen die Anerkennung bestimmter Situationen als ungerecht hat. Letztendlich suchen sie nach einer Antwort auf die Frage, warum die Gerechtigkeit für die Gesellschaft so wichtig ist ${ }^{24}$.

Es muss betont werden, dass die Gerechtigkeit vor allem eine moralische Kategorie ist und als solche seit Beginn der Geschichte des menschlichen Denkens einen Gegenstand philosophischer Reflexion darstellt. Die Philosophen verfügen über ein entsprechendes analytisches Instrumentarium, das unerlässlich ist, um auf die notwendigen Veränderungen in der Frage der Verteilung der Güter und Lasten in der Gesellschaft hinzuweisen. Auf dem Boden der Philosophie kann dann auch eine entsprechende Distanz zu den wechselnden Bedingungen gewahrt werden. Daher kann eine gewisse „Ignoranz“ in Bezug auf die sozio-ökonomischen Details und den künftigen Status der einzelnen Personen, die von John Rawls als „Schleier des Nichtwissens“ (veil of ignorance) bezeichnet wird, paradoxerweise eine Objektivierung der Festlegung der Gerechtigkeitskriterien begünstigen.

In den Wissenschaften, die sich mit einem normativen Herangehen an die Gerechtigkeit befassen, gibt es eine Skepsis, was den Wert empirischer Gerechtigkeitsforschung durch die Sozialwissenschaften betrifft, zumindest aber wird für Vorsicht gegenüber deren Ergebnissen plädiert. Das am Häufigsten vorgebrachte Argument betrifft die Befürchtung vor einem Streben nach naturalistischem Fehlschluss, d.h. dass die moralischen Normen unmittelbar aus den aktuellen Überzeugungen der Gesellschaft abgeleitet werden. Die führenden Spezialisten auf dem Gebiet der Gerechtigkeitssoziologie, die diese Vorwürfe zurückweisen, wissen die Bedeutung der philosophischen Gerechtigkeitstheorien zu schätzen. Wie Stefan Liebig und Carsten Sauer unterstreichen, die einen Gedanken von Émile Durkheim zitieren, kann die soziologische Sicht auf die Gerechtigkeit nicht auf die Berücksichtigung normativer Diskurse verzichten, wie sie der Philosophie zu eigen sind, „weil die zum Ausdruck gebrachten Ansichten Informationen darüber liefern, wie die Gerechtigkeit in einem be-

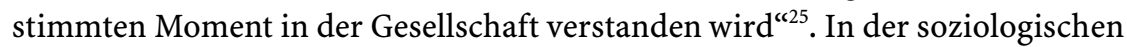
Gerechtigkeitsforschungen geht es also nicht um eine Entscheidung über die

24 Stefan Liebig / Carsten Sauer / Peter Valet, Gerechtigkeit, in: Steffen Mau / Nadine M. Schöneck (Hg.), Handwörterbuch zur Gesellschaft Deutschlands, Wiesbaden 2013, S. 286299, hier: S. 286-287.

25 Stefan Liebig / Carsten Sauer, Sociology of Justice, in: Clara Sabbagh / Manfred Schmitt (Hg.), Handbook of Social Justice Theory and Research, Part I., New York 2016, S. 37-59, hier: S. 52. 
Richtigkeit einer konkreten philosophischen Konzeption oder politischen Idee, sondern um das gesellschaftliche Verständnis von Gerechtigkeit. Wie u.a. auf dem Boden der katholischen Soziallehre bereits aufgezeigt wurde, schließt die Unveränderlichkeit der wichtigsten ethischen Normen die Dynamik der Art ihrer Formulierung und Anwendung keineswegs aus. Dies betrifft zum Beispiel die neuen sozialethischen Prinzipien, die im Kontext konkreter sozio-ökonomischer und sogar ökologischer Bedingungen formuliert wurden ${ }^{26}$. In jüngster Zeit ist man sich angesichts der zunehmenden Bedrohung und Verschmutzung der natürlichen Umwelt durch übermäßige Ausbeutung nichterneuerbarer Ressourcen schließlich ihrer Bedeutung für das Leben und die Entwicklung des Menschen und ihres Wertes als Werk des Schöpfers bewusstgeworden. Als Konsequenz davon wurde das sozialethische Prinzip der Nachhaltigkeit formuliert ${ }^{27}$. Auch die Erweiterung des Katalogs der Menschenrechte, die ihre unveränderliche Grundlage in der Würde der menschlichen Person besitzen, vollzieht sich durch ein „Erkennen“ neuer Rechte unter dem Einfluss positiver oder negativer Faktoren. Positive Bedingungen sind u.a. die Verbreitung des Bewusstseins von der Würde und dem Wert der menschlichen Person (was mit der Entwicklung von Wissenschaft und Bildung verbunden ist), die Demokratie sowie die soziale und wirtschaftliche Entwicklung. Zu den negativen Umständen gehören Situationen drastischer und lang anhaltender Verletzung der Rechte der menschlichen Person u. a. durch verschiedene Formen der Knechtung, Gewalt, totalitäre Systeme, Krieg, Armut, soziale Ausgrenzung, Analphabetismus oder Umweltverschmutzung ${ }^{28}$. Auf dem Boden der Sozialwissenschaften, die sich mit der empirischen Gerechtigkeitsforschung befassen, bedeutet die Zurückweisung des oben erwähnten Vorwurfs (einer Anmaßung des Rechts auf Ersetzen normativer Erfassungen der Gerechtigkeit auf der Grundlage einer großen Zahl von Ergebnissen repräsentativer Untersuchungen) keineswegs ein Vermeiden der Formulierung gewisser Verallgemeinerungen und Theorien. Die empirische Gerechtigkeitsforschung konzentriert sich jedoch grundsätzlich auf die Absicht, die Motive und vielfältigen Bedingungen bestimmter Weisen der Wahrnehmung der Gerechtigkeit festzustellen. Es handelt sich somit um eine Untersuchung der sozio-ökonomischen Umstände, die diese Weisen des Verständnisses von Ge-

26 Stanisław Fel / Łukasz Marczak, Powstanie i status zasady zrównoważonego rozwoju, in: Roczniki Nauk Społecznych 2/2016, S. 185-205.

27 Markus Vogt, Prinzip Nachhaltigkeit. Ein Entwurf aus theologisch-ethischer Perspektive, München 2009.

28 Stanisław Fel, John Paul II and human rights, in: Krzysztof Pilarczyk (Hg.), De revolutionibus orbium populorum Ioannis Pauli II. The Pope against social Exclusion, Warszawa 2015, S. 129-151, hier: S. 139-140. 
rechtigkeit bedingen ${ }^{29}$. Auch soll festgestellt werden, welche Konsequenzen für das tägliche Leben die verschiedenartigen Verständnisse von Gerechtigkeit haben. Außerdem soll eine Antwort auf die Frage gefunden werden, wie sich eine Situation der Ungerechtigkeit auf individuelle Verhaltensweisen oder soziale Phänomene auswirkt.

\section{Quellen}

Briefs, Götz, Zum Problem der „Grenzmoral“, in: Goetz Briefs, Ausgewählte Schriften, Bd. I: Mensch und Gesellschaft, hrsg. von Heinrich Basilius Streithoven und Rüdiger von Voss, Berlin 1980, S. 51-61.

Dylus, Aniela, Moralność krańcowa jako problem dla katolickiej nauki społecznej, Warszawa 1992.

Fel, Stanisław, John Paul II and human rights, in: Krzysztof Pilarczyk (Hg.), De revolutionibus orbium populorum Ioannis Pauli II. The Pope against social Exclusion, Warszawa 2015, S. 129-151.

Fel, Stanisław / Marczak Łukasz, Powstanie i status zasady zrównoważonego rozwoju, in: Roczniki Nauk Społecznych 2/2016, S. 185-205.

Gabriel, Ingeborg / Kirchschläger, Peter G. / Sturn Richard (Hg.), Eine Wirtschaft, die Leben fördert. Wirtschafts- und unternehmensethische Reflexionen im Anschluss an Papst Franziskus, Ostfildern 2017.

Gabriel, Ingeborg, Ökologie als Gerechtigkeitsfrage der Gegenwart, in: Ingeborg Gabriel / Petra Steinmair-Pösel (Hg.), Gerechtigkeit in einer endlichen Welt. Ökologie - Wirtschaft - Ethik, 2. Aufl., Ostfildern 2014, S. 9-31.

Gabriel, Ingeborg / Steinmair-Pösel, Petra (Hg.), Gerechtigkeit in einer endlichen Welt. Ökologie - Wirtschaft - Ethik, 2. Aufl., Ostfildern 2014.

Gabriel, Ingeborg / Schwarz, Ludwig (Hg.), Weltordnungspolitik in der Krise. Perspektiven internationaler Gerechtigkeit, Paderborn 2011.

Haller, Max / Mach, Bogdan / Zwicky, Heinrich, Egalitarismus und Antiegalitarismus zwischen gesellschaftlichen Interessen und kulturellen Leitbildern. Ergebnisse eines internationalen Vergleichs, in: Hans-Peter Müller / Bernd Wegener (Hg.), Soziale Ungleichheit und soziale Gerechtigkeit, Wiesbaden 1995, S. 221-264.

Hayek, Friedrich A. von, Recht, Gesetzgebung und Freiheit, Bd. 2: Die Illusion der sozialen Gerechtigkeit, Landsberg am Lech 1981.

Hegtvedt, Karen A. / Isom, Deena, Inequality: A Matter of Justice?, in: Jane McLeod / Edward Lawler / Michael Schwalbe (Hg.), Handbook of the social psychology of inequality, New York 2014, S. 65-94.

29 Gerold Mikula, Gerecht und ungerecht: Eine Skizze der sozialpsychologischen Gerechtigkeitsforschung, in: Martin Hild / Gisela Kubon-Gilke / Richard Sturn (Hg.), Normative und institutionelle Grundfragen der Ökonomik, Jahrbuch 1: Gerechtigkeit als Voraussetzung für effizientes Wirtschaften, Marburg 2002, S. 257-278. 
Johannes XXIII, Enzyklika Mater et magistra, vgl. http://w2.vatican.va/content/john-xxiii/ de/encyclicals/documents/hf_j-xxiii_enc_15051961_mater.html (letzter Zugriff: 25.05. 2019).

Kołakowski, Leszek, Moje słuszne poglądy na wszystko, Kraków 1999.

Künemund, Harald, Gibt es einen Generationenkonflikt?, in: Nils Goldschmidt (Hg.), Generationengerechtigkeit. Ordnungsökonomische Konzepte, Tübingen 2009, S. 11-33.

Laska, Artur, Sprawiedliwość społeczna w dyskursie polskiej zmiany systemowej, Toruń 2011.

Lengfeld, Holger / Liebig Stefan / Märker Alfredo, Politisches Engagement, Protest und die Bedeutung sozialer Ungerechtigkeit, in: Stefan Liebig / Holger Lengfeld (Hg.), Interdisziplinäre Gerechtigkeitsforschung. Zur Verknüpfung empirischer und normativer Perspektiven, Frankfurt 2002, S. 243-264.

Liebig Stefan / Sauer Carsten, Sociology of Justice, in: Clara Sabbagh / Manfred Schmitt (Hg.), Handbook of Social Justice Theory and Research, Part I. New York 2016, S. 37-59.

Liebig, Stefan / Sauer Carsten / Valet Peter, Gerechtigkeit, in: Steffen Mau / Nadine M. Schöneck (Hg.), Handwörterbuch zur Gesellschaft Deutschlands, Wiesbaden 2013, S. 286-299.

Liebig, Stefan / May, Meike, Dimensionen sozialer Gerechtigkeit, in: Aus Politik und Zeitgeschichte. Beilage zur Wochenzeitung „Das Parlament“ 47/2009 am 16.11.2009, S. 3-8.

Liebig, Stefan, Soziale Gerechtigkeit - Modelle und Befunde der soziologischen Gerechtigkeitsforschung, in: Monica Budowski / Michael Nollert (Hg.), Soziale Gerechtigkeit. Differenzen, Zürich 2008, S. 33-63.

Mazurek, Franciszek J., Katolicka nauka społeczna - status metodologiczny i główne obszary problemowe, in: Stanisław Fel / Józef Kupny (Hg.), Katolicka nauka społeczna. Podstawowe zagadnienia z życia społecznego i politycznego, Katowice 2007, S. 11-30.

Mazurek, Franciszek J., Godność osoby ludzkiej podstawą praw człowieka, Lublin 2001.

Mikula, Gerold, Gerecht und ungerecht: Eine Skizze der sozialpsychologischen Gerechtigkeitsforschung, in: Martin Hild / Gisela Kubon-Gilke / Richard Sturn (Hg.), Normative und institutionelle Grundfragen der Ökonomik, Jahrbuch 1: Gerechtigkeit als Voraussetzung für effizientes Wirtschaften, Marburg 2002, S. 257-278.

Morawski, Witold, Sprawiedliwość społeczna a transformacja systemowa. Uwagi wstępne, in: Bogdan Cichomski / Wiesława Kozek / Paweł Morawski (Hg.), Sprawiedliwość społeczna. Polska lat dziewięćdziesiątych, Warszawa 2001, S. 7-26.

Rawls, John, A Theory of Justice, Cambridge, Mass. 1971.

Schimank, Uwe, Differenzierung und Integration der modernen Gesellschaft, Wiesbaden 2005.

Schunck, Reinhard / Sauer Carsten / Valet Peter, Macht Ungerechtigkeit krank? Gesundheitliche Folgen von Einkommens(un)gerechtigkeit, in: WSI Mitteilungen 66/8/2013, S. 553-561.

Sen, Amartya, Inequality Reexamined, Cambridge 1992.

Sztompka, Piotr, Sprawiedliwość, in: Małgorzata Bogunia-Borowska (Hg.), Fundamenty dobrego społeczeństwa, Wartości, Kraków 2015, S. 233-250.

Tremmel, Jörg, Eine Theorie der Generationengerechtigkeit, Münster 2012.

Tremmel, Jörg, Generationengerechtigkeit - Versuch einer Definition, in: Handbuch der Generationengerechtigkeit, 2. Aufl., München 2003, S. 27-80. 
Vogt, Markus, Prinzip Nachhaltigkeit. Ein Entwurf aus theologisch-ethischer Perspektive, München 2009.

Wiemeyer, Joachim, Keine Freiheit ohne Gerechtigkeit. Christliche Sozialethik angesichts globaler Herausforderungen, Freiburg i. Br. 2015. 
Open-Access-Publikation im Sinne der CC-Lizenz BY 4.0

(C) 2020, Vandenhoeck \& Ruprecht $\mathrm{GmbH} \&$ Co. KG, Göttingen ISBN Print: 9783847111658 - ISBN E-Lib: 9783737011655 


\section{Macht und Herrschaft - Stiefkinder oder Schlüsselkategorien theologischer Ethik?}

In der intellektuellen Praxis ist es wie im sonstigen Leben: manches drängt sich der Wahrnehmung förmlich auf, manches hält sich vornehm zurück, der eine spielt gerne im Vordergrund, der andere bevorzugt die zweite Reihe. Mit den Begriffen aus Moraltheologie und theologischer Ethik ist es nicht anders. Da gibt es "Longseller“ - Grundkategorien der abendländischen Reflexionsgeschichte der Ethik wie Schuld und Sünde, Verantwortung und Gewissen, Vergebung und Verzeihen. ${ }^{1}$ Aber es gibt auch Nebenthemen, die, obwohl sie so gut wie nie im Vordergrund der fachlichen Verständigung stehen, dennoch einen eigenen, originellen Fokus auf die moralische Landkarte ermöglichen können. Darunter kann man etwa Kategorien wie die der Diskretion, Empathie, Leiblichkeit, Zeitlichkeit oder Identität zählen.

Auch der Themenkreis Macht und Herrschaft gehört wohl zu den Stiefkindern der theologisch-ethischen Diskussion und dies nicht zuletzt, weil es eine fehlende Reziprozität des Machtthemas in der Theologie gibt. Einerseits ist das Phänomen Macht ubiquitär: als Grundstoff des Sozialen kommt man auch im Raum der gelebten Religion, im Raum der Glaubensgemeinschaft, der Kirche nicht ohne sie aus. Soziale Beziehungen gestalten sich nicht zuletzt auch nach den Gesetzlichkeiten von Macht und Ohnmacht, Mächtigkeit, Ermächtigung, Handeln-Dürfen und Handeln-Können. Das gilt ebenso für Glaubensgemeinschaften wie für andere soziale Assoziationen.

$\mathrm{Zu}$ dieser Ubiquität von Macht und Herrschaft gibt es jedoch keine Entsprechung im kirchlichen und theologischen Diskurs. In der kirchlich-pastoralen Praxis wird „Macht“ zwar gerne in Anspruch genommen, aber sowohl über die Gefahren als auch über die Chancen praktizierter Macht und machtvoller

1 Dies spiegelt sich beispielsweise in der Darstellung von Wilhelm Korff zur Systematik der theologischen Ethik: Korff stellt den Begriff der Verantwortung ins Zentrum und betrachtet seine „Ausdifferenzierung“ etwa mit Blick auf Freiheit oder Schuld als grundlegende Aufgabe theologischer Ethik: Wilhelm Korff, Ethik. C. Theologisch. III. Systematisch, in: Lexikon für Theologie und Kirche 3, Freiburg-Basel-Rom-Wien 1995, S. 923-929, hier: S. 928. 
Beziehungen wird nur selten offen gesprochen und nachgedacht. ${ }^{2}$ Eine Mentalität der Demuthaftigkeit verstellt den Blick. Ähnlich ist es im theologischen Diskurs: Der machtvolle, herrschende Gott wird oder wurde zumindest lange Zeit eher peinlich verschwiegen (vom Pantokrator redet man hauptsächlich kunstgeschichtlich, weniger theologisch-ethisch) ${ }^{3}$. Auch dass Jesu Handeln sich innerhalb einer sozialen Gemeinschaft abspielte und sich damit unvermeidlich immer wieder die Machtfrage stellte, tritt oft in den Hintergrund des Bildes vom friedliebenden Jesus, der auf die inhaltlichen Aspekte seiner Botschaft reduziert wird.

Macht und Machtfragen werden insgesamt eher verschämt angesprochen und nicht offen und mit kreativer Freude. Wenn sie nicht verschwiegen werden, werden sie doch mindestens vernachlässigt, mehr noch haftet ihnen das Odium des Negativen und des Kritikwürdigen an. Diese Vernachlässigung ist aus zwei Gründen problematisch: Sie verhindert zum einen die Aufklärung einer de facto existierenden Machtpraxis im Raum der Religion. ${ }^{4}$ Zum anderen lässt sie, positiv formuliert, große Chancen und Potentiale aus, die eine theologische Integration und Würdigung des Machtbegriffes bieten könnten. Im Zuge der Diskussionen um sexuellen Missbrauch in der Kirche hat die Dringlichkeit dieses Bedarfs noch einmal erheblich zugenommen.

Im Folgenden möchte ich in einem ersten Schritt eine knappe Bestandsaufnahme machen: Auf welche Weise kann man in Theologie und Kirche der Macht begegnen und wie wird über sie gesprochen? Daran anschließend werde ich zweitens innerhalb des aufgezeigten Panoramas nach einem Anknüpfungspunkt für die theologische Ethik suchen. Leitend ist dabei zum einen die Absicht, ein innerliches Verhältnis zum Machtbegriff zu finden anstatt eines nur sekundären, abgeleiteten, zum anderen soll eine solche Art und Weise, mit der Macht umzugehen, dann auch theologisch qualifiziert werden. In einem dritten ausblickenden Schritt werde ich resümieren, was mit diesen Überlegungen gewonnen ist.

2 Vgl. Hermann Steinkamp, Lange Schatten der Pastoralmacht: theologisch-kritische Rückfragen, Berlin 2015.

3 Vgl. pars pro toto Mark R. Hesslinger, Das Bild des Pantokrators im Kuppelmosaik von Santa Maria dell'Ammiraglio in Palermo, in: Eckhard Leuschner / Mark R. Hesslinger (Hg.), Bild Gottes in Judentum, Christentum und Islam, Petersberg 2009, S. 93-116. Siehe zum Pantokrator in der Theologie z. B. Michael Bachmann, Gott, der „Allmächtige“: Der Pantokrator der Bibel und die Theodizeediskussion, Freiburg 2019; Ders., Göttliche Allmacht und theologische Vorsicht. Zu Rezeption, Funktion und Konnotationen des biblisch-frühchristlichen Gottesepithetons pantokrator, Stuttgart 2002.

4 Vgl. das Themenheft „Macht und Kirche. Biblische Impulse“ der Zeitschrift Bibel und Kirche $2 / 2019$. 


\section{Macht und christlicher Glaube - ein notwendiges Doppel}

Aus methodisch-pragmatischen Gründen scheint es sinnvoll, bei der Bestandsaufnahme zwischen der religiös-kirchlichen Praxis und dem Bereich der Theologie zu unterscheiden, wenngleich beide sachlich zusammengehören, da das eine Feld das andere prägt und beide nicht losgelöst voneinander, sondern in wechselseitiger Inspiration aufeinander existieren, nämlich als Theorie und Praxis.

a. Im Feld der kirchlich-religiösen Praxis begegnet „Macht“ zunächst in ihrer, von Max Weber in „Wirtschaft und Gesellschaft“ so klassisch formulierten, interaktionistischen Gestalt - als die „Chance eines Menschen oder einer Mehrzahl solcher (...), den eigenen Willen in einem Gemeinschaftshandeln auch gegen den Widerstand anderer daran Beteiligter durchzusetzen. ${ }^{\text {“5 }}$ Macht wird in der Praxis der christlichen Glaubensgemeinschaft erlebt als gouvernementales Ordnungshandeln: Es schafft und erneuert Strukturen und setzt Normen durch. Macht ist in diesem Sinne eine Ressource für die Bewahrung des Bestehenden. Zugleich ist sie freilich unverzichtbar, um die Sozialgestalt der Kirche den situativen Herausforderungen, die sich wandeln, anpassen zu können. Bei Macht in diesem ordnungsfunktionalen Sinn kann eingeteilt werden in Akteure und Unterworfene der Macht: Die einen können gestalten, die anderen müssen hinnehmen und sich arrangieren mit dem, was andernorts als Setzung vorgenommen wird. ${ }^{6}$

Die Erkenntnisse aus den vergangenen Jahren über den Missbrauch, der in kirchlichen Einrichtungen an Kindern und Jugendlichen, aber auch an Erwachsenen in pastoralen Zusammenhängen verübt wurde, bestätigen diesen Machttypus. Sie zeigen, dass eine besondere Gefährdung dann gegeben ist, wenn sich eine ordnungsfunktionale Machtausübung mit der charismatischen Aura verbindet, die vom geistlichen Träger solcher Ordnungsmacht ausgeht. Und diese Vorkommnisse haben eine weitreichende Folge: Sie diskreditieren für viele die Institution Kirche an sich und bestätigen ein Misstrauen gegenüber den

5 Max Weber, Wirtschaft und Gesellschaft. Grundriß der verstehenden Soziologie. Studienausgabe, 5. Aufl., Tübingen 1980, S. 531.

6 Ein im Anschluss an Foucault und auch Luhmann geprägter systemischer Machtbegriff, der eine dichotomisch wirkende Gegenüberstellung von „Inhabern“ und „Adressaten“ der Macht hinter sich lässt, wird hier nicht diskutiert. Zu den verschiedenen Verständnissen von Macht aus sozialwissenschaftlicher Perspektive siehe z. B.: Marco Iorio, Macht, in: Martin Hartmann / Claus Offe (Hg.), Politische Theorie und Politische Philosophie. Ein Handbuch, München 2011, S. 246-249. 
Kompetenzen einer religiösen Gemeinschaft, die Gefahren einer exekutiven Machtpraxis zu beherrschen. ${ }^{7}$

Neben dieser als problematisch konnotierten Machtpraxis (Macht im Sinne eines „Herrschafts-Handelns“) im Leben der religiösen Gemeinschaft möchte ich auf ein zweites Bedeutungsfeld hinweisen. Man könnte es, wie Christoph Hübenthal es tut, als die solidaristische Konzeption der Macht bezeichnen. ${ }^{8}$ Diese Position geht auf Hannah Arendt zurück und versteht Macht als eine Qualität, die jeder Gemeinschaftsbildung innewohnt. Sie ist nicht von anderem ableitbar, sondern ursprünglich; sie bezeichnet die menschliche Fähigkeit, so Arendt, „nicht nur zu handeln oder etwas zu tun, sondern sich mit anderen zusammenzuschließen und im Einvernehmen mit ihnen zu handeln “. ${ }^{9}$ Verschiedene Aspekte sind damit angesprochen: Zum einen richtet sich die Definition von Macht gegen ein zweckrationales Handlungsverständnis. Wirkliche Handlungsmächtigkeit zeigt sich nicht darin, dass ein Einzelner die formale, juridische Kompetenz hat, etwas zu tun, einen bestimmten Akt zu vollziehen. Handeln ist vielmehr zweckfrei, verstanden im Sinne der aristotelischen Praxis. Angesprochen ist die Frage, wie und ob überhaupt etwas geschehen und sich ereignen kann im sozialen Feld, nicht die mechanistische Frage nach dieser oder jener einzelnen Handlung für sich. Zum anderen sagt Arendt, dass Handeln dann mächtig wird, wenn es aus dem Zusammenschluss und dem Einvernehmen mit anderen heraus geschieht; dazu ist der Mensch von Natur aus fähig und deshalb ist er potentiell auch macht-fähig.

Von hier aus lässt sich der Bogen zum religiösen Feld spannen: In einem biblisch begründeten christlichen Verständnis kommt die Glaubensgemeinschaft eben erst als eine Handlungsgemeinschaft zu sich. Orthodoxie und Orthopraxie dürfen nicht voneinander getrennt werden, sie erklären sich gegenseitig. ${ }^{10}$ „Es gibt nichts Gutes, außer: Man tut es. “11, sagt Erich Kästner in seinem Epigramm „Moral“ etwas flapsig. Der Hintergrund aber trifft den christlichen Glauben: Die Umkehr, die Metanoiesis, ${ }^{12}$ bleibt kein Bewusstseinsphänomen sie stiftet vielmehr zu einer neuen Art der Gemeinschaftsbildung an. In der Wahrheit sein und dieser Wahrheit Sichtbarkeit verschaffen im Sozialen und

7 Doris Wagner, Spiritueller Missbrauch in der katholischen Kirche, Freiburg 2019; Daniel Bogner, Diese Kirche tötet, in: feinschwarz.net, vgl. https://www.feinschwarz.net/diese-kir che-toetet/ (letzter Zugriff: 20.05.2019).

8 Christoph Hübenthal, Macht. Typologische und legitimationstheoretische Anmerkungen, in: Werner Veith / Christoph Hübenthal (Hg.), Macht und Ohnmacht. Konzeptionelle und kontextuelle Erkundungen, Münster 2005, S. 45-47.

9 Hannah Arendt, Macht und Gewalt, München 1975, S. 45.

10 Auf die Bedeutung des Praxisbezugs hat u.a. die Befreiungstheologie hingewiesen, z.B. Gustavo Gutiérrez, Theologie der Befreiung, München-Mainz 1975.

11 Erich Kästner, Kurz und bündig. Epigramm, Zürich 1950, S. 39.

12 Das Motiv der Umkehr begegnet etwa in Mk 1,15: „Kehrt um und glaubt an das Evangelium!“ 
Zwischenmenschlichen, das gehört zuinnerst zusammen. Die ersten christlichen Gemeinden sind deswegen bis heute stilprägend für einen mit Hannah Arendt entworfenen Machtbegriff: Sich mit anderen zusammenschließen und im Einvernehmen mit ihnen zu handeln - wenn das gelingt, dann kann es zu geschichtsmächtigen, wirkungsvollen, nachhaltigen Veränderungen im Lauf der Dinge kommen. Macht ist in diesem Sinne die Voraussetzung dafür, dass kreative Energie wirksam wird, dass ein schöpferischer Prozess stattfindet. Was will der christliche Glaube anderes als das - diese Welt, die wirkliche, die soziale Welt, schöpferisch und nachhaltig verändern?

b. Dieser Blick auf kirchenpraktische Dimensionen der Macht legt nicht zuletzt bereits nahe, dass religiöse Praxis und die theoretische Fassung dieser Praxis zueinander gehören und sich wechselseitig bestimmen und inspirieren.

In seinem Gebet-Gedicht „Von guten Mächten wunderbar geborgen“ greift Dietrich Bonhoeffer eine Grundintuition menschlichen Nachdenkens und Empfindens über das Verhältnis von Gott und Mensch auf. ${ }^{13}$ Religiös zu sein heißt davon auszugehen, dass es etwas Höheres - höhere Mächte - gibt als den Menschen. Diesen ist der Mensch ausgesetzt, unterworfen, er muss damit umgehen. Religionswissenschaftlich und -soziologisch wurde das vielfach beschrieben. Laut Rudolf Otto etwa erfährt der Mensch in der Religion Gott als eine überwältigende Macht, vor der er erschauert, Otto spricht hier vom mysterium tremendum. ${ }^{14}$ Die spektakuläre Wendung, die der christliche Glaube nun vollzieht, betrifft den Modus der Teilhabe an dieser höheren Macht. Sie muss nämlich nicht, wie in anderen Bekenntnissen, magisch besänftigt, kultisch geschmeichelt oder priesterlich gehegt werden, sondern diese höhere Macht wird als eine geglaubt und bezeugt, die von sich aus einen Bund mit den Menschen eingeht, sich an den Menschen und sein Schicksal bindet, und die diesen Bund mit bestimmten Verheißungen verknüpft. Die Inkarnation ist nochmals explizite Bestätigung: Gott geht aus freien Stücken eine Bindung ein, er bindet sich an den Menschen. Zugleich ist sie aber auch eine Eröffnung: Die Welt des Menschen, seine soziale Welt, die irdische Wirklichkeit ist von nun an das Feld, auf dem sich die höhere Mächtigkeit dieses Gottes als wirksam erweisen muss. ${ }^{15}$

Es gibt im Christentum also Teilhabe an der höheren Macht. Es gibt aber auch gute Gründe, dass Dietrich Bonhoeffer in indikativischer Redeweise sagen kann: „von guten Mächten wunderbar geborgen“. Der christliche Glaube sagt, dass es ein Kriterium für die Qualität der höheren Macht gibt; sie ist gut, weil und

13 Dietrich Bonhoeffer, Widerstand und Ergebung, Gütersloh 1997, S. 219.

14 Rudolf Otto, Das Heilige. Über das Irrationale in der Idee des Göttlichen und sein Verhältnis zum Rationalen, München 2004, S. 13-37.

15 Diesen Gedanken entfaltet auf spezifische Weise z. B. Johann Baptist Metz, Zur Theologie der Welt, Mainz-München 1968. 
insofern sie für den Menschen gut ist. Umgekehrt formuliert: Sie ist Macht nur insofern, als sie nicht am Menschen und seinem Leben vorbei mächtig ist, sondern für dieses Leben alles will - wie anders sollte man Rettung, Erlösung, Heil umschreiben? Vor der Macht des christlichen Glaubens braucht man also keine Angst zu haben, sie will eine "gute Macht“ sein, und damit geht es um Ethik.

Das Geschäft der Ethik ist dann die Machtkritik: Wenn man um die absolute Güte der wahren Macht (Gottes) weiß, führt das zwingend dahin, die weltlich in Anspruch genommene Macht zu bewerten. Und dabei kann es um Machtpraxen diverser Regime gehen - sei dies in Form von Regierungshandeln, als Macht, die durch kulturelle Traditionen, Gewohnheiten und Mentalitäten ausgeübt wird, oder auch die Macht, die oft gar nicht als solche erkennbar, die in den ideologischen Rahmensetzungen der lebensbestimmenden Systeme von Wirtschaft, Gesundheitswesen oder Medienöffentlichkeit zu finden ist.

Die Rolle der Ethik ist in einem negativen Verfahren zu sehen: Ihr wird eine kritische Funktion zugeschrieben, sie hat das Bestehende, die weltlichen Logiken und Systeme - biblisch gesprochen: die weltlichen Mächte - zu kritisieren, aus den Angeln zu heben, in deren Hybris zu decamouflieren. Sie legt Einspruch ein, sie zeigt Widersprüche auf, sie sagt: „Nein, so nicht!“. Es ist eine prophetische Geste, aus der die ethische Rede erwächst. ${ }^{16}$ Natürlich ist die theologische Ethik der Gegenwart darum bemüht, Antworten in konkreten ethischen Einzelfragen zu geben, sie kann ja gar nicht anders. Aber in ihrem Suchen nach dem, was recht und gerecht ist, ist der treibende Motor stets ihr theologischer Rückgriff auf die größere, umfassendere Gerechtigkeit Gottes.

So sehr nun diese theologische Verankerung notwendig ist, die Ethik bliebe defizitär, wenn man hier stehen bliebe. Denn für die Ethik ist nicht nur eine Rückvergewisserung ex negativo erforderlich, sondern auch - ex positivo - ein prospektives Betrachten des Gegenstandes, aus dem sich erkennen und ermitteln lässt, wie denn nun positiv eine bestimmte Frage $\mathrm{zu}$ entscheiden ist und ein bestimmtes soziales Feld en détail ausgestaltet werden kann. Dieses Defizit wird auch deutlich, wenn man in aktuelle Lehrbücher der theologischen Ethik blickt. Einer der Zentralbegriffe, wenn nicht der Leitbegriff für eine heute aktuelle Rolle der Moraltheologie ist der Begriff der Verantwortung. Dieser Begriff ist natürlich eine unverzichtbare ethische Dimension und er ist hochaktuell, da die $\mathrm{Zu}$ schreibung von Verantwortung bei vielen Problemen der Gegenwart nicht einfach ist - gesellschaftliche Problemlagen werden komplexer, es gibt Diffusion

16 Vgl. zum prophetischen Auftrag theologischer Ethik z. B. Marianne Heimbach-Steins, Universalitätsanspruch und prophetischer Auftrag - kritische Korrektive christlicher Ethik. Zu Selbstverständnis und Perspektiven evangelisch-theologischer Ethik, in: Andreas Lob-Hüdepohl (Hg.), Ethik im Konflikt der Überzeugungen, Freiburg i. Ue. 2004, S. 95-118. 
von Verantwortlichkeit. Dennoch muss man fragen, ob, wenn die Theologie ihre ethische Rede ganz auf dem Verantwortungsterminus aufbaut, nicht ein Bindeglied fehlt, nämlich die Auskunft darüber, warum und wie diese Verantwortung zur Frage nach der Gestaltung steht - und das ist wiederum eine Frage nach der Macht.

Man könnte meinen, die Rede von der Verantwortung hätte die einstmalige Fixierung der Moraltheologie auf individuelle Sünde und Schuld abgelöst. ${ }^{17}$ Meine Hypothese lautet: Mit dem Wechsel von der Sündenfixierung auf die Verantwortungsfixierung ist ein bestimmtes Schema noch nicht durchbrochen, nämlich dass die theologisch-ethische Rede zu eng bei sich bleibt, im inneren Kreis einer religiösen Bestimmung des ethischen Sollens ohne die wirkliche Fühlung des weltlichen Materials. So aber kann sie über dieses weltliche Material nur ex negativo Nichtvereinbarkeitsaussagen ableiten. Darin liegt nun aus meiner Sicht ein wesentlicher Grund dafür, dass die Kategorie der Macht - bei der es ums positive Gestalten geht - theologisch so sehr am Rand steht. Die Theologie hat kein inneres, kein konstruktives Verhältnis zu ihr. ${ }^{18}$

Solche Überlegungen haben freilich einen provokativen Klang. Daher möchte ich im nächsten Schritt entfalten, wie die Kritik zu verstehen ist und wo ich einen theologischen Anknüpfungspunkt sehe, um ihr zu begegnen.

\section{Die Mächte der Welt - nicht mit ihnen, nicht ohne sie}

Wer über die theologisch-ethische Position zur Macht nachdenkt, muss sich mit der Rede von den "gefallenen“ oder - wie es in den protestantischen Traditionen manchmal heißt - den „rebellischen Mächten “19 auseinandersetzen. Gemeint ist die besonders bei Paulus begegnende Rede über die Kräfte und Potentiale, durch welche die Gesellschaft und das Leben des Menschen aus den Fugen geraten. Paulus spricht von Fürstentümern und Gewalten, Thronen und Mächten, aber auch von „Elementen“, „Höhen und Tiefen“, von „Gesetz“ und von „Wissen“. Vieles davon wurde früher als Relikt eines antiken Weltbildes gedeutet und theologisch vernachlässigt, aber seit längerem erscheint es viel angemessener, darin einen schlüssigen Baustein einer Theologie zu sehen, die hohe ethische Relevanz hat. Ich stütze mich in dieser Sicht vor allem auf die Überlegungen von

17 Den auf das Sündenthema vereinseitigten Entwicklungsweg der Moraltheologie zeichnet transparent nach Karl-Heinz Kleber, Historia docet: Zur Geschichte der Moraltheologie, Berlin 2005.

18 Einer der ersten Ansätze der Moraltheologie sich der Herausforderung der Macht-Thematik zu stellen, ist jener von Bernhard Häring: Bernhard Häring, Frei in Christus. Moraltheologie für die Praxis des christlichen Lebens, Freiburg i. Br. 1989.

19 Zu dieser Traditionslinie vgl. John Howard Yoder, Die Politik Jesu, Cuxhafen 2012, S. $179 \mathrm{ff}$. 
John Howard Yoder, einem US-amerikanischen Theologen aus der mennonitischen Tradition. Yoder, der unter anderem bei Karl Barth in Basel studiert hat, ist deswegen interessant, weil er gerade gegen den Hauptstrom der protestantischen Theologie das Verhältnis von Welt und Glaube neu denkt.

Anknüpfungspunkt ist für Yoder die in der neutestamentlichen, besonders der paulinischen Theologie zu findende Hermeneutik der "gefallenen Mächte ${ }^{\text {“20. }}$. Die Mächte dieser Welt werden darin einerseits relativiert, andererseits aber auch für unverzichtbar im Heilshandeln Gottes erklärt und damit ethisch qualifiziert. Im Kolosserhymnus (Kol 1,15-17) kommt das zum Ausdruck: Durch Christus ist der Mensch einerseits den Mächten der Finsternis entrissen (Vers 13), andererseits wurde in Gott alles, auch das Sichtbare, „die Throne und Herrschaften, Mächte und Gewalten“, geschaffen. Wenn, wie es weiter heißt, „alles durch ihn und auf ihn hin geschaffen“ ist, und vor allem, wenn „alles Bestand“ (17) hat, dann folgt der Relativierung eine theologische Würdigung der weltlichen Mächte, die zu bedenken ist.

Mächte und Gewalten dieser Welt sollen also Bestand haben. Diese Sinnspitze erschließt sich umso mehr, wenn man auf den lateinischen und griechischen Wortlaut blickt: Dass alles in Gott „Bestand hat“ (Kol 1,17) wird von der Vulgata mit dem Verbum „constant“ (constare) übersetzt. Im Griechischen Original

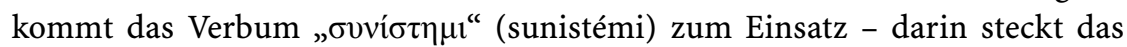
moderne Wort „System“. Man kann daraus schließen, dass die Kontexte, in denen menschliche Existenz stattfindet - Geschichte, Gesellschaft, Natur - ohne Regelhaftigkeit, System, Ordnung, mit anderen Worten: ohne Gestaltung, nicht möglich wären und dass dies keine pragmatische, sekundäre Einsicht des Menschen ist, sondern dass, wie Yoder meint, Gott darum wusste:

„Das Universum wird also nicht willkürlich, sprunghaft und unberechenbar durch eine ununterbrochene Folge neuer göttlicher Eingriffe erhalten. Es wurde als Ordnung erschaffen und, es war gut'. Die Schöpferkraft arbeitete mittelbar durch die die ganze sichtbare Wirklichkeit ordnenden Mächte.“21

In der Sprache seiner Zeit macht Paulus drei fundamentale Aussagen zu den Mächten: 1. Die Strukturen der Welt sind von Gott geschaffen. Sie sind nicht etwas Schöpfungsfremdes, sondern Material des Handelns Gottes am Menschen. 2. Diese Mächte sind allerdings gefallen, das heißt, diese Strukturen, die dem Menschen dienen sollen, tendieren dazu, ihn zu beherrschen (oder, biblisch gesprochen: zu verknechten). 3. Und dennoch können sich die Mächte der Souveränität von Gottes Vorsehung nicht ganz entziehen bzw. wie Yoder sagt: „Er kann sie immer noch gebrauchen, um Gutes zu wirken. ${ }^{\text {(22 }}$

20 Ebd., S. 160-163.

21 Ebd., S. 160.

22 Ebd., S. 161. 
Diese weltlichen Strukturen und Mächte können heute umfassend wahrgenommen werden: als Strukturen eines religiösen Systems, als intellektuelle Strukturen, als moralische Strukturen (Verhaltenskodices, Bräuche, Gewohnheiten) oder als politische Strukturen (die Kräfte von Ethnie, Klasse, Staat, Volk und Wirtschaft). Ihrem Wesen nach können all diese Strukturen als Teile einer guten Schöpfung angesehen werden. Ohne übergeordnete religiöse, intellektuelle, moralische und soziale Strukturen gäbe es weder Gesellschaft noch Geschichte noch den Menschen. Die theologische Aussage lautet demnach: Es geht nicht ohne sie. Dieses Prozedere ex negativo war jedoch auch oben schon skizziert worden - worauf kommt es nun an? Es kommt darauf an, das Mit-denMächten-sein, deren Konstanz und Systemhaftigkeit, ihr Dabei-bleiben auszuhalten, es als Ausgangspunkt, mehr noch: als vorgespurte Fährte zu nehmen für ein ethisches Vorgehen. Das veranschaulicht nochmals Yoder:

„Will Gott den Menschen also in seiner Menschlichkeit retten, so können die Mächte nicht einfach zerstört, beiseite geschoben oder ignoriert werden. Ihre Herrschaft muss gebrochen werden. Das hat Jesus getan, konkret und historisch, als er unter den Menschen wirklich frei und menschlich lebte. ${ }^{\text {“23 }}$

Abschließend möchte ich nun im dritten Punkt einen Schritt hinter den bisherigen Argumentationsgang zurücktreten und versuchen, ihn einzuordnen: Was ist mit einer solchen Perspektive eigentlich gewonnen?

\section{Ein Neueinsatz in der theologischen Ethik? Erträge und Perspektiven}

Man mag einwenden, dass der skizzierte Gedankengang sehr abstrakt ist. Weiß die theologische Tradition nicht schon um die Relevanz des weltlichen Materials für die Ethik? Die Antwort lautet: Ja, theoretisch - mit dem Inkarnations- und Schöpfungsglauben - weiß sie das, aber dennoch steht ein gutes Stück theologischer Arbeit noch aus. Denn man steht vor einem Dilemma: Auf der einen Seite gab es in der Tradition katholischer Moraltheologie den - bis heute wirkmächtigen - Versuch, Heils- und Schöpfungsordnung so eng aneinander zu binden, dass sich das ethische Soll jeweils unmittelbar aus einer theologischen Einsicht ergab. Die Sackgassen dieses Weges haben die Moraltheologie immer weiter vom realen Lauf der Dinge isoliert. Je konkreter und weltlicher die Fragen waren, die die Moraltheologie behandelte (man denke beispielsweise an die Frage der

23 Ebd., S. 164. 
moralischen Zulässigkeit der Straßenbeleuchtung im 19. Jahrhundert), desto weltferner, unglaubwürdiger und letztlich isolierter wurde sie. ${ }^{24}$

Auf der anderen Seite stehen nun die Bemühungen, gerade die Eigengesetzlichkeit der Schöpfungsordnung zu betonen. Gaudium et Spes, die Pastoralkonstitution des II. Vatikanischen Konzils, etwa spricht von der „Eigengesetzlichkeit“ aller „Einzelwirklichkeiten“ ${ }^{\text {" } 5}$ und insgesamt findet sich in der neueren katholischen ethischen Tradition diese Betonung einer Autonomie der Naturordnung. Yoders Einspruch macht sich hieran fest: Wenn die theologische Ethik dabei stehen bleibt, so Yoder, habe „Jesus Christus direkt kaum etwas mit den Schöpfungsordnungen zu tun“. Der hier mit Yoder skizzierte Ansatz kehrt aber nicht einfach zu den alten, viel zu einfachen Antworten zurück, mit denen Theologie und Ethik verkoppelt waren, sondern er will eine hermeneutisch aufgeklärte Gestalt einer solchen, im engeren Sinne theologischen Ethik sein. Um es klar zu sagen: Die Autonomie der Naturordnung wird in einer solchen Sicht nicht „kassiert“, sondern theologisch eingebunden. Was also ist damit gewonnen?

Gewonnen ist damit zunächst die Erkenntnis, dass Ethik kein zweites Momentum des christlichen Glaubens ist, sondern im Innern dieses Glaubens beheimatet bleibt. Ethik bezieht sich nicht auf diesen oder jenen „Anwendungsfall“ eines vorgängigen religiösen Inhaltes, der aus sich heraus erst einmal mit den Herausforderungen dieser modernen Welt nicht viel zu tun hätte. Eingebunden bleibt die Ethik, insofern sie den Glauben selbst als eine soziale Praxis versteht. Jesu Predigt ist eine gemeinschaftsbildende und damit soziale Praxis, sein Umkehrruf ist nicht ein „rein“ theologischer Ruf, der moralfrei wäre, sondern er fordert zu einem neuen, anderen, einem befreiten und befreienden Tun auf. Moral wiederum hat dann nicht in erster Linie die Funktion eines normativen Fallbeils mit Blick auf diese oder jene Praxis, sondern sie ist die Lehre vom Einüben einer neuen Praxis.

Gewonnen ist zudem, dass dort, wo die "gefallenen Mächte" theologisch wieder aufgefangen werden, deutlich wird, dass sie das Feld sind, auf dem sich theologisch-ethische Reflexion zu bewegen hat. Das mag trivial klingen, ist es aber nicht, denn wenn man diese Aussage ernst nimmt, bedeutet das auch, dass

24 Das Ringen um eine „autonome Moral im christlichen Kontext“ war schließlich wie eine intellektuelle Reformbewegung, um die Theologie wieder aus dem Abseits herauszuholen. (Z.B. Alfons Auer, Autonome Moral und christlicher Glaube, Düsseldorf 1971.)

25 „Durch ihr Geschaffensein selber nämlich haben alle Einzelwirklichkeiten ihren festen Eigenstand, ihre eigene Wahrheit, ihre eigene Gutheit sowie ihre Eigengesetzlichkeit und ihre eigenen Ordnungen, die der Mensch unter Anerkennung der den einzelnen Wissenschaften und Techniken eigenen Methode achten muß.“ (Papst Paul VI., Gaudium et Spes, Pastoralkonstitution über die Kirche in der Welt von heute, 36.) 
man sozialer Praxis eine normative Kompetenz zubilligt. ${ }^{26}$ Das Feld des Sozialen - Erfahrungen von Menschen, deren Lebenswirklichkeit und die Sachgesetzlichkeiten der Welt - das alles muss dann mehr sein als ein Steinbruch für ethische Normen, die ihre Normativität von woanders her beziehen.

Pate einer solchen Hermeneutik sozialer Praxis ist auf philosophischer Seite etwa der Ansatz von Axel Honneth („Das Recht der Freiheit“) ${ }^{27}$, aber auch die Überlegungen zur „affirmativen Genealogie“ des Soziologen Hans Joas. ${ }^{28}$ Ihnen geht es in verschiedenen Varianten darum einzugestehen, dass die in sozialer Praxis sich ergebende Interaktion für die Herausbildung eines normativen Anspruchs unumgehbar ist. Man könnte vereinfacht sagen: Normen fallen nicht vom Himmel, sie wachsen in Prozessen sozialer Praxis. Darin entwickelt sich ihr Anspruch, er wird unter den Bedingungen historischer und sozialer Kontingenz variiert und in seiner Tragweite moduliert. Soziale Praxis wird gewissermaßen zum „Entwickler“ eines normativ-moralischen Anspruchs. Ohne Aussagen darüber, wie sich abstrakte ethische Normen in Kontexten geschichtlich-sozialer Wirklichkeit verkörpern, wären solche Normen von äußerst geringem Aussagewert.

\section{4. $\quad$ Fazit}

Damit komme ich schließlich noch einmal zur Frage der Macht zurück: Das Nachdenken über ein spezifisches theologisches Thema - Macht und Herrschaft - hat mich zu einer Reflexion über Methode und Hermeneutik der theologischen Ethik geführt: Macht und Herrschaft sind zwar zunächst Stiefkinder der theologischen Ethik, sie sollten aber, wie ich nahegelegt habe, viel stärker als Schlüsselkategorien erkannt und integriert werden. Der nächste Schritt - den ich an dieser Stelle jedoch nicht mehr gehen kann - bestünde nun darin zu überlegen, was es für einzelne ethische Handlungsfelder bedeutet, die soziale Praxis als normativ mitverantwortliche Instanz ernst zu nehmen. ${ }^{29}$

Hannah Arendt beschreibt Macht als Qualität jeder Gemeinschaftsbildung, unableitbar, ursprünglich. ${ }^{30}$ An der Wurzel dieser ,solidaristischen ' Auffassung

26 Eine grundständige Reflexion zu diesem Gedanken findet sich z. B. in: Alexander Filipović, Erfahrung - Vernunft - Praxis. Christliche Sozialethik im Gespräch mit dem philosophischen Pragmatismus, Paderborn 2015.

27 Axel Honneth, Das Recht der Freiheit. Grundriss einer demokratischen Sittlichkeit, Frankfurt a. M. 2011.

28 Hans Joas, Die Sakralität der Person. Eine neue Genealogie der Menschenrechte, Berlin 2011.

29 Mit Blick auf das Feld der Menschenrechte habe ich dies bereits erörtert in: Daniel Bogner, Das Recht des Politischen. Ein neuer Begriff der Menschenrechte, Bielefeld 2014.

30 Vgl. Hannah Arendt, Macht und Gewalt. 
von Macht steht für Arendt eine Fähigkeit des Menschen. Es ist eine hoffnungsvolle Anthropologie, die hier durchscheint. Nicht im Exil seiner selbst, sondern in der Kooperation, in der Verwiesenheit auf die anderen entwickelt sich für den Menschen die Kraft, etwas zu gestalten oder zu verändern und wirklich schöpferisch zu sein. Man kann darin die Figur von den gefallenen Mächten wiedererkennen, die zum Ausgangspunkt für wirkliche Geschichtsmächtigkeit werden. Theologische Ethik, so meine Schlussfolgerung, ist nicht nur die Disziplin für das praktische Entscheiden aus christlichem Geist, sie ist viel breiter. Den Fragen, die Alltag und Lebenswirklichkeit täglich stellen und die nach Entscheidungen verlangen, kann sie nicht ausweichen. Aber davor, daneben und darüber hinaus ist sie getrieben zu erkunden: Was ist eigentlich der Stoff, aus dem der Mensch sich seine Werte macht? Was sind die Bedingungen, unter denen sich Menschen vereinzeln und ihre Ideen absolut setzen, was können die Bedingungen sein, welche die Fähigkeit des Menschen freisetzen, in Kooperation mit anderen - und das heißt ethisch auch: unter Einbeziehung fremder Sachkenntnis, der Subjektperspektiven der anderen - machtvoll zu handeln?

Eine solche Perspektive wäre auch eine Chance für das Selbstverständnis theologischer Ethik: Nicht mit dem Fokus auf einzelne „Fälle“, über die es zu befinden gilt, sollte sie vorgehen, sondern mit dem Interesse für Kontexte, die Handeln ermöglichen, für Gelegenheitsstrukturen, die Menschen zum Missbrauch ihrer Möglichkeiten einladen, und für Ressourcen, aus denen schöpfen will, wer dem Guten Geltung verschaffen möchte.

\section{Quellen}

Auer, Alfons, Autonome Moral und christlicher Glaube, Düsseldorf 1971.

Arendt, Hannah, Macht und Gewalt, München 1975.

Bachmann, Michael, Gott, der „Allmächtige“: Der Pantokrator der Bibel und die Theodizeediskussion, Freiburg 2019.

Bachmann, Michael, Göttliche Allmacht und theologische Vorsicht. Zu Rezeption, Funktion und Konnotationen des biblisch-frühchristlichen Gottesepithetons pantokrator, Stuttgart 2002.

Bogner, Daniel, Diese Kirche tötet, in: feinschwarz.net, vgl. https://www.feinschwarz.net/ diese-kirche-toetet/ (letzter Zugriff: 20.05.2019).

Bogner, Daniel, Das Recht des Politischen. Ein neuer Begriff der Menschenrechte, Bielefeld 2014.

Bonhoeffer, Dietrich, Widerstand und Ergebung, Gütersloh 1997.

Filipović, Alexander, Erfahrung - Vernunft - Praxis. Christliche Sozialethik im Gespräch mit dem philosophischen Pragmatismus, Paderborn 2015.

Gutiérrez, Gustavo, Theologie der Befreiung, München-Mainz 1975.

Häring, Bernhard, Frei in Christus. Moraltheologie für die Praxis des christlichen Lebens, Freiburg i. Br. 1989. 
Heimbach-Steins, Marianne, Universalitätsanspruch und prophetischer Auftrag - kritische Korrektive christlicher Ethik. Zu Selbstverständnis und Perspektiven evangelisch-theologischer Ethik, in: Andreas Lob-Hüdepohl (Hg.), Ethik im Konflikt der Überzeugungen, Freiburg i. Ue. 2004, S. 95-118.

Hesslinger, Mark R., Das Bild des Pantokrators im Kuppelmosaik von Santa Maria dell'Ammiraglio in Palermo, in: Eckhard Leuschner / Mark R Hesslinger (Hg.), Bild Gottes in Judentum, Christentum und Islam, Petersberg 2009, S. 93-116.

Honneth, Axel, Das Recht der Freiheit. Grundriss einer demokratischen Sittlichkeit, Frankfurt a. M. 2011.

Hübenthal, Christoph, Macht. Typologische und legitimationstheoretische Anmerkungen, in: Werner Veith / Christoph Hübenthal (Hg.), Macht und Ohnmacht. Konzeptionelle und kontextuelle Erkundungen, Münster 2005, S. 45-47.

Iorio, Marco, Macht, in: Martin Hartmann / Claus Offe (Hg.), Politische Theorie und Politische Philosophie. Ein Handbuch, München 2011, S. 246-249.

Joas, Hans, Die Sakralität der Person. Eine neue Genealogie der Menschenrechte, Berlin 2011.

Kästner, Erich, Kurz und bündig. Epigramm, Zürich 1950.

Kleber, Karl-Heinz, Historia docet: Zur Geschichte der Moraltheologie, Berlin 2005.

Korff, Wilhelm, Ethik. C. Theologisch. III. Systematisch, in: Lexikon für Theologie und Kirche 3, Freiburg-Basel-Rom-Wien 1995, S. 923-929.

Metz, Johann Baptist, Zur Theologie der Welt, Mainz-München 1968.

Otto, Rudolf, Das Heilige. Über das Irrationale in der Idee des Göttlichen und sein Verhältnis zum Rationalen, München 2004, S. 13-37.

Paul VI., Gaudium et Spes, Pastoralkonstitution über die Kirche in der Welt von heute, vgl. http://www.vatican.va/archive/hist_councils/ii_vatican_council/documents/vat-ii_ const_19651207_gaudium-et-spes_ge.html (letzter Zugriff: 02.07.2019).

Steinkamp, Hermann, Lange Schatten der Pastoralmacht: theologisch-kritische Rückfragen, Berlin 2015.

Themenheft „Macht und Kirche. Biblische Impulse“ der Zeitschrift Bibel und Kirche 2/2019.

Wagner, Doris, Spiritueller Missbrauch in der katholischen Kirche, Freiburg 2019.

Weber, Max, Wirtschaft und Gesellschaft. Grundriß der verstehenden Soziologie. Studienausgabe, 5.Aufl., Tübingen 1980.

Yoder, John Howard, Die Politik Jesu, Cuxhafen 2012. 
Open-Access-Publikation im Sinne der CC-Lizenz BY 4.0

(C) 2020, Vandenhoeck \& Ruprecht $\mathrm{GmbH} \&$ Co. KG, Göttingen ISBN Print: 9783847111658 - ISBN E-Lib: 9783737011655 


\section{Zum Stellenwert theologischer Argumente für die Begründung, Motivation und Entfaltung der Ethik}

Mit dem Zusammenhang der Stichworte Ethik, Religion und Menschenrechte sowie Gerechtigkeit und Dialog spannt diese Festschrift für Ingeborg Gabriel ein Themenfeld auf, dem nicht nur für das Denken der geehrten österreichischen Sozialethikerin, sondern zugleich für die aktuellen Debatten um das Selbstverständnis der Fachdisziplin „Christliche Sozialethik“ eine prägende Bedeutung zukommt. Lange stand die Verhältnisbestimmung zwischen Ethik und Religion im Schatten eines säkularen Menschenrechts- und Gerechtigkeitsdiskurses, der durch Absehung von Bezugnahmen auf religiöse Perspektiven nach Akzeptanz in der pluralen Gesellschaft strebte. Die religiöse Dimension der Ethik wurde im Rahmen der normativen Gesellschaftstheorien des Liberalismus als Privatsache des individuellen Ringens um gutes Leben verstanden und nicht als Angelegenheit von Gerechtigkeit. ${ }^{1}$ Dem kam in der katholischen Ethik das lange dominierende naturrechtliche Paradigma entgegen, das beanspruchte, aus einer übergeordneten, allgemein vernünftigen Perspektive für das Gemeinwohl in pluraler Gesellschaft sprechen zu können. ${ }^{2}$ Die Konsequenz war eine Abstinenz gegenüber spezifisch religiösen Inhalten und Axiomen auch in weiten Teilen Christlicher Sozialethik. ${ }^{3}$

Die postsäkulare Rückkehr der Religionen in den öffentlichen Raum ${ }^{4}$ hat die Diskussionslage verändert: Religion matters, sei es positiv als sinnstiftende

1 Zur Konsequenz dieser Konzeption für die hier zur Debatte stehenden Fragen vgl. Markus Vogt, Das Spannungsfeld theologischer und philosophischer Ethik als Ausgangspunkt für die Gliederung normativer Reflexion, in: Wilhelm Korff / Markus Vogt (Hg.), Gliederungssysteme angewandter Ethik, Freiburg 2016, S. 711-737.

2 Vgl. dazu Ingeborg Gabriel, Naturrecht, Menschenrechte und die theologische Fundierung der Sozialethik, in: Markus Vogt (Hg.), Theologie der Sozialethik, Freiburg 2013, S. 229-251.

$3 \mathrm{Zu}$ den damit verbundenen Axiomen des Faches sowie den heutigen Veränderungen der Theoriebildung vgl. Markus Vogt (Hg.), Theologie der Sozialethik, Freiburg 2013; Ders., Die Theo-Logik Christlicher Sozialethik, in: Johann Platzer / Elisabeth Zissler (Hg.), Bioethik und Religion. Theologische Ethik im öffentlichen Diskurs, Baden-Baden 2014, S. 143-173.

4 Jürgen Habermas, Glauben und Wissen. Rede zur Verleihung des Friedenspreises des Deutschen Buchhandels, Frankfurt 2001; aus soziologischer Perspektive: Detlef Pollack, Säkula- 
Motivation und konkret-lebensweltliche Entfaltung der Moral, was auch hinsichtlich gesellschaftlicher Zusammenhänge in neuer Weise gewürdigt wird, sei es als Konfliktstoff im Aufeinandertreffen unterschiedlicher Glaubens- und Moralvorstellungen. Ein positiver Beitrag religiöser Ethik für ein friedliches Zusammenleben lässt sich vor diesem Hintergrund nur unter der Bedingung von Dialogfähigkeit sichern. Ingeborg Gabriel hat dies früh erkannt und das dialogische Konzept einer „Ökumenischen Sozialethik“ als Programmwort ihres Fachverständnisses entfaltet. ${ }^{5}$ Ebenso hat sie vor dem Hintergrund ihrer internationalen Erfahrungen bei den Vereinten Nationen von Anfang an die Schlüsselbedeutung der Menschenrechte betont. ${ }^{6}$ Die folgenden Ausführungen erkunden das hiermit skizzierte Debattenfeld im Blick auf den Stellenwert theologischer Argumente für die Begründung, Motivation und Entfaltung der Ethik.

\section{Postsäkulare Sozialethik}

Das Bedürfnis nach einem klar erkennbaren theologischen Profil Christlicher Sozialethik ergibt sich auch aus der veränderten gesellschaftlichen Situation:

„Die Christen befinden sich zunehmend in einer Minderheitenposition sowie in einem religiös, ethisch und kulturell pluralen Kontext. Die Chancen einer direkten korporatistischen Beeinflussung staatlicher Gesetzgebung werden schwächer. Die Kirche muss sich in der Zivilgesellschaft auf überzeugende Weise Gehör verschaffen. Dies kann nur gelingen, wenn ihre Positionen ein klar erkennbares Profil aufweisen, das auch theologisch fundiert ist. Auch dies verlangt eine explizit theologische Argumentation, die freilich so kommuniziert werden muss, dass sie auch für Nicht- oder Andersgläubige möglichst verständlich und einsichtig erscheint. Sozialethik hat hier neue Übersetzungsleistungen zwischen grundlegenden Aussagen des Glaubens und der Gestaltung gesellschaftlichen Lebens zu erbringen. “7

Christliche Sozialethik gewinnt ihr Profil in einer zwischen theologischen und säkularen Sprachspielen vermittelnden Mehrsprachigkeit: Einerseits bleibt die Ausrichtung auf die allgemeine Vernunft sowie anthropologisch-humanwissenschaftliche Grunddaten der conditio humana gerade für den wissenschaftlichen Anspruch christlicher Ethik unverzichtbar. Andererseits erscheint dies

risierung - ein moderner Mythos? Studien zum religiösen Wandel in Deutschland, Tübingen 2003.

5 Ingeborg Gabriel (Hg.), Politik und Theologie in Europa. Perspektiven ökumenischer Sozialethik, Ostfildern 2008.

6 Als neuere Arbeit hierzu vgl. Ingeborg Gabriel, Menschenrechte und Religionen - Verbündete oder Gegner?, in: Peter G. Kirchschläger (Hg.), Die Verantwortung von nichtstaatlichen Akteuren gegenüber den Menschenrechten, Zürich 2017, S. 33-52.

7 Vgl. Markus Vogt / Ingeborg Gabriel (u. a.), Theologien in der Sozialethik, in: Vogt (Hg.), Theologie der Sozialethik, S. 7-20, hier: S. $12 \mathrm{f}$. 
heute nicht hinreichend. Denn es sind nicht allein abstrakte moralische Begründungen, die die Geltungskraft von Moral ausmachen, sondern oft die dahinter stehenden, meist religiös geprägten Welt- und Menschenbilder sowie Ethosformen und sinnstiftenden „großen Erzählungen“, die den Rahmen und die Geltungskraft der Moral in der Gesellschaft prägen. ${ }^{8}$

Das aber hat zur Konsequenz, dass Christliche (Sozial)Ethik gerade nicht von den spezifisch kulturellen und religiös geprägten Gehalten und Erfahrungskontexten abstrahieren sollte, sondern diese vielmehr so in den Diskurs einzubringen hat, dass daraus der „Sitz im Leben“ ihrer moralischen Vorstellungen deutlich wird. Da diese Erfahrungen und Sinnvorstellungen aber in einer pluralen Gesellschaft naturgemäß unterschiedlich sind, kommt es darauf an, sich über den Binnenraum der eigenen Gruppe hinaus verständlich zu machen.

Methodisch reflektiert wird diese Zweisprachigkeit insbesondere in der „Öffentlichen Theologie“ . Diese versteht sich explizit als Gegenentwurf zum Modell der Pazifizierung religiöser Konflikte durch Privatisierung, die zumindest dem christlichen Anspruch auf allgemeine Vernunft, Humanitäts- und Gerechtigkeitsstandards nicht gerecht wird. Sie ist insofern eine Antwort auf die Habermas'sche Diagnose der postsäkularen Gesellschaft, als sie mit dieser davon ausgeht, dass der Zusammenhalt der Gesellschaft und ein angemessenes Verständnis ihrer Grundbegriffe nicht allein über abstrakte, universale, religionsabstinent formulierte moralische Standards gesichert werden könne. Christliche Sozialethik im Anspruch Öffentlicher Theologie bedarf einer vertieften Integration biblischer Hermeneutik, um die ethischen Grundbegriffe moderner Demokratie - z. B. Menschenwürde/Personalität, Gerechtigkeit, Freiheit, Fortschritt, Entwicklung oder die Entmythologisierung politischer Macht - stärker von ihren biblischen Wurzeln und christlichen Zusammenhängen her zu erschließen und kritisch zu reflektieren. ${ }^{10}$

Dies setzt voraus, dass die weltanschauliche Neutralität des Staates nicht als politische Verallgemeinerung einer säkularistischen Weltsicht verstanden

8 Man kann die großen Erzählungen europäischer Ethik als Gebote, Tugenden, Pflichten und Bereichsethiken zusammenfassen, wobei diese Modelle ihre Überzeugungskraft stets durch historisch eingebettete Auseinandersetzungen und Sinndeutungen gewonnen haben; vgl. Wilhelm Korff / Markus Vogt (Hg.), Gliederungssysteme angewandter Ethik. Ein Handbuch. Nach einem Projekt von Wilhelm Korff, Freiburg 2016.

9 Zum Konzept der Öffentlichen Theologie vgl. José Casanova, Public Religions in the Modern World, Chicago 1994; Heinrich Bedford-Strohm, Öffentliche Theologie in der Zivilgesellschaft, in: Ingeborg Gabriel (Hg.), Politik und Theologie in Europa. Perspektiven ökumenischer Sozialethik, Ostfildern 2008, S. 340-357; Christian Albrecht / Reiner Anselm, Öffentlicher Protestantismus. Zur aktuellen Debatte um gesellschaftliche Präsenz und politische Aufgaben des evangelischen Christentums, Zürich 2017.

$10 \mathrm{Vgl}$. Thomas Söding, Biblische Sozialethik und christliche Hermeneutik. Neutestamentliche Anfragen, in: Vogt (Hg.), Theologie der Sozialethik, S. 146-188, hier: S. 174-181. 
wird. ${ }^{11}$ Es ist vielmehr davon auszugehen, dass auch religiöse Gemeinschaften das Recht haben, ihr Orientierungsangebot in ihrer genuinen Sprache in den öffentlichen Raum einzubringen:

„Säkularisierte Bürger dürfen, soweit sie in ihrer Rolle als Staatsbürger auftreten, weder religiösen Weltbildern grundsätzlich ein Wahrheitspotential absprechen, noch den gläubigen Mitbürgern das Recht bestreiten, in religiöser Sprache Beiträge zu öffentlichen Diskussionen zu machen. Eine liberale politische Kultur kann sogar von den säkularisierten Bürgern erwarten, dass sie sich an Anstrengungen beteiligen, relevante Beiträge aus der religiösen in eine öffentlich zugängliche Sprache zu übersetzen. ${ }^{\text {“12 }}$

Die Überwindung der „Theologieabstinenz“ zugunsten einer expliziten Reflexion theologischer Hintergründe wird im Kontext der postsäkularen Gesellschaft zu einer aktuellen Aufgabe Christlicher Sozialethik. Dabei sind jedoch Versuche, das Theologische unmittelbar im Sinne einer Legitimation bestimmter Staatsformen und Herrschaftsverhältnisse zu fassen, vor dem Hintergrund der geschichtlichen Erfahrungen problematisch. ${ }^{13}$ Politische Theologie bewährt sich vielmehr gerade in der Unterscheidung der Ebenen und damit der Abwehr politischer Vereinnahmungen des Theologischen. Von daher betrachtet sie die Säkularisierung des Staates, d.h. seine Entlastung von jeglichen Ansprüchen der Heilsvermittlung, als Konsequenz des christlichen Glaubens. Der säkulare Staat ist jedoch darauf angewiesen, dass die Menschen aus ihren persönlichen, meist auch religiös geprägten Wertüberzeugungen heraus verantwortlich handeln und sich auch öffentlich engagieren. Dabei ist der Einsatz für Freiheit, Frieden und Gerechtigkeit von Seiten einzelner Christen wie von Seiten der Kirchen ein elementares Zeugnis des Glaubens und keineswegs bloß „humanistisches Appeasement ${ }^{\text {“14 }}$.

Das „postsäkulare“ Bewusstsein für die Notwendigkeit, den geistig-kulturellen Wurzelgrund des Rechts und der Politik demokratisch verfasster Gesellschaften zu pflegen, um seine Begriffe zu verstehen, sein Ethos lebendig zu halten

11 Vgl. Jürgen Habermas, Zwischen Naturalismus und Religion. Philosophische Aufsätze, Frankfurt 2005; Ders.: Glaube und Wissen. Zur Diskussion des Habermas'schen Religionsverständnisses vgl. Michael Reder / Josef Schmidt, Ein Bewusstsein von dem, was fehlt. Eine Diskussion mit Jürgen Habermas, Frankfurt 2008.

12 Habermas, Zwischen Naturalismus und Religion, S. 115.

13 Vgl. dazu Friedrich W. Graf / Heinrich Meier (Hg.), Politik und Religion. Zur Diagnose der Gegenwart, München 2013; Jürgen Manemann, Carl Schmitt und die Politische Theologie. Politischer Anti-Monotheismus, Münster 2002.

14 Vgl. Wolfgang Spindler, „Humanistisches Appeasement“? Hans Barions Kritik an der Staatsund Soziallehre des Zweiten Vatikanischen Konzils, Berlin 2011; zur Kennzeichnung eines spezifisch christlichen Humanismus ist immer noch lesenswert: Jacques Maritain, Christlicher Humanismus, Heidelberg 1950; aktuell: Arnd Küppers, Menschenrechte im Spannungsfeld zwischen Gottesrede und säkularer Politik - eine sozialethische Sicht, in: Vogt (Hg.), Theologie der Sozialethik, S. 300-326, hier: S. 314-316. 
und seine Rechtauslegung nicht erstarren zu lassen, stellt eine Chance aber auch einen hohen Anspruch an Christliche Sozialethik dar. Entscheidend ist das Offenhalten moderner Lebens- und Gesellschaftsentwürfe auf den Horizont des Unverfügbaren hin, was sich sozialethisch vor allem in der Achtung der unverfügbaren Würde des Menschen konkretisiert. Ohne diesen Horizont, der das Wissen übersteigt, jedoch keineswegs negiert, greift die Begründung der Ethik zu kurz. ${ }^{15}$

\section{Die paradoxe Spannung zwischen christlichem Glauben und Menschenrechten}

Ein entscheidendes Spannungsfeld für die Debatte um das Verhältnis von religiösen und säkularen Argumenten ist die Ethik der Menschenrechte: Einerseits sind diese der Inbegriff der Emanzipation der Ethik von spezifisch kulturgebundenen und religiösen Prämissen hin zu einer Ethik mit universalem Anspruch. Ihr sozialethischer Mehrwert für Konfliktbewältigung und Friedenssicherung liegt gerade darin, dass sie in ihrer Begründung nicht auf spezifisch religiöse Axiome zurückgreifen. Denn nur so können sie als Vermittlung zwischen Menschen und Gesellschaften mit unterschiedlichen Glaubensausrichtungen und kulturellen Prägungen dienen. Andererseits stellen die Menschenrechte eine konsequente Übersetzung des christlichen Glaubens an die jedem Menschen unabhängig von Verdienst und sozialem Status zukommende Würde in die Sprache der Politik dar. ${ }^{16}$ Man kann das Verhältnis zwischen christlichem Glauben und den Menschenrechten als asymmetrisch kennzeichnen: Wer sich zum Christentum bekennt, verpflichtet sich damit auf die Menschenrechte. Wer die Menschenrechte verteidigt, muss dabei jedoch nicht notwendig auf christliche Begründungen zurückgreifen.

Dieser Asymmetrie zwischen christlichem Glauben und den Menschenrechten eignet eine paradoxe Tiefenstruktur, ${ }^{17}$ die in den vergangenen Jahrzehnten

15 Vgl. Volker Gerhardt, Glauben und Wissen. Ein notwendiger Zusammenhang, 3. Aufl., Stuttgart 2016, S. 37-49; Ludger Honnefelder, Im Spannungsfeld von Religion und Ethik, Weilerswist 2017, S. 189-207; zu einer zeittheoretischen Ausdeutung der Unverfügbarkeit und ihrer Bedeutung für die theologische Dimension Christlicher Sozialethik vgl. HansJoachim Höhn, Handeln über den Tag hinaus. Zeithorizonte der Sozialethik, in: Vogt (Hg.), Theologie der Sozialethik, S. 92-126.

16 Vgl. Gabriel, Menschenrechte und Religionen.

17 Ludger Honnefelder bringt die Paradoxie auf den Punkt: „Der Offenbarungsgaube selbst zwingt zur Annahme offenbarungsunabhängiger Ethik" (Honnefelder, Im Spannungsfeld, S. 13). Vor diesem Hintergrund ist die übliche Frage nach dem Proprium christlicher Ethik falsch gestellt, wenn sie dieses an dem festzumachen sucht, was allgemeiner Vernunft nicht zugänglich ist. 
immer wieder Anlass für heftige Kontroversen um die Konzeption von Moraltheologie und Christlicher Sozialethik wurden: Nicht wenige sehen in der Anerkennung der Autonomie der praktischen Vernunft und damit der säkularen Begründbarkeit und dem Freiheitsanspruch der Menschenrechte eine Kapitulation hinsichtlich des christlichen Propriums der Moral. Die „autonome Moral“ wurde beispielsweise in der Enzyklika Splendor veritatis lehramtlich verurteilt. ${ }^{18}$ Im April 2019 knüpfe Josef Ratzinger/Papst emeritus Benedikt XVI. mit seinen Attacken gegen Schüller und Böckle, deren Modell der Moral das Wesen des Christentums selbst infrage stelle, daran an. ${ }^{19}$ Die Russisch-Orthodoxe Kirche trat im UN-Menschrechtsrat für einen „kulturellen Vorbehalt“ gegenüber den Menschenrechten ein und versuchte damit in einer Linie mit den Regierungen von Russland, China und anderen Staaten, die dem internationalen Tribunal von Menschenrechtsverletzungen entgehen wollen, die Menschenrechte als Konzept westlich-säkularer Gesellschaften zu relativieren und ihnen den Anspruch universaler Geltung abzusprechen. ${ }^{20}$

Zuzubilligen ist, dass die Frage nach dem Proprium christlicher Moral in der geistigen Situation der nicht nur postsäkularen, sondern oft zugleich auch postchristlichen Gesellschaften in neuer Weise virulent wird. Es kommt jedoch darauf an, dabei nicht in unproduktive Argumentationsmuster zurückzufallen, sondern die Erkenntnisfortschritte der vernunft- und menschenrechtlich fundierten Moral anzuerkennen und dennoch den Stellenwert theologischer Argumente für die Ethik stark zu machen.

Am Beispiel der Genealogie der Menschenrechte hat Hans Joas eindrücklich gezeigt, wie substantiell der religiöse Anteil im geschichtlichen Prozess ihrer Entstehung und Praxis ist, zugleich aber auch, wie sehr sie gegenüber jeglicher religiösen Interpretation eigenständig sind und sein müssen. ${ }^{21}$ Demnach hat sich die gesellschaftliche Geltungskraft der Menschenrechte wesentlich in der Geschichte konkreter Auseinandersetzungen mit Gewalt und Ausgrenzungen bestimmter Personengruppen etabliert, z. B. als Kritik der Folter oder der Skla-

18 Johannes Paul II., Splendor veritatis. Enzyklika über einige grundlegende Fragen der Morallehre, Vatikan 1993, Nr. 31-53.

19 Benedikt XVI., Klima der 68er mitverantwortlich für Missbrauchsskandal (Wortlaut und Reaktionen), vgl. https://www.katholisch.de/aktuelles/aktuelle-artikel/benedikt-xvi-68ersind-verantwortlich-fur-missbrauchsskandal (letzter Zugriff: 07.06.2019).

20 Daniel Legutke, Zwischen islamischen Werten und allgemeinen Menschenrechten. Zur Rolle der Organisation für Islamische Zusammenarbeit im UN-Menschenrechtsrat, in: Amosinternational 2/2013, S. 25-35.

21 Hans Joas, Die Sakralität der Person. Eine neue Genealogie der Menschenrechte, Berlin 2011; dazu auch Bernhard Laux (Hg.), Heiligkeit und Menschenwürde. Hans Joas' Genealogie der Menschenrechte im theologischen Gespräch, Freiburg 2013; Rudolf Uertz, Menschenrechte im Spannungsfeld zwischen Gottesrede und säkularer Politik, in: Vogt (Hg.), Theologie der Sozialethik, S. 279-299. 
venhaltung. Dieses konkrete Ethos der Überwindung von Gewalt und Ausgrenzung im Lebensalltag hat die abstrakte Formulierung der Menschenrechte vorbereitet und ihnen einen gesellschaftlichen Ort gegeben. Da das Ethos immer auch kulturell und religiös geprägt ist, wird hier ein entscheidendes Feld für die Relevanz religiöser Zugänge zur Ethik sichtbar, ohne damit ihrem universalen Geltungsanspruch die Spitze abzubrechen und die Ethik auf partikuläre Kontexte zu verkürzen. ${ }^{22}$

Die Achtung der unbedingten Würde des Menschen muss sich immer wieder neu in Situationen von Leid, Krankheit, Behinderung, Schuld, Migration und erweiterten technischen Möglichkeiten (z.B. den fließenden Übergängen zwischen Leidvermeidung und Selektion im Kontext der neuen biomedizinischen Entwicklungen) bewähren. Letztlich ist der christliche Anspruch einer humanen Moral nicht allein durch abstrakte Regeln zu sichern, sondern nur in Verbindung mit dem gelebten Ethos der Verteidigung des Menschen in prekären Grenzsituationen. ${ }^{23}$ Ohne die „dichte Moral“ gelebter Solidarität wäre die gesellschaftliche Wirkkraft der Menschenrechte fundamental geschwächt. Entscheidend ist es, die religiöse Dimension der Ethik nicht einfach als Axiom zu konzeptionalisieren, das die Autonomie des Ethischen aufhebt, sondern als „Verkörperung der Gründe ${ }^{\text {“24 }}$ in einem Ethos, in einer Kultur, in Menschenbildern und Praxisformen des Sozialen, ohne die die Philosophie der Menschenrechte und das damit verbundene Ethikkonzept im Leeren hinge. Das christliche Ethos und die mit ihm verbundenen Lebensformen im Anspruch der Nachfolge Jesu sind schon deshalb keine bloße Partikularmoral, weil sie (z. B. im Gebot der Nächsten- und Feindesliebe) auf eine grenzüberschreitende Anerkennung des Anderen ausgerichtet sind. Die dünne Moral einer sich auf abstrakte Begründungen beschränkende Menschenrechtsethik verkennt, dass Moral oft erst im Kontext ihrer lebensweltlichen Entfaltung ihre vitale orientierungsstiftende Kraft gewinnt. Für die Wiederentdeckung der produktiven Kraft einer prophetisch-spirituellen und auf konkrete Lebensformen bezogenen Tradition politischer Ethik steht gegenwärtig nicht zuletzt die Lehrverkündigung von Papst Franziskus.

22 Vgl. Konrad Hilpert, Ethik der Menschenrechte: Zwischen Rhetorik und Verwirklichung, Paderborn 2018.

23 Zum Verständnis Christlicher Sozialethik als Reflexion gelebter Glaubenspraxis vgl. Bernhard Emunds (Hg.), Christliche Sozialethik - Orientierung welcher Praxis?, Baden-Baden 2018.

24 Jürgen Habermas, Über die Verkörperung von Gründen: Vortrag auf dem XXII. Deutschen Kongress für Philosophie, LMU München, 15.09.2011, vgl. https://www.youtube.com/ watch?v=Zx4DC05_3D4 (letzter Zugriff: 07.06.2019). 


\section{Der Humanismus des anderen Menschen als „immanente Transzendenz"}

Kirche und religiöser Glaube sind von hoher ethischer Relevanz, jedoch nicht in der Weise einer „Moralagentur “25, die politische Imperative mit dem Verweis auf die Autorität Gottes untermauert, sondern vielmehr von einem vertieften „vormoralischen“ Verständnis der Freiheit her: ${ }^{26}$ Als „Frohbotschaft“ (Evangelium) ist der christliche Glaube an erster Stelle ein Indikativ und kein Imperativ. Durch den Zuspruch von leistungsunabhängigem Anerkanntsein will er Menschen ermutigen, aus ihrer Verstrickung in Angst um sich selbst sowie in Schuld und verpasste Freiheit auszubrechen und das Gute zu wollen. ${ }^{27}$ Die biblische Botschaft geht davon aus, dass Gott den ersten Schritt gemacht hat und immer neu macht, indem er dem Menschen entgegenkommt, sei es in der Erfahrung des eigenen Lebens als Gabe sowie der Zuwendung und dem Glaubenszeugnis anderer Menschen, sei es in der Begegnung mit dem Nächsten, die den Menschen in die Verantwortung ruft und zum sittlichen Subjekt werden lässt.

Der jüdische Religionsphilosoph Levinas umschreibt die Begegnung mit dem Nächsten als ein Herausgerissen-Werden aus dem „Seinstrott“ der Egozentrik. Dadurch ereigne sich eine „immenente Transzendenz“: Der Mensch überschreitet (lat. transcendere) sich selbst, wächst über sich selbst hinaus, gewinnt, indem er sich für den Anderen öffnet, zugleich ein neues Verhältnis zu sich selbst, das in der europäischen Ethikgeschichte vor allem unter dem Leitbegriff „Humanismus“ reflektiert wurde. ${ }^{28}$ Levinas nennt seine phänomenologischen Analysen daher „Humanismus des anderen Menschen“29, verknüpft sie jedoch mit messianischen Perspektiven. Für christliche Theologie ist dieser Zugang in hohem Maße anschlussfähig an die Christologie. ${ }^{30}$ Biblisch ist der Zusammenhang, dass im Nächsten zugleich Gott begegnet, ein immer wiederkehrender Topos (z. B. Mt 25).

25 Hans Joas, Kirche als Moralagentur?, München 2016; zur interdisziplinären Debatte des kritischen Einwurfs von Joas vgl. Jochen Sautermeister, Kirche - Nur eine Moralagentur? Eine Selbstverortung, Freiburg 2018.

26 Zum Konzept des „Vormoralischen“ als Gegenstand moraltheoretischer Reflexion vgl. Sautermeister, Kirche - Nur eine Moralagentur?; Christoph Möllers, Die Möglichkeit der Normen. Über eine Praxis jenseits von Moralität und Kausalität, Berlin 2018.

27 Vgl. Richard Schäffler, Philosophische Einübung in die Theologie, Bd. 3: Philosophische Einübung in die Ekklesiologie und Christologie, Freiburg 2004, S. 457-470.

28 Vgl. Wolfram Winger, Personalität durch Humanität. Das ethikgeschichtliche Profil christlicher Handlungslehre bei Lactanz, Frankfurt 1999.

29 Emmanuel Levinas, Humanismus des anderen Menschen, Hamburg 2005.

30 Zur Verknüpfung anthropologischer, messianischer und christologischer Zugänge vgl. René Dausner, Christologie in messianischer Perspektive, Paderborn 2016. 
Für Levinas sind seine Analysen im Schnittfeld zwischen Anthropologie und Messianismus zugleich Ausgangspunkt für einen ganz eigenen Zugang zum Verständnis von Verantwortung: Diese sei „an-archisch“, ohne Anfang (gr. arché) in einer vermeintlich autonomen Entscheidung des Subjekts. Dieses entdecke sich selbst vielmehr erst in der sozialen Begegnung, wenn diese ihn schon in Anspruch genommen und über sich selbst hinaus verwiesen habe. ${ }^{31}$ Moral entsteht responsorisch als Antwort auf die Erfahrung des Sollens in der Begegnung mit dem Nächsten. Indem diese einen Perspektivenwechsel induziert, befreit sie den Menschen von der Selbstbezüglichkeit hin zur Anerkennung des Anderen um seiner selbst willen. Für Levinas ist das der Kern dessen, was Menschsein im Sinne von Humanität ausmacht.

Dieser Zugang lässt sich christologisch und moraltheoretisch vertiefen: ${ }^{32}$ Die christliche Zusage, von Gott vorgängig zu jeder Leistung geliebt zu sein, und aus dem Bewusstsein dieser Anerkennung heraus die Selbstfixierung loszulassen und souverän zu werden, ist der Kern des christlichen Glaubens. Sie befreit die theologische Dimension der Ethik aus dem Dunstkreis der Werkgerechtigkeit, die letztlich auf eine theologische Instrumentalisierung von Heilsangst hinausläuft, hin zum Vorrang der Gnade. Die theologische Dimension christlicher Ethik besteht nicht in der autoritativen Belohnung für Wohlverhalten, sondern in der bedingungslosen und vorgängigen Anerkennung und Liebe als Ermöglichung von Freiheit und Überwindung sklavischer Heilsangst. Sie transformiert die Ethik von der Logik der Unterwerfung unter einen generalisierten Sittenkodex hin zu einer Moral, die auf ein Handeln aus souveräner Freiheit, Selbstachtung und Lebensfreude zielt.

Dieser Hintergrund des biblischen Menschen- und Gottesbildes, das geteilte jüdisch-christliche Tradition ist, verleiht dem Sozialprinzip der Personalität als dem wichtigsten Angelpunkt Christlicher Sozialethik eine sinnstiftende Tiefendimension. Diese ist zugleich eine starke Motivationsquelle für gelebte Menschenrechtsethik. Die spezifische religiöse Kompetenz liegt dabei nicht in der Deduktion moralischer Imperative aus theologischen Prämissen (das ist es, was Joas als „Moralagentur“ karikiert), sondern in Deutungen und Erzählungen

31 Die Charakterisierung der Verantwortung als ,an-archisch“ ist ein gelungenes Wortspiel mit der Doppelbedeutung von "anfangslos“ und „herrschaftskritisch“: Wer Verantwortung übernimmt, ist kein Befehlsempfänger, sondern handelt aus eigener Überzeugung und Situationswahrnehmung. Zugleich geht Levinas über das Autonomiekonzept der Aufklärung, für das das Subjekt der absolute Ausgangspunkt der Moral ist, hinaus und ist damit kritisch gegenüber individualistisch verkürzten Moralkonzepten. Freiheit wird hier nicht als axiomatische Voraussetzung von Verantwortung gedacht, sondern als Ergebnis ihrer Praxis; sie ist vor-ursprünglich zur autonomen Willensentscheidung des Subjekts; vgl. Levinas, Humanismus, S. 61-83.

32 Vgl. Dausner, Christologie, S. 357-367. 
menschlicher Sinn- und Identitätssuche. ${ }^{33}$ Diese spannen einen kulturellen Raum auf, in dem Moral erst verhandelbar wird. Ihre Farbigkeit und ihren Sitz im Leben gewinnen diese Erzählungen meist als Darstellung von Konflikten.

\section{Interreligiöse Sozialethik und die Einbeziehung des Anderen}

Es gibt eine gewisse Strukturanalogie zwischen dem Humanismus des anderen Menschen und der Hermeneutik ökumenischer und interreligiöser Sozialethik, zu deren methodischer Grundlegung Ingeborg Gabriel wichtige Anstöße gegeben hat. ${ }^{34}$ Die Fähigkeit, sich selbst mit den Augen der anderen zu sehen, ist eine entscheidende Bewährungsprobe hinsichtlich des produktiven Umgangs mit Pluralismus. „Die Einbeziehung des Anderen ${ }^{\star 35}$ ermöglicht es, das Eigene tiefer und besser zu verstehen: Sie regt dazu an, ein reflexives Verhältnis zu sich selbst auszubilden. Wer in der Verschiedenheit die Möglichkeit wechselseitiger Bereicherung erkennt, wandelt die Wahrnehmung von Pluralität als Identitätsbedrohung in die Erfahrung von Pluralität als Chance vertiefter Identitätsfindung. Sie stärkt die Reflexion der eigenen Identität, weil diese stets begründet werden muss, und befähigt so zu einer dialogischen Öffnung.

„Die Einbeziehung des Anderen“ durch dialogische Öffnung bedeutet somit „nicht Preisgabe des Überkommenen, sondern Bewährung und Bezeugung des Eigenen im Angesicht des Anderen. ${ }^{\text {(36 }}$

Eine solche „Hermeneutik des Anderen“ ist die philosophische Basis für eine interreligiöse Sozialethik. ${ }^{37}$ Zugleich liegt sie konzeptionell dem dialogischen Prinzip des Zweiten Vatikanischen Konzils zugrunde, insbesondere seinen beiden Dokumenten Nostra Aetate und Gaudium et spes, also der Magna Charta des Dialogs der Religionen einerseits und der sozialethisch-pastoraltheologischen Verfassungsgrundlage der Kirche in der modernen Welt andererseits. ${ }^{38}$ Die

33 Vgl. Ludger Honnefelder, Was soll ich tun, wer will ich sein? Vernunft und Verantwortung, Gewissen und Schuld, Weilerswist 2017.

34 Vgl. Gabriel (Hg.), Politik und Theologie; zur interreligiösen Weiterentwicklung des Konzepts vgl. Hansjörg Schmid, Islam im europäischen Haus. Wege zu einer interreligiösen Sozialethik, Freiburg 2012.

35 Habermas wählt diese Formulierung als Titel und Leitgedanken seiner Studien zur politischen Theorie; vgl. Jürgen Habermas, Einbeziehung des Anderen. Studien zur philosophischen Theorie, Frankfurt 1996.

36 Jan-Heiner Tück, Die Einbeziehung der anderen. Zur Unhintergehbarkeit der ökumenischen Öffnung und des interreligiösen Gesprächs, in: zur debatte 3/2013, S. 21-23, hier: S. 21.

37 Vgl. Schmid, Islam im europäischen Haus.

38 Zur Schlüsselbedeutung von Gaudium et spes für den Paradigmenwechsel nachkonziliarer Sozialethik vgl. Ingeborg Gabriel, Christliche Sozialethik in der Moderne. Der kaum rezi- 
ethische Wende zum Subjekt und die interreligiöse Hermeneutik des Anderen stehen in einem notwendigen inneren Zusammenhang.

Strategien der Abschottung zur Wahrung religiöser Identität haben in pluralen, zunehmend durchlässigen Gesellschaften schlechte Chancen. Schon die Möglichkeit von Alternativen bewirkt, dass die Glaubens- und Moralvorstellungen der jeweils eigenen Gruppe für den Einzelnen nicht mehr einfach selbstverständlich sind, sondern sich rechtfertigen müssen und durch individuelle Entscheidung angeeignet oder abgelehnt werden. Pluralismuskompetenz durch die Fähigkeit zum Perspektivenwechsel zwischen unterschiedlichen Sprachspielen ist dabei eine immer wichtiger werdende Kommunikationsbedingung für eine Sozialethik unter postsäkularem Vorzeichen. Das Ziel des Dialogs ist nicht, die Differenz der Religionen, Konfessionen und Kulturen in ein Einheitskonzept aufzulösen, sondern in der Begegnung die Vielfalt als Reichtum zu entdecken, voneinander zu lernen und dort, wo es dem Wohl der Menschen dient, zu kooperieren oder zumindest friedlich zu koexistieren.

Der methodische Leitgedanke interreligiöser Sozialethik ist die Fokussierung des Dialogs auf gesellschaftlich zentrale Themen. Die Gesellschaft, in der wir leben, ist der gemeinsame Ausgangspunkt. Das entspricht dem Ansatz der Bewegung für praktisches Christentum, von der im frühen 20. Jahrhundert die moderne Ökumene ausging. Ziel einer interreligiösen Sozialethik ist nicht die Formulierung von Schnittmengen vermeintlicher theologischer Übereinstimmungen, wie sie so oft in mühsam erarbeiteten und dann kaum beachteten Konsenspapieren vorgelegt werden. Ziel ist vielmehr die Förderung fruchtbarer Denkprozesse und Irritationen durch die Hermeneutik des Anderen. Dabei spielt die Auseinandersetzung mit dem Islam um sozialethische Fragen des Zusammenlebens eine hervorgehobene Rolle. Dialogbereitschaft ist die Voraussetzung dafür, dass die in den öffentlichen Raum zurückgekehrten Religionen eine friedensfördernde Rolle spielen und sich aktiv dagegen wehren, als Eskalationsfaktor für Gewalt missbraucht zu werden. Dafür reicht es nicht, den Dialog als moralisches Postulat zu fordern. Er wird vielmehr nur dann genügend Vitalität gewinnen, wenn er im Sinne einer Hermeneutik des Anderen in der Mitte des religiösen Selbstverständnisses verankert ist.

Viele globale Konflikte wie die Folgen des Klimawandels, Welthunger und Armut, Neonationalismus, Korruption, die Corona-Krise oder die systemischen Risiken der Weltfinanzmärkte sind nur auf der Basis einer globalen Kooperation zwischen den verschiedenen Nationen und Kulturen zu lösen. Christliche Theologie mit ihrem Anspruch einer die gesamte Menschheitsfamilie generationenübergreifend umfassenden Solidarität ist dabei in besonderer Weise ge-

pierte Ansatz von Gaudium et spes, in: Jan-Heiner Tück (Hg.), Erinnerung an die Zukunft. Das Zweite Vatikanische Konzil, Freiburg 2012, S. 537-553. 
fordert. Aus christlicher Sicht ist der theologische Grund des Dialogs, dass Gott das Heil aller Menschen will.

\section{Resümee: Die epistemische Einheit von Glauben und Vernunft}

Die gesellschaftliche Brisanz der Frage nach dem Stellenwert theologischer Argumente für die Begründung, Motivation und Entfaltung der Ethik zeigt sich gegenwärtig in vielen Gestalten: Weltweit ist eine Ideologisierung religiös aufgeladener Konflikte zu beobachten, die dringend einer vernunftgeleiten ethischen Reflexion bedarf. Dabei ist die Diskurslage ausgesprochen ambivalent: Einerseits gibt es gegenwärtig aufgrund vielschichtiger Verunsicherungen eine verstärkte Nachfrage nach theologischer Ethik. Andererseits stehen deren Normen bei vielen unter dem - bisweilen selbstverschuldeten - Verdacht der Irrationalität. Die Aufgabe einer ökumenisch, interreligiös, interkulturell und interdisziplinär eingebundenen Sozialethik ist hier wesentlich eine kritische: Sie hat dazu beizutragen, dass der Rekurs auf Gott in der Begründung, Motivation und Entfaltung von Moral nicht dazu missbraucht wird, diese gegen Vernunft abzuschotten. Das Gottesargument ist keine Kompensation für einen Mangel an rationaler Begründung für eine auf gelingendes Leben und human angemessene Entfaltung ausgerichtete Moral. Im Zentrum religiöser Zugänge zur Ethik sollte vielmehr die Erfahrung und Vermittlung der Einheit von Gottes- Menschen- und Schöpfungsliebe stehen, „Glauben und Wissen sind in der konkreten Lebensführung aufeinander verwiesen und nicht voneinander zu trennen. ${ }^{\text {(39 }}$

\section{Quellen}

Albrecht, Christian / Anselm, Reiner, Öffentlicher Protestantismus. Zur aktuellen Debatte um gesellschaftliche Präsenz und politische Aufgaben des evangelischen Christentums, Zürich 2017.

Bedford-Strohm, Heinrich, Öffentliche Theologie in der Zivilgesellschaft, in: Ingeborg Gabriel (Hg.), Politik und Theologie in Europa. Perspektiven ökumenischer Sozialethik, Ostfildern 2008, S. 340-357.

39 Gerhardt, Glauben und Wissen, S. 14f. Gerhardt charakterisiert diesen Zusammenhang als „epistemische Einheit“, die in der vermeintlich aufgeklärten Vorstellung, dass Glaube lediglich Vorläufer des Wissens sei, verkannt werde. Die epistemische Einheit von Glauben und Wissen sei Voraussetzung für die lebensweltliche Verankerung der Ethik sowie für die Vernunftfähigkeit religiöser Ethik. 
Benedikt XVI., Klima der 68er mitverantwortlich für Missbrauchsskandal (Wortlaut und Reaktionen), vgl. https://www.katholisch.de/aktuelles/aktuelle-artikel/benedikt-xvi68er-sind-verantwortlich-fur-missbrauchsskandal (letzter Zugriff: 07.06. 2019).

Casanova, José, Public Religions in the Modern World, Chicago 1994.

Dausner, René, Christologie in messianischer Perspektive, Paderborn 2016.

Emunds, Bernhard (Hg.), Christliche Sozialethik - Orientierung welcher Praxis?, BadenBaden 2018.

Gabriel, Ingeborg, Menschenrechte und Religionen - Verbündete oder Gegner?, in: Peter G. Kirchschläger (Hg.), Die Verantwortung von nichtstaatlichen Akteuren gegenüber den Menschenrechten, Zürich 2017, S. 33-52.

Gabriel, Ingeborg, Naturrecht, Menschenrechte und die theologische Fundierung der Sozialethik, in: Markus Vogt (Hg.), Theologie der Sozialethik, Freiburg 2013, S. 229251.

Gabriel, Ingeborg, Christliche Sozialethik in der Moderne. Der kaum rezipierte Ansatz von Gaudium et spes, in: Jan-Heiner Tück (Hg.), Erinnerung an die Zukunft. Das Zweite Vatikanische Konzil, Freiburg 2012, S. 537-553.

Gabriel, Ingeborg (Hg.), Politik und Theologie in Europa. Perspektiven ökumenischer Sozialethik, Ostfildern 2008.

Gerhardt, Volker, Glauben und Wissen. Ein notwendiger Zusammenhang, 3. Aufl., Stuttgart 2016.

Graf, Friedrich Wilhelm / Meier, Heinrich (Hg.), Politik und Religion. Zur Diagnose der Gegenwart, München 2013.

Habermas, Jürgen, Über die Verkörperung von Gründen: Vortrag auf dem XXII. Deutschen Kongress für Philosophie, LMU München, 15.09.2011, vgl. https://www.youtube. com/watch? $\mathrm{v}=\mathrm{Zx}$ 4DC05_3D4 (letzter Zugriff. 07.06.2019).

Habermas, Jürgen, Zwischen Naturalismus und Religion. Philosophische Aufsätze, Frankfurt 2005.

Habermas, Jürgen, Glauben und Wissen. Rede zur Verleihung des Friedenspreises des Deutschen Buchhandels, Frankfurt 2001.

Habermas, Jürgen, Die Einbeziehung des Anderen. Studien zur philosophischen Theorie, Frankfurt 1996.

Hilpert, Konrad, Ethik der Menschenrechte: Zwischen Rhetorik und Verwirklichung, Paderborn 2018.

Höhn, Hans-Joachim, Handeln über den Tag hinaus. Zeithorizonte der Sozialethik, in: Markus Vogt (Hg.), Theologie der Sozialethik, Freiburg 2013, S. 92-126.

Honnefelder, Ludger, Im Spannungsfeld von Religion und Ethik, Weilerswist 2017.

Honnefelder, Ludger, Was soll ich tun, wer will ich sein? Vernunft und Verantwortung, Gewissen und Schuld, Weilerswist 2017.

Jaeggi, Rachel, Kritik von Lebensformen, Frankfurt 2014.

Joas, Hans, Kirche als Moralagentur?, München 2016.

Joas, Hans, Die Sakralität der Person. Eine neue Genealogie der Menschenrechte, Berlin 2011.

Johannes Paul II, Splendor veritatis. Enzyklika über einige grundlegende Fragen der Morallehre, Vatikan 1993, Nr. 31-53.

Korff, Wilhelm / Vogt, Markus (Hg.), Gliederungssysteme angewandter Ethik. Ein Handbuch. Nach einem Projekt von Wilhelm Korff, Freiburg 2016. 
Küppers, Arnd, Menschenrechte im Spannungsfeld zwischen Gottesrede und säkularer Politik - eine sozialethische Sicht, in: Markus Vogt (Hg.), Theologie der Sozialethik, Freiburg 2013, S. 300-326.

Laux, Bernhard (Hg.), Heiligkeit und Menschenwürde. Hans Joas' Genealogie der Menschenrechte im theologischen Gespräch, Freiburg 2013.

Legutke, Daniel, Zwischen islamischen Werten und allgemeinen Menschenrechten. Zur Rolle der Organisation für Islamische Zusammenarbeit im UN-Menschenrechtsrat, in: Amosinternational 2/2013, S. 25-35.

Levinas, Emmanuel, Humanismus des anderen Menschen, Hamburg 2005.

Manemann, Jürgen, Carl Schmitt und die Politische Theologie. Politischer Anti-Monotheismus, Münster 2002.

Maritain, Jacques, Christlicher Humanismus. Politische und geistige Fragen einer neuen Christenheit, Heidelberg 1950.

Möllers, Christoph, Die Möglichkeit der Normen. Über eine Praxis jenseits von Moralität und Kausalität, Berlin 2018.

Pollack, Detlef, Säkularisierung - ein moderner Mythos? Studien zum religiösen Wandel in Deutschland, Tübingen 2003.

Reder, Michael / Schmidt, Josef, Ein Bewusstsein von dem, was fehlt. Eine Diskussion mit Jürgen Habermas, Frankfurt 2008.

Sautermeister, Jochen, Kirche - Nur eine Moralagentur? Eine Selbstverortung, Freiburg 2018.

Schäffler, Richard, Philosophische Einübung in die Theologie, Bd. 3: Philosophische Einübung in die Ekklesiologie und Christologie, Freiburg 2004, S. 457-470.

Schmid, Hansjörg, Islam im europäischen Haus. Wege zu einer interreligiösen Sozialethik, Freiburg 2012.

Söding, Thomas, Biblische Sozialethik und christliche Hermeneutik. Neutestamentliche Anfragen, in: Markus Vogt (Hg.), Theologie der Sozialethik, Freiburg 2013, S. 146-188.

Spindler, Wolfgang, „Humanistisches Appeasement“? Hans Barions Kritik an der Staatsund Soziallehre des Zweiten Vatikanischen Konzils, Berlin 2011.

Tück, Jan-Heiner, Die Einbeziehung der anderen. Zur Unhintergehbarkeit der ökumenischen Öffnung und des interreligiösen Gesprächs, in: zur debatte 3/2013, S. 21-23.

Uertz, Rudolf, Menschenrechte im Spannungsfeld zwischen Gottesrede und säkularer Politik, in: Markus Vogt (Hg.), Theologie der Sozialethik, Freiburg 2013, S. 279-299.

Vogt, Markus, Das Spannungsfeld theologischer und philosophischer Ethik als Ausgangspunkt für die Gliederung normativer Reflexion, in: Wilhelm Korff / Markus Vogt (Hg.), Gliederungssysteme angewandter Ethik. Ein Handbuch. Nach einem Projekt von Wilhelm Korff, Freiburg 2016, S. 711-737.

Vogt, Markus, Die Theo-Logik Christlicher Sozialethik, in: Johann Platzer / Elisabeth Zissler (Hg.), Bioethik und Religion. Theologische Ethik im öffentlichen Diskurs, Baden-Baden 2014, S. 143-173.

Vogt, Markus / Gabriel, Ingeborg / Küppers, Arnd / Schallenberg, Peter / Veith, Werner, Theologien in der Sozialethik, in: Markus Vogt (Hg), Theologie der Sozialethik, Freiburg 2013, S. 7-20.

Vogt, Markus (Hg.), Theologie der Sozialethik, Quaestiones disputatae 255, Freiburg 2013.

Winger, Wolfram, Personalität durch Humanität. Das ethikgeschichtliche Profil christlicher Handlungslehre bei Lactanz, Forum Interdisziplinäre Ethik 22, Frankfurt 1999. 


\section{Die Grenze der Grenzen. Christentum, Abrahamitische Religionen, Zivilgesellschaft und die Neubestimmung des öffentlichen Raums in Europa}

\section{Vorbemerkung}

Ingeborg Gabriel ist ein herausragender Vertreter ${ }^{1}$ katholischer Intellektualität mit universalem Horizont. Sie verbindet eine tiefgründige Theologie und Spiritualität, die auf biblischen Wurzeln basiert, mit weitreichenden philosophischen, wirtschaftlichen und politischen Kenntnissen. Dabei reicht der Horizont ihres Wirkens weit über den deutschsprachigen und sogar europäischen Raum hinaus. Von ihrem Denkansatz her ist sie ein „Kind der Aufklärung“, das deren Errungenschaften gegen fundamentalistische Regressionen und postmoderne Beliebigkeiten verteidigt, ohne die Aporien und die Probleme, die sich mit der Aufklärung verbinden, aus dem Blick zu verlieren. Ihre Begegnungen mit zahlreichen Persönlichkeiten aus Politik, Religion und Wissenschaft sowie ihr Engagement in der Ökumene und im christlich-islamischen und interreligiösen Dialog haben dazu beigetragen, dass sie wie wenige Theologen unserer Zeit die Zeichen der Zeit zu lesen vermag. Im Folgenden soll einem bedeutenden Aspekt ihres intellektuellen Profils Rechnung getragen werden, nämlich dem Eintreten für ein Europa demokratisch bestimmter öffentlicher Räume, verbunden mit einer offenen Zivilgesellschaft ${ }^{2}$, zu deren Konstitution das Christentum bzw. Religionsgemeinschaften überhaupt einen wesentlichen Beitrag leisten.

1 Im Folgenden wird für die Berufs- und Funktionsbezeichnungen das grammatikalische Geschlecht verwendet. Der Autor bittet, darin sowohl das männliche als auch das weibliche „natürliche“ Geschlecht mitzulesen.

2 Ingeborg Gabriel schreibt: „One of the important consequences of modern constitutionalism is the creation of the civil sphere." Siehe Ingeborg Gabriel, Political Theology under the conditions of modernity: A catholic perspective, in: Ingeborg Gabriel / Kristina Stoeckl / Aristotle Papanikolaou (Hg.), Political Theology in Orthodox Christianity. Common Challenges - Divergent Positions, London 2017, S. 55-74, hier: S. 64. 
In der Thematisierung des Verhältnisses von Religion und Zivilgesellschaft ${ }^{3}$ in Europa sind mindestens drei Fragestellungen enthalten, die im Folgenden aufeinander bezogen werden ${ }^{4}$. Die erste Fragestellung betrifft den Stellenwert der Zivilgesellschaft heute, verbunden mit der Frage, welche affektiven und prospektiven Konnotationen diesem Begriff zukommen. Die zweite Frage bezieht sich auf den Stellenwert der Religion innerhalb der Zivilgesellschaft ${ }^{6}$, wobei dem Spezifikum und der Aufgabe der Religion innerhalb der europäischen Zivilgesellschaft nachzuspüren ist, was nicht zuletzt eine Verhältnisbestimmung von säkularer Gesellschaft und religiös orientierter Gefühlswelt impliziert. Im gegenwärtigen gesellschaftlichen Kontext schwingt dabei unausgesprochen die Frage mit, wie die europäischen Gesellschaften mit der sich verstärkenden Präsenz muslimischer Bürger und Migranten umgehen sollen. Die dritte Frage betrifft die Zukunft Europas als Hoffnungszeichen für eine weltbürgerliche Gesellschaft. Wird Europa zunehmend zu einer bedeutungslosen Formel? Ist die Europäische Union, die mit dem Begriff Europa zurzeit noch immer semantisch untrennbar verbunden ist, an ihr Ende gekommen? Kann Europa etwas Anderes darstellen als ein vergangenes imperiales Projekt?

\section{Der öffentliche Raum als Essenz des europäischen Projekts und dessen nihilistische Herausforderung}

Ein neuer europäischer Narrativ muss auf besondere Weise den öffentlichen Raum thematisieren ${ }^{7}$, d.h. einen Raum kultureller, ökonomischer und sozialer

3 Der vorliegende Beitrag erscheint in einer englischen Fassung in JRAT: The Border of Borders. Christianity and the Rethinking of Public Space, in: Interdisciplinary Journal for Religion and Transformation 5/2019, S. 514-528.

4 Der Theologe, der als einer der ersten entscheidende Impulse für diese Debatte gegeben hat, ist David Tracy. Vgl. z.B. sein bahnbrechendes Buch: The Analogical Imagination: Christian Theology and the Culture of Pluralism, New York 1981.

5 Zur historischen Genese vgl. die noch immer bahnbrechende Untersuchung von Jürgen Habermas, Strukturwandel der Öffentlichkeit: Untersuchungen zu einer Kategorie der bürgerlichen Gesellschaft, Frankfurt a. M. 1990.

6 Vgl. dazu auch Peter L. Berger, A Rumor of Angels: Modern Society and the Rediscovery of the Supernatural, New York 1970.

7 In jüngster Zeit hat Saskia Sassen einige Bücher geschrieben, die von besonderem Interesse für die Frage des öffentlichen Raums sind. In dem von ihr herausgegebenen Opus magnum "Global Networks, Linked Cities“ (Saskia Sassen, Global Networks, Linked Cities, New York 2016 [2002]) beschreibt sie paradigmatisch die Formierung neuer Megacities und den Einfluss von Globalisierung, Neoliberalismus und neuer Technologien auf diese neue Form von Urbanisierung. Von besonderer Bedeutung ist die Beobachtung, dass der öffentliche Raum, der traditionell mit Staatlichkeit verbunden war, immer mehr von supranationalen Entitäten dominiert ist, „such as global electronic markets and free trade blocks“ (Sassen 2016, S. 1-38, hier: S. 9). Ein weiteres Buch, welches erwähnt werden muss, ist David Harvey's „Rebel cities“ 
Interaktion, an dem jede/r frei partizipieren kann. In diesem Sinne könnte man den öffentlichen Raum als die Repräsentationsform europäischer Kultur betrachten. Insofern Europas kulturelle Landschaft durch ein vielschichtiges und breites Gedächtnis menschlicher Verletzbarkeit formiert ist, insofern Europa in großen (griechischen, jüdisch-christlichen, aufklärerisch-säkularen) Freiheits-Erzählungen gründet und insofern Europa eine universale, geographische Grenzen weit hinter sich lassende Bedeutung hat, ist es untrennbar an eine zivilgesellschaftliche, kulturelle, nicht zuletzt aufklärerische und jüdischchristliche (abrahamitische) Vision gebunden. Diese beinhaltet die Berufung jedes Menschen zu einer freien Begegnung in einem öffentlichen Raum, aus dem niemand ausgeschlossen ist. Dieser Raum zeichnet sich dabei dadurch aus, dass es "nicht mehr Juden und Griechen, nicht Sklaven und Freien und nicht Mann und Frau" (Gal 3,28) gibt.

Dabei darf aber auch nicht vergessen werden, dass Europa Ort und Ursprung kolonialer Unterdrückung und brutalster Kriege war sowie bis in die Gegenwart hinein durch einen exzessiven Nihilismus geprägt ist. Dieser europäische Nihilismus - der pervertierte Aspekt des europäischen Freiheitsbewusstseins - ist charakterisiert durch einen Gestus, der es erlaubt, alle Grenzen, d.h. alle kulturellen Traditionen und Beziehungen und deren Inhalte, auszulöschen. Der Europäer vermag sich von allem und jedem zu distanzieren, sodass kein Gegenstand, keine Geschichte, keine Grenze, keine Person, also im wahrsten Sinne des Wortes „Nichts“ absolute Gültigkeit besitzt. Dies wirkt wiederum auf das Freiheitsverständnis zurück, welches, in seiner sozioökonomischen Ausprägung als Neoliberalismus, die Austauschbarkeit und Ersetzbarkeit aller Inhalte begünstigt. Alles ist in diesem Denken potentiell Ware und die eigentliche Freiheit liegt in deren Konsum. Begegnendes, dem ein eigenständiger Inhalt zukommt, der sich gegen die Reduktion auf eine modische Trademark sperrt, muss diesem Zugang zufolge aufgehoben werden. Die auf diese Weise enttraditionalisierte Welt transformiert sich in eine „virtual reality“, deren Zutritt durch das Vermögen der Nutzer geregelt ist. Ein Narrativ der Europäischen Zivilgesellschaft, die durch öffentliche Räume geprägt ist, darf einerseits nicht in eine nostalgische Sehnsucht nach heteronomen vormodernen Traditionen und ihren Grenzen zurückfallen, in denen eine freie Begegnung und für alle offene Räume unmöglich waren, andererseits darf aber auch der hier angedeutete nihilistische Aspekt des europäischen Freiheitsbewusstseins nicht verdrängt werden.

(David Harvey, Rebel cities, London-New York 2012). Im zweiten Teil seiner Arbeit zeigt Harvey (in Referenz auf die Bolivianische Stadt El Alto) das Potential städtischen Widerstands gegen die Enteignung öffentlicher Räume und die Formierung neuer, solidarischer (öffentlicher) Räume. 


\section{Die Idee der universalen Freundschaft und das Heilige als nichtrepräsentierbarer Zusatz}

Die Idee universal zugänglicher öffentlicher Räume ist nicht zuletzt mit der biblischen Tradition und ihren säkularen Transformationen verknüpft. In diesem Zusammenhang könnte man darauf hinweisen, dass bereits das Ethos des Evangeliums der frühen Christen nicht zuletzt darin bestand, dass jede Person (unter Transzendierung der Grenzen von Klasse, Nation und Geschlecht) zum Freund berufen werden konnte ${ }^{8}$. Der Hintergrund dieses Ethos liegt im Leben Jesu, der zu den verlorenen „Schafen“ Israels gesandt war und dessen von ihm verkündete Basileia (Königsherrschaft Gottes) Krüppel, Sünder, Eunuchen (damals eine Art third gender jenseits der Dichotomie Mann/Frau und als solche von allen verachtet), d.h. soziale Außenseiter aller Art einschloss.

Neben dieser durch das Freundschaftsethos bewirkten Neukonfigurierung der Grenze zwischen Einschluss und Ausschluss gilt es ein weiteres Moment zu beachten, welchem große Bedeutung für das Verständnis von Grenzen und Grenzüberschreitungen in der Bibel zukommt. Man könnte dieses Moment, jenseits der Dichotomie Einschluss-Ausschluss, als theozentrischen (weil nicht vom Menschen beherrschbaren) Zusatz (biblisch auch „Rest ${ }^{(9)}$ ) bezeichnen, der das biblische Grenzverständnis entscheidend prägt. Dieses Motiv spielt bereits in den Schöpfungsberichten der Bibel eine große Rolle ${ }^{10}$ : Der siebente Tag bezeichnet dort gegenüber dem Sechs-Tage-Werk einen der göttlichen Sphäre zugehörigen Zusatz, der der Welt keinen genuinen Inhalt hinzufügt, sondern die chronologische Zeit bzw. die Schöpfung (ausgedrückt durch die ersten sechs Tage) radikal auf die Zu-Kunft Gottes öffnet. Auf diese Weise wird der siebente Tag - weder innerhalb noch jenseits der sechs Tage ${ }^{11}$ - zum messianischen Tag,

8 Vgl. Ivan Illich, The Rivers North of the Future. The Testament of Ivan Illich as Told to David Cayley, Toronto 2005.

9 Bahnbrechend für das sich aus dem biblischen Verständnis von Einschluss und Ausschluss ergebende Verständnis von Grenze sind die Arbeiten von Giorgio Agamben und Jean-Luc Nancy. Vgl. besonders: Giorgio Agamben, Il tempo che resta. Un commento alla „Lettera ai Romani“", Torino 2000; Jean-Luc Nancy, La déclosion, Paris 2005. Wie diese Grenzen in der Mystik der Neuzeit verhandelt werden und symbolische Räume schaffen, zeichnet auf geniale Weise Michel de Certeau nach. Vgl. dazu Michel de Certeau, Le fable mystique, 1:XVIe-XVIIe siècle, Paris 1982.

10 Vgl. Kurt Appel, Gott - Mensch - Zeit. Geschichtsphilosophisch-Theologische Erwägungen zu Neuem Humanismus im Ausgang von Bibel, Hegel und Musil, in: Kurt Appel (Hg.), Preis der Sterblichkeit. Christentum und Neuer Humanismus, QD 271, Freiburg-Basel-Wien 2015, S. 19-60.

11 In der christlichen Liturgie kommt dies durch die Figur des Sonntags zum Ausdruck, der als der „achte Tag“ sowohl den festlichen, heiligen siebenten als auch den profanen ersten Tag bezeichnet, d.h. mit dem ersten Tag zusammenfallend dessen Öffnung und Transzendierung bedeutet. 
was in den Evangelien dadurch zum Ausdruck gebracht wird, dass Jesus am Sabbat heilt. Dies nicht, um seinen Gegnern eine liberale Auslegung der jüdischen Tora abzuringen, sondern weil der siebente Tag jener Tag ist, durch den der Messias eintritt und in dem die Schöpfung festlich neu konfiguriert wird. Eine ähnliche Rolle spielt der Baum der Erkenntnis im zweiten Schöpfungsbericht (Gen 2,4b-3): Er ist, wie eine genaue Betrachtung des Textes zeigt ${ }^{12}$, einerseits situiert im Zentrum des Gartens (gewissermaßen als Doppelgänger des Baumes des Lebens, der gleich einer Gottheit, die mit ihrem Licht über die Welt ausstrahlt, alles Sein des Gartens am göttlichen Leben partizipieren lässt), andererseits ist er dessen "Jenseits“ und Rand, wobei diese Doppeldeutigkeit wohl bewusst gesetzt ist. Der Zusatz, der durch den Sabbat (zeitlich) bzw. den Baum der Erkenntnis (räumlich) zum Ausdruck gebracht ist, entzieht sich jeder unmittelbaren Repräsentation und schreibt eine grundlegende Öffnung in das raumzeitliche Geschehen ein. Da dieser Zusatz des siebenten Tages bzw. des Baumes der Erkenntnis die Zeit bzw. den Raum konstituiert, sind weder Raum noch Zeit identisch mit ihrer Repräsentation. Anders gesagt: Die kategoriale Welt ist niemals völlig identisch mit sich selber, alle in ihr sich zum Ausdruck bringenden Grenzen (die Verschiedenheiten der Tage und der Örter) haben ihr „Anderes“ eingeschrieben. Auf diese Weise wird verhindert, dass die Einschluss und Ausschluss markierende Grenze absolut wird. Der die Zeit konstituierende Ein-Tag ${ }^{13}$ ebenso wie der den Raum konstituierende Baum des Lebens markieren die Grenzen der Raum-Zeit und sind auf ihr Anderes bezogen, in dessen Offenheit sie stehen. Das Heilige ist damit kein abtrennbarer Raum, der sich vom Profanen abgrenzen ließe, sondern der unverfügbare Zusatz des Profanen selber, der es erlaubt, das Profane je neu zu konfigurieren.

12 „Und Gott JHWH ließ aus dem Erdboden allerlei Bäume wachsen, begehrenswert anzusehen und gut zur Nahrung, und den Baum des Lebens in der Mitte des Gartens, und den Baum der Erkenntnis des Guten und Bösen“. (Gen 2,9) Das zweite „und“, welches den Baum der Erkenntnis anzeigt, kann als Beiordnung zum Baum des Lebens gelesen werden (in diesem Falle ist der Baum der Erkenntnis parallel zum Baum des Lebens im Zentrum des Gartens situiert). Man kann es aber auch als Beiordnung zum gesamten Garten verstehen: In diesem Falle ist der Baum der Erkenntnis sozusagen außerhalb des Horizonts der durch den Garten symbolisierten Schöpfungsordnung.

13 Der biblische Text spricht konsequenterweise nicht von der Erschaffung des ersten Tages, vielmehr ist das erste Werk der Ein-Tag als konstituierendes Moment der Schöpfung. Gen 1,5b: ,und Abend war und Morgen: ein Tag“ (nicht: der erste Tag!). Vgl. Erich Zenger, Gottes Bogen in den Wolken. Untersuchungen zu Komposition und Theologie der priesterschriftlichen Urgeschichte, Stuttgarter Bibelstudien 112, Stuttgart 1983. 


\section{Die zwei Herausforderungen des öffentlichen Raums: Die Herrschaft der Auserwählten und die Allgegenwart des Unendlichen}

Diese Konzeption der Raum-Zeit wirkt sich auf das Verständnis des Unendlichen aus. In der traditionell metaphysischen Sichtweise steht das Unendliche dem Endlichen entweder gegenüber (wodurch es selber wieder zu einem Endlichen wird) oder es annihiliert Letzteres. Bezogen auf den öffentlichen Raum besteht die Konsequenz im ersten Falle in der Dominanz eines sakralen „Anderen“, das dem Endlichen entzogen ist. Dieses wird von „Auserwählten“ verwaltet, die sich legitimieren durch eine festgeschriebene Dichotomie zwischen den ihrer Sphäre Zugehörigen (in der abendländischen Tradition z. B. Christen, Männer, Besitzenden, Staatsbürger) und den Ausgeschlossenen (z.B. Juden und Muslime, Frauen, Besitzlose, Ausländer etc.). Im zweiten Falle besteht die Konsequenz in einer Ubiquität/Omnipräsenz des Unendlichen, verbunden mit einer Annihilierung alles Endlichen durch eine Instanz, in der sich alle Macht befindet. In diesem Falle vollzieht sich eine lückenlose Virtualisierung alles Endlichen zugunsten des großen Anderen, der selber allerdings nicht mehr in den Blick kommen kann und der damit jeder demokratischen Kontrolle entzogen ist. Die Konsequenz daraus liegt in einer Welt des Scheins, in der es keine Auswege, kein Offenes mehr geben kann, in der alles unbegrenzt präsentierbar und verfügbar ist und doch nur Schein ist - ohne Realität (res aliter, die Sache des Anderen), womit wir uns in die virtuelle Welt begeben, die heute allgegenwärtig ist und die traditionellen öffentlichen Räume immer weiter aushöhlt ${ }^{14}$.

\section{Unendlichkeit und Offenheit oder Die Subversion von Grenzen}

Wir finden beide Fehlformen des Unendlichen bereits paradigmatisch in den Evangelien. Die dort genannten Schriftgelehrten repräsentieren ein System des Ausschlusses, verbunden mit der Vereinnahmung des Heiligen. Die von den Schriftgelehrten zugeordnete „Ehre“ der Person ist dabei an ganz bestimmte Verhaltensweisen und soziale Normen geknüpft und Abweichungen davon („Sünder“) werden mit der Verbannung aus der Gemeinschaft und aus dem öffentlichen Leben bestraft. Die zweite Fehlform begegnet in den Dämonen: Sie repräsentieren das Apeiron, d. h. eine Form von Unendlichkeit, die jede Struktur

14 Amazon, Facebook etc. entziehen sich dem demokratischen Diskurs und der demokratischen Kontrolle und ihre Regeln sind vorgegeben, ohne den Nutzern die Mitbestimmung zu ermöglichen. 
ausgelöscht hat. Besonders interessant ist, dass v. a. im Markusevangelium berichtet wird, dass es die Dämonen sind (und nicht die Schüler oder Verwandten Jesu), die Jesus erkennen (Mk 1,24 ${ }^{15}$ ). Mit Jesus teilen sie das Außer-Kraft-Setzen von Grenzen. Während aber im Falle der Dämonen alles von einer fremden Macht gesteuert wird, zeichnet sich Jesus dadurch aus, dass er neue Öffnungen und mit ihnen neue Lebensmöglichkeiten schafft. Es geht also genau genommen bei Jesus nicht um eine Grenzenlosigkeit (nicht einmal einer solchen der Liebe), sondern um die kreative Neuschöpfung von Räumen und Zeiten, die durch Formen der Partizipation vormals Ausgeschlossener oder in ihrem Leben Erschöpfter gekennzeichnet sind. Im positiven Sinne könnte man sagen, dass das Christentum, die jüdisch-christliche Tradition, die abrahamitisch-monotheistische Tradition dazu berufen ist, neue Lebensmöglichkeiten freizulegen, indem öffentliche Räume der Begegnung durch einen spielerisch-kreativen Umgang mit Grenzen neu geschaffen werden.

Das Christentum in seiner historischen Gestalt ist geprägt von solchen Aufbrüchen und Öffnungen, ebenso aber war es immer wieder ein Projekt des Ausschlusses (zunächst v.a. gegen die Juden) bzw. einer Außer-Kraft-Setzung von Grenzen zugunsten eines absoluten (meist klerikalen) Machtanspruchs. In dessen Opposition entstehen freilich, nicht zuletzt biblische Ressourcen nutzend, dissidente Bewegungen: das säkulare Europa, die Welt des Korans, der Sozialismus u.a. Diese zwingen dazu, Grenzen neu zu verhandeln, indem sie beitragen zu einem Hinterfragen von Mechanismen der Macht und des Ausschlusses, aus dem diejenigen öffentlichen Räume Europas, die in sich plural gestaltet sind, hervorgehen. Gegen diese pluralisierte Welt freilich steht die Tradition des oben erwähnten allumfassenden Machtanspruchs, der Möglichkeit des Ausschlusses alles Lebens, der im europäischen Nihilismus ${ }^{16}$ seine letzte und vielleicht massivste Ausdrucksform findet. Dieser manifestiert sich als totalitärer Apparat, als Virtualität, in der die Sache (der Körper) des Anderen umfassend ausgelöscht wird - mit allen gegenwärtig immer stärker zu Tage tretenden ökologischen und politischen Folgen.

15 Die Frage der Dämonen „Was ist zwischen uns, Jesus von Nazareth“ ist nicht einfach rhetorisch.

16 Nietzsche muss wohl als Prophet des europäischen Nihilismus gesehen werden. Man könnte vielleicht sagen, dass der Faschismus ein Projekt der Identitätsversicherung durch Zuteilung von Einschluss (die Nation) und Ausschluss darstellt. Dagegen ist der Nationalsozialismus durch einen absoluten Nihilismus gekennzeichnet: Der Jude muss dem Diktum des Nazis gemäß sterben, aber da er gar nicht wirklich unterscheidbar vom Deutschen ist, im Zentrum der europäischen und deutschen Kultur steht, kann jeder zum todeswürdigen Juden erklärt werden... 


\section{Ein postnihilistischer Narrativ für Europa}

Dies wirft die Frage nach einem postnihilistischen Narrativ des öffentlichen Raums auf, verbunden mit der Frage, wie und ob das Christentum bzw. die abrahamitische Tradition (welche in Gestalt des Islams zumindest in Europa immer stärker das Christentum ersetzt) zu einem solchen Narrativ beitragen können. Zu bestimmen wäre in diesem Zusammenhang auch das Verhältnis von säkularer Gesellschaft und der religiösen Welt der Affekte, die nicht zuletzt auch durch den Islam immer deutlicher wird. Europas Zukunft hängt auf alle Fälle an einer fruchtbaren Verbindung von Aufklärung und Aufnahme (und auch Transformation) religiös-affektiver Geistigkeit, die durch die massive Migration von Muslimen immer stärker in die Öffentlichkeit tritt. Kann also Europa neue kreative Räume aus den Geschichten der Migranten und damit neue Formen von Öffentlichkeit schaffen oder bleibt es auf sich bezogen ein Projekt des Ausschlusses und der umfassenden Virtualisierung und Annihilierung des Anderen?

Bevor auf diese Fragen eingegangen wird, soll auf eines der bedeutsamsten Ereignisse der letzten Jahre, vielleicht Jahrzehnte zurückgekommen werden, nämlich die Massenmigration, die ganz Westeuropa betrifft. Deutschland, immer stärker das politische, wirtschaftliche und auch symbolische Zentrum jenes Europas, welches durch den Gedanken einer Europäischen (Friedens-)Union geprägt ist, entschied sich im Zuge der Massenankunft von Flüchtlingen im Jahre 2015 grosso modo für eine Politik der Aufnahme. Dabei bedeutete dieses Ereignis nicht nur die endgültige Erkenntnis Deutschlands, Einwanderungsland und erträumte Destination ganzer Völkerschaften und Kontinente zu sein, sondern vor allem - unabhängig von der Frage, welche sachpolitischen und humanen Überlegungen und Zwänge bzw. welche Zufälligkeiten bei der Entscheidung für die Grenzöffnung mitspielten - auch die Möglichkeit einer Art kollektiven Sühne für die nationalsozialistischen Verbrechen. Der Gründungsnarrativ der Europäischen Union, der in ganz besonderer Weise der zentrale Narrativ (des Westens) der Bundesrepublik Deutschland ist (und in viel geringerem Ausmaße der von Österreich, welches diesen Narrativ allen moralischen Appellen zum Trotz nie richtig internalisiert hat), besteht darin, dass sich die unsäglichen Gräuel des Nationalsozialismus niemals wiederholen dürfen. In den Ereignissen von 2015 konnte Deutschland sich und der Weltöffentlichkeit vor Augen führen, ein offenes Land zu sein, welches seine politischen Schwerpunkte nach moralischen Prämissen ausrichtet und sich dabei besonders der Menschenwürde verpflichtet fühlt. Das Gedenken der Opfer des Nationalsozialismus bewirkte gewissermaßen Narrative der Inklusion und die Bereitschaft zur Errichtung öffentlicher Räume, in denen auch die einen Platz einnehmen können, die keinen sonstigen Ort des Lebens mehr vorfanden. 
Was im Gefolge der Ereignisse von 2015 möglicherweise versäumt wurde, ist eine nach vorwärts gerichtete Sinngebung dieser Ereignisse. Es zeigt sich zwar, dass es nicht nur in Deutschland, sondern in (West-)Europa insgesamt noch eine Art Konsens darüber gibt, nicht in faschistische (oder gar nationalsozialistische) und totalitäre Politik zurückzufallen, gleichzeitig ist aber unübersehbar, dass das diesen Konsens fundierende Gedächtnis erodiert, wenn es sich nicht mit neuen Visionen und Narrativen verbindet. Man könnte hier kurz bemerken, dass Europa ein Kontinent ist, der durch große Narrative geprägt ist, von der biblischen Tradition angefangen bis hin zu den großen literarischen, historischen, kinematographischen und philosophischen Erzählungen und Romanen des 19. und 20. Jahrhunderts (man denke u. a. an Hegel, Proust, Musil, Dostojewski, Bachmann, von Trier oder Joyce), die sein historisches und moralisches Erbe prägen. Die Frage ist daher, welcher Narrativ sich heute aufdrängt.

Dabei ist als erstes zu beachten, dass Europa in der Gegenwart von Identitätsund Heimatlosen geprägt ist. Wie Schatten und Gespenster durchqueren sie den Kontinent und bevölkern die gesellschaftlichen und topographischen Ränder, zwar in umfassenden Studien katalogisiert, aber noch immer kaum Subjekte kollektiver kultureller Erzählungen und deren medialer Vermittlung. Einer der Identitätsmarker der Neuankommenden ist dabei die (vermeintliche oder auch wirkliche) religiöse Tradition ${ }^{17}$. Obgleich es Migranten oft schwerfällt, auf einem Kontinent anzukommen, in dem sich traditionelle, familiär strukturierte Bindungen und Identitäten teilweise aufgelöst haben, obgleich es noch schwerer fällt, mit dem unglaublichen Abstraktionsprozess umzugehen, der es Europäern erlaubt, sich von allem und jedem (Ereignisse, Menschen, Überlieferungen, Bindungen, sogar Geschlecht...) zu distanzieren, so gibt es doch im Bereich des Religiösen eine Art Kompensation. In der (Un-)Fähigkeit religiösen Glaubens liegt in den Augen vieler Flüchtlinge nicht nur eine Art Unterlegenheit einer sonst als übermächtig entgegentretenden Kultur ${ }^{18}$, vielmehr steckt in der Religion auch die Möglichkeit eigener Identitätsfindung in der Sphäre Gottes: Den neuen Heimaten, in denen es doch so schwer ist, wirklich heimisch zu werden, kommt angesichts der himmlischen Berufung die Funktion eines permanenten Durchgangsstadiums zu, wo man sich zwar niederlassen will, ohne aber der Illusion zu unterliegen, jemals ganz dazuzugehören...

17 Vgl. dazu Regina Pollak (Hg.), Religion and Migration, Interdisciplinary Journal for Religion and Transformation 3/1/2017, Göttingen 2017.

18 Eindrucksvoll wird das Scheitern am Kopieren europäischer Rationalität und das Ausweichen in religiöse symbolische Formen in Orhan Pamuks Roman „Schnee“ thematisiert. Vgl. Orhan Pamuk, Schnee, Frankfurt a. M. 2009. 


\section{Ein neues Zueinander von Christentum, Judentum, Islam und säkularer Welt in „Europa“}

Um zurück auf die Frage des Narrativs zu kommen, so bieten die Ereignisse der letzten Jahre eine Chance, die sogar einen moralischen Imperativ darstellt, soll Europa nicht von neuen Bürger- und Religionskriegen (und sei es auf „kleiner“ Flamme) zerfressen werden: Es handelt sich um die gerade auch im Wirken Ingeborg Gabriels zum Ausdruck kommende Vision eines Zusammenwirkens von jüdisch-christlicher Tradition, Islam und säkularer Welt, der Vision einer Neuschöpfung von Ausdrucksformen, Wahrnehmungen, Anerkennungsverhältnissen und Narrativen der Teilhabe. In anderen Worten: Europa muss seine historische Aufgabe für die gesamte globale Gesellschaft dieser Tage dahingehend erweitern, nicht nur den jahrtausendealten Antijudaismus endgültig hinter sich zu lassen und zu ächten, sondern auch die mittlerweile ebenfalls jahrtausendealte mehr oder weniger intensiv geführte Auseinandersetzung zwischen Christentum und Islam zu beenden. Es geht dabei um einen Eintritt des Islams in den öffentlichen und narrativen (und damit auch kulturellen) Raum Europas und seiner Institutionen sowie darum, einen in Europa sich verwurzelnden Islam, ein in Europa sich (neu-)verwurzelndes Christentum und eine spezifisch europäische Säkularität zu schaffen, die im Zeichen des Miteinander stehen.

\section{8. Öffentliche und private Sphäre}

Damit sind wir bei einem zentralen Proprium Europas angelangt, nämlich der Frage des öffentlichen (zivilen) Raumes und der ihm verpflichteten Gesellschaft (Zivilgesellschaft). Das besondere Verdienst der europäischen Zivilisation besteht darin, zunehmend öffentliche Räume definiert zu haben, die allen Bürgern zugänglich gemacht wurden ${ }^{19}$ : Dies betrifft nicht nur das Dorfgasthaus oder die Institution der Pfarre, sondern auch das Schul-, Gesundheits- und Transportwesen, kulturelle Einrichtungen, Architektur, Heer und Polizei, Sportstätten, das Gerichtswesen, Erholungsstätten usw. Verbunden mit dieser Kultur des öffentlichen Raumes war - dies darf nicht vergessen werden! - auch die Möglichkeit des Rückzugs ins Private. Gerade weil es funktionierende öffentliche Begegnungsstätten gab, konnte man sich daraus auch zurückziehen. Damit wird auch

19 Für Städteplanung und Architektur siehe besonders die Ausführungen von Andreas Denk, Der Raum der Wand als Bedeutungsträger. Architektur als Ausdrucksmittel in der Stadt, in: Vittorio Magnago Lampugnani / Rainer Schützeichel (Hg.), Die Stadt als Raumentwurf. Theorien und Projekte im Städtebau seit dem Ende des 19. Jahrhunderts, Berlin-München 2017, S. 263-275, hier: S. $263 \mathrm{f}$. 
ein wichtiger Bereich des biblischen Erbes berührt: Die personale, intime Beziehung zu Gott, der Gedanke einer inneren (göttlichen) Stimme in der Form des Gewissens und die Erfahrung personaler Liebe und Verantwortung (die die Dominanz des Ethos der Clans brechen konnte) haben die Konstruktion und Kultivierung einer privaten Sphäre begünstigt, die komplementär zur öffentlichen Sphäre steht. In Bezug auf das in den ersten Kapiteln über den siebenten Tag bzw. den Baum der Erkenntnis Ausgeführte kann festgehalten werden, dass die Personalität jenen nicht repräsentierbaren Zusatz, jene Offenheit darstellt, die sich in der kreativen Versetzung von Grenzen manifestiert.

\section{Die Wiederbelebung des öffentlichen Raums}

Diese öffentlichen Räume erodieren heute zunehmend: Sie werden wirtschaftlich und politisch ausgehöhlt und, im umfassenden Sinne des Wortes, immer stärker privatisiert - mit sichtbarer und auch hörbarer Konsequenz (permanente Beschallung durch Werbung an öffentlichen Plätzen, Zersiedelung, architektonische Gleichgültigkeit bei der Errichtung öffentlicher Bauten etc.). Mit der Privatisierung des Öffentlichen dringt das Öffentliche paradoxerweise auch umgekehrt immer stärker ins Private vor und bildet damit in einer Art Ununterscheidbarkeit (von öffentlich/privat) die Sphäre der Selbstdarstellung des Privaten. In diesem Zusammenhang ist die Virtualisierung der öffentlichen Räume zu thematisieren: An die Stelle einer allgemein zugänglichen Realität tritt eine unendliche Segregation der Lebensbereiche, die den Gedanken des Allgemeinen in den Hintergrund drängt bzw. ein völlig abstraktes Allgemeines, in dem nichts wirkliche Gültigkeit besitzt. Dazu steht die Virtualisierung in der großen Gefahr, den Körper des Menschen auszuschalten. Raum und Zeit und damit der Körper in seiner Widerständigkeit spielen keine Rolle mehr, die Welt kann nach den eigenen Vorstellungen beliebig modelliert und distanziert werden.

Dagegen bestünde die große Aufgabe heutiger Politik darin, öffentliche Räume wieder lebenswert zu gestalten, neue Formen der Beteiligung zu gestalten und allgemein zugänglich zu machen. Dies beinhaltet nicht nur wirtschaftliche und sicherheitspolitische Weichenstellungen, sondern auch ein kulturelles und pädagogisches Programm: Öffentliche Räume müssen ästhetisch so gestaltet sein, dass sie als lebenswert empfunden werden, dass sie Stätten der Begegnung und der kreativen Transformation sind. Dazu muss von Kleinkindesalter an die Achtung des öffentlichen Raumes gelehrt werden. Dem Staat kommt dabei eine überragende Bedeutung zu, da er dazu berufen ist, den Bestand der Zivilgesellschaft zu garantieren. 


\section{Drei mögliche Beiträge des Christentums zur Gestaltung der Zivilgesellschaft: Empathie, Einschluss der Toten und die Eröffnung einer Exit-Strategie für die Lebenden}

Bezüglich des Verhältnisses von Religion und öffentlichem Raum ist zu unterstreichen, dass die Religion niemals die zivile Sphäre für ihre Zwecke monopolisieren darf und umgekehrt auch kein Ausschluss der Religion aus der Öffentlichkeit erfolgen soll. Man könnte viel über die Funktion, den Beitrag, aber auch die Gefahren der Religionen für die Konstruktion und Erhaltung öffentlicher Räume und der mit ihnen verbundenen Zivilgesellschaft schreiben, im Zusammenhang dieses Artikels sollen aber drei besonders bedeutsame und oft vernachlässigte Bereiche herausgestrichen werden:

Der erste Beitrag der in Europa anwesenden (abrahamitischen) religiösen Traditionen im Allgemeinen und des Christentums im Speziellen für die Zivilgesellschaft besteht darin, dass die Religionen über ein ungeheures narratives und affektives Register verfügen, welches für die Agora fruchtbar gemacht werden kann und muss ${ }^{20}$ (hinter der sich im Artikel durchziehenden Oszillation zwischen den Bezeichnungen „abrahamitische Tradition/Religion“ einerseits und Christentum andererseits steckt letztlich auch die Auffassung, dass nur in einer umfassenden Ökumene der beteiligten Religionen, für deren Organisation in der gegenwärtigen Situation das Christentum aufgrund seiner Geschichte und „Infrastruktur“ besonders berufen ist, ein wirklicher Beitrag zur Zivilgesellschaft möglich ist). Letztlich darf nicht vergessen werden, dass der öffentliche Raum auf geteilten Affekten beruht, d. h. eine Art gegenseitige Grundsympathie und allgemeine Empathie voraussetzt. Gerade eine Schulung dieser Affektivität in Richtung Empathie setzt Erzählungen voraus, die darum wissen, dass der Mensch bzw. das Leben einerseits unendlich verletzbar, andererseits nicht auf empirische Fakten und auf unmittelbare handhabbare Präsenz reduzierbar sind, also über jede unmittelbare Präsenz hinausweisen. Die Religionen haben - ebenso wie Kunst und Philosophie - ein Traditionspotential, welches um die Verletzbarkeit und Unverfügbarkeit des Daseins weiß und Affekte in Richtung Empathie zu kanalisieren vermag. Gleichzeitig bringen sie auch das ungeheure Paket eines unendlichen Machtanspruchs mit sich, der durch eine starke Zivilgesellschaft - die z. B. in den Universitäten Stätten kritischer Reflexion kultiviert, die eine kritische Instanz gegenüber zivilen und religiösen Machtansprüchen darstellen (sollten) - in die Schranken zu weisen ist.

Der zweite Beitrag scheint mir ein zu wenig beachteter zu sein: Europa hat den Gedanken des öffentlichen Raums kultiviert, dabei aber zunehmend und bei-

20 Vgl. dazu besonders Pierangelo Sequeri, Il sensibile el'inatteso. Lezioni di esthetica teologica, BTC 179, Brescia 2016. 
nahe systematisch die Toten ausgeschlossen ${ }^{21}$. Unsere Kultur ist nicht zuletzt deshalb immer mehr eine solche des ewigen „Jetzt“, d.h. der virtuellen Zeitlosigkeit geworden, weil der Tod und die Toten keinen Platz darin haben. Die Religionen hatten das Reich der Toten monopolisiert. Dies führte dazu, dass mit dem Kampf gegen die religiöse Vorherrschaft dieses Reich zunehmend aus dem Horizont des Abendlandes verschwand. An dessen Stelle trat das „Nichts“22. Heute ist von den Religionen nicht zuletzt wieder ein Umgang zu lernen, der den Toten einen Platz in der Gesellschaft und in deren symbolischen Ordnungen zuweist. Es geht dabei nicht darum, die säkulare Welt auf einen Jenseitsglauben zu verpflichten, sehr wohl aber darum, einen adäquaten Umgang mit der Unverfügbarkeit der Verstorbenen und ihren je individuellen Lebensgeschichten zu finden, und zwar jenseits von deren sinnentleerter Annihilierung. Es stellt sich dabei die Frage, ob die Toten das Andere (Ausgeschlossene) der Welt der Lebenden sind oder ob nicht die Toten jenes Dritte, jenen Zusatz, jenen Rest darstellen zwischen der Welt der Lebenden und den aus ihr ausgeschlossenen und verdrängten Ängsten. Die Frage wäre also, ob nicht das Gedächtnis der Toten, welches diese in ihrer Unverfügbarkeit wahrt, ihnen aber Momente des Anwesens (in Erzählungen, in der Kunst, im Kultus...) zueignet, eine ganz entscheidende Rolle in einer Neukonfiguration des öffentlichen Raumes bedeuten könnte.

Der dritte Beitrag soll hier „Exit-Strategie“ genannt werden. Wie bereits im zweiten Abschnitt des vorliegenden Artikels betont wurde, kann das Heilige als eine separierte Sphäre aufgefasst werden, die von religiösen Mächten dominiert ist, es kann aber auch einen nicht repräsentierbaren „Zusatz“ indizieren ${ }^{23}$. Die Ambiguität der Religion offenbart sich im Umstand, dass sie einerseits das Heilige (bzw. den hier angezeigten "Zusatz") administriert, dominiert und besetzt, andererseits aber auch in einer geschlossenen, immanenten symbolischen Welt Ausgänge öffnet, die nicht repräsentierbar sind und daher auch nicht mit sich zusammenfallen und keiner Macht auf Erden (auch nicht dem „Ego“) zu-

21 Gegen diese Reduktion des Menschen auf die Sphäre der Lebenden erhebt nicht zuletzt Metz Einspruch. Siehe Johann Baptist Metz, Memoria Passionis. Ein provozierendes Gedächtnis in pluralistischer Gesellschaft, Freiburg 2006.

22 Besonders eindrücklich zeigt dies Hans-Dieter Bahr, Den Tod denken, München 2002.

23 Laurens ten Kate bringt das Phänomen eines Versprechens, welches jede Repräsentation transzendiert und damit als Ausgang einer Welt in sich geschlossener symbolischer Ordnungen dient, sehr präzise in seinem Artikel „Secularity as Sacrifice. Notes on the Dialectical Logic in Modernity and its Monotheistic Prefigurations“ zum Ausdruck: „The [...] exodus toward desert life has no other goal than wandering; the ,promised land" is not a straightforward goal to be reached after desert life; it is a promise [...] that moves on with the wandering journey, so that in the end one does not know whether the desert is the promised land after all." (Laurens ten Kate, Secularity as Sacrifice. Notes on the Dialectical Logic in Modernity and its Monotheistic Prefigurations, in: Interdisciplinary Journal for Religion and Transformation 1/2015, S. 22-45, hier: S. 39). 
gänglich sind. Auf diese Weise stellen unsere symbolischen Ordnungen niemals das Ganze, die Totalität dar, sondern verweisen auf eine „Lücke“, eine unverfügbare Entzogenheit, die als Ausgang/Exit all unserer Repräsentationen und In-Besitz-Nahmen betrachtet werden kann. „Gott“, „Transzendenz“, „Jenseits“, das „Messianische“, der heilige „Kanon“ sind Transformationen und Symbolisierungen dieser fundamentalen Offenheit, aber auch eine potentielle Subversion aller festgeschriebenen Grenzen und Selbst-Identitäten. Den öffentlichen Raum und die auf ihn basierende Zivilgesellschaft betreffend kann festgehalten werden, dass sein Ort genau jene Sphäre zwischen der Dichotomie Inklusion/ Exklusion darstellt.

\section{Conclusio}

Als Resultat der im vorliegenden Beitrag aufgerollten Fäden ergibt sich Folgendes: Europas Zivilgesellschaft basiert unter anderem auf einer Kultur eines allgemein zugänglichen öffentlichen Raumes. Dieser gründet in Erzählungen der Zugehörigkeit und der Empathie sowie der kritischen Relativierung jedes Totalitätsanspruchs. Heute geht es im Besonderen darum, die Stimmen der Migranten in diesem Raum zu hören und einen neuen Friedensnarrativ einer geteilten Öffentlichkeit von Menschen jüdisch-christlicher, säkularer und muslimischer Tradition zu formulieren. Dies schließt ein, dass die Zivilgesellschaft die Religionen, heute insbesondere den Islam, darin unterstützt, deren eigene Traditionen und affektiven Reichtum für dieses Projekt zu entfalten. Weiters bedeutet dies, von den Religionen zu lernen, dass auch den Toten - auf je neu zu bestimmende Weise - ein entsprechender Ort in den konstitutiven Erzählungen der Zivilgesellschaft einzuräumen ist. Nicht zu vergessen ist dabei, dass der öffentliche Raum aus einem Ethos lebt, welches sich der Dichotomie Einschluss/ Ausschluss ebenso entzieht wie einem Totalitätsanspruch, der alle Partikularitäten vernichtet. Vielmehr beginnt der öffentliche Raum da, wo diese Dichotomien und Machtphantasien unterminiert werden und sich Öffnungen in den Repräsentationen herrschaftlicher Macht (und ihren Orten und Zeiten) auftun. Wo diese subversiven Öffnungen kreativ gestaltet werden und zu einem Miteinander geteilter Erzählungen gerinnen, beginnt Europa.

Für einen lebenswerten, demokratischen öffentlichen Raum einzutreten, zu dem gerade auch die Universität gehört, und darin den konstruktiven Beitrag und die Berufung des Christentums sichtbar zu machen, ist eines der vielen Verdienste, die das akademische und öffentliche Wirken Ingeborg Gabriels auszeichnen. 


\section{Quellen}

Agamben, Giorgio, Il tempo che resta. Un commento alla „Lettera ai Romani“, Torino 2000. Appel, Kurt, Gott - Mensch - Zeit. Geschichtsphilosophisch Theologische Erwägungen zu Neuem Humanismus im Ausgang von Bibel, Hegel und Musil, in: Kurt Appel (Hg.), Preis der Sterblichkeit. Christentum und Neuer Humanismus, QD 271, Freiburg-BaselWien 2015, S. 19-60.

Bahr, Hans-Dieter, Den Tod denken, München 2002.

Berger, Peter L., A Rumor of Angels: Modern Society and the Rediscovery of the Supernatural, New York 1970.

Certeau, Michel de, Le fable mystique, 1: XVIe-XVIIe siècle, Paris 1982.

Denk, Andreas, Der Raum der Wand als Bedeutungsträger. Architektur als Ausdrucksmittel in der Stadt, in: Vittorio Magnago Lampugnani / Rainer Schützeichel (Hg.), Die Stadt als Raumentwurf. Theorien und Projekte im Städtebau seit dem Ende des 19. Jahrhunderts, Berlin-München 2017, S. 263-275.

Gabriel, Ingeborg, Political Theology under the conditions of modernity: A catholic perspective, in: Ingeborg Gabriel / Kristina Stoeckl / Aristotle Papanikolaou (Hg.), Political Theology in Orthodox Christianity. Common Challenges - Divergent Positions, London 2017, S. 55-74.

Habermas, Jürgen, Strukturwandel der Öffentlichkeit: Untersuchungen zu einer Kategorie der bürgerlichen Gesellschaft, Frankfurt a. M. 1990.

Harvey, David, Rebel cities, London-New York 2012.

Illich, Ivan, The Rivers North of the Future. The Testament of Ivan Illich as Told to David Cayley, Toronto 2005.

Kate, Laurens ten, Secularity as Sacrifice. Notes on the Dialectical Logic in Modernity and its Monotheistic Prefigurations, in: Interdisciplinary Journal for Religion and Transformation $1 / 2015$, S. 22-45.

Metz, Johann Baptist, Memoria Passionis. Ein provozierendes Gedächtnis in pluralistischer Gesellschaft, Freiburg 2006.

Nancy, Jean-Luc, La déclosion, Paris 2005.

Pamuk, Orhan, Schnee, Frankfurt a. M. 2009.

Regina Pollak (Hg.), Religion and Migration, Interdisciplinary Journal for Religion and Transformation 3/1/2017, Göttingen 2017.

Sassen, Saskia, Global Networks, Linked Cities, New York 2016 [2002].

Sequeri, Pierangelo, Il sensibile e l'inatteso. Lezioni di esthetica teologica, Brescia 2016. Tracy, David, The analogical imagination: Christian Theology and the culture of pluralism, New York 1981.

Zenger, Erich, Gottes Bogen in den Wolken. Untersuchungen zu Komposition und Theologie der priesterschriftlichen Urgeschichte, Stuttgarter Bibelstudien 112, Stuttgart 1983. 
Open-Access-Publikation im Sinne der CC-Lizenz BY 4.0

(C) 2020, Vandenhoeck \& Ruprecht $\mathrm{GmbH} \&$ Co. KG, Göttingen ISBN Print: 9783847111658 - ISBN E-Lib: 9783737011655 


\section{Die Welt als Gottes Innerstes. Die sozialethische Dimension in der mystischen Erfahrung Chiara Lubichs}

Von Chiara Lubich (1920-2008), der Gründerin der Fokolar-Bewegung, erschien im Jahr 1959 erstmals ein kleines Buch mit einer Zusammenstellung von geistlichen Texten ${ }^{1}$. Die erste Seite ist wie ein Programm, das das Lebenswerk Lubichs durchzieht und die unlösliche Verbindung von geistlicher Tiefe und Hingabe an die Welt ausdrückt:

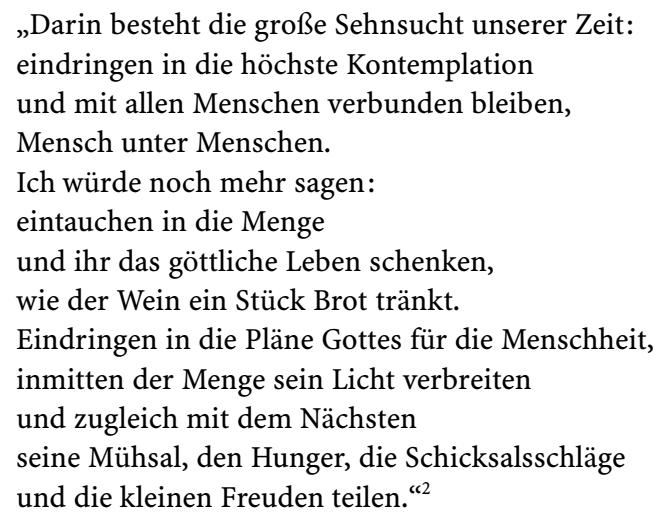

Diese Zeilen sind Ausdruck der Art, wie Chiara Lubich seit den Anfängen der Bewegung in den Kriegsjahren in Trient das christliche Leben verstanden hatte. Damals war sie überzeugt, dass das konsequente Leben aus dem Wort Gottes die soziale Frage in ihrer kriegsversehrten Heimatstadt lösen würde. Und nicht nur in Trient: im Herbst 1949 verfasste sie einen Text von ein paar wenigen Seiten, der in ihrem breiten Werk eine herausgehobene Stellung erlangen sollte: Auferste-

1 Chiara Lubich, Meditazioni, Rom 1959. Bis und mit der fünften Auflage (1964) erschien das Buch zwar mit dem nihil obstat, aber ohne den Namen der Autorin, da der Prozess der Anerkennung der Bewegung durch die katholische Kirche noch im Gang war. Es ist das meistverkaufte Buch geblieben und erschien 2008 in der 26. Auflage.

2 Deutsche Übersetzung aus: Chiara Lubich, Alle sollen eins sein. Geistliche Schriften, München 1995, S. 9. 
hung Roms. Er beschreibt in dichter, intuitiv-poetischer Sprache den Kontrast zwischen der Verheißung göttlichen Lebens, das uns in der Menschwerdung Gottes in Christus geschenkt wurde, und dem materiellen und moralischen Elend, das Lubich in der Stadt Rom, in der sie damals wohnte, wahrnahm. Der Kontrast ist aber nicht das letzte Wort. Gottes erneuerndes Feuer brennt nicht nur im Herzen der Glaubenden, sondern ist auf verborgene Weise in jedem Menschen da und wartet nur darauf, entzündet zu werden: wenn die Liebe unter den Menschen erfahrbar wird, bedeutet dies immer wieder neu das Wunder der Auferstehung.

Die Entstehung des Textes ist kennzeichnend. 1948 hatte Lubich den bekannten katholischen Schriftsteller und Politiker Igino Giordani ${ }^{3}$ kennen gelernt, damals Abgeordneter im italienischen Parlament. Dieser gab ihr in der von ihm gegründeten Zeitschrift La Via Raum, um dieses Manifest einer Erneuerung der Stadt - und damit überhaupt der Gesellschaft - zu veröffentlichen ${ }^{4}$. Erst im Jahr 1995 wurde der Text erneut in seiner ursprünglichen Form publiziert ${ }^{5}$ und hat seither vielfache Beachtung gefunden, so jüngst in einem interdisziplinären Sammelband mit Anregungen zu aktuellen gesellschaftlichen und anthropologischen Fragen ${ }^{6}$.

Der Politiker Giordani verband sich seit seiner ersten Begegnung mit Chiara - die bezeichnenderweise im Parlamentsgebäude Montecitorio stattfand - eng mit der entstehenden Bewegung. Geistliches Leben und gesellschaftliches Engagement waren für ihn untrennbar. Er wurde ein Mitbegründer der Bewegung und für Lubich ein qualifiziertes Gegenüber, durch das sie sich der sozialethischen Dimension ihres Charismas ${ }^{7}$ und der vielfältigen Verbindungen mit dem

3 Eine knappe Übersicht über das Lebenswerk Giordanis und weiterführende Literaturhinweise finden sich bei: Bernhard Callebaut, La nascita die Focolari. Storia e sociologie di un carisma (1943-1965), Roma 2017, S. 112-114.

4 Chiara Lubich, Risurrezione di Roma, in: La Via 36/1949, S. 5. Diese Wochenzeitschrift Giordanis hatte allerdings nur begrenzte Verbreitung. 1973 wurden Auszüge aus Auferstehung Roms, unter Weglassung allzu mystisch klingender Elemente, in eine Publikation Lubichs aufgenommen und fanden später Eingang in einen Sammelband: Scritti Spirituali 2, Rom 1978, S. 173-175.

5 In: Nuova Umanità. Rivista bimestrale di cultura 102/6/1995, S. 5-8. In deutscher Übersetzung ist er seit kurzem auch vollständig verfügbar (in: Das Prisma. Beiträge zu Pastoral, Spiritualität und Theologie 1/2018, S. 10-14).

6 Hubertus Blaumeiser / Anna Maria Rossi (Hg.), Resurrezione di Roma. Dialoghi interdisciplinari su città, persona e relazioni a partire da un testo di Chiara Lubich, Studi della Scuola Abbà 5, Rom 2017. Erwähnenswert ist auch die knappe Analyse von Christian Hennecke, Die Dynamik der Auferstehung. Theologisches Nachdenken über die ,Auferstehung Roms', in: Das Prisma 1/2018, S. 52-61.

7 Zum Charismabegriff, wie er auch hier verwendet wird, sei auf zwei Arbeiten hingewiesen. Christoph Hegge benutzt ihn im Kontext seiner Analyse des Platzes von Kirchlichen Bewegungen im Anschluss an das Zweite Vatikanische Konzil (Christoph Hegge, Rezeption und Charisma. Der theologische Beitrag Kirchlicher Bewegungen zur Rezeption des Zweiten Va- 
Erbe der christlichen Tradition vertieft bewusst wurde, auf deren Hintergrund erst das Besondere zum Ausdruck kommen sollte. Zugleich war Giordani ein Suchender, der sich als Familienvater ganz Gott weihen wollte. Aus Anlass dieser seiner Suche, aber letztlich unableitbar, ergab sich im Sommer 1949 der Beginn jener Zeit der speziellen mystischen Erfahrung Chiaras, die als Paradies ' 49 die ganze weitere Entwicklung der Bewegung prägen sollte.

\section{Kontext und Beginn des Paradies '49}

Der Beginn der Fokolar-Bewegung wird im Allgemeinen auf das Jahr 1943 angesetzt; die Jahreszahl ist allerdings nicht eindeutig, handelt es sich doch um einen allmählichen Prozess innerhalb des franziskanischen Drittordens in der Erzdiözese Trient. Um die Novizenmeisterin Silvia Lubich (mit dem Ordensnamen Chiara) scharte sich in den Kriegsjahren und danach eine Gruppe von jungen Menschen, denen sich bald auch Familien, Ordensleute und Priester anschlossen. Das Leben aus dem Wort, die Einheit (als Erfahrung der Gegenwart Gottes hier und jetzt wie auch als eschatologischer Zielpunkt der ganzen Menschheit) und ein spezifisches Verständnis der Heilsverwirklichung in Christus, besonders in dessen Schrei der Gottverlassenheit am Kreuz, waren erste Eckpunkte der sich herausbildenden Spiritualität. Der Erzbischof Carlo de Ferrari erkannte sowohl die kirchliche Bedeutung dieser neuen Gruppe als auch deren Besonderheit, weshalb er 1947 die Loslösung vom franziskanischen Drittorden beschloss ${ }^{8}$. Eine erste Anerkennung auf diözesaner Ebene mit eigenen Statuten (1947) ging einher mit dem Widerstand und teils schweren Anschuldigungen von Seiten bestehender kirchlicher Institutionen, vor allem der Katholischen Aktion; Carlo de Ferrari prüfte alles sorgfältig und verteidigte die junge Bewegung, wie er es in den fünfziger Jahren auch im Rahmen der italienischen Bischofskonferenz tun sollte. Die oben beschriebene Begegnung mit Igino Giordani und der Umzug Lubichs nach Rom im Dezember waren Eckpunkte eines ereignisreichen Jahres 1948 und der Hintergrund dessen, was ihr im Sommer 1949 zuteilwerden sollte.

tikanischen Konzils, Würzburg 1999). Bernhard Callebaut nähert sich ihm aus soziologischer Sicht und konzentriert sich dabei auf die Entstehungsgeschichte der Fokolar-Bewegung (Callebaut, Nascita).

8 Zur Schlüsselstellung des Erzbischofs Carlo de Ferrari in der Entstehungsgeschichte des Fokolars und zu seiner Beziehung mit Chiara ist jetzt eine umfangreiche Studie verfügbar: Lucia Abignente, „Qui c'è il dito di Dio“. Carlo de Ferrari e Chiara Lubich: il discernimento di un carisma, Roma 2017. Der breitere Kontext des katholischen Lebens in Trient wird in den entsprechenden Kapiteln bei Callebaut beschrieben (Callebaut, Nascita, besonders S. 88-100). 
Mit einigen Mitgliedern der ersten Gemeinschaft zog sich Lubich im Juli 1949 zum Ausruhen in ein Dorf in den Dolomiten zurück. Igino Giordani schloss sich ihnen für ein paar Tage an. Er wollte sich nach dem Beispiel von Politikern aus der Zeit Katharinas von Siena (deren Leben er studiert hatte und die er verehrte) mit einem privaten Gehorsamsgelübde an Chiara binden. Sie aber wollte keine spezifische Bindung zu zweit (denn Alle sollen eins sein), und der Gehorsam sollte gegenüber der Liebe (als zentralem christlichem Gebot) keinen Vorrang einnehmen. So machte sie Giordani den Vorschlag, sich in einer Eucharistiefeier gemeinsam ganz auf Jesus auszurichten, der auf ihrem und seinem „Nichts“ diejenige Einheit zustande bringen sollte, die Er wollte. Dieser Pakt der Einheit ${ }^{9}$, wie sie ihn später nannten, wurde zum Beginn des Paradies '49. Chiara beschreibt den entscheidenden Moment im Anschluss an die Messfeier so:

„Ich gehe hinein und trete vor den Tabernakel. Und ich setze dazu an, mich an Jesus in der Eucharistie zu wenden und ihn anzusprechen: „Jesus“. Aber es gelingt mir nicht. Denn jener Jesus, der im Tabernakel zugegen war, war auch hier, in mir; auch ich war er; ich war er, eins geworden mit ihm. Mich selbst konnte ich daher nicht ansprechen. Und da merkte ich, wie mir spontan das Wort „Vater“ über die Lippen kam. Und im gleichen Augenblick fand ich mich im Innern des Vaters vor. ${ }^{\text {" }}{ }^{10}$

Was darauf folgte, konnte Lubich später gelegentlich als eine Reise im Paradies beschreiben, aber dieser Ausdruck verlangt sogleich nach einer Präzisierung. Nur punktuell, vor allem am Anfang, ist es ein „Sehen“ von etwas, was ihr „an einem anderen Ort“ (im Paradies) gezeigt wird. Viel wichtiger wird dann die Erfahrung, dass es ein neues Sehen und Verstehen dessen wird, wer der Mensch und was seine Sendung in der Welt ist. Bis gegen Ende September 1949 bleibt Chiara mit einigen ihrer ersten Gefährtinnen in den Dolomiten; mit ihnen und vor allem schriftlich - mit Igino Giordani teilt sie ihre Erfahrungen. Nach der Rückkehr nach Rom brechen diese spezifisch mystischen Erfahrungen nicht ab; sie werden allerdings sporadischer und beziehen sich noch stärker auf die sie umgebende Welt (wie es z. B. im Text Auferstehung Roms zum Ausdruck kommt), auf die Kirche und auf die entstehende Bewegung.

9 Der Studienkreis Scuola Abbà hat dem so genannten Pakt der Einheit, dessen theologischer Einordnung und dessen Implikationen in einem breiteren humanwissenschaftlichen Kontext einen ganzen Band gewidmet: Vera Araújo (u. a.) (Hg.), Il Patto del '49 nell'esperienza di Chiara Lubich. Percorsi interdisciplinari, Studi della Scuola Abbà 1, Roma 2012.

10 Das italienische Original des Berichts über den Anfang des Paradies '49 ist publiziert in: Araújo, Patto, S. 11-25, hier: S. 18. 


\section{Das Textkorpus Paradies '49}

Die mystische Erfahrung Chiaras war von Beginn an eine gemeinschaftliche Erfahrung. Im „Schoß des Vaters“, wie sie es gelegentlich ausdrückt, sah sie nicht nur sich selbst, sondern eine Gruppe - sie nannte sie Anima, die Eine Seele. Alles, was Chiara erfuhr, kommunizierte sie mündlich und schriftlich, um die Anderen teilhaben zu lassen. Als jedoch Aufzeichnungen aus dieser Zeit in die Hände des Heiligen Offiziums gerieten, das zumindest seit 1949 bereits ein Dossier zu den Fokolaren eröffnet hatte ${ }^{11}$, führte dies zu schwerwiegenden Anklagen und dem Verbot dieser Schriften - für die Gründerin der Beginn einer länger dauernden dunklen Nacht. Nur ganz selten und im engen Kreis sprach Chiara über diese ihre besondere Erfahrung. Auch die erstmalige Anerkennung der Bewegung im Jahr 1962 änderte noch nichts an dieser Zurückhaltung. Eine diesbezügliche Öffnung ergab sich erst Ende der achtziger Jahre durch das Verdienst des damaligen Bischofs von Aachen, dem Theologen Klaus Hemmerle. Er stand Lubich sehr nahe und ermutigte sie, diese ihre mystische Erfahrung als ein Erbe zu sehen, das nicht nur sie persönlich betraf, sondern eigentlich der Kirche gehörte und darum für einen breiteren Kreis geöffnet werden sollte. So entstand 1990 ein kleiner interdisziplinärer Studienkreis, Scuola Abbà genannt, der sich den entsprechenden Aufzeichnungen - soweit erhalten geblieben - widmen sollte. Chiara selber leitete diese Arbeit bis ins Jahr 2004, sie sammelte und ordnete die Texte, und während sie, gereift durch die jahrzehntelange Erfahrung der ganzen Bewegung und deren vielfältigem gesellschaftlichem Engagement, sich auch existentiell noch einmal von ihnen berühren ließ, fragte sie zusammen mit den Mitgliedern der Scuola Abbà nach einer passenden Hermeneutik. Sie suchte Parallelen und mögliche Zugänge aus der Geschichte der christlichen Spiritualität und Theologie und interessierte sich für die Implikationen auf verschiedenen Gebieten des menschlichen Wissens. Im Verlauf der Jahre entstanden auf diese Weise Erklärungen, die nach und nach als Fußnoten dem Text angegliedert wurden, den Haupttext aber unberührt ließen. Das Resultat dieses Prozesses ist ein Korpus von etwa 250 Seiten, das jetzt - nach dem Tod der Autorin 2008 - als textus receptus verstanden werden kann, weil er von der Autorin selber in dieser Form authentifiziert wurde. Er steht zur Zeit erst den Mitgliedern der Scuola Abbà im vollen Umfang zur Verfügung, wobei allerdings zu ergänzen ist, dass viele einzelne Seiten und Textstücke in Publikationen der Mitglieder des Studienkreises bereits zugänglich gemacht worden sind ${ }^{12}$. Die hier folgenden Aus-

11 Callebaut, Nascita, S. 109.

12 Diese Publikationen finden sich in erster Linie in der Zeitschrift Nuova Umanità (Rom), beginnend mit dem Jahrgang 1995. 
führungen schöpfen aus dem gesamten Korpus ${ }^{13}$. Die noch ausstehende Publikation ist mit der Grund dafür, dass auch hier gelegentlich längere Textstücke wiedergegeben werden.

\section{Mystik und Politik: Gott in Jesus dem Verlassenen}

Von einer intensiven Gotteserfahrung ergriffen zu werden kann bedeuten, sich aus der Welt zurückzuziehen und inmitten dieser irdischen Wirklichkeit einen Raum offen zu halten, der an das Bleibende, Ewige erinnert und darauf hinführt. Das hat die lange Geschichte des Mönchtums seit der Zeit der Wüstenväter gezeigt. Der Weg des geistlichen Lebens kann aber auch mitten in die Welt hineinführen, nicht als ein Zweites und Abgeleitetes neben dem Eigentlichen (der Gottesbeziehung), sondern gerade als Vollzug dieser Gottesbeziehung. Petra Steinmair-Pösel, die ihre Habilitationsschrift zur Frage nach der Verbindung von Mystik und Politik verfasst hat, sieht dies in der ,inkarnatorisch-kenotischen Dimension des christlichen Glaubens " ${ }^{\text {"14 }}$ begründet. Sie zeigt dies an drei bedeutenden Frauengestalten des 20. Jahrhunderts auf, darunter auch Chiara Lubich. Ausgehend von deren geistlichen Erfahrungen, und nicht abgeleitet von allgemeinen religiösen oder naturrechtlichen Prinzipien, fragt Steinmair-Pösel „nach jenen Ressourcen in der christlichen mystischen Tradition [...], welche angesichts der eingangs erwähnten Herausforderungen inspirierende und transformierende Kraft zu entfalten vermögen. “15 Deshalb plädiert sie für die „bewusste Entscheidung für eine klar in der christlichen Tradition verwurzelte Sozialethik, die ihre Aufgabe mit Selbstbewusstsein und Demut zugleich wahrnimmt. In Zeiten der Diffusion zählt die Position. “16 Dies schließt allerdings, wie die drei von ihr aufgeführten Persönlichkeiten zeigen, die Wertschätzung des Anderen und die interreligiöse Zusammenarbeit nicht aus, sondern führt vielmehr darauf hin.

13 Dem Autor dieses Beitrags, seit dem Jahr 2000 Mitglied der Scuola Abbà, steht der ganze Text zur Verfügung. Die Angabe der Fundstellen von Zitaten orientiert sich an der durchgehenden Nummerierung der Absätze (1-1724) und Anmerkungen (1-1078). Im Folgenden werden Verweise auf dieses Textkorpus mit dem Kürzel P49 und der Angabe der Absatznummer bzw. der Anmerkungsnummer aufgenommen. Die deutsche Übersetzung entstammt der Arbeit einer Übersetzergruppe; sie ist wie das italienische Original noch nicht publiziert und als vorläufig zu betrachten.

14 Petra Steinmair-Pösel, Im Gravitationsfeld von Mystik und Politik. Christliche Sozialethik im Gespräch mit Maria Skobtsova, Dorothee Sölle und Chiara Lubich, Leiden-Paderborn 2019, S. 82.

15 Steinmair-Pösel, Gravitationsfeld, S. 105.

16 Steinmair-Pösel, Gravitationsfeld, S. $423 \mathrm{f}$. 
Bei Chiara Lubich ist dieses Zugleich von Mystik und Politik, von Konzentration und Weite mit einem Namen verbunden: Gesù Abbandonato, Jesus der Verlassene. Seit 1944, der Zeit der ersten schriftlichen Zeugnisse in Briefform, wird der gekreuzigte Christus fast nur noch mit diesem Namen angeredet, im Anschluss an den von Markus und Matthäus überlieferten Kreuzesschrei. Von der Gottverlassenheit zu reden heißt für Lubich, an die doppelte Not des Menschen in Sünde und Leid zu denken. ${ }^{17}$ Die Präsenz von Gott selbst in der Gottverlassenheit zu glauben bedeutet, inmitten des Leides an das Heil zu glauben und Heil zu erfahren, das in der Begegnung mit Gott besteht, der sich auf verborgen-geheimnisvolle Weise gerade darin zeigt. Es bedeutet, an den Sieg der Liebe zu glauben und diesen auch - punktuell und vorläufig - immer wieder zu erfahren. Von Jesus dem Verlassenen zu reden bedeutet für Chiara, dass es keinen Ort in der Welt gibt, dessen Gottverlassenheit nicht immer schon von Gott selbst erreicht und von der Verheißung des Lebens jenseits des Todes getragen wäre. Seit der ersten Intuition, die auf den 24. Januar 1944 datiert werden $\mathrm{kann}^{18}$, wird Jesus der Verlassene für sie das „einzige Buch“, aus dem sie unterrichtet werden will. ${ }^{19}$ Die Wortwahl ist nicht zufällig. Gesù Abbandonato ist immer beides: die existentielle Möglichkeit der Gottesbegegnung und der Ruf in die Nachfolge einerseits, der Schlüssel des Verstehens, der die Sicht auf Gott und auf die Welt grundlegend verändert, andererseits. So beschreibt Lubich bei der Durchsicht der Briefe aus jenen Jahren ihren Eindruck,

„(...) dass diese Liebe zu Jesus dem Verlassenen wie ein Feuer in unser Herz eingetreten war und es mit seiner explosiven Kraft durchdrungen hatte; ein Feuer, das alles verschlingt und nichts übriglässt - wie eine göttliche Leidenschaft, die Herz, Vernunft und alle Kräfte mitreißt und einbezieht, wie ein Blitz, der erleuchtet. Wir sahen. Wir verstanden. Es waren Ströme von Licht. “20

Diese „Ströme von Licht“ waren schon seit den Anfängen da, weil sonst die Entwicklung der ersten Jahre - gegen alle Widerstände - nicht erklärbar wären. Dennoch bedeutet die mystische Erfahrung der Jahre 1949-1951 nochmals eine entscheidende Vertiefung. Chiara selbst benutzt zu deren Charakterisierung wiederholt den Ausdruck intellektuelle Visionen ${ }^{21}$. Dieser Begriff aus der Ge-

17 Eine umfassende Analyse aller publizierten Schriften Lubichs im Hinblick auf die Heilsbedeutung von Jesus dem Verlassenen findet sich in: Stefan Tobler, Jesu Gottverlassenheit als Heilsereignis in der Spiritualität Chiara Lubichs. Ein Beitrag zur Überwindung der Sprachnot in der Soteriologie, Berlin-New York 2002.

18 Chiara Lubich, L'unità e Gesù Abbandonato, Roma 1984, S. 51 (deutsche Übersetzung: Jesus der Verlassene und die Einheit, München 1992, S. 39).

19 So schreibt sie es in einem Brief mit dem Datum des 30.01. 1944: Chiara Lubich, Lettere die primi tempi. Alle origini die una nuova spiritualità, Roma 2010, S. 31.

20 Lubich, L'unità, S. 60.

21 P49 Abs. 1534 (auch Anm. 144 und 364). 
schichte der Mystik ist durchaus passend, wie etwa das Werk von Edith Stein zeigt, die ihn in ihrer Analyse der Mystik von Johannes vom Kreuz verwendet. ${ }^{22}$ Um welche intellektuellen Visionen, um welches geistige Schauen geht es bei Chiara Lubich, wenn danach gefragt wird, wie die Verbindung von Gott und Welt verstanden wird und inwiefern die (mystische) Gottesbeziehung immer schon eine bestimmte Beziehung zur Welt ${ }^{23}$ mit einschließt und begründet?

\section{Die Verschränkung von Gott und Welt im Paradies '49}

\subsection{Das Bild der Strahlen - der Ausgangs- und Zielpunkt im Vater}

In einer Aufzeichnung vom 23. Juli 1949, eine Woche nach der Erfahrung des Eintretens in den „Schoß des Vaters“, erscheint erstmals das Bild von den Strahlen. Der Text lautet folgendermaßen:

„Das Himmelreich ist im Vater. Der Vater bringt sich nach außen hin zum Ausdruck wie in auseinanderstrebenden Strahlen und nach innen wie in Strahlen, die sich im Zentrum sammeln, in einem Punkt, der die Liebe ist: Gott im unendlich Kleinen, das ,Nichts-Alles' der Liebe, das WORT ${ }^{24}$ !

Die auseinanderstrebenden Strahlen sind Jesus: Durch Jesus gelangt der Vater zu allen Kindern, die außerhalb von ihm sind, an welchem Punkt auch immer sie sich befinden.

Sie nähern sich einander in dem Maße an, wie sie sich Gott nähern, indem sie sich in seinem Willen bewegen (weil sie Jesus sind).

Die Strahlen, die sich im Herzen der Sonne, im Vater sammeln, sind Wort Gottes; sie sammeln sich als WORT im WORT ...

22 Edith Stein, Kreuzeswissenschaft - Studie über Johannes vom Kreuz, Gesamtausgabe Band 18, 4. Aufl., Freiburg 2013, S. 58f, wo sie schreibt: „Zu dem, was der Verstand mit Hilfe der äußeren und inneren Sinne wahrnimmt, kommen rein geistige Mitteilungen: sie bieten sich dem Verstand ohne jede Vermittlung eines äußeren oder inneren Sinnes und ohne sein eigenes Zutun ,klar und bestimmt auf übernatürlichem Weg in reinem Empfangen dar, d.h. die Seele unternimmt nicht das Mindeste und trägt ihrerseits nichts dazu bei, wenigstens nicht selbständig und wie aus Eigenem'. Johannes unterscheidet geistige Visionen, Offenbarungen, Ansprachen und Empfindungen, fasst aber alle vier zusammen unter dem Namen intellektuelle Visionen, weil bei allen ein geistiges Schauen vorliegt.“

23 Der Begriff Welt steht in diesem Text für das Ganze der Schöpfung, unter Einbezug des Menschen und dessen (Mit-)Gestaltung dieser Welt.

24 In den Aufzeichnungen des Paradies '49 wird wechselweise entweder von Parola oder von Verbo gesprochen, wobei Parola sowohl das Schriftwort als auch Christus als Wort Gottes meinen kann, während Verbo immer das (inner-)trinitarische Sein der zweiten göttlichen Person meint, den göttlichen Logos. In der deutschen Übersetzung wird diese Unterscheidung zum Ausdruck gebracht, indem letzteres mit der Großschreibung WORT wiedergegeben wird. 
Der Vater sagt ,Liebe in unendlich vielen Klangfarben und zeugt in sich das Wort, das Liebe ist, den Sohn; und der Sohn als der, der er ist, nämlich Widerhall des Vaters, sagt ,Liebe' und kehrt zum Vater zurück!“25

Die Bildsprache scheint vorerst einmal klassisch zu sein: sie umfasst Gott und das „Himmelreich“ in ihm auf der einen Seite, die Welt außerhalb auf der anderen. Diese Aussage ist insofern grundlegend, als sie eine pantheistische Vorstellung des Gott-Welt-Verhältnisses ausschließt. Was außerhalb ist, ist aber nicht einfach von Gott getrennt; dafür steht der Name von Jesus als Ausdruck für das Eingehen Gottes in die Geschichte der Menschheit, ja der ganzen Schöpfung. In franziskanischer Tradition ${ }^{26}$ und unter Aufnahme platonischen Vokabulars spricht Lubich von den Ideen und deren Rückkehr in Gott:

„Die Strahlen, die vom Vater ausgehen (vom Herzen des Vaters) und auseinanderstreben, erreichen auch die ganze Schöpfung, die Materie, und geben ihr die Ordnung, die Liebe ist, Leben, die Idee: das WORT.

Am Ende werden die Ideen auf dem Strahl zu ihrem Schöpfer zurückkehren. In der Sonne werden sie von auseinanderstrebenden zu zusammenlaufenden Strahlen und ihr Zusammentreffen bildet das Paradies, dessen Wesen ganz Liebe ist. Dort wird es von jedem Ding die Idee geben, so wie sie schon vor der Erschaffung, von Ewigkeit her, im WORT bestand. “27

So ist also auch von zusammenlaufenden Strahlen im Innern Gottes die Rede, nicht nur im Sinne der eschatologischen Rückkehr alles Seienden, sondern als Ausdruck für Gottes unendliches Wesen. Beide Formen der Strahlen - divergierend und konvergierend - sind Ausdruck der einen Liebe Gottes, die sich innen wie außen in „unendlich vielen Klangfarben“ zeigt. So ist also von der Einheit „außerhalb“, inmitten der Vielheit der Schöpfung die Rede, und von Vielfalt im Innern des einen Gottes, des Vaters, der als Wurzel allem zugrunde liegt ${ }^{28}$.

Was Lubich in den ersten Tagen im Paradies „sah“, entsprach ihrer (der traditionellen Frömmigkeit entspringenden) Erwartung allerdings nicht:

„Ich erwartete, dass du mir die Heiligen zeigen würdest, einen nach dem anderen. Hingegen sah ich das ganze Paradies in seinem blütenreichen, sternenübersäten,

25 P49 Abs. 97-101.

$26 \mathrm{Zu}$ denken wäre etwa an die Collationes in Hexaemeron von Bonaventura (Bonaventura, Das Sechstagewerk. Ausgewählte Werke Band 3, aus dem Lateinischen übersetzt von Wilhelm Nyssen, München 1979).

27 P49 Abs. $115 \mathrm{f}$.

28 So schreibt Lubich am 24. Juli: „Sind wir erst einmal in das Himmelreich, in den Schoß des Vaters eingetreten, sind wir auf ewig in der Wurzel, die der Vater ist. Daher ist das Leben ewig, und der Lebenssaft, der in dieser Wurzel fließt, ist Liebe.“ (P49 Abs. 112). 
vielfarbigen Gewand, mit den Meeren, Bergen, Seen, Sternen, mit der Sonne, dem Mond, mit Alleen, das ganze Paradies (... $)^{\text {‘29 }}$

Sie sieht die Schöpfung in Gott - inklusive die vom Menschen gestaltete Schöpfung, hier als viali, Alleen, zwei Absätze weiter als strade, Straßen. Zumindest ansatzweise ist also - neben der Schöpfung - auch die menschliche Kulturleistung mitgemeint, wenn Chiara von den beiden Formen der Strahlen spricht, „außen“ und „innen“.

Im Dezember 1949 ist die Zeit der mystischen Erfahrung Lubichs noch nicht zu Ende, aber es hat sich doch ein bestimmter erster Kreis geschlossen. Aus jenen Tagen sind einige Texte erhalten, die auf die Intuitionen der ersten Wochen zurückblicken und sie aufgrund der späteren, mehrmonatigen Erfahrungen nochmals neu bündeln und durchdenken. Dies gilt auch für das Bild der Strahlen. So schreibt Chiara:

„Der Herr war wirklich ein Lehrmeister, als er mir das Paradies mit dem ganzen Jenseits und allem Geschaffenen gezeigt hat.

Zuerst ließ er mich die Nichtigkeit alles Geschaffenen erfahren, das heißt die Tatsache, dass es in sich selbst Nicht-Sein ist. ${ }^{30}$

Als ich im Vater angekommen war, empfand ich als konkret (Sein) nur ihn und all das, was in seinem Schoß enthalten ist.

Dann ließ er mich alle Dinge in ihrer Konkretheit wahrnehmen, indem er die geschaffene Wirklichkeit mit Vergleichen (wie dem der Sonne) erklärte, die zwar immer unzulänglich, aber für ein erstes Verstehen doch hilfreich waren. Denn er zeigte meinem Verstand den Himmel als Inneres der Sonne. Die Projektion des Vaters in sich selbst ist das WORT und all das, was in ihm enthalten ist. Das Geschaffene hingegen war die Projektion der Sonne außerhalb von sich.

Am Ende aller Erleuchtungen empfand ich die Projektion des Vaters, die Projektion der Liebe außerhalb von sich, und die Projektion in sich selbst von gleicher Konkretheit.

Denn der Vater hat den Sohn auf die Erde gesandt, um sich unter die geschaffenen Dinge zu mischen, sie zusammenzufassen und zu vergöttlichen. Jesus, der Mittler, war die Ursache der Vermählung des Ungeschaffenen mit dem Geschaffenen, der Einheit zwischen Geschaffenem und Ungeschaffenem, gleich jener zwischen dem WORT und dem Vater.

29 P49 Abs. 125 vom 24. Juli.

30 Auf die komplexe Bedeutung der Wortgruppe nulla - nullità - non essere - vanità - niente im Paradies ' 49 kann an dieser Stelle nicht eingegangen werden. Dass die Schöpfung (und mit ihr der Mensch) etwas ist und nicht nichts, wird in anderem Zusammenhang deutlich ausgedrückt, „,denn wenn ich nicht wäre, könnte Gott nicht in mir sein“, wie Chiara an einer Stelle schreibt (P49 Abs. 1172). 
Und in dieser Einheit ist jedes Ding im Innern des Vaters, und jedes Ding ist außerhalb des Vaters und enthält den Vater. Denn da jedes Ding im Sohn ist, im WORT, ist es mit dem WORT im Innern des Vaters („ich in dir“) und umfängt den Vater („du in mir“).

(„Ich in ihnen und du in mir").

Sodass am Ende alles Gott war: Gott in sich und Gott im Geschaffenen.

Zwei, aber eins geworden durch den Mittler Jesus. ${ }^{\text {“31 }}$

Auffällig ist die Aussage der gleichen Konkretheit dessen, was „außerhalb“ und was „in Gott“ ist. Die Unterscheidung wird nicht aufgehoben, aber durch die „Vermählung“ im Mittler Jesus sind die Schranken abgebrochen. Gott und Schöpfung sind je eines im Anderen, in einer Einheit „gleich jener zwischen dem WORT und dem Vater“: eine Aussage, die nur möglich ist, wenn man in der Schöpfung die Präsenz Gottes als ganz real glaubt und versteht, eine Präsenz, die im Mittler Jesus möglich geworden ist. Um sich dem Verständnis dessen $\mathrm{zu}$ nähern, was unter dieser Mittlerschaft, die offenbar so umfassende Heilsbedeutung hat, zu verstehen ist, soll nun auf einige Texte zu Jesus dem Verlassenen eingegangen werden.

\subsection{Das Nichts-Alles der Liebe: das christologische Fundament}

Wenn Lubich von Jesus (oder seltener auch von Christus) spricht, sieht sie ihn nie losgelöst vom Ganzen seines Erlösungswerkes. Dieses Werk in seinem eigentlichen Sinn wird im Kreuzesschrei der Gottverlassenheit vollbracht.

„Der wahre Jesus ist Jesus der Verlassene. Jesus in seinem Wesen ist Jesus der Verlassene. Da erlöst der Erlöser! Jesus, der alles gibt. Jesus ist Jesus der Verlassene! Er gibt das Menschliche und das Göttliche. ${ }^{\text {(32 }}$

In seinem doppelten Geben verbindet Jesus Gott und Mensch. Der Schrei der Gottverlassenheit drückt aus, dass er das Göttliche verschenkt, weil er sich die Situation der Menschen - ja der ganzen Schöpfung - zu eigen gemacht hat:

„Jesus der Verlassene hat in seinem Schrei das Nichts der Dinge zusammengefasst: ,Nichtig und flüchtig, alles ist nichtig““ ${ }^{33}$

Vom Nichts der Dinge ist die Rede, wenn und insofern sie als losgelöst von ihrem Grund und Bestand in Gott gesehen werden. Dass Jesus am Kreuzestod diesen (möglichen, oft wirklichen und jedenfalls immer auch drohenden) Zustand der

31 P49 Abs. 1004-1113.

32 P49 Abs. 486.

33 P49 Abs. 80, unter Aufnahme des Bibelverses Prediger 1,2. Die hier gewählte deutsche Übersetzung folgt der Zürcher Bibel von 2007. 
Gottferne auf sich genommen hat, wird als Geben interpretiert: Jesus lässt seine Göttlichkeit los, um sie der Menschheit zu geben. Daneben gilt das zweite Geben: er verliert sein Menschsein (im Tod eines auch von den Menschen Ausgestoßenen) und übergibt es dem Vater, in dem es aber bewahrt wird. In diesem doppelten Geben ist er zur Brücke geworden, die beide - Gott und Mensch unlöslich verbindet. Jesus der Verlassene ist an beiden Orten gleichermaßen präsent. Indem er sich in doppeltem Sinn zu „Nichts“ gemacht hat, ist er Mittler: er ist „ein Mittler, der Nichts ist ${ }^{\text {«34 }}$. Gerade als solcher aber erweist er sich als wahrer Gott:

"Jesus der Verlassene ist die Nichtigkeit und er ist das Wort; er ist das, was vergeht, und das, was bleibt, denn er ist Gott-Mensch. Als Mensch ist er alles Geschaffene und damit die Nichtigkeit alles Nichtigen; als Gott ist er das Feuer, das alle Dinge, das Nichts, in sich verzehrt und es vergöttlicht. Jesus der Verlassene hat alles Nichtige in sich aufgenommen. So wurde alles Nichtige er, und er ist Gott. ${ }^{\text {“35 }}$

Solchermaßen von Jesus dem Verlassenen zu reden bedeutet, von Gott als Liebe zu reden. Was Gott in der Erlösung für uns getan hat, ist Ausdruck seines eigenen Wesens. Die Liebe ist genau da sie selbst, wenn sie sich verschenkt und in diesem Sinn „nicht ist“:

„Jesus der Verlassene ist das Wunder des Zu-Nichts-Machens dessen, was ist. Ein Wunder, das nur versteht, wer die Liebe kennt und weiß, dass in der Liebe alles und nichts zusammenfallen.

Wenn wir das WORT im Vater betrachten, denken wir das WORT als Nichts (Nichts der Liebe), um Gott als den Einen denken zu können.

Wenn wir den Vater im WORT betrachten, denken wir den Vater als Nichts (Nichts der Liebe).

Jesus der Verlassene bekleidete das Alles mit dem Nichts, um das Nichts zunichte zu machen und all dem, was vergeht, göttlichen Bestand zu geben: ,Nichtig und flüchtig, alles ist nichtig“" 36

Jesus der Verlassene ist an beiden Orten - Gott und Welt - gleichermaßen präsent. Sein Eingehen in die Welt bis an deren untersten „Rand“ der Gottverlassenheit ist die objektive Seite der Erlösung, der Glaube daran und damit die Möglichkeit der Begegnung mit ihm mitten in dieser Welt ist die subjektive Erfahrung der Erlösung. Erlösung ist das Hineingenommen-Sein in das Wesen Gottes als Liebe - und genau das meint die Rede von der Trinität:

34 P49 Abs. 114.

35 P49 Abs. 83 vom 20. Juli.

36 P49 Abs. 1024-1027. 
„Mit jenem Schrei hat er die Menschheit erlöst und sie zur Tochter Gottes gemacht, zu Gott, zu Trinität; und in ihr hat er alles Geschaffene erlöst, in dem die Spur des dreifaltigen Lebens (dort fanden wir das Sein, das Gesetz und das Leben, und all das ist Liebe: Vater, Sohn, Heiliger Geist) durch Jesus den Verlassenen zur vollen und vollständigen Trinität gebracht wird. Wie in Jesus alles Gott ist und daher alles Trinität, auch sein Fleisch und sein Blut, so ist auch in allem, wofür er bezahlt hat, durch Teilhabe die gesamte Trinität. Es ist die Präsenz Gottes in den Dingen: vollständige Präsenz Gottes, bekleidet mit der Dinglichkeit. Lauter Eucharistie. ${ }^{\text {(37 }}$

Gewiss geht es hier um eine eschatologische Vision, wie es die ganze mystische Erfahrung Chiara Lubichs ja darstellt. Aber genau als solche drückt sie zugleich sozusagen die innere Wahrheit der Dinge aus: das, woraus und woraufhin sie geschaffen sind. Der Glaube daran verändert den Blick auf die Welt und den Umgang mit ihr.

\subsection{Mein wahres Ich im Andern: die anthropologische Konsequenz}

Im letzten Abschnitt wurde das Stichwort von der inneren Wahrheit der Dinge benutzt, als Verbindung einer eschatologischen Vision mit dem Leben hier und jetzt. Diese Denkform gilt in den Texten des Paradies ' 49 auch und besonders für den Menschen. An zwei wichtigen Stellen findet sich der Ausdruck mein wahres Ich.

Die eine Stelle gehört zu den ersten Tagen; sie findet sich in einer Notiz vom 25. Juli 1949:

„Ich (die Idee von mir) ist von Ewigkeit her im Bewusstsein Gottes, im WORT; ich bin also von Ewigkeit her vom Vater geliebt und von Ewigkeit her nehme ich den Platz ein, den der Vater mir zugeteilt hat. Und dort oben bin ich, das heißt mein wahres Ich: Christus in mir. Dort oben bin ich jenes Wort Gottes, das Gott von Ewigkeit her ausgesprochen hat. ${ }^{\text {(38 }}$

Mein wahres Ich ist Christus in mir: diese Aussage meint gerade nicht, dass letztlich alle Menschen im All-Einen aufgehen, in einer ununterschiedenen Christusförmigkeit in Gott. Vielmehr ist gemeint, dass jeder in Analogie zu Christus als dem einen Wort Gottes ein ebenso von Gott ausgesprochenes, unverwechselbares Wort ist. Diese Einmaligkeit kann ihm niemand wegnehmen, gegen die Tendenz der Welt, den Menschen gleichzuschalten oder ihn gar zu zerstören, und auch gegen seine eigene, sündhafte und selbstzerstörerische Tendenz.

37 P49 Abs. 789.

38 P49 Abs. 244. 
Christus als das wahre Ich in jedem Menschen: dieser Gedanke kommt dann wieder in jenem Text zum Tragen, der in der Einleitung genannt wurde, der Auferstehung Roms. Es geht darum, diesen Blick des Glaubens auf jeden Menschen hin auszuweiten. Auch wo Gott abwesend zu sein scheint, in Sünde, Leid und aller möglichen Negativität der menschlichen Existenz, ist das wahre Ich doch da und wartet darauf, aufzublühen. Christus in mir kann sich selber im Anderen wiedererkennen:

„Ich finde in den Anderen dasselbe Licht wieder, das auch in mir leuchtet, dieselbe göttliche Wirklichkeit, mein wahres Ich in den Anderen (selbst wenn es verschüttet ist oder aus Scham verborgen wird). Und wenn ich mich selbst wiedergefunden habe, vereine ich mich mit mir und komme - Liebe ist Leben - im Mitmenschen zur Auferstehung.

Doch es ist Jesus im Anderen, der zur Auferstehung kommt, ein anderer Christus, ein anderer Gott-Mensch, Manifestation der Güte des Vaters auf Erden, Blick Gottes auf die Menschheit. So weite ich den Christus in mir auf den Mitmenschen hin aus und bilde eine lebendige und vollständige Zelle des Mystischen Leibes Christi, eine lebendige Zelle, einen Feuerherd Gottes; Feuer, dazu bestimmt, sich auszubreiten und Licht zu geben. “39

Das Sich-Wiedererkennen im Anderen (als der gleichen Wurzel entstammend, sich dem gleichen Christus verdankend) bei bleibender Unterschiedenheit ist die Möglichkeit, christliche Gemeinschaft mitten in der Welt entstehen und wachsen zu lassen. Die hier verwendete Rede von einer vollständigen Zelle des Mystischen Leibes Christi ist somit Ausdruck für ein weites Verständnis von Kirche: sie ist $\left(\right.$ auch $\left.^{40}\right)$ mitten im Alltag zu finden. Das Engagement in der Welt ist kein Zweites neben einem anderswo verorteten Ersten. Es ist Gottesdienst, es ist „eindringen in die höchste Kontemplation und mit allen Menschen verbunden bleiben, Mensch unter Menschen“, wie es im Text des Eingangsteils ausgedrückt wurde. Nicht zufällig ist das allerletzte Wort des ganzen Textkorpus Paradies '49: Mensch. ${ }^{41}$

\section{Abschließende Bemerkungen}

Im Durchgang durch die Texte des Paradies ' 49 im Hinblick auf unsere Fragestellung ist deutlich geworden, dass die Christologie (im Sinne all dessen, was mit Jesus dem Verlassenen gemeint ist) der Schlüssel zum Verständnis der Welt,

39 P49 Abs. 719f.

40 Das in Klammern hinzugefügte „auch“ drückt aus, dass für Chiara Lubich die institutionelle Dimension der Kirche mit ihren Ämtern und Sakramenten, besonders der Eucharistie, damit nicht unwichtig wird. Das Gegenüber von charismatischer (auch: marianischer) und institutioneller Dimension der Kirche in Leben und Denken Lubichs, und besonders in den Texten des Paradies '49, würde eine gesonderte, lohnende Untersuchung erfordern.

41 P49 Abs. 1724. 
des Menschen in dieser Welt und der Präsenz Gottes in ihr bildet. In Jesus dem Verlassenen, dem Nichts-Alles der Liebe, ist Gott in der Welt und die Welt in Gott. Jesus der Verlassene steht in der Erfahrung des Paradies ' 49 sowohl für den Punkt, an dem im Innern Gottes alle Strahlen zusammenlaufen („in einem Punkt, der die Liebe ist: Gott im unendlich Kleinen “"42) wie auch für den gottfernsten Punkt der auseinanderlaufenden Strahlen. In der Unterscheidung und Zuordnung dieser beiden Weisen der Präsenz des Mittlers Jesus liegt die Möglichkeit, das Ineinander von Gott und Welt auf eine Weise zu denken, die keine Vermischung ist. Das eine ist das Innerste des Anderen, ohne seine Eigenheit zu verlieren. Die Schöpfung ist in Gott, ohne ihre Geschöpflichkeit zu verlieren, denn sie ist nicht kraft eigener Möglichkeiten dorthin gelangt, sondern hat es als Geschenk empfangen. Gott ist in der Welt, ohne seine Göttlichkeit zu verlieren, denn seine Hingabe im österlichen Heilsgeheimnis ist ja gerade Ausdruck seiner Göttlichkeit.

Der Blick auf all das, was uns umgibt und widerfährt, wird dadurch verändert. Der Mensch, der auf diese Weise glaubt, sieht in seinen Aufgaben in der Gesellschaft nicht nur eine zu erfüllende Pflicht aufgrund christlicher Grundsätze, und erst recht keinen Weg, um vor dem eigenen Gewissen oder vor einem imaginären göttlichen Gericht etwas zu verdienen. Es geht nicht darum, Gott irgendwohin zu „bringen“, sondern vielmehr ihn zu entdecken: wohin wir auch kommen, ist Gott - in Jesus dem Verlassenen - schon da. Mit dieser Aussage des Glaubens ist kein Mirakeldenken gemeint, und noch weniger geht es darum, das Widerständige, Üble und Böse, von dem die Welt voll ist, schön zu reden. Die sorgfältige Analyse der Gesellschaft mit Hilfe der entsprechenden Wissenschaften und die Suche nach immer nur vorläufigen Wegen, wie der Dienst an Mensch und Schöpfung aus christlicher Sicht in wechselnden Zeiten und Kontexten möglich ist, wird gewiss nicht überflüssig. Aber diese Suche ist von einer Grundüberzeugung getragen, die Mut macht und Grenzen überwinden hilft, weil diese in Gott, dessen Liebe auch das Nichts umfängt, schon überwunden sind.

\section{Quellen}

Abignente, Lucia, „Qui c’è il dito di Dio“. Carlo de Ferrari e Chiara Lubich: il discernimento di un carisma, Roma 2017.

Araújo, Vera et alii (Hg.), Il Patto del '49 nell'esperienza di Chiara Lubich. Percorsi interdisciplinari, Studi della Scuola Abbà 1, Roma 2012.

Blaumeiser, Hubertus / Rossi, Anna Maria (Hg.), Resurrezione di Roma. Dialoghi interdisciplinari su città, persona e relazioni a partire da un testo di Chiara Lubich, Studi della Scuola Abbà 5, Rom 2017.

42 P49 Abs. 97. 
Bonaventura, Das Sechstagewerk. Ausgewählte Werke Band 3, aus dem Lateinischen übersetzt von Wilhelm Nyssen, München 1979.

Callebaut, Bernhard, La nascita die Focolari. Storia e sociologia di un carisma (1943-1965), Roma 2017.

Hegge, Christoph, Rezeption und Charisma. Der theologische Beitrag Kirchlicher Bewegungen zur Rezeption des Zweiten Vatikanischen Konzils, Würzburg 1999.

Hennecke, Christian, Die Dynamik der Auferstehung. Theologisches Nachdenken über die ,Auferstehung Roms', in: Das Prisma. Beiträge zu Pastoral, Spiritualität und Theologie 1/2018, S. 52-61.

Lubich, Chiara, Paradiso '49, Manuskript, Rocca di Papa 2014.

Lubich, Chiara, Lettere dei primi tempi. Alle origini di una nuova spiritualità, Roma 2010.

Lubich, Chiara, Alle sollen eins sein. Geistliche Schriften, München 1995.

Lubich, Chiara, L'unità e Gesù Abbandonato, Roma 1984 (In deutscher Übersetzung: Jesus der Verlassene und die Einheit, München 1992.)

Lubich, Chiara, Scritti Spirituali Band 2, Rom 1978.

Lubich, Chiara, Meditazioni, Rom 1959.

Lubich, Chiara, Risurrezione di Roma, in: La Via 36/1949, S. 5 (später wieder in: Nuova Umanità. Rivista bimestrale di cultura 102/6/1995, S. 5-8; in deutscher Übersetzung: Auferstehung Roms, in: Das Prisma. Beiträge zu Pastoral, Spiritualität und Theologie 1/ 2018, S. 10-14).

Stein, Edith, Kreuzeswissenschaft - Studie über Johannes vom Kreuz, Gesamtausgabe Band 18, 4. Aufl., Freiburg 2013.

Steinmair-Pösel, Petra, Im Gravitationsfeld von Mystik und Politik. Christliche Sozialethik im Gespräch mit Maria Skobtsova, Dorothee Sölle und Chiara Lubich, Leiden-Paderborn 2019.

Tobler, Stefan, Jesu Gottverlassenheit als Heilsereignis in der Spiritualität Chiara Lubichs. Ein Beitrag zur Überwindung der Sprachnot in der Soteriologie, Berlin-New York 2002. 


\section{"Ein Wort, das wir bis zur Erschöpfung wiederholen müssen“. Papst Franziskus und der Dialog als Weg Christlicher Sozialethik}

Die Förderung und Durchsetzung der Menschenrechte einerseits und der globalen, intra- und intergenerationellen Gerechtigkeit andererseits sind zentrale Anliegen des akademischen und gesellschaftspolitischen Engagements Ingeborg Gabriels. Dass diese Anliegen in einer religiös und weltanschaulich pluralen, funktional ausdifferenzierten Gesellschaft sinnvoll und zukunftsweisend nur multiperspektivisch verfolgt werden können, wird sie nicht müde zu betonen. Christliche Sozialethik versteht sie deshalb in mehrfacher Hinsicht als Brückenfach: innertheologisch, zu benachbarten Disziplinen, ebenso wie nach außen, zu anderen akademischen Fachbereichen, wobei Gabriel, wie die vorliegende Festschrift sichtbar macht, den Rechtswissenschaften und der Ökonomie ${ }^{1}$ besondere Bedeutung einräumt. Aber auch Brückenschläge zu anderen Religionen ${ }^{2}$ und Konfessionen ${ }^{3}$ sind zentrale Merkmale ihres sozialethischen Profils. Immer geht es somit um die „Überbrückung“ eines Raumes zwischen Menschen, Disziplinen und Religionen, um die Ermöglichung von Begegnung durch das Wort (griechisch: diá-logos). Und so scheint es nicht nur angemessen, Gabriels sozialethischen Ansatz als im Kern dialogischen Ansatz zu charakterisieren, sondern das Thema Dialog - genauer: den Dialog, für den bereits Paul VI. in seiner Antrittsenzyklika Ecclesiam suam als Grundhaltung der Kirche in einer pluralen

1 Vgl. Ingeborg Gabriel / Peter G. Kirchschläger / Richard Sturn (Hg.), Eine Wirtschaft, die Leben fördert. Wirtschafts- und unternehmensethische Reflexionen im Anschluss an Papst Franziskus, Ostfildern 2017.

2 Vgl. Ingeborg Gabriel, Like Rosewater. Reflections on Interreligious Dialogue, in: Journal of Ecumenical Studies 45/2010, S. 1-23. Gabriel bezeichnet ein aktives Engagement im interreligiösen Dialog als moralische Verpflichtung angesichts des religiösen Pluralismus in einer globalisierten und desäkularisierten Welt und spricht in diesem Kontext von einem „dialogischen Imperativ“ (dialogical imperative). Vgl. Ebd., S. 4.

3 Vgl. Ingeborg Gabriel / Alexandros K. Papaderos / Ulrich H. J. Körtner, Perspektiven ökumenischer Sozialethik. Der Auftrag der Kirchen im größeren Europa, 2. Aufl., Ostfildern 2006; Ingeborg Gabriel / Franz Gassner (Hg.), Solidarität und Gerechtigkeit. Ökumenische Perspektiven, Ostfildern 2007; Ingeborg Gabriel, Politik und Theologie in Europa. Perspektiven ökumenischer Sozialethik, Ostfildern 2008. 
Welt geworben hatte und zu dem nun Papst Franziskus in zahlreichen Schreiben und Ansprachen aufgefordert hat - auch ins Zentrum des vorliegenden Beitrags zu stellen.

Nach einer einleitenden Darstellung des dialogischen Elements in Gabriels Arbeit wird ein kursorischer Überblick über Verwendung und Verständnis des Dialogbegriffs in den Enzykliken und nachsynodalen Lehrschreiben sowie in ausgewählten sozialethisch relevanten Texten von Papst Franziskus gegeben. Ein dritter Schritt eröffnet einen Ausblick auf weiterführende systematisierende Fragen: Thematisiert werden das Spezifische der Kommunikationsform Dialog, die essenzielle Bedeutung der (kontemplativen) Unterbrechung und des Schweigens für gelingenden Dialog, sowie das Modell eines „kenotischen Dia$\operatorname{logs}$ “.

\section{Dialogische Züge in Ingeborg Gabriels sozialethischem Zugang}

Bereits seit den 1980er Jahren beteiligte sich Gabriel an verschiedenen interreligiösen Dialog-Initiativen, seit Mitte der 1990er Jahre engagierte sie sich in der Vienna Dialogue Initiative, von 2001 bis 2008 war sie Teil des Steering Committee des Vienna Christian-Islamic Round Table, 2006 gründete sie gemeinsam mit der Juristin Irmgard Marboe die Vienna Christian-Islamic Summer University. Zudem gehört sie seit 2001 dem Board des Dialogue Institute der Temple University in Philadelphia (USA) an. ${ }^{4}$

Inhaltlich umreißt Gabriel ihr Verständnis von Dialog in einem aktuellen Beitrag mit dem Titel „All Life Is Encounter: Reflections on Interreligious Dialogue and Concrete Initiatives “5 . Dialog ist für sie mehr als nur ein Austausch von Informationen, obwohl sie die Verständigung über Fakten als Teil des Dialogs versteht. Stärker im Vordergrund stehe allerdings die persönliche und interpersonale Dimension, die umso intensiver werde, je mehr die im Dialog besprochenen Themen für die beteiligten Personen von existentieller Bedeutung seien. Dies - so Gabriel - treffe besonders für Diskussionen über religiöse und ethische Themen zu, welche von grundlegender Bedeutung für jeden Menschen seien, da sie dessen innerstes Sein beträfen. Gabriel verwendet hier die beiden Begriffe Dialog und Diskussion (dialogue/discussion) annähernd synonym. An

4 Vgl. Gabriel, Like Rosewater, S. 4-10; vgl. https://se-ktf.univie.ac.at/ueber-uns/ingeborg-ga briel/lebenslauf/ (letzter Zugriff: 31.07.2019).

5 Vgl. Ingeborg Gabriel, All Life Is Encounter: Reflections on Interreligious Dialogue and Concrete Initiatives, in: Religious Education 112/2017, S. 317-322; Gabriel, Like Rosewater, S. $10-11$. 
anderer Stelle ${ }^{6}$ erhebt sie die Frage, ob Themen im Dialog debattiert werden können (can issues be debated in dialogue), oder ob es im Dialog nur darum gehe, dem anderen zuzuhören. Klar hebt sie den Dialog von jener Scheinkommunikation (fake communication) ab, welche sie zunehmend in Politik und Gesellschaft konstatiert und durch welche sie die Freiheit und Würde der Menschen verletzt sieht. In diesem Sinn bedeutet für sie Gewalt in all ihren Formen das genaue Gegenteil von Dialog. ${ }^{7}$

Allerdings birgt gerade die Thematisierung existentiell tiefgehender religiöser und ethischer Fragen auch ein hohes Konfliktpotential, das entschärft werden kann und muss, indem jener gegenseitige Respekt gestärkt wird, der auf dem Bewusstsein basiert, dass alle Menschen als kontingente und begrenzte Wesen letztlich auf der Suche nach der Wahrheit sind, diese aber niemals vollumfänglich besitzen können. Darüber hinaus weist Gabriel auch auf eine dem Dialog inhärente Spannung hin: Einerseits bedarf dieser einer starken und reflektierten Identität bei jenen, die daran partizipieren. Die eigene Position zu verleugnen würde einen echten Dialog nämlich gerade verunmöglichen und einem billigen Synkretismus Vorschub leisten. ${ }^{8}$ Andererseits jedoch muss die Identität der Dialogpartner auch so offengehalten werden, dass es möglich ist, voneinander zu lernen. Dieses hermeneutische Prinzip anzuerkennen, bildet nach Gabriel die Grundlage dafür, dass im Dialog neue Einsichten gewonnen werden können, die niemals rein kognitiven, sondern immer auch existentiellen Charakter haben. ${ }^{9}$

Eine ganz eigene Qualität kommt nach Gabriel dem - sich von einem „Dialog des Lebens" ${ }^{\text {"10 }}$ und dem (interreligiösen) Dialog über religiöse Erfahrung und Theologie $^{11}$ im Blick auf Inhalte, Ziele und Wahrheitsansprüche abhebenden Dialog über ethische (und rechtliche) Fragen $\mathrm{zu}^{12}{ }^{12}$ Während es im interreligiösen Dialog über theologische Fragen darum geht, den anderen respektvoll zuzuhören und zu erfahren, wie sie sich verstehen, nicht jedoch darum, zu gemeinsamen Konklusionen zu kommen, besteht das Ziel des ethischen Dialogs nach Gabriel durchaus in einem Konsens über richtig und falsch sowie gerecht und ungerecht. Ein solcher liege auch im Rahmen des Möglichen, da Religionen in ethischen Fragen wesentlich weniger differieren würden als in ihren Glaubenssystemen. ${ }^{13}$ In diesem Sinne scheinen Gabriel ethische Fragen als besonders prädestiniert für

6 Vgl. Gabriel, Like Rosewater, S. 10.

7 Vgl. Gabriel, All Life Is Encounter, S. 318.

8 Vgl. Ebd., S. 317-318; S. 321-322.

9 Vgl. Ebd., S. 318.

10 Vgl. Gabriel, Like Rosewater, S. 13-14.

11 Vgl. Ebd., S. 14-18.

12 Vgl. Ebd., S. 18-23.

13 Vgl. Ebd., S. 19. Auch im Blick auf säkular-humanistische Zugänge zur Ethik hält Gabriel die Gemeinsamkeiten mit religiös fundierten Ethiken für wesentlich größer als die Differenzen. Vgl. Ebd., S. 20. 
den Dialog über Religions- und Weltanschauungsgrenzen hinweg. Zugleich sieht sie die Ethik angesichts der aktuellen Herausforderungen auch von einem dialogischen Imperativ in die Pflicht genommen.

\section{Dialog bei Papst Franziskus}

Bereits vor Abschluss des II. Vatikanums hatte Papst Paul VI. 1964 in seiner Antrittsenzyklika Ecclesiam suam den respektvollen Dialog als wesentliche Grundhaltung und authentischen Weg der Kirche angesichts der zeitgenössischen gesellschaftlichen Entwicklungen beschrieben: „Die Kirche muss zu einem Dialog mit der Welt kommen, in der sie nun einmal lebt.“ (ES 67) Diese dialogische Haltung, die geprägt sein soll von Klarheit, Sanftmut, Vertrauen und pädagogischer Klugheit (ES 83-84), realisiert sich in konzentrischen Kreisen von der Menschheit als Ganzer über die an Gott Glaubenden und die anderen christlichen Konfessionen bis hin zum innerkirchlichen Bereich - und gründet nach Paul VI. im Dialogangebot Gottes selbst. Sie gilt ihm als einer der wichtigsten Aspekte im Leben der Kirche. (Vgl. ES 60-123)

Darauf aufbauend, bildet der Dialog auch in vielen Texten von Papst Franziskus ein zentrales Motiv: Bereits in der gemeinsam mit Papst Benedikt XVI. veröffentlichten Enzyklika Lumen Fidei kommt der Begriff „Dialog“ 15 Mal vor, in der Enzyklika Laudato si' $28 \mathrm{Mal}$, in Evangelii Gaudium sogar $52 \mathrm{Mal}$. Auch in den nachsynodalen apostolischen Schreiben Amoris laetitia, Gaudete et exsultate und Christus vivit spielt der Dialog eine Rolle und nicht zuletzt misst Franziskus dem Dialog in seinen programmatischen Äußerungen zu Europa eine besondere Bedeutung bei. In den folgenden Abschnitten soll überblicksmäßig dargestellt werden, was Franziskus unter Dialog versteht, wobei besonderes Augenmerk auf jene Passagen gelegt wird, die auch sozialethisch bedeutsam erscheinen.

\subsection{Lumen fidei ${ }^{14}$}

In der Enzyklika Lumen fidei kommt das Thema Dialog in drei Zusammenhängen zur Sprache: Erstens im Kontext des Dialogs mit der hellenistischen Kultur (LF 23, 29, 32), wobei der „Hunger nach Wahrheit“ in der griechischen Antike als „ein geeignetes Gegenüber für den Dialog“ mit den ersten ChristInnen

14 Franziskus, Lumen Fidei (LF), vgl. http://w2.vatican.va/content/francesco/de/encyclicals/ documents/papa-francesco_20130629_enciclica-lumen-fidei.html (letzter Zugriff: 30.07. 2019). 
gesehen wird. Die Glaubensgewissheit der ChristInnen wird dabei als in Bewegung setzende und motivierende Kraft verstanden, die gerade nicht ideologisch verhärtet, sondern den Dialog sucht und ermöglicht (LF 34-35). Eine zweite theologisch zentrale Aussage über den Dialog gibt diesem gleichsam göttliche Dignität, indem der trinitarische Gott selbst als „ein ewiger Dialog der Gemeinschaft“ bezeichnet wird, der den Menschen einlädt, „ins Innere dieses Dialogs einzutreten“ (LF 36). Der Dekalog wird dabei verstanden als Sammlung von Weisungen, die dem Menschen helfen soll, „aus der Wüste des selbstbezogenen, in sich verschlossenen Ich herauszukommen und in Dialog mit Gott treten zu können, während man sich von seiner Barmherzigkeit umfangen lässt, um selber Barmherzigkeit zu bringen“ (LF 46). Damit in Zusammenhang steht der dritte Kontext: Glaube ist nicht einfach eine individuelle Option des Einzelnen, keine isolierte Beziehung zwischen der einzelnen Seele und dem göttlichen $\mathrm{Du}$, sondern öffnet auf Gemeinschaft hin, woran das dialogische Glaubensbekenntnis der Taufliturgie erinnert (LF 39).

\subsection{Laudato si ${ }^{15}$}

Die Enzyklika Laudato si' kann als eine einzige große und dringliche Einladung zum Dialog über „die Zukunft unseres Planeten“ (LS 14) verstanden werden: eine Einladung, die Franziskus explizit an alle Menschen richtet, „um gemeinsame Wege der Befreiung zu suchen" und die zugleich unter Christinnen und Christen zu einer Vertiefung des Verständnisses der ökologischen Verpflichtungen, die aus der eigenen Glaubensüberzeugung erwachsen, führen soll (LS 64). Diesen Dialog hält Franziskus einerseits für notwendig angesichts der ökologischen Krise, gleichzeitig beschreibt er ihn aber auch ganz grundsätzlich als den Weg der Entwicklung der Soziallehre der Kirche (LS 63), zumal das Christentum „im Dialog mit den [je] neuen geschichtlichen Gegebenheiten“ seine bleibende Aktualität zu erweisen hat (LS 121). Die von Franziskus skizzierten „Wege für den Dialog“, sollen der Menschheit dabei helfen, „aus der Spirale der Selbstzerstörung herauszukommen, in der wir untergehen“ (LS 163).

Franziskus versteht den Dialog gemeinsam mit der Reflexion und „der großherzigen Begegnung zwischen Personen“ als die eigentliche Quelle echter Weisheit, während die Tendenz der digitalen Medien zur bloßen Anhäufung von Daten nicht wirklich hilfreiches Wissen generiere, sondern im Gegenteil „sättigend und benebelnd" wirke und zu „einer Art geistiger Umweltverschmutzung“ führe (LS 47). Demgegenüber macht der Papst Dialogfähigkeit als Spezifikum des

15 Franziskus, Laudato si’ (LS), vgl. http://w2.vatican.va/content/francesco/de/encyclicals/docu ments/papa-francesco_20150524_enciclica-laudato-si.html (letzter Zugriff: 30.07.2019). 
Menschen stark: „Obwohl auch der Mensch Entwicklungsprozesse voraussetzt, schließt er etwas Neues ein, das von der Entwicklung anderer offener Systeme her nicht gänzlich erklärbar ist. Jeder von uns besitzt in sich eine persönliche Identität, die fähig ist, mit den anderen und mit Gott selbst in Dialog zu treten.“ (LS 81)

Von diesem Dialog, der auf verschiedenen Ebenen, zwischen unterschiedlichen Partnern und in mannigfachen Kontexten zu führen ist, erwartet Franziskus sich ganzheitlichere Antworten auf ökologische Herausforderungen: Zum Beispiel im Sinne einer Vermittlung zwischen fortschrittsoptimistisch-technokratischen und pessimistisch-misanthropischen Extrempositionen (LS 60). Oder auch im Sinne der Ermöglichung von Partizipation lokaler Bevölkerung und örtlicher Kulturen bei der Lösung ökologischer Fragen, „indem man die wissenschaftlich-technische Sprache in einen Dialog mit der Sprache des Volkes bringt" (LS 143).

Und schließlich steht das gesamte 5. Kapitel der Enzyklika im Zeichen des Dialogs. Darin ruft Franziskus (1.) zu einem Umweltdialog in der internationalen Politik auf, welcher zu "Lösungen von einer globalen Perspektive aus" kommt, die nicht nur „,der Verteidigung der Interessen einiger Länder dienen“ (LS 164). Auch fordert er (2.) einen Dialog im Hinblick auf neue nationale und lokale politische Konzepte, da angesichts kurzsichtiger politischer Machtkalküle oft vergessen werde, dass "die Zeit mehr wert ist als der Raum" und sich in diesem Sinn politische Größe gerade dann zeige, „wenn man in schwierigen Momenten nach bedeutenden Grundsätzen handelt und dabei an das langfristige Gemeinwohl denkt“ (LS 178). Zudem verlangt Franziskus (3.) Dialog und Transparenz in Entscheidungsprozessen, wobei er „transparente politische Prozesse, die dem Dialog unterworfen sind“ als Gegenpol zu jener Korruption versteht, ,welche die wirkliche Umweltbelastung eines Projekts um gewisser Vergünstigungen willen verheimlicht" (LS 182). Darüber hinaus spricht Franziskus von der dringenden Notwendigkeit, dass (4.) Politik und Wirtschaft im Dialog für die volle menschliche Entfaltung stehen, wobei sich die Politik nicht der Wirtschaft und diese „sich nicht dem Diktat und dem effizienzorientierten Paradigma der Technokratie unterwerfen" (LS 189) dürfe. In diesem Sinn stellt der Papst fest: „Wir brauchen eine Politik, deren Denken einen weiten Horizont umfasst und die einem neuen, ganzheitlichen Ansatz zum Durchbruch verhilft, indem sie die verschiedenen Aspekte der Krise in einen interdisziplinären Dialog aufnimmt.“ (LS 197) Für wie unerlässlich im Blick auf die Realisierung des globalen Gemeinwohls Papst Franziskus schließlich den Dialog von Religion und Wissenschaft mit ihren unterschiedlichen Zugängen zur Realität (vgl. LS 62) erachtet, macht (5.) der letzte Abschnitt des 5. Kapitels deutlich, wo er den interreligiösen Dialog, den Dialog unter den Wissenschaften und den Dialog zwischen den verschiedenen Ökologiebewegungen fordert, denn: 
„Die Schwere der ökologischen Krise verlangt von uns allen, an das Gemeinwohl zu denken und auf einem Weg des Dialogs voranzugehen, der Geduld, Askese und Großherzigkeit erfordert, immer eingedenk des Grundsatzes: ,Die Wirklichkeit steht über der Idee.““ (LS 201)

\subsection{Evangelii gaudium ${ }^{16}$}

Als Dokument des Dialogs schlechthin kann das Apostolische Schreiben Evangelii gaudium über „die Verkündigung des Evangeliums in der Welt von heute“ bezeichnet werden. Dialog meint darin „weit mehr als die Mitteilung einer Wahrheit“, nämlich „ein Gut, das nicht in Dingen besteht, sondern in den Personen selbst, die sich im Dialog einander schenken“ (EG 142). Dabei wird der Dialogfähigkeit der Kirche ad intra und ad extra fundamentale Bedeutung für die Weitergabe des Evangeliums zugemessen und mangelnder Raum für Dialog (z. B. in der Familie, EG 70) als ein Grund für den Traditionsabbruch benannt. Von den Bischöfen wird erwartet, dass sie Mitspracheregelungen und andere Formen des pastoralen Dialogs suchen und fördern, getragen von dem „Traum, alle zu erreichen“ (EG 31). Priester und PredigerInnen werden zu „herzliche[r] Nähe“ (EG 140) ermutigt, um jenen Dialog aufzunehmen, „der zwischen dem Herrn und seinem Volk bereits eröffnet wurde“ und sensibel dafür zu sein, „wo dieser ursprünglich liebevolle Dialog erstickt worden ist oder keine Frucht bringen konnte" (EG 137). Theologinnen und Theologen mahnt Franziskus, „sich nicht mit einer Schreibtisch-Theologie zufrieden [zu] geben“, sondern „mit anderen Wissenschaften und menschlichen Erfahrungen im Dialog“ zu stehen und in ihrer theologischen Forschung „den Dialog mit der Welt der Kultur und der Wissenschaft" zu fördern (EG 133).

Sozialethisch zentral sind aber vor allem jene Abschnitte, in denen Papst Franziskus „Zwei große Fragen“ benennt, „die in diesem Augenblick der Geschichte grundlegend erscheinen. [...] Es handelt sich an erster Stelle um die gesellschaftliche Eingliederung der Armen und außerdem um den Frieden und den sozialen Dialog.“ (EG 185) Angesichts der Trennungen und gewaltsamen Verwerfungen (gerade auch in den Städten) sieht der Papst die Kirche „berufen, sich in den Dienst eines schwierigen Dialogs zu stellen“, damit die Kluft zwischen Bürgern und „Nicht-Bürgern“ schwindet und die Forderungen nach „Freiheit, Beteiligung und Gerechtigkeit“ für alle „auf ein angemessenes Verständnis stoßen“ (EG 74). Damit dies gelingen kann, braucht es nach Franziskus

16 Franziskus, Evangelii Gaudium (EG), vgl. http://w2.vatican.va/content/francesco/de/apost_ exhortations/documents/papa-francesco_esortazione-ap_20131124_evangelii-gaudium.html (letzter Zugriff: 30.07.2019). 
eine wachsende Zahl an PolitikerInnen, „die fähig sind, in einen echten Dialog einzusteigen, der sich wirksam darauf ausrichtet, die tiefen Wurzeln und nicht den äußeren Anschein der Übel unserer Welt zu heilen“ (EG 205). Eine so verstandene Politik sieht er als „eine der wertvollsten Formen der Nächstenliebe, weil sie das Gemeinwohl anstrebt“" (EG 205).

Schließlich beschreibt er den „soziale[n] Dialog als Beitrag zum Frieden“ (EG 238), wobei er besonders drei Bereiche benennt, in denen die Kirche „präsent sein muss, um einen Dienst zugunsten der vollkommenen Entwicklung des Menschen zu leisten und das Gemeinwohl zu verfolgen“: Zum einen den „Dialog mit den Staaten“, des Weiteren den „Dialog mit der Gesellschaft - der den Dialog mit den Kulturen und den Wissenschaften einschließt“ und drittens den „Dialog mit anderen Glaubenden“ (EG 238). Dabei habe die Kirche „das Evangelium vom Frieden“ (Eph 6,5) einzubringen, und danach zu suchen, „wie man in einer Kultur, die den Dialog als Form der Begegnung bevorzugt, die Suche nach Einvernehmen und Übereinkünften planen kann, ohne sie jedoch von der Sorge um eine gerechte Gesellschaft zu trennen, die erinnerungsfähig ist und niemanden ausschließt" (EG 239).

Der erste wichtige Dialogpartner, die Staaten, sollten sich entlang der sozialethischen Prinzipien von Solidarität und Subsidiarität im Sinne eines politischen Dialogs für Konsensbildung engagieren. Im Dialog mit ihnen verstehe die Kirche sich als Begleiterin in der Orientierung an der Würde des Menschen und am Gemeinwohl, aber nicht als Lehrmeisterin, die über Lösungen für alle Detailfragen verfügen würde (EG 241). Im zweiten Dialog, dem zwischen Wissenschaft und Glaube, plädiere die Kirche - einen einseitigen Szientismus und Positivismus zurückweisend - für eine Synthese, welche sowohl die Erkenntnisse empirischer Wissenschaften als auch der Philosophie, der Theologie und des Glaubens einbezieht und so „dem Denken neue Horizonte öffnet und die Möglichkeiten der Vernunft erweitert“" (EG 242). Im dritten Dialog, dem mit anderen Glaubenden, beschreibt Franziskus zunächst den ökumenischen Dialog als ein wechselseitiges Beschenken (EG 246). Den Dialog mit dem Judentum hebt er eigens hervor und beschreibt ihn zumal angesichts antisemitischer Verfehlungen von ChristInnen in der Geschichte als unverzichtbar (EG 248). Besondere Bedeutung misst der Papst auch dem interreligiösen Dialog bei: Trotz Hindernissen und Schwierigkeiten, „besonders der Fundamentalismen auf beiden Seiten“ sei er "notwendige Bedingung für den Frieden in der Welt und darum eine Pflicht für die Christen wie auch die anderen Religionsgemeinschaften" (EG 250). Durch den „Dialog des Lebens“ (den anderen „gegenüber offen zu sein und dabei ihre Freuden und Leiden zu teilen“) und den „Dialog, in dem es um den sozialen Frieden und die Gerechtigkeit geht" gelange man „über das bloß Pragmatische hinaus [...] zu einem ethischen Einsatz, der neue soziale Bedingungen schafft" (EG 250). Dabei warnt der Papst vor einem oberflächlichen 
Synkretismus und ermutigt zu wahrer Offenheit, die in den tiefsten Überzeugungen feststeht und zugleich die tiefsten Überzeugungen der anderen verstehen will, wissend, dass der Dialog alle bereichern kann. Unter der Überschrift „Der Soziale Dialog im Kontext religiöser Freiheit" wirbt Franziskus schließlich dafür, Religion nicht in die Privatsphäre zu verdrängen, was keinen echten Frieden fördern würde, sondern vielmehr die humanistischen Prinzipien in den Religionen wahrzunehmen und mit Nichtglaubenden in einen Dialog über grundlegende Fragen der Ethik, Kunst und Wissenschaft zu treten. In all diesen Dialogen - so ist Franziskus überzeugt - leistet die Kirche einen Beitrag zu Gerechtigkeit und Frieden.

\subsection{Amoris laetitia ${ }^{17}$}

Das nachsynodale apostolische Schreiben Amoris laetitia greift bereits erwähnte Themen wie die Bedeutung des Dialogs bei der Glaubensweitergabe (AL 16), den Dialog mit der Gesellschaft (AL 201) und den interreligiösen Dialog (AL 248) auf. Vor allem ist es jedoch im Blick auf das Dialogverständnis des Papstes aufschlussreich, weil es - wenn auch zunächst mit Blick auf den Paar-Dialog grundlegende Haltungen benennt, welche in einem „langen und mühevollen Lernprozess“ (AL 136) erworben werden müssen:

\section{- Sich Zeit lassen und ein inneres Schweigen einnehmen:}

„Sich Zeit lassen, wertvolle Zeit, die darin besteht, geduldig und aufmerksam zuzuhören, bis der andere alles gesagt hat [...]. Das schließt ein, ein inneres Schweigen einzunehmen, um ohne ,Störsignale` im Herzen oder im Geist zuzuhören: alle Eile abzustreifen, die eigenen Bedürfnisse und Dringlichkeiten beiseite zu lassen und Raum zu geben.“ (AL 137)

\section{- Anderen wirkliche Bedeutung zumessen und ihnen mit Respekt begegnen:}

„Es liegt hier die Überzeugung zugrunde, dass alle etwas beizutragen haben, weil sie über eine andere Lebenserfahrung verfügen, weil sie etwas aus einer anderen Perspektive betrachten, weil sie andere Sorgen entwickelt haben und weil sie andere Talente und Intuitionen haben." (AL 138)

17 Franziskus, Amoris Laetitia (AL), vgl. http://w2.vatican.va/content/francesco/de/apost_ exhortations/documents/papa-francesco_esortazione-ap_20160319_amoris-laetitia.html (letzter Zugriff: 30.07.2019). 
- Geistige Weite haben und bereit sein, die eigene Sichtweise zu ändern und zu ergänzen:

„Es ist möglich, dass sich aus meinen Gedanken und denen des anderen eine neue Synthese ergeben könnte, die uns beide bereichert. Die anzustrebende Einheit ist nicht Einheitlichkeit, sondern eine ,Einheit in der Vielfalt' oder eine ,versöhnte Verschiedenheit'." (AL 139).

\section{- Anderen mit Zuneigung statt als Konkurrenten begegnen:}

„Wenn man jemanden lieben kann oder wenn wir uns von ihm geliebt fühlen, gelingt es uns, besser zu verstehen, was der andere ausdrücken und uns zu verstehen geben möchte. [...] Es ist sehr wichtig, die eigene Sicherheit auf tiefe Entscheidungen, Überzeugungen oder Werte zu gründen und nicht darauf, eine Diskussion zu gewinnen oder darauf, dass man uns Recht gibt.“ (AL 140).

- Einen eigenen, reflektierten Standpunkt besitzen und sich weiterbilden:

„Damit der Dialog der Mühe wert ist, muss man etwas zu sagen haben, und das erfordert einen inneren Reichtum, der seine Nahrung bezieht aus der Lektüre, der persönlichen Reflexion, dem Gebet und der Offenheit gegenüber der Gesellschaft" (AL 141).

\subsection{Gaudete et exsultate ${ }^{18}$}

Das apostolische Schreiben zur Heiligkeit in der Welt von heute bietet nur eine - jedoch zentrale - Aussage zum Dialog: dass es heute jenen inneren Raum wiederzuerlangen gilt, ,in dem ein aufrichtiger Dialog mit Gott“ stattfindet, der einzig heilen kann von jener Oberflächlichkeit und Hektik, in der sich Menschen des digitalen Zeitalters zu verfangen neigen, in der sie aber keine echte Freude finden, sondern nur „die Unzufriedenheit derer, die nicht wissen, wofür sie leben“(GE 29).

18 Franziskus, Gaudete et exsultate (GE), vgl. http://w2.vatican.va/content/francesco/de/apost_ exhortations/documents/papa-francesco_esortazione-ap_20180319_gaudete-et-exsultate. html (letzter Zugriff: 30.07.2019). 


\subsection{Christus vivit ${ }^{19}$}

Das nachsynodale apostolische Schreiben an die jungen Menschen wiederholt vor allem die Bedeutung des dauernden Dialogs mit Gott (CV 117, 158) und der Kultivierung der eigenen Dialogfähigkeit als Voraussetzung für die Ehe (CV 265). Darüber hinaus stellt es Dialogbereitschaft als Gegenpol zu einem überheblichen und zu Machtmissbrauch neigenden Klerikalismus dar (CV 98).

\subsection{Ansprachen im europäischen Kontext}

In seiner Ansprache an den Europarat 2014 benennt Papst Franziskus zwei zentrale Herausforderungen für Europa: die Multipolarität und die Transversalität als Realität, „die man auf dem Weg der kontinentalen Konsolidierung [des heutigen Europas] und seiner Öffnung auf die Zukunft hin nicht übersehen darf $^{\text {‘20 }}$. Er betont die Notwendigkeit einer „transversalen Kommunikation“ und beschreibt diese als Dialog, der nicht „nur innerhalb der je eigenen (politischen, religiösen, kulturellen) Organismen stattfindet ${ }^{\text {“21 }}$, sondern über Kultur- und Weltanschauungsgrenzen hinausgreift. Dies hält er für dringend geboten, denn: „Ein Europa, das nur innerhalb der geschlossenen Zugehörigkeitsgruppen dialogisiert, bleibt auf halbem Wege stehen. “22 In diesem Sinne begrüßt er entsprechende Dialogbemühungen des Europarates und spricht von einer „günstige[n] Gelegenheit für einen offenen, respektvollen und bereichernden Austausch zwischen Menschen und Gruppen verschiedener Herkunft und unterschiedlicher ethnischer, sprachlicher und religiöser Tradition in einem Geist gegenseitigen Verständnisses und gegenseitiger Achtung ${ }^{\text {«23 }}$.

Auch zwei Jahre später misst der Papst in seiner Rede anlässlich der Verleihung des Karlspreises der Fähigkeit zum Dialog - neben der Fähigkeit zur Integration und der Fähigkeit, etwas hervorzubringen - eine Schlüsselrolle zu: Dabei sieht er die Berufung Europas darin, „zum Vorbild für neue Synthesen und des Dialogs zu werden“, eine Berufung, die darin gründe, dass das Gesicht Europas „die Züge verschiedener Kulturen eingeprägt trägt und die Schönheit, die

19 Franziskus, Christus vivit (CV), vgl. http://w2.vatican.va/content/francesco/de/apost_ex hortations/documents/papa-francesco_esortazione-ap_20190325_christus-vivit.html (letzter Zugriff: 30.07.2019).

20 Franziskus, Ansprache an den Europarat, vgl. http://m.vatican.va/content/francesco/de/spee ches/2014/november/documents/papa-francesco_20141125_strasburgo-consiglio-europa. pdf (letzter Zugriff 30.07.2019), S. 6.

21 Ebd.

22 Ebd, S. 6-7.

23 Ebd., S. 7. 
aus der Überwindung der Beziehungslosigkeit kommt“.${ }^{24}$ Dialog sei deshalb ein Wort, „das wir bis zur Erschöpfung wiederholen müssen“:
„Wir sind aufgefordert, eine Kultur des Dialogs zu fördern, indem wir mit allen Mitteln Instanzen zu eröffnen suchen, damit dieser Dialog möglich wird und uns gestattet, das soziale Gefüge neu aufzubauen. Die Kultur des Dialogs impliziert einen echten Lern- prozess sowie eine Askese, die uns hilft, den Anderen als ebenbürtigen Gesprächs- partner anzuerkennen, und die uns erlaubt, den Fremden, den Migranten, den Ange- hörigen einer anderen Kultur als Subjekt zu betrachten, dem man als anerkanntem und geschätztem Gegenüber zuhört. “25

Eine solche Kultur des Dialogs geht nach Franziskus mit dem Bewusstsein einher, dass angesichts der gegenwärtigen Herausforderungen niemand einfach Zuschauer oder neutraler Beobachter sein kann, sondern alle zu persönlicher und sozialer Verantwortung gerufen sind. ${ }^{26}$

Auch in seiner Ansprache an die COMECE im Jahr 2017 betont Franziskus, dass ganz Europa ein Ort des ehrlichen und konstruktiven Dialogs sein müsse, in dem allen die gleiche Würde zukomme. Entgegen laizistischen Vorurteilen, welche den positiven Wert öffentlicher Religion nicht wahrnehmen könnten, verweist er auf die Bedeutung des interreligiösen Dialogs ${ }^{27}$, vor allem jedoch ruft er die ChristInnen auf, „den politischen Dialog zu fördern“, den er auf vielfältige Weise bedroht sieht: So konstatiert er, dass sich die Politik „eher in einen Ort des Zusammenstoßes von gegensätzlichen Kräften verwandelt“ und „die Stimme des Dialogs [...] durch die Racheschreie ersetzt“ wird, während „das Gemeinwohl nicht mehr das primäre Ziel“ zu sein scheint. ${ }^{28}$ Dies bereite extremistischen und populistischen Bewegungen den Boden, „die aus dem Protest das Herzstück ihrer politischen Botschaft machen“. ${ }^{29}$ Der Dialog werde dabei „entweder durch eine fruchtlose Konfrontation [...] oder durch eine Vorherrschaft der politischen Macht ersetzt [...]. Im ersten Fall werden die Brücken zerstört und im zweiten Fall errichtet man Mauern. “30 Gerade in dieser Situation sei es Aufgabe der ChristInnen, der Politik als sozialer Form der Liebe wieder Würde zu verleihen

24 Franziskus, Ansprache zur Verleihung des Karlspreises, vgl. http://w2.vatican.va/content/ francesco/de/speeches/2016/may/documents/papa-francesco_20160506_premio-carlomagno.html (letzter Zugriff 30.07.2019), S. 4.

25 Ebd.

26 Ebd., S. 5.

27 Vgl. Franziskus, Ansprache an die Kommission der Bischofskonferenzen der Europäischen Gemeinschaft, vgl. http://w2.vatican.va/content/francesco/de/speeches/2017/october/docu ments/papa-francesco_20171028_conferenza-comece.pdf (letzter Zugriff 30.07.2019), S. 3-4.

28 Ebd., S. 4.

29 Ebd.

30 Ebd. 
und sie als „Dienst am Gemeinwohl und nicht als Aneignung der Macht“31 erfahrbar zu machen.

\subsection{Conclusio: Das Dialogverständnis von Papst Franziskus}

Wie ein erster Durchgang durch die päpstlichen Dokumente deutlich gemacht hat, lässt sich gerade in gesellschaftspolitischen Fragen „Dialog“ als ein Schlüsselbegriff von Papst Franziskus aufzeigen.

Voraussetzungen für einen echten Dialog bilden für ihn dabei

- theologisch ein Gottesbild, das den dreifaltigen Gott selbst als dialogische Wirklichkeit versteht, die den Menschen in diesen Dialog, der Gott selbst ist, einlädt,

- anthropologisch ein Verständnis des Menschen, das intersubjektive Sprachfähigkeit, mehr noch: Dialogfähigkeit als dessen Spezifikum erkennt, sowie entsprechende Haltungen nennt, die zu kultivieren dem Menschen aufgegeben ist,

- historisch die soziopolitische und ökonomisch-ökologische Krise als Kairos für den Dialog.

Die Felder / Kontexte des Dialogs sind einerseits dadurch gekennzeichnet, dass alle eingeladen sind, andererseits hebt Franziskus aber auch einige Kontexte als besonders bedeutsam hervor, so den Dialog mit den Staaten und den politischen Dialog, zweitens den Dialog mit Gesellschaft, Kultur und Wissenschaft sowie drittens den Dialog mit anderen Glaubenden.

Als Folgen / Konsequenzen des Dialogs werden Weisheit, eine ganzheitlichere und umfassendere Sicht der Wirklichkeit, Partizipation aller an Entscheidungsprozessen, wachsende Problemlösungskompetenz in komplexen Fragen, die Belebung der politischen Kultur sowie die Überwindung von sozialen Verwerfungen und sozialer Friede erhofft.

31 Ebd. 


\section{Ausblick: Dialog als Kommunikationsform, Stille und kenotischer Dialog}

\subsection{Debatte - Diskussion - Dezision - Dialog}

Sowohl von Ingeborg Gabriel als auch von Papst Franziskus wird der Begriff „Dialog“ oft synonym zu „Gespräch“, „Debatte“ oder „Diskussion“ verwendet. Für eine weiterführende systematische Auseinandersetzung mit der Bedeutung des Dialogs im sozialethischen Kontext könnte es sich - Gabriels Hinweis auf eine mögliche Differenzierung aufgreifend - als hilfreich erweisen, unterschiedliche Kommunikationsformen zu unterscheiden und sie auf ihre Stärken und Schwächen in verschiedenen kommunikativen Settings hin zu befragen. Wann ist Dialog angemessen? Welcher Voraussetzungen bedarf er und was ist von ihm zu erwarten? Unter welchen Umständen braucht es Diskussion oder Debatte, wann vielleicht sogar eine das Gespräch (vorläufig) beendende und ins Handeln führende Dezision?

Im Anschluss an Papst Franziskus' Aufforderung zum transversalen Dialog fand im Sommer 2018 die erste DIALOP Summer School ${ }^{32}$ statt, bei der ChristInnen und SozialistInnen aus ganz Europa gemeinsam Perspektiven auf das Thema „Europe as a Common“ erarbeiteten. Ausgehend von diesen Erfahrungen schlage ich mit Thomas Stuke ${ }^{33}$ folgende Systematisierung vor, die in einem gemeinsamen Forschungsprojekt weiter vertieft wird. Die vier polaren Idealtypen akzentuieren dabei in Gesprächsformen stets präsente Orientierungsmuster. Sie bieten somit ein analytisches Raster, um Kommunikation zu orientieren und den jeweiligen Schwerpunkt zu identifizieren.

Die Notwendigkeit einer solchen Systematisierung ergibt sich u.a. aus der Erfahrung, dass Dialogfähigkeit in einer Zeit und Kultur, die stark durch die Kommunikationsformen sozialer Medien, durch „fake news“ und machtbasierte Interventionen mitgeprägt ist, nicht automatisch vorausgesetzt werden kann, sondern gleichermaßen der Einübung, der Reflexion über den kommunikativen Kontext sowie der bewussten Entscheidung bedarf. Mit anderen Worten: Es ist immer wieder gemeinsam die diskursive Frage zu stellen, in welchem Quadranten des Achsenkreuzes gerade gesprochen wird bzw. werden soll und wo-

$32 \mathrm{Zu}$ Programm, Inhalten und Vortragenden vgl. https://summer-schools.aegean.gr/EAAC 2018 (letzter Zugriff: 30.07.2019).

33 Die untenstehende Systematisierung stammt von Thomas Stuke. Sie wird in einem entsprechenden Beitrag mit dem Titel „On Dialogue between Christians and Marxists: Experiencing the ,Otherness“ on a Greek Island“ ausführlicher begründet und 2020 in den Proceedings der Summer School erscheinen. Vgl. grundlegend dazu auch: Thomas Stuke, Mit Werten führen? Weiterbildungsmanagement zwischen externen Ansprüchen und individuellen Vorstellungen, Bad Heilbrunn 2015, S. 30-37. 


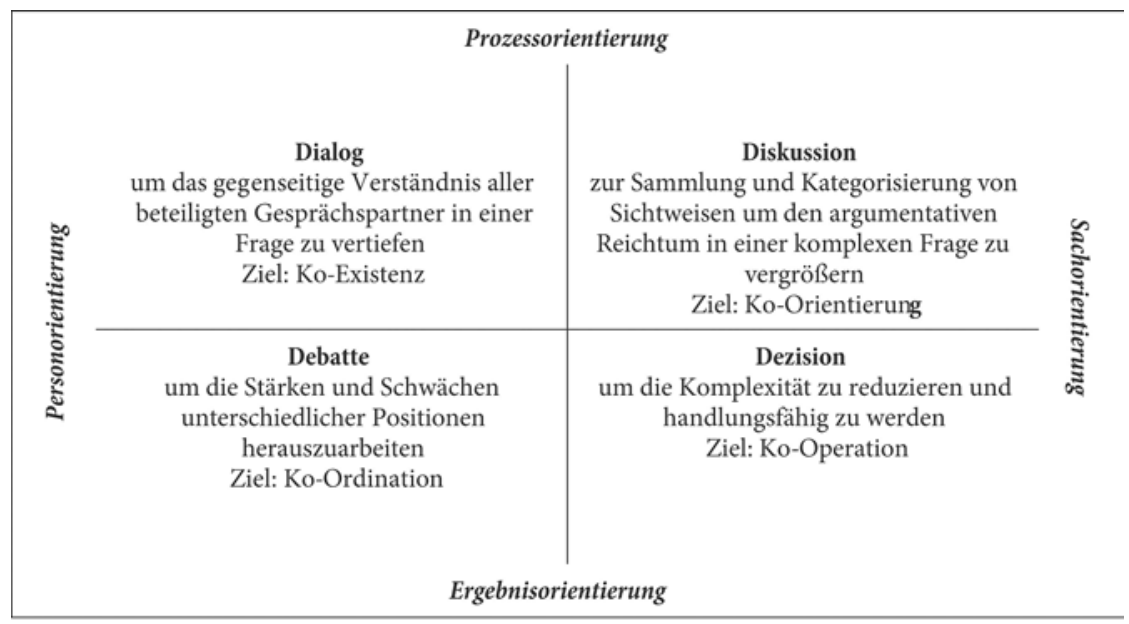

durch dies ermöglicht oder erschwert wird. Neben der dialogischen Haltung ist also auch an dialogischen Strukturen zu arbeiten.

\subsection{Die Bedeutung der Stille und des Raum-Gebens im Dialog}

In seinem „Leitfaden für den Dialog“ in Amoris laetitia (AL 136-141) nennt Papst Franziskus Stillsein und inneres Schweigen als notwendige Grundhaltungen für den Dialog, deren Einübung eine gewisse Askese verlangt. Dieses Stillsein als Innehalten und das innere und äußere Schweigen als Voraussetzung für aktives Zuhören, das erst den notwendigen Raum schafft, in den hinein der Dialogpartner sich äußern kann, ist dabei klar zu unterscheiden von einem passiven Verstummen oder gar Zum-Schweigen-gebracht-Werden. Letzteres widerspricht einem Verständnis von Dialog als einer Weise „des voraussetzungsfreien, auf unmittelbare Begegnung zielenden Umgangs des Menschen mit dem Menschen, bei dem keiner den anderen als Mittel mißbraucht ${ }^{\text {*34 }}$. Aber auch ein resigniertes Verstummen unterscheidet sich von jenem angezielten kontemplativ-kenotischen Raum-Geben, das einzig in der Rückbindung an den kenotischen Gott frei von problematischer „Selbstverneinung“ möglich ist. ${ }^{35}$

34 Gerfried W. Hunold, Dialog. IV. Theologisch-ethisch, in: Walter Kasper (u. a.) (Hg.), Lexikon für Theologie und Kirche 3,3. völlig neu bearb. Aufl., Freiburg i. Br. 1995, S. 194-195, hier: S. 194.

35 Vgl. Sarah Coakley, Macht und Unterwerfung. Spiritualität von Frauen zwischen Hingabe und Unterdrückung, Gütersloh 2007, S. 25-66. 


\subsection{Der kenotische Dialog}

Diese Form des kenotischen Dialogs wird im christlichen Kontext auf intensive Weise in der von Chiara Lubich gegründeten Fokolar-Bewegung gepflegt und reflektiert. ${ }^{36}$ Deren Charisma, dessen zwei zentrale Pole das Engagement für die Einheit und die Orientierung an Jesus dem Verlassenen (und damit dem kenotischen Jesus auf der „Talsohle des Abstiegs ${ }^{(37}{ }^{37}$ ) sind, realisiert sich in vielfältigen Dialoginitiativen: vom innerkirchlichen über den ökumenischen und interreligiösen Dialog bis hin zum Dialog mit Nichtglaubenden. Die bereits erwähnte DIALOP Summer School ist Teil davon und auf der Basis eines Appells von Papst Franziskus an Alexis Tsipras, Walter Baier (europäische politische Linke) und Franz Kronreif (Fokolar-Bewegung) zum transversalen Dialog entstanden. Sie war zugleich Ergebnis des mehrjährigen Dialogs in einer Gruppe von AtheistInnen/Linken und ChristInnen und ein Pilotprojekt dafür, wie dieser transversale und kenotische Dialog in einem internationalen und interdisziplinären akademischen Kontext eingeübt, reflektiert und also gelernt werden kann. Dass solche Dialoge angesichts der - von Gabriel in ihrem ganzen akademischen Schaffen unablässig betonten - gegenwärtigen ökologischen und politischen Herausforderungen als Weg christlicher Sozialethik dringend notwendig und deshalb entsprechende Lernorte dafür zu schaffen sind, hat nicht zuletzt Papst Franziskus wiederholt deutlich gemacht:

„Der Frieden wird in dem Maß dauerhaft sein, wie wir unsere Kinder mit den Werkzeugen des Dialogs ausrüsten und sie den "guten Kampf“ der Begegnung und der Verhandlung lehren. Auf diese Weise werden wir ihnen eine Kultur als Erbe überlassen können, die Strategien zu umreißen weiß, die nicht zum Tod, sondern zum Leben, nicht zur Ausschließung, sondern zur Integration führen. Diese Kultur des Dialogs, die in alle schulischen Lehrpläne als übergreifende Achse der Fächer aufgenommen werden müsste, wird dazu verhelfen, der jungen Generation eine andere Art der Konfliktlösung einzuprägen [...]. Rüsten wir unsere Leute mit der Kultur des Dialogs und der Begegnung aus. ${ }^{\text {(33 }}$

36 Vgl. Franz Kronreif, Kenosis als Dienst an der Einheit, in: Communio 47/2018, S. 290-301; Petra Steinmair-Pösel, Im Gravitationsfeld von Mystik und Politik. Christliche Sozialethik im Gespräch mit Maria Skobtsova, Dorothee Sölle und Chiara Lubich, Paderborn 2019, S. 302313.

37 Kronreif, Kenosis als Dienst an der Einheit, S. 292.

38 Franziskus, Ansprache zur Verleihung des Karlspreises, S. 4. 


\section{Quellen}

Coakley, Sarah, Macht und Unterwerfung. Spiritualität von Frauen zwischen Hingabe und Unterdrückung, Gütersloh 2007.

Franziskus, Evangelii Gaudium (EG), vgl. http://w2.vatican.va/content/francesco/de/ apost_exhortations/documents/papa-francesco_esortazione-ap_20131124_evangeliigaudium.html (letzter Zugriff: 30.07.2019).

Franziskus, Lumen Fidei (LF), vgl. http://w2.vatican.va/content/francesco/de/encyclicals/ documents/papa-francesco_20130629_enciclica-lumen-fidei.html (letzter Zugriff: 30.07.2019).

Franziskus, Ansprache an den Europarat, vgl. http://m.vatican.va/content/francesco/de/ speeches/2014/november/documents/papa-francesco_20141125_strasburgo-consiglioeuropa.pdf (letzter Zugriff: 30.07.2019).

Franziskus, Laudato si' (LS), vgl. http://w2.vatican.va/content/francesco/de/encyclicals/ documents/papa-francesco_20150524_enciclica-laudato-si.html (letzter Zugriff: 30.07.2019).

Franziskus, Amoris Laetitia (AL), vgl. http://w2.vatican.va/content/francesco/de/apost_ exhortations/documents/papa-francesco_esortazione-ap_20160319_amoris-laetitia. html (letzter Zugriff: 30.07.2019).

Franziskus, Ansprache zur Verleihung des Karlspreises, vgl. http://w2.vatican.va/content/ francesco/de/speeches/2016/may/documents/papa-francesco_20160506_premio-car lo-magno.html (letzter Zugriff: 30.07.2019).

Franziskus, Ansprache an die Kommission der Bischofskonferenzen der Europäischen Gemeinschaft, vgl. http://w2.vatican.va/content/francesco/de/speeches/2017/october/ documents/papa-francesco_20171028_conferenza-comece.pdf (letzter Zugriff: 30.07. 2019).

Franziskus, Gaudete et exsultate (GE), vgl. http://w2.vatican.va/content/francesco/de/ apost_exhortations/documents/papa-francesco_esortazione-ap_20180319_gaudeteet-exsultate.html (letzter Zugriff: 30.07.2019).

Franziskus, Christus vivit (CV), vgl. http://w2.vatican.va/content/francesco/de/apost_ex hortations/documents/papa-francesco_esortazione-ap_20190325_christus-vivit.html (letzter Zugriff: 30.07.2019).

Gabriel, Ingeborg / Kirchschläger, Peter G. / Sturn, Richard (Hg.), Eine Wirtschaft, die Leben fördert. Wirtschafts- und unternehmensethische Reflexionen im Anschluss an Papst Franziskus, Ostfildern 2017.

Gabriel, Ingeborg, All Life Is Encounter: Reflections on Interreligious Dialogue and Concrete Initiatives, in: Religious Education 112/2017, S. 317-322.

Gabriel, Ingeborg, Like Rosewater. Reflections on Interreligious Dialogue, in: Journal of Ecumenical Studies 45/2010, S. 1-23.

Gabriel, Ingeborg (Hg.), Politik und Theologie in Europa. Perspektiven ökumenischer Sozialethik, Ostfildern 2008.

Gabriel, Ingeborg / Gassner, Franz (Hg.), Solidarität und Gerechtigkeit. Ökumenische Perspektiven, Ostfildern 2007.

Gabriel, Ingeborg / Papaderos, Alexandros K. / Körtner, Ulrich H. J., Perspektiven ökumenischer Sozialethik. Der Auftrag der Kirchen im größeren Europa, 2. Aufl., Ostfildern 2006. 
Hunold, Gerfried W., Dialog. IV. Theologisch-ethisch, in: Walter Kasper (u.a.) (Hg.), Lexikon für Theologie und Kirche 3, 3. völlig neu bearb. Aufl., Freiburg i. Br. 1995, S. 194-195.

Kronreif, Franz, Kenosis als Dienst an der Einheit, in: Communio 47/2018, S. 290-301.

Paul VI., Ecclesiam suam (ES), vgl. http://www.vatican.va/content/paul-vi/de/encyclicals/ documents/hf_p-vi_enc_06081964_ecclesiam.html (letzter Zugriff: 21.02.2020).

Steinmair-Pösel, Petra, Im Gravitationsfeld von Mystik und Politik. Christliche Sozialethik im Gespräch mit Maria Skobtsova, Dorothee Sölle und Chiara Lubich, Paderborn 2019.

Stuke, Thomas, Mit Werten führen? Weiterbildungsmanagement zwischen externen Ansprüchen und individuellen Vorstellungen, Bad Heilbrunn 2015. 


\section{Dialog}

Open-Access-Publikation im Sinne der CC-Lizenz BY 4.0

(c) 2020, Vandenhoeck \& Ruprecht GmbH \& Co. KG, Göttingen 
Open-Access-Publikation im Sinne der CC-Lizenz BY 4.0

(C) 2020, Vandenhoeck \& Ruprecht $\mathrm{GmbH} \&$ Co. KG, Göttingen ISBN Print: 9783847111658 - ISBN E-Lib: 9783737011655 


\section{Jakob Helmut Deibl (Wien)}

\section{Interreligiöser Dialog, öffentlicher Raum und Ästhetik}

\section{Vorweg ...}

Die folgenden Zeilen adressieren sich an Ingeborg Gabriel und verstehen sich als Teil eines offenen Dialogs, der vor einigen Jahren begonnen hat und den weiterzuführen mir ein großes Anliegen ist. Sie schließen darum auch mit einer Frage.

1) Die Arbeit von Ingeborg Gabriel ist, wie mir scheint, in theologischer und sozialethischer Hinsicht, in ihren wissenschaftlichen, aber auch in den für eine breitere Öffentlichkeit gedachten Publikationen, von zwei Grundanliegen geprägt. Erstens stellt sie eine Einladung zu einer genauen und nüchternen Differenzierung dar, wo es um aktuelle Fragen am Schnittpunkt von Religion und Gesellschaft geht. Sätze wie „Dies sollte zu einer differenzierteren Sichtweise führen, wobei erst einmal zu sehen ist ... "1 geben dieses Anliegen, das Ingeborg Gabriel pointiert in strittige öffentliche Diskussionen, aber auch in von großer Verständigungsbereitschaft getragene Initiativen zum interreligiösen Dialog einbringt, gut wieder. Sie fordert damit zu einem unaufgeregten Innehalten auf. Dies kommt in einem Beitrag zur Diskussion um religiöse Symbole in der Öffentlichkeit gut zum Ausdruck:

„Nachdem die ersten Reaktionen und flotten Sprüche abgeflaut sind, scheint es daher sinnvoll, sich noch einmal die Hintergründe näher anzusehen, um so die Positionen, die quer durch alle kirchlichen und gesellschaftlichen Lager gingen, besser einordnen zu können. Klärungen in Sachen Religionsfreiheit sind besonders in religionspluralistischen Gesellschaften nötig, um den sozialen Frieden zu erhalten.“"2

1 Ingeborg Gabriel, Auf dem glatten Parkett des Religionsdiskurses, in: Der Standard am 15.05. 2019, S. 30.

2 Ingeborg Gabriel, Das Kreuz im Widerstreit, in: Christ in der Gegenwart 24/2018, S. 269-270, hier: S. 269. 
Damit ist bereits die Ebene der bloßen Analyse und Gesellschaftsbetrachtung überschritten und ein Programm formuliert, das in der Suche nach dem Beitrag der Kirchen und Religionsgemeinschaften für den sozialen Frieden besteht.

In den Worten von Ingeborg Gabriel könnte man dieses Programm, in welchem ich das zweite Grundanliegen ihrer Arbeit ausgedrückt sehe, folgendermaßen formulieren: „Die Frage auf Zukunft hin lautet: Was kann der Beitrag der katholischen Kirche [man könnte wohl hinzufügen: der christlichen Konfessionen und auch der anderen Religionen] in der gegenwärtigen politischen Situation sein? ( $^{\text {33 }}$ Wohl nicht zufällig ist von einem Beitrag die Rede: Wer einen solchen leisten möchte, weiß darum, dass es ein größeres gemeinsam geteiltes Anliegen gibt, das die eigenen Möglichkeiten übersteigt und die Mitarbeit auch anderer erfordert. Dies bedeutet eine zweifache Herausforderung für Religionsgemeinschaften: Es gibt zum einen eine legitime Erwartung der Zivilgesellschaft an sie, dass sie einen Beitrag zum sozialen Frieden und zum Umgang mit den großen Herausforderungen und Problemen der Zeit leisten. Dieser Erwartung können sie sich nicht auf Dauer entziehen. Zum anderen sind sie bei der Lösung dieser Probleme immer auch auf andere angewiesen. Eine Form des Dialogs der Religionen, aber auch der Religionen mit säkularen Weltanschauungen, ist unumgänglich. Überdies ist in obigem Zitat von einer „Frage auf Zukunft hin" die Rede. Theologisch spiegelt sich darin ein grundlegendes Verständnis von Religion wider: Ihr überschießendes, niemals in die unmittelbare Gegenwart zu bringendes Moment (das Transzendente), eröffnet eine $\mathrm{Zu}$ kunftsdimension. Religion ist mit dem Imperativ verbunden, dass Zukunft sein soll.

2) Die folgenden Überlegungen nehmen ihren Ausgangspunkt beim Österreichisch-Iranischen Religionsdialog, welcher seit den 1990er Jahren abwechselnd in Wien und Teheran stattfindet. Als ich selbst zum ersten Mal im Herbst 2015 in Wien an einer Veranstaltung dieser Initiative teilnehmen konnte, gab mir Ingeborg Gabriel, die sich von Beginn an in diesem Religionsdialog engagiert hat $^{4}$, nach meinem Referat eine wohlwollend-kritische Rückmeldung, die für mich eine wichtige Hilfe darstellte, Genre, Umfeld und Kontext der Beiträge besser einzuschätzen. Zwei Jahre später erhielt ich vor dem Aufbruch nach Teheran, wo die nächste österreichisch-iranische Dialogkonferenz stattfand, er-

3 Ingeborg Gabriel, Die Menschenrechte als Grundlage der politischen Kultur Europas, in: theologie aktuell. Die Zeitschrift der theologischen Kurse 2/34, S. 4-12, hier: S. 9 [Erstabdruck: Ingeborg Gabriel, Die Menschenrechte als Grundlage der politischen Kultur Europas, in: Helmut Renöckl / Alžbeta Dufferová / Alfred Rammer (Hg.), Rudern auf stürmischer See: Sozialethische Perspektiven in Mitteleuropa, Wien-Würzburg 2006, S. 152-161].

4 Vgl. etwa Ingeborg Gabriel, Gerechtigkeit aus christlicher Sicht, in: Andreas Bsteh / Seyed M. Mirdamadi (Hg.), Dialog. Gerechtigkeit in den internationalen und interreligiösen Beziehungen in islamischer und christlicher Perspektive, Mödling 1997, S. 51-72. 
neut wertvolle Hinweise von ihr, welche die Dialoginitiative in ein weiteres gesellschaftspolitisches Umfeld stellten. Ich hatte gelernt, dass interreligiöser Dialog nicht allein auf persönlichem Engagement beruhen kann und nicht bloß als ein theologisches Anliegen zu verstehen ist, sondern auch eine (gesellschafts)politische Dimension hat. ${ }^{5}$

Als Reminiszenz auf diese Gespräche möchte ich im Folgenden einerseits auf den interreligiösen Dialog als eine Form der theologischen Öffnung einer religiösen Tradition und andererseits auf den interreligiösen Dialog als einen Beitrag zur Gestaltung des öffentlichen Raumes eingehen. Deutlich wird dabei von zwei unterschiedlichen Seiten, dass interreligiöser Dialog nicht allein eine Aufgabe einzelner gut gewillter Teilnehmerinnen und Teilnehmer ist, sondern auch eine allgemeine - theologische und öffentlich-politische - Dimension hat. ${ }^{6}$ Nimmt man Ingeborg Gabriels Unterteilung des interreligiösen Dialogs in drei Ebenen, nämlich „dialogue of life“, „dialogue of theology and spirituality“ (bzw. ”dialogue on creed“) sowie „dialogue on ethics and politics“7 , auf, so entspricht das folgende Kapitel dem dialogue of theology and spirituality, wohingegen das daran anschließende Kapitel auf die anderen beiden Formen, den dialogue of life und den dialogue on ethics and politics bezogen werden kann. Weil mir die Fortführung des Gespräches mit Ingeborg Gabriel ein großes Anliegen ist, möchte ich im letzten Abschnitt eine Frage an sie weitergeben: Welche Rolle

5 Zum interreligiösen Dialog mit besonderer Berücksichtigung des christlich-muslimischen Dialogs vgl. Ingeborg Gabriel, All Life Is Encounter: Reflections on Interreligious Dialogue and Concrete Initiatives, Religious Education 4/2017, S. 317-322, vgl. 10.1080/00344087. 2017.1325096 (letzter Zugriff: 10.06.2019). Eine philosophische Theorie des interreligiösen Dialogs mit besonderer Berücksichtigung auch von dessen Unterbrechung, von neuen gemeinsamen Verstehenshorizonten nach dem Dialog, von den Grenzen der Hermeneutik an "the Infinite, the Incomprehensible, the Impassable" und „the Impossible" sowie von der Rückkehr zum Dialog gibt David Tracy, Western Hermeneutics and Inter-Religious Dialogue, in: Cornille Conway / Christopher Conway (Hg.), Interreligious Hermeneutics, Eugene 2010, S. 1-43.

6 Diesen Aspekt betreffend knüpfe ich an den von Karsten Lehman gemeinsam mit dem Forschungszentrum Religion and Transformation in Contemporary Society (RaT) der Universität Wien sowie der Kirchlich pädagogischen Hochschule Wien / Krems im Oktober 2019 veranstalteten Kongress „Interreligious Dialogue in Context“ an.

7 Ingeborg Gabriel, The Role of Religions in the Public Square: Elements of Transformation Process, in: Richard Potz / Sabine Kroissenbrunner / Astrid Hafner (Hg.), State, Law and Religion in Pluralistic Societies, Göttingen 2010, S. 179-190, hier: S. 189f. Hinzufügen möchte ich, dass ich im Folgenden unter dem Begriff Theologie keine bestimmte theologische Richtung einer bestimmten Religion verstehe, sondern schlicht die explizite und differenzierende Reflexion auf Formen religiöser Praxis und Tradition, wie sie innerhalb einer religiösen Tradition statthat. Allerdings gibt dieses Wort durch die Art und Weise seines Bezuges auf Gott auch Anlass zu Schwierigkeiten im Dialog. Inwiefern es als Bezeichnung geeignet ist oder manche Formen des Dialogs eher verstellt, wäre selbst in konkreten Formen des Dialogs zu klären. Die Bezeichnung „dialogue on creed“ verwendet Ingeborg Gabriel in Gabriel, All Life Is Encounter, S. 319. 
spielt Kunst im interreligiösen Dialog? Stellt interreligiöser Dialog, der sich mit Bezug auf Kunst ereignet, eine vierte - und d. h. zusätzliche - Dimension dar oder aber durchquert er die anderen drei ${ }^{8}$

\section{Interreligiöser Dialog als Form der Öffnung}

1) Interreligiöser Dialog bedeutet für jene religiösen Gemeinschaften, die sich auf ihn einlassen oder unumgänglich mit ihm konfrontiert werden, eine theologische Herausforderung. Tiefe wird der Dialog wohl besonders dann erreichen können, wenn er zur Anfrage an die eigene religiöse Tradition wird, wie diese aus ihren Quellen, Ressourcen, Riten, heiligen Texten und künstlerischen Ausdrucksformen eine Öffnung auf andere religiöse Traditionen begründen kann. Dies meint keine inklusivistische Haltung, welche andere Religionen in den Horizont der eigenen integrieren möchte und ihnen damit ihre Andersartigkeit und Fremde nimmt. Vielmehr geht es darum, in der eigenen Tradition Formen der Öffnung zu finden, welche zu einer Überschreitung hin auf eine bestimmte andere Religion oder andere Religionen im Allgemeinen ermutigen oder diese geradezu fordern. ${ }^{9}$ Als Metapher dafür scheint mir entweder das eben verwendete Motiv der Öffnung oder aber das der Dezentrierung geeignet zu sein. Dezentrierung bedeutet eine Verrückung aus dem Zentrum, das man meint, allein und in umfassender Weise besetzen zu können.

Die Elemente der Öffnung oder Dezentrierung, die sich in der Tradition einer Religion finden lassen, müssen in dieser nicht schon immer und zu allen Zeiten die Rolle der Ermöglichung einer Zuwendung zu einer anderen Tradition gespielt haben. Vielmehr kann es sich um eine kreative Neuinterpretation handeln, die Motive ans Licht bringt, welche so bisher vielleicht noch nicht gesehen wurden oder gesehen werden konnten. Die grundsätzliche Bereitschaft, sich auf die Suche nach solchen Motiven und diesen Dialog einzulassen, kann damit zu einer theologischen Erneuerung der eigenen Tradition werden. Religionen sind weder in sich einheitliche noch in der Geschichte unveränderliche Entitäten, sondern als höchst wandelbar, dynamisch und innerlich differenziert zu be-

8 Vgl. Mary Anderson, Art and Inter-Religious Dialogue, in: Catherine Cornille (Hg.), The Wiley-Blackwell Companion to Inter-Religious Dialogue, Malden-Oxford 2013, S. 99-116.

9 Für die alevitische Tradition hat dies Handan Aksünger treffend formuliert: „Hierbei spielt auch die Forschungsfrage eine Rolle, wie denn religiös begründet aus der Tradition des Alevitentums heraus eine Anerkennung der religiös und kulturell Anderen gedacht, vielleicht sogar gefordert werden kann.“ Es gehe darum, „alevitische Quellen auf ihre ,Offenheit gegenüber dem religiös und kulturell Anderen “ ' hin zu lesen, vgl. Handan Aksünger / Wolfram Weiße (Hg.), Alevitische Theologie an der Universität Hamburg. Dokumentation einer öffentlichen Antrittsvorlesung, Dokumentationsreihe der Akademie der Weltreligionen der Universität Hamburg, 3, Münster-New York 2015, S. 10 und S. 36. 
trachten. Sie enthalten Elemente der Abschließung wie der Öffnung und solche, die ambivalent sind und deshalb stark von ihrer jeweiligen Interpretation abhängen. Angesichts der Herausforderung, vor die der interreligiöse Dialog die Religionen stellt, gilt es, in ihnen gerade eine Hermeneutik der Öffnung zu entwickeln und zu pflegen.

Als mich 2017 in Teheran ein iranischer Dialogteilnehmer fragte, ob diese Hermeneutik der Öffnung, mittels der ich das Christentum interpretiere, nicht selbst ein Krisenphänomen sei, welches die Folge einer Schwächung und Marginalisierung der gesellschaftlich prägenden Kraft des Christentums sei, stimmte ich ihm mit Vorbehalt zu. Sie ist nicht nur das. In dem erwähnten Kontext eines Bedeutungsverlustes (wenigstens in Europa) ist sie auch die Wiederentdeckung von etwas, was in dieser Tradition zuinnerst angelegt ist und auf Formen der Neuinterpretation wartet.

2) Im Folgenden gehe ich auf eine zentrale Stelle im Neuen Testament ein, welche als eine derartige Form der Öffnung interpretiert werden kann, nämlich auf das Ende des Johannes-Evangeliums. Das vierte der Evangelien stellt als Ganzes eine freie Relektüre der in den anderen Evangelien erzählten Geschichte Jesu dar und steht nicht für sich selbst. Unabhängig von der Frage, welche Quellen dem Autor vorgelegen haben, zeigt dies schon sein Ort im biblischen Kanon: Wer das Neue Testament zu lesen beginnt, lernt in den drei sogenannten synoptischen Evangelien, die mit großen Parallelen, aber auch Unterschieden geschilderte Erzählung Jesu kennen. Der Leser, die Leserin wird durch die dreimalige Darstellung, welche nicht zu einer einheitlichen Jesus-Biographie harmonisiert wurde, darauf vorbereitet, dass der Umgang mit dieser Geschichte hermeneutische Kompetenz und eine Form der Offenheit verlangt. Das sich an die synoptischen Evangelien anschließende Johannes-Evangelium erzählt die Geschichte Jesu noch einmal in einer versetzen, verschobenen Weise. Dabei werden immer und immer wieder zwei Sichtweisen einander gegenübergestellt: Der Versuch, die Erzählung Jesu - oder in anderen Worten den Text der Evangelien, des Lebens Jesu, aber auch der Torah, des Volkes Israel - in einer unmittelbaren buchstäblichen Weise oder in einer freien geistigen Interpretation zu lesen: „Der Geist ist der Lebendigmachende“ (Joh 6,63). In philosophischer Sicht stellt das Evangelium vor die Alternative, das Sein, die Wirklichkeit, den Text als etwas unmittelbar Fassbares und in endlichen Schritten Bestimmbares, d.h. letztlich als etwas Technisches, anzusehen oder aber deren geistig-offene Dimension anzuerkennen. ${ }^{10}$ Man könnte in Bezug auf das Johannes-Evangelium auch von einer Relektüre der Erzählung Jesu im Geist sprechen.

10 Die Spannung zwischen einer buchstäblichen und einer geistigen Deutung des Textes ist der eigentliche das Johannes-Evangelium prägende Konflikt. Dieser lässt sich nicht auf zwei voneinander geschiedenen Größen Judentum und Christentum applizieren. Vielmehr geht es 
Das Johannes-Evangelium führt die Erzählung Jesu schrittweise zu einer Öffnung, welche am Ende den Text selbst sprengt. Die Erzählungen von den Begegnungen mit dem auferstandenen Jesus münden in eine Zusammenfassung, die gleichzeitig auch Ausweitung ist:

„Viele nun auch andere Zeichen tat Jesus vor [seinen] Schülern, die nicht geschrieben sind in diesem Buch. Diese aber sind geschrieben, damit ihr glaubt, daß Jesus der Christos ist, der Sohn Gottes, und damit ihr als Glaubende Leben habt in seinem Namen." (Joh 20,30f.)

Die Schlusswendung bringt zum Ausdruck, dass der Text, den sie beschließt, nicht alles enthält. Exemplarisch erzählt das Evangelium einige Zeichen, unbestimmbar ist jedoch deren über es hinausgehende Vielfalt. Dies ist besonders deshalb von Bedeutung, weil das Johannes-Evangelium nicht eine biblische Schrift unter anderen ist, sondern bereits die Bildung einer Ordnung vorwegnimmt. ${ }^{11}$ Diese Ordnung, die sich später zum biblischen Kanon stabilisiert, verweist auf ihr Außen, auf das, was sie nicht enthält. Dies ist von höchster Wichtigkeit: Der normative, heilige Text einer Religion überschreitet sich selbst auf sein Außen, d.h., er öffnet sich auf das andere, das er nicht umgreift.

Mit der zusammenfassend-ausweitenden Schlusspassage hat der geschriebene Text sein Ende noch nicht erreicht, denn ihr folgt noch ein Epilog, der weitere Erzählungen vom Auferstandenen enthält. Zwar ist der Text bereits an ein offenes Ende gelangt und hat ausgesprochen, dass das Evangelium nicht alle Zeichen enthält; der Vorgang des Erzählens drängt jedoch weiter, lässt sich von der ersten Schlussbemerkung nicht begrenzen: Erzählt werden nun noch zwei Geschichten überbordender Fülle, nämlich ein überreicher Fischfang (Joh 21,1-14) und die an Petrus gerichtete Frage nach der Liebe zu Jesus (Joh 21,15-23), sowie das Bekenntnis des Jüngers, den Jesus liebte zur Wahrheit des

um eine Frage der Deutung, welche sich in beiden religiösen Traditionen (in je eigener Weise) stellt - und vermutlich auch in anderen religiösen Traditionen.

11 Nicht nur stellt es eine Neukonfiguration der Erzählung des Lebens Jesu dar, wie sie in den anderen Evangelien geschildert ist, sondern bezieht sich, wie Kurt Appel deutlich macht, auch auf den Hebräischen Kanon, den $\mathrm{TeNaCh}$, indem es auf dessen Beginn und Ende anspielt: Die Meditation über die Fleischwerdung des göttlichen lógos am Beginn des Evangeliums (Joh 1) nimmt Bezug auf das göttliche Wort in Genesis 1, wohingegen sich am Ende Bezüge auf das Ende des TeNaCh finden: Wie die Chronikbücher mit der Ankündigung des Aufstiegs nach Jerusalem enden ( $2 \mathrm{Chr} 36,23)$, so findet sich auch am Ende des JohannesEvangeliums zweimal ein Hinweis auf den Aufstieg (der Aufstieg Jesu zum Vater, vgl. Joh 20,17, und der Aufstieg des Petrus aus dem Boot ans Land, vgl. Joh 21,11). In den Worten von Kurt Appel: „Das Evangelium des Johannes beginnt einen Prozess der Relektüre des $\mathrm{TeNaCh}$, aber auch der synoptischen Evangelien, einer Relektüre, die auf den Anfang und das Ende der Schrift verweist.“ (Kurt Appel, Tempe e Dio. Aperture contemporanee a partire da Hegel e Schelling, Biblioteca di teologia contemporanea 187, Brescia 2018, S. 184 [Übersetzung J.D.], vgl. auch S. 208). 
aufgeschrieben Textes (Joh 21,24). Darauf folgt eine zweite Schlusspassage, welche klar auf die erste bezogen ist.

„Es gibt aber auch viele andere (Dinge), die (der) Jesus tat, welche, wenn sie in einem [„entlang einem“ - in einem Zug] (auf)geschrieben werden, auch nicht der Kosmos selbst umgreifen / aufnehmen / erfassen könnte, die geschriebenen Bücher / die zu schreibenden Bücher." (Joh 21,25)

Spricht die erste Schlusswendung vom Text, der all die Zeichen nicht umfassen, so die zweite vom Kosmos, der sie nicht umgreifen kann. „Entlang einem“, d.h. linear, könne man all die Zeichen und Dinge, die Jesus getan hat, nicht aufschreiben, sie fügen sich keiner schon gegebenen Ordnung, sondern eröffnen eine Vielfalt der geschriebenen und der zu schreibenden Bücher. Dies bedeutet eine nicht kontrollierbare, unvorhersehbare anarchische Öffnung der biblischen Botschaft auf andere Erzählungen religiöser und nicht-religiöser Art.

3) Welche Bücher können sich dadurch angesprochen fühlen? In allgemeiner Weise könnten es die religiösen und nicht-religiösen Bücher sein, die von der geistigen, d.h. nicht instrumentalisierbaren und nicht-funktionalisierbaren Dimension der Welt erzählen, deren Wahrnehmung das Johannes-Evangelium immer neu einüben möchte. Dazu gehören Texte aus den Religionen, der Philosophie, der Poesie, der Literatur ... In spezifischerer Weise kann die erwähnte Öffnung auch als ein Tor zum Qu'ran verstanden werde, in welchem in verschobener Weise das Bild vom Ende des Johannes-Evangeliums wieder auftritt:

„Wenn das Meer Tinte für die Worte meines Herrn wäre, würde das Meer wahrlich zu Ende gehen, bevor die Worte meines Herrn zu Ende gingen, auch wenn Wir als Nachschub noch einmal seinesgleichen hinzubrächten." $(Q u ' r a n ~ 18,109)^{13}$

Gesteht man zu, dass sich Bibel und Qu'ran an dieser neuralgischen Stelle, welche ihre Überschreitung zum Ausdruck bringt, überkreuzen, wären christliche und muslimische Interpretationen auf den heiligen Text der anderen Religion verwiesen, um ihren eigenen Text in dessen Licht zu lesen. Die sich daraus ergebenden Fragen könnten folgendermaßen eine erste suchende Gestalt erhalten:

„1) Worin besteht aus christlicher Sicht die heilsgeschichtliche Bedeutung des Qu'rans? Was bedeutet es, aus christlicher Sicht den Qu'ran als Offenbarung Gottes anzusehen? Welche Auswirkungen hat dies theologisch? 2) Wie ist aus muslimischer Sicht eine Annäherung an eine authentische Bedeutung der biblischen Schriften jenseits des

12 Für die Übersetzung danke ich Alfred Dunshirn.

13 Navid Kermani spricht von einer Ähnlichkeit des Gleichnisses im Qu'ran zum Wort aus dem Johannes-Evangelium, vgl. Navid Kermani, Gott ist schön. Das ästhetische Erleben des Koran, 5. Aufl., München 2015, S. 214. Ich habe an dieser Stelle die auch von Kermani zitierte Übertragung von Friedrich Rückert verwendet. 
Interpretaments der Schriftverfälschung (tahrif) möglich? Wie lässt sich Gottes Offenbarung/Sendung in Jesus aus muslimischer Sicht verstehen? ${ }^{\text {(14 }}$

Diese Fragen weisen meines Erachtens auf ein Desiderat von hoher religiöser und gesellschaftlicher Bedeutung hin. Ihre Erörterung bedarf einer breiten Beteiligung christlicher und muslimsicher Theologinnen und Theologen, aber auch jüdischer Gelehrter und säkularer Bürgerinnen und Bürger. Dafür sind Orte eines freien Denkens notwendig, wie sie sich hoffentlich an Universitäten, Akademien, Bibliotheken und religiösen Institutionen weiterhin werden finden können, wenn sich diese als Teil des öffentlichen Raums verstehen. Dies leitet über zur Frage nach interreligiösem Dialog und öffentlichem Raum.

\section{Interreligiöser Dialog und öffentlicher Raum}

Interreligiöser Dialog ist untrennbar mit der Frage nach dem öffentlichen Raum verbunden. Er ist auf die Förderung des öffentlichen Raumes als eines gemeinsam geteilten lebbaren Raumes angewiesen.

1) Öffentlicher Raum ist eine Sphäre, die grundsätzlich für alle Menschen zugänglich ist und keine Zugangsbeschränkungen aufweist. Er ist jedoch nicht eine einfachhin verfügbare Ressource, sondern droht durch Privatisierung, Kommerzialisierung und Virtualisierung zu erodieren. Längeres Verweilen ist immer öfter an Konsumation gebunden, sodass man, betritt man den öffentlichen Raum, alsbald mit der Distinktion konfrontiert wird, ob man am Konsum teilnehmen kann oder nicht. Man ist dann im öffentlichen Raum nicht mehr als freier Bürger oder freie Bürgerin repräsentiert, sondern als Konsument oder Konsumentin. Klassische öffentliche Institutionen wie etwa die Post wandern von zentral gelegenen öffentlichen Gebäuden aus in Supermärkte, wo sie sich als Post-Shops privaten Gewerbebetrieben angleichen. Ihre ehemaligen Gebäude werden von Banken oder großen Konzernen übernommen oder stehen leer. Eine Vielzahl von Veranstaltungen führt einerseits zur Belebung öffentlicher Plätze, schränkt aber andererseits ihre vorher offene Nutzung oft auf eine bestimmte Weise der Verwendung ein und unterstellt sie nicht selten dem privaten ökonomischen Kalkül. Inwiefern das Entstehen virtueller Sphären, die selbst freilich auch öffentlichen Charakter haben können, zu einer Verarmung des Lebens an realen, nicht austauschbaren Orten führt, ist zu diskutieren.

14 Die Fragestellungen sind dem Projekt „Gottes doppelte Sendung - Jesus und Koran“ entnommen, an dem neben dem Autor dieser Zeilen Kurt Appel und Wolfgang Treitler (Universität Wien), Mouhanad Khorchide und Dina el Omari (Universität Münster) sowie Isabella Guanzini (Katholische Universität Linz) beteiligt sind. 
Die Verbindung von Religion und öffentlichem Raum wird gegenwärtig vor allem mit Blick auf die Frage der Sichtbarkeit religiöser Symbole diskutiert. Stellvertretend dafür seien die Kontroversen um den Gesichtsschleier und das Kreuz $^{15}$ genannt. Kaum jedoch wird öffentlicher Raum mit interreligiösem Dialog in Verbindung gebracht. Und doch setzt Letzterer die Existenz öffentlichen Raumes voraus, der eine allgemeine Zugänglichkeit für Menschen unterschiedlicher religiöser und nicht-religiöser Überzeugungen gewährleistet, die einander dort begegnen können. Zwar mag es eine historisch bedingte Dominanz einer Religionsgemeinschaft geben (in Österreich sind dies Kirchen an zentralen Plätzen), der öffentliche Raum verschwände jedoch, wenn eine Religionsgemeinschaft seine Kontrolle übernähme, die Bedingungen seines Zugangs regulierte und ihn über eine längere Zeit symbolisch besetzte (etwa durch ständige Inszenierung religiöser Veranstaltungen). Gibt es keine Räume gleichberechtigter Zugänglichkeit für Mitglieder aller religiösen Bekenntnisse wie auch säkularer Bürgerinnen und Bürger, bleiben Formen des Dialogs, die auf explizite Einladung einer Religionsgemeinschaft an die von ihnen verwalteten Orte erfolgen, nur punktuelle Ereignisse, denen ein breiterer Resonanzraum fehlt.

2) Versteht man interreligiösen Dialog nicht bloß als eine zu begrüßende individuelle oder gemeinschaftliche Bereitschaft und Offenheit zu gegenseitigem Austausch, sondern bedenkt ihn in seiner öffentlichen Dimension, mögen politikwissenschaftliche Konzepte, öffentlichen Raum in seiner agonalen, d.h. konfliktiven Dimension ${ }^{16}$ zu fassen, zunächst hilfreich sein: „Das kontinuierliche Aufeinandertreffen und Aushandeln von unterschiedlichen Interessen und Wertvorstellungen, von - auch widersprüchlichen - Bedeutungszuschreibungen, ist das, was öffentliche Räume ausmacht. “" ${ }^{17}$ Das Zusammenleben von Menschen unterschiedlicher Religionen stellt immer wieder vor Aushandlungsprozesse, wobei diese auch ein gewisses Maß an Verstehen der anderen Tradition erfordern. Die bloße Berufung auf die allen gleichermaßen garantierte Religionsfreiheit ersetzt das Bemühen um Formen minimalen Verstehens nicht und droht ohne sie abstrakt zu bleiben. Nimmt man den Versuch eines Verstehen-Wollens ernst, wird es fraglich, ob ein agonales Verständnis öffentlichen

15 Ingeborg Gabriel hat sich mit dem Versuch einer sachlichen Klärung in die emotional geführte Debatte eingeschaltet, vgl. Gabriel, Das Kreuz im Widerstreit, S. $269 \mathrm{f}$.

16 Vgl. Oliver Marchart, Kunst, Raum und Öffentlichkeit(en). Einige grundsätzliche Anmerkungen zum schwierigen Verhältnis von Public Art, Urbanismus und politischer Theorie, vgl. http://eipcp.net/transversal/0102/marchart/de/print (letzter Zugriff: 26. 04.2019).

17 Kathrin Wildner, La Plaza: Öffentlicher Raum als Verhandlungsraum, http://www.republi cart.net/disc/realpublicspaces/wildner01_de.htm (letzter Zugriff: 26.04.2019); vgl. auch Kathrin Wildner / Hilke Marit Berger, Das Prinzip des öffentlichen Raums, http://www.bpb. de/politik/innenpolitik/stadt-und-gesellschaft/216873/prinzip-des-oeffentlichen-raums (letzter Zugriff: 03.04.2019). 
Raumes, wie es für politische Diskurse zutreffend sein mag, ausreicht, um interreligiösen Dialog zu denken. Dieser muss vielmehr, wie im Folgenden kurz zu entfalten ist, von einem utopisch-anarchischen Verständnis her gedacht werden.

Ein utopisch-anarchisches Verständnis des öffentlichen Raumes geht davon aus, dass zwar angegeben werden kann, was ihn zerstört, nicht aber erschöpfend aufgezählt werden kann, wie er genutzt werden kann. Es gibt keinen allgemeinen Begriff, keine Regel, kein Prinzip und keine arché, aus der alle Formen, ihn zu bewohnen, ableitbar wären - was auf seine an-arch-ische Dimension hinweist. Dies hat zur Folge, dass der öffentliche Raum neue bisher noch ungedachte Formen seiner Nutzung hervorbringen kann, für die keine prinzipielle Grenze (außer der Erhaltung des öffentlichen Raumes als allen zugängliche Sphäre) angegeben werden kann - was auf seine utopische Dimension hinweist. Für den interreligiösen Dialog bedeutete dies, dass sich neue, nicht unmittelbar ableitbare Formen der Zusammenarbeit, der Begegnung und des Verständnisses einstellen können, welche die jeweils planbaren nächsten Schritte im Prozess der gegenseitigen Verständigung überschreiten können.

Dabei kann es um allgemeine Herausforderungen gehen, die spontan - und aus den jeweils eigenen religiösen Traditionen - als einander verbindend erkannt werden. Unterschiedliche religiöse Gemeinschaften können vermittelt über ein Drittes $^{18}$ - eine gemeinsame Aufgabe - einander kennen lernen. Es kann aber auch um eine spontane Freude am Erleben praktizierter Formen von Religiosität von Mitgliedern anderer Religionsgemeinschaften gehen. Vielleicht kann dieser spontane Ausdruck die unerwartete und nicht planbare Eröffnung eines gegenseitigen Austausches werden, welcher länger anhaltende Formen der Verständigung und des Kennenlernens ermöglicht. Je weniger der öffentliche Raum kommerzialisiert und damit bestimmten Interessen und Zwecken unterworfen ist, umso eher kann er zu derartigen Formen der Begegnung anregen. Je weniger der öffentliche Raum von Segregation oder Ausschluss einzelner Gruppen bestimmt ist, umso eher kann er seine verbindende Kraft auch auf unterschiedliche Religionen hin ausdehnen. Respektiert man die allgemeine, nicht von einer Gruppe beherrschbare Zugänglichkeit des öffentlichen Raumes, kann diese Zurücknahme des Eigenen auch für Formen des Dialoges die Voraussetzungen schaffen.

3) Der interreligiöse Dialog profitiert mithin von einer lebendigen Gestaltung des öffentlichen Raumes. Dies kann er auf Dauer nur, wenn sich Religionen dem öffentlichen Raum gegenüber nicht parasitär verhalten, sondern selbst zu seiner Pflege beitragen. Die Bedeutung dieser Aufgabe hat Papst Franziskus in seiner Enzyklika Laudato si' in sehr schönen Worten herausgestrichen:

18 Für den Gedanken, dass Dialog gerade immer über ein drittes, nicht positivierbares Moment erfolgen muss, danke ich Kurt Appel. 
„Nicht alle sind berufen, direkt in der Politik zu arbeiten, doch im Schoß der Gesellschaft keimt eine zahllose Vielfalt von Vereinigungen auf, die sich für das Gemeinwohl einsetzen, indem sie die natürliche und städtische Umwelt schützen. Sie kümmern sich zum Beispiel um ein öffentliches Objekt (ein Bauwerk, einen Brunnen, ein verwahrlostes Denkmal, eine Landschaft, einen Platz), um etwas, das allen gehört, zu schützen, zu sanieren, zu verbessern oder zu verschönern. In ihrer Umgebung entwickeln sich Bindungen oder werden solche zurückgewonnen, und es entsteht ein neues örtliches soziales Gewebe. So befreit sich eine Gemeinschaft von der konsumorientierten Gleichgültigkeit. Das schließt die Bildung einer gemeinsamen Identität ein, einer Geschichte, die bleibt und weitergegeben wird. Auf diese Weise wird für die Welt und für die Lebensqualität der Ärmsten gesorgt, mit einem solidarischen Empfinden, das zugleich das Bewusstsein ist, in einem gemeinsamen Haus zu wohnen, das Gott uns anvertraut hat. Diese gemeinschaftlichen Aktionen können, wenn sie Ausdruck einer hingebungsvollen Liebe sind, zu intensiven spirituellen Erfahrungen werden.“(LS 232)

Einerseits müssen Religionsgemeinschaften aktiv an der Pflege des öffentlichen Raumes teilnehmen, andererseits frage ich, ob nicht auch ihre Präsenz im öffentlichen Raum, wenn sie sich von allen Versuchen seiner (symbolischen) Beherrschung lossagen, positiv zu dessen Bereicherung beitragen kann. Ingeborg Gabriel spricht von „their positive contribution to public life“ bzw. vom „potential for the public sphere ${ }^{\text {"19 }}$. Gerade religiöse Gemeinschaften, die in einer Region eher in der Position einer Minderheit sind, lassen durch ihre Präsenz öffentlichen Raum in seiner Diversität und Vielfalt sichtbar werden. Vorausgesetzt ist in diesem Plädoyer für eine Sichtbarkeit von Religionen im öffentlichen Raum, dass dieser als solcher von den Religionsgemeinschaften akzeptiert wird, dass diese immer wieder Abschied nehmen von sich einstellenden Tendenzen machtvoller Selbstinszenierung und dass es eine rechtsstaatliche Ordnung gibt, welche nicht von religiösem Eigenrecht außer Kraft gesetzt werden kann. ${ }^{20}$

Über die Bedeutung einzelner Religionsgemeinschaften für den öffentlichen Raum hinausgehend, könnte gerade der interreligiöse Dialog zu dessen Gestaltung beitragen. Wo Dialog (wie partiell auch immer) gelingt, könnte er zum Modell für eine produktive Verständigung von Gruppen mit unterschiedlichen Grundeinstellungen oder Lebensanschauungen werden. Michael Müller bestimmt Stadt als einen Raum, in welchem „ununterbrochen Differenzen prozessiert“, d. h. vermittelt werden: „soziale Differenzen, ökonomische, räumliche,

19 Gabriel, The Role of Religions in the Public Square, S. $184 \mathrm{f}$.

20 Georg Essen führt aus, dass, „wenn eine Religion im öffentlichen Raum sagt: Unsere Tradition ist so wichtig, dass wir sie für ein gelingendes Zusammenleben einbringen möchten und entsprechend auf Kooperation mit dem Staat Wert legen, dann ist sie nachhaltig gefordert, die neuzeitliche Freiheit als Sinn- und Grundprinzip des Staates anzuerkennen.", vgl. Interview mit Georg Essen: „In Freiheit gesetzte Ordnung“, in: Herder Korrespondenz 1/ 2014, S. 15-20, hier: S. $19 f$. 
kulturelle, geschlechterspezifische oder machtpolitische ${ }^{\text {“21. }}$. Religiöse Differenzen - solche innerhalb einer Religion und solche zwischen den Religionen kommen dabei nicht in den Blick. Gerade deren Vermittlung halte ich jedoch für eine zentrale Aufgabe. Diese Vermittlung oder dieser Dialog könnte zu einem Laboratorium neuer Formen des Zusammenlebens werden. Kurt Appel spricht von einem „neuen Friedensnarrativ einer geteilten Öffentlichkeit von Menschen jüdisch-christlicher, säkularer und muslimischer Tradition“ ${ }^{\text {"22 }}$ - was sich noch auf andere religiöse Traditionen, etwa die zuerst erwähnte alevitische, ausweiten ließe.

\section{Ausblick - die Frage nach der Kunst im interreligiösen Dialog}

Nach dem interreligiösen Dialog als theologischer Aufgabe kam der Dialog als Frage, die das Zusammenleben sowie den öffentlichen Raum betrifft, in den Blick. Annähernd entspricht dies den drei Ebenen des interreligiösen Dialoges, welche Ingeborg Gabriel unterscheidet. Gerne möchte ich als Ausblick auf ein weitergehendes Gespräch die Frage stellen, ob Kunst in einem dieser drei Bereiche ihren Ort finden kann, ob sie alle drei durchquert oder aber doch eine vierte Dimension darstellt. Was ist die Rolle der ästhetischen Dimension des interreligiösen Dialogs?

Für eine Annäherung an die Frage nach der Rolle von Kunst im interreligiösen Dialog greife ich auf Überlegungen Friedrich Hölderlins aus dem „Fragment philosophischer Briefe“ (vermutlich 1796/97) zurück. ${ }^{23}$ Dieser Fragment gebliebene, von Hölderlin selbst nicht veröffentlichte Text stellt meines Erachtens einen Grundtext interreligiösen Dialogs dar. Zunächst spricht Hölderlin darin von einer Individualisierung in Bezug auf den Glauben an Gott: „Und jeder hätte demnach seinen eigenen Gott, in so ferne jeder seine eigene Sphäre hat, in der er wirkt und die er erfährt “24. Gott begegnet dem Menschen in dessen je eigener Sphäre, d.h. in der geistig-sprachlich-kulturellen Vermittlung der Umgebung, in welcher der jeweilige Mensch lebt. Allerdings ist dies nur die eine Seite, um das Verhältnis von Gott und Mensch zu fassen, denn der Mensch kann sich „auch in

21 Michael Müller, Stadt-Bild und Utopie, in: Stadtutopien, Kunst und Kirche 2/2005, S. 85-90, hier: S. 85.

22 Vgl. Kurt Appel, Religion und Zivilgesellschaft in Europa - Plädoyer für einen neuen Narrativ, in: Newsletter für Engagement und Partizipation in Europa, 4/2017, vgl. http://www.b-b-e. de/fileadmin/inhalte/aktuelles/2017/04/enl-4-17-appel-beitrag.pdf (letzter Zugriff: 27.08. 2017); Ders. Tempe e Dio, S. 191-199.

23 Johann Christian Friedrich Hölderlin, Theoretische Schriften, hrsg. von Johann Kreuzer, Hamburg 1998, S. 10-15.

24 Ebd., S. 10. 
die Lage des andern versezen [sic!], daß er die Sphäre des andern zu seiner eigenen Sphäre machen kann“. Dabei erscheint der Gedanke Gottes gerade als einer, welcher die Übersetzung der je individuellen Sphären ineinander fordert. So gibt es ein Bedürfnis der Menschen,

„ihre verschiedenen Vorstellungsarten von Göttlichem eben [...] sich einander zuzugesellen, und so der Beschränktheit, die jede einzelne Vorstellungsart hat und haben muß, ihre Freiheit zu geben, indem sie in einem harmonischen Ganzen von Vorstellungsarten begriffen ist ${ }^{\star 25}$.

Ein wesentlicher Aspekt der Schrift ist mithin, dass der Gottesgedanke oder das Gottesverhältnis nur dann in seiner Individualität und Freiheit gedacht werden kann, wenn es zu immer neuen Vermittlungs- und Übersetzungsvorgängen führt, die seine Beschränktheit aufheben.

Im selben Fragment bestimmt Hölderlin Religion über zwei der Kunst (genauer der Dichtkunst) entnommene Begriffe: „Stoff“ und „Vortrag“26. Religion lasse sich niemals nur auf ihre inhaltliche Dimension, auf ihren Stoff, reduzieren und könne nicht bloß in Gedanken existieren, sondern bedürfe immer auch ihrer lebendigen Darstellung, ihres Ausdrucks, des Vortrags. So kann etwa im Gottesdienst nicht auf die Verlesung des Evangeliums verzichtet werden, wenn dies bei allen Teilnehmenden als bekannt vorausgesetzt werden kann. Es bedarf des je neuen Vortrags, der sich nie gänzlich in der inhaltlichen Dimension auflöst und als solcher bedeutungslos würde. ${ }^{27}$

Ihre Ausdrucksformen finden Religionen in der Literatur, der Dichtung, der Musik, den bildenden Künsten, dem Tanz, der Gartenbaukunst, der Architektur etc. Ausdrucksformen der unterschiedlichen Künste werden in den Religionen aufgenommen, wiederholt, verändert, mit Bedeutung angereichert, weiterentwickelt. Dabei geht es jedoch nicht um eine einseitige Indienstnahme der Künste durch die Religion, sondern umgekehrt vermögen auch die jeweilig aufgegriffenen künstlerischen Formen den Gehalt, d.h. den Stoff, der Religion weiterzuentwickeln. Darüber hinaus ist das, was als künstlerische Form aufgenommen wird, immer auch mehr und anderes, als in einer bestimmten religiösen Verwendung zum Ausdruck kommen kann. Keine künstlerische Form, die religiöse Bedeutung erhält, erschöpft sich gänzlich in dieser. Sie ist darüber immer auch hinaus, kann direkt oder über Vermittlung auch in andere, profane Kontexte, aber auch in die Symbolwelt anderer Religionen eingehen.

25 Ebd., S. 11.

26 Ebd., S. $14 \mathrm{f}$.

27 Im Übrigen wäre es genauso widersinnig, die Rezitation von Gedichten durch Inhaltsangaben, die man von ihnen erstellt, zu ersetzen. Es gibt einen Überschuss des Vortrags, der Aufführung, der Performance. 
Religiöser Gehalt ist nie ohne seinen künstlerischen Ausdruck. Dieser ist jedoch immer auch über seine religiöse Bedeutungsdimension hinaus und ist in anderen, nicht-religiösen Bedeutungszusammenhängen präsent bzw. kann auch in die Bedeutungszusammenhänge anderer Religionen eingehen. Damit gibt es einen Überschuss der künstlerischen Ausdrucksformen. Ich frage, ob nicht genau dieser Überschuss auch eine Vermittlungsfunktion für unterschiedliche Religionsgemeinschaften annehmen könnte? Können diese in künstlerischen Ausdrucksformen, die sie in jeweils eigener Weise aufnehmen, wiederholen und weiterentwickeln, einen Ort der Begegnung finden $?^{28}$ Es wäre dies ein dritter Ort, auf den die entsprechenden Religionsgemeinschaften bezogen sind, der aber von keiner in Besitz genommen werden kann. Böte die moderne ungegenständliche Kunst (Malerei, Graphik, Skulptur, Musik ...), die auf unmittelbare Darstellung, d.h. Repräsentation, verzichtet, dabei nicht Anknüpfungspunkte gerade für den jüdisch-christlich-islamischen Dialog?

\section{Quellen}

Aksünger, Handan / Weiße, Wolfram (Hg.), Alevitische Theologie an der Universität Hamburg. Dokumentation einer öffentlichen Antrittsvorlesung, Dokumentationsreihe der Akademie der Weltreligionen der Universität Hamburg 3, Münster-New York 2015.

Anderson, Mary, Art and Inter-Religious Dialogue, in: Catherine Cornille (Hg.), The Wiley-Blackwell Companion to Inter-Religious Dialogue, Malden-Oxford 2013, S. 99116.

Appel, Kurt, Religion und Zivilgesellschaft in Europa - Plädoyer für einen neuen Narrativ, in: Newsletter für Engagement und Partizipation in Europa, 4/2017, vgl. http://www.bb-e.de/fileadmin/inhalte/aktuelles/2017/04/enl-4-17-appel-beitrag.pdf (letzter Zugriff: 27.08.2017).

Appel, Kurt, Tempe e Dio. Aperture contemporanee a partire da Hegel e Schelling, Biblioteca di teologia contemporanea 187, Brescia 2018.

Gabriel, Ingeborg, Auf dem glatten Parkett des Religionsdiskurses, in: Der Standard am 15.05.2019, S. 30 .

Gabriel, Ingeborg, Das Kreuz im Widerstreit, in: Christ in der Gegenwart 24/2018, S. 269270.

28 Um nur ein Beispiel zu nennen: Überlegungen dazu könnten an das vom Institut für Kunstgeschichte der Universität Wien durchgeführte Forschungsprojekt „Islamic Architecture and Orientalizing Style in Habsburg Bosnia, 1878-1918“ anschließen. Das Projekt untersucht, wie in Zentraleuropa ausgebildete, d.h. im christlichen Kontext beheimatete Architekten im Bau von Moscheen Elemente europäischer Baukunst mit solchen aus dem muslimischen Kontext (etwa aus Kairo und Andalusien) verbunden haben. Ließe sich über diese Elemente nicht eine Brücke zur Architektur von Kirchenbauten jener Zeit herstellen?, vgl. Islamic Architecture and Orientalizing Style in Habsburg Bosnia, 1878-1918, vgl. https:// kunstgeschichte.univie.ac.at/forschungsprojekte/ercbos/ (letzter Zugriff: 03.06.2019). 
Gabriel, Ingeborg, Die Menschenrechte als Grundlage der politischen Kultur Europas, in: theologie aktuell. Die Zeitschrift der theologischen Kurse 2/34, S. 4-12 [Erstabdruck: Gabriel, Ingeborg, Die Menschenrechte als Grundlage der politischen Kultur Europas, in: Helmut Renöckl / Alžbeta Dufferová / Alfred Rammer (Hg.), Rudern auf stürmischer See: Sozialethische Perspektiven in Mitteleuropa, Wien-Würzburg 2006, S. 152$161]$.

Gabriel, Ingeborg, All Life Is Encounter: Reflections on Interreligious Dialogue and Concrete Initiatives, Religious Education 4/2017, S. 317-322, vgl. 10.1080/00344087. 2017.1325096 (letzter Zugriff: 10.06.2019).

Gabriel, Ingeborg, The Role of Religions in the Public Square: Elements of Transformation Process, in: Richard Potz / Sabine Kroissenbrunner / Astrid Hafner (Hg.), State, Law and Religion in Pluralistic Societies, Göttingen 2010, S. 179-190.

Gabriel, Ingeborg, Gerechtigkeit aus christlicher Sicht, in: Andreas Bsteh / Seyed M. Mirdamadi (Hg.), Dialog. Gerechtigkeit in den internationalen und interreligiösen Beziehungen in islamischer und christlicher Perspektive, Mödling 1997, S. 51-72.

Hölderlin, Johann Christian Friedrich, Theoretische Schriften, hrsg. von Johann Kreuzer, Hamburg 1998.

„In Freiheit gesetzte Ordnung“. Ein Gespräch mit dem Dogmatiker Georg Essen über Religion und Staat, in: Herder Korrespondenz 1/2014, S. 15-20.

Islamic Architecture and Orientalizing Style in Habsburg Bosnia, 1878-1918, vgl. https:// kunstgeschichte.univie.ac.at/forschungsprojekte/ercbos/ (letzter Zugriff: 03.06.2019).

Kermani, Navid, Gott ist schön. Das ästhetische Erleben des Koran, 5. Aufl., München 2015.

Marchart, Oliver, Kunst, Raum und Öffentlichkeit(en). Einige grundsätzliche Anmerkungen zum schwierigen Verhältnis von Public Art, Urbanismus und politischer Theorie, vgl. http://eipcp.net/transversal/0102/marchart/de/print (letzter Zugriff: 26.04.2019).

Müller, Michael, Stadt-Bild und Utopie, in: Stadtutopien, Kunst und Kirche 2/2005 (hrsg. von Alois Kölbl / Manfred Rauchenberger), S. 85-90.

Tracy, David, Western Hermeneutics and Inter-Religious Dialogue, in: Cornille Conway / Christopher Conway (Hg.), Interreligious Hermeneutics, Eugene 2010, S. 1-43.

Wildner, Kathrin / Berger, Hilke Marit, Das Prinzip des öffentlichen Raums, vgl. http:// www.bpb.de/politik/innenpolitik/stadt-und-gesellschaft/216873/prinzip-des-oeffentli chen-raums (letzter Zugriff: 26.04.2019).

Wildner, Kathrin, La Plaza: Öffentlicher Raum als Verhandlungsraum, vgl. http://www.re publicart.net/disc/realpublicspaces/wildner01_de.htm (letzter Zugriff: 26. 04.2019). 
Open-Access-Publikation im Sinne der CC-Lizenz BY 4.0

(C) 2020, Vandenhoeck \& Ruprecht $\mathrm{GmbH} \&$ Co. KG, Göttingen ISBN Print: 9783847111658 - ISBN E-Lib: 9783737011655 


\section{Konstantinos Delikostantis (Athen)}

\section{Wie sozial ist die Orthodoxe Kirche?}

Die Zentralität des Kultes und der Liturgie, sowie die starke eschatologische Ausrichtung des ganzen kirchlichen Lebens in der Orthodoxen Kirche waren im Westen oft der Ansatzpunkt der Kritik gegen die Orthodoxie als Ort des kultischen Monismus und eines quietistischen Eschatologismus. Das Orthodoxe Christentum wurde als Fossil aus vergangenen Zeiten angesehen, mit sterilem Traditionalismus gleichgesetzt und als ein dem westlichen Geist im Prinzip fremdes Phänomen betrachtet. Selbst große Gestalten des Westens haben kein Verständnis für das östliche Paradigma der Christenheit aufbringen können. Hegel sah in Byzanz, von dem die Orthodoxie heute nach schöpft, nur „ein morsches Gebäude“, das „endlich von den kräftigen Türken zertrümmert wurde“. ${ }^{1}$ Max Scheler nannte die orthodoxe Spiritualität „eine ihrem Ursprung und Sinn nach so weltflüchtige, so passiv-kontemplative, so ästhetische, aus hellenistischer Dekadenz geborene, feine und subtile herbstliche Religiosität “. ${ }^{2}$ Adolf Harnack charakterisierte seinerseits das östliche Kirchentum, „mit seinen Priestern und seinem Kultus, mit allen den Gefäßen, Kleidern, Heiligen, Bildern und Amuletten, mit seiner Fastenordnung und seinen Festen“ als „etwas dem Evangelium Fremdes“, ja sogar als „jene Art von Religion, um deren Auflösung willen sich Jesus Christus ans Kreuz schlagen ließ “ 3

Heute noch, selbst im Rahmen der Ökumenischen Bewegung, zu deren Gründern die Orthodoxe Kirche gehört, kursiert die Ansicht, dass diese Kirche der endlosen Zeremonien, der weltabgeschiedenen Klöster und der zahllosen Frömmigkeitsbräuche, eine „ultraliturgische Kirche“ geblieben ist, die den Einsatz für die Welt als nebensächlich betrachtet. Dass eine solche Einschätzung der Orthodoxie den Tatsachen nicht gerecht wird, dass sie grundlegende Prinzipien der orthodoxen Sozialethik und das immense philanthropische und so-

1 Georg Wilhelm Friedrich Hegel, Vorlesungen über die Philosophie der Geschichte, in: Werke XII., Frankfurt a.M. 1970, S. 412.

2 Max Scheler, Über östliches und westliches Christentum, in: Gesammelte Werke VI., hrsg. von Manfred S. Frings, Bern 1963, S. 99-114, hier: S. 111.

3 Adolf von Harnack, Das Wesen des Christentums, Leipzig 1900, S. 150. 
ziale Werk der Orthodoxen Kirche, durch die Geschichte hindurch und auch in unserer Zeit, ignoriert, soll in diesem Artikel verdeutlich werden.

\section{Theologische Annäherung}

a) Während die Beschreibung des kirchlichen Lebens in der Orthodoxie mit dem Begriff „Liturgie“ sehr treffend ist, stellt das Verständnis der „Liturgie“ im Sinne eines ausschließlich kultischen Geschehens, was auch in der Wiedergabe des

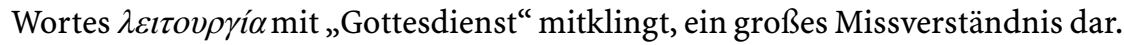
Die Liturgie lässt sich nicht in die vier Wände des Kirchenraumes einschließen. Sie bezeichnet vielmehr das Leben der Kirche in seiner Ganzheit. Das Leben der Kirche ist „ein Dienst zur Verwirklichung des Reiches Gottes auf Erden“", was nicht durch die Abwendung von der Welt, sondern gerade durch die Öffnung und die Zuwendung zur Welt geschehen kann.

Die eucharistische Feier, die das Wesen der kirchlichen Allliturgie ausmacht, ist nicht der Ort einer rein vertikalen Begegnung jedes Einzelnen mit Gott. Wie auch Ernst Benz notierte, die Liturgie bringt dem Gläubigen ,immer aufs Neue seine Stellung zu Gott und zum Nächsten zum Bewusstsein “. ${ }^{5}$ Der Mensch agiert als „relationales Wesen“, als Person. Es herrschen der „liturgische Plural“ und das , liturgische wir". Glaube, Gebet, Frömmigkeit, hören auf, „mein“ zu sein und sie werden „unser“. ${ }^{6}$ Hier handelt es sich um ein „Wir“, das „auf eine Größe anderer Ordnung als jegliche Form einer soziologischen Gesellschaft ${ }^{\star 77}$ hinweist. Die Kirche ist „keine Anhäufung von Individuen, sondern ein lebendiger Organismus, in dem die Glieder zum Haupt, d. h. Christus, und zueinander in einer existentiellen Lebensbeziehung stehen“ ${ }^{8}$ Ich spreche von einer „Kultur der Solidarität“. Man könnte auch von einem „ekklesialen Personalismus“ sprechen, um dem Vorwurf des Kommunitarismus gegen die Orthodoxie zu begegnen.

4 Anastasios Kallis, Orthodoxie. Was ist das?, Mainz 1979, S. 63.

5 Ernst Benz, Menschenwürde und Menschenrecht in der Geistesgeschichte der Östlich-Orthodoxen Kirche, in: Ders., Die russische Kirche und das abendländische Christentum, München 1966, S. 74-115, hier: S. 85.

6 Vgl. Ioannis Zizioulas, Die Welt in der eucharistischen Schau und der Mensch von heute, in: Una Sancta 25/1970, S. 342-349: Die Eucharistie beinhaltet eine positive Aufnahme der Schöpfung. Zum Kern des orthodoxen Ethos gehört der eucharistische Gebrauch der Welt. Der Christ fühlt sich nicht als Herr und Besitzer, sondern als „Priester“ der Schöpfung. Er kennt die kosmologischen Folgen der Sünde, weiß aber zugleich von der Erlösung als Erneuerung der ganzen Kreatur. In der Eucharistie wird am deutlichsten offenbar, dass das Heilsgeschehen nicht nur ein den Menschen und die menschliche Gemeinschaft betreffendes, sondern ein kosmisches Ereignis ist.

7 Kallis, Orthodoxie, S. 65.

8 Ebd. 
b) Die Eucharistie, in der sich das Wesen der Kirche realisiert und offenbart, ist ein eschatologischer Akt. Wie Metropolit Ioannis Zizioulas sagt, „die Identität, das Sein, die Ontologie der Kirche ist eschatologisch “. ${ }^{9}$ Dies wird primär in der eucharistischen Liturgie erlebt, wo alle kirchlichen Akte eschatologisch werden. Vor diesem theologischen Hintergrund ist es leicht verständlich, warum "Liturgie" das Funktionieren des Lebens der Kirche in seiner Ganzheit bezeichnet. Da das ganze Leben der Kirche eucharistisch ist, ist auch die soziale Aktion der Kirche liturgisch, ihre Diakonie ist „liturgische Diakonie“. Man spricht von der „Liturgie nach der Liturgie“, um dadurch die Zentralität der Eucharistie im Leben der Kirche zu bezeichnen. Hier darf sich aber keine Spaltung des kirchlichen Lebens einschleichen. Alexandros Papaderos bemerkt treffend: Der Begriff „Liturgie nach der Liturgie“ kann dazu verleiten, „die Diakonie als zweitrangig und inferior gegenüber dem Gottesdienstlichen der Liturgie zu sehen. Daher ist es besser, von der liturgischen Diakonie zu sprechen". ${ }^{10}$

Der starke „liturgische Impuls“ erlaubt es nicht, den sozialen Dienst der Kirche als konkurrierend oder gar als antithetisch zu ihrem liturgisch-eschatologischen Wesen anzusehen. Die christliche Diakonie ist kein Zusatz, sondern ein wesentlicher Ausdruck des kirchlichen Lebens. Sie bewegt sich jenseits der Entsozialisierung des Liturgischen und der Entliturgisierung des Sozialen. „Der Wahre und angemessene Gottesdienst ist Orthodoxie und Orthopraxie zugleich, Lobpreis Gottes und liturgische Diakonie des Menschen ". ${ }^{11}$

Es ist ganz im Sinne dieser Ausrichtung, wenn die Kirche die Sorgen, das Leid und die bedrückenden Probleme des Kirchenvolkes auf sich nimmt. „Sie wendet ihr Gesicht nicht ab vom Hunger, von der Krankheit, von den Ängsten der Menschen, auch nicht von ihren, oft blutigen Kämpfen für Freiheit ${ }^{\text {“ }}{ }^{12}$ Hier ist es wiederum der eschatologische Geist der Eucharistie, der die Kirche von der Säkularisierung rettet, indem er sie davon abhält, historische, politische und kulturelle Formationen zu verabsolutieren. Es ist nicht von ungefähr, dass die Eucharistie-zentrierte Orthodoxie, gegen die Gefahr der Säkularisierung, ständig „eschatologische Antikörper ${ }^{\text {(113 }}$ zu entwickeln vermochte.

c) Einen besonderen Platz zwischen diesen „eschatologischen Antikörpern“ beansprucht das Orthodoxe Mönchtum. Nach Georges Florovsky, kommt im

9 Ioannis Zizioulas, Kirche und Eschata, in: Pantelis Kalaitzidis (Hg.), Kirche und Eschatologie, Athen 2003, S. 24-45, hier: S. 41 (griechisch).

10 Alexandros Papaderos, Aspekte Orthodoxer Sozialethik, in: Ingeborg Gabriel / Alexandros Papaderos / Ulrich H. J. Körtner, Perspektiven Ökumenischer Sozialethik. Der Auftrag der Kirchen im größeren Europa, Mainz 2005, S. 23-126, hier: S. 68.

11 Ebd., S. 67.

12 Zizioulas, Kirche und Eschata, S. 45.

13 Ebd., S. 41. 
zönobitischen Mönchtum in einer besonderen Weise sowohl der eschatologische wie auch der gemeinschaftliche Grundzug der Östlichen Kirche klar zum Vorschein. ${ }^{14}$ Im Mönchtum stand die soziale Natur der Menschen im Vordergrund, während der Individualismus als zerstörerisch galt. Florovsky verweist auf Johannes Chrysostomus, „einen von den größten christlichen Propheten der sozialen Gleichheit und Gerechtigkeit“" ${ }^{15}$ der glaubte dass die Gesellschaft nach dem Vorbild des zönobitischen Mönchtums aufgebaut werden sollte, d.h. auf der Basis der Überwindung jeder possessiven Haltung.

Florovsky nennt drei Prinzipien, welche für die Haltung der Orthodoxen Kirche gegenüber der Gesellschaft charakteristisch sind: 1) Im Orthodoxen Osten ist das Prinzip der Gleichheit aller Menschen tief in der Seele der Gläubigen verwurzelt. „Es gibt keinen Raum für irgendwelche soziale oder rassische Unterscheidungen innerhalb der Orthodoxen Kirche, trotz ihrer komplizierten hierarchischen Struktur ${ }^{\text {" }}{ }^{16}$ 2) Die Stelle der Kirche ist an der Seite der Bedürftigen, der Armen, der Mühseligen und Beladenen und nicht der Besitzenden, an der Seite der reuigen "Zöllner" und nicht der sich selbst rechtfertigenden „Pharisäer“. Zweifelsohne ist das Prinzip, dass die Kirche ,immer auf der Seite der Demütigen und Sanftmütigen und nicht der Starken und Stolzen ${ }^{\text {“17 }}$ steht, oft vernachlässigt worden, seine Geltung wurde jedoch im Orthodoxen Osten nie in Zweifel gezogen. 3) Wegen ihrer sozialen Ausrichtung erschien die Kirche nicht als eine „dominierende Institution“. Im Östlichen Orthodoxen Christentum lebt, wie Florovsky hinzufügt, seit jeher „ein starker sozialer Instinkt, trotz der historischen Verwicklungen und Rückschritte“. ${ }^{18}$

Gewiss, die starke eschatologische Ausrichtung in der Orthodoxie, die verbunden ist mit dem Glauben an die Vergänglichkeit der geschichtlichen Mächte, an die Brüchigkeit der Institutionen und an die Vorläufigkeit aller weltlichen Einrichtungen, hat eine Distanz des Gläubigen gegenüber den Strukturen der Welt zur Folge. Das bedeutet jedoch mitnichten eine Indifferenz für das Leben des Menschen auf seinem geschichtlichen Weg, das sich ja nicht unabhängig von den Ordnungen der Welt abspielt. Nur ein Missverständnis der eschatologischen Dimension im Sinne eines antihistorischen Eschatologismus könnte eine Indifferenz gegenüber der Geschichte verursachen. In der Haltung der Orthodoxie gegenüber der Geschichte wird das „In-der-Welt-Sein“ der Kirche in seiner Gleichursprünglichkeit mit ihrem „Nicht-von-dieser-Welt-Sein“ offenbar. Wo das „In-der-Welt-Sein“ der Kirche in ein „Von-der-Welt Sein“ verwandelt wird,

14 Vgl. Georges Florovsky, Das soziale Problem in der Östlichen Orthodoxen Kirche, in: Ders., Christentum und Kultur, Werke II., Thessaloniki 1982, S. 165-180 (griechisch).

15 Ebd.

16 Ebd.

17 Ebd.

18 Ebd. 
ist weder dem Zeugnis der Kirche in der Welt noch der Welt selbst geholfen. Die Kirche kann ihr soziales Zeugnis nur geben, wenn sie sich nicht mit der Welt identifiziert, sondern ihr ursprüngliches eucharistisch-eschatologisches Wesen entfaltet.

\section{Christliche Solidarität}

Auf dieser Basis lässt sich die bewundernswerte soziale Präsenz und das Zeugnis der Philanthropie der Orthodoxen Kirche im Laufe ihrer ganzen Geschichte und auch heute, angesichts der großen sozialen und wirtschaftlichen Probleme, verstehen. Die christliche Sorge für den Mitmenschen hat sich nie nur auf die gelegentliche karitative Hilfe für die Notleidenden beschränkt. In diesem Sinne ist es ganz ungerecht, wenn sogenannte „progressive“ Intellektuelle die Kirche mit einem Krankenpfleger vergleichen, der dem Karavan der Gesellschaft folgt und dabei den Schwachen und den Kranken beisteht, ohne sich über die Ursachen des Elends Gedanken zu machen. Das kirchliche Handeln hatte auch eine "makrodiakonische“ Dimension, kritisierend, mobilisierend, organisierend, sich einsetzend für gerechte Zustände, die Möglichkeiten der jeweiligen Zeit verwendend.

Heute ist die Kirche aufgerufen, ihre soziale Substanz unter den neuen Gegebenheiten zu aktualisieren, sich gegen Entwicklungen aufzulehnen, die die Würde des Menschen verletzen, und sich für die Etablierung einer „Kultur der Solidarität ${ }^{\star 19}$ einzusetzen. Die sozialen und die ökonomischen Entwicklungen tangieren die Mitte der menschlichen Existenz. Ganz offensichtlich, das biblische „Der Mensch lebt nicht vom Brot allein“ (Mt. 4,4), bedeutet keine Unterschätzung des „Brotes“ für unser Leben. Es verweist jedoch auf die Gnade Gottes als Fundament und lichtvollen Horizont unseres Lebens, auf die ewige Bestimmung des Menschen.

In diesem Geist hat der Ökumenische Patriarch Bartholomaios in seiner Enzyklika zu Weihnachten 2012, das Jahr 2013 zum „Jahr der allmenschlichen Solidarität" ausgerufen. Sein Ziel war es, unsere Zeitgenossen für die Folgen der großen wirtschaftlichen Krise und für das Problem der ausgebreiteten Armut zu sensibilisieren und auf die dringliche Notwendigkeit von effektiven Maßnahmen für die Linderung der Not der Hungrigen und Notleidenden aufmerksam zu machen. Für den Patriarchen erschien die ökonomische Krise als das Resultat einer breiten spirituellen und moralischen Krise.

19 Delikostantis, Konstantinos, Die Kultur der Solidarität. Soziologische und theologische Annäherungen, Athen 2013 (griechisch). 
Auch das Heilige und Große Konzil der Orthodoxen Kirche (Kreta 2016), hat im Dokument „Der Auftrag der Orthodoxen Kirche in der Welt von heute“ und in seiner „Enzyklika“, im Sinne einer konsequenten Aktualisierung des eucharistisch-eschatologischen Wesens der Kirche, mutig zu den großen gegenwärtigen sozialen Problemen Stellung bezogen und auf konkrete Möglichkeiten und Wege ihrer Überwindung hingewiesen.

In der Mitte des christlichen Zeugnisses in der Welt steht die unzertrennliche Einheit von Gottesliebe und Nächstenliebe. Jesus Christus verband mit Emphase das „erste und große Gebot“ der Liebe zu Gott mit dem „Zweiten“, dem ersten „gleichen“, Gebot der Liebe zum Nächsten (Mt. 22,36-40). Und er fügte hinzu: „In diesen zwei Geboten hängt das ganze Gesetz und die Propheten“. Im Neuen Testament gibt es zwei außerordentliche Texte, welche die Beziehung zum Nächsten, den Wert der konkreten Philanthropie und Solidarität, hervorheben: das Gleichnis vom Barmherzigen Samariter (Luk. 10,25-37), die Perikope vom Weltgericht (Mt. 25,31-46).

Im Samaritergleichnis werden wir aufgerufen, „Nächster“ $\mathrm{zu}$ werden für jeden, der unsere Hilfe braucht, ohne zu fragen, ob er einer von uns oder ein Fremder ist, ohne Grenze und ohne Ausnahme. „Nichts darfst du fragen, sondern du bist immer gefragt und gefordert. Du bist immer der Nahe und der Nächste, auch gegen den Fremden und Fernen “. ${ }^{20}$ Die zwei negativen Gestalten des Gleichnisses sind der Priester und der Levit, das Prototyp des in sich geschlossenen Menschen, die Vertreter einer Religion des Buchstabens des Gesetzes, der selbstgerechten Haltung der Reinen. Sie sahen den unter die Räuber gefallenen „und gingen vorüber“, heißt es im Evangelium.

In der Erzählung vom Weltgericht identifiziert sich Christus mit seinen „geringsten Brüdern“, mit den Hungrigen, den Durstigen, den Fremden, den Nackten, den Gefangenen. Er nennt diejenigen, die ihnen geholfen haben, „die gesegneten“ seines Vaters und gibt ihnen einen Platz im Reiche Gottes. Alle die das Elend und die Not ihrer Mitmenschen ignoriert haben, sind die „Verfluchten“, welche das „ewige Feuer“ erwartet.

Es ist bemerkenswert, dass sowohl im Samaritergleichnis, wie aus den Worten des Schriftgelehrten, der Jesus „versuchte“ mit der Frage „Meister, was muss ich tun, dass ich das ewige Leben ererbe?" (Lk. 10,25) deutlich wird, als auch in der Erzählung über das Endgericht, die tätige Liebe zum Nächsten ganz eindeutig einen soteriologischen Bezug hat. In der orthodoxen Tradition wird die Hölle dargestellt als der Ort, an dem die Menschen das Gesicht des Anderen nicht sehen können, weil ihre Rücken aneinander gekettet sind. Hölle ist das Fehlen jeder Beziehung zum anderen, die Einkerkerung des Menschen in sich selbst, der homo clausus, die äußerste Entfremdung des Menschen.

20 Karl Hermann Schelkle, Theologie des Neuen Testaments III: Ethos, Düsseldorf 1970, S. 129. 
Die personzentrierte Orthodoxe Anthropologie setzt sich von allen um das Individuum zentrierten Anthropologien deutlich ab. „Personalität im Unterschied zu Individualität bedeutet, dass ich meine Identität aus einem Gemeinschaftsgeschehen herleite und nicht aus der Isolierung oder der Selbstgenügsamkeit“. ${ }^{21}$ Deswegen gilt es: „Eine Person bedeutet keine Person“.22

Das Orthodoxe Ethos kann am geeignetsten durch den Terminus „Kultur der Person“ charakterisiert werden. Das ganze kirchliche Leben ist eine „Gemeinschaft der Relationen“, wo die Freiheit, „zu der uns Christus befreit hat"

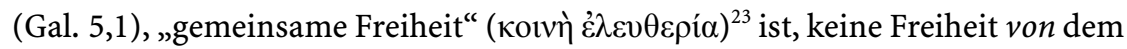
Anderen, sondern eine Freiheit mit ihm und für ihn ist, die sich als Liebe und Brüderlichkeit verwirklicht. Personsein meint Widerstand gegen den Eudämonismus, gegen die Selbstzentriertheit und die Beanspruchung des „individuellen Rechts“, welche tiefe Gräben zwischen den Menschen eröffnen. In einer Zeit, wo von Vielen die Freiheit mit der Kunst der Vermeidung von Bindung und Verpflichtung, mit der Priorität des privaten Glücks und der Selbstverwirklichung identifiziert wird, ist die Rede von Freiheit als Selbstüberwindung und Selbstverzicht ein revolutionärer Akt. ${ }^{24}$

Ganz gewiss, die Zukunft gehört nicht dem isolierten Individuum, der nur Ansprüche stellt und nicht dient. Sie gehört auch nicht dem Gemeinschaftsradikalismus und dem Kollektivismus, welche die Freiheit der Person im Namen kollektiver Zielsetzungen eliminieren, sie der „Gesellschaft“ und weltfremden Utopien opfern. Ohne echte humane Perspektive ist auch der prometheische Titanismus, sei es als szientistische Selbstüberschätzung der Wissenschaft und der Technik, welche die menschliche Arroganz nährt, oder als Deifizierung des ökonomischen Fortschritts, welche die naturalen Bedingungen des Lebens auf Erden zerstört, sei es als maßloses Machtstreben in der Politik ohne jeden Respekt für Freiheit und Gerechtigkeit. Die Zukunft gehört der Kultur der Solidarität, der vernünftigen Mitmenschlichkeit.

\section{Epilogisches}

Die christlichen Kirchen sind heute aufgerufen, unter den Zeichen einer großen weltweiten „Krise der Freiheit“ und der sich ausbreitenden Entsolidarisierung, Zeugnis zu geben vom Evangelium der Freiheit in Christus. Die Orthodoxe

21 Ioannis Zizioulas, Eschatologie und Geschichte, in: Ökumenische Rundschau 35/4/1986, S. 373-384, hier: S. 381.

22 Ders., Das Recht der Person, Sonderdruck, Akademie von Athen, Athen 1977, S. 591 (griechisch).

23 Nikolaos Kabasilas, Vom Leben in Christo, IV, PG 150, S. 493-726, hier: S. 653 A.

24 Delikostantis, Konstantinos, Der Zauber der Askese, Athen 2011 (griechisch). 
Kirche hat eine reiche und tiefe theologische Tradition, große spirituelle Reserven, deren Implikationen für die Begegnung mit den heutigen Herausforderungen verwertet werden können.

Auch heute ist die Antwort der Kirche auf die Welt die Treue zu ihrer eigenen Wahrheit, die konsequente Entfaltung ihres gemeinschaftlichen, eucharistischen und eschatologischen Wesens. Die Kirche muss in der zeitgenössischen Kultur den Geist der „Wahrheit als Gemeinschaft“ inkarnieren, wodurch sie nicht nur kulturtherapeutisch, sondern auch kulturschöpferisch in Richtung einer solidarischen Gesellschaft wirken kann. Unsere moderne und postmoderne Weltgesellschaft hat für ihren Zusammenhalt eine Wertmitte nötig. Sie kann ihre Einheit nicht allein durch Internet und Information, nicht durch Wissenschaft und Technologie, auch nicht durch Globalisierung, durch wirtschaftlichen Fortschritt und soziale Modernisierung sichern. ${ }^{25}$

Hans Maier hat in seinem Buch Welt ohne Christentum - was wäre anders?, auf die revolutionäre Anthropologie des Christentums verwiesen, die, anders als das Modell griechischer „Wohlgeratenheit“, die Armen, Behinderten, Kranken, Niedrigen, Besessenen einbezog, alteingesessene Hierarchien und völkische Schranken auflöste und eine Kultur der Brüderlichkeit und der Solidarität fundierte. Die wichtigsten humanen Errungenschaften in unserer Kultur, in Gesellschaft und Politik, beruhen auf dieser christlichen „Umwertung der Werte“. Im Blick auf die heutige Entwicklung zu einer „postchristlichen“ europäischen Kultur, stellt Maier folgende dringende Fragen:

„Wissen wir, ob die Kultur des Sozialstaats den Untergang der Nächstenliebe überleben
würde? Müsste nicht die Solidarität mit dem Nächsten verschwinden, wenn dieser nur
noch der Fremde, der Andere wäre, der Konkurrent, ja der Feind? Kann es soziale
Verantwortung überhaupt noch geben, wenn das Leben selbst (der ungeborenen
Kinder, der Alten u. a.) in Frage gestellt wird? Gibt es noch Menschenrechte, wenn die
Menschheit und ihr Schöpfer in einem „Kampf der Zivilisationen“ aus dem Blick
geraten?“ 26

Unsere Kirchen müssen heute und in aller Zukunft der Ort jener Freiheit bleiben, deren Kern die Liebe ist, die „nicht das ihre sucht“ (1.Kor. 13,5). Das ist sicherlich keine „Ressentimentmoral“, die aus der Schwäche hervorquillt, wie Friedrich Nietzsche es wollte, ${ }^{27}$ sondern Zeichen einer unermesslichen Kraft, die kein Menschenwerk, sondern Gottesgeschenk ist.

25 Vgl. Hans Küng, Weltethos für Weltpolitik und Weltwirtschaft, München 1997, S. 195.

26 Hans Meier, Welt ohne Christentum - was wäre anders?, Freiburg i. Br. 1999, S. 148-151.

27 Vgl. Friedrich Nietzsche, Zur Genealogie der Moral, in: Werke II, hrsg. von Karl Schlechta, Carl Hanser, München 1969, S. 761-900, hier: S. 791-792. 


\section{Quellen}

Benz, Ernst, Menschenwürde und Menschenrecht in der Geistesgeschichte der ÖstlichOrthodoxen Kirche, in: Ders., Die russische Kirche und das abendländische Christentum, München 1966, S. 74-115.

Delikostantis, Konstantinos, Die Kultur der Solidarität. Soziologische und theologische Annäherungen, Athen 2013 (griechisch).

Delikostantis, Konstantinos, Der Zauber der Askese, Athen 2011 (griechisch).

Florovsky, Georges, Das soziale Problem in der Östlichen Orthodoxen Kirche, in: Ders., Christentum und Kultur, Werke II., Thessaloniki 1982, S. 165-180 (griechisch).

Hegel, Georg Wilhelm Friedrich, Vorlesungen über die Philosophie der Geschichte, in: Werke XII, Frankfurt a.M. 1970.

Kabasilas, Nikolaos, Vom Leben in Christo, IV, PG 150, S. 493-726.

Kallis, Anastasios, Orthodoxie. Was ist das?, Mainz 1979.

Küng, Hans, Weltethos für Weltpolitik und Weltwirtschaft, München 1997.

Meier, Hans, Welt ohne Christentum - was wäre anders?, Freiburg i. Br. 1999.

Nietzsche, Friedrich, Zur Genealogie der Moral, in: Werke II, hrsg. von Karl Schlechta, Carl Hanser, München 1969, S. 761-900.

Papaderos, Alexandros, Aspekte Orthodoxer Sozialethik, in: Ingeborg Gabriel / Alexandros Papaderos / Ulrich H. J. Körtner, Perspektiven Ökumenischer Sozialethik. Der Auftrag der Kirchen im größeren Europa, Mainz 2005, S. 23-126.

Scheler, Max, Über östliches und westliches Christentum, in: Gesammelte Werke VI., hrsg. von Manfred S. Frings, Bern 1963, S. 99-114.

Schelkle, Karl Hermann, Theologie des Neuen Testaments III: Ethos, Düsseldorf 1970. von Harnack, Adolf, Das Wesen des Christentums, Leipzig 1900.

Zizioulas Ioannis, Kirche und Eschata, in: Pantelis Kalaitzidis (Hg.), Kirche und Eschatologie, Athen 2003, S. 24-45 (griechisch).

Zizioulas, Ioannis, Eschatologie und Geschichte, in: Ökumenische Rundschau 35/4/1986, S. 373-384.

Zizioulas, Ioannis, Das Recht der Person, Sonderdruck, Akademie von Athen, Athen 1977 (griechisch).

Zizioulas Ioannis, Die Welt in der eucharistischen Schau und der Mensch von heute, in: Una Sancta 25/1970, S. 342-349. 
Open-Access-Publikation im Sinne der CC-Lizenz BY 4.0

(C) 2020, Vandenhoeck \& Ruprecht $\mathrm{GmbH} \&$ Co. KG, Göttingen ISBN Print: 9783847111658 - ISBN E-Lib: 9783737011655 


\section{"Forgiving one another" (Col. 3,13). Ethical and Theological Reflections on Reconciliation within the Ukrainian Ecclesial Crisis}

\section{Introduction}

On $19^{\text {th }}$ April 2018, the Holy and Sacred Synod of the Ecumenical Patriarchate (EP) presided by Patriarch Bartholomew announced to "[have] received from ecclesiastical and civil authorities - representing millions of Ukrainian Orthodox Christians - a petition that requests the bestowal of autocephaly"1. Regarding this petition, the Synod decided to "closely communicate and coordinate with its sister Orthodox Churches concerning this matter"2. After the "Unifying Synod" (sobor) held on $15^{\text {th }}$ December 2018 in Kiev under the patronage of the EP, the new Orthodox Autocephalous Ukrainian Church was established and Metropolitan Epiphanios of Pereiaslav and Belotserkovsky was elected as its Primate. ${ }^{3}$ The newly elected Metropolitan received officially and solemnly the Tomos of autocephaly for the new Church on the $6^{\text {th }}$ of January in the Phanar. ${ }^{4}$

Although Constantinople's decision to grant autocephaly to a unified Orthodox Church in Ukraine should have brought ecclesial unity, in effect it generated a schism between the Russian Orthodox Church (ROC) and the Ecu-

\footnotetext{
* I am greatly thankful to my doctoral supervisor, Prof. Ingeborg Gabriel, for her support and for discussing this topic with me. I also wish to thank Dr. Răzvan Porumb (Cambridge), Dr. Viorel Coman (KU Leuven), Marius-Ștefan Ciulu (Kiel) and Dr. Petre Maican (Aberdeen) for reading and commenting on this paper. Their remarks were crucial for me.

1 Cf. Ecumenical Patriarchate, Communiqué of the Holy and Sacred Synod (04/22 2018), see: https://www.patriarchate.org/-/anakoinothen-tes-agias-kai-ieras-synodou-22-04-2018- (accessed on July $9^{\text {th }} 2019$ ).

2 Ebd.

3 Cf. Ecumenical Patriarchate, Communiqué (12/15 2018), see: https://www.patriarchate.org/-/ anakoinothen-15-12-2018- (accessed on July $\left.9^{\text {th }} 2019\right)$.

4 For the official text of the Tomos, see: Ecumenical Patriarchate, Patriarchal and Synodal Tomos for the Bestowal of the Ecclesiastical Status of Autocephaly to the Orthodox Church in Ukraine, see: https://www.patriarchate.org/announcements/-/asset_publisher/MF6geT6kma $\mathrm{DE} /$ content/patriarchikos-kai-synodikos-tomos-choregeseos-autokephalou-ekklesiastikoukathestotos-eis-ten-en-oukraniai-orthodoxon-ekklesian?_101_INSTANCE_MF6geT6kma DE_languageId=en_US (accessed on July $9^{\text {th }} 2019$ ).
} 
menical Patriarchate (EP). ${ }^{5}$ This ecclesial conflict, which takes place within the context of a political and military crisis between Ukraine und the Russian Federation, amplifies the existing Russian-Ukrainian crisis and creates a split in the Orthodox world. Local Orthodox Churches are forced to take a position in the ecclesial dispute between Kiev and Moscow, putting in danger the Pan-Orthodox unity by creating two poles: to be either pro-Russia or pro-Constantinople.

This paper will attempt to throw some light on this issue from an ethical and theological perspective. Our approach will start by presenting the social and religious context of this ecclesial conflict. Then the concept of reconciliation will be analysed from the point of view of the teaching of the gospel, which is normative for (Orthodox) Christians. Then the issue will be addressed in the light of the nationalistic tendencies and the totalitarian past of the region. Finally, the paper will offer possible models (steps) towards reconciliation both at the PanOrthodox level and at the level of the local Orthodox Churches. ${ }^{6}$

\section{Current Religious Situation in Ukraine}

To understand the complexity of the religious situation in Ukraine, it is necessary to look at the recent past of the region: After the collapse of Soviet Union in 1991, three Orthodox Churches (re)emerged. Each of them proclaimed itself as legitimate continuator of the historical Kievan Metropolis. The only one that enjoyed canonical status was the Ukrainian Orthodox Church (Moscow Patriarchate UOC-MP), currently headed by Metropolitan Onufriy (Beresowskyj) and placed under the jurisdiction of the Moscow Patriarchate. UOC-MP had also been recognised by all fourteen Orthodox autocephalous Churches. The second church has been the Ukrainian Orthodox Church (Kiev Patriarchate - UOC-KP) headed by Patriarch Filaret (Denysenko) which has never enjoyed canonically recognition. The third Orthodox Church in Ukraine is the Ukrainian Autocephalous Orthodox Church (UAOC) with a very small number of members and often labelled schismatic by all the other Orthodox Churches. Those last two Churches - UOC-KP and UAOC - were dissolved at the "Unification Council" from $15^{\text {th }}$ December 2018 and integrated in the new Ukrainian Orthodox Church.

5 The Russian Orthodox Church, Department for External Church Relations, The Holy Synod of the Russian Orthodox Church has considered it impossible to remain in the Eucharistic communion with the Patriarchate of Constantinople (10/15 2018), see: https://mospat.ru/en/ 2018/10/15/news165259/ (accessed on July $9^{\text {th }} 2019$ ).

6 A very important source of inspiration for this article, especially for the section dealing with reconciliation, is Ingeborg Gabriel, Erinnerung und Versöhnung. Zur politischen Renaissance eines theologischen Konzepts, in: Ingeborg Gabriel / Christa Schnabl / Paul M. Zulehner (ed.), Einmischungen. Zur politischen Relevanz der Theologie, Ostfildern 2001, pp. 25-47. 
Apart from these three Orthodox Churches, there is also the Ukrainian Greek Catholic Church (UGCC). This Church is the result of the Union of Brest (1596) and belongs - together with the Orthodox Churches - to the group of Ukrainian traditional churches. ${ }^{7}$

The existence of so many Orthodox Churches in only one country where they have been functioning side-by-side in a state of conflict has always represented a scandalous situation for Orthodoxy as whole and has considerably weakened the potential of the Christian faith in this country after the fall of Communism. ${ }^{8}$

Following the Orange Revolution (2003), the Maidan Revolution of dignity (2013), the annexation of the Crimean Peninsula (2014) and the military conflict in Eastern Ukraine (from 2014 up to today), the situation of the UOC-MP (canonical dependent from Moscow) has become ever more precarious. Despite its numerical and infrastructural supremacy as the only canonical Orthodox Church in Ukraine, UOC-MP has lost a significant part of its members. According to the Razumkov Center and Rating pollster, the percent of those who declare themselves as members of UOC-MP has declined from $34.5 \%$ in 2010 to $19.1 \%$ in 2018. The percentage of those who consider themselves members of UOC-KP has increased from $15.1 \%$ in 2010 to $28.7 \%$ in 2018 . In this context of divided Churches, the category of people who call themselves "only Orthodox" without giving their confessional jurisdiction has risen to $23.4 \%$ in 2018 . These percentages refer to those who consider themselves Orthodox in Ukraine ( $68.1 \%$ in 2010 and $67,3 \%$ in 2018 of identified citizens). The UGCC possesses a significant number of members, precisely $9.4 \%$ of those polled. ${ }^{9}$

The inability of the Russian Orthodox Church (ROC) to solve the problem of several schisms on Ukrainian territory may have served as official argument for the intervention of the EP in the jurisdiction of Ukraine: "For, as the Mother Church, it is reasonable to desire the restoration of unity for the divided ecclesiastical body in Ukraine, a faithful population of tens of millions, baptized and enlightened directly through the providence and missionary activity of our

7 Myroslava Rap, The Conflict between Traditional Christian Churches in Ukraine as a Conflict of Identities: Where to Search for the Prospects of Reconciliation? A Reflection in the Light of the Theories of Paul Ricoeur and John Paul Lederach, in: Political Theology 16/3/2015, p. 202.

8 This situation goes obviously against the principle of the Church's unity as exposed in Joh 17,21: "That they all may be one; as thou, Father, art in me, and I in thee, that they also may be one in us: that the world may believe that thou hast sent me".

9 According to Razumkov poll (2018) out of 30 millions of Ukrainian believers $67.3 \%$ are Orthodox Christian. Cf. Razumkov Center, Religious Information Service of Ukraine, translation by Euromaidan Press, see: http://euromaidanpress.com/2018/10/14/tomos-guideukraine-church-autocephaly/ (accessed on January $7^{\text {th }} 2019$ ); The original source (in Ukrainian): Razumkov Center, Religion and Church in Ukrainian society: a sociological study of 2018, Kiev 2018, 4 and 13, see: http://razumkov.org.ua/uploads/article/2018_Religiya.pdf (accessed on January $26^{\text {th }} 2019$ ). 
Ecumenical Throne" ${ }^{10}$. Ultimately, the intervention of the EP's was triggered by the Appeal of the Ukrainian Parliament on the $16^{\text {th }}$ June 2016 to the Ecumenical Patriarch to grant Autocephaly to the Orthodox Church in Ukraine. ${ }^{11}$

\section{Theological and ethical reflections on Reconciliation. Two possible proposals}

Reconciliation is doubtlessly one of the most important concepts in Christian theology, because it concerns the status of the relationship between God and humanity as well as that of human beings with each other. In the Biblical writings, reconciliation carries an important function. It describes the re-established communion between God and human beings through the salvific actions of Christ. After a brief biblical analysis, reconciliation will be tackled in the difficult context of nationalism.

The aim of this section is to show that the nationalistic ideology collides with the Biblical tradition of reconciliation, which is - as previously mentioned supra-national, even cosmic, as well as mutually related to other people. The nationalism - especially when it is part of an ecclesial agenda - suppresses and impedes a reconciliation process, which is a crucial exercise in Christianity.

\subsection{The biblical traditions}

In the Old Testament (OT), reconciliation is usually expressed through the term kpr piel ("to atone", "to reconcile") and refers primarily to the restauration of human communion with God, as a result of sins being forgiven by God. Leviticus

10 Cf. Press Office of the Ecumenical Patriarchate, Ecumenical Patriarch Bartholomew: "As the Mother Church, it is reasonable to desire the restoration of unity for the divided ecclesiastical body in Ukraine" (06/02 2018), see: https://www.patriarchate.org/-/oikoumenikos-pa triarches-einai-logikon-na-epithymomen-os-meter-ekklesia-ten-apokatastasin-tes-enote tos-tou-en-oukrania-dieremenou-ekklesiastikou-somat (accessed on $8^{\text {th }}$ January 2019); See also: John Chryssavgis, Pastoral Perspectives of the Ukrainian Autocephaly: A Personal Face to a Political Issue, in: Evagelos Sotiropoulos (ed.), The Ecumenical Patriarchate and Ukraine Autocephaly: Historical, Canonical, and Pastoral Perspectives, eBook 2019, pp. 11-16. Of course, there are other similar perspectives that are considering first political reasons for the EP's intervention in the Ukraine.

11 The Appeal of the National Parliament to the EP to grant Autocephaly is traditionally the first step in this process. See: Ukrainian Parliament, Resolution on the Appeal of the Verkhovna Rada of Ukraine to the All-Holy Bartholomew, Archbishop of Constantinople and New Rome, Ecumenical Patriarch to provide Autocephaly to the Orthodox Church in Ukraine (in Ukrainian), see: http://w1.c1.rada.gov.ua/pls/zweb2/webproc4_1?pf3511=59348 (accessed on January $28^{\text {th }} 2019$ ). 
16 establishes even a Day of Reconciliation (Yom Kippur), one of the most important religious celebration in the OT, in which the people of Israel are reconciled with Yahwe through bloody sacrifice (collective dimension). Apart from this celebration, there are strong regulations concerning other bloody sacrifices at the Temple. They have the same goal of reconciling the individual with God (cf. Lev 1-9; Lev 17:11). ${ }^{12}$ A second meaning refers to reconciliation as a profane act ("to cover"), defined as "a process that covers something" (a guilt). ${ }^{13}$ Reconciliation (through the verb kipper) in the sense of interpersonal reconciliation is rare in the OT. The solution of these kinds of conflicts is found especially in Genesis through the spatial separation of the conflicting parties (cf. Gen $37-50){ }^{14}$

In the New Testament, reconciliation is commonly expressed through both the

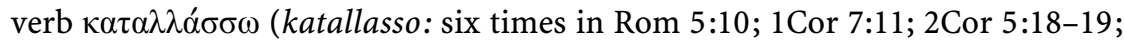
$5: 20$ ), the substantive $\kappa \alpha \tau \alpha \lambda \lambda \alpha \gamma \eta^{\prime}$ (katallage: four times in: Rm 5:11;11:15;2Cor 5:18-19) and the verb $\alpha \pi$ $\pi \alpha \tau \alpha \lambda \lambda \alpha \dot{\sigma} \sigma \sigma \omega$ (apokatallasso: three times in: Eph 2:16; Col 1:2-22). Although Jesus does not speak explicitly about reconciliation, the Gospels set inter-personal reconciliation as condition for bringing a gift to the altar ( $\delta 1 \alpha \lambda \lambda \alpha ́ \sigma \sigma \omega$ in Mt 5:24; similar contexts that demand reconciliation between people are in Lc 12:58 and in 1Cor 7:11). Forgiving, always a precondition of reconciliation, is part of the Lord's Prayer (Mt 6:12). Thus, atonement must be accomplished before reconciliation takes place. ${ }^{15}$

Paul takes the Old Testament understanding of reconciliation and interprets it with a Christological key (cf. Rm 3:25). Through Jesus' sacrifice human beings receive definitive reconciliation with God ( $\mathrm{Rm}$ 5:10-11). Based on this reconciliation, the Apostles are given "the ministry/service of reconciliation" (" $\eta$

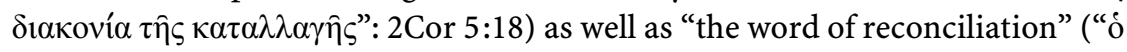

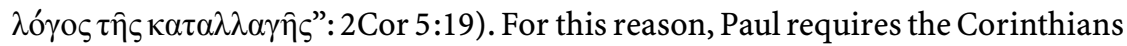

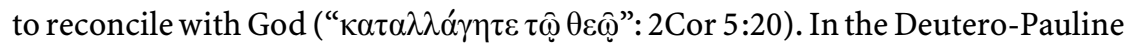
Letters, reconciliation - which is strongly connected to the issue of peace receives a supra-national (Eph 2:16) even a cosmic dimension (Col 1:20-22). The ethnic parts that were initially in opposition are now reconciled through Jesus'

12 Joachim Kügler, Versöhnung, in: Angelika Berlejung / Christian Frevel (ed.), Handbuch theologischer Grundbegriffe zum Alten und Neuen Testament, 4. ed., Darmstadt 2015, p. 447.

13 Matthias Millard / Gerd Theissen, Versöhnung, in: Frank Crüsemann / Kristian Hungar / Claudia Janssen u.a. (ed.), Sozialgeschichtliches Wörterbuch zur Bibel, München 2009, pp. 610-613, here: p. 610.

14 For a very comprehensive and detailed analysis, see: Lang, kipper / kapporet / koper / kippurim, in: Theological Dictionary of The Old Testament 7, G. Johannes Botterweck / Helmer Ringgren / Heinz-Josef Fabry (ed.), Michigan 1995, pp. 288-303.

15 Hans-Georg Link, Reconciliation, Restoration, Propitiation, Atonement, in: Colin Brown (ed.), Dictionary of New Testament Theology 3, Michigan-Devon 1975, pp. 145-148. 
cross, a "new man" is created, and thereby humankind (re)gains its access to the Father (Eph 2:18). ${ }^{16}$

Basically, the Biblical tradition contains two major models of reconciliation. The first one is collective. It emphasizes the restoration of the relation of the whole of humankind with its Creator through Jesus Christ. The Church, as collective humanity, embodies this cosmic dimension and shares it with the world through the Gospel of peace (cf. Eph 2:17). The second model is individual. It is concerned with the restauration of harmonious relationships between individuals. Forgiveness of and reconciliation with our neighbour are preconditions that must be accomplished in order to worship God - who offers us the supreme model of forgiveness and reconciliation.

\subsection{The Challenge of Nationalism}

Since the nineteenth century, a new understanding of the world has (re)emerged once with the rise of nationalism. The nationalistic ideology originates from an artificial distinction between "us" (as a specific ethnic group or nation) and "others" (a different ethnic group). "Us", the nation, receives an absolutized character and becomes the norm within the political community, to which everything - especially religion and society - is subordinated. The main purpose of this artificial distinction consists in the building of a specific national identity. Aiming to legitimate itself, nationalism applies a selective reading of history and politically instrumentalises both the wounds and the military victories of the past. $^{17}$

In such a nationalistic context - that idealises its own past and sets as its main priority the right to possess a territory as opposed to other local ethnic groups it is very difficult, if not impossible, to build a discourse about reconciliation. Only two sides that are prepared to reconsider their interpretation of the past can reconcile with each other. Nationalism simply draws its resources from an irreconcilable memory, which intends to remain so and furthermore looks to find "vindication" by discriminating other groups of people. Therefore, memory becomes an insurmountable obstacle in the search for reconciliation. ${ }^{18}$

16 Cf. Harold W. Hoehner, Ephesians. An Exegetical Commentary, Michigan 2002, pp. 381-384.

17 For an introduction into the concept of nationalism, see: Donate Kluxen-Pyta, Nationalismus, in: Lexikon für Theologie und Kirche VII, Walter Kasper (ed.), Freiburg-Basel-Rom (u. a.) 1998, p. 650; Carl-Henric Grenholm, Nationalismus, in: Theologische Realenzyklopädie XXIV, Gerhard Müller (ed.), Berlin-New York 1994, pp. 21-34. Eugen Lemberg, Nationalismus, in: Staatslexikon V, Görres-Gesellschaft (ed.), 6. ed., Freiburg 1960, pp. 896902.

18 Gabriel, Erinnerung und Versöhnung, p. 33. 
For the Orthodox countries, especially for those from the Balkans, the nineteenth century represents not only a time of political emancipation from external political influences but also the beginning of a wave of ecclesial emancipation from the Ecumenical Throne of Constantinople. During the nineteenth and twentieth centuries, the number of Orthodox local Churches that attained autocephaly ${ }^{19}$ increased from eight to fourteen. ${ }^{20}$ In this context, the idea that a political independent state must have an independent Orthodox Church emerged. This new way of thinking caused an infusion of nationalism - together with its "dark side" expressed by revolt and resistance - inside the Orthodox Church, which on several occasions put under danger the pan-orthodox unity of the Orthodox Church and sometimes even broke it as in the case of the GrecoBulgarian Schism, which lasted from 1872 until 1945. This is why, already in 1872, the concept of "ethno-phyletism" had been condemned as an ecclesiological heresy by the Orthodox Church through a Pan-Orthodox Synod held in Constantinople. ${ }^{21}$ The German theologian Anastasios Kallis speaks about nationalism as the "Achilles' heel"22 of contemporary Orthodoxy, seriously endangering the unity of Orthodoxy.

The same nationalistic narrative, but in a much more complicated context, supported furthermore by the Phanar, was insistently invoked in 2018 by Petro Poroshenko in the case of Ukrainian autocephaly. This narrative of a national independent Church in Ukraine collides with the Russian multinational conception of Church, provoking an ecclesial crisis, which at the present time seems

19 Autocephaly as ecclesial category possesses first an administrative and organizational character. It originates from early Christianity and since then it has transformed its meaning several times throughout the centuries. In modern times, it represents an emancipatory ecclesial process towards any external ecclesial authority. It was understood "that an autocephalous church elects its own primate who, with the consent of the local synod, consecrates bishops for his own church without being accountable to any external ecclesial authority". Quote from: Cyril Hovorun, Scaffolds of the Church. Towards Poststructural Ecclesiology, Eugene 2017, p. 89; This assumption still holds true for the current interpretation and additionally nowadays accounts for a main characteristic of the modern emancipated nationstate. Finally, it represents a factor of recognition for states and people that is used to build new social, cultural and ecclesial identities. About the genuine meaning of autocephaly and its transformations through the history and its importance for the modern nation state, see the chapter Strongholds: Autocephaly. Ibid., pp. 8-127.

20 Thomas Bremer / Sophie Senyk, The Current Ecclesial Situation in Ukraine: Critical Remarks, in: St. Vladimir's Theological Quarterly 63/1/2019, pp. 43-45. For a remarkable overview on Christianity and nationalism in nineteenth-century Europe, see: Hugh McLeod, Christianity and nationalism in nineteenth-century Europe, in: International Journal for the Study of the Christian Church 15/1/2015, pp. 7-22.

21 Grigorios Larentzakis, Die Häresie des Nationalismus. Menschenwürde und Menschenrechte für alle in der östlich-orthodoxen Perspektive, in: Ingeborg Gabriel (ed.), Politik und Theologie in Europa. Perspektiven ökumenischer Sozialethik, Ostfildern 2008, pp. 257-279.

22 Anastasios Kallis, Das hätte ich gerne gewusst. 100 Fragen an einen orthodoxen Theologen, Münster 2003, p. 40; Ibid., Ce este Ortodoxia?, Cluj-Napoca 2019, pp. 7-8. 
to be insurmountable. Metropolitan Hilarion Alfejew affirms openly the idea that for the ROC Russia, Ukraine and Belarus are "one spiritual space"23 that cannot be separated jurisdictionally. The point here is not to start discussing Ukrainian autocephaly per se, but only to emphasize how a nationalistic ideology - putting one's own interest first- led almost to the failure of ecclesial synodality and maybe of the autocephaly system itself.

\subsection{The Challenge of Different (Ecclesial) Identities}

Another challenge in the Ukrainian ecclesial context is that each Orthodox Church encompasses a specific identity narrative. This legitimises and influences the relationship with the other parts of society and complicates the process of reconciliation. In the following I will refer briefly to several crucial elements in relation to these narratives and to the way they operate within society.

1) The UOC-MP adopts the narrative of canonicity and legitimacy. Being the only recognised Orthodox Church in Ukraine on the Pan-Orthodox Level, the UOC-MP stresses the significance of its legitimacy that originates from the MP. Although the UOC-MP has had a privileged canonical autonomy within the MP since 1900 - coming second in importance within the $\mathrm{ROC}^{24}$ - its allegiance to Moscow is unequivocal, as it advances the concept of the Russkiy Mir (Russian World). Its main characteristics are Orthodox faith, Russian culture (especially language) and a common historical memory. According to this concept Ukraine is an integral part of the Russian World, together with Russia, Belarus and Moldova. Such an idea successively proclaimed by the Russian Orthodox Church makes the achievement of peace and reconciliation in the Ukraine very difficult, because it collides with the Ukrainian governmental claim of independence from Russia and self-determination in its political affairs. This idea obviously has major consequences on the regional level, because it instrumentalises collective memory in a proper sense of colonialism or post-imperialism and claims to influence the entire destiny of all Rus' people. ${ }^{25}$

23 Address by Metropolitan Hilarion of Volokolamsk, Russia - Ukraine - Belarus: A Common Civilizational Space? (Fribourg, Switzerland, June $1^{\text {st }}$ 2019), see: http://www.patriarchia.ru/ en/db/text/5447266.html (accessed on January $28^{\text {th }} 2019$ ).

24 UOC-MP possess basically all the privileges of one autocephalous Orthodox Church. The only exception is that the patriarch of Moscow reserved the right to confirm the bishops elected by the Sinod of UOC-MP. Cf. Nicholas E. Denysenko, The Orthodox Church in Ukraine, DeKalb 2018, pp. 170-176.

25 For more details see the chapter "The doctrine of the Rusky Mir" in: Myroslava Rap, The Public Role of the Church in Contemporary Ukrainian Society. The Contribution of the Ukrainian Greek-Catholic Church to Peace and Reconciliation, Baden-Baden 2015, pp. 8590 . 
2) In the very beginning, the UAOC promoted its liberation from Moscow as well as the "Ukrainisation" and modernisation of the Church as its own identity narrative. The UAOC invokes the heritage of the Kiev Metropolis as its own considering itself as its legitimate continuation.

3) In June 1992, the UOC-KP came into being as a merging between the majority of UAOC and a group of bishops from the Russian Orthodox Church (ROC) under the leadership of Metropolitan Filaret (Denysenko). The new Church is nation-oriented and embodies the narrative of ecclesial independence and strict separation from the MP: since Ukraine is an independent state, its Church has the right to become an independent (autocephalous) Orthodox Church as other countries have done. ${ }^{26}$ The major problem of this Church has been the lack of canonical legitimacy, which in this case belongs to the MP.

4) The UGCC also belongs to the traditional Churches of Ukraine. Its narrative collides with that of the MP because it embodies the similar idea "of unity of the Ukrainian Churches that is grounded in the original unity of the Kyivan Church as established in 988, before the factual division of Christianity between east and west in $1054^{\prime 27}$.

The healing process between these ecclesial identities in Ukraine is the primary step for the reconciliation both within society (between a pro-Occidental side in Western Ukraine and a pro-Russian side in Eastern Ukraine) and with Russia. According to Myroslava Rap, "the conflict between the traditional Ukrainian Churches is a conflict that has in its essence the problem of clashing identities in Ukraine" ${ }^{28}$. So, these different identities that conflict with each other - a fact that aggravates the tensions within the society - must be primarily thematised and reconciled. With regard to the identities of Orthodox Churches in the Ukraine, the most important attempt to reconcile these different narratives was certainly the decision of the EP from 2018 to create an Orthodox Ukrainian Church. The new ecclesial structure should unify the three existent Orthodox Churches in the Ukraine, so that all orthodox Ukrainians can enjoy the fullness of Eucharistic communion with the rest of the Orthodox world. However, the MP is disapproving strongly of this move. In its Appeal from 17 December 2018, the Synod of the UOC-MP did not recognise Constantinople's jurisdiction in Ukraine, nor the canonical legitimacy of the "Unification Council" and declared the newly established Church as schismatic. It concluded: "Moreover, as a result of recent actions of the Patriarchate of Constantinople, the possibility of the reunification of Orthodoxy in Ukraine has now been thrown aside for a very long

26 Rap, The Conflict, pp. 209-217.

27 Ibid., p. 215.

28 Ibid., p. 217. 
time, if not forever"29. This assessment is of critical importance, since it has very negative consequences for the future of Orthodoxy in Ukraine and obstructs the chances for reconciliation. Ultimately, the stance of the MP shows that the tensions between East and West within the Ukrainian society are still insurmountable.

\section{Two concrete steps for a reconciliation}

The current Ukrainian ecclesial conflict certainly has reasons rooted in the way historical, cultural (i.e. language), political and ecclesial data have been interpreted. ${ }^{30} \mathrm{~A}$ Christian perspective on this conflict however implies the question of reconciliation both as a mandate of the Gospel - as explained above - and as part of the civil society assuming a pioneering role in the multidimensional reconciliation process between Ukraine and Russia. ${ }^{31}$ Therefore, the main question of this part of the article is: What should happen at both the PanOrthodox level of the Orthodox Church as well as at the national level in order to deescalate the ecclesial conflict and engage in reconciliation? Even if these two levels interact with each other, they will be considered separately, with each level presenting a possible way out of the crisis.

\subsection{Pan-Orthodox Level}

The fact that a pan-orthodox binding consensus within the Orthodox Churches cannot be reached was undoubtably made very clear at The Holy and Great Council of the Orthodox Church of 2016. Despite preparations that lasted throughout the twentieth century, time in which the formal consensus of all local Orthodox Churches was reached concerning the Synod's agenda and draft documents, four Orthodox Churches (The Russian Orthodox Church and the Patriarchates of Antioch, Bulgaria and Georgia) decided at the last moment not to attend the Council. One of the most important consequences of this with-

29 The Orthodox Church of Russia, Appeal of The Holy Synod of the Ukrainian Orthodox Church to the hierarchy, clergy, monastics, and faithful (12/17 2018), see: https://mospat.ru/ en/2018/12/17/news168041/ (accessed on January $8^{\text {th }} 2019$ ).

30 For example, see the distinguished contribution of: Thomas Bremer / Sophia Senyk, Can history solve the conflict about Ukrainian autocephaly?, in: Public Orthodoxy, see: https:// publicorthodoxy.org/2015/09/21/the-marks-of-autocephaly/ (accessed on June $13^{\text {th }} 2019$ ).

31 Concerning the model of reconciliation that could be applied here there are some proposals worked out in the philosophy of reconciliation of Paul Ricoeur and John Paul Lederach. See the following investigations on this topic of Rap, The Conflict, p. 219; Ibid., The Public Role. 
drawal is the relativization of values such as dialogue and trust, leading to the current lack of synodality. ${ }^{32}$ This crisis reached its climax in Ukraine 2018/2019, when the Ecumenical Throne attempted on its own to solve the existing ecclesial situation. Even if a Communiqué of the Ecumenical Patriarchate from $22^{\text {nd }}$ April 2018 expressed a completely different approach, deciding "to closely communicate and coordinate with its sister Orthodox Churches concerning this matter" ${ }^{33}$, this coordination never took place.

The fact that Orthodoxy is still unable to reach a binding consensus on a panorthodox level, at least on those problems that affect the whole Orthodox world, as well as to start a reconciliation process within the Orthodox Church, reveals that the Orthodox Church is fragile from an institutional point of view. The adjective "fragile" means in this context that the pan-orthodox structure of the Orthodox Church is unable to reach corporate decisions and to initiate processes in a way that is efficacious for the entire Orthodoxy. The reason is that the decisions of such a structure are dependent on the unanimous votes of the local Orthodox Churches, which furthermore have to be approved on the local (synodal) level of each local Church. Because of the nationalist tendencies of the Orthodox local Churches, an obvious asymmetry between "synodality" and "autocephaly" emerges, in which national interests seem to devaluate the synodal system of the Church and to dictate the agenda of each local Church. ${ }^{34}$

Therefore, the emergence of a pan-orthodox structure capable to generate more stability and to stimulate a learning process of synodality is an absolutely necessary step: In order to create it, Anastasios Kallis proposes the following pan-synodal model which, even if inspired - as he writes - by the Catholic Apostolic Nunciature, is completely different from it. 1) Each local Orthodox Church sends one delegate to a centre, as for example Chambésy in Geneva; 2) The delegates are not episcopal diplomats, but diocesan bishops, appointed on a regular basis. The "privilege of honour" of the Ecumenical Patriarchate is understood in this context as a category of dignity, not of power. The authority should be understood in terms of worship (see Mk 10,43-45), so that the ecclesiastical mandate of the unity of the Church can be accomplished: "That they

32 For a detailed and very pertinent analysis regarding the lack of synodality within the Orthodox Churches after the Council of Crete see: Athanasios Vletsis, Orthodoxie "reloaded" oder das Ende der Orthodoxie? Der Ukraine-Konflikt als Chance einer neuen "Formatierung" in der Orthodoxen Kirche, in: Una Sancta. Zeitschrift für ökumenische Begegnung 74/ 2/2019, pp. 154-161.

33 Ecumenical Patriarchate, Communiqué of the Holy and Sacred Synod.

34 Another explanation for the actual lack of pan-orthodox consensus is the centrifugal orientation of the local Orthodox Churches as result of nationalistic tendencies. Razvan Porumb, Orthodoxy in Engagement with the 'Outer' World. The Dynamic of the 'InwardOutward' Cycle, in: Religions 8/13/201, pp. 1-14. 
all may be one; [...] that the world may believe" (Joh 17:21). ${ }^{35}$ Therefore, the main idea of a pan-orthodox structure should be not possessing, but worship, which is actually a liturgical category, deeply rooted in the liturgical life of the Orthodox Church. ${ }^{36}$

\subsection{National level}

At the national level, the issue of canonicity is one of the biggest sources of conflict. In this context, Nicholas Denysenko proposes the model of "canonical plurality" ${ }^{37}$ as a realistic process for achieving peace, at least in order to avoid violence. The problem of Church property should be considered, too. Practically, the Orthodox Churches from Ukraine should undertake the existent model of the Orthodox Church in America (OCA) $)^{38}$ - where a similar situation occurred when the MP bestowed it with autocephaly, but the EP did not acknowledge it. Despite this administrative division, the Churches have preserved Eucharistic communion, so that the foundation of inter-Orthodox cooperation was not affected. Eventually, they started to work together, first within the Standing Conference of the Canonical Orthodox Bishops in the Americas (SCOBA) from 1960 until 2010, and then within the Assembly of Bishops. In the Ukrainian context, a similar model of cooperation can be elaborated by a Pan-Orthodox Council of a Synaxis of Orthodox Primates - in essence a "panel" where all Orthodox Churches can bring their own contributions to the topic - to correspond to the local realities. Firstly, the aim of such a platform should be the restauration of the Eucharistic communion between the MP and the EP, inasmuch as the Eucharist is seen here as a "source of healing, not its outcome" 39 . Thereby, the restauration of Eucharistic communion would not require (or enforce) primarily an administrative union, but it could encourage it step by step. Secondly, this Pan-Orthodox Council should aim to find an administrative procedure that ensures a peaceful and transparent transition of the parishes to the new Ukrainian Orthodox

35 See Anastasios Kallis, Die orthodoxe Kirche im Spannungsfeld ihres Heiligen und Großen Konzils, in: Orthodoxes Forum 31/1\&2/2017, pp. 103-118.

36 Anastasios Kallis, Orthodoxie. Was ist das?, 8. ed., Münster 2014, p. 63.

37 Nicholas Denysenko, Healing the Ukrainian Schism. A proposal for the next step, see: https:// publicorthodoxy.org/2019/02/12/healing-the-ukrainian-schism-a-proposal-for-the-nextstep/ (accessed on February $15^{\text {th }} 2019$ ).

38 For a general presentation of OCA, see: John Anthony McGuckin, The Orthodox Church. An Introduction to its history, doctrine, and spiritual culture, Malden-Oxford 2008, pp. 80-82.

39 Denysenko, Healing the Ukrainian Schism. 
Church - especially in those contexts, which voted in favour of unification with the new ecclesial structure. ${ }^{40}$

\section{Conclusion}

One of the top priorities in the current Ukrainian ecclesial crisis should be the reconciliation of Orthodox Churches, as a first step toward the reconciliation of people from different ecclesial identities in Ukraine and eventually between Ukraine and Russia. Forgiveness and reconciliation are two categories which are deeply rooted in Christian tradition and moreover they are in fact normative for Christian life. The levels on which action is required for achieving reconciliation are as follows: 1) Pan-Orthodox Level - in order to create a more efficient panorthodox structure capable to create consensus with the Orthodox local Churches; 2) National Level - with the aim to promote peace at the level of the civil society and to restore the Eucharistic communion between Orthodox Churches.

\section{Sources}

Bremer, Thomas / Senyk, Sophia, Can history solve the conflict about Ukrainian autocephaly?, in: Public Orthodoxy, see: https://publicorthodoxy.org/2015/09/21/the-marksof-autocephaly/ (accessed on June 13 $3^{\text {th }} 2019$ ).

Bremer, Thomas / Senyk, Sophia, The Current Ecclesial Situation in Ukraine: Critical Remarks, in: St. Vladimir's Theological Quarterly 63/1/2019, pp. 27-58.

Chryssavgis, John, Pastoral Perspectives of the Ukrainian Autocephaly: A Personal Face to a Political Issue, in: Evagelos Sotiropoulos (ed.), The Ecumenical Patriarchate and Ukraine Autocephaly: Historical, Canonical, and Pastoral Perspectives, eBook 2019, pp. 11-16.

Denysenko, Nicholas E., The Orthodox Church in Ukraine, DeKalb 2018.

Denysenko, Nicholas E., Healing the Ukrainian Schism. A proposal for the next step, see: https://publicorthodoxy.org/2019/02/12/healing-the-ukrainian-schism-a-proposalfor-the-next-step/ (accessed on February $15^{\text {th }} 2019$ ).

40 The transitional process of the parishes to the new Church seems to be violent in some places. That is why a general framework must be created so that this dispute can be gradually clarified. Otherwise, under the pressure of fake news and the instant spreading of information on digital platforms, it is possible to cause confusion and to no longer be able to adequately evaluate the general situation. See, for example, Schismatics and Police beat Canonical Priest in Ternopil (Gnezdichno, Ukraine, February 4, 2019), see: http://ortho christian.com/119124.html (accessed on February 19 ${ }^{\text {th }} 2019$ ). 
Ecumenical Patriarchate, Communiqué of the Holy and Sacred Synod (04/22 2018), see: https://www.patriarchate.org/-/anakoinothen-tes-agias-kai-ieras-synodou-22-04-2018(accessed on July $8^{\text {th }} 2019$ ).

Ecumenical Patriarchate, Communiqué (12/15 2018), see: https://www.patriarchate.org/-/ anakoinothen-15-12-2018- (accessed on July $9^{\text {th }} 2019$ ).

Ecumenical Patriarchate, Patriarchal and Synodal Tomos for the Bestowal of the Ecclesiastical Status of Autocephaly to the Orthodox Church in Ukraine, see: https://www. patriarchate.org/announcements/-/asset_publisher/MF6geT6 kmaDE/content/patri archikos-kai-synodikos-tomos-choregeseos-autokephalou-ekklesiastikou-kathesto tos-eis-ten-en-oukraniai-orthodoxon-ekklesian?_101_INSTANCE_MF6geT6kmaDE_ languageId=en_US (accessed on July $9^{\text {th }}$ 2019).

Gabriel, Ingeborg, Erinnerung und Versöhnung. Zur politischen Renaissance eines theologischen Konzepts, in: Ingeborg Gabriel / Christa Schnabl / Paul M. Zulehner (ed.), Einmischungen. Zur politischen Relevanz der Theologie, Ostfildern 2001, pp. 25-47.

Grenholm, Carl-Henric, Nationalismus, in: Theologische Realenzyklopädie XXIV, hrsg v. Gerhard Müller, Berlin-New York 1994, pp. 21-34.

Hoehner, Harold W., Ephesians. An Exegetical Commentary, Michigan 2002.

Hovorun, Cyril, Scaffolds of the Church. Towards Poststructural Ecclesiology, Eugene 2017.

Kallis, Anastasios, Das hätte ich gerne gewusst. 100 Fragen an einen orthodoxen Theologen, Münster 2003.

Kallis, Anastasios, Ce este Ortodoxia?, Cluj-Napoca 2019.

Kallis, Anastasios, Die orthodoxe Kirche im Spannungsfeld ihres Heiligen und Großen Konzils, in: Orthodoxes Forum 31/1\&2/2017, pp. 103-118.

Kallis, Anastasios, Orthodoxie. Was ist das?, 8. ed., Münster 2014.

Kluxen-Pyta, Donate, Nationalismus, in: Lexikon für Theologie und Kirche VII, Walter Kasper (ed.), Freiburg-Basel-Rom (u. a.) 1998, p. 650.

Kügler, Joachim, Versöhnung, in: Angelika Berlejung / Christian Frevel (ed.), Handbuch theologischer Grundbegriffe zum Alten und Neuen Testament, 4. ed., Darmstadt 2015, p. 447.

Lang, kipper / kapporet / koper / kippurim, in: G. Johannes Botterweck, Helmer Ringgren, Heinz-Josef Fabry (ed.), Theological Dictionary of The Old Testament 7, Michigan 1995, pp. 288-303.

Larentzakis, Grigorios, Die Häresie des Nationalismus. Menschenwürde und Menschenrechte für alle in der östlich-orthodoxen Perspektive, in: Ingeborg Gabriel (ed.), Politik und Theologie in Europa. Perspektiven ökumenischer Sozialethik, Ostfildern 2008, pp. 257-279.

Lemberg, Eugen, Nationalismus, in: Staatslexikon V, Görres-Gesellschaft (ed.), 6. ed., Freiburg 1960, pp. 896-902.

Link, Hans-Georg, Reconciliation, Restoration, Propitiation, Atonement, in: Colin Brown (ed.), Dictionary of New Testament Theology 3, Michigan-Devon 1975, pp. 145-148.

Metropolitan Hilarion of Volokolamsk, Russia - Ukraine - Belarus: A Common Civilizational Space? (Fribourg, Switzerland, June $1^{\text {st }} 2019$ ), see: http://www.patriarchia.ru/en/ $\mathrm{db} /$ text/5447266.html (accessed on January $28^{\text {th }} 2019$ ).

McGuckin, John Anthony, The Orthodox Church. An Introduction to its history, doctrine, and spiritual culture, Malden-Oxford 2008. 
McLeod, Hugh, Christianity and nationalism in nineteenth-century Europe, in: International Journal for the Study of the Christian Church 15/1/2015, pp. 7-22.

Millard, Matthias / Theissen, Gerd, Versöhnung, in: Frank Crüsemann / Kristian Hungar / Claudia Janssen u. a. (ed.), Sozialgeschichtliches Wörterbuch zur Bibel, München 2009, pp. 610-613.

Porumb, Razvan, Orthodoxy in Engagement with the 'Outer' World. The Dynamic of the 'Inward-Outward' Cycle, in: Religions 8/131/2017, pp. 1-14.

Press Office of the Ecumenical Patriarchate, Ecumenical Patriarch Bartholomew: "As the Mother Church, it is reasonable to desire the restoration of unity for the divided ecclesiastical body in Ukraine" (06/02 2018), see: https://www.patriarchate.org/-/oi koumenikos-patriarches-einai-logikon-na-epithymomen-os-meter-ekklesia-ten-apo katastasin-tes-enotetos-tou-en-oukrania-dieremenou-ekklesiastikou-somat (accessed on January $8^{\text {th }}$ 2019).

Rap, Myroslava, The Conflict between Traditional Christian Churches in Ukraine as a Conflict of Identities: Where to Search for the Prospects of Reconciliation? A Reflection in the Light of the Theories of Paul Ricoeur and John Paul Lederach, in: Political Theology 16/3/2015, pp. 201-225.

Rap, Myroslava, The Public Role of the Church in Contemporary Ukrainian Society. The Contribution of the Ukrainian Greek-Catholic Church to Peace and Reconciliation, Baden-Baden 2015.

Razumkov Center, Religion and Church in Ukrainian society: a sociological study of 2018, Kiev 2018, see: http://razumkov.org.ua/uploads/article/2018_Religiya.pdf (accessed on January $26^{\text {th }} 2019$ ).

Schismatics and Police beat Canonical Priest in Ternopil (Gnezdichno, Ukraine, February 4, 2019), see: http://orthochristian.com/119124.html (accessed on February $19^{\text {th }} 2019$ ).

The Orthodox Church of Russia, Appeal of The Holy Synod of the Ukrainian Orthodox Church to the hierarchy, clergy, monastics, and faithful (12/17 2018), see: https:// mospat.ru/en/2018/12/17/news168041/ (accessed on January $8^{\text {th }} 2019$ ).

The Russian Orthodox Church, Department for External Church Relations, The Holy Synod of the Russian Orthodox Church has considered it impossible to remain in the Eucharistic communion with the Patriarchate of Constantinople (10/15 2018), see: https://mospat.ru/en/2018/10/15/news165259/ (accessed on July $9^{\text {th }} 2019$ ).

Ukrainian Parliament, Resolution on the Appeal of the Verkhovna Rada of Ukraine to the All-Holy Bartholomew, Archbishop of Constantinople and New Rome, Ecumenical Patriarch to provide Autocephaly to the Orthodox Church in Ukraine (in Ukrainian), see: http://w1.c1.rada.gov.ua/pls/zweb2/webproc4_1?pf3511=59348 (accessed on $28^{\text {th }}$ January 2019).

Vletsis, Athanasios, Orthodoxie "reloaded" oder das Ende der Orthodoxie? Der UkraineKonflikt als Chance einer neuen "Formatierung" in der Orthodoxen Kirche, in: Una Sancta. Zeitschrift für ökumenische Begegnung 74/2/2019, pp. 151-168. 
Open-Access-Publikation im Sinne der CC-Lizenz BY 4.0

(C) 2020, Vandenhoeck \& Ruprecht $\mathrm{GmbH} \&$ Co. KG, Göttingen ISBN Print: 9783847111658 - ISBN E-Lib: 9783737011655 


\section{Der Islam als Thema der Österreichischen Bischofskonferenz. Positionen und Stellungnahmen}

\section{Zunehmende Bedeutung des Islam}

$\mathrm{Zu}$ den zahlreichen Themen, mit denen sich die Ordinaria für Sozialethik der Universität Wien und langjährige Direktorin der Kommission, Justitia et Pax' der Österreichischen Bischofskonferenz Ingeborg Gabriel befasst hat, gehört auch der Dialog mit dem Islam. Sie hat dabei sowohl auf nationaler als auch internationaler Ebene zu einer Zeit das Gespräch mit dieser Weltreligion gesucht, als noch nicht im Entferntesten an die Gründung in Wien ansässiger internationaler Organisationen, die diesem Anliegen dienen sollen, gedacht worden ist.

Mittlerweile wurden Wahlkämpfe zum Thema ,Islam' geführt und Wahlen damit gewonnen. Die Frage von Asyl und Integration wurde zur Frage des Schutzes eines wie auch immer verstandenen, christlichen Abendlandes'. Der Islam wurde für manche zum Inbegriff der Bedrohung österreichischer Identität. Muslime werden mit Ausländern gleichgesetzt ${ }^{1}$, die eine fremde Kultur nach Österreich bringen, selbst wenn sie bereits seit vielen Jahren die österreichische Staatsbürgerschaft besitzen.

Dazu kamen Berichte von islamistisch motiviertem Terror im Nahen Osten, der nicht nur zur größten Christenverfolgung seit der Antike geführt hat, sondern auch zu Fluchtbewegungen, die bis in den Norden Europas reichen. Kriegerische, vor allem auch innerislamische Auseinandersetzungen tragen das Ihre dazu bei, dass der Islam von vielen weniger als Religion des Friedens, sondern als Ursache für Instabilität und Tod wahrgenommen wird. Christen und Muslime haben sich so auf den Weg gemacht, um in Europa Aufnahme und Schutz zu finden.

Diese Entwicklungen haben auch die Katholische Kirche in Österreich nicht unberührt gelassen. Die Integration von Asylwerbern ist zwar zuallererst eine

1 Die in diesem Beitrag verwendeten personenbezogenen Bezeichnungen beziehen sich, dort wo es sinnerhaltend möglich ist, unabhängig von der gewählten grammatikalischen Form auf Personen beiderlei Geschlechts. 
soziale Frage, handelt es sich dabei aber um Asylwerber mit islamischem Hintergrund, so erweitert sich die Herausforderung um zentrale Fragen nach der Bedeutung von Religion in der Gesellschaft insgesamt und der rechtlichen Stellung von Religionsgemeinschaften. Die Katholische Kirche sieht sich aufgrund ihres Selbstverständnisses, ihrer Größe, ihrer gesellschaftlichen Bedeutung und aufgrund ihrer Geschichte auch als Anwalt und Fürsprecher der kleineren Religionsgemeinschaften. Da der Islam in Österreich eine gesetzlich anerkannte Religionsgesellschaft ist, haben die rechtlichen Fragen, die ihn betreffen, möglicherweise aber auch Auswirkungen auf die Katholische Kirche, die gemeinsam mit insgesamt 16 weiteren anerkannten Kirchen und Religionsgemeinschaften denselben rechtlichen Status genießt.

Die Behandlung der durch die neue Bedeutung des Islam aufgeworfenen Fragen durch die Katholische Kirche geschieht auf unterschiedlichen Ebenen. Zu allererst findet der Kontakt im täglichen Zusammenleben zwischen Katholiken und Muslimen statt. Wer Tür an Tür und Straße an Straße mit Zuwanderern zusammenlebt, ist gefordert, zumindest implizit dazu Stellung zu beziehen, ob die Zuwanderer mit einem anderen Religionsbekenntnis als Bedrohung empfunden werden, oder ob sie möglicherweise auch Freunde werden können. Versuche von katholischen Gemeinden, Kontakte zu etablieren, sind zahlreich. Ebenfalls beziehen jene Katholiken Position, die aus gläubiger Überzeugung bei der Integration von Asylwerbern aktiv sind.

Auf der Ebene der Kirchenleitung werden die sich stellenden Fragen hingegen auf andere Weise behandelt. Neben dem ständigen Kontakt mit Vertretern des Islam, den der Referatsbischof für den interreligiösen Dialog - derzeit Militärbischof Werner Freistetter - im Auftrag der Österreichischen Bischofskonferenz wahrnimmt und dabei durch eine Kommission für Weltreligionen unterstützt wird, sowie dem Austausch in der informellen Plattform der Kirchen und Religionsgesellschaften, in der vor allem rechtlich relevante Themen behandelt werden, finden abseits der Öffentlichkeit Hintergrundgespräche der Bischöfe, allen voran des Vorsitzenden der Österreichischen Bischofskonferenz, Kardinal Christoph Schönborn, mit Vertretern des Islam und mit politischen Verantwortungsträgern statt. Nicht zuletzt muss in diesem Zusammenhang auch die Kooperation bei der Religionslehrerausbildung an der Kirchlich-Pädagogischen Hochschule Wien-Krems genannt werden, an der neben den katholischen Religionslehrern und Religionslehrern anderer Religionsgemeinschaften auch jene des Islam ausgebildet werden und einige Unterrichtsgegenstände wie Didaktik oder Erziehungswissenschaften für alle Studierenden gemeinsam gelehrt werden.

Die Österreichische Bischofskonferenz nimmt über ihr Generalsekretariat aber auch öffentlich Stellung. Sie nützt dabei eine Möglichkeit, die ihr im Gesetzgebungsverfahren gegeben wird, in dem sie ebenso wie alle anderen ge- 
setzlich anerkannten Kirchen und Religionsgesellschaften zur schriftlichen Stellungnahme zu Begutachtungsentwürfen einzelner Ministerien aufgefordert wird. Zusätzlich veröffentlicht die Bischofskonferenz Pressemitteilungen, die die rechtlichen Stellungnahmen einer breiteren Öffentlichkeit bekannt machen wollen oder Ergebnisse der Beratungen während der Vollversammlungen der Bischofskonferenz zusammenfassen.

In weiterer Folge soll eine Auswahl jener Stellungnahmen und Presseerklärungen vorgestellt werden, die die Bischofskonferenz oder deren Generalsekretariat in den vergangenen fünf Jahren veröffentlicht hat, ${ }^{2}$ und die sich auf gesetzliche Vorhaben dieser Jahre zum Themenkreis ,Islam' beziehen.

\section{Bundesgesetz über die äußeren Rechtsverhältnisse islamischer Religionsgesellschaften - Islamgesetz 2015}

Der Islam ist in Österreich aus historischen Gründen bereits seit 1912 gesetzlich anerkannt. Er genießt damit eine besondere Rechtsstellung, die ihn zu einem Kooperationspartner des Staates werden lässt. Diese Kooperation bezieht sich u. a. auf den Religionsunterricht an staatlichen Schulen oder die Möglichkeit zur Militär-, Kranken- und Gefängnisseelsorge.

Umso bedeutender war das Gesetzesprojekt zur Novellierung des Islamgesetzes, dessen Abschluss sich die Bundesregierung im Jahr 2014 vorgenommen hat. $\mathrm{Zu}$ diesem Zeitpunkt gab es in Österreich zwei gesetzlich anerkannte islamische Religionsgesellschaften, die auf unterschiedlicher gesetzlicher Grundlage anerkannt worden waren: die Islamische Glaubensgemeinschaft in Österreich wurde im Jahr 1979 aufgrund des Islamgesetzes 1912 anerkannt, die Islamisch-Alevitische Religionsgesellschaft ${ }^{3}$ hingegen im Jahr 2013 aufgrund des Anerkennungsgesetzes, das das allgemeine Verfahren zur gesetzlichen Anerkennung jeder Religionsgesellschaft, für die keine eigene gesetzliche Grundlage besteht, regelt. Daneben bestand (und besteht weiterhin) eine staatlich eingetragene Bekenntnisgemeinschaft, die sich dem Islam zuzählt und sich Islamischschiitische Glaubensgemeinschaft nennt.

Die Novelle des Islamgesetzes sollte nun ermöglichen und verlangen, dass alle islamischen Glaubensgemeinschaften unter dem Regime dieser gesetzlichen Grundlage stehen. Das gilt auch für deren jeweilige Anerkennung. Demzufolge dürfen religiöse Bezeichnungen, die einen Bezug zu einer Religionsgesellschaft

2 Die entsprechenden Texte sind entweder über die Website der Österreichischen Bischofskonferenz www.bischofskonferenz.at bzw. www.katholisch.at oder über die Website des österreichischen Parlaments www.parlament.gv.at abrufbar (letzter Zugriff: 12. 08. 2019).

3 Den Zusatz „Islamisch“ hat diese Religionsgesellschaft mittlerweile gestrichen. 
herstellen, wie das insbesondere bei Einrichtungen der Fall war, die bis dahin als zivilrechtliche Vereine organisiert waren, nur mehr mit Genehmigung der Religionsgesellschaft geführt werden. Auf diese Weise wollte man untersagen, dass zivilrechtliche Vereine die Verbreitung einer religiösen Lehre oder die religiöse Betreuung der Anhänger einer anerkannten Religionsgesellschaft zum Vereinszweck erheben. Ein solches Verbot stellte einen nicht zu unterschätzenden Eingriff in die bestehende Praxis dar. Das religiöse Gemeinschaftsleben vieler Muslime wurde nämlich bislang durch solche Vereine getragen. Der Entwurf des neuen Islamgesetzes sah hingegen die Auflösung aller Vereine vor, die nicht bereit waren, ihren Vereinszweck - und dementsprechend auch ihre Tätigkeit an die neue gesetzliche Lage anzupassen und sich entweder auf soziale Zwecke oder die Unterstützung etwa von Bau- und Renovierungstätigkeiten zu beschränken. Dementsprechend wurde vorgesehen, dass Funktionsträger islamischer Religionsgesellschaften, zu denen dann auch die Verantwortlichen von bisher in Vereinen organisierten neu zu errichtenden Kultusgemeinden gehörten, bei strafrechtlicher Verurteilung zu einer Freiheitsstrafe von mehr als einem Jahr oder bei Gefährdung der öffentlichen Sicherheit durch die Religionsgesellschaft abberufen werden müssen.

Verlangt wurde im Gesetzesentwurf ebenfalls, dass jede Glaubensgemeinschaft nach dem neuen Islamgesetz ihre Lehre und ihre Glaubensquellen in deutscher Sprache darlegen muss, sofern dies nicht schon bisher geschehen ist. Damit sollte im Falle des Antrags auf Anerkennung einer neuen Glaubensgemeinschaft die Beurteilung ermöglicht werden, ob sich die Antragstellerin ausreichend von bisher bestehenden Glaubensgemeinschafen unterscheidet. Mit dieser Bestimmung wurde daher verlangt, dass jedenfalls der Koran in einer durch die Glaubensgemeinschaft als authentisch erklärten deutschen Übersetzung vorzulegen ist.

Generell wurde im zu begutachtenden Gesetz festgehalten, dass die Lehre, die Einrichtungen und die Gebräuche islamischer Glaubensgemeinschaften den staatlichen Gesetzen nicht widersprechen dürfen und sich die Religionsgesellschaften durch eine positive Grundeinstellung gegenüber der Gesellschaft und dem Staat auszeichnen sollen. Andernfalls wäre auch die Aberkennung des rechtlichen Status möglich.

Außerdem wurden Regelungen für islamische Friedhöfe und für den Schutz islamischer Feiertage ebenso vorgesehen wie die Einrichtung Islamisch-Theologischer Studien auf universitärem Niveau. Auch die religiöse Betreuung von Angehörigen der Religionsgesellschaft in Krankenhäusern, beim Militär und in Justizanstalten und das Recht auf Berücksichtigung spezieller Speisevorschriften wurden geregelt.

Für besondere öffentliche Aufmerksamkeit hat die Bestimmung gesorgt, die festlegt, dass der laufende Betrieb einer Religionsgesellschaft aus dem Inland 
finanziert werden muss, wobei Personalsubventionen aus dem Ausland - etwa im Fall von Imamen - ebenfalls vom Verbot ausländischer Finanzierung erfasst sind. Einzig die einmalige Zuwendung in Form von Schenkungen oder Erbschaften sollte zulässig sein, sofern die Verwaltung dieses Vermögens im Inland erfolgt.

Die Österreichische Bischofskonferenz wurde wie üblich aufgefordert, zu diesem Ministerialentwurf eine Stellungnahme abzugeben. Sie hat aber entschieden, von einer formellen Stellungnahme abzusehen und sich stattdessen in Form einer Presseerklärung dazu zu äußern. Dieser Presseerklärung ist die Herbstvollversammlung der Österreichischen Bischofskonferenz 2014 vorangegangen, während deren Verlauf es zu persönlichen Begegnungen mit dem zuständigen Bundesminister Josef Ostermayer und dem für Integration zuständigen Bundesminister Sebastian Kurz gekommen ist.

Bemerkenswert ist in dieser Erklärung vom November 2014, dass die Bischöfe den Umstand für erklärungsbedürftig hielten, dass sie keine formale Stellungnahme abgegeben haben. Als Begründung führen sie zunächst an, dass sich bereits andere Institutionen, Gruppen und Einzelpersonen in großer Zahl zum Gesetzesentwurf geäußert haben. Sie berichten aber auch, dass sich einige dieser Institutionen und Personen mit teilweise sehr unterschiedlicher Einschätzung an die Katholische Kirche mit der Bitte gewendet haben, eine formale Stellungnahme abzugeben. Die Bischöfe scheinen damit, ohne dies ausdrücklich auszuführen, sowohl jene zu meinen, denen die Restriktionen im Gesetzesentwurf nicht weit genug gingen, als auch jene, die in der Novellierung eine klare Verletzung des Rechtes auf Religionsfreiheit gesehen haben.

Als weitere Begründung dafür, keine Stellungnahme abzugeben, wird der Umstand angeführt, dass es sich bei diesem Begutachtungsentwurf um ein Gesetz handelt, das eine andere Kirche oder Religionsgesellschaft betrifft und das überdies bei der betreffenden Religionsgesellschaft sowohl auf Zustimmung als auch Ablehnung gestoßen ist. Die Bischofskonferenz plädiert daher dafür, dass sich die Katholische Kirche in Österreich nicht in die Angelegenheiten anderer Kirchen oder Religionsgemeinschaften einmischt, die überdies innerhalb der betroffenen Religionsgemeinschaft kontrovers beurteilt werden.

Daher hält die Bischofskonferenz fest, dass sie entsprechend der bisherigen Gepflogenheit, sich in solchen Fällen, in denen andere Religionsgemeinschaften betroffen sind, sich einer Stellungnahme zu enthalten, auch zur Novelle des Islamgesetzes keine offizielle Stellungnahme abgibt, und ergänzt erläuternd, dass sie somit keinen Einwand erhebt, was wohl als vorsichtige Zustimmung zum vorliegenden Entwurf gedeutet werden könnte. Gleichzeitig hält sie fest, dass sie sich als Anwältin der Religionsfreiheit versteht und beabsichtigt, in religionsrechtlichen Grundsatzfragen sehr wohl Stellungnahmen abzugeben, wie sie dies auch bis dahin getan hat. 
Kann man den erläuternden Zusatz, dass kein Einwand erhoben wird, auch als etwas verhaltene Parteinahme für die Arbeit der staatlichen Organe verstehen, die den Begutachtungsentwurf erarbeitet haben, so richten die Bischöfe gleichzeitig aber auch einen Appell an dieselben staatlichen Stellen. Sie fordern nämlich, dass der Dialog mit allen Gruppen gesucht werden soll, die von der Novelle direkt betroffen sind. Dies entspreche der Überzeugung, dass nur ein breiter und ehrlicher gesellschaftlicher Dialog mit den muslimischen Mitbürgern jenen Respekt aufbauen kann, der in einer pluralen Gesellschaft nötig ist. Auch die Katholische Kirche kündigt an, diesen Dialog ihrerseits intensivieren zu wollen.

Zusammenfassend kann festgehalten werden, dass die Bischofskonferenz in einer delikaten Frage versucht hat, wichtige Grundsätze, wie den Dialog und die Religionsfreiheit, in Erinnerung zu rufen, aber gleichzeitig die Sorge der Bischöfe in der damaligen Situation herauszulesen ist, dass sie von unterschiedlichen Gruppen instrumentalisiert werden könnten. Keine offizielle Stellungnahme abzugeben und sich dennoch nicht völlig zu verschweigen, war der gewählte Weg. Er zeigt, mit welcher Sensibilität die Bischöfe in dieser Situation bestrebt waren, die Klippen, die zahlreich in den Untiefen der betreffenden Materie vorhanden sind, zu umschiffen.

\section{Bundesgesetz über das Verbot der Verhüllung des Gesichts in der Öffentlichkeit - Anti-Gesichtsverhüllungsgesetz 2017}

Im Jahr 2017 hat die Bundesregierung ein Gesetz auf den Weg gebracht, das vor allem die Integration von in Österreich aufhältigen Personen ohne österreichische Staatsbürgerschaft fördern sollte. Dafür seien den Erläuterungen zum Begutachtungsentwurf zufolge gegenseitiger Respekt und gegenseitige Wertschätzung ebenso notwendig wie klare Regeln, die den gesellschaftlichen $\mathrm{Zu}$ sammenhalt und den sozialen Frieden sichern. Man wolle sowohl den Erwerb deutscher Sprachkenntnisse fördern als auch die wirtschaftliche Selbsterhaltungsfähigkeit und die Einhaltung der österreichischen und europäischen Rechts- und Werteordnung. Dazu wurden vor allem Änderungen im Integrationsgesetz vorgeschlagen, das eine Vielzahl von Maßnahmen vorsieht, die u.a. einen Schwerpunkt auf Sprach- und Wertevermittlung legen und dabei von den betroffenen $\mathrm{zu}$ integrierenden Personen eine entsprechende Kooperation verlangen.

In diesem Zusammenhang sollte auch ein weiteres Gesetz beschlossen werden, mit dem verboten werden sollte, dass an öffentlichen Orten oder in öffentlichen Gebäuden ein Mensch seine Gesichtszüge durch Kleidung oder andere 
Gegenstände in einer Weise verhüllt oder verbirgt, dass sie nicht mehr erkennbar sind. Andernfalls drohe eine Verwaltungsstrafe von bis zu € 150,-. Von diesem Verbot sind bloß jene ausgenommen, die ihr Gesicht im Rahmen künstlerischer, kultureller oder traditioneller Veranstaltungen oder im Rahmen der Sportausübung verhüllen bzw. bei denen die Verhüllung gesundheitliche oder berufliche Gründe hat. Das Gesetz zielt damit, ohne dies ausdrücklich zu erwähnen, vor allem auf Kleidungsstücke ab, die Frauen aus vorwiegend muslimisch geprägten Ländern tragen und dabei ihr Gesicht zum Großteil oder vollkommen verhüllen. Es ist deshalb auch als ,Burkaverbot' medial bekannt geworden.

Die Intention hinter dem Anti-Gesichtsverhüllungsgesetz ist es nach Ansicht des dafür zuständigen Integrationsministeriums ebenfalls, Integration zu stärken. Integration ist nämlich dem Gesetz zufolge ein gesamtgesellschaftlicher Prozess, dessen Gelingen von der Mitwirkung aller in Österreich lebenden Menschen abhängt und auf persönlicher Interaktion beruht. Wie in den Erläuterungen zum Gesetzesvorschlag festgehalten wird, soll das Verbot vor allem dazu beitragen, die Teilhabe am gesellschaftlichen Zusammenleben zu sichern. Gleichzeitig verspricht man sich von dieser Vorschrift, dass durch sie das friedliche Zusammenleben von Menschen unterschiedlicher Herkunft und Religion in einer pluralistischen Gesellschaft gestärkt wird.

In seiner Stellungnahme zum Begutachtungsentwurf begrüßt das Generalsekretariat der Österreichischen Bischofskonferenz einerseits, dass in den Erläuterungen zum Gesetz die Kommunikationsbereitschaft als wichtige Voraussetzung für den Integrationsprozess und für ein friedliches Zusammenleben in einem demokratischen Rechtsstaat hervorgehoben wird. Andererseits sieht es aber auch einige schwerwiegende Fragen, die sich durch ein Verbot der betroffenen Kleidungsstücke ergeben.

Allen voran wird in der Stellungnahme darauf hingewiesen, dass ein generelles Verbot von Kleidungsstücken in Widerspruch zu den in der Europäischen Menschenrechtskonvention garantierten Menschenrechten stehen könnte. Um diese rechtlichen Bedenken zu widerlegen, wäre es nämlich notwendig, ausreichend zu begründen, dass die Verhüllung von Gesichtszügen eine Gefahr für die öffentliche Ordnung und Sicherheit darstellt. Dies erscheint dem Generalsekretariat der Österreichischen Bischofskonferenz jedoch nicht ausreichend ausgeführt worden zu sein.

Außerdem gibt das Generalsekretariat der Österreichischen Bischofskonferenz $\mathrm{zu}$ bedenken, dass in einer pluralen, demokratischen Gesellschaft die Verhüllung, insofern sie etwa aus Gründen religiöser Überzeugung oder kultureller Identität erfolgt, auch Ausdruck einer legitimen Vielfalt sein kann. Es wird daher befürchtet, dass ein entsprechendes Verbot das Zusammenleben der unterschiedlichen gesellschaftlichen Gruppen eher erschweren als fördern könnte 
und das wechselseitige Unverständnis zunehmen würde. Dem friedlichen $\mathrm{Zu}$ sammenleben wäre dies daher nicht zuträglich.

Als ebenfalls verfassungsrechtlich bedenklich stuft das Generalsekretariat der Österreichischen Bischofskonferenz den Umstand ein, dass das Verhüllungsverbot auch in öffentlich zugänglichen religiösen Orten und für Handlungen aus religiöser Motivation gelten soll. Es fordert daher entsprechende Ausnahmebestimmungen ein, um den Bereich der inneren Angelegenheiten anerkannter Kirchen und Religionsgesellschaften, der durch Art. 15 Staatsgrundgesetz über die allgemeinen Rechte der Staatsbürger für die im Reichsrathe vertretenen Königreiche und Länder aus dem Jahr 1867 verfassungsrechtlich geschützt ist, nicht zu verletzen.

Grundsätzlich wird festgehalten, dass die Freiheit, die Kleidung frei zu wählen und in der Öffentlichkeit tragen zu können, unabhängig von den für die Kleidungswahl ausschlaggebenden Motiven gewährleistet sein sollte. Dies gelte insbesondere für Frauen, deren Wahlfreiheit vom angestrebten Verbot in besonderem Maß betroffen wäre. Als zulässig wird jedoch der umgekehrte Weg erachtet, der die Einschränkung des Rechts auf freie Bekleidungswahl in bestimmten, konkret zu rechtfertigenden Ausnahmefällen vorsieht, wie dies beispielsweise beim Verbot der Verhüllung der Gesichtszüge bei Demonstrationen der Fall ist. Ein generelles Verbot von Kleidungsstücken in der vorgeschlagenen Form wird daher abgelehnt.

Zusätzlich zur Stellungnahme ihres Generalsekretariats hat die Österreichische Bischofskonferenz in ihrer Frühjahrsvollversammlung 2017 den Gesetzesentwurf ebenfalls beraten und eine Presseerklärung dazu veröffentlicht. Dabei bedauert sie, dass eine thematische Einschränkung der öffentlichen Debatte, die durch die Einführung gesetzlicher Bekleidungsvorschriften entsteht, Gefahr läuft, die eigentlichen Herausforderungen der Integration aus dem Blick zu verlieren.

Zwar betonen die Bischöfe, dass wir in einer Kultur des offenen Gesichts leben, die nicht zuletzt in diesem Punkt auch christlich geprägt ist, und bewerten die Vollverschleierung im öffentlichen Raum daher als ein gesellschaftlich unerwünschtes Verhalten, gleichzeitig regen sie aber an, anstelle eines allgemeinen Verbotes, klar zu regeln und zu begründen, in welchen konkreten Fällen das Gesicht zu zeigen ist. Sie nennen hier als Beispiele die Schule oder den Gerichtssaal.

Abschließend fordern die Bischöfe aber ein, dass niemand aus welchen Gründen auch immer zu einer verhüllenden Bekleidung gezwungen werden darf, insbesondere, wenn sich dieser Zwang nur gegen Frauen richtet. Im Grunde geht es nach Ansicht der Bischöfe in dieser Frage vor allem um das hohe Gut der persönlichen Freiheit. Ihr sei im Zweifelsfall gerade in unserer Gesellschaftsordnung der Vorzug zu geben. 
Zusammenfassend muss festgehalten werden, dass das Anti-Gesichtsverhüllungsgesetz zwar kein Gesetz ist, das den Islam ausdrücklich thematisiert, ihn aber zum Hintergrund hat, da es ausschließlich Frauen mit muslimischer Religionszugehörigkeit sind, die Kleidungsstücke verwenden, die ihr Gesicht verhüllen. Die Österreichische Bischofskonferenz hat sich deshalb besorgt gezeigt, ebenfalls ohne dies ausdrücklich zu thematisieren, dass den Anhängern des Islam eher mit Verboten in einer sehr persönlichen Angelegenheit wie der Kleidung begegnet wird, als deren persönliche Freiheit, vor allem auch jene der Frauen, zu fördern.

\section{Vereinbarung gemäß Art. 15a B-VG zwischen dem Bund und den Ländern über die Elementarpädagogik für die Kindergartenjahre 2018/19 bis 2021/22}

$\mathrm{Zu}$ einem weiteren Bekleidungsverbot, das vor allem Angehörige des Islam betrifft, ohne dies im Gesetzestext so zu benennen, ist es durch den im Jahr 2018 nach Art. 15a B-VG abgeschlossenen Staatsvertrag zwischen dem Bund und den Ländern gekommen. Das Ziel dieser Vereinbarung ist neben der Stärkung elementarer Bildungseinrichtungen in ihrer Rolle als erste Bildungsinstitution im Leben eines Kindes u. a. auch die Verbesserung der Bildungschancen von Kindern unabhängig von ihrer sozioökonomischen Herkunft durch vorschulische Förderung.

Dazu enthält der Vertrag sowohl zahlreiche Maßnahmen - etwa zur sprachlichen Frühförderung von Kindern oder der Vermittlung von Werteorientierung - als auch ein Verbot des Tragens weltanschaulicher oder religiös geprägter Bekleidung, die mit einer Verhüllung des Hauptes verbunden ist. Als Motiv für dieses Verbot benennt der Vertragstext die Sicherstellung der bestmöglichen Entwicklung und Entfaltung aller Kinder. Ein solches Verbot diene der erfolgreichen sozialen Integration von Kindern gemäß den lokalen Gebräuchen und Sitten, der Wahrung der verfassungsrechtlichen Grundwerte und Bildungsziele der Bundesverfassung, sowie der Gleichstellung von Mann und Frau.

Wie die Erläuterungen zum Entwurf der Vereinbarung festhalten, wird nämlich befürchtet, dass das Tragen des islamischen Kopftuches, das hier als einziges Kleidungsstück namentlich angeführt wird, von Kindern in elementaren Bildungseinrichtungen zu einer frühzeitigen geschlechtlichen Segregation führen kann, welche mit den österreichischen Grundwerten und gesellschaftlichen Normen nicht vereinbar ist. Deshalb wird betont, dass die Orientierung an religiösen Werten nicht im Widerspruch zu den Zielen der staatsbürgerlichen 
Erziehung stehen darf, die sich an den Grundwerten des Art. 14 Abs 5a B-VG orientieren soll. Ohne dies in den Erläuterungen ausdrücklich so zu benennen, sollen allerdings andere religiöse Kopfbedeckungen - wie die jüdische Kippa nicht untersagt werden. Daher bezieht sich das Verbot des Tragens weltanschaulicher und religiös geprägter Bekleidung lediglich auf solche Formen, welche das gesamte Haupthaar oder große Teile dessen verhüllen.

Das Generalsekretariat der Österreichischen Bischofskonferenz hat zu diesem Gesetzesentwurf eine Stellungnahme abgegeben. Darin wird das Anliegen geteilt, dass die Integration aller Kinder durch eine entsprechende Förderung in elementaren Bildungseinrichtungen unterstützt wird. So wird auch betont, dass die Inklusion, die als Voraussetzung für das Funktionieren einer pluralen, den Grund- und Menschenrechten verpflichteten Gesellschaft angesehen werden kann, durch Vielfalt - sei sie religiöser oder anderer Natur - nicht gefährdet wird, sondern vielmehr sogar auf dieser beruht. Es wird daher begrüßt, wenn der potentiellen Gefahr eines bereits im Kindesalter einsetzenden Segregationsprozesses wirksam begegnet wird. Dass das Tragen eines Kopftuches in elementaren Bildungseinrichtungen die Integration von Mädchen erschweren kann, ist eine Sorge, die das Generalsekretariat der Österreichischen Bischofskonferenz teilt.

Gleichzeitig werden in der Stellungnahme in Frageform einige Bedenken geäußert. Zunächst wird unter dem Hinweis, dass gesetzliche Regelungen nur dann erlassen werden sollten, wenn auch tatsächlicher Regelungsbedarf besteht, die Frage gestellt, ob die Maßnahme einem tatsächlichen, in signifikantem Ausmaß auftretenden Problem begegnet. Die Erläuterungen zum Vertragsentwurf haben eine solche Erhebung nicht erkennen lassen.

Weiters wird daran erinnert, dass das Verbot religiöser Kleidung einen Eingriff in das Recht auf Religionsfreiheit ebenso darstellt wie einen Eingriff in das Recht auf Achtung des Privat- und Familienlebens sowie in das Erziehungsrecht der Eltern. Ein solcher Eingriff kann aber zulässig sein, wenn legitime Gründe dafür vorliegen. Dazu zählt die Notwendigkeit, mit einer solchen Regelung die öffentliche Sicherheit, die öffentliche Ordnung, Gesundheit und Moral oder die Rechte und Freiheiten Anderer zu schützen. Deshalb fragt das Generalsekretariat der Österreichischen Bischofskonferenz, ob diese Gründe ausreichend vorliegen und dargelegt worden sind. Die in den Erläuterungen genannten Ziele, wie die Vermeidung einer frühzeitigen geschlechtlichen Segregation, die Verhinderung eines Widerspruchs zu den Zielen der staatsbürgerlichen Erziehung oder die

4 „Demokratie, Humanität, Solidarität, Friede und Gerechtigkeit sowie Offenheit und Toleranz gegenüber den Menschen sind Grundwerte der Schule, auf deren Grundlage sie der gesamten Bevölkerung, unabhängig von Herkunft, sozialer Lage und finanziellem Hintergrund, unter steter Sicherung und Weiterentwicklung bestmöglicher Qualität ein höchstmögliches Bildungsniveau sichert." 
Förderung der Gleichstellung von Mann und Frau lassen dem Generalsekretariat zufolge noch zu viele Fragen offen, um von der Legitimität des Grundrechtseingriffs überzeugt sein zu können.

Außerdem wird in der Stellungnahme die Frage gestellt, ob die geplante Regelung überhaupt eine geeignete Maßnahme darstellt, um das angestrebte Ziel zu erreichen. Es wird nämlich der Sorge Ausdruck verliehen, dass das geplante Verbot aufgrund der Einschränkung der individuellen Grundrechte möglicherweise die Integration gerade jener Familien erschwert oder gar unterbindet, deren Integration das erklärte Ziel der Regierung ist. Unter diesem Aspekt sollte der Einwand bewertet werden, ob nicht Aufklärung, pädagogische Begleitung und Unterstützung zielführender wären als ein Verbot, gegen dessen Verstoß auch Sanktionen angedroht werden.

Schließlich wird gefragt, ob durch die staatlichen Stellen das Einvernehmen mit den betroffenen Kirchen und Religionsgesellschaften gesucht worden ist. Immerhin, so wird festgehalten, ist Österreich ein religionsfreundlicher Staat, in dem Kirchen und Religionsgesellschaften zwar im Verhältnis zum Staat eigenständig sind, mit diesem aber in jenen Bereichen kooperieren, die für beide Seiten von Bedeutung sind. Deshalb hält es das Generalsekretariat der Österreichischen Bischofskonferenz für angebracht, in solchen grundrechtssensiblen Fragen das Einvernehmen zumindest mit den betroffenen gesetzlich anerkannten Kirchen und Religionsgesellschaften zu suchen.

Wenige Monate nach der entsprechenden Regelung für Kinder in elementaren Bildungseinrichtungen wurde durch einen parlamentarischen Initiativantrag eine Änderung des Schulunterrichtsgesetzes angeregt, die ein der Vorschrift für Kinder in elementaren Bildungseinrichtungen gleichlautendes Bekleidungsverbot für Schülerinnen (und Schüler) bis zum Ende jenes Schuljahrs vorsieht, in welchem die Betreffenden das zehnte Lebensjahr vollenden.

Das Generalsekretariat der Österreichischen Bischofskonferenz hat auch in diesem Fall eine Stellungnahme abgegeben, die neben einigen spezifischen Modifikationen in Bezug auf die Begründung des neuen Gesetzesvorschlags dieselben Fragen wie im Bereich der elementaren Bildungseinrichtungen wiederholt.

In dieser Stellungnahme fasst das Generalsekretariat der Österreichischen Bischofskonferenz aber seinen Zugang zu dieser Art von Bekleidungsverboten zusammen und hält fest, dass es nicht wünschenswert ist, wenn Kinder ein Kopftuch tragen müssen. Es sei aber ebenso wenig wünschenswert, dies gesetzlich zu verbieten. Vielmehr empfiehlt sich das Gespräch mit den Eltern und Obsorgeberechtigten.

Zusammenfassend ist im Fall des Kopftuchverbots die Art und Weise, wie das Generalsekretariat der Österreichischen Bischofskonferenz seine Stellungnahmen gestaltet hat, bemerkenswert. Es werden keine Feststellungen getroffen, 
sondern Fragen formuliert. Offensichtlich wurde auf diese Weise versucht, der Normierung eines Kopftuchverbotes nicht grundsätzlich zu widersprechen. Gleichzeitig wollte man aber darauf hinweisen, dass eine eingehende Klärung der für die Beurteilung notwendigen Sach- und Rechtsfragen bis dahin noch ausgestanden ist. Da es sich hierbei aber jedenfalls um grundrechtssensible Regelungen handelt, hat das Generalsekretariat der Österreichischen Bischofskonferenz davon abgeraten, solche Verbote zu erlassen, sofern deren sachliche und rechtliche Legitimität nicht eindeutig feststehen.

\section{Einordnung}

Im Juni 2018 haben Vertreter der Katholischen und der Evangelischen Kirche ${ }^{5}$, der Israelitischen Religionsgesellschaft ${ }^{6}$ und der Islamischen Glaubensgemeinschaft in Österreich ${ }^{7}$ aus Anlass des Weltflüchtlingstages eine gemeinsame Erklärung veröffentlicht. Darin nehmen sie auf die Fluchtbewegungen und die Aufnahme von Asylwerbern im Jahr 2015 in Österreich Bezug. Das sich seither verändernde politische Klima in Österreich haben diese Religionsvertreter zum Anlass genommen, auf die Bedeutung der Achtung der Menschenwürde, sowie der Freiheit, Demokratie, Gleichheit und Rechtsstaatlichkeit hinzuweisen. Insbesondere wird die Religionsfreiheit als wesentlicher Faktor für den Frieden hervorgehoben. Sie sei es nämlich, die erst den Dialog der Kulturen, die wechselseitige Integration und das Hervorbringen von Neuem im gesellschaftlichen Miteinander ermöglicht. Die Achtung voreinander und die Wertschätzung der jeweils eigenen Identität wird als grundlegend für die interreligiöse Begegnung erachtet.

In diesem Sinne lassen sich auch die Stellungnahmen der Österreichischen Bischofskonferenz und ihres Generalsekretariats als klares Bekenntnis zur Wahrung dieser Grundrechte lesen und in das religionsübergreifende Anliegen, der Religionsfreiheit zentrale Bedeutung beizumessen, einordnen. Dahinter steht offenbar die Annahme, dass auch jene, die in Kulturen aufgewachsen sind, in denen eine entsprechende wechselseitige Achtung nicht geübt wird, zu Trägern des gewünschten Dialogs werden, wenn sie ihn selber als wertschätzend erfahren haben.

Die Ordinaria für Sozialethik an der Universität Wien hat dafür wertvolle Beiträge geleistet, die die Mühen der Ebenen nicht gescheut haben. Die Österreichische Bischofskonferenz hat versucht, mit Ihren Stellungnahmen das Ihre

5 Kardinal Christoph Schönborn und Bischof Michael Bünker.

6 Rabbiner Schlomo Hofmeister.

7 Präsident Ibrahim Olgun. 
dazu zu tun, dass die wissenschaftlichen und menschlichen Bemühungen, an denen Ingeborg Gabriel dankenswerterweise mit großem Einsatz beteiligt war, zumindest indirekt unterstützt werden. 
Open-Access-Publikation im Sinne der CC-Lizenz BY 4.0

(C) 2020, Vandenhoeck \& Ruprecht $\mathrm{GmbH} \&$ Co. KG, Göttingen ISBN Print: 9783847111658 - ISBN E-Lib: 9783737011655 


\section{Kollektive Ethik und individuelle Ethik: Reflexionen anhand der Exodus-Erzählung}

Zuweilen wird als islamische Behandlung eines Themas nur bezeichnet, wenn der Bezugsrahmen ein oder mehrere koranische Texte ist und allenfalls noch Texte aus der Hadith-Literatur, der Überlieferungen über das Tun und die Aussagen des Propheten Muhammad, einbezogen werden. ${ }^{1}$

Dieser Beitrag stellt sich einer doppelten Herausforderung: Eine Bestimmung des Verhältnisses von Exodus und Hidschra und eine Situierung des Themenfeldes in einer religionswissenschaftlichen Perspektive, die eben nicht theologisch ist. $^{2}$

Beginnen wir mit der zweiten Herausforderung! Diese wirft zwei Fragen auf: Wie können wir ein religiös so vielfach überdeterminiertes Thema wie den Exodus und die Hidschra behandeln, ohne in theologische Kategorien zu verfallen? Warum ist dies ein Problem?

Zum einen entwickelt sich üblicherweise diese Herausforderung aus der Behandlung des Themas aus einer abrahamitischen Perspektive, die zu einem direkten Vergleich zwischen jüdischen, christlichen und islamischen Auffassungen einlädt. Wie kann sich eine andere Perspektive entfalten, die sich nicht in die abrahamitische Perspektive einordnet? Historisch können wir dies versuchen, wenn wir uns an Angelika Neuwirths Idee einer Betrachtung des Korans im Kontext der Spätantike anschließen. Damit wechseln wir auf die Ebene einer (religions-)geschichtlichen Betrachtung, die auch christliche und jüdische Aspekte einschließt, ohne diese aber zu determinierenden Faktoren unseres Themas zu machen. Also: ein Wechsel auf eine historische Betrachtung spätantiken Denkens selber. Beziehen wir nun ein, dass weite Teile der islamischen Geis-

1 Für die Gelegenheit, mich dem Thema Exodus zuzuwenden und darüber zu reflektieren, habe ich den Veranstaltern und Veranstalterinnen der Maimonides Lectures 2018 zu danken.

2 Dass eine theologische Beschäftigung mit diesem angenommenen Ereignis durchaus fruchtbar sein kann, zeigt Peter Zeilinger, Repräsentation einer Leerstelle, oder: Auszug ins Reale. Zur politischen Bedeutung des biblischen Exodus, der historisch nicht stattgefunden hat, in: Interdisciplinary Journal for Religion and Transformation in Contemporary Society 4ii/2018, S. $212-282$. 
tesgeschichte nicht dadurch bestimmt sind, dass nur und einzig auf den Koran referiert wird, vielmehr ein Kon-Text determinierend ist, der sich in einem vielfältigen Verknüpfungsprozess, in einem höchst dynamischen Rhizom zwar mit dem Koran verknüpft, aber nicht durch ihn determiniert wird, können wir einen Schritt weitergehen. Damit schließe ich u.a. an Shahab Ahmeds bahnbrechendes Werk What is Islam ? an. ${ }^{3}$ Also : ein Wechsel von der Gründungsebene auf die der historischen Entfaltung einer religiösen Tradition in ihrer vielfältigen, dynamischen und durchaus auch widersprüchlichen Geschichte.

Damit haben wir den Bezugsrahmen einer eher theologisch geneigten Diskussion verlassen, die sicherlich der Bezugnahme auf den Gründungstext bedarf - was durchaus legitim ist -, und auch den abrahamitischen Kontext verlässt, da sie auch diesbezüglich der Gründungstexte nicht (mehr) bedarf.

\section{Zum Kontext (und zum Kon-Text)}

Um den Kontext der koranischen Exoduserzählung zu verstehen, sei für den Moment Zeilinger gefolgt:

„Ich spreche hier bei der islamischen Mose-Rezeption von einer motivlichen Entsprechung (Angelika Neuwirth würde in dem Zusammenhang wohl spezifischer von einem typologischen Aufgreifen sprechen), da die Entstehung der koranischen Botschaft in der altarabischen Kultur zu einer Zeit erfolgte, in der die arabische Schrift noch nicht voll entwickelt war. Aus diesem Grund gab es auch keine schriftliche arabische narrative Literatur und somit auch keine arabischen Übersetzungen der biblischen Texte. Dennoch spielten die biblischen Überlieferungen der jüdischen wie christlichen Kultur der Spätantike - der Hebräischen Bibel, der Botschaft der christlichen Evangelien sowie der nach- wie auch außerbiblischen Fortschreibungen im jüdischen und der sowohl jüdischen wie christlichen apokryphen Literatur - in und für die Entfaltung der koranischen Botschaft eine Rolle. Insbesondere die Mose-Figur und das Exodus-Motiv werden (unabhängig von den konkreten historischen Bezügen, auf die die spätantike Kultur keine historisch-reflektierten Zugriff hatte, sondern auf die Erzählungen und ihre Tradierung angewiesen war) aufgegriffen und in die koranische Botschaft integriert. “4

Dies mag an dieser Stelle für die Nachzeichnung der Linien genügen, die sich aus der spätantiken Situation in die koranische schlagen.

3 Ahmed Shahab, What is Islam? The Importance of Being Islamic, Princeton-Oxford 2016.

4 Zeilinger, Repräsentation, S. 231 Fn.34 gestützt auf Angelika Neuwirth, Die koranische Verzauberung der Welt und ihre Entzauberung in der Geschichte, Freiburg i. Br. 2017 und Angelika Neuwirth, Der Koran als Text der Spätantike: Ein europäischer Zugang, Berlin 2010 sowie Karl-Josef Kuschel, Die Bibel im Koran: Grundlagen für das interreligiöse Gespräch, Ostfildern 2017. 


\section{Erste Herausforderung}

Wechseln wir jetzt zu der ersten Herausforderung! Wie können wir das Verhältnis von Exodus und Hidschra verstehen? Eine Randbemerkung mag uns den Forschungsstand illustrieren. In der international renommierten „Encyclopedia of the Qur'an" finden wir keinen Eintrag zum Exodus, aber natürlich reichlich zur Hidschra. Die „Encyclopaedia of Islam“, kurz EI, zeigt einen ähnlichen Befund. Sicherlich gibt es mehr Fundstellen zu Mūsā (Moses), aber das Fehlen eines spezifischen Beitrags ist signifikant. Islamwissenschaftlich scheint der Exodus kein Thema zu sein. Die Gründe oder Vermutungen darüber können an dieser Stelle nicht angestellt werden.

Zuallererst sollten wir uns trotz der Bemerkung zur zweiten Herausforderung den koranischen Textbestand vergegenwärtigen! Für unsere Diskussion ist es durchaus sinnvoll, einen Überblick über diesen Bestand zu geben. Natürlich kann an dieser Stelle kein Überblick über die Inkorporierung christlicher und jüdischer Geschichten in den Koran gegeben werden. Was aber festgehalten sei, ist, dass sich koranisch eine Vielzahl von Referenzen auf in der Spätantike kursierende Vorstellungen unterschiedlicher Provenienz finden lassen, soweit sie auf der Arabischen Halbinsel präsent waren.

Wir wollen dies kurzfassen! In Sure 28:2 bis 28:32 wird die Exoduserzählung im Detail wiedergegeben, in Sure 10:88-89 findet sich ein Gebet von Moses um Rechtleitung des Volkes Israel durch Druck (vorher wird einiges aus dem Leben Mose am Hofe Pharaos erzählt), 7:103-138 erzählen die Geschichte der Auseinandersetzung vor Pharao und die Vertreibung des israelitischen Volkes, 44 (al-duhān ):30-33 erinnern noch einmal an die Rettung des israelitischen Volkes aus der Unterdrückung.

Dies ist der koranische Textbestand, auf den sich die hier behandelten Diskussionen beziehen. Wie ist dieser Bestand nun durchgearbeitet worden?

Wenden wir uns zunächst einem umfangreichen Korankommentar zu. Unser Beispiel ist der Korankommentar Gharāìb al-Qur'ān von Nizām ad-dīn anNaisabūrī (gest. 1330 n. Chr.) ${ }^{5}$, Korankommentator, Sufi und naturphilosophischer Autor mit u. a. bedenkenswerten Gedanken zur Astronomie ${ }^{6}$, der zu seiner Zeit einer der bedeutendsten Gelehrten in Zentralasien war. ${ }^{7}$

$5 \mathrm{Zu}$ ihm vgl. Robert G. Morrison, Islam and Science, The Intellectual Career of Nizām al-Dīn alNisabūrī, London-New York 2010. Der Kommentar von an-Naisabūrī wird selten in der Forschung herangezogen (als Ausnahme vgl. Rüdiger Lohlker, Islam und Gewalt, Gewalt und Islam? Einige Überlegungen, in: Zekerija Sejdini (Hg.), Islam in Europa: Begegnungen, Konflikte und Lösungen, Münster-New York 2018, S. 111-125 und Rüdiger Lohlker, Djihad ein multidimensionaler Begriff unter besonderer Berücksichtigung der spirituellen Dimension, in: Spektrum Iran 1/2016, S. 27-40.

6 Vgl. Morrison, Islam and Science. 
In Sure 10, yūnus, Jonah, finden wir nach Vorläufergeschichten über Mūsā (Moses) in Vers 88f. die uns interessierenden Ausführungen:

„Und Mūsā sagte: ,Unser Herr, Du hast ja Fir'aun und seiner führenden Schar im diesseitigen Leben Pracht und Besitz gegeben, unser Herr, damit sie (andere) von Deinem Weg in die Irre führen. Unser Herr, lösche ihren Besitz aus und schnüre ihre Herzen fest, so daß sie nicht glauben, bis sie die schmerzhafte Strafe sehen!' (88)

und Er sagte: ,Eure beider Anrufung ist erhört. So verhaltet euch recht und folgt ja nicht dem Weg derjenigen, die nicht Bescheid wissen. ““

Im Kommentar (3:601ff.) finden wir im Wesentlichen eine erläuternde Exegese, die nur beim Punkt der Bitte um eine bewusste Irreführung des Volkes Israel einige Diskussionen referiert, die zu einer Auslegung gelangt, die gegen eine solche sich wendet. Hier - wie auch an anderen Stellen - greift an-Naisabūrī offenkundig auf ar-Rāzī (s.u.) zurück.

Systematisch spielt hier der Verweis auf das grundsätzliche Wohlwollen Gottes eine Rolle.

Gehen wir nun zu Sure 28, al-qiṣaș, die Geschichten, Vers 2ff.! Der Kommentar (5:326ff.) bietet hauptsächlich direkte Erläuterungen, lediglich die Bedrückung Moses' und seines Volkes wird genauer geschildert. Damit fügt sich diese Kommentierung systematisch ein in die Erzählung der Prüfung, Bedrückung und Erlösung.

Die relativ geringe Ausformung einer genaueren Exegese ist besonders augenfällig - besonders im Vergleich zur Kommentierung al-Naisabūrīs bei anderen Themen. Also auch hier nimmt die Exoduserzählung einen relativ geringen Rang ein.

In Sure 44, al-duhān, der Rauch, lesen wir Vers $30 \mathrm{ff}$. :

„Und Wir erretteten bereits die Kinder Isrāīls von der schmachvollen Qual! von Fircaun. Er war überheblich und einer der Maßlosen. Und Wir erwählten sie ja mit Wissen vor den (anderen) Weltenbewohnern und ließen ihnen von den Zeichen solche zukommen, die eine deutliche Prüfung enthielten."

Der Kommentar (6:100ff.) enthält nur wenige Erläuterungen, was auf die geringe Bedeutung dieses Narrativs verweist und keinen großen systematischen Ertrag bringt.

Wenden wir uns nun dem „Großen Korankommentar“, dem tafsīr al-kabìr, des Faḩr al-dīn ar-Rāzī (gest. 1209 n. Chr.) zư ${ }^{8}$, der nicht nur - dem Namen

7 Die folgenden Passagen werden zitiert nach Niz̄ām ad-Dīn al-Ḥasan b. Muhammad an-Naisabūrī, Tafsīr gharāỉb al-Qurān wa-ricāyat al-furqān, Ed. 'Umayrat, Zakarīja, Beirut 1996.

8 Zur Biographie vgl. kurz Feras Hamza u. a. (Hg.), An Anthology of Islamic Commentaries, Vol 1: On the Nature of the Divine, Oxford et a. 2010, S. 37-38; ansonsten Tony Street, Concerning the Life and Works of al-Dīn al-Rāzī, in: Peter G. Riddel / Tony Street (Hg.), Islam: Essays on Scripture, Thought and Society, Leiden 1997, S. 135-146 mit einem Fokus auf sein Testament 
gemäß - recht umfangreich ist, sondern auch eine Auslegung ist, die direkt in die islamische Frühmoderne führt. Ar-Rāzī, der ebenfalls im weitesten Sinn im zentralasiatischen Raum zu situieren ist, war nicht nur Korankommentar, auch Rechts- und Sprachgelehrter, Theologe, Logiker, sondern auch einer der wichtigsten Vertreter der nachklassischen islamischen Philosophie ${ }^{9}$ u. v. a. m. ${ }^{10}$

In Sure 10, yūnus, Jonah, ${ }^{11}$ finden wir nach Vorläufergeschichten über Mūsā (Moses) in Vers 88f. die uns interessierenden Ausführungen:

„Und Mūsā sagte: ,Unser Herr, Du hast ja Fir'aun und seiner führenden Schar im diesseitigen Leben Pracht und Besitz gegeben, unser Herr, damit sie (andere) von Deinem Weg in die Irre führen. Unser Herr, lösche ihren Besitz aus und schnüre ihre Herzen fest, so daß sie nicht glauben, bis sie die schmerzhafte Strafe sehen!' (88)

und Er sagte: ,Eure beider Anrufung ist erhört. So verhaltet euch recht und folgt ja nicht dem Weg derjenigen, die nicht Bescheid wissen.““

Der Kommentar (17:155ff.) behandelt zuerst allgemeine Fragen. Das führt aber dann zur exegetischen Diskussion, ob hier tatsächlich gemeint sein könne, dass Gott ja laut Text gebeten werde, dem Volke Israels Böses zu tun. Einer der Exegeten wird zitiert (17:155 unten): „Es ist nicht zulässig (lā yaǧūz), dass mit diesem Vers gemeint ist, was ihr erwähnt habt.“ Also eine negative Handlung Gottes gegen Gläubige.

Ar-Rāzī argumentiert aus sprachlichen Gründen, eine solche Bedrückung könne nicht gemeint sein, was er auch an vielen Stellen in seinem Kommentar erläutert habe (17:157). Dies führt er folgend in detaillierter Auseinandersetzung mit widerstreitenden Auffassungen aus.

Für den Folgevers ergibt sich, dass hier eher eine erläuternde Auslegung erfolgt.

Betrachten wir nun die beiden Verse in systematischer Hinsicht, stellen wir fest, dass zwar die Läuterung durch Strafe erwähnt wird, aber die Wohltat Gottes im Vordergrund steht. Insgesamt zeigt sich, dass die Exoduserzählung keine überragende Rolle spielt.

Eine zeitgenössische Anmerkung: Diese überragende positive Haltung, die Gott dem Volke Israels gegenüber zugeschrieben wird, erfordert eine Neurefle-

und Frank Griffel, On Fakhr al-Dīn al-Rāzī’s Life and the Patronage he received, in: Journal of Islamic Studies 18/2007, S. 313-344.

9 Sehr klar formuliert hat diese Positionierung Frank Griffel, Den Islam denken: Versuch eine Religion zu verstehen, 2. Aufl., Ditzingen 2018, S. 48-59

10 Vgl. besonders Ayman Shihadeh, The Teleological Ethics of Fakhr al- Dīn al-Rāzī, LeidenBoston 2006. Für sein Nachwirken vgl. u.a. Thomas Würtz, Islamische Theologie im 14. Jahrhundert. Auferstehungslehre, Handlungstheorie und Schöpfungsvorstellungen im Werk von Sa'd al-Dīn at-Taftāzānī, Berlin-Boston 2016.

11 Zitiert nach Faḩr ad-Dīn Muhammad b. 'Umar ar-Rāzī, at-Tafsīr al-kabīr, 3. Aufl., Kairo 1980. 
xion vorschneller Zuschreibungen eines dominierenden Antisemitismus an den Koran.

Gehen wir nun zu Sure 28, al-qiṣaș, die Geschichten! Und zwar Vers $2 \mathrm{ff}$; angesichts der Länge der Passage verzichten wir hier auf eine Wiedergabe des Textes.

Auch finden wir in hohem Maße deskriptive Kommentierungen, die ergänzt werden durch die Darstellung divergierender Auffassungen mit entsprechender Auflösung durch ar-Rāzī. Wiederum finden sich die Erzählungen über Prüfung und Erlösung sowohl von Moses (Mūsā) als auch seines Volkes.

Gehen wir zur Sure 44, al-duhān, der Rauch, Vers 30 ff.:

„Und Wir erretteten bereits die Kinder Isrāīls von der schmachvollen Qual! von Fir'aun. Er war überheblich und einer der Maßlosen. Und Wir erwählten sie ja mit Wissen vor den (anderen) Weltenbewohnern und ließen ihnen von den Zeichen solche zukommen, die eine deutliche Prüfung enthielten."

Dort heißt es im Kommentar (27:249f.), der allgemeine Maßstab, der hier zur Anwendung komme, sei die Abwendung des Schadens (darar) vom Volk der Israeliten. Es gehe um die Art und Weise des Erweises von „Wohlwollen (iḥsān) gegenüber Mūsā (Moses) und seinem Volk.“ Das Übel, das von Pharao zugefügt wird, wird näher qualifiziert. Es werden verschiedene Lesarten und andere Kommentare angeführt, die für uns ohne Belang sind. Es geht dann auch um Fragen, ob Pharao mit der schmachvollen Qual gleichzusetzen sei, was auch die Vernichtung seiner Person impliziert. Die folgenden Verse werden auch eher deskriptiv und erklärend kommentiert.

Systematisch betrachtet, geht es hier um die Prüfung durch Strafe und Erlösung. Es wird deutlich, dass die Kommentierung eher deskriptiv und erklärend ist ohne weitere Ausführung, was den nicht übermäßigen Stellenwert bei ar-Rāzī verdeutlicht, allerdings seinem generellen Stil entspricht.

Für unsere Diskussion bedeutsam ist, dass sowohl dem Propheten Musa als auch dem Volke Israels eine ähnliche Geschichte von Prüfung und Erlösung widerfährt. Dies macht Moses späterhin zu einer Vorbildgestalt für den Propheten Muhammad.

Folgen wir noch einem dritten Weg, werden wir eine weitere Weise erkennen, in der die Exoduserzählung islamisch verarbeitet wurde! Es geht um die Abhandlung fusūṣ al-hikam, deutsch zu übersetzen als Ringsteine der göttlichen Weisheit, die Neuauflage dieser Übersetzung wird gerade in Wien und Innsbruck vorbereitet. ${ }^{12}$ Diese Abhandlung wurde verfasst von Ibn al-'Arabī (gest. 1240 n. Chr.), einem der bedeutendsten islamischen Sufis ${ }^{13}$, und handelt über die

12 Für die ältere Ausgabe vgl. Hans Kofler (Übers.), Das Buch der Siegelringsteine der Weisheitssprüche. Fuṣūṣ al-Ḥikam, Graz 1970 nach der hier zitiert wird.

13 Für viele vgl. William C. Chittick, Ibn 'Arabi: Heir to the Prophets, London 2005. 
verschiedenen Propheten, die islamisch bedeutsam sind. Einer davon ist Moses (Mūsā), und damit sind wir beim Exodus wiederum.

Zuerst sei aber die Erzählung über Aaron ${ }^{14}$ betrachtet:

„Der Umstand, daß Aaron die Kraft fehlte, sich durch aktives Eingreifen bei den Verehrern des Kalbes durchzusetzen, indem er sich des Kalbes bemächtigt hätte, wie das Moses tat, ist ein Zeichen von Gottes Weisheit, die sich in dem realen Sein der Außenwelt offenbart, damit er in jeder Erscheinungsform angebetet werde, auch wenn diese (147) äußere Erscheinungsform später verschwindet; sie verschwindet aber erst, nachdem sie in der Vorstellung dessen, der sie anbetet, sich mit der Göttlichkeit (ulūhijja) umkleidet hat. “15

S. 147: „Ferner sieht Gott, daß die Gegenstände der Anbetung unter den Anbetern von verschiedener Art sind und daß jeder, der irgendein Ding anbetet, jeden anderen, der etwas anderes anbetet, für einen Ungläubigen hält und daß der Anbeter, der es an Aufmerksamkeit fehlen läßt, darüber erstaunt ist, daß die Begierde eine einheitliche oder vielmehr eine wesenhaft einzige Erscheinung ist; denn sie ist tatsächlich eine einzige Wesenheit in allen Anbetern; aus diesen Gründen führt Gott den Anbeter irre (adalla), d.h. Er versetzt ihn in ver-(148)legenes Staunen, weil er weiß, daß jeder nur seine Begierde anbetet, und zwingt ihn nicht, etwas anderes als seine Begierde anzubeten, gleichgültig ob diese Begierde mit dem Religionsgesetz übereinstimmt oder nicht. Der vollendete Gnostiker aber ist der, der leibhaftig sieht, daß jedes Objekt der Anbetung eine Erscheinungsform Gottes ist; in der Gott selbst angebetet wird. ${ }^{\text {"16 }}$

Wenden wir uns nun der Erzählung über Moses (S. 150ff.) zu:

In diesem Kapitel geht es hauptsächlich um die Prüfungen, die Moses erdulden musste, bzw. um Dinge, die ihm widerfahren sind, und deren Interpretation. Der Prüfungscharakter kann hier immer wieder bezweifelt werden. So heißt es mit Bezug auf dem Tod des Pharao „Und tatsächlich geschah es so, wie es seiner Überzeugung entsprach, aber in einer anderen äußeren Form, als er es wollte. Gott rettete ihn nämlich von der Strafe im Jenseits an seiner Seele; Gott rettete aber auch seinen Körper “17 indem er ihn als Toten erscheinen ließ und nicht einfach fortnahm, was ihn als in den Himmel entrückt erscheinen hätte lassen.

Es entfällt also hier der Exodus als Erlösungsgeschichte, da die Prüfung gar nicht im oberflächlichen Sinne aufscheint und damit der Prüfungs-Erlösungszyklus durchbrochen wird. Die Prüfung ist, wenn sie genannt wird, eine individuelle, keine kollektive im Sinne des Exodus des Volkes Israels. Die Prüfung widerfährt den einzelnen Propheten und wird dadurch lesbar für spätere Generationen.

14 Vgl. Kofler, Das Buch, S. 144-149.

15 Kofler, Das Buch, S. 146-147. Die Umschrift folgt dem zitierten Text.

16 Kofler, Das Buch, S. 147.

17 Kofler, Das Buch, S. 164. 
Wir haben jetzt einige Dinge über den Exodus gehört. Aber ist er so bedeutsam in islamischen Kontexten wie er beispielsweise für das Judentum ist? Die Antwort auf diese Frage ist so einfach, dass ich mir sie erspare ...

Eine andere Art Auszug ist islamisch bei weitem wichtiger, die des Propheten Muhammad von Mekka nach Medina: die Hidschra. ${ }^{18}$

Es sei ein Zitat gegeben, das uns auf einige Aspekte verweist, die für unsere Überlegungen bedeutsam sind und noch einmal auf die Verknüpfung mit vorislamischen Propheten deutet, die auch für die Exoduserzählung bedeutsam sind. ${ }^{19}$

„Abraham erscheint dem Muslim auch deshalb besonders verehrungswürdig, weil seine Lebensschicksale vielfach denen Muhammads ähnlich sind. Im Magallat Al Azhar [...] wird diese Tatsache ausführlich behandelt.

Zunächst stellt der Verfasser fest, daß beide, Abraham und Muhammed in ihrem ihre ,Higra' haben, d.h. daß sie von ihrem ursprünglichen Aufenthaltsort weg in eine andere Gegend gezogen sind, um dort als Propheten die göttlichen Aufträge zu vollziehen: Abraham wandert (hagara) mit Hagar, der Stammutter der Araber, und mit seinem Sohn Ismael, dem Sohn der Hagar, nach Arabien ähnlich wie Muhammed von Mekka nach Medina zog. Das war jene Auswanderung Muhammeds, die so unendliche reiche Früchte zeitigte. “20

Die Pflicht zur Hidschra ${ }^{21}$ wird durch die Jahrhunderte immer wieder reaktualisiert und wird auch für unser Thema bedeutsam.

Wird die Hidschra rein als kollektiver Akt verstanden, der die individuelle Erlösung in der kollektiven aufgehen lässt, wird die emanzipatorische Perspektive, die in der oben beschriebenen islamischen Literatur aus der nachklassischen Zeit sichtbar wurde, verdeckt. Hidschra wird zum hauptsächlich kollektiv gedachten - manchmal auch individuell vollzogenen - Akt der Entfernung aus der Gesellschaft und nicht der Emanzipation in der Gesellschaft. Einige Beispiele seien genannt: die Hidschra der Tataren von der Krim in das Osmanische Reich im 19. Jahrhundert ${ }^{22}$, die innere Hidschra von Salafisten in

18 Der Begriff der Hidschra wird hier als eingedeutscht betrachtet.

19 In etwas veralteter Terminologie sicherlich.

20 Hermann Stieglecker, Die Glaubenslehren des Islam, 2.Aufl., Paderborn et al. 1983, S. 203-204. Die Umschrift des zitierten Werkes wird übernommen.

21 Muhammad Khalid Masud, The obligation to migrate: the doctrine of hijra in Islamic law, in: Dale F. Eickelman / James Piscatori (Hg.), Muslim Travellers: Pilgrimage, Migration, and the Religious Imagination: Comparative Studies in Muslim Societies, Berkeley-Los Angeles 1990, S. 29-49.

22 Brian Glyn Williams, Hijra and forced migration from nineteenth-century Russia to the Ottoman Empire: A Critical Analysis of the Great Tatar Emigration of 1860-1861, in: Cahiers du Monde Russe 41/2000, S. 79-108. 
westeuropäischen Ländern ${ }^{23}$ und zuletzt die Hidschra in das damalige Gebiet des Islamischen Staates (IS) in Syrien. Dadurch wird die Hidschra als Code für die Konstruktion einer kollektiven, ja: kollektivistischen, Ethik erkennbar, die sich in einer spezifischen Archäologie der islamischen Textüberlieferung findet, aber immer Elemente der Identitätsbildung von Gruppen in der Moderne ${ }^{24}$ beinhaltet.

Es gibt auf jeden Fall eine solche Sichtweise bereits in früheren Jahrhunderten als dem 20. Jahrhundert. Ein Musterexemplar ist der Gelehrte des 14. Jahrhunderts, Ibn Taymiya (gest. 1328), der eine eigene Schrift über denjenigen, der wahrhaft die Hidschra unternimmt ( $m u h a \bar{a}$ ir $)$, verfasst hat, in der er wiederum eine Rückbindung an den Propheten Muhammad unternimmt. ${ }^{25}$ Die Geschichte des Begriffes der Hidschra ist sicherlich noch zu schreiben.

\section{Quellen}

Ahmed, Shahab, What is Islam? The Importance of Being Islamic, Princeton-Oxford 2016. Chittick, William C., Ibn 'Arabi: Heir to the Prophets, London 2005.

Griffel, Frank, Den Islam denken: Versuch eine Religion zu verstehen, 2. Aufl., Ditzingen 2018.

Griffel, Frank, On Fakhr al-Dīn al-Rāzī’s Life and the Patronage he received, in: Journal of Islamic Studies 18/2007, S. 313-344.

Hamza, Feras u. a. (Hg.), An Anthology of Islamic Commentaries, Vol 1: On the Nature of the Divine, Oxford et a. 2010, S. 37-38.

Kofler, Hans (Übers.), Das Buch der Siegelringsteine der Weisheitssprüche. Fuṣūṣ alHikam, Graz 1970.

Kuschel, Karl-Josef, Die Bibel im Koran: Grundlagen für das interreligiöse Gespräch, Ostfildern 2017.

Lohlker, Rüdiger, Islam und Gewalt, Gewalt und Islam? Einige Überlegungen, in: Zekerija Sejdini (Hg.), Islam in Europa: Begegnungen, Konflikte und Lösungen, Münster-New York 2018, S. 111-125.

Lohlker, Rüdiger, Djihad - ein multidimensionaler Begriff unter besonderer Berücksichtigung der spirituellen Dimension, in: Spektrum Iran 1/2016, S. 27-40.

Masud, Muhammad Khalid, The obligation to migrate: the doctrine of hijra in Islamic law, in: Dale F. Eickelman / James Piscatori (Hg.), Muslim Travellers: Pilgrimage, Migration, and the Religious Imagination: Comparative Studies in Muslim Societies, Berkeley-Los Angeles 1990, S. 29-49.

Michot, Yahya, Muslims under Non-Muslim Rule, Oxford-London 2006.

23 Susanne Olsson (2012), Swedish Puritan Salafism: A Hijra Within, in: Comparative Islamic Studies 8/2014, S. 71-92.

24 Auch die Dschihadbewegungen Westafrikas lassen sich als Ausdruck der Krise der Moderne in der islamischen Welt lesen.

25 Vgl. Yahya Michot, Muslims under Non-Muslim Rule, Oxford-London 2006, S. 66-85. 
Morrison, Robert G., Islam and Science: The Intellectual Career of Nizāam al-Dīn alNisabūrī, London-New York 2010.

an-Naisabūrī, Nizāàm al-Dīn al-Ḥasan b. Muhammad, Tafsīr gharā’ib al-Qurān wa-ricāyat al-furqān, Ed. 'Umayrat, Zakarīja, Beirut 1996.

Olsson, Susanne (2012), Swedish Puritan Salafism: A Hijra Within, in: Comparative Islamic Studies 8/2014, S. 71-92.

Neuwirth, Angelika, Die koranische Verzauberung der Welt und ihre Entzauberung in der Geschichte, Freiburg i. Br. 2017.

Neuwirth, Angelika, Der Koran als Text der Spätantike: Ein europäischer Zugang, Berlin 2010.

ar-Rāzī, Faḩr ad-Dīn Muhammad b. 'Umar, at-Tafsīr al-kabīr, 3. Aufl., Kairo 1980.

Shihadeh, Ayman, The Teleological Ethics of Fakhr al- Dīn al-Rāzī, Leiden-Boston 2006.

Stieglecker, Hermann, Die Glaubenslehren des Islam, 2. Aufl., Paderborn et al. 1983.

Street, Tony, Concerning the Life and Works of al-Dīn al-Rāzī, in: Peter G. Riddel / Tony Street (Hg.), Islam: Essays on Scripture, Thought and Society, Leiden 1997, S. 135-146.

Williams, Brian Glyn, Hijra and forced migration from nineteenth-century Russia to the Ottoman Empire: A critical analysis of the great Tatar emigration of 1860-1861, in: Cahiers du Monde Russe 41/2000, S. 79-108.

Würtz, Thomas, Islamische Theologie im 14. Jahrhundert. Auferstehungslehre, Handlungstheorie und Schöpfungsvorstellungen im Werk von Sa'd al-Dīn at-Taftāzānī, Berlin-Boston 2016.

Zeilinger, Peter, Repräsentation einer Leerstelle, oder: Auszug ins Reale. Zur politischen Bedeutung des biblischen Exodus, der historisch nicht stattgefunden hat, in: Interdisciplinary Journal for Religion and Transformation in Contemporary Society 4ii/2018, S. 212-282. 


\section{Pazifistische Intentionen neureligiöser Bewegungen. Motive des „Universalen Sufismus“ angesichts beider Weltkriege}

\section{Universalistische Tendenzen innerhalb neuer religiöser Bewegungen}

Unter neuen religiösen Bewegungen versteht man religiöse Gemeinschaften bzw. Gruppierungen, die seit den 1960er und 1970er Jahren von einer breiteren Öffentlichkeit im europäischen Kontext wahrgenommen werden, allerdings mit eher diskriminierenden Begriffen, wie ,Sekten', bezeichnet wurden, oder angesichts des Großteils ihrer damaligen Anhänger ,Jugendreligionen' genannt wurden; in den Vereinigten Staaten wurde seit den 1980er Jahren der Ausdruck ,Kultbewegung' (cult movement) oder, cults' bevorzugt, um sie von sects zu unterscheiden. In der neueren Religionswissenschaft wird demgegenüber im Interesse einer neutralen Sicht vor allem der Begriff, neureligiöse Bewegungen` (New Religious Movements) verwendet, der einerseits ihre historische Neuheit (gegenüber den traditionellen Weltreligionen) zum Ausdruck bringt, sowie deren dynamischen Charakter, insofern sie sich in einem Prozess der Veränderung verstehen. ${ }^{1}$ Des Weiteren resultiert aus einer religionswissenschaftlichen Sichtweise, dass die Entstehung solcher Bewegungen einerseits historisch viel weiter zurückgeht, nämlich bis in die Mitte des 19. Jahrhunderts, und andererseits, dass Entwicklungen, die zu neuen, von der Herkunftsreligion unterschiedenen Gemeinschaften führen, in allen großen Weltreligionen anzutreffen sind.

Aufgrund dieser pluralen Entstehungsgeschichte haben diese neuen religiösen Bewegungen auch unterschiedliche Inhalte ihres Glaubens und ihrer religiösen Praxis. Im vorliegenden Beitrag möchte ich mich einer Bewegung zuwenden, die vom Islam und dessen mystischer Tradition geprägt ist, zudem von Anfang an universalistisch ausgerichtet war und infolge davon - was im Einzelnen aufzuzeigen ist - pazifistische Intentionen verfolgt: es ist jene Richtung

1 Vgl. Johann Figl, Neureligiöse Bewegungen, in: Walter Kasper (Hg.), Lexikon für Theologie und Kirche 7, 3. Aufl., Freiburg i. Br. 1998, S. 775f.; Reinhart Hummel, Kultbewegung in: Walter Kasper (Hg.), Lexikon für Theologie und Kirche 6, 3. Aufl., Freiburg i. Br. 1997, S. 512. 
des Sufismus im Westen, die mit dem Begriff Universaler Sufismus treffend erfasst wird. ${ }^{2}$ Sie wurde von dem indischen Sufi-Lehrer Hazrat Inayat Khan vor rund 100 Jahren in den Westen gebracht, und gibt seit damals für viele Menschen des ,westlichen' Kulturraumes und darüber hinaus eine spirituelle Wegweisung des Glaubens und Lebens. ${ }^{3}$ Ich möchte hier insbesondere ihren potentiellen und realen Beitrag zum Frieden darstellen.

Diese pazifistische Intention einer Reihe von neureligiösen Bewegungen wurde in der Vergangenheit oft durch problematische Aspekte überlagert, die innerhalb einiger Gruppierungen auftraten. In der zweiten Hälfte des vergangenen Jahrhunderts entstand hinsichtlich einiger Gruppen der Verdacht, sie „würden ihre Mitglieder in psychische, soziale und finanzielle Abhängigkeiten führen, ja durch Gehirnwäsche eingliedern",", und von solchen Gruppierungen könne man kaum annehmen, dass sie einen Beitrag zum Frieden leisten könnten. ${ }^{5}$ In vergleichbarer Weise wurde eine ähnliche Problemstellung auch hinsichtlich solcher religiöser Minderheiten, die nicht neureligiöse Bewegungen sind, sondern zu großen traditionellen Religionen gehören, jedoch innerhalb der neuen Lebensumgebung eine Minorität darstellen, konstatiert. ${ }^{6}$ Diese anfängliche Sicht sollte jedoch nicht von der „Entdeckung von Friedenspotenzialen in neuen religiösen Bewegungen" abhalten, wenngleich auch in Einzelfällen partielle Gründe dafür vorlagen. ${ }^{7}$ Solche problematischen Entwicklungen waren jedoch eher in Gruppierungen anzutreffen, die gegenüber der Gesamtgesellschaft stark abgeschlossen waren, als in universalistischen Bewegungen, deren Merkmal die Offenheit für andere Religionen und Kulturen ist, und die von einer Einheit der Religionen ausgehen und für den Frieden zwischen Religionen und dadurch zum gegenseitigen Verstehen innerhalb der Gesellschaft und zwischen den Völkern beitragen wollen. Der vorliegende Beitrag möchte sich primär solchen Tendenzen innerhalb der neureligiösen Gruppierungen zuwenden.

2 Hendrikus J. Witteveen, Universaler Sufismus: Die Sufi-Botschaft von Hazrat Inayat Khan, Heilbronn 1998.

3 Vgl. Johann Figl, Mitte der Religionen. Idee und Praxis universalreligiöser Bewegungen, Darmstadt 1993, bes. S. 89 ff. Dieses Buch wird zurzeit für eine Übersetzung in Englisch vorbereitet. Mit dieser Bewegung und dem Sufi-Orden im Westen habe ich mich seit Jahren beschäftigt und bin ihren Repräsentanten und weiteren Mitgliedern wiederholt begegnet.

4 Heinz Streib, Friedensbildung und neue religiöse Bewegungen, in: Werner Haußmann / Hansjörg Biener / Klaus Hock / Reinhold Mokrosch (Hg.), Handbuch Friedenserziehung: interreligiös - interkulturell - interkonfessionell, Gütersloh 2006, S. 164-167, hier: S. 164.

5 Ebd.

6 Vgl. dazu Hans-Martin Barth / Christoph Elsas (Hg.), Religiöse Minderheiten: Potentiale für Konflikt und Frieden, IV. internationales Rudolf-Otto-Symposion, Marburg, Schenefeld 2004.

7 Vgl. Streib, Friedensbildung, S. 167. 


\section{Beispiele universalistischer Bewegungen und Neureligionen}

Universalistisch und zugleich pazifistisch orientierte Bewegungen im beschriebenen Sinn sind - wie erwähnt - im Verbreitungsgebiet aller Weltreligionen entstanden, worauf hier nur kurz anhand einiger Bewegungen exemplarisch hingewiesen werden kann. Für die Hindu-Traditionen können dafür schon Ende der 19. Jahrhunderts beispielsweise Vivekananda und sein im Anschluss an den Mystiker Ramakrishna gegründeter und nach diesem benannter Orden genannt werden, der eine inklusivistisch die anderen Religionen umfassende Spiritualität auf der Grundlage des Vedānta propagierte. Er hat diese universelle Sicht der Religionen beim Weltparlament der Religionen anlässlich der Weltausstellung in Chicago 1893 einem weiten Zuhörerkreis vor Augen gestellt und eine große positive Resonanz bei seinen ,westlichen' Zuhörern erfahren, die überwiegend dem Christentum angehörten. ${ }^{8}$ Dieses Weltparlament selbst kann aufgrund der hier erwiesenen Toleranz und Offenheit als wesentlicher Schritt in Richtung eines friedvollen Verhaltens der Religionen zueinander verstanden werden. ${ }^{9}$

Als Beispiel einer vom Buddhismus inspirierten neueren religiösen Entwicklung, die schon im Namen ihr sozial-ethisches Ziel eines gerechten $\mathrm{Zu}$ sammenlebens zum Ausdruck bringt, ist Risshō Kōseikai (dt. „Gesellschaft für Aufrichtung von Recht und mitmenschlichen Beziehungen"). Für diese in den 1930er Jahren entstandene neue japanische Religion ist die Verwirklichung von Einheit und Frieden besonders zwischen den Religionen ein zentrales Anliegen. Die Internationalisierung dieser neuen religiösen Bewegung geht vor allem auf die Förderung des interreligiösen Dialogs und des Pazifismus in den 1960er und 1970er Jahren zurück. ${ }^{10}$ Für deren Gründer Nikkyō Niwano (1906-1999) ist „Zusammenarbeit der Religionen für den Frieden“ das maßgebliche Programm. Gegenüber der exklusiven Haltung einer Religion sei heute das Bewusstsein der Einheit der Religionen zu betonen. ${ }^{11}$ Eine wesentliche Grundlage für dieses Programm ist Niwanos Überzeugung von der letztlichen Einheit aller Religionen auf der Basis der einen Wahrheit des Universums: „[t]he truth of the universe is

8 Vgl. Figl, Mitte der Religionen, S. $43 \mathrm{ff}$.

9 Vgl. dazu grundlegend: Dorothea Lüddeckens, Das Weltparlament der Religionen von 1893: Strukturen interreligiöser Begegnung im 19. Jahrhundert, Berlin 2002.

10 Ugo Dessì, Risshō Kōseika, in: Lukas Pokorny / Franz Winter (Hg.), Handbook of East Asian New Religious Movements, Leiden-Boston 2018, S. 161-175, bes. S. 164. Nikkyō Niwano ist 1965 persönlich von Papst Paul VI. als Konzilsbeobachter eingeladen worden; 1970 fand in Tōkyō die Erste Weltkonferenz der Religionen für den Frieden statt, an der Mitglieder vieler Religionen teilnahmen: vgl. dazu Marita Estor, Maria Alberta Lücker - Mitbegründerin von ,Religionen für den Frieden', in: Religionen unterwegs, 25/1/2019, S. 23-27, bes. S. 26 f.

11 Vgl. Christiane Schulze, Frieden durch Religion - ein japanisches Modell: Das interreligiöse Friedensprogramm der Rissho Kosei-kai (1957-1991), Frankfurt a. M. (u.a.) 2008, bes. S. $47 \mathrm{ff}$., mit Bezug auf: Nikkyō Niwano, Buddhist approach to peace, Tokyo 1977. 
only one. All religions are nothing but different manifestations of this truth", und aus diesem Grund sei Kooperation notwendig. ${ }^{12}$

Eine Friedensintention ist ebenso in weiteren Neuen Religionen Japans, die z. T. auch Neue religiöse Bewegungen genannt werden, anzutreffen. Ihre große Anzahl macht dieses Land zum ,klassischen` Entstehungsgebiet der neureligiösen Entwicklungen. Schon seit der ersten Hälfte des 19. Jahrhunderts haben sich in mehreren Phasen bis zur Gegenwart hunderte solcher Bewegungen entwickelt, die von den verschiedenen in Japan vorherrschenden traditionellen Religionen, wie insbesondere Shintōismus und Buddhismus, beeinflusst wurden, aber z. B. auch christliche Glaubensinhalte als auch Denkweisen des amerikanischen New Thought übernommen haben. Vielfach wurden Elemente verschiedener religiöser Überlieferungen in neuen Bewegungen integriert, sodass wiederholt von Synkretismus gesprochen wurde. Ein Beispiel einer solchen integrativen Religion ist Seichō-no-ie (wörtlich „Heim wachsenden Lebens", auch übersetzt als „Haus des Wachstums"), die von Masaharu Taniguchi gegründet und 1941 in Japan als Neue Religion registriert wurde..$^{13}$ Auch in dieser Religion ist ein „Programm für den Weltfrieden“ ausgearbeitet und in verschiedener Weise realisiert worden. Religiös motivierte Kriege werden geächtet, die Gesundung der Wirtschaft sei anzustreben und „drittens müßte die Friedensbemühung auf die Erhaltung und Bewahrung des Lebens hinauslaufen " ${ }^{14}$ Eng mit diesen Intentionen ist die Überzeugung von der „inneren Einheit aller Religionen“ verbunden. ${ }^{15}$

Auch einige vom Islam herkommende Neureligionen bzw. neureligiöse Bewegungen sind durch eine entschieden versöhnende und Frieden fördernde Ausrichtung geprägt. Es ist vor allem auf die Bahä'i-Religion hinzuweisen, die von der Einheit der Religionen ausgeht und viele Friedensinitiativen initiiert hat und unterstützt. ${ }^{16}$ Ein offizielles Dokument dafür ist die Publikation Die Verheißung des Friedens: Eine Botschaft des Universalen Hauses der Gerechtigkeit an die Völker der Welt. ${ }^{17}$ Sie ist also vom obersten Führungsgremium dieser Religionsgemeinschaft veröffentlicht worden. Darin wird die Idee der Einheit der

12 Niwano, Buddhist approach to peace, S. 167.

13 Siehe dazu Figl, Mitte der Religionen, S. $67 \mathrm{ff}$.

14 Ryuko Woirgardt, Die neuen Religionen Japans und ihr Sendungsbewußtsein im Hinblick auf den Weltfrieden: Eine Analyse am Beispiel der Seichō-no-ie-Bewegung, Frankfurt a. M. (u. a.) 1995, S. 199.

15 Vgl. Ebd., und Figl, Mitte der Religionen, S. 69.

16 Vgl. Johann Figl, Neue Religionen, in: Ders. (Hg.), Handbuch Religionswissenschaft, Innsbruck-Göttingen 2003, S. 457-484, bes. Bahá'í-Religion, Ebd., S. 470-475.

17 Siehe: The Promise of World Peace. To the Peoples of the World. A Statement by The Universal House of Justice, 1985. Die deutsche Übersetzung ist vom Nationalen Geistigen Rat der Bahā'i in Deutschland herausgegeben, 4. Aufl., Hofheim am Taunus 1988. 
Religionen als Grundlage für die Idee der Einheit der Völker und des Weltfriedens betrachtet.

Eine primär mystisch orientierte Einheitsauffassung verbunden mit der Idee eines Friedens zwischen den Religionen kennzeichnet die Botschaft Hazrat Inayat Khans und des von ihm gegründeten Sufi-Movement und des Sufi-Ordens (im Westen), die im Folgenden schwerpunktmäßig dargestellt werden soll.

\section{Einheit der Religionen - ein grundlegendes Konzept von Hazrat Inayat Khan}

\subsection{Biographische Hinweise}

Die vorliegende Darstellung wendet sich vor allem dem pazifistischen Denken sowie dem ihm entsprechenden Handeln von Inayat Khan und Mitgliedern seiner Familie zu. Bei ihm selbst ist dies eng mit Erfahrungen während und nach dem Ersten Weltkrieg verbunden, bei seinem Sohn Vilayat und der Tochter Noor-un-Nisa, die schließlich im Konzentrationslager Dachau ermordet wurde, vollzogen sich deren Aktivitäten im Widerstand gegen den Nationalsozialismus während des Zweiten Weltkriegs.

1910 kam Inayat Khan, ein großer indischer Musiker und bedeutender Sufi mit dem Ehrentitel Hazrat (wörtlich: „[göttliche] Gegenwart“) mit seinem Bruder Maheboob Khan und seinem Cousin Mohammad Ali Khan nach Amerika; es war eine Gruppe, die indische Musik in Amerika und dann in Europa aufführte. Die Musik verstand Inayat Khan als Erfüllung seiner Mission; verbunden mit seinen Vorträgen war sie auch der Weg zu seinen ersten Anhängern.

Im Jahre 1912 war dann Inayat mit seiner Gruppe nach London gekommen. Die Heirat mit Ora Ray Baker - eine entfernte Verwandte von Mary Baker Eddy, der Gründerin der neureligiösen Richtung Christian Science - war im darauffolgenden Jahr in London. Noor-un-Nisa $\left({ }^{\star} 1914\right)$ war das erste Kind Inayat Kahns und seiner Frau; es folgten die beiden Söhne Vilayat $\left({ }^{\star} 1916\right)$ und Hidayat $\left({ }^{*} 1917\right)$ und schließlich die jüngste Tochter Khair-un-Nisa $\left({ }^{*} 1919\right)$.

In dem Zeitraum von 1912 bis Mitte 1914 hatte Hazrat Inayat zahlreiche Begegnungen bei seinen vielen Aufenthalten und Reisen in England, Frankreich und besonders auch in Russland. Im späten Juni unmittelbar vor Beginn (28. Juni 1914) des Ersten Weltkrieges konnte er mit seiner Familie Russland noch verlassen. Der Weltkrieg brachte eine erzwungene Ruhe. Die Tourneen mussten eingestellt werden. Hazrat Inayat Khan war gezwungen bzw. es war ihm nun ermöglicht, sich mit seinen eigenen und eigentlichen Ideen zu befassen. Bis dorthin war die Tournee das einzige Mittel, um die Mission zu erfüllen. Die 
Aufgabe der Mission war es, die Botschaft der universalen Wahrheit, die Ost und West durch die Verbreitung der Idee der Einheit, welche der Sufismus ist, vereinen will, kundzutun. ${ }^{18}$ Nun war es möglich, diese Idee direkt zu verbreiten, nicht nur vermittels musikalischer Aufführungen; der Zeitabschnitt von 1914 bis 1920 wurde darum als Weg vom Musiker zum Murshid (also zum spirituellen Lehrer) beschrieben. ${ }^{19}$

In London wurde von Inayat der Sufi-Orden (im Westen) gegründet. Die Etablierung des Sufi-Ordens in Europa erfolgte von 1915-1919, also großteils während des Ersten Weltkrieges. Später, nach dem Krieg, bes. ab 1923, wurde dann das Sufi-Movement als Organisation in Genf gegründet.

Er machte nach der durch den Ersten Weltkrieg entstandenen Unterbrechung ab den 1920er Jahren wieder Reisen in mehrere Länder Europas und auch wieder nach Amerika.

Am 28. September 1926 verließ Inayat den Westen und fuhr nach Delhi zurück, wo er ernsthaft erkrankte. Am 5. Februar 1927 starb er infolge einer Lungenentzündung in dieser Stadt, erst 44 Jahre alt, fern von seiner Familie, die in Europa zurückgeblieben war.

\subsection{Betroffenheit durch den „letzten großen Krieg“}

Inayat Khan hat die Auswirkungen des Ersten Weltkriegs, während dessen er in London lebte, kennen gelernt. Rückblickend darauf sprach er öfters vom „großen Krieg“, in dem auch viele gottgläubige Menschen ihren Glauben verloren hätten. Auf diese triste spirituelle Situation in der Nachkriegszeit will er auch mit seiner Sufi-Botschaft, dem esoterischen und spirituellen Zentrum der Bewegung, antworten. ${ }^{20}$ Umgekehrt sieht er darin zugleich die Möglichkeit eines neuen religiösen Aufbruchs: „nach all den furchtbaren Leiden, die der letzte große Krieg über die Menschheit gebracht hat, fangen die Menschen allmählich an, ihre Augen zu öffnen“, und sie werden „dann endlich wissen und verstehen, daß die wahre Religion nichts anderes ist, als das Herz ganz offen [...] werden zu lassen und diese eine Religion dann zu leben. “21 Grundlegend für eine zusammenfassende Sicht der Überlegungen Inayat Khans hinsichtlich der Religion sind

18 Vgl. Sufi Message XII, S. 153.

19 Vgl. Elisabeth de Jong-Kessing, Inayat Khan: A biography, The Hague 1974, S. $137 \mathrm{ff}$.

20 Complete Works of Pir-O-Murshid Hazrat Inayat Khan (= CW). Original Texts: Lectures on Sufism. 1923 I: January-June, London-The Hague 1989, 71. Pir-o-Murshid bedeutet ,Haupt der Murshids'.

21 Hazrat Inayat Khan, Die Einheit der religiösen Idealen, Den Haag-London 1963, S. 31. Irrtümlich wurde in der Übersetzung, Idealen' geschrieben, es müsste eigentlich ,Ideale ' heißen (Titel der Originalausgabe: The Unity of Religious Ideals, London 1963). 
die Beiträge im Band IX der,Sufi-Message‘ mit dem bezeichnenden Titel, The Unity of Religious Ideals . $^{22}$

\subsection{Der religiös bedingte Krieg}

Hazrat Inayat Khan ist m. E. einer der wenigen religiösen Lehrer des 20. Jahrhunderts, die die Gefahren, welche von Religionen für den Frieden ausgehen, klar gesehen haben. Schon zu Beginn seines Buches Die Einheit der religiösen Ideale, das auf Vorträge im Jahr 1923 zurückgeht, schrieb er im Kapitel ,Einheit und Einheitlichkeit':

„religiöse Meinungsverschiedenheiten haben der Menschheit zahllose Kriege und Katastrophen beschert. Solches geschah, weil der Geist der Einheit nicht beachtet, die Einheitlichkeit dagegen überbewertet wurde“ ${ }^{23}$

Es sei der Geist der Zerstörung, der für die Harmonie des eigenen Lebens und dem anderer blind ist, und er denkt dabei an die Kriege, „die die Menschheit erlebt hat, besonders an den letzten mit all seinen Schrecken“, denn daran könne man diese Wahrheit erkennen. Zu solchen Verirrungen komme es auch dadurch, dass man sich auf die eigene Religion beruft, und den Unterschied zu anderen Religionen betont - dies führe nicht zur Einheit, sondern zur „Spaltung der Menschheit, die doch eine gemeinsame Herkunft und ein gemeinsames Ziel habe.“ Die so denken, „betreiben schweren Mißbrauch (!) mit der Religion“. ${ }^{24}$ Obwohl Inayat Khan betont, dass die Schriften aller Religionen die „Botschaft der Einheit als ihre zentrale Wahrheit“ enthalten, ${ }^{25}$ stellt er am Schluss dieses Buches fest:

„Hinter allen kriegerischen Auseinandersetzungen sind religiöse Einflüsse zu finden. Wann immer es einen Krieg gegeben hat, sogar bei den jüngst vergangenen Kriegen, immer war Religion mit im Spiel. Die Menschen sehen die Kriegsursachen meist im politischen Bereich, aber Religion kann ein viel gefährlicherer Kriegstreiber sein als die meisten politischen Ideen. ${ }^{“ 26}$

Die Überwindung solcher Gefahren findet er darin, „daß die Anhänger unterschiedlicher Religionen in der Erkenntnis der einen Wahrheit hinter den Religionen zusammenfinden $[\ldots]^{\text {“ }}{ }^{27}$ Und vor rund hundert Jahren postuliert er

22 Hazrat Inayat Khan, The Sufi Message of Hazrat Inayat Khan, 13 Bände, London 1960-1967, Varanasi (u. a.) 1988.

23 Hazrat Inayat Khan, Einheit der religiösen Idealen, S. 15.

24 Ebd., S. 23.

25 Ebd., S. 16.

26 Ebd., S. 327.

27 Ebd. 
etwas, das Theologen großer monotheistischer Religionen erst seit Mitte des 20. Jahrhunderts ernster nehmen. Schon 1923 sagt er bei einer sogenannten ,Sommerschule‘ zu seinen Anhängern:

„Wir sollten es anders machen als jene Theologen an den Hochschulen, die sich mit Vorliebe auf die Unterschiede zwischen Moses und Buddha konzentrieren. Wir sollten vielmehr hinter die Religionen zu schauen versuchen, um zu entdecken, worin sie übereinstimmen“; und die „Anhänger aller verschiedenen Religionen [sollten] miteinander Freundschaft schließen “ ${ }^{28}$

Diese Ausführungen werden im Kontext der Erläuterung des ,universellen Gottesdienstes' gemacht, die auch als „Kirche für alle“ bezeichnet wird, da darin alle Religionen tendenziell eingeschlossen sind. ${ }^{29}$

\subsection{Krieg und Frieden als Folgen psychischer Dynamik}

In der Deutung des Ursprungs von Kriegen geht Hazrat Inayat Khan von den Grundtendenzen psychischer Dynamik aus. Von diesem Hintergrund her beantwortet er die Frage, von woher der Krieg kommt: Er kommt von einer chaotischen Handlungsweise. Wo eine solche Aktion ist, werden ganze Nationen in einen Krieg involviert. Der chaotische Einfluss einer einzigen Person kann die ganze Welt in Hoffnungslosigkeit stürzen. ${ }^{30}$

Krieg wird hier auf eine destruktive Entwicklung in der Psyche des Menschen zurückgeführt, die zugleich das Gegenteil des mystisch anzustrebenden $\mathrm{Zu}$ standes des Friedens ist. Indirekt wird damit ausgesagt, dass eine spirituelle Suche des inneren Friedens zugleich von Konflikt fördernden Kräften bewahrt, deren Kennzeichen eine chaotische Struktur ist. Äußerer Friede wird durch innere Harmonie vorbereitet. 1924 sagt er in einem Vortrag:

"It is useless to discuss the peace of the world; what is just now necessary is to create peace in ourselves, that we ourselves become examples of love, harmony and peace; this is the only way of saving ourselves and the world“". ${ }^{31}$

\section{5. Übungen und Wirkungen der Meditation}

Dieser Zustand des Friedens, seine Erfahrung, wird durch konkrete praktische Übungen vorbereitet, unter denen Atemtechniken eine zentrale Rolle spielen,

28 Ebd., S. 327.

29 Vgl. Ebd., S. 326.

30 Vgl. CW, 1926 II, S. 517 ff., bes. S. 520.

31 CW, 1924 I, S. 174. 
um in den rechten Rhythmus zu gelangen. In der Meditation ist „der Atem der Lehrer, die Leiter vermittels der ein Schüler weiterschreitet auf seinem Weg zu Gott“; es kommt darauf an, dass der Rhythmus in der Meditation gefunden wird. ${ }^{32}$ Der Friede kommt, „wenn das Selbst in Harmonie mit dem Rhythmus des

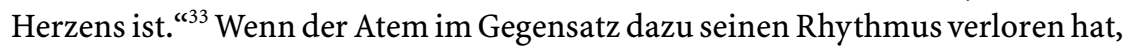
er nicht regelmäßig sondern ungleichmäßig ist, dann ist die beschriebene „chaotische Kondition“"34 gegeben, die zur Zerstörung führen kann. Im Gegensatz dazu ist es erfordert, den natürlichen Rhythmus des Seins der Seele zu erreichen, „einen Rhythmus, in dem allein die Befriedung des Lebens ist“, denn ohne einen solchen inneren Frieden kann keine Glückseligkeit ${ }^{35}$ und keine Erfüllung des Lebens ${ }^{36}$ erfahren werden.

Weitere Bedingungen zur Erlangung des Friedens sind in der Meditation das Stillschweigen und völlige Zurückhaltung gegenüber der dauernden Aktivität des Geistes. ${ }^{37}$ Es geht also um völlige Geistesberuhigung. Die körperliche Haltung als solche bringt schon Frieden, und dadurch auch die psychische Beruhigung. ${ }^{38}$

Die aufgezeigte pazifistische Intention zeigt sich auch in Gebeten Hazrat Inayat Khans, explizit im Friedensgebet. Von den - symbolisch - insgesamt sieben Strophen sei hier nur die erste wiedergegeben:

Gib Deinen Frieden, oh Herr,

der vollkommen und ewig ist,

auf dass unsere Seelen

Frieden ausstrahlen mögen. ${ }^{39}$

\subsection{Pazifismus ist nicht gleichbedeutend mit Passivismus}

Ein wesentliches Motiv der Friedensperspektive Hazrat Inayat Khans liegt in der inneren Dimension des psychischen und spirituell erreichten Friedens, doch werden dabei nicht die äußere Wirklichkeit der Religionen sowie deren Motivationen vergessen, die zu Kriegen geführt haben und führen. Auch die politische Dimension wird nicht bloß erwähnt, sondern die Erfahrung des Ersten Weltkrieges und die dadurch veranlasste Verlegung des Wohnsitzes von Frank-

32 Complete Works, 1923 I, S. 259.

33 CW, 1923 I, S. 232.

34 CW, 1926 II, S. 519.

35 Vgl. CW, 1924 II, S. 376.

36 Ebd., S. 33.

37 CW, 1923 I, S. 232.

38 CW, 1925 II, S. 243.

39 Zit. nach H. J. Witteveen, Universaler Sufismus, S. 185; vgl. Hazrat Inayat Khan, Gebete des Inayati-Orden - Gebete von Hazrat Inayat Khan, 2., überarb. Aufl., Heilbronn 2019. 
reich nach England hat ihm und seiner Familie dessen destruktive und in das konkrete Leben von Menschen eingreifende Auswirkungen schmerzlich spüren lassen.

Inayat Khan hat sich bei aller Entschiedenheit für die religiös motivierte pazifistische Ausrichtung seiner Aussagen jedoch gelegentlich auch dagegen ausgesprochen, und davon Abstand genommen, einem rein passivistischen Friedensideal zu huldigen. Einige Jahre nach Ende dieses ersten großen Krieges von globalem Ausmaß schreibt er: „The Sufi Message is not necessarily the Message of passivism. It does not teach to make peace at any cost and at every cost “. 40

Auch wenn hier eventuell der Ausdruck ,Passivismus' ein Fehler bei der Mitschrift seiner Zuhörer war, und er eigentlich ,Pazifismus' gemeint hatte, ${ }^{41}$ dann würde dies sinnverwandt heißen, dass er einem ,Pazifismus unter allen Umständen', der auf jeglichen Widerstand verzichtet, nicht zustimmt. An anderer Stelle sagt er, dass ein so verstandener Passivismus bzw. Pazifismus, der sich nicht gegen das Unrecht wehrt, nicht der Lehre der Sufis entspricht. ${ }^{42}$

Inayats Brüder und deren Familien, aber insbesondere seine beiden Kinder Noor-un-Nisa und Vilayat, die den Zweiten Weltkrieg erleben mussten, haben die komplexe Frage des Widerstandes gegen Krieg und Verfolgung nicht allein durch Worte, sondern in Taten, ja mit ihrem Leben zu beantworten versucht.

\subsection{Noor-un-Nisas Widerstand gegen die NS-Vernichtungspolitik und ihr Schicksal}

Der Ausbruch und die zerstörerische Entwicklung des Zweiten Weltkrieges war eine Herausforderung für die pazifistische Einstellung sowohl von Noor-un-Nisa als auch ihres Bruders Vilayat. Hatte schon der Erste Weltkrieg, wie erwähnt, das Schicksal ihrer Familie stark belastet, so zwang dann später der Zweite Weltkrieg wiederum zur Flucht nach London aus Frankreich, wo sie in der Zwischenkriegszeit gelebt hatten. Die große Bedrohung für die Familie zeichnete sich ab, als Hitlers Krieg zu den ersten Eroberungen benachbarter Länder führte, und sie die Nachrichten von Konzentrationslagern erreichten.

Erschüttert durch dieses Gefühl, dem Tod aufgrund der massiven Aggression der deutschen Truppen gegenüberzustehen, war es eine Frage, wie darauf zu reagieren sei. Vilayat Inayat Khan berichtet später, dass er und seine Schwester Noor-un-Nisa

40 CW 1922 I, S. 394.

41 Anmerkungen dazu Ebd.: „Although ,passivism“ was taken down, ,pacifism` or ,passivity` may have been meant $(. . .)^{\text {“. }}$

42 Vgl. Ebd., S. 339, und S. 340 mit Anmerkungen. 
sich berieten, wie sie sich verhalten sollten angesichts der Ereignisse, die ihr Leben zerstören konnten. Er schreibt:

„Im Dienst an der Botschaft der Einheit allen Seins hatten wir immer Respekt gepredigt vor allen Religionen, allen Ethnien, dem Göttlichen im Menschen. Nun wurden wir geprüft: Waren dies nur leere Worte gewesen oder würden wir mit unserem Leben für das einstehen, was wir uns geschworen hatten? Die Nachrichten über unfassbare Grausamkeiten und schändliche Mißachtungen, selbst der elementarsten Menschenrechte in den Konzentrationslagern hatten uns erreicht. “43

Noor-un-Nisa Inayat Khan war vor allem von der Verfolgung und dem Massenmord an den europäischen Juden erschüttert. Auf die Frage warum Gott so viel Böses und Schreckliches in der Welt zulassen kann, antwortet sie in ihren Geschichten mit dem höchsten Gut, mit dem ihr Schöpfer sie ausgestattet hat: der Freiheit des Menschen, das Gute zu wählen, in ihren eigenen Worten „dem Ruf des Einen an die Vielen“. ${ }^{44}$ Wie Eric Schuhmacher schreibt, entschlossen sich „Noor und ihre Geschwister [...] angesichts der Berichte über die unmenschlichen Zustände in den Konzentrationslagern rasch zum Widerstand. “45

Aber der Kampf dagegen würde ebenfalls Gewalt erfordern. „Doch sobald du bereit bist, Gewalt mit Gewalt zu erwidern, hast du Teil an der Gewalt, gegen die du zu kämpfen vorgibst! Von ganzem Herzen glaubten wir an die Gewaltlosigkeit Gandhis“; aufgrund dieser Überlegung fassten sie den Entschluss, „eine defensive Funktion“ zu übernehmen, und sich in der vordersten Front der Abwehr einzubringen. ${ }^{46}$ Vilayat trainierte im Rang eines Offiziers der British Navy auf Minensuchbooten und zu Kriegsende nahm er an der Landung der Alliierten in der Normandie teil. Noor-un-Nisa, die schon in Frankreich beim Roten Kreuz gearbeitet hatte, meldete sich in England zur Women's Auxiliary Air Force (WAAF) und wurde als Funkerin ausgebildet. Auch andere Mitglieder der Familie übernahmen wichtige Dienste in dieser schweren Zeit des Krieges: Claire, die jüngere Schwester, war beim Auxiliary Territorial Service (ATS), die Mutter diente als Krankenschwester.

43 Pir Vilayat Inayat Khan, Erinnerungen an meine Schwester Noor-un-Nisa, in: Sifat. Zeitschrift für Universalen Sufismus, 46/2/2018, S. 7-11, hier: S. 9. Dies ist das ,Sonderheft Pirzadi-Shahida Noor-un-Nisa Inayat Khan'. ,Pirzadi` ist der Titel der Tochter eines Pir, das ist ein hoher spiritueller Meister; Shahida bedeutet Märtyrerin. Vgl. auch Sara Kuehn / Lukas Pokorny, On Inayati Female Visions in Austria: Female Leadership in the Western Sufi Tradition, in: Hans Gerald Hödl / Lukas Pokorny (Hg.), Religion in Austria 4, Wien 2018, S. 53-114, bes. S. 61 und S. 99 f.

44 Eric Schumacher, Porträt der Sufiprinzessin Noor Inayat Khan. Dem Ruf des Einen an die Vielen, in: QANTARA.DE - Dialog mit der islamischen Welt, vgl. https://de.qantara.de/in halt/portraet-der-sufiprinzessin-noor-inayat-khan-dem-ruf-des-einen-an-die-vielen (letzter Zugriff: 24.05.2019).

45 Ebd.

46 Vilayat Inayat Khan, Erinnerungen, Sifat, S. $9 f$. 
Noor-un-Nisa jedoch erklärte sich schließlich freiwillig bereit, innerhalb der britischen Spezialeinheit SOE (Special Operations Executive) die Resistance in Frankreich zu unterstützen, wozu sie besonders aufgrund ihrer vorangehenden langen nachrichtendienstlichen Ausbildung sowie wegen ihrer ausgezeichneten Französisch-Kenntnisse besonders geeignet war. Dort nahm sie unter dem Codenamen Madeleine im Juni 1943 ihre Agententätigkeit auf. Wahrscheinlich wurde sie durch einen Doppelagenten verraten, infolge davon im Oktober dieses Jahres von der Gestapo festgenommen, einen Monat lang verhört, Foltern unterworfen, und dann nach Pforzheim überstellt. Von dort wurde sie nach fast einem Jahr nach Dachau deportiert, wo sie gemeinsam mit drei weiteren SOE-Agentinnen am 13. September 1944 gezwungen wurde sich vor dem Krematorium auf dem Boden niederzuknien und dann mit Genickschuss erschossen wurde. Sie war erst 30 Jahre alt. Ihr letztes Wort soll gewesen sein: ,libertéc. Die Leichen der hingerichteten Frauen wurden verbrannt.

An der KZ-Gedenkstätte Dachau erinnert eine Tafel an diese Widerstandskämpferinnen gegen den Nationalsozialismus. Alljährlich wird zu Ehren Noorun-Nisas anlässlich ihres Todestages eine offizielle Gedenkfeier abgehalten. Zum ersten Mal hatte Pir Vilayat an diesem Ort 1996 die H-moll Messe von J. S. Bach dirigiert. 2015 hatte daran ihr Neffe Hidayat Inayat Khan mit seiner Frau Aziza teilgenommen und eine Ansprache gehalten. ${ }^{47}$ Diese Feier fand in der dortigen Klosterkirche der Karmeliterinnen und gemeinsam mit diesen statt. Eine Sufi-Gemeinschaft gedenkt einer "Sufi-Heiligen in einem katholischen Kloster“, was nicht nur von Sufis als Zeichen einer „universalen Spiritualität“ angesehen werden kann, sondern auch aus katholischer Perspektive. ${ }^{48}$

Noor-un-Nisa war in ihrer Tätigkeit vom Motiv der Überwindung grausamer Gewalt geleitet. Sie hat ihre Nachrichten-Tätigkeit im Rahmen der Spionage in dieser Intention wahrgenommen. In diesem Sinn ist sie unter den gegebenen Umständen dem pazifistischen Ideal treu geblieben. Sie war entschiedene Widerstandkämpferin, weswegen sie posthum vielfach geehrt wurde, auch mit bedeutsamen Kriegsauszeichnungen, wie der Verleihung des Croix de Guerre 1946 durch Frankreich und des George Cross 1949 durch England. Ihre Aktionen dienten der Überwindung und Beendigung des grausamsten Angriffskrieges in der Geschichte der Menschheit.

Noor-un-Nisas Bruder Vilayat schreibt in seinen Erinnerungen:

„Manchmal frage ich mich, ob diejenigen, die heute ein Leben in Wohlstand führen oder zumindest die hoch zu schätzende politische Freiheit in unseren modernen Ge-

47 Vgl. Angelika Eisenmannn, Erinnerungsarbeit in der KZ-Gedenkstätte Dachau am Beispiel Noor-un-Nisa Inayat Khans, in: Sifat, S. 36-40.

48 Vgl. Tanja Latifa Mancinelli, Gedenkfeier für Noor-un-Nisa Inayat Khan im ehemaligen Konzentrationslager Dachau, in: Sifat, S. 41-43, bes. S. 42. 
sellschaften genießen, überhaupt realisieren, dass sie dies jenen Menschen verdanken, die für sie gestorben sind und gefoltert wurden. ${ }^{\text {“49 }}$

Um dieses Bewusstsein zu gewährleisten kommt auch den christlichen Kirchen aufgrund des „Evangeliums von der Versöhnung“ (2. Kor. 5:18) „eine besondere zivilgesellschaftliche Rolle $\mathrm{zu}$ “; dabei geht es darum

„ethische Maßstäbe angesichts historischer Gräuel zu klären und den Opfern posthum wie immer unvollkommen jene Gerechtigkeit widerfahren zu lassen, die die Lebenden mit der Geschichte ein wenig versöhnt. ${ }^{\text {“50 }}$

\section{Quellen}

Barth, Hans-Martin / Elsas, Christoph (Hg.), Religiöse Minderheiten: Potentiale für Konflikt und Frieden, IV. internationales Rudolf-Otto-Symposion, Marburg, Schenefeld 2004.

de Jong-Kessing, Elisabeth, Inayat Khan: A biography, The Hague 1974.

Dessì, Ugo, Risshō Kōseika, in: Lukas Pokorny / Franz Winter (Hg.), Handbook of East Asian New Religious Movements, Leiden-Boston 2018.

Estor, Marita, Maria Alberta Lücker - Mitbegründerin von ,Religionen für den Frieden', in: Religionen unterwegs, 25/1/2019, S. 23-27.

Figl, Johann, Neue Religionen, in: Ders. (Hg.), Handbuch Religionswissenschaft, Innsbruck-Göttingen 2003.

Figl, Johann, Neureligiöse Bewegungen, in: Walter Kasper (Hg.), Lexikon für Theologie und Kirche 7, 3. Aufl., Freiburg i. Br. 1998.

Figl, Johann, Mitte der Religionen. Idee und Praxis universalreligiöser Bewegungen, Darmstadt 1993.

Gabriel, Ingeborg, Europa - quo vadis? Wirtschaft und Politik aus sozialethischer Sicht, in: Zur Debatte 1/2019.

Hazrat Inayat Khan, Gebete des Inayati-Orden - Gebete von Hazrat Inayat Khan, 2. überarb. Aufl., Heilbronn 2019.

Hazrat Inayat Khan, Complete Works of Pir-O-Murshid Hazrat Inayat Khan $(=\mathrm{CW})$. Original Texts: Lectures on Sufism 1922-1926, London-The Hague 1989-2018.

Hazrat Inayat Khan, The Sufi Message of Hazrat Inayat Khan, 13 Bände, London 1960-1967, Bd. $14=$ Index to Volume I-XIII, Varanasi (u. a.) 1988.

Hazrat Inayat Khan, Die Einheit der religiösen Idealen [sic! ], Den Haag-London 1963 (Titel der Originalausgabe: The Unity of Religious Ideals, London 1963).

Hummel, Reinhart, Kultbewegung, in: Walter Kasper (Hg.), Lexikon für Theologie und Kirche 6, 3. Aufl., Freiburg i. Br. 1997.

Kuehn, Sara / Pokorny, Lukas, On Inayati Female Visions in Austria: Female Leadership in the Western Sufi Tradition, in: Hans Gerald Hödl / Lukas Pokorny (Hg.), Religion in Austria 4, Wien 2018.

49 Vilayat Inayat Khan, Erinnerungen, Sifat, S. 11.

50 Ingeborg Gabriel, Europa - quo vadis? Wirtschaft und Politik aus sozialethischer Sicht, in: Zur Debatte 1/2019, S. 45-48, hier: S. 48. 
Lüddeckens, Dorothea, Das Weltparlament der Religionen von 1893: Strukturen interreligiöser Begegnung im 19. Jahrhundert, Berlin 2002.

Nationaler Geistiger Rat der Bahá'í in Deutschland (Hg.), Die Verheißung des Friedens: Eine Botschaft des Universalen Hauses der Gerechtigkeit an die Völker der Welt, 4. Aufl., Hofheim am Taunus 1988 (Titel der Originalausgabe: The Promise of World Peace. To the Peoples of the World. A Statement by The Universal House of Justice, 1985).

Niwano, Nikkyō, Buddhist approach to peace, Tokyo 1977.

Schulze, Christiane, Frieden durch Religion - ein japanisches Modell: Das interreligiöse Friedensprogramm der Rissho Kosei-kai (1957-1991), Frankfurt a. M. (u. a.) 2008.

Schumacher, Eric, Porträt der Sufiprinzessin Noor Inayat Khan. Dem Ruf des Einen an die Vielen, in: QANTARA.DE - Dialog mit der islamischen Welt, vgl. https://de.qantara.de/ inhalt/portraet-der-sufiprinzessin-noor-inayat-khan-dem-ruf-des-einen-an-die-vielen (letzter Zugriff: 24.05.2019).

Sifat. Zeitschrift für Universalen Sufismus, 46/2/2018: ,Sonderheft Pirzadi-Shahida Noor-unNisa Inayat Khan'.

Streib, Heinz, Friedensbildung und neue religiöse Bewegungen, in: Werner Haußmann / Hansjörg Biener / Klaus Hock / Reinhold Mokrosch (Hg.), Handbuch Friedenserziehung: interreligiös - interkulturell - interkonfessionell, Gütersloh 2006.

Witteveen, Hendrikus J., Universaler Sufismus: Die Sufi-Botschaft von Hazrat Inayat Khan, Heilbronn 1998.

Woirgardt, Ryuko, Die neuen Religionen Japans und ihr Sendungsbewußtsein im Hinblick auf den Weltfrieden: Eine Analyse am Beispiel der Seichō-no-ie-Bewegung, Frankfurt a. M. (u. a.) 1995. 


\section{Hans Gerald Hödl (Wien)}

\section{Demokratie und sakrales Königtum. Zentralmacht und Konsens im präkolonialen Afrika ${ }^{1}$}

Dieser Beitrag geht von der Diskussion zwischen den beiden Philosophen Kwasi Wiredu und Emmanuel Chukwudi Eze um eine afrikanische Form der Demokratie aus. ${ }^{2}$ Ein Punkt in Ezes Kritik an Wiredus - an der politischen Struktur des Ashanti-Königreiches orientierten - Modell ist dessen Darstellung des ,sakralen Königtums“ (divine kingship) in afrikanischen Gesellschaften mit zentralisierten Machtstrukturen als ein genuin nicht politisches Amt, das nicht in Konflikt mit einer konsensdemokratischen Entscheidungsfindung käme, in die der Herrscher vielmehr einbezogen sei. Beide gehen dabei kaum auf historisch vorfindbare „Königtümer“ im präkolonialen Afrika ein, sondern verbleiben auf einer theoretischen Ebene. Mich davon absetzend, gehe ich exemplarisch auf das Königtum in einer ost- und drei westafrikanischen Gesellschaften im präkolonialen Afrika ein, in Hinblick auf zwei Fragen: Wie wird es in den Mythen begründet und was ist seine konkrete politische Rolle?

1 In diesem Essay wird mit „Afrika“ oder „afrikanisch“ das „subsaharische“ Afrika verstanden. Damit ist nicht impliziert, dass es sich dabei um ein kulturell einheitliches Gebiet handle.

2 Kwasi Wiredu, Demokratie und Konsensus in traditioneller afrikanischer Politik, in: Franziska Dübgen / Stefan Skupien (Hg.), Afrikanische Politische Philosophie, Frankfurt a.M. 2015, S. 168-181; Emmanuel Chukwudi Eze, Demokratie oder Konsensus? Eine Antwort auf Wiredu, in: Dübgen / Skupien (Hg.), Afrikanische Politische Philosophie, S. 182-197. Die englischen Originale: Kwasi Wiredu, Democracy and Consensus in African Traditional Politics. A Plea for a Non-Party Polity, in: Emmanuel Chukwudi Eze (Hg.), Postcolonial African Philosophy. A Critical Reader, Oxford 1997, S. 303-312; Emmanuel Chukwudi Eze, Democracy or Consensus? A Response to Wiredu, in: ebd., S. 313-323. 


\section{Emmanuel Chukwudi Ezes Kritik an Kwasi Wiredus Konzept der „konsensuellen“ Demokratie nach „afrikanischem“ Vorbild}

\subsection{Wiredus „konsensdemokratisches Modell“}

In einem Artikel aus 1996 hat Wiredu ein konsensuelles Modell der Demokratie vorgeschlagen, ${ }^{3}$ das auf traditionellen afrikanischen Weisen der Legitimation politischer Herrschaft beruht. Dieses sei zur Lösung der politischen Probleme in den jungen afrikanischen Staaten besser geeignet als die importierte Form der „Mehrheitsdemokratie“. Er greift dabei - nachdem er die Verschiedenheit afrikanischer politischer Systeme kurz anspricht - auf Kofi Busias Darstellung des politischen Systems der Ashanti zurück. ${ }^{4}$ Hinsichtlich der von Fortes / EvansPritchard getroffenen Unterscheidung zwischen Gesellschaften mit zentraler Autorität und solchen, die man aufgrund des Fehlens der letzteren als „anarchistisch“ bezeichnen könnte, bemerkt er, dass „Konsensualität“ in wenig zentralisierten Gesellschaften nicht unbedingt stärker ausgebildet wäre als in solchen mit starker Zentralmacht. ${ }^{5}$ Er sucht nun am Beispiel der Ashanti zu zeigen, wie die Macht des Ashantehene ${ }^{6}$ mit konsensueller Demokratie verbunden war, resp. auf ihr beruhte. Grundlage des politischen Systems waren Lineages mit ihren Oberhäuptern, die wiederum in aus mehreren Familienverbänden bestehenden politischen Einheiten dem regierenden Rat angehörten. Das Amt des „Chiefs“ in letzteren war zwar erblich, aber der geeignete Kandidat wurde in

3 Ohne ein solches Modell im Detail auszuarbeiten.

4 Kofi A. Busia, The Position of the Chief in the Modern Political System of Ashanti. A Study of Contemporary Social Changes on Ashanti Political Institutions, London 1968.

5 Für „anarchistische“ nennt er Bemba und Banyankole, für „zentralisierte“ Ashanti und Zulu und verweist dafür auf Meyer Fortes / Edward E. Evans-Pritchard (Hg.), African Political Systems, 4. Aufl., London e.a. 1950; die einzige Quelle zu afrikanischen politischen Systemen außerhalb der Akan-Sprachgruppe, die er zitiert.

6 Der Ashantehene ist der Herrscher über eine Art Föderation von Ashanti-Staaten (zu dieser s. Busia, Position, S. 85-101; zum Ashantehene ebd., S. 96-99; s.a. Edward Geoffrey Parrinder, Divine Kingship in West Africa, in: Numen 3/1956, S. 111-121, hier: S. 111). Er ist auch Haupt des Rats eines der 7 Hauptclans der Ashanti, welchem 7 weitere Chiefs angehören (Busia, Position, S. 218). Das Ashantireich entstand um 1700, als Osei Tutu aus den Ashanti-Gesellschaften eine „single strong union“ geformt hat (Robert O. Collins / James M. Burns, A History of Sub-Saharan Africa, 2. Aufl., Cambridge 2014, S. 140; s.a. Busia, Position, S. 96), von Vansina als „Föderation“ bezeichnet (s. u., Anm.31). Die Einheit wurde durch einen goldenen Stuhl, den der Priester Okomfo Anokye vom Himmel gebracht hatte, symbolisiert, in dem die Seele der Ashanti enthalten war, zu der sie Treue schworen (Collins / Burns, History, S. 140; Busia, Position, S. 96; Parrinder, Kingship, S. 112). 
einer Art Wahl gefunden, die auf dem Konsensprinzip beruhte. ${ }^{7}$ Die Entscheidungen des Chiefs waren nicht autokratisch, sondern vom Konsens der Räte bestimmt. So konnte sich jede Lineage theoretisch in der Zentralmacht repräsentiert fühlen. Die Heiligkeit des sakralen Königtums wurde lt. Wiredu aus der Verbindung zu den Ahnen abgeleitet. ${ }^{8}$ Die Oberhäupter hätten zwar a) selbstherrlich regieren können, wären dann aber wohl abgesetzt worden ${ }^{9}$ und b) ihren Willen nur als Mitglied des Rates aufgrund der Überzeugungskraft ihrer Ideen durchsetzen können.

Wiredu betont das bewusste Festhalten am Konsensprinzip bis zur höchsten Ebene der Macht und führt einige Sprichwörter resp. ein „Kunstmotiv“"10 der Ashanti als Beleg dafür an, dass Konsens die Grundlage der Gesellschaft gebildet hätte. Das letztere ist die Darstellung eines Krokodils mit 2 Köpfen, die einander um Nahrung bekämpfen. Er erläutert an diesem Beispiel das Grundprinzip des von ihm entworfenen Modells der „Konsensdemokratie“: Die beiden Köpfe würden demnach aufhören, einander zu bekämpfen, wenn ihnen klar wäre, dass die Nahrung für denselben Körper, dem sie angehören, bestimmt ist, egal auf welchem Weg sie in den Verdauungstrakt gelangt. Menschen haben demnach „die Fähigkeit, sich durch Differenzen hindurch bis zum tiefsten Grund der Identität ihrer Interessen durchzukämpfen“, es gäbe in menschlichen Beziehungen für die Ashanti „kein Problem [...] das nicht durch Dialog gelöst werden könnte“. ${ }^{11}$ Man kann sich fragen, ob dem wirklich so ist, und, ob, selbst wenn dem so sei, eine konsensuelle Demokratie dafür geeigneter sei als eine repräsentative.

\subsection{Die Kritik Ezes an Wiredus Modell}

In seiner Kritik diskutiert Eze diese beiden Fragen. Zunächst betont er, dass Wiredu unter Konsensdemokratie weder ein Einparteiensystem versteht noch ein solches unterstützt. Wiredu sehe in seinem Konsensmodell einen demokratischen Rahmen, der alle Stimmen an der Entscheidungsfindung teilnehmen

7 Die „Wahlmodalitäten“ von „Elders“ „Chiefs“ und des Nkwankwaahene (der Repräsentant der „commoners“) unter Einbezug der Königinmutter usw. werden detailliert bei Busia, Position, S. 7-13, geschildert.

8 Er bezieht sich dabei auf William E. Abraham, The Mind of Africa, Accra 2015 (reprint), S. 38-115. Dort werden die Akan als paradigmatisch für alle afrikanischen Gesellschaften behandelt.

9 Wiredu, Demokratie, S. 173. Ebd., S. 172 weist er darauf hin, dass bestimmte Gründe dazu führten, dass das prinzipiell lebenslang ausgeübte Amt nicht lebenslang ausgeübt würde.

10 Ebd., S. 174; man kann es ein „Sprichwort“ nennen, weil es eben eine „Lebensweisheit“ versinnbildlicht.

11 Ebd., S. 174. 
lässt. ${ }^{12}$ Eze nennt das ein "esoterisches“ Modell, das man im Diskurs um Staatsmodelle im postkolonialen Afrika als eine Option für eine „Rückkehr zum Ursprung ${ }^{\text {“13 }}$ charakterisieren könnte, als Alternative zu importierten, „exoterischen“ Demokratieverständnissen, die Eze - in Abhebung von „konsensueller Demokratie“ - als „kontroversiell ${ }^{\text {“14 }}$ bezeichnet. In der Folge geht er zunächst auf Wiredus Darstellung der Tradition ein. Er bemerkt, dass Wiredu in Bezug auf die Qualifikation zum Amt des Chiefs einer Lineage das Hindernis der „moralischen Degeneration" nennt, es aber a) nicht näher beschreibt und es b) fraglich ist, inwiefern die moralischen Codes der Ashanti für ganz Afrika gelten. ${ }^{15}$ Hier zitiert er Wiredu ungenau, wenn er schreibt, dieser meine „[...] that qualification for the political office [...] involves moral considerations:, moral degeneration' is an impediment for this office ". ${ }^{16}$ Das kann man aus Wiredus Ausführungen schließen, dieser schreibt aber, dass moralische Degeneration u. a. ein Grund dafür sei, dass das Amt nicht lebenslang ausgeübt werde: „This office [...] is for life, unless moral, intellectual, or physical degeneration sets in “. ${ }^{17}$ Es geht primär um die Frage der Absetzung von Lineage Chiefs bis zum Ashantehene. In der Literatur werden dafür Gründe angegeben, bei Parrinder etwa für die Absetzung eines Königs bei den Ashanti: „chronic drunkenness, cruelty, impotence or madness “. ${ }^{18}$ Zumindest für „cruelty“ und „madness“ gilt, dass diese Kategorien kulturell recht unterschiedlich definiert sein können. Busia nennt sowohl „moralische“ als auch „physische“ (Blindheit, Lepra usw.) Gründe für Entthronungen von Chiefs. ${ }^{19}$

Eze hebt dann auf die von Wiredu angeführten Quellen der Legitimation des sakralen Königtums ab: die Ahnen, das Göttliche, das „Heilige“ und die Überzeugungskraft der Ideen des Herrschers. Er bezweifelt, dass die letztgenannte Quelle, die eigentlich „politische" Legitimation $\operatorname{se}^{20}{ }^{20}$ und kritisiert die mit dem Bild der Krokodilköpfe illustrierte Ansicht Wiredus von der grundlegenden Einheit der Interessen in einer Gesellschaft, denn dieses setze voraus, dass keines

12 Eze, Antwort, S. 184-185.

13 Ebd., S. 182.

14 Ebd., S. 183.

15 Ebd., S. 186.

16 Eze, Response, S. 316.

17 Wiredu, Democracy, S. 305.

18 Parrinder, Kingship, S. 111.

19 Busia, Position, S. 21-22; unter den „moralischen “ Gründen finden sich etwa „drunkenness“, „dealing in charms and noxious medicine“ und „not following the advice of his elders“. Letzterer Fall (er betraf den Chief von Juaben) ist ein Argument für Wiredus Schilderung der Stellung der Chiefs vis-a-vis ihrer Ratgeber.

20 Weder sei es wahrscheinlich, dass nur eine der genannten Quellen ausschlaggebend sei, noch, dass der König oder die Untertanen die „Überzeugungskraft der Ideen“ für die alleinige Herrschaftslegitimation gehalten hätten (Eze, Antwort, S. 187). 
ihrer Mitglieder „eine individualisierte Struktur des Begehrens“21 entwickelt hätte. ${ }^{22}$ Er bringt ein Verständnis von Demokratie ins Spiel, das auf dem Prinzip beruht, einen Rahmen für „Zustimmung“ und „Nichtzustimmung“ so zu institutionalisieren, dass die Interessen beider Seiten gewahrt bleiben. Anders gesagt: einer parlamentarischen Demokratie mit Gewaltentrennung und einer nicht unterdrückten Opposition. Im Endeffekt stehen sich zwei Modelle des Interessensausgleichs gegenüber: Ezes Ansatz bei der Institutionalisierung der „Nichtzustimmung“, die mittels gewählter Repräsentanten Raum im Kräftespiel ebenso hat, wie die jeweilige Regierung und ihr Programm, und Wiredus Modell, das vorsieht, so lange zu verhandeln, bis alle zugestimmt haben.

\section{Sakrale Herrschaft}

Dieser Diskurs wirft weitere Fragen auf. Zunächst: Ist das von Wiredu dargestellte politische System der Ashanti das genuin "afrikanische“ System politischer Legitimation? Matthew Bradley zufolge hat es im präkolonialen Afrika sowohl in dezentralisierten als auch in zentralisierten Gesellschaften ${ }^{23}$ von sog. „westlichen “ Demokratien unterschiedene demokratische Systeme gegeben. ${ }^{24} \mathrm{Er}$ nennt 3 Arten, die auch in der zeitgenössischen politischen Landschaft Afrikas noch zu finden wären: ${ }^{25}$ a) „Communalism“, mit der dezentralisierten traditionellen Gesellschaftsordnung der Igbo als Beispiel; ${ }^{26}$ b) „Nonpartyism“, wofür er Uganda in den 1990er Jahren als Beispiel nennt; dieses System beruht auf Direktwahlen, lokale „Komites“ werden direkt gewählt und wählen die nächsthöheren Instanzen politischer Repräsentation usw. ${ }^{27}$ c) „Chieftancy“, heute noch im südlichen Afrika verbreitet, charakterisiert durch die Partizipation von Clanoberhäuptern, die eine ähnliche politische Funktion erfüllen wie in „westlichen“ Demokratien Protagonisten zivilgesellschaftlicher Institutionen. Brad-

21 Ebd., Hervorhebungen Eze („individuated structure of desire“ im englischen Original).

22 Das weist darauf hin, dass die Rede von „traditionellen Gesellschaften“ auf soziale Ordnungen rekurriert, in denen das Individuum zuerst durch seinen Ort im sozialen Gefüge definiert ist und wenig Raum für weiteres individuelles Begehren bleibt. Eze zeigt, dass im postkolonialen Afrika ein solches Modell kaum zur Lösung der Probleme in globale ökonomische Beziehungen eingebundener multiethnischer Staaten dienen kann.

23 Da lt. Wiredu zentralisierte Systeme das Konsensprinzip sorgfältig kultiviert hätten (Wiredu, Demokratie, S. 173), konzentriere ich mich hier auf solche.

24 Mattew Todd Bradley, „The Other“. Precursory African Conceptions of Democracy, in: International Studies Review 7/2005, S. 407-431.

25 Ebd., S. 410-413.

26 „[...] where village elders present issues directly to village citizens with everyone having input into the discussions and ultimate decision" (Ebd., S. 410).

27 Was lt. Bradley zu „fluidity, stability, and transparency in the process“ führe (Ebd., S. 411). 
ley geht dann auf präkoloniale Formen afrikanischer Demokratie ein. ${ }^{28}$ Er nennt 5 Formen dezentralisierter ${ }^{29}$ und 2 Formen zentralisierter Gesellschaften, die jedoch demokratisch verfasst gewesen seien: „Pyramidale“ und „verbindende “ ${ }^{30}$ Als typisch pyramidale Gesellschaft nennt er das Yorùbá Königreich Ọyọ́, in dem aus Lineage-Häuptern gebildete Räte dem König als zentraler Autorität gegenüber standen. ${ }^{31}$ „Verbindende“ meint, dass zusätzlich zu Lineages repräsentierenden Räten diese transzendierende „zivilgesellschaftliche“ Komites an der Entscheidungsfindung Teil haben. ${ }^{32}$ Gegen die These durchgängig demokratischer Verfasstheit afrikanischer Königreiche spricht die schon 1962 von Jan Vansina unter strukturellem Gesichtspunkt getroffene Unterscheidung von 5 Typen afrikanischer Königreiche, unter denen auch das von Busia dargestellte Ashanti-Königtum angeführt wird. ${ }^{33}$ Vansinas Darstellung lässt es zweifelhaft erscheinen, dass in „traditionellen“ afrikanischen Gesellschaften alle Bevölkerungsgruppen in einen konsensuellen Entscheidungsprozess eingebunden waren. ${ }^{34}$ Wiredus Ausführungen werfen auch die Frage auf, ${ }^{35}$ ob „sakrales Königtum" in Afrika stets unpolitisch verstanden wurde, im Sinne einer klaren Scheidung von sakraler Legitimation des Herrschers ${ }^{36}$ von auf der Überzeugungskraft von Ideen beruhender politischer Legitimation. Lt. Vansina waren

28 „Throughout [...] the precolonial era, African political systems were essentially democratic“ (Ebd., S. 415). Er nennt die auch von Wiredu zitierte Studie Busias als Evidenz dafür, dass es "extensive anthropological evidence of democratic governance in indigenous African states“ gibt - man kann sich ernsthaft fragen, wie man aus einer Studie zu einer westafrikanischen Gesellschaft ein solches generalisierendes Urteil ableiten kann.

29 Ebd., S. 414-416; diese werden hier, wo auf Sozietäten mit Zentralmacht fokussiert wird, nicht berücksichtigt.

30 Ebd., S. 416; mit „verbindende“ habe ich Bradleys Ausdruck „associational“ übersetzt.

31 Ebd.: „federal power is counterbalanced in a kind of checks and balances“; auf Ọyọ́ gehe ich u. näher ein.

32 Ebd., S. 417; Bradley berücksichtigt weder die Wiredu-Eze-Kontroverse noch Jan Vansina, A Comparison of African Kingdoms, in: Africa: Journal of the International African Institute 32/1962, S. 324-335.

33 Als das einzige Beispiel für den Typus „Föderation“: „The only clear case of a federation in Africa seems to be the Ashanti Union. Here the king rules over the external affairs of the federation of chiefs, over which he presides. He is then only primus inter pares" (Vansina, Comparison, S. 333). Die Einteilung in fünf Typen ergibt sich aus zwei Variablen, dem Grad an Zentralautorität und der Nachfolgeregelung der Chiefdoms a) in der königlichen Linie oder b) in aristokratischen Abstammungslinien hereditär oder c) vom König eingesetzt.

34 So, wenn er einen Typus „despotisch“ nennt („The king appoints all other officials and wields absolute power"; Vansina, Comparison, S. 333); Beispiele sind etwa Bunyoro, Ruanda und Kongo im 16. Jahrhundert (dass Kongo später anders organisiert war, weist auf die Ahistorizität von Wiredus Argumentation hin).

35 Eine Frage, die Eze zwar theoretisch, aber nicht anhand von historischen Beispielen abhandelt.

36 In rein „symbolischer“, „mythischer“, „religiöser“ Bedeutung. 
alle Königreiche im präkolonialen Afrika sakrale Königtümer im Sinne James G. Frazers. ${ }^{37}$

Die Institution des sogenannten „sakralen Königtums“, wie in Frazers Theorie entworfen, ist Jahrzehnte lang kontrovers diskutiert worden.$^{38}$ Lt. Frazer war das Königtum bei Völkern mit agrarischer Wirtschaftsform eng mit dem Gedeihen der Vegetation verbunden. In seiner Lesart ist ritueller Königsmord wesentlicher Bestandteil sakralen Königtums. Schwinden die Kräfte des Königs, muss die göttliche Macht auf den Nachfolger übertragen werden, wozu die Tötung des Königs dient. ${ }^{39}$ Afrikanische Bezugspunkte für seine Theorie bilden Ethnien, in denen seinen Quellen zufolge ritueller Königsmord oder -selbstmord stattgefunden hat, wobei er die ostafrikanischen Shilluk und die westafrikanischen Òyộ́-Yorùbá erwähnt. ${ }^{40} \mathrm{Ob}$ Frazers Interpretation zutrifft oder nicht, „sakrales Königtum“ findet sich in mehreren afrikanischen Gesellschaften. ${ }^{41}$ Wiredu stellt jedoch, ohne Bezug auf die lange Diskussion zu nehmen, apodiktisch die Natur des sakralen Königtums fest. Um seine These der Scheidung von Sakralität des Amtes von realer politischer Macht zu überprüfen, will ich kurz auf die in Ursprungsmythen gegebene Begründung der Institution des Königtums und auf die reale Macht des Königs in einigen afrikanischen Gesellschaften eingehen.

\subsection{Gründungs- und Ursprungsmythen: Legitimation zentralisierter Herrschaft}

In den Mythen der Yorùbá ${ }^{42}$ finden sich zwei Arten der Begründung königlicher Herrschaft. Erstens, indem das Herrschergeschlecht sich eine direkte göttliche

37 Vansina, Comparison, S. 325.

38 Vgl. dazu Wyatt MacGaffey, Kingship in Sub-Saharan Africa, in: Mircea Eliade (Hg.), The Encyclopedia of Religion 8, New York 1987, S. 322-325. Sehr ausführlich Gillian FeeleyHarnik, Issues in Divine Kingship, in: Annual Review of Anthropology 14/1985, S. 273-313.

39 Er interpretiert auch Mythen getöteter Gottheiten im Kontext rituellen Königmordes (James George Frazer, The Golden Bough. A Study in Magic and Religion, abridged ed., London 1995, S. 264-266; S. 335; S. 384).

40 Frazer, Bough, S. 264-266; S. 271; auf das Königtum der Yorùbá und Shilluk gehe ich noch ein.

41 Vgl. MacGaffey, Kingship, und Audrey Richards, Keeping the King Divine, in: Proceedings of the Royal Anthropological Institute of Great Britain and Ireland 1968, S. 23-35, hier: S. 23.

42 Der Name „Yorùbá“ stammt von den Haussa, nördlichen Nachbarn des Königreiches Òyọ́. Er wurde zunächst nur für die Òyọ́ benutzt. Die „Yorùbá“-sprachigen Ethnien sahen sich, trotz Sprachgemeinschaft und geteilten Abstammungsmythos nicht als Teile einer übergreifenden Ethnie. Kollektivbezeichnungen für Yorùbá-sprachige entstanden erst in Diasporasituationen in Amerika und Afrika (John D.Y. Peel, Religious Encounter and the Making of the Yoruba. Bloomington-Indianapolis 2003, S. 283-285). In der Schreibweise des Yorùbá ver- 
Abkunft gibt. Der Mythos erzählt, dass die Welt in Ile Ifé erschaffen wurde, dem Stadtkönigtum, auf das sich alle anderen Yorùbá Königreiche ${ }^{43}$ zurückführen. Ọbàtálá (der Hauptòrìșà von Ifé) und Odùdúwà (der Stammvater der Yorùbá) gehören zu den deszendierten Òrìșà, ${ }^{44}$ den Irùnmolé, die am Anfang der Welt vom Himmel herabgekommen sind, um auf der bis dato leeren Wasserfläche die Erde auszubreiten, Menschen zu erschaffen und den Kosmos zu strukturieren. ${ }^{45}$ Dieser Mythe zufolge gab es einen Kampf um die Herrschaft zwischen Odùdúwàs Leuten, den Ifé, und Ọbàtálás Leuten, den Igbo, der durch die Intervention einer Frau namens Mọrèmi, die ihren Sohn geopfert hat, beendet wurde. ${ }^{46}$ Odùdúwà gilt als der erste Oọ̀ni ${ }^{47}$ von Ifé, die anderen Yorùbá-Königreiche führen sich auf ihn, resp. seinen Sohn Ộrànmíyan zurück. Ọbàtálá gilt als vierter Oba von Ifé und als dessen Hauptòrìsà. Das jährliche Fest für Ọbàtálá in Ifé ist eine dramatischrituelle Aufführung der im Mythos überlieferten Gründungsgeschichte, in der vor allem die Spannung zwischen den Herrschaftsansprüchen der beiden Òrìșà, Odùdúwà und Ọbàtálá, thematisiert wird. ${ }^{48}$ Dieser mythologische Komplex enthält a) eine „göttliche“ Begründung des königlichen Herrschaftsanspruches, weiß b) um einen primordialen Kampf um die Macht, legt c) eine genealogische Herrschaftsbegründung fest, die in der göttlichen Sendung Odùdúwàs gründet, und berichtet d) von einem mit Herrschaftsstabilisierung verbundenen Men-

wende ich diakritische Zeichen für Tonhöhen (ó für Hoch-, ò für Tief-, o für Mittelton) und geschlossene Vokale (ọ usw.), ș für „sch“. In Zitaten aus der Literatur folge ich der dort jeweils verwendeten Schreibweise. Bei der Vokalisation des Yorùbá folge ich in der Regel Emanuel Bọlaji Idowu, Olódùmarè. God in Yoruba Belief, London 1962.

43 Und das historische Königreich von Benin. Zu dessen Herkunftsmythe vgl. Leonhard Harding, Das Königreich Benin. Geschichte - Kultur - Wirtschaft, München 2010, S. 57-61.

44 Òrìsà ist der Name für die Yorùbá-,,Gottheiten“ im Zentrum der religiösen Aktivitäten. Olódùmarè, der Hochgott, ist ein Deus otiosus. Die politische Herrschaft in Yorùbá-Königreichen ist mit den Òrị̀à verbunden.

$45 \mathrm{Zu}$ den verschiedenen Versionen des Mythos vgl. Idowu, Olódùmarè, S. 19-21; S. 23; Harold Scheub, A Dictionary of African Mythology. The Mythmaker as Storyteller, Oxford e.a. 2000, S. 196; Stephen Belcher, African Myths of Origin, London e.a. 2003, S. 310-313; Jacob K. Olúpọnnà, City of 201 Gods. Ilé - Ifé in Time, Space, and the Imagination, Berkely e.a. 2011, S. 29; Uli Beier, Yoruba Myths, Cambridge 1980, S. 7-10; Robert S. Smith, Kingdoms of the Yoruba, London 1969, S. 11; Newell S. Booth, God and the Gods in West Africa, in: Newell S. Booth (Hg.), African Religions. A Symposion. New York e.a. 1977, S. 159-181, hier: S. 163165.

46 Igbo $=$ „Waldmenschen“, nicht ident mit den südöstlichen Nachbarn der Yorùbá in Nigeria; vgl. insgesamt Ọmófọlábọ S. Àjàyí, Yoruba Dance. The Semiotics of Movement and Body Attitude in a Nigerian Culture. Trenton, NJ 1998, S. 49-50; Olúpọnà, City, S. 207; Belcher, Myths, S. 313-315; zu Mọrèmi s.a. Olúpọnnà, City, S. 203-223. Nach Idowu, Olódùmarè, S. 23, war Orișànlà (ein anderer Name für Obàtálá) die Schutzgottheit der ansässigen Bevölkerung, die mit der eingewanderten Odúdùwá-Gruppe in Konflikt kam.

47 Der Titel des Königs - „Oba“ heißt König, aber in jedem Yorùbá-Königreich hat der Oba einen eigenen Titel.

48 Eine genaue Beschreibung bei Àjàyí, Dance, S. 51-76. 
schenopfer. Ein anderer Mythos, den man dem Genre der „Migrationsmythen“ zuweisen kann, erzählt, dass Odùdúwà ein mekkanischer Prinz gewesen sei, der, wegen Abfalls vom muslimischen Glauben aus Mekka vertrieben, in Ifé sein Königreich gegründet habe. Dieser Mythos verbindet die Entstehung der Yorùbá Stadtkultur mit dem Islam. ${ }^{49}$ Zwischen ihm und den Mythen, die die Legitimation von Königen der Yorùbá-Reiche aus einer Abstammung aus Ifé herleiten, besteht eine Ähnlichkeit: Man gibt sich eine Herkunft aus einer etablierten fremden Dynastie. ${ }^{50}$ Wir finden das auch bei den Königen von Mali: Dessen erster Herrscher, Barmandana, wurde Muslim, ${ }^{51}$ als Reichsgründer gilt in den oralen Traditionen aber Sundiata (Sun-Djața), ${ }^{52}$ der von Lawalo abstammen sollte, einem Sohn (oder Enkelsohn) von Bilal, dem ersten Muezzin des Islam, einem freigelassenen schwarzen Sklaven. ${ }^{53}$ Damit gab man sich eine Abstammung, die die Herrschaft mit dem Propheten verbunden hat. ${ }^{54}$

Züge einer „Migrationsmythe“ weist auch der Gründungsmythos des Anfang des 17. Jahrhunderts in Abomey etablierten Fon-Königreiches Dahomey auf. Er führt die Abstammung der königlichen Familie ${ }^{55}$ auf eine Prinzessin mit Namen Aligbonon zurück, die mit einem Leoparden Beischlaf hatte, woraus Agasu, der tohwiyo ${ }^{56}$ des Clans, hervorgegangen sei. ${ }^{57}$ Der Überlieferung zufolge hat sich

49 Bei Samuel Johnson, The History of the Yorubas. From the Earliest Times to the Beginning of the British Protectorate, London 1921, stammt Odúdùwà von dem aus Mekka vertriebenen Lamurudu ab.

50 MacGaffey, Kingship, S. 325, nennt eine Interpretation dieser Art von Abstammungserzählungen, wonach diese die Fremdheit/Abgehobenheit des Königs vom Volk betonen sollten.

51 Ibn Khaldūn (1332-1406) nennt ihn als ersten König von Mali (Nehemiah Levtzion / Jay Spaulding (Hg.), Medieval West Africa. Views from Arab Scholars and Merchants, 3. Aufl., Princeton, NJ 2011, S. 90); s.a. Basil Davidson, A History of West Africa 1000-1800. London 1977, S. 48-49 (dort 1050 als Regierungszeit).

52 Bei Ibn Khaldūn (1332-1406) „Mari-(D)jața“ (Levtzion / Spaulding, Medieval, S. 90); zu dessen Identität mit Sun-Djața vgl. Nehemia Levtzion, The Thirteenth- and FourteenthCentury Kings of Mali, in: The Journal of African History 4/1963, S. 341-353, hier: S. 343; Ebd., S. 353 Regierungszeit Sun-Djatas 1230-1255.

53 Vgl. David Robinson, Muslim Societies in African Histories, Cambridge e.a. 2004, S. 54-55; vgl. David C. Conrad, Islam in the Oral Traditions of Mali. Bilali and Surakata, in: The Journal of African History 26/1985, S. 33-49, hier: S. 35-39.

54 Conrad, Islam, S. 25, nennt als ein in Westafrika wichtiges islamisches Ideal „the notion that direct ancestral links to the Prophet $[\ldots]$ were $[\ldots]$ sources of prestige, and genealogies $[\ldots]$ were manipulated accordingly".

55 „Alladohonu“ (Leute aus Allada), meint speziell die königliche Familie Dahomeys (Edna G. Bay, Wives of the Leopard. Gender, Politics and Culture in the Kingdom of Dahomey. Charlottesville-London 1998, S. 353).

56 Der tohwiyo ist im Denken der Fon der Stammvater eines Clans (Robin Law, History and Legitimacy. Aspects of the Use of the Past in Precolonial Dahomey, in: History in Africa 15/ 1988, S. 431-456, hier: S. 434). Nach Mercier ist der Clan Grundlage des sozialen Lebens der Fon. Dessen Mitglieder teilen ein gemeinsames Wesen und üben denselben Kult ihres tohwiyo aus (Paul Mercier, The Fon of Dahomey, in: Daryll Forde (Hg.), African Worlds. Studies 
eine Gruppe von Adja-Edelleuten in Allada angesiedelt; ein Streit unter drei Prinzen habe dazu geführt, dass zwei Allada verlassen hätten und Porto Novo ${ }^{58}$ und Abomey gegründet haben. Wegbadja gilt in der Tradition als der eigentliche Gründer des Königreichs..$^{59}$ Die Bedeutung des Namens „Danhomé“ wird meist mit „Im Bauch von Dan“ wiedergegeben: Demnach haben Dakadonu oder Wegbadja von einem König Namens Dan Land gefordert, bis dieser ihn gefragt habe, ob er denn auch seinen Bauch wolle, worauf er von jenem getötet wurde. Der königliche Palast sei über dem Leichnam errichtet worden. ${ }^{60}$ Der Gründer der Dynastie ist also ein erfolgreichen Eroberer.

Ein Migrationsmythos ist auch bei den ostafrikanischen Shilluk überliefert, einem Luo-sprachigen Volk, das sein Königtum auf den im König (Reth) anwesenden Kulturheros Nyikang zurückführt. ${ }^{61}$ Dieser hat das Volk an seinen jetzigen Wohnort geführt und dabei - gemeinsam mit seinem Sohn Dak - große Taten vollbracht, u.a. die Erschaffung von Menschen aus Tieren. ${ }^{62}$ Ein My-

in the Cosmological Ideas and Social Values of African Peoples. New Introduction by Wendy James, Hamburg 1999, S. 210-234, hier: S. 225). Nach Bay, Wives, S. 14, meint „t5“ "agent“, „hwiyo“ „worshipped“ und ist der tohwiyo meist ein wildes Tier. Man kann das als eine Art „Totemismus“ ansehen.

57 Auguste Le Hérissé, L’ancien royaume du Dahomey. Mœurs, religion, histoire, Paris 1911, S. 10; Bay, Wives, S. 48-49; S. 72-73; Law, History, S. 434. Wahrscheinlich ist die Ethnie der Fon durch Vermischung einer eingewanderten Ewe-sprachigen Gruppe aus Adja, Tado (heute in Togo) mit der ansässigen Yorùbá-sprachigen Bevölkerung (Gedevi) entstanden (Jaques Lombard, The Kingdom of Dahomey, in: Daryll Forde / Phyllis M. Kaberry (Hg.), West African Kingdoms in the Nineteenth Century, Oxford 1967, S. 70-92, hier: S. 70-72; S. 73).

58 Historiker führen die Gründung der Stadt durch Migranten aus Allada auf die Zeit um 1730 zurück (vgl. Yves Person, Chronologie du royaume gun de Hogbonu (Porto-Novo), in: Cahiers d'Études Africaines 15/1975, S. 217-238), als Abomeys Herrscher Agaja Allada seinem Reich einverleibt hat (Marie-Josée Pineau-Jamous, Porto-Novo. Royauté, localité et parenté, in: Cahiers d'Études Africaines 26/1986, S. 547-576, hier: S. 549).

59 Nach Le Hérissé, Royaume, S. 13, der zweite König (1650-1680) nach Dakadonu, von dem er allerdings bemerkt: „Dako n'est pas à proprement parler le fondateur du Dahomey“ (Ebd., S. 12). Nach Bay, Wives, S. 49, war Wegbadja der erste König. Ebd., S. 73, nennt sie Dakadonu den Gründer Dahomeys, dessen Sohn Wegbadja erster König wurde. Richard Burton nennt im Anhang seines Berichts aus den 1860er Jahren Wegbadja den ersten „König“ von Dahomey, Dakodonu sei bloß ein „Chief“" gewesen (zit. n. Law, History, S. 439).

60 Bay, Wives, S. 50; Law, History, S. 432. Nach anderen Versionen hat Akaba, Wegbadjas Sohn, diese Tat ausgeführt. Zur Theorie, Akaba sei der erste König gewesen, vgl. Bay, Wives S. 323.

61 Nyikang ,is [...] the first reth of the Shilluk [...] the soul of Nyikang is reincarnate in every reth, and thus exists both in the past and the present." (Paul Philip Howell / W. P. G. Thomson, The Death of a Reth of the Shilluk and the Installation of his Succesor, in: Sudan Notes and Records 27/1946, S. 5-85, hier: S. 8; vgl. Godfrey Lienhardt, The Shilluk of the Upper Nile, in: Forde, African Worlds, S. 138-163, hier: S. 153; David Graeber, The Divine Kingship of the Shilluk. On Violence, Utopia, and the Human Condition, or, Elements for an Archaeology of Sovereignty, in: HAU: Journal of Ethnographic Theory 1/2011, S. 1-62, hier: S. 3; S. 24.

62 Nyikang gilt nicht als Schöpfer der Menschheit. Er hat eine vorhandene Gruppe an einen neuen Ort geführt und dort aus Tieren Menschen gemacht. Das könnte auf Totemismus 
thenkomplex, der sich auf eine Migration im 16. Jahrhundert beziehen dürfte, ${ }^{63}$ reflektiert die Spannung zwischen Matri- und Patrilinearität: ${ }^{64}$ Nyikangs Vater Okwa, ein von einer göttlichen Kuh abstammender König in einem fernen Land, paarte sich mit einer Tochter des Krokodils, der Mutter Nyikangs, ${ }^{65}$ der mit seinen Gefolgsleuten das Land verlässt und im Land des Königs Dimo dessen Tochter heiratet. Einer seiner beiden Söhne, Dak, der die königliche Lineage begründet, tötet die Enkelkinder des Krokodils. ${ }^{66}$ Daks eifersüchtige Onkel (die Mutterbrüder), beschließen, ihn zu töten. Nyikang stellt eine Statue aus Ambatch-Holz her, ${ }^{67}$ die er in der Nähe von Dak platziert, der sein Instrument spielt. In der Meinung, sie sei Dak, stechen die Onkel auf sie ein. Nyikang behauptet, sein Sohn sei getötet worden. Beim Trauerritual kommt Dak aus seinem Versteck, worauf seine Onkel fliehen. Es kommt wegen einer Kuh zu einem Konflikt mit der Sonne, in dessen Verlauf Dak den Sohn der Sonne besiegt, dessen Arme abschneidet und dessen silberne Armreifen an sich nimmt. Nyikang trifft die Sonne mit seiner Dechsel, worauf jene zum Himmel geht. ${ }^{68}$ Mit den Armreifen des Sonnensohns erweckt er seine toten Krieger wieder zum Leben. ${ }^{69}$

hinweisen; Charles G. Seligman, The Religion of the Pagan Tribes of the White Nile, in: Africa. Journal of the International African Institute 4/1931, S. 1-21; hier: S. 3-4, hat bei den Shilluk kein ausgeprägtes totemistisches Clanystem festgestellt. Der Hochgott ist Juok, "present $[\ldots]$ in all things $[\ldots]$ the explanation of the unknown $[\ldots]$ justification of all the supernatural phenomena [...]" (Howell /Thomson, Reth, S. 5; vgl. Seligman, Religion, S. 3-5; Lienhardt, Shilluk, S. 154-156).

63 ,The Shilluk appear to have originated in the sixteenth century with the invasion of the White Nile region from the south by a small Luo-speaking group [...], associated in Shilluk lore with [...] Nyikang" (Patricia Mercer, Shilluk Trade and Politics from the Mid-Seventeenth Century to 1861, in: The Journal of African History 12/1971, S. 407-426, hier: S. 410.

64 In diese Richtung interpretiert Godfrey Lienhardt den Mythenkomplex (Nilotic Kings and Their Mothers' Kin, in: Africa. Journal of the International African Institute 25/1955, S. 29-42, hier: S. 29-30, S. 32-36; zum Mythos vgl. a. Lienhardt, Shilluk, S. 145-150; Graeber, Kingship, S. 21-25; Scheub, Dictionary, S. 189-190.

65 Nyakaya, als Flussgottheit verehrt. Lt. Seligman ,the embodiment of the totality of riverine creatures and phenomena" (zit. n. Graeber, Kingship, S. 22).

66 Lt. Lienhardt ein Hinweis auf die Spannung zwischen väterlicher und mütterlicher Lineage: „The crocodiles are the agnatic kin of [...] the mother of the Shilluk royal clan“ (Lienhardt, Kings, S. 33).

67 Eine sehr leichte Holzart; in der Inthronisation des neuen Reth verwendete Statuen von Nyikang und Dak - als Symbole der Ewigkeit des Königsamts interpretiert - sind daraus gefertigt (Graeber, Kingship, S. 23).

68 Aus den oben, Anm. 63, zitierten Versionen geht nicht klar hervor, ob die Sonne jetzt erst zum Himmel geht (der Mythos den jetzigen Ort der Sonne erläutert) oder dorthin zurückkehrt.

69 Die Armreifen und Statuen von Dak und Nyikang (abstrakte, nicht figürliche, s. die Zeichnung bei Howell / Thomson, Reth, auf der Rückseite des Blattes zwischen S. 40 und S. 41) spielen in den Inthronisationsriten eine zentrale Rolle (Howell / Thomson, Reth, S. 37-72). Lienhardt, Shilluk, S. 148f; lt. Howell / Thomson, Reth, S. 71, trägt der neue Reth am Schlusstag der Inthronisierung silberne Armreifen. 
Lt. Howell / Thomson treffen alle Eigenschaften des „sakralen Königs“ bei Frazer auf den Reth $\mathrm{zu}^{70}{ }^{70}$ allerdings differenzieren sie, was die rituelle Tötung des Königs betrifft: Die faktische Tötung des Reth aus Alters- oder Schwächegründen durch eine seiner Frauen wird nur durch Tradition gestützt (es wird also erzählt), während es für die Ermordung des Königs durch potentielle Nachfolger neben klaren Belegen aus der Tradition auch deutliche Evidenz in der Feldforschung gibt. ${ }^{71}$ Die auf Evans-Pritchard folgende Diskussion um die rituelle Tötung des Königs ${ }^{72}$ resümiert Graeber so: „The ,did Africans really kill their kings?' debate raged for years, ending [...] with a general recognition that at least in some cases - the Shilluk being included [...] - yes, they did." ${ }^{\text {73 }}$

Man kann folgende Spielarten eines „sakralen Königtums“ in den von mir zitierten Überlieferungen finden: eine, auf den ersten Blick, direkte „göttliche“ Abkunft von Odùdúwà, der ein Migrationsmythos gegenübersteht, der jenen als mekkanischen Prinzen sieht, womit die nicht-muslimischen Yorùbá-Königreiche in Beziehung zur islamischen Kultur gesetzt werden. ${ }^{74}$ Von Nyikang wird gesagt, er sei nicht gestorben, sondern gegangen wie der Wind. ${ }^{75}$ Er stellt a) die Totalität der Shilluk dar und ist b) in den einzelnen Reth, seinen Nachfolgern, anwesend gedacht. Der Herrscher von Dahomey geht auf einen besonderen tohwiyo zurück. Im Falle von Mali haben wir das In- oder Nebeneinander traditioneller oraler Überlieferungen und muslimischer Traditionen vor uns: Ibn Battuta zeigte sich verwundert darüber, dass die Untertanen dem malischen Herrscher Ehrenbezeugungen wie einem paganen „sakralen“ Herrscher erwiesen. ${ }^{76}$ Die Könige Malis haben wohl ihre mit dem Ahnenkult verbundene Rolle als

70 Der König hat Macht über die Natur, diese kann willentlich oder unbeabsichtigt ausgeübt werden, er wird als das „dynamic center of the universe“ angesehen und somit hängt die gute Ordnung der Welt von seinem Wohlergehen und seinen Handlungen ab, die beide reguliert werden müssen (Howell / Thomson, Reth, S. 10).

71 Dafür werden die Vorsichtsmaßnahmen (inkl. des Verbotes, dass potentielle Thronfolger Fashoda, die Residenz des Königs betreten) zum Schutz des Reth als Indizien angeführt (Howell / Thomson, Reth, S. 10-11).

72 Evans-Pritchard hat das als Ideologie, nicht etwas tatsächlich Geschehenes behandelt: Edward E. Evans-Pritchard, The Divine Kingship of the Shilluk of the Nilotic Sudan. The Frazer Lecture, 1948, in: HAU: Journal of Ethnographic Theory 1/2011, S. 407-422; Ders., The Shilluk King-Killing, in: Man, 51/1951, S. 116.

73 Graeber, Kingship, S. 4.

74 Eine andere Version lässt ihn aus Medina kommen; vgl. etwa Robin Law, The Oỵo Empire c. 1600-c.1836. A West African Imperialism in the Era of the Atlantic Slave Trade, Aldershot 1991 (Reprint d. 1. Aufl. 1977), S. 27. Solche Erzählungen ohne historischen Wert drücken den Wunsch einiger Yorùbá-Könige aus, sich mit der „prestigious civilization of Islam“ zu verbinden, resp. in den Versionen, in denen Odùdúwà ein Apostat ist, stützen sie die Gegnerschaft der Yorùbá gegenüber dem Kalifat von Sokoto (Law, Ọyọ, S. 28-29; Zitat: S. 29).

75 Graeber, Kingship, S. 24; Howell / Thomson, Reth, S. 40.

76 Nehemia Levtzion, Islam in the Bilad al-Sudan to 1800, in: Nehemia Levtzion / Randall L. Pouwels (Hg.), The History of Islam in Africa, Athens, 2. Aufl., Ohio 2010, S. 63-91, S. 65: „In 
traditionelle Herrscher nie ganz aufgegeben, ${ }^{77}$ Sundiata wird in den oral tradierten Volksepen als ein über magische Kräfte, die ihm zum Sieg über seine Feinde verholfen haben, verfügender Eroberer geschildert. Man kann hier nicht wirklich von einem „sakralen Königtum“ im Sinne Frazers sprechen. Die Herkunft einer königlichen Lineage ist der gemeinsame Plot aller dieser Erzählungen, was auf eine grundlegende soziale Struktur in den hier angesprochenen Gesellschaften hinweist: die Ordnung nach Abstammung. Die königliche Lineage ist dann stets hervorgehoben, die zentralisierte Macht findet in allen diesen Mythen ihre Begründung in einer exklusiven Herkunft. Neben Migration spielen Eroberung und politische Auseinandersetzungen eine Rolle in diesen Mythen: Die Reichsgründung in Abomey ist mit Eroberung verbunden, die mythischen Helden der Shilluk sind siegreiche Feldherren, die Erzählung vom Sieg über die Sonne hat Eingang in die Inthronisationsriten gefunden, in denen auch Schaukämpfe ihren Platz haben, ${ }^{78}$ Sundiata ist ein Eroberer. In den Mythen werden aber auch politische Spannungen erwähnt: die Rivalität zwischen Odùdúwà und Obàtálá, die als eine Erzählung, die sich auf Konflikte zwischen eingewanderten und bereits ansässigen Bevölkerungsgruppen bezieht, interpretiert worden ist, ${ }^{79}$ oder die Auseinandersetzung zwischen Patri- und Matrilinearität in den Geschichten um Dak.

Der König ist nicht von Geburt an „göttlich“, sondern wird zum „sakralen Herrscher" erst durch Inthronisationsriten: Die Shilluk übertragen die Präsenz Nyikangs vom Vorgänger über die rituell verwendete Statue auf den neuen Reth, der nun als Nyikang die Einheit der Shilluk darstellt. In Òyọ́ wurde der Vorgänger im buchstäblichen Sinn vom neuen Herrscher einverleibt, ${ }^{80}$ während in Daho-

eleventh-century Ghana, under a non-Muslim king, only those who followed the king's religion kneeled down and sprinkled themselves with dust [...]. In the Islamized empire of Mali, all subjects $[\ldots]$ had to follow the custom [...] under non-Muslim rulers, Muslims were not obliged to perform some traditional ceremonial acts, but under Islamized kings, who [...] combined Islamic and traditional elements, pre-Islamic customs had to be accommodated“.

77 Levtzion, Bilad al Sudan, S. 66-68, führt aus, dass die frühen Herrscher stärker an der traditionellen Religion orientiert gewesen sind, während die Mansa zur Zeit der größten Machtentfaltung großen Eifer für den Islam an den Tag legten, die Könige sich aber im 15. Jahrhundert, als das Reich wieder auf das Malinke-Kernland reduziert worden ist, stärker den traditionellen Riten widmeten. Die großen muslimischen Herrscher des 14. Jahrhunderts sind entsprechend v. a. aus arabischen Quellen bekannt, Sundiata aber ist der Held der Volksepen.

78 Evans-Pritchard, Divine Kingship, S. 416-417; Lienhardt, Shilluk, S. 153-154; Graeber, Kingship, S. 37; S. 39; Burkhard Schnepel, Continuity despite and through Death. Regicide and Royal Shrines among the Shilluk of Southern Sudan, in: Africa. Journal of the International African Institute 61/1991, S. 40-70, hier: S. 60; S. 64.

79 Olúpọnnà, City, S. 207.

80 Der König musste ein Mahl mit dem Herz seines Vorgängers einnehmen (Morton Williams, Ogboni, S. 371). 
mey die Verbindung des Herrschers mit den Ahnen im Mittelpunkt jährlicher Rituale gestanden hat, den jährlichen „customs“ (hwetanu), in denen mittels Opfern die Ahnen der königlichen Familie gestärkt wurden. ${ }^{81}$ Die in diesen Zeremonien implizierte „Abgehobenheit“ des Königs, seine Entfernung vom Alltag, ${ }^{82}$ hat wohl Wiredu darin beeinflusst, das sakrale vom politischen Amt zu unterscheiden.

\section{Demokratie und Königtum: die faktische Macht des Königs}

Für Wiredus These ist entscheidend, ob der „König“ hinsichtlich seiner Sakralität eine rein religiös-rituelle Rolle gespielt hat ${ }^{83}$ und in der konkreten Politik ein von beratenden Gremien abhängiger Herrscher war, resp. ein Mitglied eines obersten, „demokratisch“ konstituierten, auf Konsensbildung ausgerichteten Rates, in dem er eine Stimme unter anderen hatte.

Ein klares Gegenbeispiel ist der Herrscher von Dahomey, kposu (von kpo, Leopard) ${ }^{84}$ oder dada (Vater) genannt: ${ }^{85}$ Die politische Organisation Abomeys kann nach Lombard geradezu als eine absolutistische Monarchie im strengen Sinn bezeichnet werden, ${ }^{86}$ dieser Absolutismus sei aber nicht mit Tyrannei gleichzusetzen - allerdings sind die Einschränkungen der königlichen Macht hier nicht die von Busia für die Ashanti beschriebenen, sondern „age-old traditions, established by his predecessors and bolstered by the great respect accorded the royal ancestors" ${ }^{87}$ Das relativiert die drastische Beschreibung bei Foa. ${ }^{88}$ Der König galt, wie Le Hérissé schreibt, als Besitzer des Landes, ${ }^{89}$ was ihm

81 „The well-being of the state was dependent upon the [...] support of the deceased kings“ (Bay, Wives, S. 12).

82 Der Reth war etwa hauptsächlich auf die Königsstadt Fashoda, ein Oba der Yorùbá auf den Palast beschränkt.

83 Als Repräsentant des Reichsgründers, einer Lineage, oder der Einheit des Königreiches.

84 Zusätzlich zur Mythe der Deszendenz der Alladohonu von einem Leoparden gab es bei den Gedevi, den Ansässigen zur Zeit der Eroberung des Kernlandes von Dahomey durch die Alladohonu den Kult des Vodun „kpo“ (Bay, Wives, S. 74; S. 242).

85 Zu den Namen siehe Robin Law, The Slave Coast of West Africa 1550-1750. The Impact of the Atlantic Slave Trade on an African Society, Oxford 1991, S. 73.

86 „At the top of the Dahomey hierarchy, dominating all social categories and wielding absolute authority over all officials, stood the king [...] All state polities, in theory, possess a system of checks and balances [...] On both centralized and decentralized states most kings were limited by some kind of control from subjects or royals. In Abomey, however, we are confronted with a form of absolute monarchy [...]" (Lombard, Dahomey, S. 77-78). Diese absolute Macht hat sich auf Justiz, Militär und Politik bezogen (Ebd., S. 79).

87 Ebd., S. 78.

88 „La forme de gouvernement du Dahomey est le régime monarchique absolu et sans contrôle. Il donne lieu, de la part du roi, à toutes sortes d'abus“ (Edouard Foa, Le Dahomey. Histoire - 
nicht nur Abgaben einbrachte, sondern auch das Recht, Töchter der Untertanen in seinen Harem aufzunehmen und die Praxis, den gesamten Besitz von Titelträgern (die vom Herrscher ernannt wurden) bei deren Tod (symbolisch) einzuziehen, begründete. ${ }^{90}$ Diese Formen von Besteuerung der Bevölkerung waren nach Robin Law nicht nur in Dahomey, sondern insgesamt in den Königreichen an der Sklavenküste üblich. ${ }^{91}$

Der königliche Clan ${ }^{92}$ bildete entsprechend die „Oberschicht“ der Gesellschaft, deren weitere Gruppen Beamte, Freie Gemeine ${ }^{93}$ und Sklaven waren. ${ }^{94}$ Durch die dort durchgeführten Staatsriten war der königliche Palast nicht nur politisches, sondern auch religiöses Zentrum Dahomeys, wo es 1000e verschiedener Vodun ${ }^{95}$ gegeben hat. Mit den Menschen durch komplexe Beziehungen verbunden, lebten sie in Kutome, dem Land der Toten und Geister, einem Spiegelbild der irdischen Welt. Gebete, Divinationen und Opferriten dienten der Kommunikation zwischen diesen beiden Welten. Die königliche Familie regierte hier wie dort, der soziale Status und Wohlstand von Familien hier beeinflusste deren sozialen Status und Wohlstand dort. Entkleidete der König einen Mann seiner Ämter und zog dessen Besitz ein, verloren auch dessen Ahnen in Kutome an Bedeutung. Wenn ein Vodun hier erhöht wurde, beeinflusste das seinen Status dort. ${ }^{96}$ Die Könige benutzten dieses System, indem sie bestimmte Vodun

Géographie - Mœurs - Coutumes - Commerce - Industrie. Expéditions Françaises (1891-1894), Paris 1895, S. 265).

89, „[...]tout ce qui naissait, existait ou se conservait sur le sol du Dahomey appartient au roi“ (Le Herissé, Royaume, S. 247).

90$, „[... $]$ qu' à la mort a chacque chef de groupe familial le roi fit le simulacre de prendre les biens familiaux pour les rendre aussitôt au nouveau titulaire de la dignitéc (Le Herissè, Royaume, S. 248).

91 Law, Slave Coast, S. 92-96; er nennt noch zusätzlich „tax in labour“ (Arbeiten auf den Feldern des Königs) und erörtert die Unterschiede im Einbehalten der Besitztümer verstorbener Titelträger in den einzelnen Königreichen (in Dahomey wurde demzufolge nur ein geringer Teil vom König tatsächlich einbehalten).

92 Aus den Nachkommen aller Könige bestehend, hierarchisch nach Verwandtschaftsnähe zum regierenden König geordnet, eine „leisure class“ innerhalb der Palastanlagen, die die soziale Struktur des Reiches außerhalb des Palastes wiedergaben; vgl. dazu und zum Folgenden Lombard, Dahomey, S. 74-75.

93 Freie Gemeine waren Bauern und Handwerker und bildeten den Hauptteil der Armee. Die Verwaltungsbeamten in verschiedenen Rängen (theoretisch alle aus den Reihen der freien Gemeinen) waren etwa Minister des Königs, Dorfoberhäupter, Militärs oder hochrangige Priester.

94 Sklaven waren immer fremder Herkunft, zumeist Kriegsgefangene. Nicht in den Sklavenhandel verkaufte wurden für Menschenopfer im Staatsritual oder als Arbeiter auf den Plantagen des Königs verwendet.

95 Bezeichnet die Religion und ihre „Gottheiten“. Vgl. zum Folgenden Bay, Wives, S. 21-24.

96 „Un lien de solidarité unit les vodũ et les hommes; ils se complètent et ne pourraient se passer les uns des autres. Par leurs prières et leurs sacrifices, les hommes, donnent de la force aux vodü. Plus les offrandes sont nombreuses et magnifiques, plus les divinités ont de force [...] 
stärkten, andere schwächten. ${ }^{97}$ Das wichtigste staatliche Ritual mit ausgeprägtem Opferwesen waren die bereits erwähnten „customs“. Sie bestanden u. a. aus Tierund Menschenopfern, militärischen Schaukämpfen, Verleihen von Auszeichnungen und Ämtern, Bestrafungen von Verbrechern und Regimefeinden, Erlassen von Gesetzen und Einheben von Steuern und Tributzahlungen. ${ }^{98}$ Die in Westafrika verbreitete Praxis der Menschenopfer ${ }^{99}$ war - als königliche Machtdemonstration und Monopolisierung der Todesstrafe - am Königshof zentralisiert. ${ }^{100}$ Damit wurde Macht und Wohlstand signalisiert. Opferzwecke waren aber auch das Überbringen von Botschaften an die Ahnen in Kutome, die Rekrutierung von Sklaven für diese, oder einfach deren Ernährung und Stärkung. ${ }^{101}$

Die Zentralisierung der politischen Macht ist, einigen Autoren zufolge, in den Yorùbá Königreichen weniger ausgeprägt gewesen als in Dahomey, aber auch als bei den Ashanti. Man kann aufgrund der Varianz in den politischen Systemen der einzelnen Königreiche nicht von einer von allen geteilten politischen Ordnung sprechen. ${ }^{102}$ Es gab zumindest vier Modelle, ${ }^{103}$ von denen ich nur auf das

si leur nombre décroit, les vodũ s'affaiblissent“" (Bernard Maupoil, La Géomancie à l'ancienne Côte des Esclaves, Paris 1943, S. 57).

97 „Choices of which vodun to revere and which to neglect were made consciously as an attempt to alter power relationships among the gods for the benefit of the monarchy and the state. But because the world of the gods and that of humanity reflected each other, the social structures and hierarchy of the vodun represented changing conceptions of the nature of power by the Dahomean ruler [...] the gods in Dahomey have a history, one created by the monarchy in its own image" (Edna G. Bay, Belief, Legitimacy and the Kpojito. An Institutional History of the ,Queen Mother' in Precolonial Dahomey, in: The Journal of African History 36/1995, S. 1-27, hier: S. 3-4).

98 Lombard, Dahomey, S. 85-86; Bay, Wives, S. 12-13; S. 65-67; S. 125-128; umfassend zur historischen Entwicklung und Quellenlage: Catherine Coquery-Vidrovitch, La fête des coutumes au Dahomey. Historique et Essai d'interprétation, in: Annales. Histoire, Sciences Sociales 19/1964, S. 696-716.

99 In Dahomey wurden in der Regel Kriegsgefangene (Sklaven) und Verbrecher geopfert, aber auch Mitglieder der königlichen Familie oder wichtige Funktionäre im Palast, um beim Tod des Königs diesen nach Kutome zu begleiten und den neuen König abzusichern. Einen historischen Überblick zu Menschenopfern in Westafrika, der Forschungs- und Interpretationsgeschichte und deren methodologische Probleme berücksichtigt, gibt Robin Law, Human Sacrifice in Pre-Colonial West Africa, in: African Affairs 84/1985, S. 53-87; zu Dahomey Ebd., S. 67-69.

$100, \ldots[. .$.$] les sacrifices étaient une prérogative royale. Ni les princes, ni les riches traitants, qui$ distribuaient de l'alcool, des tissus, des cauris et sacrifiaient des animaux, n'avaient le droit de condamner un homme à la mort" (Coquery-Vidrovitch, fête, S. 710). Lt. Law, Sacrifice, S. 74, entstand das Monopol erst in den 1840er Jahren.

101 „Bewässern der Gräber“ mit dem Blut der Opfer. Law, Sacrifice, S. 68; Coquery-Vidrovitch, fête, S. 707-709; diese Praxis sieht letztere im Glauben an die Spiegelbildlichkeit des Jenseits begründet (Ebd., S. 708).

102 Auch wenn Nathaniel A. Fadipe, The Sociology of the Yoruba, Ibadan 1970, S. 198, als grundsätzliche Regierungsform aller Yorùbá-Reiche die Monarchie nennt. Ausnahmen wären Städte, die von einem baálè („,Vater/Besitzer des Landes“), dem Chief eines Anwesens 
von Ọyọ́ und den abhängigen Königtümern eingehe. Nach Peter Lloyd handelte es sich dabei um ein „Stammeskönigtum“ (tribal kingdom), das sich nicht zu einer „zentralisierten Monarchie“ (centralised monarchy) entwickelt habe. In ersterem ist der König einerseits sakral, andererseits ein säkularer Herrscher, aber kein Autokrat, sondern mehr Schiedsmann zwischen den ihre Abstammungslinien vertretenden Chiefs, den eigentlichen Entscheidungsträgern. An der Entwicklung von Ọyọ́ sucht er, in eher deterministischer Art, zu zeigen, warum ein „tribal kingdom“ zu einer zentralisierten Monarchie ${ }^{104}$ wird oder nicht. $^{105}$

Allerdings hat es in Ọyọ́ durchaus politische Veränderungen gegeben. Prinzipiell standen sich der Aláàfin, ${ }^{106}$ Herr der Welt und des Lebens, Eigentümer des Landes und „Gefährte der Götter“, der theoretisch absolute Macht besaß und der Òyoó Mesi, ein Rat aus 7 Lineage-Häuptern, der die Macht des Aláàfin einschränkte, gegenüber. Der Ọyọ́ Mesi spielte u. a. eine zentrale Rolle in Staatsriten; jedes Mitglied hatte in dem von ihm repräsentierten Teil der Stadt judizielle Autorität. ${ }^{107}$ In der „imperialen Periode ${ }^{\text {“108 }}$ weitete er seine Macht aus, zunächst bei der Thronfolge, die früher auf den ältesten Sohn (Titel: Arẹmọ) ging. Nun wurde er von Mitgliedern der königlichen Abstammungslinie gewählt, der Ọyọ́

(compound) regiert werden. Solche Städte (etwa Ibadan vor 1936) sind wohl eher von einer Zentralmacht abhängige Einheiten als selbst eine solche.

103 Fadipe, Sociology, S. 199. Neben dem Ọyọo-Modell dasjenige von Ifé, der Ijebu und der Egba; Peter C. Lloyd zufolge könnte man „write a textbook [...] on comparative political systems, drawing almost all one's examples from the Yoruba“" (zit. n. William Bascom, The Yoruba of Southwest Nigeria, New York e.a. 1969, S. 29). Es erübrigt sich hier, auf alle diese Systeme einzugehen; bei Bascom, Yoruba, wird das System in Ifé erörtert. Einen Überblick über Regierungsformen in verschiedenen Yorùbá-Königreichen gibt Peter C. Lloyd, The Political Development of Yoruba Kingdoms in the Eighteenth and Nineteenth Centuries, London 1971.

104 Womit innere Organisationsform und nicht äußere Machtentfaltung gemeint ist; Ọyọ́ war in seiner „imperialen Periode“ eine Zentralmacht in einem großen Gebiet abhängiger/tributpflichtiger Reiche.

105 Lloyd, Development. Kritik an dieser Theorie übt Robin Law, Anthropological Models in Yoruba History, in: Africa. Journal of the International African Institute 43/1973, S. 18-26; vgl. a. Robert Smith, Event and Portent: The Fall of Old Oyo, a Problem in Historical Explanation, in: Africa. Journal of the International African Institute 41/1971, S. 186-199.

106 „Besitzer des Palastes“, Königstitel in Ọyoọ́, in der Nacholge Òrànmíyans, des legendären Gründers von Ọyọ́; nur aus einer der drei königlichen Lineages konnte der Aláàfin gewählt werden; vgl. Law, Ọyọ́, S. 66.

107 Beschreibungen nach Peter Morton-Williams, The Yoruba Ogboni Cult in Oyo, in: Africa. Journal of the International African Institute 30/1960, S. 362-374, hier: S. 363; vgl. Law, Ò̀yọ́, S. 65-67; S. 73-76.

108 Lt. Law, Òyọ́, S. 58, c. 1600-1832. Òyọ́s frühe Geschichte liegt im mythischen Dunkel. Nach der Eroberung Ộyọ́s durch die Nupe gab es eine Zeit im Exil, bis der Aláàfin Abipa um 1600 das alte Ọyộ wieder erobert hat. Anfang des 19. Jahrhunderts destabilisierte sich das Reich, um 1835 ging Òyọ̣ unter und das neue Ọyọ̣ wurde weiter südlich gegründet (Law, Ebd., S. 47-56). 
Mesi musste die Wahl bestätigen. ${ }^{109}$ Er konnte auch den Aláàfin absetzen ${ }^{110}$ - aufgrund der Sakralität des Königsamtes (theoretisch) nur als Aufforderung zum Selbstmord - aber selbst nicht kollektiv abgesetzt werden. Dieses Recht beruht wohl darauf, dass der Bașọrun - Oberhaupt des Ọ̀yọ Mesi - beim Staatskult das Orakel stellte, ob die Opfer des Aláàfin angenommen worden seien. ${ }^{111}$ Odarawu (Ende 17. Jahrhundert) dürfte der erste abgesetzte Aláàfin gewesen sein; der dadurch gesteigerten Macht des Ọyọ́ Mesi suchte sich sein Nachfolger, Karan, zu widersetzen, indem er der Aufforderung zum Selbstmord nicht nachkam, woraufhin er ermordet wurde.

Es folgte eine Zeit, in der fast alle Aláàfin abgesetzt oder ermordet wurden und der Baṣọrun Gaba die Staatsmacht an sich riss (1754-74), bis es dem Aláàfin Abiodun nach einigen Jahren als nomineller Herrscher unter effektiver Herrschaft Gabas, gelang, u.a. mit Hilfe der Herrscher abhängiger Städte, Gaba zu stürzen. Einerseits wird der Aufstieg Gabas zur Macht als Reaktion auf den Despotismus einiger Aláàfin erklärt, andererseits seine Herrschaft selbst als despotisch, die Mitglieder seiner Lineage bevorzugend, geschildert. ${ }^{112}$ Eine nachhaltige Stabilisierung der Herrschaft gelang nicht, und nach Abiodun ging das Reich aus verschiedenen Gründen zugrunde. ${ }^{113} \mathrm{Im}$ danach südlich der alten Stadt neu gegründeten Ọyọ́ wurde die Praxis des Selbstmordes des Arẹmọ sistiert und es gab keine Königsabsetzungen mehr, nachdem eine dritte Kraft zwischen Aláàfin und Ọyọ́ Mesi eingeführt wurde: Die Ògbóni-Gesellschaft, ein die Lineages transzendierender „Ältestenbund“, der die Macht des Ọyọ́ Mesi einschränkte. ${ }^{114}$ Sieht man von den äußeren Umständen für den Untergang Ọyọ́s ab, so ist wohl einer der Gründe dafür darin zu suchen, dass keine klare Zentralmacht ausgebildet worden ist. Wie der Kampf um eine solche im 18. Jahrhundert belegt, kann man im von Machtkämpfen bestimmten politischen Alltag keineswegs von konsensdemokratischen Vorgängen sprechen, auch wenn in Theorie und Praxis ein System der Einschränkung der politischen Macht des

109 Die Erbfolge durch den Arẹmọ war im Exil und in der ersten Hälfte der „imperialen Periode“ die Regel. Wohl ab dem Tod des Aláàfin Ojigi in den 1730ern musste der Arẹmọ beim Tod des Aláàfin Selbstmord verüben (eine Maßnahme gegen Patrizid) und der Nachfolger wurde gewählt (S. Law, Òyọo, S. 57; S. 66-67).

110 Zum Folgenden Law, Ọyộ, S. 57; S. 73; S. 77; S. 242.

111 Law, Ò̀yọ́, S. 73; S. 77.

112 Zu Gaba und Abiodun vgl. Law, Ọ̀yọ́, S. 80; S. 200f; S. 234; S. 242; Interpretationen kann ich hier nicht diskutieren.

113 S. Law, Òyọ́, S. 245-299.

114 Er musste etwa einstimmig einer Absetzung des Aláăfin zustimmen. Hier kann weder auf die Beziehungen zwischen Aláàfin, Ògbóni und Ọyọ́ Mesi noch auf den Ògbóni-Kult eingegangen werden. Vgl., dazu Morton-Williams, Ogboni. Dass der Kult erst im neuen Ọyọ́ eingeführt wurde, belegt Joseph A. Atanda, The Yoruba Ogboni Cult. Did it Exist in Old Oyọ?, in: Journal of the Historical Society of Nigeria 6/1973, S. 365-372. 
Aláàfin bestanden hat, das auf Repräsentanten der Lineages beruhte, deren Mitglieder sich somit - theoretisch - in der Politik vertreten fühlen konnten.

Verglichen mit den komplexen politischen Strukturen in Dahomey und Ọyọ́ kann man bei den Shilluk nicht von einem ausgeprägten Staatswesen sprechen. ${ }^{115}$ Wie Howell anhand der Untersuchung der Rolle des Reth im Tatausgleich bei Tötungsdelikten gezeigt hat, war dessen „Jurisdiktion“ auf Vermittlung zwischen den beteiligten Parteien, nachdem diese jenen angerufen haben, beschränkt, auch die Abgaben an den König in diesen Fällen sind eher als Bezahlung für rituelle Funktionen denn als Pönale anzusehen. ${ }^{116}$ Das legt den Schluss nahe, dass der Reth, trotz seiner theoretisch absoluten Macht in erster Linie die - sich in den umfänglichen Inthronisationsritualen manifestierende rituelle Rolle des sakralen Herrschers als Repräsentant der Einheit des Volkes gespielt hat. Dennoch hat es freilich auch eine historische Entwicklung dieser erst im 17. Jahrhundert entstandenen Institution über die Zeit der Präsenz des ottomanischen Reichs im Sudan und die englische Herrschaft mit indirect rule gegeben. $^{117}$

\section{Schlussbetrachtung}

Die angeführten Beispiele zeigen deutlich, dass das Konstrukt eines afrikanischen „sakralen Königtums“ aus der Sicht westlicher Forscher des frühen 20. Jahrhunderts, auf das sich Wiredu offensichtlich bezieht, so nicht aufrechterhalten werden kann. Zu unterschiedlich sind, bei allen gemeinsamen Zügen, sowohl die Begründungen, die in den Mythen gegeben werden, als auch die reale politische Macht der jeweiligen Herrscher, von absoluter Macht über eine flexible Machtposition gegenüber anderen Playern, die stets neu ausverhandelt bzw. erkämpft wird, bis zu einer rein rituellen Rolle. Das Königtum ist jeweils an eine, in den grundlegend nach Clans organisierten Gesellschaften eine Vorrangstellung einnehmende Lineage gebunden. Das gilt auch für Mali. Das Beispiel Mali zeigt - wie die bereits erwähnten historischen Entwicklungen - die Ahistorizität von Wiredus Ausführungen auf: Muslimische Herrscher hat es in West- und

115 „In comparison with [...] such highly developed political institutions as are found in some African kingdoms, [...] the Shilluk system cannot be said to have reached a high degree of rigidity or efficiency“ (Paul Philip Howell, Observations on the Shilluk of the Upper Nile. The Laws of Homicide and the Legal Functions of the „Reth“, in: Africa. Journal of the International African Institute 22/1952, S. 97-119, hier: S. 106).

116 Howell, Observations.

117 Graeber, Kingship, S. 15-19; Ebd., S. 1, bezeichnet er das Shilluk-Reich als „not a state by any of the usual definitions of the term - the king lacked any sort of administration and had little systematic power". 
Ostafrika - und zwar infolge von Handelsbeziehungen - lange vor den direkten Handelsbeziehungen mit Europäern und dem Kolonialismus gegeben. Außerdem entstanden ab dem 17. Jahrhundert in Westafrika muslimische Staaten (Emirate), in denen es zu muslimischen Reformbewegungen kam, die wiederum die politische Landschaft beeinflussten. ${ }^{118}$ Diese historische Ebene blendet Wiredu aus, es wird ein präkolonialer „afrikanischer“, quasi überzeitlicher Status konstruiert. Man müsste noch auf die Struktur der genannten Gesellschaften eingehen. Westafrikanische Königreiche haben z.B. alle die Institution der Sklaverei gekannt, und Menschenopfer bzw. die rituelle Tötung von Menschen waren übliche Praxis, auch bei den Ashanti. Darauf kann ich nur mehr hinweisen. ${ }^{119}$ Wie Robin Law angemerkt hat, ist eine Verbindung von Menschenopfern mit der sich etablierenden Zentralautorität, die wir hier als „Königtum“ bezeichnet haben, durchaus wahrscheinlich. ${ }^{120}$ Mir scheint in der Ausblendung solcher Aspekte der afrikanischen Geschichte - deren Gewalttätigkeit in verschiedensten Formen sich auch in anderen menschlichen Gesellschaften weltweit findet - ein ähnlicher Zug am Werk wie in der Ausblendung der Geschichte Afrikas: Eine gewisse Verklärung der präkolonialen Vergangenheit in eine zeitlose, panafrikanische Identität, die es so nie gegeben hat.

\section{Quellen}

Abraham, William E., The Mind of Africa, Accra 2015 (reprint).

Àjàyí, Ọmófọlábọ S., Yoruba Dance. The Semiotics of Movement and Body Attitude in a Nigerian Culture, Trenton, NJ 1998.

Atanda, Joseph Adebowale, The Yoruba Ogboni Cult. Did it Exist in Old Oyọ?, in: Journal of the Historical Society of Nigeria 6/1973, S. 365-372.

Bascom, William, The Yoruba of Southwest Nigeria, New York e.a. 1969.

Bay, Edna G., Wives of the Leopard. Gender, Politics and Culture in the Kingdom of Dahomey, Charlottesville-London 1998.

Bay, Edna G., Belief, Legitimacy and the Kpojito. An Institutional History of the ,Queen Mother' in Precolonial Dahomey, in: The Journal of African History 36/1995, S. 1-27. Beier, Uli, Yoruba Myths, Cambridge 1980.

Belcher, Stephen, African Myths of Origin, London e.a. 2003.

Booth, Newell S., God and the Gods in West Africa, in: Newell S. Booth (Hg.), African Religions. A Symposion. New York e.a. 1977, S. 159-181.

118 Zur Rolle muslimischer Rebellen im Untergang Òyọós vgl. Law, Oyọ, S. 265-260.

119 Ohne diese Praxis in Bezug zum politischen System zu setzen und die verschiedenen Erklärungen zu diskutieren; $\mathrm{Zu}$ mit dem Königtum verbundenen Menschenopfern bei den Ashanti s. Law, Sacrifice, S. $69 \mathrm{f}$.

120 Law, Sacrifice, S. 74, S. $86 \mathrm{f}$. 
Bradley, Mattew Todd, „The Other“. Precursory African Conceptions of Democracy, in: International Studies Review 7/2005, S. 407-431.

Busia, Kofi A., The Position of the Chief in the Modern Political System of Ashanti. A Study of Contemporary Social Changes on Ashanti Political Institutions, London 1968.

Collins, Robert O. / Burns, James M., A History of Sub-Saharan Africa, 2. Aufl., Cambridge 2014.

Conrad, David C., Islam in the Oral Traditions of Mali. Bilali and Surakata, in: The Journal of African History 26/1985, S. 33-49.

Coquery-Vidrovitch, Catherine, La fête des coutumes au Dahomey. Historique et Essai d'interprétation, in: Annales. Histoire, Sciences Sociales 19/1964, S. 696-716.

Davidson, Basil, A History of West Africa 1000-1800, London 1977.

Evans-Pritchard, Edward E., The Divine Kingship of the Shilluk of the Nilotic Sudan. The Frazer Lecture, 1948, in: HAU: Journal of Ethnographic Theory 1/2011, S. 407-422.

Evans-Pritchard, Edward E., The Shilluk King-Killing, in: Man 51/1951, S. 116.

Eze, Emmanuel Chukwudi, Demokratie oder Konsensus? Eine Antwort auf Wiredu, in: Franziska Dübgen / Stefan Skupien (Hg.), Afrikanische Politische Philosophie, Frankfurt a.M. 2015, S. 182-197.

Eze, Emmanuel Chukwudi, Democracy or Consensus? A Response to Wiredu, in: Ders. (Hg.), Postcolonial African Philosophy. A Critical Reader, Oxford 1997, S. 313-323.

Fadipe, Nathaniel Akinremi, The Sociology of the Yoruba, Ibadan 1970.

Feeley-Harnik, Gillian, Issues in Divine Kingship, in: Annual Review of Anthropology 14/ 1985, S. 273-313.

Foa, Edouard, Le Dahomey. Histoire - Géographie - Mœurs - Coutumes - Commerce Industrie. Expéditions Françaises (1891-1894), Paris 1895.

Fortes, Meyer / Evans-Pritchard, Edward E. (Hg.), African Political Systems, 4. Aufl., London e.a. 1950.

Frazer, James George, The Golden Bough. A Study in Magic and Religion, abridged ed., London 1995.

Graeber, David, The Divine Kingship of the Shilluk. On Violence, Utopia, and the Human Condition, or, Elements for an Archaeology of Sovereignty, in: HAU: Journal of Ethnographic Theory 1/2011, S. 1-62.

Harding, Leonhard, Das Königreich Benin. Geschichte - Kultur - Wirtschaft, München 2010.

Hérissé, Auguste Le, L'ancien royaume du Dahomey. Mœurs, religion, histoire, Paris 1911.

Howell, Paul Philip, Observations on the Shilluk of the Upper Nile. The Laws of Homicide and the Legal Functions of the „Reth“, in: Africa. Journal of the International African Institute 22/1952, S. 97-119.

Howell, Paul Philip / Thomson, W. P. G., The Death of a Reth of the Shilluk and the Installation of his Successor, in: Sudan Notes and Records 27/1946, S. 5-85.

Idowu, Emanuel Bọlaji, Olódùmarè. God in Yoruba Belief, London 1962.

Johnson, Samuel, The History of the Yorubas. From the Earliest Times to the Beginning of the British Protectorate, London 1921.

Law, Robin, The Slave Coast of West Africa 1550-1750. The Impact of the Atlantic Slave Trade on an African Society, Oxford 1991.

Law, Robin, The Oyo Empire c. 1600-c.1836. A West African Imperialism in the Era of the Atlantic Slave Trade, Aldershot 1991 (Reprint der 1. Aufl. 1977). 
Law, Robin, History and Legitimacy. Aspects of the Use of the Past in Precolonial Dahomey, in: History in Africa 15/1988, S. 431-456.

Law, Robin, Human Sacrifice in Pre-Colonial West Africa, in: African Affairs 84/1985, S. 53-87.

Law, Robin, Anthropological Models in Yoruba History, in: Africa. Journal of the International African Institute 43/1973, S. 18-26.

Levtzion, Nehemiah / Spaulding, Jay (Hg.), Medieval West Africa. Views from Arab Scholars and Merchants, 3. Aufl., Princeton, NJ 2011.

Levtzion, Nehemia, Islam in the Bilad al-Sudan to 1800, in: Nehemia Levtzion / Randall L. Pouwels (Hg.), The History of Islam in Africa, Athens, 2. Aufl., Ohio 2010, S. 63-91.

Levtzion, Nehemia, The Thirteenth- and Fourteenth-Century Kings of Mali, in: The Journal of African History 4/1963, S. 341-353.

Lienhardt, Godfrey, The Shilluk of the Upper Nile, in: Daryll Forde (Hg.), African Worlds. Studies in the Cosmological Ideas and Social Values of African Peoples. New Introduction by Wendy James, Hamburg 1999.

Lienhardt, Godfrey, Nilotic Kings and Their Mothers' Kin, in: Africa. Journal of the International African Institute 25/1955, S. 29-42.

Lloyd, Peter C., The Political Development of Yoruba Kingdoms in the Eighteenth and Nineteenth Centuries, London 1971.

Lombard, Jaques, The Kingdom of Dahomey, in: Daryll Forde / Phyllis M. Kaberry (Hg.), West African Kingdoms in the Nineteenth Century, Oxford 1967, S. 70-92.

MacGaffey, Wyatt, Kingship in Sub-Saharan Africa, in: Mircea Eliade (Hg.), The Encyclopedia of Religion 8, New York 1987, S. 322-325.

Maupoil, Bernard, La Géomancie à l'ancienne Côte des Esclaves, Paris 1943.

Mercer, Patricia, Shilluk Trade and Politics from the Mid-Seventeenth Century to 1861, in: The Journal of African History 12/1971, S. 407-426.

Mercier, Paul, The Fon of Dahomey. in: Daryll Forde (Hg.), African Worlds. Studies in the Cosmological Ideas and Social Values of African Peoples. New Introduction by Wendy James, Hamburg 1999, S. 210-234.

Morton-Williams, Peter, The Yoruba Ogboni Cult in Oyo, in: Africa. Journal of the International African Institute 30/1960, S. 362-374.

Olúpọ̀nà, Jacob K., City of 201 Gods. Ilé - Ifé in Time, Space, and the Imagination, Berkely e.a. 2011.

Parrinder, Edward Geoffrey, Divine Kingship in West Africa, in: Numen 3/1956, S. 111-121.

Peel, John David Yeadon, Religious Encounter and the Making of the Yoruba. Bloomington-Indianapolis 2003.

Person, Yves, Chronologie du royaume gun de Hogbonu (Porto-Novo), in: Cahiers d'Études Africaines 15/1975, S. 217-238.

Pineau-Jamous, Marie-Josée, Porto-Novo. Royauté, localité et parenté, in: Cahiers d'Études Africaines 26/1986, S. 547-576.

Richards, Audrey, Keeping the King Divine, in: Proceedings of the Royal Anthropological Institute of Great Britain and Ireland 1968, S. 23-35.

Robinson, David, Muslim Societies in African Histories, Cambridge e.a. 2004.

Scheub, Harold, A Dictionary of African Mythology. The Mythmaker as Storyteller, Oxford e.a. 2000. 
Schnepel, Burkhard, Continuity despite and through Death. Regicide and Royal Shrines among the Shilluk of Southern Sudan, in: Africa. Journal of the International African Institute 61/1991, S. 40-70.

Seligman, Charles Gabriel, The Religion of the Pagan Tribes of the White Nile, in: Africa. Journal of the International African Institute 4/1931, S. 1-21.

Smith, Robert, Event and Portent. The Fall of Old Oyo, a Problem in Historical Explanation, in: Africa. Journal of the International African Institute 41/1971, S. 186-199.

Smith, Robert S., Kingdoms of the Yoruba, London 1969.

Vansina, Jan, A Comparison of African Kingdoms, in: Africa: Journal of the International African Institute 32/1962, S. 324-335.

Wiredu, Kwasi, Demokratie und Konsensus in traditioneller afrikanischer Politik, in: Franziska Dübgen / Stefan Skupien (Hg.), Afrikanische Politische Philosophie, Frankfurt a.M. 2015, S. 168-181.

Wiredu, Kwasi, Democracy and Consensus in African Traditional Politics. A Plea for a Non-Party Polity, in: Emmanuel Chukwudi Eze (Hg.), Postcolonial African Philosophy. A Critical Reader, Oxford 1997, S. 303-312. 
Open-Access-Publikation im Sinne der CC-Lizenz BY 4.0

(C) 2020, Vandenhoeck \& Ruprecht $\mathrm{GmbH} \&$ Co. KG, Göttingen ISBN Print: 9783847111658 - ISBN E-Lib: 9783737011655 


\section{Menschenrechte}

Open-Access-Publikation im Sinne der CC-Lizenz BY 4.0

(c) 2020, Vandenhoeck \& Ruprecht GmbH \& Co. KG, Göttingen 
Open-Access-Publikation im Sinne der CC-Lizenz BY 4.0

(C) 2020, Vandenhoeck \& Ruprecht $\mathrm{GmbH} \&$ Co. KG, Göttingen ISBN Print: 9783847111658 - ISBN E-Lib: 9783737011655 


\section{Menschenrechte und „traditionelle Werte“: Eine hoffnungslos vergiftete Debatte?}

\section{Menschenrechte zwischen Kontinuität und Diskontinuität}

Menschenrechte sind Rechte gleicher Freiheit für alle Menschen, begründet in der unantastbaren Würde jedes einzelnen Menschen. Artikel 1 der Allgemeinen Erklärung der Menschenrechte der Vereinten Nationen von 1948 fasst ihr normatives Profil in dem vielzitierten Satz zusammen: „Alle Menschen sind frei und gleich an Würde und Rechten geboren." Mit dieser universalistischen, emanzipatorischen und egalitären Ausrichtung erweisen sich die Menschenrechte als eine spezifisch moderne Rechtsfigur. Ihr historischer Durchbruch geschah im Kontext der demokratischen Revolutionen im ausgehenden 18. Jahrhundert, zunächst in Amerika und Frankreich. Ins internationale Recht fanden sie nach dem Zweiten Weltkrieg Eingang. Nachdem bereits die UN-Charta von 1945 die Menschenrechte unter den fundamentalen Zielen der internationalen Gemeinschaft aufgeführt hatte, entfaltete die Allgemeine Erklärung der Menschenrechte drei Jahre später den universalen Anspruch gleicher Würde und gleicher Freiheit inhaltlich in Gestalt von dreißig Artikeln. Aus der Allgemeinen Erklärung sind in der Folgezeit mehrere völkerrechtlich verbindliche Menschenrechtskonventionen entstanden.

Wie verhalten sich die unverkennbar modernen Menschenrechte zu den unterschiedlichen Formen eines traditionellen, religiös eingebetteten Ethos? Repräsentieren sie einen radikalen („revolutionären“) Bruch, oder lassen sie sich eher als („evolutionäre“) Weiterentwicklung verstehen? Die Klärung dieser Frage ist nicht nur von akademischem Interesse, sondern hat erhebliche Auswirkung auf die Akzeptanzchancen der Menschenrechtsidee. Wenn man die Menschenrechte in völliger Diskontinuität zu traditionellen Ethosformen sieht, wäre ihre Anerkennung nur um den Preis einer Abkehr von der je eigenen Tradition möglich. Dies jedoch wäre eine Zumutung, die bei vielen Menschen verständlicherweise auf Ablehnung stoßen dürfte - insbesondere bei denjenigen, denen ihre jeweilige ethische Tradition wichtig bleibt, weil sie sich davon geprägt und getragen sehen. Die Gegenposition, die die Menschenrechte eher in 
Kontinuität zu traditionellen Wertvorstellungen sieht, ist jedoch nicht weniger problematisch, steht sie doch in der Gefahr, die kritisch-emanzipatorische Orientierung modernen Rechts abzublenden oder zu nivellieren. Weitreichende Missverständnisse in der Theorie und Praxis der Menschenrechte wären damit vorprogrammiert. ${ }^{1}$

Diskontinuitäts- und Kontinuitätszuschreibungen finden sich bis heute in manchen Varianten, zum Beispiel in der katholischen Sozialethik. In ihrer Unsicherheit im Umgang mit dem Anspruch moderner Freiheitsrechte pendelte die Katholische Kirche lange Zeit zwischen beiden Polen hin und her, und manche Schwankungen finden sich auch heute noch. Bekanntlich lehnte die Kirche die Menschenrechte über anderthalb Jahrhunderte hinweg als Manifestation einer gottlosen jakobinischen Ideologie vehement ab. Nach einer Zwischenphase vorsichtiger Annäherung gelang auf dem Zweiten Vatikanischen Konzil dann der systematische Durchbruch zur Anerkennung der Menschenrechte, insbesondere der Religionsfreiheit. ${ }^{2}$ Wie der Titel des einschlägigen Konzilsdokuments von 1965 - Dignitatis Humanae - verdeutlicht, war dafür vor allem die Idee der Menschenwürde leitend, in deren Licht die Kirche nun die grundlegenden Freiheitsrechte würdigen konnte. ${ }^{3}$ Nach der schlussendlichen Überwindung der traditionellen polemischen Abwehrposition zeigten sich unterdessen bald Tendenzen, die Menschenrechte - als „christliche Werte in moderner Gestalt“ - in die eigene ethisch-religiöse Tradition schlicht zu vereinnahmen. Hatte die offizielle Verdammung der Menschenrechte, kulminierend im berüchtigten „Syllabus Errorum“von 1864, Annäherungen für lange Zeit aussichtslos erscheinen lassen, so wird die Konfliktgeschichte zwischen Katholischer Kirche und Menschenrechtsidee im Rückblick heute gern auf bloße „Missverständnisse“ reduziert.

In einem Grundsatzdokument aus dem Jahre 2008 zeigt sich die Russisch-Orthodoxe Kirche nach wie vor ausgesprochen skeptisch gegenüber den Menschenrechten; zu mehr als einem „Ja-Aber“ - mit Akzent auf dem „Aber“ kann sie sich darin nicht durchringen. ${ }^{4}$ Während der für die Menschenrechte

1 Exemplarisch genannt sei nur die menschenrechtliche Verbürgung der Gleichberechtigung der Geschlechter oder die Emanzipation sexueller Minderheiten, die inhaltlich über traditionelle Ethosformen klar hinausgehen.

2 Vgl. Konrad Hilpert, Menschenrechte und Theologie. Forschungsbeiträge zur ethischen Dimension der Menschenrechte, Freiburg 2001, S. 385-401.

3 Vgl. Marianne Heimbach-Steins, Religionsfreiheit. Ein Menschenrecht unter Druck, Paderborn 2012, S. 51-101.

4 Vgl. Moskauer Patriarchat, The Russian Orthodox Church's Basic Teachings on Human Dignity, Freedom and Rights, 2008, vgl. http://www.mospat.ru/en/documents/dignity-freedomrights (letzter Zugriff: 04. 06.2019). Kritisch dazu: Joachim Willems, Die Russisch-Orthodoxe Kirche und die Menschenrechte, in: Heiner Bielefeldt / Volkmar Deile / Brigitte Hamm (u. a.) 
tragende Begriff der Würde des Menschen auf die biblische und die patristische Tradition zurückgeführt und damit theologisch anerkannt, zugleich aber ein Stück weit vereinnahmt wird, bleibt die Russisch-Orthodoxie ansonsten ausgesprochen defensiv gegenüber dem Freiheitsanspruch der Menschenrechte, der mit Libertinage und moralischer Dekadenz assoziiert wird. Der Zusammenhang von Würde und Rechten der Menschen, wie er im oben zitierten Artikel 1 der Allgemeinen Erklärung der Menschenrechte festgehalten ist, wird im Positionspapier tendenziell aufgelöst. ${ }^{5}$

Nach wie vor viel Unsicherheit besteht im islamischen Kontext. Die oft verwirrenden Debatten um Menschenrechte im Islam bewegen sich, systematisch gesehen, ebenfalls häufig zwischen den Polen von Abwehr und Vereinnahmung. Im ersteren Fall gilt der Menschenrechtsanspruch als ein traditionsfremdes Oktroi, das deshalb auf mehr oder weniger offenen Widerstand stößt; dafür gibt es zahlreiche Beispiele insbesondere in den fundamentalistischen und konservativen Ausprägungen des Islams. Im letzteren Fall läuft die vermeintliche Versöhnung zwischen Islam und Menschenrechten oft darauf hinaus, etwaige Differenzen zwischen Scharia-Tradition und modernen Freiheitsrechten auszublenden, zu relativieren oder schlicht zu leugnen. Manchmal rutschen Abwehr und Vereinnahmung sogar in eins. Ein bizarres Beispiel bietet die Kairoer Erklärung der Organisation der Islamischen Konferenz über Menschenrechte im Islam von 1990. ${ }^{6}$ Die darin stattfindende Amalgamierung von Menschenrechten und Scharia hat zur Folge, dass der eigenständige normative Anspruch der Menschenrechte völlig erdrückt wird. ${ }^{7}$

(Hg.), Religionsfreiheit. Jahrbuch Menschenrechte 2009, Wien-Köln-Weimar 2008, S. 152165.

5 Wichtig ist mir die Klarstellung, dass das zitierte Papier der Russisch-Orthodoxen Kirchen keineswegs als repräsentativ für die Positionen innerhalb der Orthodoxie gelten kann, die sehr unterschiedlich ausfallen. Vgl. dazu die Aufsätze orthodoxer Theologen (insbesondere Konstantinos Delikostantis und Grigorios Larentzakis) in: Ingeborg Gabriel (Hg.), Politik und Theologie in Europa. Perspektiven ökumenischer Sozialethik, Ostfildern 2008.

6 Abrufbar unter: https://www.fmreview.org/Human-Rights/cairo (letzter Zugriff: 04.06. 2019). Die "Organization of the Islamic Conference“ (OIC) hat sich im Jahre 2011 - unter Beibehaltung des Akronyms - in „Organization of Islamic Cooperation“ umbenannt. Wiederum sei betont, dass diese - rechtlich nicht verbindliche - Erklärung keineswegs repräsentativ für alle Strömungen des Islams ist.

7 Dass weder die Gleichberechtigung der Geschlechter noch die Religionsfreiheit in der Kairoer Erklärung vorkommen, ist bezeichnend. 


\section{Die VN-Resolution über „traditional values“}

Die genannten Beispiele, die sich leicht ergänzen ließen, sollten kurz illustrieren, wie viel bei der Verhältnisbestimmung von modernen Menschenrechten und ethischen Traditionen auf dem Spiel steht: Es geht um nichts weniger als um die Legitimität und die Akzeptanzchancen des Menschenrechtsanspruchs im Ganzen. Klärungen sind deshalb vordringlich. Insofern könnte man eine Chance darin sehen, dass auch die Vereinten Nationen dieses Thema mittlerweile ausdrücklich aufgegriffen haben. Die entsprechenden Debatten im Genfer VN-Menschenrechtsrat mündeten in die Verabschiedung einer Resolution vom 27. September 2012, die den programmatischen Titel trägt: „Promoting human rights and fundamental freedoms through a better understanding of traditional values of humankind: best practices". ${ }^{8}$

Bei näherem Hinsehen zeigt sich indes, dass diese Resolution weder zur Klärung der anstehenden Sachfrage noch zur Entschärfung des darin angelegten Konfliktpotenzials beiträgt. Ganz im Gegenteil. Aufschlussreich ist bereits die Tatsache, dass die Resolution nur eine äußerst knappe Mehrheit fand. Von den 47 Mitgliedstaaten des Menschenrechtsrats ${ }^{9}$ stimmten gerade einmal 25 für die Resolution; 15 stimmten dagegen, und die verbleibenden 7 Mitglieder enthielten sich. Viel knapper geht es nicht. Bemerkenswert ist außerdem, wer dafür und wer dagegen gestimmt hat. Unter den Befürwortern finden sich zahlreiche autoritär regierte Staaten, darunter China, Katar, Saudi-Arabien und insbesondere Russland, das sich schon im Vorfeld für die Resolution stark gemacht hatte. Die Staaten der Europäischen Union sowie die USA standen demgegenüber im Lager der Gegner.

Inhaltlich sagt der Resolutionstext nicht viel aus. Er ist weder besonders provokant, noch leistet er echte Klärungen, geschweige denn dass er analytisch in die Tiefe ginge. Was am meisten überrascht, ist der Eindruck von Belanglosigkeit, der sich bei der Lektüre aufdrängt. Es fehlt jede konzeptionelle und inhaltliche Prägnanz. Wie üblich, bezieht sich die Resolution des Menschenrechtsrats zunächst auf diverse bestehende Menschenrechtsinstrumente, insbesondere das Mutterdokument der internationalen Menschenrechte, die Allgemeine Erklärung von 1948; deren Geltung wird bekräftigt. Die Kernaussage besteht in dem Postulat, dass eine Besinnung auf „traditionelle Werte“ der Menschheit menschenrechtliches Engagement stärken könnte. In diesem Sinne

8 UN-Dok. A/HRC/RES/21/3 (verabschiedet am 27. September 2012, veröffentlicht in editierter Form am 9. Oktober 2012).

9 Der VN-Menschenrechtsrat fungiert als Unterorgan der VN-Generalversammlung. Während alle Staaten der Vereinten Nationen an den Beratungen aktiv teilnehmen können, bleibt das Stimmrecht den jeweils für drei Jahre nach einem Regionalschlüssel gewählten 47 Mitgliedern vorbehalten. 
stellt die Resolution fest: „traditional values, especially those shared by all humanity, can be practically applied in the promotion and protection of human rights and upholding human dignity, in particular in the process of human rights education". ${ }^{10}$ Kaum jemand würde dem widersprechen, zumal es sich um eine vage „Kann“-Aussage handelt. An anderer Stelle werden gesellschaftliche Institutionen wie die Familie oder die Schule in ihrer Bedeutung für die Wertevermittlung gewürdigt. ${ }^{11}$ Auch das ist keine besonders aufregende Aussage. Vor allem aber vermisst man jeden Ansatz einer Definition der hier angesprochenen „traditional values“. Angesichts der Diffusität der Werte-Semantik könnte sich jeder hierunter etwas ganz Anderes vorstellen. Immerhin formuliert die Resolution das Caveat, dass Traditionen nicht gegen die Menschenwürde und die Menschenrechte ausgespielt werden dürfen: „(...) traditions shall not be invoked to justify practices contrary to human dignity and violating international human rights law“. ${ }^{12}$ Mehr Klarheit schafft der Text nicht.

Wer nur den Resolutionstext als solchen liest, dürfte sich schwertun, die politische Aufregung nachzuvollziehen, die er ausgelöst hat. Wie kann eine solch blasse, belanglos klingende Resolution den Menschenrechtsrat polarisieren, ja spalten? Gerade diese semantische Diffusität macht jedoch das Problem aus. Die Sorge ist nicht unangebracht, dass die Vermischung der mittlerweile recht präzise definierten und in rechtsverbindlichen Konventionen gehärten Menschenrechtsnormen mit undefinierten „traditional values“ die normativen Konturen der Menschenrechte aufweichen könnte. Möglicherweise ist dies sogar die „hidden agenda“ hinter dem Projekt. Wie passt beispielswiese das klar definierte Verbot der Geschlechterdiskriminierung mit kontextuell äußert variablen und letztlich undefinierten „Familienwerten“ zusammen? Wie soll man mit Spannungen umgehen, die aus dem Recht auf Meinungsfreiheit mitsamt seinem Provokationspotenzial einerseits und traditionellen Vorstellungen von Gemeinschaftsloyalität andererseits entspringen können? Unterscheidet sich die Religionsfreiheit als universalistisch gefasstes Freiheitsfreiheit nicht fundamental von traditionellen Toleranzkonzepten, wie sie sich in christlichem oder islamischem Kontext entwickelt haben? Wie soll man dann aber mit solchen kategorialen Differenzen umgehen? Der Resolutionstext gibt auf solche Fragen nicht nur keine Antworten, sondern lässt auch gar kein Problembewusstsein bezüglich etwaiger Spannungen erkennen, die von vornherein harmonisierend überspielt werden. Genau diese Ausblendung bereitet Unbehagen. Die Amalgamierung einer diffusen Wertesemantik mit positiv definierten Menschen-

10 Abschnitt 4.

11 Vgl. Abschnitt 2.

12 Präambel. 
rechtsnormen gibt sicherlich keinen Zugewinn an Präzision, sondern dürfte die bisher erreichten Standards eher vernebeln. ${ }^{13}$

Obwohl es mithin gute Gründe für die Skepsis gegenüber dem Resolutionstext gibt, birgt seine Ablehnung jedoch ebenfalls Risiken. Denn durch ein Nein zu den "traditional values" könnte sich der Eindruck verfestigen, die Menschenrechte seien ein traditionsloses, ja traditionszerstörendes „Konstrukt" westlich-liberaler Eliten, die sich dem herkömmlichen Ethos der Bevölkerungen völlig entfremdet hätten. Damit aber würde ein Grundmotiv konservativer Menschenrechtskritik einmal mehr revitalisiert, das die Entwicklung der Menschenrechte von Anfang an begleitet hat - paradigmatisch bereits in Edmund Burkes 1790 veröffentlichter Streitschrift gegen die Französische Revolution. ${ }^{14}$ Burke kontrastiert in seinem Essay die Menschenrechtserklärung der Revolution mit den gewachsenen, von Generation zu Generation weitergegebenen Rechten der Engländer. Während letztere aufgrund ihrer Rückbindung an eine konkrete Tradition verlässlich seien, wohne den revolutionären Menschenrechten aufgrund ihrer Abstraktheit das Potenzial zur Selbstzerstörung inne; denn es fehle ihnen die stabilisierende und moderierende Kraft gewachsener Traditionen. Dieses polemische Leitmotiv wurde wenig später von Joseph de Maistre, dem führenden Intellektuellen der Gegenrevolution aufgegriffen und hat sich in vielen Varianten bis in die Gegenwart erhalten. Es verbindet sich häufig mit der Ablehnung angeblich einseitig "westlicher" normativer Vorstellungen. ${ }^{15}$ Diejenigen Staaten, die der Resolution des Menschenrechtsrats zu ,traditional values“ aus nachvollziehbaren Gründen die Zustimmung verweigern, leiten womöglich Wasser auf die Mühlen solcher Kritik. Ungewollt bedienen sie damit das Klischee, die Menschenrechte seien traditionsfremd und dem echten Leben völlig enthoben - mit anderen Worten: das Produkt intellektueller Schreibtischtäter, die typischerweise in den Hauptstädten des Westens residieren. Dies wiederum spielt der antiliberalen Propaganda autoritärer Regime in die Hände, die die Menschenrechte gern als volksfremdes Oktroi, als Manifestation moralischer Dekadenz und als illegitime Intervention des (westlichen) Auslands stigmatisieren.

13 Hinzu kommt die Sorge, der als undefiniertes Blankett verwendete Begriff der „traditionellen Werte" könne längerfristig zum Trägerbegriff für ein Rollback vor allem in Fragen der Gender-Gerechtigkeit werden. Zwar enthält der Text selbst dazu keine unmittelbaren Hinweise, der weitere Kontext der Debatte gibt diesem Verdacht allerdings durchaus Nahrung.

14 Vgl. Edmund Burke, Betrachtungen über die Französische Revolution, übersetzt von Friedrich Gentz, Zürich o.J., S. 195.

15 Vgl. Adamantia Pollis / Peter Schwab, Human Rights: A Western Concept with Limited Applicability, in: Human Rights: Cultural and Ideological Perspectives, New York 1979, S. $1-18$. 
Der Begriff der „traditional values“ ist im VN-Kontext durch gezielte Politisierung regelrecht vergiftet worden, was die sachliche Auseinandersetzung erheblich erschwert. Dies ist umso bedauerlicher, als die Thematik selbst ja dringender Klärung bedürftig wäre. Die Gefahr besteht, dass sich die Grundsatzdebatte über das Verhältnis moderner Menschenrechte zu ethischen Traditionen durch Negierung der jeweils entgegengesetzten Extremposition nur noch im Kreise dreht.

\section{Hermeneutisch sensible „Posttraditionalität“ der Menschenrechte}

Die Spannung, die die Debatte über „traditional values“ und Menschenrechte durchzieht - Tradition versus Moderne, Kontextualität versus Universalismus, Historizität versus normative Unbedingtheit usw. - lässt sich weder harmonisierend überspielen noch mit einem Schlag aufheben. Sie kann aber auch nicht durch einen Kompromiss auf halber Linie entschärft werden, sondern verlangt nach systematischer Klärung. Ohne eine prinzipielle Klärung droht der Anspruch der Menschenrechte insgesamt zu verschwimmen. Er könnte entweder einem historischen Kontextualismus verfallen, in dem die Menschenrechtsidee ihre normative Prägnanz verlieren würde, oder in einen sterilen Gegensatz zu gewachsenen ethischen Traditionen geraten, der für die Akzeptanzchancen der Menschenrechte verheerend wäre.

Als Ausgangspunkt für die anstehende Klärung kann das Faktum der Pluralität dienen, das die modernen Gesellschaften durchweg kennzeichnet. Im Kontext von Modernisierungsprozessen hat sich solche Pluralität oft krisenhaft Bahn gebrochen, wie sich paradigmatisch an den frühneuzeitlichen europäischen Konfessionskriegen zeigen lässt. Schon damals stellte sich die Frage, wie ein faires Miteinander zwischen unterschiedlichen Gruppierungen gelingen konnte, mit neuer Radikalität. Solange ethische und rechtliche Ordnungsvorstellungen unmittelbar dem Selbstverständnis einer bestimmten konfessionellen Tradition entsprangen, war ein Zusammenleben mit Andersgläubigen auf gleicher Augenhöhe praktisch ausgeschlossen. Wie auch hätte eine substanzielle Verständigung gelingen können, wenn die einen auf das päpstlich beglaubigte Naturrecht setzen, während die anderen im Papst den „Antichrist“ sahen. Vertreibungen, Diskriminierung oder Zwangsbekehrungen wurden allenfalls durch Phasen einer pragmatischen Toleranzpolitik abgelöst, auf die aber letztlich nie 
Verlass sein konnte. Das Dilemma, das sich hier auftut, wurde zu einem entscheidenden Movens der neuzeitlichen europäischen Aufklärung. ${ }^{16}$

Neben die inzwischen erheblich angewachsene Vielfalt der Religionen, Konfessionen und Weltanschauungen ist heute zugleich eine Pluralität der Lebensformen getreten, zu der nicht zuletzt unterschiedliche Familienformen gehören, wie man sie sich in der Vergangenheit nicht hätte vorstellen können. Auch ethische Traditionen im weitesten Sinne gibt es offenbar nur im Plural, und dieser Plural durchzieht nicht nur die „Weltgesellschaft“, sondern mehr und mehr auch einzelne Gesellschaften, konkrete Nachbarschaften, berufliche Kollegien, Freundeskreise und nicht selten auch Familien. Unter solchen Bedingungen lässt sich ein faires Miteinander nicht mehr - oder jedenfalls nicht mehr ohne Weiteres - unter Rückgriff auf je eigene Gewohnheiten und ethischen Traditionen organisieren.

Menschenrechte sind eine normative Antwort auf diese sich oft krisenhaft manifestierende Grundkonstellation. ${ }^{17}$ Sie stehen deshalb, systematisch gesehen, nicht unmittelbar in der Linie ethischer Traditionen, sondern nehmen davon bewusst Abstand. Nur im Abstand zu den jeweiligen Traditionen können die Menschenrechte ein normatives Angebot formulieren, das der Gestaltung des potenziell konflikthaften Pluralismus moderner Gesellschaften dienen kann. Der von konservativen Kreisen häufig vorgebrachte Vorwurf der Abstraktheit hat insofern einen richtigen Kern: In der Tat verlangen die Menschenrechte eine „Abstraktion“: Ohne die - immer wieder neu zu leistende - Abstandnahme von den bis dato herrschenden ethischen Traditionen und ihren vielen gewachsenen Besonderheiten kann sich der spezifische Geltungsanspruch der Menschenrechte nicht entfalten. ${ }^{18}$

Die inhaltliche Antwort der Menschenrechte auf den irreversiblen Pluralismus besteht darin, ihn konditional zu akzeptieren. Die Vielfalt der religiösen Überzeugungen, kulturellen Prägungen, ethischen Orientierungen usw. gilt fortan nicht mehr als Signum des Niedergangs, der Schwäche oder „Dekadenz“, sondern als Bestandteil gesellschaftlicher Normalität, ja mehr noch: als Chance wechselseitigen produktiven Ansporns. Diese Anerkennung von Vielfalt geschieht nun aber nicht im Modus vorbehaltloser Toleranz, eines strukturlosen Multikulturalismus oder eines schlichten (Gewohnheits-)Rechtspluralismus. Denn durch die jeweiligen Manifestationen von Vielfalt hindurch gilt die Anerkennung stets den Menschen, die all dies tragen. Subjekt der Menschenrechte ist zuletzt immer der Mensch. Von dorther ergibt sich eine kritische Distanz

16 Vgl. Ernst Cassirer, Die Philosophie der Aufklärung, Hamburg 1998, S. 219.

17 Vgl. Heiner Bielefeldt, Philosophie der Menschenrechte, Darmstadt 1998.

18 Diese Komponente kommt zu kurz in der ansonsten bahnbrechenden Studie von Hans Joas, Die Sakralität der Person. Eine neue Genealogie der Menschenrechte, Frankfurt a.M. 2011. 
gegenüber den je konkreten Manifestationen von Pluralität. So schützt das Menschenrecht der Religionsfreiheit nicht etwa die Religionen als solche (z. B. deren Integrität, Reputation oder Ehre), sondern die Menschen, die sich in Freiheit zu ihnen bekennen - oder auch nicht bekennen; es geht um ihre Würde, Freiheit und Gleichheit. Ähnliches lässt sich über die Meinungsfreiheit sagen. Sie verlangt nicht die vorbehaltlose Wertschätzung jedweder Meinungsäußerung, sondern zielt wiederum auf Respekt für den Menschen als Subjekt eigener Positionierung in politischen und sonstigen Streitfragen. (Auch dann für Meinungsfreiheit einzutreten, wenn man die jeweils vorgetragene Position nicht teilt, ist seit Voltaire geradezu zum Beleg menschenrechtlichen Bewusstseins geworden). Ein anderes Beispiel bieten kulturelle Minderheitenrechte. Sie dienen nicht dazu, eine bestehende kulturelle Vielfalt gleichsam museal zu konservieren, sondern wollen wiederum den betroffenen Menschen institutionellen Rückhalt geben, ihre jeweiligen Traditionen in Freiheit weiterzuentwickeln sofern sie sich dafür entscheiden.

Man könnte die Liste der Beispiele leicht erweitern, an denen sich die Grundstruktur der Menschenrechte illustrieren lässt: Sie anerkennen die mittlerweile entstandene und sich womöglich weiter entwickelnde Vielfalt stets indirekt, nämlich dadurch, dass sie die Menschen als verantwortliche Subjekte rechtlich stärken. ${ }^{19}$ Diese charakteristische Indirektheit impliziert zugleich ein Moment der Konditionalität: Anerkennung der Vielfalt geschieht nicht ohne Wenn und Aber, sondern unter der Bedingung, dass diese plausiblerweise als Manifestation menschlicher Würde, Freiheit und Gleichheit verstanden werden kann. Dies impliziert kritische Vorbehalte in allen einschlägigen Feldern. Konkret: Religiöser Zwang - etwa in Gestalt von Einschüchterungsmaßnahmen gegenüber potenziellen „Abtrünnigen“ - kann keinesfalls akzeptiert werden; entsprechende Praktiken fallen demnach auch nicht unter die Religionsfreiheit. Wenn Meinungsäußerungen darauf hinauslaufen, durch hasserfüllte Sprechakte bestimmte Menschen bewusst aus der Kommunikationsgemeinschaft zu exkommunizieren, muss der Staat - im Rahmen der dafür vorgesehenen Kriterien - ggf. Grenzen setzen. Kulturelle Minderheitenrechte vergattern Menschen keineswegs auf ihre vorgegebene kulturelle Identität; wer sich aus freien Stücken dem gesellschaftlichen Mainstream anschließen und deshalb kulturell „assimilieren" möchte, hat dazu alle Freiheit.

Letzter tragender Grund der Menschenrechte ist die Würde des Menschen als eines Verantwortungssubjekts. Alle Menschenrechte dienen dazu, diesen Respekt in unterschiedlichen Lebensbereichen wirksam zu unterstützen. Sie geben dem gebotenen Respekt vor der Würde des Menschen als Verantwortungssub-

19 Vgl. dazu - am Beispiel der Religionsfreiheit entwickelt - Heiner Bielefeldt / Michael Wiener, Religious Freedom under Scrutiny, Pennsylvania 2020, S. 13-46. 
jekt dadurch institutionellen Rückhalt, dass sie dem Menschen Freiheit zusprechen. Diese Freiheit muss sozialkompatibel ausgestaltet werden und kann deshalb nicht grenzenlos sein. Entscheidend aber ist, dass die Grenzen der Freiheit nun nicht mehr wie zuvor durch Traditionen, Gewohnheiten, Geschlechterrollen, Statuspositionen usw. gezogenen werden, sondern sich ihrerseits am Maßstab der Freiheit orientieren. Eine legitime Grenze der Freiheit ist deshalb vor allem die Freiheit der anderen - genauer: die gleiche Freiheit der anderen. Freiheit und Gleichheit gehören im Menschenrechtskontext systematisch zusammen. ${ }^{20}$ Nur im Gespann mit dem Gleichheitsprinzip kann das Freiheitsprinzip seine ordnungsstiftende Funktion entfalten. Historisch ist dies ein Novum.

Aus dieser emanzipatorischen Stoßrichtung der modernen Menschenrechtsidee ergeben sich immer wieder Spannungen und Konflikte mit ethischen Traditionen; nicht selten sind solche Konflikte zu regelrechten Kulturkämpfen eskaliert, die manchmal unvermeidlich gewesen sein mögen. Vielerorts finden solche Kulturkämpfe auch in der Gegenwart statt - man denke nur an die oft polarisierten Kontroversen über Genderfragen. Wer die sich hier auftuenden Differenzen harmonisierend überspielt oder nicht wahrhaben will, verbaut sich ein angemessenes Verständnis des modernen egalitären Freiheitsrechts. Die konfliktträchtige Differenz zwischen modernen Menschenrechten und ethischen Traditionen bildet dennoch keine vollständige Dichotomie; sie lässt sich nicht als „Nullsummenkonflikt" begreifen, in dem die eine Seite stets verliert, was die andere gewinnt. Vielmehr bergen die Konflikte auch Lösungsmöglichkeiten. Denn die menschenrechtlichen Kernbegriffe finden sich vielfach schon in traditionellen ethischen Vorstellungen - wenn auch meist mit sehr anderen systematischen Konnotationen und Konstellationen. Dies gilt beispielsweise für die Idee der Menschenwürde, die Begriffe von Schuld und Gewissen, soziale Gerechtigkeitsvorstellungen, spezifische Solidaritätserwartungen, unterschiedliche Respekt- und Fürsorgeverhältnisse oder den Rekurs auf Widerstand gegen Ungerechtigkeiten. Die im menschenrechtlichen Denken angelegte Abstandnahme („Abstraktion“) gegenüber traditionellen Ethosformen birgt daher auch Chancen für eine Weiterentwicklung genau dieser Traditionen. Im Lichte moderner Menschenrechte kann eine reflexive Distanz entstehen, die Chancen für reformerische Neu-Orientierungen und für die Wiederentdeckung traditioneller ethischer Potenziale birgt, die gleichzeitig neu akzentuiert und systematisch zentriert werden können.

Ein Beispiel bietet die bereits erwähnte Konzilserklärung Dignitatis Humanae. Wenn sie sich zur Begründung der Religionsfreiheit und anderer Men-

20 Vgl. Gerhard Luf, Freiheit und Gleichheit. Die Aktualität im politischen Denken Kants, WienHeidelberg 1978. 
schenrechte auf die Idee der Menschenwürde beruft, geschieht dies einerseits durchaus mit theologischem Selbstbewusstsein. Das Konzil will sich nicht einfach einem modernen Trend anpassen, sondern die eigene biblische und kirchliche Tradition fruchtbar machen. Andererseits ist den Verfassern der Erklärung sehr bewusst, dass sie Neuland betreten. Die freiheitsrechtliche Systematik, die den Menschenrechtsansatz trägt, stellt gegenüber den kirchlichen Traditionen eben doch auch ein Novum dar, und dies wird offen angesprochen. So lautet der erste Satz der Konzilserklärung:

„Die Würde der menschlichen Person kommt den Menschen unserer Zeit immer mehr zum Bewusstsein, und es wächst die Zahl derer, die den Anspruch erheben, dass die Menschen bei ihrem Tun ihr eigenes Urteil und eine verantwortliche Freiheit besitzen und davon Gebrauch machen sollen, nicht unter Zwang, sondern vom Bewusstsein der Freiheit geleitet. “21

Menschenrechte sind gekennzeichnet durch ein Moment der Diskontinuität und bewussten Abstandnahme - wenn man so will: „Abstraktion“ - gegenüber ethischen Traditionen, denen sie mit der Forderung nach Anerkennung gleicher Würde und gleicher Freiheit für alle Menschen kritisch gegenübertreten. Insofern lassen sich die Menschenrechte als „posttraditionelle“ Normstruktur begreifen. Diese ihre posttraditionelle Qualität, die unübersehbares Konfliktpotenzial birgt, zielt aber nicht auf die schlichte Negation traditioneller Ethikformen, sondern auf deren Öffnung. Moderne Menschenrechte sind kein Freibrief dafür, ohne Not Kulturkämpfe vom Zaun zu brechen. Sie sind weder ikonoklastisch noch in einem schlicht dichotomischem Sinne anti-traditionell, wie konservative Kritiker immer wieder befürchtet haben. Vielmehr repräsentieren sie eine hermeneutisch sensible Posttraditionalität. Der Respekt der Menschenwürde, der den Menschenrechtsansatz im Ganzen trägt, verlangt einen angemessenen „hinhörenden“ Umgang mit den Menschen und ergo auch mit ihren jeweils existierenden religiösen, weltanschaulichen, kulturellen und ethischen Prägungen.

\section{Abschließende Bemerkung}

Die Kontroverse um die angemessene Verhältnisbestimmung zwischen modernen Menschenrechten und traditionellen ethischen Werten wird weitergehen. Leider hat die Resolution des Menschenrechtsrats vom September 2012 diesbezüglich keine Klärung erbracht, sondern bestehende Fronten weiter verhärtet. Dass die westlichen Mitgliedstaaten des Menschenrechtsrats der Resolution

21 Dignitatis humanae, Abschnitt 1. 
damals geschlossen ihre Zustimmung verweigerten, hatte gute Gründe für sich. Denn eine harmonisierende Vermengung moderner Rechtsstandards mit undefinierten „traditional values“, wie im Resolutionstext angelegt, birgt das Risiko einer Relativierung des menschenrechtlichen Geltungsanspruchs und einer Vernebelung seiner emanzipatorischen Orientierung. Eine schlichte Absage an die Debatte zu traditionellen Werten reicht indes ebenfalls nicht hin. Bemühungen um eine wirkliche Klärung bleiben daher vordringlich.

Um in der Sache voranzukommen, sind auf allen Seiten hermeneutische Anstrengungen nötig. Unter Bedingungen eines faktisch irreversiblen Pluralismus der Religionen, Kulturen und ethischen Vorstellungen, kann ein ungebrochener Rekurs auf Gewohnheiten und ethischen Traditionen nicht gelingen. Schlimmer noch: Er gerät gewollt oder ungewollt zur fundamentalistischen Absage an diskursive Verständigung über Grenzen hinweg, die längst auch inmitten der Gesellschaften verlaufen. Im Gegenzug gilt aber auch, dass die Menschenrechte ihr im Respekt der Menschenwürde aller angelegtes friedensstiftendes Potenzial nur dann glaubhaft entfalten können, wenn ihr kritischer „posttraditionaler" Geltungsanspruch mit hermeneutischer Sensibilität für die Entwicklungsmöglichkeiten traditioneller Ethosformen einhergeht. In ikonoklastischer Verhärtung könnte die Menschenrechtsidee sonst auch ihrerseits fundamentalistische Züge entwickeln.

\section{Quellen}

Bielefeldt, Heiner / Wiener, Michael, Religious Freedom under Scrutiny, Pennsylvania 2020.

Bielefeldt, Heiner, Philosophie der Menschenrechte, Darmstadt 1998.

Burke, Edmund, Betrachtungen über die Französische Revolution. Aus dem Englischen übersetzt von Friedrich Gentz, Zürich o. J.

Cairo Declaration of Human Rights in Islam, vgl. https://www.fmreview.org/HumanRights/cairo (letzter Zugriff: 04.06.2019).

Cassirer, Ernst, Die Philosophie der Aufklärung, Hamburg 1998.

Delikostantis, Konstantinos, Die Menschenrechte aus orthodoxer Sicht, in: Ingeborg Gabriel (Hg.), Politik und Theologie in Europa. Perspektiven ökumenischer Sozialethik, Ostfildern 2008, S. 81-98.

Dignitatis humanae, Erklärung über die Religionsfreiheit, vgl. http://www.vatican.va/archi ve/hist_councils/ii_vatican_council/documents/vat-ii_decl_19651207_dignitatis-hum anae_ge.html (letzter Zugriff: 04.06.2019).

Heimbach-Steins, Marianne, Religionsfreiheit. Ein Menschenrecht unter Druck, Paderborn 2012.

Hilpert, Konrad, Menschenrechte und Theologie. Forschungsbeiträge zur ethischen Dimension der Menschenrechte, Freiburg 2001. 
Joas, Hans, Die Sakralität der Person. Eine neue Genealogie der Menschenrechte, Frankfurt a.M. 2011.

Larentzakis, Grigorios, Die Häresie des Nationalismus. Menschenwürde und Menschenrechte für alle in der östlich-orthodoxen Perspektive, in: Ingeborg Gabriel (Hg.), Politik und Theologie in Europa. Perspektiven ökumenischer Sozialethik, Ostfildern 2008, S. 257-279.

Luf, Gerhard, Freiheit und Gleichheit. Die Aktualität im politischen Denken Kants, WienHeidelberg 1978.

Moskauer Patriarchat, The Russian Orthodox Church's Basic Teachings on Human Dignity, Freedom and Rights, 2008, vgl. http://www.mospat.ru/en/documents/dignityfreedom-rights (letzter Zugriff: 04. 06.2019).

Pollis, Adamantia / Schwab, Peter, Human Rights: A Western Concept with Limited Applicability, in: Human Rights: Cultural and Ideological Perspectives, New York 1979, S. 1-18.

UN-Dok. A/HRC/RES/21/3, Promoting human rights and fundamental freedoms through a better understanding of traditional values of humankind: best practices, vgl. https:// digitallibrary.un.org/record/735730 (letzter Zugriff: 04.06.2019).

Willems, Joachim, Die Russisch-Orthodoxe Kirche und die Menschenrechte, in: Heiner Bielefeldt / Volkmar Deile / Brigitte Hamm (u.a.) (Hg.), Religionsfreiheit. Jahrbuch Menschenrechte 2009, Wien-Köln-Weimar 2008, S. 152-165. 
Open-Access-Publikation im Sinne der CC-Lizenz BY 4.0

(C) 2020, Vandenhoeck \& Ruprecht $\mathrm{GmbH} \&$ Co. KG, Göttingen ISBN Print: 9783847111658 - ISBN E-Lib: 9783737011655 


\section{Das Recht auf Religions- und Weltanschauungsfreiheit - Kompass demokratischer Religionspolitik?}

\section{Religionsfreiheit und Demokratie - Annäherungen an ein komplexes Thema}

Die Stichwort-Kombination „Religionsfreiheit und Demokratie“ legt die Annahme nahe, dass Religion als Faktor des gesellschaftlichen Lebens und als geistige Ressource, mit der umzugehen oder die zu ignorieren der Freiheit der Einzelnen überantwortet ist, für demokratische Gemeinwesen politische Relevanz besitzt. Das Thema markiert eine Facette der Diskussion um die Zukunft demokratischer Gesellschaften, die Konfliktstoff und eine Reihe ungelöster Fragen birgt, jedenfalls aber in der gegenwärtigen Lage europäischer Gesellschaften nicht ignoriert werden kann. Damit greift der Beitrag ${ }^{1}$ eine Frage im Spektrum politischer Ethik auf, die auch im wissenschaftlichen Oeuvre von Ingeborg Gabriel eine zentrale Rolle spielt. Sie hat in ihrer akademischen wie in ihrer (gesellschafts-)politischen Tätigkeit wesentlich dazu beigetragen, menschenrechtlich fokussierte ethische Impulse aus christlicher Sicht in die akademische wie in die öffentliche Debatte einzuspeisen. Dafür sei ihr an dieser Stelle und mit den folgenden Überlegungen ein herzlicher und kollegialer Dank gesagt.

Auf der einen Seite steht ein spezifisches Freiheitsrecht der Person zur Diskussion, ein Menschenrecht, das in vielen völkerrechtlichen Verträgen und Konventionen festgeschrieben und als Grundrecht Bestandteil zahlreicher moderner Staatsverfassungen ist. Demokratie und Menschenrechte zusammenzudenken - das eine als Voraussetzung des anderen -, legen sowohl die historisch-politische Entwicklung moderner westlicher Gesellschaften als auch systematische Gründe nahe, insbesondere die Bedeutung von Freiheit als Voraussetzung für politische Partizipation und damit für das Funktionieren demokratischer Willensbildung. Das Verhältnis von Religionsfreiheit und De-

1 Die folgenden Überlegungen habe ich in einer kürzeren Fassung beim Symposium Dürnstein zum Thema „Demokratie! Zumutung oder Zukunft“ (07.-09.03.2019) zur Diskussion gestellt. 
mokratie stellt demnach einen Spezialfall dieses Zusammenhangs dar. Moderne demokratische Gesellschaften sind typischerweise durch eine große weltanschauliche bzw. religiöse Pluralität und Heterogenität geprägt, die vielfältigen Konfliktstoff bergen. Zugleich werden sie durch demokratieskeptische, teils offen antidemokratische - manchmal mit religiösen Kräften alliierte - Tendenzen herausgefordert. „Religionspolitik“ gewinnt angesichts dessen an öffentlicher wie wissenschaftlicher Aufmerksamkeit. ${ }^{2}$ Deshalb werde ich Argumentationsweisen, die in Religion und der Freiheit der Religionsausübung eine Gefahrenquelle für demokratische Gesellschaften sehen, erörtern (2).

Auf der anderen Seite wird mit dem Stichwort Demokratie ein Modell politischer Herrschaft bzw. eine Staats- und Gesellschaftsform aufgerufen. Es schreibt die politische Herrschaft dem „Demos“ als Souverän zu und basiert dementsprechend - bei allen realen Unterschieden existierender demokratischer Gesellschaften und Systeme - auf der Einigung auf eine Verfassung, auf den Prinzipien der Gewaltenteilung, der politischen Partizipation der BürgerInnen, der Delegation politischer Macht auf Zeit sowie der Kontrolle der MandatsträgerInnen durch die Bürgerschaft mit der Möglichkeit, das politische Mandat auch wieder zu entziehen. Es setzt regelhafte und transparente Verfahren voraus, die politische Kommunikation und Entscheidungsfindung zu organisieren, mit politischem Dissens umzugehen und zwischen dissentierenden Positionen Handlungsfähigkeit durch Kompromissbildung herzustellen. Veränderungspotential demokratischer Gesellschaften liegt u.a. in der digitalen Revolutionierung der Kommunikationsmedien sowie in dem Bedeutungsgewinn supra- bzw. postnationaler Konstellationen - das gilt gerade für das moderne Europa. $\mathrm{Zu}$ gleich stellen aber Dynamiken der Re-Nationalisierung und Identitätspolitiken, die stark auf das nationale Moment, zuweilen aber auch auf religiöse Identitätsmarker setzen, repräsentative Demokratien vor neue Herausforderungen. Unter dem Vorzeichen von Mobilität und Migration ${ }^{3}$ stehen die Integrationsfähigkeit und der Zusammenhalt demokratischer Gesellschaften auf dem Prüf-

2 Vgl. u.a. Daniel Gerster / Viola van Melis / Ulrich Willems (Hg.), Religionspolitik heute. Problemfelder und Perspektiven in Deutschland, Freiburg i. Br. 2018; Marianne Heimbach-Steins (Hg.), Religion(en) in der Einwanderungsgesellschaft. Jahrbuch für Christliche Sozialwissenschaften 58/2017, Münster 2017; Antonius Liedhegener / Laura Lots, Religionspolitik zwischen Konflikt und Integration. Politikwissenschaftliche und sozialethische Positionen zur Religionspolitik in Deutschland, in: Jahrbuch für Christliche Sozialwissenschaften 58/2017, Münster 2017, S. 211-248.

3 Mit dem Stichwort Migration werden ein immens vielschichtiger Phänomenkomplex (Binnen- und internationale Migration; erzwungene Wanderung i.S. von Flucht; unterschiedliche ökologische, ökonomische, religiöse Gründe für Wanderungsbewegungen etc.) und eine Reihe damit verbundener politischer und sozialer Probleme aufgerufen, die hier nicht im Einzelnen dargelegt werden können. Vgl. dazu u. a. Marianne Heimbach-Steins, Grenzverläufe gesellschaftlicher Gerechtigkeit. Migration - Zugehörigkeit - Beteiligung, Gesellschaft Ethik - Religion 5, Paderborn 2016. 
stand. Wer in einer Gesellschaft leben darf, wer (wie weitgehend) partizipationsberechtigt ist, wie sich Staatsbürgerschaft und Zugehörigkeit zueinander verhalten und welche Rolle dabei ethnische, kulturelle und religiöse Aspekte spielen, ist $\mathrm{zu}$ einem Fragenkomplex geworden, der kontroverse und vielfach ideologisch aufgeladene öffentliche Debatten nährt und eingespielten demokratischen Verfahren angesichts heterogener Erfahrungshintergründe in Einwanderungsgesellschaften die Selbstverständlichkeit nimmt. In diesem Kontext stellt sich die Frage, welcher Stellenwert dem religiösen Freiheitsrecht in einer Demokratie zukommen soll, neu (3).

\section{Geht von Religion und dem Recht auf freie Religionsausübung eine Gefahr für die Demokratie aus?}

In diesem Abschnitt werde ich fragen, ob und inwiefern Religion und freie Religionsausübung in der Gesellschaft Konfliktpotentiale für die Demokratie bzw. für eine demokratische Gesellschaft implizieren (können) und wie diese ggf. zu gewichten sind. Drei Einwände, die in der gesellschaftlichen und politischen Öffentlichkeit und in der wissenschaftlichen Debatte erörtert werden, stelle ich in der gebotenen Kürze typisierend vor und wäge sie aus sozialethischer Perspektive ab.

Erster Einwand: Religion ist nicht kompatibel mit weltanschaulichem Pluralismus.

Skepsis gegenüber der Demokratieverträglichkeit von Religion wird an der Erwartung festgemacht, religiöse Wahrheits- bzw. Geltungsansprüche seien mit dem weltanschaulichen Pluralismus moderner Gesellschaften grundsätzlich nicht verträglich. Denn wer selbst den Zugang zur Wahrheit zu besitzen glaube, werde deren Geltungsanspruch unbedingt verteidigen und könne folglich weder konkurrierenden Geltungsansprüchen Toleranz oder gar Anerkennung zollen noch ein positives Verhältnis zu der in politischen Entscheidungsprozessen notwendigen Relativierung von Geltungsansprüchen einnehmen. ${ }^{4}$

Für solche Skepsis geben religiöse Stimmen zuweilen Anlass, und zwar v. a. in Fragen, die nicht unmittelbar die religiöse Wahrheit, sondern religiös konnotierte Moralerwartungen betreffen. Beispiele dafür sind etwa die in vielen Gesellschaften höchst kontrovers geführten Debatten um den Schutz des ungeborenen Lebens oder um die rechtliche Anerkennung gleichgeschlechtlicher

4 Vgl. u. a. Karl-Heinz Ladeur / Ino Augsberg, Toleranz - Recht - Religion. Die Herausforderung des „,neutralen “Staates durch neue Formen der Religiosität in der postmodernen Gesellschaft, Tübingen 2007. 
Partnerschaften. Unabhängig von den (hier nicht zu diskutierenden) inhaltlichen Fragen ist dabei zu unterscheiden zwischen der Ebene gesellschaftlicher Artikulation kontroverser Positionen aus religiösen Gründen und den Erwartungen, die seitens der Repräsentanten religiöser Überzeugungen an die demokratisch legitimierten politischen Institutionen und Entscheidungsprozesse gerichtet werden. Gesellschaftliche Kontroversen können, wenn sie ernsthaft und im Ringen um die Suche nach verantwortbaren Wegen geführt werden, auf allen Seiten zu Erkenntnisfortschritten führen. In einer freiheitlichen Gesellschaft gibt es keinen guten Grund, religiösen und anderen partikularen Positionen, die vielleicht Teile der Bevölkerung irritieren, von vornherein das Recht auf Artikulation und Gehör zu verweigern. Wenn sie Plausibilität für bestimmte Überzeugungen oder Positionen beanspruchen, müssen sie diese argumentativ vertreten, sich dem öffentlichen Streit stellen und dabei - wie alle Akteure auf der Bühne gesellschaftlicher Öffentlichkeiten - bestimmte Standards des Respekts einhalten. Weder religiöse Akteure noch Vertreterinnen anderer weltanschaulicher Ansprüche können erwarten, dass politische Entscheidungen die eigene Position „eins zu eins“ abbilden; sie sind herausgefordert, Ergebnisse fairer Kompromissbildung wenigstens zu respektieren.

Der Verdacht prinzipieller Unfähigkeit zur Toleranz gegenüber Andersdenkenden, Andersglaubenden oder Anderslebenden wird vielfach v. a. gegen Angehörige nicht-christlicher religiöser Bekenntnisse, namentlich des Islam, erhoben. In allen religiösen Bekenntniszusammenhängen gibt es Menschen, die das eigene Bekenntnis fanatisch und intolerant gegenüber allen anderen behaupten; jedoch ist die pauschale Unterstellung der Intoleranz gegenüber einer Religion ihrerseits eine ideologische und intolerante Behauptung, die einer genaueren Kenntnisnahme der Traditionen, religiösen Praxen und Bekenntnisrichtungen innerhalb dieser Religion kaum standhalten wird. In der Regel stehen dahinter unzulässige Verallgemeinerungen von Einzelerfahrungen bzw. Vorurteile, die in ihrer Pauschalität weder durch Erfahrung gedeckt noch argumentativ belastbar sind.

Zweiter Einwand: Die Beanspruchung von Religionsfreiheit durch religiöse Akteure zielt auf die Verteidigung von Privilegien

Wenn religiöse Organisationen / Kirchen für Religionsfreiheit eintreten bzw. dieses Recht im eigenen Namen reklamieren, wird ihnen zuweilen vorgehalten, es gehe ihnen (nur) um die Sicherung von Privilegien, nicht aber um ein grundlegendes Menschenrecht, das ja auch - und je nach Situation vielleicht sogar prioritär - für Andere verteidigt werden müsste. Dieser Vorwurf bezieht sich auf die Tatsache, dass sich aus dem individuellen Recht auf Religionsfreiheit bestimmte Freiheiten der Religionsgemeinschaften ableiten. Insofern die Religionsausübung auch gemeinschaftlich möglich sein muss, folgen daraus be- 
stimmte organisatorische / institutionelle Erfordernisse - wie etwa der Bau von Gotteshäusern oder die Möglichkeit, religiöse Unterweisung anzubieten. Religiöse Gemeinschaften können sich in solchen Zusammenhängen legitimer Weise auf das Recht auf Religionsfreiheit ihrer Gläubigen beziehen. Der eigene Anspruch muss sich aber daran bewähren, dass im Zweifelsfall auch die entsprechenden Rechte der Gläubigen anderer religiöser Gemeinschaften unterstützt und verteidigt und dass auch Ansprüche aus der negativen Religionsfreiheit respektiert werden.

Interpretationen, die einseitig die positive Religions(ausübungs)freiheit betonen - und diese mindestens implizit nur auf die eigene Religion, die Rechte ihrer Gläubigen und die Freiheit der eigenen Organisationen beziehen, bleiben diesbezüglich defizitär. Wenn unter Verweis auf die Religionsfreiheit faktisch Privilegien beansprucht werden, ist das darin liegende Missverständnis des individuellen Freiheitsrechts aufzuklären und als nicht gerechtfertigter Anspruch zurückzuweisen.

Dritter Einwand: Religion begünstigt die Entwicklung von „Parallelgesellschaften"

Eine weitere Gefahr für den Zusammenhalt der Gesellschaft und die demokratische Kultur wird in der Bildung sogenannter „Parallelgesellschaften“ gesehen. ${ }^{5}$ Dieser Einwand scheint mir weniger religionspolitisch als integrationspolitisch diskussionsbedürftig. Er richtet sich auf eingewanderte Bevölkerungsgruppen, die ihre „mitgebrachte“ Religion als eine Ressource der Identitätsvergewisserung in einer fremden - und nicht in jedem Fall selbstverständlich gastfreundlichen bzw. für Diversität offenen - Umgebung zu leben versuchen. Je weniger die Aufnahmegesellschaft ihrerseits Integration unterstützt, umso mehr werden Menschen, die dadurch auf ihr Fremdsein und -bleiben festgelegt werden, eine ihr Anderssein legitimierende Religiosität als Distinktionsmerkmal und als Ressource der Beheimatung pflegen. Insofern ist der genannte Verdacht falsch adressiert; er wäre in eine Kritik integrationspolitischer Versäumnisse zu transformieren. ${ }^{6}$

Dabei ist festzuhalten: Religion kann ein Medium der Integration sein; mindestens bindet sie Neuzugewanderte mit einer gewissen Wahrscheinlichkeit an die Gruppe der religiös gleichgesinnten Landsleute. Sie kann aber (u. U. gerade durch die Verstärkung der Gruppenbindung) auch zur Desintegration führen. V.a. wenn der rechtliche Ordnungsrahmen der aufnehmenden Gesell-

5 Vgl. u. a. Jürgen Leibold / Steffen Kühnel / Wilhelm Heitmeyer, Abschottung von Muslimen durch generalisierte Islamkritik?, in: Aus Politik und Zeitgeschichte 1-2/2006 (Themenheft Parallelgesellschaften), S. 3-10, vgl. http://www.bpb.de/apuz/30007/abschottung-von-musli men-durch-generalisierte-islamkritik? $\mathrm{p}=$ all (letzter Zugriff: 16.05.2019).

6 Vgl. u. a. Heimbach-Steins, Grenzverläufe, S. 115-117. 
schaft negiert - und ggf. religiös legitimierte Gewalt eingesetzt - wird, ist dies für das Zusammenleben in einer demokratischen Gesellschaft nicht tolerierbar. Die aufnehmende demokratische Gesellschaft ist ihrerseits herausgefordert, durch eine aktive Integrationspolitik solchen desintegrativen Dynamiken präventiv entgegenzuwirken.

In manchen Kontexten wird die Sorge vor der Entwicklung von Parallelgesellschaften durch Ansprüche auf Zulassung eines religiösen Sonderrechtes genährt. Solche Ansinnen nähren den Verdacht einer mangelnden Bereitschaft, das staatliche Rechtswesen und Gewaltmonopol anzuerkennen. Hierin ist m.E. tatsächlich ein Problem für den gesellschaftlichen Zusammenhalt zu sehen; denn es tangiert bzw. relativiert den gemeinsamen Ordnungsrahmen, der für Menschen mit unterschiedlichen weltanschaulichen und religiösen Optionen und mit divergenten Vorstellungen eines guten Lebens eine Art Basiskonsens für das Zusammenleben und die Gestaltung demokratischer Prozesse darstellt. ${ }^{7}$ Diesen anzutasten, indem religiösem Sonderrecht - etwa im Bereich des Familienrechts - stattgegeben wird, könnte grundrechtliche Standards aushebeln, die der Staat allen Personen, die in seinem Rechtsbereich leben, zu garantieren hat. Relevant kann dies etwa sein bezüglich der Geschlechtergleichstellung, der gleichberechtigten Bildungsbeteiligung von Jungen und Mädchen, des Schutzes von Minderjährigen etc., aber auch der politischen und ökonomischen Partizipation, der Berufsfreiheit und des Erbrechts. Solche Tendenzen könnten also letzten Endes auch die Ordnung insgesamt gefährden (weil relativieren), die das Recht auf Religionsfreiheit als Teil eines Systems von Menschen- bzw. Grundrechten zu garantieren vermag.

Die knapp diskutierten Einwände gegenüber der Verträglichkeit von Religion und der Demokratieförderlichkeit der Religionsfreiheit reflektieren die Erfahrung, dass Religion in modernen Gesellschaften tatsächlich als "Störfaktor" auftreten kann. Sie konvergieren in dem Verdacht, Religion sei in der modernen, weltanschaulich pluralen Gesellschaft nicht sozial verträglich. Ein so weitreichendes Urteil nimmt Religion als gesellschaftliches Phänomen jedoch ausschließlich von ihren problematischen Erscheinungs- und Wirkungsformen her wahr. Die Argumente werden, schaut man die Debatten etwa der letzten zwei Jahrzehnte an, zwar v. a. in Bezug auf den in Europa zunehmend stärker vertretenen Islam entwickelt. Sie werden aber gelegentlich auch generalisierend gegen religiöse Akteure bzw. organisierte Religion insgesamt vorgebracht. Das führt, wie der ehemalige Sonderberichterstatter für das Menschenrecht auf Religions- und Weltanschauungsfreiheit bei den UN berichtet, auf der internationalen Bühne sogar dazu, dass das Recht auf Religionsfreiheit bisweilen gar nicht

7 Vgl. u. a. Heiner Bielefeldt, Menschenrechte in der Einwanderungsgesellschaft. Plädoyer für einen aufgeklärten Multikulturalismus, Bielefeld 2007, S. 105-107. 
mehr in einer Linie mit den anderen menschenrechtlich verbürgten Freiheitsansprüchen, sondern geradezu in Opposition dazu wahrgenommen wird, so als ob „die Menschenrechte“ gegen „die Religionsfreiheit“ verteidigt werden müssten und nicht die Religionsfreiheit als eines dieser Menschenrechte. ${ }^{8}$ Die Ausklammerung der Religionsfreiheit aus dem Zusammenhang der Menschenrechte nährt den Verdacht, dass eine solche Wahrnehmung tendenziös einseitig ist und konstruktive Potentiale von Religion ignoriert.

\section{Kann und soll das Recht auf Religionsfreiheit als Kompass für die Religionspolitik demokratischer Gesellschaften fungieren?}

Um die in der Überschrift gestellte Frage zu beantworten, muss zuerst in Erinnerung gerufen werden, was das Recht auf Religionsfreiheit bedeutet, was es schützt, wie es den Staat beansprucht und gegen welche Missverständnisse es abzusichern ist.

\subsection{Schutzbereich und Anforderungen des Rechtes auf Religionsfreiheit ${ }^{9}$}

Religionsfreiheit ist als komplexes individuelles Freiheitsrecht im Kanon der allgemeinen Menschenrechte verankert. ${ }^{10}$ Es umfasst Glaubens- bzw. Weltanschauungsfreiheit, Gewissens- und Bekenntnisfreiheit (forum internum); diese genießen absoluten Schutz. Außerdem wird die individuelle und gemeinschaftliche Religionsausübungsfreiheit (forum externum) im Rahmen der unteilbaren Menschenrechte (also nicht absolut) geschützt. Der Schutzanspruch richtet sich gegen jeden Zwang in religiösen Dingen und sichert zudem positive Ansprüche, die sich aus dem Respekt vor der religiösen bzw. weltanschaulichen Überzeugung einer Person ergeben: Er umfasst u. a. die Freiheit der Eltern zur

8 Vgl. Heiner Bielefeldt, Religionsfreiheit als heilsame Provokation. Dankesrede anlässlich der Verleihung des Alfons Auer-Ethik-Preises, in: Theologische Quartalschrift 198/2018, S. 146162, hier: S. 155-158.

9 Das Folgende basiert auf Marianne Heimbach-Steins, Religion zwischen Privatheit und Öffentlichkeit. Eine christlich-ethische Perspektive, in: Martin Dürnberger (Hg.), Öffentlichkeiten. Salzburger Hochschulwochen 2017, Innsbruck-Wien 2018a, S. 23-75, hier: S. 42-44.

10 Das Recht auf „Gedanken-, Gewissens-, Religions- und Weltanschauungsfreiheit“ ist in der Allgemeinen Erklärung der Menschenrechte der Vereinten Nationen (Art. 18) formuliert; es ist völkerrechtlich verbindlich verankert im Pakt für bürgerliche und politische Rechte der Vereinten Nationen (Art. 18), in einer Reihe von UN-Konventionen ebenso wie in der Europäischen Menschenrechtskonvention (Art. 9). 
religiösen Erziehung ihrer Kinder gemäß den eigenen Überzeugungen und - ganz fundamental - die Freiheit, das religiöse Bekenntnis beziehungsweise die Weltanschauung zu wechseln. Geschützt sind die Freiheit des Individuums, einen Glauben zu haben, zu bekennen und zu praktizieren (positive Religionsfreiheit), und ebenso die Freiheit, keinen Glauben zu haben, zu bekennen und zu praktizieren (negative Religionsfreiheit).

Als Garantie-Instanz des „fairen, diskriminierungsfreien Umgangs mit religiöser und weltanschaulicher Vielfalt ${ }^{\star 11}$ kann der Staat seine Schutzfunktion gegenüber den entsprechenden Überzeugungen der Individuen nur unter der Bedingung ausüben, dass er sich nicht selbst an ein bestimmtes religiöses oder weltanschauliches Bekenntnis bindet. Deshalb sind der Staat und seine Organe gehalten, den Religionen und Weltanschauungen in der Haltung „respektvoller Nicht-Identifikation ${ }^{\text {" } 12}$ zu begegnen. Sie sollen alle Rechtsunterworfenen in den Entfaltungsmöglichkeiten ihrer religiösen und weltanschaulichen Überzeugungen und Praxen gleichberechtigen, ohne sich selbst mit einer dieser Optionen zu identifizieren. In diesem Sinne ist der Staat als Grundrechtsstaat in einem normativen Sinne säkular, jedoch gerade nicht säkularistisch ${ }^{13}$.

Gegen ein verbreitetes Missverständnis ist zu betonen: Das Recht auf Religionsfreiheit schützt nicht Religion als solche, sondern die Freiheit von Individuen im Hinblick auf ihre religiösen und weltanschaulichen Überzeugungen und entsprechendes individuelles und gemeinschaftliches Handeln. Als Menschenrecht gilt es nicht nur für TrägerInnen einer bestimmten religiösen Überzeugung oder einer bestimmten Nationalität, sondern für jeden Menschen. ${ }^{14}$ Der Schutz der religiösen Freiheit ist nicht an den Bürgerstatus gebunden.

\subsection{Was spricht für die Religionsfreiheit als Kompass demokratischer} Religionspolitik?

Vor dem Hintergrund der Klärungen zu Charakter und Gehalt des Rechtes auf Religionsfreiheit können nun Argumente erörtert werden, die für eine an diesem Freiheitsrecht Maß nehmende Religionspolitik sprechen könnten. Dieser Ar-

11 Bielefeldt, Menschenrechte, S. 76.

12 Bielefeldt, Menschenrechte, S. 77-80.

13 Vgl. Marianne Heimbach-Steins, Gleiche Religionsfreiheit. Status und Stellenwert eines komplexen menschenrechtlichen Anspruchs, in: Daniel Gerster (u. a.) (Hg.), Religionspolitik heute. Problemfelder und Perspektiven in Deutschland, Freiburg i. Br. 2018b, S. 141161.

14 Entsprechend gilt es als Jedermann-Grundrecht auf der Ebene des Grundgesetzes innerhalb der staatlichen Rechtsordnung für jede unter dieser Ordnung lebende Person - nicht nur für Bürgerinnen und Bürger (s. o.). 
gumentation liegt die Arbeitshypothese zugrunde, eine freiheitliche Religionspolitik trage besser zur Förderung der Demokratie bei als eine Politik, die den Faktor Religion ignoriert oder die Religionsausübung ausschließlich in der Privatsphäre zulassen möchte. Folgende Argumente scheinen mir diesbezüglich Gewicht zu haben:

Erstens: Das Individualgrundrecht der Religionsfreiheit ermöglicht, schützt und begünstigt die öffentliche Auseinandersetzung um kontroverse Fragen des Zusammenlebens und der Gesellschaftsentwicklung.

Die grundrechtliche Verankerung der Religionsfreiheit bekundet Respekt vor weltanschaulicher und religiöser Vielfalt. Sie schützt religiöse und nicht-religiöse Überzeugungen grundsätzlich in gleicher Weise und nimmt die politischen Gemeinwesen in die Pflicht, den öffentlichen Raum so $\mathrm{zu}$ pflegen, dass die Einzelnen ihre Überzeugungen individuell und gemeinschaftlich leben können. Es sichert damit einen Anspruch auf öffentliche Artikulation religiöser und weltanschaulicher Überzeugungen und ermöglicht Auseinandersetzung und Verständigung zwischen divergierenden, konkurrierenden oder einander widersprechenden Überzeugungen im öffentlichen Raum.

$\mathrm{Zu}$ Recht wird das Potential von Religion als „Wertegenerator“ bzw. als Quelle der Kommunikation von Werten und über Werte in einer pluralen Gesellschaft geltend gemacht. Religiöse Menschen- und Weltbilder können in Kontroversen über ethisch bedeutsame Aspekte des Zusammenlebens - von Herausforderungen des Lebensschutzes über Organspende bis zum Einsatz gentechnischer Verfahren an Menschen, Tieren und Pflanzen, um nur wenige Beispiele zu nennen - Impulse setzen, Nachdenklichkeit auslösen, einseitig verwertungsorientierte Denk- und Argumentationsmuster irritieren und damit konstruktiv und kritisch auf die Austragung gesellschaftlicher Konflikte einwirken.

Religiöse Akteure werden - auch in Kooperation mit anderen gesellschaftlichen Kräften - ethische Impulse in öffentliche und (vor-)parlamentarische Debatten eintragen, die gegen Tendenzen zur Ökonomisierung aller Lebensvollzüge einseitig leistungs- und nutzenorientierte Einstellungen und Erwartungen kritisieren und für den Schutz der Würde jedes Menschen als etwas, das nicht abstimmbar ist und nicht dem Votum von Mehrheiten untergeordnet werden darf, eintreten.

Wenn der Staat seiner Aufgabe nachkommt, die Religionsfreiheit zu garantieren, kann Religion - über Interventionen religiös überzeugter BürgerInnen (und auch politischer MandatsträgerInnen) als ein Faktor in demokratischen Prozessen wirksam werden, der qualitative Aspekte in politischen Abwägungen stark macht. Dies kann dazu beitragen, Entscheidungsprozesse, an deren Ende Mehrheitsentscheidungen stehen werden, zu differenzieren und zu intensivieren sowie ethische Grenzen dessen aufzuzeigen, was durch Mehrheitsentscheidun- 
gen abstimmbar sein kann. Das betrifft vor allem den Schutz der Würde jedes Menschen als nicht abstimmbare Grundlage eines menschenrechtlich orientierten Zusammenlebens. Darin liegt eine Chance zur Stärkung und anwaltlichen Vertretung der Rechte und Anliegen besonders verletzlicher Akteure der Gesellschaft - z. B. Kinder, Menschen, die hinsichtlich ihrer Geschlechtsidentität nicht den gesellschaftlich akzeptierten Normvorstellungen entsprechen, Menschen mit einer Beeinträchtigung, Menschen mit einer Demenzerkrankung sowie im Hinblick auf Menschen / Gruppen, die von demokratischen Entscheidungen betroffen sind, ohne dass sie überhaupt Möglichkeiten der Beteiligung haben - z. B. Menschen ohne Bürgerstatus oder Angehörige zukünftiger Generationen.

Zweitens: Das Recht auf Religionsfreiheit schützt Religionsausübung als zivilgesellschaftliche Ressource und Potential für demokratisches Lernen und Demokratieentwicklung.

Ohne Zweifel sind Einwände gegenüber der nicht-demokratischen Verfasstheit, einem Mangel an Partizipationsrechten und rechtlicher Kultur gegenüber einem religiösen Akteur wie der römisch-katholischen Kirche berechtigt. Dennoch - oder vielleicht gerade deswegen - scheint mir der Hinweis wichtig, dass sich auch in einem solchen institutionell-religiösen Zusammenhang beachtliche Übungsfelder für demokratische Praxen entwickeln können. So wird im Kontext religiöser Jugend-, Sozial- und Frauenverbände nicht nur ein in anderen gesellschaftlichen Bereichen kaum erreichtes Maß an sozialem Engagement freigesetzt, sondern es werden auch basisdemokratische Praxen entwickelt und eingeübt. In Deutschland, wo das katholische Verbändewesen traditionell stark gewesen ist, hat eine erhebliche Zahl (ehemals) religiös gebundener PolitikerInnen ihre "politische Sozialisation" in kirchlichen Verbänden erfahren und schöpft aus dieser Ressource im politischen Engagement. Nebenbei bemerkt erwächst daraus auch eine auf das Innere der Religionsgemeinschaft gerichtete Dynamik: Denn dieses Potential bildet zugleich eine starke Ressource der kritischen Begleitung und Entwicklung der Kirche selbst, insofern die politisch sensibilisierten, demokratieerfahrenen Akteure ihren eigenen institutionell-religiösen Background mit einer hohen Sensibilität für Freiheits- und Partizipationsdefizite wahrnehmen und sich entsprechend artikulieren.

Drittens: Das Recht auf Religionsfreiheit bildet ein Korrektiv gegenüber der Versuchung (identitäts-)politischer Instrumentalisierung von Religion.

Wenn politisches Engagement mit religiöser Verwurzelung einhergeht und sich u. U. daraus nährt, kann das positive Wirkungen zeitigen. Es kann aber in demokratischen Kontexten auch zu einer Gratwanderung werden. Das wird immer dann der Fall sein, wenn der religiöse Impetus auf der Ebene des Staatshandelns 
mit dem Gebot der „respektvollen Nicht-Identifikation“ abgeglichen werden muss. Es kann auch dann der Fall sein, wenn starke religiöse Identitätsmarker (wie z.B. die Behauptung einer "christlichen Leitkultur") nicht nur in bestimmten politischen Programmatiken behauptet werden, sondern in demokratischen Entscheidungszusammenhängen auf den normativen Anspruch der Anerkennung weltanschaulicher Pluralität der Gesellschaft treffen.

In den letzten Jahren ist v. a. bei einem Teil der erstarkten rechtspopulistischen Kräfte in verschiedenen europäischen Ländern eine Tendenz zur identitätspolitischen Beanspruchung von Religion zu beobachten. Einerseits wird affirmierend - man könnte auch sagen: vereinnahmend - auf christliche Topoi (christliches Abendland, Verteidigung christlicher Familienwerte u.ä.) Bezug genommen; andererseits wird der Bezug auf christliche Motive dafür beansprucht, die Abgrenzung bzw. Ausgrenzung von „fremder“ Religion, konkret des Islam, zu betreiben, der meist ohne weitere Differenzierung mit „Islamismus“ gleichgesetzt wird. Diese doppelte identitätspolitische Strategie lässt sich in Deutschland sehr deutlich in der Programmatik der Partei „Alternative für Deutschland“ nachvollziehen. Sie ist nicht nur antipluralistisch, sondern zugleich explizit gegen das Menschen- bzw. Grundrecht auf Religionsfreiheit ausgerichtet, insofern sie einem bestimmten religiösen Bekenntnis das gleiche Recht auf öffentliches Erscheinen rundweg abspricht, näherhin die Religionsausübungsfreiheit für Muslime weitestgehend bestreitet. ${ }^{15}$

Gegen solche Bestreitungen gleicher Freiheit, die inzwischen im parlamentarischen Raum vieler westlicher Demokratien angekommen sind und - so stellt es sich in den Wochen vor der Europawahl 2019 dar - auch auf der europäischen Ebene deutlich an Stärke gewinnen könnten, bildet das grundrechtlich verbürgte, vom Staat zu schützende Recht auf Religionsfreiheit ein wichtiges Korrektiv und eine Berufungsinstanz. Für eine freiheitliche Demokratie scheinen die rechtlichen Sicherungen gleicher Freiheit daher umso wichtiger, je lauter die Kräfte der Bestreitung werden. Allerdings genügt der rechtliche Rahmen allein nicht. Es bedarf zugleich gesellschaftlicher Prozesse, um das Bewusstsein für die auf dem Spiel stehenden Werte wechselseitigen Respekts und der Anerkennung von Pluralität in freier und öffentlicher Kommunikation zu schärfen. Hierzu können - das wäre ein eigenes Thema - religiöse Akteure einiges beitragen, sofern sie über gesellschaftliche, rechtlich gesicherte Handlungsspielräume verfügen.

15 Vgl. Marianne Heimbach-Steins / Alexander Filipović / Josef Becker / Maren Behrensen / Theresa Wasserer, Grundpositionen der Partei „Alternative für Deutschland“ und der Katholischen Soziallehre im Vergleich, Institut für Christliche Sozialwissenschaften AP Nr. 8, Münster 2017, S. 24-33, vgl. http://www.uni-muenster.de/imperia/md/content/fb2/c-syste matischetheologie/christlichesozialwissenschaften/heimbach-steins/ics-arbeitspapiere/ics _ap_8_afd_kathsl.pdf (letzter Zugriff: 16.05.2019). 
Viertens: Das Recht auf Religionsfreiheit konstituiert nicht nur einen öffentlichen Raum für die Religion(sausübung), sondern auch für deren kritische Begleitung durch die Öffentlichkeit.

Mit dem Recht auf Religionsfreiheit sichert der Staat die Rahmenbedingungen für das öffentliche Erscheinen-Können von Religion. Zugleich eröffnet er damit einen Raum für die demokratische Öffentlichkeit, religiöse Überzeugungen und das Agieren religiöser Akteure / Institutionen in dieser Öffentlichkeit kritisch zu begleiten. Unbeschadet des in einigen Rechtsordnungen ausdrücklich gesicherten Selbstbestimmungsrechtes der Religionsgemeinschaften schließt das die Möglichkeit und die Notwendigkeit ein, die Demokratie- und Pluralitätsfähigkeit dieser Akteure immer wieder auf den Prüfstand zu stellen.

So hatten etwa in den letzten Jahren immer wieder (höchst)gerichtliche Verfahren die legitime Reichweite von Anforderungen, die religiöse Tendenzbetriebe an die Loyalität von Mitarbeitenden stellen, zu klären. ${ }^{16}$ Beide große Kirchen in Deutschland waren und sind davon betroffen und mussten ihre internen dienstrechtlichen Anforderungen nachjustieren. Ein anderes Beispiel ist die Etablierung von islamischem Religionsunterricht und islamischer Theologie im staatlichen Schul- und Hochschulwesen in Deutschland, wodurch dieses Segment religiöser Bildung den Regeln staatlicher Schulaufsicht und Qualitätssicherung unterstellt wird. Besonders drastisch belegen m. E. die Aufdeckung der Skandale um sexualisierte Gewalt gegen Minderjährige durch Priester und Ordensmänner in der katholischen Kirche und der andauernde, zähe Prozess der rechtlichen und der innerinstitutionellen Aufarbeitung die grundlegende Einsicht, dass religiöse Institutionen die kritische Öffentlichkeit als Korrektiv brauchen. Eine Verdrängung von Religion und religiösem Ausdruck aus der Öffentlichkeit mit dem (wie gezeigt, stark vereinfachenden und problematischen) Argument, sie sei wenig sozialverträglich, ist daher auch insofern kontraproduktiv, als das Kritisierte dann gerade aus dem Licht der Öffentlichkeit und damit auch aus dem Raum öffentlicher Kritik ausgeschlossen würde. Gerade wer religiösen Akteuren skeptisch gegenübersteht, sollte deren Verbleiben in der Öffentlichkeit erst recht einfordern.

16 Hier ist z. B. an das Grundsatzurteil des deutschen Bundesarbeitsgerichts vom 20. Februar 2019 zu erinnern, mit dem, nach einem fast zehn Jahre andauernden Rechtsstreit und einem Urteil des EuGH [vgl. http://curia.europa.eu/juris/document/document.jsf?text=\&docid= 205521\& pageIndex $=0 \&$ doclang $=\mathrm{DE} \&$ mode $=$ req $\&$ dir $=\&$ occ $=$ first $\&$ part $=1 \quad$ (letzter $\mathrm{Zu}$ griff: 16.05.2019)], die Kündigung eines katholischen Chefarztes durch seinen Arbeitgeber ein katholisches Krankenhaus in Düsseldorf - aufgrund seiner Wiederheirat nach Scheidung für unwirksam erklärt wurde. 


\section{4. $\quad$ Fazit}

Mein Argumentationsgang läuft auf ein entschiedenes Plädoyer für eine freiheitliche Religionspolitik hinaus. Sie scheint mir gerade angesichts bedenklicher Allianzen zwischen freiheitsfeindlichen religiösen und letztlich demokratiefeindlichen politischen Kräften heute wichtiger denn je. In gewissen politischen, auch von manchen religiösen Kräften unterstützten Tendenzen der letzten Jahre ist zu beobachten, wie die Infragestellung des menschenrechtlichen Charakters der Religionsfreiheit aus fragwürdigen identitätspolitischen Interessen mit der populistischen Kaperung des Demokratieverständnisses Hand in Hand geht eine unselige Allianz, gegen die die rechtliche, politische und zivilgesellschaftliche Stärkung der Werte gleicher Freiheit einschließlich der Freiheit des Glaubens, der Weltanschauung, des Gewissens und der Religionsausübung neue Bedeutung gewinnt. Vor diesem Hintergrund schließe ich mit zwei Gedanken: Der Schutz und die Umsetzung der Religionsfreiheit sollte erstens als ein Gradmesser für ein freiheitliches Demokratieverständnis unbedingt ernst genommen werden. Religion und Demokratie sollten zweitens unter den Vorzeichen ihrer wechselseitig humanisierenden Potentiale und in ihrer Ambivalenz wahrgenommen und ohne idealistische Überhöhung als Zukunftsressourcen gepflegt werden.

\section{Quellen}

Bielefeldt, Heiner, Religionsfreiheit als heilsame Provokation. Dankesrede anlässlich der Verleihung des Alfons Auer-Ethik-Preises, in: Theologische Quartalschrift 198/2018, S. $146-162$.

Bielefeldt, Heiner, Menschenrechte in der Einwanderungsgesellschaft. Plädoyer für einen aufgeklärten Multikulturalismus, Bielefeld 2007.

Gerster, Daniel / van Melis, Viola / Willems, Ulrich (Hg.), Religionspolitik heute. Problemfelder und Perspektiven in Deutschland, Freiburg i. Br. 2018.

Heimbach-Steins, Marianne, Religion zwischen Privatheit und Öffentlichkeit. Eine christlich-ethische Perspektive, in: Martin Dürnberger (Hg.), Öffentlichkeiten. Salzburger Hochschulwochen 2017, Innsbruck-Wien 2018, S. 23-75.

Heimbach-Steins, Marianne, Gleiche Religionsfreiheit. Status und Stellenwert eines komplexen menschenrechtlichen Anspruchs, in: Daniel Gerster (u.a.) (Hg.), Religionspolitik heute. Problemfelder und Perspektiven in Deutschland, Freiburg i. Br. 2018, S. 141-161.

Heimbach-Steins, Marianne (Hg.), Religion(en) in der Einwanderungsgesellschaft. Jahrbuch für Christliche Sozialwissenschaften 58/2017, Münster 2017.

Heimbach-Steins, Marianne / Filipović, Alexander / Becker, Josef / Behrensen, Maren / Wasserer, Theresa, Grundpositionen der Partei „Alternative für Deutschland“ und der Katholischen Soziallehre im Vergleich, Institut für Christliche Sozialwissenschaften AP 
Nr. 8, Münster 2017, vgl. http://www.uni-muenster.de/imperia/md/content/fb2/c-syste matischetheologie/christlichesozialwissenschaften/heimbach-steins/ics-arbeitspapie re/ics_ap_8_afd_kathsl.pdf (letzter Zugriff: 16.05.2019).

Heimbach-Steins, Marianne, Grenzverläufe gesellschaftlicher Gerechtigkeit. Migration Zugehörigkeit - Beteiligung, Gesellschaft - Ethik - Religion 5, Paderborn 2016.

Ladeur, Karl-Heinz / Augsberg, Ino, Toleranz - Recht - Religion. Die Herausforderung des „neutralen“ Staates durch neue Formen der Religiosität in der postmodernen Gesellschaft, Tübingen 2007.

Leibold, Jürgen / Kühnel, Steffen / Heitmeyer, Wilhelm, Abschottung von Muslimen durch generalisierte Islamkritik?, in: Aus Politik und Zeitgeschichte 1-2/2006 (Themenheft Parallelgesellschaften), S. 3-10, vgl. http://www.bpb.de/apuz/30007/abschottung-vonmuslimen-durch-generalisierte-islamkritik? $p=$ all (letzter Zugriff: 16. 05.2019).

Liedhegener, Antonius / Lots, Laura, Religionspolitik zwischen Konflikt und Integration. Politikwissenschaftliche und sozialethische Positionen zur Religionspolitik in Deutschland, in: Jahrbuch für Christliche Sozialwissenschaften 58/2017, Münster 2017, S. 211248. 


\section{Stefan Hammer (Wien)}

\section{Politische Säkularität heute}

Im vielfältigen Werk von Ingeborg Gabriel nimmt das Verhältnis von Religion und Menschenrechten einen prominenten Platz ein. Fast zwangsläufig kommt dabei auch immer wieder das Konzept der Säkularität von Politik und Staat ganz grundsätzlich zur Sprache. ${ }^{1}$ Mit diesem Thema beschäftigt sich der folgende Beitrag.

I.

Mit der Pluralisierung und Diversifizierung des Religiösen, die sich in globaler Dimension noch potenziert, verliert auch der Komplementärbegriff des Säkularen zunehmend an Kontur. Diese Erosion erfasst insbesondere auch den Begriff der politischen bzw. staatlichen Säkularität, der in der westlichen Welt über lange Zeit, wenn auch in Varianten, als verfestigter institutioneller Standard wahrgenommen wurde. Freilich hat das Religiöse als soziales Phänomen keineswegs so sehr an Bestimmtheit eingebüßt, dass die herkömmliche, religionsbezogene Rede von Säkularität keinen Sinn mehr machen würde. Es soll im Folgenden vielmehr darum gehen, ob ihr noch ein eigenständiger normativer Stellenwert zukommt und sie nicht vielmehr in den allgemeinen Prinzipien liberaler Verfassungsstaatlichkeit aufgeht. Aus diesem Gesichtspunkt wird politische Säkularität heute zunehmend zur Diskussion gestellt.

Zunächst muss schon aufgrund der neueren religiösen Pluralisierung im westlich geprägten Umfeld bezweifelt werden, ob der liberale Anspruch gleicher religiöser Selbstbestimmung es noch zulässt, das Verhältnis des Staates zur Religion auf einen bestimmten Grad von Abgrenzung oder gar Ausgrenzung

1 Aus neuerer Zeit etwa: Ingeborg Gabriel, Menschenrechte und Religionen - Verbündete oder Gegner?, in: Peter G. Kirchschläger (Hg.), Die Verantwortung von nichtstaatlichen Akteuren gegenüber den Menschenrechten, Religionsrechtliche Studien 4, Zürich 2017, S. 33-52, hier: S. $48-50$. 
(„wall of separation“) festzuschreiben. ${ }^{2}$ Die Einsicht, dass es hier weniger auf staatliche Religionsdistanz als auf religiös-weltanschauliche Neutralität des Staates ankommt, ist aber nicht mehr so neu; vielmehr lässt sich diese staatliche Neutralität selbst als ein aufgeklärtes Konzept politischer Säkularität verstehen, das diese nicht (mehr) als selbsttragendes etatistisches Prinzip begreift, sondern als funktionalen Aspekt gleicher religiöser Selbstbestimmung aller. Das Ausmaß der zulässigen Hereinnahme von Religion in die (abgestuften) Bereiche staatlicher Öffentlichkeit bestimmt sich sohin danach, was mit der maximalen gleichen Freiheit aller noch vereinbar ist.

Indes überschreitet die Vielfalt der sozialen Phänomene, in denen Ansprüche auf Anerkennung ethisch fundierter Lebensführung heute begegnen, längst die herkömmlichen Formen von Religiosität und religiöser Zugehörigkeit. Über die in der Garantie gleicher Glaubens- und Gewissensfreiheit implizierte religiös-weltanschauliche Neutralität des Staates hinaus stellt sich daher die weiter reichende Frage, ob die gleiche Religionsfreiheit als normativer Bezugspunkt noch ausreicht, um den liberalen Prinzipien einer gleichwertigen rechtlichen Anerkennung der verschiedenartigsten Erscheinungsformen werthaft geprägter Lebensführung zu genügen. Im Zeichen des Regulativs liberaler Rechtsgleichheit geht es somit nicht mehr um das Verhältnis des Staates bloß zu dem, was herkömmlich als „Religion“ verstanden wird, sondern zu allen sozialen Phänomenen, in denen sich heute Ansprüche auf Anerkennung ethisch selbstbestimmter individueller und kollektiver Lebensformen artikulieren. Inwiefern, so kann man die Frage zusammenfassen, hat es in einem freiheitlichen Gemeinwesen überhaupt noch eine besondere Bewandtnis mit der Religion? ${ }^{3}$ Mit der schwindenden Bestimmtheit des Religiösen als Bezugspunkt liberaler Staatlichkeit schwindet somit auch die Bestimmtheit seiner „Säkularität“.

Noch weiter befeuert werden diese Erosionsprozesse durch kritische Standpunkte, die den Begriff der Säkularität als Komplementärbegriff zu „Religion“ in einem europäisch-westlich geprägten Religionsverständnis befangen sehen, das nicht universalisierbar sei. ${ }^{4}$ Religion als sozial ausdifferenziertes Phänomen, das wesentlich durch „Verinnerlichung“ geprägt ist, erscheint aus dieser Perspektive als Resultat spezifischer konfliktischer Entwicklungen in der europäischen Moderne, die allererst eine religionsfreie Sphäre des Öffentlichen hervorgebracht hat, die ihrerseits auf die Wahrnehmung von „Religion“ zurückwirkt. So hätten das „Religiöse“ und das „Säkulare“ als Komplementärbegriffe keine Entsprechung außerhalb jenes historischen Entstehungszusammenhangs der

2 Vgl. z. B. Veit Bader, Secularism or Democracy? Associational Governance of Religious Diversity, Amsterdam 2007.

3 Cécile Laborde, Conclusion: Is Religion Special?, in: Jean L. Cohen / Cécile Laborde (Hg.), Religion, Secularism, and Constitutional Democracy, New York 2016, S. 342-350.

4 So z. B. Talal Asad, Formations of the Secular: Christianity, Islam, Modernity, Stanford 2003. 
europäischen Moderne. Angesichts von Verhältnissen, in denen das Religiöse oft ein kaum unterscheidbares Moment integraler kultureller Traditionen und Lebensformen bildet, erscheint das Postulat einer säkularen Sphäre des Politischen als falscher Universalismus, der sich in Wahrheit als eurozentrisch partikular erweist.

Diese Kritik muss nicht zwangsläufig antiliberalen Tendenzen einer Absorption ethisch-religiöser Autonomie in einer politischen Leitkultur das Wort reden, wie sie heute allenthalben beobachtet werden können. Im Gegenteil. So plädiert etwa Tariq Modood für eine gleichwertige Berücksichtigung von unterschiedlichen Ausformungen von Weltanschauungen, Lebensweisen, Kulturen, Traditionen, in einem liberalen Modell gleicher Rechte. ${ }^{5}$ Mangels einer normativ relevanten Spezifizität von „Religion“ geht damit auch der Begriff der Säkularität in einem umfassenderen Modell auf, das an das Paradigma kultureller Selbstbestimmungsrechte anschließt, als solches aber auch einer liberalen Ausbalancierung durch korrelierende Rechte individueller Selbstbestimmung nicht entgegensteht.

Die beispielhaft skizzierten Ansätze ziehen höchst unterschiedliche Folgerungen in Bezug auf die Art, wie all diese verschiedenartigen Zugehörigkeiten, Ausrichtungen und Prägungen rechtlich verarbeitet werden können. Sie reichen von unterschiedsloser Verbindlichkeit allgemeiner Regeln und staatlicher Indifferenz gegenüber Besonderheiten ${ }^{6}$ bis zu weitestmöglicher rechtlicher Berücksichtigung ethisch-kulturell-religiös-weltanschaulicher Diversität in Form differenzierender Regelungen (insb. sog. reasonable accomodation). ${ }^{7}$ Auch wenn sich diese Folgerungen aus überkommener, religionsfokussierter Sicht im Ergebnis entweder als religionsdistanziert oder religionsfreundlich erweisen, so bildet dieser Unterschied nicht das entscheidende Kriterium. Gemeinsam ist solchen Ansätzen vielmehr die Frage, bis zu welchem Grad in einem System gleicher Rechte die Diversität ethisch fundierter Lebensweisen rechtlich berücksichtigt werden kann, unabhängig davon, ob diese nach herkömmlichem Verständnis als „religiös“ gelten können oder nicht. Unter dieser Perspektive hängt der Wert einer normativen Rede von „Säkularität“ davon ab, ob es eben mit der Religion überhaupt eine besondere normative Bewandtnis hat, die sie aus der allgegenwärtigen Diversität werthaft geprägter Lebenspraktiken und -formen heraushebt. Wenn das nicht der Fall ist, müsste Säkularität aufgehen in der Freiheitlichkeit eines Systems gleicher Rechte, die nicht davon abhängt, inwieweit dieses System säkular ist, sondern inwieweit es liberal ist.

\footnotetext{
5 Tariq Modood, Multiculturalizing Secularism, in: Phil Zuckerman / John R. Shook (Hg.), The Oxford Handbook of Secularism, Oxford 2017, S. 354-368.

6 Ronald Dworkin, Religion without God, Cambridge 2013, Kapitel 4.

7 Modood, Secularism.
} 
II.

Nimmt man die Zurückhaltung wahr, die der liberale Multikulturalismus allenthalben gegenüber einer politischen Affirmation religiöser Vielfalt zeigt, so kommt damit indirekt in den Blick, dass es mit der Religion doch etwas Besonderes auf sich haben könnte. Woran liegt es, dass z. B. Will Kymlicka als einer der prononciertesten Verfechter einer Politik des multikulturellen Pluralismus eine gleichgeartete Politik des multi-religiösen Pluralismus ablehnt ${ }^{8}$ In solchen Vorbehalten dürften verschüttete Begründungsmomente für politische Säkularität wirksam werden, die sich im Rückblick auf deren europäische Entstehungsgeschichte vergegenwärtigen lassen.

Die zentrale Frage am Beginn der europäischen Moderne war, wie die konfessionelle Spaltung politisch verarbeitet werden sollte. Die Herausforderung war nicht eine Vielfalt kultureller Identitäten, sondern der Konflikt zwischen unvereinbaren Wahrheitsansprüchen, die auch die Rechtfertigung politischer Herrschaft selbst betrafen: Noch konnte politische Herrschaft einerseits nur im Gesamtzusammenhang mit der Verwirklichung eines göttlichen Heilsplans für die Christenheit begriffen werden, andererseits aber war klar geworden, dass die tiefgreifende Entzweiung über die göttlichen Vorgaben hiefür nicht mehr überwunden werden konnte. Gegenüber der möglichen und anfangs auch weithin real gezogenen Konsequenz des politischen Religionszwangs lautete die andere, innovative Alternative zunächst „Toleranz“. Sie sollte sich als die zukunftsweisende herausstellen und bildet eine wesentliche Grundlage für das, was nach späterer Begriffsbildung heute unter „(politischer) Säkularität“ verstanden wird.

Wenn Michel de l'Hôpital 1665 unter dem Eindruck der französischen Religionskriege postuliert, die Frage sei nicht, was die richtige Religion sei, sondern wie man zusammen leben könne, so artikuliert sich darin ein fundamentaler Paradigmenwechsel, den man mit David Heyd mit dem Begriff Gestalt-Switch aus der Wahrnehmungspsychologie in Verbindung bringen kann: ${ }^{9}$ Die politische Durchsetzung des für richtig gehaltenen religiösen Heilsplans und die politische Zulassung religiösen Irrtums bilden Standpunkte, zwischen denen man „switchen“ kann, die aber nicht zugleich eingenommen werden können. Im Interesse der Erhaltung der Möglichkeit politischen Zusammenlebens wird der erste Standpunkt zugunsten des zweiten zurückgesetzt. In der politischen Toleranz der frühen europäischen Neuzeit artikuliert sich die Bereitschaft, die Frage der Begründbarkeit unvereinbarer religiöser Geltungsansprüche als

8 Will Kymlicka, Multicultural Citizenship, Oxford 1995.

9 David Heyd, Introduction, in: Ders. (Hg.), Toleration: An Elusive Virtue, Princeton 1996, S. 317. 
Grundlage für die Rechtfertigung politischer Herrschaft auf Dauer zu suspendieren.

Dieser Paradigmenwechsel hat nun einerseits einen Prozess ausgelöst, der über die bürgerliche Verfassungsbewegung letztendlich in die rechtliche Gewährleistung religiöser und weltanschaulicher Autonomie in Form subjektiver Rechte gemündet hat. Toleranz erscheint solcherart in grundrechtlich gesicherter Freiheit institutionell aufgegangen und damit obsolet, und Säkularität erscheint bloß als Implikation religiös-weltanschaulicher Neutralität, der eine transitorische Relevanz nur solange zukommt, als man von einem einigermaßen kompakten Phänomen Religion noch sprechen kann. Mit der zunehmenden Diffundierung des Religiösen in der Vielfalt kulturell-werthafter Prägungen scheint auch sie ihren selbständigen Stellenwert nun zu verlieren und in den rechtlichen Garantien einer voll entwickelten liberalen Verfassungsstaatlichkeit aufzugehen.

Woher rührt also das Festhalten an Säkularität als einem selbständigen normativen Faktor des liberalen Verfassungsstaates?

Blickt man zunächst auf den anfänglichen Toleranzgedanken zurück, so scheint er ein überschießendes Potential politischer Ethik zu beinhalten, dessen fortdauernde Aktualität nicht in den institutionellen Errungenschaften freiheitlicher Verfassungsstaatlichkeit aufgegangen ist. Gerade mit der grundrechtlichen Gewährleistung von Glaubens- und Gewissensfreiheit sind ja im demokratischen Staat die Chancen für Zivilgesellschaft und Gesinnungsgemeinschaften eröffnet, auf Politik gerade auch aus religiösen Überzeugungen heraus einzuwirken. Die in der religiösen Neutralität der freiheitlichen Grundrechtsdemokratie implizierte Säkularität garantiert gerade nicht, dass die religiöse Beeinflussung von Politik durch die Bürger, die ihre politische Freiheit wahrnehmen, stets aus einer toleranten Gesinnung heraus erfolgt. Anders gewendet zeigt sich in dieser Problematik das politische Potential von Religion. Sie erschöpft sich nicht in der Ausübung der grundrechtlich gesicherten gesellschaftlich-privaten Freiheit, ein eigenes Leben nach eigenen Überzeugungen zu führen. Religionsfreiheit selbst ist nicht nur private, sondern auch kommunikativ-politische Freiheit, und Ausübung von Religion ist nicht nur tätige Manifestation der eigenen Identität, sondern potentiell stets auch demokratische Mitgestaltung von Politik. Indirekt hat sie somit stets auch Anteil an der fortlaufenden Legitimation politischer Herrschaft und bleibt somit latent immer „öffentliche Religion“.

Dieses politische Potential von Religion ist es, was die politische Tugend religiöser Toleranz bis heute nicht obsolet macht. Auch im freiheitlichen Verfassungsstaat bleibt demokratische Politik stets angewiesen auf ein freiheitsverträgliches politisches Verhalten seiner Bürger. Nun haben manche lange Zeit hindurch gerade von den tradierten religiösen Prägungen in christlichen 
Großkirchen selbst die gesellschaftliche Stabilisierung eines freiheitlichen politischen Ethos erwartet; manch anderen mag aber die Abhängigkeit eines solchen Ethos von einer Fundierung in „öffentlichen Religionen“, die noch dazu an Vielfalt massiv zugenommen haben, als allzu riskant erscheinen. Darin liegt wohl der Grund für die tiefe Skepsis, mit der auch Verfechter eines affirmativen und grundrechtlich maximal geschützten kulturellen Pluralismus einem öffentlich-institutionellen „empowerment“ von Religion begegnen. Insbesondere im Lichte rezenterer Entwicklungen, die die Erinnerung an das Gewaltpotential von „öffentlichen Religionen“ im frühneuzeitlichen Europa im historischen Gedächtnis wieder wachrufen, sucht man, politische Säkularität als institutionelles Bollwerk zu reaktivieren, um die Gefahren abzuwehren, die man gerade den Religionen zuschreibt. Diese institutionelle Säkularität besteht dann im Ergebnis eben darin, dass die ansonsten propagierte multikulturelle Inklusion gerade nicht für Religionen gelten soll. Bei aller Bemühung um die Optimierung eines Systems maximaler Gewährleistung privater und öffentlicher Freiheit trachtet man, einem drohenden Rückfall hinter die Errungenschaften dieses liberalen Projekts dadurch vorzubeugen, dass man jene Gefahrenquellen, in denen man diese Bedrohung hauptsächlich verortet, nämlich erstarkende öffentliche Religionen, möglichst in Schach zu halten versucht. Sie sollen die säkular konzipierte Legitimität freiheitlicher Verfassungsstaatlichkeit nicht (wieder) infrage stellen können.

\section{III.}

Diese legitimationsbezogene Verteidigung politischer Säkularität entspricht dem, was z. B. auch „Begründungsneutralität "10 oder ,justificatory secularism " ${ }^{\text {"11 }}$ genannt wurde. Es geht nun nicht mehr nur darum, allen religiösen Ausrichtungen und Prägungen eine gleichwertige Entfaltungsmöglichkeit in einem freiheitlichen System gleicher Rechte zu sichern, sondern um Ausgrenzung aller religiös geprägten Fragen der Rechtfertigung eines solchen Systems selbst. In ihrem spezifischen Religionsbezug muss dieses Konzept von Säkularität aber letztlich ähnlichen Diffusionsprozessen ausgesetzt sein, wie sie schon zuvor für Säkularität als Moment der mit einem System gleicher Freiheiten implizierten religiös-weltanschaulicher Neutralität des Staates aufgewiesen wurden. Nicht nur in Religionen, sondern in allen weltanschaulichen, ja gesellschaftspolitischen Grundorientierungen können sich politische Rechtfertigungsansprüche

10 Horst Dreier, Staat ohne Gott, 2. Aufl., München 2018, S. 106-112.

11 Cécile Laborde, Justificatory Secularism, in: Gavin D’Costa (u. a.) (Hg.), Religion in a Liberal State: Cross-Disciplinary Reflections, Cambridge 2013, S. 164-186. 
finden, die in Grundüberzeugungen und Intuitionen wurzeln, deren Vereinbarkeit mit einem freiheitlichen Politikprojekt in Frage gestellt werden kann.

Eine daraus gezogene Konsequenz, die sich systematisch als Fortschreibung einer rechtfertigungsbezogenen Säkularität bzw. Begründungsneutralität verstehen lässt, besteht nun darin, alle sogenannten umfassenden Lehren („comprehensive doctrines" ${ }^{12}$, also weltanschauliche Hintergrundannahmen über das Wesen des Menschen und seine Bestimmung in der Welt, ob sie nun religiös imprägniert sind oder nicht, aus dem öffentlichen politischen Diskurs auszugrenzen. Diskursteilnehmer sollen damit auf säkulare Vernunft und damit auf Argumentationsweisen verpflichtet werden, die für alle nachvollziehbar sind, unabhängig davon, ob und welche letztlich unbegründbaren, also „metaphysischen“ Grundannahmen sie als mögliche Anhänger unterschiedlichster „umfassender Lehren“ oder Weltanschauungen teilen. Obwohl Religionen als paradigmatisch für solche „umfassenden Lehren“ gelten, trifft diese Ausgrenzung nun nicht mehr nur die irgendwie als „religiös“ identifizierbaren Lehren. Auch als „justificatory secularism“ geht somit Säkularität nach dieser Auffassung letztlich auf in der für alle staatlich-politischen Entscheidungen geltenden Forderung, dass ihre jeweiligen Begründungen nicht von ethisch-weltanschaulichen Voraussetzungen abhängen sollen, die nicht allgemein geteilt werden („epistemic accessibility"). ${ }^{13}$

In der Tat erscheint dies zunächst als folgerichtige Konsequenz aus einer Entwicklung, in der die politische Ausklammerung konfessioneller Grundsatzfragen begleitet und unterfangen wurde von der das liberale Staatsverständnis prägenden Unterscheidung von Recht und Moral: Das Recht soll sich darauf beschränken, sittliche Autonomie und eine dementsprechende Lebensführung zu ermöglichen, soweit dies mit der gleichen Freiheit aller anderen vereinbar ist. Der damit postulierte Verzicht auf politische Durchsetzung von Konzepten sittlicher Lebensführung bedingt in weiterer Konsequenz auch das Postulat, dass diesbezügliche Streitfragen aus der Rechtfertigung eines liberalen Rechtssystems ausgeschieden bleiben müssen. Darauf zielt der in der liberalen politischen Theorie weithin vertretene Ansatz, zwischen dem „Guten“ und dem „Gerechten“ zu unterscheiden. Gelänge diese Unterscheidung, so könnten aus den normativen Geltungsansprüchen, die im politischen Diskurs erhoben werden, fein säuberlich jene Aspekte ausgeschieden werden, die Fragen der Gerechtigkeit als Fragen nach einem Rechtssystem wohlgeordneter Freiheit überschreiten. Das Anliegen der rechtfertigungsbezogenen Säkularität von Staat und Politik wäre damit aufgegangen in einer durchgängigen Metaphysikfreiheit der öffentlichen Vernunft.

12 John Rawls, Political Liberalism, New York 1993.

13 Dazu Cécile Laborde, Liberalism's Religion, Cambridge 2017, S. 117-132. 
Indessen bleibt zu bezweifeln, dass Konzepte des Gerechten von Konzepten des guten, sittlich „richtigen“ (Zusammen-)Lebens durchgängig ablösbar sind, ob also, was auf das Gleiche hinausläuft, eine öffentliche politische Vernunft von jeglicher „Kontaminierung“ durch „umfassende Lehren“ freigehalten werden kann. Die fundamentale Unterscheidung zwischen Recht und Moral bildet zwar ein unhintergehbares normatives Regulativ, durch welches einem freiheitlichen Rechtssystem aufgegeben bleibt, sittliche Selbstbestimmung zu ermöglichen, ohne ihr inhaltlich vorzugreifen. Dieses Regulativ erweist sich aber als nie definitiv einlösbar, weil seine je konkrete Umsetzung auf sittliche Grundannahmen angewiesen bleibt, die es stets zugleich als zu partikulären „umfassenden Lehren“ gehörig zu überwinden trachtet. Prinzipien des „Gerechten“ als Kriterien für die Legitimation des Gemeinwesens bleiben also unhintergehbar auf Momente des "Guten“ angewiesen, die sich unter liberalem Anspruch zugleich fortdauernd selbst zu neutralisieren suchen.

An Beispielen mangelt es nicht. Sie zeigen sich einmal an fast allen Fragen, die einen unabweisbaren Bezug zum Anspruch der Menschenwürde aufweisen: Inwieweit soll ungeborenem oder sterbendem menschlichen Leben oder der natürlichen genetischen Integrität des Menschen eine rechtlich gesicherte Unverfügbarkeit zuerkannt werden? Weitere Fragen betreffen heute etwa den rechtlichen Umgang mit der Vielfalt geschlechtlicher Partnerschaften und familiärer Lebensformen, vor allem aber das Verhältnis des Menschen zu seiner eigenen Zukunft und zur Zukunft seiner Umwelt: Welcher rechtliche Status soll künftigen Generationen und ihren (Über-)Lebensinteressen zuerkannt werden? Welchen Zuschnitt soll der rechtliche Schutz des Tierwohls oder der Integrität von Natur und Umwelt haben, und welchen Stellenwert soll er im System der Rechtsgüter einnehmen?

Solche Fragen weisen unvermeidlich Bezüge zu Elementen umfassender Weltanschauungen auf. Für die Grenzfragen des direkten Umgangs mit menschlichem Leben liegt dies auf der Hand, sind hier doch ethische Intuitionen über Begriff und Sinngebung menschlichen Daseins unmittelbar wirksam. Aber auch Fragen des Umgangs mit der Umwelt und den natürlichen Lebensgrundlagen der Menschheit lassen sich nicht allein mit freistehenden, weltanschaulich unbeeinflussten Argumenten bewältigen. Das zeigen die in diesem Zusammenhang vielfach artikulierte zivilisatorische Entfremdungskritik ebenso wie die vielfältigen Postulate eines „Umdenkens“ zugunsten eines Lebens im „Einklang“ mit Natur, Um-, Mit- und Nachwelt.

Es scheint also, als ob das Anliegen, den politischen Diskurs von Einflüssen umfassender, „metaphysischer“ Theorien unterschiedlichster Prägung freizuhalten, nicht einlösbar wäre. Versteht man dieses Anliegen als Fortschreibung dessen, was der Prozess politischer Säkularisierung einst in Gang gesetzt hat, so hätte es als normative Vorgabe nicht nur den spezifischen Religionsbezug ver- 
loren, sondern wäre in seiner verbreiterten, in alle weltanschaulichen Felder hinein diffundierten Form letztlich auch gar nicht mehr erfüllbar.

\section{IV.}

Charakteristisch für den Umgang liberaler politischer Praxis mit Problemfeldern, wie sie eben angesprochen wurden, ist es, explizite Positionen zu den letztlich darin implizierten weltanschaulichen Grundfragen zu vermeiden. Es könnte sein, dass nun gerade darin mehr liegt als eine bloße Verlegenheit in Ermangelung eines besser fundierten Umgangs mit unvermeidlicher weltanschaulicher Pluralität.

Michel de l'Hôpital hat in seinem oben zitierten Postulat wohl vorausgesetzt, dass Fragen nach der Möglichkeit politischen Zusammenlebens ablösbar sind von der Frage, welches die richtige Religion sei. In Bezug auf die vielfältigen weltanschaulichen Implikationen insbesondere (aber nicht nur) gegenwärtiger Fragen des politischen Zusammenlebens erscheint eine solche Ablösbarkeit zweifehlhaft. Doch scheint sein Postulat auch noch ein anderes Moment zu implizieren, das im Kontext der Diskussion um Möglichkeiten und Grenzen der Toleranz verdeutlicht werden kann: Als politische Tugend impliziert Toleranz durchaus eine eigene Stellungnahme zu jenen umstrittenen Wahrheitsfragen, die um der Möglichkeit politischen Zusammenlebens willen von einer verbindlichen politischen Entscheidung ausgenommen bleiben sollen. Um dieses $\mathrm{Zu}$ sammenlebens willen nimmt man vielmehr in Kauf, dass Auffassungen, die man selbst für falsch hält, auch gesellschaftliche Wirksamkeit entfalten können. Das unterscheidet Toleranz als politische Haltung von weltanschaulicher Indifferenz.

Nun liegt die Folgerung nahe, dass Toleranz als politische Tugend zwar vom einzelnen Bürger erwartet werden kann, das politische Gemeinwesen aber weltanschaulicher Indifferenz verpflichtet sein muss, weil bloße Toleranz eben eigene Wahrheitsansprüche implizieren würde, die es als politisches Gemeinwesen selbst gar nicht erheben dürfte. Für Staat und Politik ließe sich weltanschauliche Indifferenz jedoch nur insoweit verwirklichen, als sich die Rechtfertigung politischen Handelns restlos auf Prinzipien gründen lässt, die sich von weltanschaulichen Implikationen kategorial ablösen lassen. Diese Neutralität ist allerdings, wie bereits angedeutet, immer nur vorläufig und wird stets „eingeholt" von je neu sich zeigenden weltanschaulichen Intuitionen und Prägungen. Es gibt also keinen ultimativen Punkt, von dem aus sich Rechtfertigung von Politik in einem definitiv weltanschauungsindifferenten Zuschnitt leisten ließe. Solches bleibt dem politischen Prozess immer nur als ein Regulativ aufgegeben, das selbst stets weltanschaulich vermittelt ist. 
Angesichts dieser unentrinnbaren, weil konstitutiven weltanschaulichen Befangenheit von Politik verbleibt nur mehr die Suche nach einem Säkularitätsverständnis, das wiederum auf die Tugend der Toleranz bezogen wird und gleichsam deren institutionellen Niederschlag bildet. Es geht hier, um es nochmals klarzustellen, nicht mehr darum, die private Freiheit von Orientierungen und Praktiken über bloße politische Duldung hinaus durch institutionelle Garantien grundrechtlicher Art abzusichern. Es gilt vielmehr, den das rechtliche System gleicher Freiheit überschießenden Aspekt von Toleranz, nämlich die politische Duldung der Gleichzeitigkeit widersprechender Rechtfertigungsansprüche an dieses System selbst, auf die Rechtfertigungsstruktur des liberalen Gemeinwesens zu beziehen.

Im Umgang mit dieser rechtfertigungsbezogenen Diversität begegnen in einschlägigen Sachbereichen immer wieder politische Entscheidungen, die wie prinzipienlose Kompromisse wirken, weil sie keinem der widerstreitenden Geltungsansprüche gerecht werden. Dies zeigt sich in Materien wie Schwangerschaftsabbruch, Forschung an Embryonen, Gentechnik, aber auch Tierschutz. Man kann eine solche politische Herangehensweise jedoch auch als ein Bemühen darum verstehen, dass sich widersprechende weltanschauliche Grundauffassungen darin wenigstens insoweit berücksichtigt sehen können, als ihnen ihre jeweilige Unwiderlegbarkeit zugestanden wird. So finden sich in einschlägigen Regelungszusammenhängen vielfach Elemente, die als Zugeständnis an die mögliche Rechtfertigbarkeit gegensätzlicher Grundpositionen gelesen werden können, auch wenn diese im betreffenden Regelungskomplex dann insgesamt nur fragmentarisch und inkonsistent umgesetzt sein können. Regelungen zum Schwangerschaftsabbruch oder zur Reproduktionsmedizin etwa können als Zugeständnisse an die Unverfügbarkeit sowohl des menschlichen Lebens als auch der reproduktiven Selbstbestimmung der Frau gelesen werden. Desgleichen kann in Regelungen zur Rechtsstellung des Tieres sowohl eine Anerkennung seiner Würde als auch eine Bestätigung seiner sachgleichen Verfügbarkeit für den Menschen gesehen werden. In Wahrheit werden die konfligierenden Grundpositionen damit rechtlich weder bestätigt noch entkräftet, sondern bloß in ihrer Relevanz anerkannt und zugleich unentschieden stehen gelassen. Daher können solche Lösungen weder als Beispiele für einen „überlappenden Konsens“ im Sinne von John Rawls ${ }^{14}$ gelten, noch gar für eine definitive, hinreichende Rechtfertigung aus weltanschauungsfreien Prinzipien. Sie lassen die involvierten Grundsatzfragen vielmehr erkennbar unbeantwortet und halten sie so zugleich für den fortlaufenden politischen Prozess offen.

Auf diese Weise gerinnt die zunächst als persönliche Haltung verstandene Toleranz zur Disposition des politischen Systems, weltanschaulich (also durch

14 Rawls, Liberalism, S. 134-149. 
„umfassende Lehren“) imprägnierte politische Geltungsansprüche nicht aus der Rechtfertigung politischer Entscheidungen zu eliminieren, sondern sie zu suspendieren und zugleich in Latenz zu halten. Bei diesem Muster handelt es sich nicht oder höchstens marginal um ein justiziables Verfassungsprinzip, wohl aber um eine politische Praxis, die keineswegs prinzipienlos ist, sondern in der sich heute vielleicht der normative Kern politischer Säkularität ausmachen lässt. ${ }^{15}$ Sie geht nicht restlos auf in einem liberalen System der Rechte, das sich ein- für allemal weltanschauungsfrei rechtfertigen und juristisch implementieren ließe. Die beständige Revision und Optimierung eines solchen Systems bleibt vielmehr einem pluralen politischen Prozess aufgegeben, der auch auf argumentative Beiträge angewiesen bleibt, die sich aus weltanschaulich bedingten Intuitionen und Hintergrundannahmen speisen. ${ }^{16}$ So verstanden verlangt Säkularität nicht nach weniger, sondern nach mehr argumentativer Durchlässigkeit der staatlich-politischen Sphäre auch gegenüber weltanschaulich-religiösen Grundpositionen, welche sie in ihrer Relevanz anerkennt, ohne sie sich zu eigen zu machen.

\section{Quellen}

Asad, Talal, Formations of the Secular: Christianity, Islam, Modernity, Stanford 2003 (deutsch: Ordnungen des Säkularen: Christentum, Islam, Moderne, Paderborn 2017).

Bader, Veit, Secularism or Democracy? Associational Governance of Religious Diversity, Amsterdam 2007.

Dreier, Horst, Staat ohne Gott, 2. Aufl., München 2018.

Dworkin, Ronald, Religion without God, Cambridge 2013 (deutsch: Religion ohne Gott, Berlin 2014).

Gabriel, Ingeborg, Menschenrechte und Religionen - Verbündete oder Gegner?, in: Peter G. Kirchschläger (Hg.), Die Verantwortung von nichtstaatlichen Akteuren gegenüber den Menschenrechten, Religionsrechtliche Studien 4, Zürich 2017, S. 33-52.

Habermas, Jürgen, Religion in der Öffentlichkeit. Kognitive Voraussetzungen für den „öffentlichen Vernunftgebrauch“ religiöser und säkularer Bürger, in: Jürgen Habermas, Zwischen Naturalismus und Religion, Frankfurt a. M. 2005, S. 119-154.

Hammer, Stefan, The Meaning of Political Secularity: Turning Conflict into Debate, in: Richard Potz (u. a.) (Hg.), State, Law and Religion in Pluralistic Societies - Austrian and Indonesian Perspectives, Göttingen 2010, S. 173-177.

15 Vgl. Stefan Hammer, The Meaning of Political Secularity: Turning Conflict into Debate, in: Richard Potz (u. a.) (Hg.), State, Law and Religion in Pluralistic Societies - Austrian and Indonesian Perspectives, Göttingen 2010, S. 173-177.

16 Jürgen Habermas, Religion in der Öffentlichkeit. Kognitive Voraussetzungen für den „öffentlichen Vernunftgebrauch“ religiöser und säkularer Bürger, in: Ders., Zwischen Naturalismus und Religion, Frankfurt a. M. 2005, S. 119-154. 
Heyd, David, Introduction, in: Ders. (Hg.), Toleration: An Elusive Virtue, Princeton 1996, S. 3-17.

Kymlicka, Will, Multicultural Citizenship, Oxford 1995.

Laborde, Cécile, Liberalism's Religion, Cambridge 2017.

Laborde, Cécile, Conclusion: Is Religion Special?, in: Jean L. Cohen / Cécile Laborde (Hg.), Religion, Secularism, and Constitutional Democracy, New York 2016, S. 342-350.

Laborde, Cécile, Justificatory Secularism, in: Gavin D’Costa (u.a.) (Hg.), Religion in a Liberal State: Cross-Disciplinary Reflections, Cambridge 2013, S. 164-186.

Modood, Tariq, Multiculturalizing Secularism, in: Phil Zuckerman / John R. Shook (Hg.), The Oxford Handbook of Secularism, Oxford 2017, S. 354-368.

Rawls, John, Political Liberalism, New York 1993. 
Peter G. Kirchschläger (Luzern)

\section{Liberaler Rechtsstaat - Menschenrechte - Religions- und Weltanschauungsgemeinschaften}

\section{Religions- und Weltanschauungsgemeinschaften und Menschenrechte}

Religions- und Weltanschauungsgemeinschaften ${ }^{1}$ haben mit Begriffen, Ideen und Konzepten (z. B. Menschenwürde, Personenbegriff) und mit ihrem gesellschaftlichen und politischen Gewicht zur Entstehung der Menschenrechte beigetragen. ${ }^{2}$ Diese Prozesse spielten sich in unterschiedlicher Intensität auf einer religiösen, weltanschaulichen, auf einer rechtlich nationalen und auf einer rechtlich internationalen Ebene ab. ${ }^{3}$ Nicht nur im Bereich der Menschenrechtsgeschichte, sondern in der Rechtsgeschichte im Allgemeinen ist die Rolle des Religiösen wohl nicht zu unterschätzen. ${ }^{4}$

Leider gibt es auch zahlreiche Beispiele für das Gegenteil, nämlich dass Religions- und Weltanschauungsgemeinschaften als „ein Problem oder Hemmschuh des Menschenrechtsdenkens " ${ }^{\text {(5 }}$ aufgetreten sind oder auf der „falschen Seite“ - nicht der Opfer von Menschenrechtsverletzungen, sondern der Täter standen und mit Letzteren gemeinsame Sache machten. Beispiele von Menschenrechtsverletzungen könnten aufgezählt werden, bei denen Religions- und Weltanschauungsgemeinschaften entweder stille Beobachter, Komplizen oder sogar selbst Subjekte waren. Und leider spricht nicht nur die Praxis diesbezüglich eine klare Sprache. Auch in der Theorie finden sich Beispiele, wo Erklä-

1 Vgl. dazu Peter G. Kirchschläger, Menschenrechte und Religionen. Nichtstaatliche Akteure und ihr Verhältnis zu den Menschenrechten, Gesellschaft - Ethik - Religion 7, Paderborn 2016.

2 Vgl. Heiner Bielefeldt, Die Menschenrechte als „das Erbe der gesamten Menschheit“, in: Ders. / Winfried Brugger / Klaus Dicke (Hg.), Würde und Recht des Menschen, FS Johannes Schwartländer, Würzburg 1992, S. 143-160.

3 Vgl. Hans Joas, Sind die Menschenrechte westlich?, München 2015, S. 22-23.

4 Vgl. z. B. Harold J. Berman, Law and Revolution. The Formation of the Western Legal Tradition, Cambridge 1983.

5 Antonius Liedhegener / Ines-Jacqueline Werkner, Religion und Menschenrechte als sozialphilosophische und politische Herausforderung der Gegenwart. Einleitung, in: Dies. (Hg.), Religion, Menschenrechte und Menschenrechtspolitik, Wiesbaden 2010, S. 9-25, hier: S. 14. 
rungen, Stellungnahmen und andere Texte von Religions- und Weltanschauungsgemeinschaften die Menschenrechte an sich, einzelner Menschen, spezifische Menschenrechte einzelner Menschen, die Menschenrechte aller Menschen oder spezifische Menschenrechte aller Menschen ablehnen. ${ }^{6}$

Das Verhältnis zwischen Religions- und Weltanschauungsgemeinschaften und Menschenrechten lässt sich zusammenfassen: „Religion entertains a complex relation with human rights, the core of which can be theorized as a twofold dynamic of religious appropriation and rejection of human rights. " ${ }^{7}$ Innovationen wie die Menschenrechte lösen bei Religions- und Weltanschauungsgemeinschaften aus, dass sich diese zu den Menschenrechten in Beziehung setzen und diese deuten wollen. Dabei verorten sie sich zwischen den Extremen radikaler Ablehnung und der Inanspruchnahme, die eigene Tradition als den eigentlichen Ursprung der Innovation anzusehen. ${ }^{8}$

Darüber hinaus bleibt bei Aneignung die Möglichkeit außen vor, dass Religions- und Weltanschauungen Menschenrechte als etwas Eigenes (wieder-)entdecken. Denn bei einer Aneignung handelt es sich um Ideen, Prinzipien und Werte, die von außen kommen. Hingegen existieren Menschenrechte bzw. Glaubensüberzeugungen, Lehren, Traditionen, Ideen, Prinzipien und Werte mit inhaltlichen Berührungspunkten zu den Menschenrechten auch in Religionen und Weltanschauungen. Somit müssen diese nicht angeeignet werden, sondern als Eigenes freigelegt und entfaltet werden bzw. zu ihnen ein Bezug und eine Beziehung aufgebaut werden.

Des Weiteren kommt es auch im Spannungsfeld zwischen diesen beiden Polen der Zustimmung und des Engagements für die Menschenrechte einerseits und der Ablehnung der Menschenrechte und des Widerstands gegen sie andererseits zu Handlungen, an bzw. bei denen Religions- und Weltanschauungsgemeinschaften beteiligt sind bzw. sogar eine Schlüsselrolle einnehmen. Religions- und Weltanschauungsgemeinschaften ringen in der Moderne mit dem „Monument Menschenrechte ${ }^{\text {"9 }}$, an dem keiner vorbeikommt und das von niemandem in seiner Existenz negiert werden kann, weil es sich bereits als zu wirkungsmächtig erweist. Es strahlt in diesem Sinne in Religions- und Weltanschauungsgemeinschaften hinein. Es fordert sie heraus und wirkt in seiner Dynamik durch den

6 Vgl. Hans Joas, Die Sakralität der Person. Eine neue Genealogie der Menschenrechte, Berlin 2011, S. 204.

7 Marco Ventura, Human rights within religion, in: Silvio Ferrari (Hg.), Routledge Handbook of Law and Religion, London 2015, S. 161-178, hier: S. 161.

8 Vgl. beispielsweise dazu ausführlicher zum katholischen Menschenrechtsdenken des 20. Jahrhunderts: Samuel Moyn, Personalismus, Gemeinschaft und Ursprünge der Menschenrechte, in: Stefan-Ludwig Hoffmann (Hg.), Moralpolitik. Geschichte der Menschenrechte im 20. Jahrhundert, Göttingen 2010, S. 63-91. Vgl. dazu auch Joas, Sakralität der Person, S. 204.

9 Joas, Sakralität der Person, S. 280. 
Schutz individualrechtlicher Ansprüche aller Menschen auf Kollektive. Religions- und Weltanschauungsgemeinschaften suchen Wege, wie sie vor ihrem Glaubens-, Wissens-, Denk- und Verstehenshorizont und mit ihrem Glauben, ihren Überzeugungen, ihren Lehren, Werten und Prinzipien einen Zugang zu den Menschenrechten finden und ihren Binnendiskurs an die Menschenrechte anknüpfen können. Sie fragen nach Möglichkeiten, ihre Religion und Weltanschauung mit den Menschenrechten in Einklang zu bringen, diese anzueignen bzw. als Eigenes zu entdecken - ja wie sie allenfalls sogar eine eigene Begründung dafür liefern könnten, dass alle Menschen Trägerinnen und Träger von Menschenrechten sind.

Schließlich sind die Grenzen dieses Spannungsfeldes zwischen den beiden Polen der Zustimmung und des Engagements für die Menschenrechte und der Ablehnung der und des Widerstands gegen die Menschenrechte nicht identisch mit den Grenzen von Religions- und Weltanschauungsgemeinschaften, sondern verlaufen vielmehr entlang von liberalen und illiberalen Gruppierungen und Strömungen - binnenreligiös und binnenweltanschaulich sowie religions- und weltanschauungsübergreifend. ${ }^{10}$

\section{Staatliche Menschenrechtspflichten in Religions- und Weltanschauungsgemeinschaften}

Die Ambivalenz von Religions- und Weltanschauungsgemeinschaften gegenüber den Menschenrechten rückt die Frage in den Vordergrund, was es für den liberalen Rechtsstaat bedeutet, wenn es zu Menschenrechtsverletzungen in bzw. durch Religions- und Weltanschauungsgemeinschaften kommen sollte. Menschenrechte richten sich ja in erster Linie an Staaten. Primär tragen Staaten die Verantwortung für die Durchsetzung und Realisierung der Menschenrechte. Die moralische Begründung der Menschenrechte und ihrer Universalität basierend auf dem Prinzip der Verletzbarkeit ${ }^{11}$ verpflichtet primär (aber nicht alleinig) den Staat dazu, die Menschenrechte zu achten und zu respektieren, zu schützen, durchzusetzen und zu realisieren. Denn alle Menschen haben als Trägerinnen bzw. Träger von Menschenrechten den moralisch begründeten Anspruch, dass der Staat primär (aber nicht alleinig) ihre Menschenrechte achtet, schützt, durchsetzt und realisiert.

10 Vgl. Jonathan Sacks, Swords Into Plowshares, in: The Wall Street Journal Review, October 3-4/2015, C1-C2, hier: C2.

11 Vgl. Peter G. Kirchschläger, Wie können Menschenrechte begründet werden? Ein für religiöse und säkulare Menschenrechtskonzeptionen anschlussfähiger Ansatz, ReligionsRecht im Dialog 15, Münster 2013a. 
Dabei handelt es sich nicht um eine alleinige Verantwortung. Sekundär stehen auch nichtstaatliche Akteure wie z. B. Religions- und Weltanschauungsgemeinschaften in der Pflicht. ${ }^{12}$ Ein ausschließlich auf den Staat ausgerichtetes Menschenrechtsverständnis würde sowohl dem Auftrag der Menschenrechte, alle Menschen in den essentiellen Elementen und Bereichen der menschlichen Existenz zu schützen, die der Mensch braucht zum Überleben und zum Leben als Mensch, als auch der gegenwärtigen globalisierten Realität nicht gerecht. „Die Verengung der Perspektive auf den (National-)Staat würde heute dazu führen, zu übersehen, in welchem Maße nichtstaatliche, v. a. ökonomische Gewalt Urheber von Menschenrechtsverletzungen sind. “" ${ }^{13}$ Primär gegenüber dem Staat, aber auch demnach sekundär gegenüber nichtstaatlichen Akteuren können Menschenrechte Abwehr- (Unterlassen, Untätigkeit), Leistungs- (positives Tun) und Schutzansprüche (Vermeidung von Übergriffen in menschenrechtlich geschützten Elementen und Bereichen) beinhalten.

Der Hinweis auf diese komplementäre Verantwortung von nichtstaatlichen Akteuren für die Menschenrechte zielt keineswegs auf eine Verkleinerung der Verantwortung von Staaten ab. Dies wäre auch nicht legitimierbar. Staaten sind als Völkerrechtssubjekte rechtlich verbindlich an Achtung, Schutz, Durchsetzung und Realisierung der Menschenrechte gebunden. ${ }^{14}$ Mit gesetzgeberischen und administrativen Mitteln haben sie dafür zu sorgen, dass die Menschenrechte verwirklicht werden. In der rechtlichen Dimension der Menschenrechte erfährt dieser nationale Menschenrechtsschutz eine Ergänzung durch regionale und internationale Menschenrechtsmechanismen, damit das staatliche Wirken überwacht und im Dienste der Gewährleistung des universellen Menschenrechtsschutzes substantiell ergänzt wird. Dieses „staatenzentrierte“ Menschenrechtsverständnis entspricht auch der konzeptionellen Entstehung der Menschenrechte in der rechtlichen Dimension als Rechtsansprüche des Individuums gegenüber dem Staat. Daher hängt auch ihre Umsetzung - sowohl national,

12 Vgl. Peter G Kirchschläger (Hg.), Die Verantwortung von nichtstaatlichen Akteuren gegenüber den Menschenrechten, Religionsrechtliche Studien 4, Zürich 2017; Peter G. Kirchschläger, Wirtschaft und Menschenrechte, in: Ingeborg Gabriel / Peter G. Kirchschläger / Richard Sturn (Hg.), Eine Wirtschaft, die Leben fördert. Wirtschafts- und unternehmensethische Reflexionen im Anschluss an Papst Franziskus, Ostfildern 2017, S. 241-264; Peter G. Kirchschläger, Multinationale Konzerne und Menschenrechte, in: ETHICA 23/3/2015, S. $261-280$.

13 Hans Jörg Sandkühler, Art. Menschenrechte, in: Ders. (Hg.), Enzyklopädie Philosophie, Hamburg 2010, Sp. 1530-1553, hier: Sp. 1550.

14 Vgl. Walter Kälin, Einführung, in: Ders. / Lars Müller / Judith Wyttenbach (Hg.), Bild der Menschenrechte, Baden 2004, S. 14-37, hier: S. 17; Christoph A. Spenlé, Neue Entwicklungen im Völkerrecht. Zur Umsetzung des internationalen Paktes über wirtschaftliche, soziale und kulturelle Rechte von 1966 (UNO-Pakt I), in: Peter G. Kirchschläger (u.a.) (Hg.), Menschenrechte und Wirtschaft im Spannungsfeld zwischen State und Nonstate Actors, Internationales Menschenrechtsforum Luzern IHRF 2, Bern 2005, S. 197-224. 
regional als auch international - immer auch vom Staat ab. So schränken die Menschenrechte einerseits die Souveränität des Staates ein, da sie auch an die Einhaltung der Menschenrechte gebunden ist. Andererseits sind die Menschenrechte auf den Staat angewiesen, weil er entscheidend zur Durchsetzung der Menschenrechte beitragen muss.

Dies bedeutet aber nicht, dass nichtstaatliche Akteure wie z. B. Religions- und Weltanschauungsgemeinschaften nicht ebenfalls in der Verantwortung stehen, die Menschenrechte zu achten. Das Eine schließt das Andere nicht aus. Vielmehr werden beide - Staaten und nichtstaatliche Akteure - gemäß ihrer unterschiedlichen Natur für die Durchsetzung der Menschenrechte in die Pflicht genommen. In der rechtlichen Dimension der Menschenrechte sind nichtstaatliche Akteure dann zur Verantwortung zu ziehen, wenn ihr Entscheiden und Handeln ergänzend zu den staatlichen Verpflichtungen, die gleich bleiben, zur Achtung, zum Schutz, zur Durchsetzung und zur Realisierung der Menschenrechte beitragen.

Selbstverständlich muss diesbezüglich in der rechtlichen Dimension der Menschenrechte in Bezug auf die Durchsetzung und Realisierung derselben beachtet werden, dass sie als Teil des Völkerrechts nur auf Staaten eine unmittelbare völkerrechtliche Wirkung erzielen, weil nichtstaatliche Akteure, wie z. B. in der Regel Religions- und Weltanschauungsgemeinschaften, keine Völkerrechtssubjekte darstellen. Sollte angesichts von Problemen bei der Durchsetzung und Realisierung der Menschenrechte dieser Unterschied in Bezug auf ihre Völkerrechtssubjektivität zwischen Staaten und nichtstaatlichen Akteuren in Zukunft behoben werden, würden grundsätzlich zwei Möglichkeiten zur Verfügung stehen: der Ausbau des völkerrechtlichen Rahmens oder eine entsprechende Anpassung des nationalen Rechts. Angesichts der gegenwärtigen Wirklichkeit könnten konkrete Verbesserungen im Dienste der Achtung, des Schutzes, der Durchsetzung und der Realisierung der Menschenrechte sowohl am völkerrechtlichen Rahmen als auch im nationalen Recht notwendig sein. Denn die Menschenrechte sind immer noch als „Minderheitsphänomen“ zu bezeichnen nicht etwa, weil ihre universelle Geltung damit in Frage gestellt werden soll, sondern weil leider die Mehrheit der Menschen gegenwärtig nicht in den Genuss der Realisierung ihrer Menschenrechte kommt. ${ }^{15}$ Diese Optimierung würde der moralischen und rechtlichen Verpflichtung von nichtstaatlichen Akteuren - wie z. B. von Religions- und Weltanschauungsgemeinschaften - für die Realisierung der Menschenrechte besser Rechnung tragen.

15 Vgl. Amnesty International, Jahresbericht von Amnesty International 2018, vgl. https:// www.amnesty.ch/de/ueber-amnesty/publikationen/amnesty-report/jahre/2018/publikati on-rights-today-menschenrechte-2018/amnesty_jahresbericht_menschenrechte_2018. pdf (letzter Zugriff: 15.04.2019). 
Wenn nun der Staat moralisch begründet die Menschenrechte zu achten, zu schützen, durchzusetzen und zu realisieren hat, gilt es im Anschluss daran zu klären, ob der Staat dem „nur“ außerhalb oder auch innerhalb von Religionsund Weltanschauungsgemeinschaften nachkommen muss. Sollten Religionsund Weltanschauungsgemeinschaften als nichtstaatliche Akteure allenfalls ihrer zu den Menschenrechten korrespondierenden moralischen und rechtlichen Verpflichtung nicht nachkommen, stellt sich die Frage, ob dann der Staat die Menschenrechte in Religions- und Weltanschauungsgemeinschaften durchsetzen muss. Auf der Grundlage der moralischen Begründung der Menschenrechte und ihrer Universalität mit dem Prinzip der Verletzbarkeit kann festgehalten werden, dass die mit den Menschenrechten korrespondierenden und moralisch begründeten Verpflichtungen des Staates auch die Gewährleistung umfassen, dass nichtstaatliche Akteurinnen und Akteure wie Religions- und Weltanschauungsgemeinschaften die Menschenrechte achten, schützen, durchsetzen und $\mathrm{zu}$ ihrer Realisierung beitragen. „The human rights treaties all place the primary responsibility for compliance on states and rely on states to regulate the behavior of non-state actors. ${ }^{\text {“16 }}$ Denn alle Menschen haben als Trägerinnen bzw. Träger von Menschenrechten überall und immer den Anspruch, dass ihre Menschenrechte geachtet, geschützt, durchgesetzt und realisiert werden - innerhalb und außerhalb von Religions- und Weltanschauungsgemeinschaften. Es obliegt dem Staat, Religions- und Weltanschauungsgemeinschaften als nichtstaatliche Akteure in ihren Beiträgen zu Demokratie, Friedensordnung, Recht und Gerechtigkeit ${ }^{17}$ zu fördern, gleichzeitig aber auch deren Achtung und Respekt durch Religions- und Weltanschauungsgemeinschaften sicherzustellen. „Die Religionsgemeinschaften sind Kräfte, die diese rechtstaatlichen Elemente zum Teil positiv mitgestalten, zum Teil aber auch strapazieren “18, gerade wenn man bei Letzterem an illiberale Kräfte und Gruppen in Religions- und Weltanschauungsgemeinschaften denkt.

Wenn nun aber die Staaten sicherstellen müssen, dass Religions- und Weltanschauungsgemeinschaften ihrer Verantwortung nachkommen und die Menschenrechte achten, schützen und zu ihrer Realisierung beitragen, dann umfasst dies indirekt rechtliche Verpflichtungen für Religions- und Weltanschauungsgemeinschaften. Religions- und Weltanschauungsgemeinschaften

16 Charles Beitz, The Idea of Human Rights, Oxford 2009, S. 124.

17 Vgl. Adrian Loretan, Überpositive Gerechtigkeitskriterien sind unentbehrlich! Rechtsphilosophische Überlegungen, in: Paul Richli (Hg.), Wo bleibt die Gerechtigkeit? Antworten aus Theologie, Philosophie und Rechtswissenschaft, Zürich 2005, S. 39-66.

18 Felix Hafner / Georg Gremmelspacher, Beziehungen zwischen Staat und Religionsgemeinschaften in der Schweiz, in: Denise Buser (u. a.) (Hg.), Menschenrechte konkret - Integration im Alltag, Referate des 2. Basler Menschenrechtssymposions und weitere Beiträge, Basel 2005, S. 67-86, hier: S. 85. 
müssen daher innerhalb und außerhalb ihrer Gemeinschaften die Menschenrechte aller Menschen achten, schützen, durchsetzen und zu ihrer Realisierung beitragen. Denn alle Menschen bleiben auch ihnen gegenüber Trägerinnen und Träger von Menschenrechten. Anders formuliert geben Menschen an der Kirchentür, beim Betreten eines hinduistischen oder buddhistischen Tempels, beim Aufsuchen einer Synagoge oder beim Ausziehen der Schuhe am Eingang einer Moschee nicht ihre Menschenrechte ab ...

An den Staaten liegt es demzufolge, sich auch aktiv dafür einzusetzen, dass Religions- und Weltanschauungsgemeinschaften nicht den Menschenrechtsschutz beeinträchtigen und dass sie ihre Verantwortung für die Menschenrechte wahrnehmen. Für Staaten und für Religions- und Weltanschauungsgemeinschaften bedeutet dies ebenfalls, Opfern von Menschenrechtsverletzungen durch Religions- und Weltanschauungsgemeinschaften Zugang zu wirksamen Mechanismen zur Wiedergutmachung und Streitbeilegung zu verschaffen.

Aufgrund der moralischen Begründung der Menschenrechte korrespondieren mit diesen positive und negative Pflichten für die Duty-Bearers - primär die Staaten und sekundär in einer Komplementarität dazu nichtstaatliche Akteure (wie z.B. Religions- und Weltanschauungsgemeinschaften) -, weil den moralisch begründet menschenrechtlich geschützten Ansprüchen aller Menschen entsprochen werden muss. Denn Menschenrechte bilden moralisch begründbare Ansprüche aller Menschen auf korrespondierende Pflichten negativer und positiver Natur (Unterlassungspflichten, Hilfspflichten, Schutzpflichten) und Ermächtigungsrechte (die Einrichtung von Institutionen bildet die zu ihnen korrespondierende Pflicht), die in erster Linie, aber nicht allein den Staaten zukommen und denen Staaten sowohl außerhalb als auch innerhalb von Religions- und Weltanschauungsgemeinschaften nachkommen müssen.

Sollten essentielle Elemente und Bereiche der menschlichen Existenz aller Menschen, die ein Mensch braucht, um zu überleben und als Mensch zu leben, außerhalb und auch innerhalb von bzw. durch Religions- und Weltanschauungsgemeinschaften verletzt werden - z.B. durch Diskriminierung und Ungleichbehandlung ${ }^{19}$-, dann kommen die mit den Menschenrechten korrespondierenden staatlichen Pflichten zum Tragen. Der Staat ist demnach dazu verpflichtet, angesichts von Menschenrechtsverletzungen - seien sie außerhalb, seien sie innerhalb von Religions- und Weltanschauungsgemeinschaften - aktiv $\mathrm{zu}$ werden, einzugreifen und diese $\mathrm{zu}$ stoppen und vorzubeugen. ${ }^{20}$

19 Vgl. Christoph Elsas / Edith Franke / Angela Standhartinger (Hg.), Geschlechtergerechtigkeit: Herausforderung der Religionen, Berlin 2014.

20 Vgl. Franz Heribert Köck, Die Grundrechte im Spannungsfeld von Kirche und Staat - unterbelichtete Aspekte des Problems, in: Stefan Häring (Hg.), In mandatis meditari, FS Hans Paarhammer, Berlin 2012, S. 1035-1054, hier: S. 1043; Susan Moller Okin, Justice, Gender 
Auch wenn aufgrund der auf dem Prinzip der Verletzbarkeit basierenden moralischen Begründung der Menschenrechte mit den Menschenrechten positive und negative Plichten für die Duty-Bearers korrespondieren, stellt sich dennoch die Frage nach einer Ausnahmeregelung im Falle von Religions- und Weltanschauungsgemeinschaften und nach einer Unterlassung von staatlichen Interventionen in solchen. Für eine Ausnahmeregelung und für eine Unterlassung eines Eingreifens von staatlicher Seite in Religions- und Weltanschauungsgemeinschaften spricht gemäß einem kommunitaristischen Ansatz, dass angesichts einer Menschenrechtsverletzung innerhalb einer religiösen bzw. weltanschauungsbasierten Gemeinschaft die Friedensfunktion der Neutralität des Staates darin besteht, nicht zu intervenieren, „da staatliches Eingreifen in die Binnenstruktur geschlossener Gruppierungen und Gemeinschaften immer konfliktfördernd ist ${ }^{\text {«21. }}$.

Gegen diesen Einwand ist jedoch anzuführen, dass eine solche Ausnahme bzw. Unterlassung den legitimen Ansprüchen der Trägerinnen und Träger von Menschenrechten bzw. von potentiellen oder reellen Opfern von Menschenrechtsverletzungen innerhalb bzw. von Religions- und Weltanschauungsgemeinschaften nicht gerecht wird. Denn eine derartige Zurückhaltung würde bedeuten, dass in diesem Fall das kollektive Recht auf Religionsfreiheit faktisch andere Menschenrechte aushebeln würde, da der Staat unter Bezugnahme auf das kollektive Recht auf Religionsfreiheit angesichts von Menschenrechtsverletzungen nichts unternehmen würde. Religions- und Weltanschauungsgemeinschaften würden so gleichsam von allem - insbesondere von den mit den Menschenrechten korrespondierenden Pflichten - dispensiert werden ${ }^{22}$ und einen absoluten Freipass erhalten. Zudem gilt es zu beachten, dass kollektive Menschenrechte immer im Dienst der besseren Durchsetzung und Realisierung individueller Menschenrechte stehen und niemals individuelle Menschenrechte verletzen dürfen.

Aus pragmatischer Sicht kann diesbezüglich zudem hinzugefügt werden, dass staatliche Intervention verschiedene Formen finden kann (z. B. Mediation u. ä.). Dies kann die berechtigte Sorge vor dem konfliktfördernden Potential des staatlichen Eingreifens mindern.

Ebenfalls pragmatisch betrachtet kommt noch hinzu, dass der Zwang zum Verlassen einer Religions- oder Weltanschauungsgemeinschaft auch soziale und

and the Family, New York 1989, S. 116-117; vgl. dazu Joseph Raz, The Morality of Freedom, Oxford 1986, S. 427-429.

21 Walter Kälin, Grundrechte im Kulturkonflikt. Freiheit und Gleichheit in der Einwanderungsgesellschaft, Zürich 2000, S. 47.

22 Vgl. Adrian Loretan, Religionsfreiheit im Kontext der Grundrechte. Ein Überblick, in: Ders. (Hg.), Religionsfreiheit im Kontext der Grundrechte, Religionsrechtliche Studien 2, Zürich 2011a, S. 9-14, hier: 9-10. 
ökonomische Folgen für einen Staat haben kann, sodass ein Staat schon allein deswegen ein Interesse an zwangsfrei funktionierenden Religions- und Weltanschauungsgemeinschaften besitzt. ${ }^{23}$

Mögliche Wege der staatlichen Intervention stellen die Förderung von interner Rechtsentwicklung der Religions- und Weltanschauungsgemeinschaften $^{24}$, die öffentlich-rechtliche Anerkennung von Religions- und Weltanschauungsgemeinschaften durch den Staat ${ }^{25}$, die unterschiedliche Gestaltung der Kooperation mit Religions- und Weltanschauungsgemeinschaften ${ }^{26}$ und damit verbunden der Einzug von Steuern durch den Staat für Religions- und Weltanschauungsgemeinschaften sowie die Wahrnehmung eines religionspolitischen Auftrags dar. „Dieser Auftrag bezieht sich namentlich auch darauf, dass die Religionsgemeinschaften, welche die Grundwerte des Rechtsstaates anerkennen, unterstützt werden. “ ${ }^{\text {} 7}$

Des Weiteren können bei der Frage der öffentlich-rechtlichen Anerkennung von Religions- und Weltanschauungsgemeinschaften die Menschenrechte als Kriterien für die Bewertung derselben durch den Rechtsstaat dienen. Menschenrechtsverletzungen wie z. B. Diskriminierung und Ungleichbehandlung in bzw. durch Religions- und Weltanschauungsgemeinschaften sollten aus menschenrechtlicher Sicht beim Namen genannt werden ${ }^{28}$ und korporative Rechtsansprüche ${ }^{29}$ in den Menschenrechten aller Menschen ihre Grenzen finden.

$23 \mathrm{Vgl}$. Moses Mendelssohn, Jerusalem oder über die religiöse Macht und Judentum, Hamburg 2005.

24 Vgl. Adrian Loretan, Staatliches Religionsrecht in pluraler Gesellschaft. Anforderungen an die interne Rechtsentwicklung der Religionsgemeinschaften, in: Judith Könemann / Ders. (Hg.), Religiöse Vielfalt und der Religionsfrieden. Herausforderungen für die christlichen Kirchen, Beiträge zur Pastoralsoziologie 11, Zürich 2009, S. 144-160.

25 Vgl. dazu Adrian Loretan / Quirin Weber / Alexander H. E. Morawa, Freiheit und Religion. Die Anerkennung weiterer Religionsgemeinschaften in der Schweiz, ReligionsRecht im Dialog 17, Münster 2014; René Pahud de Mortanges, Zwischen religiöser Pluralisierung und Säkularisierung: Aktuelle Entwicklungen bei der staatlichen Anerkennung von Religionsgemeinschaften, in: Gerhard Schwarz / Beat Sitter-Liver / Adrian Holderegger / Brigitte Tag (Hg.), Religion, Liberalität und Rechtsstaat. Ein offenes Spannungsverhältnis, Zürich 2015, S. 225-237; Felix Hafner, Mehr Freiheit durch Anerkennung? Anmerkungen zur öffentlichen Anerkennung von Religionsgemeinschaften, in: Stephan Breitenmoser / Bernhard Ehrenzeller / Marco Sassòli / Walter Stoffel / Beatrice Pfeier (Hg.), Human Rights, Democracy and the Rule of Law. Liber amicorum Luzius Wildhaber, Zürich 2007, S. 1001-1022.

26 Vgl. dazu Judith Wyttenbach, Kooperation von Staat und Religionsgemeinschaften in der Schweiz im Kontext der Grundrechte, in: Loretan (Hg.), Religionsfreiheit im Kontext der Grundrechte, S. 377-413.

27 Hafner / Gremmelspacher, Beziehungen, S. 85.

28 Vgl. Denise Buser, Die unheilige Diskriminierung: eine juristische Auslegeordnung für die Interessenabwägung zwischen Geschlechtergleichstellung und Religionsfreiheit beim $\mathrm{Zu}$ gang zu religiösen Leitungsämtern, ReligionsRecht im Dialog 16, Zürich 2014.

29 Vgl. Will Kymlicka, Multicultural Citizenship, Oxford1995, S. 38. 
Zudem kann staatliche Intervention auch bedeuten, durch Bildung, Information, Sensibilisierung und Bewusstseinsbildung die Diskurs-, Toleranz- und Pluralitätsfähigkeiten von Religions- und Weltanschauungsgemeinschaften ${ }^{30} \mathrm{zu}$ fördern und den Dialog und Austausch zwischen Staat und Religions- und Weltanschauungsgemeinschaften „als Partner einer multireligiösen Gesellschaft, die durch einen demokratischen Rechtsstaat zusammengehalten wird ${ }^{\text {‘31 }}$, $\mathrm{zu}$ ermutigen und zu aktivieren bzw. Beiträge von Religions- und Weltanschauungsgemeinschaften in ihrem Verhältnis zum Staat anzuregen. Denn der Staat profitiert davon, wenn Religions- und Weltanschauungsgemeinschaften ,aus ihrer Binnenperspektive das Verhältnis der religiösen Gemeinde (a) zum liberalen Staat, (b) zu anderen Religionsgemeinschaften und (c) zur säkularisierten Gesellschaft im Ganzen neu bestimmen. ${ }^{\text {“32 }}$

Darüber hinaus tragen Religions- und Weltanschauungsgemeinschaften zum öffentlichen Diskurs einer Gesellschaft über ihren Glaubens-, Wissens-, Denkund Verstehenshorizont und über ihre Sinnstiftung bei.

„Daher muss der liberale Staat den säkularen Bürgern nicht nur zumuten, religiöse Mitbürger, die ihnen in der politischen Öffentlichkeit begegnen, als Personen ernst zu nehmen. Er darf von ihnen sogar erwarten, dass sie nicht ausschließen, in den artikulierten Inhalten religiöser Stellungnahmen und Äußerungen gegebenenfalls eigene verdrängte Institutionen wiederzuerkennen - also potenzielle Wahrheitsgehalte, die sich in eine öffentliche, religiös ungebundene Argumentation einbringen lassen. ${ }^{\text {“33 }}$

Schließlich erweist es sich für die Achtung des Rechts auf Gedanken-, Gewissensund Religionsfreiheit als entscheidend, dass Religions- und Weltanschauungsgemeinschaften öffentlich erläutern, „worin sie selbst das Schützenswerte sehen ${ }^{\text {‘34 }}$ und „was es konkret ist, das durch die Freiheit der Religionsausübung

30 Vgl. Adrian Holderegger, Religion - Säkularisierung - Postsäkularität. Marginalien zu umstrittenen Begriffen, in: Schwarz / Sitter-Liver / Holderegger / Tag (Hg.), Religion, Liberalität und Rechtsstaat, S. 65-77, hier: S. 74.

31 Adrian Loretan, Der (säkulare) Rechtsstaat und die Religionen. Modelle des Zusammenwirkens in den USA, in Europa und in der Schweiz, in: Edmund Arens / Samuel Martin Behloul / Christoph Gellner / Friedrich Huber / Ulrich Kopač / Ders., Religion und Gesellschaft, Theologische Berichte 30, Freiburg i. Ü. 2007, S. 134-196, hier: S. 182.

32 Jürgen Habermas, Intoleranz und Diskriminierung, in: Aram Mattioli (u.a.) (Hg.), Intoleranz im Zeitalter der Revolutionen. Europa 1770-1848, Zürich 2004, S. 43-56; vgl. Friedrich Wilhelm Graf, Der freiheitliche Rechtsstaat und die Religion, in: Schwarz / Sitter-Liver / Holderegger / Tag (Hg.), Religion, Liberalität und Rechtsstaat, S. 79-86.

33 Jürgen Habermas, Wie viel Religion verträgt der liberale Staat?, in: Schwarz / Sitter-Liver / Holderegger / Tag (Hg.), Religion, Liberalität und Rechtsstaat, S. 47-52, hier: S. 52.

34 Marianne Heimbach-Steins, Religionsfreiheit - Kriterium gerechter Religionspolitik, in: Schwarz / Sitter-Liver / Holderegger / Tag (Hg.), Religion, Liberalität und Rechtsstaat, S. 8791, hier: S. 90. 
für die Einzelnen und die religiösen Gemeinschaften gesichert werden soll ${ }^{\text {“35, }}$ was der Staat ebenfalls gezielt fördern kann. ${ }^{36}$

Rechtliche Normen und ihre Durchsetzung bilden wesentliche Pfeiler der friedlichen Koexistenz einer Gesellschaft. Das Zusammenleben einer Gesellschaft wird aber offensichtlich nicht nur durch rechtliche Rahmenbedingungen und Regeln geformt. Ein Ethos und sozialer Druck, die mit diesen rechtlichen Normen korrespondieren oder u.a. auch von Religions- und Weltanschauungsgemeinschaften ausgehen können, prägen ebenfalls das gesellschaftliche Zusammenleben innerhalb eines Rechtssystems.

Eine Gesellschaft erweist sich deshalb nur dann als menschenrechtskonform, wenn auch ihr Ethos mit den Menschenrechten korrespondiert und sie menschenrechtswidrigen sozialen Druck abzubauen vermag (z. B. durch strafrechtliche Verfolgung von häuslicher Gewalt, durch Bildung u. a.). Dementsprechend muss die Beurteilung der rechtlichen Umsetzung und Realisierung von Menschenrechten in einem Staat auch deren Auswirkungen (z. B. ökonomisch) berücksichtigen und überprüfen, ob das Ethos in diesem konkreten Kontext mit dem Recht korrespondiert (z. B. ob nicht die Gleichheit des Rechts durch die Ungleichheit des Ethos konterkariert wird und schließlich in Ungleichheit mündet). Dies kann in Situationen, die menschenrechtlich geschützte Elemente und Bereiche betreffen, beispielsweise das Unterlassen einer Intervention ins Private, aber auch das Eingreifen des Staates ins Private verlangen, damit der Staat seinen mit den Menschenrechten korrespondierenden Pflichten nachkommt - z. B. bei häuslicher Gewalt. Dabei kommt der Opferschutz vor der Privatsphäre. Analog kann dies auch angesichts von Menschenrechtsverletzungen in Religions- und Weltanschauungsgemeinschaften gedacht werden.

$\mathrm{Zu}$ Menschenrechtsverletzungen in Religions- und Weltanschauungsgemeinschaften kann auch folgendes Szenario gehören:

„Freilich können Kollektive - insbesondere auch Kirchen und Religionsgemeinschaften - erhebliche Machtstellungen einnehmen. [...] Nicht selten besteht ein internes Machtgefälle mit entsprechendem Konfliktpotential: Wer für das Kollektiv formulierte Regeln nicht zu akzeptieren vermag, stellt sich in den Gegensatz zur Religionsgemeinschaft als Ganzer; eine Ausgangslage, die zu Spannungen zwischen individueller Glaubensüberzeugung und für alle geltender Glaubensregel innerhalb der gleichen Religionsgemeinschaft führen kann. Dies läuft im Endergebnis auf eine Grundrechts-

35 Ebd., S. 91.

36 Vgl. Für eine ausführliche Liste: Kent Greenawalt, Religion and the Constitution 2: Establishment and Fairness, New Jersey 2009a; Ders., Religion and the Constitution 1: Free Exercise and Fairness, New Jersey 2009b. 
kollision von Einzel- und Gruppenrechten im Bereich der religiösen Grundrechte heraus. ${ }^{37}$

Selbst wenn den Angehörigen und Mitgliedern die Möglichkeit des Austritts aus der Religions- bzw. Weltanschauungsgemeinschaft frei offensteht, hilft dies nur bedingt weiter. Denn faktisch erweist sich ein Austritt aus einer Religions- oder Weltanschauungsgemeinschaft als nicht so einfach möglich und realisierbar, da eine Trennung von gesellschaftlichem bzw. kulturellem Zusammenleben und Religion großmehrheitlich nicht der Realität entspricht. Zeugnis dafür gibt die folgende Aussage einer Angehörigen einer Religions- und Weltanschauungsgemeinschaft zur Option eines Austritts aufgrund von Diskriminierung innerhalb ihrer Gemeinschaft: „Wenn ich austreten würde aus meiner Religions- und Kulturgemeinschaft, würde dies für mich Folgendes bedeuten: Ich ziehe alle Kleider hier aus und versuche nackt in der Welt weiter zu leben. ${ }^{\text {“38 }}$ In den Menschenrechten selbst - insbesondere beim Recht auf Nichtdiskriminierung kommt diese besondere Qualität von Religion und Weltanschauung zum Zug. Sie wird von den Menschenrechten geachtet und respektiert. Gleichzeitig gestaltet sie es als äußerst schwierig und in vielen Fällen als geradezu unmöglich, aus einer Religions- und Weltanschauungsgemeinschaft einfach so auszutreten bzw. diese zu wechseln. Diese Realität der Austritts-Option unterstreicht die Notwendigkeit, dass der Staat und die internationale Gemeinschaft gezielt anstreben sollten, Religions- und Weltanschauungsgemeinschaften mit den Menschenrechten zu versöhnen. ${ }^{39}$

Die Fokussierung auf die Austritts-Option durch den Staat kann zur Folge haben, dass durch die Distanzierung des Staates von Angelegenheiten in Religions- und Weltanschauungsgemeinschaften - unter Verweis auf die Freiwilligkeit der Zugehörigkeit zu einer Gemeinschaft bzw. die offenstehende Austrittsmöglichkeit - illiberale Kräfte in Religions- und Weltanschauungsgemeinschaften gefördert und liberale Kräfte bedroht und aus Religions- und Weltanschauungsgemeinschaften gedrängt werden. Damit verbunden könnte es zu einer indirekten staatlichen Förderung von illiberalen Strömungen, Gruppen und „Wahrheiten“ in Religions- und Weltanschauungsgemeinschaften kommen. Wenn z. B. aus der Sicht von bestimmten Gruppen in Religions- und Weltanschauungsgemeinschaften Menschenrechtsverletzungen in oder von Religionsund Weltanschauungsgemeinschaften möglicherweise notwendig erscheinen

37 Felix Hafner, Religionsfreiheit im Kontext der Menschenrechte, in: Loretan (Hg.), Religionsfreiheit im Kontext der Grundrechte, S. 121-161, hier: S. 144.

38 Adrian Loretan, Religionsfreiheit im Kontext der Grundrechte. Ein Überblick, in: Ders. (Hg.), Religionsfreiheit im Kontext der Grundrechte, S. 9-14, hier: S. 10.

39 Vgl. Madhavi Sunder, Keeping Faith: Reconciling Women's Human Rights and Religion, in: John Jr. Witte / Christian Green (Hg.), Religion and Human Rights. An Introduction, Oxford 2012, S. 281-298. 
mögen, um den Fortbestand der Gemeinschaft sicherzustellen, und daher im Dienste der Tradition zulässig zu sein scheinen, bleibt dies aus diesem Grund und auch vom Standpunkt eines Rechtsstaates aufgrund der Universalität der Menschenrechte inakzeptabel und muss von staatlicher Seite unterbunden und vorgebeugt werden.

Angesichts von Menschenrechtsverletzungen durch bzw. in Religions- und Weltanschauungsgemeinschaften muss der Staat auch eingreifen, um sich nicht selbst zu unterwandern und aufzugeben. Denn die Menschenrechte bilden das Fundament des Rechtsstaates. Der Staat kann daher keine Parallelgesellschaften mit eigenem menschenrechtswidrigem Recht dulden, sondern muss in deren Unterbindung und Prävention aktiv werden, sein bzw. bleiben - immer vor Augen das einzelne Individuum, das Trägerin bzw. Träger von Menschenrechten ist und auch innerhalb von Religions- und Weltanschauungsgemeinschaften nicht Opfer von Menschenrechtsverletzungen sein bzw. werden darf.

Die Glaubwürdigkeit und Kohärenz des Staates stehen auf dem Spiel. In ihren diesbezüglichen Entscheidungen, Maßnahmen und Handlungen müssen Staaten jedoch darauf achten, dass „nicht die Mittel ungeduldiger Interventionen die normativen Zwecke selber verletzen und zugleich den Widerstand derer provozieren, die befreit werden sollen. “ ${ }^{* 40}$

Es stellt sich an dieser Stelle die Frage, ob die staatliche Pflicht, etwas angesichts von Menschenrechtsverletzungen in bzw. durch Religions- oder Weltanschauungsgemeinschaften zu unternehmen, auch in Situationen gültig bleibt, wenn eine reelle Austrittsoption in einer Religions- oder Weltanschauungsgemeinschaft bestehen würde, in der zum einen die oben beschriebene besondere Qualität von Religion und Weltanschauung abgeschwächt oder gar nicht vorhanden wäre, und in der zum anderen die Folgen eines Austritts weder soziale Exklusion noch negative Auswirkungen auf das weitere Leben und auf die Fortexistenz außerhalb der Religions- und Weltanschauungsgemeinschaft sowie auch keine finanziellen Nachteile hervorrufen würden. Bereits im Zuge der Formulierung dieser Frage wird offensichtlich, dass allenfalls der zweite Teil möglicherweise denkbar wäre. Im ersten Teil - der Möglichkeit einer Abschwächung oder eines Nichtvorhandenseins der besonderen Qualität von Religion und Weltanschauung - kann davon wohl aufgrund des Wesens von Religion und Weltanschauung nicht die Rede sein, zumal sich dieser Aspekt von außen nicht beurteilen lässt.

In diesem Sinne muss die Frage anders gestellt werden, nämlich ob der Staat auch eingreifen muss, falls ein Austritt aus einer Religions- oder Weltanschauungsgemeinschaft freistehen würde und möglich wäre sowie keine soziale Ex-

40 Ingeborg Maus, Menschenrechte, Demokratie und Frieden. Perspektiven globaler Ordnung, Frankfurt a. M. 2015, S. 225. 
klusion, keine negativen Auswirkungen auf das weitere Leben und die Fortexistenz außerhalb der Religions- und Weltanschauungsgemeinschaft und keine finanziellen Nachteile auslösen würde. In anderen Worten ist zu prüfen, ob eine Differenzierung zwischen Religions- und Weltanschauungsgemeinschaften, die einen Austritt ermöglichen, und Religions- und Weltanschauungsgemeinschaften, die keinen Austritt ermöglichen, die Grundlage einer Skala für den Umgang des Staates mit den Religions- und Weltanschauungsgemeinschaften bilden könnte. Dies würde in anderen Worten bedeuten: Je freier die Austrittsoption jedem einzelnen Mitglied offensteht, desto mehr Zugeständnisse im Bereich der Menschenrechte könnte der Staat der jeweiligen Religions- und Weltanschauungsgemeinschaft machen.

Natürlich spielt es aus menschenrechtlicher Sicht eine Rolle, ob eine Religions- und Weltanschauungsgemeinschaft die Austrittsfreiheit anerkennt und gewährleistet, weil es sich dabei um ein menschenrechtlich geschütztes Element der menschlichen Existenz handelt. Daher besteht diesbezüglicher spezifischer Handlungsbedarf von staatlicher Seite, wenn eine Religions- und Weltanschauungsgemeinschaft die Austrittsfreiheit nicht achtet und garantiert.

Gegen eine grundsätzliche Skalierung von Religions- und Weltanschauungsgemeinschaften auf der Basis des Kriteriums der Gewährleistung bzw. Nichtgewährleistung von Austrittsfreiheit und für staatliche Interventionen auch in der oben beschriebenen Situation spricht jedoch erstens die Universalität der Menschenrechte - d. h. die Geltung der Menschenrechte innerhalb und auBerhalb von Religions- und Weltanschauungsgemeinschaften -, die der Staat durchzusetzen hat. Dieses Argument lässt sich mit einem analogen Beispiel von einem anderen nichtstaatlichen Akteur verdeutlichen: Bei einer Menschenrechtsverletzung am Arbeitsplatz würde der Staat auch eingreifen und nicht von einer Intervention absehen mit dem Verweis darauf, dass die betroffene Person ja den Job wechseln kann und daher kein Handlungsbedarf besteht - selbst wenn sich aus dem Arbeitsplatzwechsel keine negativen Konsequenzen ergeben.

Damit verbunden ist zweitens die Gefahr der Unterwanderung des Staates und seiner Rechtstaatlichkeit im Falle eines Wegschauens und Nichteingreifens von staatlicher Seite als Argument für eine staatliche Intervention auch unter den oben aufgeführten Bedingungen aufzuführen.

Drittens spricht das Prinzip der Unteilbarkeit der Menschenrechte gegen eine solche Skalierung. Das Prinzip der Unteilbarkeit besagt, dass alle Menschenrechte aller Menschen geachtet, geschützt, durchgesetzt und realisiert werden müssen und keine Auswahl vorgenommen werden darf. Denn alle Menschenrechte dienen als Minimalstandard dem Schutz der essentiellen Elemente und Bereiche der menschlichen Existenz aller Menschen, die ein Mensch braucht, um zu überleben und als Mensch zu leben. 
Viertens spricht das Risiko der indirekten staatlichen Förderung von illiberalen Strömungen, Gruppen und „Wahrheiten“ in Religions- und Weltanschauungsgemeinschaften für staatliches Handeln in der oben genannten Situation.

Zusätzlich ergibt sich in Verbindung damit noch die Frage, ob eine andere Form der Skalierung von Religions- und Weltanschauungsgemeinschaften unter Bezugnahme auf das jeweils verletzte Menschenrecht sinnvoll wäre. In anderen Worten würde dies bedeuten, dass man Religions- und Weltanschauungsgemeinschaften nicht allgemein - die Menschenrechte gelten oder gelten nicht bzw. dieses Menschenrecht gilt bzw. gilt nicht in der jeweiligen Religions- und Weltanschauungsgemeinschaft - betrachten würde, sondern im Umgang mit Religions- und Weltanschauungsgemeinschaften von staatlicher Seite differenziert berücksichtigen würde, welches Menschenrecht in der jeweiligen Religionsund Weltanschauungsgemeinschaft verletzt wird. Beispielsweise würde man zwischen Folter, die auch selbstgewählt als freies Mitglied einer Gemeinschaft nicht akzeptabel wäre und ein Einschreiten des Staates verlangen würde, und Diskriminierung, die selbstgewählt als freies Mitglied einer Gemeinschaft von staatlicher Seite zu tolerieren wäre, unterscheiden. Gegen eine solche Skalierung auf der Grundlage der subjektiven Schwere bzw. Bedeutung des jeweiligen Menschenrechts sprechen das Prinzip der Unteilbarkeit und das Prinzip der Interdependenz der Menschenrechte. Das Prinzip der Interdependenz bedeutet, dass sich alle Menschenrechte aller Menschen gegenseitig bedingen.

Die mit den Menschenrechten korrespondierende primäre (nicht alleinige) Verantwortung von Staaten umfasst auch, Probleme und Defizite bei der Durchsetzung und Realisierung der Menschenrechte zu erkennen und darauf substantiell zu reagieren. Dies kann auch beinhalten, neue wirkungsvollere rechtliche Instrumente und Durchsetzungsmechanismen zu entwickeln, um die Achtung, den Schutz, die Durchsetzung und die Realisierung der Menschenrechte zu verbessern.

Eine solche Entwicklung, nämlich angesichts von Ungerechtigkeiten ${ }^{41}$ und einer unzureichenden und nicht zufriedenstellenden Umsetzung von bestehenden Menschenrechten neue rechtliche Instrumente zu schaffen und Optimierung an bestehenden Durchsetzungsmechanismen vorzunehmen, kennt die Menschenrechtstradition auch aus anderen Bereichen. Beispielsweise wurde mit der UN-Kinderrechtskonvention von 1989 auf die Realität reagiert, dass Kinder - obwohl sie selbstverständlich Menschen und daher Trägerinnen und Träger von Menschenrechten sind - bis dahin Gefahr gelaufen waren, nicht in gleichem Maße wie Erwachsene in den Genuss ihrer Menschenrechte zu kom-

41 Vgl. Peter G. Kirchschläger, Religionsfreiheit - ein Menschenrecht im Konflikt, in: Freiburger Zeitschrift für Philosophie und Theologie 60/2/2013b, S. 353-374. 
men. ${ }^{42}$ Durch die UN-Kinderrechtskonvention von 1989 wurde diese Situation verbessert.

Da die Geltung der Menschenrechte innerhalb und außerhalb von Religionsund Weltanschauungsgemeinschaften begründet werden $\mathrm{kann}^{43}$, müssen sich Staaten bei Religions- und Weltanschauungsgemeinschaften - wie auch bei anderen nichtstaatlichen Akteuren - stets die Frage stellen, ob in deren Einflusssphäre Verbesserungs- und Handlungsbedarf besteht. Dabei stehen keine neuen rechtlichen Verpflichtungen für Religions- und Weltanschauungsgemeinschaften im Fokus. Vielmehr geht es darum, die universelle Geltung der Menschenrechte innerhalb und außerhalb von Religions- und Weltanschauungsgemeinschaften auch wirklich umzusetzen und zu realisieren. Dies kann bedingen, in der Einflusssphäre von Religions- und Weltanschauungsgemeinschaften Anpassungen vorzunehmen, falls es Staaten bzw. Religions- und Weltanschauungsgemeinschaften nicht gelingen sollte, dort Achtung, Schutz, Durchsetzung und Realisierung der Menschenrechte zu garantieren.

\section{Handlungsfelder}

In diesem Beitrag wurde die Anwendung der Menschenrechte im Verhältnis zwischen Staat und Religions- und Weltanschauungsgemeinschaften reflektiert und begründet. Im Zuge dessen stand die Frage im Zentrum, ob der Staat - falls Religions- und Weltanschauungsgemeinschaften dem nicht selbst nachkommen die Achtung, den Schutz und die Realisierung der Menschenrechte auch innerhalb von Religions- und Weltanschauungsgemeinschaften durchsetzen muss. Vor dem Hintergrund dieser Überlegungen wurde argumentiert, dass die moralische Begründung der Menschenrechte und ihrer Universalität basierend auf dem Prinzip der Verletzbarkeit den Staat primär (aber nicht alleinig) dazu verpflichtet, die Menschenrechte $\mathrm{zu}$ achten, zu schützen, durchzusetzen und $\mathrm{zu}$ realisieren. Die moralische Begründung der Menschenrechte und ihrer Universalität basierend auf dem Prinzip der Verletzbarkeit begründet auch die Verantwortung für die Optimierung der Durchsetzung und Realisierung der Menschenrechte im Bereich von Non-State Actors, d. h. dass der Staat beispielsweise angesichts von Menschenrechtsverletzungen in Religions- und Weltanschauungsgemeinschaften aktiv werden und eingreifen muss. Denn alle Menschen haben als Trägerinnen bzw. Träger von Menschenrechten den moralisch be-

42 Vgl. Peter G. Kirchschläger / Thomas Kirchschläger, Rights of the Child and Human Rights, in: Carol Bellamy / Jean Zermatten / Ders. / Ders. (Hg.), Realizing the Rights of the Child, Swiss Human Rights Book 2, Zürich 2007, S. 23-27.

43 Vgl. Kirchschläger, Wie können Menschenrechte begründet werden? 
gründeten Anspruch, dass ihre Menschenrechte geachtet, geschützt, durchgesetzt und realisiert werden - aufgrund der universellen Geltung der Menschenrechte außerhalb und innerhalb von Religions- und Weltanschauungsgemeinschaften.

Unter Bezugnahme auf die begründeten, mit den Menschenrechten korrespondierenden positiven und negativen Plichten primär der Staaten und sekundär der nichtstaatlichen Akteure (wie z. B. Religions- und Weltanschauungsgemeinschaften) wurde dann moralisch legitimiert, dass Staaten diesen positiven und negativen Pflichten sowohl außerhalb als auch innerhalb von Religions- und Weltanschauungsgemeinschaften nachkommen müssen. Konkret bedeutet dies, dass der Staat begründet dazu verpflichtet ist, angesichts von Menschenrechtsverletzungen innerhalb und außerhalb von Religions- und Weltanschauungsgemeinschaften aktiv zu werden, einzugreifen und diese zu stoppen und vorzubeugen.

In der Folge wurden schließlich mögliche Gegenargumente, die den Staat doch von Interventionspflichten in Religions- und Weltanschauungsgemeinschaften befreien könnten, entkräftet. Damit wurde untermauert, dass der Staat - falls Religions- und Weltanschauungsgemeinschaften dem nicht selbst nachkommen - die Achtung, den Schutz und die Realisierung der Menschenrechte auch in Religions- und Weltanschauungsgemeinschaften durchsetzen muss.

Auf dieser normativen und argumentativen Grundlage der universellen Geltung der Menschenrechte für und in Religions- und Weltanschauungsgemeinschaften stellt sich die Frage, ob es nicht notwendig wäre, religiöse Menschen, Gläubige, Mitglieder bzw. Angehörige von Religions- und Weltanschauungsgemeinschaften auf internationaler Ebene in den Fokus zu nehmen und ihre Menschenrechtssituation konkret zu verbessern. Denn es scheint eine Spannung zwischen der moralisch begründeten universellen Geltung der Menschenrechte in und für Religions- und Weltanschauungsgemeinschaften und der Realität von Trägerinnen und Träger von Menschenrechten bzw. Opfern von Menschenrechtsverletzungen in Religions- und Weltanschauungsgemeinschaften zu bestehen. In anderen Worten stellt sich die Frage, wo man Menschenrechtsverletzungen innerhalb einer Religions- und Weltanschauungsgemeinschaft einklagen kann. Denn die Staaten schützen sich vor einer derartigen Auseinandersetzung mit Religions- und Weltanschauungsgemeinschaften meistens mit dem Verweis auf die kollektive Religionsfreiheit. Die Religions- und Weltanschauungsgemeinschaften selbst weisen häufig solche Anschuldigungen zurück, weil sie sich sonst beschmutzt fühlen.

Hinsichtlich einer Optimierung denke ich an die Weiterentwicklung der bisherigen Rechtspraxis, bei Menschenrechtsverletzungen durch bzw. in Religions- und Weltanschauungsgemeinschaften mit dem Verweis auf die Freiwilligkeit der Mitgliedschaft und Teilnahme sowie auf die jedem Menschen offenstehende Austrittsmöglichkeit nicht $\mathrm{zu}$ intervenieren, hin $\mathrm{zu}$ einer Praxis der 
Durchsetzung und Realisierung der Menschenrechte in und durch Religionsund Weltanschauungsgemeinschaften. Denn von einem Menschen, der in einer Religions- oder Weltanschauungsgemeinschaft zu Hause ist, kann nicht verlangt werden, dass sie bzw. er ihre bzw. diese verlassen muss, weil ihre bzw. seine Menschenrechte in oder durch diese Religions- oder Weltanschauungsgemeinschaft verletzt werden oder worden sind, während diese Menschenrechtsverletzungen für diese Religions- oder Weltanschauungsgemeinschaft ohne Konsequenzen bleiben.

Dies kann auch beinhalten, neue Rechtsinstrumente zu schaffen, die sicherstellen, dass religiöse Menschen, Gläubige, Mitglieder bzw. Angehörige von Religions- und Weltanschauungsgemeinschaften auch den gleichen Zugang zu allen Menschenrechten haben - außerhalb und innerhalb ihrer Gemeinschaften. Denn die gegenwärtige Situation scheint sich auf Optionen (z. B. Freiwilligkeit der Mitgliedschaft und Teilnahme, offenstehende Austrittsmöglichkeit u.ä.) abzustützen, die für religiöse Menschen, Gläubige, Mitglieder bzw. Angehörige von Religions- und Weltanschauungsgemeinschaften real deswegen nicht bestehen, da u. a. sozialer Druck, sozioökonomische Einbettung von Zugehörigkeit und die Macht und der Einfluss dieser Religions- und Weltanschauungsgemeinschaften auf den Lebenskontext bzw. auf das Leben der Menschen diese zumindest einschränken, wenn nicht sogar ganz ausschließen. Teilweise kommen noch Todesdrohungen hinzu, welche die Austrittssituation noch massiv verschärfen.

Schließlich sind die negativen Auswirkungen auf die Autorität und die universelle Geltung der Menschenrechte nicht zu unterschätzen, wenn Menschenrechte von und in Religions- und Weltanschauungsgemeinschaften stets nicht geachtet, geschützt, durchgesetzt und realisiert werden bzw. wenn Religionsund Weltanschauungsgemeinschaften in der Realität angeblich „menschenrechtsfreie“ Räume und somit scheinbare Ausnahmen zur Universalität der Menschenrechte bilden würden. Dies käme einer steten Unterwanderung der Menschenrechte gleich. Sie ist daher zu verhindern und zu vermeiden.

Bei diesen neuen Rechtsinstrumenten ginge es keinesfalls um zusätzliche rechtliche Verpflichtungen für Staaten und/oder Religions- und Weltanschauungsgemeinschaften, sondern um die Optimierung der Durchsetzung und Realisierung bereits bestehender rechtlicher Verpflichtungen bzw. Rechtsansprüche.

Damit verbunden ergibt sich die Anfrage, ob Staaten auf nationaler Ebene nicht grundsätzlich überprüfen sollten, ob sie nicht - selbst in Religions- und Weltanschauungsgemeinschaften - intervenieren sollten, wenn in bzw. durch Religions- und Weltanschauungsgemeinschaften Menschenrechte verletzt werden. Dabei stehen den Staaten - wie oben deutlich wurde - verschiedene Wege und Instrumente offen, wie sie mit Religions- und Weltanschauungsgemeinschaften 
umgehen und in diese eingreifen können, sollte es dort zu Menschenrechtsverletzungen kommen. Dabei muss auch bedacht werden, dass ein allfälliger Kampf einer einzelnen Person gegen eine Institution Erstere auf verlorenem Posten zurücklässt, es sei denn, sie kann ihre bzw. seine Menschenrechte geltend machen, die jedem Menschen überall zukommen. Diese moralisch begründete universelle Geltung der Menschenrechte darf nicht mehr vor Religions- und Weltanschauungsgemeinschaften Halt machen. Denn Letztere behalten stets ihre „menschliche Seite“, die sie potentiell für Machtmissbrauch und Menschenrechtsverletzungen anfällig macht. Bei diesen Überlegungen handelt es sich auch um eine Einladung an die Rechtswissenschaften, die Ermöglichung von Klagen aus Religions- und Weltanschauungsgemeinschaften noch genauer zu klären.

\section{Quellen}

Amnesty International, Jahresbericht von Amnesty International 2018, vgl. https:// www.amnesty.ch/de/ueber-amnesty/publikationen/amnesty-report/jahre/2018/pu blikation-rights-today-menschenrechte-2018/amnesty_jahresbericht_menschen rechte_2018.pdf (letzter Zugriff: 15.04.2019).

Beitz, Charles, The Idea of Human Rights, Oxford 2009.

Berman, Harold J., Law and Revolution. The Formation of the Western Legal Tradition, Cambridge 1983.

Bielefeldt, Heiner, Die Menschenrechte als „das Erbe der gesamten Menschheit“, in: Ders. I Winfried Brugger / Klaus Dicke (Hg.), Würde und Recht des Menschen, FS Johannes Schwartländer, Würzburg 1992, S. 143-160.

Buser, Denise, Die unheilige Diskriminierung: eine juristische Auslegeordnung für die Interessenabwägung zwischen Geschlechtergleichstellung und Religionsfreiheit beim Zugang zu religiösen Leitungsämtern, ReligionsRecht im Dialog 16, Zürich 2014.

Elsas, Christoph / Franke, Edith / Standhartinger, Angela (Hg.), Geschlechtergerechtigkeit: Herausforderung der Religionen, Berlin 2014.

Graf, Friedrich Wilhelm, Der freiheitliche Rechtsstaat und die Religion, in: Gerhard Schwarz / Beat Sitter-Liver / Adrian Holderegger / Brigitte Tag (Hg.), Religion, Liberalität und Rechtsstaat. Ein offenes Spannungsverhältnis, Zürich 2015, S. 79-86.

Greenawalt, Kent, Religion and the Constitution 2: Establishment and Fairness, New Jersey 2009a, S. 6-13.

Greenawalt, Kent, Religion and the Constitution 1: Free Exercise and Fairness, New Jersey 2009b.

Habermas, Jürgen, Wie viel Religion verträgt der liberale Staat?, in: Gerhard Schwarz I Beat Sitter-Liver / Adrian Holderegger / Brigitte Tag (Hg.), Religion, Liberalität und Rechtsstaat. Ein offenes Spannungsverhältnis, Zürich 2015, S. 47-52.

Habermas, Jürgen, Intoleranz und Diskriminierung, in: Aram Mattioli (u.a.) (Hg.), Intoleranz im Zeitalter der Revolutionen. Europa 1770-1848, Zürich 2004, S. 43-56. 
Hafner, Felix, Religionsfreiheit im Kontext der Menschenrechte, in: Adrian Loretan (Hg.), Religionsfreiheit im Kontext der Grundrechte, Religionsrechtliche Studien 2, Zürich 2011, S. 121-161.

Hafner, Felix, Mehr Freiheit durch Anerkennung? Anmerkungen zur öffentlichen Anerkennung von Religionsgemeinschaften, in: Stephan Breitenmoser / Bernhard Ehrenzeller / Marco Sassòli / Walter Stoffel / Beatrice Pfeier (Hg.), Human Rights, Democracy and the Rule of Law. Liber amicorum Luzius Wildhaber, Zürich 2007, S. 1001-1022.

Hafner, Felix / Gremmelspacher, Georg, Beziehungen zwischen Staat und Religionsgemeinschaften in der Schweiz, in: Denise Buser (u. a.) (Hg.), Menschenrechte konkret Integration im Alltag, Referate des 2. Basler Menschenrechtssymposions und weitere Beiträge, Basel 2005, S. 67-86.

Heimbach-Steins, Marianne, Religionsfreiheit - Kriterium gerechter Religionspolitik, in: Gerhard Schwarz / Beat Sitter-Liver / Adrian Holderegger / Brigitte Tag (Hg.), Religion, Liberalität und Rechtsstaat. Ein offenes Spannungsverhältnis, Zürich 2015, S. 87-91. Holderegger, Adrian, Religion - Säkularisierung - Postsäkularität. Marginalien zu umstrittenen Begriffen, in: Gerhard Schwarz / Beat Sitter-Liver / Adrian Holderegger / Brigitte Tag (Hg.), Religion, Liberalität und Rechtsstaat. Ein offenes Spannungsverhältnis, Zürich 2015, S. 65-77.

Joas, Hans, Sind die Menschenrechte westlich?, München 2015.

Joas, Hans, Die Sakralität der Person. Eine neue Genealogie der Menschenrechte, Berlin 2011.

Kälin, Walter, Einführung, in: Ders. / Lars Müller / Judith Wyttenbach (Hg.), Bild der Menschenrechte, Baden 2004, S. 14-37.

Kälin, Walter, Grundrechte im Kulturkonflikt. Freiheit und Gleichheit in der Einwanderungsgesellschaft, Zürich 2000.

Kirchschläger, Peter G. (Hg.), Die Verantwortung von nichtstaatlichen Akteuren gegenüber den Menschenrechten, Religionsrechtliche Studien 4, Zürich 2017.

Kirchschläger, Peter G., Wirtschaft und Menschenrechte, in: Ingeborg Gabriel / Peter G. Kirchschläger / Richard Sturn (Hg.), Eine Wirtschaft, die Leben fördert. Wirtschaftsund unternehmensethische Reflexionen im Anschluss an Papst Franziskus, Ostfildern 2017, S. 241-264.

Kirchschläger, Peter G., Menschenrechte und Religionen. Nichtstaatliche Akteure und ihr Verhältnis zu den Menschenrechten, Gesellschaft - Ethik - Religion 7, Paderborn 2016.

Kirchschläger, Peter G., Multinationale Konzerne und Menschenrechte, in: ETHICA 23/3/ 2015, S. 261-280.

Kirchschläger, Peter G., Wie können Menschenrechte begründet werden? Ein für religiöse und säkulare Menschenrechtskonzeptionen anschlussfähiger Ansatz, ReligionsRecht im Dialog 15, Münster 2013a.

Kirchschläger, Peter G., Religionsfreiheit - ein Menschenrecht im Konflikt, in: Freiburger Zeitschrift für Philosophie und Theologie 60/2/2013b, S. 353-374.

Kirchschläger, Peter G. / Kirchschläger, Thomas, Rights of the Child and Human Rights, in: Carol Bellamy / Jean Zermatten / Ders. / Ders. (Hg.), Realizing the Rights of the Child, Swiss Human Rights Book 2, Zürich 2007, S. 23-27.

Köck, Franz Heribert, Die Grundrechte im Spannungsfeld von Kirche und Staat - unterbelichtete Aspekte des Problems, in: Stefan Häring (Hg.), In mandatis meditari, FS Hans Paarhammer, Berlin 2012, S. 1035-1054. 
Kymlicka, Will, Multicultural Citizenship, Oxford 1995.

Liedhegener, Antonius / Werkner, Ines-Jacqueline, Religion und Menschenrechte als sozialphilosophische und politische Herausforderung der Gegenwart. Einleitung, in: Dies. (Hg.), Religion, Menschenrechte und Menschenrechtspolitik, Wiesbaden 2010, S. 9-25.

Loretan, Adrian / Weber, Quirin / Morawa, Alexander H. E., Freiheit und Religion. Die Anerkennung weiterer Religionsgemeinschaften in der Schweiz, ReligionsRecht im Dialog 17, Münster 2014.

Loretan, Adrian, Kirche und Staat in der Schweiz im Horizont einer globalisieren Gesellschaft, in: Ders. (Hg.), Religionsfreiheit im Kontext der Grundrechte, Religionsrechtliche Studien 2, Zürich 2011a., S. 414-442.

Loretan, Adrian, Religionsfreiheit im Kontext der Grundrechte. Ein Überblick, in: Ders. (Hg.), Religionsfreiheit im Kontext der Grundrechte, Religionsrechtliche Studien 2, Zürich 2011b, S. 9-14.

Loretan, Adrian, Staatliches Religionsrecht in pluraler Gesellschaft. Anforderungen an die interne Rechtsentwicklung der Religionsgemeinschaften, in: Judith Könemann / Adrian Loretan (Hg.), Religiöse Vielfalt und der Religionsfrieden. Herausforderungen für die christlichen Kirchen, Beiträge zur Pastoralsoziologie 11, Zürich 2009, S. 144160.

Loretan, Adrian, Der (säkulare) Rechtsstaat und die Religionen. Modelle des Zusammenwirkens in den USA, in Europa und in der Schweiz, in: Edmund Arens / Samuel Martin Behloul / Christoph Gellner / Friedrich Huber / Ulrich Kopač / Adrian Loretan, Religion und Gesellschaft, Theologische Berichte 30, Freiburg i. Ü. 2007, S. 134-196. Loretan, Adrian, Überpositive Gerechtigkeitskriterien sind unentbehrlich! Rechtsphilosophische Überlegungen, in: Paul Richli (Hg.), Wo bleibt die Gerechtigkeit? Antworten aus Theologie, Philosophie und Rechtswissenschaft, Zürich 2005, S. 39-66.

Maus, Ingeborg, Menschenrechte, Demokratie und Frieden. Perspektiven globaler Ordnung, Frankfurt a. M. 2015.

Mendelssohn, Moses, Jerusalem oder über die religiöse Macht und Judentum, Hamburg 2005.

Moller Okin, Susan, Justice, Gender and the Family, New York 1989.

Moyn, Samuel, Personalismus, Gemeinschaft und Ursprünge der Menschenrechte, in: Stefan-Ludwig Hoffmann (Hg.), Moralpolitik. Geschichte der Menschenrechte im 20. Jahrhundert, Göttingen 2010, S. 63-91.

Pahud de Mortanges, René, Zwischen religiöser Pluralisierung und Säkularisierung: Aktuelle Entwicklungen bei der staatlichen Anerkennung von Religionsgemeinschaften, in: Gerhard Schwarz / Beat Sitter-Liver / Adrian Holderegger / Brigitte Tag (Hg.), Religion, Liberalität und Rechtsstaat. Ein offenes Spannungsverhältnis, Zürich 2015, S. 225-237.

Raz, Joseph, The Morality of Freedom, Oxford 1986.

Sacks, Jonathan, Swords Into Plowshares, in: The Wall Street Journal Review, October 3-4/ 2015, C1-C2.

Sandkühler, Hans Jörg, Art. Menschenrechte, in: Ders. (Hg.), Enzyklopädie Philosophie, Hamburg 2010, Sp. 1530-1553.

Spenlé, Christoph A., Neue Entwicklungen im Völkerrecht. Zur Umsetzung des internationalen Paktes über wirtschaftliche, soziale und kulturelle Rechte von 1966 (UNO-Pakt 
I), in: Peter G. Kirchschläger (u.a.) (Hg.), Menschenrechte und Wirtschaft im Spannungsfeld zwischen State und Nonstate Actors, Internationales Menschenrechtsforum Luzern IHRF 2, Bern 2005, S. 197-224.

Sunder, Madhavi, Keeping Faith: Reconciling Women's Human Rights and Religion, in: John Jr. Witte / Christian Green (Hg.), Religion and Human Rights. An Introduction, Oxford 2012, S. 281-298.

Ventura, Marco, Human rights within religion, in: Silivio Ferrari (Hg.), Routledge Handbook of Law and Religion, London 2015, S. 161-178.

Wyttenbach, Judith, Kooperation von Staat und Religionsgemeinschaften in der Schweiz im Kontext der Grundrechte, in: Adrian Loretan (Hg.), Religionsfreiheit im Kontext der Grundrechte, Religionsrechtliche Studien 2, Zürich 2011, S. 377-413. 


\section{Die Pluralität des europäischen Rechtsraums und das Religionsrecht}

\section{Einleitung}

Der europäische Rechtsraum hat in den letzten Jahrzehnten einen hohen Grad an Komplexität erreicht. Diese hat mehrere Ursachen. Einerseits sind auf europäischer Ebene um den Europarat und die Europäische Union mehrere einander überlappende Rechtskreise entstanden. Andererseits ist es insbesondere durch das supranationale Recht der Europäischen Union zur Überlagerung und Durchdringung der mitgliedstaatlichen Rechtsordnungen gekommen.

Diese unterschiedlichen normativen Komplexe bzw. Ebenen sind nicht in eine Normenhierarchie eingebunden und stellen unterschiedliche normative Ansprüche. Sie stehen häufig parallel zu einander, wobei sie „sich wechselseitig anregen, gegenseitig verbinden, ineinandergreifen und durchdringen, ohne zu einheitlichen Superordnungen zu verschmelzen, die ihre Teile absorbieren “. ${ }^{1}$ Die Vernetzung von staatlichen Rechtsordnungen, völkerrechtlichen Regimes, supranationalem Recht und transnationalen Regelungsarrangements ${ }^{2}$ verlangt „ein neuartiges Kollisionsrecht als horizontales Verfassungsrecht“. ${ }^{3}$

Auf der Suche nach neuen theoretischen Ansätzen reagierte die Rechtswissenschaft oft mit einer geradezu ,entfesselten juristischen Phantasie [...] um

1 Marc Amstutz, Zwischenwelten. Zur Emergenz einer interlegalen Rechtsmethodik im europäischen Privatrecht, in: Christian Joerges / Gunther Teubler (Hg.), Rechtsverfassungsrecht, Recht-Fertigung zwischen Privatrechtsdogmatik und Gesellschaftstheorie, Baden-Baden 2003, S. 213-237, hier: S. 213.

2 Unter „Transnationalem Recht“ wird eine grenzüberschreitende horizontale Verflüssigung des Rechts durch überwiegend, wenn auch nicht ausschließlich nicht-staatliche Akteure verstanden, die sich regelmäßig auf einzelne Sachbereiche beschränken (vgl. dazu die grundlegenden Überlegungen von Lars Viellechner, Transnationalisierung des Rechts, Weilerswist 2013). Zu diesen nicht-staatlichen Akteuren und internationalen Organisationen muss man wohl auch religiöse Akteure zählen, und zwar nicht nur die katholische Kirche und ihr globales Modell. In den letzten Jahrzehnten agieren auch amerikanische Freikirchen, islamische Organisationen und orthodoxe Kirchen zunehmend als transnationale Akteure. Diese Thematik soll jedoch hier nicht weiter verfolgt werden.

3 Viellechner, Transnationalisierung, S. $265 \mathrm{ff}$. 
diese Entwicklungen rechtlich zu bewältigen, [was] neuartige, teilweise gewagte Begrifflichkeiten hervorgetrieben“ bzw. ironisch-resignierend zur Rede von „UNO’s (unidentified normative objects)“ geführt hat. ${ }^{4}$ Vom vorhandenen Instrumentarium wird meist auf die verschiedenen Theorien zum „Rechtspluralismus“ (legal pluralism) verwiesen, ${ }^{5}$ der damit zu einem der „schillerndsten Begriffe der heutigen Rechtstheorie ${ }^{\text {“6 }}$ geworden ist. Diese Konjunktur darf nicht weiter verwundern, gehört doch „Pluralismus“, verstanden als ein normatives Konzept zur Bewältigung der zunehmenden Vielfalt politischer, kultureller und religiöser Vorstellungen in der Gesellschaft zu den politik- und sozialwissenschaftlichen Schlüsselbegriffen der Gegenwart. Die Sicherung von Pluralismus wird als notwendig für das Funktionieren des freiheitlich-demokratischen Rechtsstaates gesehen. ${ }^{7}$ Aus religionsrechtlicher Sicht bedeutsam ist hier, dass der Europäische Gerichtshof für Menschenrechte (EGMR) in ständiger Rechtsprechung die autonome Existenz von Religionsgemeinschaften als unabdingbar für den Pluralismus in einer demokratischen Gesellschaft bezeichnet, als ein

4 Gunther Teubner, Transnationales Recht: Legitimation durch horizontale Grundrechtswirkung, Zugleich Besprechung von Lars Viellechner: Transnationalisierung des Rechts, in: Juristenzeitung 70/2015, S. 506-510, hier: S. 506f. Ulrich Beck hat 2000 pointiert den Verdacht geäußert, der souveräne neuzeitliche Staat wäre längst in einen „Super-Supra-Inter-Post-NeoTrans-Nation state" umgewandelt, vgl. Ulrich Beck, The cosmopolitan perspective: sociology of the second age of modernity, in: British Journal of Sociology 51/2000, S. 79-105, hier: S. 80.

5 Auf den Begriff gebracht wurde „Rechtspluralismus“ (legal pluralism) in der Rechtsanthropologie, wo er für das Nebeneinanderbestehen von staatlichem Recht und traditionellem (Gewohnheits-)recht in europäischen Kolonialgebieten verwendet wurde. 1969 organisierte der Rechtshistoriker John Gilissen eine Tagung mit diesem Titel. Mit der Veröffentlichung der Tagungsbeiträge, insbesondere des Grundsatzpapiers von Jacques Vanderlinden (Le pluralisme juridique: essai de synthèse, in: John Gilissen (Hg.), Le Pluralisme juridique, Brüssel 1971, S. 19-56) wurde der Begriff „legal pluralism“ wissenschaftlich etabliert. Zum Zentrum der Forschung entwickelt sich in der Folge die rechtsethnologische Schule der Niederlande, die sich mit dem komplexen Nebeneinanderbestehen von 'ādāt-Recht, des traditionellen und lokalen Rechtssystems in Indonesien, von religiösem Recht - im Konkreten das islamische Recht - und dem durch die Kolonialmacht und später durch die Republik Indonesien bestimmten Staatsrecht befasste. Grundlegend: John Griffiths, What is legal pluralism?, in: Journal of Legal Pluralism 24/1986, S. 1-55. Siehe weiters: Franz v. Benda-Beckmann, Rechtspluralismus: Analytische Begriffsbildung oder politisch-ideologisches Programm?, in: Zeitschrift für Ethnologie 119/1994, S. 1-16; Brian Z. Tamanaha, A non-essentialist version of legal pluralism, in: Journal of Law and Society 27/2000, S. 296-321. Einen deutschsprachigen Überblick bietet Ralf Seinecke, Das Recht des Rechtspluralismus, Tübingen 2015.

6 Seinecke, Rechtspluralismus, VII.

7 Insbesondere im deutschen Sprachraum spielen hier die Erfahrungen mit der nationalsozialistischen Staatslehre eine Rolle, vgl. Ernst Forsthoff (Der totale Staat, Hamburg 1933, S. 28): „Zusammenfassend läßt sich feststellen, daß unter der Geltung der Weimarer Verfassung der deutsche Staat zugrunde ging, weil er zum Raub des gesellschaftlichen Pluralismus wurde." 
„Herzstück des Schutzes“, den Art. 9 der Europäischen Menschenrechtskonvention (EMRK) gewährleistet. ${ }^{8}$

„Rechtspluralismus“ gehört jedenfalls zu jenen Begriffen, die in letzter Zeit auch in europarechtliche Diskurse Eingang gefunden haben. ${ }^{9}$ Im Schrifttum wird unter Hinweis auf den alteuropäischen Rechtspluralismus ${ }^{10}$ sogar von einem „new medievalism“ bzw. einer „neo-mediävalen“ Ordnung übergreifender Jurisdiktionen, segmentierter Autoritäten und multipler Loyalitäten gesprochen. ${ }^{11}$

In den Sog dieses komplexen Systems von Rechtskreisen und Rechtsebenen in Europa geraten vor allem „Querschnittsmaterien“, die in diesen pluralen Netzwerken oft mehrfach verstrickt sind. Dabei kommt es zu Parallelentwicklungen und Übertragungen, die auf ihre Konvergenzen zu untersuchen sind. Dies gilt unter anderem auch für das Religionsrecht, das ausgehend vom Grundrechtsschutz und anknüpfend an die normative Berücksichtigung religiöser und weltanschaulicher Interessen quer durch die Rechtsordnung in allen Rechtskreisen und auf allen Ebenen relevant werden konnte. Dadurch entstand zwar kein systematisches europäisches Religionsrecht, aber es bildeten sich religionsrechtliche Schwerpunkte heraus, die im europäischen Normengeflecht zu

8 So beispielsweise in EGMR (Große Kammer) 26. 10. 2000, Appl 30985/96 (Hasan und Chaush vs Bulgarien).

9 Ein interessanter, hier nicht weiter zu verfolgender Verweis auf „Rechtspluralismus“ findet sich im Sondervotum des russischen Richters Anatoly Kovler zur Entscheidung des EGMR über das Verbot der Refah-Partei in der Türkei aus 2003 (Die Wohlfahrtspartei, Erbakan u. a. gegen Türkei (31.07 2001, 13.02.2003 (Große Kammer) Appl 41340/98 ua). Er bemängelt, dass die Urteilsbegründung zu wenig auf die Möglichkeiten und Grenzen eines Rechtspluralismus in modernen Gesellschaften eingeht. Nicht nur die Rechtsanthropologie, sondern auch das moderne Verfassungsrecht würde unter bestimmten Voraussetzungen zugestehen, dass Angehörige von Minderheiten aller Art mehr als einen personalen Status innehaben. Obwohl er mit der vorliegenden Entscheidung grundsätzlich einverstanden war, kritisierte Kovler, dass sie ohne weitere Auseinandersetzung impliziert, dass die Einführung verschiedener Rechtssysteme auf Grund des religiösen Bekenntnisses mit der EMRK unvereinbar sei.

10 Dabei wird vor allem auf den alteuropäischen Rechtspluralismus und auf die - bei Rechtshistorikern vor allem in Detailfragen nicht unumstrittenen - Thesen des amerikanischen Rechtshistorikers Harold Berman hingewiesen (Harold J. Berman, Law and Revolution. The Formation of the Western Legal Tradition, Cambridge, Mass. 1983). Als Ausgangspunkt dieses alteuropäischen Rechtspluralismus sieht Berman die Ausdifferenzierung von weltlicher und geistlicher Macht seit dem Mittelalter, welche in letzter Konsequenz in die Säkularisierung der politischen Ordnung führte. In diesem Spannungsfeld konnten sich noch weitere Freiräume - wie etwa Feudalrecht, Stadtrecht, Handelsrecht - entwickeln, welche die rechtliche Vielfalt noch erweiterten. Dieser auf das Mittelalter zurückgehende alteuropäische Rechtspluralismus wurde durch den souveränen neuzeitlichen Staat durch die Etablierung der Einheit der Rechtsordnung als zentraler „Errungenschaft“ des neuzeitlichen demokratischen Rechtsstaates zumindest formal beendet.

11 Hedley Bull, The Anarchical Society: A Study of Order in World Politics, 3. Aufl., New York 1997, S. $254 \mathrm{ff}$. 
Querverweisen und damit zu Vereinheitlichungsprozessen führen. Solche Tendenzen soll dieser Beitrag in den Blick nehmen, der Ingeborg Gabriel in Erinnerung an gemeinsame Seminare zur Religionsfreiheit in Europa und in Anbetracht ihrer Tätigkeit als Sonderbeauftragte der OSZE im Kampf gegen Rassismus, Fremdenfeindlichkeit und Diskriminierung mit Fokus auf Christen und Angehörige anderer Religionen in den Jahren 2017 und 2019, gewidmet ist.

\section{Die Pluralität der europäischen Rechtskreise und das Religionsrecht}

\subsection{Unionseuropa und Konventionseuropa}

Zwei Rechtskreise stehen naheliegender Weise im Mittelpunkt, die Europäische Union (Unionseuropa) $)^{12}$ und das Europa des Europarates (Konventionseuropa). Einerseits sind die Mitgliedstaaten der EU auch Unterzeichner der EMRK und der vierzehn Zusatzprotokolle, umgekehrt ist der Kreis der Konventionsstaaten größer als jener der EU.

Schon seit jeher hat die Rechtsprechung der Straßburger Konventionsorgane im Grundrechtsbereich wesentlich zur Ausprägung eines europäischen (Mindest-)Standards beigetragen und damit eine wichtige harmonisierende und integrative Rolle gespielt. Diese hat durch den sich allmählich herausgebildeten „europäischen Grundrechtsdialog“ zwischen dem EGMR und dem EuGH eine deutliche Verdichtung und Harmonisierung erfahren.

Im Grundrechtsbereich stellt die EMRK - schon seit langem vielfach als „Teilverfassung Europas auf dem Gebiet der Menschenrechte" bezeichnet - den wesentlichsten gemeinsamen Bezugspunkt dar. Seit der Proklamation der „Europäischen Grundrechtscharta“ 2000 in Nizza bestehen sogar zwei Grundrechtskataloge nebeneinander, deren Verhältnis zueinander es zu bestimmen gilt. Durch den Vertrag von Lissabon mit dem vorgesehenen Beitritt der EU zur EMRK hat diese Entwicklung einen Höhepunkt erfahren. Die Realisierung wurde allerdings 2014 durch das Gutachten 2/13 des EuGH blockiert, ${ }^{13}$ in dem er

12 Die Europäische Union enthält ihrerseits noch den Europäischen Wirtschaftsraum (EWR) und den Schengenraum als eigene Rechtsräume. Eine kartographische Darstellung aller in Europa wirksamen Rechtskreise produziert jedenfalls verwirrende Überschneidungen: Christopher Harding, The Identity of European Law: Mapping Out the European Legal Space, in: European Law Journal 6/2000, S. 128-147.

13 EuGH Gutachten 2/13 vom 18.12.2014, vgl. https://eur-lex.europa.eu/legal-content/DE/ TXT/?uri=CELEX:62013CV0002 (letzter Zugriff: 15.04.2019). Dieser Grundrechtsverbund wird bereits seit langem von einem gewissen Konkurrenzverhältnis zwischen den beiden Gerichten geprägt. Wenn der EGMR in seiner Rechtsprechung die Verweigerung einer 
das ausverhandelte Beitrittsabkommen mit den primärrechtlichen Beitrittsvoraussetzungen und dabei insbesondere mit der Autonomie der Unionsrechtsordnung für unvereinbar erklärt hat. ${ }^{14}$ Dass die Europäische Kommission mit dieser Entscheidung nicht gerade glücklich ist, machte Jean-Claude Juncker in seiner Rede vor der Parlamentarischen Versammlung des Europarats am 19. April 2016 deutlich:

„Die Europäische Union ist verpflichtet, dieser Konvention beizutreten - eine Verpflichtung, die in unseren EU-Verträgen festgelegt ist. Lassen Sie mich klar und deutlich sagen: Dieser Beitritt, der Beitritt zur Konvention ist eine politische Priorität für die von mir geführte Kommission und für mich persönlich. Wir arbeiten an einer Lösung und wir werden nicht eher ruhen, bis wir eine Lösung gefunden haben. “15

Der Grundrechtsschutz stellt sich jedenfalls auch aus religiös-weltanschaulicher Perspektive als ein komplexes, vielschichtiges Gefüge dar, in dem diverse Vorgaben der involvierten Rechtskreise gleichsam gebündelt werden. Dementsprechend heißt es auch in Art. 6 Abs. 2 EUV, dass die Union die Grundrechte achtet, wie sie sich aus der EMRK und aus den gemeinsamen Verfassungsüberlieferungen der Mitgliedstaaten als allgemeine Grundsätze des Gemeinschaftsrechts ergeben.

Es wurden aber nicht nur der Grundrechtsschutz im Allgemeinen und damit auch die Religionsfreiheit im Rahmen des „europäischen Grundrechtsverbundes" deutlich ausgebaut, sondern es wurde auch religiösen Interessen in den vom europäischen Recht erfassten Bereichen verstärkt Rechnung getragen. Das Gemeinschafts- bzw. Unionsrecht hat allerdings lange Zeit die Religionsgemeinschaften als institutionelle Bezugs- und Kristallisationspunkte religiöser Interessen kaum in den Blick genommen. Dies liegt daran, dass das Gemeinschafts-/ Unionsrecht keine expliziten religionsrechtlichen Kompetenzen aufweist. Da aber andererseits keine „Bereichsausnahme“ vorliegt, d.h. keine Exemtion aus dem Geltungsbereich des Unionsrechts, kommt es im Hinblick auf den Charakter des Religionsrechts als „Querschnittsmaterie“ in zunehmendem Maß zu

Vorlage an den EuGH unter Umständen als eine Verletzung von Art. 6 Abs. 1 EMRK wertet, dann ist das einerseits ein „EuGH-freundlicher Akt“ greift aber andererseits in das Verhältnis zwischen EuGH und mitgliedstaatlichen Gerichten ein, was im Grunde genommen eine Einmischung in die Unionsrechtsordnung bedeutet. Vgl. dazu den Überblick bei Ulrich Haltern, Europarecht, Dogmatik im Kontext II: Rule of Law - Verbunddogmatik - Grundrechte, 3. Aufl., Tübingen 2017, Rn. $418 \mathrm{ff}$.

14 Vgl. dazu umfassend Christopher Schmidt, Grund- und Menschenrechte in Europa. Das neue System des Grund- und Menschenrechtsschutzes in der Europäischen Union nach dem Inkrafttreten des Vertrags von Lissabon und dem Beitritt der Union zur EMRK, Jus Europaeum 56, Baden-Baden 2013, S. 63-114; Daniel Engel, Der Beitritt der Europäischen Union zur EMRK, Jus Internationale et Europaeum 110, Tübingen 2015; Haltern, Europarecht, Rn. 1638-1646.

15 Vgl. http://europa.eu/rapid/press-release_SPEECH-16-1487_en.htm (letzter Zugriff: 15.04. 2019). 
einer Erstreckung des Unionsrechts auf die religiöse Sphäre. Das Gemeinschaftsrecht wurde daher von seiner Grundstruktur her zunächst als religionsrechtlich blind bzw. indifferent beschrieben. ${ }^{16}$ In der Folge wurde dann von einem „klandestinen Religionsrecht“ gesprochen, also von einem „zwar verborgenen, tatsächlich aber existierenden Recht, das sich in europäischer Rechtssetzung, Rechtsprechung und Rechtswirklichkeit gebildet hat ${ }^{\text {“. }}{ }^{17}$

Diese Zurückhaltung kann seit den 1990-er Jahren endgültig als überwunden angesehen werden. Es kam in zunehmendem Maß zu einer Relevierung der religiösen Dimension, was nicht zuletzt auch damit zusammenhing, dass sich die Europäische Gemeinschaft als Europäische Union immer mehr von einer Wirtschaftsgemeinschaft zu einer verdichteten Rechtsgemeinschaft entwickelt hat. $^{18}$

Ein „europäisches Religionsrecht" hat nunmehr deutliche Konturen erhalten und auch der Terminus als solcher ist aus dem einschlägigen Schrifttum nicht mehr wegzudenken. Gerhard Robbers hält daher 2011 fest: „Längst hat sich ein eigenes und eigenständiges Religionsrecht der Europäischen Union entwickelt, ein europäisches Religionsrecht im Werden" ${ }^{19}$ Peter Häberle spricht im selben Jahr davon, dass sich seit dem Vertrag von Maastricht „ein begrenzendes und ,anregendes' Religionsverfassungsrecht als Teilverfassung Europas etabliert" habe. ${ }^{20}$

16 So Axel v. Campenhausen in der Mitte der 1990-er Jahre: Staatskirchenrecht, 3. Aufl., München 1996, S. 409.

17 Gerhard Robbers, Europa und die Kirchen, in: Stimmen der Zeit 216/1998, S. 147-157, hier: S. 150.

18 Damit wurde auch die Frage nach der europäischen Identität und der diese bestimmenden Werte virulent. Wenig überraschend wurde im Zuge dieser Debatte auch die religiöse Dimension ins Spiel gebracht, und dabei insbesondere auf die christlichen Wurzeln verwiesen. Das einschlägige Schrifttum ist inzwischen unübersehbar geworden. Einerseits gehört der immer wieder verwendete Hinweis auf die durch drei Hügel - Areopag, Capitol, Golgatha versinnbildlichten Grundlagen Europas zu den Mantren der europäischen Geistesgeschichte. Für das neuzeitliche Europa wird schließlich die Polarität von Christentum und Aufklärung als konstitutiv angesehen: ,The European cultural integration mode, including the form of religious governance, has been emerging as an institutional and legal framework to come to terms with originally Western European religious and secular diversity.“, vgl. Willfried Spohn, Europeanization, Religion and Collective Identities in an Enlarging Europe. A Multiple Modernities Perspective, in: European Journal of Social Theory 12/2009, S. 358-374, hier: S. 363.

19 Gerhard Robbers, Religionsrechtliche Bestimmungen in der Europäischen Union, auf der Homepage der Universität Trier, vgl. https://www.uni-trier.de/index.php?id=7526\& L=2 (letzter Zugriff: 28.01.2018).

20 Peter Häberle, Europäische Verfassungslehre, 7. Aufl., Baden-Baden 2011, S. 524. 


\subsection{Organisation für Sicherheit und Zusammenarbeit in Europa (OSZE) und das Religionsrecht}

Die aus der Helsinki-Konferenz für Sicherheit und Zusammenarbeit in Europa (KSZE) hervorgegangene Organisation für Sicherheit und Zusammenarbeit in Europa (OSZE) stellt gewissermaßen einen weiteren europäischen Rechtskreis dar. Es handelt sich um politische Willenserklärungen von hohem Rang, die dementsprechend auch keinen durchsetzbaren Rechtsschutz vorsehen, denen jedoch zumindest eine auf Verpflichtung ausgerichtete normative Tendenz zugeschrieben werden kann. Besonders hervorzuheben ist auch die historische Bedeutung, die dem OSZE-(KSZE)Prozess im Zusammenhang mit der Durchsetzung der Menschenrechte in den damals sozialistischen Staaten Europas zukam. ${ }^{21}$ Nunmehr sind diese Staaten Mitglieder des Europarates bzw. Unterzeichner der EMRK. In religionsrechtlicher Hinsicht haben im Rahmen der KSZE vor allem die Konferenzen von Helsinki 1975, Madrid 1983 und Wien 1989 Bedeutung erlangt. Durch die Schlussakte von Madrid wurde eine verengte individualrechtliche Sicht überwunden und die korporative bzw. institutionelle Komponente der Religionsfreiheit und damit auch das Selbstbestimmungsrecht der Religionsgemeinschaften betont. In die Schlussakte von Wien wurde schließlich eine umfangreiche Zusammenstellung der sich aus der Garantie der Religionsfreiheit ergebenden einzelnen Gewährleistungen aufgenommen. ${ }^{22}$

Nach der Wende nahm 1991 das Büro für demokratische Institutionen und Menschenrechte (ODIHR) ${ }^{23}$ mit Sitz in Warschau seine Tätigkeit auf. 1997 wurde ein Expertenbeirat für Religions- und Glaubensfreiheit als beratendes Gremium für Anfragen und Stellungnahmen bestellt, ${ }^{24}$ der die Guidelines for Review of Legislation Pertaining to Freedom of Religion or Belief verfasste. ${ }^{25}$ Sie enthalten einen Überblick und Anregungen für die Überprüfung einschlägiger Gesetze. ${ }^{26}$ In den an sich verdienstvollen Stellungnahmen zu Gesetzesvorhaben tritt

21 Ingeborg Gabriel hat als Mitarbeiterin von Rudolf Weiler in dem 1967 gegründeten Universitätszentrum für Friedensforschung (UZF) mit den Forschungsschwerpunkten Friedensethik und Internationale Ethik in Kooperation insbesondere mit der Russischen Akade mie der Wissenschaften einschlägige Grundlagenforschung betrieben.

22 Theodor Schweisfurth / Karin Oellers-Frahm, Dokumente der KSZE, München 1993.

23 Vgl. http://www.osce.org/odihr (letzter Zugriff: 15.04.2019).

24 OSCE, ODIHR Panel of Experts on Freedom of Religion or Belief, vgl. http://www.osce.org/pu blications/odihr/2007/06/24813_888_en.pdf (letzter Zugriff: 15.04.2019).

25 Guidelines for Review of Legislation Pertaining to Freedom of Religion or Belief, http://www. osce.org/odihr/13993 (letzter Zugriff: 15.04.2019).

26 OSCE, Guidelines for Review of Legislation Pertaining to Religion or Belief, Introduction, S. 5f. (letzter Zugriff: 15.04.2019). 
manchmal auch eine überraschende Unkenntnis des nationalen Religionsrechts zu Tage. ${ }^{27}$

Die Tätigkeit der OSZE widerspiegelt auch die für die letzten Jahre charakteristische Tendenz Religions- und Weltanschauungsfreiheit bzw. Religionsrecht zunehmend auf Sicherheitsfragen und das Antidiskriminierungsrecht zu fokussieren. ${ }^{28}$ Bereits die Schlussakten von Budapest 1994 und Istanbul 1999 stellten Querverbindungen zum Missbrauch von Religion für aggressive nationalistische Ziele und zu Fremdenfeindlichkeit und Antisemitismus her. 2004 wurde von der OSZE eine Abteilung für Toleranz und Nichtdiskriminierung eingerichtet, die sich schwerpunktmäßig auch mit Religions- und Weltanschauungsfreiheit befasst. Von den Dokumenten seien die Maßnahmen gegen Antisemitismus, ${ }^{29}$ gegen die Diskriminierung von Muslimen ${ }^{30}$ und zur Vertiefung von Religions- und Weltanschauungsfreiheit hervorgehoben ${ }^{31}$ deren politischer Einfluss auf das Religionsrecht nicht unterschätzt werden darf.

\subsection{Die Säulen des europäischen Religionsrechts ${ }^{32}$}

Bei dem sich solchermaßen herausbildenden „europäischen Religionsrecht“ handelt es sich jedenfalls nicht um eine systematische, mehr oder weniger geschlossene Erfassung der die religiöse Sphäre betreffenden Normen im Sinn des staatlichen Religionsrechts. Das europäische Religionsrecht setzt sich vielmehr aus einer inzwischen durchaus beachtlichen Anzahl relevanter Normen zusammen, die den verschiedenartigen europäischen Rechtskreisen entstammen

27 So zeigt etwa die kritische Stellungnahme zum Entwurf des österreichischen Islamgesetzes 2015 überraschende Unkenntnis bezüglich der verfassungsrechtlichen Grundlagen des österreichischen Religionsrechts auf, wenn hinsichtlich der öffentlichen Religionsausübung auf den Stand des Staatsgrundgesetzes 1867 verwiesen wird und nicht auf die seit dem Staatsvertrag von St. Germain 1919 geltende Rechtslage, vgl. https://www.osce.org/odihr/ 126575 ?download=true (letzter Zugriff: 15.04.2019).

28 Vgl. dazu etwa Hans Michael Heinig, Das Religionsrecht zwischen der Sicherung freiheitlicher Vielfalt und der Abwehr fundamentalistischer Bedrohungen, in: Gerhard Besier / Hermann Lübbe (Hg.), Politische Religion und Religionspolitik, Göttingen (u.a.) 2005, S. 197-216.

29 Office for Democratic Institutions and Human Rights, Anti Semitism, vgl. http://www.osce. org/odihr/20053.html (letzter Zugriff: 15.04.2019).

30 Office for Democratic Institutions and Human Rights, Discrimination against Muslims, vgl. http://www.osce.org/odihr/20055.html (15.04.2019).

31 Office for Democratic Institutions and Human Rights, Freedom of religion or belief, vgl. http://www.osce.org/odihr/20056.html (15.04.2019).

32 Vgl. dazu Richard Potz / Brigitte Schinkele, Europarecht - Wie hast Du's mit der Religion?, in: Kurt Appel / Christian Danz / Richard Potz / Sieglinde K. Rosenberger / Angelika Walser (Hg.), Religion in Europa heute, Religion and Transformation in Contemporary European Society 1, Göttingen 2012, S. 129-160, hier: S. 135 f. 
und unterschiedliche rechtliche Qualität bzw. Wirkungskraft aufweisen. Dabei schälen sich im Wesentlichen folgende tragende "Säulen“ eines europäischen Religionsrechts heraus:

1. Schutz der Religions- und Weltanschauungsfreiheit im Rahmen des „europäischen Grundrechtsverbundes" mit der zentralen Bedeutung der EMRK als law making treaty ${ }^{33}$ und dem Grundrechtskatalog der Grundrechte-Charta der Europäischen Union, die beide durch den Vertrag von Lissabon eine wesentliche Aufwertung erfahren haben. Dies findet seinen Niederschlag im Grundrechtsdialog zwischen EGMR und EuGH. Hier besteht eine weitere Vernetzung, da die „Verfassungsüberlieferungen der Mitgliedstaaten“ in dieses System eingebunden sind (so Art. 6 Abs. 2 EUV), wobei vor allem der Straßburger Judikatur große Bedeutung bei Herausbildung eines europäischen religionsrechtlichen ordre public zukommt.

Eine unterstützende Rolle spielt auch der Expertenbeirat für Religions- und Glaubensfreiheit bei der OSZE als beratendes Gremium für einschlägige Anfragen und Stellungnahmen.

2. Anerkennung des Status von Religions- und Weltanschauungsgemeinschaften (Art. 17 Abs. 1 und 2 AEUV), sowie die Institutionalisierung eines Dialogs mit diesen (Art. 17 Abs. 3 AEUV). Seit jeher wurde von den Straßburger Instanzen den Konventionsstaaten beim Grundrecht der Religionsfreiheit ein weiter Gestaltungsspielraum eingeräumt. Die Vielfalt der religionsrechtlichen Systeme sollte und soll unangetastet bleiben. Diese Sensibilität findet sich grundsätzlich auch im Unionsrecht wieder. Es bedarf in diesem Bereich einer besonderen Kontextsensibilität des EuGHs, vergleichbar der „Margin of Appreciation"-Doktrin des EGMR. Die Bestimmung des Art. 17 AEUV enthält also einen Achtungsanspruch, der ein Beeinträchtigungsverbot miteinschließt, und ist daher primär einzubinden in den in Art. 6 des Unionsvertrages verankerten Grundrechtsschutz. Daraus resultiert ein Schutz jedenfalls der sich in den einzelnen Mitgliedstaaten aus der religionsrechtlichen Grundkonzeption ergebenden Strukturprinzipien. Wie weit auch einzelne materielle Rechtspositionen davon umfasst sind, bedarf einer auf den Einzelfall bezogenen Grenzziehung, wobei das „Beeinträchtigungsverbot“ für eine bestimmte Rechtsvorschrift umso eher zu gelten haben wird, ,je stärker sie Ausdruck der grundsätzlichen Regelung des Staat-Kirche-Verhältnisses in dem jeweiligen Mitgliedstaat ist. “" ${ }^{\text {"34 Der den }}$ Kirchen und Religionsgemeinschaften zu verleihende religionsrechtliche Status stellt einen Ausfluss der kollektiven bzw. korporativen Religionsfreiheit dar,

33 Christoph Grabenwarter / Katharina Pabel, EMRK, 6. Aufl., Basel-Wien 2016, §2, Rn. 1.

34 Christian Walter, Religion und Recht der Europäischen Union, in: Andreas Zimmermann (Hg.), Religion und Internationales Recht, Berlin 2006, S. 207-226, hier: S. 225 f. unter Berufung auf Stefan Muckel, Die Rechtsstellung der Kirchen und Religionsgemeinschaften nach dem Vertrag über eine Verfassung für Europa, in: DÖV 58/2005, S. 191-200, hier: S. 199. 
einschließlich eines Selbstbestimmungsrechts. Gerade dieses hat in den beiden letzten Dezennien in der Straßburger Judikatur deutlichere Konturen erhalten.

In diesem Zusammenhang ist auch auf die oben erwähnten Guidelines for Review of Legislation Pertaining to Freedom of Religion or Belief des Expertenbeirats für Religions- und Glaubensfreiheit bei der OSZE zu verweisen.

3. Antidiskriminierungsmaßnahmen (Art. 10 und Art. 19 AEUV). Durch 13 EGV des Vertrags von Amsterdam, der in Art. 19 AEUV übernommen wurde, war es erstmals zu einer ausdrücklichen Erfassung der religiösen Dimension des Lebens in einem Gründungsvertrag gekommen, ohne dass es vermittelnder Umwege über andere Bestimmungen des Primärrechts bedurfte. Im religionsrechtlichen Kontext ist vor allem auf die auf der Grundlage dieser Ermächtigungsnorm ergangenen Gleichbehandlungsrahmen-Richtlinie 2000/78/EG (Antidiskriminierungs-Richtlinie) und Antirassismus-Richtlinie 2000/43/EG sowie das in deren Umsetzung in den Folgejahren jeweils ergangene mitgliedstaatliche Gleichbehandlungsrecht hinzuweisen. Die ersten Urteile des EuGH zum Antidiskriminierungsrecht im religionsrechtlichen Kontext wurden mit besonderer Spannung erwartet, ${ }^{35}$ und prompt wurde bereits in den unterschiedlichen Zugängen zum Tragen eines islamischen Kopftuchs am Arbeitsplatz in den Schlussanträgen der jeweils befassten Generalanwältinnen die Bandbreite der religionsrechtlichen Grundfragen fassbar. ${ }^{36}$

Ergänzend ist hier auch auf die Tätigkeit der bei der OSZE eingerichteten Abteilung für Toleranz und Nichtdiskriminierung zu verweisen, die sich schwerpunktmäßig auch mit Religions- und Weltanschauungsfreiheit befasst.

4. Im Sekundärrecht finden sich verschiedene Rechtsvorschriften, die entweder ein spezielles Diskriminierungsverbot enthalten, für einzelne religionsrechtliche Materien ein Sonderrecht schaffen oder auch mittelbare Auswirkungen auf Religionsgemeinschaften als Teilnehmer am Wirtschaftsleben haben.

35 EuGH 14.3.2017, C-157/15, Samira Achbita \& Centrum voor gelijkheid van kansen en voor racismebestrijding / G4S Secure Solutions NV und C-188/15, Asma Bougnaoui und Association de défense des droits de l'homme (ADDH) / Micropole SA, vormals Micropole Univers SA, vgl. dazu den Kommentar von Richard Potz in. öarr 65/2018, S. 180-212.

36 Schlussanträge GA J. Kokott vom 31.05.2016 (Samira Achbita) mit einem „laizistischen“ Zugang, vgl. http://curia.europa.eu/juris/document/document.jsf?docid=179082\& doc lang=DE (letzter Zugriff: 19.06.2019); Schlussanträge GA E. und Sharpston vom 13.6.2016 (Asma Bougnaoui) mit einem die öffentliche Sichtbarkeit von Religion in ausgewogener Weise berücksichtigenden Zugang, vgl. http://curia.europa.eu/juris/document/document. jsf?docid=181584\& doclang=DE (letzter Zugriff: 19.06.2019). Der Gerichtshof hat sich dann allerdings in den beiden Entscheidungen um eine Harmonisierung bemüht. 


\section{Das europäische Mehrebenensystem}

Das zentrale Moment des europäischen Rechtspluralismus ist durch das Spannungsfeld von mitgliedstaatlichem und europäischem Recht bestimmt. ${ }^{37}$

Im Zuge der Europäisierung der mitgliedstaatlichen Rechtsordnungen kommt es zu einem „Prozess fortschreitender Beeinflussung, Wandlung und Überformung [...] durch die Rechtsmassen europäischen Rechts und durch das in ihnen wirksame Rechtsdenken“ ${ }^{38}$ So kann man die „Architektur ihres Rechts nicht als Einheit [sondern] eher als Vernetzung von Rechtsregimen, Rechtsordnungen

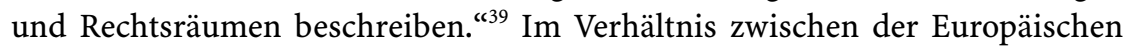
Union und ihren Mitgliedstaaten wurzelt dieser Vorgang in dem bereits 1964 vom EuGH ausgesprochenen Vorrang des Gemeinschaftsrechts vor dem nationalen Recht. ${ }^{40}$ Im Rahmen dieses Prozesses kommt es zu vielfältigen wechselseitigen Beeinflussungen, die beiden oben angesprochenen Rechtskreise werden durch die „Verfassungsüberlieferungen der Mitgliedstaaten“ verklammert und überlagert, die ihrerseits in das Rechtssystem der Europäischen Menschenrechtskonvention eingebunden sind. Ulrich Haltern spricht von einem „Tandemsystem “. ${ }^{41}$

Für das Verhältnis von Unionsrecht und nationalen Rechtsordnungen in der „Post-Maastricht-Ära“" ${ }^{\text {“2 }}$ hat sich inzwischen der Begriff „Mehrebenenrecht“ bzw. „Mehrebenensystem“ („Multi-Level Governance ${ }^{\text {“433) }}$ etabliert. In diesem kommt es nicht zu einer Aufteilung von Kompetenzen nach sich territorial ausschließenden Zuständigkeiten, wie das traditionell in föderalistischen Verfassungen vorgesehen war, sondern es entstanden territorial überlappende $\mathrm{Zu}$ ständigkeiten in einem nicht abgestuften System.

Die nationalen Rechtsordnungen und das Unionsrecht gelten in diesem System gleichberechtigt nebeneinander und sind ohne Über- und Unterordnung und ohne scharfe Kompetenztrennung miteinander verflochten. Seit dem Ver-

37 Auf die hohe europapolitische Aktualität des Themas Bundesstaat versus Staatenbund soll hier nicht weiter eingegangen werden.

38 Eberhard Schmidt-Aßmann, Zur Europäisierung des allgemeinen Verwaltungsrechts, in: Peter Badura / Rupert Scholz (Hg.), Wege und Verfahren des Verfassungslebens, Festschrift für Peter Lerche zum 65. Geburtstag, München 1993, S. 513-527; Haltern, Europarecht, besonders Rn. $545 \mathrm{ff}$.

39 Haltern, Europarecht, Rn. 2.

40 EuGH, Urteil vom 15.07. 1964, Rs 6/64 (Flaminio Costa / E.N.E.L.).

41 Ulrich Haltern, Europarecht, Rn. 7, Rn. 123.

42 Durch den Vertrag von Maastricht kam es nach der Wende $1989 \mathrm{zu}$ einem entscheidenden Schritt in der Vertiefung der EU, wozu auch die ausdrückliche Verankerung der Grundrechte im Primärrecht gehörte (Art. F Abs. 2).

43 Lisbeth Hooghe / Gary Marks, Types of Multi-Level Governance, in: European Integration online Papers (EIoP) 5/11/2001 mit Literaturübersicht, vgl. http://eiop.or.at/eiop/texte/2001011a.htm (letzter Zugriff. 19.06.2019); Christopher Harding, Identity, S. $144 \mathrm{ff.}$ 
trag von Lissabon wird geradezu von einer Mehrebenen-Verfassung gesprochen. ${ }^{44}$ Dementsprechend kommen im Kollisionsfall keine durch hierarchische Strukturen bestimmte Instrumentarien zur Anwendung, sondern vielmehr solche, die durch Koordination und Kooperation geprägt sind. Angesichts eines derartigen Ebenenausgleichs erscheinen nationale Rechtsordnung und Gemeinschafts- bzw. Unionsrechtsordnung als zwei Teilordnungen, die erst in ihrem Zusammenwirken die für den Normunterworfenen maßgebliche „Gegenseitigkeitsordnung“ ergeben. Heinig nennt diesen Vorgang der Rechtsfindung einen „Kompatibilisierungsprozess“ ${ }^{45}$ Die Sicherung der Kompatibilität der Entscheidungen geschieht durch die Bindung beider Bereiche und ihrer Höchstgerichte an eine Reihe von gemeinsamen Prinzipien, deren Geltung auf einem Akt der gegenseitigen Anerkennung beruht. ${ }^{46}$

Im Bereich der Grundrechte kam es von jeher zu einer entsprechenden gegenseitigen Beeinflussung zwischen den beiden Ebenen, die sich sukzessive in Richtung einer Harmonisierung verdichtet hat. Dabei stellt die EMRK den wesentlichsten gemeinsamen Bezugspunkt dar. Vor diesem Hintergrund ist mit Stefan Mückl festzuhalten, „dass die beiden europäischen Grundrechtsebenen und die nationalen Grundrechtsregime in ein Komplimentärverhältnis treten und kumulativ, aber funktionsspezifisch die Grundrechte der Bürger und ihrer Vereinigungen sichern. ${ }^{\text {(47 }}$

Besondere Bedeutung gewinnt diese Komplementarität im Verhältnis zwischen dem EuGH und den nationalen Gerichten. ${ }^{48}$ Da die nationalen Gerichte das Unionsrecht anzuwenden haben, stellt es „weniger eine dem nationalen Recht gegengelagerte Rechtsordnung [dar], die die nationale Souveränität einzu-

44 Ingolf Pernice, The Treaty of Lisbon: Multilevel Constitutionalism in the European Union, in: European Law Review 27/2002, S. 511-529, zu finden auch unter http://www.whi-berlin.de/ pernice-constitutionalism.htm (letzter Zugriff: 12.04.2019).

45 Hans Michael Heinig, Art. 13 und die korporative Religionsfreiheit nach dem Grundgesetz. Zugleich ein Beitrag zu den Perspektiven eines europäischen Religions(verfassungs)rechts, in: Andreas Haratsch (u. a.) (Hg.), Religion und Weltanschauung im säkularen Staat, Stuttgart (u. a.) 2001, S. 215-254, hier: S. $244 \mathrm{ff}$ unter Berufung auf Görg Haverkate, Verfassungslehre. Verfassung als Gegenseitigkeitsordnung, München 1992; Potz / Schinkele, Europarecht, S. 134.

46 Diese Entwicklung hat auch eine globale Dimension. Nationale Gerichte ziehen bei der Auslegung des nationalen Rechts zunehmend internationale Quellen heran, nicht zuletzt auch weil internationale Gerichte immer öfter gleichgelagerte Fälle entscheiden. Anne-Marie Slaughter, A Global Community of Courts, in: Harvard International Law Journal 44/2003, S. 191-219.

47 Stefan Mückl, Europäisierung des Staatskirchenrechts, Baden-Baden 2005, S. 427.

48 Vgl. Anne-Marie Slaughter / Alec Stone Sweet / Joseph Weiler, The European Court and natio nal courts - doctrine and jurisprudence: legal change in its social context, Oxford 1997. 
schränken droht, sondern eine Rechtsordnung, die Teil des nationalen Rechts zu sein scheint. " ${ }^{* 49}$

Ausdruck dieser Konstellation ist insbesondere auch das Vorabentscheidungsverfahren gemäß Art. 267 AEUV, ${ }^{50}$ denn es stellt „nichts anderes als den Ausdruck eines Instruments der gerichtlichen Zusammenarbeit, das auf dem Gedanken des Dialogs und des gegenseitigen Vertrauens zweier Gerichte beruht", 51 dar.

„Die mit der Anwendung des Rechts einschließlich des Gemeinschaftsrechts betrauten nationalen Gerichte stellen einen unabdingbaren Bestandteil der Gemeinschaftsrechtsordnung dar. An der Schnittstelle mehrerer Rechtssysteme leisten sie einen wichtigen Beitrag zur wirksamen Anwendung des Gemeinschaftsrechts und letztlich zur Weiterentwicklung des europäischen Integrationsprozesses. Es ist daher verständlich, dass der Gerichtshof in seiner Rechtsprechung immer wieder die entscheidende Rolle der nationalen Gerichte bei der Durchführung des Gemeinschaftsrechts hervorgehoben hat. ${ }^{\text {“52 }}$

Damit lässt man Gerichte allerdings wie political actors aussehen, wie ausdrücklich in den Schlussanträgen von Generalanwalt Léger im Fall Köbler nachzulesen ist:

„Seine [des nationalen Gerichts] Position ist umso strategischer, als es das Zusammenspiel seines innerstaatlichen Rechts mit dem Gemeinschaftsrecht zu beurteilen und daraus die gebotenen Konsequenzen zu ziehen hat. Somit ist es nicht mehr unbedingt, wie Montesquieu es einst ausgedrückt hat, das Sprachrohr des Gesetzes. ${ }^{\text {“53 }}$

Das Vorabentscheidungsverfahren führt einerseits zur Politisierung des Rechts und andererseits zu einer Verrechtlichung der Politik auch in den Mitgliedstaaten. ${ }^{54}$ Eingriffe in nationale Traditionen und Entwicklungen sind aber gerade im Falle des Religionsrechts oft überaus sensibel. Es sind daher die je unterschiedlichen religionsrechtlichen Traditionen und Regelungen der Mitgliedstaaten zu berücksichtigen, wobei ein Ebenenausgleich das Subsidiaritäts- und Verhältnismäßigkeitsprinzip sowie die Achtung nationaler Identität, religiöser und kultureller Vielfalt im Auge haben muss.

49 Haltern, Europarecht, Rn. 348.

50 Haltern, Europarecht, Rn. 117-136.

51 Schlussanträge GA Léger vom 9.12.2003 (Kommission/Italienische Republik), Slg. 2003, I05581, Rn. 112.

52 Schlussanträge GA Léger vom 8.04.2003 (Köbler), Slg. 2003, I-10239, Rn. 53.

53 Ebda, Rn. 59.

54 Auf die auch in diesem Zusammenhang geäußerte Kritik am EuGH kann hier nicht weiter eingegangen werden, vgl. dazu die Übersicht bei Haltern, Europarecht, Rn. 50-86. 


\section{Schlussbemerkung}

Auch im europäischen Religionsrecht machen sich gegenwärtig tiefgreifende Transformationsprozesse bemerkbar, ${ }^{55}$ die zu einem nicht unwesentlichen Teil der religiös-weltanschaulichen Pluralisierung der europäischen Gesellschaft zu verdanken sind. Diese Entwicklung führt zeitgleich zu zwei antagonistischen Tendenzen, die auch in der Rechtsprechung der europäischen Gerichtshöfe ihren Niederschlag finden: Einerseits findet eine weitere Säkularisierung statt, und andererseits ist vielfach von der Wiederkehr der Religion bzw. von Religion in den öffentlichen Räumen die Rede, in der auch der neuen religiös-weltanschaulichen Vielfalt Rechnung getragen wird. ${ }^{56}$

$\mathrm{Zu}$ Recht weist Ingeborg Gabriel in einem Presse-Interview darauf hin, dass „dem Thema Religionsfreiheit bzw. dem Zusammenspiel und Zusammenleben verschiedener Religionen künftig noch mehr Aufmerksamkeit [zukommen wird] “. ${ }^{57}$ Gabriel verweist darin auch auf die Gefahr, dass der neue religiöse Pluralismus „zur Verdrängung der Religionen aus dem öffentlichen Raum führen" könnte. Im religionsrechtlichen Kontext wird in Zukunft insbesondere darauf zu achten sein, inwiefern es zu dieser Reaktion im jeweiligen Umgang mit der zunehmenden religiösen Pluralität der europäischen Gesellschaft kommen wird.

In der Rechtsprechung von EGMR und EuGH zeigen sich jedenfalls einige Inkonsistenzen wenn es um die öffentliche Präsenz von Religion geht, die oft mit den Schlagworten Säkularisierung, Laizität des Staates, „Religion ist Privatsache" kontrastiert wird. ${ }^{58}$ Auch auf europäischer Ebene tritt damit eine religionspolitische Herausforderung deutlich zu Tage, denn

„je mehr sich die Politik den religiösen Orientierungen eines Teils der Bürger in einem radikalen ,Säkularismus' verschließt und je weniger sie berechtigte soziale Erwartungen und Orientierungsbedürfnisse zu erfüllen vermag, desto mehr wird sich Religion

55 Brigitte Schinkele, Religion und Staat - ein synchroner religionsrechtlicher Überblick, in: Franz Gmainer-Pranzl / Astrid Ingruber / Markus Ladstätter (Hg.), Interreligiöser Dialog in Österreich, Dokumentation der Tagungen zur Förderung des interreligiösen Dialogs, 2012-2015 (St. Virgil/Salzburg), (im Druck).

56 Richard Potz, Religion in öffentlichen Räumen, in: Christian Danz / André Ritter, (Hg.), Zwischen Kruzifix und Minarett. Religion im Fokus der Öffentlichkeit, Studien zum interreligiösen Dialog 11, Münster (u. a.) 2012, S. 65-74.

57 https://www.katholisch.at/aktuelles/2018/02/16/osze-gabriel-betont-konfliktloesungspoten zial-von-religionen (letzter Zugriff: 15.04.2017).

58 Burkhard Josef Berkmann, Die zweifach negative Religionsfreiheit in der jüngsten Rechtsprechung des Europäischen Gerichtshofs für Menschenrechte, in: öarr 59/2012, S. 98-134. 
politisieren, sich als Quelle alternativer Identitäten und sozialer Praxen etablieren und damit erhebliche Konflikte generieren. ${ }^{\text {c }} 9$

Immer wieder zeigt sich die missverständliche Deutung der Wendung „Religion ist Privatsache“. In dieser geht es nicht mehr nur darum, dass Glaubensentscheidungen eine höchstpersönliche „private“ Angelegenheit sind, sondern es wird im laizistischen Sinn die Zulässigkeit religiöser Manifestationen in der Öffentlichkeit in Frage gestellt. Es wird unter Überstrapazierung der negativen Religionsfreiheit ein Recht auf einen religionsfreien öffentlichen Raum postuliert, womit man Geister des 19. Jahrhunderts beschwört, die der pluralistische Rechtsstaat schon längst losgeworden sein sollte.

\section{Quellen}

Amstutz, Marc, Zwischenwelten. Zur Emergenz einer interlegalen Rechtsmethodik im europäischen Privatrecht, in: Christian Joerges / Gunther Teubler (Hg.), Rechtsverfassungsrecht, Recht-Fertigung zwischen Privatrechtsdogmatik und Gesellschaftstheorie, Baden-Baden 2003, S. 213-237.

Beck, Ulrich, The cosmopolitan perspective: sociology of the second age of modernity, in: British Journal of Sociology 51/2000, S. 79-105.

Benda-Beckmann, Franz v., Rechtspluralismus: Analytische Begriffsbildung oder politisch-ideologisches Programm?, in: Zeitschrift für Ethnologie 119/1994, S. 1-16.

Berkmann, Burkhard Josef, Die zweifach negative Religionsfreiheit in der jüngsten Rechtsprechung des Europäischen Gerichtshofs für Menschenrechte, in: öarr 59/2012, S. 98-134.

Berman, Harold J., Law and Revolution. The Formation of the Western Legal Tradition, Cambridge, Mass 1983 [dt: Recht und Revolution. Die Bildung der westlichen Rechtstradition, Frankfurt 1991].

Bull, Hedley, The Anarchical Society: A Study of Order in World Politics, 3. Aufl., New York 1997.

Campenhausen, Axel v., In der Mitte der 1990-er Jahre: Staatskirchenrecht, 3. Aufl., München 1996.

Engel, Daniel, Der Beitritt der Europäischen Union zur EMRK, Jus Internationale et Europaeum 110, Tübingen 2015.

Forsthoff, Ernst, Der totale Staat, Hamburg 1933.

Grabenwarter, Christoph / Pabel, Katharina, EMRK, 6. Aufl., Basel-Wien 2016.

Griffiths, John, What is legal pluralism?, in: Journal of Legal Pluralism 24/1986, S. 1-55.

Guidelines for Review of Legislation Pertaining to Freedom of Religion or Belief, vgl. http://www.osce.org/odihr/13993 (letzter Zugriff: 15.04.2019).

Häberle, Peter, Europäische Verfassungslehre, 7. Aufl., Baden-Baden 2011.

59 Michael Minkenberg / Ulrich Willems, Politik und Religion im Übergang - Tendenzen und Forschungsfragen am Beginn des 21. Jahrhunderts, in: Dies. (Hg.), Politik und Religion, Wiesbaden 2003, S. 13-41, hier: S. $22 \mathrm{f}$. 
Haltern, Ulrich, Europarecht, Dogmatik im Kontext II: Rule of Law - Verbunddogmatik Grundrechte, 3. Aufl., Tübingen 2017.

Harding, Christopher, The Identity of European Law: Mapping Out the European Legal Space, in: European Law Journal 6/2000, S. 128-147.

Haverkate, Görg, Verfassungslehre. Verfassung als Gegenseitigkeitsordnung, München 1992.

Heinig, Hans Michael, Das Religionsrecht zwischen der Sicherung freiheitlicher Vielfalt und der Abwehr fundamentalistischer Bedrohungen, in: Gerhard Besier / Hermann Lübbe (Hg.), Politische Religion und Religionspolitik, Göttingen (u. a.) 2005, S. 197216.

Heinig, Hans Michael, Art. 13 und die korporative Religionsfreiheit nach dem Grundgesetz. Zugleich ein Beitrag zu den Perspektiven eines europäischen Religions(verfassungs)rechts, in: Andreas Haratsch (u.a.) (Hg.), Religion und Weltanschauung im säkularen Staat, Stuttgart (u. a.) 2001, S. 215-254.

Hooghe, Lisbeth / Marks, Gary, Types of Multi-Level Governance, in: European Integration online Papers (EIoP) 5/11/2001, mit Literaturübersicht, vgl. http://eiop.or.at/eiop/tex te/2001-011a.htm (letzter Zugriff: 19.06.2019).

Minkenberg, Michael / Willems, Ulrich, Politik und Religion im Übergang - Tendenzen und Forschungsfragen am Beginn des 21. Jahrhunderts, in: Dies. (Hg.), Politik und Religion, Wiesbaden 2003, S. 13-41.

Muckel, Stefan, Die Rechtsstellung der Kirchen und Religionsgemeinschaften nach dem Vertrag über eine Verfassung für Europa, in: DÖV 58/2005, S. 191-200.

Mückl, Stefan, Europäisierung des Staatskirchenrechts, Baden-Baden 2005.

Office for Democratic Institutions and Human Rights, Anti Semitism, vgl. http://www. osce.org/odihr/20053.html (letzter Zugriff: 15.04.2019).

Office for Democratic Institutions and Human Rights, Discrimination against Muslims, vgl. http://www.osce.org/odihr/20055.html (letzter Zugriff: 15. 04.2019).

Office for Democratic Institutions and Human Rights, Freedom of religion or belief, vgl. http://www.osce.org/odihr/20056.html (letzter Zugriff: 15.04.2019).

OSCE, ODIHR Panel of Experts on Freedom of Religion or Belief, vgl. http://www.osce.org/ publications/odihr/2007/06/24813_888_en.pdf (letzter Zugriff: 15.04.2019).

OSCE, Guidelines for Review of Legislation Pertaining to Religion or Belief, https://www. osce.org/odihr/13993 (letzter Zugriff: 15.02.2020).

Pernice, Ingolf, The Treaty of Lisbon: Multilevel Constitutionalism in the European Union, in: European Law Review 27/2002, S. 511-529.

Potz, Richard / Schinkele, Brigitte, Europarecht - Wie hast Du's mit der Religion?, in: Kurt Appel / Christian Danz / Richard Potz / Sieglinde K. Rosenberger / Angelika Walser (Hg.), Religion in Europa heute, Religion and Transformation in Contemporary European Society 1, Göttingen 2012, S. 129-160.

Potz, Richard, Religion in öffentlichen Räumen, in: Christian Danz / André Ritter (Hg.), Zwischen Kruzifix und Minarett. Religion im Fokus der Öffentlichkeit, Studien zum interreligiösen Dialog 11, Münster (u. a.) 2012, S. 65-74.

Potz, Richard, Kommentar zu EuGH 14.3.2017, C-157/15, Samira Achbita \& Centrum voor gelijkheid van kansen en voor racismebestrijding / G4S Secure Solutions NV und C-188/ 15, Asma Bougnaoui und Association de défense des droits de l'homme (ADDH) / Micropole SA, vormals Micropole Univers SA, in: öarr 65/2018, S. 180-212. 
Robbers, Gerhard, Europa und die Kirchen, in: Stimmen der Zeit 216/1998, S. 147-157. Robbers, Gerhard, Religionsrechtliche Bestimmungen in der Europäischen Union, auf der Homepage der Universität Trier, vgl. https://www.uni-trier.de/index.php?id=7526\& L $=2$ (letzter Zugriff: 28.01.2018).

Schinkele, Brigitte, Religion und Staat - ein synchroner religionsrechtlicher Überblick, in: Franz Gmainer-Pranzl / Astrid Ingruber / Markus Ladstätter (Hg.), Interreligiöser Dialog in Österreich, Dokumentation der Tagungen zur Förderung des interreligiösen Dialogs, 2012-2015 (St. Virgil/Salzburg), (im Druck).

Schmidt, Christopher, Grund- und Menschenrechte in Europa. Das neue System des Grund- und Menschenrechtsschutzes in der Europäischen Union nach dem Inkrafttreten des Vertrags von Lissabon und dem Beitritt der Union zur EMRK, Jus Europaeum 56, Baden-Baden 2013, S. 63-114.

Schmidt-Aßmann, Eberhard, Zur Europäisierung des allgemeinen Verwaltungsrechts, in: Peter Badura / Rupert Scholz (Hg.), Wege und Verfahren des Verfassungslebens, Festschrift für Peter Lerche zum 65. Geburtstag, München 1993, S. 513-527.

Schweisfurth, Theodor / Oellers-Frahm, Karin, Dokumente der KSZE, München 1993.

Seinecke, Ralf, Das Recht des Rechtspluralismus, Tübingen 2015.

Slaughter, Anne-Marie / Stone Sweet, Alec / Weiler, Joseph, The European Court and national courts - doctrine and jurisprudence: legal change in its social context, Oxford 1997.

Slaughter, Anne-Marie, A Global Community of Courts, in: Harvard International Law Journal 44/2003, S. 191-219.

Spohn, Willfried, Europeanization, Religion and Collective Identities in an Enlarging Europe. A Multiple Modernities Perspective, in: European Journal of Social Theory 12/ 2009, S. 358-374.

Tamanaha, Brian Z., A non-essentialist version of legal pluralism, in: Journal of Law and Society 27/2000, S. 296-321.

Teubner, Gunther, Transnationales Recht: Legitimation durch horizontale Grundrechtswirkung, Zugleich Besprechung von Lars Viellechner: Transnationalisierung des Rechts, in: Juristenzeitung 70/2015, S. 506-510.

Vanderlinden, Jacques, Le pluralisme juridique: essai de synthèse, in: John Gilissen (Hg.), Le Pluralisme juridique, Brüssel 1971, S. 19-56.

Viellechner, Lars, Transnationalisierung des Rechts, Weilerswist 2013.

Walter, Christian, Religion und Recht der Europäischen Union, in: Andreas Zimmermann (Hg.), Religion und Internationales Recht, Berlin 2006, S. 207-226. 
Open-Access-Publikation im Sinne der CC-Lizenz BY 4.0

(C) 2020, Vandenhoeck \& Ruprecht $\mathrm{GmbH} \&$ Co. KG, Göttingen ISBN Print: 9783847111658 - ISBN E-Lib: 9783737011655 


\section{Wolfgang Palaver (Innsbruck)}

\section{Religionsfreiheit in Österreich: Ein kritischer Blick}

In mindestens zwei Bereichen hat Ingeborg Gabriel die sozialethische Diskussion entscheidend weitergeführt. Einmal muss ihr Engagement hinsichtlich einer sozialethischen Ökumene hervorgehoben werden, die als Schritt hin zu einer interreligiösen Sozialethik unabdingbar ist. ${ }^{1}$ Der zweite Bereich betrifft ihre intensive Auseinandersetzung mit der Menschenrechtsethik und insbesondere mit dem grundlegenden Recht auf Religionsfreiheit. ${ }^{2}$ In dieser Hinsicht setzt sie jene Tradition in der katholischen Soziallehre fort, die durch die 1963 von Papst Johannes XXIII. veröffentlichte Enzyklika Pacem in terris eingeleitet wurde und in der Erklärung des Zweiten Vatikanischen Konzils über die Religionsfreiheit Dignitatis humanae ihren Höhepunkt fand. Für das friedliche Zusammenleben in unserer von weltanschaulicher Vielfalt geprägten Welt ist das Grundrecht der Religionsfreiheit unabdingbar. ${ }^{3} 2017$ wurde Ingeborg Gabriel zur OSZE Sonderbeauftragten im Kampf gegen Rassismus, Fremdenfeindlich-

1 Ingeborg Gabriel / Alexandros K. Papaderos / Ulrich H. J. Körtner (Hg.), Perspektiven ökumenischer Sozialethik: Der Auftrag der Kirchen im größeren Europa, 2.Aufl., Mainz 2006; Ingeborg Gabriel / Petra Steinmair-Pösel (Hg.), Gerechtigkeit in einer endlichen Welt: Ökologie - Wirtschaft - Ethik, Ostfildern 2013; Ingeborg Gabriel / Aristotle Papanikolaou / Kristina Stoeckl, Political Theologies in Orthodox Christianity: Common Challenges and Divergent Positions, London 2017. Vgl. dazu Hansjörg Schmid, Islam im europäischen Haus. Wege zu einer interreligiösen Sozialethik, Freiburg i. Br. 2012, S. 30-45.

2 Ingeborg Gabriel, Religious Pluralism, Freedom of Religion, and Responsibilities of State, Society and Religious Communities, in: Stefan Hammer / Fatimah Husein (Hg.), Religious Pluralism and Religious Freedom: Religions, Society and the State in Dialogue, Contributions to the Austrian-Indonesian Dialogue, Yogyakarta 2013, S. 213-219; Ingeborg Gabriel, Freedom of Religion, in: Manfred Nowak / Karolina M. Januszewski / Tina Hofstätter (Hg.), All Human Rights for All: Vienna Manual on Human Rights, Vienna 2012, S. 392-396; Ingeborg Gabriel, Naturrecht, Menschenrechte und die theologische Fundierung der Sozialethik, in: Markus Vogt (Hg.), Theologie der Sozialethik, Freiburg i. Br. 2013, S. 229-251.

3 Wolfgang Palaver, Christentum im säkularen Kontext. Grenzen und Chancen, in: Daniela Kästle / Martina Kraml / Hamideh Mohagheghi (Hg.), Heilig - Tabu: Christen und Muslime wagen Begegnungen, Ostfildern 2009, S. 311-318; Irene Klissenbauer, Das Ringen um Religionsfreiheit. Die Positionen von John Courtney Murray und Fethullah Gülen im Vergleich, Religionsrecht im Dialog 19, Wien 2015. 
keit und Diskriminierung, mit Fokus auf Christen und Angehörige anderer Religionen, ernannt. In einem Interview betont sie zu Recht, dass Einschränkungen der Religionsfreiheit als Seismograph für die Menschenrechtslage in einem Land dienen. ${ }^{4}$ Sie verweist dabei auch auf die Zunahme der Diskriminierung und Feindlichkeit gegen Christen und vermerkt, dass Christen vor allem dort zum Opfer werden, „wo islamistische Extremisten im Vormarsch sind“ und eine „anti-westlich aufgeheizten Stimmung " vorherrscht. ${ }^{5}$ Sie distanziert sich aber sogleich von einseitigen Sichtweisen, indem sie darauf hinweist, dass nicht nur islamistische Extremisten die Religion für ihre politischen Zwecke instrumentalisieren, sondern auch „militante rechte Kreise“, die sich auf „jüdischchristliche Werte berufen". ${ }^{6}$

In der gegenwärtigen Welt lässt sich eine Verschlechterung der Religionsfreiheit beobachten. Ingeborg Gabriel verweist auf entsprechende Probleme in Saudi-Arabien, Nordkorea, China, Pakistan und im Iran. ${ }^{7}$ In vielen Ländern sind es oft Christen, denen das Recht auf Religionsfreiheit verweigert oder nur eingeschränkt zugestanden wird. In dieser Hinsicht besteht akuter Handlungsbedarf auf internationaler Ebene.

Der folgende Beitrag widmet sich allerdings nicht dieser Problematik, sondern setzt sich kritisch mit der Religionsfreiheit in Österreich auseinander. Auf den ersten Blick scheint Österreich ein Vorzeigeland in Sachen Religionsfreiheit zu sein. Ein genaueres Hinschauen zeigt allerdings Probleme, die zum Teil mit der historischen Entwicklung des Verhältnisses von Kirche und Staat in Österreich zusammenhängen. Als konkretes Beispiel dient die Nichtanerkennung jener alevitischen Gläubigen in Österreich, die sich aufgrund ihrer Erfahrungen in der Türkei von einer Nähe zum Islam und entsprechenden Institutionen bewusst distanzieren.

\section{Der eingeschränkte religiöse Markt der Religionen in Europa}

Die Religionsfreiheit hat sich in Europa im Unterschied zu den USA viel langsamer und auch eingeschränkter entwickelt. Hauptursache dafür war sicher das in Europa bis ins 20. Jahrhundert vorherrschende konstantinische Bündnis von Kirche und Staat. Nachwirkungen dieses Unterschieds lassen sich noch heute erkennen, wenn etwa der Religionssoziologe José Casanova als einen wesentlichen Unterschied zwischen den USA und Europa festhält, dass der in Europa

\footnotetext{
4 Ingeborg Gabriel / Berthold Siegmar, Wiener Theologin neue OSZE Beauftragte, in: Kirche In 31/4/2017, S. 14-15.

5 Gabriel / Siegmar, Wiener Theologin, S. 15.

6 Ebd.

7 Gabriel, Freedom, S. 394.
} 
vorherrschende Säkularismus mit seiner Tendenz, Religion in die Privatsphäre zu verbannen, für Europas Angst vor der Religion verantwortlich sei. ${ }^{8}$ Nach Casanova fällt es den europäischen Gesellschaften viel schwerer, „,der Religion im öffentlichen Leben und in der Organisierung und Mobilisierung kollektiver Gruppenidentitäten eine legitime Rolle zuzuerkennen“. 9 Konkret bündelt sich diese Angst in einer zunehmend skeptischen Haltung gegenüber dem Islam, der aufgrund seines Anspruchs auf Öffentlichkeit häufig mit seiner fundamentalistischen Variante gleichgesetzt wird. In Österreich zeigt sich das zurzeit am deutlichsten im fast alle politischen Parteien umfassenden Kampf gegen den „politischen Islam“. Als Idealbild steht im Hintergrund dieses Kampfes ein ganz in den Privatbereich abgedrängter Islam.

Die von Casanova diagnostizierte religiöse Situation Europas zeigt sich auch in entsprechenden Religionsindizes. Brian Grim und Roger Finke haben aufbauend auf den anerkannten jährlichen „International Religious Freedom Report“ des US-Außenministeriums den „Government Regulation Index“ erstellt, der staatliche Einschränkungen der Religionsfreiheit mittels einer Skala zwischen 0 für keine Restriktionen und 10 für bloß eine staatlich erlaubte Religion bewertet. ${ }^{10}$ Dieser Index zeigt, dass westeuropäische Länder zwar weniger Religionsfreiheit als die USA aufweisen, aber dennoch relativ gute Bewertungen erhalten. Für den Zeitraum 2003 bis 2008 ergeben sich für westeuropäische Länder wie Deutschland (2,2), Frankreich $(2,9)$, Österreich $(1,1)$ Werte, die unter dem weltweiten Durchschnitt $(3,0)$ liegen. ${ }^{11}$ Die von Gabriel erwähnten problematischen Länder weisen demgegenüber sehr hohe Werte auf: Saudi-Arabien $(9,8)$, Nordkorea $(8,9)$, China $(9,0)$, Pakistan $(8,8)$ und Iran $(9,0)$. Dieser Index scheint also westeuropäischen Ländern ein sehr positives Verhältnis zur Religionsfreiheit $\mathrm{zu}$ bestätigen. ${ }^{12}$

8 José Casanova, Europas Angst vor der Religion, Berlin 2009.

9 José Casanova, Der Ort der Religion im säkularen Europa, in: Transit 27/2004, S. 86-106, hier: S. 97.

10 Brian J. Grim / Roger Finke, International Religion Indexes: Government Regulation, Government Favoritism, and Social Regulation of Religion, in: Interdisciplinary Journal of Research on Religion 2/1/2006, S. 1-40; Brian J. Grim / Roger Finke, The Price of Freedom Denied: Religious Persecution and Conflict in the 21st Century, Cambridge studies in social theory, religion and politics, New York 2011; vgl. Rodney Stark, The Triumph of Christianity: How the Jesus Movement Became the World's Largest Religion, New York 2011, S. 378-379; Benjamin Schewel, Seven Ways of Looking at Religion: The Major Narratives, New Haven 2017, S. 67.

11 Diese nach der Methode von Grim und Finke erhobenen Werte finden sich auf der Website der Association of Religion Data Archives (ARDA), vgl. http://www.thearda.com/internatio naldata/regions/ (letzter Zugriff: 24.06.2019).

12 Ein direkter Vergleich mit den USA ist nicht möglich, da das US-Außenministerium im „International Religious Freedom Report“ nur Länder außerhalb der USA untersucht. 
Doch Grim und Finke haben noch einen weiteren Religionsindex - den „Government Favoritism Index“ - entwickelt, der staatliche Privilegierungen von bestimmten Religionen in die Bewertung aufnimmt. Dieser Index bewertet wieder zwischen 0 (keine Privilegien) und 10 (extreme Bevorzugung). Hier ergibt sich nun ein Bild, das auch für Westeuropa deutliche Einschränkungen der Religionsfreiheit bescheinigt: Deutschland $(6,3)$, Frankreich $(5,0)$ und Österreich $(6,1)$ liegen über dem weltweiten Durchschnitt $(4,6)$ und unterscheiden sich kaum von einem Land wie der Türkei mit einem Wert von 6,8 (die Türkei weist für den „Government Regulation Index“ einen Wert von 5,1 auf). Viele westeuropäische Länder kennen keinen mit den USA vergleichbaren freien Markt der Religionen.

\section{Einschränkungen der Religionsfreiheit in Österreich}

Der für Österreich ausgewiesene relativ hohe Wert von 6,1 für den „Government Favoritism Index “lässt sich leicht durch konkrete Beispiele anschaulich machen. So findet sich in Österreich ein dreistufiges Modell des staatlichen Verhältnisses zu den Religionen. An oberster Stelle stehen sechzehn gesetzlich anerkannte Kirchen oder Religionsgesellschaften wie z. B. die römisch-katholische Kirche, die evangelische Kirche, die orthodoxe Kirche, die Israelitische Religionsgesellschaft, die Islamische Glaubensgemeinschaft in Österreich oder auch die Alevitische Glaubensgemeinschaft in Österreich. Nur diese Religionsgesellschaften haben das Recht auf Religionsunterricht an öffentlichen Schulen oder können Privatschulen mit Öffentlichkeitsrecht errichten. Auch steuerliche Begünstigungen gehören zu den Privilegien dieser ersten Gruppe. Auf der zweiten Stufe befinden sich - und das erst seit dem Jahr 1998 - die Religiösen Bekenntnisgemeinschaften mit Rechtspersönlichkeit. Dazu zählen unter anderem die Alt-Alevitische Glaubensgemeinschaft in Österreich, die Bahá'í-Religionsgemeinschaft Österreich oder die Hinduistische Religionsgesellschaft in Österreich. In einer dritten Gruppe befinden sich schließlich jene religiösen Gemeinschaften, die der Staat als solche nicht anerkennt und die sich rechtlich nur gemäß dem allgemeinen Vereinsrecht konstituieren können. Selbst dieser dritte Weg musste aber erst mühsam erstritten werden, weil das Vereinsgesetz von 1867 Religionsgesellschaften davon ausschloss und es erst $2002 \mathrm{zu}$ einer entsprechenden Öffnung für Religionen kam. ${ }^{13}$ Ein entscheidendes Kriterium

13 Herbert Kalb / Richard Potz / Brigitte Schinkele, Religionsrecht, Wien 2003, S. 127-129; Franz Graf-Stuhlhofer, Frisches Wasser auf dürres Land: Festschrift zum 50-jährigen Bestehen des Bundes der Baptistengemeinde in Österreich, Baptismus-Studien 7, Kassel 2005, S. 210. 
für die erste Gruppe ist die Anzahl der Mitglieder der jeweiligen Gemeinschaft. Diese Mindest-Mitgliederzahl von mindestens zwei Promille der Bevölkerung nach der letzten Volkszählung (Bundesgesetz über die Rechtspersönlichkeit von religiösen Bekenntnisgemeinschaften BekGG \$11 Abs. 1d; nach Volkszählung 2001: 16.264) verhindert, dass kleinere Religionsgemeinschaften gesetzlich anerkannt werden können. Eine Diskriminierung zeigt sich schon allein dadurch, dass zahlreiche aktuell anerkannte Kirchen und Religionsgesellschaften in Österreich unter dieser Zahl liegen und nach diesem Kriterium gar nicht mehr anerkannt werden könnten (z.B.: Altkatholische Kirche, Israelitische Religionsgesellschaft, Neuapostolische Kirche, Buddhistische Religionsgesellschaft). ${ }^{14}$ Vor dem Erlass des BekGG von 1998 genügten etwa 2.000 Mitglieder. ${ }^{15}$ Ein interessantes Beispiel ist auch die in Österreich anerkannte Kirche Jesu Christi der Heiligen der Letzten Tage (Mormonen), der nur etwas mehr als zweitausend Mitglieder angehören. Der Grund für die Anerkennung ist im österreichischen Staatsvertrag von $1955 \mathrm{zu}$ suchen, denn ursprünglich wurde der Antrag auf Anerkennung 1953 zurückgewiesen. Die Anerkennung erfolgte im September 1955, „wobei politische bzw. religionspolitische Überlegungen eine Rolle gespielt haben dürften “. ${ }^{16}$ Die Mormonen gehören zu den wichtigen Religionsgemeinschaften in den USA, einem der Vertragspartner des österreichischen Staatsvertrags. Die Baptisten, die auch ungefähr zweitausend Mitglieder haben, konnten aufgrund dieser Zahl nicht als Religionsgesellschaft anerkannt werden. Zu Recht kritisierte der österreichische Rechtswissenschaftler Richard Potz 2010 die geltende Rechtslage. Die „Mindest-Mitgliederzahl von 16.000“ sei „viel zu hoch angesetzt“ und er „erinnerte auch daran, dass die österreichische Regelung vom Europäischen Gerichtshof für Menschenrechte in Straßburg mehrmals verurteilt worden sei. Deshalb brauche es eine Revision des derzeitigen Gesetzes. Die anerkannten Kirchen, allen voran die katholische und die evangelische Kirche, sollten von sich aus aktiv werden und grundrechtskonforme Lösungen erarbeiten ". ${ }^{17}$ Erst als sich die Anhänger des Bundes der Baptistengemeinden, des Bundes Evangelikaler Gemeinden, der ELAIA Christengemeinden, der Freien Christengemeinde - Pfingstgemeinde und der Mennonitischen Freikirche in Österreich gemeinsam um eine Anerkennung bemühten, erhielten diese 2013 als „Freikirchen in Österreich“ mit ca. 20.000 Mitgliedern den Status einer an-

14 Kalb / Potz / Schinkele, Religionsrecht, S. 98f.

15 Im Unterschied zu Österreich gilt in Deutschland eine niedere Schwelle von nur einem Promille, die einerseits auf das jeweilige Bundesland bezogen ist und die andererseits auch nicht schematisch angewandt werden soll. Siehe: Barbara Gartner, Aktuelle Herausforderungen für den Rechtsstaat einer plurireligiösen Gesellschaft, in: öarr 57/1/2010, S. 37-65, hier: S. 44-48.

16 Kalb / Potz / Schinkele, Religionsrecht, S. 650.

17 http://baptisten.at/site/aktuelles/2010/anerkennung (letzter Zugriff: 24. 06. 2019). 
erkannten Kirche. Für die Bahá'í-Religionsgemeinschaft ist dieser Weg aufgrund der zu kleinen Mitgliederzahl noch immer versperrt. ${ }^{18}$

Im Hintergrund dieser Gesetzeslage wirkt das lange andauernde Bündnis von Staat und katholischer Kirche nach. Nur langsam öffnete sich der österreichische Staat für den religiösen Pluralismus. Auf staatlicher Seite besteht bis heute eine Tendenz zur paternalistischen Bevormundung von Religionsgemeinschaften oder das rechtliche Verhältnis zu diesen tendenziell in Analogie zur römisch-katholischen Kirche zu gestalten. So zwingt beispielsweisen das neue Islamgesetz von 2015, dass es nur Moscheen im Rahmen der Islamischen Glaubensgemeinschaft in Österreich geben darf. Eine solche Position ahmt katholische Verhältnisse nach, wird aber den nicht hierarchisch strukturierten Religionen kaum gerecht. Anerkannte Religionsgemeinschaften wie die römisch-katholische Kirche sind wiederum vor allem an der Erhaltung der bestehenden Privilegien interessiert und engagieren sich zu wenig für eine volle Verwirklichung der Religionsfreiheit.

Die konkreten Folgen dieser religionspolitischen Lage zeigen sich dann beispielsweise in der Haltung der jüngsten ÖVP-FPÖ-Regierung, die Kopftücher in Kindergärten und Schulen verboten hat, aber gleichzeitig kein Problem mit dem Kruzifix in Klassenzimmern hat. Auch die jüngste Diskussion über die Feiertagsregelung des Karfreitags, der für Protestanten und Altkatholiken seit 1952 bzw. seit 1955 ein Feiertag war, zeigt Spuren der alten Verhältnisse. ${ }^{19}$ Zurecht verwarf der EuGH diese Regelung, weil er darin eine rechtlich unhaltbare Privilegierung sah. Der typische Protest aus der herkömmlichen Sicht von Kirche und Staat in Österreich mit ihrem weitgehenden Unverständnis für den religiösen Pluralismus richtet sich sogleich gegen die Entscheidung des EuGHs. Beispiel dafür ist der ehemalige Präsident des österreichischen Nationalrates und ÖVP-Politiker Andreas Khol, der in dieser Entscheidung ein „weiteres Beispiel der zentralisierenden, das vielbeschworene Subsidiaritätsprinzip missachtenden Rechtsprechung dieses Gerichtes" sah. ${ }^{20}$ Tatsächlich hat der EuGH nur dem weltanschaulichen Pluralismus Rechnung getragen. Die dann erfolgte Regelung der Bundesregierung ging zwar einen Schritt in die richtige Richtung, indem nun allen Religionsgemeinschaften das Recht zusteht, einen Urlaubstag als „persönlichen Feiertag“ zu nehmen. Die Tatsache, dass die Protestanten und Altkatholiken ihren bisherigen Feiertag verloren haben, hätte aber

18 Manfred Hutter, Handbuch Bahā’̄i: Geschichte - Theologie - Gesellschaftsbezug, Stuttgart 2009, S. 78.

19 Rudolf Leeb, Der Karfreitag in Österreich, in: Die Presse am 19.04.2019, S. 26-27; Adalbert Krims, Der Karfreitag. Historische Hintergründe, in: Kritisches Christentum 426/427/2019, S. 3-7.

20 Andreas Khol, Missverständnisse um Religion, Kirche und Staat in Österreich, in: Tiroler Tageszeitung Nr. 89 am 30.03.2019, S. 18. 
durch die Aufgabe eines der gesetzlich geschützten Feiertage der römisch-katholischen Kirche kompensiert werden können. Der liturgisch weniger wichtige Pfingstmontag könnte beispielsweise als flexibler persönlicher Feiertag für alle Religionsgemeinschaften zur Verfügung gestellt werden. Leider hat sich die römisch-katholische Kirche in der Diskussion viel zu still verhalten, sodass ein solcher Vorschlag gar nicht ernsthaft diskutiert wurde.

Die größten Probleme im Bereich der Religionsfreiheit zeigen sich allerdings im Umgang mit dem Islam und seinem weiteren Umfeld. Das neue Islamgesetz von 2015 weist zwar in einigen Bereichen deutliche Fortschritte gegenüber seinem Vorgänger aus dem Jahre 1912 auf, wozu beispielsweise die Errichtung einer theologischen Ausbildung an der Universität Wien gehört. Auf der anderen Seite zeigt dieses Gesetz aber auch, wie sehr der Staat immer noch paternalistisch in Religionsbelange einzugreifen versucht. Am auffälligsten in dieser Hinsicht ist das Verbot, für die gewöhnlichen Tätigkeiten der Religionsgesellschaft Mittel aus dem Ausland zu verwenden (Islamgesetz $\$ 6$ Abs. 2). Diese Regelung findet eine erstaunliche Parallele im Religionsgesetz Chinas, das ein ähnliches Verbot ausspricht, um ausländische Einmischungen in religiöse Angelegenheiten zu verhindert. Zurecht kritisierte der Theologe und Friedensforscher Heinz-Günter Stobbe diese Einschränkung der Religionsfreiheit in China. Er hielt fest, dass „das strenge Verbot irgendwelcher struktureller oder finanzieller Verbindungen zwischen chinesischen Religionsgemeinschaften und ihren nicht-chinesischen Schwesterorganisationen alle Christen trifft, besonders empfindlich natürlich die römisch-katholische Kirche mit ihrer konstitutiv übernationalen Struktur“. ${ }^{21}$ Österreich kommt in seinem Islamgesetz dieser chinesischen Regelung sehr nahe und schränkt die Religionsfreiheit auf ähnliche Weise ein. Die römisch-katholische Kirche in Österreich hätte eigentlich laut dagegen protestieren müssen. Abschließend möchte ich das hinsichtlich der Religionsfreiheit problematische Agieren des österreichischen Staates im Blick auf das Alevitentum darstellen.

21 Heinz-Günther Stobbe, Christenfeindliche Gewalt: Opfer und Täter. Christen im Interessensund Machtgeflecht von Gesellschaft, Staat und Kirche, in: Georg Plasger / Heinz-Günther Stobbe (Hg.), Gewalt gegen Christen. Formen, Gründe, Hintergründe, Leipzig 2014, S. 9-71, hier: S. 58. 


\section{3. Österreichs (Nicht-)Anerkennung der Aleviten als indirekte Parteinahme für die Religionspolitik der Türkei}

Im anatolischen Alevismus bündeln sich verschiedene religiöse Traditionen, wie ein sozial-revolutionär gedeuteter schiitischer Islam, ein auf die Mystik des Haci Bektas Veli (13. Jahrhundert) zurückgehender Sufismus, sowie vorislamische und auch christlich-gnostische Traditionen. ${ }^{22}$ Die kritische Sicht der Aleviten gegenüber Zentralismus und Hierarchie führte im Osmanischen Reich zu jahrhundertlanger Verfolgung und Unterdrückung. Atatürks Trennung von Religion und Staat erleichterte die Situation der Aleviten und erklärt, warum bis heute viele von ihnen Atatürk verehren. Staatliche Anerkennung gewährte aber auch der Kemalismus den Aleviten nicht und sie blieben weiterhin religiöser Diskriminierung ausgesetzt. Das gilt bis heute so für die 15 bis 20 Millionen Aleviten in der Türkei. ${ }^{23}$ Am 26. April 2016 urteilte der Europäische Gerichtshof für Menschenrechte, dass der türkische Staat gegen die Religionsfreiheit (Art. 9) und gegen das Diskriminierungsverbot (Art. 14) in Bezug auf die Aleviten verstoße. ${ }^{24}$ Das Sivas-Massaker von 1993, bei dem während eines Festivals für den Dichter Pir Sultan Abdal (1480-1550) 33 Menschen - die meisten von ihnen alevitische Intellektuelle und Künstler - von einem fundamentalistischen Mob getötet wurden, wirkte als Katalysator für die Aleviten sich jenseits politischer Ideologien zu organisieren. ${ }^{25}$ In der Türkei beauftrage der damalige Staatspräsident Süleyman Demirel den Professor für Völkerrecht und alevitischen Funktionär İzzettin Doğan mit der Organisation der Aleviten. Doğan hat sich seither bemüht den Alevismus eng mit dem Islam zu verbinden, ja ihn sogar als den „eigentlichen Islam“ zu verstehen. ${ }^{26}$ Dieser staatsloyale Versuch einer Re-Islamisierung wurde aber von jenen alevitischen Gruppen abgelehnt, die sich als eigenständige, vom Islam weitgehend unabhängige Religion verstanden. Diese Polarisierung setzte sich auch in Europa fort, wo das Sivas-Massaker ebenso zur Gründung von alevitischen Vereinen beitrug.

22 Susanne Heine / Rüdiger Lohlker / Richard Potz, Muslime in Österreich. Geschichte, Lebenswelt, Religion. Grundlagen für den Dialog, Innsbruck 2012, S. 89-91; vgl. Ursula Spuler-Stegemann, Ist die Alevitische Gemeinde Deutschland e.V. eine Religionsgemeinschaft? Religionswissenschaftliches Gutachten erstattet dem Ministerium für Schule, Jugend und Kinder des Landes Nordrhein-Westfalen, Marburg 2003; Zeynep Arslan, Eine religiöse Ethnie mit Multi-Identitäten. Die europäisch-anatolischen Alevit_Innen auf dem Weg zur Institutionalisierung ihres Glaubenssystems, Religionswissenschaft 26, Wien 2016, S. 18-42.

23 Klissenbauer, Ringen um Religionsfreiheit, S. 146.

24 Handan Aksünger, Zur Situation der anatolischen Aleviten in Deutschland und Österreich, in: Österreichischer Integrationsfonds (ÖIF) (Hg.), Islam europäischer Prägung, Wien 2017, S. 161-181, hier: S. 171.

25 Arslan, Ethnie, S. 111-114.

26 Arslan, Ethnie, S. 162. 
Im Blick auf die Religionsfreiheit in Österreich ist vor allem die komplexe Entwicklung der staatlichen Anerkennung der insgesamt 80.000 Aleviten genauer zu untersuchen. Diese Entwicklung ist einerseits von der unter den Aleviten vorherrschenden Spannung bezüglich ihrer Nähe oder Ferne zum Islam bestimmt und andererseits auch vom österreichischen Islamgesetz, das die Anerkennung im Vergleich beispielsweise zu Deutschland deutlich erschwerte. Uneinigkeiten zwischen den verschiedenen Strömungen führten dazu, dass ab 2009 drei unterschiedliche Anträge um Anerkennung als Bekenntnisgemeinschaft an den österreichischen Staat gestellt wurden. Ursprünglich wurde innerhalb des Dachverbands der „Föderation der Aleviten-Gemeinden Österreich“ an einem gemeinsamen Antrag gearbeitet. Dann aber schärte der Kulturverein der Aleviten in Wien aus und stellte noch zwei Wochen vor dem Dachverband den Antrag, als „Islamisch Alevitische Religionsgesellschaft“ anerkannt zu werden. Der Dachverband hingegen wollte sich nicht als Teil des Islams verstehen und stellte den Antrag auf Anerkennung als „Alevitische Religionsgesellschaft“. Schließlich gab es auch noch einen Antrag der kurdischen Aleviten, die besonders vorislamische Traditionen wie z. B. den Zoroastrismus betonten.

Der Antrag der „Islamisch Alevitischen Religionsgesellschaft“ scheiterte zuerst am Einspruch der Islamische Glaubensgemeinschaft (IGGiÖ), der der Antrag zur Stellungnahme von der staatlichen Behörde vorgelegt wurde. Die IGGiÖ argumentierte, dass es sich beim Alevitentum um eine dem Islam theologisch entgegenstehende Religion handle. Der Antrag wurde daraufhin abgelehnt, weil nach staatlicher Auffassung alle islamischen Gruppen dem Islamgesetz von 1912 zuzuordnen seien. Mit einem Entscheid des Verfassungsgerichtshof vom 1.12. 2010 wurde diese Entscheidung aber unter Verweis auf die Religionsfreiheit aufgehoben, weil „die religionsrechtliche Statuierung einer weiteren sich als ,islamisch' verstehenden Religionsgemeinschaft neben der nach dem Islamgesetz konstituierten IGGiÖ“ zulässig sei. ${ }^{27}$ Daraufhin wurde die „Islamisch Alevitische Religionsgesellschaft" am 16.12.2010 als Bekenntnisgemeinschaft anerkannt. Am 22. Mai 2013 erfolgte schließlich auch die Anerkennung der Islamischen Aleviten als gesetzliche Religionsgesellschaft. Das Kultusamt genehmigte am 5.11.2015 außerdem eine Namensänderung in „Alevitische Glaubensgemeinschaft in Österreich (ALEVI)“. Damit fiel einerseits mit dem Wort „islamisch“ genau jenes Wort weg, das die Spaltung im Dachverband ursprünglich verursacht hatte. Andererseits wurde dadurch aber eine Genehmi-

27 Richard Potz, Das Islamgesetz 1912 - eine österreichische Besonderheit, in: SIAK-Journal Zeitschrift für Polizeiwissenschaft und polizeiliche Praxis 1/2013, S. 45-54, hier: S. 52. 
gung des Antrags des Dachverbandes noch zusätzlich erschwert. ${ }^{28}$ Die gesetzliche Anerkennung ermöglicht es, dass die Islamischen Aleviten nun so wie die anderen anerkannten Kirchen und Religionsgesellschaften Religionsunterricht an öffentlichen Schulen erteilen.

Auch die kurdischen Aleviten erreichten 2013 als Alt-Alevitische Glaubensgemeinschaft in Österreich die Anerkennung als Bekenntnisgemeinschaft. Abgelehnt wurde hingegen am 11. Mai 2015 der Antrag der „Föderation der Aleviten Gemeinden in Österreich“ (AABF). Diese Ablehnung erfolgte unter Berufung auf das Bundesgesetz über die Rechtspersönlichkeit von religiösen Bekenntnisgemeinschaften (BekGG $\$ 5$ Abs. 2), wonach sowohl der Name der Religionsgemeinschaft als auch deren Lehre sich nicht genügend von bereits anerkannten Religionsgesellschaften unterscheiden würde. Hier kam jenes Ausschließlichkeitsprinzip zur Anwendung, das der Verfassungsgerichtshof 2010 im Blick auf den Islam eigentlich schon zurückgewiesen hatte. ${ }^{29}$ Damit ist eine rechtlich bedenkliche Privilegierung der anerkannten Alevitischen Glaubensgemeinschaft gegeben. Wenn der religionspolitische Hintergrund in der Türkei mitbedacht wird, hat sich hier der österreichische Staat zugunsten jener Strömung entschieden, die sich der türkischen Re-Islamisierung gegenüber stärker öffnete und jene Gruppe zurückgewiesen, die aufgrund der langjährigen Unterdrückung und Nichtanerkennung sich gegenüber einer Einbindung in islamische Strukturen verweigerte. Aus der Sicht der Religionsfreiheit war das eine sehr bedenkliche Entscheidung. Aufgrund der durchaus problematischen Tatsache, dass das neue Islamgesetz von 2015 auch die Islamische Alevitische Glaubensgemeinschaft miteinbezieht (\$16-17) und gemäß $\$ 31$ Abs. 3 Vereine aufzulösen sind, die sich nicht den Erfordernissen des Gesetzes anpassen, sind die Vereine der „Föderation der Aleviten Gemeinden in Österreich“ in ihrem Bestand und religiösen Aktivitäten bedroht. Konkret liegt mir ein Brief des Kultusamtes im österreichischen Bundeskanzleramt vom Oktober 2018 vor, in dem einer alevitischen Gemeinde in Tirol vorgeschrieben wird, „die Verbreitung der religiösen Lehre der Alevitischen Glaubensgemeinschaft" und alle weiteren religiösen Aktivitäten sofort zu unterlassen. Zu Recht haben die beiden Gutachter und Religionsrechtsexperten Richard Potz und Brigitte Schinkele schon 2016 für die AABF betont,

„dass der Versuch, die AABF unter die Schirmherrschaft der IAGÖ bzw. ALEVI zu assimilieren, in einem eindeutigen Widerspruch zur österreichischen Verfassung (Art. 2 St GG, Art. 7 B-VG) und zur Europäischen Menschenrechtskonvention (Art. 9)

28 Stefan Hammer, Die Aleviten im österreichischen Religionsrecht - ein Kampf um Anerkennung. Der schwere Abschied vom Ausschließlichkeitsgrundsatz, in: öarr 65/1/2018, S. 1-17, hier: S. $10 \mathrm{f}$.

29 Hammer, Aleviten, S. 4. 
stehen. Wenn es in Österreich rechtsstaatlich zugeht, darf der Staat nicht erzwingen, dass sich die AABF dem Islamgesetz unterwirft. Vielmehr müsse eine juristische Lösung gesucht werden, unter welchen Bedingungen es zwei Alevitische Gruppierungen in Österreich geben kann. ${ }^{\text {"30 }}$

Der Verwaltungsgerichtshof Wien hat am 30.1.2019 den Antrag der AABF um die Anerkennung als eigenständige Glaubensgemeinschaft mit der Begründung abgelehnt, dass die vorgelegte Lehre in weiten Teilen wortident mit der gesetzlich anerkannten Religionsgemeinschaft „Islamische Alevitische Glaubensgemeinschaft Österreich" sei. ${ }^{31}$

Im Hintergrund all dieser Entscheidungen steht das immer noch von den alten konstantinischen Verhältnissen geprägte paternalistische Verhältnis des österreichischen Staates zu den Religionsgemeinschaften. Ein Ausdruck dafür ist das neue Islamgesetz von 2015, das das Verhältnis zu den Aleviten im Rahmen des Islamgesetzes behandelt und so religiöse Unterschiede einebnet, um aus staatlicher Sicht alles leichter handhabbar zu machen. Bezeichnend ist eine Aussage des langjährigen Leiters des österreichischen Kultusamtes Oliver Henhapel in einem Interview mit Zeynep Arslan aus dem Jahre 2010: „In Deutschland kann jeder seine eigene islamische Religionsgemeinschaft haben, wie er will und auch sich bezeichnen wie er will. Und ich sehe das nicht ganz unkritisch. In Ungarn gibt es mittlerweile 200-300 Religionsgesellschaften, weil sie einen Regelungsmechanismus, wie eine Vereinsanmeldung haben. ${ }^{\text {“32 Aus der }}$ Perspektive bürokratischer Pragmatik ist eine solche Aussage verständlich. Paternalistisch ist es aber, wenn Henhapel den Staat um des „Religionsfriedens“ willen als „Marktregulierungsbehörde“ einfordert. ${ }^{33}$ Die hierarchisch strukturierte katholische Kirche ist hier als Idealbild eines staatlichen Partners vorausgesetzt: „Es ist nicht ganz so einfach. Vor allem bei Religionsgemeinschaften wie der Islam und Judentum, die keine hierarchischen Konstruktionen haben. Bei den Katholiken ist das klar. ,Rom hat entschieden, die Sache ist beendet‘ . “34 Um Religionsfreiheit zu gewähren, müssen solche Vorstellungen überwunden werden. Es ist nicht legitim, dass der österreichische Staat im Konflikt zwischen verschiedenen alevitischen Strömungen selbst Partei ergreift. ${ }^{35}$ Die indirekte Bevorzugung jener Gruppe, die der türkischen Religionspolitik mit ihrer sehr

30 Aksünger, Situation, S. 179.

31 https://religion.orf.at/stories/2961904/ (letzter Zugriff: 24.06.2019).

32 Zit. nach Arslan, Ethnie, S. 203.

33 Zit. nach Zeynep Arslan, Die anatolischen AlevitInnen in der Diaspora: Am Beispiel der Alevitischen Minderheit in Österreich, Dissertation an der Universität Wien, Fakultät für Sozialwissenschaften, Wien 2010, S. 272.

34 Zit. nach: Arslan, AlevitInnen in der Diaspora, S. 272.

35 Hammer, Aleviten, S. $16 \mathrm{f}$. 
eingeschränkten Religionsfreiheit nähersteht, sollte uns in Österreich zur Änderung unseres Religionsrechtes und der damit verbundenen Praxis führen.

\section{Quellen}

Aksünger, Handan, Zur Situation der anatolischen Aleviten in Deutschland und Österreich, in: Österreichischer Integrationsfonds (ÖIF) (Hg.), Islam europäischer Prägung, Wien 2017, S. 161-181.

Arslan, Zeynep, Eine religiöse Ethnie mit Multi-Identitäten. Die europäisch-anatolischen Alevit_Innen auf dem Weg zur Institutionalisierung ihres Glaubenssystems, Religionswissenschaft 26, Wien 2016.

Arslan, Zeynep, Die anatolischen AlevitInnen in der Diaspora: Am Beispiel der Alevitischen Minderheit in Österreich, Dissertation an der Universität Wien, Fakultät für Sozialwissenschaften, Wien 2010.

Association of Religion Data Archives (ARDA), vgl. http://www.thearda.com/internatio naldata/regions/ (letzter Zugriff: 24.06.2019).

Casanova, José, Europas Angst vor der Religion, übersetzt von Rolf Schieder, Berlin 2009. Casanova, José, Der Ort der Religion im säkularen Europa, in: Transit 27/2004, S. 86-106.

Gabriel, Ingeborg / Papanikolaou, Aristotle / Stoeckl, Kristina (Hg.), Political Theologies in Orthodox Christianity: Common Challenges and Divergent Positions, London 2017.

Gabriel, Ingeborg / Siegmar, Berthold, Wiener Theologin neue OSZE Beauftragte, in: Kirche In 31/4/2017, S. 14-15.

Gabriel, Ingeborg, Naturrecht, Menschenrechte und die theologische Fundierung der Sozialethik, in: Markus Vogt (Hg.), Theologie der Sozialethik, Quaestiones disputatae 255, Freiburg i. Br. 2013, S. 229-251.

Gabriel, Ingeborg, Religious Pluralism, Freedom of Religion, and Responsibilities of State, Society and Religious Communities, in: Stefan Hammer / Fatimah Husein (Hg.), Religious Pluralism and Religious Freedom: Religions, Society and the State in Dialogue, Contributions to the Austrian-Indonesian Dialogue, Yogyakarta 2013, S. 213-219.

Gabriel, Ingeborg / Steinmair-Pösel, Petra (Hg.), Gerechtigkeit in einer endlichen Welt: Ökologie - Wirtschaft - Ethik, Ostfildern 2013.

Gabriel, Ingeborg, Freedom of Religion, in: Manfred Nowak / Karolina M. Januszewski / Tina Hofstätter (Hg.), All Human Rights for All: Vienna Manual on Human Rights, Vienna 2012, S. 392-396.

Gabriel, Ingeborg / Papaderos, Alexandros K. / Körtner, Ulrich H. J. (Hg.), Perspektiven ökumenischer Sozialethik: Der Auftrag der Kirchen im größeren Europa, 2.Aufl., Mainz 2006.

Gartner, Barbara, Aktuelle Herausforderungen für den Rechtsstaat einer plurireligiösen Gesellschaft, in: öarr 57/1/2010, S. 37-65.

Graf-Stuhlhofer, Franz (Hg.), Frisches Wasser auf dürres Land: Festschrift zum 50-jährigen Bestehen des Bundes der Baptistengemeinde in Österreich, Baptismus-Studien 7, Kassel 2005. 
Grim, Brian J. / Finke, Roger, The Price of Freedom Denied: Religious Persecution and Conflict in the 21st Century, Cambridge studies in social theory, religion and politics, New York 2011.

Grim, Brian J. / Finke, Roger, International Religion Indexes: Government Regulation, Government Favoritism, and Social Regulation of Religion, in: Interdisciplinary Journal of Research on Religion 2/1/2006, S. 1-40.

Hammer, Stefan, Die Aleviten im österreichischen Religionsrecht - ein Kampf um Anerkennung. Der schwere Abschied vom Ausschließlichkeitsgrundsatz, in: öarr 65/1/2018, S. $1-17$.

Heine, Susanne / Lohlker, Rüdiger / Potz, Richard, Muslime in Österreich. Geschichte, Lebenswelt, Religion. Grundlagen für den Dialog, Innsbruck 2012.

Hutter, Manfred, Handbuch Bahā'ī: Geschichte - Theologie - Gesellschaftsbezug, Stuttgart 2009.

Kalb, Herbert / Potz, Richard / Schinkele, Brigitte, Religionsrecht, Wien 2003.

Khol, Andreas, Missverständnisse um Religion, Kirche und Staat in Österreich, in: Tiroler Tageszeitung Nr. 89 am 30.3.2019, S. 18.

Klissenbauer, Irene, Das Ringen um Religionsfreiheit. Die Positionen von John Courtney Murray und Fethullah Gülen im Vergleich, Religionsrecht im Dialog 19, Wien 2015.

Krims, Adalbert, Der Karfreitag. Historische Hintergründe, in: Kritisches Christentum 426/427/2019, S. 3-7.

Leeb, Rudolf, Der Karfreitag in Österreich, in: Die Presse am 19.04.2019, S. 26-27.

Palaver, Wolfgang, Christentum im säkularen Kontext. Grenzen und Chancen, in: Daniela Kästle / Martina Kraml / Hamideh Mohagheghi (Hg.), Heilig - Tabu: Christen und Muslime wagen Begegnungen, Kommunikative Theologie 13, Ostfildern 2009, S. 311318.

Potz, Richard, Das Islamgesetz 1912 - eine österreichische Besonderheit, in: SIAK-Journal - Zeitschrift für Polizeiwissenschaft und polizeiliche Praxis 1/2013, S. 45-54.

Schewel, Benjamin, Seven Ways of Looking at Religion: The Major Narratives, New Haven 2017.

Schmid, Hansjörg, Islam im europäischen Haus. Wege zu einer interreligiösen Sozialethik, Freiburg i. Br. 2012.

Spuler-Stegemann, Ursula, Ist die Alevitische Gemeinde Deutschland e.V. eine Religionsgemeinschaft? Religionswissenschaftliches Gutachten erstattet dem Ministerium für Schule, Jugend und Kinder des Landes Nordrhein-Westfalen, Marburg 2003.

Stark, Rodney, The Triumph of Christianity: How the Jesus Movement Became the World's Largest Religion, New York 2011.

Stobbe, Heinz-Günther, Christenfeindliche Gewalt: Opfer und Täter. Christen im Interessens- und Machtgeflecht von Gesellschaft, Staat und Kirche, in: Georg Plasger / Heinz-Günther Stobbe (Hg.), Gewalt gegen Christen. Formen, Gründe, Hintergründe, Leipzig 2014, S. 9-71.

https://religion.orf.at/stories/2961904/ (letzter Zugriff: 24.06.2019).

http://baptisten.at/site/aktuelles/2010/anerkennung (letzter Zugriff: 24. 06. 2019). 
Open-Access-Publikation im Sinne der CC-Lizenz BY 4.0

(C) 2020, Vandenhoeck \& Ruprecht $\mathrm{GmbH} \&$ Co. KG, Göttingen ISBN Print: 9783847111658 - ISBN E-Lib: 9783737011655 


\section{The impact of religion on universal human rights in Brunei's Syariah Penal Code}

\section{Introduction}

In her academic work, Ingeborg Gabriel has been particularly interested in the relationship between religions, above all the three monotheistic religions Judaism, Christianity and Islam, and human rights. ${ }^{1}$ When we established an inter-disciplinary research platform, and later research centre, at the University of Vienna and started a Vienna Master of Arts in Human Rights, Ingeborg Gabriel introduced a theological perspective into our inter-disciplinary discourse. ${ }^{2}$ As scientific director of the Vienna Master and one of the first graduates of this intensive two years postgraduate course, we therefore decided to dedicate this contribution to the relationship between religion and human rights.

There are indeed many parallels between religion and human rights. Both concepts are based on certain universal values, such as human dignity, life, property, marriage and the family as the "natural and fundamental group unit of society", as specified in Article 16 of the Universal Declaration of Human Rights of 1948. While religions usually express these values in the form of commandments (You shall not kill, steal or commit adultery), human rights empower individuals with the rights to life, property or marriage. The mutual respect of human rights by all human beings also derives from the "Golden Rule" which constitutes a "moral norm found in practically all religions": " others, what you do not want to have done unto yourself". Another parallel between religions and human rights is the special status of humans as having

1 See, e. g., Ingeborg Gabriel, The Role of Religions in the Public Square: Elements of a Transformation Process, in: Richard Potz / Sabine Kroissenbrunner / Astrid Hafner (eds.), State, Law and Religion in Pluralistic Societies: Austrian and Indonesian Perspectives, Göttingen 2010, pp. 179-190.

2 See Ingeborg Gabriel, Human Rights from a Theological Perspective, in: Manfred Nowak / Karolina M. Januszewski / Tina Hofstätter (eds.), All Human Rights for All - Vienna Manual on Human Rights, Vienna-Graz 2012, pp. 33-35.

3 Ibid, p. 34. 
been created by God in his image and acting as his representatives on earth. ${ }^{4}$ Human dignity as the main criterion distinguishing human beings from other creatures has often been based on the idea that God has created humans in his image. ${ }^{5}$ Ingeborg Gabriel rightly observes that the "religious insistence on the dignity of human beings (or realising the Divine in themselves) can be a strong incentive to reduce human suffering". 6 "This shows that from the point of view of theology there is a large overlapping consensus between the basic intentions of human rights and the moral demands of religion".

On the other hand, we should also recognize that throughout history, religions have often fostered conflict, discrimination and atrocities committed in their name - or have been misused to these ends. Freedom of religion is one of the oldest and most important human rights and "a vanguard of a movement which led to the American and French revolutions and their human rights declarations". ${ }^{8}$ At the same time, freedom of religion is one of the most controversial human rights. This has to do with a certain tendency of religions to claim to be in the sole possession of the "absolute truth" which leads them not to respect the freedom of those with a different faith, feeling instead called upon to "convert" them. ${ }^{9}$ As long as governments try to remain neutral or secular and prohibit proselytism as an impermissible interference with other religions, such tendencies usually do not pose a major problem. If governments, however, follow a system of a state religion or clearly give priority treatment to one religious community, the danger of arbitrary or discriminatory treatment arises. ${ }^{10}$ Many armed conflicts and atrocities, from the 30 Years War in Europe during the $17^{\text {th }}$ century to the armed conflicts in Bosnia and Herzegovina during the 1990s, a multitude of armed conflicts and major human rights violations in the Middle East, in Iran, Afghanistan, Pakistan, India or Myanmar give evidence of the dangers of religious radicalisation and the misuse of religion by governments and non-state actors, including armed and terrorist groups.

The history of human rights is also a history of rationalism during the Age of Enlightenment against the power of authoritarian regimes, which claimed that

4 Ibid, p. 33.

5 Cf., e.g., Heiner Bielefeldt, Menschenwürde - Der Grund der Menschenrechte, Berlin 2008, p. 12; Manfred Nowak, Menschenwürde und Menschenrechte, Wien 2018, p. $31 \mathrm{f}$.

6 Gabriel, The Role of Religions, p. 34.

7 Ibid, p. 35.

8 Ingeborg Gabriel, Freedom of Religion, in: Nowak / Januszewski / Hofstätter (eds.), All Human Rights for All, pp. 392-395.

9 See Manfred Nowak, U.N. Covenant on Civil and Political Rights - CCPR Commentary, 2.ed., Kehl-Strasbourg-Arlington 2005, p. 408.

10 Cf., e. g., Manfred Nowak / Tanja Vospernik, Permissible Restrictions on Freedom of Religion or Belief, in: Tore Lindholm / W. Cole Durham / Bahia G. Tahzib-Lie (eds.), Facilitating Freedom of Religion or Belief: A Deskbook, Dordrecht 2004, pp. 147-172, here: p. 160. 
their absolute power derived from God. It seems like an irony of history that in the late $20^{\text {th }}$ and early $21^{\text {st }}$ centuries, such regimes gain power again in many parts of the world, above all in Islamic states. If governments again impose religious laws, this seems like falling back into the dark times of the Middle Ages. In the following, we will explain this by the recent introduction of Islamic criminal law in Brunei.

\section{Case Study of Brunei Darussalam's Syariah Penal Code}

\subsection{The Syariah Penal Code Order 2013}

The introduction of Brunei Darussalam's Syariah Penal Code ("SPCO" - Syariah being another spelling for sharia) captured the world's attention for two reasons: It contains corporal punishments, which are unusually cruel and brutal, such as flogging, amputation and stoning to death; and it foresees these punishments for acts which should not be considered crimes at all. We shall analyse this Penal Code through the lens of international human rights law, whose universality has been affirmed in the Universal Declaration of Human Rights ("UDHR") and a variety of binding international human rights treaties, including the International Covenant on Civil and Political Rights (ICCPR) of 1966, the Convention on the Elimination of All Forms of Discrimination against Women (CEDAW) of 1979 or the Convention on the Rights of the Child of 1989. The universality of human rights has also been reaffirmed in the 1993 Vienna Declaration and Programme of Action, ${ }^{11}$ as well as the 2012 Human Rights Declaration of the Association of Southeast Asian Nations ("ASEAN Declaration"). ${ }^{12}$

Brunei Darussalam (hereinafter referred to as "Brunei"), a former British protectorate which gained independence in 1984, is governed by Sultan Hassanal Bolkiah, who was proclaimed Sultan in 1967. The Sultan is one of the last absolutist monarchs on the planet, holding the offices of Prime Minister, Minister of Defence, Minister of Finance and Economy, and Minister of Foreign Affairs. ${ }^{13}$ The Constitution of Brunei guarantees the Sultan supreme executive authority

11 World Conference on Human Rights, Vienna Declaration and Programme of Action of 12 July 1993, A/CONF.157/23, para. 5.

12 Association of Southeast Asian Nations, ASEAN Human Rights Declaration of 18 November 2012, para. 7.

13 Prime Minister's Office Brunei Darussalam, see: http://www.pmo.gov.bn/Pages/Prime-Mi nister.aspx (accessed on May 20 $0^{\text {th }} 2019$ ). 
(Section 4 (1)), and enshrines Islam as the official religion of the State (Section 3 (1)) with the Sultan at its head (Section $2(2)){ }^{14}$

Brunei is ranked $39^{\text {th }}$ in the 2018 UN Human Development Index, among the highest of all Muslim-majority countries (Saudi Arabia is equally ranked $39^{\text {th }}$, Qatar is $37^{\text {th }}$, the United Arab Emirates are ranked $34^{\text {th }}$ ), and the $2^{\text {nd }}$ highest ranked of Southeast Asian countries (lower only than Singapore on $9^{\text {th }}$ ). ${ }^{15}$ The people of Brunei enjoy a high living standard, do not pay income tax and have access to free healthcare and education financed largely through Brunei's natural oil and gas reserves. ${ }^{16}$ However, it is also the only State within ASEAN which does not have a parliament (nor general elections and an organised opposition) or an independent civil society to speak of, and has technically been under a state of emergency since 1962, caused by a failed uprising. ${ }^{17}$ It only takes the $152^{\text {nd }}$ place on the 2019 World Press Freedom Index of Reporters without Borders, with a press freedom situation categorised as bad (the second lowest category). ${ }^{18}$

In October 2013, Brunei adopted the SPCO, ${ }^{19}$ becoming the first State in Southeast Asia to adopt sharia law. This amendment was 20 years in the making, its drafting having first been announced already in the 1990s, and it was not uncontroversial within the government and the royal family: "The SPCO's enactment reflects the now uncontested influence of the Islamic bureaucracy on the Sultan's domestic policies and the gradual defeat of its critics over the past two decades." ${ }^{20}$ The SPCO's actual entry into force was phased and subject to notification, so it was not until the notification of December 2018 that the substantive heart of the new law - Part IV which includes the offences - was scheduled for 3 April 2019. ${ }^{21}$

14 Constitution of Brunei Darussalam, Revised Edition 2011, see: http://www.agc.gov.bn/AG C\%20Images/LOB/cons_doc/constitution_i.pdf (accessed on May $20^{\text {th }}$ 2019).

15 United Nations Development Programme, Human Development Indices and Indicators 2018 Statistical Update, New York 2018, p. 22.

16 Dominik M. Müller, Brunei in 2015 - Oil Revenues Down, Sharia on the Rise, in: Asian Survey 56/1/Jan/Feb 2016, pp. 162-167, here: p. 162.

17 Dominik M. Müller, Brunei Darussalam in 2016 - The Sultan Is Not Amused, in: Asian Survey 57/1/Jan/Feb 2017, pp. 199-205, here: p. 199.

18 Reporters Without Borders, Brunei, see: https://rsf.org/en/brunei (accessed on May $20^{\text {th }}$ 2019). According to Freedom House, Freedom House, Freedom in the World 2019 - Brunei, see: https://freedomhouse.org/report/freedom-world/2019/brunei (accessed on May $20^{\text {th }}$ 2019), Brunei ranks as "not free" (political rights 6/7, civil liberties 5/7, with 7 being least free).

19 Syariah Penal Code Order 2013 of 22 October 2013, see: http://www.agc.gov.bn/AGC\%20I mages/LAWS/Gazette_PDF/2013/EN/syariah\%20penal\%20code\%20order2013.pdf (accessed on May $20^{\text {th }} 2019$ ).

20 Müller, Brunei in 2015, p. 166.

21 Notification of commencement of 29 December 2018, see: http://www.agc.gov.bn/AGC\%20 Images/LAWS/Gazette_PDF/2018/S068.pdf (accessed on May 20 ${ }^{\text {th }} 2019$ ). 
Amputation is one of the punishments foreseen in the SPCO, though only if the crime is proven by a specific type of evidence: a confession of the accused, or the testimony of two witnesses. The SPCO sanctions sariqah - theft above a value of USD 250 - with amputation of the right hand for the first offence, of the left foot for the second offence, and imprisonment of up to 15 years for the third offence. Hirabah - armed robbery - may be punishable by death as hadd (punishment mandated by God - though not by stoning), or by amputation of both the right hand and left foot, again depending on the type of evidence. Is other evidence used to secure the conviction, punishment may consist of fine of up to USD 56,000 and/or up to 14 years imprisonment in the case of theft, imprisonment of up to 30 years and up to 40 lashes with a whip in the case of robbery. $^{22}$

The SPCO foresees the punishment of death by stoning or up to 100 lashes, given a confession of the accused or the testimony of four witnesses, for zina (extramarital sexual intercourse involving at least one Muslim party-sometimes understood as adultery), ${ }^{23}$ zina bil-jabar (extramarital rape), ${ }^{24}$ and liwat (sexual intercourse between two men, or anal sex - "done against nature" - of an unmarried heterosexual couple, regardless of their religion) ${ }^{25}$. Sexual intercourse between two women - musahaqah - is likewise criminalised, though the punishment of a fine of USD 40,000, imprisonment of up to ten years, or up to 40 lashes is comparatively milder. ${ }^{26}$ Irtidad by Muslims - which includes apostasy as well as acts such as declaring oneself a god and deriding the Qur'an and the hadith - is punishable by death as hadd, imprisonment or whipping. ${ }^{27}$ Likewise, contempt or derision of the prophet, Qur'an or the hadith by a non-Muslim is punishable by death. ${ }^{28}$ The drinking of liquor or intoxicating drinks by a Muslim is punishable by up to 80 lashes and up to two years imprisonment. ${ }^{29}$

Finally, though not threatened with capital or corporal punishment, the SPCO criminalises the following acts: pregnancy or childbirth of unmarried Muslim women (except in cases of rape), with the burden of proof resting on the woman; ${ }^{30}$ khalwat which includes at least one Muslim partner - extramarital cohabitation of a couple, or "isolating oneself in close proximity that can leads to suspicion that they are committing an immoral act; ${ }^{31}$ cross-dressing; $;^{32}$ "enticing

22 SPCO 2013, section 53-63.

23 Ibid, section $68 \mathrm{f}$.

24 Ibid, section $75 \mathrm{f}$.

25 Ibid, section 82 .

26 Ibid, section 92.

27 Ibid, section $107-112$.

28 Ibid, section 221-222.

29 Ibid, section 104.

30 Ibid, section 94.

31 Ibid, section 196. 
or causing" a married Muslim woman to leave the matrimonial home, or the custody of her parent or guardian, for which the court may order her return; the woman herself is likewise punishable if she does not have a "reasonable excuse". 33

Brunei has accepted very few international human rights obligations, and accordingly relatively little international oversight: It has ratified only three UN human rights treaties - the Convention on the Elimination of All Forms of Discrimination against Women (CEDAW), the Convention on the Rights of Persons with Disabilities (CRPD), as well as the quasi-universally accepted Convention on the Rights of the Child (CRC) - and none of the corresponding Optional Protocols (OPs) allowing for individual complaints to be examined by independent UN treaty monitoring bodies. ${ }^{34}$ In South-East Asia, only Brunei's immediate neighbour Malaysia has a similarly low record, having ratified the same treaties as Brunei, with one difference: Brunei signed the Convention against Torture and Other Cruel Inhuman or Degrading Treatment or Punishment ("CAT") in 2015, and the government recently affirmed Brunei's intention to ratify the Convention in the near future. ${ }^{35}$ It has not yet ratified the CAT, but with its signature the government has taken on the obligation "to refrain from acts which would defeat the object and purpose" of the CAT, according to Article 18 of the Vienna Convention on the Law of Treaties. ${ }^{36}$ This means that by having signed the CAT, Brunei has expressed its willingness to be bound by this treaty through ratification and, therefore, should not act contrary to the object and purpose of this treaty, which clearly is to eradicate torture and other forms of ill-treatment.

General reservations were made by Brunei at the ratification of all three treaties, each "regarding those provisions of the said Convention that may be contrary to the Constitution of Brunei Darussalam and to the beliefs and principles of Islam, the official religion of Brunei Darussalam." These reservations were - rightly - opposed by numerous other States parties on the grounds that they are very general and far-reaching, who consider them to be incompatible with the object and purpose of the treaties, and therefore inadmissible according

32 Ibid, section 198.

33 Ibid, section 201-202.

34 UN Treaty Body Database - Ratification Status for Brunei Darussalam, see: https://tbinter net.ohchr.org/_layouts/15/TreatyBodyExternal/Treaty.aspx?CountryID=25\& Lang=EN (accessed on May $20^{\text {th }} 2019$ ).

35 Ministry of Foreign Affairs of Brunei Darussalam, Communication of 7 April 2019, see: http://www.mfa.gov.bn/PublishingImages/Lists/Press\%20Room/AllItems/Special\%20Proce dures\%20(Reply\%20letter\%20 from\%20YBDE).pdf (accessed on May $20^{\text {th }} 2019$ ).

36 Vienna Convention on the Law of Treaties of 23 May 1969, Art 18. 
to Article 19 of the Vienna Convention on the Law of Treaties as well as the respective Articles in the Conventions themselves. ${ }^{37}$

Despite having only ratified three UN human rights conventions, and signed one more, Brunei's SPCO manages to violate all of these treaties. ${ }^{38}$ In the following, we shall only focus on the issues of capital as well as corporal punishment.

\subsection{Punishment of death by stoning}

While Brunei, even before the SPCO, had not entirely abolished the death penalty, it is classified as 'abolitionist in practice' by Amnesty International, noting that while "death by hanging was maintained as punishment for several offences including murder, terrorism and drug-related crimes", no one had been executed in Brunei for over ten years. ${ }^{39}$ Death Penalty Worldwide, likewise, classifies Brunei as 'abolitionist de facto' and places the last known execution in Brunei in $1957 .{ }^{40}$ In the last ten years, Brunei is known to have imposed a death sentence only twice, in $2015^{41}$ and in $2017,{ }^{42}$ both on foreign nationals, though one for murder and the other for drug trafficking.

37 UNTC - Convention on the Rights of the Child, see: https://treaties.un.org/Pages/View Details.aspx ?src $=$ IND\& mtdsg_no=IV-11\& chapter $=4 \&$ lang $=$ en $\left(\right.$ accessed on May $20^{\text {th }}$ 2019); UNTC - Convention on the Rights of Persons with Disabilities, see: https://treaties.un. org/pages/ViewDetails.aspx ?src $=$ TREATY \& $\mathrm{mtdsg \_ no}=\mathrm{IV}-15 \&$ chapter $=4 \quad$ (accessed on May $20^{\text {th }} 2019$ ); UNTC - Convention on the Elimination of All Forms of Discrimination against Women https://treaties.un.org/Pages/ViewDetails.aspx?src=IND\& mtdsg_no=IV$8 \&$ chapter $=4 \&$ lang $=$ en (accessed on May $20^{\text {th }} 2019$ ).

38 The discriminatory character of the SPCO with regard to women should be glaringly obvious in the criminalisation of, inter alia, extramarital pregnancy or childbirth of Muslim women, with the burden of proof to rebut resting on the woman; the limitation of the crime of zina biljabar to extramarital rape; as well as the criminalisation of an unmarried Muslim woman leaving the custody of her guardian; these provisions likely violate Articles 2 and 5 of CEDAW. The CRPD, in its Articles 10 and 15, incorporates the right to life and the absolute prohibition of torture or cruel, inhuman or degrading treatment or punishment, and the Committee on the Rights of Persons with Disabilities has previously expressed concern over the "enforcement of mutilation as a form of criminal sentence, and the stigmatization of persons who have impairment as a consequence of such punishment" as well as the special vulnerability of persons with disabilities to the death penalty (United Nations Committee on the Rights of Persons with Disabilities, Concluding observations on the initial report of the Islamic Republic of Iran of 10 May 2017, CRPD/C/IRN/CO/1, paras. 22f., 32f.).

39 Amnesty International, Brunei Darussalam, see: https://www.amnesty.org/en/countries/ asia-and-the-pacific/brunei-darussalam/ (accessed on May $20^{\text {th }} 2019$ ).

40 Death Penalty Worldwide, Brunei, see: http://www.deathpenaltyworldwide.org/countrysearch-post.cfm?country=Brunei (accessed on May $20^{\text {th }} 2019$ ).

41 Amnesty International, Death Sentences and Executions 2015, see: https://www.amnesty. org/download/documents/act5034872016english.pdf, 27. 
Stoning as a method of execution was introduced in Brunei through the SPCO, and is currently legal and/or practiced by at least seven other States, though reliable reports are rare $;^{43}$ in addition, it is practiced regionally or extrajudicially in a handful more. Like in most States with sharia legal orders, Brunei limits stoning to certain offences: extramarital sexual intercourse involving at least one Muslim party, ${ }^{44}$ extramarital rape, ${ }^{45}$ and sexual intercourse between two men, or anal sex of an unmarried heterosexual couple, regardless of their religion. ${ }^{46}$ The death penalty is foreseen for other crimes as well, though the usual method of execution in Brunei is hanging. ${ }^{47}$

The absolute prohibition of torture is one of the core elements of the international human rights system. Enshrined from the beginning in Article 5 of the UDHR, and given a prominent place in Article 7 ICCPR as well as regional human rights treaties, ${ }^{48}$ it was strengthened in 1984 by the adoption of a special treaty (CAT), which includes in Article 1 the following legal definition of torture:

"For the purposes of this Convention, the term 'torture' means any act by which severe pain or suffering, whether physical or mental, is intentionally inflicted on a person for such purposes as obtaining from him or a third person information or a confession, punishing him for an act he or a third person has committed or is suspected of having committed, or intimidating or coercing him or a third person, or for any reason based on discrimination of any kind, when such pain or suffering is inflicted by or at the instigation of or with the consent or acquiescence of a public official or other person acting in an official capacity." ${ }^{39}$

Above all, however, the absolute prohibition of torture is considered a norm of ius cogens. According to Article 53 of the Vienna Convention on the Law of Treaties, ius cogens is "a norm accepted and recognized by the international

42 Amnesty International, Death Sentences and Executions 2017, see: https://www.amnesty. org/download/documents/act5079552018english.pdf, 20.

43 Death Penalty Worldwide, see: http://www.deathpenaltyworldwide.org/country-filter.cfm? region $=\&$ method $=$ Stoning \& language $=$ en $\left(\right.$ accessed on May $\left.20^{\text {th }} 2019\right)$.

44 SPCO 2013, section $68 \mathrm{f}$.

45 Ibid, section $75 \mathrm{f}$.

46 Ibid, section 82.

47 Death Penalty Worldwide, Brunei.

48 Article 3 of the European Convention for the Protection of Human Rights and Fundamental Freedoms of 4 November 1950; Article 5(2) of the American Convention on Human Rights of 22 November 1969; Article 5 of the African Charter on Human and People's Rights of 27 June 1981; torture is likewise prohibited in Article 20 of the Cairo Declaration on Human Rights in Islam of 5 August 1990 of the Organisation of Islamic Cooperation, but all rights contained in this Declaration are subject to sharia (Article 24).

49 For a legal analysis of the definition of torture see, e. g., Manfred Nowak / Elisabeth McArthur, The United Nations Convention against Torture: A Commentary, Oxford 2008, p. 28, at p. $66 \mathrm{ff}$; Manfred Nowak, Challenges to the Absolute Nature of the Prohibition of Torture and Ill-Treatment, in: Netherlands Quarterly of Human Rights 23/4, December 2005, pp. 674-688. 
community of States as a whole as a norm from which no derogation is permitted and which can be modified only by a subsequent norm of general international law having the same character." 50

There remains little doubt that death by stoning as a method of execution is a violation of the absolute prohibition of torture under international human rights law: It is a method of execution designed to inflict prolonged pain and suffering, often resulting in a slow death from blunt force trauma or extensive blood loss. Its aim is thus to inflict severe physical and mental pain or suffering for the purposes of punishment, perfectly fitting the definition of torture in Article 1 of the CAT. The victim is usually unable to move, immobilised by being buried up to the chest in the ground, adding an element of powerlessness. ${ }^{51}$

If Brunei does ratify the CAT, the SPCO will be closely examined by the UN Committee against Torture, as the treaty body responsible for the interpretation of the CAT. However, most likely its verdict will not come as a particular surprise - one only needs to look towards the recent Concluding Observations adopted on the second periodic report of Mauritania to find out what the Committee thinks of such laws:

The Committee notes with concern that the Criminal Code still contains provisions authorizing corporal punishment for crimes punishable by hadd penalties (public stoning to death, whipping and amputation), for some of which there is no statute of limitations ... The Committee is also concerned about the provisions of article 303 of the Criminal Code, which stipulates that 'there is neither crime nor offence when the homicide, wounds and blows have been ordered pursuant to the law, by a legitimate authority'.... While there is a de facto moratorium on the death penalty and corporal punishment, the Committee remains concerned about their persistence in the law and their possible use in future. ... [The Committee] calls on the State party to: (i) amend the Criminal Code to bring it into compliance with the State party's obligations under the Convention and other international standards, in particular by abolishing hadd and qisas penalties ... The Committee also recommends that the State party abolish the death penalty and commute death sentences to prison sentences. ${ }^{52}$

Similarly, the former United Nations Human Rights Commission deemed execution by stoning a "particularly cruel or inhuman means of execution" and called for its immediate abolition; ${ }^{53}$ and the Human Rights Committee, which

50 See also Nowak, CCPR Commentary, p. $157 \mathrm{f}$.

51 The powerlessness is an important criterion for the definition of torture, in addition to the ones spelled out in article 1 CAT. See Nowak / McArthur, CAT Commentary, p. 76.

52 United Nations Committee against Torture, Concluding observations on the second periodic report of Mauritania of 4 September 2018, CAT/C/MRT/CO/2, para. $34 \mathrm{f}$.

53 United Nations Commission on Human Rights, Resolution 2005/59: The Question of the Death Penalty of 20 April 2005, E/CN.4/RES/2005/59, para. 7(i). 
monitors compliance with the ICCPR, has found that stoning as a method of execution is contrary to the prohibition of torture enshrined in Article 7 ICCPR. ${ }^{54}$

\subsection{The death penalty for "most serious crimes"}

The right to life is enshrined in Article 3 of the UDHR and further concretised in Article 6 of the ICCPR, which reserves the use of the death penalty to cases of "the most serious crimes". Brunei's SPCO contains capital punishment for such crimes as private and consensual sexual intercourse between adults, apostasy as well as contempt or derision of the prophet, Qur'an or the hadith, none of which can rise to the level of 'most serious', or even 'crimes,' as these acts in most States are not criminalised at all. The UN Human Rights Committee limits the category of 'most serious' to "intentional killing", explicitly excludes sexual offences from the category of "most serious", and concludes that "under no circumstances can the death penalty ever be applied as a sanction against conduct whose very criminalization violates the Covenant, including adultery, homosexuality, apostasy." 55

\subsection{Mandatory death sentences}

The SPCO prescribes exactly what acts shall receive capital punishment - so exactly, in fact, that there is absolutely no room for the consideration of the specific circumstances of the case. This is the case for death by stoning as well as other capital sentences foreseen by the SPCO, for the crimes of robbery, extramarital sex, extramarital rape, same-sex sexual intercourse and extramarital anal sex, apostasy and related crimes; as well as qatl (intentional killing). ${ }^{56}$ The Human Rights Committee has long held that mandatory death sentences are arbitrary in nature, and the arbitrary deprivation of life is absolutely pro-

54 United Nations Human Rights Committee, General comment No. 36 (2018) on article 6 of the ICCPR, on the right to life of 30 October 2018, CCPR/C/GC/36, para. 40; United Nations Human Rights Committee, Concluding observations on the third periodic report of the Islamic Republic of Iran of 29 November 2011, CCPR/C/IRN/CO/3, para. 12.

55 UN Human Rights Committee, General comment No. 36, para. 35f.; UN Human Rights Committee, Islamic Republic of Iran, para. 12; similarly UN Commission on Human Rights, Resolution 2005/59, para. 5 (f): “To ensure that 'most serious crimes' does not go beyond intentional crimes with lethal or extremely grave consequences and that the death penalty is not imposed for non-violent acts such as financial crimes, religious practice or expression of conscience and sexual relations between consenting adults."

56 SPCO 2013, section 124. 
hibited. ${ }^{57}$ Similarly, the Committee against Torture showed concern over the mandatory death penalty for acts of apostasy, which was not in line with the CAT. $^{58}$

\subsection{Corporal punishment}

Already in 1997, the UN Special Rapporteur on Torture expressed his conviction that corporal punishment such as amputation and flogging is "inconsistent with the prohibition of torture and other cruel, inhuman or degrading treatment or punishment enshrined, inter alia , in the UDHR, the ICCPR, ... and the CAT," noting that even when States ground these punishments in Islamic law "there exists a great divergence of views among Islamic scholars and clerics ... [and] that the overwhelming majority of member States of the Organization of the Islamic Conference do not have corporal punishment in their domestic laws." ${ }^{29}$

The Committee against Torture has since unequivocally stated that the practice of corporal punishments such as flogging or amputation - as foreseen in the SPCO - are a violation of the CAT since they amount to torture and cruel, inhuman or degrading treatment or punishment," and called for their immediate abolition. ${ }^{60}$ In the consideration of the initial State report of Yemen, the Committee against Torture expressed its grounds for concern:

On the matter of flogging, the Committee had been apprised that the purpose of the punishment was not so much to inflict pain as to humiliate the victim.... If the purpose was to inflict pain, the punishment would seem to violate article 1 , and if the object was simply to humiliate the victim, it appeared to constitute a violation of article $16 .^{61}$

Likewise, the Human Rights Committee has expressed the "firm opinion of the Committee that corporal punishment constitutes cruel, inhuman and degrading treatment or punishment contrary to article 7 of the Covenant. The Committee finds that by imposing a sentence of whipping ... the State party has violated" the absolute prohibition of torture and cruel, inhuman and degrading treatment or punishment. ${ }^{62}$

57 UN Human Rights Committee, General comment No. 36, para. 37.

$58 \mathrm{UN}$ Committee against Torture, CAT/C/MRT/CO/2, para. $34 \mathrm{f}$.

59 Nigel S. Rodney, Report of the Special Rapporteur to the Commission on Human Rights of 10 January 1997, E/CN.4/1997/7, para 10.

60 United Nations Committee against Torture, Concluding observations on the second periodic report of Saudi Arabia of 8 June 2016, CAT/C/SAU/CO/2, para. 10f. See also Nowak / McArthur, CAT Commentary, pp. 543-547 and pp. 561-564.

61 UN CAT/C/SR.583, para. 10.

62 United Nations Human Rights Committee, George Osbourne v. Jamaica, Communication No. 759/1997, views of 13 April 2000, CCPR/C/68/D/759/1997 (2000), para. 9.1.; United 


\subsection{The rights of children}

The SPCO imposes criminal responsibility - as well as the corresponding sentences, including death by stoning, flogging and amputation - on all mukallaf, which is defined in the SPCO as "a person who has attained the age of 15 years ... and [is] of sound mind". ${ }^{63}$ Even children below the age of 15 may be punished for offences such as extramarital sex and extramarital rape when deemed old enough to know the difference between right or wrong by the special juvenile punishment of whipping not exceeding 40 strokes. $^{64}$

Brunei has ratified, along with nearly every other UN member State, the CRC, which defines 'child' as "every human being below the age of eighteen years" ${ }^{65}$ Article 19 of the CRC stipulates that all children under 18 years of age must be protected from all forms of physical or mental violence. ${ }^{66}$ Article 37 (a) of the CRC obliges State Parties to ensure that "no child shall be subjected to torture or other cruel, inhuman or degrading treatment or punishment. Neither capital punishment nor life imprisonment without possibility of release shall be imposed for offences committed by persons below eighteen years of age." ${ }^{\prime 67}$ This is an absolute prohibition of the death penalty for children up to the age of $18,{ }^{68}$ which, due to the near-universal ratification of the CRC, has attained the status of customary international law. Article 40 of the CRC requires States to "recognize the right of every child alleged as, accused of, or recognized as having infringed the penal law to be treated in a manner consistent with the promotion of the child's sense of dignity and worth." ${ }^{\prime 9}$ The Committee has since affirmed that "there is no ambiguity: 'all forms of physical or mental violence' does not leave room for any level of legalized violence against children" and "in a minority of States, corporal punishment using canes or whips is still authorized as a sentence of the courts for child offenders. As frequently reiterated by the Committee, the Convention requires the repeal of all such provisions." 70

Nations Human Rights Committee, CCPR General Comment No. 20 on Article 7 on the Prohibition of Torture, or Other Cruel, Inhuman or Degrading Treatment or Punishment of 10 March 1992, para 5: "the prohibition must extend to corporal punishment".

63 SPCO 2013, section 2.

64 Ibid, sections 70, 79.

65 United Nations Convention on the Rights of the Child of 20 November 1989, Article 1.

66 UN Convention on the Rights of the Child, Article 19.

67 Ibid, Article 37 (a).

68 See also United Nations Committee on the Rights of the Child, General Comment No. 10 (2007) on children's rights in juvenile justice of 25 April 2007, CRC/C/GC/10, para. $75 \mathrm{f}$.

69 UN Convention on the Rights of the Child, Article 40.

70 United Nations Committee on the Rights of the Child, General Comment No. 8 (2006) on the right of the child to protection from corporal punishment and other cruel or degrading forms of punishment of 2 March 2007, CRC/C/GC/8, paras. 18, 32. 


\subsection{The global trend towards abolition of capital punishment}

So far, we have only considered certain aspects surrounding the death penalty, such as the method of execution and the crimes for which capital punishment may be imposed, as clear violations of international law. This has to do with the fact that the more fundamental question, namely whether capital punishment as such violates international law, is still highly controversial in human rights theory and practice. Those who argue that capital punishment is still compatible with international law refer to the continuing practice of the death penalty in powerful states, including the United States, Japan, China, Indonesia, Iran, Saudi Arabia and other Islamic states, and to the fact that Article 6 ICCPR and similar provisions in regional human rights treaties are formulated in a manner which permits the death penalty under certain conditions (only for the 'most serious crimes', not against children and pregnant women etc.) as an explicit exception of the right to life. It follows logically, according to this line of systematic legal reasoning, that capital punishment as such cannot be considered as a cruel, inhuman or degrading punishment.

Those who argue, including the authors of the present article, that capital punishment in any case constitutes a cruel and inhuman punishment which even amounts to torture and which is, therefore, absolutely prohibited under international law, base themselves on a dynamic interpretation of these terms. When the ICCPR was drafted, corporal and capital punishment were still widely practiced in all regions of the world which is the reason for the explicit exemption of the death penalty from the right to life. In the meantime, our understanding of the term 'cruel, inhuman or degrading punishment' has evolved to an extent that all forms of corporal punishment are today considered as inhuman or at least degrading and, therefore, absolutely prohibited under international law and jurisprudence. ${ }^{71}$ For the same reason, capital punishment has been increasingly recognized as cruel, inhuman and degrading and, therefore, abolished by the majority of states in all regions. Pioneers were European and Latin American states. Already in 1983, on the initiative of the former Austrian Minister of Justice Christian Broda, the death penalty was abolished in times of peace within the Council of Europe by the $6^{\text {th }}$ Additional Protocol (AP) to the European Convention on Human Rights, followed in 2002 by the $13^{\text {th }}$ AP also in times of war. Similarly, the Organisation of American States (OAS) adopted in 1990 a Protocol to the American Convention on Human Rights to Abolish the Death Penalty. In reality, all European states with the exception of Belarus and almost all Latin American states have abolished the death penalty in the meantime.

71 See above under 2.5. 
Article 6(6) ICCPR already foresees the gradual abolition of the death penalty: "Nothing in this article shall be invoked to delay or to prevent the abolition of capital punishment by any State Party to the present Covenant”. In 1990, UN member states adopted the Second Optional Protocol to the ICCPR, Aiming at the Abolition of the Death Penalty. This OP, of course, only binds those states which have ratified it. Nevertheless, the trend towards abolition continues, and the UN General Assembly regularly appeals to the remaining retentionist states to at least adopt a moratorium and to stop executions. ${ }^{72}$

In our opinion, time has come to also change the systematic interpretation of Articles 6 and 7 ICCPR. How can capital punishment still be considered as not inhuman or degrading if even light forms of corporal punishment are considered as inhuman or degrading and, therefore, absolutely prohibited under international law? ${ }^{73}$ After all, capital punishment is an aggravated form of corporal punishment. It also fulfils all criteria of the definition of torture, namely the deliberate infliction of severe pain or suffering, whether physical or mental, on a powerless person by a public official for a specific purpose, such as punishment. Since the prohibition of torture is a norm of ius cogens, which binds all states irrespective of whether they have ratified the CAT or any other treaty prohibiting torture, capital punishment is also absolutely prohibited under international law.

\subsection{Reactions of the United Nations}

Both the adoption of the SPCO in 2013 and the entry into force of its most controversial substantive provisions in 2019 were met by outrage. Incidentally, both events occurred in close proximity to Brunei's Universal Periodic Review ("UPR") at the Human Rights Council, and the effect is measurable: In Brunei's second UPR in 2014, 14 States issued recommendations concerning the repeal, review or amendment of the SPCO, based on its failure to meet international human rights standards; all of these were merely 'noted' by Brunei. In addition, numerous recommendations concerning the upholding of the moratorium on, as well as the abolition of the death penalty, were similarly not accepted. The only relevant recommendations which were supported by Brunei came from States with similar legal orders (Pakistan, Iran and Saudi Arabia) and concerned training, awareness raising and capacity building to promote just implementa-

72 See United Nations General Assembly, Resolution 73/175: Moratorium on the use of the death penalty of 17 December 2018, A/RES/73/175.

73 See the development of this legal reasoning in Nowak, CCPR Commentary, p. $168 \mathrm{ff}$; ; Nowak / McArthur, CAT Commentary, p. $564 \mathrm{ff}$. 
tion and understanding of the SPCO. ${ }^{74}$ In the third UPR of Brunei, conducted in May 2019 shortly after the entry into force of the most controversial parts of the SPCO, the number of States explicitly referring to the penal code and recommending its suspension, review or repeal had risen to 33 , with only one more positive recommendation from Venezuela. ${ }^{75}$

The United Nations reacted in other ways as well: In a joint communication, five mandate-holders of Human Rights Council Special Procedures sent a joint letter to Brunei, expressing their grave concern over "the imposition of cruel, inhuman and degrading punishments (...) in connection with the criminalisation of adultery and consensual same sex relations," urging the revocation and complete repeal of the SPCO, laying out much the same arguments as above. ${ }^{76}$ The Government of Brunei responded to the letter with affirmations of national sovereignty and an offer to clear up the "misconceptions" about the SPCO on the part of the United Nations: The SPCO "aims to respect and protect the legitimate rights of all individuals, society and nationality of any faith and race," focussing "more on prevention than punishment", with the aim to "educate, deter, rehabilitate and nurture rather than to punish." The SPCO "does not criminalise nor has any intention to victimise a person's status based on sexual orientation or belief, including same-sex relations," and accordingly the offences of adultery and sodomy would not apply to non-Muslims. It also cited the very high evidentiary standard for capital and corporal punishments, which may lead the convictions of hadd to "rest solely on confessions". The laws of the SPCO were "not man-made but ordained by Allah (...) and not to be misunderstood as any kind of radicalisation."

Several of these claims are patently false. The offences of adultery and sodomy $d o$ apply to non-Muslims, the former if one of the partners is Muslim, the latter applies to 'any person' regardless of religion. Likewise the absurd claim that a law criminalising acts to be sanctioned with punishments which amount to torture

74 United Nations Working Group on the Universal Periodic Review, Addendum to the Report on Brunei Darussalam, A/HRC/27/11/add.1, outcome (3).

75 United Nations Working Group on the Universal Periodic Review, Draft Report - Brunei Darussalam of 14 May 2019, A/HRC/WG.6/33/L.9, see: https://extranet.ohchr.org/sites/upr/ Sessions/33session/BruneiDarussalam/Documents/A_HRC_WG.6_33_L_9_Brunei\%20Dar ussalam_Draft\%20Report.docx (accessed on May $20^{\text {th }} 2019$ ).

76 United Nations Special Rapporteur on extrajudicial, summary or arbitrary executions, Special Rapporteur on freedom of religion or belief, Independent Expert on protection against violence and discrimination based on sexual orientation and gender identity, Special Rapporteur on torture and other cruel, inhuman or degrading treatment or punishment, and Special Rapporteur on violence against women, its causes and consequences and Working Group on the issue of discrimination against women in law and in practice, Joint Communication of 1 April 2019, see: https://www.ohchr.org/Documents/Issues/SexualOrientation/ Legislation/OL_BRN_01.04.19.pdf (accessed on May $20^{\text {th }}$ 2019).

77 Ministry of Foreign Affairs of Brunei Darussalam, Communication. 
or cruel, inhuman and degrading treatment or punishment could focus 'more on prevention' and aim to 'rehabilitate and nurture' should be relegated to the domain of pure fiction. Some of these claims are, on the other hand, attempts to split hairs: While the SPCO may not explicitly criminalise a person's status based on sexual orientation by itself, it certainly criminalises all human beings who act on their sexual orientation by having sexual intercourse in the realm of their private life. Furthermore, the reliance on confessions of the accused for the imposition of hadd punishments is its own kind of evil, as the mandate-holders point out in their communication: This substantially "increases the risk of torture and other cruel, inhuman or degrading treatment or punishment and, therefore, is incompatible with the obligation under customary international law to prevent such abuse." 78

Following an international outcry and significant media coverage, the Sultan has since announced in a televised speech that the death penalty imposed under the new laws would not be enforced and the existing de-facto moratorium extended to the new SPCO. ${ }^{79}$ However, as the former Special Rapporteur on extrajudicial, summary or arbitrary executions, Philip Alston, rightly pointed out, even if the sentence is never carried out, the mere possibility that it can threaten the accused for years until overturned or commuted constitutes a form of cruel, inhuman or degrading treatment or punishment. Assurances that an offence which continues to be recognized by the law will never be applied in practice are neither justified nor convincing. The very existence of such laws invites abuse by individuals. ${ }^{80}$

\section{Conclusions}

The case study of Brunei's Syariah Penal Code illustrates that when governments declare a State religion and impose in the $21^{\text {st }}$ century religious criminal laws which were drafted by religious leaders many hundreds of years ago in totally different historical contexts, such laws are usually in conflict with contemporary human rights standards. International human rights law, which developed by the United Nations and regional organisations in reaction to the Holocaust in the course of the second half of the $20^{\text {th }}$ century, is inspired by the concept of human

78 Special Procedures joint communication, p. $3 \mathrm{f}$.

79 Nile Bowie, Western boycotts soften Brunei's sharia law, see: https://www.asiatimes.com/ 2019/05/article/western-boycotts-soften-bruneis-sharia-law/, 7 May 2019 (accessed on May $20^{\text {th }} 2019$ ).

80 Philip Alston, Report of the Special Rapporteur on Extrajudicial, Summary or Arbitrary Executions to the United Nations Commission on Human Rights of 7 January 2006, E/CN.4/ 2006/53/Add.4, para 35. 
dignity and constitutes the only universally accepted value system of our time. ${ }^{81}$ All States are legally bound by universal human rights standards, which are laid down in a multitude of international human rights treaties as well as customary international law. Some of the core standards directly related to infringements of human dignity, such as the prohibition of slavery and torture as well as discrimination based on race or gender, have even gained the status of ius cogens binding on all States. ${ }^{82}$

All forms of corporal and capital punishment amount to torture, cruel, inhuman or degrading punishment and are, therefore, absolutely prohibited under international law. But even for those who do not yet accept this legal interpretation, there can be no doubt that most of the crimes and punishments introduced in the SPCO violate Brunei's legal international obligations, as explained in detail by our legal analysis in light of international jurisprudence and practice. The Government of Brunei, therefore, has the legal obligation to immediately repeal this cruel religious law before it will be implemented in practice.

\section{Sources}

African Charter on Human and People's Rights of 27 June 1981.

Alston, Philip, Report of the Special Rapporteur on Extrajudicial, Summary or Arbitrary Executions to the United Nations Commission on Human Rights of 7 January 2006, E/ CN.4/2006/53/Add.4.

American Convention on Human Rights of 22 November 1969.

Amnesty International, Brunei Darussalam, see: https:/www.amnesty.org/en/countries/ asia-and-the-pacific/brunei-darussalam/ (accessed on May $20^{\text {th }} 2019$ ).

Amnesty International, Death Sentences and Executions 2017, see: https://www.amnesty. org/download/documents/act5079552018english.pdf (accessed on May 20 $0^{\text {th }} 2019$ ).

Amnesty International, Death Sentences and Executions 2015, see: https://www.amnesty. org/download/documents/act5034872016english.pdf (accessed on May 20 ${ }^{\text {th }} 2019$ ).

Association of Southeast Asian Nations, ASEAN Human Rights Declaration of 18 November 2012.

Bielefeldt, Heiner, Menschenwürde - Der Grund der Menschenrechte, Berlin 2008.

Bowie, Nile, Western boycotts soften Brunei's sharia law, see: https://www.asiatimes.com/ 2019/05/article/western-boycotts-soften-bruneis-sharia-law/, 7 May 2019 (accessed on May $20^{\text {th }} 2019$ ).

Cairo Declaration on Human Rights in Islam of 5 August 1990.

Constitution of Brunei Darussalam, Revised Edition 2011, see: http://www.agc.gov.bn/ AGC\%20Images/LOB/cons_doc/constitution_i.pdf (accessed on May 20th 2019).

81 See, e.g., Manfred Nowak, Introduction to the International Human Rights System, Leiden 2003, p. 1.

82 See Nowak, Menschenwürde und Menschenrechte, p. $55 \mathrm{ff}$. 
Death Penalty Worldwide, see: http://www.deathpenaltyworldwide.org/country-filter. $\mathrm{cfm}$ ?region $=\&$ method $=$ Stoning\& language $=$ en $\left(\right.$ accessed on May $\left.20^{\text {th }} 2019\right)$.

Death Penalty Worldwide, Brunei, see: http://www.deathpenaltyworldwide.org/countrysearch-post.cfm? country $=$ Brunei $\left(\right.$ accessed on May $\left.20^{\text {th }} 2019\right)$.

European Convention for the Protection of Human Rights and Fundamental Freedoms of 4 November 1950.

Freedom House, Freedom in the World 2019 - Brunei, see: https://freedomhouse.org/ report/freedom-world/2019/brunei (accessed on May $20^{\text {th }} 2019$ ).

Gabriel, Ingeborg, Freedom of Religion, in: Manfred Nowak / Karolina M. Januszewski / Tina Hofstätter (eds.), All Human Rights for All - Vienna Manual on Human Rights, Vienna-Graz 2012, pp. 392-395.

Gabriel, Ingeborg, Human Rights from a Theological Perspective, in: Manfred Nowak / Karolina M. Januszewski / Tina Hofstätter (eds.), All Human Rights for All - Vienna Manual on Human Rights, Vienna-Graz 2012, pp. 33-35.

Gabriel, Ingeborg, The Role of Religions in the Public Square: Elements of a Transformation Process, in: Richard Potz / Sabine Kroissenbrunner / Astrid Hafner (eds.), State, Law and Religion in Pluralistic Societies: Austrian and Indonesian Perspectives, Göttingen 2010, pp. 179-190.

Ministry of Foreign Affairs of Brunei Darussalam, Communication of 7 April 2019, see: http://www.mfa.gov.bn/PublishingImages/Lists/Press\%20Room/AllItems/Special\%20 Procedures\%20(Reply\%20letter\%20 from\%20YBDE).pdf (accessed on May 20 $0^{\text {th }} 2019$ ).

Müller, Dominik M., Brunei Darussalam in 2016 - The Sultan Is Not Amused, in: Asian Survey 57/1/ Jan/Feb 2017, pp. 199-205.

Müller, Dominik M., Brunei in 2015 - Oil Revenues Down, Sharia on the Rise, in: Asian Survey 56/1/ Jan/Feb 2016, pp. 162-167.

Notification of commencement of 29 December 2018, see: http://www.agc.gov.bn/AG C\%20Images/LAWS/Gazette_PDF/2018/S068.pdf (accessed on May $20^{\text {th }} 2019$ ).

Nowak, Manfred, Menschenwürde und Menschenrechte, Wien 2018.

Nowak, Manfred / McArthur, Elisabeth, The United Nations Convention against Torture: A Commentary, Oxford 2008.

Nowak, Manfred, Challenges to the Absolute Nature of the Prohibition of Torture and IllTreatment, in: Netherlands Quarterly of Human Rights 23/4, December 2005, pp. 674688.

Nowak, Manfred, U.N. Covenant on Civil and Political Rights - CCPR Commentary, 2.ed., Kehl-Strasbourg-Arlington 2005.

Nowak, Manfred / Vospernik, Tanja, Permissible Restrictions on Freedom of Religion or Belief, in: Tore Lindholm / W. Cole Durham / Bahia G. Tahzib-Lie (eds.), Facilitating Freedom of Religion or Belief: A Deskbook, Dordrecht 2004, pp. 147-172.

Nowak, Manfred, Introduction to the International Human Rights System, Leiden 2003. Prime Minister's Office Brunei Darussalam, see: http://www.pmo.gov.bn/Pages/PrimeMinister.aspx (accessed on May 20 $0^{\text {th }} 2019$ ).

Reporters Without Borders, Brunei, see: https://rsf.org/en/brunei (accessed on May $20^{\text {th }}$ 2019).

Rodney, Nigel S., Report of the Special Rapporteur to the Commission on Human Rights of 10 January 1997, E/CN.4/1997/7, see: https://documents-dds-ny.un.org/doc/UNDOC/ GEN/G97/101/13/PDF/G9710113.pdf (accessed on May 20 ${ }^{\text {th }} 2019$ ). 
Syariah Penal Code Order 2013 of 22 October 2013, see: http://www.agc.gov.bn/AG C\%20Images/LAWS/Gazette_PDF/2013/EN/syariah\%20penal\%20code\%20order2013. pdf (accessed on May 20 2019).

United Nations Commission on Human Rights, Resolution 2005/59: The Question of the Death Penalty of 20 April 2005, E/CN.4/RES/2005/59.

United Nations Committee against Torture, Concluding observations on the second periodic report of Mauritania of 4 September 2018, CAT/C/MRT/CO/2.

United Nations Committee against Torture, Concluding observations on the second periodic report of Saudi Arabia of 8 June 2016, CAT/C/SAU/CO/2.

United Nations Committee on the Rights of Persons with Disabilities, Concluding observations on the initial report of the Islamic Republic of Iran of 10 May 2017, CRPD/C/ IRN/CO/1.

United Nations Committee on the Rights of the Child, General Comment No. 10 (2007) on children's rights in juvenile justice of 25 April 2007, CRC/C/GC/10.

United Nations Committee on the Rights of the Child, General Comment No. 8 (2006) on the right of the child to protection from corporal punishment and other cruel or degrading forms of punishment of 2 March 2007, CRC/C/GC/8.

United Nations Convention on the Rights of the Child of 20 November 1989.

United Nations Development Programme, Human Development Indices and Indicators 2018 Statistical Update, New York 2018, p. 22.

United Nations General Assembly, Resolution 73/175: Moratorium on the use of the death penalty of 17 December 2018, A/RES/73/175.

United Nations Human Rights Committee, Concluding observations on the third periodic report of the Islamic Republic of Iran of 29 November 2011, CCPR/C/IRN/CO/3.

United Nations Human Rights Committee, General comment No. 36 (2018) on article 6 of the ICCPR on the right to life of 30 October 2018, CCPR/C/GC/36.

United Nations Human Rights Committee, General comment No. 20 on article 7 on the prohibition of torture, or other cruel, inhuman or degrading treatment or punishment of 10 March 1992.

United Nations Human Rights Committee, George Osbourne v. Jamaica, Communication No. 759/1997, CCPR/C/68/D/759/1997 (2000).

United Nations Special Rapporteur on extrajudicial, summary or arbitrary executions, Special Rapporteur on freedom of religion or belief, Independent Expert on protection against violence and discrimination based on sexual orientation and gender identity, Special Rapporteur on torture and other cruel, inhuman or degrading treatment or punishment, and Special Rapporteur on violence against women, its causes and consequences and Working Group on the issue of discrimination against women in law and in practice, Joint Communication of 1 April 2019, see: https://www.ohchr.org/Docu ments/Issues/SexualOrientation/Legislation/OL_BRN_01.04.19.pdf (accessed on May $20^{\text {th }} 2019$ ).

United Nations Working Group on the Universal Periodic Review, Addendum to the Report on Brunei Darussalam, A/HRC/27/11/add.1, outcome (3).

United Nations Working Group on the Universal Periodic Review, Draft Report - Brunei Darussalam of 14 May 2019, A/HRC/WG.6/33/L.9, see: https://extranet.ohchr.org/sites/ upr/Sessions/33session/BruneiDarussalam/Documents/A_HRC_WG.6_33_L_9_Brunei \%20Darussalam_Draft\%20Report.docx (accessed on May 20 ${ }^{\text {th }} 2019$ ). 
UNTC - Convention on the Rights of the Child, see: https://treaties.un.org/Pages/View Details.aspx?src $=$ IND\& mtdsg_no $=$ IV-11\& chapter $=4 \&$ lang $=$ en $($ accessed on May $20^{\text {th }} 2019$ ).

UNTC - Convention on the Rights of Persons with Disabilities, see: https://treaties.un.org/ pages/ViewDetails.aspx $?$ src $=$ TREATY $\&$ mtdsg_no $=I V-15 \&$ chapter $=4$ (accessed on May $20^{\text {th }} 2019$ ).

UNTC - Convention on the Elimination of All Forms of Discrimination against Women https://treaties.un.org/Pages/ViewDetails.aspx?src=IND\& mtdsg_no=IV-8\& chapter $=4 \&$ lang $=$ en (accessed on May $20^{\text {th }} 2019$ ).

UN Treaty Body Database - Ratification Status for Brunei Darussalam, see: https://tbin ternet.ohchr.org/_layouts/15/TreatyBodyExternal/Treaty.aspx?CountryID=25\&Lang $=\mathrm{EN}$ (accessed on May 20 $0^{\text {th }} 2019$ ).

Vienna Convention on the Law of Treaties of 23 May 1969.

World Conference on Human Rights, Vienna Declaration and Programme of Action of 12 July 1993, A/CONF.157/23. 


\section{Islamischer Schleier versus Emanzipation? Religions- und Weltanschauungsfreiheit als Teil der Frauenrechte}

Der seit Jahren mehr oder weniger heftig geführte „Kopftuchstreit“ ist für viele zum Symbol einer Auseinandersetzung um unterschiedliche Wert- und Weltvorstellungen an sich geworden. ${ }^{1}$

Während BefürworterInnen eines allgemeinen Verschleierungs- und Kopftuchverbots, wie etwa Alice Schwarzer ${ }^{2}$ oder Seyran Ateş ${ }^{3}$ argumentieren, dass der islamische Schleier ${ }^{4}$ unabhängig von seiner Form Zeichen der Unterdrückung der Frau im Namen eines politisch instrumentalisierten Islams und niemals selbstgewähltes Symbol sei, betonen KritikerInnen eines solchen, wie etwa Martha Nussbaum ${ }^{5}$ oder Carla Amina Baghajati ${ }^{6}$ die unterschiedlichen Moti-

1 Wenn gerade auch die sozialethische Perspektive die Frage aufdrängt - und gemeinsam mit der Jubilarin habe ich sie mir mehrfach gestellt - warum die Bekleidung der Frau so viel mehr für Aufregung sorgt, als globalere Themen, wie extreme Armut - $60 \%$ der hungernden Menschen weltweit sind Frauen und Mädchen -, die massive Ausbeutung von Menschen $71 \%$ der weltweiten Opfer von moderner Sklaverei sind Frauen -, der Menschenhandel, dessen Opfer mehrheitlich Frauen und Mädchen sind usw., so scheint die Thematisierung dieser Frage gerade aufgrund ihrer öffentlichen Präsenz dennoch notwendig. Die Möglichkeit mich solchen Fragen aus einer theologischen und menschenrechtlichen Perspektive annähern zu können, verdanke ich der Jubilarin, Ingeborg G. Gabriel. Hierfür und für so vieles andere möchte ich ihr mit dem folgenden Beitrag danken.

2 Alice Schwarzer, Die große Verschleierung: für Integration, gegen Islamismus, Köln 2010.

3 Seyran Ateş, Der Multikulti-Irrtum: Wie wir in Deutschland besser zusammenleben können, 6. Aufl., Berlin 2016, insb. S. 119-138.

4 Der Begriff des „,islamischen Schleiers“ wird im Folgenden als Überbegriff für unterschiedliche Formen der Kopf- bzw. Körperverhüllung für geschlechtsreife Frauen im Islam, d.i. für Hijab, Burka, Niqab, Chador, Jilbab und Bushiya, verwendet, für das islamische Kopftuch, das Haare, Ohren, Hals und Ausschnitt bedeckt, wird der Begriff Hijab verwendet.

5 Martha Nussbaum, Veiled Threats?, in: The Opinion Pages in The New York Times am 11.07. 2010, vgl. https://opinionator.blogs.nytimes.com/2010/07/11/veiled-threats/ (letzter Zugriff: 13.06.2019).

6 Carla Amina Baghajati, Muslimin sein: 25 Fragen - 25 Orientierungen, Innsbruck 2015, insb. S. 115f. Siehe in diesem Zusammenhang auch die Deklaration „Musliminnen am Wort. Gegen jede Verbotspolitik auf unseren Köpfen! Für unser Selbstbestimmungsrecht! Und die volle Teilhabe an einer pluralen Gesellschaft!“, die am 12.03.2019 in Wien präsentiert wurde. Unterzeichnet wurde diese von mehr als 3.500 Musliminnen, Projektleiterinnen der Initiative 
vationen einen islamischen Schleier zu tragen sowie das Selbstbestimmungsrecht der Frau.

Die Ausweitung der Frage nach der Zulässigkeit einen Hijab, d.i. ein islamisches Kopftuch, das Haare, Ohren, Hals und Ausschnitt bedeckt, als religiöses Symbol in der Öffentlichkeit zu tragen auf die Frage nach der Zulässigkeit von Vollverschleierungen und von unterschiedlichen Varianten des islamischen Kopftuchs getragen von Kindern in Kindergärten und Volksschulen, lässt die Notwendigkeit erkennen die große Bandbreite an verschiedensten Fragestellungen differenziert zu betrachten. ${ }^{7}$ Damit möchte der folgende Beitrag auch einem der Grundanliegen der Arbeit Ingeborg G. Gabriels folgen, durch ein unaufgeregtes Innehalten und eine differenzierte Betrachtung der Hintergründe, ${ }^{8}$ zur Verständigung und damit zu sozialem Frieden beizutragen.

Für den dabei gewählten Fokus auf die Frage nach dem Verhältnis von Frauenrechten und Religions- und Weltanschauungsfreiheit am Beispiel des islamischen Schleiers - getragen von geschlechtsreifen Frauen - ist im Folgenden in einem ersten Schritt auf den Bedeutungsgehalt des islamischen Schleiers einzugehen. Davon ausgehend ist anzufragen inwieweit das Tragen eines solchen vom Recht auf Religions- und Weltanschauungsfreiheit abgedeckt wird. Problematisiert werden soll dabei in einem zweiten Schritt die zeitgenössisch zunehmend sichtbar werdende Hierarchisierung von Frauenrechten und dem Recht auf Religions- und Weltanschauungsfreiheit, die sich auch innerhalb der Debatten rund um den „Kopftuchstreit“ etwa anhand von Positionen wie jener Alice Schwarzers erkennen lässt.

Zentrales Anliegen des Beitrags ist es dabei die durch eine solche Hierarchisierung entstehenden Schieflagen aufzuzeigen und darüber hinaus auf die Pluralität menschlichen Lebens - exemplarisch an der Deutung und den Varianten des islamischen Schleiers aufgezeigt - zu verweisen, die eine allzu vereinfachende Beantwortung derartiger Fragen verbietet.

waren Carla Amina Baghajati und Zeynep Elibol. Das Dokument kann eingesehen werden unter: http://www.derislam.at/iggo/index.php? $\mathrm{f}=$ news \& shownews=2136 (letzter Zugriff: 13.03.2019).

7 Um dieser Anforderung gerecht werden zu können, ist im Folgenden die Diskussion um Hijab-tragende Kinder auszusparen. Im Besonderen weil hierfür zusätzliche Reflexionen notwendig wären, die den Umfang dieses Beitrags übersteigen. Zu nennen sind in diesem Zusammenhang entwicklungspsychologische Aspekte, die UN-Kinderrechtskonvention und ihre Bedeutung für diese Frage, ebenso wie die notwendige Diskussion des Umstandes, dass unterschiedliche Traditionen innerhalb des Islams das Tragen des Hijabs (dasselbe gilt für Vollverschleierungen) ausschließlich für die religiös mündige Frau im Islam, d.h. für Frauen mit körperlicher und geistiger Reife, kennen.

8 Vgl. hierzu etwa: Ingeborg Gabriel, Das Kreuz im Widerstreit, in: Christ in der Gegenwart 24/ 2018, S. 269-270. 


\section{Die Bedeutung des islamischen Schleiers - Hinweise aus der Zeichentheorie}

Eine der am kontroversesten diskutieren Fragen des „Kopftuchstreits“ ist, ob Hijab $^{9}$, Burka $^{10}, \mathrm{Niqab}^{11}$, Chador $^{12}$, Jilbab $^{13}$ beziehungsweise Bushiya ${ }^{14}$ religiöse oder lediglich politische Symbole oder letztlich überhaupt bloß Zeichen der Unterdrückung der Frau sind. Die Bedeutung der Beantwortung dieser Frage liegt nicht zuletzt darin, dass je nach Einschätzung unterschiedliche Rechte zum Tragen kommen und so auch die Frage ob Frauen gezwungen werden dürfen oder dazu befreit werden müssen derartige Kleidungsstücke in der Öffentlichkeit abzulegen höchst unterschiedlich beantwortet wird.

Für eine erste Annäherung an diese Thematik erweist sich ein Blick auf die Zeichentheorie und den Bedeutungsgehalt von Symbolen als hilfreich. Dabei zeigt sich, dass ein Teil der Schwierigkeit diese zu interpretieren auch darin $\mathrm{zu}$ sehen ist, dass Symbole (von griech. sýmbolon), wie Cassirer ${ }^{15}$ betonte, als Darstellung beziehungsweise Hinweis auf etwas Anderes - im Gegensatz zum Zeichen - nie in völliger Klarheit auf ihren Bezugsgegenstand verweisen. Vielmehr verfügen sie über eine gewisse Offenheit, die sich letztlich auch dadurch erklärt, dass „die gegenständliche Entsprechung, die zueinander gehörige Dinge auszeichnet, [...] erst im Hinblick auf die durch die Erinnerung beteiligter Menschen hergestellte Sinngebung, sinnfällig' [wird]. “16 Diese Überlegungen der Zeichentheorie aufgreifend unterscheidet Susanne K. Langer zwischen dis-

9 Hijab als englische Transkription von arabisch بأجح. Im Folgenden im engeren Sinn verwendet als Bezeichnung für ein islamisches Kopftuch, das Haare, Ohren, Hals sowie Ausschnitt bedeckt.

10 Die Burka ist ein weites Gewand, das über den Kopf gezogen wird und den weiblichen Körper bis zu den Zehen komplett verhüllt. Das Gesichtsfeld ist mit einem undurchsichtigen Gitter bedeckt, das das Sehen nach vorne ermöglicht.

11 Der Niqab ist ein Gesichtsschleier, der das Gesicht bedeckt, dabei aber meist einen Schlitz für die Augen freilässt. Wird häufig in Verbindung mit einem Chador/Abaya getragen.

12 Der Chador ist ein weites Tuch, das über die normale Kleidung gezogen wird und so Kopf, Körper und Haare komplett verhüllt, das Gesicht wird dabei frei gelassen. Der Chador hat im Gegensatz etwa zur Burka - keinen Verschluss und wird so meist mit Nadeln zusammengesteckt.

13 Jilbab im Kontext von Indonesien bezeichnet ein Kleidungsstück, das den ganzen Körper sowie die Haare bedeckt. Im Kontext von Nordafrika bezeichnet es gewöhnlich ein langes Kleid.

14 Bushiya oder Ghatwa bezeichnet ein dünnes schwarzes Tuch, das als Gesichtsschleier dient und meist in Verbindung mit Niqab getragen wird.

15 Vgl. Ernst Cassirer, Philosophie der symbolischen Formen, 3 Bde., 1. Aufl., Berlin 1923-1929, Nachdruck, 10. Aufl., Darmstadt 1994.

16 Dietmar Mieth, Symbol, in: Hubert Cancik / Burkhard Gladigow / Karl-Heinz Kohl (Hg.), Handbuch religionswissenschaftlicher Grundbegriffe V: Säkularisierung - Zwischenwesen, Stuttgart 2001, S. 134-138, hier: S. 135. 
kursiven und präsentativen Symbolen. ${ }^{17}$ Während erstere einen klar angebbaren Bezugsgegenstand aufweisen, haben präsentative Symbole keine feststehende Eigenbedeutung, weil sich diese immer nur aus dem jeweiligen Kontext ergibt. So kann etwa eine Glühbirne auf einem Schalter diesen als Lichtschalter kenntlich machen und das Symbol der Glühbirne für „Licht“ stehen, in einem anderen Kontext jedoch Symbol für Innovation und Kreativität, Idee oder Lösung sein.

Dieselbe Kontextabhängigkeit lässt sich bei religiösen Symbolen erkennen. Nicht nur, dass sie Gültigkeit primär nur innerhalb der Interpretationsgemeinschaft (z. B. einer Religionsgemeinschaft) besitzen, selbst in dieser und im Laufe der Zeit können sie nochmals unterschiedliche Deutungsvarianten erfahren.

Gerade die Diskussionen um die Bedeutung und damit auch den Grad der Verpflichtung Hijab, Burka, Niqab, Chador, Jilbab beziehungsweise Bushiya zu tragen, lassen dies besonders deutlich erkennen. Verneinen doch bereits die außer- und innerislamisch kontrovers geführten Diskussionen, vor allem aber die ungeheure Breite an Interpretationen und Varianten des islamischen Schleiers innerhalb jener Gruppierungen, die zumindest dahingehend übereinstimmen, dass das Tragen von Schleiern unterschiedlicher Art aus religiösen Gründen geboten ist, die Möglichkeit dieses Symbol als Träger einer einzigen Bedeutung zu interpretieren.

Eben weil diesen Symbolen aber ein festgelegter Bedeutungsgehalt fehlt und ein solcher auch nicht objektiv, vergleichbar einer mathematischen Formel, ${ }^{18}$ hergeleitet werden, sondern immer nur in einem konkreten Kontext und das heißt letztlich in und für eine Gruppe (d.i. Interpretationsgemeinschaft) „festgelegt" werden kann, können Hijab, Burka, Niqab, Chador, Jilbab beziehungsweise Bushiya (ebenso wie andere Symbole) theoretisch sowohl als rein religiös, als auch als rein politisch oder auch als beides zugleich oder auch in einer anderen Weise gedeutet werden. Wie im Folgenden zumindest skizzenhaft aufgezeigt werden wird, sind in der Praxis die Grenzen dabei meist fließend.

17 Susanne K. Langer, Philosophie auf neuem Wege: das Symbol im Denken, im Ritus und in der Kunst, übers. Ada Löwith, Frankfurt a. M. 1984; vgl. hierzu auch: Symbols; symbolism, in: John Bowker (ed.), The Oxford Dictionary of World Religions, Oxford-New York 1997, S. 934-935.

18 Vgl. Hans Gerald Hödl, Kopftuch, Kreuz und Menora: Der Beitrag der Symboltheorie zu aktuellen Debatten, in: feinschwarz.net - Theologisches Feuilleton am 23.07.2018, vgl. https://www.feinschwarz.net/kopftuch-kreuz-und-menora/ (letzter Zugriff: 25.01.2019). 


\section{Der islamische Schleier als "pious fashion “ ${ }^{419}$ ?}

Für die zeitgenössischen politisch stark gefärbten und häufig instrumentalisierten Diskussionen rund um den islamischen Schleier erweisen sich in diesem Zusammenhang im Besonderen die Untersuchungen der Ethikerin Elizabeth Bucar als hilfreiche Korrektur, da sie die Diskussionen vor dem Hintergrund konkreter historischer Kontexte betrachtet und damit die häufig vernachlässigten Lebensrealitäten von Frauen mit in den Blick nimmt. In diesem Zusammenhang erklärt sich auch die zum Teil absurd anmutende Fixierung auf Kleidung als solche (anstatt etwa auf globalere Themen wie Armut, Gewalt, Ausbeutung o. ä.), da diese wie Bucar betont eben häufig nicht nur funktionelle Kleidung ist, sondern kulturelles, ökonomisches und religiöses Phänomen, das letztlich auch gesellschaftliches Zusammenleben beeinflussen kann. ${ }^{20}$

Bucar arbeitet im Detail heraus, dass sich aufgrund der unterschiedlichsten sozialen, politischen und religiösen Gründe ganz allgemein eine ungeheure Komplexität der Kleidungspraktiken muslimischer Frauen zeigt, die eine einheitliche Interpretation der Motivation "pious fashion“ $z$ u tragen verbietet. ${ }^{21}$ So verweist Bucar etwa darauf, dass die zunehmende Beliebtheit von islamischen Schleiern in Indonesien gerade nicht - wie etwa in der Türkei - als Ausdruck einer Verbundenheit mit alten, traditionellen Werten, sondern als Zeichen einer neuen, zukunftsorientierten Weltsicht verstanden wird. ${ }^{22}$ Ähnliche Unterschiede lassen sich mit Blick auf den Chador erkennen, der in der Türkei vielfach als Zeichen besonderer Frömmigkeit verstanden wird, im Iran hingegen lange Zeit vor allem Symbol der Befürwortung der Revolution von 1979 war. ${ }^{23}$ Wie Bucar betont, wurde der Chador im Iran ab 2000 für Frauen zunehmend Voraussetzung, um Zugang zu politischen Ämtern zu erhalten und gleichzeitig Symbol dafür ein politisches Amt innezuhaben und strategisches Mittel gerade auch für

19 Aufgrund der spezifischen Bedeutung des Begriffs „pious fashion“ soll dieser im Folgenden im Original verwendet werden. Bucar verweist dabei auf den Umstand, dass der Begriff „fashion“ mehr ausdrückt als der Begriff der „Kleidung“, da „fashion“ nicht einen funktionalen Aspekt meint, sondern auch darüberhinausgehende, wie etwa das Moment der Identitätsstiftung und der Kommunikation. Der Begriff „pious“ soll den religiösen Aspekt zum Ausdruck bringen, der wesentlich davon geprägt ist, dass er in diesem Verständnis immer auch ethische Implikationen mit sich bringt und so auch das Moment der Moralität beinhaltet. Während Bucar sich nicht nur auf den islamischen Schleier, sondern auch auf andere modisch-religiöse Accessoires bezieht, müssen diese aufgrund des Umfangs des Beitrages ausgespart bleiben, vgl. Elizabeth Bucar, Pious Fashion. How Muslim Women Dress, Cambridge-London 2017, S. 2f. Siehe hierzu auch: Elizabeth Bucar, The Islamic Veil: A Beginner's Guide, New York 2012.

20 Bucar, Pious Fashion, S. $8 \mathrm{ff}$.

21 Ebd.

22 Ebd., S. 6.

23 Ebd., S. 48. 
Frauenrechtsaktivistinnen visuell zu signalisieren, dass ihr Einsatz dem muslimischen Gemeinwohl dient, nicht der Zurückweisung religiöser Normen: ${ }^{24}$ „[r] ather than a simple indication of Islamism, the chador [in Iran] can indicate political allegiance to the Islamic Republic, create political capital, or demonstrate social distinction. “25

Mode verstanden als nonverbale Kommunikation lässt also nicht nur Aussagen über die eigene (religiöse) Identität $\mathrm{zu}$, sondern dient häufig auch als Mittel zur Abgrenzung, wobei diese nicht nur gegenüber (vermeintlich) Andersgläubigen, sondern insbesondere auch gegenüber anderen politischen Gruppen beziehungsweise sozialen Schichten stattfindet. ${ }^{26}$ Besonders deutlich wird dies, ebenso wie die Bedeutung des Moments der Identitätsstiftung, in Ländern, in denen Muslime und Musliminnen gerade nicht der Mehrheit angehören. $^{27}$

Interessant ist in diesem Zusammenhang, dass „pious fashion“ Bucar zufolge somit nicht nur Aussagen über die eigene Person - hinsichtlich der religiösen Identität, politischen Einstellung oder moralischen Wertvorstellung - zulässt, sondern, dass damit vielfach auch Erwartungshaltungen an andere ausgedrückt werden:

„Pious fashion can also communicate [...] , a moral demand on others': by wearing modest religious dress, an individual claims to be a pious woman, and that claim in turn demands that she be treated accordingly. ${ }^{228}$

In diesem Kontext ist hervorzuheben, dass wie Bucar betont, wenn auch Frauen, die „pious fashion“ tragen davon überzeugt sind oder zumindest akzeptieren, dass ihnen dieser Kleidungsstil von der Offenbarung her vorgeschrieben ist, die Diskussion darüber was genau dies für die Praxis bedeutet, so gut wie nie in Auseinandersetzung mit Heiligen Texten stattfindet, sondern in der alltäglichen (Neu-)Zusammenstellung entsprechender Outfits. ${ }^{29}$

Die dabei sichtbar werdende enge Verbindung von Ethik, Ästhetik und moralischen Wertvorstellungen, denen durch die Kleiderwahl Ausdruck verliehen wird, ist dabei nicht als spezifisch islamisches Phänomen zu betrachten, zeigen sich ähnliche Diskussionen auch in den 60ern in Europa hinsichtlich des $\mathrm{Zu}$ sammenhangs von Moral und Minirock. ${ }^{30}$ Dabei weisen beide Diskussionen auf

24 Ebd., S. 49.

25 Ebd., S. 50.

26 Ebd., S. 14.

27 Für Österreich siehe hierzu etwa die unterschiedlichen Beiträge in: Amani Abuzahra (Hg.), Mehr Kopf als Tuch: Muslimische Frauen am Wort, 2. Aufl., Innsbruck-Wien 2018.

28 Bucar, Pious Fashion, S. 15.

29 Ebd., S. 16.

30 Cyprian Piskurek, Moral außer Mode? Der Minirock und die permissiveness der 1960er, in: Jürgen Kramer / Anette Pankratz / Claus-Ulrich Viol (Hg.), Mini \& Mini. Ikonen der Pop- 
eine kritische Auseinandersetzung mit vorgegebenen Normen und eine Inanspruchnahme eigener Deutungshoheit. Offenkundig wird dies zeitgenössisch auch in muslimischen Jugendkulturen, die über Social-Media-Kanäle und Mode, Fragen von Religion, Tradition, Zugehörigkeit, Identität, Geschlechterrollen und (Post-)Moderne diskutieren. ${ }^{31}$ Dies hat letztlich auch Einfluss auf traditionelle Argumentationen, da sich junge Muslime und Musliminnen gerade durch die populäre Kultur, die sich zum Teil als machtvolles Instrument erweist, „kritisch-reflektierend mit ihrer Identität, ihren kulturellen Ordnungs- und Regelsystemen auseinander[setzen] und [diese dadurch] transformieren. “ ${ }^{* 32}$

Wenn auch nicht übersehen werden darf, dass „pious fashion“, wie etwa der islamische Schleier die Gefahr in sich birgt als Zwangsinstrument genutzt zu werden, ist gleichzeitig anzuerkennen, dass dieselbe Kleidung in anderen Kontexten auch befreiend beziehungsweise bestärkend empfunden werden kann. ${ }^{33}$ So hebt Bucar etwa für Indonesien hervor, dass „pious fashion“ zeitgenössisch vor allem als Symbol für Kosmopolitismus, ${ }^{34}$ Kultiviertheit, muslimische Weiblichkeit und guten Geschmack gilt. Relativiert wird dies jedoch insofern als gerade in Indonesien in den letzten Jahren unterschiedliche Bestimmungen geändert und Kleidungsvorschriften eingeführt wurden, die die Freiheit der Frauen z. T. massiv beschränken. ${ }^{35}$

Gerade dies macht aber auch deutlich, dass der entscheidende Unterschied in den rechtlichen Rahmenbedingungen, sozialen Kontrollmechanismen sowie dem Bildungsstand der einzelnen Frau liegt, die letztlich in Kombination die

kultur zwischen Dekonstruktion und Rekonstruktion, Kultur- und Medientheorie, Bielefeld 2009, S. 63-74.

31 Vgl. hierzu etwa die Auftritte sogenannter Hijab-Fashionistas, vgl. https://www.hautehijab. com/blogs/hijab-fashion/28-most-influential-hijabi-bloggers (letzter Zugriff: 14.02.2019), ebenso wie Diskussionen rund um Stereotyping angesichts des Musikvideos „Somewhere in America" etwa bei Sana Saeed, Somewhere in America, Muslim Women are ,Cool', Islamic Monthly, December 2/2013, vgl. https://www.theislamicmonthly.com/somewhere-in-ameri ca-muslim-women-are-cool/ (letzter Zugriff: 14.02.2019). Für eine wissenschaftliche Auseinandersetzung sei verwiesen auf die unterschiedlichen Teilprojekte im Rahmen des Habilitationsprojekts „Muslim Lifestyle“ von Fatma Sagir, vgl. http://www.kaee.uni-freiburg. de/personen/wimi/sagir (letzter Zugriff: 14.02.2019). Sowie Fatma Sagir (Hg.), Rocking Islam. Music and the Making of New Muslim Identities, Waxmann Verlag (im Erscheinen).

32 Fatma Sagir, Mipster und Modest Fashionistas, vgl. http://www.pr.uni-freiburg.de/pm/exper tendienst/weltmaedchentag-sagir (letzter Zugriff: 14.02.2019).

33 Vgl. Bucar, Pious Fashion, S. 92.

34 Wie Bucar erläutert in diesem Kontext meist verstanden als „globally informed, as well as urban and upwardly mobile", vgl. Ebd., S. 112.

35 Vgl. hierzu: Susanne Schröter, Repressive Ästhetik, Vortrag im Rahmen der Konferenz „Das islamische Kopftuch - Symbol der Würde oder der Unterdrückung?“, Frankfurter Forschungszentrum Globaler Islam am Exzellenzcluster „Normative Ordnungen“ an der Goethe-Universität, 08.05.2019. 
Freiwilligkeit der Wahl derartiger Kleidung ebenso wie ihre Deutung beeinflussen. ${ }^{36}$

Die Sinngebung des islamischen Schleiers offen zu lassen, ist damit nicht nur Folge der Anerkennung der Realität, d.i. des Bestehens unterschiedlicher Kontexte und damit der Pluralität menschlichen Lebens. Vor allem aber ist es Konsequenz der Anerkennung von Freiheitsrechten in liberalen demokratischen Staaten, die durch die Garantie staatlicher Neutralität Freiräume gerade auch für solche Interpretationsspielräume eröffnen. Besonders deutlich zeigt sich dies wie im Folgenden näher auszuführen ist - angesichts des Rechts auf Religionsund Weltanschauungsfreiheit, zu dessen Schutzbereich auch gehört derartige Symbole tragen zu können - ebenso wie das Recht sie nicht tragen zu müssen beziehungsweise sie wieder ablegen zu können! Dabei ist angesichts zeitgenössischer Diskussionen hervorzuheben, dass wenn es auch kein uneingeschränktes Recht religiöse Symbole zu tragen gibt, eine Einschränkung derartiger Rechte in jedem Fall aber einer guten Begründung und genauen Abwägung bedarf.

\section{Der islamische Schleier und das Recht auf Religions- und Weltanschauungsfreiheit}

Für die Frage nach der Zulässigkeit einen islamischen Schleier in der Öffentlichkeit zu tragen ist es von Bedeutung zu sehen, dass aufgrund des Umstandes, dass ein Großteil der islamischen Religionsgelehrten sowie zahlreiche Musliminnen $^{37}$ die „Kopfverschleierung für die geschlechtsreife muslimische Frau nach wie vor für obligatorisch “38 halten, der islamische Schleier - innerhalb dieser Interpretationsgemeinschaften (!) - zum Zeichen der Frömmigkeit und damit zum Ausdruck der eigenen Religiosität wird. ${ }^{39}$

36 Vgl. hierzu auch Yasemin Karakasoğlu, Frauen mit Kopftuch in Deutschland, Bundeszentrale für politische Bildung, 28.06.2005, vgl. http://www.bpb.de/politik/innenpolitik/konflikt stoff-kopftuch/63273/einstieg-in-die-debatte (letzter Zugriff: 23.02.2019).

37 Exemplarisch kann hier verwiesen werden auf: Yasemin Karakasoğlu, Stellungnahme zu den Motiven von jungen Musliminnen in Deutschland für das Anlegen des Kopftuches, Essen 2003.

38 Rotraud Wielandt, Die Vorschrift des Kopftuchtragens für die muslimische Frau: Grundlagen und aktueller innerislamischer Diskussionsstand, Vortrag von Rotraud Wielandt im Rahmen der Deutschen Islam Konferenz 2008, vgl. http://www.deutsche-islam-konferenz. de/SharedDocs/Anlagen/DIK/DE/Downloads/Sonstiges/Wielandt_Kopftuch.html (letzter Zugriff: 01.02.2019).

39 Zur theologischen Begründung siehe z. B.: Bucar: The Islamic Veil, insb. Kapitel 2. 
Für den Schutzbereich der Religions- und Weltanschauungsfreiheit ist dies insofern relevant als dieses Menschenrecht ${ }^{40}$ nicht nur die Freiheit umfasst sich eine religiöse oder nicht-religiöse Weltanschauung $\mathrm{zu}$ bilden, eine solche $\mathrm{zu}$ wählen oder sich der Wahl zu enthalten, sondern auch die Freiheit seiner Überzeugung alleine und in Gemeinschaft, privat und öffentlich Ausdruck zu verleihen. Dabei besteht die - für das freiheitliche Moment der Religions- und Weltanschauungsfreiheit zentrale - zweifache (positive und negative) Dimension des Rechts darin, dass zu der Gewährleistung darüber hinaus zählt, dass kein Mensch gezwungen werden darf seiner Überzeugung Ausdruck zu verleihen beziehungsweise an religiösen Handlungen teilzunehmen. So ist auch das Recht, seinen Glauben zu wechseln, also das Recht aus einer Religionsgemeinschaft auszutreten, um in eine neue einzutreten, ebenso wie das Recht sich nach Austritt aus einer Gemeinschaft keiner anderen anzuschließen, ausdrücklich in Art.9 Abs.1 der Europäischen Menschenrechtskonvention verankert. ${ }^{41}$

Das Tragen eines islamischen Schleiers als Ausdruck der eigenen religiösen Überzeugung fällt somit in den Schutzbereich der Religions- und Weltanschauungsfreiheit. Dabei ist es von Bedeutung zu sehen, dass dies zugleich den Zwang ein derartiges Symbol zu tragen ausschließen muss, da die positive und die negative Dimension der Religionsfreiheit „gleichrangige Erscheinungsformen des mehrdimensionalen Grundrechts sind“". ${ }^{42}$ Daraus folgt zwar nicht zwingend, dass der islamische Schleier als Folge der Religionsfreiheit immer und überall getragen werden kann, da das Recht auf Religions- und Weltanschauungsfreiheit nicht absolut gilt, dass aber eine Einschränkung dieses Rechts gut begründet und bei möglichen Spannungen oder Kollisionen, die zwischen der positiven und der negativen Dimension der Religionsfreiheit entstehen können, „im Wege ,praktischer Konkordanz' (K. Hesse) zu einem schonenden Ausgleich zu bringen “43 sind. Demzufolge muss auch bei einer Kollision von Grundrechten das Hauptaugenmerk darauf liegen eine Lösung zu finden, die die Verwirklichung beider Rechte so gut wie möglich gewährleistet. Eine Begrenzung der Grundrechte bedarf also einer besonderen Prüfung und einer Achtung des Verhältnismäßigkeitsprinzips.

40 Garantiert in Art. 9 der Europäischen Menschenrechtskonvention, dem Art. 18. des Internationalen Pakts über bürgerliche und politische Rechte 1966 und in der Verfassung der Vereinigten Staaten durch die Verankerung des Rechts auf Religionsfreiheit in dieser, vgl. z. B. Europäische Menschenrechtskonvention, Art. 18, vgl. https://www.echr.coe.int/Documents/ Convention_DEU.pdf (letzter Zugriff: 15.04.2019).

41 Vgl. Irene Klissenbauer, Das Ringen um Religionsfreiheit. Die Positionen von John Courtney Murray und Fethullah Gülen im Vergleich, ReligionsRecht im Dialog 19, Wien 2015, S. 41.

42 Ebd.

43 Richard Potz / Brigitte Schinkele, Religionsrecht im Überblick, 2. überarb. Aufl., Wien 2007, S. 31. 
Für die Frage nach der Zulässigkeit einen islamischen Schleier in der Öffentlichkeit zu tragen ergibt sich daraus einerseits die Notwendigkeit Varianten des islamischen Schleiers voneinander zu unterscheiden und andererseits $\mathrm{zu}$ differenzieren in welcher Position eine Frau steht, die einen islamischen Schleier in der Öffentlichkeit tragen möchte. Je nachdem sind unterschiedliche Rechtsfragen miteinander verknüpft, die im Detail zu betrachten und im Konfliktfall gegeneinander abzuwägen sind.

So sind etwa, wie Böckenförde ausführlich darstellt, bei der Hijab-tragenden Lehrerin ihre Bekenntnisfreiheit, ihr Zugangsrecht zum öffentlichen Lehramt unabhängig von ihrem Bekenntnis, der Bildungs- und Erziehungsauftrag der staatlichen Schule in Verbindung mit dem Prinzip religiös-weltanschaulicher Neutralität, die negative Bekenntnisfreiheit der Schüler und Schülerinnen beziehungsweise deren Eltern sowie das elterliche Erziehungsrecht einander zuzuordnen und im Konfliktfall zu einem Ausgleich bringen. ${ }^{44}$

Stärkstes Argument mag hier die von Seiten der Lehrperson geforderte Repräsentation des Staates und damit seiner religiös-weltanschaulicher Neutralität sein, wiewohl zu diskutieren wäre, ob diese nicht stärker durch Verhalten und Äußerungen zum Ausdruck kommt, als durch etwaige Kleidungsstücke beziehungsweise inwiefern Lehrpersonen auch als Individuen mit persönlichen Weltanschauungen auftreten können und im Sinne der für gelingenden Unterricht notwendigen Authentizität sogar müssen. ${ }^{45}$ Dabei ist es von Bedeutung zu sehen, dass die hierbei geforderte Neutralität in jedem Fall nur für Lehrpersonen, nicht jedoch für Lernende gilt. So steht bei der Frage nach der Zulässigkeit islamische Kopftücher in Schulen als Lernende zu tragen die positive Religionsfreiheit der betreffenden Schülerin sowie ihr Recht auf Bildung der negativen Religionsfreiheit etwaiger Mitschüler und Mitschülerinnen gegenüber. Berichte über Ausgrenzungsmechanismen und religiös motiviertes Mobbing in Schulen sind in diesem Kontext durchaus ernst zu nehmen, ${ }^{46}$ sollten aber nicht zu vorschnellen Einschränkungen von Menschenrechten, wie dem Recht auf Religions-

44 Ernst-Wolfgang Böckenförde, „Kopftuchstreit“ auf dem richtigen Weg?, in: Neue Juristische Wochenschrift 54/10/Oktober 2001, S. 723-728, hier: S. 723. Siehe hierzu auch: Heiner Bielefeldt, Zur aktuellen Kopftuchdebatte in Deutschland. Anmerkungen aus der Perspektive der Menschenrechte, Deutsches Institut für Menschenrechte, Policy Paper Nr. 3, Berlin 2004.

45 Vgl. hierzu etwa den Vortrag von Christoph Kolbe, Sinn im Unterricht - Authentisch lehren, in: Zeitschrift Existenzanalyse in Pädagogik und Schule am 27.01.2010, S. 25-28; Ders., Die personale Motivation und Dialogfähigkeit in der Pädagogik, in: Kurt Aregger / Eva Maria Waibel (Hg.), Schulleben und Lebensschule. Beiträge einer existentiellen Pädagogik, Donauwörth-Luzern 2006, S. 36-46.

46 Vgl. Susanne Wiesinger, Kulturkampf im Klassenzimmer: Wie der Islam die Schulen verändert. Bericht einer Lehrerin, Wien 2018. Siehe hierzu auch: Melisa Erkurt, Generation Haram, in: Biber am 06.12.2016, vgl. https://www.dasbiber.at/content/generation-haram (letzter Zugriff: 15.03.2019). 
und Weltanschauungsfreiheit, führen, zumal es dadurch - wie näher auszuführen ist - gerade für Frauen und Mädchen häufig nicht zu einer Entlastung, sondern zu Mehrfachdiskriminierungen kommt, weil sie so nicht nur Gefahr laufen aufgrund ihres Frau-seins, sondern zusätzlich auch aufgrund ihrer Religion diskriminiert zu werden.

Im Hintergrund dabei - dies gilt für die Frage der Zulässigkeit unterschiedlicher Bekleidungen von Lehrpersonen und Lernenden gleichermaßen - steht die bisher nur unzureichend geführte Diskussion über die Bedeutung und vor allem die Umsetzung des Auftrags an Schulen zwangsfreie Räume zu bieten. Im Besonderen hierbei zu beachten ist die Frage, wie Lernende den Umgang mit Pluralität - als eine notwendige Kompetenz heutiger Zeit - einüben können beziehungsweise welche Verantwortung hierbei Schulen und Lehrpersonen zukommt.

Eine etwas andere Konstellation ergibt sich hinsichtlich der Frage nach der Zulässigkeit Burka, Niqab beziehungsweise Bushiya in der Öffentlichkeit zu tragen. So stehen hierbei, wie etwa das Anti-Gesichtsverhüllungsgesetz in Österreich zeigt, ${ }^{47}$ der Religionsfreiheit der Burka-, Niqab- beziehungsweise Bushiya-tragenden Frau sicherheitspolitische Bedenken, aber auch die Sorge um die Sicherung „der zwischenmenschlichen Kommunikation im öffentlichen Raum “48, die als „wesentliche Funktionsbedingung für ein friedliches Zusammenleben “49 beschrieben wird, gegenüber. Deutlich wird zweiteres vor allem auch angesichts Burka-, Niqab- beziehungsweise Bushiya-tragenden Schülerinnen, wo die Frage der Möglichkeit offener Kommunikation zwischen Lehrperson (sowie Mitschülern und Mitschülerinnen) und Lernender zu diskutieren wäre. Dabei ist anzumerken, dass gerade für den schulischen Kontext in Österreich jedoch kaum Fälle von Gesichtsschleier-tragenden Mädchen dokumentiert sind. ${ }^{50}$

Die in der Rechtsprechung diskutierten Fälle zeigen deutlich, dass es gute Gründe für eine Einschränkung der Religionsfreiheit und damit auch des Rechts religiöse Symbole zu tragen geben kann. Etwa immer dann, wenn Sicherheitsbedenken höher zu bewerten sind, wie deutlich wird etwa angesichts der Verbots beim Lenken eines Autos Bekleidung zu tragen, die die Sicht eingeschränkt.

47 Vgl. hierzu auch Benedikt Kommenda, Islam und Recht. Kein Minarett und keine Burka, in: Rainer Nowak / Erich Kocina (Hg.), Gehört der Islam zu Österreich, Wien-Graz-Klagenfurt 2017, S. 95-103, besonders: S. $101 \mathrm{ff}$.

48 Bundesministerium für Inneres, Verbot Gesichtsverhüllung in Österreich - Information zum Anti-Gesichtsverhüllungsgesetz (AGesVG), vgl. https://www.bmeia.gv.at/reise-aufenthalt/ einreise-und-aufenthalt-in-oesterreich/vollverschleierungsverbot-in-oesterreich/ (letzter Zugriff: 01.02.2019) [in Kraft seit 1. Oktober 2017].

49 Ebd.

50 Dasselbe gilt für den öffentlichen Raum, sodass das Tragen von Burka, Niqab bzw. Bushiya in Österreich als Randphänomen gesehen werden kann. 
Gerade die unterschiedlichen Beispiele lassen aber auch deutlich werden, das derartige Verbote auf konkrete Situationen und Orte abstellen müssen, so der den Menschenrechten inhärenten Forderung, Menschenrechte nicht gegeneinander auszuspielen, Rechnung getragen werden soll. Die daraus folgende notwendige Einzelfallabwägung erscheint umso dringlicher als bei all diesen Diskussionen - neben der politischen Dimension derartiger Debatten - die Frage hinzukommt, inwieweit Frauen (vor allem Mädchen) tatsächlich frei sind den islamischen Schleier zu tragen beziehungsweise abzulegen. Sich dieser Frage zu widmen ist Teilbereich auch eines Einsatzes für Frauenrechte. Aus ihrem Gesichtspunkt sind besonders jene Fälle zu problematisieren, in denen das Tragen eines islamischen Schleiers Frauen unter Zwang vorgeschrieben ist. Wo dies der Fall ist, erweist sich der islamische Schleier - wenn auch nicht für alle Frauen ausschließlich - der Intention der politischen und/oder religiösen Machthaber nach stets als Mittel, Frauen aus der Öffentlichkeit auszugrenzen. ${ }^{51}$

Ein derartiges Vorgehen - auch dies ist angesichts zeitgenössischer Diskussionen besonders zu betonen - verstößt nicht nur gegen die in den Menschenrechten festgeschriebene Gleichberechtigung von Männern und Frauen, sondern auch gegen das Recht auf Religions- und Weltanschauungsfreiheit. Nicht zuletzt aus diesem Grund trägt eine zum Teil aus diesen problematischen Verhältnissen von Frauen abgeleitete Priorisierung von Frauenrechten gegenüber dem Recht auf Religions- und Weltanschauungsfreiheit nicht dazu bei Frauen vor Unterdrückung und Diskriminierung zu schützen. ${ }^{52}$ Vielmehr schadet eine derartige Hierarchisierung - wie im Folgenden darzustellen ist - letztlich den Menschenrechten als solchen und damit auch allen Frauen (und Männern), nicht zuletzt weil eine solche Gegenüberstellung zahlreiche Missverständnisse hinsichtlich der beiden Rechtsbereiche aufweist.

51 Siehe etwa die Gesetzeslage im Iran, wo auch ein „schlecht getragener“ Hijab z. T. geahndet wird, vgl. etwa Bucar, Pious Fashion, S. 24-73.

52 Zur Hierarchisierung dieser siehe: Anne Jenichen, Frauenrechte und Religionsfreiheit in Europa - ein Plädoyer für Versöhnung statt Hierarchisierung, in: Karrieren und Lebenswelten - Irritationen, Dynamiken, Strategien 6/3/2014, S. 139-146; Roger Trigg, Equality, Freedom \& Religion, Oxford 2013; Abdelfattah Amor, Study on Freedom of Religion or Belief and the Status of Women in the Light of Religion and Traditions, Report submitted by Mr. Abdelfattah Amor, Special Rapporteur, in accordance with Commission on Human Rights resolution 2001/42, vgl. https://documents-dds-ny.un.org/doc/UNDOC/GEN/G08/110/35/ PDF/G0811035.pdf?OpenElement (letzter Zugriff: 12.02.2019). 


\section{Frauenrechte und Religions- und Weltanschauungsfreiheit im Konflikt?}

Die zeitgenössisch sowohl in öffentlichen Diskussionen als auch der Rechtsprechung sichtbar werdende Hierarchisierung von Frauenrechten und Religions- und Weltanschauungsfreiheit erscheint vor allem deshalb so problematisch, ${ }^{53}$ weil sie dem Menschenrechtsverständnis an sich widerspricht. So sind - etwa der Wiener Deklaration von 1993 zufolge - Menschenrechte immer so zu interpretieren, dass sie einander verstärken und nicht zerstören.

Problematisch erscheint ein solcher Zugang aber auch deshalb, weil er Frauen dazu zwingt zwischen zwei bloß vermeintlichen Gegensätzen zu wählen, obwohl der damit aufgebaute abstrakte Antagonismus zwischen den beiden Menschenrechten der Lebensrealität zahlreicher Frauen nicht entspricht. Vielmehr führt dieser häufig zu einer Mehrfachdiskriminierung ${ }^{54}$ und damit zu einer zusätzlichen Belastung und Einschränkung von Frauen.

Besonders deutlich wird dies in jenen Fällen, in denen das Recht von Frauen auf freie Religionsausübung durch eine vorschnelle Kriminalisierung religiöser Praktiken eingeschränkt wird. So ist hervorzuheben, dass auch wenn Frauenrechte und das Recht auf Religions- und Weltanschauungsfreiheit kollidieren können, sie nicht prinzipiell gegensätzlich sind, sondern dass vielmehr die Geschlechtergleichstellung auch das Recht von Frauen auf freie Religionsausübung umfasst. ${ }^{55}$ Dies hervorzuheben ist zentral, weil gerade auch die Religionsausübung ebenso wie die Interpretation von Religion geschlechterspezifisch geprägt sein kann. Im Kampf um Frauenrechte spielt der gleichzeitige Einsatz für Religionsfreiheit aber auch deshalb eine in seiner Bedeutung kaum zu überschätzende Rolle, weil eben diese garantiert, dass Frauen (ebenso wie Männer) nicht aufgrund ihrer Weltanschauung unterdrückt und diskriminiert werden dürfen.

Ein Frauenrechte und Religions- und Weltanschauungsfreiheit verbindender Einsatz ist somit einerseits aufgrund der individuellen Dimension und dem damit notwendigen Schutz vor Diskriminierung und Einschränkung der Religions- und Weltanschauungsfreiheit von Bedeutung. Zentral ist ein solcher Fokus auf die Religions- und Weltanschauungsfreiheit als Teil der Frauenrechte aber andererseits auch deshalb, weil es gerade die Religions- und Weltanschauungsfreiheit ist, die die notwendigen Freiräume schafft, um auch die religiöse Legitimierung der Unterdrückung von Frauen und damit die Frage nach

53 Vgl. hierzu u. a. Jenichen, Frauenrechte und Religionsfreiheit; etwas allgemeiner zur Frage nach Gleichheit, Freiheit und Religionen mit besonderem Blick auf Antidiskriminierungsrichtlinien vgl. Trigg, Equality.

54 Heiner Bielefeldt / Nazila Ghanea / Michael Wiener, Women, in: Ibid, Freedom of Religion or Belief. An International Law Commentary, Oxford 2015, S. 363-389, hier: S. 366.

55 Jenichen, Frauenrechte und Religionsfreiheit, S. 39. 
der prinzipiellen Deutungshoheit innerhalb von Religionsgemeinschaften kritisch aufzugreifen. Durch eben diese hierbei eröffneten Freiräume könnten und müssten auch die Religionen zum Einsatz für Geschlechtergerechtigkeit beitragen. Umso mehr als gerade die monotheistischen Religionen, als prophetische Religionen „von ihrem Grundverständnis her ein beachtliches Potential für gesellschaftlichen Widerstand gegen jede Form von ungerechter Herrschaft ${ }^{\text {“ }}{ }$ enthalten.

Neben der großen Bedeutung, die eine solche Reflexion von Machtansprüchen und Deutungshoheiten für Frauen selbst hat, ist diese auch für Religionen kaum zu überschätzen, da emanzipatorische Ansätze dadurch auch in diese hineingetragen werden können. Dies wiederum wirkt auf den Einsatz für Frauenrechte selbst zurück.

Eine Folge eines derartigen Fokus auf die Religions- und Weltanschauungsfreiheit als Teil der Frauenrechte wäre demnach religiöse (auch innerreligiöse!) Pluralität ernst zu nehmen, ebenso wie den Umstand, dass auch Emanzipationsbestrebungen unterschiedlich aussehen können.

\section{Für Frauenrechte und das Recht auf Religions- und Weltanschauungsfreiheit}

Wenn es auch unstrittig ist, dass der islamische Schleier ganz klar Zeichen der Unterdrückung sein kann und in diesen Fällen als Zwangsinstrument genutzt wird, ist zu betonen, dass er zugleich immer auch anderes sein kann - nämlich Symbol der Religionszugehörigkeit, Teil der Identität und Zeichen einer selbstgesetzten Grenze der Intimität. ${ }^{57}$

Aufgrund der präsentativen Symbolen innewohnenden Offenheit und Kontextabhängigkeit muss eine in zeitgenössischen Diskussionen häufig sichtbar werdende Fixierung auf eine eindeutige und letztgültige Interpretation ihrer Bedeutung unbefriedigend bleiben. Gerade mit Blick auf einen Einsatz für Frauenrechte sollte demgegenüber stärker hervorgehoben werden, dass der islamische Schleier - ebenso wie andere religiöse Symbole - letztlich nur dann

56 Ingeborg Gabriel, Menschenrechte und Religionen - Verbündete oder Gegner?, in: Peter G. Kirchschläger (Hg.), Die Verantwortung von nichtstaatlichen Akteuren gegenüber den Menschenrechten, Religionsrechtliche Studien 4, Zürich 2017, S. 33-52, hier: S. 43; aber auch: Dies., Menschenrechte. Perspektiven christlicher Ethik, in: Staatslexikon. Recht Wirtschaft - Gesellschaft 3: Herrschaft - Migration, 8. völlig neu bearb. Aufl., Freiburg i. Br. 2019, Sp. 1547-1552, hier: Sp. 1550f.

57 Mansur Seddiqzai, Kopftuch: Wie freiwillig ist die Entscheidung?, in: Die Zeit am 05.04. 2018, vgl. https://www.zeit.de/gesellschaft/zeitgeschehen/2018-03/kopftuch-islam-frauenfreiheit-unterdrueckung-zukunft/seite-2 (letzter Zugriff: 01.03.2019). 
wirklich „Zeichen der Freiheit“ sein kann, wenn Religions- und Weltanschauungsfreiheit und Gleichberechtigung aller Menschen garantiert sind. Erst dies ermöglicht nämlich die Inanspruchnahme positiver ebenso wie negativer Freiheit gleichermaßen, wodurch eine wirkliche Entscheidung für oder gegen ein Symbol erst getroffen werden kann.

Nicht zuletzt aus diesem Grund erscheinen einfache Verbote religiöser Symbole ohne Beachtung des je konkreten Kontextes nicht hilfreich zu sein. Im Besonderen da diese die für die freiheitliche Wirkung des Rechts auf Religionsfreiheit zentrale doppelte Dimension dieses Rechts und damit den Umstand missachten, dass der Einsatz für die Freiheit den islamischen Schleier nicht zu tragen bzw. ihn ablegen zu können, Hand in Hand gehen muss mit dem Einsatz für die Freiheit den islamischen Schleier tragen zu können. Höchst problematisch erweisen sich Lösungsversuche mittels Verboten aber auch dadurch, dass sie die konkreten Lebensrealitäten und damit das Potential für Frauenrechte auch religiöse Machtansprüche kritisch zu reflektieren und Deutungshoheit auch für sich selbst zu beanspruchen außer Acht lassen.

Statt also einen bloß vermeintlichen Gegensatz zwischen Frauenrechten und dem Recht auf Religions- und Weltanschauungsfreiheit beziehungsweise zwischen Emanzipation und Religiosität aufzumachen, sollte das Hauptaugenmerk vielmehr darauf liegen, Frauen und vor allem jungen Mädchen Zugang zu Bildung, vor allem aber zu Handlungsmacht zu garantieren und sie darin zu unterstützen selbstständig und unabhängig leben zu können. ${ }^{58}$ Um dies zu ermöglichen gilt es ganz generell Strukturen und Praktiken zu bekämpfen, die Geschlechterungleichheit stützen. Dazu gilt es einerseits „die Autonomie von Frauen auf Kosten der von Religionsgemeinschaften zu stärken sowie ihre sozialen, ökonomischen, rechtlichen und politischen Lebensbedingungen so $\mathrm{zu}$ ändern, dass sie individuelle Wahlmöglichkeiten auch tatsächlich haben. ${ }^{\text {“59 }}$ Andererseits müssen Religionen und ihre Traditionen auf geschlechtsspezifische Stereotype kritisch befragt werden. Gerade hierfür müssen Frauen auch hinsichtlich ihrer Fähigkeit bestärkt werden sich theologischen Fragen zu widmen. Gelingen kann dies vor allem dadurch, dass die Vielfalt innerhalb von Religionen ebenso wie jene der Wege der Emanzipation anerkannt und gestärkt werden und die Menschenrechte gemeinsam bejaht und in der Praxis umgesetzt werden. Gerade den Religionen kommt hierbei, aufgrund der Notwendigkeit die Menschenrechte auch theologisch und ethisch aus den Glaubenstraditionen zu fundieren, entscheidende Bedeutung $\mathrm{zu}^{60}$

58 Vgl. Jenichen, Frauenrechte und Religionsfreiheit, S. 142.

59 Ebd.

60 Vgl. Gabriel, Menschenrechte und Religionen, S. 34. 
In diesem Kontext gilt es auch einer Instrumentalisierung von frauenrechtlichen Anliegen entgegenzuwirken, ${ }^{61}$ die sich in jenen Debatten zeigt, in denen sich der (bloß vermeintliche) Einsatz für Frauenrechte letztlich auf eine „Abgrenzung einer ,modernen' und ,liberalen' Gesellschaft von ,traditionellen ' und ,illiberalen' Gesellschaften “62 beschränkt. Besonders deutlich wird dieser Missbrauch frauenrechtlicher Anliegen dabei dadurch, dass viele Verschleierungsverbote fordernde politische Akteure und Akteurinnen sich dabei ausschließlich gegen den Islam und Migration wenden, sich jedoch nicht für Geschlechtergerechtigkeit als solche einsetzen, sondern bloß für eine Ausgrenzung bestimmter nicht als zugehörig definierter Gruppen, was sie letztlich selbst als illiberal entlarvt. $^{63}$

Angesichts der Diskussionen um den islamischen Schleier zeigt sich dies besonders häufig, wobei übersehen wird, dass die Tendenz Kleidung von Frauen vorrangig als Ausdruck ihrer Persönlichkeit und ihrer moralischen Wertvorstellungen (und damit ihrer Schutzwürdigkeit) zu deuten nicht nur auf mehrheitlich muslimisch geprägte Länder beziehungsweise Communities beschränkt ist. Dieselbe Problematik wird auch in Europa augenscheinlich wie etwa zuletzt im Rahmen der Gerichtsfälle rund um die Vergewaltigungsvorwürfe von GinaLisa Lohfink in Deutschland ${ }^{64}$ beziehungsweise in Anbetracht des Freispruchs in einem Vergewaltigungsprozess in Irland, der eine unter dem Hashtag \#ThisIsNotConsent ${ }^{65}$ bekanntgewordene Protestwelle nach sich zog. ${ }^{66}$

Dies zu betonen ist mit Blick auf die Frage nach der Zulässigkeit islamische Schleier in der Öffentlichkeit zu tragen vor allem deshalb von Bedeutung, weil es deutlich macht, dass die im Hintergrund stehenden Diskussionen - um Frauenund Männerbilder und Geschlechtergerechtigkeit - weltweit unabgeschlossen sind. Dasselbe gilt für den weltweit notwendigen Einsatz für Frauenrechte. ${ }^{67}$

61 Brigitte Theißl, Law and Order statt „heilige“ Frauenrechte, in: dieStandard am 27.09.2017, vgl. https://derstandard.at/2000064800343/Law-and-Order-statt-heilige-Frauenrechte (letzter Zugriff: 01.03.2019).

62 Jenichen, Frauenrechte und Religionsfreiheit, S. 141.

63 Leila Hadj Abdou, „Gender Nationalism“: The new (old) politics of belonging, in: OZP Austrian Journal of Political Science Vol. 46/1/2017, S. 83-88, insb. S. $85 \mathrm{ff}$.

64 Vgl. etwa Dagmar Rosenfeld, Gina-Lisa Lohfink: Der falsche Fall, in: Die Zeit am 23. 06. 2016, https://www.zeit.de/2016/27/gina-lisa-lohfink-vergewaltigung-sexualstrafrecht (letzter Zugriff: 01.03.2019).

65 Vgl. https://www.thisisnotconsent.com/ (letzter Zugriff: 01.03.2019).

66 Proteste nach Prozess um Vergewaltigung in Irland: Ein Tanga ist kein Ja, dieStandard am 15. 11.2018, vgl. https://derstandard.at/2000091399522/Proteste-in-Irland-Ein-Tanga-ist-keinJa (letzter Zugriff: 01.03.2019).

67 United Nations Human Rights, Women's Rights are Human Rights, Geneva-New York 2014, insb. S. 41-117. Für einen guten Überblick über die unterschiedlichsten Problemfelder im Bereich der Frauenrechte mit aktuellen Zahlen siehe die Studien und Berichterstattungen: https://www.hrw.org/de/topic/frauenrechte (letzter Zugriff: 23.02.2019). 
Gerade hierbei spielen religiöse Frauenrechtsorganisationen und Theologinnen und Theologen, die sich der Umsetzung der Geschlechtergerechtigkeit verschrieben haben, eine zentrale Rolle, umso mehr als sie dazu beitragen können, bisher unterbelichtete Mehrfachdiskriminierungen, ${ }^{68}$ aufzuzeigen und unterschiedliche Lebensrealitäten und Emanzipationswege als Bereicherung in die Diskussionen einzubringen. Kaum zu überschätzen ist dabei ihre Rolle auch innerhalb der eigenen Interpretationsgemeinschaft, in der gerade durch diese neue Diskussionen angestoßen werden können. ${ }^{69}$

Ein echter Einsatz für Religions- und Weltanschauungsfreiheit kann nur dann als solcher gelten, wenn er die positive und die negative Komponente dieser Freiheit gleichermaßen verteidigt und sich für die Freiheit aller Menschen - Männer und Frauen gleichermaßen - stark macht. Religions- und Weltanschauungsfreiheit muss also letztlich in Verbindung stehen mit einem Einsatz für Frauenrechte. Gleichzeitig muss ein Kampf für Frauenrechte deutlich machen, dass das Recht auf Religions- und Weltanschauungsfreiheit Teil der Frauenrechte ist, nicht zuletzt, weil die Garantie sich eine religiöse oder nicht-religiöse Weltanschauung zu bilden, eine solche zu wählen und nach eigenem Ermessen und in Freiheit zum Ausdruck zu bringen (oder dies nicht zu tun!) für Frauen ebenso gelten muss, wie für Männer. ${ }^{70}$

\section{Quellen}

Abuzahra, Amani (Hg.), Mehr Kopf als Tuch: Muslimische Frauen am Wort, 2. Aufl., Innsbruck-Wien 2018.

Amor, Abdelfattah, Study on Freedom of Religion or Belief and the Status of Women in the Light of Religion and Traditions, Report submitted by Mr. Abdelfattah Amor, Special Rapporteur, in accordance with Commission on Human Rights resolution 2001/42, vgl. https://documents-dds-ny.un.org/doc/UNDOC/GEN/G08/110/35/PDF/G0811035.pdf? OpenElement (letzter Zugriff: 12.02.2019).

Ateş, Seyran, Der Multikulti-Irrtum: Wie wir in Deutschland besser zusammenleben können, 6. Aufl., Berlin 2016.

Baghajati, Carla Amina, Muslimin sein: 25 Fragen - 25 Orientierungen, Innsbruck 2015. Baghajati, Carla Amina / Elibol, Zeynep (Projektleiterinnen), Deklaration „Musliminnen am Wort. Gegen jede Verbotspolitik auf unseren Köpfen! Für unser Selbstbestimmungsrecht! Und die volle Teilhabe an einer pluralen Gesellschaft!“, am 12.03.2019 in

68 Vgl. hierzu Bielefeldt / Ghanea / Wiener: Women, S. 366.

69 Für den katholischen Bereich siehe hier etwa: Ingeborg Gabriel, Time to renew the Church's commitment to women, in: CTEWC-Forum, vgl. http://www.catholicethics.com/forum-sub missions/time-to-renew-the-churchs-commitment-to-women (letzter Zugriff: 15.03.2019).

70 Ich danke Astrid Mattes-Zippenfenig für die kritische Lektüre des Manuskripts und die hilfreichen Hinweise und Anmerkungen. 
Wien präsentiert, vgl. http://www.derislam.at/iggo/index.php?f=news\& shownews= 2136 (letzter Zugriff: 13.03.2019).

Bielefeldt, Heiner / Ghanea, Nazila / Wiener, Michael, Women, in: Ibid, Freedom of Religion or Belief. An International Law Commentary, Oxford 2015, S. 363-389.

Bielefeldt, Heiner, Zur aktuellen Kopftuchdebatte in Deutschland. Anmerkungen aus der Perspektive der Menschenrechte, Deutsches Institut für Menschenrechte, Policy Paper Nr. 3, Berlin 2004.

Bowker, John (ed.), The Oxford Dictionary of World Religions, Oxford-New York 1997, S. 934-935 [Symbols; symbolism].

Böckenförde, Ernst-Wolfgang, „Kopftuchstreit“ auf dem richtigen Weg?, in: Neue Juristische Wochenschrift 54/10/Oktober 2001, S. 723-728.

Bucar, Elizabeth, Pious Fashion. How Muslim Women Dress, Cambridge-London 2017.

Bucar, Elizabeth, The Islamic Veil: A Beginner's Guide, New York 2012.

Bundesministerium für Inneres, Verbot Gesichtsverhüllung in Österreich - Information zum Anti-Gesichtsverhüllungsgesetz (AGesVG), vgl. https://www.bmeia.gv.at/reise-auf enthalt/einreise-und-aufenthalt-in-oesterreich/vollverschleierungsverbot-in-oester reich/ (letzter Zugriff: 01.02.2019).

Cassirer, Ernst, Philosophie der symbolischen Formen, 3 Bde., 1. Aufl., Berlin 1923-1929, Nachdruck 10. Aufl., Darmstadt 1994.

Erkurt, Melisa, Generation Haram, in: Biber am 06.12.2016, vgl. https://www.dasbiber.at/ content/generation-haram (letzter Zugriff: 15.03.2019).

Europäische Menschenrechtskonvention, Art. 18, vgl. https://www.echr.coe.int/Docu ments/Convention_DEU.pdf (letzter Zugriff: 15.04.2019).

Gabriel, Ingeborg, Menschenrechte. Perspektiven christlicher Ethik, in: Staatslexikon. Recht - Wirtschaft - Gesellschaft 3: Herrschaft - Migration, hrsg. von Görres-Gesellschaft und Herder Verlag, 8. völlig neu bearb. Aufl., Freiburg i. Br. 2019, Sp.1547-1552.

Gabriel, Ingeborg, Time to renew the Church's commitment to women, in: CTEWCForum, vgl. http://www.catholicethics.com/forum-submissions/time-to-renew-thechurchs-commitment-to-women (letzter Zugriff: 15.03.2019).

Gabriel, Ingeborg, Das Kreuz im Widerstreit, in: Christ in der Gegenwart 24/2018, S. $269-270$.

Gabriel, Ingeborg, Menschenrechte und Religionen - Verbündete oder Gegner?, in: Peter G. Kirchschläger (Hg.), Die Verantwortung von nichtstaatlichen Akteuren gegenüber den Menschenrechten, Religionsrechtliche Studien 4, Zürich 2017, S. 33-52.

Hadj Abdou, Leila, „Gender Nationalism“: The new (old) politics of belonging, in: OZP Austrian Journal of Political Science Vol. 46/1/2017, S. 83-88.

Hödl, Hans Gerald, Kopftuch, Kreuz und Menora: Der Beitrag der Symboltheorie zu aktuellen Debatten, in: feinschwarz.net - Theologisches Feuilleton am 23.07.2018, vgl. https://www.feinschwarz.net/kopftuch-kreuz-und-menora/ (letzter Zugriff: 25.01. 2019).

Jenichen, Anne, Frauenrechte und Religionsfreiheit in Europa - ein Plädoyer für Versöhnung statt Hierarchisierung, in: Karrieren und Lebenswelten - Irritationen, Dynamiken, Strategien 6/3/2014, S. 139-146.

Karakasoğlu, Yasemin, Frauen mit Kopftuch in Deutschland, Bundeszentrale für politische Bildung, 28.06.2005, vgl. http://www.bpb.de/politik/innenpolitik/konfliktstoff-kopf tuch/63273/einstieg-in-die-debatte (letzter Zugriff: 23.02.2019). 
Karakasoğlu, Yasemin, Stellungnahme zu den Motiven von jungen Musliminnen in Deutschland für das Anlegen des Kopftuches, Essen 2003.

Klissenbauer, Irene, Das Ringen um Religionsfreiheit. Die Positionen von John Courtney Murray und Fethullah Gülen im Vergleich, ReligionsRecht im Dialog 19, Wien 2015.

Kolbe, Christoph, Sinn im Unterricht - Authentisch lehren, in: Zeitschrift Existenzanalyse in Pädagogik und Schule am 27.01.2010, S. 25-28.

Kolbe, Christoph, Die personale Motivation und Dialogfähigkeit in der Pädagogik, in: Kurt Aregger / Eva Maria Waibel (Hg.), Schulleben und Lebensschule. Beiträge einer existentiellen Pädagogik, Donauwörth-Luzern 2006, S. 36-46.

Kommenda, Benedikt, Islam und Recht. Kein Minarett und keine Burka, in: Rainer Nowak / Erich Kocina (Hg.), Gehört der Islam zu Österreich, Wien-Graz-Klagenfurt 2017, S. 95-103.

Langer, Susanne K., Philosophie auf neuem Wege: das Symbol im Denken, im Ritus und in der Kunst, übers. Ada Löwith, Frankfurt a. M. 1984.

Mieth, Dietmar, Symbol, in: Hubert Cancik / Burkhard Gladigow / Karl-Heinz Kohl (Hg.), Handbuch religionswissenschaftlicher Grundbegriffe V: Säkularisierung - Zwischenwesen, Stuttgart 2001, S. 134-138.

Nussbaum, Martha, Veiled Threats?, in: The Opinion Pages in The New York Times am 11.07.2010, vgl. https://opinionator.blogs.nytimes.com/2010/07/11/veiled-threats/ (letzter Zugriff: 13.06.2019).

Piskurek, Cyprian, Moral außer Mode? Der Minirock und die permissiveness der 1960er, in: Jürgen Kramer / Anette Pankratz / Claus-Ulrich Viol (Hg.), Mini \& Mini. Ikonen der Popkultur zwischen Dekonstruktion und Rekonstruktion, Kultur- und Medientheorie, Bielefeld 2009, S. 63-74.

Potz, Richard / Schinkele, Brigitte, Religionsrecht im Überblick, 2. überarb. Aufl., Wien 2007.

Rosenfeld, Dagmar, Gina-Lisa Lohfink: Der falsche Fall, in: Die Zeit am 23.06.2016, https://www.zeit.de/2016/27/gina-lisa-lohfink-vergewaltigung-sexualstrafrecht (letzter Zugriff: 01.03.2019).

Saeed, Sana, Somewhere in America, Muslim Women are ,Cool', Islamic Monthly, December 2/2013, vgl. https://www.theislamicmonthly.com/somewhere-in-america-mus lim-women-are-cool/ (letzter Zugriff: 14.02.2019).

Sagir, Fatma (Hg.), Rocking Islam. Music and the Making of New Muslim Identities, Waxmann Verlag (im Erscheinen).

Sagir, Fatma, Mipster und Modest Fashionistas, vgl. http://www.pr.uni-freiburg.de/pm/ex pertendienst/weltmaedchentag-sagir (letzter Zugriff: 14.02.2019).

Schröter, Susanne, Repressive Ästhetik, Vortrag im Rahmen der Konferenz „Das islamische Kopftuch - Symbol der Würde oder der Unterdrückung?“, Frankfurter Forschungszentrum Globaler Islam am Exzellenzcluster „Normative Ordnungen“ an der Goethe-Universität, 08.05.2019.

Schwarzer, Alice, Die große Verschleierung: für Integration, gegen Islamismus, Köln 2010. Seddiqzai, Mansur, Kopftuch: Wie freiwillig ist die Entscheidung?, in: Die Zeit am 05.04. 2018, vgl. https://www.zeit.de/gesellschaft/zeitgeschehen/2018-03/kopftuch-islamfrauen-freiheit-unterdrueckung-zukunft/seite-2 (letzter Zugriff: 01.03.2019). 
Theißl, Brigitte, Law and Order statt „heilige“ Frauenrechte, in: dieStandard am 27.09. 2017, vgl. https://derstandard.at/2000064800343/Law-and-Order-statt-heilige-Frauen rechte (letzter Zugriff: 01.03.2019).

Trigg, Roger, Equality, Freedom \& Religion, Oxford 2013.

United Nations Human Rights, Women's Rights are Human Rights, Geneva-New York 2014.

Wielandt, Rotraud, Die Vorschrift des Kopftuchtragens für die muslimische Frau: Grundlagen und aktueller innerislamischer Diskussionsstand, Vortrag von Rotraud Wielandt im Rahmen der Deutschen Islam Konferenz 2008, vgl. http://www.deutsche-is lam-konferenz.de/SharedDocs/Anlagen/DIK/DE/Downloads/Sonstiges/Wielandt_ Kopftuch.html (letzter Zugriff: 01.02.2019).

Wiesinger, Susanne, Kulturkampf im Klassenzimmer: Wie der Islam die Schulen verändert. Bericht einer Lehrerin, Wien 2018.

Weiters:

Hijab-Fashionistas, vgl. https://www.hautehijab.com/blogs/hijab-fashion/28-most-influ ential-hijabi-bloggers (letzter Zugriff: 14.02.2019).

Teilprojekte im Rahmen des Habilitationsprojekts „Muslim Lifestyle“von Fatma Sagir, vgl. http://www.kaee.uni-freiburg.de/personen/wimi/sagir (letzter Zugriff: 14.02.2019).

https://www.thisisnotconsent.com/ (letzter Zugriff: 01.03.2019).

Ein Tanga ist kein Ja, dieStandard am 15.11.2018, vgl. https://derstandard.at/2000091399 522/Proteste-in-Irland-Ein-Tanga-ist-kein-Ja (letzter Zugriff: 01.03.2019).

https://www.hrw.org/de/topic/frauenrechte (letzter Zugriff: 23.02.2019). 


\section{Günter Virt (Wien)}

\section{Menschenrechte im Prozess. Erfahrungen im hermeneutischen Zirkel von Theorie und Praxis}

Mit den folgenden Überlegungen möchte der Verfasser seiner verehrten Kollegin Ingeborg Gabriel die jahrelange Verbundenheit zum Ausdruck bringen. Gemeinsam war und ist uns stets das Engagement für Menschenrechte. Ingeborg Gabriel hat in ihrem Aufsatz „Menschenrechte und Religionen: Kann der Brückenschlag gelingen?" ${ }^{\text {“1 }}$ einen wichtigen aktuellen Impuls gegeben, den ich mit großem Interesse und Gewinn gelesen habe. Sie hat sich darin in ihrem Abschnitt: zwei „Theologische Stolpersteine: Säkularität - Anthropozentrik - Individualismus - Pflichtvergessenheit" vor allem mit den Problemen auseinandergesetzt, die sich für Religionen mit den Menschenrechtsdokumenten der UNO und des Europarates sowie der Europäischen Union zeigen. Sie hat aber auch theologische Ressourcen für die Menschenrechte in den Religionen benannt. ${ }^{2}$ Ingeborg Gabriel hat stets bei ihren Reflexionen auf die Menschenrechte auch die konkrete Praxis im Blick behalten.

Nun haben sich mittlerweile ranghohe Repräsentanten der großen Weltreligionen im Forum der UNO getroffen. Sie haben am 25. Juni 2018 in Genf eine Deklaration für eine Bewegung spiritueller weltweiter Konvergenz zur Unterstützung gleicher Bürgerrechte verabschiedet, in der die Selbstverpflichtung zu einem regelmäßigen Audit unter der Schirmherrschaft der Vereinten Nationen enthalten ist. ${ }^{3}$ Diese Weltkonferenz der Religionen im Rahmen der Vereinten

1 Ingeborg Gabriel, Menschenrechte und Religionen: Kann der Brückenschlag gelingen? Theologische Stolpersteine und Ressourcen, in: Brigitte Schinkele / René Kuppe / Stefan Schima (u. a.) (Hg.), Recht - Religion - Kultur, Festschrift für Richard Potz zum 70. Geburtstag, Wien 2014, S. 87-101.

2 Ebd., S. 98-101.

3 World Conference, Religions, Creeds and Value Systems: Joining Forces to Enhance Equal Citizenship Rights, Outcome Declaration, „Moving Towards Greater Spiritual Convergence Worldwide in Support of Equal Citizenship Rights“, Geneva, 25 June 2018, vgl. https://www. gchragd.org/sites/default/files/ENG_Outcome\%20Declaration\%20World\%20Conference.pdf (letzter Zugriff: 15.04.2019). 
Nationen betont die Verwurzelung (rooted) des Konzeptes der gleichen Bürgerrechte in der Allgemeinen Erklärung der Menschenrechte der UNO von 1948. ${ }^{4}$

In diesem Zusammenhang wird ausdrücklich auf Art. 18 Bezug genommen, dass jeder Mensch Anspruch auf Gedanken-, Gewissens- und Religionsfreiheit hat.

In dem 10 Punkte umfassenden globalen Strategieplan wird ausdrücklich der Respekt vor der Gleichrangigkeit von Mann und Frau, der zu garantieren ist und der so jeder Form von Diskriminierung entgegenwirkt, genannt (Nr. 5 und Nr. 6); ebenso die Respektierung der Religionsfreiheit. Explizit werden in dieser Deklaration also die beiden wichtigsten konkreten Stolpersteine im interreligiösen Dialog konsensmäßig als Bürgerrechte festgehalten. Warum also die Schwierigkeiten auf der Ebene der Menschenrechte? Wie ist die Beziehung von Bürgerrechten und Menschenrechten näherhin zu bestimmen?

Die zitierte Deklaration argumentiert in einem Beziehungsdreieck zwischen Bürgerrechten, Menschenrechten und universellen Werten. Doch was ist mit Werten genauerhin gemeint? Wie ist das Verhältnis dieser drei Größen genau zu bestimmen? Warum der Einstieg bei den Bürgerrechten? Gelingt auf der Ebene der Bürgerrechte leichter ein Konsens, weil der Islam sich beim Begriff der Staatsbürgerschaft auf die Verfassung von Medina 622 berufen kann und so ein Autoritätsargument ins Treffen führen kann? Handelt es sich beim Konzept der Bürgerrechte um ,eingeschränkte Menschenrechte“, die eben nur für die Bürger des eigenen Staates gewährt und nicht für alle Menschen auf dem Staatsgebiet gewährleistet werden - also eine Partikularisierung der Menschenrechte? Besteht hier nicht die Gefahr einer Fixierung auf die Partikularisierung der Menschenrechte - ein innerer Widerspruch? Oder könnte es sich auch um einen Schritt auf einem vermutlich langen Weg zur Gewährleistung (und nicht Gewährung) von Menschenrechten für wirklich alle Menschen handeln? Hat nicht auch die gemeinsame Erklärung beim Besuch von Papst Franziskus und dem Großimam von Al-Azhar, Ahmad Al-Tayyeb, in Abu Dhabi den Begriff der Bürgerrechte verwendet? ${ }^{5}$ Die weitere Geschichte wird es zeigen müssen, wie gemeinsam Antworten auf diese offenen Fragen gefunden werden können.

Auch in Österreich wird im FPÖ Parteiprogramm darüber nachgedacht, statt der Europäischen Konvention der Menschenrechte (EMRK), die in Österreich seit 1966 im Verfassungsrang steht, eine Art bloß nationale Grundrechtscharta

4 Allgemeine Erklärung der Menschenrechte, vgl. www.un.org/depts/german/menschenrechte/ aemr.pdf (letzter Zugriff: 29.03.2019).

5 Dokument über die Brüderlichkeit aller Menschen - Für ein friedliches Zusammenleben in der Welt, Apostolische Reise von Papst Franziskus in die Vereinigten Arabischen Emirate (3.-5. Februar 2019), vgl. http://w2.vatican.va/content/francesco/de/travels/2019/outside/ documents/papa-francesco_20190204_documento-fratellanza-umana.html (letzter Zugriff: 15.04.2019). 
zu schaffen, die dann nur für die eigenen Staatsbürger gilt und andere Menschen ausschließt. Auch im Zusammenhang mit dem Brexit gab es ja im U.K. Stimmen, die für den Austritt aus der EMRK plädierten.

Diese Beispiele zeigen wie sehr sich der Menschenrechtsdiskurs und damit die kodifizierten Menschenrechtsdokumente selbst in einem Prozess befinden.

Über die Geschichte der Menschenrechte sind Bibliotheken geschrieben worden. In diesem Essay aber soll an einigen ausgewählten konkreten Beispielen darüber nachgedacht werden, welche Bedeutung das effiziente Engagement für die Weiterentwicklung von Menschenrechtsdokumenten in den entscheidenden Institutionen und die Ergänzung bestehender Menschenrechtskonventionen haben kann und soll. Ich beschränke mich auf die Europäischen Menschenrechtskonventionen des Europarates und die Menschenrechtscharta der EU. Die Allgemeine Erklärung der Menschenrechte der UNO ist ja eine reine Deklaration und hat für die Staaten keine bindende Wirkung. Die Europäische Menschenrechtskonvention des Europarates (EMRK) von 1949 hingegen ist die erste rechtlich bindende Menschenrechtskonvention ${ }^{6}$ und zwar für alle derzeit 47 Mitgliedsstaaten des Europarates, da mit der Konvention der Europäische Menschenrechtsgerichtshof in Straßburg geschaffen wurde. Dieser Gerichtshof hat bis 2018 ca. 840.000 Menschenrechtsbeschwerden erledigt und davon ca. 22.000 Urteile gefällt und damit auch die Rechtssituation in den Mitgliedsstaaten entscheidend beeinflusst, was eben manchen nationalistisch orientierten politischen Parteien gar nicht gefällt.

Da vermutlich nicht viele theologische Ethiker geltende Menschenrechtsdokumente verfasst haben und an der Weiterentwicklung von bestehenden Menschenrechtsartikeln mitgearbeitet haben, möchte ich die folgenden Überlegungen in drei Schritte gliedern:

1. Das Zustandekommen und die Formulierung der Recommendation 1418/99 zum Schutz der Menschenwürde und Menschenrechte Sterbender und terminal Kranker des Europarates: ein Erfahrungsbericht aus der Praxis.

2. Reflexionen zur Aufgabe, Rolle und Methode des theologischen Ethikers.

3. Kritische Abschlussüberlegungen zum Zusammenhang von Menschenbild und Gottesbild bei der Begründung der Menschenwürde.

6 Europäische Menschenrechtskonvention, vgl. https://www.echr.coe.int/Documents/Conven tion_DEU.pdf (letzter Zugriff: 15.04.2019). 


\section{Ein Erfahrungsbericht}

Hier soll ein Erfahrungsbericht aus der Praxis der Verfassung eines Menschenrechtsdokuments vorgelegt und dann auf die Hermeneutik im Theorie-Praxis Zirkel reflektiert werden.

Die damalige Vizepräsidentin des Europarates, die österreichische Abgeordnete zur parlamentarischen Versammlung des Europarates Edeltraud Gatterer war mit einem noch nicht gezeichneten Entwurf eines Dokumentes „to justify to hasten death“ - eine euphemistische Umschreibung für die Tötung auf Verlangen - konfrontiert. Geistesgegenwärtig nahm sie sich selbst des Themas an und schlug vor, selbst einen Draft zu diesem einzubringen. Durch Zufall fiel ihr mein gerade erschienenes Buch Leben bis zum Ende (Innsbruck 1998) in die Hände. Sie ersuchte nun mich, einen einschlägigen Draft zu erstellen. Die gerade in Oviedo aufgelegte Menschenrechtskonvention zur Biomedizin, enthielt zu diesem Thema keinen Artikel, da es nach jahrelangem Ringen dazu keine Einigung im Europarat gab. Es gab also eine Lücke.

Im Jahr 1998 bekam ich nun einen Brief vom Generalsekretariat des Europarats in Straßburg mit der Bitte, einen Draft über die „Erfüllung der Wünsche Sterbender und terminal Kranker“ zu verfassen. Dieser Titel hätte das Ergebnis ja bereits vorgegeben: „Sie wünschen - wir töten (mit einigen Sorgfaltsbedingungen)“. So habe ich diesen Wunsch nicht erfüllt, sondern in eigener Verantwortung mit einem kleinen Team von Ärzten, Juristen, Ethikern und Politikern am Institut für Ethik und Recht in der Medizin an der Universität Wien einen Text zum „Schutz der Menschenwürde und Menschenrechte Sterbender und terminal Kranker“ erstellt. (1993 wurde auf meine Initiative nach langer intensiver Vorarbeit das interdisziplinäre Senatsinstitut „Für Ethik und Recht in der Medizin“ gegründet. Die Notwendigkeit für dieses Konzept hat sich mir aufgedrängt, da ich als einziger Ethiker in der Expertenkommission im Bundeskanzleramt nach den Patientenmorden in Lainz die Relevanz dieser Lücke und auch die Dringlichkeit eines solchen interdisziplinären Instituts für Forschung und Lehre gesehen habe).

Unser Textvorschlag wurde zunächst im Sozialausschuss der parlamentarischen Versammlung des Europarates in Paris anfangs Jänner 1999 unter ungewöhnlich hoher Beteiligung von Abgeordneten diskutiert. Gemeinsam mit Frau Edeltraud Gatterer, einem Arzt und einem Kollegen aus den Niederlanden galt es, unser Dokument vorzustellen und zu argumentieren. Die lange und intensive Debatte im Ausschuss drehte sich vor allem um das Verständnis von Autonomie sowie die Unterscheidung zwischen Töten und Zulassen des Sterbens unter bestimmten Voraussetzungen. Unser Dokument wurde mit großer Mehrheit als Grundlage für die weiteren Ausschussarbeiten angenommen und kam am 
25. Juni 1999 ins Plenum der parlamentarischen Versammlung zur Debatte und zur Abstimmung.

Der Inhalt war klar und einfach in drei Punkte gegliedert und vermied alle Fachausdrücke und auch Reizworte wie Euthanasie mit all den theoretischen Begriffsunterscheidungen. Einleitend wurde zunächst die Zuständigkeit des Europarates für Menschenrechte benannt; dann die spezifischen Ängste der Menschen vor dem Sterben in unserer Gesellschaft kurz analysiert und damit die Probleme formuliert, für die es einer Richtungsentscheidung bedurfte. Diese haben wir in drei Punkten vorgegeben:

Erstens den vorrangigen Aufbau und Ausbau der palliativen Medizin und Pflege (palliative care) in den Mitgliedstaaten, sowie die Konzepte der interdisziplinären Ausbildung und Weiterbildung der Heilberufe detailliert beschrieben.

Zweitens die Autonomie der Patienten als Abwehrrecht gefordert, dass niemand gegen seinen Willen medizinisch behandelt oder weiterbehandelt wird. Der oft so leidvolle Sterbeprozess soll nicht unnötig verlängert werden. Zudem haben wir die Mitgliedsstaaten aufgefordert dem Institut der Patientenverfügungen eine rechtlich gültige Form zu geben (Patientenverfügungsgesetze für den Fall, dass ein Mensch sich nicht mehr äußern und aktuell mitteilen kann)

Drittens eine klare Absage an die Tötung auf Verlangen begründet mit Bezug auf Art 2. der EMRK, dass „niemand in den Mitgliedsstaaten absichtlich seines Lebens beraubt werden soll“ “ ${ }^{7}$ Dies gilt auch für terminal Kranke. Der Wunsch nach Tötung stellt daher niemals eine Rechtfertigung für eine Tötungshandlung dar. Es gibt keinen Anspruch darauf, getötet zu werden.

Dem Dokument haben wir ausführliche Erläuterungen hinzugefügt (explanatory memorandum). ${ }^{8}$ Explizit haben wir darin dem Europarat auch ein profundes Verständnis von Menschenwürde gleichsam ins Stammbuch geschrieben.

Nach stundenlanger z. T. sehr heftig und emotional geführter Debatte wurde in der parlamentarischen Versammlung abgestimmt. Unser Text wurde als Menschenrechtsdokument mit so großer Mehrheit angenommen, dass man erstaunlicherweise fast von einem Konsensdokument in dieser schwierigen Problematik sprechen kann. Hierauf wurde es vom Ministerrat, an den sich solche Empfehlungen wenden, willkommen geheißen und mittlerweile hat der Europäische Menschenrechtsgerichtshof Entscheidungen mehrfach mit ausdrücklichem Bezug auf die Recommendation getroffen (z. B. Diane Pretty vs U.K.).

7 Europäische Menschenrechtskonvention, Art. 2, vgl. https://www.echr.coe.int/Documents/ Convention_DEU.pdf (letzter Zugriff: 15.04.2019).

8 Recommendation 1418 (1999), Protection of the human rights and dignity of the terminally ill and the dying, vgl. http://assembly.coe.int/nw/xml/XRef/Xref-XML2HTML-en.asp?fileid= 16722 (letzter Zugriff: 08.05.2019). 
Doch damit war die Arbeit nicht getan. In der Folge, fehlte es nicht an Versuchen, diese Empfehlung auszuhöhlen mit dem Hinweis auf die Erfahrungen der BENELUXstaaten mit ihren Euthanasiegesetzgebungen. Wiederum galt es, in mehreren Europaratshearings 2002 und 2004 in Paris profund zu argumentieren und die Abgeordneten mit Publikationen vorzubereiten für die Weiterarbeit an diesem Menschenrechtsdokument. (Da die Abgeordneten jeweils von den nationalen Parlamenten entsandt werden, kommt es zu einem raschen Wechsel der Personen). Eine Bestreitung der Recommendation kam im Jahr 2005 vom liberalen Abgeordneten Dick Marty aus der Schweiz. Daher habe ich damals in der Schweizer Zeitschrift Orientierung nochmals die Recommendation zum Schutz der Menschenwürde und Menschenrechte Sterbender und terminal Kranker mit einem aktuellen Argumentarium zum Gebrauch für die Abgeordneten publiziert. ${ }^{9}$ Bei einer Abstimmung über den Report von Dick Marty wurde die Recommendation 1418/99 gegen diese Einwände wiederum mit großer Mehrheit bestätigt.

In einigen Mitgliedsstaaten wurde unsere Anregung, die Verbindlichkeit von Patientenverfügungsdokumenten mit nationalen Gesetzen $\mathrm{zu}$ regeln bereits verwirklicht (so z. B. in Österreich und in Deutschland). Es fehlen aber noch viele Mitgliedsländer. Schließlich finden immer wieder Konferenzen generell zur Umsetzung der Recommendation in einzelnen Mitgliedsstaaten statt. So wurde ich z.B. am 7.10.2016 zum Eröffnungsvortrag einer EuroparatsKonferenz in Armenien eingeladen, bei der mir zum Bewusstsein kam, wie viel ethische Arbeit bei der Umsetzung der Menschenrechtsrecommendation noch zu leisten sein wird, vor allem in den Nachfolgestaaten der Sowjetunion angesichts der dort alltäglichen Praxis im Umgang mit Sterbenden.

Der Europarat arbeitete selbst weiter an den Aufträgen der Recommendation. Ein sehr umfangreicher und detaillierter Report zur Palliativpflege und Medizin wurde 2008 (von Dr. Wolfgang Wodarg) erarbeitet und zuletzt - ein Leitfaden für die Entscheidungsprozesse am Lebensende „end of life decisions“. (Die Probleme mit den Euthanasiegesetzen in einigen wenigen Ländern wurden dort ausgespart). Bei der Konferenz zur Vorstellung dieses Dokuments wurde ich am 5.05.2014 zum Abschlussvortrag eingeladen und habe bei dieser Gelegenheit fünf Vorschläge zu Weiterarbeit mit der Recommendation gemacht:

- Erstellung einer Überblicksstudie in allen 47 Mitgliedsstaaten über den gleichen Zugang zur Palliativversorgung und deren Qualität.

- Erarbeitung eine Studie zum Konzept und zur Qualität der interdisziplinären Aus- und Weiterbildung der Heilberufe, die es mit Sterbenden zu tun haben.

- eine Überblicksstudie über die medizinischen Indikationen und Praxis bei der palliativen Sedierung.

9 Günter Virt, Aktuelle Debatten um die Euthanasie, in: Orientierung 67/2/2003, S. 16-19. 
- eine profunde Studie zum Autonomieverständnis bei Sterbenden.

- die Zielvorstellung, die Recommendation 1418/99 zu einem Zusatzprotokoll zur Oviedo Konvention des Europarates zu machen.

In einem kleinen Ausblick möchte ich auch noch auf eine sehr konkrete Anregung der Leitethikkommission der EU (EGE, der ich von 2001 bis 2016 angehörte) zu sprechen kommen. In der opinion 27 vom 16.1.2013 „Ethical Framework for Assessing Research, Production and Use of Energy“ haben wir nach einer ausführlichen Analyse der möglicherweise einschlägigen Artikel der Menschenrechtsdokumente und der EU Regulierungen der EU empfohlen, bei der nächsten Revision der Menschenrechtscharta ausdrücklich den ausreichenden Zugang zu Energiedienstleistungen als Menschenrecht zu etablieren. Die bisherigen Menschenrechtsdokumente haben hier eine Lücke, die geschlossen werden sollte.

Nach diesem kurzen narrativ gehaltenen Erfahrungsbericht bei der Verfassung eines Menschenrechtsdokuments des Europarats und den Anregungen zur Füllung einer Lücke in den Menschenrechten in der EU, gilt es nun auf die Methode zu reflektieren, mit denen ein theologischer Ethiker diese Aufgabe in säkularen europäischen Institutionen erfüllen kann.

\section{Reflexion auf Aufgabe, Rolle und Methode des theologischen Ethikers}

Die Aufgaben wachsen einem zu durch die konkreten Herausforderungen und Einladungen. Zum Mitglied der European Group on Ethics (15 Mitglieder: 5 Ethiker, 5 Juristen, 5 Naturwissenschaftler) wird man persönlich vom Präsidenten der Europäischen Kommission berufen auf Grund von Publikationen, Erfahrungen und Empfehlungen. Von 2001 bis 2016 war ich drei Perioden lang Mitglied dieser EGE, die den Präsidenten in der ethischen Bewertung neuer Technologien berät (als Grundlage und Weichenstellung für EU-Normen - Direktiven, die in den nationalen Parlamenten umgesetzt werden müssen mit einem gewissen Spielraum und Verordnungen, die mit der Veröffentlichung im Amtsblatt unmittelbar in Kraft treten) und habe an 13 Opinions mitgewirkt.

Seine Rolle in diesem säkularen Umfeld der Ethikkommissionen in den europäischen Institutionen Europarat und EU, muss der theologische Ethiker erst finden, inmitten vieler Vorurteile, die einem begegnen können. Manchmal ist es keine einfache Gewissensentscheidung, ob man weiter mitarbeiten kann oder sich zurückziehen muss (so geschehen bei der EU Opinion zur Patentierbarkeit von Erfindungen mit humanen embryonalen Stammzellen siehe weiter unten). 
Für die effiziente Mitarbeit in solchen Kommissionen bedarf es einer klaren Methode. Meist geht es in der EGE ja um die ethische Beurteilung von neuen Technologien (z.B. Nanotechnologie, synthetische Biologie usw.) oder neuen gesellschaftlichen Entwicklungen im Gebrauch der Techniken (ICT, Überwachungstechniken, citizen science, personalised medicine usw.) als Grundlage für die Gesetzgebung in der EU. Es gilt für den Theologen, indirekt angesprochene theologische Themen im säkularen Kleid zu identifizieren, anzusprechen und mit einer adäquaten Fragestellung sich in den neuen Forschungsfeldern zu orientieren.

Gemeinsam mit Ingeborg Gabriel durfte ich vor Jahren ein Seminar machen zur Methode ethischer Urteilsfindung im Modell einer autonomen Moral im Horizont des christlichen Glaubens. Dieser von Alfons Auer nach dem Erscheinen der Enzyklika Humanae Vitae in die vehemente ethische Debatte zur Normbegründung und Normenkontrolle eingebrachte Ansatz erweist sich in seiner Dynamik immer noch als solide methodische Grundlage nicht nur alte Positionen zu überprüfen, sondern sich in neuen Fragestellungen rasch und klar als theologischer Ethiker zu orientieren. ${ }^{10}$

Bei diesem Ansatz geht es umfassend sowohl um die Diskussion der vorhandenen ethischen Vorverständnisse als auch deren Überprüfung nach einem rational einsichtigen Dreischritt:

- empirische Orientierung und Grundlegung unter Berücksichtigung der neuesten wissenschaftlichen Erkenntnisse zu neuen konkreten Handlungsproblemen.

- anthropologische Integrierung des empirischen Wissens der Zeit, damit es zu keinem naturalistischen Fehlschluss kommt.

- ethische Normierung auf der Basis der beiden vorangegangenen Methodenschritte meist durch Güterabwägung, die wiederum offen ist für neuerliche Überprüfung in diesem Dreischritt.

Auf allen drei Ebenen gilt es differenziert die Wechselwirkung zwischen dem christlichen Sinnhorizont und den säkularen Einsichten zu reflektieren. Auf diese Weise kann der christliche „Sinnüberschuss“ anschlussfähig werden für den säkularen Ethikbetrieb. Diese Wechselwirkung lässt sich am besten unter den Stichworten stimulieren, integrieren, kritisieren und motivieren reflektieren. Dies soll im Folgenden in aller gebotenen Kürze an Beispielen geschehen. ${ }^{11}$

10 Alfons Auer, Autonome Moral und christlicher Glaube, Düsseldorf 1971.

11 vgl. zum folgenden auch Günter Virt, Was bleibt von der Theologie? Als Moraltheologe im Räderwerk wissenschafts- und politikberatender Ethikgremien, in: Paul-Chummar Chittilappilly (Hg.), Horizonte gegenwärtiger Ethik, FS für Josef Schuster, Freiburg 2016, S. 280-290; sowie Günter Virt, Theologie als Dimension bioethischer Politikberatung, in: Salzburger Theologische Zeitschrift 7/2003, S. 180-195. 
- Stimulieren und beleben: Was als Horizonterweiterung und nicht als Einengung in die Diskussion eingebracht wird, kann auch von den anderen Mitgliedern angenommen werden. Der Theologe kann auch untergründig theologisch relevante Begriffe und Themen gleichsam als „indirekte Theologie“ ansprechen. So wurde z.B. bei der Arbeit der EGE Opinion über synthetische Biologie immer wieder der Begriff „Creation of life“ verwendet und es bedurfte ausdauernder Argumentation darüber, was Schöpfung bedeutet, bis dieser Ausdruck dann an allen Textstellen eliminiert wurde. Es waren fruchtbare Dialoge, in denen auch die säkularen Gesprächspartner eingeladen wurden über den eigenen Sinnhorizont im Hintergrund zu sprechen, über den ja sonst meist nicht reflektiert wird. Der Theologe kann auf diese Weise eher fragend als behauptend den Gesprächspartnern helfen, über diesen eigenen Hintergrund zu sprechen und so belebend in der Gruppe wirken.

Da es in solchen Ethikkommissionen nicht nur interdisziplinär, sondern stets transdisziplinär zugeht, kann der Theologe manchmal durch seine transdisziplinären Fragen auch Anregungen geben für neue Forschungshypothesen. Bei der Arbeit der EGE Opinion über ethische Aspekte der Nanotechnologie brachte ich die Frage ein, welche Bedeutung diese neue Technik für die regenerative Medizin mit Stammzellen haben könnte. Die EGE folgte dieser Anregung mit der weitblickenden Anregung: „Stammzelltherapie verbunden mit Nanotechnologie bietet versprechende Möglichkeiten für die Regeneration beschädigter Gewebe. Stammzellen können identifiziert, aktiviert und gelenkt werden genau an den Ort, wo Gewebe im Organismus beschädigt ist. “12 (Kapitel 2.2.5b)

- Integrieren und einordnen: Die Arbeit an der Recommendation über die Menschenwürde und Menschenrechte terminal Kranker kann als Beispiel dienen, wie der Theologe, der sich über seinen sinnstiftenden Glaubenshorizont Rechenschaft gibt, die alle Menschen betreffenden Probleme des Sterbens so ordnet, dass alle wichtigen Anliegen ausbalanciert zur Geltung kommen. Es gilt, die Integrationskraft des Prinzips Menschenwürde im Horizont theologischer Tiefenhermeneutik zur Geltung zu bringen, auf die zum Abschluss dieses Essays eingegangen wird.

- Kritik wagen: Nicht immer kann der Theologe im Räderwerk säkularer Ethikkommissionen Güterabwägungen ordnend und integrierend mittragen und beeinflussen. Wenn der ethische Fixpunkt ethischer Güterabwägungen, nämlich die Menschenwürde selbst in Frage gestellt oder eingeschränkt wird, bedarf es konstruktiver Kritik. Der Präsident der Europäischen Kommission hat

12 European Group on Ethics in Science and New Technologies (European Commission), Opinion on the ethical aspects of nanomedicine, Brüssel 17.01.2007, vgl. https://publicati ons.europa.eu/en/publication-detail/-/publication/4d7d9c99-2129-42e1-993e-c815b91f2 56b (letzter Zugriff: 17.04.2019). 
bei seinen Besuchen in der EGE immer wieder darauf hingewiesen, dass er mit 28 (nach dem Brexit nur mehr 27) Kommissaren im selben Raum, in dem wir arbeiteten, einen Konsens erzielen muss. Er erwartet daher auch von seiner Ethikberatergruppe ein ausgewogenes Konsensdokument und ersuchte uns so lange zu diskutieren, bis alle wichtigen Aspekte in unserer oft mehr als 100 Seiten umfassenden Opinion kompromisshaft berücksichtigt sind. Bei der Menschenwürde gibt es aber keine Kompromisse.

Gleich bei der ersten Opinion, bei der ich in der EGE mitwirken durfte, bekam ich Gewissensschwierigkeiten. Es ging um die Patentierbarkeit von Erfindungen mit embryonalen Stammzellen, die also die Zerstörung embryonaler Menschen zur Voraussetzung haben. Ein Mitglied schied nach einigen Sitzungen aus, als klar wurde, dass die Gruppe bei der Patentierbarkeit nicht adäquat zwischen adulten und humanen embryonalen Stammzellen zu unterscheiden bereit war. Ich entschied mich in der EGE weiterzuarbeiten und nahm zum Schluss als erster in der Geschichte der Gruppe, die 1993 vom damaligen EU-Präsidenten Jaques Delors ins Leben gerufen wurde, meine Zuflucht zu einer dissent Opinion, d.h. ich unterzeichnete die Opinion 16 erst, nachdem ich meine Gründe formulierte, warum aus moralischen Gründen Erfindungen mit Stammzellen, die die Vernichtung embryonaler Menschen zur Voraussetzung haben, in Europa nicht patentierbar sein sollen. Diesen Schluss habe ich mit der Interpretation der Biopatentrichtlinie, um die in der EU ca. 10 Jahre gerungen wurde - sind Patente doch eine wichtige „Währung“ in der Welt und ein enormer Anreiz für die Forschung und Forschungsrichtung - begründet. In der EGE wurde meine Interpretation der Richtlinie akzeptiert und meine Argumente bei der Pressekonferenz mit dem gleichen Gewicht dargestellt wie die Mehrheitsposition (einer gegen elf damals). Der Mut zur Kritik aus theologischer Motivation, aber mit einer einleuchtenden Interpretation der Biopatentrichtlinie formuliert, machte sich bezahlt. Das Europäische Patentamt bat mich, in einem ,amici curiae“ Brief meine Argumente noch ausführlicher darzustellen. Nach einigen Jahren und zähen Verhandlungen hat sich das Europäische Patentamt meinen Argumenten angeschlossen. Nach einem neuerlichen Versuch, ein Patent mit embryonalen Stammzellen anzumelden, hat sich auch der Europäische Gerichtshof in letzter Instanz meinen Argumenten angeschlossen.

Die Forschung ist nicht zuletzt deswegen auf der Suche nach Alternativen mit sog. induzierten pluripotenten Stammzellen, d.h. rückwärtsentwickelten Körperzellen, bereits mit den ersten von Ethikkommissionen geprüften Heilungsversuchen unterwegs. Mit embryonalen Stammzellen konnte nach negativ verlaufenen Tierversuchen aus verschiedenen Gründen noch kein Heilversuch an Menschen bewilligt werden. Die konstruktive Kritik hat sich also nicht negativ auf die Forschung ausgewirkt, sondern sie geradezu vorangetrieben. 
- Was motiviert? Motive sind höchstpersönlich und hängen mit der tiefen eigenen Einstellung, also dem Glauben zusammen. Mich leitet die theologisch begründete Überzeugung, dass es keine doppelte Wahrheit über den Menschen geben kann: einerseits eine medizinische und andererseits dazu im Widerspruch eine ethische. Sollte Heilung nur mit unethischen Mitteln möglich sein? Mich leitet die christlich begründete Hoffnung, zeigen zu können, dass das ethisch Richtige sich langfristig auch als das medizinisch Richtige, sozial Verträgliche und im Solidarsystem langfristig auch Finanzierbare erweist. Diese ständige, mühsame und unabschließbare Übersetzungsarbeit zwischen den verschiedenen angesprochenen Ebenen bedarf einer starken Motivation. Sie wird im Tiefsten durch die Glaubenseinsicht geleitet, dass jede Verletzung der Würde des Menschen eine Verletzung Gottes selbst ist, wie die lateinamerikanische Bischofssynode von Puebla formulierte (Nr. 306). Damit sind wir bei der Frage nach der tiefenhermeneutischen Begründung der Menschenwürde und der darauf aufbauenden Menschenrechte gelandet.

\section{Kritische Schlussüberlegungen zum Zusammenhang von Menschenbild und Gottesbild}

Warum tun sich manche Religionen mit den Menschenrechten so schwer? Warum taten sich auch die christlichen Autoritäten lange Zeit mit den Menschenrechten so schwer? Ingeborg Gabriel hat einleuchtende Gründe in ihrem eingangs zitierten Artikel genannt. Haben diese verschiedenen Gründe aber vielleicht eine gemeinsame Wurzel, die noch tiefer liegt als die von ihr genannten Aspekte Säkularität, Anthropozentrik, Individualismus und Pflichtvergessenheit? Menschliche Einsichten und Handlungen haben viele Ebenen, wobei eine jeweils auf die andere dahinterliegende verweist. Der Mensch ist ein sehr vielschichtiges Wesen.

„Woran glaubt, wer nicht glaubt?“13, hat Kardinal Martini einmal in einem Dialogbuch mit Umberto Eco gefragt. In diesem wie in vielen Dialogen zeigte sich immer wieder die Bedeutung der sog. negativen Theologie, die ernst nimmt, dass Gott immer größer ist, als unsere Gottesbilder. „Wenn du ihn verstehst, dann ist es sicher nicht Gott“, hat schon Augustinus formuliert. Voreilig behauptete Glaubenssätze, die immer auf Analogien beruhen, können leicht zur Ideologie werden, sie nehmen die Transzendenz Gottes nicht ernst.

Dennoch will der Mensch über das Sein-Gebende-Geheimnis am Grund des Daseins auch nachdenken und sprechen. Dies ist immer nur in Analogien

13 Carlo Maria Martini, Umberto Eco, Woran glaubt, wer nicht glaubt, Rom 1996. 
möglich. Bei keiner analogen Aussage darf jemals übersehen werden, dass bei aller Ähnlichkeit die Unähnlichkeit noch größer ist ${ }^{14}$. Im Grund ist auch die Rede von Gott als Person eine analoge Aussage, ausgehend von der Selbsterfahrung des Menschen als Person. Die Geschichte zeigt aber, wie der menschliche Personbegriff von Beginn an in Wechselwirkung mit dem Geheimnis Gottes entwickelt wurde.

Die Offenbarungsreligionen sprechen nun von einer Selbstmitteilung Gottes in der Geschichte der Glaubenserfahrung der Religionsgemeinschaft. Bei aller Übereinstimmung, die einen Dialog überhaupt erst möglich macht, sind die Differenzen im Umgang mit dieser Analogie doch noch größer.

Wenn der Schöpfergott ein einsamer Gott ist, dann kann er als Person nicht ohne Beziehung zu anderen Personen gedacht werden in dieser Analogie. Das aber bedeutet, dass die einsame göttliche Person eine Schöpfung und in ihr personale Geschöpfe gleichsam braucht. Der Mensch als Person ist also im tiefsten theologisch "gebraucht" und nicht freigegeben in sein Eigensein. Er kann in seiner Eigenwürde nicht wirklich wahrgenommen werden. Der Mensch ist nicht wirklich frei, alles ist im letzten „,kismet“. Schöpfung als Gabe des Seins an das Geschöpf zum Selber-Sein in Freiheit, setzt in dieser Analogie voraus, dass Gott dieses Geschöpf nicht braucht, weil er in sich selbst vollendete personale Gemeinschaft ist und kein einsamer. ${ }^{15}$

In der Heilsgeschichte des alten und des neuen Bundes teilt Gott sich immer transparenter (wir sprechen von Offenbarung) mit, vom Beginn an aber als das schöpferische Geheimnis, das seine Nähe zusagt und verheißt (Gen. 3,14). Transzendenz und Nähe wachsen in der Geschichte seither nicht gegeneinander, sondern miteinander. Der Gott, der größer ist als alles Denkbare und jenseits aller unserer geschaffenen endlichen Vermögen, kommt uns als Mensch unsagbar nahe und wird uns im Geist des Menschgewordenen innerlicher als wir uns selbst sind. (Augustinus formuliert dies in einem Sprachspiel Deus superior summo meo et interior intimo me).

Dies zeigt sich auch in der biblischen Gottesrede. Wenn Gott spricht, dann spricht der Vater Jesu Christi. ${ }^{16}$ Gegen Ende des Neuen Testaments spricht immer häufiger „der Heilige Geist“" als Subjekt göttlicher Rede (Offb. 2,7 u.ö. 22,17). Jesus wird als das Wort Gottes schlechthin bezeichnet, in dem Gott sich restlos ohne Vorbehalte ausspricht. Dass es sich nicht nur um eine pädagogische Rede

14 Vgl. zum 4. Laterankonzil: Heinrich Denzinger, Kompendium der Glaubensbekenntnisse und kirchlichen Lehrentscheidungen, hrsg. von Peter Hünermann, 37. Aufl., Freiburg-BaselWien 1991, 806.

15 Gisbert Greshake, Der dreieine Gott. Eine trinitarische Theologie, Freiburg-Basel-Wien 1997, bes. S. $467 \mathrm{ff}$.

16 vgl. Karl Rahner, Theos im Neuen Testament, in: Schriften zur Theologie I, Einsiedeln 1956, S. 91-187. 
Gottes handelt, angepasst an das Fassungsvermögen, sondern um eine restlose Selbstmitteilung ohne Vorbehalte, zeigt sich wohl am deutlichsten am Kreuz Jesu: Da wird wirklich alles gegeben; da bleibt keine Reserve und kein Vorbehalt. Wie Gott sich zeigt, so ist er.

Dies zu glauben setzt eine Auseinandersetzung des Menschen mit einer reinen Gabe voraus. Kann der Mensch angesichts der Gebrochenheit von Geben und Nehmen an die reine Gabe ohne jede ökonomische Hinterabsicht glauben ${ }^{17}$

Fairerweise muss im religionstheologischen Dialog zugegeben werden, dass die christlichen Kirchen, als sie an die Macht kamen als Staatsreligion im römischen Reich, ihren Glauben an den dreieinen Gott nicht wirklich ernst genommen haben. Zur Unterstützung der Monarchie und der monarchisch hierarchischen Verfassung der Kirche haben sie das Monarchische im Gottesbild betont und tun es bis heute. Eine Kirche, die ihren trinitarischen Gottesglauben wirklich ernst nimmt, müsste Differenzierungen verwirklichen und zumindest einmal bei der Gewaltenteilung beginnen.

Im Umgang mit den entsetzlichen Untaten im Zusammenhang mit sexuellem Missbrauch von Kindern und Jugendlichen, Frauen und Männern, darf die Kirche nicht hängenbleiben beim Bereich der Sexualität, sondern muss zu den tieferen Wurzeln des Machtmissbrauchs vordringen. Die Frage der Macht hängt immer auch mit dem Gottesbild zusammen. Wenn es gelingt die Konsequenzen aus dem trinitarischen Gottesbild zu ziehen wird ein wirklich menschenwürdiger Umgang auch innerhalb der Kirche vertieft möglich.

So bleibt die langfristige Hoffnung, dass der Menschenrechtsdialog in $\mathrm{Zu}$ kunft sich sowohl innerhalb der Religionen als auch zwischen den Religionen als erfahrbare Heilsgeschichte erweisen wird.

\section{Quellen}

Auer, Alfons, Autonome Moral und christlicher Glaube, Düsseldorf 1971.

Allgemeine Erklärung der Menschenrechte, vgl. www.un.org/depts/german/menschen rechte/aemr.pdf (letzter Zugriff: 29.03.2019).

Denzinger, Heinrich, Kompendium der Glaubensbekenntnisse und kirchlichen Lehrentscheidungen, hrsg von Peter Hünermann, 37. Aufl., Freiburg-Basel-Wien 1991.

Dokument über die Brüderlichkeit aller Menschen - Für ein friedliches Zusammenleben in der Welt, Apostolische Reise von Papst Franziskus in die Vereinigten Arabischen Emirate (3.-5. Februar 2019), vgl. http://w2.vatican.va/content/francesco/de/travels/ 2019/outside/documents/papa-francesco_20190204_documento-fratellanza-umana. html (letzter Zugriff: 15.04.2019).

17 Vgl. Martin Lintner, Eine Ethik des Schenkens. Von einer anthropologischen zu einer theologisch-ethischen Deutung der Gabe und ihrer Aporien, Berlin 2006. 
European Group on Ethics in Science and New Technologies (European Commission), Opinion on the ethical aspects of nanomedicine, Brüssel 17.1.2007, vgl. https://publica tions.europa.eu/en/publication-detail/-/publication/4d7d9c99-2129-42e1-993e-c815b 91 f256b (letzter Zugriff: 17.04.2019).

Europäische Menschenrechtskonvention, vgl. https://www.echr.coe.int/Documents/Con vention_DEU.pdf (letzter Zugriff: 15.04.2019).

Gabriel, Ingeborg, Menschenrechte und Religionen: Kann der Brückenschlag gelingen? Theologische Stolpersteine und Ressourcen, in: Brigitte Schinkele / René Kuppe / Stefan Schima (u. a.) (Hg.), Recht - Religion - Kultur, Festschrift für Richard Potz zum 70. Geburtstag, Wien 2014, S. 87-101.

Greshake, Gisbert, Der dreieine Gott. Eine trinitarische Theologie, Freiburg-Basel-Wien 1997.

Lintner, Martin, Eine Ethik des Schenkens. Von einer anthropologischen zu einer theologisch-ethischen Deutung der Gabe und ihrer Aporien, Berlin 2006.

Martini, Carlo Maria, Umberto Eco, Woran glaubt, wer nicht glaubt, Rom 1996.

Rahner, Karl, Theos im Neuen Testament, in: Schriften zur Theologie I, Einsiedeln 1956, S. 91-187.

Recommendation 1418 (1999), Protection of the human rights and dignity of the terminally ill and the dying, vgl. http://assembly.coe.int/nw/xml/XRef/Xref-XML2HTMLen.asp?fileid=16722 (letzter Zugriff: 08.05.2019).

Virt, Günter, Was bleibt von der Theologie? Als Moraltheologe im Räderwerk wissenschafts- und politikberatender Ethikgremien, in: Paul-Chummar Chittilappilly (Hg.), Horizonte gegenwärtiger Ethik, FS für Josef Schuster, Freiburg 2016, S. 280-290.

Virt, Günter, Theologie als Dimension bioethischer Politikberatung, in: Salzburger Theologische Zeitschrift 7/2003, S. 180-195.

Virt, Günter, Aktuelle Debatten um die Euthanasie, in: Orientierung 67/2/2003, S. 16-19. World Conference, Religions, Creeds and Value Systems: Joining Forces to Enhance Equal Citizenship Rights, Outcome Declaration, „Moving Towards Greater Spiritual Convergence Worldwide in Support of Equal Citizenship Rights“, Geneva, 25 June 2018, vgl. https://www.gchragd.org/sites/default/files/ENG_Outcome\%20Declaration\%20World \%20Conference.pdf (letzter Zugriff: 15.04.2019). 


\section{Recht auf reproduktive Autonomie. Sinn und Problematik eines aktuellen menschenrechtlichen Topos}

\section{Der Wunsch nach einem eigenen Kind als Gegenstand der Grund- und Menschenrechte}

Der Wunsch nach einem eigenen Kind ist ein wichtiger Bestandteil dessen, was viele, vielleicht sogar die meisten erwachsenen Menschen unter einem glückenden Lebensentwurf und einem gelingenden Leben verstehen. Die Nichterfüllung des über eine lange Zeit bestehenden, aber nicht in Erfüllung gehenden Wunschs kann aller Erfahrung nach zu einer erheblichen Belastung werden.

Der Wunsch nach dem eigenen Kind ist aber nicht nur etwas sehr Privates, sondern geht auch den Staat und die Rechtordnung an. Als schutzwürdig erscheint er nämlich nicht nur in dem elementaren Sinn, dass sein eigener Fortbestand davon abhängt, dass es unter seinen Bürgern viele gibt, die sich Kinder wünschen oder wenigstens bereit sind, Kindern Aufnahme, Annahme und Fürsorge zu gewähren, sondern auch in der speziellen Hinsicht, dass er diesen Wunsch in seiner leiblich-seelischen Intimität schützt und seine Realisierung respektiert sowie die Bedingungen für die öffentliche Anerkennung förderlich ausgestaltet und die damit verbundenen Belastungen für die Eltern tragbar macht. Schutz durch den Staat bedeutet also immer Enthaltung des Staats von Einmischung in das Kinderbekommen, Unterstützung der Familiengründung als solcher durch für alle geltende Regelungen und Bereitstellung einzelfallbezogener Hilfen zur Ausfüllung der Elternrolle, solange diese notwendig ist.

Dementsprechend braucht der Wunsch, ein bzw. kein Kind zu haben, und der Entschluss, ein (gemeinsames) Kind zu zeugen oder sich dagegen zu entscheiden, weder auf seine Notwendigkeit hin überprüft noch gegenüber staatlichen Organen gerechtfertigt werden.

Ihren Niederschlag und ihre rechtliche Gewährleistung hat die Freiheit zur Fortpflanzung im Recht auf Ehe und Familie gefunden. Die Gegenrealität, auf deren Folie es formuliert, gefordert und rechtlich gewährleistet wurde, waren die weit bis ins 19. Jahrhundert üblichen Heiratsverbote und Zölibatsklauseln für 
bestimmte Berufe einerseits und staatliche Gesetze, die Menschen mit bestimmten Merkmalen von der Möglichkeit zu heiraten ausschlossen und dadurch oder durch Zwangssterilisation bestimmter Personenkreise die Entstehung von Nachwuchs verhindern wollten, im nationalsozialistischen Staat. Vor allem durch die Erfindung der sogenannten Pille Anfang der 1960er Jahre und deren unmittelbar danach einsetzende breite Nutzung sowie das Gelingen der assistierten Reproduktion in den späten 1970er Jahren und deren schon kurz darauf erfolgte Etablierung in der Frauen- und Geburtsmedizin hat sich der Schutzbereich der Fortpflanzung erheblich ausgeweitet. Er umfasst seither nämlich auch die Empfängnisverhütung und bei eingeschränkter Fruchtbarkeit, reproduktionsmedizinische Verfahren in Anspruch nehmen zu dürfen, um trotzdem zu einem Kind $\mathrm{zu}$ kommen. De facto hat sich im allgemeinen Bewusstsein das Geschehen der menschlichen Fortpflanzung selbst stark verändert, insofern es tendenziell von einem Widerfahrnis zu einer aktiven Handlung geworden ist ${ }^{1}$. Parallel fand im medizinischen Feld eine Transformation von einer existenziellen Bedürfnisintention zu einer therapeutischen Anspruchssituation statt. ${ }^{2}$ Die Vergrößerung des Spielraums, innerhalb dessen Eltern, aber auch Nochnichteltern und sogar Nichteltern über die Entstehung oder Nichtentstehung von Nachwuchs bestimmen können, wird in Rechtswissenschaft und Ethik seit einiger Zeit als Recht auf reproduktiver Autonomie, auf reproduktive Freiheit oder auf Fortpflanzungsfreiheit beschrieben und begrifflich gefasst.

In den rechtsphilosophischen und verfassungstheoretischen Begründungen dieses Rechts auf reproduktive Autonomie wird übereinstimmend auf die allgemeine Handlungsfreiheit und das Persönlichkeitsrecht sowie auf den Schutz von Ehe und Familie, der das Recht auf Familiengründung einschließe, verwiesen. ${ }^{3}$ Je nachdem, welches dieser beiden Grundrechte als prioritär für die

1 So Christiane Woopen, Die ,Natur des Menschen' als Maßstab für die Reproduktionsmedizin, in: Giovanni Maio / Jens Clausen / Oliver Müller (Hg.), Mensch ohne Maß? Reichweite und Grenzen anthropologischer Argumente in der biomedizinischen Ethik, Freiburg 2008, S. 288302, hier: S. 292-294.

2 Jochen Sautermeister, Identität im Werden - Herausforderungen der Fortpflanzungsmedizin aus theologisch-ethischer Sicht, in: Zeitschrift für Medizinische Ethik 62/2/2016, S. 91-106, hier: S. 96.

3 Beispielhaft genannt seien: Münchner Kommentar zum BGB ${ }^{7} 2017 \$ 1591$ Rn. 45 (Wellenhofer); Jörg Neuner, Das Recht auf reproduktive Selbstbestimmung. Facetten durchkreuzter Nachwuchsplanung, in: Archiv für die civilistische Praxis 214/2014, S. 459-510; Jens Kersten, Regulierungsauftrag für den Staat im Bereich der Fortpflanzungsmedizin, in: Neue Zeitschrift für Verwaltungsrecht 37/2018, S. 1248-1254; Friederike Wapler, Reproduktive Autonomie: rechtliche und rechtsethische Überlegungen, in: Susanne Baer / Ute Sacksofsky (Hg.), Autonomie im Recht - Geschlechtertheoretisch vermessen, Baden-Baden 2018, S. 185-213; Anne Röthel, Autonomie als Bezugspunkt für eine Kritik der rechtlichen Regulierung des Zugangs zu reproduktiven Verfahren, in: Baer / Sacksofsky (Hg.), Autonomie im Recht, S. 215-227; Nina Dethloff, Reproduktive Autonomie, in: Baer / Sacksofsky (Hg.), Autonomie im Recht, 
Interpretation der Fortpflanzungsfreiheit betrachtet wird, ergeben sich allerdings unterschiedliche Konzepte: Gilt der Wunsch nach einem Kind primär als Element der individuellen Persönlichkeit und ihre Handlungen zur Realisierung dieses Wunsches als zentraler Bereich der Selbstbestimmung, dann geht es vorranging um den Schutz der Freiheit des einzelnen Menschen, mit seiner Furchtbarkeit umzugehen und sein Leben bis in dessen körperliche Zustände hinein zu bestimmen. Wird der Wunsch nach einem Kind und die dazu geeigneten Aktivitäten hingegen als Voraussetzung und erster Schritt zu einer Familiengründung verstanden, geht es vorrangig um den Schutz des gemeinschaftlich gefassten Entschlusses zur sozialen Lebensgemeinschaft und zur Übernahme der Elternrolle.

In der konkreten Wirklichkeit müssen sich diese beiden Sichtweisen nicht ausschließen. Vielmehr dürfte es sogar meistens so sein, dass die Gründung einer Familie auch eine Weise der Verwirklichung und Gestaltung der persönlichen Identität der werdenden Eltern ist. Gleichwohl ist der Unterschied zwischen den beiden Konzepten im theoretischen Zugang nicht bedeutungslos, insofern er für die Bestimmung des Kreises der Träger dieses Rechts auf Fortpflanzung unmittelbare Auswirkungen hat; insbesondere dafür, ob auch Alleinstehende und gleichgeschlechtliche Paare einen entsprechenden Anspruch haben. Die sich seit einiger Zeit etablierende Redeweise von reproduktiver Autonomie ${ }^{4}$ ordnet sich nämlich nicht nur semantisch dem Selbstbestimmungsdiskurs zu, der die gesamte Medizinethik durchzieht ${ }^{5}$, sondern legt schon in seiner Begrifflichkeit eine Parteinahme zugunsten der Ableitung aus dem Recht der individuellen Persönlichkeit nahe.

Einer solchen unmittelbaren oder wenigstens prioritären Zuordnung stehen sozialethisch allerdings durchaus gewichtige Einwände entgegen. Zunächst war das Recht, sich in Nachkommenschaft fortzupflanzen, ja eine Errungenschaft, die immer in engem Kontext mit dem Recht, sich mit einer Partnerin bzw. einem Partner eigener Wahl zu verbinden und als Folge hiervon Kinder zu erzeugen, aufgetreten und als Grund- bzw. Menschenrecht gefordert und schließlich verbürgt worden. Auch in Menschenrechtsdokumenten aus jüngerer Zeit wie dem

S. 229-237. Im Blick auf die Gesetzeslage in Österreich informiert umfassend Philip Czech, Fortpflanzungsfreiheit. Das Recht auf selbstbestimmte Reproduktion in der Europäischen Menschenrechtskonvention, Wien 2015. Im Blick auf diejenige der Schweiz: Andrea Büchler, Reproduktive Autonomie und Selbstbestimmung. Dimensionen, Umgang und Grenzen an den Anfängen menschlichen Lebens, Basel 2017.

4 Aus philosophischer Sicht einflussreich für die Debatten: Ronald Dworkin, Die Grenzen des Lebens. Abtreibung, Euthanasie und persönliche Freiheit, Reinbek 1994 (orig.: New York 1993), S. 207-245; Erin L. Nelson, Law, Policy and Reproductive Autonomy, Oxford-Portland 2013.

5 Statt anderer: Tom L. Beauchamp / James F. Childress, Principles of Biomedical Ethics, 6. Aufl., New York 2008. 
Übereinkommen über die Rechte von Menschen mit Behinderungen von 2006 oder der Charta der Grundrechte der Europäischen Union von 2007 wird ähnlich formuliert. Die Behindertenrechtskonvention garantiert allen Menschen mit Behinderungen das Recht, ,im heiratsfähigen Alter, auf der Grundlage des freien und vollen Einverständnisses der künftigen Ehegatten eine Ehe zu schließen und eine Familie zu gründen“ sowie das Recht „auf freie und verantwortungsbewusste Entscheidung über die Anzahl ihrer Kinder und die Geburtenabstände sowie auf Zugang zu altersgemäßer Information sowie Aufklärung über Fortpflanzung und Familienplanung [...] und [...] die notwendigen Mittel zur Ausübung dieser Rechte “6. Die EU-Grundrechte-Charta nennt in Teil II mit der Überschrift „Freiheiten“: „das Recht, eine Ehe einzugehen und eine Familie zu gründen“(Art. 9) und in Teil III mit der Überschrift „Gleichheit“: „Kinder haben Anspruch auf den Schutz und die Fürsorge, die für ihr Wohlergehen notwendig sind.“ Und: „Jedes Kind hat Anspruch auf regelmäßige persönliche Beziehungen und direkte Kontakte zu beiden Elternteilen, $[\ldots]^{\text {“7 }}$.

Das Recht, Kinder zu haben, ist mithin in der Rechtsgeschichte immer als das Recht verstanden worden, miteinander Kinder in die Welt zu bringen und für sie zu sorgen. ${ }^{8}$ Das war so selbstverständlich in der Konstellation Mann-Frau gedacht, dass es gar nicht ausdrücklich gesagt werden musste. Was hingegen explizit thematisiert wurde, war die Stoßrichtung gegen die verbietende, vorschreibende oder auch nur erlaubende Einflussnahme staatlicher und wirtschaftlicher Autoritäten und gegen den elterlichen Willen als (im Konflikt) ausschlaggebende Instanz.

Die historische Genese eines Rechts ist zwar nicht zwingend für seine aktuelle Auslegung und Begründung. So wenig wie der Hinweis auf naturale Zusammenhänge bei der „normalen“ Zeugung mittels sexueller Vereinigung eines Mannes und einer Frau. Trotzdem sind auch bei der Anwendung reproduktionsmedizinischer Zeugungsverfahren die biologischen Realisierungsbedingungen für die menschliche Fortpflanzung nicht einfach schlechthin aufgehoben oder außer Kraft gesetzt. Denn zu jeder Zeugung - ob auf sexuellem Weg oder mit medizinischer Assistenz bewirkt - braucht es männliche und weibliche Keimzellen; und ein Kind kann sich daraus nur entwickeln, wenn das aus den Gameten entstandene Lebewesen in der Gebärmutter einer Frau über Monate hinweg beschützt und versorgt wird und heranreifen kann. Die Interaktion von männlichen und weiblichen Elementen einerseits und von heranwachsendem

6 Art. 23 Abs. 1 BRK, deutsche Fassung vgl. https://www.behindertenrechtskonvention.info/ schutz-von-ehe-und-familie-3900/ (letzter Zugriff: 17.05.2019).

7 Art. 24 Abs. 1 und Abs. 3 EU-GR Charta, deutsche Fassung vgl.: https://www.europarl.europa. eu/charter/pdf/text_de.pdf (letzter Zugriff: 17.05.2019).

8 S. dazu näheres in: Konrad Hilpert, Ethik der Menschenrechte. Zwischen Rhetorik und Verwirklichung, Paderborn 2019, S. 133-136. 
Embryo und Mutter ist so grundlegend und nachhaltig, dass ausnahmslos jeder Mensch Kind einer bestimmten genetischen Mutter und eines bestimmten genetischen Vaters sowie einer bestimmten biologischen Mutter bleibt, egal wie die im Anschluss folgende soziale Elternschaft organisiert gewesen sein mag. Dass die Abstammung alles andere als unbedeutend und vernachlässigbar ist, ist auch von den intensiven und zum Teil jahrelangen Bemühungen von Kindern, die bei nichtgenetischen bzw. nichtbiologischen Eltern aufgewachsen sind, bekannt und wird in zahlreichen Ländern längst in Gestalt eines eigenen Rechtsanspruchs auf Kenntnis der eigenen Abstammung als einem Teil der Identität anerkannt. ${ }^{9}$

Schließlich fällt kritisch auch die Tatsache ins Gewicht, dass „Kinderhaben“ eine höchst komplexe und zeitlich lang andauernde Gesamthandlung ist. Die Fokussierung auf den Akt des „Bestellens“ ist, gleich ob er sexuell oder mit medizinischer Unterstützung erfolgt, nur ein Aufmerken auf den wichtigen Schritt der Inauguration, der aber durch die Chiffrierung mit dem Begriff „reproduktive Autonomie“ in Gefahr gerät, andere wesentliche Dimensionen des „Kinderhabens“ wie Erziehung, Fürsorge, das Leben miteinander Teilen, Wahrnehmung und (förderliche, im schlechten Fall auch störende) Einflussnahme auf die körperliche, seelische, soziale und intellektuelle Entwicklung des Kindes, auszublenden.

Von daher wäre ernsthaft zu erwägen, ob das Recht, Kinder zu bekommen, rechtssystematisch tatsächlich der Gruppe der subjektiven Freiheitsrechte des Individuums zugeordnet werden muss, oder ob es nicht angemessener wäre, es einer eigenen Gruppe von gemeinschaftlich ausgeübten Freiheitsrechten zuzuteilen.

Keine der mir bekannten Menschenrechtskonventionen und Verfassungstexte selbst enthält bislang ein explizites Grundrecht auf Reproduktion oder Fortpflanzung. Das steht in deutlichem Gegensatz zu der Tatsache, dass diese Ausdrucksweise in der jüngeren verfassungsrechtlichen Literatur durchweg üblich ist ${ }^{10}$. Die sozialethisch aber durchaus berechtigte und sinnvolle Frage, ob es sich bei diesem abgeleiteten Grundrecht in Wirklichkeit nicht um ein duales (ähnlich wie das Rechts zur Eheschließung) oder ein gemeinschaftlich ausgeübtes Grundrecht (ähnlich wie die Rechte auf Meinungsfreiheit und Versammlungs-

9 Zur Schicksalhaftigkeit und Unverlierbarkeit familiärer Herkunftsbeziehungen und ihren moralischen Konsequenzen s. die Ausführungen von Barbara Bleisch, Warum wir unseren Eltern nichts schulden, München 2018.

10 Sehr entschieden für die reproduktive Selbstbestimmung als Konkretisierung des Persönlichkeitsrechts plädieren etwa: Jens Kersten, Regulierungsauftrag für den Staat; Wapler, Reproduktive Autonomie, in: Baer / Sacksofsky (Hg.), Autonomie im Recht. Für ein Grundrecht auf bioethische Selbstbestimmung als Ausfluss des allgemeinen Persönlichkeitsrechts plädiert schon früh: Martin Koppernock, Das Grundrecht auf bioethische Selbstbestimmung: Zur Rekonstruktion des allgemeinen Persönlichkeitsrechts, BadenBaden 1997, S. 95 f., S. 131-158 u. a. 
freiheit ja erst Relevanz bekommen konnten, wenn mehrere Individuen beteiligt sind), handelt, wird in der einschlägigen rechtswissenschaftlichen Literatur kaum ${ }^{11}$ gestellt. Die Verengung der Aufmerksamkeit auf die freie Entscheidung der Frau, die sich ein Kind wünscht, und darauf, in welchem Umfang medizinische Hilfe in Anspruch genommen wird, um diesem Wunsch zur Erfüllung zu verhelfen, ist im Verhältnis zur Lebenslänglichkeit des erzeugten neuen Menschen, zur Schicksalshaftigkeit der ihm durch die Elternpersonen bereiteten Umstände des Aufwachsens, zu den Strapazen und der Folgenschwere der Erziehungs,,arbeit" und auch des Aufwands an Rücksichtnahme, an gegenseitiger Abstimmung und an Verzicht auf Eigeninteressen, um der Elternrolle gerecht werden zu können, zu einseitig und zu punktuell. Auch besteht die Gefahr, das Potential an Konflikten in den wechselseitigen Beziehungen zu verkennen oder - in Folge einer sublimen Idealisierung des Verständnisses von Autonomie - zu vergessen $^{12}$, dass Autonomie ein Ideal ist, das in der Realität nie vollständig verwirklicht werden kann. In Rechtspraxis und öffentlichem Bewusstsein aber könnte die Etablierung der Formel „reproduktive Autonomie“ im Sinne eines subjektiven Abwehrrechts durchaus den Weg bahnen für die weitere Forderung, auch über die Art und Weise der Entstehung und der genetischen Ausstattung eines gewünschten Kindes bestimmen (im Sinne von Wählen) zu dürfen. In der US-amerikanischen Debatte gibt es im Umfeld des Redens von reproductive freedom längst das Stichwort von procreative autonomy bzw. choice ${ }^{13}$. Auch

11 In dieser Richtung jedoch: Anne Röthel, Autonomie im Familienrecht der Gegenwart, in: Juristenzeitung 72/2017, S. 116-123, die die Asymmetrie des Eltern-Kind-Verhältnisses hervorhebt. Ferner: Dagmar Coester-Waltjen, Reproduktive Autonomie aus rechtlicher Sicht, in: Claudia Wiesemann / Alfred Simon (Hg.), Patientenautonomie. Theoretische Grundlagen - Praktische Anwendungen, Münster 2013, S. 222-236. Für die prioritäre Herleitung des Rechts aus dem Grundrecht auf Ehe und Familie plädiert auch Andreas Spickhoff (Hg.), Medizinrecht, München 2018 (Müller-Terpitz: GG Art. 6, Rn. 1, 2). Die theologisch-ethische Arbeit von Caroline Witting (Reproduktive Autonomie. Über das Potenzial eines umstrittenen Begriffs, Münster 2018) gibt gleich in der Einleitung zu bedenken, „dass das Ziel der unterschiedlichen Reproduktionspraktiken, also die Geburt eines Kindes, nicht von einer einzelnen Person realisiert werden" könne (S. 13), weshalb reproduktive Autonomie „nicht ausschließlich als ein Recht oder Vermögen“, „das ein Subjekt alleine betrifft“ beschrieben werden, sondern als „Autonomie der beteiligten Akteure“ verstanden werden solle (S. 13).

12 Auf diese Möglichkeit weist im Anschluss an Arbeiten von Eva Illouz Anne Röthel, Autonomie als Bezugspunkt für eine Kritik der rechtlichen Regulierung des Zugangs zu reproduktiven Verfahren, in: Baer / Sacksofsky (Hg.), Autonomie im Recht, S. 218-222 hin. Zur feministischen und kommunitaristischen Kritik am Autonomieverständnis in der medizinischen Ethik s. auch den Beitrag von Johann S. Ach / Bettina Schöne-Seifert, „Relationale Autonomie“. Eine kritische Analyse, in: Wiesemann / Simon (Hg.), Patientenautonomie, S. $42-60$.

13 Belege bei Katharina Beier / Claudia Wiesemann, Reproduktive Autonomie in der liberalen Demokratie. Eine ethische Analyse, in: Wiesemann / Simon (Hg.), Patientenautonomie, S. 205-221, hier: S. 217. 
wenn diese Forderung derzeit im europäischen Kontext als „eine die individuelle Perspektive überschreitende Praxis“ beurteilt wird, die neue grundsätzliche Probleme aufwerfe, gibt es nach den Erfahrungen mit bioethischen Debatten in den letzten Jahrzehnten durchaus keine Gewähr, dass entsprechende Diskussionen im Zuge einer ausgeweiteten Rede von Autonomierechten nicht eines Tages unvermeidlich sein werden. Der Hinweis darauf, dass hier und bis heute der Realisierung eines solchen Anspruchs technische Grenzen gesetzt sind, reicht jedenfalls nicht.

Pate gestanden für die Rede vom Recht auf die reproduktive Autonomie hat offensichtlich der Topos vom Recht auf reproduktive Gesundheit. Hierbei handelt es sich um eine starke Neubildung, die auf der Weltbevölkerungskonferenz von Kairo 1994 gebildet und zur Grundlage der internationalen Bevölkerungspolitik erklärt wurde ${ }^{14}$. Damit sollen alle in früheren Dokumenten bereits deklarierten und in den internationalen Konventionen ${ }^{15}$ völkerrechtlich geschützten Teilrechte zusammengefasst werden. Sein Kontext ist demnach die Bevölkerungs- und Entwicklungspolitik. Die Idee, alle grundrechtlichen Gewährleistungen, die die menschliche Fortpflanzung betreffen, in einem einzigen Recht, eben dem Recht auf reproduktive Autonomie (bzw. auf Fortpflanzung) zusammenzufassen, ist also vom internationalen Recht angestoßen und eine Analogiebildung, die sich in der verfassungsrechtlichen Literatur durchzusetzen beginnt. Weshalb allerdings bei der Auslegung „die individuelle Selbstbestimmung als vorrangig gegenüber kollektiven Interessen verstanden werden soll“16, erscheint - ganz abgesehen von der pejorativen Charakterisierung des „Schutzes einer avisierten sozialen Gemeinschaft und ihrer kollektiven reproduktiven Entfaltung “17 als „kollektive Interessen“ - angesichts der skizzierten Problemlage alles andere als evident.

14 United Nations (ed.), Programme of action - adopted at the International Conference on Population and Development, Cairo 1994, Kap. 7.2, vgl. https://www.unfpa.org/sites/default/ files/event-pdf/PoA_en.pdf (letzter Zugriff: 17.05.2019).

15 Einzelnachweise bei Wapler, Reproduktive Autonomie, in: Baer / Sacksofsky (Hg.), Autonomie im Recht, S. 186-189.

16 Ebd., S. 191.

17 Ebd., S. 190. 


\section{Ethische Grenzen}

Menschliche Fortpflanzung ist ein hohes Gut. Sich mit einem Partner zu verbinden und Kinder zu haben, ist als Gegenstand eines Menschenrechts formuliert worden, weil mächtige Obrigkeiten, staatliche Politik, Familienstrukturen und wirtschaftliche Interessen immer wieder und mit Nachdruck in diesen für die Lebensgestaltung und das Zusammenleben elementaren Bereich eingegriffen und damit großes Leid verursacht haben. Wenn Recht und Staat Ehe, Familie und das Kinderbekommen als Grundrecht schützen, geht es deshalb nicht nur um die Abwehr der Übergriffe, die sich in der Geschichte als Eheverbote, eugenische Gebote, sogar als staatlich verordnete Kastration bzw. Sterilisation bis hin zur Ermordung von für als schädlich deklarierter Personen manifestiert haben, sondern auch um den Zugang zum Wissen und zum Nutzen der Möglichkeiten, mit Hilfe der Medizin Schwangerschaft als Folge von sexueller Aktivität zu vermeiden oder umgekehrt einem unerfüllten Kinderwunsch doch noch die Chance zu einer Schwangerschaft zu bahnen. Der Umstand, dass die dafür notwendigen medizinischen Verfahren aufwendig, im Vergleich zur üblichen Zeugung neuartig und einigermaßen artifiziell (eben nicht-,,natürlich“) sind, ist noch kein hinreichender Grund, sie zu versagen. Denn der unerfüllte Kinderwunsch wird vielfach als Leid, Kränkung oder Minderwertigkeit erlebt. Ein generelles Verbot aller reproduktionsmedizinischer Behandlungsmöglichkeiten, die geeignet wäre, die Fähigkeit zur Fortpflanzung herzustellen bzw. wiederherzustellen, würde das Recht der Partner, die sich ein gemeinsames Kind wünschen, verletzen. Dennoch sind Beschränkungen dieses Rechts denkbar, etwa wenn dies zum Schutz höherer oder gleichrangiger Güter notwendig wäre. Beschränkungen des Rechts auf Fortpflanzung bedürfen also sehr starker ethischer Gründe.

Während sich die Debatten nach der Etablierung der reproduktionsmedizinischen Verfahren in der Geburtsmedizin in den 1980er Jahren vor allem, wenn auch nicht ausschließlich, auf den Schutz der dabei entstehenden Embryonen bezogen, hat sich der Schwerpunkt der Diskussionen in der medizinischen Ethik und in der Rechtsethik in den letzten Jahren unter dem Einfluss der Ausweitung der medizinischen Handlungsspielräume und eines zunehmenden Reproduktions, ,tourismus“ verschoben. Der Schutz der in vitro erzeugten Embryonen ist zwar immer noch ein zentrales Thema, doch kann man eine Stagnation in der Gewinnung neuer Argumente nicht übersehen. Dafür rücken die Beachtung des Kindeswohls, die Frage, wer berechtigt ist, diese Verfahren in Anspruch zu nehmen, und die Erweiterung der reproduktionsmedizinischen Assistenz durch die Spende von Gameten sowie der Modus ihrer Gewinnung in den Vordergrund der Überlegungen. 
Am meisten Übereinstimmung besteht hierbei in der Forderung nach Vereinbarkeit mit dem Kindeswohl, also einer guten körperlichen und seelischen Entwicklung der so gezeugten Kinder. Beim Kindeswohl handelt es sich um einen Gesichtspunkt, der auch schon früher Beachtung gefunden hat, etwa, wenn es um die Begründung für die Verbote von heterologer Befruchtung, Eizellspende, Leihmutterschaft u. a. m. ging. Denn diese Begründungen für Verbote hoben auf eine Gefährdung des Kindeswohls ab, bewirkt durch die (von vornherein in Kauf genommene) Spaltung der Mutterschaft in eine genetische und eine biologische. Da sich diese Annahme durch inzwischen angestellte Untersuchungen empirisch nicht bestätigen ließ, entfällt der stärkste Grund für das Verbot. Richtig bleibt gleichwohl die grundsätzliche Forderung, dass die Erzeugung von Embryonen im Rahmen von In-vitro-Fertilisation und die medizinische Unterstützung zum Schwangerwerden nur unter Bedingungen stattfinden sollen, unter denen die Fürsorgebeziehung mit einer Frau/Mutter gewährleistet und die eigentliche Motivation ist.

Dennoch wird dort, wo in der neueren Literatur auf den Aspekt des Kindeswohls näher eingegangen wird, häufig auch auf die rechtslogische Schwierigkeit aufmerksam gemacht ${ }^{18}$, dass das Wohlergehen eines Kindes im Zusammenhang mit fortpflanzungsmedizinischen Hilfen eine zukünftige und außerdem ziemlich unbestimmte Größe ist und seine Beachtung argumentativ darauf hinauslaufen könnte, dass das Kind, dessen Wohl geschützt werden soll, erst gar nicht entstünde; nur reale Kinder könnten aber Träger von grundrechtlichen Schutzansprüchen sein, nicht niemals existierende Personen. In der Verfassungstheorie behilft man sich hier mit dem Konstrukt einer „Vorwirkung“ der Grundrechte, also mit der Beachtlichkeit der Rechte, die einem Kind im Fall seiner Geburt zustehen würden. Was in den diesbezüglichen juristischen Erwägungen erstaunlicherweise nicht vorkommt, ist die in der Sozialethik im Zuge pädagogischer und vor allem ökologischer Diskussionen ausgebildete Figur advokatorisch, also stellvertretend, zur Sprache gebrachter Ansprüche und Interessen. ${ }^{19}$ Dem Einwand der notorischen Unkonkretheit des Begriffs des Kindeswohls kann wenigstens der erfolgreiche Versuch entgegengehalten werden,

18 Koppernock, Das Grundrecht auf bioethische Selbstbestimmung, S. 154; Spickhoff / Müller-Terpitz, Medizinrecht, 2018, GG Art. 6 Rn. 13; Hartmut Kreß, Rechtssicherheit und vorwirkende Kinderrechte. Ein künftiges Gesetz zur Fortpflanzungsmedizin im Kontext des Transplantationsgesetzes, in: Der Gynäkologe 51/2018, S. 627-632; Kersten, Regulierungsauftrag für den Staat, S. 1250f.; Coester-Waltjen, Reproduktive Autonomie aus rechtlicher Sicht in: Wiesemann / Simon (Hg.), Patientenautonomie, S. 229f.; Wapler, Reproduktive Autonomie in: Baer / Sacksofsky (Hg.), Autonomie im Recht, S. 212.

19 In diesem Sinn etwa Sigrid Graumann, Fortpflanzungsmedizin aus ethischer Sicht - alte und neue Fragen, in: Marcus Düwell / Klaus Steigleder (Hg.), Bioethik. Eine Einführung, Frankfurt a.M. 2003, S. 246-257, hier: S. 248f. 
diesen Begriff durch eine Liste von standardisierten Kinderrechten schärfer zu konturieren.

In den ersten Jahrzehnten der Anwendung der Reproduktionsmedizin war es gängige und durch verbindliche Richtlinien der ärztlichen Standesorganisationen abgesicherte ${ }^{20}$ Praxis, die Methoden assistierter Fortpflanzung auf kinderlose Paare zu beschränken, die verheiratet sind oder zumindest in einer festen heterosexuellen Partnerschaft miteinander verbunden sind. Diese Beschränkung kann von denen, die eine der anderen Familienformen, die in der gesellschaftlichen Wirklichkeit inzwischen gelebt werden (unverheiratet Zusammenlebende, Alleinerziehende, Adoptivfamilien, Familien mit Stiefelternteil, Patchwork Familien) als eine sie selbst diskriminierende Bevorzugung erlebt werden. Jedenfalls sind auch in diesen anderen Familienkonstellationen Wünsche nach einem Kind nicht auszuschließen und ebenso wenig ein Leiden als Folge des Ausbleibens der Erfüllung dieses Wunsches.

Es kann nicht geleugnet werden, dass sich in den letzten Jahrzehnten die familialen Lebensformen tiefgreifend gewandelt haben. So wie Partnerschaften sehr unterschiedlich gelebt werden, ist auch das Spektrum heutiger Familienwirklichkeiten vielfältig geworden. Die vielfältigen Arrangements werden nicht nur gelebt, sondern sind auch gesellschaftlich weithin akzeptiert. Das mag man bedauern, wenn man selbst die persönliche Aneignung und Ausgestaltung der tradierten, öffentlich anerkannten, institutionalisierten Lebensform der (heterosexuellen) Ehe für die beste Voraussetzung für das Aufwachsen von Kindern hält. Dieses Bedauern drängt aber weder die gelebte Praxis zurück noch hebt es die veränderte Auffassung von Familie auf. Kern dieses Wandels ist die faktische Entflechtung von Paarbeziehung und Elternschaft. ${ }^{21}$ Seit der Öffnung des Begriffs und des Instituts der Ehe „für alle" in fast allen europäischen Ländern (in Deutschland 2017), lässt sich das Recht auf Elternschaft bzw. auf Fortpflanzung weder mehr an die Existenz einer formalisierten Ehelichkeit noch auch an die Verschiedengeschlechtlichkeit der Ehegatten, die ein gemeinsames Kind wün-

20 (Muster-)Richtlinie zur Durchführung der assistierten Reproduktion, Text in: Deutsches Ärzteblatt 2006, A 1392-1395. In Abs. 3.1.1. heißt es: „Methoden der assistierten Reproduktion sollen unter Beachtung des Kindeswohls grundsätzlich nur bei Ehepaaren angewandt werden. Dabei darf grundsätzlich nur Samen des Ehemanns verwandt werden; sollen Samenzellen eines Dritten verwandt werden, sind die unter 5.3. genannten Voraussetzungen zu beachten. Methoden der assistierten Reproduktion können auch bei einer nicht verheirateten Frau angewandt werden. Dies gilt nur, wenn die behandelnde Ärztin/der behandelnde Arzt zu der Einschätzung gelangt ist, dass die Frau mit einem nicht verheirateten Mann in einer festgefügten Partnerschaft zusammenlebt und dieser Mann die Vaterschaft an dem so gezeugten Kind anerkennen wird. Dabei darf grundsätzlich nur der Samen des Partners verwandt werden; sollen Samenzellen eines Dritten verwandt werden, sind die unter 5.3. genannten Vorrausetzungen zu beachten.“

21 So Nina Dethloff, Familienrecht in Europa - Quo vadis?, in: Neue Juristische Wochenschrift 2018, S. 23-38, hier: S. 23. 
schen, binden. Was Familie als umfassende Gemeinschaft von (erwachsenen) Eltern und Kindern konkret ist, ist weitgehend das Resultat der Entscheidung der Elternpersonen geworden. Dies schließt in letzter Konsequenz auch die Kompetenz des Paars ein, bei Kinderwunsch reproduktionsmedizinische Hilfe in Anspruch zu nehmen, wenn dieser Wunsch auf andere Weise (Zeugung auf natürlichem Weg, Aufnahme von Stiefkindern, Adoption bzw. Pflege fremder Kinder) nicht in Erfüllung gehen kann.

Auch hier gibt es wie beim Hinweis auf das Kindeswohl so etwas wie eine Inversion der Argumentation: Sprach früher der Schutz besonders der Frau vor unabgesicherter Zuweisung rollenspezifischer Pflichten, vor Überforderung durch reproduktive Zumutungen und vor Überforderung durch gesundheitliche Risiken in Folge der hormonellen Überstimulation, schließlich auch vor körperlicher und seelischer Ausnutzung für eine eher restriktive Regelung der reproduktionsmedizinischen Möglichkeiten, so steht heute beim Schutz der Frauen und prospektiven Eltern die Selbstbestimmtheit der Entscheidung für Partnerschaft, Mutter- bzw. Vaterschaft und für familiäres Miteinander (oder gerade deren Verzicht) im Vordergrund, die durch äußere Zwänge weder eingeschränkt noch suggestiv nahegelegt werden soll.

Aus ethischem Blickwinkel wird man eine solche stark positivistisch-normative Sicht der Entwicklung etwas relativieren: Bei dem zugrundeliegenden Wandlungsprozess handelt es sich biographisch „nur“ um eine Momentaufnahme. Konkret sind Partner- und Familienbeziehungen hingegen um vieles dynamischer. So entwickeln sich eben auch viele (sicher nicht alle) der alternativ gestarteten Lebensgemeinschaften im Lauf der Zeit und besonders ab dem Zeitpunkt, wo Verantwortung für Kinder übernommen wird, in Richtung der Institutionen Ehe und Familie.

Schließlich ist noch die Frage der Entgeltlichkeit näher zu betrachten. Diese Debatte wird aktuell vor allem im Blick auf die Eizellspende und die Leihmutterschaft geführt. ${ }^{22}$ Ein Gesichtspunkt hierbei ist, dass es die Praxis, Eizellen als Teil des eigenen Körpers beziehungsweise eine Schwangerschaft als Dienstleistung für andere gegen Bezahlung anzubieten, in einer Reihe von Ländern längst gibt. Ein anderer Gesichtspunkt ist der, dass mit der Zurverfügungstellung von Eizellen und der Übernahme einer Schwangerschaft für eine andere Frau erhebliche Mühen, Rücksichtnahme, Risiken und Strapazen verbunden sind, für die eine Art von Aufwandsentschädigung gerecht und billig erscheint. Leihmutterschaft ist aber auch als solche ein Problem, weil in und aufgrund der

22 Die sogenannte Embryonenspende stellt eine eigene Problematik dar. Hier geht es nämlich nicht (oder jedenfalls nicht vorrangig) um eine Form von Kauf, sondern um die Frage der Verantwortung für die im Interesse einer Kinderwunschbehandlung entstandenen, aber nicht mehr "gebrauchten“ Vorkernstadien und allenfalls auch um die dadurch mögliche Hilfestellung für andere kinderlose Paare. 
biologischen Mutterschaft ein besonders enges und über viele Monate sich erstreckendes Verhältnis zwischen Kind und schwangerer Frau entsteht. Dieser engen und mit Gefühlen verbundenen Beziehung ist die Bezahlung mit Geld nicht angemessen. Manche sehen in ihr schon deshalb einen Würdeverstoß.

Begründete Befürchtungen gehen vor allem in Richtung einer Ausbeutung von ökonomisch schlecht situierten Frauen und einer Förderung der Bequemlichkeit von vermögenden Frauen, die die Mühen des Kinderbekommens an andere delegieren möchten (in der Fachliteratur gibt es hierfür den Terminus „Kommodifizierung“). Als bestes Mittel, das Entstehen eines Handels mit Eizellen und Leihmutterschaft auszuschalten, erschien bisher deren vollständige Verbote. Inzwischen hat sich allerdings gezeigt, dass diese bestehenden Verbote in nicht unbeträchtlicher Zahl umgangen werden, indem man in Länder ausweicht, wo diese Verfahren legal sind. Schon allein durch die Existenz eines solchen "Tourismus" geraten die entsprechenden nationalen Verbote unter Druck. Verzweifelte Eltern, die bisher erfolglos ein Kind wünschten, können nicht nachvollziehen, dass ihnen ein medizinisches Verfahren, dass die Chance eröffnet, trotz aller Schwierigkeiten doch noch zu einem (genetisch wenigstens zum Teil) eigenen Kind kommen zu können, staatlicherseits verweigert wird.

Außerdem zeigt die Zulassung der Eizellspende bzw. der Leihmutterschaft in vielen Ländern, dass es auch soziale Konstellationen gibt, in denen ökonomische Anreize ausgeschlossen werden können und die primäre Motivation offensichtlich in der Absicht liegt, einer gut bekannten Frau zu helfen (sogenannte altruistische Spenden bzw. Tragemutterschaften).

Insgesamt handelt es sich bei der Frage Spende und Aufwandsentschädigung um ein hoch sensibles Feld. Die Semantik des Spendens ist von vornherein positiv besetzt und kann deshalb in der Auseinandersetzung auch dazu führen, dass ganz heterogene Motive und Interessen miteinander vermengt werden. Beim heutigen Stand der Praxis kann eine zufriedenstellende und wirksame Regelung vielleicht nur noch durch internationales Recht erreicht werden.

\section{Verantwortung und Kontingenzbewusstsein}

Was in der juristischen Literatur seit einiger Zeit gerne „reproduktive Autonomie" genannt wird, hat in der Sprache der theologischen Ethik seit den Diskussionen um die Empfängnisverhütung in den 1960er Jahren eine Entsprechung, nämlich: „verantwortete Elternschaft“. Das mag für manche Ohren betulich klingen. Aber dieser Begriff verortet das, worum es geht, in einem anderen bzw. in einem ganzheitlicheren anthropologischen Kontext, nämlich demjenigen der Entscheidung für Elternschaft zu einem Kind. Elternschaft aber ist mehr als „Fortpflanzung“ (ein Begriff, der aus der Botanik stammend nur das biologische 
Geschehen erfasst) und mehr als „Reproduktion“ (ein Begriff, der stark auf die technische, steuernd-kontrollierende Seite des medizinischen Personals abhebt).

„Elternschaft“ ist aber auch ein Hinweis darauf, dass das Verhältnis zu einem Kind von Beginn an ein Verhältnis besonderer Art ist: Weder Tausch noch Vertrag noch Reziprozität machen den Kern dieses Verhältnisses aus, sondern die besondere Qualität einer Beziehung, die umfassend ist in der Fürsorge und die zudem den Partner, eventuell auch bereits vorhandene Kinder, das größere Familien- und Bekanntensystem, die konkreten Lebensumstände und den Willen, das Kind gesellschaftsfähig zu machen, umfasst. Bereits die Entscheidung dafür, Eltern zu werden - gleich durch welche Methode - enthält eine Selbstbindung, die einer anderen Logik gehorcht als interessenbezogene Entscheidungen; sie will von vornherein den Raum schaffen, in dem sich eine Beziehung entwickeln und wachsen kann.

Es gehört auch zur Übernahme der Elternrolle, dass die Verantwortung für die Entstehung des Kindes nicht konditionierbar ist in dem Sinne, dass das „bestellte" Kind nur dann als eigenes angenommen würde, wenn es bestimmte Eigenschaften hätte. Das gilt im natürlichen System wie im artifiziellen und sollte es auch dann bleiben, wenn eines Tages technisch die eine oder andere Einflussnahme bzw. Auswahlmöglichkeit erreichbar schiene. Denn sonst müsste das Kind aus Gründen der Gleichheit auch berechtigt sein, spätestens nach Erreichen seines Erwachsenseins seine Eltern für sein Dasein und sein Sosein zur Rechenschaft zu ziehen.

Kinderbekommen und Elternschaft bleiben trotz der gewachsenen Möglichkeiten reproduktionsmedizinischer Assistenz auch weiterhin mit dem Risiko behaftet, enttäuscht zu werden und zu scheitern. In philosophischer und theologischer Sprache kann man stattdessen auch sagen: Ein im Schwangerwerden sich erfüllender Kinderwunsch und die Geburt eines Kindes haben existenziell die Eigenart einer Gabe ${ }^{23}$. Sie sind eben nicht Inhalt eines Rechts, das man von irgendjemanden oder einer Institution einfordern könnte. Einforderbar ist allenfalls die Enthaltung von Übergriffen und die Bereitstellung möglicher Hilfen, wenn die verfügbar sind und ihre Anwendung aussichtsreich ist. Aber auch im Fall einer Behandlung ist das mit Hilfe erzeugte Kind trotz aller Aktivitäten nicht ein Produkt, sondern ein Geschenk. Dieser Gabe-Charakter hält über die Zeit an, was daran ersichtlich ist, dass Kinder und Schwangere höchst verletzlich sind. Sie sind nämlich einerseits auf andere angewiesen, sind aber andererseits in besonderer Weise auch der Rücksichtslosigkeit ihrer Umwelten ausgeliefert.

23 Zur Theorie der Gabe in Sozialwissenschaften, Philosophie und Theologie s. u.a. Veronika Hoffmann, Skizzen zu einer Theologie der Gabe: Rechtfertigung, Opfer, Eucharistie, Gottesund Nächstenliebe, Freiburg i. Br. 2013. 
Wegen dieses Risikos zu scheitern und wegen dieser besonderen Verletzlichkeit ${ }^{24}$ sollte das medizinisch assistierte Kinderbekommen in allen Schritten in ein qualitativ hochwertiges Beratungsangebot eingebettet sein, in dem nicht nur die medizinischen und rechtlichen Aspekte zur Sprache gebracht werden, sondern auch die psychischen und die sozialen. ${ }^{25}$

\section{Quellen}

Ach, Johann S. / Schöne-Seifert, Bettina, „Relationale Autonomie“. Eine kritische Analyse, in: Claudia Wiesemann / Alfred Simon (Hg.), Patientenautonomie. Theoretische Grundlagen - Praktische Anwendungen, Münster 2013, S. 42-60.

Baer, Susanne / Sacksofsky, Ute (Hg.), Autonomie im Recht - geschlechtertheoretisch vermessen, Baden-Baden 2018.

Beauchamp, Tom L. / Childress, James F., Principles of Biomedical Ethics, 6.Aufl., New York 2009.

Beier, Katharina / Wiesemann, Claudia, Reproduktive Autonomie in der liberalen Demokratie. Eine ethische Analyse, in: Claudia Wiesemann / Alfred Simon (Hg.), Patientenautonomie. Theoretische Grundlagen - Praktische Anwendungen, Münster 2013, S. 222-236.

Bleisch, Barbara, Warum wir unseren Eltern nichts schulden, München 2018.

Büchler, Andrea, Reproduktive Autonomie und Selbstbestimmung. Dimensionen, Umgang und Grenzen an den Anfängen menschlichen Lebens, Basel 2017.

Coester-Waltjen, Dagmar, Reproduktive Autonomie aus rechtlicher Sicht, in: Claudia Wiesemann / Alfred Simon (Hg.), Patientenautonomie. Theoretische Grundlagen Praktische Anwendungen, Münster 2013, S. 222-236.

Czech, Philipp, Fortpflanzungsfreiheit. Das Recht auf selbstbestimmte Reproduktion in der Europäischen Menschenrechtskonvention, Wien 2015.

Dethloff, Nina, Familienrecht in Europa - Quo vadis?, in: Neue Juristische Wochenschrift 2018, S. 23-38.

Dethloff, Nina, Reproduktive Autonomie, in: Susanne Baer / Ute Sacksofsky (Hg.), Autonomie im Recht - geschlechtertheoretisch vermessen, Baden-Baden 2018, S. 229-137.

Dworkin, Ronald, Die Grenzen des Lebens. Abtreibung, Euthanasie und persönliche Freiheit, Reinbek 1994.

Düwell, Marcus / Steigleder, Klaus (Hg.), Bioethik. Eine Einführung, Frankfurt a. M. 2003.

EU (ed.), Charta der Grundrechte der Europäischen Union 2007 (EU-GR Charta), vgl. https://www.europarl.europa.eu/charter/pdf/text_de.pdf (letzter Zugriff: 17.05.2019).

24 Deshalb kann die Sinnspitze guter Beratung über Kinderwünsche mit Angelika Walser (Ein Kind um jeden Preis? Unerfüllter Kinderwunsch und künstliche Befruchtung. Eine Orientierung, Innsbruck 2014) in der Hilfe gesehen werden, , die eigene Stimme“ zu entdecken und zu hören (s. bes. S. 104-118).

25 Vgl. Sautermeister, Identität im Werden, S. 102-104. 
Graumann, Sigrid, Fortpflanzungsmedizin aus ethischer Sicht - alte und neue Fragen, in: Marcus Düwell / Klaus Steigleder (Hg.), Bioethik. Eine Einführung, Frankfurt a. M. 2003, S. 246-257.

Hilpert, Konrad, Ethik der Menschenrechte. Zwischen Rhetorik und Verwirklichung, Paderborn 2019.

Hoffmann, Veronika, Skizzen zu einer Theologie der Gabe: Rechtfertigung, Opfer, Eucharistie, Gottes- und Nächstenliebe, Freiburg i. Br. 2013.

Kappernock, Martin, Das Grundrecht auf bioethische Selbstbestimmung: Zur Rekonstruktion des allgemeinen Persönlichkeitsrechts, Baden-Baden 1997.

Kersten, Jens, Regulierungsauftrag für den Staat im Bereich der Fortpflanzungsmedizin, in: Neue Zeitschrift für Verwaltungsrecht 37/2018, S. 1248-1254.

Kreß, Hartmut, Rechtssicherheit und vorwirkende Kinderrechte. Ein künftiges Gesetz zur Fortpflanzungsmedizin im Kontext des Transplantationsgesetzes, in: Der Gynäkologe 51/2018, S. 627-632.

Maio, Giovanni / Clausen, Jens / Müller, Oliver (Hg.), Mensch ohne Maß? Reichweite und Grenzen anthropologischer Argumente in der biomedizinischen Ethik, Freiburg i. Br. 2008.

Nelson, Erin L., Law, Policy and Reproductive Autonomy, Oxford-Portland 2013.

Neuner, Jörg, Das Recht auf reproduktive Selbstbestimmung. Facetten durchkreuzter Nachwuchsplanung, in: Archiv für die civilistische Praxis 214/2014, S. 459-510.

Richtlinie zur Durchführung der assistierten Reproduktion 2006, Text in: Deutsches Ärzteblatt 2006, A 1392-1395.

Röthel, Anne, Autonomie als Bezugspunkt für eine Kritik der rechtlichen Regulierung des Zugangs zu reproduktiven Verfahren, in: Susanne Baer / Ute Sacksofsky (Hg.), Autonomie im Recht - geschlechtertheoretisch vermessen, Baden-Baden 2018, S. 215-227.

Röthel, Anne, Autonomie im Familienrecht der Gegenwart, in: Juristenzeitung 72/2017, S. 116-123.

Sautermeister, Jochen, Identität im Werden - Herausforderungen der Fortpflanzungsmedizin aus theologisch-ethischer Sicht, in: Zeitschrift für Medizinische Ethik 62/2/ 2016, S. 91-106.

Spickhoff, Andreas (Hg.), Medizinrecht, 3. Aufl., München 2018.

United Nations (ed.), Programme of action - adopted at the International Conference on Population and Development, Cairo 1994, vgl. https://www.unfpa.org/sites/default/ files/event-pdf/PoA_en.pdf (letzter Zugriff: 17.05.2019).

United Nations (ed.), Übereinkommen über die Rechte von Menschen mit Behinderungen 2008 (CRPB), vgl. https://www.behindertenrechtskonvention.info/schutz-von-eheund-familie-3900/ (letzter Zugriff: 17.05.2019).

Walser, Angelika, Ein Kind um jeden Preis? Unerfüllter Kinderwunsch und künstliche Befruchtung. Eine Orientierung, Innsbruck 2014.

Wapler, Friederike, Reproduktive Autonomie: rechtliche und rechtsethische Überlegungen, in: Susanne Baer / Ute Sacksofsky (Hg.), Autonomie im Recht - geschlechtertheoretisch vermessen, Baden-Baden 2018, S. 185-213.

Wiesemann, Claudia / Simon, Alfred (Hg.), Patientenautonomie. Theoretische Grundlagen - Praktische Anwendungen, Münster 2013.

Witting, Caroline, Reproduktive Autonomie. Über das Potenzial eines umstrittenen Begriffs, Münster 2018. 
Woopen, Christiane, Die,Natur des Menschen' als Maßstab für die Reproduktionsmedizin, in: Giovanni Maio / Jens Clausen / Oliver Müller (Hg.), Mensch ohne Maß? Reichweite und Grenzen anthropologischer Argumente in der biomedizinischen Ethik, Freiburg i. Br. 2008, S. 288-302. 


\section{Politik und Gesellschaft}


Open-Access-Publikation im Sinne der CC-Lizenz BY 4.0

(C) 2020, Vandenhoeck \& Ruprecht $\mathrm{GmbH} \&$ Co. KG, Göttingen ISBN Print: 9783847111658 - ISBN E-Lib: 9783737011655 


\title{
Kreuzesabnahme. Wie in Wien die religiösen Symbole aus den Hörsälen der katholischen Theologie verschwanden - ein Nachruf
}

\author{
„Erst verschwinden die Zeichen, dann das Bezeichnete.“
}

Thomas Hürlimann

\section{Der Kreuz-Erlass in Bayern als fragwürdiger Akt einer Politisierung von Religion}

Das Kreuz hat in letzter Zeit erneut Anlass für öffentliche Kontroversen gegeben. Während religiöse Symbole mancherorts mit Verweis auf die weltanschauliche Neutralität staatlicher Institutionen abgehängt und entfernt werden, ist im Freistaat Bayern unter Ministerpräsident Markus Söder ein gegenläufiger Erlass ergangen, ab dem 1. Juni 2018 ,im Eingangsbereich eines jeden Dienstgebäudes [...] als Ausdruck der geschichtlichen und kulturellen Prägung Bayerns gut sichtbar ein Kreuz anzubringen“" . Der Erlass hat ein polyphones Echo erzeugt: Befürworter haben darauf hingewiesen, das Kreuz sei ein kulturelles Symbol, das Identität und Geschichte Bayerns Jahrhunderte lang geprägt habe. Es stehe für Nächstenliebe, Friedfertigkeit und Toleranz. Gegner des Erlasses hingegen haben die politische Instrumentalisierung des Kreuzes kritisiert. Manche unter ihnen sind so weit gegangen, der bayrischen Staatsregierung „Blasphemie“ und „Häresie“ vorzuwerfen. Das ist gewiss übertrieben, aber der Erlass ist aus religionsrechtlicher Sicht höchst bedenklich, da er die Grenzen der weltanschaulichen Neutralität des Staates überschreitet und die Trennung der Sphären von Politik und Religion zugunsten des Christentums unterläuft. So wenig es darum gehen kann, im Sinne der französischen laicité das Zeichen des Kreuzes wie andere religiöse Symbole auch aus dem öffentlichen Raum zu verbannen, so sehr ist - wie Ingeborg Gabriel in einem umsichtigen Kommentar zur Debatte herausgestellt hat - „daran festzuhalten, dass das Recht auf Religionsfreiheit als staatliches Grundrecht und damit die religiöse Neutralität des Staates eine

1 Allgemeine Geschäftsordnung für die Behörden des Freistaats Bayern, \$28, vgl. http://www.ge setze-bayern.de/Content/Document/BayAGO-28 (letzter Zugriff: 03.04.2019). 
Verwendung des Kreuzes als staatliches Symbol nicht zulässt. Der säkulare Staat schafft dadurch Freiheitsräume, dass er selbst keinem religiösen Bekenntnis verpflichtet ist. “2 In der Tat, der freiheitlich säkulare Rechtstaat, den die katholische Kirche auf dem Zweiten Vatikanischen Konzil nach einem langen Lernprozess amtlich anerkannt hat, garantiert den gesetzlichen Rahmen, in dem sich religiöse Akteure frei entfalten können. Wenn der Staat nun aber selbst eine bestimmte Religion privilegiert, was im Umkehrschluss immer bedeutet, andere Religionen zu benachteiligen, gefährdet er jene friedliche Koexistenz der Religionen, die er doch eigentlich fördern sollte. Die Politisierung von Religion und ihrer Symbole fällt hinter die Errungenschaft des modernen weltanschaulich neutralen Rechtsstaates zurück. ${ }^{3}$

\section{Der Rektoratserlass der Universität Wien und das Verschwinden der religiösen Symbole aus den Hörsälen}

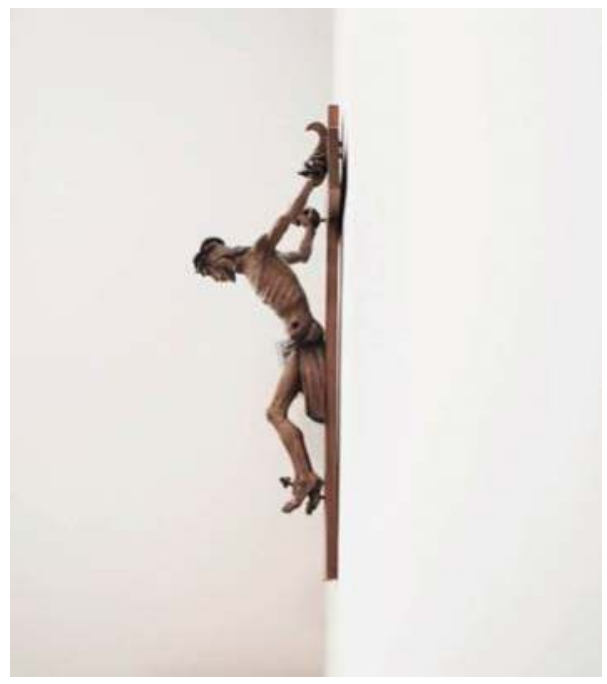

Abbildung 1: „Das Kreuz im Hörsaal 47 - kurz vor der Entfernung“, Foto: Johanna Tück

2 Ingeborg Gabriel, Das Kreuz im Widerstreit, in: Christi in der Gegenwart 24/2018, S. 269-270.

3 So auch Irene Klissenbauer, Kein bayrischer Konstantin - aus der Geschichte lernen, in: catholicnewsagency am 17. Mai 2018: „Wo der Staat sich lediglich einer Religion oder Weltanschauung zuwendet, verstößt er gegen das Grundprinzip der staatlichen Neutralität, da dieses besagt, dass der Staat sich hinsichtlich seiner normativen Grundlagen eben nicht von einer bestimmten Religion beeinflussen lässt, weil dies notwendig zur Diskriminierung der ,Anderen' führt.“ 
Anders gelagert ist der Fall an der Universität Wien. Im Wintersemester 2017/ 18 haben die Professorinnen und Professoren der dortigen Katholisch-Theologischen Fakultät zum letzten Mal ihre Vorlesungen in den Hörsälen gehalten, die seit 1884, dem Datum der Fertigstellung des Hauptgebäudes der Universität an der Ringstraße, der katholischen Theologie zugewiesen waren. Die Säle im imperialen Prachtbau, der seinerzeit vom Architekten Heinrich von Ferstel (1828-1883) im Stil der Hochrenaissance geschaffen wurde, waren hoch und hell, sie boten ideale Rahmenbedingungen für die Lehre. Gleichwohl hat das Rektorat wegen verschärfter Brandschutzbestimmungen und erhöhten Bürobedarfs für neu berufene Professuren per Erlass entschieden, diese Hörsäle im zweiten Obergeschoss aufzugeben und baulich umzuwidmen. Ab dem Sommersemester 2019 wurde der Lehrbetrieb der katholischen Theologie daher in das Untergeschoss der Universität verlegt. Manche haben dies bedauert und in dem Vorgang auch eine symbolische Degradierung gesehen. Zu Unrecht! Denn die Argumente der Universitätsleitung waren der Sache nach gut begründet, auch ließ eine solche von einer Hermeneutik des Verdachts geleitete Kritik unbeachtet, dass andere Fächer von der Regelung ebenfalls betroffen sind. Sie vergaß, dass die Theologie keine Privilegien bei der Hörsaalzuweisung geltend machen kann.

Hellhörig machte hingegen der eher beiläufig gegebene Hinweis, dass im Zusammenhang der Hörsaalverlegung auch die religiösen Symbole - will sagen: die Kruzifixe - von den Wänden verschwinden sollten. Die Sache war umso misslicher, als dazu kein entsprechender inneruniversitärer oder innerfakultärer Konsultations- oder Meinungsbildungsprozess stattgefunden hatte. Das Argument des Rektorats lautete: Die Nutzung der neuen Hörsäle solle zentral verwaltet und fächerübergreifend geregelt werden, um eine optimale Raumauslastung zu erzielen. Man legte Wert auf die Feststellung, dass die Universität Wien nicht die Kreuze aus den Hörsälen verschwinden lasse, sondern dass es künftig keine Hörsäle für die Theologie mehr geben werde. Das mag man für sophisticated halten, aber der Unterschied verdient Beachtung. Die Theologie verlor mit den Hörsälen die Möglichkeit, diese durch eigene religiöse Symbole öffentlich zu kennzeichnen. Das Ergebnis war dennoch das Gleiche: Kreuze würde es an den Wänden der Hörsäle keine mehr geben!

\section{Der Abschied vom Kreuz - religionsrechtlich alternativlos?}

Der Vorgang ist religionspolitisch delikat und lohnt auch im Abstand von einem Jahr noch einen rückblickenden Kommentar. Kirchendistanzierte Kreise vertraten bekanntlich schon länger die Auffassung, dass an einer staatlichen Universität religiöse Symbole nichts zu suchen haben. Sie hielten es denn auch für einen überfälligen Akt, die Kruzifixe als Relikte einer problematischen Symbiose 
von Staat und Kirche zu entfernen. ${ }^{4}$ Ihre Forderung nach einem Abschied vom Kreuz entspricht einem schleichenden Akzeptanzverlust des Christentums in den spätmodernen Gesellschaften Westeuropas, der durch die skandalösen Fälle von sexuellem Missbrauch durch Priester, Bischöfe und Kardinäle sowie die systemische Vertuschung dieser Delikte noch einmal einen zusätzlichen Schub erhalten hat. Auch ist klar, dass Lehrende und Studierende an der Universität Wien unterschiedliche religiöse Überzeugungen und weltanschauliche Orientierungen mitbringen. Nicht nur Agnostiker und bekennende Atheisten dürften Schwierigkeiten mit dem Kreuz haben. Auch für Juden und Muslime ist das Kreuz ein ambivalentes Symbol, wie eine historisch sensibilisierte und interreligiös ausgerichtete Theologie nicht bestreiten wird. Im kulturellen Gedächtnis der Juden hallt der Gottesmordvorwurf, der erstmals von Melito von Sardes in der Mitte des 2. Jahrhunderts ${ }^{5}$ erhoben wurde, bis heute nach, und im kollektiven Erinnerungshaushalt der Muslime sind die Kreuzzüge des Mittelalters noch immer präsent. Die Entscheidung der Universitätsleitung, gegenüber allen Religionen und Weltanschauungen eine Haltung der Äquidistanz einzunehmen, erschien vor diesem Hintergrund nachvollziehbar.

Dennoch bleibt Unbehagen. Das Kreuz ist das zentrale Symbol des Christentums, der akademischen Theologie an den staatlichen Universitäten ist es aufgegeben, den Ereigniszusammenhang von Leben, Tod und Auferweckung Jesu vor dem Hintergrund kritischer Anfragen deutend zu erschließen und die humanisierende Kraft der memoria passionis in Erinnerung zu rufen. Daran erinnert das Zeichen des Kreuzes in den Hörsälen der Theologie. Die in einigen europäischen Ländern kontrovers diskutierte Frage, ob Kreuze in Klassenzimmern angebracht werden dürfen oder nicht, hat der Europäische Gerichtshof für Menschenrechte im März 2011 dem Ermessensspielraum des jeweiligen Unterzeichnerstaates der Europäischen Menschenrechtskonvention überlassen, dabei aber festgestellt, das Kreuz sei „ein passives Symbol“. Österreichische Juristen mögen beurteilen, ob sich dieses Urteil analog auf Hörsäle an staatlichen Universitäten übertragen lässt. Das Prinzip der Religionsfreiheit müsste in jedem Fall gewahrt bleiben. Es kann nicht die staatliche Autorität sein, die den Raum mit christlichen Symbolen ausstattet. Allenfalls ist es möglich, dass sie der katholischen Theologie diese Möglichkeit gewährt. Dieser Weg aber wurde in Wien nicht beschritten, obwohl er der Freundschaftsklausel im Artikel 22 des Kon-

4 Auf dieser Linie konnte der Kommentar von Dietmar Neuwirth, Kaum zu glauben. Bis vor Kurzem gab es an der Uni Wien Kreuze an der Wand. Jetzt sind sie weg, in: Die Presse am 25.02.2018, gelesen werden. Dazu meine Replik: Jan-Heiner Tück, Uni Wien ohne Kreuze: Sind Rektoren sakrosankt?, in: Die Presse am 01.03.2018.

5 Vgl. dazu meinen Versuch: Jan-Heiner Tück, Gottesmord? Die Paschahomilie des Melito von Sardes, in: IKaZ Communio 47/2018, S. 200-205, sowie Hansjörg auf der Mauer, Die Osterfeier in der alten Kirche, aus dem Nachlass hrsg. von R. Meßner und W. G. Schöpf, Münster 2003. 
kordats zwischen dem Heiligen Stuhl und der Republik Österreich entsprochen hätte, die vorsieht, solche Details in wechselseitigem Einvernehmen zu lösen. ${ }^{6}$

\section{Die skandalöse Semantik des Kreuzes}

Allerdings ist Wachsamkeit geboten, wenn das Kreuz zum historischen Kultursymbol heruntergestuft und sein theologisches Provokationspotential verharmlost wird. Es ist und bleibt ein Skandal, das Sterben eines unschuldigen Menschen sichtbar zu machen, von dem Christinnen und Christen öffentlich bekennen, dass er der Christus und Sohn Gottes ist. Das Kreuz bringt ans Licht, was gerne in der Grauzone gehalten, abgedrängt und vergessen wird: das ungerechte Leiden der Opfer, die keine Stimme haben oder mundtot gemacht werden, aber auch und nicht minder die Anmaßung der Täter, die gerne so tun, als hätten ihre Taten gar nicht stattgefunden. Das Kreuz erinnert an die Verwundbarkeit und Fehlbarkeit menschlicher Existenz, es spiegelt die Erlösungsbedürftigkeit und Sterblichkeit. Es ist aber auch, wie Ingeborg Gabriel zu Recht in Erinnerung gerufen hat, „Zeichen gewaltfreien Widerstands gegen Unrecht und Inhumanität sowie Zeichen für die Hoffnung auf die Auferstehung und das ewige Leben" "7. Gerade in Zeiten, in denen die Imperative der Leistung und Effizienzsteigerung im universitären Bereich immer mehr um sich greifen, die Ökonomisierung des Wissens das bedrohte Humanum ${ }^{8}$ zunehmend aus dem

6 Das Konkordat zwischen dem Heiligen Stuhl und der Österreichischen Bundesregierung wurde am 5. Juni 1933 von Kardinalstaatssekretär Eugenio Paccelli, Bundeskanzler Engelbert Dollfuß sowie Justizminister Kurt Schuschnigg unterzeichnet, es trat allerdings erst am 1. Mai 1934 - gleichzeitig mit der autoritären Ständestaat-Verfassung in Kraft. Die historische Entstehung des Konkordates, das der katholischen Kirche den Status einer Körperschaft des öffentlichen Rechtes zusichert, wird von Kritikern bis heute als „Geburtsfehler" bemängelt. Die „Initiative für Aufhebung der Kirchen-Privilegien“ vom April 2013 forderte mit der klaren Trennung von Staat und Kirche auch die Aufhebung des Konkordates, wurde aber nur von $0,89 \%$ der wahlberechtigten Bürgerinnen und Bürger in Österreich unterstützt. Vgl. Erika Weinzierl, Das österreichische Konkordat von 1933 von der Unterzeichnung bis zur Ratifikation, in: Hans Paarhammer / Franz Pototschnig / Alfred Rinnerthaler (Hg.), 60 Jahre Österreichisches Konkordat, Veröffentlichungen des Internationalen Forschungszentrums für Grundfragen der Wissenschaften Salzburg N. F. 56, München 1994, S. 119-134.

7 Gabriel, Das Kreuz im Widerstreit, S. 270.

8 Man vergisst leicht, dass dem Wort humanitas ein etymologischer Anklang an humus eingeschrieben ist. Im Unterschied zur Neuzeit verstand man im Mittelalter unter Humanität weniger die Größe des Menschen als vielmehr seine erdgebundene Niedrigkeit und Hinfälligkeit. Die Nähe zur humilitas - Demut und Dienstbereitschaft - liegt auf der Hand. Vgl. Thomas Pröpper, Theologische Anthropologie I, Freiburg i. Br. 2011, S. 133. - Auf die Bedeutung der christlichen Sozialethik im Horizont einer Moderne, die durchaus auch ambivalente Folgewirkungen aufweist, hat Ingeborg Gabriel hingewiesen in ihrem programmatischen Beitrag: Christliche Sozialethik in der Moderne. Der kaum rezipierte Ansatz von 
Blick verliert und Transhumanisten unverblümt ausrufen, den Menschen digital und biotechnisch unverwundbar, ja unsterblich zu machen, ist das Kreuz ein Gegenzeichen, das die wissenschaftliche Vernunft vor Hybris und Selbstüberschätzung warnen kann. Jedenfalls kann es zur Wachsamkeit mahnen, wenn vereinzelte Akteure der Lebenswissenschaften mit Glücksversprechungen aufwarten, die das Zeug zum Religionsersatz haben, wenn sie nichts weniger als eine "Auferstehungstechnologie“ (Botho Strauß) in Aussicht stellen. ${ }^{9}$

\section{Ein symbolpolitischer Einschnitt mit leicht laizistischen Gefälle}

Hinzu kommt in Wien ein historischer Gesichtspunkt, der das Unbehagen verstärkt. Mutmaßlich hängen seit 1384, dem Gründungsdatum der ältesten Katholisch-Theologischen Fakultät im deutschen Sprach- und Kulturraum, Kruzifixe in den Hörsälen. Ihre Größe und Plastizität mögen zuletzt manchen verstört und den Verdacht einer Glorifizierung des Leidens genährt haben. Allerdings, sie im Jahre 2018 im Namen einer fächerübergreifenden neuen Raumnutzung leise zu entfernen, ist ein symbolpolitischer Einschnitt von historischer Tragweite, den man zum Anlass eines universitätsöffentlichen Disputes hätte nutzen können und sollen. Man stelle sich nur für einen Augenblick vor, alle Professoren, die im Laufe von über sechs Jahrhunderten an der Theologischen Fakultät gelehrt haben, träten zu einer imaginären Versammlung im Großen Festsaal der Universität zusammen und würden über den Entschluss des Rektorats zu Rate sitzen. „Tradition lässt sich als erweitertes Stimmrecht fassen“, hat Gilbert K. Chesterton einmal notiert und ergänzt: „Tradition bedeutet, dass man der am meisten im Schatten stehenden Klasse, unseren Vorfahren, Stimmrecht verleiht. Tradition ist Demokratie für die Toten. “ ${ }^{10}$

Neben der historischen Zäsur, die man - je nach Standort - beklagen oder auch begrüßen kann, wirft der Vorgang die Frage auf, welches Verständnis von Religionsfreiheit im Hintergrund steht, wenn die Universitätsleitung in den neuen Hörsälen ausnahmslos keine religiösen Symbole mehr zulässt. Selbstverständlich kann man die Maßnahme im Namen der weltanschaulichen Neutralität des Staates rechtfertigen. Der Rektoratsbeschluss erweckt allerdings den Eindruck eines leicht laizistischen Gefälles und muss sich dem Einwand stellen,

Gaudium et spes, in: Jan-Heiner Tück (Hg.), Erinnerung an die Zukunft. Das Zweite Vatikanische Konzil, 2. Aufl., Freiburg i. Br. 2013, S. 605-621.

9 Vgl. Klaus Müller, Endlich unsterblich. Zwischen Körperkult und Cyberworld, Kevelaer 2009.

10 Gilbert Keith Chesterton, Orthodoxie. Eine Handreichung für die Ungläubigen, aus dem Englischen übersetzt von Monika Noll und Ulrich Enderwitz, Frankfurt a. M. 2001, S. 99. 
dass durch das Entfernen der religiösen Symbole die Nichtreligiösen möglicherweise privilegiert werden. ${ }^{11}$ Überdies provoziert er die ideologiekritische Rückfrage, wie das entstehende symbolische Vakuum neu gefüllt wird. Es wäre naiv zu glauben, dass die Universität eine ideologiefreie Zone wäre, in der es keine Akteure gäbe, welche die Leerstelle gerne neu und anders besetzen.

\section{Verpasste Chancen und deutliche Worte}

Das kooperative Staat-Kirche-Verhältnis in Österreich hätte auch eine Regelung erlaubt, abweichend von der fächerübergreifenden Hörsaalvergabe in wenigstens einem der Räume das Kreuz zu belassen. Dieser Kompromiss, der an der Universität Innsbruck nach einem zähen Ringen zwischen Universitätsleitung und Theologischer Fakultät immerhin erzielt wurde, hätte auch in Wien ein Erinnerungssignal gesetzt, dass die europäischen Universitäten im Mittelalter aus den Kloster- und Kathedralschulen hervorgegangen sind. Außerdem hätte eine solche Lösung dem Umstand Rechnung getragen, dass sich der weltanschaulich neutrale Staat Universitäten leistet, in deren Fächerkanon Religionsforschung nicht nur aus der Beobachter-, sondern auch aus der Teilnehmerperspektive, nämlich durch bekenntnisgebundene Theologien, betrieben wird. ${ }^{12}$

Der Abschied von den Kreuzen aus den Hörsälen der Universität hätte so nicht kommen müssen. Es wäre fataler Ausdruck einer „retrospektiven Fatalitätsillusion“ (Raymond Aron), davon auszugehen, dass alles so kommen musste, wie es gekommen ist. Das hieße, den Freiheitsspielräumen der handelnden Akteure im

11 Vgl. meine Intervention: Jan-Heiner Tück, Gegen die weiße Wand. Ein leicht laizistisches Gefälle: In Wien sollen die Theologen künftig in Hörsälen ohne Kreuz unterrichten. Ist das richtig?, in: F.A.Z. am 15.02.2018 (Nr. 39), S. 9, sowie die zustimmende Replik von Georg Essen, Ungleiche Zumutungen beim Blick auf die weiße Wand. Der Abbau von Privilegien für das Christentum darf nicht die Religionslosen privilegieren, in: F.A.Z. am 19.02.2018 (Nr. 42), S. 13.

12 Der Beschluss der Fakultätsleitung, beim Rektorat den Antrag zu stellen, einen der neuen Hörsäle dem Andenken Franz Kardinal Königs (1905-2004) zu widmen, mag man als Vorschlag zur Güte werten. König war habilitierter Religionswissenschaftler und Ehrendoktor der Universität Wien. Das Rektorat hat dem Antrag der Fakultätsleitung inzwischen positiv entsprochen. Bei der Einweihung des „Franz-König-Hörsaals“ am 3. Oktober 2019 - der Kardinalstitel wurde vom Senat der Universität kassiert - erinnerte die Historikerin und langjährige Büroleiterin von Kardinal König, Dr. Annemarie Fenzl, daran, dass dieser die Theologie nicht als „Wärmestube für müde Geister“, sondern als „gefährliche Wissenschaft“ verstanden habe. Das ist ein denkwürdiges Wort. Gleichwohl wird auch der Name von Franz König bei all den großen Verdiensten, die dieser sich um die Erzdiözese Wien, die Kirche von Österreich, die Erneuerung der katholischen Weltkirche auf dem Zweiten Vatikanischen Konzil (1962-1965) erworben hat, nicht das Zeichen des Gekreuzigten und Auferstandenen ersetzen können, dem Paulus im Hymnus des Philipperbriefs „den Namen über alle Namen“ (Phil 2,10) zugeschrieben hat. 
Rückblick allzu wenig Gewicht beizumessen. Die ganze Geschichte wäre anders verlaufen, wenn sich mehr Stimmen bereitgefunden hätten, die Rektoratsentscheidung zu diskutieren und freimütig zu problematisieren. Aber weder die Fakultätsleitung noch das Kollegium der Professorinnen und Professoren der katholischen Theologie haben sich dazu durchringen können, eine gemeinsame Stellungnahme an das Rektorat abzugeben. ${ }^{13}$ Die einen fanden es peinlich, im Kontext einer säkularen Universität auf den Erhalt religiöser Symbole zu drängen; andere verwiesen auf die subversive Logik des Kreuzes, das jede Identitätssymbolik sprengt, und empfahlen im Sinne der Kenosis eine Selbstrücknahme des Zeichens; wieder andere machten sich Sorgen, dass eine Problematisierung der Rektoratsentscheidung eine kulturkämpferische Situation herbeiführen könne, die am Ende gegen die katholische Theologie überhaupt gewendet werden könnte; bei wieder anderen mag schließlich ein Quäntchen Autoritäts- und Erlasshörigkeit gegenüber dem Rektorat eine Rolle gespielt haben, lieber zu schweigen statt das offene Wort zu ergreifen. Auch der Magnus Cancellarius der Fakultät hat sich in dieser Angelegenheit vornehm zurückgehalten, wohl, weil er die Autonomie der Universität durch eine kirchliche Intervention nicht antasten wollte.

Allein Wolfgang Thierse, SPD-Politiker und ehemaliger Präsident des Parlaments der Bundesrepublik Deutschland, hat sich als Festredner beim Dies Facultatis im Oktober 2018 öffentlich und klar zu den Vorgängen geäußert. In seinem Vortrag hat Thierse, der die Verdrängung christlicher Symbole aus dem öffentlichen Raum aus den Zeiten der DDR noch in lebendiger Erinnerung hat, zunächst herausgestellt, dass Religion Teil der Moderne ist. Nicht die Religion sei am Ende, sondern die klassischen Säkularisierungstheorien, welche meinten, das Ende der Religion mit fortschreitender Modernisierung der Gesellschaften prognostizieren zu können. Damit hänge eine signifikante Verschiebung von religiös homogenen zu religiös und weltanschaulich pluralen Gesellschaften zusammen - ein vielschichtiger Transformationsprozess, der in Europa durch die Migrationsbewegungen noch zugenommen hat und der auch den säkularen Staat vor neue Herausforderungen stellt. Thierse warb nun dafür, im Unterschied zum französischen Modell der strikten Trennung von Politik und Religion den weltanschaulich neutralen Staat als religionsermöglichende, nicht aber als eine religionsneutralisierende oder gar religionsnegierende Größe zu verstehen. Auf der Basis der grundgesetzlich festgeschriebenen Religionsfreiheit sollten Juden, Muslime und Christen, aber auch Agnostiker und Atheisten aus ihren inneren

13 Ein Vorstoß des Kirchenhistorikers ao. Univ.-Prof. Dr. Rupert Klieber, den einzigen feuerpolizeilich unbedenklichen alten Hörsaal direkt neben dem Dekanat samt Kreuz für die katholische Theologie zu erhalten, wurde - auch wegen mangelnder Unterstützung durch das Leitungsteam - vom Rektorat ebenfalls abgelehnt. 
Überzeugungen heraus das ethische und kulturelle Fundament des Gemeinwesens öffentlich mitgestalten können. Die Werte, Sinnpotentiale und Normen der Religionen und Weltanschauungsgemeinschaften dürften nicht in die Privatsphäre abgedrängt werden, das Fehlen religiöser Symbole solle im öffentlichen Raum nicht privilegiert werden. In diesem Zusammenhang hat der Berliner Politiker für das Verschwinden der religiösen Symbole aus den Hörsälen der Universität Wien Worte gefunden, die man in dieser Deutlichkeit von keinem österreichischen Akteur in Theologie, Politik und Kirche vernommen hat:

„Und hier an der Wiener Universität betone ich: Dem konfliktträchtigen religiös-weltanschaulichen Pluralismus sollte der religionsneutrale Staat nicht durch institutionelle Bilderstürmerei begegnen, durch Säuberung öffentlicher Räume von religiösen Symbolen. Er hat weder das Recht noch die Pflicht zur Nivellierung faktischer religiöser Pluralität - etwa zugunsten einer religionslosen bzw. religionsverbergenden Neutralität. ${ }^{\text {(14 }}$

\section{Der Fingerzeig einer Skulptur und eine offene Frage}

Die Frage aber, die bleibt, ist: Muss die Achtung vor der Andersheit Andersdenkender und Andersgläubiger so weit gehen, dass das Eigene keinen Raum mehr hat und haben darf? Konkreter: dass das Kruzifix als sichtbares Zeichen für das Selbstverständnis bekenntnisgebundener Theologien keinen Ort mehr hat in den Hörsälen der Universität Wien? „Erst verschwinden die Zeichen, dann das Bezeichnete“, hat der Schweizer Schriftsteller Thomas Hürlimann im Rahmen seiner Wiener Poetik-Vorlesung vermerkt - und Kunst und Literatur die seismographische Aufgabe zugeschrieben, die leisen Veränderungen zu registrieren und das Verschwundene im Medium von Bild und Sprache gegenwärtig zu halten. ${ }^{15}$ Und in der Tat: Wer Augen hat zu sehen, kann an der Ringstraßen-Architektur eine erstaunliche Entdeckung machen. Das, was im Tiefparterre inzwischen verschwunden ist, das Kreuz, ist oben auf der Fassade des Universitätsgebäudes nach wie vor da. Dort thront die Skulptur der sacra theologia mit einem langstieligen Kreuz! Für die einen mag das nicht mehr als ein historistisches Zitat sein, ein bloßes Ornament eben, das Heinrich von Ferstels Prachtbau ziert. Andere erinnert die denkmalgeschützte Statue in der Giebelgruppe von Edmund Hellmer daran, dass die wissenschaftliche Reflexion über Gott unter dem Dach der europäischen Universitäten seit deren Gründung im Mittelalter

14 Wolfgang Thierse, Religion in pluralistischer Gesellschaft und im weltanschaulich neutralen Staat, in: Internationale Katholische Zeitschrift Communio 47/2019, S. 66-79, hier S. 73.

15 Vgl. Thomas Hürlimann / Jan-Heiner Tück, Die Anwesenheit des Abwesenden. Wenn die Stunde der Literatur schlägt - über die Anstößigkeit des Kreuzes, in: Neue Zürcher Zeitung am 11.05.2016 (Nr. 108), S. 23. 
einen Ort hat. ${ }^{16}$ Für die akademische Theologie heute aber ist die in Stein gemeißelte Skulptur, die bislang allen Witterungen und Moden standgehalten hat, Anstoß, die Anstößigkeit des Kreuzes nicht zu vergessen, von der schon Paulus gesprochen hat (1 Kor. 1,17-31), und die Frage freimütig zu stellen: Was fehlt, wenn das Kreuz fehlt?

\section{Quellen}

Auf der Mauer, Hansjörg, Die Osterfeier in der alten Kirche, aus dem Nachlass hrsg. von R. Meßner und W. G. Schöpf, Münster 2003.

Chesterton, Gilbert Keith, Orthodoxie. Eine Handreichung für die Ungläubigen, aus dem Englischen übersetzt von Monika Noll und Ulrich Enderwitz, Frankfurt a. M. 2001.

Essen, Georg, Ungleiche Zumutungen beim Blick auf die weiße Wand. Der Abbau von Privilegien für das Christentum darf nicht die Religionslosen privilegieren, in: F.A.Z. am 19.02.2018 (Nr. 42), S. 13.

Gabriel, Ingeborg, Das Kreuz im Widerstreit, in: Christi in der Gegenwart 24/2018, S. 269-270.

Gabriel, Ingeborg, Christliche Sozialethik in der Moderne. Der kaum rezipierte Ansatz von Gaudium et spes, in: Jan-Heiner Tück (Hg.), Erinnerung an die Zukunft. Das Zweite Vatikanische Konzil, 2. Aufl., Freiburg i. Br. 2013, S. 605-621.

Hoping, Helmut (Hg.), Universität ohne Gott? Theologie im Haus der Wissenschaften, Freiburg i. Br. 2006.

Hürlimann, Thomas / Tück, Jan-Heiner, Die Anwesenheit des Abwesenden. Wenn die Stunde der Literatur schlägt - über die Anstößigkeit des Kreuzes, in: Neue Zürcher Zeitung am 11.05.2016 (Nr. 108), S. 23.

Klissenbauer, Irene, Kein bayrischer Konstantin - aus der Geschichte lernen, in: catholicnewsagency am 17.05.2018, vgl. https://de.catholicnewsagency.com/article/keinbayerischer-konstantin-0277 (letzter Zugriff: 06.07.2019).

Müller, Klaus, Endlich unsterblich. Zwischen Körperkult und Cyberworld, Kevelaer 2009.

Neuwirth, Dietmar, Kaum zu glauben. Bis vor Kurzem gab es an der Uni Wien Kreuze an der Wand. Jetzt sind sie weg, in: Die Presse am 25.02.2018.

Pröpper, Thomas, Theologische Anthropologie I, Freiburg i. Br. 2011.

Thierse, Wolfgang, Religion in pluralistischer Gesellschaft und im weltanschaulich neutralen Staat, in: Internationale Katholische Zeitschrift Communio 47/2019, S. 66-79.

Tück, Jan-Heiner, Uni Wien ohne Kreuze: Sind Rektoren sakrosankt?, in: Die Presse am 01.03.2018.

Tück, Jan-Heiner, Gottesmord? Die Paschahomilie des Melito von Sardes, in: IKaZ Communio 47/2018, S. 200-205.

Tück, Jan-Heiner, Gegen die weiße Wand. Ein leicht laizistisches Gefälle: In Wien sollen die Theologen künftig in Hörsälen ohne Kreuz unterrichten. Ist das richtig?, in: F.A.Z. am 15.02.2018 (Nr. 39), S. 9.

16 Vgl. Helmut Hoping (Hg.), Universität ohne Gott? Theologie im Haus der Wissenschaften, Freiburg i. Br. 2006. 
Erika Weinzierl, Das österreichische Konkordat von 1933 von der Unterzeichnung bis zur Ratifikation, in: Hans Paarhammer / Franz Pototschnig / Alfred Rinnerthaler (Hg.), 60 Jahre Österreichisches Konkordat, Veröffentlichungen des Internationalen Forschungszentrums für Grundfragen der Wissenschaften Salzburg N.F. 56, München 1994, S. 119-134.

\section{Weiteres}

Allgemeine Geschäftsordnung für die Behörden des Freistaats Bayern, $\$ 28$, zitiert nach: http://www.gesetze-bayern.de/Content/Document/BayAGO-28 (letzter Zugriff: 03.04. 2019). 
Open-Access-Publikation im Sinne der CC-Lizenz BY 4.0

(C) 2020, Vandenhoeck \& Ruprecht $\mathrm{GmbH} \&$ Co. KG, Göttingen ISBN Print: 9783847111658 - ISBN E-Lib: 9783737011655 


\section{Grenzen der Pastoral - Pastoral an Schwellen und Grenzen. Thesen für die Zukunft kirchlichen Handelns}

SozialethikerInnen sind Grenzgängerinnen: Ihre Wissenschaftsdisziplin ist im Spannungsfeld von Theologie, Philosophie, Sozialwissenschaften, Politik, Gesellschaft und Wirtschaft angesiedelt. Übliche Disziplinengrenzen überschreiten sie, um im Dialog unterschiedlichster Disziplinen voneinander zu lernen. In den vergangenen Jahren kam das Fach unter Druck: Ist es nicht Teil der Theologischen Ethik? Oder nicht doch ein philosophisches Fach? Sozialethik ist ein Schwellenfach - und verlangt von seinen VertreterInnen zumeist eine Mehrfachkompetenz, wie die jüngsten Ausschreibungen von Lehrstühlen dieses Faches zeigen.

Das Motiv der Grenze und der Grenzziehungen ist eines, das die Sozialethik mit der Pastoraltheologie verbindet. ${ }^{1}$ Für mich ist es der Anlass, zunächst grundsätzlicher auf das Motiv der Grenze zu schauen, um dann auf konkrete gegenwärtige Grenzfälle in Gesellschaft, Kirche und Pastoral zu blicken. Schließen möchte ich mit Visionen, inwiefern solche Grenzen heute auch Übergänge, Schwellen in eine spannende Zukunft kirchlichen Handelns sein können.

\section{Das Motiv der "Grenze“ und der Schwelle}

Die gegenwärtige Situation der Kirche wird mit unterschiedlichsten Metaphern beschrieben: Rainer Bucher spricht von der „Provokation der Krise“; ${ }^{3}$ Müller

1 Daher widme ich diesen Beitrag auch gerne Ingeborg Gabriel anlässlich ihrer Emeritierung. Sie ist eine Grenzgängerin zwischen Theologie, Diplomatie (OSZE) und Wirtschaft und eine Verfechterin der Bedeutung der Menschenrechte - wo es gerade auch um das Sichern von persönlichen Grenzen und Rechten geht.

2 Vgl. dazu Näheres in: Johann Pock, Kirche an der Schwelle. Überlegungen zu einem (neuen) Krisenparadigma, in: Rainer Bucher (u. a.) (Hg.), Nach der Macht. Zur Lage der katholischen Kirche in Österreich, Würzburg 2014, S. 157-174. 
von einer „Kirche im Übergang“4. Für andere stehen wir in einer Zeit der „Transformation“; ; auch die Zukunftsmetapher wird beschworen ${ }^{6}$ und das „Jenseits der Kirche“" untersucht. Jüngste Entwicklungen im Zusammenhang mit dem Aufdecken von Missbrauchsfällen führen sogar zur Frage, ob die (katholische) Kirche nicht an einer Zeitenwende steht.

Gleichzeitig werden diese Metaphern aber auch hinterfragt ${ }^{8}$ bzw. ins Positive gewendet: Krise ist Chance, Krisenzeiten sind Gründerzeiten, Grenzen stellen einen Übergang zu etwas Neuem dar etc. Alle diese Beiträge sind sich jedoch in dem einen Punkt einig: alte Sicherheiten und Gewissheiten sind in Bewegung geraten; Gewohntes ändert sich - und diese Veränderungen haben einen Einfluss darauf, wie sich die Kirche organisiert bzw. wie sie wahrgenommen wird.

Andrea Komlosy, Professorin am Institut für Wirtschafts- und Sozialgeschichte der Universität Wien, spürt dem Phänomen der Grenze nach und untersucht „räumliche und soziale Trennlinien im Zeitenlauf ${ }^{\star 9}$. Ihr Resümee lautet: „Grenze als Politik verweist auf Grenze als Prozess, als Aufgabe, als Aktivität. “10 Grenzen haben sich im Verlauf der Zeiten verändert. Sie dienen unterschiedlichen Zielen - und sie sind ein soziales, kulturelles und auch religiöses Gestaltungselement von Gesellschaften.

Eine spezielle Form von Grenzen sind Schwellen. Ich finde die Schwellenmetapher spannend für die Situation, in der wir stehen. Schwellen sind ein Teil eines abgrenzenden Bauwerks - und ermöglichen dennoch zugleich, diese Grenze zu überwinden. Zusammen mit der Tür trennt die Schwelle unterschiedliche Bereiche: außen und innen, hell und dunkel, profan und heilig, kalt und warm, Unsicherheit und Sicherheit, Fremde und Heimat.

3 So z. B. Rainer Bucher (Hg.), Die Provokation der Krise. Zwölf Fragen und Antworten zur Lage der Kirche, Würzburg 2004.

4 Peter Hünermann, Im Übergang. Das Zweite Vatikanum als Konzil einer neuen Epoche, in: Herder Korrespondenz 67/11/2013, S. 560-565; Gerhard Ludwig Müller, Kirche im Übergang. Welche Reform benötigen wir?, in: Deutsches Pfarrerblatt 113/8/2013, S. 437-443; Philipp Gassert, Krisen und Übergänge. Der weltpolitische Kontext des 2. Vatikanums zu Beginn der 1960er-Jahre, in: Münchener theologische Zeitschrift 64/4/2013, S. 306-316.

5 Heinrich Bedford-Strohm, Große Transformation. Wie die Kirchen die ökologisch-soziale Neuausrichtung der Gesellschaft mitgestalten können, in: Zeitzeichen 14/5/2013, S. 8-11; Rainer Bucher, Die Ordensgemeinschaften in der aktuellen Transformationskrise der katholischen Kirche, Vortrag am 20. November 2012 beim Österreichischen Ordenstag in Wien-Lainz, in: Ordensnachrichten 51/6/2012, S. 17-32.

6 Vgl. u. a. Ferdinand R. Prostmeier (Hg.), Zukunft der Kirche - Kirche der Zukunft. Bestandsaufnahmen - Modelle - Perspektiven, Regensburg 2004.

7 Frank Bösch (Hg.), Jenseits der Kirche. Die Öffnung religiöser Räume seit den 1950er Jahren, Geschichte der Religion in der Neuzeit 5, Göttingen 2013.

8 Stefan Orth, Welche Krise?, in: Herder Korrespondenz 65/4/2011, S. 163-165.

9 Andrea Komlosy, Grenzen. Räumliche und soziale Trennlinien im Zeitenlauf, Wien 2018.

10 Komlosy, Grenzen, S. 230. 
Gleichzeitig ist die Schwelle im Gegensatz zur Tür, zur Wand, zur Mauer oder zum Stacheldraht doch eine eher symbolische Trennlinie, da sie ja nicht nur der Trennung, sondern vor allem der Ermöglichung des Überschreitens der Grenze dient, also dem nicht zufälligen, sondern bewussten Hineingehen in einen neuen Raum.

Wenn das „Dahinter“ einer Schwelle unbekannt ist, ist mit der Schwelle auch eine gewisse „Schwellenangst“ verbunden: Das Überschreiten bedeutet eine mögliche Gefährdung. Man weiß nicht, was einen dahinter erwartet - und dies gilt für das Überschreiten in beide Richtungen. Und wie sehr Grenzen und Schwellen mit Ängsten verbunden sind, haben nicht zuletzt die letzten Jahre und die politischen Spiele mit den Grenzen gezeigt.

Schwellen und Grenzen zu überschreiten, bekannte Wege zu verlassen - das gehört nun von seinen Ursprüngen an zum Wesen des Christentums. Und ist nicht der ganze Ritualschatz dazu da, Schwellen und Übergänge gut zu begleiten und zu gestalten? Ist nicht der Kern der christlichen Religion das Überschreiten der absoluten Schwelle schlechthin - nämlich des Todes?

So berichtet bereits die Apostelgeschichte mehrfach von der krisenhaften Entwicklung der frühen Kirche. Beispielhaft sei hier auf Apg. 10 verwiesen: Der heidnische Hauptmann Kornelius schickt nach Simon Petrus, um sich taufen zu lassen. Petrus hat eine Vision, durch welche ihm klar wird, dass er eine Grenze überschreiten muss. Gott zeigt ihm unreine Tiere und macht ihm deutlich: Was ich für rein erkläre, erkläre du nicht für unrein. Damit berichtet Apg. 10 vom Übergang des einen Kirchenverständnisses zu einem anderen - von der rein judenchristlichen Kirche hin zur gemischten Kirche mit den Heidenchristen. ${ }^{11}$ Was hier geschildert wird, ist eine Schwelle, ein Übergang - und das Überschreiten dieser Schwelle. Und es wird deutlich, dass dieses Überschreiten Mut braucht, Vertrauen in den Geist Gottes (bzw. in die Kirchen-Visionen), das Eingehen auf die (geänderten) Bedürfnisse, die von den Menschen her an die Institution (welche hier durch Petrus repräsentiert wird) herangetragen werden, und die Energie, diesen Schritt jenen gegenüber zu begründen und zu verteidigen, die noch vor dieser Schwelle stehen (wie es beispielhaft am Apostelkonzil erfolgt ist).

Das Christentum steht im Dienst solcher Grenzüberschreitungen und ist gewissermaßen „Schwellenkunde“ - und es steht selbst immer wieder an solchen Grenzen und Schwellen, von denen ich im Folgenden einige benennen möchte mit ihren möglichen Chancen für die Zukunft.

11 Vgl. dazu Näheres u. a. bei Klaus Kliesch, Der revolutionäre Schritt des Urchristentums: Petrus und die Heidenmission (Apg 10,1-11,18), in: Bibel und Kirche 55/2/2000, S. 74-78. 


\section{Aktuelle Grenzen und Schwellen}

Dass wir heute in unserer Zeit und in unserem Land an solchen Grenzen und Schwellen stehen, ist wohl jedem und jeder deutlich. ${ }^{12}$ Dies zeigen nicht zuletzt die jüngsten Europawahlen im Mai 2019, die im Zentrum von der Frage der Identität (von Nationen und von Europa) und einer verstärkten Abgrenzung nach außen geprägt wurden (mit einem deutlichen Rechtsruck in ganz Europa). Andrea Komlosy hat in einer Typologie der Grenzen acht unterschiedliche Typen von Grenzen benannt: Elementare, politische, militärische, Kolonialgrenzen, Fronten, Phantomgrenzen, kulturelle und wirtschaftlich-soziale Grenzen.

Ich möchte hier vor allem auf die elementaren, auf die kulturellen und die wirtschaftlich-sozialen Grenzen eingehen - und zwar zunächst im Blick auf den gesellschaftlichen Wandel und seine Grenzüberschreitungen, und dann im Blick auf die kirchlichen Veränderungsprozesse (die ich zu den kulturellen und den sozialen Bereichen rechne).

\subsection{Gesellschaftlicher Wandel ${ }^{13}$}

Eine Diagnose unserer Gesellschaft zeigt aus soziologischer Sicht, dass wir von Entwicklungen geprägt werden, die wir nicht persönlich beeinflussen können, die aber unser persönliches wie auch gemeinschaftliches Leben stark beeinflussen: Dazu gehört zunächst die Individualisierung aller Lebensbereiche mit dem Imperativ: Jeder ist seines Glückes Schmied! Mit der Individualisierung einher geht der Verlust von traditionellen Sicherheiten: Woran kann ich mich heute noch halten? Wer kann mir garantieren, dass es meinen Job, meine Firma, meine Lebensgrundlagen in einigen Jahren noch geben wird?

Verstärkt wird diese Individualisierung durch eine gleichzeitige Pluralisierung. Viele Male am Tag können und müssen wir wählen zwischen verschiedenen Angeboten: Im Supermarkt, bei der Auswahl kultureller Angebote; bei der Wahl von Verkehrsmitteln etc. Die Auswahl an Angeboten für alle Lebensbereiche ist in den letzten Jahren enorm gewachsen.

Diese Pluralisierung betrifft aber unser Leben noch unmittelbarer: neben die traditionellen Lebensformen von Ehe oder Single-Dasein sind mittlerweile neue und ganz unterschiedliche Lebensformen getreten. Ja sogar die Geschlechtsidentitäten haben sich pluralisiert: Es gibt heute nicht mehr nur Mann und Frau.

12 Wie sehr die Covid-19 Pandemie, die in Europa mit Februar 2020 begann, ebenfalls eine solche Schwelle darstellt, kann zur Zeit der Drucklegung des Beitrags nur angedeutet, aber nicht mehr ausführlich aufgegriffen werden.

13 Vgl. dazu auch die Ergebnisse der Europäischen Wertestudie, vgl. https://www.wertefor schung.at/projekte/europaeische-wertestudie/ (letzter Zugriff: 27.05.2019). 
Facebook gibt z.B. 60 unterschiedliche Möglichkeiten für eine Geschlechtsidentität an.

Damit sind wir aber auch bei einer weiteren Entwicklung, nämlich der Digitalisierung und der Auflösung der Grenzen durch die neuen Medien: Mit den sogenannten „sozialen Medien“ wie Facebook, Twitter oder Instagram ist man unmittelbar mit der ganzen Welt vernetzt. Die räumliche Grenze ist für diese Medien ebenso egal wie die üblichen Hemmschwellen in der unmittelbaren Begegnung von Menschen. Damit sind auch die Grenzen der persönlichen Intimsphäre in Auflösung begriffen. Die jüngste Datenschutzverordnung möchte hier neue Grenzen einziehen - im Wissen darum, dass sich durch Handys, Tablets und diverse andere elektronische Geräte mittlerweile ganz viele Grenzen aufgelöst haben.

Schließlich möchte ich noch eine Entwicklung nennen, die in den vergangenen Jahren zu den massivsten Veränderungen in unserer Gesellschaft geführt hat - nämlich die Migrations- und Flüchtlingsbewegungen. Angetrieben durch Hunger, Kriege oder aussichtslose Lebensumstände haben sich so viele Menschen weltweit aufgemacht und haben die Grenzen ihrer eigenen Heimat überschritten, wie wohl selten zuvor. Bewusst ist uns dies in Europa aber erst so richtig geworden, als die eigenen Landesgrenzen so stark überschritten wurden, dass Existenzängste auch bei uns gewachsen sind.

Und hier haben nicht zuletzt einige symbolisch ausgeschlachtete Grenzüberschreitungen wie jene des sogenannten "Grenzsturms“ in Spielfeld im Herbst 2015 dazu geführt, dass plötzlich wieder physische Grenzen hochgezogen werden, wo davor die grüne, offene Grenze zumindest für einige Jahre dominiert hat.

Dass in ganz Europa in den vergangenen Jahren nun fast ausnahmslos jene Parteien Wahlen gewonnen haben, die diese Ängste der Menschen aufgreifen und bedienen, die für geschlossene Grenzen sind und ein Bild einer „heilen Heimatswelt" malen, zeigt, wie tiefgreifend diese Ängste tatsächlich sind. Angestoßen durch die Völkerwanderungen wird das Heimat-Motiv revitalisiert; plötzlich heißt es wieder „Wir“ und „die anderen“ - und Grenzen zwischen Völkergruppen steigen wieder gewissermaßen aus dem Sumpf der Geschichte empor. Längst überwunden geglaubte Ressentiments feiern wieder Renaissance - und dies 100 Jahre nach dem Ende des Ersten Weltkriegs und 80 Jahre nach dem sogenannten „Anschluss“.

Interessant ist dies auch insofern, als gleichzeitig unser Leben extrem globalisiert ist - und Globalisierung meint ja letztlich die Auflösung nationaler Grenzen hin zu einer Weltidentität. Was kann man denn noch vor Ort, regional entscheiden - und wo sind wir abhängig von den Entscheidungen in Brüssel; oder noch eher von den Entwicklungen der großen Firmen? Ich glaube, dass die derzeitigen nationalistischen Entwicklungen in Europa auch eine Reaktion auf 
diese undurchschaubaren Mechanismen sind, deren Steuerungsmechanismen man nicht mehr in der Hand hat. Dann möchte man zumindest den Bereich, den man selbst überblickt, gut kontrollieren können.

Diese Gesellschaftsdiagnose könnte man nun noch lange weiterführen. Ich möchte sie aber als Folie sehen für die nun folgende Diagnose kirchlicher Entwicklungen.

\subsection{Kirchliche Entwicklungen}

Ich habe bewusst die gesellschaftlichen Entwicklungen etwas breiter vorangestellt, damit deutlich wird: Viele unserer kirchlichen Entwicklungen sind nicht hausgemacht, sondern sind Teil dieser globalen Bewegungen, gewollt oder ungewollt - wie auch so manche kirchlichen Entwicklungen der Vergangenheit nur im Kontext politischer oder gesellschaftlicher Ereignisse zu sehen sind.

Wenn ich mir die regionalen kirchlichen Entwicklungen in Österreich ansehe, so möchte ich vor allem drei herausgreifen, die mir für die kommende Zeit zentral zu sein scheinen.

Das erste ist der Umbruch in der Ordenslandschaft. Nach der Statistik der Orden für $2017^{14}$ gibt es 5.033 Ordensfrauen und Ordensmänner in Österreich, davon 3.353 Ordensfrauen und 1.681 Ordensmänner (1.225 Priester und 430 Brüder).

Die Gesamtzahl der Ordensfrauen ist von 1980 bis 2017 von 10.598 auf 3353 gesunken - also auf weniger als ein Drittel. Bei den Ordensmännern ist der Rückgang weniger dramatisch - da gab es nach $2197 \mathrm{im}$ Jahr 1980 sogar einen Anstieg auf über 3000 Mitte der 1980er Jahre. Seither sinkt diese Zahl aber ebenfalls auf derzeit 1681 Ordensmänner. Dramatisiert wird diese Zahl noch durch die Altersstruktur: Von den 3353 Ordensfrauen sind $58 \%$ über 75 Jahre alt (1955 Frauen), $20 \%$ sind zwischen 65 und 75 Jahre, $19 \%$ zwischen 40 und 65 Jahre und nur $3 \%$ (110 Ordensfrauen) sind unter 40 Jahre alt. Bei den Ordensmännern verteilen sich die Altersgruppen etwas besser.

Die Ordensgemeinschaften sehen das zu einem guten Teil jedoch sehr nüchtern: Das, was über Jahrzehnte von Ordensfrauen geleistet wurde, wird jetzt von Frauen in anderen Lebensformen geleistet. Die Vorsitzende der Frauenorden, Sr. Beatrix Mayrhofer, meinte dazu: „Es ist Sache Gottes, welche Berufungen er schenkt. ${ }^{\text {"15 }}$ Dennoch bedeutet dies für die Kirche in Österreich, dass sich ihr Gesicht verändert: In vielen Einrichtungen, die bisher von Ordensleuten ge-

14 Ordensgemeinschaften Österreich, Zahlen und Statistiken 2018, vgl. https://www.ordensge meinschaften.at/presseraum/zahlen (letzter Zugriff: 02.05.2018).

15 https://www.canisius.at/9123/orden-in-zahlen (letzter Zugriff: 29.05.2019). 
tragen wurden, sind keine Ordensleute mehr sichtbar. Der Auftrag wird sein zu überlegen, wie ohne diese sichtbare Präsenz das, wofür die Ordensgemeinschaften stehen, weitergeführt wird.

Diese Veränderung betrifft aber nicht nur die Orden, die als Sozial-Kongregationen im 19. Jahrhundert als Reaktion auf vielfältige Nöte gegründet worden sind. Es gibt auch einen Rückzug von traditionellen Orden aus vielen Standorten, die sie teilweise jahrhundertelang geprägt haben. Und hier kommen wir nun zu einer weiteren Grenz-Veränderung: Viele Ordensprovinzen sind in den letzten Jahren zusammengelegt worden; ganz Mitteleuropa ist inzwischen meist eine einzige Provinz: Franziskaner mit ganz Österreich und Südtirol; Dominikaner mit Süddeutschland und Österreich; bei den Kreuzschwestern (auch „Ingenbohl-Schwestern“ genannt) wurden die Provinzen 2007 aus Österreich, Ungarn, Bayern sowie das Vikariat Slowenien zur Provinz Europa Mitte zusammengeführt. Zugleich konzentriert man sich auf wenige Orte und auf spezifische Aufgaben - die immer seltener in der Pfarrseelsorge liegen.

Damit sind wir bei einem zweiten Umbruch - nämlich jenem in der Pfarrseelsorge. In Österreich hat sich seit der josefinischen Reform eine sehr kleinteilige Pfarrstruktur entwickelt. Jeder sollte in seinem Nahraum eine Pfarrkirche haben - und natürlich auch einen zuständigen Pfarrer. Dieses Pfarrsystem ist in den vergangenen Jahren aus verschiedenen Gründen in Bewegung gekommen. Einer der wichtigsten Gründe: Die Diözesen haben nicht mehr genügend Priester, um die vorhandenen Pfarren mit je einem pastor proprius zu besetzen.

Viele der momentanen Strukturüberlegungen der Diözesen haben mit diesen Veränderungen zu tun. Ein Blick in die Geschichte zeigt, dass die Pfarrgrenzen eingeführt wurden, um den Unterhalt der Seelsorger durch die zugehörigen Pfründe abzusichern und um die Zuständigkeit für die Sakramentenspendung klar zu regeln. Diese Einführung der Grenzen ging noch von einer relativ immobilen Gesellschaft aus. Politische und kirchliche Grenzen waren zumeist mit ökonomischen Interessen verbunden. Im mittelalterlichen Europa gab es keine Freizügigkeit der Bewegung - die meisten Menschen waren auf Gedeih und Verderb an das Herrschaftsgebiet ihres Grundherren, häufig auch des kirchlichen Grundherren, gebunden. ${ }^{16}$ Mit der steigenden Industrialisierung wurde es zugelassen, dass immer mehr Arbeitskräfte in die Städte und ihr Umfeld abwanderten. Die staatlichen Grenzen kontrollierten weiterhin $\mathrm{Zu}$ - und Abwanderung. Aber seither haben sich die kirchlichen Grenzen im Erleben der Menschen vor allem im städtischen Bereich immer mehr aufgelöst.

Und wie auch der Staat mittlerweile viele seiner Dienstleistungen privatisiert hat, wie z.B. Bahn, Post, Gesundheit etc., so geht es auch den traditionellen Kirchen: Sie sind verstärkt dem „Marktdruck“ ausgesetzt. Sie sind nicht mehr

16 Vgl. dazu Näheres in: Komlosy, Grenzen. 
die einzigen Anbieter am Sinn-Markt - und die kirchlichen Grenzziehungen wie Pfarrgrenzen, Dekanate oder Diözesen passen hier für viele Menschen nicht mehr.

Man könnte das bejammern - oder aber auch als Chance sehen. Dies fordert die Kirchen heraus, die eigenen Dienstleistungen anzuschauen: Sakramentenfeiern, seelsorgliche Begleitung, Begräbnisse, diverse Rituale - immer mehr Menschen schauen hier auf Qualität und nicht auf eine formale Zuständigkeit. Man könnte sagen: Es geht somit um eine deutliche Profilierung des eigenen Kerngeschäftes. Nun ist aber auch klar: private Dienstleister übernehmen nur lukrative Geschäfte, z. B. lukrative Bahnstrecken. Die kleineren Regionen bleiben auf der Strecke.

Dies stellt in einer Umbruchszeit sehr wohl eine wichtige Anfrage an die Kirche dar: Wie sieht eine „Option für die Armen“, eine „arme Kirche für die Armen “ in dieser Hinsicht aus? ${ }^{17}$ Ist nicht gerade das Bleiben in der Fläche, auch an den Rändern und Grenzen, etwas, was die Kirche auszeichnet - und eben nicht das Sich-Zurückziehen auf einige sehr gut gehende und einfacher zu versorgende Zentren?

Gerade unter dem Aspekt der „Grenze“ ist die römisch-katholische Kirche ja auch eine spannende Organisation: Sie ist eine der ersten „globalen Institutionen“, mit einer Verbindung von Zentralisierung (durch den Vatikan in Rom) und Regionalisierung durch die Bischöfe vor Ort. Als Mitglied dieser Kirche habe ich weltweite Rechte! Gleichzeitig lebt diese Kirche aber von den kleinen Gemeinden und Gemeinschaften vor Ort und nicht von den Zentren.

Ein dritter kirchlicher Umbruch betrifft die Menschen selbst und ihr Selbstverständnis als Christinnen und Christen. Im Gefolge des II. Vatikanums hat sich das Verständnis des gemeinsamen Priestertums entwickelt. Neue pastorale Berufe sind entstanden. Es gibt ein Erwachen des Bewusstseins, „Volk Gottes“ zu sein mit dem Selbstbewusstsein, die eigenen Charismen einbringen zu können und zwar dort, wo man selber möchte, und nicht dort, wo man aufgrund irgendwelcher Grenzziehungen zugehörig ist.

Papst Franziskus fördert mit seiner Theologie diese Selbstständigkeit der Christen. Er wendet sich gegen jegliche Art der Klerikalisierung - und er fordert die Menschen auf, eine Kirche zu werden, die sich missionarisch nach außen richtet. Im Zentrum steht bei ihm ein Begriff, den er in fast allen seinen zentralen Veröffentlichungen verwendet: die Freude.

Der Impuls des Papstes ist zugleich ein Impuls, die katholische Kirche regionaler zu denken. Es ist spannend, wie er auf den regionalen Impuls der deutschen Bischofskonferenz reagiert, in Fällen von konfessionsverbindenden

17 Vgl. dazu Johann Pock / Regina Polak / Frank Sauer / Rainald Tippow, Kirche der Armen?, Würzburg 2019. 
Ehen den evangelischen Partnern die Möglichkeit zu geben, im katholischen Gottesdienst zur Kommunion zu gehen. In einem Gespräch zwischen deutschen Bischöfen und der Glaubenskongregation wurde 2018 gesagt: Das ist Sache der Bischöfe vor Ort. „Möglichst einmütig“ sollen sie selbst zu einer Entscheidung kommen - aber eben regional, nicht zentral in Rom. ${ }^{18}$

Interessanterweise hat der Papst in seinem Apostolischen Schreiben Gaudete et exsultate (vom 19.03.2018) ${ }^{19}$ eine weitere Grenze gewissermaßen geöffnet bzw. zumindest relativiert: die Grenze zwischen profan und heilig. Denn er stellt darin fest, dass Heiligkeit mitten im Profanen zu finden ist. Damit wird deutlich: Damit die Kirche ihren Auftrag erfüllen kann, in der jeweiligen Zeit Christus zu verkündigen und am Wachsen des Reiches Gottes mitzuarbeiten, muss sie sich auch verändern und Schwellen überschreiten.

\section{Worin liegen Visionen für die Zukunft im Überschreiten bisheriger Grenzen?}

Im Folgenden sollen ausgehend von der erhobenen Situation thesenartig mögliche Entwicklungslinien und Herausforderungen für die Zukunft der katholischen Kirche bzw. überhaupt der Religionen in Österreich benannt werden. Dies ist natürlich eine sehr subjektive Auswahl und zeigt meine persönlichen Optionen an.

\subsection{Aus Kirchenzugehörigkeit wird Religionszugehörigkeit; das Außen bestimmt auch das Innen}

Die römisch-katholische Kirche in Österreich muss sich von der Vorstellung verabschieden, dass das ganze Land „katholisch“ ist. Stolz und Könemann halten angesichts der Analyse der religiösen Gegenwartssituation fest, dass sich die religiös-spirituellen Anbieter (zu denen eben auch die christlichen Kirchen gehören) „bleibend auf eine Situation einstellen müssen, in der die Individuen ihnen nicht mehr aus Tradition, sondern aufgrund bewusster Entscheidung angehören bzw. ihre Dienste und Leistungen in Anspruch nehmen. ${ }^{\text {20 Die }}$

18 Leider werden diese Anregungen des Papstes derzeit nicht zugleich kirchenrechtlich festgehalten, sodass eine rechtliche Umsetzung dieser Anregungen nicht gegeben ist.

19 Franziskus, Apostolisches Schreiben Gaudete et exsultate, vgl. http://w2.vatican.va/content/ francesco/de/apost_exhortations/documents/papa-francesco_esortazione-ap_20180319_ gaudete-et-exsultate.html (letzter Zugriff: 10.05.2019).

20 Jörg Stolz / Judith Könemann, Religion und Spiritualität in der Ich-Gesellschaft, Zürich 2014, S. 216. 
Bruchlinie wird in Hinkunft auch nicht mehr zwischen den Konfessionen liegen - sondern eher zwischen jenen, die bewusst, entschieden und mit Engagement ihren Glauben leben (z. B. eine steigende Zahl von Freikirchlichen); und auf der anderen Seite jenen, die aktiv und militant gegen Religionen vorgehen und diese mit ihren Symbolen, Riten und Rechten aus der Öffentlichkeit verbannt sehen möchten.

Zugleich hat Thomas Großbölting für Deutschland eine Entwicklung benannt, die so auch für Österreich gilt: ${ }^{21}$ Es gibt eine unaufhaltsame Veränderung der Menschen hin zu kirchenunabhängigen religiösen Einstellungen. Die Religionsgemeinschaften haben in der Geschichte einen großen Anteil an der Entwicklung des Landes. Aber auch hier gilt, dass sie mittlerweile „eine Stimme unter vielen [sind] (...) und keine exklusiven Ansprüche entwickeln kann" ${ }^{\text {“22 }}$. Die christlichen Kirchen haben kein Monopol mehr auf die Deutung der Welt. Nicht zuletzt durch die Migration und die Globalisierung haben auch andere Religionen (allen voran der Islam) bei uns Fuß gefasst und werden weiter wachsen. ${ }^{23}$ Aber auch für sie gilt, dass die Menschen bewusster ihre Religion wählen - und diese Religion auch individuell gestalten, unabhängig von Vorschriften der Kirchen oder Religionsinstitutionen.

Diese Entwicklungen sind ernst zu nehmen. Die Vision liegt darin, dass der Anstoß von außen dazu führt, das „Eigene“ bewusster zu machen. Es geht um eine Entwicklung weg von einem Traditionschristentum hin zu einem Verständnis christlichen Lebens, das bewusster christlich ist.

Die katholische Kirche muss sich angesichts der Veränderungen die Frage nach ihrem „Kerngeschäft“ stellen. Theologisch steht sie im Dienst des Wachsens des Reiches Gottes und hat keinen Selbstzweck. Gerade der aktuelle Zukunftsprozess in vielen österreichischen Diözesen kann hier dazu dienen, gewachsene Strukturen dahingehend zu analysieren und zu verändern, dass sie besser diesem Kerngeschäft entsprechen: dem Leben und Glauben der Menschen zu dienen; Seelsorge anzubieten; sich den Armen, Ausgestoßenen und Verlierern der gesellschaftlichen Entwicklungen zuzuwenden; den Gottesbezug und die Gottesfrage in der jeweiligen Zeit wachzuhalten.

Das Kerngeschäft wurde in der katholischen Kirche zumeist mit der Spendung der Sakramente beantwortet - diese gehören natürlich zu den zentralen Heilsmitteln der Kirche. Zum zentralen Auftrag gehört jedoch immer auch die Mission, die Sendung in die jeweilige Zeit, die gegenwärtig nicht zuletzt durch

21 Vgl. Thomas Großbölting, Der verlorene Himmel. Glaube in Deutschland seit 1945, Göttingen 2013, besonders Kap. 3 .

22 Großbölting, Der verlorene Himmel, S. 271.

23 Vgl. Karl Vocelka, Multikonfessionelles Österreich: Religionen in Geschichte und Gegenwart, Wien 2013. Er zeigt auf, wie sehr Österreich auch im Laufe der Geschichte bereits geprägt war durch unterschiedliche Religionen und Konfessionen. 
Migration, Globalisierung und einem Auseinanderdriften von reich und arm gekennzeichnet ist. Das Motiv der Schwelle verweist die Kirchen darauf, in Umbruchszeiten die Identität nicht nur innen zu suchen, sondern auch im „außen“.

\subsection{Die Religionsfreiheit ist zu schützen}

Zur Vision einer Grenzen überschreitenden Kirche gehört zentral die Religionsfreiheit. Religionsfreiheit ist ein hoher Wert in einer pluralen Gesellschaft bei gleichzeitigem Selbstbewusstsein der jeweiligen Religionen. Eine zentrale Entwicklung, angestoßen vom II. Vatikanum, ist die Anerkennung von Religionsfreiheit wie auch die Förderung der ökumenischen Beziehungen. Auch die österreichische Bischofskonferenz betont, dass ein religiös-weltanschaulich neutraler Staat nicht einem radikalen Laizismus verpflichtet sein dürfe, der in seiner strikten Ablehnung von Religion einen Absolutheitsanspruch stellt. Denn gerade weil Religionen wesentlich auch Werte und Sinn einbringen, tragen sie zu jenen Voraussetzungen bei, von denen der demokratisch verfasste Staat lebt, ohne sie selbst erzeugen oder garantieren zu können.

Deshalb betonen die Bischöfe zu Recht: „Der moderne Staat ist daher, um tatsächlich neutral und unparteiisch zu sein, bestens beraten, Religion nicht gesellschaftlich zu marginalisieren, sondern ihr einen entsprechenden Platz auch im öffentlichen Raum zu sichern. ${ }^{\text {“24 }}$ Religion stellt einen zentralen Teil der Gesellschaft dar und darf sich nicht aus der Öffentlichkeit verbannen lassen. Diese Religionsfreiheit gilt aber nicht exklusiv für die katholische Kirche oder die Christen, sondern für alle Bürgerinnen und Bürger.

\subsection{Interne Herausforderungen}

Bei all den gesellschaftlichen Herausforderungen gibt es gleichzeitig kircheninternen Reformstau. Die aktuellen Strukturreformen zeigen, dass die katholische Kirche immer noch stark priesterzentriert ist. Zugleich gibt es derzeit eine große Veränderung des Priesterbildes. ${ }^{25}$ Dieser ist in den neuen Strukturen

24 Wortlaut der Presseerklärungen der Herbstvollversammlung der Österreichischen Bischofskonferenz, 09.-12. November 2009, Benediktinerabtei Michaelbeuern, vgl. https:// www.bischofskonferenz.at/2009/presseerklaerungen-der-herbstvollversammlung (letzter Zugriff: 29.05.2019).

25 Vgl. dazu Johann Pock, Können Priester noch Seelsorger sein? Überlegungen zu den aktuellen Veränderungen des Berufsprofils, in: Erich Garhammer / Hans Hobelsberger / Martina Blasberg-Kuhnke / Johann Pock (Hg.), Seelsorge: die Kunst der Künste. Zur Theologie und 
immer weniger „Seelsorger“ als vielmehr „Manager“ der Gemeinden. Er wird zuständig für immer größere Einheiten und immer mehr Personen. Eine Seelsorgestudie in Deutschland und Wien aus dem Jahr 2017/2018 zeigt die Ansprüche drastisch auf. Sehr anschaulich fasst ein Kommentar zur Studie zusammen:

„Denn heute haben an ihre Leistungsgrenzen stoßende Seelsorger als durch Seelsorgeeinheiten ,reisende Sakramentenspender' oftmals nicht nur XXL-Pfarreien zu verwalten, sondern es kommt noch ein weiteres Moment hinzu: die Unterwerfung unter marktförmige Logiken. Als Manager des Katholizismus vor Ort sehen sich Priester heute Gemeindemitgliedern gegenüber, die ihre pastoralen Vorlieben in der Rolle von KlientInnen und KundInnen entsprechend ihrer jeweiligen ästhetischen Präferenz auswählen und eine entsprechende Dienstleistung erwarten. “26

Zaghafte Stimmen (mittlerweile auch von Papst Franziskus) deuten eine mögliche Öffnung der Zulassungskriterien zum Priestertum an. Eine Stimme darin ist der Jesuit Stefan Kiechle, der bis 2017 Provinzial der Deutschen Jesuitenprovinz war. ${ }^{27}$ Er ermutigt zur Zulassung von verheirateten Männer (oder auch Frauen) zu den heiligen Weihen: „Eine Abspaltung traditioneller Katholiken von der Kirche wäre vielleicht weniger gravierend als das weitere Aussterben der Priester. “28 Denn dadurch wäre gerade die regelmäßige Eucharistiefeier vielerorts in Gefahr.

Meines Erachtens führt an der Veränderung der Weihezulassungsbedingungen kein Weg vorbei - und dies nicht primär aufgrund der pastoralen Notsituationen, sondern aufgrund der seelsorglichen Herausforderungen der heutigen Zeit. Wie lange es dauert, bis diese Schwelle überschritten wird, ist schwer abzuschätzen; vorsichtige Schritte in dieser Richtung wurden gesetzt, z. B. auf der Amazoniensynode 2019. Und auch wenn Papst Franziskus in seinem nachsynodalen Schreiben Querida Amazonia diesbezüglich keine Entscheidung getroffen hat, hat er die Türe auch nicht zugemacht. Dass der Papst regionale Wege und Entscheidungen unterstützt, sollte Mut machen, auch hier den Fuß einmal auf die Schwelle zu setzen.

Praxis der Seelsorge, Studien zur Theologie und Praxis der Seelsorge 100, Würzburg 2017, S. 111-121.

26 Daniela Blum / Florian Bock, „... nicht nur Engel, sondern auch Götter“versus Abschied von Hochwürden, Zeitschrift für Pastoraltheologie 37/1/2017, S. 181-194, hier: S. 193.

27 https://www.jesuiten.org/slides-startseite/stimmen-der-zeit.html (letzter Zugriff: 04. 05.2019). 28 Ebd. 


\subsection{Neue Gemeinschaften statt traditioneller Orden?}

Und schließlich verändert ein Umbruch die kirchliche Landschaft ganz zentral: der Umbruch in der Ordenslandschaft. Was das absehbare Verschwinden vor allem so mancher Frauenorden mit caritativer Ausrichtung für die geistliche Entwicklung der österreichischen Diözesen bedeuten wird, kann wohl erst in einigen Jahrzehnten beurteilt werden. Hingegen gibt es neue Gemeinschaften, die vor allem im Jugendbereich Anklang finden: Gemeinschaft Emmanuel, Fokolare, charismatische Erneuerung, Loretto-Gemeinschaft u. a. haben eine stark missionarische Ausrichtung - wobei Mission dabei nicht immer gleich verstanden wird. Wie sehr diese Gemeinschaften als Ergänzung oder als Ersatz zur traditionellen territorial ausgerichteten Pfarrseelsorge zu sehen sind, wird sich ebenfalls in naher Zukunft zeigen. Ich glaube, dass es in der nahen Zukunft ein gutes Miteinander braucht - zwischen dem, was die gewachsenen Strukturen immer noch an Halt, Tradition und Sicherheit bieten können; und dem, was in den neuen Bewegungen an Dynamik und Aufbruch vorhanden ist.

\subsection{Präsenz in der digitalen Welt}

Ein letztes: Wir leben zunehmend in einer digitalisierten Welt, ob wir wollen oder nicht. Die sozialen Medien sind heute vergleichbar mit dem Areopag Athens zur Zeit des Paulus. Die Kirchen sollten nicht über das Fehlen von Jugendlichen in kirchlichen Veranstaltungen und Gottesdiensten jammern - vielmehr gilt auch hier: Kirche (und auch Wissenschaft) hat sich an jene Orte zu begeben, wo die Jugendlichen sind, und hat das Gespräch mit ihnen zu suchen (und hier auch von ihnen zu lernen).

Digitalisierung ist nicht einfach ein anderes neues Medium, in das man die bisherigen Kommunikationsformen einfach übertragen könnte. Es ist gewissermaßen ein neues „Betriebssystem“ - und damit sind alte Grenzen (geographisch, kulturell etc.) passé, und neue Schwellen und Grenzen entstehen (wie z. B. die Frage nach den ethischen Konsequenzen von Digitalisierung).

Die Schwelle in die „virtual reality“ mag für manche groß sein. Und dennoch führt kein Weg daran vorbei. Wir sind m. E. erst am Anfang, zu verstehen, wie sehr sich unser Leben durch Handy, Digitalisierung und die neuen Medien verändert. Die aktuelle Covid-19 Pandemie bringt gerade im Bereich der Digitalisierung einen unerwarteten Innovationsschub mit sich. 


\section{Fazit: Pastoral an Schwellen und Grenzen}

Aus der aktuellen Entwicklung der Religionen schließe ich, dass im selben Maß, wie sich unser Alltagsleben z. B. im letzten Jahrzehnt durch das Internet und jetzt durch die Smartphones verändert hat, sich auch die religiöse Praxis bzw. das Verhältnis zu dem, wofür die Religionen stehen, verändert - nämlich SinnDeutungen anzubieten und Hilfen zum Bestehen von Lebenswenden und Krisen bereitzustellen.

Die römisch-katholische Kirche wird zwar in den nächsten Jahrzehnten die größte Glaubensgemeinschaft in Österreich bleiben; vor allem in den jüngeren Generationen wird jedoch die Zahl der Personen ohne Religionszugehörigkeit bzw. muslimischen Glaubens zunehmen. Die größte Herausforderung wird jedoch für alle Religionsgemeinschaften darin liegen, wie sie auf die sich verändernden gesellschaftlichen, wirtschaftlichen und politischen Umstände reagieren und ob sie bereit sind, ihre internen Strukturen so zu reformieren, dass sie aktiv an der Gestaltung der Zukunft des Landes mitwirken können. Die Coronakrise als aktuellste Krise wird hierbei eine nicht unwesentliche Rolle spielen im Blick auf kirchliche Reformprozesse.

Die katholische Kirche bringt eine Fülle an Erfahrung an der Bearbeitung von Übergängen und Schwellen mit - sowohl durch die eigenen geschichtlichen Veränderungsprozesse als auch durch die Fülle an Ritenkompetenz und Begleitungsarbeit an solchen Übergängen, nicht zuletzt am Übergang von Leben und Tod.

Die Religionen stellen jedenfalls einen wesentlichen Faktor zum gelingenden Leben dar - und dieses spielt sich an immer neuen Grenzen und Schwellen ab.

\section{Quellen}

Bedford-Strohm, Heinrich, Große Transformation. Wie die Kirchen die ökologisch-soziale Neuausrichtung der Gesellschaft mitgestalten können, in: Zeitzeichen 14/5/2013, S. 8-11.

Blum, Daniela / Bock, Florian, „... nicht nur Engel, sondern auch Götter“versus Abschied von Hochwürden, Zeitschrift für Pastoraltheologie 37/1/2017, S. 181-194.

Bösch, Frank (Hg.), Jenseits der Kirche. Die Öffnung religiöser Räume seit den 1950er Jahren, Geschichte der Religion in der Neuzeit 5, Göttingen 2013.

Bucher, Rainer, Die Ordensgemeinschaften in der aktuellen Transformationskrise der katholischen Kirche, Vortrag am 20. November 2012 beim Österreichischen Ordenstag in Wien-Lainz, in: Ordensnachrichten 51/6/2012, S. 17-32.

Bucher, Rainer (Hg.), Die Provokation der Krise. Zwölf Fragen und Antworten zur Lage der Kirche, Würzburg 2004. 
Europäische Wertestudie, vgl. https://www.werteforschung.at/projekte/europaeische-wer testudie/ (letzter Zugriff: 27.05.2019).

Franziskus, Apostolisches Schreiben „Gaudete et exsultate“, vgl. http://w2.vatican.va/con tent/francesco/de/apost_exhortations/documents/papa-francesco_esortazione-ap_20 180319_gaudete-et-exsultate.html (letzter Zugriff: 10.05.2019).

Gassert, Philipp, Krisen und Übergänge. Der weltpolitische Kontext des 2. Vatikanums zu Beginn der 1960er-Jahre, in: Münchener theologische Zeitschrift 64/4/2013, S. 306316.

Großbölting, Thomas, Der verlorene Himmel. Glaube in Deutschland seit 1945, Göttingen 2013.

Hünermann, Peter, Im Übergang. Das Zweite Vatikanum als Konzil einer neuen Epoche, in: Herder Korrespondenz 67/11/2013, S. 560-565.

Kliesch, Klaus, Der revolutionäre Schritt des Urchristentums: Petrus und die Heidenmission (Apg 10,1-11,18), in: Bibel und Kirche 55/2/2000, S. 74-78.

Komlosy, Andrea, Grenzen. Räumliche und soziale Trennlinien im Zeitenlauf, Wien 2018.

Müller, Gerhard Ludwig, Kirche im Übergang. Welche Reform benötigen wir?, in: Deutsches Pfarrerblatt 113/8/2013, S. 437-443.

Ordensgemeinschaften Österreich, Zahlen und Statistiken 2018, vgl. https://www.ordens gemeinschaften.at/presseraum/zahlen (letzter Zugriff 02.05.2018).

Orth, Stefan, Welche Krise?, in: Herder Korrespondenz 65/4/2011, S. 163-165.

Pock, Johann / Polak, Regina / Sauer, Frank / Tippow, Rainald, Kirche der Armen?, Würzburg 2020.

Pock, Johann, Können Priester noch Seelsorger sein? Überlegungen zu den aktuellen Veränderungen des Berufsprofils, in: Erich Garhammer / Hans Hobelsberger / Martina Blasberg-Kuhnke / Johann Pock (Hg.), Seelsorge: die Kunst der Künste. Zur Theologie und Praxis der Seelsorge, Studien zur Theologie und Praxis der Seelsorge 100, Würzburg 2017, S. 111-121.

Pock, Johann, Kirche an der Schwelle. Überlegungen zu einem (neuen) Krisenparadigma, in: Rainer Bucher (u. a.) (Hg.), Nach der Macht. Zur Lage der katholischen Kirche in Österreich, Würzburg 2014, S. 157-174.

Prostmeier, Ferdinand R. (Hg.), Zukunft der Kirche - Kirche der Zukunft. Bestandsaufnahmen - Modelle - Perspektiven, Regensburg 2004.

Stolz, Jörg / Könemann, Judith, Religion und Spiritualität in der Ich-Gesellschaft, Zürich 2014.

Vocelka, Karl, Multikonfessionelles Österreich: Religionen in Geschichte und Gegenwart, Wien 2013.

Wortlaut der Presseerklärungen der Herbstvollversammlung der Österreichischen Bischofskonferenz, 09.-12. November 2009, Benediktinerabtei Michaelbeuern, vgl. https://www.bischofskonferenz.at/2009/presseerklaerungen-der-herbstvollversamm lung (letzter Zugriff: 29.05.2019).

https://www.canisius.at/9123/orden-in-zahlen (letzter Zugriff: 29.05.2019).

https://www.jesuiten.org/slides-startseite/stimmen-der-zeit.html (letzter Zugriff: 04.05. 2019). 
Open-Access-Publikation im Sinne der CC-Lizenz BY 4.0

(C) 2020, Vandenhoeck \& Ruprecht $\mathrm{GmbH} \&$ Co. KG, Göttingen ISBN Print: 9783847111658 - ISBN E-Lib: 9783737011655 


\section{Peter Klasvogt (Dortmund)}

\section{Epochenwandel. Auf der Suche nach einer neuen Erzählung}

\section{Auflösung milieugestützter Lebenswelten}

\section{Zerbrechen homogener Deutungsmuster}

„Was bleibt übrig, wenn der Kitt der Erzählungen fehlt? Bilder (milliardenfach) und Events (millionenfach), unverbunden, arithmetisch gereiht, atomisiert und zerstückelt. Keine Entwicklung, nur Trailer, gedreht von einer völlig überreizten medialen Erregungsindustrie.“" (Richard David Precht)

„Ich bin dagegen. Worum geht's?" - Ein beliebter Kalauer aus den 68er Jahren, die Karikatur eines Gesprächseinstiegs, symptomatisch für den damaligen Trend, grundsätzlich erst einmal alles Bestehende, Geltende, Verbindliche in Frage zu stellen. Es war der gefühlte Aufbruch in eine neue Zeit, in der jede Autorität hinterfragt und alle Traditionen angezweifelt wurden, eine Abrechnung mit dem Überkommenen, Angestaubten, Verbrauchten, so jedenfalls die damalige Stimmung. "Unter Roben und Talaren steckt der Muff von tausend Jahren“. Ob das Neue allerdings immer auch schon das Bessere war, musste sich nachfolgend erst erweisen und blieb den Beweis oft schuldig.

In unseren Zeiten dagegen zeigt sich eine Grundskepsis nicht primär gegenüber dem Alten, Gewohnten, Bewährten, sondern gegenüber allem Neuen, Anderen, Fremden, wohl aus einem Gefühl der Unbehaustheit heraus in einer globalen, digitalisierten Welt, die immer unübersichtlicher, uneinsehbarer, unbeherrschbarer wird. Dabei ist es oft weniger ein Reflex intellektueller Überheblichkeit, sich allein schon aus Gründen der Selbstachtung immer noch einmal vom Mainstream abzugrenzen und sich den Luxus einer abweichenden Meinung zu leisten. Eher schon ist es ein Indikator für eine Gesellschaft, in der das Vertraute und Gewohnte zum Sperrgebiet für alles mutiert, was als übergriffig empfunden wird. Entsprechend aufgeladen ist der Begriff „Heimat“, der die Sehnsucht nach Verankerung, Stabilität, Identität suggeriert. Menschen fühlen

1 Richard David Precht, Europa: Unsere gereizten Seelen, in: Die Zeit 40/2016 am 22.09. 2016. 
sich als vermeintliche Opfer einer Globalisierung, die auf allen Gebieten in die Privatsphäre hineingreift und zu Verunsicherung und Identitätsverlust führt. Die neuen Möglichkeiten der Digitalisierung gestatten zwar weltweite Kommunikation in Echtzeit, die aber exponentiell als Einwegkommunikation erfahren und genutzt wird: das Internet als Echoraum der eigenen Vorurteile, ein Medium der Selbstexploration. Da ist keiner, auf den man hören, dem man zustimmen oder widersprechen müsste oder den man überhaupt überzeugen wollte.

Auf der Institutionenebene führt diese Haltung zu Partikularismus und Gruppenegoismus, zu Populismus und Nationalismus - längst überwunden geglaubte Sammlungsbewegungen, die in der gegenwärtigen Weltlage wieder Konjunktur haben. Verlässliche Politik, die auf langfristige Partnerschaften und Bündnisse setzt, wird dem kurzfristigen (Schein)Erfolg geopfert. Die Kunst der Diplomatie, die auf Konferenzen und internationalen Foren in tage- und wochenlanger Feinarbeit den Konsens sucht, mit dem alle Beteiligten leben können, weicht der direkten Konfrontation; an die Stelle einer gemeinwohlorientierten Verantwortungsethik tritt die eigenwohlfokussierte Pokermentalität der „Dealmaker". Damit aber wird leichtfertig Vertrauen verspielt, die wichtigste und teuerste Ressource in den internationalen Beziehungen, mit nachhaltigen Folgeschäden. Denn der Typus der machtbewussten, rücksichtslosen und erfolgsversessenen Leitfiguren findet seine Bewunderer, Anhänger, Nachahmer - und Wähler! - und wird damit stilprägend für die (Un)Kultur in der Breite der Gesellschaft.

Indem die Opfermentalität der eigenen Klientel stilisiert wird, legitimiert sich auch der Politikstil einer neuen Rücksichtslosigkeit, der auf „alternativen Fakten " beruht: nicht wahrhaben wollen, was wahrgenommen werden könnte - und müsste (!), um aber umso dominanter und brutaler die eigenen Interessen durchzusetzen. In all dem artikuliert sich eine neue Form der Arroganz, die sich über alles erhebt, was nicht der eigenen Wahrnehmung, Meinung, Weltdeutung entspricht, was auf gesellschaftlicher Ebene schließlich zur Spaltung und Atomisierung, letztlich zum Demokratieverlust führt.

Der Nationalismus ist zurück, und nicht nur in Europa. Als Reaktion auf allgemeine Faktoren wie die Globalisierung, die Digitalisierung, die Einwanderung, die wirtschaftliche Ungleichheit und Arbeitslosigkeit sowie ein empfundenes Eliten-Versagen entstehen weltweit nationalistische, populistische, anti-pluralistische Strömungen, die Prinzipien und Werte einer freiheitlichen Demokratie zunehmend in Frage stellen. Mit der Idealisierung einer vermeintlichen Identität des Staates und des Staatsvolkes verbinden sich konkrete Vorstellungen, wer zu diesem vermeintlichen Volk dazugehört bzw. dazugehören darf oder muss, und wer nicht, oft verbunden mit einer Kritik am Establishment, 
den „herrschenden Eliten“. Andersdenkenden wird das Recht auf Meinungsäußerung, Partizipation und Rechtsschutz abgesprochen.

Angesichts solcher spalterischen und zersetzenden Phänomene und Tendenzen braucht es in einer pluralistischen, widersprüchlichen, konfliktreichen (Welt)Gesellschaft Menschen, Organisationen und Institutionen, die sich für den gesellschaftlichen Zusammenhalt einsetzen: die nicht aus- und abgrenzen, sondern einbinden, vernetzen, versöhnen. Eben FÜR-Sprecher, die sich für das ethische Fundament gelingender Demokratie einsetzen, für die Akzeptanz grundlegender Maßstäbe, Normen und Werte, die eine tendenziell gemeinsame Vorstellung von der Freiheit und ihrer Kostbarkeit haben, vom Inhalt und Umfang von Gerechtigkeit, vom Wert und der Notwendigkeit von Solidarität, gemeinsamer oder wenigstens verwandter Vorstellungen von sinnvollem und gutem Leben, von der Würde jedes Menschen, von der Integrität der Person, von Respekt und Toleranz, von Anstand und Fairness.

„Die Verantwortung für [...] dieses ethische Fundament unseres Zusammenlebens tragen - neben der besonderen staatlichen Zuständigkeit im Bildungssystem - alle Bürger, insbesondere aber die kulturellen Kräfte einer Gesellschaft und darin eben auch und in besonderer Weise Religions- und Weltanschauungsgemeinschaften und also auch und gerade die christlichen Kirchen. “2

\section{Regressive Tendenzen einer Wohlfühlgesellschaft}

Vielleicht ist das die Tragik unserer Zeit, dass wir noch nie so viel und so gut kommunizieren konnten - und zugleich verlernt haben, uns konstruktiv und ergebnisoffen auseinanderzusetzen mit dem, der anders denkt, anders lebt, anders handelt - eben weil er anders ist.

„Wir müssen wieder lernen, zu streiten, ohne Schaum vorm Mund, und lernen, unsere Unterschiede auszuhalten. Wer Streit hat, kann sich auch wieder zusammenraufen. [...] Aber wer gar nicht spricht und erst recht nicht zuhört, kommt Lösungen kein Stück näher. Sprachlosigkeit heißt Stillstand. “3

Und wo nur noch monologisch die je eigenen Ansichten, Meinungen und Vorurteile in die Welt hinausposaunt werden, da ist die Perspektive des Ganzen, des Gemeinwohls abhandengekommen, damit auch die Bereitschaft und Fähigkeit zum Dialog, zum Kompromiss, zum Konsens. „Unsere Demokratie [...] setzt uns

2 Wolfgang Thierse, Erwartungen an die Kirche. Zum fundamentalen Dienst der Kirche an der Politik, in: Peter Klasvogt / Stefan Klug (Hg.), Europa - Wertegemeinschaft oder Wirtschaftsunion? Zur Prägekraft des Katholizismus in Mitteleuropa, Paderborn 2015, S. 110-117, hier: S. 113.

3 Frank-Walter Steinmeier, Weihnachtsansprache, 24. Dezember 2018. 
der ständigen Gefahr aus, dass auch der andere mal Recht haben könnte. Am Ende einen Kompromiss zu finden, das ist keine Schwäche, sondern das zeichnet uns aus! Die Fähigkeit zum Kompromiss ist die Stärke der Demokratie. “4

Dialog, so scheint es, ist ein „Luxus“, den sich leisten kann, wer seiner selbst gewiss ist. Wer dagegen in seiner Identität verunsichert ist, grenzt sich ab und meidet das Risiko der Auseinandersetzung: das Neue, der Andere könnte ihm ja den Boden unter den Füßen wegziehen und das Fremde ihn überfremden. Dieses Gefühl der Inferiorität, denn darum handelt es sich letztlich, kann sich auch einer ganzen Generation und einer ganzen (Teil)Gesellschaft bemächtigen. Dann geht es primär um Selbstsorge, Selbstbewahrung, Selbstinszenierung - und um Selbstgenügsamkeit, mehr schon ein Zeichen von Regression, wo man sich selbst genug ist und es nicht mehr nötig hat, sich mit dem Anderen abzugeben. Man ist an Alexis de Tocqueville erinnert, der schon 1835 diese Phänomene im Amerika seiner Zeit beschrieb.

„Uninteressierte Bürger, ein Volk von Händlern, nicht mit dem Gemeinwohl beschäftigt, sondern mit sich selbst. Je stärker der Wohlstand steigt, umso unpolitischer die Menschen. Und je unbegrenzter der Liberalismus schaltet und waltet, umso blasser das politische Bewusstsein der Bürger. Am Ende, so prophezeite Tocqueville, werde die Demokratie ausgehöhlt sein. Die Bürger verzichteten auf ihre Beteiligung, und der Staat wandelt sich zu einer alles erfassenden Wohlfühldiktatur, ästhetisch egalitär, politisch totalitär und bestechend smart. ${ }^{\text {" }}$

Das klingt wie eine Parabel auf unsere heutige Wohlfühlgesellschaft, in der sich jeder selbst der Nächste ist.

Da mag man sich mit Wehmut daran erinnern, wie noch unter dem Eindruck der Katastrophe des Zweiten Weltkriegs die Einsicht da war, dass es eine Weltorganisation zur Förderung von Frieden und Freundschaft zwischen den Nationen geben müsse - in dem Bewusstsein: „Alle Menschen sind frei und gleich an Würde und Rechten geboren“ (Art. 2 der Allgemeinen Erklärung der Menschenrechte, 1948). Doch noch nie standen die Menschenrechte, wie sie 1948 in Paris niedergelegt wurden, derart unter Druck wie in diesen Tagen. Denn gerade deren Universalität - seinerzeit Frucht eines geglückten Prozesses der „Wertegeneralisierung“ (Hans Joas) - wird von Regierungen auf der ganzen Welt zunehmend und systematisch in Frage gestellt. Schlimmer noch: Selbst die Legitimität und Notwendigkeit universeller Menschenrechte steht unter Beschuss. Wir sind, mit einem Wort von Heinrich Geiselberger, „Zeugen eines Zurück-

4 Ebd.

5 Precht, Europa. 
fallens hinter ein für unhintergehbar erachtetes Niveau der ,Zivilisiertheit‘. “6 Schon macht das Wort von der „regressiven Moderne“" ${ }^{\text {"7 }}$ die Runde; und wie es scheint, ist etwas an ein Ende gekommen, was wir noch gar nicht richtig ins Wort fassen können.

\title{
3. Größe und Grenze gesellschaftlicher Aufbrüche
}

\author{
Anfang und Ende der Großen Erzählungen
}

„Der Siegeszug des Wissens hinterläßt ein Pluriversum der Sprachspiele, eine Maskerade der Differenzen und der Diskurse. Es gibt keine Einheit der Vernunft in der Vielheit ihrer Stimmen. Die Moderne ist kein Projekt, sondern eine Akkumulation. “8

Es war der französische Philosoph Jean-François Lyotard, der radikal mit der Vorstellung aufräumte, in einem Zeitalter der verbindlichen Erzählungen zu leben. ${ }^{9}$ An die Stelle des Aufklärungsmythos von der Selbstbefreiung des Individuums (Kant) bzw. der Erzählung vom allmählichen Zu-sich-selbst-kommen des Geistes als Ziel der Geschichte (Hegel), so Lyotard, seien mit dem Anbruch der Moderne die wissenschaftlichen Beweisführungen und der Positivismus getreten. Ohne einen Anflug von Trauer beschrieb Lyotard das Zerbrechen der Einheit, der „Großen Erzählungen“ über Fortschritt und der Vernunft, Arbeit und Emanzipation, „daß es nun mit den Tröstungen des europäischen Geistes ein Ende habe“10. Doch darf bezweifelt werden, ob die positivistische Geschichtsdeutung nicht doch zu kurz greift, wenn Lyotard verkündete, „die Sehnsucht nach der großen Erzählung ist für den Großteil der Menschen selbst verloren "11. Die Grundsatzerzählung mag ausgedient haben, wie Daniel Hornuff zu bedenken gibt. Statt ihrer sei „die richtungsweisende, übergeordnete Erzäh-

6 Heinrich Geiselberger, in: Arjun Appadurai / Zygmunt Bauman / Donatella della Porta (Hg.), Die große Regression. Eine internationale Debatte über die geistige Situation der Zeit, Berlin 2017, S. 9.

7 Vgl. Jürgen Oßenbrügge, „March for Sozialgeographie“? Rechtspopulismus als Zumutung und die regressive Moderne als Herausforderung der Humangeographie, in: Geographica Helvetica 73/2018, S. 309-319, hier: S. 311.

8 Thomas Assheuer, Im Widerstreit. Zum Tod des Philosophen Jean-François Lyotard, in: Die Zeit am 23.04.1998.

9 Jean-François Lyotard, La condition postmoderne: Rapport sur le savoir, Paris 1979.

10 Assheuer, Im Widerstreit.

11 Jean-François Lyotard, zit. n. Daniel Hornuff, Deutschlandfunkkultur, Politisches Feuilleton, Archiv, Beitrag vom 2. Februar 2017, vgl. https://www.deutschlandfunkkultur.de/auf-der-su che-nach-neuen-narrativen-die-welt-ist-radikal.1005.de.html?dram:article_id=377906 (letzter Zugriff: 29.04.2019). 
lung $[\ldots]$ von der radikalen Subjektivität der vielen kleinen Erzählungen abgelöst worden." ${ }^{\text {"12 }}$

\section{1. „Nie wieder Krieg!“-Wirtschaftsentwicklung als Friedenssicherung}

Zumindest können mit Blick auf die jüngere Geschichte doch solche Erzählungen von gesellschaftsrelevanter und identitätsstiftender Macht ausgemacht werden. Es war ein geschichtlicher Kairos, als im Nachkriegseuropa mit Jean Monnet, Robert Schuman, Alcide De Gasperi und Konrad Adenauer christlich inspirierte Politiker den Weg zum dauerhaften Frieden erkannten. Dazu bedurfte es nicht nur des guten Willens einiger weniger, sondern einer strukturellen und institutionellen Absicherung des europäischen Gemeinschaftsprojekts als Voraussetzung für eine europäische Friedenssicherung, was mit dem Friedensnobelpreis 2012 eine unverhoffte Bestätigung und Bestärkung erhielt. Vielleicht doch eine späte Gegenrede zu Lyotards Abgesang auf das Ende der Großen Erzählungen. „Das Nie wieder Krieg, der Gründungsnarrativ der Europäischen Union, brauchte keinen Legitimierungsausweis. Es wurde verstanden und als Leitmotiv bis in die jüngste Vergangenheit transportiert. ${ }^{\text {“13 }}$

\section{2. „Wir sind das Volk!“ - Der Ruf nach Freiheit und Einheit}

Auch die jüngere deutsche (Wiedervereinigungs)Geschichte ist von einem Narrativ getragen. Die Erinnerung ist noch lebendig: Montagsdemonstrationen in Leipzig und in vielen anderen ostdeutschen Städten, die ihren Ausgang bezeichnenderweise in den Kirchen nahmen, die in einem sozialistisch eng reglementierten System vielen als ein letzter Ort der Freiheit galt. Es war ein historischer Moment nationalen Aufbegehrens, in dem immer lauter und furchtloser skandiert wurde: „Wir sind das Volk“. Und was war das für eine emotionale Begeisterung, als 1989 die Berliner Mauer fiel! „Deutschland einig Vaterland", so der vieltausendstimmige Chor, zunächst im Osten und dann auch im Westen. Eine Sternstunde deutsch-deutscher Begegnungs- und Willkommenskultur, als die Vision eines ,einigen Vaterlandes“ die Herzen der Menschen wärmen konnte und Spaltung eines Landes, ja Kontinentes überwunden schien.

12 Ebd.

13 Alexander Görlach, Eine neue Botschaft muss her, in: Die Zeit am 30.09.2016. 


\section{3. „Alle Menschen werden Brüder“ - Überwindung der Teilung Europas}

Auch auf europäischer Ebene wirkte diese Aufbruchsstimmung der deutschen Wiedervereinigung wie ein völkerverbindendes Narrativ. Für einen Moment wurde wahr, was unter den Klängen von Beethovens Neunter zur Europahymne mutierte: „Alle Menschen werden Brüder“, verbunden mit der Aussicht, dass Europa nunmehr „mit beiden Lungenflügeln atme“ (Johannes Paul II.) und die Völker Europas im "gemeinsamen Haus" (Gorbatschow) in gutnachbarschaftlicher Beziehung einträchtig miteinander auskommen würden. Dahinter stand die Überzeugung, dass der Aufbau einer menschenwürdigen Gesellschaft auf der Grundlage des ethischen Prinzips der sozialen Gerechtigkeit erfolgen müsse, unter Wahrung der Balance zwischen Einheit und Freiheit. „Im Prozess seiner derzeitigen Neugestaltung ist Europa vor allem aufgerufen, seine wahre Identität wiederzuerlangen. “" ${ }^{14}$ Ein Glücksfall für den Europäischen Kontinent, aber auch ein Versprechen, das bis heute noch nicht eingelöst ist.

\subsection{Willkommenskultur - Solidarität als identitätsstiftendes Momentum}

Für ein kurzes Zeitfenster gab es - Jahre später - noch einmal eine große Welle der Solidarität und Mitmenschlichkeit, als im September 2015 eine Massenbewegung von Geflüchteten an die Grenzen unseres Hoffnungskontinentes stießen und sich an vielen Orten jenes Wunder der Willkommenskultur ereignete, von nicht wenigen mit Bewunderung und Verwunderung registriert. Da überbot sich plötzlich eine Gesellschaft an Hilfsbereitschaft und Generosität, berauscht von der eigenen Weltoffenheit. Die Bilder vom Münchener Hauptbahnhof zeigten, was später „Willkommenskultur“ genannt wurde: das Selbstbild einer solidarischen Gesellschaft, die Mobilisierung vielfältigen ehrenamtlichen Engagements, das bis heute anhält und nachhaltig zur Integration der Heimatlosen beiträgt.

\section{Die Macht der Gewöhnung - Ende eines Narrativs}

Doch die Frage bleibt, ob jene gesellschaftlichen Veränderungsprozesse, von der großen Mehrheit getragen, auf die Dauer selbsttragend sind; ob die Begeisterung über den emotional aufgeladenen Moment hinaus nachhaltig identitätsbildend ist oder nicht doch mit der Gewöhnung Erosionsprozesse einsetzen, Abnutzungseffekte sichtbar werden und nicht selten die Aufbruchsbewegungen zum

14 Papst Johannes Paul II., Nachsynodales Schreiben „Ecclesia in Europa“, 28. Juni 2003, S. 109. 
Stillstand bringen oder gar wieder zurückfahren. Denn Hoffnung, die sich nicht erfüllt, oder deren Realisierung (zu lange) auf sich warten lässt, erst recht utopische Versprechen und Verheißungen, führen am Ende zu Desillusionierung und Enttäuschung; euphorische Stimmungen kippen dann allzu leicht um in Resignation, Wut und Verzweiflung. Die jüngere Geschichte bis in die Gegenwart liefert dafür ein Anschauungsmaterial.

\subsection{In Friedenszeiten wächst Eigennutz ...}

„Nie wieder Krieg“: So erfolgreich das Gründungsnarrativ zum Aufbau nationenübergreifender politischer Strukturen in Europa beigetragen hat, auf der Basis gemeinsamer Grundrechte und Grundwerte: In Zeiten politischer Stabilität und wirtschaftlicher Prosperität verblasst der Wert der Friedensdividende und die Bereitschaft zur „Verwirklichung einer immer engeren Union der Völker Europas [...], in der die Entscheidungen möglichst offen und möglichst bürgernah getroffen werden" (Lissaboner Vertrag, Art 1). An die Stelle gemeinsamen solidarischen Handelns treten schleichend Kosten-Nutzen-Überlegungen einzelner Mitgliedstaaten („I want my money back“) - bis hin zum ökonomistisch und nationalistisch motivierten Austritt. Ende eines Narrativs.

\subsection{Mit der Zielerreichung wachsen die Ansprüche}

„Wir sind das Volk“: Was auf den Straßen Ostdeutschlands selbstbewusst-trotzig eingefordert wurde, wie Wiederherstellung der nationalen Einheit, hat allerdings auch seinen Preis. Denn die Bereitschaft, über Jahrzehnte finanzielle Opfer für die Gleichstellung der Lebensverhältnisse, in Ost und West zu erbringen, nimmt mit der Zeit ab, und den desillusionierten und enttäuschten Freiheitskämpfern von einst und den „Zurückgebliebenen“ in den Transformationsgebieten bleibt das schale Gefühl der Zu-kurz-Gekommenen, der lästigen armen Verwandtschaft, die sich am Katzentisch des prosperierenden Westens mit den Brotkrumen sozialer Wohltaten (sprich Transferleistungen) zufrieden geben muss. Die Abstimmung mit den Füßen, sprich der Wegzug der Jungen und Gebildeten, die Ausbildung und Arbeit, aber auch bessere Lebensverhältnisse im Westen suchen und finden, die Entvölkerung ganzer Städte und die Verödung vermeintlich blühender Landschaften, auch die demütigende Alimentierung des Ostens durch den Westen, führt am Ende zu Nostalgie und Resignation, zu Protest und Demokratieverlust. Ende eines Narrativs. 


\subsection{Mit der Ankunft wachsen die Probleme}

„Willkommenskultur“ war gestern. Gefühle erkalten, Begeisterung schwindet, Stimmungen können kippen. Da genügt ein singuläres Ereignis von hoher Symbolkraft, wie es die Übergriffe am Kölner Hauptbahnhof in der Silvesternacht 2016 waren, und ein ganzes Land geht urplötzlich auf Abstand. So hat sich die euphorische Stimmung des Willkommens, medial inszeniert und politisch instrumentalisiert, bald verflüchtigt und ist alsbald einer Stimmung fortgesetzter Mäkeleien gewichen, die sich in Pegida-Märschen und populistisch-nationalistischen Hetzparolen Bahn bricht.

„Solange die Etablierten [die „Biodeutschen“, die alten Bundesländer, Westeuropa, ..., Anm. d. Verf.] die Außenseiter nur pädagogisch behandeln können, indem sie Unterstützung fürs Nachlernen und Aufholen anbieten, fügt sich nichts -, und solange die Außenseiter die Etablierten damit reizen, dass sie immer mehr fordern und zugleich immer weniger erwarten, fügt sich erst recht nichts. Es breitet sich nur die Stimmung einer wechselseitigen Stornierung von Energien und des wechselseitigen Verpassens von Begegnungen aus. ${ }^{\text {"15 }}$

Auch hier: Ende eines Narrativs.

\subsection{Auch unter Brüdern gibt es Neid und Streit}

„Alle Menschen werden Brüder“: Was so einleuchtend und selbsterklärend klingt, kommt alsbald an sein Ende, wenn „Brüder“ miteinander auskommen müssen. Das gilt auch innerhalb der Europäischen Union, die nur mühsam die fortbestehende Spaltung des Kontinents überdeckt. Während die Transformationsländer im Bemühen um Selbstvergewisserung und Selbstbestätigung die Respektierung der eigenen nationalen, religiösen, kulturellen Identität von den etablierten Ländern der Union erwarten und entsprechende Solidarität und Integrationsleistungen beanspruchen, vergiftet das Migrationsthema zusätzlich das Klima. ${ }^{16}$ Da verwundert es nicht, dass in Zeiten von Globalisierung und weltweiten Wanderungsbewegungen Ängste geschürt und fremdenfeindliche Stimmungen entfacht werden. Diese sind im pluralitätserfahrenen Westeuropa allerdings anders konnotiert und motiviert als in den postkommunistischen Ländern. „Die Frage, die man sich im Westen stellt, ist, wie man mit einer

15 Heinz Bude, Das Gefühl der Welt. Über die Macht von Stimmungen, München 2016, S. 99.

16 Heinz Bude: „Die Etablierten blicken [...] oft in einer Stimmung aus hochmütiger Angespanntheit, missgünstiger Aufmerksamkeit und unnachgiebiger Verbissenheit auf die Außenseiter. Da gibt es keine Heiterkeit, keine Gelassenheit, keine Großzügigkeit.“ in: Bude, Gefühl der Welt, S. 95. 
multikulturellen Gesellschaft am besten umgeht. Im Osten will man verhindern, dass eine multikulturelle Gesellschaft entsteht. ${ }^{17}$ Die Analyse der unterschiedlichen Bedrohungsszenarien lässt die je verschiedene Motivlage nationalistischer und populistischer Propaganda in Ost und West besser verstehen.

„Im Westen geht es nun darum, dass die politischen und ethnischen Mehrheiten befürchten, dass sie nicht genug politische Macht haben werden, um ihre kulturelle $\mathrm{He}-$ gemonie bewahren zu können. Deshalb rückt die Frage der kulturellen Identität im politischen Diskurs in den Vordergrund. In Osteuropa ist das Problem ein völlig anderes. Ganze Landstriche sind durch Emigration in den Westen entvölkert. “18

Da ist es mit der „Ode an die Freude“ schnell vorbei. Ende eines Narrativs.

Sehnsucht nach Sinn, nach Kohärenz und einem tragenden Grund: eine Illusion? Wenn man auf die jüngere Geschichte in Europa schaut, fanden die großen geschichtlichen Aufbrüche und Bewegungen immer unter dem Eindruck eines gemeinsam geteilten und getragenen Narrativs statt, die aber immer auch ihr Ende fanden, wenn Zweifel an der Sinnhaftigkeit im Konkreten aufkamen. Doch „eine Welt ohne narrative Ordnung wäre eine Welt ohne Bedeutung, ohne politische Vision - und ohne Opfer für das Gemeinwohl. “19 Umso desillusionierender ist es, wenn eine Gesellschaft wieder in Einzelinteressen, Partikularismen, individuelle oder nationale Egoismen ... zerfällt. Doch dies kann durchaus unterschiedlich bewertet werden:

„Firmenchefs und Politiker stimmen gemeinsam mit Architekten und Künstlern in ein Narrativ der Sehnsucht nach der lang vergessenen Möglichkeit einer, besseren ' Zukunft ein. Sie stützen sich auf einen lange unterdrückten Glauben (,yes we can', change we can believe in') [...]. Wenn die moderne Perspektive auf Idealismus und Ideale (vereinfacht gesagt) tatsächlich als fanatisch und/oder naiv beschrieben werden kann, die postmoderne Mentalität dagegen als gleichgültig und/oder skeptisch, dann kann die Haltung der gegenwärtigen Generation - im Kern ist es nämlich nichts anderes als eine an Generationen gebundene Haltung - als eine Art informierte Naivität oder pragmatischer Idealismus verstanden werden. “20

Ist das also die Antwort: Pragmatischer Idealismus anstelle der Bereitschaft, sich von Zukunftsvisionen leiten zu lassen und sich den globalen Herausforderungen zu stellen? Wenn dies eine Generationenfrage ist, dann gestehe ich freimütig,

17 Ivan Krastev - Leiter des „Centre for Liberal Strategies“ in Sofia -, Eine Geschichte zweier Europas, Interview, in: Wiener Zeitung am 27.07.2018.

18 Ebd.

19 Ronald R. Krebs, Narrative and the Making of US National Security, Cambridge 2015, S. 295.

20 Robin van den Akker / Timotheus Vermeulen, Anmerkungen zur Metamoderne, Hamburg 2015, S. 21. 
dass ich nicht zu dieser Generation gehöre - und Ingeborg Gabriel, soweit ich sie einschätze, auch nicht.

\title{
5. Weltgesellschaft vor epochalen Herausforderungen
}

Weltgemeinwohl als das neue Narrativ

\begin{abstract}
„Wenn eine Weltordnung zusammenbricht, beginnt das Nachdenken darüber. Doch offenbar gilt das nicht für den heute vorherrschenden Typus der Gesellschaftstheorie, der in universalistischer Erhabenheit und schlafwandlerischer Sicherheit über den Niederungen des epochalen Wandels - Klimawandel, Finanzkrise, Krise der Demokratie und der nationalstaatlichen Institutionen - hinwegschwebt, [...] weil sie ausschließt, was zu beobachten ist: ein Paradigmenwechsel von Gesellschaft und Politik in der Moderne. “21
\end{abstract}

Die alarmistische Analyse, die Ulrich Beck im Blick auf die Existenzkrise der Europäischen Union schon 2011 unter dem Eindruck der Staatsschuldenkrise formuliert hat - mit einem sarkastischen Seitenhieb auf die eigene Zunft der Systemtheoretiker -, dürfte sich unter dem Eindruck der zunehmenden Globalisierung und Digitalisierung noch verschärft haben. All das beschreibt, dass etwas zu Ende geht. Aber was soll kommen - oder ist schon im Werden? Wir haben es heute in der Tat mit einem epochalen Paradigmenwechsel zu tun, vergleichbar der Transformation von agrarisch geprägten Gesellschaftsformen zur Gesellschaft im Industriezeitalter, nur dass sich der aktuelle gesellschaftliche Wandel ungleich schneller vollzieht und in Zeiten von Individualisierung und der Herauslösung aus traditionellen Bindungen einseitig zu Lasten des Einzelnen geht. Darauf rekurriert Beck mit seinem Konzept der Risikogesellschaft, denn

„im Gegensatz zum ersten Industriezeitalter der Moderne im 19. Jahrhundert sind diese Risiken nicht länger regional eingrenzbar und technisch beherrschbar. Neue technische Innovationen führen zu Risiken, die nicht mehr nationalstaatlich oder schichtspezifisch abgrenzbar sind. Sie entwickeln sich zu Globalgefährdungen, inklusiver neuartiger sozialer und politischer Dynamiken“. ${ }^{22}$

Dementsprechend bedarf es auch globaler Anstrengungen, die großen Probleme der Menschheit gemeinsam anzugehen, so mühsam das ist. Dabei fehlt es nicht an Einsichten, wohl aber an der Ernsthaftigkeit, nationalstaatliche Interessen zu

21 Ulrich Beck, Kooperieren oder scheitern, die Existenzkrise der Europäischen Union, in: Blätter für deutsche und internationale Politik 2/2011, S. 41-53.

22 Stefan Gschiegl, Politik und Recht: Studienbuch, 2. Aufl., Wien 2015, Kap. 10,1: Die Risikogesellschaft als Resultat einer zweiten Moderne. 
überwinden und sich für die Lösung globaler Probleme einzusetzen. ${ }^{23}$ Doch angesichts der globalen Herausforderungen - ob Klimawandel, Welternährung, atomare Abrüstung, Erhalt der Biodiversität, um nur einige zu nennen - braucht es ein neues Narrativ, eine große Erzählung, die heute weltumspannend Menschen dazu bewegt, sich für das Weltgemeinwohl einzusetzen. Natürlich ist da in erster Linie an die Vereinten Nationen zu denken, die der Weltgesellschaft etwa mit der UN-Agenda 2030 für nachhaltige Entwicklung (SDGs) ein „globales Narrativ" (Dirk Messner) an die Hand gegeben haben. ${ }^{24}$ Aber internationale Konferenzen und Vereinbarungen bleiben seltsam blass und wirken technokratisch abgehoben. Es braucht vielmehr eine neue große Erzählung oder, etwas bescheidener, ein Plausibilität vermittelndes sinnstiftendes Narrativ, das die universalen Grundwerte transportiert und Emotionen bindet, ein gemeinsam geteiltes Bild von starker Strahlkraft, das Orientierung gibt, Kräfte bündelt, Zuversicht vermittelt und Menschen unterschiedlichster kultureller, sozialer, weltanschaulicher Prägungen hinter einer Idee versammelt. Doch während sich einstmals große Nationen ihrem Amputationsschmerz hingeben, nostalgisch berauscht am Glanz früherer Zeiten (eines British Empire, einer Grande Nation, der ruhmreichen Sowjetunion oder des Osmanischen Reichs ...), oder ihre Eigeninteressen dank ihrer militärischen, geostrategischen oder wirtschaftspolitischen Stärke ausspielen (unverblümt etwa unter dem Anspruch „America first“ oder getarnt als Projekt der „Neuen Seidenstraße“), gerät die gemeinsame Verpflichtung ins Hintertreffen, als Weltgemeinschaft auch globale Verantwortung für das Wohlergehen aller Menschen zu übernehmen.

\section{Global Leadership - Aufbau einer Kultur der Begegnung und der globalen Zivilisation des Bundes}

Da bräuchte es eine moralische Autorität von Weltgeltung, die sich die Ziele des Weltgemeinwohls zu eigen macht und dazu in der Lage ist, weltweit Menschen und Nationen zu gemeinsamem Handeln zu bewegen. Insofern liegt es nahe, diesbezüglich an die Rolle der Religionen und ihre geistlichen Führer zu denken - und hier insbesondere an Papst Franziskus, das geistliche Oberhaupt von

23 Doch mit der Globalisierung entstehen auch neue Bedrohungsszenarien, denn „die zunehmende Vernetztheit der Menschen dank neuester Informationstechnologie und die Globalisierung der Märkte erzeugt neben den von diesen offerierten Möglichkeiten eben auch Risiken, wie die Gefahr der sozialen Vereinsamung oder der allgemeinen Prekarisierung der Lebensverhältnisse. Die Risikogesellschaft fördert den Prozess der Emanzipation und Individualisierung, der die Stabilität vorgegebener und bewährter Lebensformen in zunehmendem Maße auflöst“, vgl. Stefan Gschiegl, Politik und Recht, Kap. 10,1.

24 Vgl. Alexander Heinrich, Neue Agenda für die Zeit nach 2015, in: Das Parlament 2015. 
immerhin 1,3 Milliarden Katholiken, der sich mit seiner universalen Botschaft des Weltgemeinwohls nicht nur an die eigene Glaubensgemeinschaft wendet, sondern an die ganze Menschheitsfamilie: „Der Epochenwandel, den wir erleben“, so der Papst, „ist keine Epoche des Wandels, sondern ein Epochenwandel“, und er fordert dazu auf,

„sich nicht nur für die Begegnung zwischen Menschen, Kulturen und Völkern und für einen Bund zwischen den Zivilisationen einzusetzen, sondern dafür, mit allen gemeinsam die epochale Herausforderung zu überwinden, eine gemeinsame Kultur der Begegnung und eine globale Zivilisation des Bundes aufzubauen. ${ }^{\text {"25 }}$

Dazu bedarf es der Sammlung aller positiven Kräfte, die sich von diesem Narrativ, dem Ziel einer "globalen Zivilisation des Bundes“ inspirieren und bewegen lassen.

Dies wurde auf bemerkenswerte Weise deutlich, als sich Papst Franziskus mit seinem sozial-ökologischen Ansatz an die Weltgemeinschaft wandte und dazu mahnte, „dass ein wirklich ökologischer Ansatz sich immer in einen sozialen Ansatz verwandelt, der die Gerechtigkeit in die Umweltdiskussionen aufnehmen muss, um die Klage der Armen ebenso zu hören wie die Klage der Erde.“ (LS 49). Teilnehmer der Weltklimakonferenz 2015 in Paris gaben zu Protokoll, dass das Päpstliche Schreiben das meistdiskutierte Hintergrundpapier auf dem UNGipfel war und das Zustandekommen der Schlusserklärung und die Selbstverpflichtung der Unterzeichnerstaaten maßgeblich beeinflusst hat. Dabei präsentiert der Papst der Weltgemeinschaft nicht selbsterdachte Ziele, sondern nimmt Maß am Schöpfungsauftrag des Menschen: dazu „berufen, die Werkzeuge Gottes des Vaters zu sein, damit unser Planet das sei, was Er sich erträumte, als Er ihn erschuf, und seinem Plan des Friedens, der Schönheit und der Fülle entspreche“ (LS 53), verbunden mit der nüchternen Erkenntnis:

„Das Problem ist, dass wir noch nicht über die Kultur verfügen, die es braucht, um dieser Krise entgegenzutreten. Es ist notwendig, leaderships zu bilden, die Wege aufzeigen, indem sie versuchen, die Bedürfnisse der gegenwärtigen Generationen unter Einbeziehung aller zu berücksichtigen, ohne die kommenden Generationen zu beeinträchtigen.“ (LS 53).

Als global leader sucht Papst Franziskus im Sinne seiner Programmatik des Weltgemeinwohls den Kontakt und die Nähe zu anderen charismatischen Religionsführern in dem Anliegen, unbeschadet der Vertiefung des ökumenischen und interreligiösen Dialogs auf die Nöte der Menschen, etwa der weltweiten Fluchtbewegungen, aufmerksam zu machen und „Allianzen zu bilden, die in der Lage sind, Räume der Aufnahme, des Schutzes, der Förderung und Integration

25 Papst Franziskus, Begegnung mit der Gemeinschaft der Fokolarbewegung, Loppiano (Florenz), 10.05.2018. 
zu eröffnen, Räume also, in denen Würde möglich ist. “26 Weltweite Beachtung fand sein unprätentiöses Eintreten für Migranten, als er zusammen mit anderen Kirchen- bzw. Religionsführern Flüchtlingslager auf Lampedusa, auf Lesbos oder in Jordanien besuchte und der Weltgemeinschaft eindringlich ins Gewissen redete:

„Es ist eine Wunde, die zum Himmel schreit. Deshalb wollen wir nicht, dass die Gleichgültigkeit und das Schweigen unsere Antwort darauf seien (vgl. Ex 3,7). Besonders angesichts der vielen Millionen Flüchtlinge und anderer zur Migration Gezwungener, die internationalen Schutz suchen, ganz zu schweigen von den Opfern des Menschenhandels und neuer Formen der Sklaverei durch kriminelle Organisationen. Niemand kann diesem Leid gleichgültig gegenüberstehen. ${ }^{\text {“27 }}$

Als moralische Autorität mit Weltgeltung ist Papst Franziskus ein bevorzugter Partner der Vereinten Nationen, wenn es etwa darum geht, die Weltreligionen zum gemeinsam Handeln für die Verwirklichung der Nachhaltigkeitsziele (SDGs) zu gewinnen. ${ }^{28}$ Gleichzeitig ist der Vatikan auch eine Top-Adresse, um Politiker und Wirtschaftsführer aus aller Welt auf ethisch verantwortliche Formen des Wirtschaftens zu verpflichten, die nachhaltig und gemeinwohldienend sind und die Rechte und die Würde des Einzelnen wie das Wohl der Gemeinschaft in sozialer Verantwortung respektieren. ${ }^{29}$

In dem historischen „Dokument über die Brüderlichkeit aller Menschen für ein friedliches Zusammenleben in der Welt" (Abu Dhabi, 04.02.2019) bringt Papst Franziskus zusammen mit dem Kairoer Großimam Ahmad Mohammad Al-Tayyeb seine Hoffnung zum Ausdruck,

„dass diese Erklärung eine Einladung zur Versöhnung und zur Brüderlichkeit unter allen Glaubenden, besser noch unter Glaubenden und Nichtglaubenden sowie unter allen Menschen guten Willens;

dass sie ein Aufruf sei an jedes wache Gewissen, das sich von der abweichenden Gewalt und dem blinden Extremismus lossagt; ein Aufruf an den, der die Werte der Toleranz und Brüderlichkeit, die von den Religionen gefördert und unterstützt werden, liebt;

dass sie ein Zeugnis für die Größe des Glaubens an Gott sei, der die getrennten Herzen eint und den menschlichen Geist erhebt;

26 Papst Franziskus, Ansprache beim Besuch der Caritas, Rabat, 30. März 2019.

27 Ebd.

28 Vgl. z. B. die Konferenz des Dikasteriums für Integrale Menschliche Entwicklung: „Religions and the Sustainable Development Goals (SDGs). Listening to the cry of the earth and of the poor", Vatican City, New Synod Hall, 07.-09.03.2019.

29 Vgl. z. B. das jüngste Dokument zur Wirtschaftsethik: Congregation for the Doctrine of the Faith - Dicastery for Promoting Integral Human Development: Considerations for an Ethical Discernment Regarding Some Aspects of the Present Economic Financial System, 14.05. 2018. 
dass sie ein Symbol für die Umarmung zwischen Ost und West, Nord und Süd sowie zwischen allen, die glauben, dass Gott uns erschaffen hat, damit wir uns kennen, unter uns zusammenarbeiten und als Brüder und Schwestern leben, die sich lieben.

Das hoffen und suchen wir zu verwirklichen, um einen universalen Frieden zu erreichen, den alle Menschen in diesem Leben genießen können. “30

Leben für eine "globale Zivilisation des Bundes“: Es ist der Beginn einer neuen Erzählung von religiöser Kraft: in der Bereitschaft zur Übernahme globaler Weltverantwortung - damit die Menschheit eine Zukunft hat.

\section{Quellen}

Assheuer, Thomas, Im Widerstreit. Zum Tod des Philosophen Jean-François Lyotard, in: Die Zeit am 23.04.1998.

Beck, Ulrich, Kooperieren oder scheitern, die Existenzkrise der Europäischen Union, in: Blätter für deutsche und internationale Politik 2/2011, S. 41-53.

Bude, Heinz, Das Gefühl der Welt. Über die Macht von Stimmungen, München 2016.

Congregation for the Doctrine of the Faith - Dicastery for Promoting Integral Human Development: Considerations for an Ethical Discernment Regarding Some Aspects of the Present Economic Financial System, 14.05.2018.

Dikasterium für Integrale Menschliche Entwicklung, Konferenz: „Religions and the Sustainable Development Goals (SDGs). Listening to the cry of the earth and of the poor", Vatican City, New Synod Hall, 7.-9.03.2019.

Geiselberger, Heinrich, in: Arjun Appadurai / Zygmunt Bauman / Donatella della Porta (Hg.), Die große Regression. Eine internationale Debatte über die geistige Situation der Zeit, Berlin 2017.

Görlach, Alexander, Eine neue Botschaft muss her, in: Die Zeit am 30.09.2016.

Gschiegl, Stefan, Politik und Recht: Studienbuch, 2. Aufl., Wien 2015.

Heinrich, Alexander, Neue Agenda für die Zeit nach 2015, in: Das Parlament 2015.

Krastev, Ivan, Eine Geschichte zweier Europas, Interview, in: Wiener Zeitung am 27.07. 2018.

Krebs, Ronald R., Narrative and the Making of US National Security, Cambridge 2015. Lyotard, Jean-François, zit. n. Daniel Hornuff, Deutschlandfunkkultur, Politisches Feuilleton, Archiv, Beitrag vom 2. Februar 2017, vgl. https://www.deutschlandfunkkultur. de/auf-der-suche-nach-neuen-narrativen-die-welt-ist-radikal.1005.de.html?dram:arti cle_id=377906 (letzter Zugriff: 29.04.2019).

Lyotard, Jean-François, La condition postmoderne: Rapport sur le savoir, Paris 1979.

30 Dokument über die Brüderlichkeit aller Menschen - Für ein friedliches Zusammenleben in der Welt, Apostolische Reise von Papst Franziskus in die Vereinigten Arabischen Emirate (3.-5. Februar 2019), vgl. http://w2.vatican.va/content/francesco/de/travels/2019/outside/ documents/papa-francesco_20190204_documento-fratellanza-umana.html (letzter Zugriff: 10.05.2019). 
Oßenbrügge, Jürgen, „March for Sozialgeographie“? Rechtspopulismus als Zumutung und die regressive Moderne als Herausforderung der Humangeographie, in: Geographica Helvetica 73/2018, S. 309-319.

Papst Franziskus / Ahmad Al-Tayyeb: Dokument über die Brüderlichkeit aller Menschen Für ein friedliches Zusammenleben in der Welt, Apostolische Reise von Papst Franziskus in die Vereinigten Arabischen Emirate (3.-5. Februar 2019), vgl. http://w2.vati can.va/content/francesco/de/travels/2019/outside/documents/papa-francesco_201902 04_documento-fratellanza-umana.html (letzter Zugriff: 10.05.2019).

Papst Franziskus, Begegnung mit der Gemeinschaft der Fokolarbewegung, Loppiano (Florenz), 10.5.2018.

Papst Franziskus, Ansprache beim Besuch der Caritas, Rabat, 30. März 2019.

Papst Johannes Paul II., Nachsynodales Schreiben „Ecclesia in Europa“, 28. Juni 2003.

Precht, Richard David, Europa: Unsere gereizten Seelen, in: Die Zeit 40/2016 am 22.09. 2016.

Steinmeier, Frank-Walter, Weihnachtsansprache, 24. Dezember 2018.

Thierse, Wolfgang, Erwartungen an die Kirche. Zum fundamentalen Dienst der Kirche an der Politik, in: Peter Klasvogt / Stefan Klug (Hg.), Europa - Wertegemeinschaft oder Wirtschaftsunion? Zur Prägekraft des Katholizismus in Mitteleuropa, Paderborn 2015, S. 110-117.

Van den Akker, Robin / Vermeulen, Timotheus, Anmerkungen zur Metamoderne, Hamburg 2015. 


\section{Wie kann das friedliche Zusammenleben freier und gleicher Menschen in einer pluralistischen Gesellschaft dauerhaft gelingen?}

Religiöse Vielfalt ist eine Herausforderung für den Rechtsstaat und die Religionsgemeinschaften nach innen. Auf die Frage nach der Toleranz innerhalb der Religionsgemeinschaften werden kommunitaristische, feministische und liberale Ansätze vorgestellt. Die staatlichen Grundrechte bilden einen Rahmen, innerhalb dessen Konflikte heute immer häufiger vor Gericht ausgetragen werden.

\section{Pluralismus in der Gesellschaft}

\subsection{Rechtsphilosophische Grundlagen}

1783 plädierte Moses Mendelssohn in „Jerusalem oder über religiöse Macht und Judentum “1 für Gewissensfreiheit und Toleranz. „Sogar in Amerika, notiert Mendelssohn besorgt [...], stimme der Kongress das alte Lied an und spreche

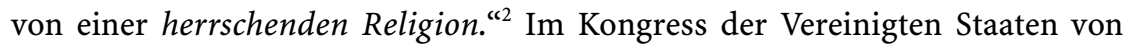
Amerika wurde eine „Bill for Support of Christian Denominations“ eingebracht. Diese sollte das anglikanische Christentum zur „established religion“ erklären und ihm den Status einer Staatsreligion in den USA verleihen. ${ }^{3}$ James Madison, ${ }^{4}$

1 Moses Mendelssohn, Jerusalem oder über die religiöse Macht und Judentum, Philosophische Bibliothek 565, Hamburg 2005.

2 Shmuel Feiner, Moses Mendelssohn. Ein jüdischer Denker in der Zeit der Aufklärung, aus dem Hebräischen übersetzt von Inge Yassur, Göttingen 2009, S. 167.

3 Das Ringen um eine Staatsreligion in den USA dauerte sehr lange. Erstmals wurde im Staate Maryland 1649, mit Hilfe katholischer Bürger, die Staatsreligion in der Verfassung verboten. 1654 kamen die Puritaner wieder an die Macht und verboten erneut die Ausübung des katholischen und anglikanischen Glaubens, vgl. Marcel Stüssi, Models of Religious Freedom. Switzerland, The United States, and Syria by Analytical, Methodological, and Eclectic Representation, ReligionsRecht im Dialog 12, Münster 2011, S. 79-93. Katholische Bürger zählten wegen ihrer Verfolgung in den USA zu jenen, die 1649 erstmals das Verbot einer Staatskirche einführten. Es muss also unterschieden werden zwischen der Lehre einer Religion und dem bürgerlichen Handeln von deren Mitgliedern. In der katholischen Kirche wurde auf 
Bill Jefferson ${ }^{5}$ und der Berliner Philosoph Moses Mendelssohn anerkannten keine Staatsreligion mehr, sondern akzeptierten nur das individuelle Gewissen des Einzelnen. Mit dem „First Amendment“ von 1797, ${ }^{6}$ das die Staatsreligion verbot, begann die neue Zeitepoche des Religionsverfassungsrechts. Die Religionsfreiheit des Individuums fand definitiv Eingang in die Verfassungen, z. B. in die Schweizer Verfassung von 1874.

Seither haben in einer liberalen Demokratie alle Bürgerinnen und Bürger das Grundrecht auf freie Wahl ihrer religiösen, später auch weltanschaulichen $\mathrm{Zu}$ gehörigkeit. Unabhängig von der jeweiligen Religionszughörigkeit bindet alle die Pflicht, die säkularen Prinzipien eines Rechtsstaates zu akzeptieren, d.h. also auch jene „Leitlinien einer Neutralitätskonzeption",7 die „die religiöse und ethische Neutralität des Staates ${ }^{\text {“8 }}$ vorschreiben. Diese Grundsätze sollten Bürgerinnen und Bürger aus ihrem Glaubensverständnis heraus begründen und verantworten können.

Die Philosophie der Aufklärung entwickelt verschiedene Konzepte der Toleranz und der Religionsfreiheit. Sie entwirft Vorstellungen einer multireligiösen Gesellschaft, in welcher Angehörige einer Minderheitenreligion die gleichen bürgerlichen Rechte erhalten wie die Gläubigen der Mehrheitsreligion. ${ }^{9}$ Der Philosoph Mendelssohn wendet sich vom bisherigen Konzept „Kirche und Staat ${ }^{\star 10}$ bzw. „Staat und Religion ${ }^{\text {“11 }}$ ab und stellt die bis dato neue Frage, wem die

dem Zweiten Vatikanischen Konzil 1965 durch die Konzilserklärung Dignitatis humanae die Religionsfreiheit lehramtlich anerkannt.

4 „Madison believed this approach was required in order to protect the church from the state.“ Vgl. Stüssi, Models of Religious Freedom, S. 88-96, hier: S. 93.

5 „To Jefferson's mind, religious tolerance was best achieved by, building a wall of separation between Church and State." Stüssi, Models of Religious Freedom, S. 92.

6 „Congress shall make no law respecting an establishment of religion, nor prohibiting the free exercise thereof." Stüssi, Models of Religious Freedom, S. 92.

7 Vgl. Lorenz Engi, Die religiöse und ethische Neutralität des Staates, Theoretischer Hintergrund, dogmatischer Gehalt und praktische Bedeutung eines Grundsatzes des schweizerischen Staatsrechts, Zürich 2017, S. 120-137.

8 Vgl. Ebd.

9 Vgl. Mendelssohn, Jerusalem, Berlin 1783 bzw. Hamburg 2005.

10 Der erste Entwurf von Mendelssohn, Jerusalem, S. 29, beginnt mit dem Satz: „Kirche u. Staat. Grenzstreitigkeit zwischen denselben hat schreckliche Uebel verursachet.“ „In seinen Briefen über Toleranz legt er [John Locke] die Definition zu Grund: Ein Staat sei eine Gesellschaft von Menschen, die sich vereinigen, um ihre zeitliche Wohlfahrt gemeinschaftlich zu befördern. Hieraus folgt alsdann ganz natürlich, dass der Staat sich um die Gesinnungen der Bürger, ihre ewige Glückseligkeit betreffend, gar nicht zu bekümmern, sondern jeden zu dulden habe, der sich bürgerlich gut aufführt, das heisst seinen Mitbürgern, in Absicht ihrer zeitlichen Glückseligkeit, nicht hinderlich ist." Ebd. S. 37

11 Die definitive Fassung von Mendelssohn, Jerusalem, S. 33, beginnt mit „Staat und Religion bürgerliche und geistliche Verfassung - weltliches und kirchliches Ansehen - diese Stützen des gesellschaftlichen Lebens $[\ldots .$. “. 
Sorge für das Ewige anvertraut werden solle, ${ }^{12}$ der Kirche oder dem Staat? Der Aufklärer Mendelssohn weist beide Möglichkeiten ab und entwickelt eine dritte. Denn beide, Staat und Kirche, „vertragen sich selten anders, als um ein drittes moralisches Wesen, die Freiheit des Gewissens, die von ihrer Uneinigkeit einigen Vorteil zu ziehen weiss" ${ }^{13}{ }^{13}$ In Gesellschaften, die auf der Grundidee größtmöglicher Selbstbestimmung des Einzelnen entstehen, ist schon für Mendelssohn als Vertreter der Aufklärung eine Vielfalt von religiösen Meinungen die Konsequenz der Freiheit.

Die Bedeutung der Religionsfreiheit wird seit der Aufklärung weiterentwickelt. So erklärte 1975 der Ökumenische Rat der Kirchen in Nairobi: „Keine Religionsgemeinschaft darf für sich Religionsfreiheit beanspruchen, ohne selbst die Glaubensüberzeugungen und die grundlegenden Menschenrechte der anderen $\mathrm{zu}$ respektieren und zu wahren. “14

Dass religiöse und weltanschauliche Konflikte die inzwischen pluralistisch gewordenen Gesellschaften nicht zerreissen, ist auf das Grundrecht der Religionsfreiheit zurückzuführen. Dieser grundrechtliche Ansatz bietet den Religionsgemeinschaften auch innerhalb des Rechtsstaates einen institutionellen Rahmen für die Lösung ihrer eigenen Konflikte, wie weiter unten noch zu zeigen sein wird.

\subsection{Aktuelle Herausforderung}

Im Kontext der rechtlichen Anerkennung weiterer Religionsgemeinschaften schreibt Charles Taylor in einem Gutachten: „Der Umgang mit moralischer und religiöser Vielfalt ist eine der grössten Herausforderungen, mit denen unsere Gesellschaften gegenwärtig konfrontiert sind. “' ${ }^{15}$ Das Thema der religiösen und kulturellen Pluralisierung der westlichen Gesellschaften hat sich seit den späten 1990er Jahren in den öffentlichen Debatten des Westens stark etabliert. Die enge Bindung des Staates an eine Religionsgemeinschaft

„würde aus den Anhängern anderer Religionen und aus Menschen ohne Religion Bürger zweiter Klasse machen. Daher hat der demokratische Staat in seinem Verhältnis zu den verschiedenen Religionen neutral oder unparteilich zu sein. Zudem muss er alle

12 Vgl. Ebd., S. 38.

13 Ebd., S. 33.

14 Hanfried Krüger / Walter Müller-Römheld (Hg.), Bericht aus Nairobi 1975. Ergebnisse Erlebnisse - Ereignisse. Offizieller Bericht aus der Fünften Vollversammlung des Ökumenischen Rates der Kirchen, 23.11-10.12.1975 in Nairobi (Kenia)-Frankfurt a. M. 1976, S. 80.

15 Jocelyn Maclure / Charles Taylor, Laizität und Gewissensfreiheit, Berlin 2011, S. 9. 
Bürger gleich behandeln, ob sie auf der Basis religiöser Überzeugungen handeln oder nicht. "16

Die Neutralität des demokratischen und liberalen Staates kann jedoch nicht absolut sein. Der Staat ist gegenüber den Glaubens- und Wertesystemen der Bürgerinnen und Bürger neutral. Zugleich aber verteidigt er die Gleichheit und Freiheit der Bürger, „ihre eigenen Ziele zu verfolgen. Der Staat ergreift demnach Partei für die Gleichheit und Autonomie der Bürger “17. Diese klare Parteinahme des Staates für die Freiheitsrechte jeder Bürgerin und jedes Bürgers macht das Luzerner Gutachten des Zentrums für Religionsverfassungsrecht bereits im Titel „Freiheit und Religion“ deutlich. ${ }^{18}$ Die Expertise hat sich der Herausforderung gestellt, für die direkt-demokratische Schweiz eine Antwort auf die Frage nach der „Anerkennung weiterer Religionsgemeinschaften “19 $\mathrm{zu}$ erarbeiten. Es kommt dabei nicht zufällig der Freiheit des Individuums, den Freiheitsrechten, das erste Wort zu. So setzte sich das Luzerner Gutachten indirekt auch mit der Frage John Rawls' auseinander: „Wie kann eine stabile und gerechte Gesellschaft freier und gleicher Bürger, die durch vernünftige und gleichwohl einander ausschliessende religiöse, philosophische und moralische Lehren einschneidend voneinander getrennt sind, dauerhaft bestehen?" ${ }^{\text {(20 }}$ Gerade die religiöse und weltanschauliche Vielfalt wird unsere westlichen Gesellschaften in den nächsten Jahrzehnten noch öfters beschäftigen. ${ }^{21}$

16 Ebd., S. 17.

17 Ebd., S. 26.

18 Vgl. Adrian Loretan / Quirin Weber / Alexander H.E. Morawa, Freiheit und Religion. Die Anerkennung weiterer Religionsgemeinschaften in der Schweiz, ReligionsRecht im Dialog 17, Münster 2014.

19 So der Untertitel der Expertise.

20 John Rawls, Politischer Liberalismus, Frankfurt 2003, S. 14.

21 Sowohl die Eidgenössische Kommission gegen Rassismus wie auch die Behörden verschiedener Kantone, darunter ein Bildungsdirektor und verschiedene Religionsgemeinschaften, suchten das Gespräch. Ein großes Interesse der Schweizer Medien hat die beiden Autoren Weber und Loretan über vier Monate sehr gefordert, nachdem Dr. Maizar als Präsident des Rates der Religionen der Schweiz die Expertise in der NZZ am Sonntag ganzseitig thematisierte, vgl. Katharina Bracher, Gutachten stützt Forderung nach islamischer Landeskirche. Öffentlichrechtliche Anerkennung, in: NZZ am Sonntag 1 am 05.01.2004, S. 6. 


\section{Pluralismus als Herausforderung für den Diskurs innerhalb der Religionsgemeinschaften ${ }^{22}$}

Der Pluralismus ist auch für die Religionsgemeinschaften nach innen eine neue Herausforderung. Vor dem Rechtsstaat stellt das Vertreten häretischer Lehren keine Rechtsverletzung mehr dar. Diejenigen, die die Autorität einer Religion nicht länger anerkennen, können aus der Religionsgemeinschaft austreten. Sie geraten dadurch in keinen Konflikt mit der Staatsgewalt. Die individuelle Religionsfreiheit als staatliches Austrittsrecht schützt das Individuum vor der Religionsgemeinschaft, die einen Glaubensabfall ${ }^{23}$ verhindern will.

Aber werden mit diesem Austrittsrecht auch interne Religionskonflikte gelöst? Die Möglichkeit, frei seinen Austritt aus oder seine Konversion zu einer anderen Religionsgemeinschaft zu erklären, kennen die meisten Religionsgemeinschaften nicht, noch sehen sie ihn in ihrem eigenen Recht vor. Eine Muslima zeigte im Rahmen einer Veranstaltung der Eidgenössischen Kommission gegen Rassismus auf, dass sie ihre Religionsgemeinschaft trotz der verfassungsmässigen Garantie von BV Art. 15 Abs. 4 auf Grund der persönlichen Folgen nicht verlassen könne. Die Religionsgemeinschaften sind zum Teil weltumspannende Großorganisationen sowie Arbeitgeberinnen großer Bildungseinrichtungen. Zudem bilden sie für Gläubige eine emotionale und kulturelle Heimat, die meist nicht leichthin aufgegeben werden kann, ohne dass Familien- oder Freundschaftsbande zu zerreissen drohen. Ein staatlicher Austritt, der von der Religionsgemeinschaft als Glaubensabfall (Apostasie) bewertet wird, kann durch religiöses Recht theoretisch mit dem Tode, der Enterbung, der Scheidung oder dem Verlust jeden Rechtsschutzes in der Primärgesellschaft bedroht werden. ${ }^{24} \mathrm{Da}$ in

22 Bei dieser Thematik stütze ich mich auf eine früher veröffentlichte Studie: Adrian Loretan, Religionsfreiheit und Gleichstellung aus religionsrechtlicher und rechtsphilosophischer Sicht, in: Ders., Religionen im Kontext der Menschenrechte, Religionsrechtliche Studien 1, Zürich 2010, S. 111-134.

23 Vgl. Von der Religion abfallen, Radio SRF 2 Kultur, Sendung Kontext, 12.02.2018.mp3, vgl. https://www.srf.ch/sendungen/kontext/von-der-religion-abfallen (letzter Zugriff: 01.04. 2019).

24 „Apostasie, der Abfall vom Glauben (ridda), ist nach der klassischen islamischen Rechtslehre ein Tatbestand, der von einem männlichen erwachsenen Muslim, der ohne Zwang und ohne Alkoholeinfluss handelt, begangen werden kann. Apostasie erstreckt sich nicht nur auf die verbale Leugnung Gottes, sondern auf jegliche Konversion vom Islam, sowie auf Handlungen, Unterlassungen und sogar Gedanken und wird mit einer Reihe von zivilrechtlichen Konsequenzen - von einer erzwungenen Ehescheidung bis hin zur faktischen Enteignung und zuletzt mit der Todesstrafe belegt. Obgleich nach der klassischen islamischen Rechtslehre die Bestrafung der Apostasie eines genau geregelten Verfahrens durch ein Gericht mit eindeutig nachweisbaren Äußerungen oder Handlungen und Zeugenaussagen bedarf, kommen in der Praxis auch Bestrafungen durch Dritte vor, da der Apostat vom Moment des Vorwurfs an kaum mehr Rechtsschutz geniesst.“ (Fazit der unveröff. schriftlichen Arbeit zum Hauptseminar „Religious Life Style and Law“ (HS 2013) der Islamwissenschaftlerin 
liberalen Staaten das Strafmonopol beim Staat liegt, ist die Ausübung dieser Bestrafungen, die in das staatliche Gewaltmonopol eingreifen, verboten. Trotzdem kommt es immer wieder zu „Bestrafungen“ der Ausgetretenen, weil ein Individuum gegen religiöses Recht verstoßen haben soll. ${ }^{25}$

Es stellt sich zusätzlich die Frage: Wie werden Konflikte zwischen dem Individuum und seiner Religionsgemeinschaft innerhalb der Religionsgemeinschaft gelöst? Welche Rolle spielt der Staat dabei? Oder gelten Menschenrechte auch in den Religionen ${ }^{26}$ Wie ist das Verhältnis von kollektiver Religionsfreiheit zu den anderen Grundrechten einer Verfassung $?^{27}$ Wie verhält sich der Staat z. B. $\mathrm{zu}$ den „vielen Gesichtern des Islam ${ }^{\text {“28 }}$ und gegenüber jenen Vertretern einer Religionsgemeinschaft, die einen säkularen Rechtsstaat und damit dessen Gewaltmonopol und Grundrechte ablehnen $?^{29}$ Auf diese Fragen nach der Toleranz innerhalb der Religionsgemeinschaften finden sich verschiedene Antworten. Im Folgenden sollen kommunitaristische, feministische und liberale Ansätze kurz umrissen werden.

\subsection{Kommunitaristische Ansätze}

Die Vertreter der kommunitaristischen Ansätze wollen unabhängig von den Mitgliedern Korporativrechte begründen. Die hohe Bedeutung der Gruppe gegenüber dem Individuum erlaube es, dass die Grundrechte der betroffenen Mitglieder zu Gunsten der Gruppe eingeschränkt werden können. Dies bringt „ein Potential gruppeninterner Unterdrückung ${ }^{\star 30} \mathrm{mit}$ sich, wie Texte von Charles

Ann-Katrin Gässlein zum Thema: Der Abfall vom Glauben nach der Interpretation reformorientierter islamischer Theologie).

25 Vgl. Von der Religion abfallen, Radio SRF 2 Kultur.

26 Vgl. Loretan, Religionen im Kontext der Menschenrechte; Peter G. Kirchschläger (Hg.), Die Verantwortung von nichtstaatlichen Akteuren gegenüber den Menschenrechten, Religionsrechtlichen Studien 4, Zürich 2017.

27 Vgl. Adrian Loretan (Hg.), Religionsfreiheit im Kontext der Grundrechte, Religionsrechtliche Studien 2, Zürich 2011; Adrian Loretan, Wahrheitsansprüche im Kontext der Freiheitsrechte, Religionsrechtliche Studien 3, Zürich 2017.

$28 \mathrm{Vgl}$. Elham Manea, Ich will nicht schweigen. Der Islam, der Westen und die Menschenrechte, Freiburg i. Br. 2009, S. 80-95; Dies., Women and Shari'a Law: The Impact of Legal Pluralism in the UK, London 2016.

29 Vgl. Dies., Der alltägliche Islamismus. Terror beginnt, wo wir ihn zulassen, aus dem Englischen übersetzt von Elsbeth Ranke und Claudia Van den Block, München 2018; Beat Stauffer, Kräftemessen oder Kollusion? Das undurchsichtige Verhältnis zwischen gemässigten und radikalen Islamisten in Tunesien, in: Neue Zürcher Zeitung 166 am 19.07.2012, S. 41; Im Netz der Salafisten, ARD Fernsehsendung am 16.07.2012.

30 Jürgen Habermas, Kulturelle Gleichbehandlung - und die Grenzen des postmodernen Liberalismus, in: Deutsche Zeitschrift für Philosophie 51/2003, S. 367-394, hier: S. 388. 
Taylor $^{31}$ und Michael Walzer zeigen. Walzer ist bereit, interne Unterdrückung zu tolerieren, solange die Mitgliedschaft freiwillig ist. Bei Eingriffen, wie beispielsweise der geschlechtsbegründeten Herabsetzung will er Toleranz walten lassen, außer wenn Frauen zu einer bestimmten Praxis gezwungen werden. ${ }^{32} \mathrm{Mit}$ diesem Ansatz wären z. B. die Diskriminierung von Frauen in Leitungsfunktionen oder im Eheverständnis in verschiedenen Religionsgemeinschaften vertretbar. Gerade in der privaten Sphäre erweise sich die vollständige Durchsetzung tatsächlicher Gleichheit von Mann und Frau - so Walzer - als problematisches Instrument, das zur Auflösung traditioneller, vormoderner Kulturen führe. Deshalb müssten gemäß Walzer Staat und Mehrheitsgesellschaften auf die Durchsetzung der Geschlechtergleichheit verzichten. Dies läuft allerdings auf die Abschaffung der Grundrechte für die Mitglieder in der religiösen Gruppe hinaus. Es wird zudem zugestimmt, dass intolerante Haltungen in einem gewissen Ausmaß hinzunehmen seien, weil Kulturtraditionen und religiöse Gruppen, die sie leben, einen - auch grundrechtlich geschützten - kollektiven Eigenwert besitzen. Der Aspekt, dass innerhalb solcher Gruppen sozialisierte Mädchen und Frauen ihre eigene Diskriminierung und letztlich Minderwertigkeit gegenüber Männern als selbstverständlich ansehen, wird durch den Ansatz nicht abgebildet. Denn so haben es die Mädchen und Frauen sehr schwer, die propagierte Möglichkeit eines freiwilligen Ausstiegs auch zu kennen und wahrzunehmen, wie Elham Manea für die englischen Shari'a-Councils empirisch nachweist. ${ }^{33}$

Der kommunitaristische Ansatz wird gemäß Walter Kälin „der Friedensfunktion staatlicher Neutralität [...] gerecht, da staatliches Eingreifen in die Binnenstruktur geschlossener Gruppierungen und Gemeinschaften immer Konflikt fördernd ist ${ }^{\text {«34 }}$. Somit ist für Kälin der kommunitaristische Ansatz realistischer und leichter mit traditioneller juristischer Grundrechtsdogmatik zu vereinbaren als die im Folgenden darzustellenden liberalen und feministischen Ansätze. In der Rechtswissenschaft ist es also durchaus denkbar, durch das Grundrecht der Religionsfreiheit das Grundrecht der Gleichstellung der Geschlechter stark einzuschränken. ${ }^{35}$ Für viele Vertreter der Rechtswissenschaft

31 Vgl. Charles Taylor, Multikulturalismus und die Politik der Anerkennung, Frankfurt a.M. 1993, S. 52. Er vertritt die These: Man könnte für die französischsprachigen Bürger von Quebec „die französische Sprache als eine kollektive Ressource betrachten, deren sich Individuen bedienen wollen, und könnte sich deshalb für ihre Erhaltung einsetzen“.

32 Vgl. Michael Walzer, On Toleration, New Haven-London 1997, S. 62-66.

33 Vgl. Manea, Women and Shari'a Law.

34 Walter Kälin, Grundrechte im Kulturkonflikt. Freiheit und Gleichheit in der Einwanderungsgesellschaft, Zürich 2000, S. 47.

35 Anderer Meinung ist Denise Buser, Die unheilige Diskriminierung. Eine juristische Auslegeordnung für die Interessenabwägung zwischen Geschlechtergleichstellung und Religionsfreiheit beim Zugang zu religiösen Leitungsämtern, ReligionsRecht im Dialog 16, WienMünster 2014. Denise Buser, Unholy Discrimination. An overview of the legal rules gover- 
scheint es schwierig bis unmöglich, die Gleichstellung der Geschlechter und die Religionsfreiheit zusammenzudenken. Die Encyclopedia Britannica geht in ihrem Verständnis für die Ungleichheit sogar noch weiter, wenn sie anmerkt, dass das, „was in einer Kultur moralisch ist, in einer anderen unmoralisch sein [kann] und wiederum in einer anderen ethisch neutral. Beispielsweise galt es nicht als unmoralisch, ein Mädchen nach seiner Geburt [...] zu töten.“36

\subsection{Feministische Ansätze}

Wenn es keine Gender-Vorurteile gäbe, hätte „das Phänomen der ,fehlenden Frauen' in Indien, China und vielen anderen Ländern [...] stark zurückgehen müssen. [...] Leider hat das relativ neue Phänomen, dass Gender-Vorurteile die Geburtenziffern beeinflussen, in die entgegengesetzte Richtung gewirkt. “" ${ }^{\text {"37 Die }}$ religiösen oder weltanschaulichen Geschlechter-Vorurteile tragen zu gesellschaftlichen Vorstellungen der angeblichen Minderwertigkeit der Frauen bei, die sich auf die Mortalität der Frauen auswirkt. Feministische Ansätze ${ }^{38}$ beurteilen daher die diskriminierenden kulturellen und religiösen Gruppen anders. Sie stellen fest, dass staatliche Zurückhaltung gegenüber gruppeninterner Diskriminierung ${ }^{39}$ faktisch Parteinahme für die, die andere diskriminieren, bedeutet. Die Zurückhaltung des Staates und der Mehrheitsgesellschaft gegenüber gruppeninterner Diskriminierung kann zur Folge haben, dass Frauen schutzlos den

ning the consideration of the balance of interests between gender equality and the freedom of religion in access to leading spiritual offices, ReligionsRecht im Dialog 25 (bzw. Law and Religion 25) Wien 2017.

36 Art. The Concept and Components of Culture, in: The New Encyclopaedia Britannica, Macropaedia Knowledge in Depth 16, ed. by Jacob E. Safra, 15. Aufl., Chicago 2007, S. 874-893, hier: S. 881; vgl. „Sag mir, wo die Mädchen sind?", Kreuz und quer-Beitrag in 3sat am 6. Mai 2014: In Indien fehlen etwa 50 Millionen Frauen und Mädchen, weil man sie nicht leben oder gar nicht zur Welt kommen lässt. Der Film ,Kajarya' von Madhureeta Anand bringt dieses schwierige Thema zur Sprache.

37 Amartya Sen, Die Idee der Gerechtigkeit, aus dem Englischen übersetzt von Christa Krüger, München 2010, S. 195.

38 Vgl. Buser, Diskriminierung; Dies. u. a. (Hg.), Gleichstellung der Geschlechter und die Kirchen. Ein Beitrag zur menschenrechtlichen und ökumenischen Diskussion, Freiburger Veröffentlichungen zum Religionsrecht 3, Freiburg-Schweiz 1999; Stella Ahlers, Gleichstellung der Frau in Staat und Kirche. Ein problematisches Spannungsverhältnis, ReligionsRecht im Dialog 2, Diss. Luzern 2005.

39 Als weiterführenden Beleg für gruppeninterne Diskriminierung vgl. die Arte Reportage „Indiens verlorene Töchter“ (2015), vgl. https://www.youtube.com/watch?v=77qJwcGdy94 (letzter Zugriff: 16.07.2018), die sehr anschaulich die lebenslange Diskriminierung zeigt und eine klare Verbindung zur Machtfrage herstellt. 
sozialen Zwängen und eigentlicher Unterdrückung ausgeliefert werden. ${ }^{40}$ Der Staat darf nicht neutral bleiben, weil vormoderne, althergebrachte Privilegien und Diskriminierungen sonst nicht beseitigt werden können. So habe der Staat auch in der privaten Sphäre zu intervenieren, wenn er die Grundrechte wirklich umsetzen wolle. ${ }^{41}$ In diesem Zusammenhang ist hinsichtlich der tatsächlichen Durchsetzung des Gleichstellungsauftrags eine Analyse der Rolle der Gerichte ${ }^{42}$ anzuregen. Auf die Religionsfreiheit bezogen heißt das, dass in den Religionsgemeinschaften die korporative Religionsfreiheit Grundrechte wie die Gleichstellung der Geschlechter außer Kraft setzt oder doch stark reduziert. ${ }^{43}$

Um die privaten Angelegenheiten des Ehepaares nicht beurteilen zu müssen, hat der Staat über Jahrhunderte bei der Thematik der Vergewaltigung in der Ehe Zurückhaltung geübt. Dieses Verhalten des Staates bedeutete faktisch eine Parteinahme für den Vergewaltiger in der Ehe. In Zukunft werden staatliche Organe auch bei Vergewaltigung und Diskriminierungen in den Religionsgemeinschaften nicht mehr wegschauen können. Die sexuellen Übergriffe in den Kirchen und Religionsgemeinschaften durch Religionsdiener, die klar auch eine Form von Machtmissbrauch sind, haben dies mit aller Deutlichkeit gezeigt. So wird z. B. bereits verstärkt der völkerrechtliche Rechtsschutz, insbesondere die Kinderrechtskonvention von 1989 der Vereinten Nationen, bei der Beaufsichtigung der religiösen oder weltanschaulichen Privatschulen durch staatliche Stellen herangezogen. ${ }^{44}$

40 Die Abtreibung qua Geschlecht ist z. B. in Indien seit 1996 ausdrücklich verboten und werdenden Eltern darf das Geschlecht offiziell nicht mitgeteilt werden, vgl. https://www.nzz.ch/ panorama/abtreibung-weiblicher-foeten-indien-hat-zu-wenig-maedchen-und-kuenftigzu-wenig-frauen-ld.131607 (letzter Zugriff: 01.04.2019). Die Rechtsdurchsetzung funktioniert aber trotz des vorhandenen Gesetzes nicht.

41 Vgl. Susan Moller Okin, Justice, Gender and Family, New York 1989, S. 116f.

42 Vgl. Ute Sacksofsky, Die Gleichberechtigung von Mann und Frau - besser aufgehoben beim Europäischen Gerichtshof oder beim Bundesverfassungsgericht, in: Charlotte Gaitanides (Hg.), Europa und seine Verfassung. Festschrift für Manfred Zuleeg zum 70. Geburtstag, Baden-Baden, 2005, S. 323-340; vgl. auch Konrad Sahlfeld, Aspekte der Religionsfreiheit im Lichte der Rechtsprechung der EMRK-Organe, des UNO-Menschenrechtsausschusses und nationaler Gerichte, Luzerner Beiträge zur Rechtswissenschaft 3, Zürich 2004.

43 Es ist mit keinem Wort gesagt, „dass etwa ein Gleichstellungsgesetz und, viel wichtiger, die verfassungsrechtlich geschützte Gleichstellung von Mann und Frau automatisch auf eine öffentlich-rechtlich verfasste Kirche keine Anwendung finden sollte. Eine gerichtliche Klärung dieser Frage erschiene wünschenswert.“ [Sahlfeld, Aspekte, S. 187f.]. Felix Hafner / Denise Buser, Frauenordination via Gleichstellungsgesetz? Die Anwendbarkeit des Gleichstellungsgesetzes auf die Dienstverhältnisse in der römisch-katholischen Kirche, in: Aktuelle juristische Praxis 10/1996, S. 1207-1214, hier: S. 1207.

$44 \mathrm{Vgl}$. dazu die sehr umfangreichen irischen Untersuchungsberichte: Commission to Inquire into Child Abuse, Report, Vols. I-V, Government Publications, Dublin 2009 (Ryan); Commission of Investigation, Report into the Catholic Archdiocese of Dublin, July 2009, Government Publications, Dublin 2009 (Murphy); Commission of Investigation, Report into the Catholic Diocese of Cloyne, Government Publications, Dublin 2010 (Cloyne); vgl. auch 


\subsection{Liberale Ansätze}

Was soll Vorrang haben, der Schutz der Gruppenautonomie oder der Schutz der Entscheidungsfreiheit der Mitglieder? Dies war schon eine Streitfrage beim Verständnis von Glaubens- und Gewissensfreiheit in der Bundesverfassung von 1874. ${ }^{45}$ Will Kymlicka nimmt die kommunitaristische Kritik am Liberalismus auf und verbindet deshalb individuelle Autonomie mit dem Schutz kultureller Gruppenidentität. Das Verständnis der Erzählungen der eigenen Kultur und Religion (Schriftstudium) bildet eine Vorbedingung dafür, dass wir sinnvolle Entscheidungen über unsere Lebensführung treffen können. Kulturen sind aber nicht schon an sich wertvoll, sondern sie erlangen ihren besonderen Wert deshalb, weil Menschen erst über kulturelle Erfahrungen Zugang zu verschiedenen Optionen haben. Deshalb sind im Interesse individueller Autonomie Kulturen zu schützen. Kymlicka ${ }^{46}$ unterscheidet dabei zwischen berechtigten und unberechtigten korporativen Rechten. Mit ersteren kann sich eine religiöse oder weltanschauliche Organisation nach außen hin, gegen Pressionen ihres gesellschaftlichen Umfeldes, wehren. Problematisch wird es, wenn mittels korporativer Rechte im Inneren einer Religionsgemeinschaft eine Veränderung des gewohnten Religionslebens von Seiten der diskriminierenden Religionsmitglieder verhindert wird.

\section{Lösungsansätze}

Nach diesen drei Sichtweisen auf die inneren Religionskonflikte einer grundrechtlich organisierten Gesellschaft werden im Folgenden Lösungsansätze vorgestellt, die sich an den Grundrechtskatalogen der Verfassung orientieren.

den im Internet verfügbaren Film „submission“ von Theo van Gogh über das Thema im Islam. Das Thema harrt der Bearbeitung durch Mitglieder der jeweiligen Religionsgemeinschaften.

45 Die individualistische Konzeption der religiösen Freiheitsrechte zeigt sich bereits in den Materialien zur Entstehung dieses Artikels; vgl. Pius Hafner, Staat und Kirche im Kanton Luzern. Historische und rechtliche Grundlagen, Freiburg (Schweiz) 1991, S. 200 Anm. 95. 46 Vgl. Will Kymlicka, Multicultural Citizenship, Oxford 1995, S. 38. 


\subsection{Gruppenrechte als derivate Rechte ${ }^{47}$}

In der Anerkennung von fest gefügten kulturellen Gruppenrechten sehen verschiedene Autoren (Reese Schäfer, Steven Rockefeller, Jürgen Habermas) eine Gefahr für die Demokratie. ${ }^{48}$ Gefährlich für die Demokratie erscheint vor allem die Anerkennung von Gruppen mit stark fundamentalistischen Tendenzen. ${ }^{49}$ In ihrer Ausübung sind die Gruppenrechte der liberalen Intuition zufolge nur dann legitim, „wenn diese sich als derivate Rechte - im Sinne einer Ableitung aus den kulturellen Rechten der einzelnen Gruppenmitglieder - verstehen lassen “50.

In pluralistischen Gesellschaften können religiöse Gruppen ihr Erbe nur durch die Zustimmung der Mitglieder von einer Generation an die nächste weitergeben. Das Überleben von Religionsgemeinschaften kann nicht durch die Gewährung korporativer Rechte von Staats wegen garantiert werden. Eine religiöse Überlieferung muss sich so darstellen können, dass auch Mitglieder in einer grundrechtlich geschützten Gesellschaft davon überzeugt werden, dass es sich lohnt, diese Tradition weiterzuführen. Kann mit dem Selbstbestimmungsrecht im Rahmen der Religionsfreiheit das Nicht-Inkulturieren in eine Menschenrechtskultur geschützt werden? Anders gefragt: Darf der religiös neutrale Staat Weltanschauungsgemeinschaften und Religionsgemeinschaften vor den Veränderungswünschen ihrer eigenen diskriminierten Mitglieder schützen?

Ich fasse thesenartig zusammen: Für Kommunitaristen und für einige Gerichte scheint es lediglich die Alternative zwischen der Religionsfreiheit oder der Gleichstellung der Geschlechter zu geben. Wer dagegen die Religionsfreiheit und die Gleichstellung der Geschlechter zusammen denken will, betritt schwieriges Terrain. Arbeiten zum Thema „Gleichstellung der Geschlechter und Religionsfreiheit" bleiben Forschungsdesiderate.

47 Man könnte diesen Ansatz der derivaten Rechte weitgehend auch durch die klare Unterscheidung von kollektiven und korporativen Grundrechten einbringen. Die kollektiven Rechte sind Individualrechte, die nur im Verbund wahrgenommen werden können (z. B. das Recht auf Versammlung, Demonstration, Streik oder religiöse Betätigung „in Gemeinschaft mit anderen“, z.B. Art. 15 Abs. 2 BV); es sind aber nicht Rechte einer Körperschaft (eines Vereins, einer Partei, Gewerkschaft oder Kirche), sondern eben der einzelnen Personen.

48 Die Demokratie fordert ,alle Kulturen dazu auf, von jenen intellektuellen und moralischen Werten abzulassen, die sich mit den Ideen von Freiheit, Gleichheit und beharrlicher kooperativ-experimenteller Suche nach Wahrheit und Wohlergehen nicht vertragen." Steven Rockefeller, Kommentar, in: Taylor, Multikulturalismus, S. 95-108, hier: S. 101.

49 Sie lassen keinen Spielraum offen, „in dem eine Partei ohne Preisgabe des eigenen Geltungsanspruchs die anderen Parteien als Mitstreiter um authentische Wahrheiten anerkennen kann“. Jürgen Habermas, Anerkennungskämpfe im demokratischen Rechtsstaat, in: Taylor, Multikulturalismus, S. 147-196, hier: S. 177.

50 Habermas, Kulturelle Gleichbehandlung, S. 387. 


\subsection{Verhältnis von Assimilation und Differenz}

Die verschiedenen Grundrechtsansätze geben unterschiedliche Antworten auf die Frage, inwieweit Religionsgemeinschaften auf der Basis grundrechtlicher Freiheit zu gestalten sind. Es kommt nicht nur im Bereich des Religionsverfassungsrechts darauf an, welche Grundrechtspolitik ein Staat verfolgt. Dürfen die Religionsgemeinschaften ihre eigenen kulturellen Traditionen und Werte unter Umständen in Abweichung von Verfassung und Gesetz leben? Wo ist der kulturellen Vielfalt das Prinzip der Rechtsgleichheit entgegenzuhalten? Damit ist ein normatives Grundproblem angesprochen: Die Frage nach dem richtigen Verhältnis von Assimilation und Differenz.

Assimilation meint dabei die Eingliederung von Minderheiten mit eigenen kulturellen Traditionen und Werten in die Mehrheitsgesellschaft im Sinne einer Angleichung der Werte und Verhaltensweisen an die Mehrheit. Von Differenz wird gesprochen, wo Menschen sich selbst von der Mehrheit kulturell abgrenzen oder aber von dieser als andersartig eingestuft und behandelt werden. Walter Kälin zufolge, lässt sich „die Spannung zwischen Assimilation und Differenz, bzw. zwischen Gleichheit und Freiheit in differenzierter Weise entschärfen [...] , wenn der Gedanke der Integration zum Ausgangspunkt genommen wird. “51

\subsubsection{Fünf Modelle der Grundrechtspolitik}

Das Grundrechtsverständnis staatlicher Gerichte und Behörden prägt das Zusammenleben der Religions- und Weltanschauungsgemeinschaften. Sie machen deutlich, dass grundrechtsbezogene Fragestellungen nicht allein juristisch determiniert sind. Die fünf Modelle, die im Folgenden skizziert werden, geben keine Patentrezepte für alle nur irgendwie denkbaren Situationen. Sie können aber „bekannte Fragestellungen aus einem anderen Blickwinkel betrachten und dabei neue Verständnishorizonte eröffnen “52. Es gilt verstehen zu lernen, auf welcher Grundrechtspolitik die eigene Analyse, die Analyse eines Gerichtes oder einer Behörde basiert.

1. Die Politik der Neutralität stellt im Sinne der weltanschaulichen Neutralität des Staates die formale Gleichbehandlung aller Menschen, ungeachtet von

51 Walter Kälin, Grundrechte in der Einwanderungsgesellschaft: Integration zwischen Assimilation und Multikulturalismus, in: Hans-Rudolf Wicker (u. a.) (Hg.), Migration und die Schweiz, Zürich 2003, S. 139-160, hier: S. 143. Der Begriff der Integration ist allerdings komplex und bedarf der Klärung.

52 Dieter Kraus, Rezension von: Walter Kälin, Grundrechte im Kulturkonflikt. Freiheit und Gleichheit in der Einwanderungsgesellschaft, Zürich 2000, in: SZKR 2002, Bern 2003, S. 207-209, hier: S. 207. 
Religion und kultureller Herkunft, in den Mittelpunkt. Der Staat darf sich mit keiner Religion identifizieren.

2. Die Politik des Schutzes der eigenen Identität strebt kulturelle Homogenität im Sinne der Mehrheit an. Die Minderheit hat sich mehr oder weniger anzupassen.

3. Die Politik des Minderheitenschutzes setzt den Akzent auf den Schutz ethnischer, religiöser oder sprachlicher Minderheiten und ihrer Lebensformen.

4. Die Politik der Anerkennung will im Sinne von Charles Taylor ${ }^{53}$ kulturelle Gruppierungen in ihrer Identität schützen, weil Missachtung ihrer Gruppenidentität auch Menschen verletzen und herabsetzen kann.

5. Die Politik des Multikulturalismus nimmt das Konzept „eine Nation, viele Völker, viele Kulturen“ zum Ausgangpunkt.

Kulturelle Autonomie und damit Differenz, welche durch den Schutz der grundrechtlich gewährleisteten Freiheiten aufrechterhalten wird, fördern die Modelle drei bis fünf. Es ist zu analysieren, welche Grundrechtspolitik in einem bestimmten Kanton bzw. Land zu einer bestimmten Zeit vorherrschend ist. Deutsche Gerichte argumentieren oft, „dass der Schutz der eigenen kulturellen Identität ein legitimes Anliegen sei, während das schweizerische Bundesgericht in der Regel den Grundsatz der religiösen Neutralität betont. [...] Wiederum anders ist der Ausgangspunkt des kanadischen Supreme Court, wenn er seine Entscheide mit dem Hinweis auf das multikulturelle Erbe Kanadas begründet. “ ${ }^{\text {"54 }}$ Das Verhältnis von Gleichheit und Freiheit, also von Assimilation und Differenz, lässt sich nach Walter Kälin nicht generell, sondern nur bereichsspezifisch bestimmen. Er unterscheidet deshalb mit Hanna Arendt drei Sphären ${ }^{55}$ :

1. In der staatlichen Sphäre treten Menschen in staatlicher Funktion auf oder sind als Private direkt der staatlichen Gewalt unterworfen. Die staatliche Sphäre ist also von so genannten Subordinationsverhältnissen geprägt. Deshalb will Kälin hier den Aspekt der weitestgehenden Gleichbehandlung dominieren lassen. Das Diskriminierungsverbot untersagt Gesetzgebern und Behörden, Minderheiten durch Ungleichbehandlung herabzusetzen. Formale Gleichbehandlung wirkt im Ergebnis allerdings dort diskriminierend, wo sie sich für Menschen marginalisierend auswirkt (indirekte Diskriminierung).

53 Vgl. Taylor, Multikulturalismus, S. 13f.: Er ist der Meinung, dass „unsere Identität teilweise von der Anerkennung oder Nichtanerkennung [...] durch die anderen geprägt [werde], so dass ein Mensch oder eine Gruppe von Menschen wirklich Schaden nehmen, [...] wenn die Umgebung oder die Gesellschaft ein einschränkendes, herabwürdigendes oder verächtliches Bild ihrer selbst zurückspiegelt. Nichtanerkennung oder Verkennung kann Leiden verursachen, kann eine Form von Unterdrückung sein."

54 Kälin, Grundrechte in der Einwanderungsgesellschaft, S. 141.

55 Vgl. Kälin, Grundrechte im Kulturkonflikt, S. 92. 
2. Die öffentliche Sphäre ist jener Bereich, der nicht mehr staatlich, aber auch nicht privat ist. In ihr spielen sich die meisten sozialen Aktionen ab, sodass hier ein Ausgleich zwischen Gleichheit und Differenz nötig ist. Hier kämpfen Menschen um Anerkennung, ökonomischen Gewinn und gesellschaftliche Macht. Der Staat tritt als Anbieter von Dienstleistungen auf (öffentliche Schulen und Spitäler) und reguliert Beziehungen von verschiedenen Kategorien von Privaten, wie z. B. durch das Religionsverfassungsrecht.

3. Die private Sphäre ist der Ort enger zwischenmenschlicher Beziehungen. Hier ist der Schutz von Werten wie Vertrauen oder Zuneigung bedeutsam, der durch die staatliche Anerkennung weitreichender Autonomie verwirklicht wird. Diese Sphäre ist daher durch Autonomie und Ausschluss charakterisiert. Der Staat hat diese Autonomie zu respektieren und darf nur dort eingreifen, wo die Grenzen dessen, was im Wege der Toleranz hingenommen werden muss, überschritten werden. Im privaten Bereich steht seine Rolle als Überwachungs- und Schutzorgan für Opfer privater Übergriffe im Vordergrund.

Diese drei Sphären stellen also verschiedene Kategorien der Beziehungen zwischen Privaten und staatlichen Behörden im liberalen Verfassungsstaat westlicher Prägung dar.

„Wendet man dieses analytische Raster auf die Gerichtspraxis an, ergeben die vielfältigen und unterschiedlichen Urteile zu interkulturellen Fragestellungen ein weit kohärenteres Bild als es auf den ersten Blick scheinen mag. Viele der Widersprüche lösen sich auf, weil unterschiedliche Resultate darin begründet sind, dass die konkreten Fälle nicht in der gleichen Sphäre angesiedelt sind. Gleichzeitig erlaubt diese Betrachtungsweise, den [...] Grundrechtspolitiken ihren jeweils richtigen Ort zuzuweisen. ${ }^{c 56}$

\subsubsection{Das Grundrecht der Religionsfreiheit}

Im direkt-demokratischen Rechtsstaat der Schweiz haben sich die Bürger und Bürgerinnen die Rechtsnormen selbst gegeben. Die Bundesverfassung garantiert die Religionsfreiheit des Individuums (Art.15 BV), das über seinen Glauben und seine Ausdrucksform entscheiden kann. Religion ist damit kein theokratisches Gefängnis, aus dem man nicht entweichen kann, sondern Religions- und Weltanschauungsgemeinschaften sind offene und freie Gemeinschaften, aus denen man de iure jederzeit austreten kann. Dies wird ausdrücklich von Staats wegen garantiert. $\mathrm{Ob}$ es de facto auch durchgesetzt werden kann, ist, wie oben angesprochen, eine ganz andere Frage.

Rechtsstaatliche Normen können von Religionsgemeinschaften nicht abgelehnt werden. Dennoch sehen einige Religionsgemeinschaften keinen Religionsaustritt vor. Damit stoßen ein staatliches und ein religiöses Normensystem

56 Kälin, Grundrechte in der Einwanderungsgesellschaft, S. 152. 
aufeinander. ${ }^{57}$ Es ist eine Lösung zu erarbeiten. Denn Religionsfreiheit ist im Kontext der Grundrechte ${ }^{58} \mathrm{zu}$ verstehen, nicht aber als ein kollektives Sonderrecht, das einer Religionsgemeinschaft einen Sonderbereich erlaubt, in dem andere Grundrechte, wie z.B. die Gleichstellung der Geschlechter oder das Austrittsrecht, nicht beachtet werden müssen. Die Religionsfreiheit ist nur im Kontext der anderen Grundrechte des säkularen Rechtsstaates zu denken. Der Rechtsstaat muss religiös neutral sein, damit keine Religions- und Weltanschauungsgemeinschaft bevorzugt wird, wie das im religiösen Rechtsstaat der Fall ist. Deshalb ist dieser säkulare Rechtsstaat als Grundlage für eine Friedensordnung einer pluralistischen Gesellschaft primär von allen Religions- und Weltanschauungsgemeinschaften anzuerkennen.

Aus dem Grundrecht der Religionsfreiheit wird die religiöse und weltanschauliche Neutralität des Staates abgleitet. In einem einschlägigen Bundesgerichtsurteil heißt es:

„Die Glaubens-, Gewissens- und Kultusfreiheit verpflichtet die staatlichen Organe zu religiöser Neutralität. [...] Das Neutralitätsgebot hat nicht den Sinn, das religiöse oder weltanschauliche Moment aus der Staatstätigkeit völlig auszuschliessen. Es verlangt vielmehr die unparteiische, gleichmässige Berücksichtigung der in einer pluralistischen Gesellschaft auftretenden religiösen und weltanschaulichen Überzeugungen. Der Staat soll sich bei öffentlichen Handlungen konfessioneller oder religiöser Erwägungen enthalten, welche geneigt wären, die Freiheit der Bürger in einer pluralistischen Gesellschaft zu verletzen. ${ }^{\text {59 }}$

Aus der Religionsfreiheit (Art. 15 BV), aber auch aus dem Gleichstellungsgebot (Art. 8 BV) ergibt sich hinsichtlich der verschiedenen Religionsgemeinschaften ein Paritätsgebot, d.h. Ungleichbehandlungen bestimmter Religionsgemeinschaften sind ausgeschlossen, wenn nicht rechtfertigende sachliche Unterschiede oder Gründe ${ }^{60}$ vorliegen.

Das Gebot der Toleranz, das ebenfalls aus der Religionsfreiheit abgeleitet wird, verlangt als objektiver Verfassungsgrundsatz „Achtung vor der Würde, der Persönlichkeit und den abweichenden Glaubensansichten und Gewissensentscheidungen anderer und damit Mässigung eigener exzessiver Forderungen und

57 Vgl. Christian Jäggi, Doppelte Normativitäten zwischen staatlichen und religiösen Geltungsansprüchen. Am Beispiel der katholischen Kirche, der muslimischen Gemeinschaften und der Bahá'i-Gemeinde in der Schweiz, Münster 2016.

58 Vgl. Loretan, Religionsfreiheit im Kontext der Grundrechte; Ders., Wahrheitsansprüche im Kontext der Freiheitsrechte.

59 BGE 118 Ia 46 (infoSekta), S. 58.

60 Z.B. kann eine Religionsgemeinschaft ohne Mitgliederstruktur solange nicht öffentlich-rechtlich anerkannt werden bis klar ist, wer besteuert wird und wer wann seine Mitgliedschaft durch einen Religionsaustritt gekündigt hat. 
Ansprüche auf Verwirklichung glaubensmässiger Vorstellungen. ${ }^{\text {“61 }}$ Das Toleranzgebot will damit die Bewährung eines offenen und auf gegenseitiger Achtung beruhenden Zusammenlebens fördern.

Die Einsicht, dass die Anerkennung von Grundrechten „von wesentlicher Bedeutung für die politische Integration von Gesellschaften ist, gilt daher auch für die Religionsfreiheit als Individualrech $t^{62}$ und zwar sowohl was ihre negative als auch was ihre positive Seite betrifft. ${ }^{(63}$ Sahlfeld hat hier Gerichtsfälle analysiert und gezeigt, dass bisher dem Grundrecht der Religionsfreiheit eine integrierende Funktion durch die Gerichte zukommt. ${ }^{64}$

\section{4. $\quad$ Fazit}

Religiöser Pluralismus und kulturelle Vielfalt können zu Spannungen führen, die von den Beteiligten an kulturellen Kategorien wie Religion, Sprache und ethnischer Herkunft festgemacht werden können. Die Grundrechte bilden einen Rahmen, innerhalb dessen solche Konflikte heute immer häufiger vor Gericht ausgetragen werden. Die Gerichte suchen den Ausgleich zwischen den oft gegensätzlichen, aber gleichberechtigten Anliegen der Gleichheit und der Differenz. Sie verlangen von der eingesessenen Mehrheit und der zugewanderten Minderheit einander ein Stück entgegenzugehen, ohne die jeweils eigenen Traditionen und Identitäten aufgeben zu müssen.

Was hält dann pluralistische Gesellschaften noch zusammen? Nicht Religion oder Zivilreligion wie bisher, sondern das Recht ist für die Integration moderner Gesellschaften von eminenter Bedeutung. ${ }^{65}{ }_{\text {}}$ Mag der moderne Staat entstanden

61 Ueli Friederich, Kirchen und Glaubensgemeinschaften im pluralistischen Staat. Zur Bedeutung der Religionsfreiheit im schweizerischen Staatskirchenrecht, Bern 1993, S. $350 \mathrm{f}$.

$62 \mathrm{Zu}$ Gunsten der korporativen Religionsfreiheit sei auf ein in der politischen Diskussion über das Verhältnis von Staat und Religionsgemeinschaft bislang wenig beachtetes Argument hingewiesen, das ebenfalls auf Grundrechte und politische Integration Bezug nimmt. Es besagt, dass die besondere Bedeutung der Religionsgemeinschaften für die Realisierung positiver Religionsfreiheit eine Förderung durch den Staat rechtfertigt.

63 Stefan Grotefeld, Politische Integration und rechtliche Anerkennung von Religionsgemeinschaften. Überlegungen aus sozialethischer Sicht, in: Schweizerisches Jahrbuch für Kirchenrecht 1999, Bern 2000, S. 107-143, hier: S. 135.

64 Vgl. Sahlfeld, Aspekte.

65 Mit dieser These analysiert der Soziologe Jens Jetzkowitz die Gerichtsurteile des deutschen Bundesverfassungsgerichts zu Fragen der Religion und durchleuchtet so die Inklusionsmechanismen des deutschen Rechtssystems, um auf diese Weise Aussagen über die Integrationskapazität der deutschen Gesellschaft zu treffen. Vgl. Jens Jetzkowitz, Recht und Religion in der modernen Gesellschaft. Soziologische Theorie und Analyse am Beispiel der Rechtsprechung des Bundesverfassungsgerichts in Sachen „Religion“ zwischen den Jahren 1983 und 1997, Marburger Beiträge zur Sozialwissenschaftlichen Forschung 11, Münster 2000. 
sein, als sich das weltliche Recht von seiner religiösen Determiniertheit zu lösen begann, so wird er doch auf Dauer nicht fortbestehen können, wenn er aufhört, Religion zur Kenntnis zu nehmen und sich weigern sollte, ihr Raum zu gewähren. ${ }^{\text {“66 }}$ Der Rechtsstaat wird Grundrechtsverletzungen auch innerhalb der Religionsgemeinschaften in Zukunft nicht übergehen können. Daher ist es von entscheidender Bedeutung, dass auch Religionsgemeinschaften nach innen in menschenrechtlichen Kategorien zu denken beginnen. Diese religionsverfassungsrechtlichen Defizite sind wissenschaftlich aufzuarbeiten. Die Rechtswissenschaften werden im interdisziplinären Austausch mit Theologie ${ }^{67}$, Religionswissenschaften und Islamwissenschaften entsprechende Grundlagenforschung zu leisten haben.

\section{Quellen}

Ahlers, Stella, Gleichstellung der Frau in Staat und Kirche. Ein problematisches Spannungsverhältnis, ReligionsRecht im Dialog 2, Diss. Luzern 2005.

Baumeister, Martin / Böhnke, Michael / Heimbach-Steins, Marianne / Wendel, Saskia (Hg.), Menschenrechte in der katholischen Kirche. Historische, systematische und praktische Perspektiven, Gesellschaft - Ethik - Religion 12, Paderborn 2018.

Bracher, Katharina, Gutachten stützt Forderung nach islamischer Landeskirche. Öffentlichrechtliche Anerkennung, in: NZZ am Sonntag 1 am 05.01.2004, S. 6.

Buser, Denise, Unholy Discrimination. An overview of the legal rules governing the consideration of the balance of interests between gender equality and the freedom of religion in access to leading spiritual offices, ReligionsRecht im Dialog 25 (bzw. Law and Religion 25), Wien 2017.

Buser, Denise, Die unheilige Diskriminierung. Eine juristische Auslegeordnung für die Interessenabwägung zwischen Geschlechtergleichstellung und Religionsfreiheit beim Zugang zu religiösen Leitungsämtern, ReligionsRecht im Dialog 16, Wien-Münster 2014.

Buser, Denise / Loretan, Adrian (u. a.) (Hg.), Gleichstellung der Geschlechter und die Kirchen. Ein Beitrag zur menschenrechtlichen und ökumenischen Diskussion, Freiburger Veröffentlichungen zum Religionsrecht 3, Freiburg (Schweiz) 1999.

66 Dieter Kraus, Schweizerisches und europäisches Religionsrecht im Dialog, in: Schweizerisches Jahrbuch für Kirchenrecht 2002, Bern 2003, S. 11-38, hier: S. 38.

67 Vgl. z. B. Martin Baumeister / Michael Böhnke / Marianne Heimbach-Steins / Saskia Wendel (Hg.), Menschenrechte in der katholischen Kirche. Historische, systematische und praktische Perspektiven, Gesellschaft - Ethik - Religion 12, Paderborn 2018; Marianne HeimbachSteins (Hg.), Menschenrechte in der katholischen Kirche, Jahrbuch für christliche Sozialwissenschaften 55, Münster 2014. Gerne erinnere ich mich an das Korreferat von Frau Prof. Dr. Gabriel in Rom und die anschliessende Diskussion, sowie an die lebhaften Frühstücksgespräche bei den Sozialethischen Kongressen mit der Frühaufsteherin Gabriel in Innsbruck, Münster und Rom. 
Commission to Inquire into Child Abuse, Report, Vols. I-V, Government Publications, Dublin 2009 (Ryan).

Commission of Investigation, Report into the Catholic Diocese of Cloyne, Government Publications, Dublin 2010 (Cloyne).

Commission of Investigation, Report into the Catholic Archdiocese of Dublin, July 2009, Government Publications, Dublin 2009 (Murphy).

Engi, Lorenz, Die religiöse und ethische Neutralität des Staates, Theoretischer Hintergrund, dogmatischer Gehalt und praktische Bedeutung eines Grundsatzes des schweizerischen Staatsrechts, Zürich 2017.

Feiner, Shmuel, Moses Mendelssohn. Ein jüdischer Denker in der Zeit der Aufklärung, aus dem Hebräischen übersetzt von Inge Yassur, Göttingen 2009.

Friederich, Ueli, Kirchen und Glaubensgemeinschaften im pluralistischen Staat. Zur Bedeutung der Religionsfreiheit im schweizerischen Staatskirchenrecht, Bern 1993.

Gässlein, Ann-Katrin, Der Abfall vom Glauben nach der Interpretation reformorientierter islamischer Theologie (unveröff. schriftliche Arbeit zum Hauptseminar „Religious Life Style and Law" 2013).

Grotefeld, Stefan, Politische Integration und rechtliche Anerkennung von Religionsgemeinschaften. Überlegungen aus sozialethischer Sicht, in: Schweizerisches Jahrbuch für Kirchenrecht 1999, Bern 2000, S. 107-143.

Habermas, Jürgen, Kulturelle Gleichbehandlung - und die Grenzen des postmodernen Liberalismus, in: Deutsche Zeitschrift für Philosophie 51/2003, S. 367-394.

Habermas, Jürgen, Anerkennungskämpfe im demokratischen Rechtsstaat, in: Taylor, Multikulturalismus und die Politik der Anerkennung, Frankfurt a.M. 1993, S. 147-196.

Hafner, Felix / Buser, Denise, Frauenordination via Gleichstellungsgesetz? Die Anwendbarkeit des Gleichstellungsgesetzes auf die Dienstverhältnisse in der römisch-katholischen Kirche, in: Aktuelle juristische Praxis 10/1996, S. 1207-1214.

Hafner, Pius, Staat und Kirche im Kanton Luzern. Historische und rechtliche Grundlagen, Freiburg (Schweiz) 1991.

Heimbach-Steins, Marianne (Hg.), Menschenrechte in der katholischen Kirche, Jahrbuch für christliche Sozialwissenschaften 55, Münster 2014.

Jäggi, Christian, Doppelte Normativitäten zwischen staatlichen und religiösen Geltungsansprüchen. Am Beispiel der katholischen Kirche, der muslimischen Gemeinschaften und der Bahá'i-Gemeinde in der Schweiz, Münster 2016.

Jetzkowitz, Jens, Recht und Religion in der modernen Gesellschaft. Soziologische Theorie und Analyse am Beispiel der Rechtsprechung des Bundesverfassungsgerichts in Sachen „Religion“ zwischen den Jahren 1983 und 1997, Marburger Beiträge zur Sozialwissenschaftlichen Forschung 11, Münster 2000.

Kälin, Walter, Grundrechte in der Einwanderungsgesellschaft: Integration zwischen Assimilation und Multikulturalismus, in: Hans-Rudolf Wicker / Rosita Fibbi / Werner Haug (Hg.), Migration und die Schweiz, Zürich 2003, S. 139-160.

Kälin, Walter, Grundrechte im Kulturkonflikt. Freiheit und Gleichheit in der Einwanderungsgesellschaft, Zürich 2000.

Kirchschläger, Peter G. (Hg.), Die Verantwortung von nichtstaatlichen Akteuren gegenüber den Menschenrechten, Religionsrechtlichen Studien 4, Zürich 2017.

Kraus, Dieter, Schweizerisches und europäisches Religionsrecht im Dialog, in: Schweizerisches Jahrbuch für Kirchenrecht 2002, Bern 2003, S. 11-38. 
Kraus, Dieter, Rezension von: Walter Kälin, Grundrechte im Kulturkonflikt. Freiheit und Gleichheit in der Einwanderungsgesellschaft, Zürich 2000, in: SZKR 2002, Bern 2003, S. 207-209.

Krüger, Hanfried / Müller-Römheld, Walter (Hg.), Bericht aus Nairobi 1975. Ergebnisse Erlebnisse - Ereignisse. Offizieller Bericht aus der Fünften Vollversammlung des Ökumenischen Rates der Kirchen, 23.11-10.12.1975 in Nairobi (Kenia)-Frankfurt a. M. 1976.

Kymlicka, Will, Multicultural Citizenship, Oxford 1995.

Loretan, Adrian, Wahrheitsansprüche im Kontext der Freiheitsrechte, Religionsrechtliche Studien 3, Zürich 2017.

Loretan, Adrian / Weber, Quirin / Morawa, Alexander H.E., Freiheit und Religion. Die Anerkennung weiterer Religionsgemeinschaften in der Schweiz, ReligionsRecht im Dialog 17, Münster 2014.

Loretan, Adrian (Hg.), Religionsfreiheit im Kontext der Grundrechte, Religionsrechtliche Studien 2, Zürich 2011.

Loretan, Adrian, Religionsfreiheit und Gleichstellung aus religionsrechtlicher und rechtsphilosophischer Sicht, in: Ders., Religionen im Kontext der Menschenrechte, Religionsrechtliche Studien 1, Zürich 2010, S. 111-134.

Maclure, Jocelyn / Taylor, Charles, Laizität und Gewissensfreiheit, Berlin 2011 (Titel der Originalausgabe Laïcité et liberté, Editions de Boréal 2010).

Manea, Elham, Der allägliche Islamismus. Terror beginnt, wo wir ihn zulassen, aus dem Englischen übersetzt von Elsbeth Ranke und Claudia Van den Block, München 2018.

Manea, Elham, Women and Shari'a Law: The Impact of Legal Pluralism in the UK, London 2016.

Manea, Elham, Ich will nicht schweigen. Der Islam, der Westen und die Menschenrechte, Freiburg i. Br. 2009.

Mendelssohn, Moses, Jerusalem oder über die religiöse Macht und Judentum, Philosophische Bibliothek 565, Hamburg 2005.

Moller Okin, Susan, Justice, Gender and Family, New York 1989.

Rawls, John, Politischer Liberalismus, Frankfurt 2003 (Titel der Originalausgabe: Political Liberalism, Colombia University Press, New York 1993).

Rockefeller, Steven, Kommentar, in: Taylor, Multikulturalismus und die Politik der Anerkennung, Frankfurt a.M. 1993, S. 95-108.

Sacksofsky, Ute, Die Gleichberechtigung von Mann und Frau - besser aufgehoben beim Europäischen Gerichtshof oder beim Bundesverfassungsgericht, in: Charlotte Gaitanides (Hg.), Europa und seine Verfassung. Festschrift für Manfred Zuleeg zum 70. Geburtstag, Baden-Baden 2005, S. 323-340.

Sahlfeld, Konrad, Aspekte der Religionsfreiheit im Lichte der Rechtsprechung der EMRK-Organe, des UNO-Menschenrechtsausschusses und nationaler Gerichte, Luzerner Beiträge zur Rechtswissenschaft 3, Zürich 2004.

Sen, Amartya, Die Idee der Gerechtigkeit, aus dem Englischen übersetzt von Christa Krüger, München 2010 (Titel der Originalausgabe: The Idea of Justice, Penguin Books 2009).

Stauffer, Beat, Kräftemessen oder Kollusion? Das undurchsichtige Verhältnis zwischen gemässigten und radikalen Islamisten in Tunesien, in: Neue Zürcher Zeitung 166 am 19.07.2012, S. 41. 
Stüssi, Marcel, Models of Religious Freedom. Switzerland, The United States, and Syria by Analytical, Methodological, and Eclectic Representation, ReligionsRecht im Dialog 12, Münster 2011.

Taylor, Charles, Multikulturalismus und die Politik der Anerkennung, Frankfurt a.M. 1993. Walzer, Michael, On Toleration, New Haven-London 1997.

Weiters:

Von der Religion abfallen, Radio SRF 2 Kultur, Sendung Kontext, 12.02.2018.mp3, vgl. https://www.srf.ch/sendungen/kontext/von-der-religion-abfallen (letzter Zugriff: 01.04. 2019).

Im Netz der Salafisten, ARD Fernsehsendung am 16.07.2012.

Art. The Concept and Components of Culture, in: The New Encyclopaedia Britannica, Macropaedia Knowledge in Depth 16, ed. by Jacob E. Safra, 15. Aufl., Chicago 2007, S. 874-893.

„Sag mir, wo die Mädchen sind?“, Kreuz und quer-Beitrag in 3sat am 06.05.2014.

Arte Reportage „Indiens verlorene Töchter“ (2015), online unter: https://www.youtube. com/watch?v=77qJwcGdy94 (letzter Zugriff: 16.07.2018).

Indien hat zu wenig Mädchen - und künftig zu wenig Frauen, in: Neue Zürcher Zeitung am 30.11.2016, vgl. https://www.nzz.ch/panorama/abtreibung-weiblicher-foeten-indienhat-zu-wenig-maedchen-und-kuenftig-zu-wenig-frauen-ld.131607 (letzter Zugriff: 01.04.2019). 


\section{Orthodoxe Theologie und politische Philosophie: Postsäkularität in Russland}

Die Stellung der Religion im säkularen öffentlichen Raum und die Gültigkeit religiöser Argumente unter Bedingungen der politischen Moderne sind wichtige Themen der politischen Philosophie. ${ }^{1}$ Umfassende Visionen des "guten Lebens“, wie sie von religiösen Traditionen aufrechterhalten werden, stehen unweigerlich im Konflikt mit den „dünnen“, säkularen und prozeduralen Vorstellungen dessen, was eine pluralistische politische Gemeinschaft zusammenhält. Das orthodoxe Christentum, wie jede andere religiöse Tradition, ist herausgefordert, sein Verhältnis zur politischen Moderne zu definieren. ${ }^{2}$ Für den größten Teil der modernen Geschichte verlief diese Definitionsarbeit in der religiös-säkularen Beziehung als Einbahnstraße: Es waren die religiösen Traditionen, die sich mit der Säkularisierung als sozialem Prozess und mit dem Säkularismus als zunehmend vorherrschender Weltsicht auseinandersetzen mussten. Im zwanzigsten Jahrhundert bedeutete dies für die Kirchen im kommunistischen Osteuropa eine regelrechte Unterdrückung; in der westlichen Welt herrschte zwar mehr Freiheit, doch konnten Kirchen und Religionsgemeinschaften die säkulare Weltordnung entweder insgesamt ablehnen - in diesem Fall betrachtete sie die säkulare Seite als "fundamentalistisch“ - oder sie konnten versuchen, sich mit der säkularen Ordnung zu arrangieren - in diesem Fall wurden sie als „modernisierend" angesehen. ${ }^{3}$

Welchen Weg auch immer die Kirchen und religiösen Gemeinschaften wählten, es blieb ein einseitiger Schritt; es ging um die Auseinandersetzung der

1 Eine längere Version dieses Aufsatzes in englischer Sprache, verfasst gemeinsam mit Dmitry Uzlaner, ist hier erschienen: Kristina Stoeckl / Dmitry Uzlaner, The Russian Postsecular, in: Christoph Schneider (ed.), Theology and Philosophy in Eastern Orthodoxy: Essays on Orthodox Christianity and Contemporary Thought, Eugene, OR 2019, S. 32-52. Der gekürzte Abdruck erfolgt mit Genehmigung des Co-Autors.

2 Kristina Stoeckl / Ingeborg Gabriel / Aristotle Papanikolaou (Hg.), Political Theologies in Orthodox Christianity, London-New York 2017.

3 Kristina Stoeckl, Modernity and Political Theologies, in: Stoeckl / Gabriel / Papanikolaou (Hg.), Political Theologies, S. 15-24. 
Religion mit der politischen Moderne. In den letzten Jahren hat dieses Einbahnstraßenmodell der religiös-säkularen Beziehung jedoch an Überzeugungskraft verloren und ist einem Modell gewichen, welches das Verhältnis zwischen politischer Moderne und Religion auf eine reziproke Weise betrachtet. Zwei Faktoren waren ausschlaggebend für diese Verschiebung. Erstens die soziologische Beobachtung, dass die Religionen trotz aller Vorhersagen über ihren bevorstehenden Niedergang weiterhin eine wichtige Rolle in der modernen Welt spielen. ${ }^{4}$ Der zweite ist ein philosophischer und konzeptioneller Wandel, der die normative Gültigkeit und demokratische Legitimität des Säkularismus als Quintessenz der politischen Moderne in Frage stellt. ${ }^{5}$ Infolgedessen haben die heutigen Debatten über die säkular-religiösen Beziehungen den Charakter einer Einbahnstraße verloren und beginnen, einer zweispurigen Fahrbahn zu ähneln; es sind jetzt beide, die säkulare und die religiöse Seite, die gegen-und miteinander die Bedingungen ihres Zusammenlebens definieren. Der Begriff, der sowohl die soziologische als auch die normative Neuheit dieses Moments einfängt, ist Postsäkularität.

Das osteuropäische orthodoxe Christentum ist von dieser Situation stärker herausgefordert als die westlichen Kirchen: soziologisch, weil die orthodoxen Kirchen in Osteuropa im 20. Jahrhundert zuerst mit repressiven politischen Verhältnissen und danach mit rasantem gesellschaftlichen und politischen Wandel konfrontiert waren, während die westlichen Kirchen nach dem Ende des Zweiten Weltkriegs kontinuierlichen Wandel erlebten; und normativ, weil im Rahmen der politischen Transition nach dem Fall des Kommunismus Fragen nach staatskirchlichen Beziehungen und der Rolle der Religion in der Öffentlichkeit, im Westen weitgehend bereits gelöst, für die orthodoxen Kirchen neu beantwortet werden mussten.

In dieser Situation ist vor allem in Russland der Begriff der „postsäkularen Gesellschaft“ von Theologen und Philosophen aktiv rezipiert worden. Der russische postsäkulare philosophische und theologische Diskurs über Postsäkularität ist geprägt von dem Wunsch, einen Mittelweg zwischen Antimodernismus und Modernisierung zu definieren oder, getreu der Straßenmetapher, eine zweispurige Fahrbahn in einem Labyrinth von Einbahnstraßen anzulegen. Der russische postsäkulare Diskus ist jedoch nicht immun gegen ideologische Instrumentalisierung und wird immer wieder zur Rechtfertigung der in vielen Aspekten illiberalen und undemokratischen Hinwendung Russlands zu „traditionellen Werten“ verwendet.

4 José Casanova, Public Religions in the Modern World, Chicago 1994; Peter L. Berger (Hg.), The Desecularization of the World: Resurgent Religion and World Politics, Washington, D.C.Grand Rapids, Mich. 1999.

5 Veit Bader, Secularism or Democracy? Associational Governance of Religious Diversity, Amsterdam 2007. 


\section{Was ist Postsäkularität?}

Die wohl gängigste Definition von Postsäkularität im westlichen Wissenschaftsdiskurs ist diejenige von Jürgen Habermas. ${ }^{6}$ Diese ist fest im politischen Liberalismus von John Rawls verankert: ein ideologischer Säkularismus sei kein integraler Bestandteil des Liberalismus, liberale Demokratie sollte sich vielmehr durch „reflexiven“ Säkularismus auszeichnen. ${ }^{7}$ Der Säkularismus als politische Ideologie, so das Argument, diskriminiere religiöse Bürger. Grundsätzlich müsse es allen Bürgern freistehen, an politischen Debatten teilzunehmen, sofern sie bereit sind, über politische Normen in angemessener Weise und im Hinblick auf einen für alle gültigen Konsens zu beraten (der „überlappende Konsens“). Habermas selbst bezeichnet diese Art der Argumentation als „post-metaphysisch“, weil sie die Gültigkeit moralischer und politischer Prinzipien nicht durch den Verweis auf einen transzendenten Bezugspunkt, sondern durch einen immanenten Reflexionsprozess bestätigt. Die Bedingungen der Teilnahme am demokratischen Diskurs sind jedoch nicht gleichberechtigt, wenn der säkulare öffentliche Diskurs es religiösen Bürgern erschwert, ihre Argumente vorzubringen. Habermas antwortet auf dieses besondere Problem mit der Behauptung, dass nicht nur religiöse Bürger aufgefordert werden sollten, ihre Ansprüche in die Sprache des säkularen öffentlichen Diskurses zu übersetzen, sondern auch die nicht-religiösen Bürger aufgefordert seien, ihren Teil dazu beizutragen, nämlich ihre säkularistischen Bestrebungen zu reduzieren. Eine solche gegenseitige Übersetzungsarbeit könne zu dem führen, was er „den komplementären Lernprozess“ nennt. Habermas’ Konzepte der Übersetzung und des komplementären Lernens basieren auf der Idee, dass Religionen einen Modernisierungsprozess durchlaufen, um den Herausforderungen des religiösen Pluralismus, der modernen Wissenschaft, des positiven Rechts und der profanen Moral zu begegnen. Dieser Begriff der „Modernisierung des religiösen Bewusstseins“ wurde von einigen Kommentatoren einer säkularistischen und eurozentrischen Voreingenommenheit bezichtigt, die darin nur eine abgeschwächte Version des alten Einbahnstraßenmodells religiös-säkularer Bezie-

6 Jürgen Habermas, Dialogue. Jürgen Habermas and Charles Taylor, in: Judith Butler / Eduardo Mendieta / Jonathan Van Antwerpen (Hg.), The Power of Religion in the Public Sphere, Columbia 2011, S. 60-69; Michiel Leezenberg, How Ethnocentric Is the Concept of the Postsecular?, in: Arie L. Molendijk / Justin Beaumont / Christoph Jedan (Hg.), Exploring the Post-Secular. The Religious, the Political and the Urban, Leiden 2010, S. 91-112.

7 Craig Calhoun / Mark Juergensmeyer / Jonathan Van Antwerpen (Hg.), Rethinking Secularism, Oxford 2011; Alessandro Ferrara / Volker Kaul / David Rasmussen, Philosophy and Social Criticism. Special Issue: Postsecularism and Multicultural Jurisdictions 36/2010; Philip Gorski et al. (Hg.), The Post-Secular in Question. Religion in Contemporary Societies, New York 2012. 
hungen sehen, in dem religiöse Traditionen nur auf säkulare Entwicklungen und Ideen reagieren. ${ }^{8}$

Die Habermas'sche Version der Postsäkularität kann als die einflussreichste Definition bezeichnet werden. Aber neben dieser Definition von Habermas gibt es alternative Sichtweisen von Postsäkularität. Beispiele für diese alternativen Definitionen finden sich in Werken von John Caputo, insbesondere in seinem On religion, oder in John Milbanks Beyond secular reason und der von ihm initiierten Bewegung der „Radical Orthodoxy“. ${ }^{9}$ Diese nicht-habermasianischen Interpretationen von Postsäkularität zielen auf eine direkte Kritik und eine Neudeutung der westlichen Aufklärung ab. Sie interpretieren die Postsäkularität als einen wichtigen Wendepunkt in der Genealogie des modernen Denkens. Die Postsäkularität wird in dieser Hinsicht zu einem konstitutiven Element einer postmodernen Wendung, die ein Umdenken in Bezug auf die wichtigsten Grundsätze der Moderne markiert, wobei die Kritik der modernen Ablehnung der Religion der wichtigste Wendepunkt ist. Wenn man die Grundprinzipien der säkularen Moderne überdenke, behaupten sie, so müsse man auch die Unterscheidungen, die Habermas lieber intakt lassen würde, überdenken - also das Verhältnis von Glaube und Vernunft, Religion und Säkularität, Philosophie und Theologie. Die nicht-habermasianischen Interpretationen der Postsäkularität betrachten die Postsäkularität also nicht nur als ein Umdenken der antireligiösen Voreingenommenheit des modernen säkularen Denkens, sondern auch als Überdenken der säkularen Vernunft selbst, bis hin zur Erwägung der Möglichkeit, über die säkulare Moderne hinauszugehen und alternative Versionen davon zu entwickeln. Eine solche „starke”“ Version der Postsäkularität ist aus orthodoxer theologischer Sicht - die traditionell modernitätskritisch ist - durchaus attraktiv. Kein Wunder also, dass es diese nicht-habermasianischen Versionen der Postsäkularität waren, die im russischen philosophischen und theologischen Kontext zuallererst rezipiert und entwickelt wurden.

8 Z.B. Badredine Arfi, Habermas and the Aporia of Translating Religion in Democracy, in: European Journal of Social Theory 18/4/November 1/2015, S. 489-506; Maeve Cooke, Salvaging and Secularizing the Semantic Contents of Religion: The Limitations of Habermas's Postmetaphysical Proposal, in: International Journal for Philosophy of Religion 60/1/3/2006, S. 187-207.

9 John D. Caputo, On Religion, London-New York 2000; John Milbank / Catherine Pickstock / Graham Ward (Hg.), Radical Orthodoxy, London-New York 1999; John Milbank, Theology and Social Theory: Beyond Secular Reason, Holboken 1993. 


\section{Postsäkularität im russisch-orthodoxen Diskurs}

Der erste wissenschaftliche Artikel, der den Begriff „postsäkular“ systematisch ins Russische einführte, war der Aufsatz Ein Postsäkulares Zeitalter: Religion und Kultur heute von Alexander Kyrlezhev, veröffentlicht $2004 .^{10}$ Es dauerte danach noch ein paar Jahre, bis eine systematischere Rezeption einsetzte. Die Autoren, die den Begriff aktiv in die russische Debatte einführten, waren Theologen, Philosophen und Religionssoziologen. ${ }^{11}$ Die vorherrschende Verwendung des Begriffs war adjektivisch „postsäkular“ (postsekuliarnyi), wie in „postsäkularer Gesellschaft“, „postsäkularer Welt“ oder „postsäkularer Philosophie“, aber auch die Substantive „Postsäkularismus“ (postsekuliarizm) und „Postsäkularität“ (postsekuliarnost’) wurden verwendet. Die Popularität des Begriffs beruht auf zwei Faktoren: Erstens waren theologische und philosophische Debatten über Religion, Säkularismus, Moderne und Politik, wie fast alle anderen philosophischen Trends im Westen, neue Denkanstöße in einem postsowjetischen Kontext, der jahrzehntelang von den westlichen Geisteswissenschaften abgeschirmt gewesen war. Postsäkularität war also ein Thema der Zeit, das zu Recht aufgegriffen wurde. Zweitens hatte der Begriff Postsäkularität eine unmittelbare empirische und praktische Plausibilität angesichts der öffentlichen Rolle, welche die Russische Orthodoxe Kirche verstärkt im russischen Staat spielte.

Die russische Rezeption des Begriffs der Postsäkularität ist nicht-habermasianisch (aber nicht notwendig anti-habermasianisch); und zwar in dem Sinne, dass Ideen von Habermas eine untergeordnete Rolle bei der Konzeptualisierung von Postsäkularität spielen. Habermas' Begriff der postsäkularen Gesellschaft ist eher normativ als beschreibend, während die russische Interpretation der Postsäkularität eher beschreibender als normativ vorgeht. Die russische Rezeption interessierte sich nicht für Habermas’ „postmetaphysischen Postsäku-

10 Aleksandr Kyrlezhev (Александр Кырлежев), Постсекулярная Епоха: Заметки О РелигиозноКультурной Ситуации (the Postsecular Age: Religion and Culture Today), in: Континент 120/ 2004, S. 181-187.

11 Dmitry A. Uzlaner (Дмитрый А. Узланер), В Каком Смысле Современный Мир Может Быть Назван Постсекулярным [in Which Sense Can the Contemporary World Be Called Postsecular],in: Континент 136/2008, S. 16; Ders., Введение В Постсекулярную Философию [Introduction to Postsecular Philosophy], in: Логос 3/83/2011, S. 2-32; Ders., Картография Постсекулярного [Cartography of the Postsecular], in: Отечественные записки 1/2013, S. 17.; Andrey Shishkov, Осмысление Понятия „Постсекулярное“ В Русскоязычной Периодике За Последнее Десятилетие [Making Sense of the ,Postsecular ' in Russian Language Publications for the Last Ten Years], in: Bogoslov.ru 28 April 2010; Sergej S. Horuzhy (Сергей С. Хоружий), Постсекуляризм И Антропология [Postsecularism and Anthropology], in: Человек.ru 8 /2012, S. 15-34; Aleksandr Morozov, Has the Postsecular Age Begun?, in: Religion, State, and Society 36/1/2008, S. 39-44. 
larismus“, wie Bengtson ihn nennt. ${ }^{12}$ Stattdessen betont sie den Zusammenhang zwischen Postsäkularität und Postmoderne. „Der Beginn des postsäkularen Zeitalters fällt mit dem Beginn des postmodernen Zeitalters zusammen“, schreibt Kyrlezhev, denn „die Postmoderne gibt Religion, Religiosität Freiheit“ “. ${ }^{13}$ In vielerlei Hinsicht spiegelt Kyrlezhevs Vision die der Theologie der Radical Orthodoxy wider:

„(...) die theoretischen Grundlagen für das Säkulare wurden systematisch abgebaut. Wenn wir also das Aufkommen der Postmoderne erleben, dann sollten wir auch das Aufkommen des Postsäkularen sehen. Und insofern, als sich die christliche Theologie des zwanzigsten Jahrhunderts mit dem Projekt der Aufklärung verbündete und sich mit einem ,apologetischen' Projekt der Korrelation mit dem weltlichen Denken abfand, muss der Untergang der Moderne auch das Ende einer solchen Theologie bedeuten “ ${ }^{14}$

Es ist kein Wunder, dass Alexander Kyrlezhev zusammen mit anderen Interpreten der Postsäkularität einer der wichtigsten Popularisierer des Projekts Radical Orthodoxy in Russland war.

Postsäkularität ist in dieser Interpretation zunächst ein deskriptiver Begriff. Er beschreibt das Ende der Säkularisierung, was sich im russischen Kontext auf das Ende des sowjetischen atheistischen Projekts und den Beginn der postsowjetischen religiösen Wiederbelebung oder Desäkularisierung ${ }^{15}$ bezieht. Das Scheitern des sowjetischen Projekts wird von Kyrlezhev als das Scheitern des modernen Säkularismus als solches interpretiert. Der sowjetische Kommunismus ist zu Ende gegangen, und in ähnlicher Weise ist auch das Zeitalter der Säkularisierung aus russisch-orthodoxer Sicht zu Ende gegangen. Der westliche Säkularismus - auch wenn er sich auf viel weniger gewalttätige antireligiöse Weise entfaltet hat als der sowjetische Atheismus - wird als nicht weniger veraltet und überdenkenswert angesehen. Gleichzeitig widersetzt sich Kyrlezhev jedem Versuch, die religiöse Vergangenheit zu verherrlichen oder eine allheilende orthodoxe „Tradition“ zu postulieren, die sich im Russland des einundzwanzigsten Jahrhunderts behaupten sollte. Stattdessen spricht er von einem „postsäkularen Religionsmodell“, von einer religiösen Haltung der Auseinandersetzung mit der Welt, die auf der einen Seite die „vorsäkulare Phantasie“ überwindet, der Welt als solcher Gestalt zu geben, und auf der anderen Seite der „antisäkularen Phantasie" absagt, die Welt zu bekämpfen. ${ }^{16}$ Kyrlezhev bleibt jedoch ziemlich vage, wie genau wir uns dieses „postsäkulare Religionsmodell“ vorstellen sollen. Diese

12 Josef Bengtson, Explorations in Post-Secular Metaphysics, London-New York, NY 2016.

13 Kyrlezhev, Постсекулярная Епоха.

14 Ebd., S. 258.

15 Vyacheslav Karpov, De-Secularization: A Conceptual Framework, in: Journal of Church and State 52/2/2010, S. 232-270.

16 Aleksandr Kyrlezhev, On the Possibility or Impossibility of an Eastern Orthodox Political Theology, in: Stoeckl / Gabriel / Papanikolaou (Hg.), Political Theologies, S. 181-187. 
Vagheit, dieses Fehlen einer präzisen normativen Vision - welche die stärkste Seite des habermasianischen Ansatzes ist - wird zu einer echten theoretischen und praktischen Herausforderung für die russische Interpretation der Postsäkularität. Sie erweist sich als zu schwach gegenüber Versuchen seitens kirchlicher Akteure, die Theorie der Postsäkularität für bestimmte ideologische Projekte zu vereinnahmen.

\section{Instrumentalisierung der Postsäkularität in Russland}

Im russischen Kontext sind vage Appelle an die vermeintlich „religionsfreundliche“ Verfasstheit im Namen der postsäkularen Gesellschaft zu einem wichtigen Argument für die Stärkung der Beziehungen zwischen traditionellen religiösen Organisationen und russischen staatlichen Institutionen geworden. Jede Kritik an dieser Annäherung wird als Versuch interpretiert, an veralteten Formen des Säkularismus festzuhalten. Die „postsäkulare Kritik“ wird auch als Argument im Rahmen von Debatten über die Stellung der Religion im russischen Bildungssystem verwendet, zum Beispiel zur Legitimation für die Einführung von Theologie an Universitäten und Religionsunterricht an Schulen. Wichtige Kirchenführer wie Metropolit Hilarion haben sich auf den Begriff der postsäkularen Gesellschaft bezogen, um die Aufnahme religiöser Themen in die Lehrpläne der öffentlichen Schulen zu rechtfertigen. Patriarch Kirill verweist auf die Postsäkularität im Sinne einer „neuen postsäkularen Epoche“, in der „der starre und aggressive Säkularismus dominante Positionen im sozialen und kulturellen Leben verliert“. Man könnte fast sagen, dass der Begriff der „postsäkularen Gesellschaft“ Teil der offiziellen Rhetorik der Russischen Orthodoxen Kirche geworden ist.

Es ist kein Wunder, dass der Begriff Postsäkularität in diesem Zusammenhang auf scharfe Kritik stößt. Einige Gegner kritisieren die Theorie der Postsäkularität als ideologisches Instrument, das die sehr schwachen Fundamente des russischen säkularen Staates erschüttert. In der Logik dieser Kritik führt die postsäkulare Dekonstruktion des Säkularismus zu nichts Neuem. Anstatt mehr demokratische Gleichheit oder neue Legitimität zu bringen, führt sie zur Zerstörung wichtiger Errungenschaften der säkularen Moderne - Wissenschaft, weltlicher Staat, „zivilisierte“ Religion, Liberalismus. Die postsäkulare Theorie, so warnen die Kritiker in Russland, ist nur eine Strategie zur Neuinstallation einer autokratischen Ordnung. ${ }^{17}$

17 Anton N. Dannenberg (Антон Данненберг), Тупики 'Постсекулярного'. Новейшие Философско-Теологические Концепции Как Выражение Кризиса Западного Христианства [Deadlocks of ,the Postsecular`. The Latest Philosophical and Theological Concepts as an Expression of 
Diese begriffliche Umkehrung lässt all jene, die sich mit der Ausarbeitung der postsäkularen Theorie beschäftigen, mit mehr Fragen als Antworten zurück. Als analytisches Konzept bedeutet Postsäkularität, dass Forscher und Forscherinnen die soziale und normative Bedeutung der Religion unvoreingenommen betrachten sollten, bis hin zum Überdenken der Konfiguration der religiös-säkularen Trennlinien. Es bedeutet die Suche nach neuen Formen und Modellen der säkular-religiösen Beziehung unter Bedingungen der Moderne. Die Postsäkularität wird von den meisten Theoretikern, von Habermas über Caputo bis hin zu Kyrlezhev, als Chance für Veränderung, Kreativität und komplementäres Lernen interpretiert. Aber die Realität der meisten russisch-orthodoxen Debatten über die postsäkulare Gesellschaft, die das theoretische Konzept in eine ideologische Waffe verwandeln, zeigt deutlich, dass der neue Begriff leicht verwendet werden kann, um alte und sehr bekannte Gegnerschaften zu rechtfertigen. Der postsäkulare Diskurs wird damit zu einem Konfliktfeld.

\section{Quellen}

Appolonov, Alexey V. (Апполонов Алексей В.), Россия Пострелигиозная [Postreligious Russia], in: Отечественные записки 52/1/2013, vgl. http://www.strana-oz.ru/2013/1/ rossiya-postreligioznaya (letzter Zugriff: 31.05 .2019 ).

Arfi, Badredine, Habermas and the Aporia of Translating Religion in Democracy, in: European Journal of Social Theory 18/4/November 1/2015, S. 489-506.

Bader, Veit, Secularism or Democracy? Associational Governance of Religious Diversity, Amsterdam 2007.

Bengtson, Josef, Explorations in Post-Secular Metaphysics, London-New York 2016.

Berger, Peter L. (Hg.), The Desecularization of the World: Resurgent Religion and World Politics, Washington, D.C.-Grand Rapids, Mich. 1999.

Calhoun, Craig / Juergensmeyer, Mark / Antwerpen, Jonathan Van (Hg.), Rethinking Secularism, Oxford 2011.

Caputo, John D., On Religion, London-New York 2000.

Casanova, José, Public Religions in the Modern World, Chicago 1994.

Cooke, Maeve, Salvaging and Secularizing the Semantic Contents of Religion: The Limitations of Habermas's Postmetaphysical Proposal, in: International Journal for Philosophy of Religion 60/1/3/2006, S. 187-207.

Dannenberg, Anton N. (Данненберг Антон), Тупики 'Постсекулярного'. Новейшие Философско-Теологические Концепции Как Выражение Кризиса Западного Христианства [Deadlocks of ,the Postsecular'. The Latest Philosophical and Theological Concepts as an Expression of the Crisis of Western Christianity], in: Научный богословский портал

the Crisis of Western Christianity], in: Научный богословский портал Богословру (n.y.); Alexey V. Appolonov (Алексей В. Апполонов), Россия Пострелигиозная [Postreligious Russia], in: Отечественные записки 52/1/2013. 
Богословру (n.y.), vgl. http://www.bogoslov.ru/text/3430693.html (letzter Zugriff: 31.05.2019).

Ferrara, Alessandro / Kaul, Volker / Rasmussen, David, Philosophy and Social Criticism. Special Issue: Postsecularism and Multicultural Jurisdictions 36/2010.

Gorski, Philip / Kyuman Kim, David / Torpey, John / Antwerpen, Jonathan Van (Hg.), The Post-Secular in Question. Religion in Contemporary Societies, New York 2012.

Habermas, Jürgen, Dialogue. Jürgen Habermas and Charles Taylor, in: Judith Butler / Eduardo Mendieta / Jonathan Van Antwerpen (Hg.), The Power of Religion in the Public Sphere, Columbia 2011, S. 60-69.

Horuzhy, Sergej S. (Хоружий Сергей С.), Постсекуляризм И Антропология [Postsecularism and Anthropology], in: Человек.ru 8/2012, S. 15-34.

Karpov, Vyacheslav, De-Secularization: A Conceptual Framework, in: Journal of Church and State 52/2/2010, S. 232-270.

Kyrlezhev, Aleksandr, On the Possibility or Impossibility of an Eastern Orthodox Political Theology, in: Kristina Stoeckl / Ingeborg Gabriel / Aristotle Papanikolaou (Hg.), Political Theologies in Orthodox Christianity, London-New York 2017, S. 181-187.

Kyrlezhev, Aleksandr (Кырлежев, Александр), Постсекулярная Епоха: Заметки О Религиозно-Культурной Ситуации (the Postsecular Age: Religion and Culture Today), in: Континент 120/2004, S. 252-264.

Leezenberg, Michiel, How Ethnocentric Is the Concept of the Postsecular?, in: Arie L. Molendijk / Justin Beaumont / Christoph Jedan (Hg.), Exploring the Post-Secular. The Religious, the Political and the Urban, Leiden 2010, S. 91-112.

Milbank, John / Pickstock, Catherine / Ward, Graham (Hg.), Radical Orthodoxy, LondonNew York 1999.

Milbank, John, Theology and Social Theory: Beyond Secular Reason, Holboken 1993.

Morozov, Aleksandr, Has the Postsecular Age Begun?, in: Religion, State, and Society 36/1/ 2008, S. 39-44.

Shishkov, Andrey, Осмысление Понятия „Постсекулярное“ В Русскоязычной Периодике За Последнее Десятилетие [Making Sense of the ,Postsecular' in Russian Language Publications for the Last Ten Years], in: Bogoslov.ru 28 April 2010, vgl. http://www.bogos lov.ru/text/733826.html (letzter Zugriff: 31.05.2019).

Stoeckl, Kristina / Uzlaner, Dmitry, The Russian Postsecular, in: Christoph Schneider (ed.), Theology and Philosophy in Eastern Orthodoxy: Essays on Orthodox Christianity and Contemporary Thought, Eugene, OR 2019, S. 32-52.

Stoeckl, Kristina, Modernity and Political Theologies, in: Kristina Stoeckl / Ingeborg Gabriel / Aristotle Papanikolaou (Hg.), Political Theologies in Orthodox Christianity, London-New York 2017, S. 15-24.

Stoeckl, Kristina / Gabriel, Ingeborg / Papanikolaou, Aristotle (Hg.), Political Theologies in Orthodox Christianity, London-New York 2017.

Uzlaner, Dmitry А. (Узланер, Дмитрый А.), Картография Постсекулярного [Cartography of the Postsecular], in: Отечественные записки 1/2013, S. 17.

Uzlaner, Dmitry А. (Узланер, Дмитрый А.), Введение В Постсекулярную Философию [Introduction to Postsecular Philosophy], in: Логос 3/83/2011, S. 2-32.

Uzlaner, Dmitry A. (Узланер, Дмитрый А.), В Каком Смысле Современный Мир Может Быть Назван Постсекулярным [in Which Sense Can the Contemporary World Be Called Postsecular], in: Континент 136/2008, S. 16. 
Open-Access-Publikation im Sinne der CC-Lizenz BY 4.0

(C) 2020, Vandenhoeck \& Ruprecht $\mathrm{GmbH} \&$ Co. KG, Göttingen ISBN Print: 9783847111658 - ISBN E-Lib: 9783737011655 


\section{Richard Sturn (Graz)}

\section{Soziale Gerechtigkeit und populistische Polarisierung}

\section{Einleitung}

Ein Gespenst geht um - nicht nur in Europa und nicht erst seit gestern. Es wird heutzutage gewöhnlich mit dem schillernden Begriff „Populismus“ umschrieben. Die Strömungen der gemäßigten Linken als auch der gemäßigten Rechten tun sich ausgesprochen schwer, damit umzugehen. Bei Konfrontationen schlagen sich ihre Vertreter selten gut. Ihren populistischen Kontrahenten scheint hingegen vieles nicht zu schaden, was ansonsten als absolutes No-Go gilt, nicht zuletzt die Verbreitung von offenkundigem Unfug.

Noch mühsamer nehmen sich die Versuche des ehemaligen politischen Mainstreams aus, wirksame Gegenkonzepte für die mittlere bis lange Frist und wirksame politische Gegenstrategien für die kurze bis mittlere Frist zu entwickeln. Man könnte die verschiedenen Ansätze (von Umarmung über partielle Adaption bis Ausgrenzung) durchgehen, die derzeit von London über Paris und München bis Wien probiert werden. Alle sind voller Fallstricke und daher nur in Ausnahmefällen geeignet, von der medialen Öffentlichkeit als zukunftsweisender Fixpunkt offensiven politischen Handelns wahrgenommen oder gar gepriesen zu werden. Weltweit manifestiert sich die Krise der Demokratie nicht zuletzt darin, dass mehr und mehr Figuren an die Macht gelangen, von denen eine problematische Dynamik erwartet werden kann. Die Krise betrifft nicht nur Länder wie Ungarn, Polen, Brasilien oder die Türkei, sondern auch klassische Demokratien wie die USA und Italien. Im Vereinigten Königreich versuchte die altehrwürdige Partei der Tories, sich mit fragwürdigen plebiszitären Manövern auf den Schaumkronen populistischer Brandung zu behaupten, um in weiterer Folge ein klägliches Brexit-Schauspiel in mehreren Akten zum Besten zu geben Ausgang trotz formell vollzogenem Brexit ungewiss.

Was sind die Ursachen dieser Schwierigkeiten? Eine wesentliche ist, dass der gemäßigte Mainstream immer noch nur bruchstückhafte Vorstellungen vom grundlegend anders gearteten Politik-Framing der heutigen Populisten hat. Diese Bruchstücke beziehen sich meist auf die sattsam bekannten Koordinaten 
einzelner Politikfelder (seit geraumer Zeit namentlich Migration und Flucht), welche die Populisten besetzen - und auf denen sie den Mainstream in die Defensive drängen.

Die entscheidenden Unterschiede im Politik-Framing sind jedoch auf einer grundlegenderen Ebene. Sie betreffen die Frage nach der Funktion und der Form von Politik in modernen Gesellschaften. Es gibt einen Schlüsselautor, der das anders geartete Politik-Framing der Populisten - auch aufgrund der intellektuellen Qualität seiner Beiträge - besser als andere erschließt: Carl Schmitt. Nicht ohne Grund ist er bei manchen aktuellen Vordenkern des Populismus hoch im Kurs. Man kann sich auf den Webseiten im intellektuellen Umfeld des deutschsprachigen Rechtspopulismus davon überzeugen, wie Carl Schmitt diese beeinflusst. Auch manche zunächst unverständlich scheinende Wortspende (etwa die populistische Benutzung des Worts Bürgerkrieg zur Kennzeichnung politischer Entwicklungsperspektiven in friedlichen europäischen Ländern) weist darauf hin. Carl Schmitts Einfluss beschränkt sich indes nicht auf den deutschsprachigen Raum und nicht auf den Rechtspopulismus. Über Vermittlung linker Politologen wie Chantal Mouffe und Ernesto Laclau ist eine weichgespülte Version von Schmitts Denken auch im spanischen Linkspopulismus (Podemos) von Bedeutung.

In seinem Essay Der Begriff des Politischen ${ }^{1}$ propagiert Schmitt die Idee, dass die Grundlage und das Lebenselixier von Politik die Freund-Feind-Unterscheidung wäre, so wie Moralsysteme oder die Ökonomie nicht ohne die entsprechenden Unterscheidungen zwischen Gut-Böse bzw. Rentabel-Nichtrentabel funktionieren würden. Echte Politik findet gemäß Schmitt immer im Horizont existentieller Konflikte statt. Innenpolitisch beziehe sich „die reale Möglichkeit des Kampfs, die immer vorhanden sein muß, damit von Politik gesprochen werden kann $[\ldots]$ auf den Bürgerkrieg. “2

Diese Begriffsbestimmung verbindet Schmitt mit einer überaus interessanten und gelehrten Diskussion von Problemen der Politik im 19. und frühen 20. Jahrhundert. Aus heutiger Sicht bemerkenswert daran sind v.a. zwei Aspekte: Erstens der von ihm diagnostizierte Gegensatz zwischen dem Liberalismus des 19. und der Demokratie des 20 Jahrhunderts: Demokratie wäre ihrem Wesen nach illiberal. Zweitens eine kritische Analyse der Neutralisierung von Politik und der versuchten Auflösung politischer Probleme in Marktbeziehungen. Dies sieht er als die Grundtendenz liberaler Epochen an. Tatsächlich berührt Schmitt hier einen neuralgischen Punkt: Wirkmächtige Versionen des Wirtschaftsliberalismus propagieren mentale Modelle, die ausblenden, dass Politik typischerweise mit der - wie auch immer gearteten - Vermittlung unter-

1 Carl Schmitt, Der Begriff des Politischen, Berlin 1963.

2 Ebd., S. 32. 
schiedlicher Interessen und Verteilungsproblemen zu tun hat. Sowohl Margaret Thatchers „There is no alternative“ als auch die Rede von der „marktkonformen Demokratie" unterschlagen, dass es fast immer politische Alternativen gibt, die sich in der Verteilung der Vorteile unterscheiden. Womöglich ist dieser blinde Fleck des Liberalismus einer der Gründe für die Schmitt-Renaissance und die mittlerweile diagnostizierte „Krise des Liberalismus“.

Die Hauptschwierigkeit des Mainstreams mit einem Populismus, der in einem Schmitt-Politik-Framing operiert, erschließt sich jedoch durch eine Leerstelle, die speziell aus ökonomischer Sicht schockierend erscheint: das völlige Fehlen der Idee, dass Politik systematisch auf eine bestimmte Art von Problemen und deren Lösung bezogen ist. Wir finden dies deshalb so schockierend, weil sich dies als unentbehrliche Leitidee für Gestaltungsprobleme moderner Wirtschaften erwiesen hat. Sie ist Grundlage wirtschaftswissenschaftlicher Analysen zu Politik, Staat und öffentlichem Sektor: Staat und Politik sind demnach dazu da, Probleme zu lösen. Probleme, die der Markt nicht lösen kann, teils, weil die Lösung nur auf kollektiver Ebene möglich ist, teils, weil diese Lösung zwar im gemeinsamen Interesse ist, jedoch auch Interessenskonflikte beinhaltet, die nicht in Vertragsbeziehungen zum allseitigen Vorteil aufgelöst werden können. Eine derartige Problemlösungsdimension von Politik wird auf den über 80 Seiten von Der Begriff des Politischen nicht einmal in einer Fußnote in Erwägung gezogen.

Die heutigen Populisten können selbstverständlich objektive Probleme nicht komplett ignorieren. Bezeichnend ist jedoch, dass der Problemlösungshorizont auf zwei Arten marginalisiert wird: Durch aktive Problemleugnung wie im Falle des anthropogenen Klimawandels einerseits und andererseits durch bunte $\mathrm{Pa}$ letten widersprüchlicher „Lösungsansätze“, aus denen sich jeder nach Gusto etwas aussuchen kann. Dass diese Lösungen hinten und vorne nicht zusammenpassen, da sie von ultraliberalen Privatisierungsideen bis zu ultraprotektionistischer Regulierung reichen, stört politisch nicht im Geringsten - solange man sich nicht im problemorientierten Framing befindet.

Das Lebenselixier des Populismus ist die wirksame Verankerung eines Freund-Feind-Gegensatzes, der die Problem-Lösungsdimension von Politik überblendet. Solange man sich im Schmitt'schen Koordinatensystem des Politischen befindet, geht der Vorwurf mangelnder Lösungskompetenz ins Leere. Politik dient Schmitt zufolge eben nicht primär der Lösung spezifischer Probleme, sondern der Abarbeitung anthropologisch grundierter Antriebe. In diesem Sinn betont er, dass ,alle echten politischen Theorien den Menschen als ,böse' voraussetzen, [...] als gefährliches und dynamisches Wesen “3. Denn: Wenn die Sphäre des Politischen von der Freund-Feind-Unterscheidung bestimmt ist, „können politische [...] Gedankengänge nicht gut einen anthropo-

3 Ebd., S. 61. 
logischen Optimismus zum Ausgangspunkt nehmen. “4 (Dazu ist anzumerken, dass nach heutigem Stand der empirischen Verhaltenswissenschaften weder die optimistischen noch die pessimistischen Menschenbilder Bestätigung finden, sondern eher eine Mischung unterschiedlicher Antriebe, die je nach Kontext „mobilisiert“ werden.)

\section{Drei Paradigmen des Politischen}

Um die einleitend aufgeworfenen Fragen einigermaßen präzise diskutieren $\mathrm{zu}$ können, ist es nun erforderlich, auf die Logik der Politik bzw. des „Politischen“ über das Schmitt'sche Freund-Feind-Schema hinaus einzugehen. Es sind drei diametral verschiedene Diskussionskontexte von Politik (im Folgenden „Paradigmen“ genannt) in Betracht zu ziehen, welche das Politische und damit auch den Stellenwert von Demokratie unter ganz unterschiedlichen Aspekten verorten.

1. Instrumentelles Paradigma: Politik wird als kollektiver Mechanismus der systematischen Bearbeitung bestimmter Probleme gesehen, zumal solcher, die marktförmiges Handeln nicht oder nicht zufriedenstellend zu lösen vermag. Manche Ansätze betonen dabei insbesondere Politik als Instrument zur Erlangung gruppenspezifischer Vorteile (bzw. Beseitigung von Nachteilen); bei anderen steht Politik als Instrument der Bereitstellung öffentlicher Güter im weitesten Sinn im Vordergrund ${ }^{5}$. Eine ökonomisch-theoretische Kodifizierung eines solch „progressiven“ instrumentellen Paradigmas ist Richard Musgraves Dreiteilung der öffentlichen Aufgaben in allokative, distributive und stabilisierungspolitische Aufgaben.

2. Paradigma der normativen Theorie: Politik als systematischer Ort anspruchsvoller Interaktionsformen, die einer Sozietät vernunftbegabter, freier Akteure angemessen sind. Die Akzente können hierbei unterschiedlich sein: (i) aristotelische Vorstellungen eines in das Wertgefüge der Polis eingebetteten "guten Lebens" in der Polis (anspruchsvolle Politik als tugendethisch aufgeladene Lebensform), (ii) republikanische Traditionen der civic virtues oder aber (iii) die deliberative Demokratie à la Habermas oder Rawls. Im Zentrum stehen jedenfalls Regeln, Prozeduren und Prozesse von Politik, die mit begründbaren

4 Ebd., S. 64.

5 Oft ist dies mit Vorstellungen sozialen Nutzens bzw. des Gemeinwohls als Maßstab für die Vorzugswürdigkeit sozialer Konsequenzen verbunden bzw. mit sozialen Wohlfahrtsfunktionen, die das Abwägen der Vorzugswürdigkeit alternativer Konsequenzen erlauben. 
Rechten, Tugenden oder anderen normativ ausgezeichneten Aspekten verwoben sind und als Angelpunkt des Zusammenlebens menschlicher Akteure in freien Gesellschaften angesehen werden.

3. Carl-Schmitt-Paradigma: Die prägnanteste Darstellung im 20. Jahrhundert findet sich in Carl Schmitts Der Begriff des Politischen (1933). Das Politische als Sphäre der Abarbeitung identitätsbasierter Freund-Feind-Gegensätze (usthem); also allgemein von Logiken, die sich aus Hypothesen der politischen Psychologie und Anthropologie ergeben.

Das dritte „Paradigma“ wird von einer heterogenen Schar antirationalistischer/ vernunftskeptischer Denker vertreten. Das Politikverständnis des US-amerikanischen Pragmatismus (John Dewey) ist dem ersten Paradigma zuzurechnen. Varianten dieses Paradigmas wurden in den modernen Wirtschaftswissenschaften am ausführlichsten bearbeitet und teils kontrovers diskutiert. Das zweite Paradigma ist vorwiegend die Domäne der politischen Theorie bzw. politischen Philosophie und umfasst ein breites Spektrum unterschiedlicher Ansätze normativer Theorie. Wir werden sehen, dass die Schwierigkeiten und Möglichkeiten von Politik in den aktuellen Transformationsprozessen nicht zu verstehen sind, ohne Einsichten aus allen drei „Paradigmen“ zu nutzen, so wie dies auch im Hinblick auf vergangene Epochen des Politischen in unterschiedlicher Gewichtung der Fall ist. Beispielsweise sind erfolgreiche politische Prozesse um die Entstehung von Verfassungen bzw. eines ordnungspolitischen Rahmens wohl nicht ohne deliberative Momente denkbar, in denen Motive eines normativen Paradigmas wirkmächtig werden. ${ }^{6}$ Die Phase politischer Stabilität und einer aufgabenorientierten Expansion des öffentlichen Sektors nach dem Zweiten Weltkrieg folgte im Wesentlichen der Logik des progressiv-instrumentellen Paradigmas. Während dieser Epoche wurden die vom Schmitt-Paradigma betonten Energien der Polarisierung teils vom Ost-West-Gegensatz absorbiert. Das innenpolitische Residuum dieser Antagonismen wurde zumal in den deutschsprachigen Ländern und Skandinavien sozialpartnerschaftlich sublimiert: d.h., den Akteuren war durchaus bewusst, dass Politik auch Verteilungsfragen zu lösen hat. Sozialpartnerschaft bedeutete, dass dies möglichst in einem Win-Win-Framing im Kontext von Allokations- und Stabilisierungspolitik erfolgte. Dagegen sind in Zeiten politischer Krisen und Instabilität die im Schmitt-Paradigma betonten Kräfte nicht zuletzt deshalb dominant, weil die Politik Allokations- und Stabilisierungsprobleme nicht lösen kann, will oder (gemäß herrschender Ideologie) soll. Dies trifft für die Weimarer Republik zu; entsprechende Tendenzen begleiten aber auch die aktuelle Schwächephase des

6 Vgl. Jon Elster (Hg.), Deliberative Democracy, Cambridge 2008. 
progressiv-instrumentellen und aktuelle diagnostische Defizite des normativen Paradigmas: Chantal Mouffe ist vorbehaltlos zuzustimmen, dass Schmitt ein Schlüssel zum Verständnis rezenter Hochkonjunkturen des Populismus ist.

Abstimmungsmechanismen, deliberatives Argumentieren und „Bargaining“ sind drei verschiedene Modi der Erzeugung politischer Lösungen, die in Abhängigkeit von Problemstellung, Problemebene und situativen Umständen mehr oder minder große Bedeutung erlangen. Sofern sich Vertreter des instrumentellen Paradigmas mit politischen Prozessen befassen stehen typischerweise Abstimmungsprozesse im Zentrum, mitunter ergänzt durch die Analyse der Eigenschaften des politischen Bargaining. Im Kontext deliberativer Demokratie und republikanischer Traditionen kommt der argumentativen Suche nach allgemein akzeptablen Antworten besondere Aufmerksamkeit zu. Carl Schmitt beschäftigt sich mit politischem Bargaining, dessen innenpolitische Ausprägung er in pluralistischen Demokratien allerdings als Degenerationsform des Politischen betrachtet. Die bei Schmitt thematisierte Eskalation von Gewaltmitteln entspricht im Prinzip der Logik des Bargainings; der Verzicht darauf setzt schon einen mehr oder minder anspruchsvollen Ordnungsrahmen voraus.

Mouffe ${ }^{8}$ diagnostiziert beim instrumentellen Paradigma ideologisch überschießenden Individualismus und eine marktanaloge Perspektive auf die Politik. Letztere trifft zwar für politikskeptische Strömungen (wie die von James Buchanan begründete Virginia School of Public Choice) zu, nicht jedoch auf progressive Versionen des instrumentellen Paradigmas. Diese verknüpfen Abstimmungsverfahren mit politischen Problemlösungen. Wenn man davon ausgeht, dass Politik/Staat/öffentlichem Sektor in der Moderne die Lösung von Problemen obliegt, die marktförmig nicht zu lösen sind, kommt man um den instrumentellen Ansatz nicht herum. Es greift daher zu kurz, das instrumentelle Paradigma mit schnödem Ökonomismus oder Neoliberalismus zu assoziieren auch in historischer Perspektive: Bis zu einem gewissen Grad ist die Politik als Problemlöserin (zumal in Form des demokratischen Staats) eine historische Realität - und zwar von Problemen, die unabhängig von der konfliktorischen Logik des Politischen à la Schmitt entstehen, so heute z. B. aufgrund der Interdependenzen von Ökonomie und Ökologie.

Viel ausführlicher als mit den Vertretern des instrumentellen Paradigmas setzt sich Mouffe mit einer bestimmten Variante des „normativen“ Paradigmas auseinander, wobei sie insbesondere die deliberative Demokratie à la Habermas ${ }^{9}$

7 Beispielsweise Chantal Mouffe, Über das Politische, Frankfurt 2007.

8 Ebd., S. 20.

9 Wie man bei Mouffe (2007) gut nachvollziehen kann, sind die offiziellen Hauptgegner (i) Vertreter des normativen Paradigmas wie Habermas und Rawls sowie (ii) Beck und Giddens, welche die teils unübersichtliche plurale Konstellation der „Zweiten Moderne“ (Obsoleszenz traditioneller Polarisierungen) betonen. Realpolitisch sind indes Schmittianismus und libe- 
aufs Korn nimmt (vom Politikverständnis anderer „normativer“ Varianten wie etwa Hannah Arendts distanziert sie sich en passant). Kern der Kritik ist, dass Habermas et al. wohlmeinenden Normativismus propagierten, dessen Fluchtpunkt des argumentativ anzustrebenden Konsenses den Realitäten des Politischen nicht gerecht wird. Mag sein. Dennoch ist ihr entgegenzuhalten, dass nicht nur das „instrumentelle“, sondern auch das „normative“ Paradigma Einsichten bietet, die jenen verschlossen bleiben, welche es als blutleeren Normativismus oder Moralismus abtun. So hat Schumpeter, der alles andere als ein Normativist war, darauf verwiesen, dass der im 19. Jahrhundert v.a. vom Ökonomischen getriebene moderne Rationalisierungsprozess dazu führte, dass bestimmte normative Standards (etwa Nicht-Diskriminierung, instrumentelle Rationalität und utilitaristische Kalküle) über die Ökonomie hinaus wirkmächtig wurden. Dass bestimmte Konzepte nicht nur in der politischen Philosophie (etwa der Universalisierbarkeit und Unparteilichkeit) oft ohne empirische Bodenhaftung diskutiert werden, impliziert nicht, dass sie empirisch irrelevant sind. Sie können bis zu einem gewissen Grad die Einstellungen und Bewertungen von Akteuren prägen. Auch wenn sie sie nicht prägen, so sind sie doch heute für die meisten verständlich, sodass ein Appell daran nicht immer ein hoffnungsloses Unterfangen ist. Darüber hinaus dürften sie historisch eine funktionale Rolle bei der Fundierung und Ausdehnung der Reichweite von Politik als Problemlösung gespielt haben, etwa in verfassungsgebenden Prozessen, wie Jon Elsters historische Analyse der Entstehung der US-Verfassung darlegt.

Für eine „realistische“ Theorie des Politischen und dessen Rolle in Transformationsprozessen ist es vorteilhaft, Einsichten aus allen drei Paradigmen in Betracht zu ziehen. Indes: Politik als institutionelles Gefüge, welches jene Rahmenbedingungen weiterentwickelt, unter denen die Ökonomie dem Leben der Menschen dient und nicht entfremdende Eigendynamiken entwickelt, baut vor allem auf eine Kombination des Werte-Paradigmas mit dem instrumentellen Problemlösungs-Paradigma. Soziale Gerechtigkeit ist ein Konzept, das in hohem Maße zur Förderung einer solchen Kombination in problemadäquater Form geeignet ist. Denn richtig verstanden ist soziale Gerechtigkeit weder vage noch abgehoben und abstrakt. Schon gar nicht ist sie ein Trugbild, wie F. A. Hayek ${ }^{10}$ meinte - oder Bestandteil einer „Ethik als Mittel des Recht-Habens“, die in pluralistischen Gesellschaften zu einer instabilen „Tyrannei der Werte“ führen kann. Denn „soziale Gerechtigkeit“ wurde in Traditionen entwickelt, die das

raler Normativismus symbiotisch in asymmetrischen Polarisierungen miteinander verbunden (Gutmenschen vs. Schmuddelpopulismus). Und betrachtet man die ideologische Mischung der 1968er-Bewegung, dann ist mitunter eine direkte Kombination von Schmittianismus und linkem Normativismus anzutreffen, während das instrumentelle Element schwach ausgeprägt war.

10 Friedrich Hayek, Law, Legislation and Liberty, London 1976. 
Anliegen verfolgten, dem Diskurs über Gerechtigkeit Bodenhaftung zu verleihen und ihn in Verbindung mit den sozioökonomischen Gegebenheiten moderner Gesellschaften zu bringen.

\section{Soziale Gerechtigkeit: Normative Theorie mit Bodenhaftung}

Gustav Schmoller widerspricht in seinem Essay zur Gerechtigkeit in der politischen Ökonomie der Konzeption, die im Unterschied zwischen Arm und Reich nur ein Naturereignis sieht. Er argumentiert, diese Verteilung werde - obwohl durch die unsichtbare Hand des Markts („Angebot und Nachfrage“) vermittelt letztlich nicht von „Naturphänomenen“ bestimmt. Die Verteilungsmuster werden vielmehr von den vorherrschenden Institutionen bestimmt. Diese Institutionen sind kein Produkt blinder Kräfte, sondern ein historisch kontingentes Produkt aus menschlichen Gefühlen und Gedanken, aus menschlichem Handeln, menschlichen Gesetzen und Sitten, wie Schmoller betont. ${ }^{11}$ Laut Schmoller liefert diese Erkenntnis eine Basis für die Antwort auf die seiner Meinung nach zentrale Frage im Hinblick auf die Rolle der Gerechtigkeit ${ }^{12}$.

Schmoller geht es vor allem um Folgendes: (Soziale) Gerechtigkeit ist konzeptionell relevant für die Diskussion moderner Institutionen und sie ist der normative Dreh- und Angelpunkt einer Sozialpolitik, die weder eine technokratische Umverteilung noch eine statische Einbettung der Märkte bedeutet. Der Fortschritt in Bezug auf die institutionelle Realisierung ethischer Normen ist Schlüssel für den allgemeinen Fortschritt und Gedeihen. In den kulturellen Bereichen von Religion und Ethos (nicht in Technologie und Ökonomie) wird das Potenzial der Menschheit in einem aufstrebenden Stadium zuerst sichtbar. Idealerweise sind Ethos und damit einhergehende institutionelle Arrangements angesichts der jeweiligen historischen Phase auf der Höhe der Kulturaufgaben. In der gegenwärtigen Zivilisationsphase regulieren öffentliche Institutionen (insbesondere auch der Staat) die Kräfte, die in der Marktwirtschaft freigesetzt werden. Diese Institutionen regeln somit die Einkommensverteilung. In diesem Sinne ist die Marktwirtschaft keine natürliche Ordnung. Marktvergütungen sind nicht „natürlich“, da sie von menschlichen Artefakten (Institutionen) beeinflusst werden. Schmoller sieht eine dialektische Dynamik in der Entwicklung der Individualität, die sich zusammen mit einer immer gerechteren öffentlichen Ordnung entwickelt. Fortschritt impliziert, dass soziale Interdependenzen mit immer weniger zwanghaften und machtbezogenen Mitteln vermittelt werden; es

11 Gustav Schmoller, The Idea of Justice in Political Economy, in: The Annals of the American Academy of Political and Social Science 4/1894, S. 1-41, hier: S. 22.

12 Ebd., S. 3. 
ist immer weniger möglich, Formen der Regulierung durchzusetzen, die nicht fast alle als "gerecht" befürworten. ${ }^{13}$

Schmoller ist der Ansicht, dass dies alles von Wirtschaftswissenschaftlern zu Unrecht vernachlässigt wird, die Verteilungsgerechtigkeit als unwissenschaftlich ablehnen. Diese Ökonomen sind der Meinung, dass Menschen, die eine gerechte Verteilung der Einkommen verlangen, töricht sind oder einem Trugbild unterliegen, ähnlich töricht wie jene, die Gott wegen Naturkatastrophen tadeln. Schmoller betont, er verlange nicht, dass die Verteilungsgerechtigkeit von Einkommen oder Reichtum „absolut“ gelte, dass jedoch die zahlreichen wirtschaftlichen Akte, die (auf der Grundlage von Tausch und Arbeitsteilung) andere und ganze Gemeinschaften betreffen, gerecht sein müssen. Schmoller begründet dies wie folgt: Soweit menschliches Handeln die Einkommensverteilung beeinflusse, würden sozialpsychologische Prozesse ausgelöst, deren Endergebnis Urteile wären, wonach diese Verteilung als gerecht und jene als ungerecht angesehen würde. Daher wird die normative Diskussion über Verteilung faktisch relevant sein. In der politischen Ökonomie wäre es laut Schmoller dumm, faktisch auftretende normative Diskussionen und Konflikte zu ignorieren, da sie reale Auswirkungen haben werden: Es wird oft von großer Bedeutung für den Fortgang sozioökonomischer Dynamiken sein, welche Wirkung billigende oder missbilligende Urteile über die Gerechtigkeit der Verteilungskonsequenzen ökonomischer Prozesse faktisch ausüben, sei es in privatwirtschaftlichen Aushandlungsprozessen, sei es in weitere Folge im politischen Raum. Schmoller zufolge stehen Institutionen nicht über der Geschichte. Bei jeder institutionellen Konkretisierung von Normativität ist zu fragen: Wie ist sie entstanden? Welche Vorstellungen von Gerechtigkeit hat sie hervorgebracht? Welche Notwendigkeit besteht für sie heute ? $^{14}$

Besonders fruchtbare Ansätze in die Richtung eines solchen Denkens finden wir nun bei jenen Autoren, denen die Konzeptualisierung von „sozialer Gerechtigkeit" ein Anliegen war. Gerechtigkeitsnormen werden dabei zum einen als ein soziales Phänomen betrachtet, das man nur versteht, wenn man die Entwicklung und Funktion von Gerechtigkeit theoretisch und empirisch erfasst. Daran anschließende normative Theorie beleuchtet „soziale Gerechtigkeit“ als umfassendes normatives Konzept, das seine Motivation in der komplexen Mehrebenenstruktur moderner Gesellschaften findet. Zum sozialtheoretischen Diskussionsstrang gehören zeitgenössische Wissenschaftler wie Peter Corning ${ }^{15}$,

13 Ders., Die Gerechtigkeit in der Volkswirtschaft, in: Gustav Schmoller (Hg.), Jahrbuch für Gesetzgebung, Verwaltung und Volkswirtschaft 5, Leipzig 1881, S. 19-54; Ders., The Idea of Justice.

14 Ders., The Idea of Justice, S. 4-19.

15 Peter Corning, The Fair Society. The Science of Human Nature and the Pursuit of Social Justice, Chicago-London 2011. 
der versucht, das Streben nach sozialer Gerechtigkeit zu erklären, indem er Erkenntnisse aus der Spiel-, Evolutions- und Verhaltenstheorie aufnimmt. Darüber hinaus schließt er ältere Theoretiker ein, die sich auf ein organischeres Gesellschaftsverständnis berufen, wie etwa diejenigen, die den Begriff der sozialen Gerechtigkeit in englischer Sprache prägten, darunter der Harvard-Ökonom Thomas Nixon Carver ${ }^{16}$. Einer ausgeprägt sozialtheoretisch argumentierenden Tradition zuzurechnen sind auch einflussreiche Stränge des katholischen Sozialdenkens: Beispiele sind Luigi Taparelli (1793-1862) und Heinrich Pesch (1854-1926). Einen normativ-theoretischen Fokus haben einschlägige Arbeiten des Rechtsphilosophen Peter Koller, der soziale Gerechtigkeit als Summe aller auf die verschiedenen Ebenen der institutionellen Grundordnung der Gesellschaft anzuwendenden Anforderungen definiert. ${ }^{17}$ Soziale Gerechtigkeit wird daher als ein übergreifendes Konzept betrachtet, das Verteilungsgerechtigkeit, kommutative Gerechtigkeit, politische Gerechtigkeit und korrektive Gerechtigkeit umfasst.

Einige Denker bemühen sich, die normative Theorie und erklärende Sozialtheorie der Gerechtigkeit zusammenzuführen. Dazu gehören zwei politische Philosophen, die sich systematisch und explizit mit der Rolle der Sozialwissenschaften auseinandersetzen: David Miller ${ }^{18}$ und John Rawls ${ }^{19}$. Beide betonen die Besonderheiten der komplexen institutionellen Ordnungen der „Großen Gesellschaften“ - ein Begriff, der von Adam Smith, Hayek und Taparelli verwendet wird. Diese Besonderheiten motivieren zu einem umfassenderen Blick auf die Anforderungen der Gerechtigkeit, der durch sozioökonomischer Analyse dieser Gesellschaften unterstützt wird. Ab den 1840er-Jahren benutzten Gelehrte unterschiedlicher Richtungen in diesem Sinn den Begriff „soziale Gerechtigkeit“ und drückten damit zwei verwandte Arten von Anliegen aus. Eines dieser Anliegen ist durch die Idee begründet, dass die Komplexität der großen Gesellschaften einen übergeordneten integrierten normativen Rahmen für die $\mathrm{Ab}$ wägung von Gerechtigkeitsansprüchen erfordert. Das zweite betont die Bedeutung der sozioökonomischen Theorie (einschließlich der Empirie) für die Untersuchung der Rolle der Gerechtigkeit in der modernen Gesellschaft.

Den ersten Punkt kann man bearbeiten, indem der Begriff der sozialen Gerechtigkeit aus der Perspektive der normativen Theorie betrachtet wird. Eine

16 Thomas N. Carver, Essays in Social Justice, Cambridge 1915.

17 Peter Koller, Soziale Gerechtigkeit. Begriff und Begründung, in: Nikolaus Forgó / Alexander Somek (Hg.), Vienna Working Papers in Legal Theory, Political Philosophy and Applied Ethics 24, Wien 2001a, S. 1-57; Ders (Hg.), Gerechtigkeit im politischen Diskurs der Gegenwart, Wien 2001b; Ders., Soziale Gerechtigkeit, in: Anna Goppel / Corinna Mieth / Christian Neuhäuser (Hg.), Handbuch Gerechtigkeit, Stuttgart 2016, S. 118-124.

18 David Miller, Principles of Social Justice, Cambridge-London 1999.

19 John Rawls, A Theory of Justice, Cambridge 1971. 
transparente Darstellung wird in der Analyse sozialer Gerechtigkeit als Konzept der normativen Theorie von Peter Koller entwickelt. Kollers Definition von sozialer Gerechtigkeit bezieht sich explizit auf verschiedene Bereiche sozialer Interaktionen, die unterschiedliche Dimensionen von Gerechtigkeit beinhalten (Verteilungsgerechtigkeit, kommutative Gerechtigkeit, politische Gerechtigkeit und korrektive Gerechtigkeit). Unter der Annahme ausgeprägter Wechselwirkungen zwischen diesen Bereichen ist ein angemessenes, integriertes Konzept sozialer Gerechtigkeit sinnvoll. Angesichts solcher Abhängigkeiten kann die isolierte Betrachtung der unterschiedlichen Dimensionen (wie Verteilungsgerechtigkeit) die Ursache für blinde Flecken sein: Krasse Vermögensungleichheiten können etwa kommutative Gerechtigkeit aushebeln, weil die Freiwilligkeit des vertragsvermittelten Austausches nicht plausibel ist, wenn die Armen gleichsam bei Strafe des Untergangs in den Arbeitsmarkt gezwungen werden. ${ }^{20}$

Für den politischen Philosophen David Miller ist soziale Gerechtigkeit ein Mehrebenen-Konzept, bei dem unterschiedliche Arten von Anspruchsmotivationen, einschließlich der Bedürfnisse, des Verdienstes und der Gleichheit, berücksichtigt werden, die unterschiedlichen Bereichen sozialer Interaktionen entsprechen. Miller betont ausdrücklich die unabdingbare Rolle der Sozialwissenschaften (einschließlich der Sozialpsychologie und der empirischen Erforschung der Gerechtigkeit) für jede Diskussion über soziale Gerechtigkeit: Das dritte Kapitel seines Buches ist der Demonstration gewidmet, dass die sozialwissenschaftlichen und philosophischen Untersuchungen von Gerechtigkeit notwendigerweise voneinander abhängen. ${ }^{21}$ Zusammenfassend skizziert Miller einige Argumente, die sich auf die unterschiedlichen Perspektiven verschiedener Dimensionen sozialer Gerechtigkeit (Notwendigkeit, Verdienst, Gleichheit) unter Bedingungen der „Globalisierung“ beziehen.

Der wichtigste Denker, der den Begriff „soziale Gerechtigkeit“ explizit verwendet, ist John Rawls. Er zielt auf eine bestimmte Relevanz für einen bestimmten Typ von Gesellschaften ab. Sein Gerechtigkeitskonzept ist sorgfältig auf zeitgenössische Marktgesellschaften ausgerichtet. Das relevante Design basiert auf Annahmen, die ohne sozioökonomische Theorie und empirische Sozialwissenschaften nicht beurteilt werden können. Das facettenreiche Gebäude von Rawls umfasst daher Diskussionen im Zusammenhang mit Wirtschaftswissenschaften und Sozialpsychologie und berücksichtigt Probleme der sozialen Koordination, Effizienz und Stabilität. ${ }^{22}$ Diskussionen über Gegenseitigkeit, Gerechtigkeitssinn und Neid spielen eine nicht zu vernachlässigende Rolle. Der

20 Koller, Gerechtigkeit, S. 1-57; Ders. (Hg.), Gerechtigkeit im politischen Diskurs; Ders., Soziale Gerechtigkeit.

21 Miller, Social Justice, S. 43.

22 Rawls, Justice; Brian Barry, John Rawls and the Search for Stability, in: Gerald Dworkin (Hg.), Ethics, Juli/1995, S. 874-915. 
Schlüsselteil der Architektur, die diese sozioökonomischen Aspekte ordnet, ist dem von Hume eingeführten theoretischen Apparat entliehen. ${ }^{23}$ Dazu gehören die (empirischen) „Gerechtigkeitsbedingungen“, die durch moderate Knappheit und begrenzte Großzügigkeit gekennzeichnet sind, sowie die logische Bedeutung allgemeiner Regeln. ${ }^{24}$ Auf der Grundlage dieser Gerechtigkeitsbedingungen definiert Rawls soziale Gerechtigkeit als die erste Tugend sozialer Institutionen. All dies führt zu einem Rahmen, in dem soziale Gerechtigkeit nicht mit Verteilungsgerechtigkeit gleichgesetzt wird. ${ }^{25}$

\section{Ausblick}

Man geht wahrscheinlich nicht fehl, einen Zusammenhang der multiplen Krisen der Gegenwart mit zwei widersprüchlichen Tendenzen zu suchen: (1) Jener Abwertung von Politik, die von neoliberalen Strömungen seit den 1970er-Jahren erfolgreich propagiert wird und die suggeriert, dass Politikversagen allgegenwärtig wäre, wobei Entpolitisierung und Privatisierung als logische Lösungen erscheinen. (2) Die Überfrachtung von Politik mit widersprüchlichen Wertvorgaben. Die Abwertung von Politik hat zwei sich wechselseitig ergänzende Erscheinungsformen: einerseits den Imperativ marktkonformer Politik und andererseits die Illusion anti-politischer Politik, die mit dem Populismus verbunden ist. Diese Politik lebt von der periodischen Erzeugung politischer Blasen. Sie lässt in ihrer Rhetorik die klassischen Hauptrollen moderner Politik (die Lösung von Problemen vor dem Hintergrund von Interessenskonflikten) und die typischen Mechanismen demokratischer Politik, welche Kompromisse ermöglichen, hinter sich.

Daneben gibt es aber auch Phänomene mittlerer Reichweite, von denen nicht ganz klar ist, ob es sich dabei um Symptome oder sekundäre Krisenursachen handelt. Eines davon ist jene Parzellierung des öffentlichen Diskurses, die vor einiger Zeit etwa in der Berichterstattung über die Fluchtbewegungen wahrzunehmen war und zum Teil immer noch ist. In einflussreichen Medien verstärkte sich die Polarisierung zwischen einem Realismus-Diskurs und einem Menschenrechte-Diskurs: Sowohl in der politischen Berichterstattung als auch im politischen Kommentar dominiert der Realismus-Diskurs, in dem sich die angebliche „Realitätsverweigerung“ Merkels zum kritischen Schlüsselbegriff entwickelte. Dieser Part wurde nicht nur von selbststilisierten Spezialisten für ab-

23 David Hume, A Treatise of Human Nature, London 1739/40; Ders., Enquiries Concerning Human Understanding and Concerning the Principles of Morals, London, Edinburgh 1777.

24 John Rawls, The Law of People, Cambridge 1999, S. 240.

25 Ders., A Theory of Justice, Cambridge 1971, S. 110. 
gebrühten Realismus übernommen, sondern sickerte in den redaktionellen Mainstream ein. Auch einige Aspekte, die durchaus realpolitisch relevant sein können, wurden ins abgehoben-normativistische Eck abgedrängt. Die politische Irrelevanz humanitärer Aspekte im Koordinatensystem des selbststilisierten Realismus dingfest zu machen, scheint in weiten Kreisen zum argumentativen Selbstläufer geworden zu sein. Bei manchen sieht man den düsteren „Realismus“ Joseph de Maistres durchscheinen, der Menschenrechte (und überhaupt die Rede von „dem Menschen“) zur Zeit der französischen Revolution als Hirngespinst ohne empirische Basis lächerlich machte. Gleichzeitig wird das Aufbrechen bestehender politischer Verhältnisse (die Bekämpfung von „Stillstand“ und „Establishment“) zur absoluten Priorität - eine Priorität, die kaum durch realpolitische Erwägungen zu relativieren ist. Das Interessante dabei ist, dass die dabei geltend gemachten Motive, Ziele und Theorien völlig unterschiedlich und zum Teil unvereinbar sind.

Eine vitale Demokratie beschränkt sich nicht auf Wahlmechanismen, sondern ist auf den kontroversen Diskurs der Angelegenheiten öffentlichen Interesses aus verschiedenen Blickwinkeln angewiesen. Ansonsten verkommt sie zu Wettbewerb zwischen Machtkartellen, die durch Gefälligkeiten und Klientelismus zusammengehalten werden. Demokratie kann weder unter Bedingungen populistischer Polarisierung Bestand haben noch unter der neoliberal-instrumentellen Fiktion, es gäbe keine Alternative zur Rationalität des Markts als Kompass oder gar Richtschnur für alle Lebensbereiche. Angesichts dieser Skylla und Charybdis - die im Unterschied zur griechischen Mythologie noch dazu mitunter unheilvolle Fusionen eingehen - wäre es an der Zeit, Konzepte sozialer Gerechtigkeit weiterzuentwickeln, mit Blick auf Bodenhaftung und aktuelle Herausforderungen der digitalen Globalisierung. Nur so kann der unsinnige Gegensatz zwischen Realismus und Humanismus überwunden werden. Und nur so kann jene babylonische Sprachverwirrung überwunden werden, die dadurch entstanden ist, dass in vielen Ländern der Parteienwettbewerb weder Wettbewerb um die besseren Problemlösungen noch das Austragen echter Interessengegensätze ist, sondern die Konfrontation unterschiedlicher Paradigmen des Politischen.

\section{Quellen}

Barry, Brian, John Rawls and the Search for Stability, in: Gerald Dworkin (Hg.), Ethics 105, S. 874-915.

Carver, Thomas N., Essays in Social Justice, Cambridge 1915.

Corning, Peter, The Fair Society. The Science of Human Nature and the Pursuit of Social Justice, Chicago-London 2011.

Elster, Jon (Hg.), Deliberative Democracy, Cambridge 2008. 
Hayek, Friedrich, Law, Legislation and Liberty, Vol. 2: The Mirage of Social Justice, London 1976.

Hume, David, A Treatise of Human Nature, London 1739/40.

Hume, David, Enquiries Concerning Human Understanding and Concerning the Principles of Morals, London, Edinburgh 1777.

Koller, Peter, Soziale Gerechtigkeit, in: Anna Goppel / Corinna Mieth / Christian Neuhäuser (Hg.), Handbuch Gerechtigkeit, Stuttgart 2016, S. 118-124.

Koller, Peter, Soziale Gerechtigkeit. Begriff und Begründung, in: Nikolaus Forgó / Alexander Somek (Hg.), Vienna Working Papers in Legal Theory, Political Philosophy, and Applied Ethics 24, Wien 2001a, S. 1-57.

Koller, Peter (Hg.), Gerechtigkeit im politischen Diskurs der Gegenwart, Wien 2001b.

Miller, David, Principles of Social Justice, Cambridge (MA)-London 1999.

Mouffe, Chantal, Über das Politische, Frankfurt 2007.

Rawls, John, The Law of People, Cambridge 1999.

Rawls, John, A Theory of Justice, Cambridge 1971.

Schmitt, Carl, Der Begriff des Politischen. Text von 1932 mit einem Vorwort und drei Corollarien, Berlin 1963.

Schmoller, Gustav, The Idea of Justice in Political Economy, in: The Annals of the American Academy of Political and Social Science 4/1894, S. 1-41.

Schmoller, Gustav, Die Gerechtigkeit in der Volkswirtschaft, in: Gustav Schmoller (Hg.), Jahrbuch für Gesetzgebung, Verwaltung und Volkswirtschaft 5, Leipzig 1881, S. 19-54.

Smith, Adam, Theory of Moral Sentiments, 6. Aufl., London 1790.

Smith, Adam, An Inquiry into the Nature and Causes of the Wealth of Nations, London 1776. 


\section{Neue religiöse Intoleranz und die Abkehr vom Modell des religiösen Pluralismus: Religionspolitische Transformation in Österreich?}

\section{Wahrnehmungen und Vorüberlegungen}

In Folge der Zuwanderung einer großen Zahl Schutz suchender Menschen nach Europa im Sommer 2015 wurde nicht nur die Asyl- und Migrationspolitik, sondern auch die Religionspolitik in Österreich erheblich verändert. Bis in das Jahr 2015 hinein, in dem mit der Novellierung des Islamgesetzes ein bemerkenswert differenziertes Modell der Religionspolitik erneuert und weite Spielräume für die religiöse Praxis unterschiedlicher Religionsgemeinschaften bekräftigt wurden, konnte die Republik Österreich als Beispiel für einen elaborierten religiösen Pluralismus gelten. Seit dem Herbst 2015 häuften sich dann Initiativen für eine Beschränkung religiöser Freiheitsspielräume, und zwar vor allem für Muslime. Kopftuchverbote und „Niqabverbote“ sowie beispielsweise eine erstaunlich scharfe und pauschalisierende Polemik gegen Kindergärten in muslimischer Trägerschaft wurden nicht nur zu Wahlkampfschlagern, sondern fanden nach und nach Einzug in die Gesetzgebung. Beachtlich ist diese Entwicklung in verschiedener Hinsicht: Erstens findet eine als Integrationspolitik deklarierte Vermischung von Zuwanderungspolitik und Religionspolitik statt (so ist etwa das Gesichtsverhüllungsverbot Teil der Integrationsgesetzgebung ${ }^{1}$ ). Zweitens werden Zuwanderungsphänomene kulturalisiert, das heißt es geht in den politischen und öffentlichen Diskursen immer weniger um Zuwanderung aus bestimmten politischen Herkunftskontexten (also aus bestimmten Staaten), sondern um Zuwanderung von religiösen Menschen, namentlich von Muslimen. Und drittens überrascht die Geschwindigkeit, in der die eng mit der österreichischen Geschichte der Neuzeit verbundene Tradition einer grundsätzlich re-

1 Vgl. \$1 des Bundesgesetzes über das Verbot der Verhüllung des Gesichts in der Öffentlichkeit (Anti-Gesichtsverhüllungsgesetz - AGesVG): ,Ziele dieses Bundesgesetzes sind die Förderung von Integration durch die Stärkung der Teilhabe an der Gesellschaft und die Sicherung des friedlichen Zusammenlebens in Österreich. Integration ist ein gesamtgesellschaftlicher Prozess, dessen Gelingen von der Mitwirkung aller in Österreich lebenden Menschen abhängt und auf persönlicher Interaktion beruht.“ 
ligionsfreundlichen Politik zu einer religionsskeptischen und vor allem islamfeindlichen Politik der Einschränkung religiöser Freiheiten verändert wurde. Zwei dieser Beobachtungen sollen im Folgenden etwas genauer thematisiert werden, und zwar die Kulturalisierungstendenz anhand der Überlegungen von Martha Nussbaum zu einer „neuen religiösen Intoleranz" sowie der religionspolitische Modellwechsel anhand eigener Überlegungen der vergangenen Jahre.

\section{2. „Neue religiöse Intoleranz“ als Gegenwartsphänomen}

Martha Nussbaum beansprucht für ihre religionsphilosophischen und religionspolitischen Schriften ${ }^{2}$, eine Position innerhalb der Tradition der politischen Philosophie des Liberalismus zu entwickeln. Mit dem Band The New Religious Intolerance (2012) wendet sich Nussbaum gegen eine zunehmende Diskreditierung und Diskriminierung religiöser Orientierung und Lebenspraxis. ${ }^{3}$ Sie wählt dazu - ganz ähnlich ihrem Vorgehen im Rahmen des capabilities approach - einen im weiteren Sinne anthropologischen Zugang, indem sie den Begriff der Angst in einem weiten Spektrum unterschiedlicher Bezüge skizziert und das Phänomen der Angst als Grund für die zunehmende religiöse Intoleranz rekonstruiert. Mit der Formel „neue religiöse Intoleranz" beschreibt Nussbaum eine offen artikulierte Skepsis gegenüber religiösen Orientierungen und Verhaltensweisen, die sich in gesellschaftlichen Praktiken, öffentlichen Diskursen und letztlich auch in der Gesetzgebung niederschlägt. Eine Vielzahl von Belegen findet sie sowohl in US-amerikanischen Zusammenhängen als auch in gegenwärtigen Auseinandersetzungen in Europa. Einer breiteren Öffentlichkeit ist Nussbaums Position bekannt geworden, als sie 2010 mit Einträgen in einem Blog der New York Times („Opinionator“) in die religionspolitische Debatte eingegriffen und das Tragen des Niqabs durch muslimische Frauen verteidigt hat. Die in mehreren europäischen Gesellschaften und politischen Gemeinwesen vorhandenen Bestrebungen, das Tragen von verschleiernden Kleidungsstücken in der Öffentlichkeit zu verbieten, wurden zum Ziel ihrer scharfen und teilweise polemischen Kritik. In ihren Ausführungen verweist sie auf unterschiedliche historische Entwicklungen in den USA und in Europa: In Folge und im Schatten der Religionskriege entwickelte sich in Europa zunächst eine Koexistenz von in

2 Vgl. zum Religionskonflikt in Indien Martha Nussbaum, The Clash Within. Democracy, Religious Violence, and India's Future, Cambridge-London 2007; vgl. zur US-amerikanischen Tradition der „gleichen religiösen Freiheit“ Martha Nussbaum, Liberty of Conscience. In Defense of America's Tradition of Religious Equality, New York 2008.

3 Martha Nussbaum, The New Religious Intolerance. Overcoming the Politics of Fear in an Anxious Age, Cambridge-London 2012, dt. Martha Nussbaum, Die neue religiöse Intoleranz. Ein Ausweg aus der Politik der Angst, 2. Aufl., Darmstadt 2014. 
unterschiedlicher Weise religiös geprägten bzw. mit engen Religion-Politik-Verknüpfungen ausgestatteten politischen Gemeinwesen. Zwar gab es hier Formen der Toleranz, aber es war eine Toleranz im Sinne einer Duldung oder eines opportunen Gewährenlassens von Religionen, die vom jeweils etablierten Bekenntnis abwichen. Dementsprechend „säkularistisch“, also mit einer ausdrücklichen und nachdrücklichen Skepsis gegenüber der Religion ausgestattet, entwickelte sich dann der kontinentaleuropäische Liberalismus insbesondere in Folge der französischen Revolution. Aus durchaus guten Gründen, nämlich um das offenkundig unruhestiftende Potential der Religionen einzuhegen, wurde nach und nach die säkularistische oder laizistische Tendenz der Verdrängung der Religion aus der Öffentlichkeit entwickelt. Deshalb war bzw. ist etwa im französischen Laizismus die Angst vor und die Intoleranz gegenüber Religionen besonders ausgeprägt, was etwa im Verbot des Niqab und in weitreichenden Kopftuchverboten zum Ausdruck kommt. In den USA dagegen konnte sich - ohne den historischen Ballast der Religionskriege europäischen Ausmaßes eine Tradition der religiösen Pluralität entwickeln. Diese ist einerseits mit der Separation von Religion und Politik verbunden, lässt andererseits aber weite Spielräume für religiöse Orientierungen und Praxis. Die Frage, um welche religiösen Orientierungen es sich jeweils handelt, tritt - jedenfalls grundsätzlich - in den Hintergrund. „Die Idee, dass politische Grundsätze nicht zugunsten einer Religion die anderen vernachlässigen, sondern gleichen Respekt für alle bezeigen sollten, funktionierte in den amerikanischen Kolonien viel besser und letztlich auch in der neuen Nation. ${ }^{\text {“4 }}$ Nussbaum leugnet natürlich nicht, dass es eine Diskriminierung von Katholiken und anderen religiösen Denominationen in den USA gab und gibt; sie befürwortet aber das in den USA favorisierte Prinzip des gleichen Respekts gegenüber den unterschiedlichen Religionen und sieht in ihm auch den Schlüssel für die Lösung des gegenwärtigen Problems der religiösen Intoleranz. Deshalb sieht sie in der Bewältigung dieses Problems die USA auf einem besseren Weg als Europa - und dies noch vor der Zunahme der populistischen Verwerfungen in der europäischen Politik seit 2015, allerdings auch vor dem Antritt der Trump-Administration. „Heute wissen wir, wie gute politische Grundsätze auf dem Feld des religiösen Respekts und der Gleichheit aller Menschen aussehen. In den USA, aber viel uneinheitlicher in Europa, werden diese Grundsätze in Gesetz und öffentlichem Leben beachtet. Doch sie bleiben in Zeiten der Angst fragil. “5 Es liegt auf der Hand, dass sich die Situation inzwischen verschärft hat. Die Angriffe vor allem gegen den Islam sind schärfer geworden, Ungleichbehandlungen sind nicht nur in Europa ausgeweitet worden, sondern konnten auch in den USA zum politischen Programm werden.

4 Nussbaum, Die neue religiöse Intoleranz, S. 196.

5 Nussbaum, Liberty of Conscience, S. 197 (eig. Übers.). 
Den Begriff der Angst thematisiert Nussbaum, wie gesagt, ausführlich in einer philosophisch-anthropologischen Perspektive. ${ }^{6}$ Als typisches Beispiel für religiöse Intoleranz auf der Grundlage von Angst und daraus resultierender Abneigung gegenüber religiöser Praxis erörtert Nussbaum das Minarettverbot in der Schweiz. Auch dabei sei es, so Nussbaum, um die Angst vor der Zerstörung schweizerischer Werte gegangen. Die muslimische Minderheit wurde zum Angreifer und zur Invasionsmacht stilisiert, die Minarette buchstäblich zu Symbolen dieses Angriffs, die dementsprechend auf Plakaten und in Computerspielen graphisch als Raketen dargestellt wurden, „die sich überall in einer idyllischen schweizerischen Landschaft erheben "7. In ähnlicher Weise gelte dies für Bedeckungsverbote, die darauf zielen, das Tragen von Kopftuch und Niqab durch muslimische Frauen in der Öffentlichkeit zu unterbinden. Nussbaum schildert ausführlich, wie dabei Ängste vor Unbekanntem mit angenommenen Gefahrenpotentialen verknüpft werden: Frauen, die aus religiösen Gründen eine bestimmte Kleidung tragen, werden als Gefährdungsfaktoren im Hinblick auf Überfremdung im Allgemeinen und im Hinblick auf eine mögliche terroristische Attacke im Besonderen identifiziert. Sie werden zuerst gesellschaftlich diskreditiert und anschließend rechtlich diskriminiert. Durch die Bedeckungs- und Verschleierungsverbote ist es muslimischen Frauen, die das Tragen dieser Kleidung in der Öffentlichkeit aus religiösen Gründen für verbindlich halten, letztlich nicht mehr möglich, sich in der Öffentlichkeit zu bewegen. Genau solche Folgen der Angst und der Projektion von Gefahren auf Angehörige bestimmter Religionen sind es, die Nussbaum als Ausdruck religiöser Intoleranz bezeichnet.

Die „Politik der Angst“ fungiert demnach gewissermaßen als Gegenmodell zur Politik der Unparteilichkeit, die die politische Philosophie des Liberalismus auszeichnet. Nussbaums eigenes Modell einer der religiösen Vielfalt der Gegenwart und dem liberalen Prinzip des gleichen Respekts gegenüber allen Religionen angemessenen Politik ruht auf zwei Prinzipien. Diese „sind, historisch gesehen, eher amerikanisch als europäisch. Europäer teilen einige der Grundvoraussetzungen (den Gedanken der Menschenwürde und Gleichheit), doch insgesamt haben sie nicht in gleichem Maße gesetzliche Systeme errichtet, die auf Gerechtigkeit gegenüber Minderheiten bei allen Themen achten, wo Mehrheiten die Gesetze machen". 8

In normativer Hinsicht gründet sich Nussbaums Konzeption auf zwei Prinzipien: Das erste Prinzip ist jenes der gleichen Würde aller Menschen, das nach Nussbaums Auffassung sowohl gut begründet ist als auch über ein hohes $\mathrm{Zu}$ -

\footnotetext{
6 Vgl. Christian Spieß, Zwischen Gewalt und Menschenrechten. Religion im Spannungsfeld der Moderne, Paderborn 2016, S. 35-40.

7 Nussbaum, Neue religiöse Intoleranz, S. 47.

8 Ebd., S. 59.
} 
stimmungspotenzial verfügt. Das zweite Prinzip, in dem die eigentliche Besonderheit dieses Ansatzes liegt, ist das Prinzip der Vulnerabilität bzw. der Verletzlichkeit: „Wir können durch schlechte Zustände in der Welt ernsthaft behindert werden, bei unseren Aktivitäten aufgehalten oder gar verletzt und innerlich beschädigt werden. “9 Die Verletzlichkeitsprämisse bedeutet, „dass wir, um dem Gewissen (überall) gleichen Respekt entgegenzubringen, [...] Bedingungen schaffen müssen, die die Freiheit des Glaubens, des Glaubensausdrucks und der Glaubenspraxis [...] schützen". ${ }^{10}$ Mit diesem zweiten Prinzip verschiebt sich Nussbaums Argumentation von einer Politik strikter Gleichbehandlung zu einer Politik der Akkommodation - von „Lockes Neutrality“ zu „Accomodation“, wie sie sagt. Mit diesem Begriff der Akkommodation (in der deutschen Übersetzung sehr unglücklich teils mit „Ausgleich“, teils mit „Anpassung“ wiedergegeben) verbindet Nussbaum die besondere Rücksicht auf das Gewissen religiöser, aber auch atheistischer Menschen, die im Gleichbehandlungsgrundsatz nicht enthalten ist. ${ }^{11}$ Politische Gemeinwesen müssen sich mit Rücksicht auf die Vulnerabilität des Menschen an besondere (religiöse) Lebensformen „anpassen“. Wohlgemerkt: Es geht um die Anpassung der politischen Gemeinwesen an die religiösen Lebensformen, nicht umgekehrt - im Sinne der Assimilation um die Anpassung der religiösen Menschen und Gruppen an einen vorgegebenen (säkularen oder auch religiös geprägten) Standard. Die beiden Prinzipien gleiche Würde und Vulnerabilität - verschränkt Nussbaum schließlich zu einem dritten Prinzip, demzufolge „die Freiheit umfassend und für alle gleich sein muss“. ${ }^{12}$ Dieses Prinzip, so jedenfalls Nussbaum, weist große Ähnlichkeit zu John Rawls' Idee auf, wonach die Gerechtigkeit das größte Maß an Freiheit erfordere, das mit einer entsprechend großen Freiheit aller anderen vereinbar ist. Um dorthin zu gelangen, bedarf es nach Nussbaums Auffassung aber eben einer besonderen Rücksicht auf Vulnerabilität. ${ }^{13}$

Nussbaums Analyse der Fragilität des gleichen Respekts vor unterschiedlichen religiösen Überzeugungen erscheint angesichts gegenwärtiger Entwicklungen plausibel. Und ihre normative Konzeption einer Kombination von Gleichheitsprinzip und besonderem Respekt vor religiösen Überzeugungen, erscheint für eine Religionspolitik in weltanschaulich pluralen Gesellschaften angemessen. Ohne Nussbaum im Detail zu folgen, soll ihr Ansatz im Folgenden

9 Ebd., S. 63.

10 Ebd., S. 64.

11 Nussbaum, The New Religious Intolerance, S. 68-90.

12 Ebd., S. 64.

13 Vgl. dazu (und zu einer Gegenüberstellung mit der gänzlich anderen Position von Mark Lilla) Christian Spieß, Neue Intoleranz gegenüber Religionen und Bedrohung durch politische Theologien: Martha Nussbaum und Mark Lilla, in: Oliver Hidalgo / Christian Polke (Hg.), Staat und Religion, Wiesbaden 2017, S. 429-441. 
mit drei Modellen der Religionspolitik konfrontiert werden, bevor die Religionspolitik in Österreich in diese Überlegungen eingeordnet werden kann.

\section{Drei Modelle der Religionspolitik angesichts des Faktums des Pluralismus}

Den folgenden Ausführungen liegen drei Prämissen (auf den Ebenen Politik, Gesellschaft und Individuum) zugrunde: Erstens kann das politische Modell der „westlichen Moderne“ - also etwa: freiheitliche Verfassungsstaaten mit ausgeprägten demokratischen Mitwirkungsrechten - nicht mehr ohne weiteres als selbstverständliches Ziel politischer Entwicklung betrachtet werden; vielmehr steht dieses Modell zur Disposition. Das schließt unterschiedliche Bestimmungen des Verhältnisses von Religion und Politik ein. ${ }^{14}$ Ähnliches gilt zweitens für den Bedeutungswandel des Religiösen in unterschiedlichen Gesellschaften, also für die gesellschaftliche Säkularisierung, die äußerst disparat verläuft. ${ }^{15}$ Und drittens haben sich diese Säkularisierungsdynamiken auf die persönlichen Haltungen der Individuen zu Religion und Religiosität in unterschiedlicher Weise ausgewirkt. ${ }^{16}$ Für die Verhältnisbestimmung von Religion und Politik bedeutet dies, dass im Rahmen säkularer Verfassungsstaatlichkeit religiöse Pluralität in sehr unterschiedlicher Weise gestaltet und eingehegt werden kann. Bereits die Bandbreite der religionspolitischen Varianten im westlichen Europa ist enorm. Der knappe Verweis auf liberale Grundrechte, auf das Recht auf Religionsfreiheit, reicht bei weitem nicht mehr aus, um eine religionspolitische Position zu begründen und zu konturieren. Dies haben die Streitpunkte der vergangenen Jahre eigentlich eindringlich vor Augen geführt. Es geht bei den zahlreichen Ansprüchen, die religiöse Menschen oder Religionsgemeinschaften vortragen, inzwischen häufig um Ausnahmen und Privilegien, um die Zulassung von Handlungsweisen, die aus religiösen Gründen erlaubt sein sollen. Für die Beschneidung von Knaben etwa wird ein solches Privileg beansprucht, ohne dass darüber hinaus die allgemeinen Regeln des Strafgesetzbuchs zur Körperverlet-

14 Vgl. David Martin, A General Theory of Secularization, Oxford 1978.

15 Vgl. José Casanova, Public Religions in the Modern World, Chicago-London 1994; zur enormen Spannweite der unterschiedlichen Interpretationen der Säkularisierung vgl. Karl Gabriel / Christel Gärtner / Detlef Pollack (Hg.), Umstrittene Säkularisierung. Soziologische und Historische Analysen zur Differenzierung von Religion und Politik, Berlin 2012.

16 Vgl. v. a. die verschiedenen Arbeiten von Charles Taylor, in deren Zentrum letztlich die Frage nach der Veränderung religiöser Orientierung (oder Identität) der Individuen angesichts der Säkularisierungen (bzw. „Säkularismen“) steht; z. B. Charles Taylor, Quellen des Selbst. Die Entstehung der neuzeitlichen Identität, Frankfurt 1996; Charles Taylor, Ein säkulares Zeitalter, Berlin 2009. 
zung in Frage gestellt werden. Dass derartige Sonderbehandlungsansprüche problematisch sind, zeigt das heftig umstrittene Urteil des Kölner Landgerichts, in dem für die religiös motivierte Beschneidung eines Knaben der Tatbestand der Körperverletzung festgestellt wird. Zwar befremdet es natürlich, wie freimütig das Gericht das „Wohl des Kindes“ glaubt bestimmen zu können und sich sogar anmaßt, von einem „Interesse des Kindes“ zu wissen, „später selbst über seine Religionszugehörigkeit entscheiden zu können“. ${ }^{17}$ Aber der entscheidende Hinweis, dass die Religionsfreiheit in Verbindung mit dem Erziehungsrecht der Eltern einerseits mit dem Recht des Kindes auf körperliche Unversehrtheit andererseits konkurriert, verweist auf die entscheidende Frage: Welche Spielräume räumt der säkulare Staat für religiöse Praxis ein? Es geht nicht nur um die Frage, ob ein Menschenrecht gewährt wird oder nicht, sondern es geht um die Abwägung unterschiedlicher, konkurrierender und bei nüchterner Betrachtung jeweils gut begründeter Ansprüche.

Im Wesentlichen können drei Möglichkeiten unterschieden werden, wie die Politik diese Herausforderung annimmt: erstens das Modell einer etablierten und privilegierten Religion; zweitens das Modell der Laicité; drittens das Modell eines religionspolitischen Pluralismus. Das Modell der Privilegierung (etwa einer established church oder einer Staatskirche) geht von einer legitimen Verbindung von Religion und Politik aus. Das Modell der Laicité geht davon aus, dass zum einen Religion und Politik getrennt sind und dass zum anderen die Religion so weit wie möglich aus der Öffentlichkeit verdrängt werden soll; begründet wird dies in der Regel mit den schädlichen Wirkungen oder Potentialen der Religion. Das Modell des religionspolitischen Pluralismus geht von grundsätzlich gleichen Freiheitsrechten der unterschiedlichen Religionsgemeinschaften aus. Selbstverständlich begegnen in der Regel Mischformen dieser Modelle. So befindet sich die Laicité in Frankreich (und erst recht jene in der Türkei oder in Indien) in einem ständigen Wandel beispielsweise im Hinblick auf die Rolle religiöser Bildungsträger. Das formal staatskirchliche System des Vereinigten Königreichs bietet erhebliche Spielräume für religiösen Pluralismus. Das tendenziell religionspluralistische System der Bundesrepublik Deutschland wiederum weist Spuren der Privilegierung der christlichen Kirchen auf. Zwar lassen sich also die europäischen Nationalstaaten jeweils grob einem der drei religionspolitischen Modelle zuordnen. Gerade das Beispiel Deutschland zeigt aber, dass auch innerhalb eines Nationalstaates (und innerhalb einer entsprechenden Rechtsprechung) alle drei Tendenzen nebeneinander existieren können. Einen der prominentesten religionspolitischen Konflikte stellt in Deutschland der „Kopftuchstreit“ dar, bei dem es seit vielen Jahren um die Frage geht, ob eine Lehrerin an einer staatlichen Pflichtschule ein religiös motiviertes

17 Landgericht Köln, Aktenzeichen 151 Ns 169/11, Urteil vom 7. Mai 2012. 
Kopftuch tragen darf. Einerseits wurde - im Sinne der negativen Religionsfreiheit - beansprucht, dass Kinder in der staatlichen Pflichtschule nicht mit den religiösen Überzeugungen einer Lehrerin konfrontiert werden dürfen. Andererseits wurde - im Sinne der positiven Religionsfreiheit - das Recht der muslimischen Lehrerin auf das Tragen einer ihrer religiösen Orientierung angemessenen Kleidung hervorgehoben. In Deutschland tendierten Gesetzgebung und Rechtsprechung in der Folge zunächst zu einer stärkeren Gewichtung der negativen Religionsfreiheit und der staatlichen Neutralitätspflicht. Das Religionsausübungsrecht wurde demgegenüber als weniger relevant bewertet. Später zeigten sich Varianten verschiedener Art. ${ }^{18}$ Die in Bayern praktizierte unterschiedliche Behandlung der Religionen - namentlich des Christentums und des Islam - hat der Auseinandersetzung in Bezug auf den Gleichheitsgrundsatz eine besondere Wendung gegeben. Der Bayerische Verfassungsgerichtshof weist in seiner Entscheidung ${ }^{19}$ darauf hin, dass die Bekenntnisfreiheit der Lehrkräfte mit der negativen Religionsfreiheit der Schülerinnen und Schüler sowie der Eltern, die die von der Lehrkraft zum Ausdruck gebrachte Überzeugung nicht teilen, kollidiere. Die Religionsfreiheit, so die Auffassung des Gerichts, schließe das Recht der Eltern ein, ihrem Kind die von ihnen für richtig gehaltene religiöse oder weltanschauliche Erziehung zu vermitteln. Dabei könnten sie zwar nicht beanspruchen, generell vom Staat vor fremden Bekenntnisäußerungen geschützt zu werden. Im Fall der Lehrerin an einer staatlichen Schule sei aber die besondere Situation gegeben, dass die Lehrkraft bei der Wahrnehmung des Schuldienstes nicht nur auf der Seite des Staates stehe, sondern dass der Staat durch sie handle. Zudem sei im Schulunterricht das Gebot der staatlichen Neutralität gegenüber Religionsgemeinschaften zu wahren. Dies mutet zunächst wie die klassische laizistische Argumentation an, bekommt dann aber eine überraschende Wendung: Die staatliche Neutralität und der Gleichbehandlungsgrundsatz würden, so der Bayerische Verfassungsgerichtshof, nicht beeinträchtigt, wenn religiös konnotierte Kleidungsstücke nicht im Allgemeinen verboten werden, sondern nur in Bezug auf bestimmte Religionsgemeinschaften. Demnach darf zwar das muslimische Kopftuch verboten werden, zugleich aber dürfen christliche Symbole und christlich konnotierte Kleidungsstücke - etwa eine Ordenstracht - erlaubt werden. Dies sei zulässig, weil der Bayerischen Verfassung eine christliche Wertordnung zugrunde liege und in der Präambel sogar eine Staats- und Gesellschaftsordnung ohne Gott abgelehnt werde. Der Sinn des Neutralitätsgrundsatzes könne also nicht die Eliminierung alles Religiösen sein. Die Verfassung bestimme ausdrücklich, „dass die Schüler nach

18 Vgl. zum Folgenden Spieß, Zwischen Gewalt und Menschenrechten, S. 122-125.

19 Bayerischer Verfassungsgerichtshof, Aktenzeichen Vf. 11-VII-05, Entscheidung vom 15. Januar 2007. 
den Grundsätzen der christlichen Bekenntnisse zu unterrichten und zu erziehen sind“. ${ }^{20}$ Recht lapidar und für juristische Verhältnisse wohl reichlich unspezifisch formuliert das Gericht: „Der Begriff der religiös-weltanschaulichen Neutralität des Staates ist vielschichtig. “21 Bemerkenswert ist zudem, dass en passant auch die negative Religionsfreiheit muslimischer Schüler und Schülerinnen geringer bewertet wird als jene ihrer christlichen Klassenkameraden.

Gegenüber dieser offenen Ungleichbehandlung der Religionen entspricht die Variante eines zur Laicité tendierenden Verbots sämtlicher religiöser Zugehörigkeitsbekundungen zumindest dem Gleichbehandlungsgrundsatz. Im „Berliner Neutralitätsgesetz" heißt es dementsprechend:

„Lehrkräfte und andere Beschäftigte mit pädagogischem Auftrag in den öffentlichen Schulen nach dem Schulgesetz dürfen innerhalb des Dienstes keine sichtbaren religiösen oder weltanschaulichen Symbole, die für die Betrachterin oder den Betrachter eine Zugehörigkeit zu einer bestimmten Religions- oder Weltanschauungsgemeinschaft demonstrieren, und keine auffallenden religiös oder weltanschaulich geprägten Kleidungsstücke tragen. “22

Abgesehen davon, dass das positive Recht auf Religionsausübung bei dieser auf Gleichbehandlung zielenden Regelung zugunsten der negativen Religionsfreiheit praktisch völlig auf der Strecke bleibt, wird offensichtlich auch nicht bedacht, dass ein solches Verbot für Personen, für die eine bestimmte Kleidung ein Teil der religiösen Lebensform ist, wesentlich stärkere einschränkende Verbotswirkungen hat als für Personen, für die dies nicht der Fall ist - von Gleichbehandlung kann also nur eingeschränkt die Rede sein.

Die Position des Bayerischen Verfassungsgerichtshofs repräsentiert die oben genannte erste Form der Religionspolitik (Bevorzugung einer bestimmten Religion bzw. religiösen Orientierung). Die Position des Berliner Neutralitätsgesetzes repräsentiert die zweite oben genannte Form der Religionspolitik (Gleichbehandlung unterschiedlicher religiöser Orientierungen). Beide Positionen tendieren aber - im ersten Fall de jure, im zweiten Fall de facto - zur Benachteiligung der muslimischen Lehrerin. Nur eine Position, die der dritten oben genannten Form der Religionspolitik eines religiösen Pluralismus entspricht, berücksichtigt die besondere Bedeutung des Kopftuchs als Teil der religiösen Lebensform und der personalen Identität der muslimischen Lehrerin. Eine solche Position wird seit 2015 vom deutschen Bundesverfassungsgericht vertreten. In seinem Beschluss zum Schulgesetz des Landes Nordrhein-Westfalen, das ein generelles Verbot religiöser Kennzeichen vorsah, formuliert das Gericht die Auffassung, dass weder eine Bevorzugung einer Religion gegenüber

20 Ebd.

21 Ebd.

22 Gesetz zu Artikel 29 der Verfassung von Berlin vom 27. Januar 2005, \$2. 
anderen Religionen noch eine pauschale Restriktion der Bekenntnisfreiheit zulässig ist. Demnach gewährleistet der „Schutz des Grundrechts auf Glaubensund Bekenntnisfreiheit [...] auch Lehrkräften in der öffentlichen bekenntnisoffenen Gemeinschaftsschule die Freiheit, einem aus religiösen Gründen als verpflichtend verstandenen Bedeckungsgebot zu genügen, wie dies etwa durch das Tragen eines islamischen Kopftuchs der Fall sein kann. ${ }^{(23}$ Es geht demnach um das Befolgen eines religiösen Gebotes, das im Fall der Beschwerdeführerinnen vor dem Verfassungsgericht als „unbedingte religiöse Pflicht und als elementare[r] Bestandteil einer am Islam orientierten Lebensweise" aufgefasst wird.

„Diese religiöse Fundierung der Bekleidungswahl ist auch mit Rücksicht auf die im Islam vertretenen unterschiedlichen Auffassungen zum sogenannten Bedeckungsgebot nach geistigem Gehalt und äußerer Erscheinung hinreichend plausibel. Dabei kommt es nicht darauf an, dass der genaue Inhalt der Bekleidungsvorschriften für Frauen unter islamischen Gelehrten durchaus umstritten ist. ${ }^{\text {"24 }}$

Die personale Identität der betroffenen Frauen ist berührt, insofern plausibel dargelegt wird, dass es sich beim Gebot, ein Kopftuch zu tragen,

„entsprechend dem Selbstverständnis von Teilen im Islam [...] um ein imperatives religiöses Bedeckungsgebot in der Öffentlichkeit handelt, das zudem nachvollziehbar [die] persönliche Identität berührt [...]. Dass auf diese Weise derzeit faktisch vor allem muslimische Frauen von der qualifizierten beruflichen Tätigkeit als Pädagoginnen ferngehalten werden, steht zugleich in einem rechtfertigungsbedürftigen Spannungsverhältnis zum Gebot der tatsächlichen Gleichberechtigung von Frauen [...]. Vor diesem Hintergrund greift das gesetzliche Bekundungsverbot in ihr Grundrecht auf Glaubens- und Bekenntnisfreiheit trotz seiner zeitlichen und örtlichen Begrenzung auf den schulischen Bereich mit erheblich größerem Gewicht ein, als dies bei einer religiösen Übung ohne plausiblen Verbindlichkeitsanspruch der Fall wäre.“25

\section{Fazit: Plädoyer für eine präzis deklarierte Religionspolitik}

Der säkulare Verfassungsstaat betrachtet religiöse Menschen prima facie nicht als Störenfriede und Religionsgemeinschaften nicht als Fremdkörper, sondern als Personen oder Kollektive, die das Recht haben, ihre jeweiligen Vorstellungen eines guten Lebens und ihre damit korrespondierenden Lebenspläne zu verwirklichen. Die Religion hat in dieser Hinsicht also einen positiv bestimmten Ort im Menschenrechtsethos und in der modernen Staatsidee. Säkulare Verfas-

23 Bundesverfassungsgericht, Beschluss des Ersten Senats vom 27. Januar 2015-1 BvR 471/10, Leitsätze und Rn. 83.

24 Ebd., Rn. 88f.

25 Ebd., Rn. 96. 
sungsstaaten haben aber auch die Pflicht, religiöse Ansprüche und Praxisformen in einem allgemeinen System der Freiheit zu ordnen; dies schließt auch die Aufgabe ein, Menschen vor möglichen negativen Effekten der Religion zu schützen. Es kommt offenkundig mitunter zu Konflikten zwischen Menschen unterschiedlicher ethnischer und kultureller Herkunft, zwischen Religiösen unterschiedlicher Provenienz, zwischen religiösen und nicht-religiösen Menschen. Die Aufgabe der Politik ist es, den Trägern dieser unterschiedlichen Orientierungen gerecht zu werden und für die entsprechenden Lebensformen in einem für alle erträglichen bzw. grundsätzlich zustimmungsfähigen Maß Freiheitsspielräume zu öffnen und zu gewährleisten. „In den modernen westlichen Industriegesellschaften ist das Grundrecht der Religionsfreiheit zu einem zentralen Instrument der Verarbeitung von Kulturkonflikten geworden. “26

Dass die Prozesse der „Verarbeitung von Kulturkonflikten“ dabei nicht neutral sind, zeigt sich schon in der Wahrnehmung und diskursiven Verarbeitung religiöser Ansprüche, wenn etwa davon die Rede ist, dass Frauen eine Bedeckung tragen müssen (anstatt: dass sie eine Bedeckung tragen dürfen). Dies entspricht zwar möglicherweise der Perspektive der Mehrheitsgesellschaft, für die das Tragen einer Kopfbedeckung unüblich und außergewöhnlich ist. Aber solche, auf Konventionen beruhenden Wahrnehmungsmuster dürfen politische Entscheidungen über die Reichweite und die Ausgestaltung des Menschenrechts auf Religionsfreiheit, das letztlich natürlich auch ein Minderheitenrecht ist, nicht maßgeblich beeinflussen. Denn natürlich geht es nicht nur um die Frage, ob es Frauen erlaubt sein sollte, in der Öffentlichkeit eine Kopfbedeckung oder auch eine Verschleierung zu tragen, sondern ebenso um die Frage, ob Frauen von einem säkularen Rechtsstaat gezwungen werden dürfen, sich ohne die aus ihrer Sicht angemessene Kleidung in der Öffentlichkeit zu bewegen - und ob es im Zweifelsfall, wenn sie sich nicht ohne Verschleierung in der Öffentlichkeit bewegen möchten, eben hinzunehmen ist, dass sich diese Frauen gar nicht mehr in der Öffentlichkeit bewegen. Gerade an diesem markanten Beispiel wird deutlich, dass sich die Religionspolitik der Republik Österreich in den vergangenen Jahren erkennbar von einem Pluralismus mit weiten Freiheitsspielräumen entfernt hat und heute deutliche Merkmale der Ungleichbehandlung aufweist - und zwar eine Ungleichbehandlung, die insbesondere die Benachteiligung von Muslimen impliziert. Sowohl in den gesellschaftlichen Debatten als auch in den politischen Entscheidungen finden sich Spuren einer „neuen religiösen Intoleranz" im Sinne Martha Nussbaums. Ob sich letztlich wirklich eine Transformation der österreichischen Religionspolitik zum Modell einer privilegierten Religion oder zum Modell einer religionsskeptischen Laicité vollzieht, lässt sich

26 Christian Walter, Religionsverfassungsrecht in vergleichender und internationaler Perspektive, Tübingen 2006, S. 536. 
noch nicht sagen. Dies hängt vor allem von künftigen Regierungskonstellationen und nicht zuletzt auch von der Art und Weise ab, wie sich die einst religiös verwurzelte Volkspartei künftig religionspolitisch profiliert. Die eigentümliche Regelung des Karfreitagsfeiertags lässt eher eine insgesamt religionsdistanzierte Tendenz erwarten.

An dieser Stelle soll gar nicht für ein bestimmtes Modell der Religionspolitik plädiert werden ${ }^{27}$, sondern nur für eine ehrliche und präzise Deklaration der Religionspolitik. Es soll für eine größere politisch-ethische Sensibilität im Hinblick auf religionspolitische Änderungen und mögliche Weichenstellungen plädiert werden, und auch dafür, dass religionspolitische Gesetzgebung mit islamfeindlicher Tendenz nicht in integrationspolitischer oder bildungspolitischer Tarnung versteckt wird. Wenn die Politik nicht mehr das Modell des religiösen Pluralismus auf der Grundlage gleicher Religionsfreiheit als vorzugswürdiges Modell anerkennt, sondern zunehmend religionsskeptisch agiert oder eine Religion bzw. Konfession privilegiert und eine andere benachteiligt, sollte das zumindest eindeutig deklariert und offen mit politischen Argumenten begründet werden.

\section{Quellen}

Bayerischer Verfassungsgerichtshof, Aktenzeichen Vf. 11-VII-05, Entscheidung vom 15. Januar 2007.

Bundesgesetz, Gesamte Rechtsvorschrift für Anti-Gesichtsverhüllungsgesetz, Fassung vom 13.06.2019, Rechtsinformation des Bundes, vgl. https://www.ris.bka.gv.at/Gelten deFassung.wxe? Abfrage $=$ Bundesnormen \& Gesetzesnummer $=20009892$ (letzter Zugriff: 13.06.2019).

Bundesverfassungsgericht, Beschluss des Ersten Senats vom 27. Januar 2015-1 BvR 471/ 10, Leitsätze und Rn. 83.

Casanova, José, Public Religions in the Modern World, Chicago-London 1994.

Gabriel, Karl / Gärtner, Christel / Pollack, Detlef (Hg.), Umstrittene Säkularisierung. Soziologische und Historische Analysen zur Differenzierung von Religion und Politik, Berlin 2012.

Landgericht Köln, Aktenzeichen 151 Ns 169/11, Urteil vom 7. Mai 2012.

Martin, David, A General Theory of Secularization, Oxford 1978.

Nussbaum, Martha, The New Religious Intolerance. Overcoming the Politics of Fear in an Anxious Age, Cambridge-London 2012 (dt. Martha Nussbaum, Die neue religiöse Intoleranz. Ein Ausweg aus der Politik der Angst, 2. Aufl., Darmstadt 2014).

27 Vgl. dazu etwa Christian Spieß, Religionsfreiheit zwischen gleicher Freiheit und Anerkennung der Diversität. Plädoyer für eine Politik des Religionsfreundlichen Liberalismus, in: Theologie und Glaube 108/2018, S. 3-22. 
Nussbaum, Martha, Liberty of Conscience. In Defense of America's Tradition of Religious Equality, New York 2008.

Nussbaum, Martha, The Clash Within. Democracy, Religious Violence, and India's Future, Cambridge-London 2007.

Spieß, Christian, Religionsfreiheit zwischen gleicher Freiheit und Anerkennung der Diversität. Plädoyer für eine Politik des Religionsfreundlichen Liberalismus, in: Theologie und Glaube 108/2018, S. 3-22.

Spieß, Christian, Neue Intoleranz gegenüber Religionen und Bedrohung durch politische Theologien: Martha Nussbaum und Mark Lilla, in: Oliver Hidalgo / Christian Polke (Hg.), Staat und Religion, Wiesbaden 2017, S. 429-441.

Spieß, Christian, Zwischen Gewalt und Menschenrechten. Religion im Spannungsfeld der Moderne, Paderborn 2016.

Taylor, Charles, Ein säkulares Zeitalter, Berlin 2009.

Taylor, Charles, Quellen des Selbst. Die Entstehung der neuzeitlichen Identität, Frankfurt 1996.

Walter, Christian, Religionsverfassungsrecht in vergleichender und internationaler Perspektive, Tübingen 2006. 
Open-Access-Publikation im Sinne der CC-Lizenz BY 4.0

(C) 2020, Vandenhoeck \& Ruprecht $\mathrm{GmbH} \&$ Co. KG, Göttingen ISBN Print: 9783847111658 - ISBN E-Lib: 9783737011655 


\section{Linda Hogan (Dublin)}

\section{Designing an Ethical Future: Can Artificial Intelligence Help?}

Throughout her illustrious career Ingeborg Gabriel has identified and tackled some of the most pressing ethical issues of the day. A social ethicist of note, she has written on human rights, inequality and poverty, migration, solidarity and justice, as well as on political and social ethics in Europe. Moreover, she has not only made an impact in academia, where her reputation is undisputed, but she has also engaged policy-makers, politicians and civil society activists with the objective of shaping the broader political debates about the future direction of society, and specifically how to ensure an ethical future. As the editors highlight, she believes that the achievement of justice is a permanent challenge and she recognizes the need for dialogue in the search for a more humane society. In this search for a more humane society new challenges constantly emerge, often related to the upper limits of technology. Today many of the ethical challenges are associated with the implications of the artificial intelligence (AI) revolution. As a result, it is important that the ethical implications of this technology, particularly for the field of social ethics, be interrogated.

\section{Societal Impacts of Deep Learning and Artificial Intelligence}

The media is replete with accounts of the unpredictable impacts of artificial intelligence. We are familiar with Tay, the Twitterbot designed by Microsoft engineers who unleashed a stream of racist, sexist, homophobic and Holocaust-denying tweets as it 'learned from' what was tweeted at it. The ongoing political fallout from the abuse of Facebook's News Feed algorithm and the pervasiveness of fake news online during the 2016 U.S. presidential election provides an even more stark example of how deep learning and artificial intelligence has begun to challenge many of the assumptions and norms on which societies have heretofore depended. Indeed, the ubiquity and convergence of technologies, together with the speed of their development means that many of us are unaware of the depth of their impact and of the ethical challenges that they 
may pose. Some commentators warn of a dystopian future, with the displacement of humans by superintelligences and deepening polarisation and inequality. Others anticipate a future of greater wealth and opportunity and of significant scientific advances. Whatever the ultimate outcome however, the accelerating developments in AI and machine learning will continue to have a fundamental impact on all aspects of our lives and will continue to be deployed in the arenas of policing, health, justice, education, business, media and military with sometimes dubious and often unanticipated outcomes. There have had been many false dawns in the field of artificial intelligence in the last five decades, and many of the predictions about the ubiquity and impact of artificial intelligence have not materialised. However technological developments particularly in the last decade suggest that a threshold has now been reached whereby the combined impact of deep learning, big data and significant global financial investment in these technologies is transforming core activities across many different sectors, with the potential for significant societal impact.

\section{Public Perceptions of Al: Ambivalence}

Although public discussion of AI has ebbed and flowed since the 1950s when the language of AI first began to be used, the topic has had a renaissance in the past decade. Analysing the long-term trends in the public perception of AI over a 30-year period, Fast and Horvitz note that discussion of AI has increased sharply since 2009, and that these discussions have been consistently more optimistic than pessimistic. They have found that 'hopes for AI in healthcare and education have increased over time,' however, when examining specific aspects of AI they find that 'worries of loss of control of AI, ethical concerns for AI, and the negative impact of AI on work have grown in recent years.' ${ }^{\text {.1 }}$ These findings are mirrored in recent country-specific investigations of the public perception of AI. In 2016 the Royal Society commissioned IPSOS MORI ${ }^{2}$ to survey $1,000 \mathrm{UK}$ residents on their knowledge of and perception of the benefits of deep learning and AI in different spheres of life. Those surveyed saw the greatest potential benefits in the fields of healthcare and education. However, although people could see some benefits with the use of $\mathrm{AI}$ in other fields, these were overshadowed by public disquiet. With AI deployment in the field of social care respondents were worried about the loss of human interaction, in the field of marketing there was significant

1 Ethan Fast / Eric Horvitz, Long-Term Trends in the Public Perception of Artificial Intelligence, Proceedings of the Association for the Advancement of Artificial Intelligence, 2017, pp. 963969.

2 IPSOS Mori, Public Views of Machine Learning, Findings from public research and engagement conducted on behalf of the Royal Society, London 2017. 
concern about manipulation, and in the field of finance they expressed unease about financial monitoring. Deploying AI in the context of crime detection and assessing risk of offending was also seen to have benefits. However, respondents were nervous about the dangers of stereotyping. The 2018 Bristows report Artificial Intelligence: Public Perception, Attitude and Trust provides a more extensive analysis of the UK public's understanding of, expectations from and attitudes to the use of AI. It concluded that public understanding of AI is broad but not deep, that expectations are high, but certainly not entirely positive, that young people are most optimistic about AI, that employment concerns exist, but potential workplace benefits are acknowledged, and that privacy and data protection implications are not well understood. ${ }^{3}$ Respondents also indicated that the AI industry should be accountable and responsible to the public, with more than two-thirds believing that AI should be regulated by governments or supra-national regulatory bodies, as well as wanting self-regulation by the AI industry. The 2017 Eurobarometer Attitudes towards the impact of digitisation and automation on daily life $e^{4}$ is perhaps the most extensive analysis of public perception of AI since it is based on face-to-face interviews with 28,000 EU citizens from different social and demographic categories in their native language in the 28 Member States. Here again most of respondents were positive about the impact the most recent digital technologies have had on society, the economy and their quality of life, although, similar to the Fast and Horvitz findings, there were significant variations based on age, social is class educational attainment and gender. Trust in online social network stories is weak, and related to the reliability of the brand, and citizens expect companies, national governments and EU institutions to take action in order to manage the digital changes. The analysis of a comparable survey in the USA was released in January 2019. Produced by Zhang and Dafoe, and part-funded by the Ethics and Governance of AI Fund 'Artificial Intelligence: American Attitudes and Trends' also shows that there is mixed support for AI and that, like in Europe, support for developing AI is greater among those who are wealthy, educated, male, or have experience with technology. There are also varying degrees of trust in organizations' capacity to develop and manage AI for the best interests of the public. ${ }^{5}$ Regarding the institutions in which those surveyed have confidence to manage the implications of AI in the best interests of the public, results indicate that there is 'a fair amount of confidence' in universities, the U.S. military, and various scientific organizations, technology companies (ex-

3 Bristows, Artificial Intelligence: Public Perception, Attitude and Trust, London 2018.

4 European Commission, Eurobarometer, Attitudes towards the impact of digitisation and automation on daily life, Brussels 2017.

5 Baobao Zhang / Allan Dafoe, Artificial Intelligence: American Attitudes and Trends, Center for the Governance of AI, Future of Humanity Institute, University of Oxford, January 2019. 
cluding Facebook), and intelligence organizations, with low levels of trust in federal or state governments, and the UN, with lowest levels of trust in Facebook.

\section{The Challenges of Al for Social Ethics}

The 2017 Pew Research Centre Report Code-Dependent Pros and Cons of the Algorithmic Age $e^{6}$ also captures the ambivalence that the public and researchers alike feel about deep learning and AI. Moreover, it also identifies some of the fundamental ethical questions of concern to the public, about the values that are embedded in machine learning and AI, about threats to civil liberties, the magnification of bias and discrimination, about political manipulation, financial monitoring and lack of transparency, and about the risks of moral decision-making by algorithm. For example, facial recognition systems based on deep learning have the capacity to make surveillance systems far more powerful thereby risking undermining civil and political liberties. Technologies like Google Facenet Facebook's DeepFace or the FindFace App can not only determine identities with near-perfect accuracy, but they can also identify and anticipate behaviour patterns amongst citizens. The deployment of these technologies is widespread, but citizens are generally unaware of levels of surveillance. China provides a particularly extreme example of the extensive and mostly hidden deployment of surveillance technologies. The most recent exposé was in May 2019 when Techcrunch exposed how China uses facial recognition to detect ethnicities and to label them as Han Chinese or Uyghur Muslims. ${ }^{7}$ Indeed Forbes describes the city of Xinjiang as 'an unconstrained high-tech surveillance laboratory' where, as also reported by Human Rights Watch, the smartphone app that is used by the police packages multiple data sources on monitored citizens and then tracks them so that "by monitoring the "trajectory" and location data of their phones, ID cards, and vehicles; it also monitoring the use of electricity and gas stations of everybody in the region. ${ }^{8}$ The report goes on to note that 'this is consistent with Xinjiang local government statements that emphasize officials must collect data for the IJOP system in a "comprehensive manner" from "ev-

\footnotetext{
6 Pew Research Centre, Code-Dependent Pros and Cons of the Algorithmic Age, Washington, DC 2017.

7 Techcrunch May 3 2019, see: https://techcrunch.com/2019/05/03/china-smart-city-exposed/ (accessed on May $21^{\text {st }} 2019$ ).

8 Human Rights Watch, China's Algorithms of Repression Reverse Engineering a Xinjiang Police Mass Surveillance App, New York, May $1^{\text {st }} 2019$.
} 
eryone in every household". ${ }^{9}$ In the hands of authoritarian governments these powerful technologies amplify existing threats to freedom and equality. However, the ethical threats these technologies pose transcend their potentially immoral use by authoritarian governments. Rather, the extent of data collected, the facility to model and triangulate, together with their predictive capacity also pose significant risks to civil and political liberties in democratic societies, and in particular to marginalised individuals and groups. As noted by the Berkman Klein Centre in its assessment of 'Artificial Intelligence and Human Rights' in relation to the rights to equality, free expression, association, assembly and work (...) the impact of AI (..) has been more negative than positive to date. ${ }^{, 10}$

The predictive capacity of deep learning algorithms raises further ethical challenges. Predictive technologies are already extensively deployed in financial, health and criminal justice systems and assessments of their equity relative to traditional human-based systems vary. For example, The Berkman Klein Centre report notes a number of arenas where the deployment of AI has had positive outcomes. Regarding access to the financial system it has found that 'compared to the status quo credit scoring algorithms, the introduction of AI into the lending process is likely to have an overall positive impact on the ability of low-income borrowers to access credit'. This is because the wide variety of data sources used seems to improve the ability of well-qualified individuals from marginalised communities to access credit. ${ }^{11}$ However, determining the ethical and human rights impacts of the predictive dimension of AI technologies is complex, in part because these technologies are being implemented in existing social institutions that already discriminate to a greater or lesser extent. A further complexity relates to the nature, quality and extent of the data on which the predictive capacity of AI depends. In Weapons of Math Destruction: How Big Data Increases Inequality and Threatens Democracy, Cathy O' Neill argues that predictive analytics based on algorithms tend to punish the poor. ${ }^{12}$ She uses algorithmic hiring practices as one example, but her analysis extends to a range of social and economic contexts, arguing that in most cases, on account of the partial, discriminatory and decontextualized nature of the data on which AI is trained, or trains itself, it is inevitable that machine learning accentuates existing biases and exclusions. Moreover, she points out that as AI is embedded further

9 Zak Doffman, China Is Using Facial Recognition To Track Ethnic Minorities, Even In Beijing, in: Forbes May 3/2019.

10 Filippo Raso / Hannah Hilligoss / Vivek Krishnamurthy / Christopher Bavitz / Levin Kim, Artificial Intelligence and Human Rights, Opportunities and Risks, Cambridge MA., Berkman Klein Centre 2018.

11 Ibid., p. 31.

12 Cathy O' Neill, Weapons of Math Destruction: How Big Data Increases Inequality and Threatens Democracy, USA 2016. 
and deeper into business practices the problem of the amplification and reinscription of bias becomes a major ethical problem. The transparency and explicability of decisions, i.e. the problem of the black box', is also an issue although some recently developed techniques like rule extraction go some way to address this issue.

\section{Beneficial Al: How and Who?}

Max Tegmark characterises the responses to AI as being composed of three different kinds. There are, he argues, the techno-sceptics, the digital utopians and those who belong to the beneficial AI movement. ${ }^{13}$ The techno-sceptics deem the prospect of superintelligences and other such developments to be unlikely and believe that the current conversation is simply a re-run of an earlier apocalyptic discussion based on similarly extravagant claims. Digital utopians exemplified, according to Tegmark, by Larry Page of Google believe that 'digital life is the natural and desirable next step in the cosmic evolution and that if we let digital minds be free rather than try to stop or enslave them, the outcome is almost certain to be good ${ }^{14}$ Those promoting the beneficial AI movement by contrast see great potential for AI, but insist that the goal must be beneficial intelligence, not simply undirected intelligence. They recognise that the questions raised by $\mathrm{AI}$ are of monumental moral significance for humanity and are focused on ensuring that technological developments and ethical conversations go hand in hand. ${ }^{15}$

If technological developments and ethical conversations are to go hand in hand then this current moment presents us with an opportunity to consider which values ought to be embedded in the design of AI, in whose interest, and for whose benefit the contexts of AI deployment should be decided and what kinds of regulatory and supervisory structures are needed? Like all major technological developments through history, AI will transform social and political norms, and will create new contexts in which there will be beneficiaries and losers. It will alter the nature of work, will revolutionise healthcare and will provide personalised versions of medicine, education, information and entertainment for those who can pay. Indeed, this is well understood by the public, as seen from the multiple analyses of their perception of AI and its impact. As the question of which values ought to guide AI development is discussed it is important to remember that AI is not developed or deployed in a vacuum. Rather, the values that are embedded and

13 Max Tegmark, Life 3.0 Being Human in the age of Artificial Intelligence, USA 2017.

14 Ibid., pp. 30-37.

15 Idem. 
replicated in AI are precisely the values that are already operative in society. Thus, the values that a society prioritises (whether these be efficiency, wealth accumulation, personal autonomy, equality, shared benefit), the explicit or unacknowledged biases that it purveys (for example assumptions about the links between ethnicity or race and social responsibility/mobility), the trade-offs that a society accepts (for example, personalisation over privacy) and the inequalities that it tolerates, will not only be embedded in AI systems, but will also be amplified through AI. Of course, AI brings new challenges and new ethical questions, however at its most fundamental level the deployment of reflexive/ self-learning algorithms/systems replicate and magnify the values around which a society is already structured and amplify existing patterns of human decision-making. The only decisions AI makes are those that it is designed to make.

\section{Trustworthy Al and Value Sensitive Design}

In April 2018, the European Commission published a Communication, which set out a blueprint for a three-pronged approach to increase public and private investment in Artificial Intelligence, to prepare for socio-economic changes and to ensure an appropriate ethical and legal framework. As part of this approach, the Commission established the Artificial Intelligence High-Level Expert Working Group (AI HLEG), aiming to support the creation of the European Union's strategy on AI. A core component of the strategy has been to support the development of ethical, human-centric AI. The most recent stage in that strategic process has been the issuing of 'Ethics Guidelines for Trustworthy AI', ${ }^{16}$ which sets out a framework for achieving ethical AI. Following in the path of its 2015 'Opinion on (Legal Questions Related to) Robotics and $\mathrm{AI}^{17}$ the report is unambiguous in its conviction that the design and development of AI should respect the fundamental values and the rights of freedom, autonomy, human dignity, non-discrimination and equality. In the 2019 Guidelines it distils these fundamental values to four. These are the principles respect for human autonomy, prevention of harm, fairness and explicability. In addition to enumerating the ethical principles and their correlated values that must be respected in the development, deployment and use of AI systems, the 'Ethics Guidelines' also provide guidance on how Trustworthy AI can be realised, by listing seven requirements that AI systems should meet in order to be trustworthy. These are:

16 European Commission, High-Level Expert Group on Artificial Intelligence, Ethics Guidelines for Trustworthy AI, Brussels 2019.

17 European Commission, Expert Group on Ethics, Opinion on (Legal Questions Related to) Robotics and AI, Brussels 2015. 
human agency and oversight, technical robustness and safety, privacy and data governance, transparency, diversity, non-discrimination and fairness, societal and environmental well-being and accountability. In addition, it establishes a concrete and non-exhaustive assessment list aimed at operationalising the key requirements of Trustworthy AI. Taken together this multi-levelled initiative gives concrete expression to the precautionary principle that has long been the hallmark of EU responses to technological development. It also recognises the importance of proportionality in respect of risks. The assessment list for operationalising Trustworthy AI is being piloted in different contexts and by multiple stakeholders (there is an Open Call for participants) and this, together with the creation of a forum to exchange best practices for the implementation of Trustworthy AI indicates the seriousness with which the EU is pursuing this path.

Although only recently released, the 'Ethics Guidelines' have already been criticised, both by those who believe that 'Europe will not win the AI race by philosophizing on the side-lines or applying the precautionary principle to $\mathrm{AI}^{18}$ and those who believe that 'the Trustworthy AI narrative is, in reality, about developing future markets and using ethics debates as elegant public decorations for a large-scale investment strategy. ${ }^{19}$ On this latter point, Metzinger has come to this conclusion, in part because of what he regards as the dominance of industry representatives on the Expert Group as well the side-lining and co-option of ethicists to industry interests. Whatever the truth of this perception, the EU 'Ethics Guidelines' represent a significant milestone in the articulation of an international standard for trustworthy AI. Moreover, notwithstanding the European Union's leadership in the conversation about ethical AI, the scientists and engineers responsible for developing these technologies have also played a key role in highlighting the need for ethical considerations to be part of the design process. Already in 2015 the IEEE released its 'Ethically Aligned Design', which is focused on ensuring that every 'stakeholder involved in the design and development of autonomous and intelligent systems is educated, trained, and empowered to prioritize ethical considerations so that these technologies are advanced for the benefit of humanity.' ${ }^{20}$ The 2017 Asilomar 'Conference on Beneficial AI' also drew significant numbers of industry stakeholders, researchers, and engineers and the resulting 'Asilomar Principles' commit to the alignment in AI design and use with the values of dignity freedom, cultural

18 See: https://www.euronews.com/2019/02/05/the-eu-s-softball-approach-to-artificial-intelli gence-will-lose-to-china-s-hardball-view (accessed on May $21^{\text {st }} 2019$ ).

19 This is the view of Thomas Metzinger, Professor of Theoretical Philosophy at the University of Mainz and a member of the AI HLEG, see: https://www.tagesspiegel.de/politik/eu-gui delines-ethics-washing-made-in-europe/24195496.html (accessed on May $21^{\text {st }} 2019$ ).

20 IEEE, Ethically Aligned Design 2018, see: https://standards.ieee.org/industry-connections/ ec/autonomous-systems.html (accessed on May $21^{\text {st }} 2019$ ). 
diversity, shared benefit and shared prosperity. Complementary international initiatives including those led by the UN, ${ }^{21}$ the OECD Expert Group on AI in Society, ${ }^{22}$ the Australian Human Rights Commission, ${ }^{23}$ the Canadian government ${ }^{24}$ and the US government under President Obama ${ }^{25}$ suggest that governments, international organisations and professional associations recognise the importance and urgency of these conversations. The question is whether and how these ethical principles, guidelines and frameworks can be supported by legally-binding protections for citizens.

\section{Is it too Late?}

An analysis of the multiple principles and frameworks for ethical or trustworthy AI suggest that there is a reasonable consensus on the values that should guide the design and deployment of AI. Yet there is a fundamental distrust. This distrust arises, in part, because of the lack of knowledge and understanding of AI and its implications, and particularly because of the realisation, after-the-fact, of the ubiquity of these systems. Bristows' conclusion that public understanding of AI is broad but not deep attests to this. There is also a legitimate concern about the pre-eminent role that for-profits play in this industry, as well as a concern about the concentration of this technological capacity amongst a few major players. Moreover, the controversies surrounding the various ethics Committees and initiatives housed in these major players have only served to undermine confidence in the willingness of the industry to develop AI according to the ethical principles they have adopted. ${ }^{26}$

While there is good reason to be sceptical about the prospects of ethical, human-centric and trustworthy AI, there are, nevertheless examples of ethical discussions throughout the $20^{\text {th }}$ century that have impacted, and sometimes constrained, technological developments in the public interest. For example,

21 See the AI For Good Series which is the UN's platform for dialogue on AI.

22 In 2018 the OECD's Committee on Digital Economy Policy established an Expert Group on AI in Society.

23 Australian Human Rights Commission, Artificial Intelligence, Governance and Leadership 2019, see: https://www.humanrights.gov.au/our-work/rights-and-freedoms/publications/ar tificial-intelligence-governance-and-leadership (accessed on May $21^{\text {st }} 2019$ ).

24 Government of Canada, Responsible Use of AI 2019, see: https://www.canada.ca/en/gover $\mathrm{nment/system/digital-government/modern-emerging-technologies/responsible-use-ai.html}$ (accessed on May 21 $1^{\text {st }} 2019$ ).

25 Executive Office of the President National Science and Technology Council Committee on Technology, Preparing for the Future of Artificial Intelligence, Washington DC. 2016.

26 For example in March 2019 Google established an Advanced Technology External Advisory Council (ATEAC) to consider the challenges that arise under its Google AI Principles (announced in June 2018). However, in April 2019 it was disbanded. 
through the 1950s in the fields of both biomedical sciences and nuclear energy there was a perception that Pandora's Box had been opened and that ethics could not set the framework for technological development but could only deal with the negative consequences after the fact. Moreover, there was a scepticism about what the establishment of ethical principles could achieve in the face of the momentum associated with scientific advancement. Yet, in the biomedical field, the principles of non-maleficence and beneficence, human dignity, autonomy, equality and consent (frequently criticized for their abstract nature) have indeed shaped the regulatory environment, and have been codified in ethical and legal instruments, at the national, transnational and global level. For example, the Helsinki Declaration (1964) has determined what is acceptable in terms of research on human subjects, and recognises that the research imperative can never take precedence over the interests of individual research subjects. There are also comparable international ethical codes determining the purposes and limits on genome research, the use and sale of human organs, and the regulation of reproductive technologies etc. Similarly, in the arena of nuclear energy there is a global governance and inspection regime that deals with safety, security and non-proliferation. Although frequently under strain, both the IAEA, and the Non-proliferation Treaty (1968) have performed important supervisory and mitigating functions over the decades since their inception. In the field of AI there is not, as yet, an international governance framework to address the ethical and human rights issues raised by AI. However, the development of such a regime is essential, and urgent, especially since $\mathrm{AI}$ is at a significant threshold and can be scaled either positively or negatively.

Many of our conversations tend to cluster around the threats and risks that AI poses to employment, to the reliability of news, to civil liberties. However, with the title 'Designing an Ethical Future: Can AI Help?' I wish to suggest that, although AI creates some new ethical problems, for the most part it highlights existing ethical problems, for example of systemic biases, inequality, lack of transparency, deficits in accountability in big business and government. These ethical challenges already pose a threat to the achievement of justice, but they risk being amplified and re-inscribed in and through machine learning and AI. Thus, AI provides this generation with a moment of opportunity and a moment of reckoning. It provides an opportunity to understand the high moral stakes that are associated with the scaling of these technologies, an opportunity to appreciate the risks to society when democratic principles are sacrificed in the pursuit of either efficiency or profit, an opportunity for the public to resist the lure of convenience and to engage with the digital revolution as citizens rather than simply consumers. Global initiatives like ICT4D (Information and Com- 
munications Technologies for Development ${ }^{27}$ ), as well as local ones like the Ethics Canvas ${ }^{28}$ provide hope that ethical analysis, evaluation and oversight will go hand-in-hand with technological development. In every era of transformation there are questions about how to forge an ethical future and we face these fundamental questions today. Big data, machine learning and AI raise new ethical questions and re-frame old ones in a new and more momentous context. The question is whether we have the ethical imagination and the political will to address them? Only time will tell.

\section{Sources}

Australian Human Rights Commission, Artificial Intelligence, Governance and Leadership 2019, see: https://www.humanrights.gov.au/our-work/rights-and-freedoms/publications /artificial-intelligence-governance-and-leadership (accessed on May $21^{\text {st }} 2019$ ).

Bristows, Artificial Intelligence: Public Perception, Attitude and Trust, London 2018.

Doffman, Zak, China Is Using Facial Recognition to Track Ethnic Minorities, Even In Beijing, in: Forbes May 3/2019.

European Commission, High-Level Expert Group on Artificial Intelligence, Ethics Guidelines for Trustworthy AI, Brussels 2019.

European Commission, Eurobarometer, Attitudes towards the impact of digitisation and automation on daily life, Brussels 2017.

European Commission, Expert Group on Ethics, Opinion on (Legal Questions Related to) Robotics and AI, Brussels 2015.

Executive Office of the President National Science and Technology Council Committee on Technology, Preparing for the Future of Artificial Intelligence, Washington DC. 2016.

Fast, Ethan / Horvitz, Eric, Long-Term Trends in the Public Perception of Artificial Intelligence, Proceedings of the Association for the Advancement of Artificial Intelligence, 2017, pp. 963-969.

Government of Canada, Responsible Use of AI 2019, see: https://www.canada.ca/en/gov ernment/system/digital-government/modern-emerging-technologies/responsibleuse-ai.html (accessed on May $21^{\text {st }} 2019$ ).

Human Rights Watch, China's Algorithms of Repression Reverse Engineering a Xinjiang Police Mass Surveillance App, 1 May 2019.

IEEE, Ethically Aligned Design 2018, see: https://standards.ieee.org/industry-connecti ons/ec/autonomous-systems.html (accessed on May $21^{\text {st }} 2019$ ).

27 ICT4D (Information and Communications Technologies for Development) is an initiative aimed at bridging the digital divide and aiding economic development by ensuring equitable access to up-to-date communications technologies. A number of projects are examining how to leverage AI for development and in support of the Sustainable Development Goals.

28 Designed in Trinity College Dublin by Wessel Reijers and Dave Lewis the Ethics Canvas is a tool that requires designers of adaptive algorithms to interrogate the ethical implications of their technologies while they are developing them, see: https://www.ethicscanvas.org/can vas/index.php (accessed on May $21^{\text {st }} 2019$ ). 
IPSOS Mori, Public Views of Machine Learning, Findings from public research and engagement conducted on behalf of the Royal Society, London 2017.

Pew Research Centre, Code-Dependent Pros and Cons of the Algorithmic Age, Washington DC. 2017.

O' Neill, Cathy, Weapons of Math Destruction: How Big Data Increases Inequality and Threatens Democracy, USA 2016.

Raso, Filippo / Hilligoss, Hannah / Krishnamurthy, Vivek / Bavitz, Christopher / Kim, Levin, Artificial Intelligence and Human Rights, Opportunities and Risks, Cambridge MA., Berkman Klein Centre, 2018.

Techcrunch May 3 2019, see: https://techcrunch.com/2019/05/03/china-smart-city-ex posed/ (accessed on May $21^{\text {st }} 2019$ ).

Tegmark, Max, Life 3.0, Being Human in the age of Artificial Intelligence, USA 2017.

Zhang, Baobao / Dafoe, Allan, Artificial Intelligence: American Attitudes and Trends, Center for the Governance of AI, Future of Humanity Institute, University of Oxford, January 2019. 


\section{Ulrich H.J. Körtner (Wien)}

\section{Verantwortungsethik in Medizin und Pflege}

\section{Grundfragen der Medizin- und Pflegeethik}

Nicht nur in der Medizin, sondern auch in der Pflege und in der Altenhilfe treten ethische Fragestellungen, bisweilen auch Konflikte auf, deren Lösung nicht nur ein intensives Nachdenken und eine bestimmte Kommunikationskultur, sondern auch ein gewisses ethisches Fachwissen verlangen. So ist neben der Medizinethik in jüngerer Zeit auch eine eigenständige Pflegeethik entstanden.

In unserer Alltagssprache werden die Begriffe „Ethik“ und „Moral“ häufig synonym verwendet. Firmen und Banken beklagen die schlechte „Zahlungsmoral“ ihrer Kunden. Militärische Vorgesetzte kritisieren die „schlechte Moral“ ihrer Truppe. Trainer und Fans sind von der „Spielermoral“ ihres Vereins enttäuscht. Ein „unmoralisches Angebot“ kann aber ebenso gut als „unethisch“ zurückgewiesen werden. Gesundheits- und umweltbewusste Kunden oder auch Menschen mit einer Sensibilität für die Probleme der Dritten Welt verlangen nach „ethischen Produkten“.

Die Wörter „Moral“ und „Ethik“ stehen in den genannten Beispielen für Einsatzbereitschaft, Ehrlichkeit und Fairness, für Umweltbewusstsein und Gerechtigkeitssinn. Mit alldem haben es Moral und Ethik auch tatsächlich zu tun. Wir müssen aber begrifflich zwischen Moral und Ethik unterscheiden.

Ist Ethik allgemein eine kritische Theorie der Moral, so sind Gegenstand und Aufgabe der Medizin die Reflexion medizinischen Handelns und Planens, aber auch der medizinischen Forschung, unter sittlichen Gesichtspunkten. Entsprechend gilt von der Pflegeethik, das sie das pflegerische Handeln und Planen unter sittlichen Gesichtspunkten reflektiert. ${ }^{1}$

Alle Ethik kreist um den Begriff des Guten. Moral und Ethik fragen nach dem Guten. Die Unterscheidung zwischen Gut und Böse bzw. Gut und Schlecht ist für jede moralische Beurteilung menschlichen Handelns grundlegend. Nun lassen sich aber verschiedene Bedeutungen des Guten unterscheiden. Wir unter-

1 Vgl. Ulrich H.J. Körtner, Grundkurs Pflegeethik, 3. Aufl., Wien 2017. 
scheiden zwischen dem technisch Guten („Ich kann gut spritzen“), dem ästhetisch Guten („Das war ein guter Film“; „Es hat mir gut geschmeckt“) und dem moralisch Guten („Das ist eine gute Tat“; „Er ist ein guter Mensch“).

In Medizin und Pflege spricht man von "good clinical practice“. Doch was „state of the art" medizinisch-technisch oder pflegerisch-technisch gut ist, muss noch nicht in moralischer Hinsicht gut sein.

„Häufig gilt unausgesprochen die Überzeugung, Ärzte oder Pflegende würden Probleme einfach sachgerecht, das heißt fachlich lösen. Wäre dies tatsächlich der Fall, dann hätten wir es bei den Ärzten mit Medizintechnikern zu tun, die den Namen Arzt nicht verdienen würden, und bei den Pflegenden mit Pflegerobotern, die den Namen Schwester oder Pfleger nicht verdienen würden. “2

Medizin- und Pflegeethik stellen nicht nur die Frage, ob sich das medizinische oder pflegerische Handeln und das Verhalten von Ärzten und Pflegekräften im Allgemeinen wie im konkreten Einzelfall ethisch begründen oder im Nachhinein ethisch rechtfertigen lassen. Ethisch zu prüfen sind auch die institutionellen und organisationalen Rahmenbedingungen, unter denen medizinisches und pflegerisches Handeln stattfindet. Ob Pflege in einem Krankenhaus der Maximalversorgung oder in einer Pflegeeinrichtung stattfindet, ob es sich um einen mobilen Pflegedienst oder einen Rettungsdienst handelt, ob stationär oder zu Hause gepflegt wird, all das macht einen Unterschied. Es macht auch einen erheblichen Unterschied, ob ich eine Person nur für kurze Zeit medizinisch betreue und pflege oder ob ich im Bereich der Langzeitpflege zu der zu pflegenden Person und ihren Angehörigen im Laufe der Zeit eine engere persönliche Beziehung aufbaue.

Die Organisationsstrukturen und die vorhandenen oder eingeschränkten Ressourcen haben erheblichen Einfluss auf das Pflegegeschehen, auf die alltäglichen und routinierten Abläufe. Gleiches gilt für die baulichen Voraussetzungen, von der Größe der Zimmer bis zur Gesamtarchitektur einer Einrichtung einschließlich ihrer Außenanlagen und ihrer Lage innerhalb einer Ortschaft oder eines Stadtviertels. Medizinethik und Pflegeethik als ethische Theorien des ärztlichen und pflegerischen Ethos befassen sich außerdem mit den Einstellungen und Haltungen von Ärzten, Pflegekräften sowie Sanitätern und ihrer Einbettung in die ethische Kultur von Einrichtungen oder Organisationen des Gesundheitswesens.

Medizin- und Pflegeethik sind Teil einer umfassenden Ethik des Gesundheitswesens. Die WHO definiert das Gesundheitswesen (engl. health care system) als die Gesamtheit aller Institutionen, die Güter und Dienstleistungen zur

2 Kath. Krankenhausverband Deutschlands e.V. / Deutscher Evangelischer Krankenhausverband e.V., Ethik-Komitee im Krankenhaus, Selbstverlag des Kath. Krankenhausverbands Deutschland e.V., Freiburg i.Br. 1997, S. 9. 
Erhaltung oder Wiederherstellung der menschlichen Gesundheit anbieten und erbringen, sowie jener Institutionen, die dazu beitragen, dass Menschen mit ihrer Krankheit oder Behinderung ein Leben mit bestmöglicher Lebensqualität führen können. Ethik im Gesundheitswesen hat einen zweifachen Gegenstand: zum einen das institutionelle Gefüge des Gesundheitswesens und seine unmittelbaren Interaktionspartner, zum anderen das individuelle und das gemeinschaftliche Handeln innerhalb des Gesundheitswesens. ${ }^{3}$

Die organisatorischen Rahmenbedingungen beeinflussen nicht nur das Handeln des medizinischen und pflegerischen Personals. Sie bestimmen auch die Lebens- und Entfaltungsmöglichkeiten der Patientinnen und Patienten in einem Krankenhaus oder der Bewohnerinnen und Bewohner einer Pflegeeinrichtung. Die Freiheitsgrade in der persönlichen Lebensführung oder bei den Aktivitäten des täglichen Lebens werden durch die räumlichen Gegebenheiten und organisatorischen Abläufe erheblich beeinflusst. Die Selbstbestimmung kann durch sie unter Umständen erheblich eingeschränkt werden. Zu bedenken ist auch, dass sich pflegebedürftige Menschen oftmals nicht langfristig und freiwillig zur Übersiedlung in eine Pflegeeinrichtung oder ein Altenwohnheim entschließen, sondern aufgrund einer dramatischen Veränderung ihrer Lebenssituation ihre gewohnte häusliche Umgebung verlassen müssen. Bei Menschen, für die ein Betreuer als gesetzlicher Vertreter bestellt ist, kann die Entscheidung über den Aufenthaltsort dem Betroffenen überhaupt entzogen sein. Pflegeethik hat all diese genannten Aspekte mit zu bedenken, welche die Interaktion zwischen Pflegekräften und Bewohnern mit beeinflussen.

Neben den Ärzten und Pflegekräften sowie den Bewohnerinnen und Bewohnern sind aber auch noch andere Akteure in die ethische Reflexion einzubeziehen. Da sind zum einen die Angehörigen oder die gesetzlichen Betreuerinnen und Betreuer. Da sind aber auch noch die übrigen Berufsgruppen, die in Krankenhäusern oder Einrichtungen der Pflege und Altenhilfe tätig sind: Sozialarbeiter, Physio- und Ergotherapeuten, ehrenamtliche Kräfte, die Besuchsdienste leisten, Seelsorger und Seelsorgerinnen.

Wie in der Medizinethik lassen sich auch in der Pflegeethik generell drei Ebenen unterscheiden: ${ }^{4} 1$. die personale Ebene: Ebene der interaktionellen Beziehungen (Bereich des direkten diagnostischen, therapeutischen und pflegerischen Kontaktes); 2. die strukturelle Ebene: Ebene der Institutionen (Gesundheitswesen und seine Einrichtungen, Gesundheitspolitik, soziale Faktoren von Gesundheit und Krankheit, Medizinökonomie/Gesundheitsökonomie), 3. die kulturelle Ebene: Ebene der Einstellungen und Werthaltungen (individuelles und

3 Vgl. Jürgen Wallner, Ethik im Gesundheitswesen. Eine Einführung, UTB 2612, Wien 2004.

4 Vgl. Eberhard Amelung (Hg.), Ethisches Denken in der Medizin. Ein Lehrbuch, Berlin (u. a.) 1992. 
allgemeines Verständnis von Gesundheit und Krankheit, tatsächliches Gesundheitsverhalten).

Auf der personalen Ebene ist u. a. der Zusammenhang von Gesundheit bzw. Krankheit oder Pflegebedürftigkeit und Lebensgeschichte des Patienten oder der Patientin zu beachten. ${ }^{5}$ Es ist also auch zu fragen, welche Bedeutung, d.h. welchen Sinn z. B. medizinische Maßnahmen oder der Verzicht auf solche im $\mathrm{Zu}$ sammenhang mit der Biografie des oder der Betroffenen haben.

Auf der strukturellen Ebene zeigt sich, dass Gesundheit und Krankheit, Heilung und Krankheitslinderung sowie unterschiedliche Grade der Pflegebedürftigkeit abhängig vom System des Gesundheitswesens sind. Ein zentrales ethisches Problem ist die Verteilungsgerechtigkeit (Problem der Allokation auf der Mikro- und Makroebene) und die zwangsweise (!) Beteiligung am (Ver-)sicherungssystem im Sinne der Solidar- und Gefahrengemeinschaft. Gesundheit ist nicht nur ein individuelles, sondern auch ein soziales Zukunftsgut. Systembedingte Aporien (unlösbare Fragen) bestehen u.a. im Missverhältnis zwischen Rationalität von Einzelentscheidungen und Irrationalitäten des Gesamtsystems.

Auf der kulturellen Ebene sind allgemeine Grundwerte und Normen zu beachten, die in einer Gesellschaft akzeptiert werden. Fragen des Menschenbildes, der religiösen und weltanschaulichen Überzeugungen beschränken sich nicht auf die persönliche Einstellung derer, die in Einrichtungen des Gesundheitswesens oder der Altenhilfe tätig sind, sowie die Überzeugungen der Patienten, Bewohner oder Klienten. Sie erstrecken sich auch auf die Grundeinstellungen und das Ethos der gesamten Einrichtung oder Organisation - man denke also an die Johanniter-Unfall-Hilfe, den Malteser Hilfsdienst, das Rote Kreuz oder Arbeiter-Samariter-Bund -, des Unternehmens oder gar eines ganzen Konzerns. Es geht also auch um Unternehmensleitbilder und die Frage, in welcher Weise sie die alltägliche Praxis vor Ort prägen und inwiefern sie für Entscheidungen auf den unterschiedlichen Führungsebenen, aber auch für die einzelnen Mitarbeiterinnen und Mitarbeiter Orientierung bieten oder gar verbindlich sind. Wie soll z.B. eine diakonische Einrichtung mit dem weltanschaulichen und religiösen Pluralismus umgehen, der unsere heutige Gesellschaft kennzeichnet? Wie kann das Angebot an Seelsorge und Spiritualität in einem Haus mit christlicher Prägung ausschauen, das Menschen mit anderen Überzeugungen und religiöser Orientierung respektiert? Wie will man mit ethischen Konflikten umgehen, die zwischen der ethischen Grundorientierung einer Einrichtung und der persön-

5 Vgl. Dietrich Ritschl, Das „story“-Konzept in der medizinischen Ethik, in: Ders., Konzepte: Ökumene, Medizin, Ethik. Gesammelte Aufsätze, München 1986, S. 201-212; Ders., Zur Theorie und Ethik der Medizin. Philosophische und theologische Anmerkungen, NeukirchenVluyn 2004. 
lichen Überzeugungen von Patienten oder Bewohnern aufbrechen können, etwa wenn es um Fragen der Sterbehilfe oder des Suizids geht?

Auf der kulturellen Ebene sind auch die Fragen der interkulturellen und transkulturellen Pflege angesiedelt. Unter den transkulturellen Werten steht in der abendländischen Tradition an vorderster Stelle die Idee der Menschenrechte, welche den Gedanken der Menschenwürde zur Voraussetzung haben. Die Geltung von Menschenwürde und Menschenrechten wird heute universal behauptet (Allgemeine Erklärung der Menschenrechte von 1948). Im Judentum und im Christentum wird der Gedanke der Menschenwürde aus der Gottebenbildlichkeit des Menschen abgeleitet, die ihm bedingungslos, d. h. unabhängig von seiner körperlichen und geistigen Verfassung, zukommt. Auch der Islam bekennt sich zu den Menschenrechten, interpretiert sie aber im Rahmen der Scharia (islamisches Recht), woraus Konflikte mit dem westlichen Menschenrechtsverständnis entstehen können.

Ethik in Medizin, Pflege und Altenhilfe, aber auch in der Unfallhilfe, kann letztlich nur von einem systemischen Ansatz aus betrieben werden. Das bedeutet nun allerdings nicht, dass sich alle Fragen der Ethik in diesem Bereich auf die Ebene der Organisations- oder der Sozialethik verschieben lassen. Das würde nämlich bedeuten, die persönliche Verantwortung, die jeder und jede von uns hat, an die Institutionen und Organisationen im Gesundheits- und Sozialwesen zu delegieren. So gewiss mein persönliches Handeln, Tun und Lassen immer auch von gesellschaftlichen und organisatorischen Rahmenbedingungen mitbestimmt wird, habe ich doch für meine Lebensführung und meinen Umgang mit anderen Menschen eine persönliche Verantwortung. So wichtig die sozialethische und organisationsethische Dimension in Medizin, Pflege und Unfallhilfe auch ist, so unaufgebbar bleiben doch daneben die individual- und die personalethische Dimension. Unter Individualethik verstehe ich die ethische Reflexion meines Umgangs mit mir selbst. Wie gehe ich z. B. mit meiner eigenen Gesundheit und mit meinem Körper um. Wie ist es um meine Selbstpflege und Selbstachtung bestellt, ohne die ich wohl kaum in der Lage sein werde, auch anderen Menschen die nötige Achtung und Empathie entgegenzubringen? Unter Personalethik verstehe ich ethische Reflexion, die sich auf alle Ich-Du-Beziehungen richtet, also z. B. auf die direkte Interaktion zwischen Arzt, Pflegkräften oder Sanitäter und Patient oder Bewohner.

\section{Verantwortung}

Auf allen drei genannten Ebenen, der individualethischen ebenso wie der personal- und sozialethischen Ebene ist Verantwortung ein ethischer Schlüsselbegriff. Der Begriff der Verantwortung begegnet uns in unterschiedlichen $\mathrm{Zu}$ - 
sammenhängen. Wir sprechen nicht nur von moralischer, sondern auch von politischer Verantwortung. Daneben kennen wir einen haftungsrechtlichen Verantwortungsbegriff. Wenn wir über Verantwortung als ethisches Prinzip von Medizin und Pflege nachdenken, ist es wichtig, die verschiedenen Bedeutungen des Verantwortungsbegriffs zu unterscheiden. ${ }^{6}$ Für die ethische Diskussion über den Geltungsbereich und die Begründung einer Verantwortungsethik ist es schon deshalb notwendig, die unterschiedlichen Verwendungen des Verantwortungsbegriffs auseinander zu halten, weil andernfalls sein ethischer Gehalt verdunkelt wird, oder aber die Kommunikation sämtlicher Teilsysteme der Gesellschaft moralisch überfrachtet wird.

In der ethischen Theoriebildung der philosophischen und theologischen Tradition spielt der Verantwortungsbegriff bis zum Beginn des 20. Jahrhunderts keine besondere Rolle. Durch Max Weber in die Diskussion eingeführt, ist „Verantwortung“ nach dem Ersten Weltkrieg zu einem neuen Grundwort unserer Sprache aufgestiegen, das mehr und mehr an die Stelle des ethischen Begriffs der Pflicht getreten ist. Durch die globalen Gefahren, denen sich Mensch und Natur heute ausgesetzt sehen, hat der Begriff der Verantwortung in der öffentlichen Diskussion nochmals an Bedeutung gewonnen. Er gilt heute als Leitbegriff einer zukunftsorientierten, um das Überleben der Menschheit besorgten Ethik.

Die Tragfähigkeit des Verantwortungsbegriffs als Grundprinzip einer den heutigen Anforderungen genügenden Ethik bedarf allerdings einer Überprüfung. Dafür gibt es mehrere Gründe. Zum einen lässt sich gegenläufig zur verantwortungsethischen Diskussion ein Trend zur Entmoralisierung des Verantwortungsbegriffs beobachten. Zum anderen lässt sich zeigen, dass jede Theorie der Verantwortung nachgeordnet gegenüber einer Theorie der Moral ist, und zwar deshalb, weil der Verantwortungsbegriff als solcher wertneutral ist, jede ethische Verantwortungstheorie folglich von moralischen Wertsetzungen lebt, die sie selbst nicht begründen kann.

Begriffsgeschichtlich stammen das Wort „verantworten“ und seine Derivate aus der Rechtssphäre. „Verantworten“ heißt ursprünglich „(sich) vor Gericht verteidigen“ (lat. respondere, probare). Hiervon ist die allgemeine Bedeutung „sich rechtfertigen“ abgeleitet. Der Verantwortungsbegriff steht in enger Verbindung mit demjenigen der Zurechnung (lat. imputatio). Häufig werden „Verantwortung“ und „Zurechnung“ synonym gebraucht. Verantwortung impliziert einerseits ein zurechnungsfähiges Handlungssubjekt, andererseits - in Analogie zum Richter - eine die Zurechnungsfähigkeit feststellende und eine konkrete Handlung samt ihren Folgen dem bestimmten Subjekt zurechnende Instanz. Das Substantiv „Verantwortung“ ist erst seit der zweiten Hälfte des

6 Vgl. Körtner, Pflegeethik, S. $85 \mathrm{ff}$. 
15. Jahrhunderts nachweisbar. Es meint ursprünglich ebenfalls die Rechtfertigung vor Gericht (lat. apologia, defensio), wird nun aber auch auf die Rechtfertigung vor dem Richterstuhl Gottes gemünzt. In späterer Zeit bezeichnet die Vokabel einerseits allgemein jede Form der Rechtfertigung, andererseits den Zustand der Verantwortlichkeit.

Neben den juristischen und den religiösen Verantwortungsbegriff ist, von beiden abgeleitet und zugleich doch unterschieden, im 20. Jahrhundert der moralische getreten. Von diesem sind nochmals $\mathrm{zu}$ unterscheiden sein politischer Gebrauch sowie der funktionale Begriff der Aufgabenverantwortung. Während in beiden Fällen moralische und außermoralische Konnotationen einander überlappen, ist der versicherungstechnische Begriff der Gefährdungshaftung, welcher im Zusammenhang mit der Abschätzung technologischer Risiken eine zentrale Rolle spielt, vom moralischen Verantwortungsbegriff weitgehend abgekoppelt. Für die ethische Diskussion über den Geltungsbereich und die Begründung einer Verantwortungsethik ist es wichtig, die unterschiedlichen Verwendungen des Verantwortungsbegriffs auseinander zu halten, weil andernfalls sein ethischer Gehalt verdunkelt wird, oder aber die Kommunikation sämtlicher Teilsysteme der Gesellschaft moralisch überfrachtet wird. Die ideologische Moralisierung aller gesellschaftlichen Bereiche führt nicht etwa zu einer Schärfung des moralischen Bewusstseins, sondern im Gegenteil zur inflationären Entwertung aller Ethik.

Als ethischer Terminus ermöglicht der Begriff der Verantwortung eine umfassende Bestimmung der ethischen Grundsituation. Ihre Charakterisierung als forensische oder - erweitert gedacht - als dialogische wirft demnach die Frage nach dem Subjekt von Verantwortung, nach der Verantwortungsinstanz und nach dem Verantwortungsbereich oder Gegenstand und Maß der Verantwortung auf. Der Begriff der Zurechnung macht zugleich klar, dass es sich bei jeder Form der Verantwortung um eine interpersonale, soziale Konstruktion handelt.

Verantwortung als soziale Konstruktion entsteht, wenn jemandem Verantwortung übertragen, jemand zur Verantwortung gezogen wird oder bereit ist, Verantwortung für andere und gegenüber anderen zu übernehmen. Das Subjekt der Verantwortung wird grundsätzlich nicht allein durch seine Selbstwahl oder seinen Entschluss konstituiert, sondern durch Imputation, d.h. durch Zurechnung. Es findet sich also immer schon in Bezügen vor, die zu einem Verantwortungsverhältnis werden können. Es ist daher ein Vorzug des Verantwortungsbegriffs, dass er die fragwürdige Trennung von Individualethik und Sozialethik vermeidet und damit der Vergesellschaftung des Handelns in der modernen Gesellschaft Rechnung trägt.

Ein weiterer Vorteil des Verantwortungsbegriffs besteht darin, dass er die Zukunftsdimension unseres Handelns zum ausdrücklichen Gegenstand ethischer Reflexion erhebt. Bezieht sich der Verantwortungsbegriff als forensischer 
von Haus aus auf bereits begangene Handlungen und deren Folgen, so impliziert er als ethischer Begriff auch die Notwendigkeit künftiger Rechenschaftspflicht.

Die moralische Verantwortung des Arztes oder der Pflegekraft besteht nicht nur gegenüber Vorgesetzten, sondern auch gegenüber dem Patienten sowie gegenüber dem eigenen Gewissen; für einen religiösen Menschen auch gegenüber Gott. Im beruflichen Alltag stellen sich ganz handfeste Fragen:

- Wem gegenüber fühle ich mich in meinem Beruf moralisch verantwortlich?

- Wie verhält sich meine Verantwortung, die ich im rechtlichen Sinne habe, zu meiner moralischen Verantwortung?

- Ist mein Handeln schon allein dadurch ethisch gerechtfertigt, dass ich mich an gesetzliche Vorschriften oder an die Anweisungen von Vorgesetzten halte?

- Lassen sich Fälle denken, in denen Recht und Moral in Konflikt geraten?

- Gibt es Gewissensentscheidungen, bei denen aus moralischen Gründen geltendes, bestehendes Recht missachtet werden darf oder sogar muss?

- Wo fühle ich mich im moralischen Sinne allein verantwortlich, wo mitverantwortlich und wo nicht verantwortlich?

- Welche Taktiken gibt es, der eigenen Verantwortung auszuweichen oder sie auf andere abzuschieben? Wie weit habe ich das selbst schon getan?

- In welchen Situationen habe ich mich als Opfer derartiger Versuche gefühlt? Wie gehe ich mit solchen Situationen um? Mit wem kann ich darüber offen sprechen?

Recht und Moral bzw. Ethik als Theorie der Moral können im Einzelfall in Konflikt geraten. Man denke nur an die Verabreichung von Psychopharmaka bei trauernden oder verängstigten Patienten oder an die medikamentöse Sedierung/ Fixierung von „umtriebigen“ Demenzpatienten. Die Wahrnehmung von Verantwortung kann unter Umständen bedeuten, Verordnungen aus Gewissensgründen zu verweigern. Eine solche Handlungsweise setzt allerdings voraus, dass die Pflegeperson ihr Verhalten gründlich reflektiert hat und auch fähig ist, eine ethisch fundierte Begründung oder Rechtfertigung des eigenen Tuns zu geben.

Im Begriff der Verantwortung steckt die Vokabel „Antwort“. Sie weist darauf hin, dass die Moralfähigkeit des Menschen mit seinem Personsein gegeben ist. Vor allem der dialogische Personalismus (Martin Buber, Franz Rosenzweig, Ferdinand Ebner) hat den Umstand zu Bewusstsein gebracht, dass es Personalität nur als intersubjektives Phänomen gibt. Die Existenz von Personen ist also grundlegend an sprachliche Kommunikation gebunden, ohne doch in ihr völlig aufzugehen. Zum Ich wird der Mensch nur, wenn er als ein Du angeredet wird. Personale Kommunikation aber impliziert den Anspruch auf Achtung dessen, der mich als Du anspricht. Dieser Anspruch auf Achtung bzw. Anerkennung kann im Einzelfall missachtet oder zurückgewiesen werden. Er ist aber mit dem 
Anredegeschehen als solchem gegeben und zwingt in jedem Fall zu einer Stellungnahme.

Moral basiert also auf der Notwendigkeit der Stellungnahme zu dem mit der zwischenmenschlichen Kommunikation gegebenen Anspruch auf Anerkennung der Person. Die moralische Ebene wird in dem Moment beschritten, wo mich jemand fragt: „Warum tust du das bzw. warum hast du das getan? Weshalb tust du mir das an?" Oder wo er eine Forderung oder Bitte an mich richtet.

Wir können allgemein sagen, dass mit der sprachlichen Kommunikation die Notwendigkeit von Verantwortung in einem moralischen Sinne gesetzt ist, insofern jede Anrede nach Antwort bzw. Erwiderung verlangt, auch wenn sie in der Ablehnung des an mich gerichteten Anspruchs bestehen kann. Moral ist mit anderen Worten eine Implikation von Personalität, Personalität also der Grund von Moral, Achtung der Person aber deren Verwirklichung.

Ein dialogisch konzipierter Verantwortungsbegriff ist allerdings ethisch noch nicht hinreichend, da es auch nicht-reziproke Verantwortungsverhältnisse gibt. Moralische Verantwortung besteht nicht nur gegenüber anderen, sondern auch für andere. Beispiele für Verantwortung, die Menschen für andere haben (nicht-reziproke Verantwortung) sind die Verantwortung von Eltern für ihre unmündigen Kinder oder die Verantwortung von Ärzten, Ärztinnen und Pflegenden für nicht zustimmungsfähige, z. B. für bewusstlose oder geistig verwirrte Patienten. Auch für das Wohl von Tieren, über die Menschen verfügen (z. B. Haustiere oder Nutztiere), tragen Menschen Verantwortung.

Das Prinzip Verantwortung bedarf also der Ergänzung durch das Prinzip der Fürsorglichkeit. Dieses kann zum Prinzip der Gerechtigkeit in Konflikt geraten. Manche Ethiker sehen zwischen Fürsorglichkeit und Gerechtigkeit sogar einen unlösbaren Dauerkonflikt. Die Prinzipien der Fürsorglichkeit (Care-Ethik) und der Gerechtigkeit sind jedoch nicht alternativ zu sehen, sondern müssen einander ergänzen.

In der beruflichen Praxis stellen sich wieder konkrete Fragen:

- Wie weit reicht meine Verantwortung für den Patienten, die Patientin?

- Wie weit ist sie oder er für sich selbst verantwortlich?

- Wo versuchen Patienten oder Patientinnen von ihrer Eigenverantwortung abzulenken?

- In welchen Situationen sind Patienten und Patientinnen mit dem Appell an ihre Eigenverantwortung überfordert?

- Was soll man tun, wenn Patienten oder Patientinnen in den Augen der Pflegenden unverantwortlich handeln oder entscheiden?

- Welche Konflikte zwischen der Eigenverantwortung des Patienten oder der Patientin und der Verantwortung der Pflegenden kann es geben? 


\section{Medizin und Pflege im Spannungsfeld von Autonomie und Fürsorge}

Wie aber verhält sich das Prinzip Verantwortung zur Autonomie des Patienten? Dessen Autonomie und Selbstbestimmungsrecht gehören heute zu den grundlegenden ethischen Prinzipien in Medizin und Pflege. Um das Selbstbestimmungsrecht auch dann noch zu wahren und zu stärken, wenn Patienten nicht mehr selbst entscheiden können, gibt es Instrumente wie Patientenverfügungen, Vorsorgevollmachten und Betreuungsverfügungen, deren Verbindlichkeit inzwischen auch gesetzlich geregelt ist. Ihre konkrete Auslegung und Anwendung kann im Einzelfall allerdings strittig sein. Das gilt insbesondere für Menschen, die an einer Demenzerkrankung leiden oder aus anderen Gründen ihre rechtliche Zustimmungsfähigkeit eingebüßt haben, gleichwohl aber bei Bewusstsein sind.

Konzeptionen einer „Care“-Ethik, die vor allem in der heutigen Medizinethik eine wichtige Rolle spielen, setzen voraus, dass Sorge (lat. cura) im Sinne der Selbstsorge und der Fürsorge, ein entscheidendes Grundmotiv menschlicher Lebensführung ist. Das Ethos des Helfens und seine Menschlichkeit gründen ganz wesentlich in der Erfahrung unserer Verletzlichkeit, der eigenen wie der Verletzlichkeit des Anderen. Wechselseitige Hilfsbedürftigkeit ist gerade kein Mangel, sondern im Gegenteil eine Grundbedingung menschlicher Lebensfülle und menschlicher Daseinserfüllung. Zeiten eigener Krankheit, aber auch die Erfahrung der Krankheit des Anderen machen uns dies auf besonders eindringliche Weise bewusst.

Hilfreich sind in diesem Zusammenhang Überlegungen von Farideh Akashe-Böhme und Gernot Böhme zur Autonomie kranker und leidender Menschen. Gegenüber paternalistischen Medizinkonzepten spielt die Autonomie des Patienten in den gegenwärtigen medizinethischen Debatten - gerade auch in der Diskussion über Therapieabbruch, Sterbehilfe und Patientenverfügungen - eine tragende Rolle. Oftmals besteht die Gefahr, dass von einem abstrakten Autonomiebegriff ausgegangen wird, welcher der tatsächlichen Hilfs- und Schutzbedürftigkeit kranker Menschen nicht gerecht wird. Gehört Krankheit zum Leben dazu, ist, wie das Ehepaar Böhme argumentiert, nicht Autonomie, sondern Souveränität das angemessene Persönlichkeitsideal. „Ein Mensch ist souverän, wenn er mit sich etwas geschehen lassen und Abhängigkeiten hinnehmen

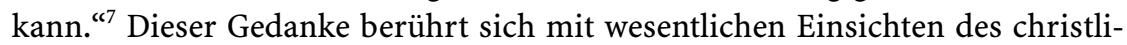
chen Glaubens und seines Verständnisses von Menschenwürde, die auch Schwerstkranke und Menschen mit Behinderungen nicht verlieren können.

7 Farideh Akashe-Böhme / Gernot Böhme, Mit Krankheit leben. Von der Kunst, mit Schmerz und Leid umzugehen, Beck'sche Reihe 1620, München 2005, S. 62; vgl. Ebd., S. 85. 
$\mathrm{Zu}$ bedenken ist auch, dass Abhängigkeit und Freiheit keineswegs eine Alternative sein müssen. Paradoxerweise kann nämlich die Leugnung von Hilfsbedürftigkeit zur Einschränkung der persönlichen Freiheit führen, ihre Anerkennung dagegen zu einem neuen Freiheitsgewinn. Beispiel Bewegungsfreiheit: Den Rollator oder Rollstuhl abzulehnen, bedeutet für Betroffene möglicherweise eine Einschränkung ihrer Mobilität. Anzuerkennen, dass man künftig auf einen Rollstuhl angewiesen ist, erhöht die Mobilität. Dieser Freiheitsgewinn ist freilich auch mit einer Verlusterfahrung und einem Abschiedsschmerz verbunden. Er setzt voraus zu akzeptieren, dass bestimmte Maßnahmen der Rehabilitation, die darauf zielen, dass die Person wieder selbständig gehen kann, erfolglos bleiben. Ähnliche Beispiele lassen sich auch für andere Aktivitäten des täglichen Lebens finden, z. B. bei Inkontinenz. Selbstverständlich geht es zunächst darum, eine bestehende Inkontinenz durch geeignete Maßnahmen zu beseitigen. Sofern dies aber nicht gelingt, kann die Verwendung von Inkontinenzmaterial oder eines Dauerkatheters dazu beitragen, dass die betroffene Person wieder mobiler wird - z. B. sind längere Ausflüge möglich - und in der Nacht besser schlafen kann als zuvor. Dass die Anerkennung von Abhängigkeit oder Hilfsbedürftigkeit einen Freiheitsgewinn ermöglicht, bedeutet selbstverständlich nicht, vorschnell alle Versuche abzubrechen, die zur Diskussion stehende Abhängigkeit zu beseitigen oder zu verringern. Die ethische Aufgabe besteht vielmehr darin, in jedem konkreten Einzelfall auszuloten, wie lange der Einsatz gegen eine verstärkte Abhängigkeit im Interesse der pflegebedürftigen Person sinnvoll ist oder nicht.

Die Situation von Hilfsbedürftigkeit und Hilfeleistung hat stets mit Machtfragen zu tun. Sie treten auch in der medizinischen Versorgung, Pflege, Psychotherapie und Betreuung von Menschen mit erworbenen Hirnschädigungen auf. Die Hilfsbedürftigkeit ist durch Schwäche und Abhängigkeit bis hin zur Ohnmacht charakterisiert. Zwischen Helfenden und Hilfsbedürftigen besteht eine asymmetrische Beziehung, über die z.B. auch die Leitvorstellung der Patientenautonomie nicht hinwegtäuschen kann. Es wäre verfehlt, das Phänomen der Macht in Medizin, Psychotherapie und Pflege, aber auch in der Ergo- oder Physiotherapie, überhaupt leugnen oder ablehnen zu wollen. Wer heilen oder helfen will, will schließlich zugunsten der Patientin oder des Pflegebedürftigen die Situation verändern und verbessern. Dazu bedarf es der Macht, Veränderungen bewirken zu können, und der heilenden Kräfte, die von Medizin und Pflege ausgehen. Es lassen sich aber zwei Formen der Macht unterscheiden, nämlich einerseits eine der Medizin oder der Pflege innewohnende Macht, die dem Patienten oder der Patientin zur Wiedererlangung von Selbstständigkeit verhelfen will, und eine Form der Macht, die Zwang und Abhängigkeit zum Ziel hat. ${ }^{8}$

8 Vgl. Körtner, Pflegeethik, S. 76ff, im Anschluss an Patricia Benner und Carol Gilligan. 
Die Ambivalenz der helfenden Macht besteht darin, dass sie selbst zum Zwang und zur Herrschsucht pervertieren kann. Gerade der Versuch, einem Menschen zur Selbsthilfe zu helfen, kann an die Grenze des Zwangs stoßen, z. B., wenn der oder die Pflegende Übungen mit Patienten oder Patientinnen macht und sie antreibt, Dinge zu tun, die für die Pflegebedürftigen mit Schmerzen verbunden sind, sodass sie sie von sich aus nicht zu tun bereit wären. Auf der einen Seite steht das Prinzip der Nichtdirektivität, auf der anderen Seite die paternalistische Manipulation, die sich gerade aufgrund der Hilfsbedürftigkeit oftmals gar nicht ganz vermeiden lässt.

Ethische Probleme brechen in der Medizin und in der Pflege auf, wenn Autonomie und Fürsorge zueinander in Spannung treten. Konkret stellt sich die Frage, welche Freiheiten man Patienten oder Bewohnern lassen kann, ohne dass sie sich selbst oder Dritte gefährden oder gar schädigen. Man denke etwa an den Bewegungsdrang von Demenzkranken, die vielleicht hochgradig sturzgefährdet sind. Auch können Patienten mit einer Hirnschädigung außerhalb des geschützten Raumes ihrer Pflegeeinrichtung leicht die Orientierung verlieren und möglicherweise nicht wieder nach Hause finden. Hier gilt es immer wieder abzuwägen zwischen Zulassung und Einschränkung der persönlichen Freiheit. Hier gilt es auch abzuwägen zwischen dem Recht auf Privat- und Intimsphäre und Mitteln der Kontrolle, z. B. durch elektronische Sender.

Patienten als Subjekte ernstnehmen und achten, bedeutet grundsätzlich, dass sie nicht nur als Objekte von Medizin und Pflege zu behandeln, sondern auf ihre Eigenverantwortung anzusprechen sind. Das beginnt nicht erst im Fall einer Erkrankung oder eines Unfalls, sondern schon im Vorfeld beim verantwortlichen Umgang mit der eigenen Gesundheit und dem eigenen Körper und der gesundheitlichen Vorsorge.

Wenn heute zu recht mehr Eigenverantwortung im Gesundheitswesen gefordert wird, bei der Prävention ebenso wie bei der Therapie und ihrer Finanzierung, so bleibt diese Forderung abstrakt und unsozial, wenn nicht zugleich von der Teilhabe- oder Befähigungsgerechtigkeit gesprochen wird. Vielen Menschen fehlen die sachliche Kompetenz und die finanziellen Mittel, derart selbstverantwortlich entscheiden zu können, wie in der Gesundheitspolitik heute propagiert wird. Damit Menschen aus sozial schwachen Schichten Eigenverantwortung für ihre Gesundheit übernehmen können, müssen sie dazu allererst befähigt werden. Um die dafür notwendige Bildung und das entsprechende Einkommen zu erlangen, bedarf es einer aktiven und aktivierenden Sozialpolitik. ${ }^{9}$ Ohne eine solche bleibt die politische Maßgabe eines Umbaus und

9 Vgl. Peter Dabrock, Tauschgerechtigkeit im Gesundheitssystem? Kritische Anfragen an Otfried Höffes Forderung nach einem Paradigmenwechsel, in: Zeitschrift für Evangelische Ethik 43/1999, S. 2-22, hier S. 15. 
einer Verschlankung des Sozialstaats ebenso zynisch wie die Forderung nach Kostendämpfung im Gesundheitswesen auf dem Rücken der Patienten, welche soziale Ungleichheiten verstärkt. Auch das ist eine Frage der Verantwortungsethik. Eine die Gesundheitspolitik einschließende Sozial- und Wohlfahrtspolitik muss die Zugangschancen, d.h. die kontextabhängige Befähigung zur Eigenverantwortung thematisieren, statt kontextlos und im Ergebnis möglicherweise zynisch auf ein abstraktes Autonomieprinzip zu setzen, das der konkreten Hilfsbedürftigkeit von Kranken und Pflegebedürftigen nicht gerecht wird.

Aus christlicher Sicht sei hinzugefügt, dass die Teilhabe an der Gesundheitsversorgung weder allein eine Frage der Verteilungs- noch der Tauschgerechtigkeit, sondern auch eine der Barmherzigkeit ist. Das der Sozialgesetzgebung und der Pflichtversicherung zugrundeliegende Solidaritätsprinzip ist vom Ethos der Barmherzigkeit historisch und systematisch zwar zu unterscheiden. Allerdings wäre die Entstehung eines Gesundheitswesens im Abendland historisch ohne den Einfluss des Christentums nicht denkbar gewesen. In der Debatte um die Reform des Gesundheitswesens und seiner künftigen Finanzierung steht nicht nur eine Neubestimmung des Solidaritätsprinzips und seiner Reichweite im Verhältnis zur individuellen Autonomie bzw. zur Subsidiarität zur Diskussion. Auf der Tagesordnung steht vielmehr auch eine Kultur des Erbarmens.

\section{Quellen}

Akashe-Böhme, Farideh / Böhme, Gernot, Mit Krankheit leben. Von der Kunst, mit Schmerz und Leid umzugehen, Beck'sche Reihe 1620, München 2005.

Amelung, Eberhard (Hg.), Ethisches Denken in der Medizin. Ein Lehrbuch, Berlin (u. a.) 1992.

Dabrock, Peter, Tauschgerechtigkeit im Gesundheitssystem? Kritische Anfragen an Otfried Höffes Forderung nach einem Paradigmenwechsel, in: Zeitschrift für Evangelische Ethik 43/1999, S. 2-22.

Kath. Krankenhausverband Deutschlands e.V. / Deutscher Evangelischer Krankenhausverband e.V., Ethik-Komitee im Krankenhaus, Selbstverlag des Kath. Krankenhausverbands Deutschland e.V., Freiburg i.Br. 1997.

Körtner, Ulrich H.J., Grundkurs Pflegeethik, 3. Aufl., Wien 2017.

Ritschl, Dietrich, Das „story“-Konzept in der medizinischen Ethik, in: Ders., Konzepte: Ökumene, Medizin, Ethik. Gesammelte Aufsätze, München 1986, S. 201-212.

Ritschl, Dietrich, Zur Theorie und Ethik der Medizin. Philosophische und theologische Anmerkungen, Neukirchen-Vluyn 2004.

Wallner, Jürgen, Ethik im Gesundheitswesen. Eine Einführung, UTB 2612, Wien 2004. 
Open-Access-Publikation im Sinne der CC-Lizenz BY 4.0

(C) 2020, Vandenhoeck \& Ruprecht $\mathrm{GmbH} \&$ Co. KG, Göttingen ISBN Print: 9783847111658 - ISBN E-Lib: 9783737011655 


\section{Integrität: Die Tugend der Tugenden. Der christliche Beitrag zu einer globalen Tugend für Wirtschaft und Politik}

\section{Vorbemerkung: Wiederentdeckung der Tugendethik}

Ich stehe immer mit einem Bein in der akademischen Lehre, Forschung und Publikationen in der Theologischen Fakultät der Universität Basel ${ }^{1}$ und mit Lehraufträgen in Afrika, Asien und Lateinamerika. ${ }^{2}$ Mit dem andern Bein stehe ich in der praktischen Umsetzung in Entwicklungszusammenarbeit, kirchlicher Ethikforschung, Kooperation mit Unternehmen und der Privatwirtschaft, und dem - von mir 2004 gegründeten - globalen Ethiknetzwerk Globethics.net ${ }^{3}$ als Direktor 2008-2016 und seither als Stiftungsratspräsident. Ich bin sehr dankbar, dass Ingeborg Gabriel als Nationaler Kontakt Österreich von Globethics.net dient ${ }^{4}$. Zudem versuche ich Ethik auch umzusetzen mit christlichen Unternehmern in China als Direktor der (von einem chinesischen Unternehmer und mir gegründeten) Geneva Agape Foundation ${ }^{5}$. Angewandte Ethik war deshalb immer mein Schwerpunkt, besonders Wirtschaftsethik, politische Ethik und Umweltethik. ${ }^{6}$ Dabei war mir seit meinem Studium die Strukturenethik besonders wichtig, also die Frage, wie man nicht nur ethische Orientierung für das Handeln des Einzelnen (Individualethik) und die direkten zwischenmenschlichen Beziehungen (interpersonelle oder Personalethik) erarbeiten kann, sondern wie Gesetze und Standards so gestaltet werden können, dass sie christlichen ethischen Werten entsprechen und so Handlungshilfen darstellen, gleichsam Krücken zum Gehen oder Leitplanken auf einer Straße. Die meisten wenn nicht alle

1 Der vorliegende Beitrag ist die bisher unveröffentlichte deutschsprachige Abschiedsvorlesung an der Universität Basel vom 2. November 2016.

2 Siehe https://www.christophstueckelberger.ch/teaching/ (letzter Zugriff: 24.04. 2019).

3 www.globethics.net (letzter Zugriff: 24.04. 2019).

4 https://www.globethics.net/about-us/national-contacts (letzter Zugriff: 24. 04.2019).

5 www.gafoundation.world (letzter Zugriff: 24.04.2019).

6 Eine Auswahl von 88 meiner Artikel/Beiträge aus drei Jahrzehnten in 4 Bänden mit 1500 Seiten ist im Juni 2016 erschienen: Christoph Stückelberger, Global Ethics Applied, Globethics Publications, Genf 2016, Vol.1-4. 
Menschen sind ethisch überfordert, wenn sie nicht einen rechtlichen und gesellschaftlichen Orientierungsrahmen haben.

Vor diesem Hintergrund waren mir die Tugendethiken immer etwas suspekt als zu kurz gegriffen mit dem moralisierenden Appell an die Einzelnen. In den letzten Jahren habe ich aber die Bedeutung und den Wert der Tugendethik vermehrt betont. Dies aus der praktischen Erfahrung, dass die Vielzahl von Regelungen, Standards, internationalen Konventionen und nationalen Gesetzen zwar sehr notwendig sind, aber nicht greifen, wenn sie nicht von inneren Überzeugungen der Bevölkerung und besonders der Führungskräfte in allen Bereichen der Gesellschaft getragen sind. Deshalb auch mein Fokus der letzten Jahre auf Führungsethik, leadership ethics. Dazu kommt, dass scheinbar selbstverständliche Tugenden wie Ehrlichkeit und Wahrhaftigkeit stark abzubröckeln scheinen, wir in der Ethik also „back zu basics“ gehen müssen, gleichsam Grundregeln des Anstandes wieder buchstabieren müssen. Ich bin wohl nicht der Einzige, der unter der Verluderung des Politikstils im amerikanischen Wahlkampf wie in politischen Auseinandersetzungen in manchen Ländern leidet. Eine Journalistin fragte kürzlich in der Neuen Zürcher Zeitung „Der amerikanische Wahlkampf ist an einem neuen Tiefpunkt angelangt. Doch wie integer muss ein Staatsoberhaupt sein? ${ }^{\text {“7 }}$ Donald Trump ist ein spezieller schockierender Fall zur Frage der Integrität von Führungspersönlichkeiten in der Politik. Doch nicht nur in der Politik, sondern in allen Sektoren der Gesellschaft wie Wirtschaft, Hochschulen, Sport, Film und Kirchen/Religionsgemeinschaften sind viele Führungspersönlichkeiten unter Beschuss wegen mangelnder persönlicher Integrität und korruptem Verhalten.

Doch der Werteverlust betrifft nicht nur Führungskräfte. In Kenia habe ich das folgende schockierende Ergebnis einer Repräsentativbefragung unter Kenias Jugendlichen wahrnehmen müssen: Mehr als die Hälfte der Kenianischen Jugendlichen haben keine Skrupel, Geld mit unlauteren Methoden zu verdienen. Etwa die Hälfte sagte, sie hätten kein Problem mit Steuerhinterziehung oder Annahme von Schmiergeld, solange sie nicht im Gefängnis landen. $47 \%$ beteuerten, sie bewunderten Menschen, die Geld machen mit allen nötigen Mitteln („through hook or crook“), während $35 \%$ aussagten, sie würden ohne weiteres Schmiergeld zahlen oder annehmen. ${ }^{8}$

Damit sind wir bereits mitten im Thema Integrität. Ich konzentriere mich dabei auf die christliche Ethik, obwohl ich in den letzten 15 Jahren sehr stark

7 Marie-Astrid Langer, US Präsidentenwahl: Eine Frage der Integrität, in: Neue Zürcher Zeitung am 13.10.2016, vgl. https://www.nzz.ch/international/wahlen-in-den-usa-ld.127107 (letzter Zugriff: 24.04.2019).

8 Umfrage des East African Institute, Kenya, Jan 2016, vgl. http://www.nation.co.ke/news/Ken yan-youth-have-no-qualms-with-corruption-survey-shows/1056-3038800-pb8ydw/index. html (letzter Zugriff: 24.04.2019). 
interreligiöse Ethik betrieben habe. Ich werde in diesem Beitrag drei Schritte gehen: Zuerst Werte und Tugenden im Generellen, in der Geschichte der Ethik und in biblischer Perspektive kurz darlegen, danach die biblisch-christliche Sicht von Integrität als Tugend und schließlich Folgerungen und Empfehlungen, wie Individuen, Institutionen und Staaten Integrität in ihren Wirkungsfeldern fördern können.

\section{Tugenden in der Ethikgeschichte und in der Bibel}

„Tugenden bezeichnen vorzügliches Verhalten durch 1) grundlegende menschliche Fähigkeiten auf intellektueller, moralischer und spiritueller Ebene, 2) die sich am Guten orientieren und 3) die die Lebensqualität von Individuen und Gesellschaften verbessern. ${ }^{\text {“9 }}$ So werden in der klassischen Philosophie die Vorzüge von Tugenden beschrieben.

Die philosophische Theorie der Tugenden wurde in der griechischen Philosophie, besonders von Plato und Aristoteles, basierend auf Sokrates, entwickelt. Danach kann ein gutes Leben durch Verbesserung des Verhaltens erreicht werden. Plato entwickelte die vier Kardinal-Tugenden: Weisheit/prudentia, Mut/ fortitudo, Gerechtigkeit/iustitia und Besonnenheit (griechisch sophrosyne/

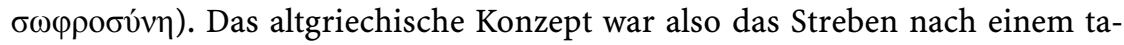
dellosen Charakter, der sich äußert in Maßhalten, Reinheit, Selbstkontrolle usw.

Nach biblischer Wertordnung, ist das Leben der Menschen gebildet als Ebenbild Gottes. Das Leben der Glaubenden richtet sich auf das Reich Gottes und seine Wertordnung aus, von dem es seine Vision und seinen Horizont erhält. Werte und Tugenden sind Ausdruck dieser Reich-Gottes-Orientierung.

Im Alten Testament sind Tugenden besonders in den Büchern Exodus, Deuteronomium und in den Weisheitsschriften der Sprüche und Weisheit prominent verankert. Die griechischen vier Kardinaltugenden kommen auch im ATvor, was zeigt, dass sie in der Alten Welt allgemeine Gültigkeit genossen: So werden „Klugheit und Besonnenheit“ (Spr. 1,4) als Ziel der ethischen Reifung Jugendlicher am Anfang des Buches der Sprüche genannt.

Im Neuen Testament hat Paulus sieben Tugenden erwähnt, drei theologische Glaube, Hoffnung und Liebe und die vier klassischen Kardinaltugenden. Er betonte, dass ein Leben in der Liebe Christi ein tugendhaftes Leben ist: Ein Leben, das Gott dient, allen Menschen dient ohne Vorurteil nach Klassen, ein Leben, das staatliche Autorität und öffentliche Ordnung respektiert (Röm. 12-15). Auch die paulinische Beschreibung der Gaben des Heiligen

9 Steven Titus Craig, Art. Vertus, Dictionnaire encyclopédique d'éthique chrétienne, Éditions du Cerf, Paris 2003, S. 2073-2093. 
Geistes und der Liebe (1 Kor. 12-13), der Vergleich des alten Menschen in Adam und des neuen Menschen in Christus (Kol. 3,5-4,6) sowie die Beschreibung des neuen Lebens als Folge der Einheit mit Christus (Eph.4-5) beschreiben christliche Tugenden. Aber Tugenden dienen nach neutestamentlicher Sicht nicht vor allem der Reinigung und Heiligung des Individuums, sondern sie dienen der sozialen Orientierung und dem Gemeinschaftsleben der christlichen (Ur-)Gemeinden. Lasst uns die Tugendkataloge in den Briefen an die Kolosser, Epheser und Galater kurz anschauen. ${ }^{10}$ Darin werden wir bereits Elemente dessen, was Integrität bedeutet, entdecken:

\begin{tabular}{|c|c|}
\hline $\begin{array}{l}\text { Das alte Leben } \\
\text { (Kol. 3,5-17, v. } 5 \text { und 8) } \\
\text { Unzucht } \\
\text { Unreinheit } \\
\text { Leidenschaft } \\
\text { Böse Begierde } \\
\text { Habgier } \\
\text { Götzendienst } \\
\text { Zorn } \\
\text { Wut } \\
\text { Bosheit, Üble Nachrede }\end{array}$ & $\begin{array}{l}\text { Das neue Leben (Kol. 3,5-17) } \\
\text { Erbarmen, Güte, Demut, Sanftmut, Geduld } 12 \\
\text { Ertragt euch gegenseitig, vergebt einander } 13 \\
\text { Liebe, Friede Christi, Einheit, Dankbarkeit } 14 \mathrm{f} \\
\text { Ermahnt einander in aller Weisheit } 16 \\
\\
\text { Spirituelle/geistliche Tugenden V. 3,16 und 4,2-4 } \\
\text { Singt Gott, von der Gnade erfüllt } 16 \\
\text { Handelt im Namen Jesu Christi } 17 \\
\text { Dankt Gott } 15 \text { und } 17\end{array}$ \\
\hline $\begin{array}{l}\text { Das alte Leben (Eph. 4,17-32) } \\
\text { Torheit und Unverstand } 17 \\
\text { Unwissend, verstockt } 18 \\
\text { Abgestumpft, Süchten } \\
\text { verfallen } 19 \\
\text { Trügerische Begierden } 22\end{array}$ & $\begin{array}{l}\text { Das neue Leben (Eph. 4,17-32) } \\
\text { Das alte Leben ablegen } 22 \\
\text { Den neuen Menschen anziehen } 24 \\
\text { Falschheit überwinden, Wahrhaftig sein } 24 \mathrm{f} \text {. } \\
\text { Den Zorn überwinden bevor die Sonne untergeht } 26 \\
\text { Nicht stehlen, sondern mit Arbeit seinen } \\
\text { Lebensunterhalt verdienen und damit auch } \\
\text { Notleidenden helfen } 28 \\
\text { Gutes, Aufbauendes sagen, das Freude bereitet } 29 \\
\text { Den Geist Gottes nicht traurig machen } 30 \\
\text { Bitterkeit, Wut, Zorn, Geschrei und üble Rede } \\
\text { überwinden } 31 \\
\text { Gütig und einfühlsam zueinander sein } 32 \\
\text { Einander vergeben } 32\end{array}$ \\
\hline
\end{tabular}

10 Bibelübersetzung Zürcher Bibel, 2007. Z. T. vereinzelt eigene Übersetzung aus dem Griechischen. 
(Fortsetzung)

\begin{tabular}{|l|l|}
\hline Das alte Leben (Eph. 5,1-21) & Das neue Leben (Eph. 5,1-21) \\
Unzucht, Unreinheit, Gier 3 & Als Kinder des Lichtes leben 8 \\
Dummes Geschwätz, Prahlerei 4 & In Güte, Gerechtigkeit, Wahrhaftigkeit leben 8 \\
Falschen Idolen anhängen 5 & Finsternis aufdecken, \\
Finsternis 8 & in Transparenz leben 11 \\
Arbeit in der Schattenwirtschaft 11 & In Weisheit leben 16 \\
Sich wie Törichte verhalten 15 & Die Zeit gut nutzen 16 \\
Nicht auf Gott hören 17 & Den Willen Gottes tun und leben 17 \\
Alkohol- und andere Sucht 18 & Mit dem Geist Gottes erfüllt sein 18 \\
& \\
\hline
\end{tabular}

Im Laufe der Kirchengeschichte hatte Thomas von Aquin den größten Einfluss auf die christliche Tugendlehre für Jahrhunderte. Sie bildet bis heute den Kern der katholischen Kardinaltugenden, basierend auf den klassischen griechischen. Die Reformatoren hingegen ersetzten die Tugendlehre durch die Betonung des Heils/der Befreiung allein aus Glauben. Tugenden waren damit nicht abgeschafft, aber relativiert und in einen neuen Heilskontext gestellt.

Nicht zuletzt durch Reformation und Aufklärung hatte die Moderne die Tugendlehren vielfach abgelehnt oder skeptisch aufgenommen. Nach dem Zweiten Weltkrieg mit seinen zerstörerischen ethischen Entgleisungen wurde dann die Tugendethik rehabilitiert, mit deutlicher Wirkung in der zweiten Hälfte des 20. Jahrhunderts. Joseph Pieper (1939), Elisabeth Anscombe (1958), Alasdair MacIntyre (1981), Charles Taylor (1985, 1998) und Martha Nussbaum (1986) sind zeitgenössische Philosophinnen und Theologen, die die Tugenden wieder aufgenommen haben. Ich selbst habe Tugenden in meinen Publikationen der letzten zehn Jahre verstärkt aufgenommen. ${ }^{11}$

\section{Integrität in aktuellen internationalen Kontexten}

Vor diesem Hintergrund der Neubewertung von Tugenden möchte ich im Folgenden den Fokus auf die Tugend der Integrität legen, zunächst deskriptiv in weltweiten aktuellen Zusammenhängen. Integrität/Integrity/intégrité ist $\mathrm{zu}$ einem stark beachteten Modewort geworden. Im multilateralen Vokabular der UNO und anderer internationaler Organisationen ist Integrität beinahe zu einem

11 Z.B. Christoph Stückelberger, Umwelt und Entwicklung. Eine sozialethische Orientierung, Stuttgart 1997, S. 68-69; S. 239-338. 
Synonym für Korruptionsbekämpfung geworden. ${ }^{12}$ So ist in der Weltbankgruppe die „Vize-Präsidentschaft Integrität“ (Integrity Vice Presidency) die Anti-korruptionseinheit. „Global Integrity“ ist eine Methodologie zur Klassifizierung der Transparenz zwischen Ländern ${ }^{13}$. Die Nichtregierungsorganisation „IntegrityAction“ unterstützt Aktivitäten besonders von Jugendlichen, die öffentliche Entwicklungsprojekte von Städten und Regierungen kritisch begleitet, sozusagen als demokratische Kontrolle von unten wo parlamentarische Kontrollen zu schwach sind. ${ }^{14}$ „Integrität im Management ${ }^{\text {“15 }}$ ist zu einem neuen Zweig der Unternehmensethik und der ethischen Führungskonzepte gewor$\operatorname{den}^{16}$. Das "Center for Public Integrity“ in den USA ${ }^{17}$ betreibt investigativen Journalismus, um Machtmissbrauch im öffentlichen Bereich aufzudecken. „Faith and Public Integrity Network“ und die private, aus christlicher Haltung operierende Beratungsfirma „Trident Integrity in Malaysia“ engagieren sich besonders in der Korruptionsbekämpfung aus christlicher Sicht.

Integrität ist $\mathrm{zu}$ einem fast magischen Wort geworden, um den Ruf nach ethischem, glaubwürdigem Verhalten einzufordern. Damit ist Integrität zu einer Antwort auf die weltweite Krise des Vertrauens in Autoritäten geworden. Die jährlichen Vertrauensbarometer, z. B. der „Edelman Trust Barometer ${ }^{\text {“18 }}$, zeigen, dass das Vertrauen in Führungsspitzen in Politik, Unternehmen, Medien, aber auch religiösen und akademischen Organisationen angeschlagen ist (wobei es zwischen den Sektoren und Ländern deutliche Unterschiede gibt).

Ein konkretes Beispiel auf nationaler Ebene erlebe ich in der Demokratischen Republik Kongo DRK. Alle großen religiösen Institutionen (christliche Denominationen sowie die islamische Gemeinschaft) haben gemeinsam eine „Kommission für Integrität und Mediation in Wahlen“ (Commission intégrité et

12 World Bank Group, Integrity Vice Presidency: Annual Update Fiscal Year 2014. +5 Years of Fighting Corruption, Washington 2014, vgl. www.worldbank.org/integrity (letzter Zugriff: 24.04.2019).

13 Global Integrity. Innovations for Transparency and Accountability, vgl. www.globalintegri ty.org (letzter Zugriff: 24.04.2019).

14 www.integrityaction.org (letzter Zugriff: 24.04.2019).

15 Christophe Baki-Boisier, L'intégrité, mon glaive, Toulouse 2014; Patrick Renz / Bruno Frischherz / Irena Wettstein, Integrität im Managementalltag. Ethische Dilemmas im Managementalltag erfassen und lösen, Berlin-Heidelberg 2015; Thomas Maak / Peter Ulrich (Hg.), Integre Unternehmensführung. Ethisches Orientierungswissen für die Wirtschaftspraxis, Stuttgart 2007.

16 Horst Steinmann / Brigitte Kustermann, Unternehmensethik und Management: Überlegungen zur Integration der Unternehmensethik in den Managementprozess, in: Handbuch der Wirtschaftsethik 3, Gütersloh 1999, S. 214-216 (Der Integritäts-Ansatz).

17 www.publicintegrity.org (letzter Zugriff: 24.04.2019). Das Ziel: „To serve democracy by revealing abuses of power, corruption and betrayal of public trust by powerful public and private institutions, using the tools of investigative journalism."

18 www.edelman.com/insights/intellectual-property/2016-edelman-trust-barometer (letzter Zugriff: 24.04.2019). 
médiation électorale CIME) gebildet. Ich wurde gebeten, die Religionsgemeinschaften mit einem mehrjährigen Trainingsprogramm zu unterstützen, das wir FIER nennen („Formation pour l'intégrité des élections responsible“). Integrität in diesem äußerst komplexen politischen, wirtschaftlichen und religiösen Umfeld bedeutet der Aufruf an alle Gesellschaftsgruppen nach Transparenz, Ehrlichkeit, Glaubwürdigkeit und Verlässlichkeit in Wahlprozessen. Die Religionsgemeinschaften haben sich gemeinsam das Ziel gesetzt, eine „culture d'intégrité“, eine Kultur der Integrität, zu fördern.

Neben dieser direkten ethischen Bedeutung von Integrität kommt der Begriff in weiteren Zusammenhängen vor, die durchaus ethische Relevanz haben:

So hat „Integrität“ direkte politische und territoriale Bedeutung. In zwischenstaatlichen und innerstaatlichen Konflikten, besonders gegenüber Segregationsbewegungen, wird die „Territoriale Integrität“ eines Staatswesens beansprucht, d.h. die Respektierung der aktuellen Grenzen. „The territorial integrity of the DRC shall be respected “19 sagte Antonio Di Rupo, damals Premierminister von Belgien, vor der UNO 2012. Integrität ist offizieller Begriff des Völkerrechts.

In der Bioethik heißt ein Prinzip, die „Integrität von Lebewesen“, Menschen, Tieren und anderen Organismen, zu schützen. Schutz der Integrität von Lebewesen und der Biodiversität sind die zwei Kriterien, die in der Schweizer Bundesverfassung im Zusammenhang mit Gentechnologie festgeschrieben sind. Organismen dürfen in der Schweiz also nur genetisch modifiziert werden, wenn ihre Integrität gewahrt wird. Ich hatte die Ehre, während neun Jahren (gefolgt von Kollege Georg Pfleiderer) als Mitglied der Eidgenössischen Ethikkommission im Außerhumanbereich EKAH mir den Kopf zu zerbrechen, welche Kriterien denn nun gelten, um Integrität zu wahren. ${ }^{20}$ Das zeigt, dass es nicht nur um eigene Integrität geht, sondern um das eigene Verhalten zum Schutz der Integrität des Anderen, von menschlichen und nichtmenschlichen Lebewesen.

In der wissenschaftlichen Forschung und Forschungsethik bedeutet Integrität z.B. Absage an Plagiate oder die Veröffentlichung nicht nur unterstützender (z.B. medizinischer) Testresultate, sondern auch der negativen. So gibt es ein „Netzwerk Ethik und Integrität“, „Ethics and Integrity Network“, das sich ausschließlich mit Integrität in der Forschung beschäftigt. ${ }^{21}$

„Integrität der Umwelt“ („Environmental integrity“) ist eines der fünf Kapitel der Erdcharta, die 1992 in Rio de Janeiro von der UN-Staatengemeinschaft angenommen wurde. Integrität der Umwelt schließt den Schutz der Umwelt und der Biodiversität ein.

19 Antonio Di Rupo, Belgium's Prime Minister, addressing the UN AGM on 26 September 2012.

20 http://www.ekah.admin.ch/fr/page-daccueil (in French) (letzter Zugriff: 24.04.2019).

21 http://www.ethics-and-integrity.net/ (letzter Zugriff: 24.04.2019). 
Die „Integrität einer Person“ und die „Integrität einer Gemeinschaft“ sind in den Menschenrechten und den Rechten der Völker der Sache nach in vielen dieser Rechte festgehalten.

Integrität von Personen, Gemeinschaften und Organismen heißt nun nach protestantischer Ethik nicht Unantastbarkeit eines Lebewesens oder eines Organismus im Sinne der Bewahrung eines (de facto nie dagewesenen) paradiesischen Urzustandes. Im Gegenteil, Bewahrung der Integrität heißt das Entwicklungs- und Veränderungspotential eines Organismus in einer dynamischen Weise auch für die Zukunft zu gewährleisten. Die Verheißung eines neuen Himmels und einer neuen Erde (Off. 21,21) bedeutet, dass Integrität von Organismen in dieser eschatologischen, dynamischen und zukunftsgerichteten Perspektive zu deuten ist.

Integrität ist demnach nicht nur eine individuelle Tugend, sondern auch eine Charakterisierung und Zielsetzung für Gemeinschaften. „Eine Integritätskultur weben“, ein Ausdruck eines promovierten Wirtschaftsethikers und Kollegen aus dem Kongo, ist ein wunderschöner Ausdruck dafür. ${ }^{22}$

\section{Integrität in der Bibel}

Das Wort „Integrität“ erscheint in der Bibel nur im Alten Testament und nur spärlich, aber erhellend. Integrität wird besonders von den Richtern eingefordert, schon im Rahmen der Ablehnung von Korruption an Gerichten zur Zeit der Einsetzung der ersten Richter (Ex. 23,3.8).

Aufrichtigkeit (Spr. 1,3) ist nahe bei Integrität. Absage an andere Götter als Treue zu und Vertrauen in Gott (Jos. 24,14) zeigt, dass Treue zu Gott und Integrität im Alten Testament beinahe Synonyme sind.

Andere Aspekte von Integrität werden in folgenden Zusammenhängen erwähnt: die Reinheit des Herzens und die Treue des Glaubenden gegenüber Gott. So dankt David Gott, dass er treu zu den Treuen und integer gegenüber den Integren (blameless, intègres) ist (2 Sam. 22,21-26).

Ein biblischer Text zur Integrität, den wir als „klassisch“ bezeichnen könnten, ist Psalm 15,2-5 (Übersetzung Luther 1912/Gute Nachricht):

„Herr, wer darf deine Hütte betreten?

Wen lässt du wohnen auf deinem heiligen Berg?

Wer ohne Tadel einhergeht

und recht tut und redet die Wahrheit von Herzen;

wer mit seiner Zunge nicht verleumdet

22 Corneille Ntamwenge, L'éthique des affaires au Congo. Tisser une culture d'intégrité en Afrique Centrale, Globethics.net Focus 11, Geneva 2013. 
seinem Nächsten kein Arges tut [...] und seinen Nächsten nicht schmäht; wer tut, was er geschworen hat selbst dann, wenn es ihm Nachteil bringt; wer sein Geld nicht auf Wucher gibt und sich nicht dazu bestechen lässt, schuldlose Menschen um ihr Recht zu bringen.

Wer sich an diese Regel hält, der steht für immer auf sicherem Grund.“

Dies ist eine eindrückliche Beschreibung einer Person mit Integrität, mit elf Charakteristika:

Geradlinig, ehrlich, wahrhaftig, in der Sprache kontrolliert, fair, gewaltfrei, mutig, an der Wahrhaftigkeit orientiert, Versprechen einhaltend, korruptionsfrei, standfest.

Die vier Kardinaltugenden sind auch hier bereits angelegt. Der Schluss weist auf einen wichtigen Aspekt von Integrität hin: die integre Person ist nicht frei von Versuchungen, sondern wird versucht wie alle anderen, aber hat die Kraft zu widerstehen gegenüber Gier, Korruption, Machtmissbrauch usw. Die integre Person mag wanken, aber nicht fallen, wie ein anderer Psalm sagt.

Ebenfalls wichtig für Integrität ist die im Text genannte Tugend, Versprechen einzuhalten. Glaubwürdigkeit hängt weitgehend davon ab. Hart ist es, Versprechen einzuhalten, besonders, wenn man dabei verliert. Z. B. das Versprechen, als Kandidat/in für ein politisches Mandat ein Wahlresultat zu akzeptieren, ist einfacher einzulösen, wenn man die Wahl gewinnt, als wenn man sie verliert. Versprechen einhalten hat einen Preis. Integre Personen sind bereit, den Preis zu zahlen und die eigene Integrität als höheres Gut zu werten denn den Erhalt von Macht oder Reichtum. Der Psalm zeigt auch, dass Integrität das Wohl der Gemeinschaft im Blick hat und Korruption widersteht. Der Lohn für Ehrlichkeit und Integrität ist Friede des Herzens und ein Leben in Sicherheit: „Leben in Ehrlichkeit heißt leben in Sicherheit“, wie es in Sprüche 10,9 heißt.

Im Neuen Testament mag Integrität weniger präzis beschrieben sein als im Alten. Doch die erwähnten paulinischen und nachpaulinischen Tugendkataloge sind weitgehend Beschreibungen einer aufrichtigen, ehrlichen, integren Person. Das Neue Testament geht aber entscheidend über das Alte bezüglich Integrität hinaus, indem die Integrität nicht primär in der Befolgung des Gesetzes und der vielen Ordnungen besteht, sondern im Praktizieren der Liebe im Sinne der Bergpredigt. Damit erhält Integrität einen Fokus, einen Brennpunkt, an dem die Person gemessen wird. Augustinus' Wort „Dilige - et fac quod vis“, „Liebe - und tue dann was du willst“ könnte man sagen: „Liebe - und du wirst integer sein.“ Feindesliebe ist demnach der größte und schwierigste Akt der Integrität. 


\section{Integrität und Macht}

Die größte Herausforderung für Integrität ist Macht. Aus ethischer Sicht ist Macht per se weder negativ noch positiv. Macht als Fähigkeit der Umsetzung und Durchsetzung einer Entscheidung ist notwendig zur Umsetzung von Zielen und ethischen Werten und zur Umsetzung von Versprechen. Eine Person kann für eine Handlung nur verantwortlich gemacht werden, wenn sie auch die Fähigkeiten (Macht) hat, eine Handlung umzusetzen: Wissen für die richtige Entscheidung, Geld zur Finanzierung einer Handlung, die Macht von Koalitionen, um demokratische Mehrheiten zu gewinnen, die Macht der Kommunikation für den öffentlichen Diskurs usw.

Solche Macht ist nun aber ständig gefährdet missbraucht zu werden. Das hat theologisch gesprochen einfach damit zu tun, dass alle Menschen ohne Ausnahme unvollkommen (Sünder) sind, das heißt immer wieder unfähig sind, den Willen Gottes zu tun, ständig der Versuchung ausgesetzt (wer immer den Willen Gottes tun würde, wäre Gott). Deshalb brauchen alle Menschen die Korrektur durch die Mitmenschen, besonders im Umgang mit Macht. Auch integre Personen sind der Versuchung des Machtmissbrauchs ausgesetzt. Gerade weil sie das wissen, akzeptieren sie Machtkontrolle. Das ist der theologisch tiefere Grund für die Notwendigkeit von fünf Mächten im modernen Rechtsstaat, die je ihre Rolle in der Machtkontrolle spielen: die Legislative, die Exekutive, die Judikative, die Medien und die Zivilgesellschaft.

Die Bibel enthält sehr viele Texte über Versuchungen zum Machtmissbrauch. Sie geben wichtige Hinweise für politische Ethik und auf eine Ethik der Integrität. Die bekannteste Geschichte ist die Versuchung Jesu (Lk. 4,1-12). Als Mensch wurde auch Jesus versucht durch Macht, Geld und übernatürliche Wunderkräfte. Sein Widerstand gegen diese Versuchung war gemäß Lukasevangelium die erste wichtige Handlung auf dem Weg zu seinem Ruf als Persönlichkeit mit Integrität.

Ein anderer eindrücklicher Text zum Widerstand gegen Machtmissbrauch findet sich in Sirach. Zur Zeit des blutigen Makkabäeraufstandes im Jahr 167 v. Chr. heißt der Ratschlag: „Versuche nicht, Richter zu werden, wenn du es nicht schaffst, Ungerechtigkeit zu überwinden, weil du von einer Persönlichkeit wie einem Prinzen beeinflusst werden könntest und damit deine eigene Integrität kompromittieren würdest.“ (Sir. 7,6, eigene Übersetzung). Das heißt: Strebe also nicht ein Amt mit viel Ehre und Macht an, wenn du ihm nicht gewachsen bist. Wenn du der Versuchung der Macht nicht gewachsen bist, wirst du deine Integrität verlieren. 


\section{Integrität als zeitgemäße Tugend für Individuen}

Aus christlich-ethischer Sicht lässt sich Integrität wie folgt zusammenfassend beschreiben:

Integrität ist eine Kombination und Integration von verschiedenen Tugenden und Werten: Ehrlichkeit, Respekt, Verantwortung, Aufrichtigkeit, Wahrhaftigkeit, Rechtschaffenheit, Geradlinigkeit, Weisheit und Charakterstärke. Integrität heißt, zu den eigenen Werten und Überzeugungen zu stehen - aus christlicher Sicht: den Willen Gottes zu tun - auch und gerade wenn es mit Kosten verbunden ist oder Leiden verursacht. „Integrität heißt das Richtige zu tun, auch wenn niemand zuschaut.“ (C.S. Lewis). Das Richtige tun, was notwendig ist und nicht nur was profitabel ist. Integrität heißt auch, aus intrinsischer Motivation $\mathrm{zu}$ handeln und nicht nur aus extrinsischer Motivation, weil es eine vorgesetzte Person erwartet oder es ein Modetrend ist. Eine integre Person respektiert Gesetze und Regeln und setzt sie um. Sie hat den Mut korrekt zu handeln, auch wenn die Mehrheit nicht folgt, die Autoritäten nicht applaudieren und es finanziell etwas kostet. Sie kann Interessenkonflikte erkennen, transparent machen und mit ihnen umgehen. Eine Person mit Integrität kann eigene Fehler eingestehen, eigene Grenzen erkennen und in Gemeinschaft mit anderen Korrekturen vornehmen.

Integer zu sein ist sehr schwierig in einer Zeit, wo öffentliche Lüge, Unehrlichkeit, Korruption und mediale Selbstdarstellung zunehmen und sogar belohnt zu werden scheinen und wo die Grenzen von virtueller und physischer Realität so fließend werden, dass oft schwer zu erkennen ist, was nun Wahrhaftigkeit und Integrität bedeutet. Und genau deshalb ist die eingangs beschriebene Sehnsucht nach öffentlichen Persönlichkeiten mit Integrität wie das Bedürfnis nach Freunden, denen man vertrauen kann, so groß.

Integrität ist dann auf dem Prüfstand, wenn sie nichts wert zu sein scheint. Integer zu bleiben in einer Umgebung, wo Lüge, Betrug, Unehrlichkeit und Ausbeutung an der Tagesordnung sind, ist eine große Herausforderung. In solchen Situationen braucht eine integre Person große Ausdauer und Widerstandskraft. Die integre Person fühlt sich allein, nicht verstanden, ohne Unterstützung und als naiv oder idealistisch belächelt. Es sind Zeiten des Leidens und Zweifels, wo Gewalt über Gewaltfreiheit herrscht, das Pferd stärker ist als der Esel, um das Bild vom integren Jesus auf dem Esel aufzunehmen. In solch schweren Zeiten wird sich die integre Person an die biblischen Verheißungen halten, dass die unehrliche Person vielleicht zwar kurzfristig viele Vorteile genießt, aber die gerechte Person gesegnet wird. „Redliche Menschen dürfen im Land bleiben, die Treulosen aber werden weggefegt.“ (Spr. 2,21 f.) „Gesegnet sind alle, die keine Gewalt anwenden, denn Gott wird ihnen die Erde zum Besitz geben.“ (Mt. 5,5) 
Darin liegt die spirituelle Kraft der integren Persönlichkeit.

Der Mut zur Integrität hat einen Preis. So begegne ich durch unser globales Ethiknetzwerk Globethics.net immer wieder Menschen, die diesen Preis zu zahlen bereit sind und gerade damit zu Persönlichkeiten der Integrität werden. Der Präsident-CEO einer großen staatlichen Firma in Afrika ist letztes Jahr nur sechs Monate nach seiner Ernennung zurückgetreten, weil ihm nicht die Kompetenzen gegeben wurden, mit der Korruption in der Firma so aufzuräumen, wie er das gegenüber der Öffentlichkeit versprochen hatte. Er hatte auf Macht, Geld und Einfluss verzichtet, um seinen exzellenten Ruf als integre, nicht korrumpierbare Persönlichkeit zu wahren. Das zweite Beispiel ist ein Freund aus Asien, der als Direktor einer hoch angesehenen akademischen Institution nominiert wurde. Er machte zur Bedingung seines Amtsantritts, dass er vorherige korrupte Direktoriumsmitglieder ersetzen könne. Da ihm dies von den politischen Aufsichtsbehörden nicht gewährt wurde, hat er die Stelle ausgeschlagen. Die zwei Beispiele zeigen auch, dass solche mutigen Entscheide oft nur möglich sind, wenn ein gewisses sozial-familiäres und finanzielles Sicherheitsnetz besteht, um nicht im Leeren zu stehen.

Viele weitere Beispiele von integren Persönlichkeiten können genannt werden. Z. B. Nelson Mandela, der als Inbegriff von Integrität unter afrikanischen Führern gilt. ${ }^{23}$ Oder Erich Walser, Schweizer Unternehmer und 2015 verstorbener Direktor des Verbandes der Schweizer Versicherungen, der im Nachruf explizit als integre Persönlichkeit geehrt wurde. ${ }^{24}$ Integre Personen müssen nicht Heilige und nicht perfekt sein, aber mutige, aufrichtige Personen mit Grundwerten, die sie nicht aufgeben.

\section{Integrität in systemischer Sicht und als Institutionenkultur}

Manche mögen die Tugendethik als individualistisch abtun. In der Tat bezeichnen Tugenden wie erwähnt insbesondere persönliche Haltungen und individuelle Handlungen. Aber Integrität ist nicht (nur) für Heilige und ethische Helden gedacht, sondern kann auch von Normalsterblichen gelebt und in der Transformation von Institutionen umgesetzt werden. Die Tugend der Integrität ist ein ganzheitlicher Zugang zur Lösung von Problemen und der Überwindung von Untugenden (Lastern). Christliche Strukturenethik zeigt die Bedeutung von

23 See the comparison of Mandela and Mugabe in Christoph Stückelberger, Responsible Leadership Handbook. For Staff and Boards, Geneva 2014, S. 105-107, Free download at www.glo bethics.net/publications (letzter Zugriff: 24.04.2019).

24 Urs Berger / Lucius Dürr, Gestalter und Brückenbauer, in: Neue Zürcher Zeitung am 07.01. 2015. 
Strukturen und Institutionen zur Unterstützung individuellen ethischen Verhaltens auf. Beispiele:

Professionelle und institutionelle Verhaltenskodizes ${ }^{25}$, Komitees für Forschungsethik in universitärer Bildung oder Spitälern, Sanktionsmechanismen gegen Plagiate, Ethikunterricht in Schulen, Antikorruptionsplakate in Flughäfen, Erziehungsunterstützung für Familien etc.

\section{Integrität als politischer und wirtschaftlicher Referenzpunkt}

Zur Förderung von Integrität ist ein rechtlicher und wirtschaftlicher Rahmen sehr wichtig. Gesetze und Regulierungen sowie deren Implementierungsmechanismen sind entscheidend, um Individuen zur Integrität zu führen. Zahlreiche Instrumente zur Förderung von finanzieller Transparenz im Bankenwesen, öffentlichen Beschaffungswesen, transparenten Wahl- und Abstimmungsverfahren inkl. Universitätsverwaltungen und Berufungsverfahren sind in den letzten Jahren geschaffen worden. Sie sind wichtige Stützen und gleichsam Krücken (Gehhilfen) für die Integrität.

Gleichzeitig beobachte ich nun vermehrt eine Delegation von Werten und Tugenden an rechtliche Autoritäten. Am deutlichsten ist dies im Finanzsektor. Banker und besonders Privatbankiers waren früher hoch geschätzte Persönlichkeiten mit Integrität. Als Folge der zahlreichen Missbräuche und Skandale im Bankensektor und dem dramatischen Verlust des Vertrauens in Banker, wurden die Kontrollmechanismen so verschärft, dass heute die Compliance Manager, also jene, die die Einhaltung der Regeln überwachen, gleichsam die modernen Inquisitionsinstanzen, die Macht in der Finanzwelt darstellen, wie ich in der Ethikberatung von Firmen und Banken immer wieder feststelle. Damit werden Werte und Tugenden an die Aufsichtsbehörden delegiert, die extrinsische Motivation ersetzt die intrinsische. Damit schlägt nun das Pendel vom Neoliberalismus zum Neo-Etatismus. Als Ethiker plädiere ich für eine Balance von Eigenverantwortung, rechtlichem Rahmen und ökonomischen Anreizen/Sanktionen, um Integrität zu fördern.

Die Nichtregierungsorganisation „IntegrityAction“, mit der ich zusammenarbeite, definiert öffentliche Integrität (public integrity) wie folgt:

„Public or organisational integrity is the set of characteristics that justify trustworthiness and generate trust among stakeholders. Integrity creates the conditions for organisations to intelligently resist corruption and to be more trusted and efficient.

25 See the collection of over 1000 codes of professional ethics online, free downloadable: http://www.globethics.net/web/codes-of-ethics/collection-articles?layoutPlid=4297674 (letzter Zugriff: 24.04.2019). 
IntegrityAction takes integrity to be the alignment of four factors: Accountability, Competence, Ethics and Corruption control.“26

In eigenen Worten fassen ich Integrität so zusammen: Integrität bedeutet eine Haltung und ein Verhalten, das auf Verantwortung, Transparenz, Kompetenz, Wertorientierung, Mut und Korruptionsfreiheit beruht.

\section{Zusammenfassung}

Tugendethik ist ein wichtiger Pfeiler der Ethik. Dies gilt besonders in der heutigen Zeit der Globalisierung und des Relativismus, wo allgemeinmenschliche Tugenden, die als selbstverständlich angenommen wurden, immer weniger respektiert werden. Die Christliche Tugendethik nimmt dabei globale, interkulturell seit über 2500 Jahren anerkannte Tugenden, die man auch globale Tugenden nennen kann, auf und knüpft daran an. Dies gilt auch für die Tugend der Integrität. Der spezifisch christliche Beitrag liegt dabei nicht so sehr im Inhalt dieser Tugend als in der Befähigung der Glaubenden, Integrität zu leben aus der befreienden Zusage des Segens Gottes, aus dem Mut und der inneren Unabhängigkeit, die aus der Christusbeziehung entsteht und mit der Energie und Gewissheit des Heiligen Geistes.

Die Kirchen und integren Führungspersönlichkeiten sind aufgerufen, deutlicher ihre Stimme zu erheben, wo Personen aus Politik, Wirtschaft, Medien, Zivilgesellschaft, Sport und Kultur die Wahrheit mit Füßen treten, Lügen ungestraft verbreiten, eine politische Kultur des Hasses, der Verleumdung, der Verdächtigungen, der populistischen Anbiederung und narzisstischen Selbstdarstellung fördern.

Einer solchen Un-Kultur ist entgegenzutreten. Das international stark angeschlagene Vertrauen in Politik, Wirtschaft, Finanzwesen, Sport, Medien und Religionsgemeinschaften, das der Nährboden für gefährliche Populismen und ideologische Extremismen bildet, lässt sich nur widerherstellen durch mutige Personen und Persönlichkeiten mit Integrität! Das von mir gegründete und präsidierte globale Ethiknetzwerk Globethics.net vereint Personen mit dem Ziel lokale und globale Koalitionen für eine Kultur der Integrität zu bilden!

26 www.integrityaction.org (letzter Zugriff: 24.04.2019). 


\section{Quellen}

Baki-Boisier, Christophe, L'intégrité, mon glaive, Toulouse 2014.

Berger, Urs / Dürr, Lucius, Gestalter und Brückenbauer, in: Neue Zürcher Zeitung am 07.01.2015.

Di Rupo, Antonio, Belgium's Prime Minister, addressing the UN AGM on 26 September 2012.

Craig, Steven Titus, Art. Vertus, Dictionnaire encyclopédique d'éthique chrétienne, Éditions du Cerf, Paris 2003, S. 2073-2093.

Global Integrity. Innovations for Transparency and Accountability, vgl. www.globalintegri ty.org (letzter Zugriff: 24.04.2019).

Langer, Marie-Astrid, US Präsidentenwahl: Eine Frage der Integrität, in: Neue Zürcher Zeitung am 13.10.2016, vgl. https://www.nzz.ch/international/wahlen-in-den-usa-ld. 127107 (letzter Zugriff: 24.04.2019).

Maak, Thomas / Ulrich, Peter (Hg.), Integre Unternehmensführung. Ethisches Orientierungswissen für die Wirtschaftspraxis, Stuttgart 2007.

Ntamwenge, Corneille, L'éthique des affaires au Congo. Tisser une culture d'intégrité en Afrique Centrale, Globethics.net Focus 11, Geneva 2013.

Renz, Patrick / Frischherz, Bruno / Wettstein, Irena, Integrität im Managementalltag. Ethische Dilemmas im Managementalltag erfassen und lösen, Berlin-Heidelberg 2015.

Steinmann, Horst / Kustermann, Brigitte, Unternehmensethik und Management: Überlegungen zur Integration der Unternehmensethik in den Managementprozess, in: Handbuch der Wirtschaftsethik 3, Gütersloh 1999, S. 214-216 (Der Integritäts-Ansatz).

Stückelberger, Christoph, Global Ethics Applied, Globethics Publications, Genf 2016, Vol. 1-4.

Stückelberger, Christoph, Responsible Leadership Handbook. For Staff and Boards, Geneva 2014.

Stückelberger, Christoph, Umwelt und Entwicklung. Eine sozialethische Orientierung, Stuttgart 1997.

Umfrage des East African Institute, Kenya, Jan 2016, vgl. http://www.nation.co.ke/news/ Kenyan-youth-have-no-qualms-with-corruption-survey-shows/1056-3038800-pb8yd w/index.html (letzter Zugriff: 24.04.2019).

World Bank Group, Integrity Vice Presidency: Annual Update Fiscal Year 2014. +5 Years of Fighting Corruption, Washington 2014, vgl. www.worldbank.org/integrity (letzter Zugriff: 24.04.2019).

https://www.christophstueckelberger.ch/teaching/ (letzter Zugriff: 24.04.2019).

www.globethics.net (letzter Zugriff: 24.04.2019).

www.gafoundation.world (letzter Zugriff: 24.04.2019).

www.edelman.com/insights/intellectual-property/2016-edelman-trust-barometer (letzter

Zugriff: 24.04.2019).

http://www.ekah.admin.ch/fr/page-daccueil (in French) (letzter Zugriff: 24. 04. 2019).

http://www.ethics-and-integrity.net/ (letzter Zugriff: 24.04.2019).

www.integrityaction.org (letzter Zugriff: 24.04.2019).

www.publicintegrity.org (letzter Zugriff: 24.04.2019). 
Open-Access-Publikation im Sinne der CC-Lizenz BY 4.0

(C) 2020, Vandenhoeck \& Ruprecht $\mathrm{GmbH} \&$ Co. KG, Göttingen ISBN Print: 9783847111658 - ISBN E-Lib: 9783737011655 


\section{Wirtschaftsethik}

Open-Access-Publikation im Sinne der CC-Lizenz BY 4.0

(c) 2020, Vandenhoeck \& Ruprecht GmbH \& Co. KG, Göttingen 
Open-Access-Publikation im Sinne der CC-Lizenz BY 4.0

(C) 2020, Vandenhoeck \& Ruprecht $\mathrm{GmbH} \&$ Co. KG, Göttingen ISBN Print: 9783847111658 - ISBN E-Lib: 9783737011655 


\section{Investment within the Framework of the "Environment, Society and Governance". A Catholic Church Perspective}

\section{Introduction}

The global financial crisis (2008-2011), whose roots lay in questionable, if not aberrant, practices in the financial markets had a lot of lessons to teach about the financial industry. The former Pontifical Council for Justice and Peace of the Holy See made itself an advocate of some of these lessons, publishing a small study in which it called for a reform of the international financial and monetary systems in the context of a global public authority. In so doing, the Vatican Dicastery was inspired and guided by the suggestion of the Council Fathers of Vatican II that "giving witness and voice to the faith of the whole people of God"', the Church provides eloquent proof of her solidarity with, as well as her respect and love for the entire human family with which it is bound up, by engaging with it in conversation about its various problems. ${ }^{2}$ The study, "Towards reforming the International financial and monetary systems in the context of global public authority" ${ }^{\text {3 }}$ sought to initiate one such conversation, at the same time making suggestions for ending the crisis and avoiding its recurrence.

Since then, the Vatican Dicastery (for Justice and Peace) has merged with three others, becoming now the Dicastery for Promoting Integral Human Development. ${ }^{4}$ Following the publication of the Encyclical Letter of Pope Francis, Laudato si: On the Care of our Common Home (2015), on integral ecology and on how everything on earth and in our common home is interconnected, the attention of the new Vatican Dicastery is engaged by the specific area of the world of finance which may be referred to as the management of financial assets or

1 Paul VI., Gaudium et Spes, Vatican 1965, 1.

2 Ibid.

3 Pontifical Council for Justice and Peace, Towards Reforming the International Financial and Monetary Systems in the Context of Global Public Authority, Vatican 2011.

4 Apostolic Letter issued Motu Proprio by the Supreme Pontiff Francis Instituting the Dicastery for promoting Integral Human Development, August 2016. 
investing, ${ }^{5}$ and on how this financial activity promotes the wellbeing of both the earth and its people (inhabitants).

By way of making a modest contribution to the Festschrift, which celebrates the career and ministry of o. Univ.-Prof. Dr. Ingeborg G. Gabriel, one may couch the interest and pursuit of the Vatican Dicastery as "investment within the framework of the environment, society and governance"!

\section{Towards an Identification of an ESG Framework}

Pope Francis jolted the conscience of a world infatuated with money, its transactions and its processing hub of the stock markets, when he asked, rhetorically, "can it be that it is not a news item when an elderly homeless person dies of exposure, but it is news when the stock market loses two points?"6 Thus, though money is a useful tool of communication and encounter, as Pope Francis observed, addressing members of the Fortune-Time Global Forum 2016 during their visit to the Vatican, ${ }^{7}$ it may not supplant or replace the human person in importance. "Money", according to Pope Francis, "must serve, not rule." the Holy Father links problems in the financial sector to a

"profound human crisis: the denial of the primacy of the human person! We have created new idols. The worship of the ancient golden calf (cf. Ex 32:1-35) has returned in a new and ruthless guise in the idolatry of money and the dictatorship of an impersonal economy lacking a truly human purpose."

Accordingly, we should expand our efforts to align the management of finance and our assets with the wellbeing and inclusive flourishing of the entire human family, not according to some invisible hand, but according to the visible hand of, for example, the four classical principles of Catholic social teaching: $:^{10}$ because they do inspire harmonious living in society, and promote within the human family a sharper insight into its full destiny on earth, namely, to coexist for the

5 Though conceived, as observed above, as a follow up on the "Note" of the Pontifical Council for Justice and Peace, Towards Reforming the International Financial and Monetary Systems in the Context of Global Public Authority (2011), it is proper to note that the publication of this document, Mensuram Bonam, now follows upon the publication of Oeconomicae et Pecuniariae Questiones, Considerations for an ethical discernment Regarding some Aspects of the Present Economic-Financial System (2018) by the Congregation for Doctrine and Faith and the Dicastery for Promoting Integral Human development.

6 Francis, Evangelii Gaudium, Vatican 2013, 53.

7 September $6^{\text {th }}, 2016$.

8 Francis, Evangelii Gaudium, Vatican 2013, 58.

9 Ibid., 55.

10 Cf. Compendium of Social Teaching of the Church, $\$ 160$; “This understanding is such that it inspires harmonious living in society.” $\$ 77$. 
common good, to fashion a world to man's surpassing dignity, and to meet the urgencies of our age with a gallant and unified effort born of love. ${ }^{11}$ These classical principles are:

1) Personality/Personhood, as an expression of every human person's metaphysically added value, understood as a bearer and owner of inalienable and irreplaceable dignity.

2) Solidarity, not as a vague sense of compassion, but, as the virtue, in the words of Pope John Paul II, which makes one commit really to the wellbeing of another.

3) Subsidiarity, according to which "all societies of a superior order must adopt attitudes of help (subsidium) - therefore of support, promotion, development - with respect to lower order of societies". ${ }^{12}$ Solidarity and subsidiarity thus have, as scope, the development of persons and their dignity.

4) Common good, understood not as gross national product or gross domestic product, but as the guarantee of the personal, familial and associative good. The common good of every person in a human community is thus the fundamental right to life and to its full realization.

5) To these four principles, one may now add, in the light of the UN celebration of "Earth Day" and of Pope Francis' Encyclical letter on integral ecology, "care of the earth", our common home.

In principle, then, the financial system, its operation and transactions must be grounded and guided, not primarily by profit and maximisation of returns for investors and shareholders, but by moral principles that are the fruit of faith and charity, ${ }^{13}$ and which construct a veritable ESG Framework (Environment, Society, and Governance).

The necessity, on the one hand, of a moral compass in financial investment and operations is also confirmed by Pope Benedict XVI who observes wisely in his Encyclical Letter, Caritas in veritate, that, "the economic sphere is neither ethically neutral, nor inherently inhuman and opposed to society. It is part and parcel of human activity, and precisely because it is human, it must be structured and governed in an ethical manner." ${ }^{14}$ On the other hand, the need for such moral guidance to promote an ESG framework is also confirmed by the Bishops of the United States who in their 1986 Pastoral Letter, "Economic Justice for all”, observed, "Economic life raises social and moral questions for each of us and for

11 Cf. Gaudium et spes, 91.

12 Cf. Compendium, \$185-186.

13 The recently published text Oeconomicae et Pecuniariae makes the same call.

14 Benedict XVI, Caritas in Veritate, Vatican 2009, 36. 
society as a whole", ${ }^{15}$ and that "it is in making decisions about managing resources and investments that we give proof of our Christian identity (moral fibre) and the conviction that local and global economies must be viewed not only in terms of production and distribution, but also in terms of their effect on the environment and the dignity of the human person". ${ }^{16}$

It is noteworthy that when the United States Bishops talk of "effect" of global and local economies, they speak of the environment and the dignity of human persons; and these are two crucial parameters of the ESG framework.

In what follows, I shall briefly present (trace out) the significance (basis) of the ESG framework in Church teaching, and illustrate how it is pursued in economics, business and investing through the application of the principles of the Church's Social Teaching.

\section{The ESG Framework in Church Teaching}

In the Judeo-Christian Scriptures, the teachings about the origins of the world and of human beings in the creation narratives (Gen 1:3) are set within a network of relationships: God and human persons, the human person and his/her neighbour, and the person and creation. As a relational being, the human person is a subject of dignity, called to coexist with other members of the human family, indeed, to be their keeper (Gen 4:9), and to care for creation with a view to ensuring the common good of all. These teachings are the foundation and the moral compass for evaluating the justice of these fundamental relationships and the virtuousness of the conduct of human persons, including their financial activities.

Thus, according to the Book of Wisdom, the human person is "to govern the world in holiness and justice, and to render judgment in integrity of heart." (Wis 9:13). In view of this, Abraham was chosen already in the Book of Genesis "to charge his children and his household after him to keep the way of the Lord by doing righteousness and justice" (Gen 18:19). In the Scriptures generally, but especially in the prophetic tradition, "doing righteousness and justice" takes the form of an unconditional fidelity to God and his covenant laws, and a reverential concern for the neighbour and for creation. When, as in Isaiah $24: 4$, the people sin, transgressing God's covenant laws, the earth languishes and is laid waste, and its inhabitants suffer. Thus, not only do the Covenant laws and the prophets call for obedience, they also both proscribe abusive treatment and exploitation of

15 United States Catholic Bishops, Pastoral Letter on Catholic Social Teaching and the U.S. Economy, Economic Justice for All, Washington 1986, 6.

16 Cf. Ibid., Pastoral Letter on investments, environment and the dignity of the human person. 
the poor and prescribe great solicitude for the poor and the earth. It is for this reason, for instance, that there is a legislation to observe a jubilee year, to give the poor a new lease on life and to allow the land to rest (Lev 25; Dt 15).

This unity of reciprocal relationships, especially between human beings and creation, is what inspired Pope Benedict XVI to observe that "the book of nature is one and indivisible," and that "it takes in not only the environment but also life, sexuality, marriage, the family, social relations: in a word, integral human development. Our duties towards the environment are linked to our duties towards the human person, considered in himself and in relation to others". ${ }^{17}$

Let us recall, by the way, the classic definition of the State by St. Augustine in his great book "De civitate Dei". The accounts of the origins of the world and the human family in the Book of Genesis inspired St. Augustine to teach about the need for the State (and its governance) by the human person in his book, "De Civitate Dei". There, referring to the account of the murder of Abel by Cain, St. Augustine underlines the necessity of a "status iustitiae", because that episode of murder unleashed complete anarchy. According to this original insight of St. Augustine, a minimal guarantee of a minimal state of minimal justice is the ultimate goal of every State. For, the purpose and the goal of the State is nothing else than the welfare of its citizens (person), and every person, because every person is a subject of dignity, created by God in his image and likeness.

In other words, the State, per se, has no value, without the human person, the bearer of dignity; but the existence of a person is also inconceivable without the State. Without the State, as St. Augustine argued, the person is nothing, because the person would be living under and among an anarchic gang of robbers. ${ }^{18}$

Again, on account of this unity of reciprocal relationship between the person and the State, the extinction of the State and the Nation, through bad governance or otherwise, is quickly followed by the extinction of the human person. Accordingly, the security of every human person, especially the weak, the unborn and newly born, the handicapped and the dying is the sole purpose and raison d'être of a good State, which must be more than a "gang of robbers". This underlines the significant role and place of good governance in a State!

17 Caritas in veritate, 51.

18 St. Augustine underlines this in the famous $4^{\text {th }}$ chapter of the $4^{\text {th }}$ book of "De civitate Dei" (Remota iustitia quid sunt regna nisi magna latrocinia?). 


\section{The Church's Social Principles (CSP) and the Application of an ESC Framework}

Our question now is not about investment business in general and society in a general and abstract sense. The question now is about actual decisions by real leaders in economics, investment and politics, and how the CSP help promote ESG business and investing.

As Pope Francis explains an observation, we made earlier,

"We can no longer trust in the unseen forces and the invisible hand of the market. Growth in justice requires more than economic growth. While presupposing such growth, it requires decisions, programmes, mechanisms and processes specifically geared to a better distribution of income, the creation of sources of employment and an integral promotion of the poor which goes beyond a simple welfare mentality." ${ }^{\prime 19}$

Accordingly, business leaders and investors need to develop good habits of discernment, a process of discovering the good in the concrete here and now, by employing the great principles of human dignity, the common good, subsidiarity and solidarity as beacons to shed light on the reality before them, and, as lenses, to focus on it properly. Within the complex reality of business, these same beacons or lenses will help make sound judgments and act properly about their investments. I want to touch briefly on three investment objectives that connect discernment with outcomes.

1. The first objective is to invest in the production of Good Goods. Businesses must attend to people's needs by producing goods that are truly good and services that truly serve. Businesses have an ability or opportunity to provide what everyone needs in the way of food, shelter, and so on. But are they truly good? The answer does not reduce to price or to legalities. Rather it should be asked: How do these products and services contribute directly or indirectly to human well-being? Customers are not just objects or consumers, but persons. Further, businesses must be alert for opportunities to serve deprived populations and people in significant need. Solidarity with the poor and care of environment (creation) are facets of the service which business provides to the common good.

2. Second, businesses should invest in the provision of Good Work. By organizing good and productive work, businesses make a contribution to the community by fostering the special dignity of human work. Businesses are communities that require investment in their training, working environment etc., not mere commodities! Further, applying the principle of subsidiarity contributes to the full human development of employees, by providing them with opportunities to exercise appropriate authority as they contribute to the mission

19 Evangelii Gaudium, 204. 
of the organisation. They also allow workers to influence the overall direction of the business and accept their right to participate in intermediary bodies such as unions. In well-defined functions, the front-line and middle levels should exercise authority and should receive the needed training and resources in order to succeed. In a time when knowledge and information continue to be increasingly important factors of production, applying the principle of subsidiarity can justify investment in staff, in order to strengthen "the initiative, innovation and creativity, as well as the sense of common responsibility" ${ }^{\prime 20}$ in companies.

3. The third objective is Good Wealth and its distribution. By being good stewards of the resources given to them, businesses create sustainable wealth through efficient and productive processes that produce healthy profits. But generating wealth in a business is insufficient without the wider context of stewardship for the natural and cultural environment, and just distribution to all stakeholders who have made the wealth possible and depend on it: employees, customers, investors, suppliers, and the larger community.

These three objectives show that businesses and required investments are multidimensional realities. They are not to be reduced to a single objective such as maximizing profit or enhancing shareholder wealth - just as marriage may not be reduced to sentiment between partners, or education to credentials for a career. Rather, a flourishing business enterprise contributes to the larger common good by investing in its threefold goals or purpose of good goods, good work and good wealth.

Here are instances of the ESG framework, and here are beacons and lenses provided by the CSP, to businesses and their investment activities and cultures. The CSP are principles, which guide the discernment of the investment areas or needs of community (services, goods), navigating the challenges of investment options and deciding on what is right and truly useful, instead of the ethically inadequate and sometimes even perverse.

Thus, what the ESG framework seeks to promote coincides with what the Popes have frequently talked about, as the need for greater social and environmental responsibility on the part of the business world. Pope Benedict XVI writes in his Encyclical Letter, Caritas in veritate, that,

"there is nevertheless a growing conviction that business management cannot concern itself only with the interests of the proprietors, but must also assume responsibility for all the other stakeholders who contribute to the life of the business: the workers, the clients, the suppliers of various elements of production, the community of reference." ${ }^{21}$

20 Vocation, $\$ 48$.

21 Caritas in Veritate, 40. 
Pope Francis extended this responsibility further, when, in his address to the World Economic Forum 2014, he said:

"Those working in these sectors have a precise responsibility towards others, particularly those who are most frail, weak and vulnerable. In fact, those who have demonstrated an aptitude for being innovative and for improving the lives of many people by their ingenuity and professional expertise can further contribute by putting their skills at the service of those who are still living in dire poverty."22

\section{Care of the Earth, our Common Home}

The precarious state of our common home has been the result largely of a false economic model that we have followed for too long. It is a voracious economic model, which is exclusively profit-oriented, short-term sighted, and perpetuates the myth of unlimited economic growth. While we see its disastrous impacts on the natural world and in the lives of people, we are still resistant to change.

"Economic powers continue to justify the current global system where priority tends to be given to (...) the pursuit of financial gain, which fail to take the context into account, let alone the effects on human dignity and the natural environment" (LS 56).

We are aware that "by itself the market cannot guarantee integral human development and social inclusion" (LS 109) and that "environmental protection cannot be assured solely on the basis of financial calculations of costs and benefits" (LS 190). We need a paradigm shift in all our economic activities, inspired again by $\operatorname{CSD}(\mathrm{P})$.

All economic activities should be at the service of the entire human community. As Pope Paul VI wrote: "God intended the Earth and everything in it for the use of all human beings and peoples. (...) created goods should flow fairly to all". ${ }^{23}$ It is an essential component of the Church's social teachings. "The principle of the subordination of private property to the universal destination of goods, and thus the right of everyone to their use, is a golden rule of social conduct and 'the first principle of the whole ethical and social order'."24 (LS 93).

It is laudable that the Austrian Bishops Conference in union with the Religious Orders of Austria have published a set of guidelines for the economic management and financial investments of the Church to serve humanity and creation. Alongside negative exclusionary criteria (non-demand), which prevent cooperation and engagement in forms of behaviour which are ethically unacceptable,

22 Francis, Message to The Executive Chairman of The World Economic Forum on the occasion of the Annual Meeting at Davos-Klosters (Switzerland), 17 ${ }^{\text {th }}$ January 2014.

23 Paul VI, Populorum Progressio, n.22.

24 John Paul II, Laborem Exercens, Vatican 1981, n.19. 
the best-in-class approach (demand) or "cooperation in the good" is applied as a means of exerting a positive influence in view of a bold transformation of life-styles and economic policies and decisions. "This is intended to help produce a role model effect, so that overall ethical standards in the sectors improve." 25

Prof. Ingeborg Gabriel, as an economist and a theologian, is fully committed to this transforming goal of raising accountability and ethical standards in economics and politics, and thus improving the wellbeing of both people and creation. "An economy in the original sense of the word of well-guided management of the house (home) demands a new orientation towards ecology in order to realize the necessary balance of existing resources and their economic use on the national and global level." ${ }^{26}$ May her efforts for integral development continue to pave the way towards a "bold cultural revolution" (LS 114) where all peoples and creatures can live together in justice and peace.

\section{Sources}

Benedict XVI, Caritas in veritate, Vatican 2009, see: http://www.vatican.va/content/bene dict-xvi/en/encyclicals/documents/hf_ben-xvi_enc_20090629_caritas-in-veritate.html (accessed on $21^{\text {st }}$ December 2019).

Francis, Laudato si', Vatican 2015, see: http://www.vatican.va/content/francesco/en/en cyclicals/documents/papa-francesco_20150524_enciclica-laudato-si.html (accessed on $21^{\text {st }}$ December 2019).

Francis, Message to The Executive Chairman of The World Economic Forum on the occasion of the Annual Meeting at Davos-Klosters (Switzerland), $17^{\text {th }}$ January 2014.

John Paul II, Laborem Exercens, Vatican 1981, see: http://www.vatican.va/content/johnpaul-ii/en/encyclicals/documents/hf_jp-ii_enc_14091981_laborem-exercens.html (accessed on $21^{\text {st }}$ December 2019).

Paul VI, Populorum Progressio, Vatican 1967, see: http://www.vatican.va/content/paul-vi/ en/encyclicals/documents/hf_p-vi_enc_26031967_populorum.html (accessed on $21^{\text {st }}$ December 2019).

25 Financial Investments as Cooperation: Ethical Investment Guidelines of the Austrian Bishops' Conference and the Religious Orders of Austria, published in: Amtsblatt der Österreichischen Bischofskonferenz Nr. 74 ( $1^{\text {st }}$ January 2018). See also: Changing the World through Investment? An Aid to Orientation on ethically-related Investment. A Study by the Group of Experts on 'World Economy and Social Ethics'. German Bishops' Conference Research Group on the Universal Tasks of the Church, Bonn, July 2010. See also Klaus Gabriel in this present Festschrift (p. 637-650): "The Just before the Profitable: On the Development and actual econonomic-ethical Challenges of ethical and sustainable Investments." (German).

26 Ingeborg Gabriel, Zur Einführung - Ökologie als Gerechtigkeitsfrage der Gegenwart, in: Ingeborg Gabriel / Petra Steinmair-Pösel (Hg.), Gerechtigkeit in einer endlichen Welt: Ökologie - Wirtschaft - Ethik, Ostfildern 2013, p. 9-31, here: p. 16 (tr. Franz Gassner). 
Paul VI, Gaudium et Spes. Pastoral Constitution on the Church in the modern World, Vatican 1965, see: http://www.vatican.va/archive/hist_councils/ii_vatican_council/ documents/vat-ii_const_19651207_gaudium-et-spes_en.html (accessed on 21 ${ }^{\text {st }}$ December 2019).

Apostolic Letter issued Motu Proprio by the Supreme Pontiff Francis Instituting the Dicastery for promoting Integral Human Development, August 2016.

Austrian Bishops' Conference and the Religious Orders of Austria, Financial Investments as Cooperation: Ethical Investment Guidelines of the Austrian Bishops' Conference and the Religious Orders of Austria, in: Amtsblatt der Österreichischen Bischofskonferenz 74, $1^{\text {st }}$ January 2018.

Congregation for Doctrine and Faith and the Dicastery for Promoting Integral Human development, Oeconomicae et Pecuniariae Questiones, Considerations for an ethical discernment Regarding some Aspects of the Present Economic-Financial System, Vatican 2018.

Gabriel, Ingeborg, Zur Einführung - Ökologie als Gerechtigkeitsfrage der Gegenwart, in: Ibid. / Petra Steinmair-Pösel (ed.), Gerechtigkeit in einer endlichen Welt: Ökologie Wirtschaft - Ethik, Ostfildern 2013, pp. 9-31.

German Bishops' Conference Research Group on the Universal Tasks of the Church, Changing the World through Investment? An Aid to Orientation on ethically-related Investment. A Study by the Group of Experts on 'World Economy and Social Ethics', Bonn 2010.

Pontifical Council for Justice and Peace, Towards Reforming the International Financial and Monetary Systems in the Context of Global Public Authority, Vatican 2011.

Pontifical Council for Justice and Peace, Compendium of social teaching of the Church, Rom 2004.

United States Catholic Bishops, Pastoral Letter on Catholic Social Teaching and the U.S. Economy, Economic Justice for All, Washington 1986. 


\section{Wirtschaft - mehr als Wirtschaft: Sozialethische Bemerkungen}

\section{Wirtschaft - auf Wirtschaft begrenzt?}

Im Prozess sozialer Differenzierung tendiert unsere Gesellschaft zu Trennungsmodellen. In der Beachtung der für die jeweiligen Bereiche maßgeblichen Eigengesetzlichkeiten können die Möglichkeiten durch Sachgerechtigkeit in einem höheren Maß ausgeschöpft werden. Die Autonomie der Wirtschaft beispielsweise befreit diese weitgehend von politischer Bevormundung, und damit kann die Effizienz erhöht werden. Wenn das II. Vatikanische Konzil in der Pastoralkonstitution Gaudium et spes diese „Autonomie der irdischen Wirklichkeiten“ in der Nummer 36 im „Differenzgrundsatz“, wie ihn Friedhelm Hengsbach ${ }^{1}$ bezeichnet, betont und damit die Wertschätzung für den jeweiligen Bereich verbindet, so wird in diesem Zusammenhang auch die Freisetzung dieser Bereiche von gewissen „verengt ganzheitlichen" Ethikmodellen angesprochen. Wenn aber nun in einer Verselbstständigung der Bereiche das Ganze in den jeweiligen Teilbereich rückt, so kann daraus eine Zersplitterung, die für den Menschen in vielen Beziehungen herausfordernd ist, folgen. Es stimmt: Business of business is bussiness, wie mitunter behauptet wird, aber ein Geschäft hat auch Grundlagen, die nicht nur über das Geschäft allein gestaltet werden können.

Deswegen fordert das II. Vatikanische Konzil die relative, oder wie es das Konzil nennt, die richtige Autonomie irdischer Wirklichkeiten ein, eine Autonomie, die auf das Ganze gelungenen menschlichen Lebens für alle zurückgebunden bleibt und damit die einzelnen Bereiche in diese Relation des Ganzen setzt. Die Wahrnehmung der Eigengesetzlichkeiten wird damit in den Bezug des Dienstes am Ganzen genommen. Ganz konkret geht es etwa um die Frage, wie Wirtschaft gestaltet sein muss, um zum Wohle möglichst aller Menschen beizutragen. In der ethischen Herausforderung bedeutet dies, die jeweiligen wirtschaftlichen Prozesse, etwa Produktion, Distribution und Konsum, in ihrer

1 Friedhelm Hengsbach, Die Arbeit hat Vorrang. Eine Option katholischer Soziallehre, Mainz 1982, S. $279 \mathrm{ff}$. 
Gestaltungsnotwendigkeit zu sehen, zugleich aber auch, diese Prozesse auf das Ganze der Wirtschaft und darüber hinaus auf das Ganze des Menschen zu beziehen, um daraus Gestaltbarkeit, die auf den Menschen bezogen ist, zu gewinnen. In einer absoluten Autonomie des Bereiches Wirtschaft muss sich der Mensch an die wirtschaftlichen Gegebenheiten anpassen. In der Relation auf den Menschen hin in der relativen Autonomie findet aber beispielsweise die Frage, wie wir arbeiten wollen, eine Einbindung in die Frage, wie wir leben wollen.

Bereichsethiken sind deswegen angesichts einer Entwicklung, die mit dem Schlagwort „Viele Ethiken, keine Moral“2 charakterisiert werden kann, immer auch in den Bezug des Ganzen zu stellen. Hier kommt das zum Vorschein, was Ferdinand W. Menne als „transitorische Ethik“ fasst, wenn er schreibt:

„Gegenüber allen regionalen bzw. sektoriellen Wertsystemen, in denen sich mehr oder minder verhüllte Interessen formulieren, könnte es zur generellen Aufgabe werden, das Ganze ethisch als Perspektive zu erhalten; man könnte auch sagen (ohne damit inhaltlich viel gesagt zu haben): das Interesse am Menschen (= an allen Menschen), der in komplexen Lebensverhältnissen existiert, gegen Widerstände wachzuhalten “33.

Das heißt nun nicht, dass Ethik sich anmaßen darf, das Ganze zu bestimmen, sondern es geht darum, den Blick auf das Ganze offen zu halten.

\section{Interesse und Reduktion der Komplexität}

Zwei Punkte nur will ich im Anschluss an das Zitat von Menne ansprechen: die Formung der Gesellschaft über Interessen und die Reduktion der Komplexität über Betonung der Sachgesetzlichkeiten mit Ausschluss dessen, was nicht diesen Sachgesetzlichkeiten folgt.

Zur Interessensorientierung: Menschliches Gestalten findet Antrieb in den Interessen, die Bedürfnissen folgen. Dieser Interessensgebundenheit auch als Ausdruck menschlicher Naturverhaftetheit gilt es gerecht zu werden. Interessen als Artikulation partieller Bedürfnisse dürfen aber nicht absolut gesetzt werden, denn diesen partiellen Interessen fehlt oft der Bezug auf das, was der Mensch als Ganzes sein könnte. Den Bedürfnissen wie den Interessen fehlt in ihrer Partikularität, die ihnen notwendigerweise innewohnt, die Möglichkeit der Repräsentanz des Ganzen. Das hat Auswirkungen auf eine von Interessensdurchsetzung geprägte Gesellschaft.

2 Gerhard Zecha, Viele Ethiken und keine Moral. Zur Problematik des wissenschaftlichen Werterelativismus, in: Paul Weingartner (Hg.), Die eine Ethik in der pluralistischen Gesellschaft, Innsbruck 1978, S. 157-182.

3 Ferdinand W. Menne, Wertsysteme und Realität. Soziologische Stichworte, in: Anselm Hertz (Hg.), Moral, Mainz 1972, S. 34-59, hier: S. 58. 
„Die moderne Gesellschaft ist gekennzeichnet durch das Aufstacheln der Bedürfnisse und durch das Hervorbringen immer neuer. Zugleich ist die Möglichkeit beschränkt, diese Bedürfnisse zu befriedigen. ${ }^{44}$ So formuliert Theodor Strohm in Bezugnahme auf Karen Horneys Buch Der neurotische Mensch unserer Zeit. In der Steigerung der einzelnen Bedürfnisse und in der Erweiterung des Spektrums der Bedürfnisse liegt zugleich auch ein Grund dafür, dass die Institutionen immer weniger fähig sind, die Bedürfnisse zu befriedigen, eine Aufgabe, unter der sie eigentlich angetreten sind. Dazu kommt noch, dass in einer Anspruchshaltung, die Ansprüche für sich und nicht so sehr an sich stellt, die Zuständigkeit zur Befriedigung der Bedürfnisse oft einseitig den Institutionen zugewiesen, und in der Tatsache, dass sich diese Bedürfnisse verselbstständigen, das institutionelle Potenzial zu ihrer Befriedigung oft überdehnt wird.

In der Ausrichtung auf sofortige Bedürfnisbefriedigung werden zudem Sehnsüchte verdeckt, Sehnsüchte, die der Gesamtstruktur des Menschen gerecht werden wollen. In seiner Kleinen Theologie der Sehnsucht umschreibt Dieter Emeis diese so: „Die Sehnsucht ist das Werben Gottes um die Menschen, nicht unter dem Niveau zu leben, auf das hin Gott sie entworfen hat. ${ }^{45}$ Und dieser Entwurf kann nicht durch Verkürzung auf Bedürfnisse eingeholt werden. Bloße Sozialtechnik droht beispielsweise nur allzu leicht abzusinken in Interessenwahrnehmung, die dann nur zu oft in Korruption endet.

Einseitige Reduktion der Komplexität über wirtschaftliche Parameter: Und hier kommt der zweite Punkt zum Tragen, die Reduktion der Komplexität über eine einseitige Logik des Marktes und der Wirtschaft. Wenn alles wirtschaftsund in weiterer Reduktion geldmäßig gelöst werden soll, kommt es zu einer Überforderung auch wirtschaftlicher Potenziale.

Die aus dem Gesellschaftsganzen ausdifferenzierte Wirtschaft konzentriert sich jetzt in dieser Reduktion idealtypisch auf die „genuin“ wirtschaftlichen Abläufe, nämlich die mit dem Mittel Geld in klarer Verrechnung zu gestaltenden Vorgänge. Dadurch erfährt Wirtschaft nicht nur eine Akzentsetzung, sondern in der Realität eine Einschränkung. Um es an der Arbeit und am Produkt zu zeigen: Es wird der Tendenz nach nur das als Arbeit verstanden, was abhängige, mit einem Lohn, also mit Geld, honorierte Erwerbsarbeit ist. Darin erfährt nun auch der Arbeitende eine beschränkte Betrachtung auf seine Produktionsfunktion, Arbeit wird einseitig als Humankapital gesehen. Und das Produkt wird zum einseitig wirtschaftlichen Gut, das vorwiegend nur auf geldmäßig unmittelbare Verrechenbarkeit abstellt und die auch im Produkt gelegene Beziehungsebene

4 Theodor Strohm, Aspekte des Terrorismus in sozialethischer Sicht, in: Zeitschrift für evangelische Ethik 23/1979, S. 118-132, hier: S. 125.

5 Dieter Emeis, Kleine Theologie der Sehnsucht, in: Katechetische Blätter 122/1997, S. 150-153, hier: S. 153. 
verdeckt. Damit kommt etwa die im Produkt in vielen Punkten auch gegebene relationale Qualität ins Hintertreffen.

Weil von Menschen gestaltet, ist das wirtschaftliche Geschäft nun aber nicht auf den speziell wirtschaftlichen Faktor zu begrenzen, sondern es ist auch die relationale, die Beziehungs-Ebene mit zu berücksichtigen, die dann im Indirektmachen über Internetbankgeschäfte beispielsweise teilweise gekappt wird. Wenn sich einmal ein Bankmanager darüber beklagte, dass nur noch Bankräuber real in die Filiale kommen, so ist auch dieser Beziehungsverlust über Mittel, die die Beziehung indirekt machen, zu bedenken. Über diese Mittel kann aber „objektiviert“, „deckungsgleich“ gemacht werden, und damit, wie es in dieser Reduktion oft vorkommt, auch Ethik ausgeklammert werden.

\section{Work-Life-Balance, ein verräterischer Ausdruck der Trennung von Arbeit und Leben?}

Work-Life-Balance ist schon durch die gängige Abkürzung WLB ein eingeführter Begriff und wird in weiten Kreisen auch zum Markenzeichen für sensible Arbeitsanalyse stilisiert. Damit die Arbeit nicht das Leben erschlägt, bedarf es des Bemühens um Ausgleich und Balance, ein wichtiger Akzent, denn Arbeit hat auch Aspekte, die vom „wahren Leben“ wegführen.

Die Rede von der Work-Life-Balance suggeriert aber auch eine Trennung von Arbeit und Leben in einer Art und Weise, als ob es sich um Bereiche handelte, die auf Grund ihrer fundamentalen Verschiedenheit und der daraus folgenden Unvereinbarkeit zur Balance und zum Ausgleich gebracht werden müssten. Es hat den Anschein, als ob Arbeit nicht Leben bzw. sogar gegen das Leben gerichtet wäre. Das würde nun implizieren, dass Arbeit auf den wirtschaftlichen Faktor, der vom Leben "gereinigt“ ist, reduziert werden könnte. In einem solchen Konzept spielt sich Leben anderswo, jedenfalls außerhalb der Arbeit, vielleicht in der Familie oder in der Freizeit, ab. Arbeit hat im Erwerb der Ressourcen für die Gestaltung des Lebens dann bloß instrumentellen Charakter, ist also reduziert auf diese Bereitstellung der Ressourcen für die Freizeit oder die Familie, in denen sich dann das „wirkliche Leben“ abspielen kann. Zugegeben, die Arbeit folgt ihren Gesetzmäßigkeiten, die bei entsprechender Gestaltung auch eine Reduktion des Lebens in verschiedenen Punkten bedeuten können, aber das Leben spielt sich auch in der Arbeit ab, in der der Mensch wie in anderen Bereichen mehr Mensch werden kann.

Denn ist es nicht auch der ganze Mensch, der arbeitet? Ihn auf den technischen Aspekt der Arbeit zu reduzieren, ihn zum Humankapital zu verkürzen, heißt doch, dem Menschen, aber auch der Arbeit, nicht gerecht zu werden. Bleibt 
der Mensch doch auch in der Arbeit Mensch und bleibt die Arbeit trotz aller Reduziertheiten Bereich der Lebensgestaltung.

Auch wenn der Mensch in diese Funktion genommen ist - er bleibt Mensch, und zwar ganzer Mensch. Schon auf diesem Hintergrund der Arbeit, in der der Mensch als Mensch in der Wirtschaft tätig ist, verbietet sich eine Verengung der Ethik auf wirtschaftliche Verträge, die nur die Bestimmung von Mitteln in ihrer Angepasstheit im Auge haben.

In der Sicht vom Menschen her, der nicht auf einzelne Bereiche deckungsgenau aufgeteilt werden kann, ist zudem eine Identitätsbildung nur in der $\mathrm{Zu}$ sammenschau der Bereiche möglich. Ganz Arbeitsmensch, ganz Familienmensch, ganz Freizeitmensch sein zu müssen und zu wollen, führt meist dazu, dass der Mensch ganz kaputt wird. Dies gilt auch für die Gesellschaft, die als Zivilgesellschaft in Ausrichtung auf Frieden und Ausgleich der Bereiche in möglichst harmonischer, wenn auch mitunter spannender Weise gestaltet werden will.

\section{Caritas in veritate und die drei Ebenen der Wirtschaft}

Die Enzyklika Caritas in veritate von Papst Benedikt XVI. aus dem Jahre 2009 versucht aus einem ganzheitlichen Menschen- und Gesellschaftsbild heraus Orientierung für eine Gesellschaft im Umbruch zu geben. Dabei ist es besonders die Weitung der Perspektiven, die in Bezug auf die Wirtschaft zum Teil überraschende Zugänge ermöglicht.

\subsection{Geschenkhaftigkeit und Unentgeltlichkeit als Momente der Wirtschaft}

Papst Benedikt XVI. stellt die Wirtschaft in einen weiteren Rahmen. Wirtschaft wird in dieser Sicht über die „reine Wirtschaft“, die es nicht gibt, hinaus als Kulturprojekt betrachtet. Unter der Überschrift „Brüderlichkeit, wirtschaftliche Entwicklung und Zivilgesellschaft" widmet sich das dritte Kapitel dieser Enzyklika der Ausweitung unseres zum Teil beengten Ansatzes von Wirtschaft. Gleich im ersten Satz dieses Kapitels heißt es programmatisch:

„Die Liebe in der Wahrheit stellt den Menschen vor die staunenswerte Erfahrung des Geschenks. Die Unentgeltlichkeit ist in seinem Leben in vielerlei Formen gegenwärtig, die aufgrund einer nur produktivistischen und utilitaristischen Sicht des Daseins jedoch oft nicht erkannt werden. Der Mensch ist für das Geschenk geschaffen, das seine transzendente Dimension ausdrückt und umsetzt. Manchmal ist der moderne Mensch fälschlicherweise der Überzeugung, der einzige Urheber seiner selbst, seines Lebens und der Gesellschaft zu sein. Diese Überheblichkeit ist eine Folge des egoistischen 
Sich-in-sich-selbst-Verschließens und rührt - in Begriffen des Glaubens gesprochen von der Ursünde her.“ (Nr. 34)

Der Mensch kann also nicht nur auf dem Hintergrund seiner Leistung bewertet werden, sondern es bedarf wesentlich auch der Berücksichtigung dieser Geschenkhaftigkeit, die ihn unverrechenbar macht, weil er sich in dieser überschreitet.

„Die Überzeugung, sich selbst zu genügen und in der Lage zu sein, das in der Geschichte gegenwärtige Übel allein durch das eigene Handeln überwinden zu können, hat den Menschen dazu verleitet, das Glück und das Heil in immanenten Formen des materiellen Wohlstands und des sozialen Engagements zu sehen. Weiter hat die Überzeugung, dass die Wirtschaft Autonomie erfordert und keine moralische $>$ Beeinflussung $<\mathrm{zu}$ lassen darf, den Menschen dazu gedrängt, das Werkzeug der Wirtschaft sogar auf zerstörerische Weise zu missbrauchen." (Nr. 34)

Der Verschluss der Gesellschaft findet aber nicht nur durch die Wirtschaft etwa in einer „Kolonialisierung der Lebenswelt“ durch Wirtschaft statt, wie sie Jürgen Habermas $^{6}$ analysiert hat, sondern es zeigt sich auch eine Verengung in der Wirtschaft selbst, wenn in ihr dieser transzendenten Dimension des Menschen nicht Rechnung getragen wird. Das Geschenk, das „seinem Wesen nach den Verdienst“ übertrifft und dessen Gesetz „das Übermaß“ ist (Nr. 34), muss nach dem Papst auch in der Wirtschaft Platz gewinnen, damit das Prinzip Brüderlichkeit bzw. Geschwisterlichkeit sich in der Wirtschaft zeigen kann. Damit entwickelt sich ein inklusives Wirtschaftsverständnis. Hierin zeigt sich ein Zweifaches:

„Bei der Behandlung dieser entscheidenden Frage müssen wir einerseits präzisieren, dass die Logik des Geschenks die Gerechtigkeit nicht ausschließt oder ihr in einem zweiten Moment und von außen hinzugefügt wird, und andererseits, dass eine wirtschaftliche, gesellschaftliche und politische Entwicklung, die wahrhaft menschlich sein will, dem Prinzip der Unentgeltlichkeit als Ausdruck der Brüderlichkeit Raum geben muss.“ (Nr. 34)

Der Mensch als Person ist nicht reduzierbar auf Preisrelationen. In der Tatsache, dass es der Mensch ist, der in der Wirtschaft tätig wird, und der Mensch unverrechenbare Würde und nicht nur verrechenbaren Wert besitzt, stellt diese Unentgeltlichkeit nicht etwas außerhalb der Wirtschaft dem Menschen „Dazu-Kommendes“, sondern einen wesentlichen Teil einer Wirtschaft, die auf das Ganze des Gelingens menschlichen Lebens für alle bezogen ist, dar. Dabei ist Gerechtigkeit weiterhin wesentlicher Bestandteil, sie steht aber unter der Prämisse der Liebe als einer „Sehbedingung der Gerechtigkeit“, umgekehrt ist Ge-

6 Jürgen Habermas, Theorie des kommunikativen Handelns 2, 4. Aufl., Frankfurt a. M. 1987, bes. S. $452 \mathrm{ff}$. 
rechtigkeit das auch verrechenbare Mindestmaß der Liebe, weil Liebe dabei das Übermaß sein kann. In einer solchen Dynamik finden Gerechtigkeit und Liebe ihren inneren Zusammenhang, der nicht darin seinen Ausdruck findet, dass ein Mehr an Gerechtigkeit ein Weniger an Barmherzigkeit oder Liebe bedeutet, sondern darin, dass dieser Zusammenhang eine aufeinander bezogene Steigerung zum Ziel hat.

\subsection{Der Markt - nur eine Frage der Tauschgerechtigkeit?}

Die Frage ist nun, wie solches auf dem Markt zum Tragen kommen könnte, einem Markt, der ja gerade in der jetzigen Form nicht immer als ein Ort der liebenden Begegnung angesehen werden kann, obwohl gerade diese oft marktgemäß gestaltet zu werden droht. Über die Zuordnung zur ausgleichenden bzw. Tauschgerechtigkeit, „die die Beziehungen des Gebens und Empfangens zwischen gleichwertigen Subjekten regelt“ (Nr. 35), hinaus ist der Markt, um ethisch annehmbare Ergebnisse zu erzielen, darauf angewiesen, dass distributive Gerechtigkeit und darüberhinausgehend soziale Gerechtigkeit als Voraussetzung und als Ergebnis des Markthandelns das Fundament bilden. Ein Tausch unter stark Ungleichen weist nicht nur die Tendenz auf, zu problematischen wirtschaftlichen Ergebnissen zu führen, sondern er birgt auch die Gefahr in sich, die Gesellschaft zu spalten.

„Denn wenn der Markt nur dem Prinzip der Gleichwertigkeit der getauschten Güter überlassen wird, ist er nicht in der Lage, für den sozialen Zusammenhalt zu sorgen, den er jedoch braucht, um gut zu funktionieren. Ohne solidarische und von gegenseitigem Vertrauen geprägte Handlungsweisen in seinem Inneren kann der Markt die ihm eigene wirtschaftliche Funktion nicht vollkommen erfüllen." (Nr. 35)

Dann fügt Benedikt noch hinzu: „Heute ist dieses Vertrauen verloren gegangen, und der Vertrauensverlust ist ein schwerer Verlust. "Weiter heißt es in Caritas in veritate:

„Es ist im Interesse des Marktes, Emanzipierung zu fördern, aber um dies zu erreichen, darf er sich nicht nur auf sich selbst verlassen, denn er ist nicht in der Lage, von sich aus das zu erreichen, was seine Möglichkeiten übersteigt. Er muss vielmehr auf die moralischen Kräfte anderer Subjekte zurückgreifen, die diese hervorbringen können.“ (Nr. 35)

Hier wäre Politik gefragt. „Es darf daher nicht vergessen werden, dass die Trennung zwischen der Wirtschaftstätigkeit, der die Aufgabe der Schaffung des Reichtums zukäme, und der Politik, die sich mittels Umverteilung um die Gerechtigkeit zu kümmern habe, schwere Störungen verursacht.“ (Nr. 36) Das bedeutet nun nicht einen Ruf nach einer integralistischen Politik, das bedeutet 
aber das Einbeziehen sozialer und politischer Ziele in den wirtschaftlichen Prozess. Dazu bedarf es des Einsetzens des Marktes als eines Mittels. Wie der Papst betont, ist der Markt

„an sich nicht ein Ort der Unterdrückung des Armen durch den Reichen und darf daher auch nicht dazu werden. Die Gesellschaft muss sich nicht vor dem Markt schützen, als ob seine Entwicklung ipso facto zur Zerstörung wahrhaft menschlicher Beziehungen führen würde. Es ist sicher richtig, dass der Markt eine negative Ausrichtung haben kann, nicht weil dies seinem Wesen entspräche, sondern weil eine gewisse Ideologie ihm diese Ausrichtung geben kann. Es darf nicht vergessen werden, dass es den Markt nicht in einer Reinform gibt. Er erhält seine Gestalt durch die kulturellen Gegebenheiten, die ihm eine konkrete Prägung und Orientierung geben." (Nr. 36)

Auch der vorgebliche „reine Markt“ - und besonders der - steht in ideologischer Vereinnahmung durch das dann reduzierte Wirtschaftsdenken, das etwa die relationale Seite von Gütern, nicht nur der relationalen Güter an sich, nicht mitbedenken lässt. Der Papst betont:

„Die Soziallehre der Kirche ist der Ansicht, dass wahrhaft menschliche Beziehungen in Freundschaft und Gemeinschaft, Solidarität und Gegenseitigkeit auch innerhalb der Wirtschaftstätigkeit und nicht nur außerhalb oder $>$ nach $<$ dieser gelebt werden können. Der Bereich der Wirtschaft ist weder moralisch neutral noch von seinem Wesen her unmenschlich und antisozial. Er gehört zum Tun des Menschen und muss, gerade weil er menschlich ist, nach moralischen Gesichtspunkten strukturiert und institutionalisiert werden." (Nr. 36)

„So hat jede wirtschaftliche Entscheidung eine moralische Konsequenz.“ (Nr. 37) Vielleicht ist das Moralische nicht nur auf die Konsequenzen zu beschränken, sondern in jeder Entscheidung kommt darüber hinaus die Person als moralisches Subjekt zum Tragen. Eine oft vorgenommene Gegenüberstellung von Wirtschaft und Ethik etwa dergestalt, dass Ethik das Wirtschaftliche beschränke und Wirtschaft mit Ethik unvereinbar sei, verbietet sich deswegen. Ethik, Gerechtigkeit sind nicht etwas, was dazu kommt, sondern sie sind dem Wirtschaftlichen in diesem Sinne innewohnend.

\subsection{Wirtschaft in der Verzahnung von Markt, Staat und Zivilgesellschaft}

Denn Wirtschaften spielt sich auf drei ineinander gehenden Ebenen ab.

„Das Wirtschaftsleben braucht ohne Zweifel Verträge, um den Tausch von einander entsprechenden Werten zu regeln. Ebenso sind jedoch gerechte Gesetze, von der Politik geleitete Mechanismen zur Umverteilung, und darüber hinaus Werke, die vom Geist des Schenkens geprägt sind, nötig. Die globalisierte Wirtschaft scheint die erste Logik, jene des vertraglich vereinbarten Gütertausches, zu bevorzugen, aber direkt und indirekt 
zeigt sie, dass sie auch die anderen beiden Formen braucht, die Logik der Politik und die Logik des Geschenks ohne Gegenleistung.“ (Nr. 37)

Erst in dieser dreifachen Bezugnahme wird Wirtschaft zu dem Kulturprojekt, das sie aufgrund der in ihr handelnden Menschen und der vielfachen Qualität der Handlungsebenen, die Bedarfsdeckung, Zusammenleben und Beziehung zum Ausdruck bringen, ist. Dabei ist es genau dieses Ineinander, das heute gefragt ist. In Bezugnahme auf die Nummer 35 der Enzyklika Centesimus annus seines Vorgängers Johannes Paul II. sieht Benedikt die Notwendigkeit eines Systems mit drei Subjekten: dem Markt, dem Staat und der Zivilgesellschaft. Wörtlich heißt es dann in der Nummer 38 zur Position seines Vorgängers:

„In der Zivilgesellschaft sah er den geeignetsten Bereich für eine Wirtschaft der Unentgeltlichkeit und der Brüderlichkeit, aber er wollte diese nicht für die anderen beiden Bereiche ausschließen. Heute können wir sagen, dass das Wirtschaftsleben als eine mehrdimensionale Realität verstanden werden muss: In allen muss in unterschiedlichem Umfang und in eigenen Formen der Aspekt der brüderlichen Gegenseitigkeit vorhanden sein. In der Zeit der Globalisierung kann die Wirtschaftstätigkeit nicht auf die Unentgeltlichkeit verzichten, die die Solidarität und das Verantwortungsbewusstsein für die Gerechtigkeit und das Gemeinwohl in seinen verschiedenen Subjekten und Akteuren verbreitet und nährt. Es handelt sich dabei schließlich um eine konkrete und tiefgründige Form wirtschaftlicher Demokratie.“

Entgegen den verabsolutierenden funktionalen Differenzierungen wird hier die Einbettung der Wirtschaft betont - und das als Notwendigkeit besonders in der heutigen Zeit.

Somit ist aber ein neuer Typ von Unternehmen gefordert. Wie „die nach wechselseitigen und sozialen Zielen strebenden Produktionsverbände“ (Nr. 38), die der Papst einfordert, nun konkret organisiert sein sollen, damit diese „Kreuzung und Vermischung der unternehmerischen Verhaltensweisen“ und eine spürbare „Zivilisierung der Wirtschaft“ (Nr. 38) Platz greifen kann, das ist eine wesentliche Frage. Und wie ist es mit den gewinnorientierten Unternehmen: Sind diese von der Unentgeltlichkeit „befreit“, oder gilt auch für sie, dass sie ohne die Unentgeltlichkeit die Gerechtigkeit nicht erreichen können? Ist es nicht die Quadratur des Kreises, wenn es abschließend in der Nummer 38 heißt: „Liebe in der Wahrheit bedeutet in diesem Fall, dass jenen wirtschaftlichen Initiativen Gestalt und Struktur verliehen wird, die den Gewinn zwar nicht ausschließen, aber über die Logik des Äquivalenzprinzips und des Gewinns als Selbstzweck hinausgehen wollen." Offenbar sind damit nicht nur als gemeinnützig konstruierte Nichtregierungsorganisationen oder Vereine gemeint, sondern in der konkreten Wirtschaft stehende Unternehmen. Über die umverteilende Wirkung des Staates hinaus bedarf es da auch der Präzisierung dessen, was Unentgeltlichkeit konkret bedeuten könnte. Der Papst schreibt: 


\begin{abstract}
„Wenn die Logik des Marktes und die Logik des Staates mit gegenseitigem Einverständnis auf dem Monopol ihrer jeweiligen Einflussbereiche beharren, gehen langfristig die Solidarität in den Beziehungen zwischen den Bürgern, die Anteilnahme und die Beteiligung sowie die unentgeltliche Tätigkeit verloren. Diese unterscheiden sich vom ,Geben, um zu haben', das die Logik des Tausches ausmacht, und vom, Geben aus Pflicht', das für die öffentlichen Verhaltensweisen gilt, die durch staatliche Gesetze auferlegt werden. Die Überwindung der Unterentwicklung erfordert ein Eingreifen nicht nur zur Verbesserung der auf Gütertausch beruhenden Transaktionen, nicht nur im Bereich der Leistungen der öffentlichen Hilfseinrichtungen, sondern vor allem eine fortschreitende Offenheit auf weltweiter Ebene für wirtschaftliche Tätigkeiten, die sich durch einen Anteil von Unentgeltlichkeit und Gemeinschaft auszeichnen. Die exklusive Kombination Markt-Staat zersetzt den Gemeinschaftssinn. Die Formen solidarischen Wirtschaftslebens hingegen, die ihren fruchtbarsten Boden im Bereich der Zivilgesellschaft finden, ohne sich auf diese zu beschränken, schaffen Solidarität. Es gibt keinen Markt der Unentgeltlichkeit, und eine Haltung der Unentgeltlichkeit kann nicht per Gesetz verordnet werden. Dennoch brauchen sowohl der Markt als auch die Politik Menschen, die zur Hingabe aneinander bereit sind.“ (Nr. 39)
\end{abstract}

Es geht also wieder um die Menschen, die als in der Wirtschaft Tätige diesen Moment der Unentgeltlichkeit einbringen. Ihnen muss dazu in den Unternehmen der Platz geschaffen werden.

\title{
5. Ethik als Eröffnen von Perspektiven in heutiger Wirtschaft
}

In Bezug auf die Wirtschaft bedeutet das, Wirtschaft in Perspektiven zu stellen. Diese sollen mit Imperativen kurz angedeutet werden.

\section{Wirtschafte wirtschaftsgerecht!}

Dieser Imperativ zielt darauf ab, Sachgesetzlichkeiten der Wirtschaft zu beachten. In der Achtung der relativen Autonomie der irdischen Wirklichkeiten ist es notwendig, den Sachbereich Wirtschaft in der „Natur der Sache“ zu gestalten. Hier ist das Prinzip der ausreichenden Sachkenntnis ${ }^{7}$ angesprochen. Es gilt beispielsweise, die Regelmäßigkeiten von Angebot und Nachfrage zu beachten, realitätsgemäße Schritte in Bezug auf Umgang mit Knappheiten oder Arbeitsmarktgesetzmäßigkeiten in das Handeln einzubeziehen.

Es gibt jedoch nicht die Wirtschaft, die unabhängig von gesellschaftlichen und Umweltbedingungen nur so und nicht anders gestaltet werden könnte, obwohl man dies mit dem sogenannten TINA (There is no alternative)-Prinzip

7 Vgl. dazu: Wolfgang Schmitz, Das Prinzip der ausreichenden Sachkenntnis. Voraussetzung für die gesellschaftgestaltende Kraft der Kirche, in: Gesellschaft und Politik 28/4/1992, S. 1719. 
immer wieder suggeriert. So gilt es, trotz aller Beachtung wirtschaftlicher Sachgesetzmäßigkeiten, die Frage zu stellen: Welche Wirtschaft? Um diese Entscheidung treffen zu können, bedarf es der Eröffnung von Perspektiven durch andere Imperative.

\section{Wirtschafte menschengerecht!}

Menschen, die sich im Bereich der Wirtschaft finden, sind nicht allein über ihre wirtschaftlichen Bedürfnisse und Ziele als Produzenten oder Konsumenten etwa bestimmbar. Wenn sich der Werbeslogan „Der Mensch als Mittelpunkt“ auf die tatsächliche Umgangsweise mit ihm unter dem Schlagwort „Der Mensch als Mittel.Punkt“ pervertiert, wird man nicht nur dem Menschen nicht gerecht, sondern auch der Wirtschaft nicht. Der Mensch bringt nämlich in die Wirtschaft nicht nur unmittelbar monetär Verrechenbares ein, sondern auch sich als Mensch in Unentgeltlichkeit.

\section{Wirtschafte mitweltgerecht!}

Wirtschaften spielt sich in einer Umwelt ab, die die Wirtschaft beeinflusst und von dieser beeinflusst wird. Diese Zusammenhänge sollten dazu führen, dass die Perspektive der Umwelt auf Mitwelt erweitert wird. Dabei liegt aber gerade darin, dass Umwelt auch in ihrem Eigenwert gesehen und nicht vollständig für die Wirtschaft instrumentalisiert wird, das Bezugsverhältnis zwischen Wirtschaft und Umwelt.

\section{Wirtschafte zukunftsgerecht!}

Die Gegenwartsorientierung der Wirtschaft lässt Zukunft oft außer Blick geraten. Die Art und Weise, wie wir heute wirtschaften, hat wesentliche Auswirkungen auf zukünftiges Wirtschaften. Im Begriff der Nachhaltigkeit finden nicht nur die zukünftige wirtschaftliche Möglichkeitskonstellation, sondern darüberhinausgehend die gesamte Zukunftskonstellation, die das Wirtschaftliche mitbeinhaltet, aber über dieses hinausgeht, ihren Platz. Es ist das Spiel von Zusammen und Getrennt, von Abhängigkeit und Unabhängigkeit, das hier zum Tragen kommt.

\section{Wirtschafte gesellschaftsgerecht!}

Die Form von Produktion, Distribution oder Konsum hat wesentlichen Einfluss auf das Gefüge der Gesellschaft, wie etwa die Begriffe industrielle Gesellschaft, Freihandelsgesellschaft oder Wegwerfgesellschaft zeigen. Zugleich bestimmen gesellschaftliche Formationen als Realisierungsrahmen die verschiedenen Bereiche von Wirtschaft und die Gewichte dieser verschiedenen Bereiche. 
Diese Imperative zeigen die Beziehungen, in denen Wirtschaft steht, wobei diese Beziehungen nicht als exklusiv für die Wirtschaft geltend gemacht werden können. Vielmehr handelt es sich dabei um ein vielfältiges Bezugsverhältnis.

\section{Annäherung an das Thema über die „Ware“}

Der Warencharakter im Sinne der Reduktion auf ein handelsbares wirtschaftliches Gut in allen Dimensionen legt Wirtschaft auf Tauschgerechtigkeit fest. Güter stellen aber auch eine Relation zwischen Menschen, die nicht auf den Gebrauchswert des Gutes zu reduzieren ist, dar. Wenn versucht wird, den Gebrauchswert in den Vordergrund zu rücken, so zeigt schon der Handel, dass es einer Übereinkunft zwischen Produzenten, Händlern und Konsumenten bedarf, wobei die Beziehung eine wesentliche Rolle spielt, auch wenn diese etwa im Internethandel auf eine formale Beziehung reduziert werden soll.

Wenn Tibor Scitovsky ${ }^{8}$ in seiner Joyless Economy zwischen comfort und creativity goods unterscheidet, so setzt er einen Akzent auf den Unterschied der Befriedigung, die aus beiden gezogen werden kann. Comfort goods, aus denen Befriedigung im direkten Konsum gezogen werden soll und in denen eine Anpassung des Konsumenten an das Gut erfolgt, kappen oft die Beziehung, die durch Güter hergestellt werden kann, im direkten Konsum, eine Befriedigung, die mit der Ausweitung des Konsums tendenziell abnimmt, während durch creativity goods die in der Beziehung gelegene Befriedigung gerade im Einbeziehen dieser Beziehung ausgeweitet wird. Wie Luigino Bruni und Stefano Zamagni in ihrer Studie Civil Economy. Efficiency, Equity, Public Happiness zeigen, sind relationale Güter typische Kreativitätsgüter, der Markt aber tendiert dazu, Kreativitätsgüter durch comfort goods zu ersetzen. Und die Autoren illustrieren das Ergebnis mit dem Beispiel des Fernsehens, das auf zweifache Weise die relationalen Güter einschränkt:

"The time spent watching the TV acts against relational goods in two ways: it is time subtracted from cultivating relationships with others, but it is also a consumption of simulated relational goods. In fact, when television programs offer products that resemble true human relationships (e.g., talk shows and so-called reality shows), what they are really offering are comfort goods, which displace the true relational goods. ${ }^{\text {" }}$

Durch die mit der Marktförmigkeit gegebenen Indirektheit und der damit gegebenen Steigerungstendenz, die im Schaffen von Abhängigkeiten zur Steigerung des Genusses ein immer höheres Ausmaß in Bezug auf das Gut erfordert,

8 Vgl. Zu diesem Aspekt von Scitovsky: Luigino Bruni / Stefano Zamagni, Civil Economy. Efficiency, Equity, Public Happiness, Frontiers of Business Ethics 2, Bern 2007, S. 247 ff.

9 Ebd., S. 249. 
wird der Sog hin zu diesen Konsumgütern verstärkt, damit aber auch eine Beengung der relationalen Güter. Das heißt nun nicht, dass nicht auch Konsumgüter wichtig sind, es bedeutet aber, die Bezüge, die mit den Konsumgütern ermöglicht werden, auch zu nützen. Ein Gut ist nämlich mehr als ein rein auf den Tausch zu reduzierendes Ding, sondern in ihm und im Tausch sollen auch Bezüge eröffnet werden, die die Entfaltung des Menschseins fördern. In Indirektheiten und Anonymität aber stehen diese Bezüge in der Gefahr, gekappt zu werden.

\section{Die Share Economy als über das rein Wirtschaftliche hinausgehendes Wirtschaftsmodell?}

Auto-Sharing ist in vielen, besonders städtischen, Kontexten eine neue Form des Umgangs mit Wirtschaft im Teilen des Eigentums, in welchem nun nicht mehr nur die Rechenhaftigkeit, sondern auch die in der Sozialpflichtigkeit gelegene Beziehung eine Rolle spielt. Dies ist besonders angesichts des Autos als Statussymbol eine bemerkenswerte Entwicklung. Oder man gestaltet Wirtschaft auf dem Hintergrund des Austauschs von Talenten, die in erster Linie Eigentum nutzen, aber nicht schaffen und damit auch die Beziehungsebene verstärken, wobei das Element der Unentgeltlichkeit zum Tragen kommt. Die Eigentum-schaffende und dadurch zum Teil wenigstens solidarische Strukturen zerstörende Geldwirtschaft soll einer solidarischen Wirtschaft der Nutzung von gemeinsamen Ressourcen und vereinigenden Talenten Platz machen. Private Taxidienste auf der Grundlage, dass jeder und jede mit seinem Auto Taxianbieter sein kann, und Couch-Sharing als Ergänzung zu einer Tourismuswirtschaft, die auf explizite für Touristen gedachte Übernachtungsmöglichkeiten setzt, das sind nur einige unter Sharing laufende Neuerungen, die wieder auf alte Zusammenhänge setzen und Nachbarschaftshilfe unter dem Zeichen einer weltweiten Informationstechnologie zu gestalten suchen. Wie aber Papst Benedikt XVI. in seiner Enzyklika Caritas in veritate Nr. 19 betonte, die Globalisierung hat uns zu Nachbarn gemacht, aber nicht zu Bekannten. Unter diesen Vorzeichen nun ist es fraglich, ob das System, das im kleineren Rahmen sehr innovativ sein kann, nicht in größeren Zusammenhängen pervertiert wird. Und auch wenn Teilen als Signalwort für ethisch daherkommt, es muss nicht alles ethisch sein, was unter „Teilen“ läuft. Ein Problem besteht ja darin, das System der herkömmlichen Wirtschaft in ihren Infrastrukturangeboten zu nutzen, ohne etwa den Steuerbeitrag zu deren Erhaltung zu leisten. Es finden also weitgehende Veränderungen statt, die Nils Ole Oermann so umschreibt:

„Während Unternehmen Geld damit verdienten, indem sie für Produkte die Kosten reduzierten, gelingt es durch den digital angebahnten Tausch in der share economy, ein 
und dieselbe Sache effektiver zu nutzen (Carsharing) oder immer wieder zu replizieren (Musiktauschbörsen). Ökonomisch wird dies für jene zur Bedrohung, die auf klassischen Kanälen wie etwa Ladenzeilen diese Produkte angeboten haben, und für Firmen wie Google oder Facebook, die dadurch erfolgreich wurden, dass sie ein digitales Monopol auf die Kontrolle von Verkaufs- und Produktionskanälen und der dazu notwendigen Suchmaschinen und sozialen Netzwerke ausübten. “10

Wenn diese Entwicklung nur auf dem wirtschaftlichen Hintergrund angestoßen und weiterverfolgt wird, kann der Anstoß in Richtung Erweiterung der Grundlage des Wirtschaftens wieder zurückgenommen werden.

In diesem Zusammenhang stellt Oermann gewichtige Fragen:

„Gelten für diese neuen Formen der Marktwirtschaft als digitale Tauschwirtschaft wirtschaftsethisch andere Regeln und Standards? Fest steht: Wenn aus dem Willen, etwas zu kaufen, ein Wettlauf um Zugang wird, ändern sich oft auch die ökonomischen wie regulatorischen Rahmenbedingungen. Eine akute wirtschaftsethische Herausforderung der digital economy scheint darin zu bestehen, dass global bestellbare Angebote oder lokal angebotene Dienste aus dem Internet nationale Sozialstandards unterlaufen. (...) Wie soll man damit politisch, ökonomisch oder ethisch umgehen? Und wie entwickeln sich Arbeitsmärkte und ganze Industrien, wenn aus ebendiesen Konsumenten flächendeckend Prosumenten werden? “11

Das ist nur eine kleine Auswahl von Fragen, die Oermann stellt. Sie zeigen aber eines: Wirtschaft bedarf auch unter den Bedingungen des Teilens konkreter Gestaltung, damit das Teilen zum Gelingen des Lebens aller und damit zur Erweiterung des beengten Wirtschaftsverständnisses führen kann.

All das ist wirtschaftsethisch wichtig, es geht ja darum, ob eine neue Form von Wirtschaft, die Gesellschaft nicht über Eigentum trennt, sondern über Teilung von Eigentum zu vereinen sucht und damit die aus dem Teilen entstehenden menschlichen Beziehungen als eine Grundlage mitberücksichtigt, möglich ist. Gibt es so etwas wie Gemeinschaftsökonomie als ein gesamtheitliches Konzept, das nicht nur in ethischen Forderungen, sondern auch in gelebter Wirtschaft in einer solidarischen Gesellschaft existieren kann? Um das zu erreichen, wird es notwendig sein, nach dem Stellenwert der Wirtschaft als gesamter in der Gesellschaft zu fragen, was in die Frage mündet, was eine Wirtschaft wie zum Gelingen des Ganzen eines geglückten Lebens beitragen kann. Solches lässt nach den Werten fragen, die ein menschlichen Leben tragen.

10 Nils Ole Oermann, Wirtschaftsethik. Vom freien Markt bis zur Share Economy, München 2015, S. $117 \mathrm{f}$.

11 Ebd., S. 118. 


\section{Schlussbemerkung}

Ingeborg Gabriel schreibt:

„Die weit verbreitete Ablehnung der Ethik in unserer Zeit dient laut Franziskus den Interessen jener, die sich der Relativierung ihres Geld- und Machtstrebens widersetzen. Sie ist deshalb im Namen der Humanität sowie des Glaubens an einen Gott, vor dem die Menschen rechenschaftspflichtig sind, unbedingt zu stärken. Denn ohne eine theoretisch, d.h. ethisch fundierte moralische Praxis sei weder ein soziales Gleichgewicht noch eine menschlichere Gesellschaft möglich. ${ }^{\text {112 }}$

Dieses Plädoyer für Ethik von Papst Franziskus, dem sich Gabriel anschließt, zielt auch darauf ab, aus Wirtschaft ein den Menschen, die Gesellschaft und die Umwelt förderndes Kulturprojekt zu gestalten. Für dieses Plädoyer und die Wahrnehmung der sich aus diesem ergebenden Konsequenzen sei Kollegin Gabriel herzlichst gedankt.

\section{Quellen}

Bruni, Luigino / Zamagni, Stefano, Civil Economy. Efficiency, Equity, Public Happiness, Frontiers of Business Ethics 2, Bern 2007.

Emeis, Dieter, Kleine Theologie der Sehnsucht, in: Katechetische Blätter 122/1997, S. $150-153$.

Gabriel, Ingeborg, Ökonomik - Theologie - Sozialethik. Divergenzen und Konvergenzen, in: Dies / Peter G. Kirchschläger / Richard Sturn (Hg.), Eine Wirtschaft, die Leben fördert, Ostfildern 2017, S. 23-49.

Habermas, Jürgen, Theorie des kommunikativen Handelns 2, 4. Aufl., Frankfurt a. M. 1987.

Hengsbach, Friedhelm, Die Arbeit hat Vorrang. Eine Option katholischer Soziallehre, Mainz 1982.

Menne, Ferdinand W., Wertsysteme und Realität. Soziologische Stichworte, in: Anselm Hertz (Hg.), Moral, Mainz 1972, S. 34-59.

Oermann, Nils Ole, Wirtschaftsethik. Vom freien Markt bis zur Share Economy, München 2015.

Schmitz, Wolfgang, Das Prinzip der ausreichenden Sachkenntnis. Voraussetzung für die gesellschaftgestaltende Kraft der Kirche, in: Gesellschaft und Politik 28/4/1992, S. 17-19.

Strohm, Theodor, Aspekte des Terrorismus in sozialethischer Sicht, in: Zeitschrift für evangelische Ethik 23/1979, S. 118-132.

12 Ingeborg Gabriel, Ökonomik - Theologie - Sozialethik. Divergenzen und Konvergenzen, in: Dies / Peter G. Kirchschläger /Richard Sturn (Hg.), Eine Wirtschaft, die Leben fördert, Ostfildern 2017, S. 23-49, hier: S. 40. 
Zecha, Gerhard, Viele Ethiken und keine Moral. Zur Problematik des wissenschaftlichen Werterelativismus, in: Paul Weingartner (Hg.), Die eine Ethik in der pluralistischen Gesellschaft, Innsbruck 1978, S. 157-182. 


\section{Michaela Schaffhauser-Linzatti (Wien)}

\section{Tue Gutes und Berichte darüber}

\section{Anstelle einer traditionellen Einleitung}

Externes Rechnungswesen ist scheinbar das langweiligste aller betriebswirtschaftlichen Fächer. Oder kennen Sie jemanden, den es innerlich danach drängt, endlich seine Buchhaltung und Steuererklärung machen zu dürfen?

Jedoch verbirgt sich hinter den schnöden Auflistungen und Tabellen Information, die spannender nicht sein könnte: die in Zahlen gegossene „Wahrheit“ über ein Unternehmen. Unternehmensexterne Fachkundige verstehen diese Information $\mathrm{zu}$ interpretieren. Unternehmensinterne Ersteller beschäftigt hauptsächlich die Frage, wie man denn diese Wahrheit im Rahmen - oder noch besser an der Grenze - der einengenden gesetzlichen Vorschriften bestmöglich im Sinne des Unternehmens darstellt.

Mit der Frage nach der Wahrheit trifft die Rechnungslegung auf Kernfragen der Philosophie und Theologie. Prof. Gabriel stellt durch ihre akademische Ausbildung in beiden Bereichen eine Brücke zwischen Ökonomie und Religion dar und vertritt in ihren Schriften ${ }^{1}$ eine ganz klare Position zugunsten einer menschenwürdigen sozialen Marktwirtschaft. ${ }^{2}$

Ich lernte Prof. Gabriel im Rahmen meiner Funktionen als Senatorin und Studienprogrammleiterin kennen. Wir entwickelten für das Mastercurriculum Betriebswirtschaftslehre die Lehrveranstaltung "Solidarische Ökonomie“, die den Studierenden der wirtschaftswissenschaftlichen Fakultät einen Blick über

1 Ingeborg Gabriel, Libertäre Tea Party statt katholischer Soziallehre?, in: Die Tagespost, klarer Kurs, katholischer Journalismus, Kolumne am 13.09.2018; Dies., Wohlstand für alle durch Marktwirtschaft? Eine Antwort auf Martin Rhonheimer, in: Zeitschrift für soziales und wirtschaftliches Engagement, Gesellschaft und Politik 53/1/2017: Wohlstand für alle durch Marktwirtschaft - Illusion oder Wirklichkeit?, S. 39-43; Dies. / Peter G. Kirchschläger / Richard Sturn (Hg.), Eine Wirtschaft die Leben fördert, Wirtschafts- und unternehmensethische Reflexionen im Anschluss an Papst Franziskus, Ostfildern 2017; Ingeborg Gabriel, Das tägliche Brot für alle, Welternährung als Gerechtigkeitsfrage der Gegenwart, in: Communio. Internationale Katholische Zeitschrift 46/2017, S. 52-65.

2 Franziskus, Laudato si' 189; 922. 
die betriebswirtschaftlichen Grenzen eines Unternehmens bietet und zur Reflexion anregen soll, inwieweit unternehmerisches, rein auf Gewinnmaximierung orientiertes Handeln in Einklang mit gesamtgesellschaftlicher Entwicklung und ethischem Verhalten steht. Diese Lehrveranstaltung ist im deutschsprachigen Raum einzigartig und wird aufgrund ihres Erfolges nun unter meiner Verantwortung weitergeführt; Prof. Gabriel begleitet weiterhin mit Grundsatzreferaten und Gästen - herzlichen Dank auch im Namen aller Studierenden!

Über diese gemeinsame Lehre wurde ich zur Konferenz „Eine Wirtschaft, die Leben fördert" eingeladen und durfte einen Beitrag zum gleichnamigen Tagungsband gestalten. ${ }^{3}$

Die Anregungen aus Lehrveranstaltung, Tagungsbeitrag und zahlreichen persönliche Gesprächen mit Prof. Gabriel eröffneten mir ein neues Forschungsgebiet, das Ökonomie, Ethik und deren Rahmenbedingungen verknüpft. Sie sind Ausgangslage für die folgenden Gedanken, die für mich Impetus und gleichsam Arbeitsauftrag geworden sind.

Nach einem Abriss ökonomischer Entwicklungen aus einem ethischen Blickwinkel wird beispielshaft anhand von Ansätzen der Sozial- und Humankapitalbilanz aufgezeigt, wie künftige Wege von per se gewinnorientierten Unternehmen im Sinne einer nachhaltigen Wirtschaft und des Gemeinwohles in der unternehmerischen Außendarstellung reflektiert werden könnten. Innerhalb der Wirtschaftsethik besetzt Reporting eine wichtige Nische, die nicht nur der Informationsgewinnung dient, sondern auch die Wechselwirkungen von unternehmerischer Handlung und Berichterstattung darüber offensichtlich werden lässt.

\section{Anstelle einer traditionellen Rechnungslegung}

Weltweit sind Unternehmen verpflichtet, über ihre wirtschaftlichen Tätigkeiten als Spiegelbild ihrer Handlungen und daraus resultierenden Erfolge Bericht zu erstatten. ${ }^{4}$ In der Sprache der unternehmerischen Rechnungslegung bedeutet das neutrale Wort „Erfolg“ ein nach gesetzlichen Vorschriften kalkuliertes monetäres Ergebnis, das sowohl ein Gewinn als auch ein Verlust sein kann. Stand früher ausschließlich der Erfolg im Zentrum dieser Reports, rücken gesamtge-

3 Michaela Schaffhauser-Linzatti, Bilden die traditionelle Rechnungslegung oder alternative Bilanzen Gemeinwohl und Glück ab?, Vortrag im Rahmen der Konferenz „Wirtschaft - Gemeinwohl - Glück. Interdisziplinäre Zugänge zur Wirtschaftsethik“, 9.-11. April 2015, Universität Wien, vgl. https://se-ktf.univie.ac.at/veranstaltungen/tagung-wirtschaft-gemein wohl-glueck/ (letzter Zugriff: 25.07.2019).

4 Michaela Schaffhauser-Linzatti, Rechnungswesen Schritt für Schritt, 4. Aufl., Wien 2019, S. 20, S. 54 . 
sellschaftliche Erfordernisse im Sinne einer Nachhaltigkeitsberichterstattung immer mehr in den Vordergrund, die Erfolg nicht nur in ökonomischen Größen, sondern auch anhand von sozialen und ökologischen Auswirkungen darstellen soll.

Ich sehe diese Entwicklung als Gegentrend zur im wahrsten Sinne des Wortes grenzenlosen Globalisierung der Wirtschaft, die seit Mitte des vorigen Jahrhunderts eine Zunahme überregionaler Verflechtungen und eine Stärkung international agierender Unternehmen zulasten nationalstaatlicher Wirtschafts- und Sozialpolitik bedingt. ${ }^{5}$ Durch diese neu entstandenen Machtverhältnisse drängt rein gewinnorientiertes Handeln als einzig gültige Unternehmensmaxime ${ }^{6}$ eine Ökonomie, die sich der Ressourcen- und Bedürfnisgerechtigkeit verpflichtet fühlt, immer mehr in den Hintergrund ${ }^{7}$. Die rasant aufgehende Schere bei der Einkommensverteilung und die wachsende Armut einer großen Bevölkerungsmehrheit bei gleichzeitigem Anstieg des Vermögens einer verschwindenden Minderheit ${ }^{8}$ verlangt nach neuen Ansätzen der Wirtschaftswissenschaften zur gesellschaftlich optimalen Ressourcenallokation. Gewinn in philosophisch-ethischem Sinn sollte nicht in monetärem Ertrag minus Aufwendungen, sondern als ein Mehr an menschlicher Lebenserfüllung berechnet werden. ${ }^{9}$

Bereits Aristoteles erkennt die Untrennbarkeit von moralischem, wirtschaftlichem und politischem Handeln. Für ihn ist ein über die familiären Notwendigkeiten hinausgehendes Streben nach Reichtum und Gewinnmaximierung ethisch nicht zu rechtfertigen. ${ }^{10}$ Seine Unterscheidung zwischen der widernatürlichen Erwerbskunst der Chrematistik als Kunst des Gelderwerbs und der natürlichen Erwerbskunst der Ökonomik als lebensdienliche Hauswirtschaft ${ }^{11}$ prägten bis ins Mittelalter die islamische und christliche Auffassung

5 Armin von Bogdandy, Globalization and Europe: How to Square Democracy, Globalization and International Law, in: European Journal of International Law 15/2004, S. 885-906, hier: S. 888; Katharina J. Srnka, Marketing. Ethik \& Kultur, Wirtschafts- und Unternehmensethik 12, München 2005, S. 1.

6 Milton Friedman, Capitalism and Freedom, in: 40th anniversary edition Chicago, ChicagoLondon 2002, S. 133.

7 Elisabeth Göbel, Unternehmensethik, 3. Aufl., Trier 2013, S. $181 \mathrm{ff}$.

8 Michael F. Förster, Einkommensverteilung und Armut im OECD-Raum, in: Dimensions of Inequality in the EU (Dimensionen der Ungleichheit in der EU), Workshops Proceedings of OeNB Workshops 16, Österreichische Nationalbank Eurosystem, 2008.

9 Walter Kerber, Sozialethik, Grundkurs Philosophie 13, Stuttgart-Berlin 1998, S. 117, S. 138.

10 Aristoteles, Nikomachische Ethik, Stuttgart 1997; Christian A. Conrad, Wirtschaftsethik: Eine Voraussetzung für Produktivität, Wiesbaden 2016, S. 17, Annemarie Pieper, Einführung in die Ethik, 6. Aufl., Basel 2007, S. $66 \mathrm{ff}$.

11 Karl Polanyi, Aristotle Discovers the Economy, in: George Dalton (Hg.), Primitive, Archaic and Modern Economies, Essays of Karl Polanyi, New York 1968. 
von wirtschaftlichem Handeln ${ }^{12}$, die erst durch die neue Entwicklung des Kapitalismus abgelöst wurde. Unverständlicherweise wird der Gründervater der Nationalökonomie Adam Smith auf seine wirtschaftswissenschaftlichen Thesen zum freien Markt reduziert, seine Ausführungen zu Moral und Sittlichkeit in wirtschaftlichem Handeln gerieten in Vergessenheit ${ }^{13}$.

Die Bedeutung von sozialer Gerechtigkeit und Umweltpolitik wird in der Denkschule des Ordoliberalismus Mitte des 20. Jahrhunderts wieder von Walter Eucken ${ }^{14}$ hervorgehoben, der im Rahmen des Verursacherprinzips die Verantwortung der wirtschaftlichen Leistungsträger für die Gesellschaft fordert. Die Soziale Marktwirtschaft führt diese Leitideen des freien Wettbewerbs mit „gesichertem sozialen Fortschritt “15 fort. Sie war „nach den schrecklichen Erfahrungen des 20. Jahrhunderts die Antwort auf die Erfahrungen einer ungebremsten Marktwirtschaft mit Massenarbeitslosigkeit und Verelendung weiter Schichten in Europa im Zuge der Weltwirtschaftskrise ${ }^{\text {"16 }}$ und wird z.B. in Österreich von Riegler ${ }^{17}$ im Rahmen der Ökosozialen Marktwirtschaft durch Nachhaltigkeit und Umweltschutz ergänzt. Die aktuellste Entwicklung einer moralischen Ökonomik wurde durch Felber und seiner Gemeinwohl-Ökonomie initialisiert ${ }^{18}$, auch der Genossenschaftsgedanke rückt wieder zunehmend in die Öffentlichkeit ${ }^{19}$.

Aus christlich-ethischer Sicht bekennt sich die katholische Kirche zu Marktwirtschaft und Privateigentum als bestmögliche auch nicht-monetäre Ressourcenallokation, die auch Produktionsvielfalt und unternehmerische Kreativität begünstigt ${ }^{20}$. Diese Wirtschaftsordnung schafft aber per se keine sozialgerechte Verteilung und Umweltschutz ${ }^{21}$, sondern führt zu oligarchischen

12 Joseph Vogl, Das Gespenst des Kapitals (minima oeconomica), 3. Aufl., Zürich 2010, S. 124; Jacques Le Goff, Wucherzins und Höllenqualen: Ökonomie und Religion im Mittelalter, 2. Aufl., Stuttgart 2008.

13 Adam Smith, The Theory of Moral Sentiments, Düsseldorf 1759; Adam Smith, Der Wohlstand der Nationen: Eine Untersuchung seiner Natur und seiner Ursachen, 8. Aufl., München 1999.

14 Walter Eucken, Grundsätze der Wirtschaftspolitik, Zürich 1952.

15 Alfred Müller-Arnack, Wirtschaftsordnung und Wirtschaftspolitik, Studien und Konzepte zur Sozialen Marktwirtschaft und zur Europäischen Integration, Bern 1976, S. 245.

16 Gabriel, Wohlstand für alle durch Marktwirtschaft?, S. 39f.

17 Josef Riegler, Antworten für die Zukunft. Ökosoziale Marktwirtschaft. Politische Akademie der Österreichischen Volkspartei, Wien 1990.

18 Christian Felber, Die Gemeinwohl-Ökonomie, erw. 6. Aufl., Frankfurt a. M. 2012; Christian Felber, Neue Werte für die Wirtschaft: Eine Alternative zu Kommunismus und Kapitalismus, 4. Aufl., Wien 2008.

19 Gabriel, Das tägliche Brot für alle, S. 59.

20 Gabriel, Das tägliche Brot für alle, S. 58, S. 62; Franziskus, Laudato si' 203, 927.

21 Joachim Wiemeyer, Unternehmensethik aus christlich-sozialethischer Sicht, in: Katholische Sozialwissenschaftliche Zentralstelle (Hg.), Kirche und Gesellschaft 403/2013, S. 8. 
Machtzentren und schlussendlich zu Marktversagen ${ }^{22}$, kurzfristige ${ }^{23}$ Profitmaximierung als ultimativer Ausdruck von Gier - und dessen Folgen - werden vom Tanz um das Goldene Kalb ${ }^{24}$ bis in heutigen modernen Ausdrucksformen ${ }^{25}$ thematisiert. Die Wirtschaftskrise 2008 hat die Grenzen der aktuellen Wirtschaftsordnung, den Wandel von Homo Sapiens über Homo Faber und Homo Oeconomicus bis hin zum jetzigen Homo Consumens ${ }^{26}$ mit der daraus folgenden Wegwerfgesellschaft schmerzhaft aufgezeigt. Gemeinsam mit renommierten Ökonomen ${ }^{27}$ wie Gary S. Becker warnt Papst Franziskus vor einer „überbordenden Finanzindustrie und steigender Exklusion “28, die ihre Gewinne internalisiert, ohne die externalisierten Kosten wie Umweltschädigungen oder Arbeitslosigkeit zu tragen. Dadurch werden überhaupt erst die Voraussetzungen für diese Gewinne geschaffen, Gabriel ${ }^{29}$ weist in diesem Zusammenhang auf das Böckenförde-Paradoxon hin, wonach „der freiheitliche, säkularisierte Staat von Voraussetzungen [lebt], die er selbst nicht garantieren kann “30. Sie betont die Notwendigkeit der Zusammenführung von Freiheit und Solidarität, auch in entsprechenden Institutionen, als Voraussetzung eines allgemeinen Wohlstandes im Rahmen der freien Marktwirtschaft, ebenso wie „im Hinblick auf das Gemeinwohl [...] für uns heute die dringende Notwendigkeit [besteht], dass Politik und Wirtschaft sich im Dialog entschieden in den Dienst des Lebens stellen, besonders in den des menschlichen Lebens ${ }^{\text {“31 }}$. Daher bedarf es neben einer klaren ethischen Grundlage entsprechender Regulierungen ${ }^{32}$; es sind konsequenterweise nicht nur „öko-soziale Institutionen auf staatlicher Ebene

22 Kongregation für die Glaubenslehre, Dikasterium für den Dienst zugunsten der ganzheitlichen Entwicklung des Menschen, Oeconomicae et pecuniariae quaestiones, Erwägungen zu einer ethischen Unterscheidung bezüglich einiger Aspekte des gegenwärtigen Finanzwirtschaftssystems, Vatikan 2018.; Franziskus, Laudato si' 203, 927.

23 Francesco Perrini / Antonio Tencati, Sustainability and Stakeholder Management: the Need for New Corporate Performance Evaluation and Reporting Systems, in: Business Strategy and Environment 15/2006, S. 296-308, hier: S. 297.

242 Moses (Exodus) 32.

25 Jim Steinman / Michael Kunze, Tanz der Vampire, Die unstillbare Gier, Musical, 1997.

26 Pieper, Einführung in die Ethik, S. 69; Eckhard Meinberg, Homo Oeconomicus, Das neue Menschenbild im Zeichen der ökologischen Krise, Darmstadt 1995.

27 Philip Alexander Münch, Die globale Finanzkrise als Kumulation von Dilemmastrukturen, Plädoyer für eine Ethik mit ökonomischer Methode, Peter Löscher-Stiftungslehrstuhl für Wirtschaftsethik, Technische Universität München, München 2012, S. 12 f.

28 Gabriel, Libertäre Tea Party.

29 Gabriel, Wohlstand für alle durch Marktwirtschaft?, S. 39f.

30 Ernst-Wolfgang Böckenförde, Der säkularisierte Staat. Sein Charakter, seine Rechtfertigung und seine Probleme im 21. Jahrhundert, Themenband 86 der Carl Friedrich von Siemens Stiftung, München 2007, S. 60.

31 Franziskus, Laudato si' 109, 891.

32 Kongregation für die Glaubenslehre. 
[einzurichten] ${ }^{33}$, sondern auch solche, die für das soziale und ökologische Weltgemeinwohl global zuständig sind. (...) Diese ist die Gemeinwohlaufgabe des Staates bzw. supranationaler Akteure. ${ }^{(34}$

Folglich hat eine öko-soziale, gerechte Wirtschaftspolitik als Ordnungspolitik den Rahmen für unternehmerisches Handeln im Spannungsfeld zwischen der Freiheit im Sinne wirtschaftlicher Effizienz und Verpflichtung im Sinne der Sozialethik ${ }^{35}$ derart zu gestalten, dass Gemeinwohlziele erreicht werden und gleichzeitig nur ein Minimum an Moral, das über die Einhaltung der Gesetze hinausgeht, verlangt werden muss ${ }^{36}$. Wirtschaft und Gesellschaft sind kein Nullsummenspiel, bei dem sich Gewinne und Verluste innerhalb einer Gruppe ausgleichen ${ }^{37}$. Wie spieltheoretische Ansätze zum Beispiel im Gefangenendilemma beweisen, führt individuell rationales Handeln oft nicht zu einem gesamtoptimalen Ergebnis ${ }^{38}$ und begünstigt Trittbrettfahrer, z. B. bei Steueroptimierung im Ausland. Da aber nicht alle wirtschaftlichen Aktivitäten rechtlich geregelt werden können, bedarf es geschickt gestalteter Anreizsysteme, die über gesellschaftliche Sanktionsmechanismen ethisches Handeln hervorrufen ${ }^{39}$. Diese wirtschaftliche Moral über bestehende Gesetze hinaus ist auch deswegen notwendig, da Rechtsordnungen oft hinter wirtschaftlichen Entwicklungen nachhinken, globales Wirtschaften nicht an einem einzigen Rechtssystem festzumachen ist und somit Schlupflöcher hervorbringt, und gesetzliche Vorschriften oft Freiräume ermöglichen ${ }^{40}$.

Diese einzufordernde Wirtschaftsethik als wichtiger Teilbereich der Sozialethik umfasst einerseits als Ordnungsethik die Gestaltung von Rahmenbedingungen, andererseits als Unternehmensethik das Verhalten der Wirtschaftssubjekte. ${ }^{41}$ Daraus können drei Betrachtungsebenen der Wirtschaftsethik abgeleitet werden, die auch Prof. Gabriel als Grundstruktur in ihrer Lehrveranstaltung „Solidarische Ökonomie“ präsentiert: Die Makroebene umfasst die Ethik einzelner Wirtschaftssysteme, z. B. des Kapitalismus, die Mesoebene bezieht sich auf Unternehmen und die Mikroebene beschäftigt sich mit ethischen Fragen einzelner Personen, z. B. des Managements oder von Kunden.

33 Anm. Autorin.

34 Gabriel, Wohlstand für alle durch Marktwirtschaft?, S. 41.

35 Göbel, Unternehmensethik, S. 24.

36 Kerber, Sozialethik, S. $130 \mathrm{ff}$.

37 Robert Axelrod, The Evolution of Cooperation, Cambridge 1984.

38 John von Neumann / Oskar Morgenstern, Theory of Games and Economic Behavior, Princeton, NJ 1944.

39 Karl Homann, Die [Relevanz] der Ökonomik für die Implementation ethischer Zielsetzungen, in: Wilhelm Korff (Hg.), Handbuch der Wirtschaftsethik 1: Verhältnisbestimmung von Wirtschaft und Ethik, Gütersloh 1999, S. 322-343, hier: S. 330.

40 Wiemeyer, Unternehmensethik aus christlich-sozialethischer Sicht, S. 5.

41 Kerber, Sozialethik, S. 112. 
Srnka ${ }^{42}$ zieht eine Supraebene der Weltwirtschaftsethik und eine Verbandsebene von Unternehmensverbänden ein, Enderle ${ }^{43}$ ergänzt diese drei Ebenen aufgrund ihrer ethischen Auswirkungen und Zugänge um das Ausmaß internationaler Zusammenhänge. Zusammenfassen lässt sich die Wirtschaftsethik aus ihren vielen kleinen Steinen, die sich in ihrer Gesamtheit $\mathrm{zu}$ einem Gesamtbild zusammensetzen.

Eines dieser kleinen Steine behandelt die Unternehmensberichterstattung im Rahmen der Rechnungslegung. Zahlreiche Skandale seit Ende des 20. Jahrhunderts im Bereich des externen Rechnungswesens haben zu einer intensiven Befassung in Zusammenhang mit ethischen Fragestellungen, v. a. dem Zusammenhang vom Verhaltenswesen von Buchhaltern, Wirtschaftsprüfern, Unternehmenskultur, Governance-Strukturen sowie Kontrollmechanismen, geführt ${ }^{44}$.

Grundsätzlich gilt zu unterscheiden, ob ein Unternehmen ethisch handelt, oder ob seine Berichterstattung darüber ethisch gestaltet ist. Da Darstellung und Handlung zumindest teilweise interagieren, muss ein Unternehmen nachweisliche Aktionen setzen, um der verpflichteten Berichterstattung gerecht $\mathrm{zu}$ werden. Weil aber grosso modo die Wirtschaft genau diese Transparenz vermeiden will, ist kollektiver unternehmerischer Widerstand gegen Veränderungen entsprechender Normensetzung vorhersehbar.

Die Beschäftigung mit diesen - auch bewusst gestalteten - Informationsasymmetrien zwischen Ersteller und Empfänger von Unternehmensdaten reicht weit zurück, z. B. durch den Stakeholderansatz von Friedman ${ }^{45}$ und hat durch die aktuelle Diskussion über Nachhaltigkeit ${ }^{46}$ und Corporate Social Responsibility ${ }^{47}$ den Weg in die öffentliche Wahrnehmung geschafft ${ }^{48}$. Information über das Dreieck der Nachhaltigkeit oder die triple bottom line - Ökonomie, Ökologie,

42 Srnka, Marketing. Ethik \& Kultur, S. 12.

43 Georges Enderle, Exploring and Conceptualizing International Business Ethics, in: Journal of Business Ethics 127/4/ 2014, S. 723-735, hier: S. 724.

44 Paul Jaijairam, Ethics in Accounting, in: Journal of Finance and Accountancy 23, Bronx Community College, New York 2017, S. 1 ff; Kerber, Sozialethik, S. 22.

45 Friedman, Capitalism and Freedom, S. 133.

46 Klaus Fichter, Wettbewerbsvorteile durch freiwillige Umweltberichterstattung, in: Ökologisches Wirtschaften, Ergebnisse einer IÖW-Untersuchung für das hessische Wirtschaftsministerium 1/1998, S. 7-9.

47 CSR Guide, Jahrbuch für unternehmerische Verantwortung, Wien 2016; Göbel, Unternehmensethik, S. 275f; Michael S. Aßländer / Janina Curbach, The Corporation as Citoyen? Towards a New Understanding of Corporate Citizenship, in: Journal of Business Ethics 120/4/ 2014, S. 541-554, hier: S. 541.

48 Markus Palenberg / Wolfgang Reinicke / Jan Martin Witte, Trends in non-financial reporting, Paper prepared for the United Nations Environment Programme, Division of Technology, Industry and Ecnomomics (DTIE), global public policy institute (GPPi), Berlin 2006. 
Soziales - ist mittlerweile Standard und teilweise sogar gesetzlich gefordert ${ }^{49}$. Leider scheint das Pendel wieder in die Gegenrichtung zu schlagen. Es werden Berichte über ökologische und soziale Aktivitäten von einzelnen Stakeholdergruppen als negativ im Sinne von Intransparenz wichtiger Tatsachen interpretiert und Verschleierung unterstellt. ${ }^{50}$ Tatsächlich werden diese Berichte oft als Imagekampagne und Aktienkursbeeinflussung missbraucht und hintergehen somit die essenzielle Transparenz ${ }^{51}$; auch mangelnde Qualität wegen fehlenden bzw. weniger umfangreichen Audits durch Wirtschaftsprüfer wird als Argument zur Ablehnung solcher Berichte vorgeschoben ${ }^{52}$. Nach wie vor liegt der Schwerpunkt auf den Unternehmensfinanzen und einer Shareholderorientierung, was sich z. B. durch die fair value Bewertung und das Zurückdrängen des Vorsichtsprinzips und des Stakeholderansatzes in der internationalen Rechnungslegung manifestiert. ${ }^{53}$ Alleine die Tatsache, dass Regulierungsentscheidungen im Bereich der Rechnungslegung privaten, wirtschaftsgelenkten Organisationen ${ }^{54}$ vorbei an staatlicher, parlamentarischer Kontrolle überantwortet und somit privatisiert wurden, zeigt das mangelnde öffentliche Interesse und das wahre Gesicht der Wirtschaftspolitik.

Für mich steht die Frage einer fundamentalen Neugestaltung der unternehmerischen Berichterstattung mit einer ausgeglichenen triple bottom line aus ökonomischer UND ethischer Sicht im Sinn eines umfassenden Stakeholderansatzes außer Streit. Ich habe in zahlreichen Schriften deren Notwendigkeit abgeleitet und Lösungswege vorgeschlagen. ${ }^{55}$ Anhand des Teilaspektes „Sozia-

49 Josef Baumüller / Michaela Schaffhauser-Linzatti, Nichtfinanzielle Erklärung oder nicht-finanzieller Bericht? Abwägungen zur Ausübung des Wahlrechts in \$243b Abs 6 UGB, in: CFO aktuell 102/3/2017, S. 102.

50 Tom J. Brown / Peter A. Dacin, The Company and the Product: Corporate Associations and Consumer Product Responses, in: Journal of Marketing 61/1/1997, S. 68-84, hier: S. 81; Steen Vallentin, Pensionsinvestering, etik og offentlighed: en systemteoretisk analyse af offentlig meningsdannelse, Samfungslitteratur, København 2001.

51 Tom Sieber / Barbara E. Weißenberger, / Tatjana Oberdörster / Jörg Baetge, Let's talk strategy : the impact of voluntary strategy disclosure on the cost of equity capital, in: Business Research 7/2014, S. 263-312, hier: S. 297; Mette Morsing / Majken Schultz, Corporate social responsibility communication: stakeholder information, response and involvement strategies, in: Business Ethics: A European Review 15/4/2006, S. 323-338, hier: S. 327.

52 Göbel, Unternehmensethik, S. 286.

53 Martin Held / Gisela Kubon-Gilke / Richard Sturn (Hg.), Unsere Institutionen in Zeiten der Krise, Jahrbuch Normative und institutionelle Grundfragen der Ökonomik 13, Marburg 2014, S. $152 \mathrm{ff}$; IASCF, Constitution, revised and approved by the Trustees January 2013, International Financial Accounting Committee Foundation, 2013.

54 Held / Kubon-Gilke / Sturn, Unsere Institutionen in Zeiten der Krise, S. 165.

55 Michaela Schaffhauser-Linzatti / Peter G. Kirchschläger, Sustainability and ethics in financial reporting: an empirical study of German, Austrian, and Swiss groups, in: Adam Lindgreen / Christine Vallaster / Shumaila Yousafzai / Bernhard Hirsch (Hg.), Measuring and Controlling Sustainability: Spanning Theory, London-New York 2018; Peter G. Kirchschläger / Michaela 
les“ zeige ich im Folgenden Entwicklungsstränge auf, um in der Schlussbetrachtung anhand der von Gabriel strukturierten drei Ebenen konkrete Handlungsempfehlungen abzuleiten. Sprachlich irritierend wurde in der deutschsprachigen Literatur für diese alternativen Berichte die Bezeichnung „Bilanzen“ gewählt, da diese nicht (nur) eine Gegenüberstellung von in Geld bewertetem Vermögen und Kapital, sondern viel umfassender auch eine narrative Information und Bewertung umfassen.

Spätestens seit Adam Smith ${ }^{56}$ und Max Weber ${ }^{57}$ sind Auswirkungen auf Veränderungen des Produktionsprozesses, meist bedingt durch Innovationen (siehe zum Beispiel Schumpeters schöpferische Zerstörung) ${ }^{58}$ auch auf die Mitarbeiter und die Gesellschaft als Ganzes erforscht, sie werden aber vom traditionellen volkswirtschaftlichen und unternehmerischen Rechnungswesen falsch abgebildet: Autounfälle erhöhen das Bruttosozialprodukt; soziale Leistungen des Unternehmens oder Ausbildung der Mitarbeiter sind gewinnreduzierend. „Wert hat sein qualitatives Moment verloren“59 und wird nur noch auf quantifizierbare Gegenstände reduziert.

Auf gesamtgesellschaftlicher Ebene entstanden nach dem 2. Weltkrieg vor allem in den $\mathrm{USA}^{60}$ Sozialbilanzen, die sich an der volkswirtschaftlichen Gesamtrechnung orientierten, Zahlungsströme zwischen der Makro- und der Mesoebene abbildeten und qualitative Elemente einfügten. In Großbritannien ${ }^{61}$ und Deutschland ${ }^{62}$ konnten sich trotz ihrer Praxisbewährung eher unterneh-

Schaffhauser-Linzatti, Challenges of Extra-Financial Information in Respect to Sustainability, in: 12th Interdisciplinary Workshop on Intangibles, Intellectual Capital and Extra financial Information, Sankt Petersburg 2016; Michaela Schaffhauser-Linzatti, Welchen Beitrag kann die unternehmerische Rechnungslegung zu einer Ethik der Nachhaltigkeit leisten?, in: Gabriel / Kirchschläger / Sturn (Hg.), Eine Wirtschaft, S. 319-336, hier: S. $319 \mathrm{ff} ;$ Michaela Schaffhauser-Linzatti / Peter G. Kirchschläger, Ethik in Integrated Reports, Transparente Kommunikation von Corporate Social Responsibility und Nachhaltigkeit-Aktivitäten von Unternehmen, in: Linard Nadig / Ulrich Egle (Hg.), CARF Luzern 2016 Controlling. Accounting. Risiko. Finanzen, IFZ - Hochschule Luzern, 2016, S. 263-282, hier: S. $263 \mathrm{ff}$.

56 Smith, Der Wohlstand der Nationen.

57 Max Weber, Soziologische Grundbegriffe, 6. Aufl., Tübingen 1984.

58 Peter Uwe Kupsch / Rainer Marr / Arnold Picot, Innovationswirtschafts, in: Edmund Heinen, Industriebetriebslehre, Entscheidungen im Industriebetrieb, 9. Aufl., Heidelberg 1991, S. 1069-1156, hier: S. $1069 \mathrm{ff}$.

59 Pieper, Einführung in die Ethik, S. 70.

60 Dudley Seers, Social Accounting, in: Economic Record - The Economic Society of Australia 22.1/1946, S. 117-132, hier: S. 117 ff.; John P. Powelson, Social Accounting, in: The Accounting Review 30.4/1955, S. 651-659, hier: S. 651 ff.; David F. Linowes, Measuring Social Programs in Business, New York 1972; Richard Stone, The Accounts of Society, in: Nobel Memorial Lecture, Journal of Applied Econometrics 1986, S. 5-28, hier: S. $5 \mathrm{ff}$.

61 Accounting Standards Steering Committee (ASSC), The Corporate Report, 1975.

62 Elmar Pieroth, Sozialbilanzen in der Bundesrepublik Deutschland, Düsseldorf-Wien 1978; Meinolf Dierkes, Die Sozialbilanz, Ein gesellschaftsbezogenes Informations- und Rechnungslegungssystem, Frankfurt-New York 1974; Arbeitskreis „Sozialbilanz-Praxis“, Sozial- 
mensorientierte Ansätze nicht durchsetzen, während Frankreich mit dem immer noch gültigen Code du Travail ein entsprechendes Gesetz verabschiedete, wonach die Auswirkungen von unternehmerischem Handeln in Bezug auf die soziale Situation der Mitarbeiter aufgezeigt werden müssen ${ }^{63}$. Eine Renaissance erlebte die Sozialbilanz z.B. mit dem SAAS-Zertifikat, das v.a. die Menschenrechte in den Vordergrund stellt ${ }^{64}$ oder dem Bruttonationalglück, das eine Gesellschaft nicht nur anhand finanzieller Kenngrößen abzubilden versucht ${ }^{65}$.

Unternehmensorientierte Wissensbilanzen entstanden parallel zur Entwicklung der postindustriellen Wissensgesellschaft ${ }^{66}$. Sie versuchen, dem immateriellen Charakter des neuen Vermögens „Wissen“, das nicht seiner Bedeutung entsprechend in der Bilanz abgebildet ist, gerecht zu werden und wissensbasierte Prozesse, Investitionen in immaterielle Vermögenswerte sowie die Ergebnisse dieser Prozesse und Ergebnisse sichtbar zu machen ${ }^{67}$. Die Ansätze der ersten Welle, des Human Ressource Accounting ${ }^{68}$, waren von der Idee geprägt „to put people on the balance sheet ${ }^{\text {“69 }}$. Sie erweiterten und verbesserten die traditionelle doppelte Buchhaltung durch monetäre Bewertung von Leistungen von und für Mitarbeiter durch Berücksichtigung korrespondierender Kosten, Erfolge ${ }^{70}$ oder Marktwerte $^{71}$.

bilanz heute, Empfehlungen des Arbeitskreises „Sozialbilanz Praxis“, 1977; Heinz Schulte, Die Sozialbilanz der STEAG Aktiengesellschaft, in: Betriebswirtschaftliche Forschung und Praxis 26.4/1974, S. 277-294, hier: S. $277 \mathrm{ff}$.

63 Institut National de la Statisique et des Etudes Economiques (INSEE), Systeme elargi de comptabilite nationale, Les collections de l'INSEE, 198-199, ser. C/1976, S. 44-45, hier: S. 44f; Hans-Jürgen Martens, Zur Einführung der Sozialbilanz in Frankreich, in: Zeitschrift für Unternehmens- und Gesellschaftsrecht 8.3/1979, S. 387-391, hier: S. $387 \mathrm{ff}$.

64 Dirk Ulrich Gilbert / Andreas Rasche, Discourse Ethics and Social Accountability, The Ethics of SA 8000, in: Business Ethics Quarterly 17.2/2007, S. 187-216, hier: S. 187ff.; Social Accountability Accreditation Service (SAAS), vgl. http://www.saasaccreditation.org/ (letzter Zugriff: 17.06.2019).

65 Tobias Pfaff, Das „Bruttonationalglück“ als Leitlinie der Politik in Bhutan - eine ordnungspolitische Analyse, in: ORDO, Jahrbuch für die Ordnung von Wirtschaft und Gesellschaft 62/2011, S. 365-385, hier: S. $365 \mathrm{ff}$.

66 Thomas A. Stewart, Der vierte Produktionsfaktor, Wachstum und Wettbewerbsvorteile durch Wissensmanagement, München 1998; Peter Drucker, Die postkapitalistische Gesellschaft, Düsseldorf 1993.

67 Johan Roos / Goran Roos / Nicola Carlo Dragonetti / Leif Edvinsson, Intellectual Capital. Navigating the New Business Landscape, New York 1997.

68 Michaela Schaffhauser-Linzatti, Wissensbilanzierung als Instrument der Unternehmensbewertung, Jahresforum 2004, Wien 2004.

69 Robin Roslender, Accounting for Human Resources Revisited, Insights from the Intellectual Capital Field, in: Magdy G. Abdel-Kader (Hg.), Review of Management Accounting Research, London 2011, S. 85-110, hier: S. 87; James S. Hekimian / Curtis H. Jones, Put people on your balance sheet, in: Harvard business review (HBR) 45.1/1967, S. 105-113.

70 Roger H. Hermanson, Accounting for Human Assets. Bureau of Business and Economic Research, Graduate School of Business Administration, Occasional Paper 14/1964, S. 1-69, 
In der zweiten Welle, dem Intellectual Capital Reporting, stellen überwiegend Praktiker auf verbale Berichte mit quantitativen Indikatoren sowie verbalen Narrationen $\mathrm{ab}^{72}$. Akademisch orientierte Ansätze verknüpfen Unternehmensdaten durch mathematische Modelle wie fuzzy logic ${ }^{73}$. Der einzige nachhaltig realisierte Ansatz, das sogenannte ARC-Modell Seibersdorf ${ }^{74}$, wurde als weltweit erste Wissensbilanz in $\$ 13$ Abs 6 UG $2002^{75}$ kodifiziert und dient nicht nur der Dokumentation und Kommunikation, sondern auch als eine Basis für die Ressourcenallokation zwischen Universitäten und dem Bundesministerium ${ }^{76}$.

hier: S. 1 ff.; Bikki Jaggi / Hon-Shiang Lau, Toward a Model for Human Resource Valuation, in: The Accounting Review 49.2/1974, S. 321-329, hier: S. 321 ff.; Eric G. Flamholtz, A Model for Human Resource Valuation. A Stochastic Process with Service Rewards, in: The Accounting Review 46.2/1971, S. 253-267, hier: S. 253 ff.; Michaela Schaffhauser-Linzatti / Hans Moritsch, Human Resource Accounting, A Real Options Approach, working paper, 2003.

71 Stephen Albert / Keith Bradley, The Management of Intellectual Capital, in: Report of the Business Performance Group (LSE), 1995, S. 101-107, hier: S. $101 \mathrm{ff}$.

72 Karl Erik Sveiby, The Intangible Assets Monitor, vgl. https://www.sveiby.com/files/pdf/the-in tangible-assets-monitor.pdf (letzter Zugriff: 17.06.2019); Leif Edvinsson / Gisela Brünig, Aktivposten Wissenskapital, Unsichtbare Werte bilanzierbar machen, Wiesbaden 2000, S. 131; Roos / Roos / Dragonetti / Edvinsson, Intellectual Capital; Leif Edvinsson / Michael S. Malone, Intellectual capital. Realizing your company's true value by finding its hidden brainpower, New York 1997.

73 Lofti A. Zadeh, Fuzzy Sets, Information and Control. Department of Electrical Engineering and Electronics Research Laboratory 8, Berkeley 1965; Stefania Veltri / Giovanni Mastroleo / Michaela Schaffhauser-Linzatti, The Development of a Corporate Intellectual Capital Index in the Austrian University Sector Using a Fuzzy Logic Approach, 5th European Institute for Advanced Studies in Management (EIASM), Workshop on Visualizing, Measuring, and Managing Intangibles \& Intellectual Capital, 2009.

74 Karl-Heinz Leitner / Martin Sammer / Marion Grabbober / Doris Schartinger / Christian Zielowski, Wissensbilanzierung für Universitäten, Auftragsprojekt für das bm:bwk. Sektion VII, Sektion VIII Seibersdorf 2001.

75 Bundesgesetz über die Organisation der Universitäten und ihre Studien (Universitätsgesetz 2002 - UG) StF: BGBl. I Nr. 120/2002 idF BGBl. I Nr. 3/2019.

76 Otto Altenburger / Michaela Schaffhauser-Linzatti, Instrumente zur Steuerung von intellektuellem Kapital -eine Analyse anhand österreichischer Universitäten, 9th Workshop der Kommission „Hochschulmanagement“ im Verband der Hochschullehrer für Betriebswirtschaft e.V. (VHB), Münster 2007; Otto Altenburger / Michaela Schaffhauser-Linzatti, The Suitability of Intellectual Capital Reports for the Quantitative Measurement of Overall University Performance, in: Isabell M. Welpe / Jutta Wollersheim / Stefanie Ringelhan / Margit Osterloh (Hg.), Incentives and Performance: Governance of Research Organizations, Schweiz 2015, S. 379-396; Otto Altenburger / Michaela Schaffhauser-Linzatti, Ratios on Intangibles as an Instrument for Budget Allocation: Conceptual Thoughts about Improvements for Austrian Public Universities, 4th International Forum on Knowledge Asset Dynamics and Intellectual Asset Centre Congress, Glasgow 2009; Michaela Schaffhauser-Linzatti, Die Wissensbilanz als Innovatives Managementinstrument im öffentlichen Bereich, Aktuelle Entwicklungen der Wissensbilanzierung als Controllinginstrument in öffentlichen Verwaltungen, insbesondere im Hochschulwesen an der Johannes Kepler Universität Linz, Wien 2010. 
Gemeinsam ist Sozialbilanzen und Wissensbilanzen, dass aufgrund der erhöhten Bewusstseinsbildung in der Gesellschaft einzelne Berichtselemente Eingang in die gesetzlichen Vorschriften zur Rechnungslegung gefunden haben ${ }^{77}$, aber weder einer der zahlreichen monetären oder qualitativen Ansätze als Gesamtmodell berücksichtigt wurden. Die Grundideen dieser Ansätze, die allerdings keine konkreten Fragen nach Unternehmensethik oder Menschenrechten aufwerfen, gingen in die Integrationsbilanzen der Nachhaltigkeits- und Social Responsibility-Bewegung auf. Sie versuchen, die triple bottom line mit einer ökonomischen, ökologischen und sozialen Dimension ${ }^{78}$ abzubilden und miteinander zu verbinden, wobei der unternehmerische Geschäftsbericht um Narrationen und Kennzahlen ergänzt wird ${ }^{79}$. Noch sind Integrationsbilanzen nicht ausgereift genug, um den Paradigmenwechsel von einer Shareholdervalue-Ära zu einer Postshareholdervalue-Ära ${ }^{80}$ und die notwendigen, auch von der christlichen Ethik geforderten Stakeholderinteressen abzubilden ${ }^{81}$. Unter den zahlreichen Ansätzen scheinen sich als Standards die G4 Sustainability Reporting Guidelines der Global Reporting Initiative ${ }^{82}$ und vor allem das International Integrated Reporting Framework $<\mathrm{IR}>^{83}$ herauszukristallisieren, das bereits in Dänemark und Südafrika verpflichtend anzuwenden ist ${ }^{84}$. Sein Ziel ist die überwiegend qualitative Abbildung des Wertschöpfungsprozesses zur Erlangung einer effizienteren und produktiveren Ressourcenallokation von Finanzkapital, Erzeugnissen, intellektuelles Kapital, Humankapital, Sozialkapital und

77 Nadia Bernaz, Enhancing Corporate Accountability for Human Rights Violations: Is Extraterritoriality the Magic Potion?, in: Journal of Business Ethics 117/2012, S. 493-511, hier: S. $495 \mathrm{f}$; ; Halina Szejnwald Brown / Martin de Jong / David L. Levy, Building institutions based on information disclosure: lessons from GRI's sustainability reporting, in: Journal of Cleaner Production 17/2009, S. 571-580, hier: S. 573; Perrini / Tencati, Sustainability and Stakeholder Management, S. $296 \mathrm{ff}$.

78 Sungchul Choi / Alex Ng, Environmental and Economic Dimensions of Sustainability and Price Effects on Consumer Responses, in: Journal of Business Ethics 104/2/2011, S. 269-282.

79 Kirchschläger / Schaffhauser-Linzatti, Challenges of Extra-Financial Information.

80 Meinolf Dierkes / Lutz Marz / Ariane Berthoin Antal, Sozialbilanzen: Konzeptioneller Kern und diskursive Karriere einer zivilgesellschaftlichen Innovation, in: WZB Discussion Paper, Leibniz 2002.

81 Alexander Gabriel, Normative Grundlagen der freiwilligen Veröffentlichung und Prüfung von Nachhaltigkeitsberichten, Eine empirische Analyse auf dem europäischen Kapitalmarkt, Wiesbaden 2015; Wiemeyer, Unternehmensethik aus christlich-sozialethischer Sicht, S. 8.

82 G4 Sustainability Reporting Guidelines der Global Reporting Initiative (G4), 2016; Markus J. Milne / Rob Gray, W(h)ither Ecology? The Triple Bottom Line, the Global Reporting Initiative, and Corporate Sustainability Reporting, in: Journal of Business Ethics 118.1/2013, S. 13-29, hier: S. $13 \mathrm{ff}$.

83 International Integrated Reporting Council (IIRC), 2016.

84 Ernst \& Young, 2012: Jetzt geht's ums Ganze. Was Sie schon heute über Integrated Reporting wissen sollten. Broschüre 2012, vgl. http://www.ey.com/Publication/vwLUAssets/Broschue re_-_Jetzt_gehts_ums_Ganze/\$FILE/Brosch_IntegrReportg.pdf (letzter Zugriff: 17.06. 2019); IIRC, 2016. 
natürlichen Ressourcen ${ }^{85}$, wobei Schaffhauser-Linzatti/Kirchschläger ${ }^{86}$ auch bei diesem erfolgversprechendsten Ansatz methodische Schwächen der erhofften nachhaltigen und ethischen Berichterstattung aufzeigen.

\section{Anstelle einer traditionellen Schlussbetrachtung}

Was sind nun die nächsten Schritte hin zu einer ethischen Berichterstattung? Was gibt es konkret zu tun? Lassen Sie mich auf Basis der in den vorigen Kapiteln abgeleiteten Beobachtungen und Gedanken Handlungsempfehlungen für die von Prof. Gabriel strukturierten drei Ebenen ableiten.

Auf der Makroebene sind zunächst globale und supranationale Gesetzgeber und Normensetzer gefragt, ein ehrliches Bekenntnis zu Moral in der Wirtschaft abzulegen. Auch schon Lippenbekenntnisse, so verschlagen und abzulehnen sie grundsätzlich sind, geben denjenigen, die guten Willens sind, die Möglichkeit, sich in den Prozess der Regelungsänderungen und Erweiterungen der Unternehmensberichterstattung einzuhaken und öffentlich ihre Forderungen und Ideen zu präsentieren. Es liegen über hundert wissenschaftlich fundierte Ansätze zur Bewertung der triple bottom line vor ${ }^{87}$. Diese gilt es zu kombinieren und praxistauglich umzugestalten, fundamentale Neuerfindungen sind nicht vonnöten. Entscheidend wird es sein, die von den Kultur- und Wirtschaftsräumen geprägten äußerst heterogenen Reportingtraditionen so ausgewogen zu berücksichtigen, dass kein „Wirtschaftsimperialismus " ${ }^{\text {"88 }}$ einer globalen Akzeptanz und Implementierung entgegensteht. Hier tragen auch die Big Four Wirtschaftsprüfungsgesellschaften eine maßgebliche Verantwortung.

Auf der Mesoebene der einzelnen Unternehmen müssen endlich Stakeholderorientierung und Nachhaltigkeit als einzige zielführende Strategie zur langfristigen Gewinnmaximierung in das Bewusstsein der Eigentümer treten und kurzsichtiges Trittbrettfahren als Pyrrhussieg erkannt werden. Hier geht es weniger um ethische Einsichten der handelnden Akteure, sondern um ein $\mathrm{Zu}$ sammenspiel mit den von der Makroebene vorgegebenen Rahmenbedingungen und der Rezeption des Marktes. Ein gutes Beispiel ist die Social Corporate Governance Bewegung, die zur großflächigen freiwilligen Einführung von Code

85 Otto Altenburger / Michaela Schaffhauser-Linzatti, Integrated Reporting für Universitäten? Eine Analyse aus österreichischer Sicht, 16. Workshop Hochschulmanagement, Hochschule für Künste Bremen, Bremen 2014; IIRC, 2016.

86 Schaffhauser-Linzatti, Kirchschläger, Ethik in Integrated Reports, S. $263 \mathrm{ff}$.

87 Perrini / Tencati, Sustainability and Stakeholder Management, S. $296 \mathrm{ff}$.

88 Göbel, Unternehmensethik, S. 278. 
of Conduct, Compliance-Richtlinien und auch Nachhaltigkeitsberichten geführt hat. $^{89}$

Auf der Mikroebene der handelnden Individuen sind durch Anreizsetzungen, z.B. Aufnahme von ethischer Berichterstattung in die Balance Scorecard einzelner Mitarbeiter, mögliche Zielkonflikte zur Zielerreichung monetärer Größen wie Umsatzsteigerung oder Erhöhung des EBIT-margin zu entschärfen und Zusatznutzen aus den Reports zu schaffen. ${ }^{90}$ Nachweislich wird die anfangs starke emotionale Involviertheit der Mitarbeiter in neue Berichtsformen durch eine Reportingmüdigkeit verdrängt, daher muss der Übergang von intrinsischer zu extrinsischer Motivation bewusst gestaltet werden, z. B. durch Aufzeigen der kurssteigernden Wirkung einer Aufnahme in den Dow Jones Sustainability Index. ${ }^{91}$ Auch Kunden tragen Verantwortung: Erwiesenermaßen ${ }^{92}$ starten einzelne Unternehmen nach von ihnen verursachten sozialen oder Umweltkatastrophen zur Abfederung des Reputationsverlustes Imagekampagnen u. a. durch Nachhaltigkeitsberichte, die sich durch eine hohe Diskrepanz von Selbstdarstellung und tatsächlichen Handlungen entlarven, aber von der Öffentlichkeit und den Kunden weder thematisiert noch längerfristig beobachtet werden.

Wie legt man nun den Samen zu einer ethischen Wirtschaft und Berichterstattung darüber? Jeder von uns trägt durch sein Verhalten als Erwerbstätiger und Konsument individuell dazu bei ${ }^{93}$; neben Familie, Religion und öffentlicher Bewusstseinsgestaltung u.a. durch Politik und Medien stehen auch Ausbildungsstätten in der Verantwortung ${ }^{94}$, zum Beispiel durch Verankerung entsprechender Lehrinhalte in wirtschaftswissenschaftlichen Curricula oder größere Wertschätzung wirtschaftsethischer Themen in der Forschung.

Die Entwicklungen der letzten Jahre geben Hoffnung, dass sich Ethik und Nachhaltigkeit langfristig als fester Bestandteil der globalen Ökonomie etablieren konnten und „dass geeignete Kommunikationsformen dazu beitragen [...], die Inkohärenz von unternehmerischem Handeln und seiner Berichterstattung zugunsten einer transparenten, integrierten und umfassenden Information durch Veröffentlichungspflichten zu reduzieren ${ }^{(95}$. Es gilt, stets das big picture einer ethischen, nachhaltigen und solidarischen Wirtschaft vor Augen zu

89 Florian Wettstein, Waiting for the Mountain to Move: The Role of Multinational Corporations in the Quest for Global Justice, in: notizie di POLITEIA XXIX 111/2013, S. 13-21, hier: S. 21.

90 Göbel, Unternehmensethik, S. 286.

91 Szejnwald Brown / de Jong / Levy, Building institutions based on information disclosure, S. 574.

92 Wiemeyer, Unternehmensethik aus christlich-sozialethischer Sicht, S. 9.

93 Kerber, Sozialethik, S. 13.

94 Kongregation für die Glaubenslehre.

95 Kirchschläger / Schaffhauser-Linzatti, Challenges of Extra-Financial Information; Schaffhauser-Linzatti, Welchen Beitrag, S. 319-336. 
haben. Dafür sind dicke Bretter zu bohren, es gilt, sich nicht durch Rückschläge entmutigen zu lassen. Prof. Gabriel hat durch ihre wissenschaftlichen Arbeiten, ihre Lehrtätigkeit und ihr konkretes Handeln in der Praxis einen unverzichtbaren Beitrag geleistet.

\section{Quellen}

Accounting Standards Steering Committee (ASSC), The Corporate Report, 1975.

Albert, Stephen / Bradley, Keith, The Management of Intellectual Capital, in: Report of the Business Performance Group (LSE) 1995, S. 101-107.

Altenburger, Otto / Schaffhauser-Linzatti, Michaela, The Suitability of Intellectual Capital Reports for the Quantitative Measurement of Overall University Performance, in: Isabell M. Welpe / Jutta Wollersheim / Stefanie Ringelhan / Margit Osterloh (Hg.), Incentives and Performance: Governance of Research Organizations, Schweiz 2015, S. 379-396.

Altenburger, Otto / Schaffhauser-Linzatti, Michaela, Integrated Reporting für Universitäten? Eine Analyse aus österreichischer Sicht, 16. Workshop Hochschulmanagement, Hochschule für Künste Bremen, Bremen 2014.

Altenburger, Otto / Schaffhauser-Linzatti, Michaela, Ratios on Intangibles as an Instrument for Budget Allocation: Conceptual Thoughts about Improvements for Austrian Public Universities, 4th International Forum on Knowledge Asset Dynamics and Intellectual Asset Centre Congress, Glasgow 2009.

Altenburger, Otto / Schaffhauser-Linzatti, Michaela, Instrumente zur Steuerung von intellektuellem Kapital - eine Analyse anhand österreichischer Universitäten, 9th Workshop der Kommission „Hochschulmanagement“ im Verband der Hochschullehrer für Betriebswirtschaft e.V. (VHB), Münster 2007.

Arbeitskreis „Sozialbilanz-Praxis“, Sozialbilanz heute, Empfehlungen des Arbeitskreises „Sozialbilanz Praxis“, 1977.

Aristoteles, Nikomachische Ethik, übersetzt mit Nachwort von Franz Dirlmeier, Stuttgart 1997.

Aßländer, Michael S. / Curbach, Janina, The Corporation as Citoyen? Towards a New Understanding of Corporate Citizenship, in: Journal of Business Ethics 120/4/2014, S. 541-554.

Axelrod, Robert, The Evolution of Cooperation, Cambridge 1984.

Baumüller, Josef / Schaffhauser-Linzatti, Michaela, Nichtfinanzielle Erklärung oder nichtfinanzieller Bericht? Abwägungen zur Ausübung des Wahlrechts in \$243b Abs 6 UGB, in: CFO aktuell 102/3/2017, S. 102.

Bernaz, Nadia, Enhancing Corporate Accountability for Human Rights Violations: Is Extraterritoriality the Magic Potion?, in: Journal of Business Ethics 117/2012, S. 493511.

Böckenförde, Ernst-Wolfgang, Der säkularisierte Staat. Sein Charakter, seine Rechtfertigung und seine Probleme im 21. Jahrhundert, Themenband 86 der Carl Friedrich von Siemens Stiftung, Carl Friedrich von Siemensstiftung, München 2007. 
Bogdandy, Armin von, Globalization and Europe: How to Square Democracy, Globalization and International Law, in: European Journal of International Law 15/2004, S. 885906.

Brown, Tom J. / Dacin, Peter A., The Company and the Product: Corporate Associations and Consumer Product Responses, in: Journal of Marketing 61/1/1997, S. 68-84.

Bundesgesetz über die Organisation der Universitäten und ihre Studien (Universitätsgesetz 2002 - UG) StF: BGBl. I Nr. 120/2002 idF BGBl. I Nr. 3/2019.

Choi, Sungchul / Ng, Alex, Environmental and Economic Dimensions of Sustainability and Price Effects on Consumer Responses, in: Journal of Business Ethics 104/2/2011, S. 269-282.

Conrad, Christian A., Wirtschaftsethik: Eine Voraussetzung für Produktivität, Wiesbaden 2016.

CSR Guide, Jahrbuch für unternehmerische Verantwortung, Wien 2016.

Dierkes, Meinolf / Marz, Lutz / Berthoin, Antal Ariane, Sozialbilanzen: Konzeptioneller Kern und diskursive Karriere einer zivilgesellschaftlichen Innovation, in: WZB Discussion Paper, Leibniz 2002.

Dierkes, Meinolf, Die Sozialbilanz, Ein gesellschaftsbezogenes Informations- und Rechnungslegungssystem, Frankfurt-New York 1974.

Drucker, Peter, Die postkapitalistische Gesellschaft, Düsseldorf 1993.

Edvinsson, Leif / Brünig, Gisela, Aktivposten Wissenskapital, Unsichtbare Werte bilanzierbar machen, Wiesbaden 2000.

Edvinsson, Leif / Malone, Michael S., Intellectual capital. Realizing your company's true value by finding its hidden brainpower, New York 1997.

Enderle, Georges, Exploring and Conceptualizing International Business Ethics, in: Journal of Business Ethics 127/4/2014, S. 723-735.

Ernst \& Young, Jetzt geht's ums Ganze. Was Sie schon heute über Integrated Reporting wissen sollten. Broschüre 2012, vgl. http://www.ey.com/Publication/vwLUAssets/Bro schuere_-_Jetzt_gehts_ums_Ganze/\$FILE/Brosch_IntegrReportg.pdf (letzter Zugriff: 17.06.2019).

Eucken, Walter, Grundsätze der Wirtschaftspolitik, Zürich 1952.

Felber, Christian, Die Gemeinwohl-Ökonomie, erw. 6. Aufl., Frankfurt a. M. 2012.

Felber, Christian, Neue Werte für die Wirtschaft: Eine Alternative zu Kommunismus und Kapitalismus, 4. Aufl., Wien 2008.

Fichter, Klaus, Wettbewerbsvorteile durch freiwillige Umweltberichterstattung, in: Ökologisches Wirtschaften, Ergebnisse einer IÖW-Untersuchung für das hessische Wirtschaftsministerium 1/1998, S. 7-9.

Flamholtz, Eric G., A Model for Human Resource Valuation. A Stochastic Process with Service Rewards, in: The Accounting Review 46.2/1971, S. 253-267.

Förster, Michael F., Einkommensverteilung und Armut im OECD-Raum, in: Dimensions of Inequality in the EU (Dimensionen der Ungleichheit in der EU), Workshops Proceedings of OeNB Workshops 16, Österreichische Nationalbank Eurosystem, 2008.

Franziskus, Laudato si', Vatikan 2015, vgl. http://w2.vatican.va/content/francesco/de/ency clicals/documents/papa-francesco_20150524_enciclica-laudato-si.html (letzter Zugriff: 25.06.2019).

Friedman, Milton, Capitalism and Freedom, in: 40th anniversary edition Chicago, Chicago-London 2002. 
G4 Sustainability Reporting Guidelines der Global Reporting Initiative (G4), 2016.

Gabriel, Alexander, Normative Grundlagen der freiwilligen Veröffentlichung und Prüfung von Nachhaltigkeitsberichten, Eine empirische Analyse auf dem europäischen Kapitalmarkt, Wiesbaden 2015.

Gabriel, Ingeborg, Libertäre Tea Party statt katholischer Soziallehre?, in: Die Tagespost, klarer Kurs, katholischer Journalismus, Kolumne am 13.09.2018.

Gabriel, Ingeborg, Das tägliche Brot für alle, Welternährung als Gerechtigkeitsfrage der Gegenwart, in: Communio. Internationale Katholische Zeitschrift 46/2017, S. 52-65.

Gabriel, Ingeborg / Kirchschläger, Peter G. / Sturn, Richard (Hg.), Eine Wirtschaft die Leben fördert, Wirtschafts- und unternehmensethische Reflexionen im Anschluss an Papst Franziskus, Ostfildern 2017.

Gabriel, Ingeborg, Wohlstand für alle durch Marktwirtschaft? Eine Antwort auf Martin Rhonheimer, in: Zeitschrift für soziales und wirtschaftliches Engagement, Gesellschaft und Politik 53/1/2017: Wohlstand für alle durch Marktwirtschaft - Illusion oder Wirklichkeit?, hrsg. v. Helmut Kukacka u. Alexander Rauner, S. 39-43.

Gilbert, Dirk Ulrich / Rasche, Andreas, Discourse Ethics and Social Accountability, The Ethics of SA 8000, in: Business Ethics Quarterly 17.2/2007, S. 187-216.

Göbel, Elisabeth, Unternehmensethik, 3. Aufl., Trier 2013.

Hekimian, James S. / Jones, Curtis H., Put people on your balance sheet, in: Harvard business review (HBR) 45.1/1967, S. 105-113.

Held, Martin / Kubon-Gilke, Gisela / Sturn, Richard (Hg.), Unsere Institutionen in Zeiten der Krise, Jahrbuch Normative und institutionelle Grundfragen der Ökonomik 13, Marburg 2014.

Hermanson, Roger H., Accounting for Human Assets. Bureau of Business and Economic Research, Graduate School of Business Administration, Occasional Paper 14/1964, S. 1-69.

Homann, Karl, Die [Relevanz] der Ökonomik für die Implementation ethischer Zielsetzungen, in: Wilhelm Korff (Hg.), Handbuch der Wirtschaftsethik 1: Verhältnisbestimmung von Wirtschaft und Ethik, Gütersloh 1999, S. 322-343.

IASCF, Constitution, revised and approved by the Trustees January 2013, International Financial Accounting Committee Foundation, 2013.

Institut National de la Statisique et des Etudes Economiques (INSEE), Systeme elargi de comptabilite nationale, Les collections de l'INSEE, 198-199, ser. C/1976, S. 44-45.

International Integrated Reporting Council (IIRC), 2016.

Jaggi, Bikki / Lau, Hon-Shiang, Toward a Model for Human Resource Valuation, in: The Accounting Review 49.2/1974, S. 321-329.

Jaijairam, Paul, Ethics in Accounting, in: Journal of Finance and Accountancy 23, Bronx Community College, New York 2017.

Kerber, Walter, Sozialethik, Grundkurs Philosophie 13, Stuttgart-Berlin 1998.

Kirchschläger, Peter G. / Schaffhauser-Linzatti, Michaela, Challenges of Extra-Financial Information in Respect to Sustainability, in: 12th Interdisciplinary Workshop on Intangibles, Intellectual Capital and Extra Financial Information, Sankt Petersburg 2016.

Kongregation für die Glaubenslehre, Dikasterium für den Dienst zugunsten der ganzheitlichen Entwicklung des Menschen, Oeconomicae et pecuniariae quaestiones, Erwägungen zu einer ethischen Unterscheidung bezüglich einiger Aspekte des gegenwärtigen Finanzwirtschaftssystems, Vatikan 2018. 
Kupsch, Peter Uwe / Marr, Rainer / Picot, Arnold, Innovationswirtschaft, in: Edmund Heinen, Industriebetriebslehre, Entscheidungen im Industriebetrieb, 9. Aufl., Heidelberg 1991, S. 1069-1156.

Le Goff, Jacques, Wucherzins und Höllenqualen: Ökonomie und Religion im Mittelalter, 2. Aufl., Stuttgart 2008.

Leitner, Karl-Heinz / Sammer, Martin / Grabbober, Marion / Schartinger, Doris / Zielowski, Christian, Wissensbilanzierung für Universitäten, Auftragsprojekt für das bm:bwk. Sektion VII, Sektion VIII Seibersdorf 2001.

Linowes, David F., Measuring Social Programs in Business, New York 1972.

Martens, Hans-Jürgen, Zur Einführung der Sozialbilanz in Frankreich, in: Zeitschrift für Unternehmens- und Gesellschaftsrecht 8.3/1979, S. 387-391.

Meinberg, Eckhard, Homo Oeconomicus, Das neue Menschenbild im Zeichen der ökologischen Krise, Darmstadt 1995.

Milne, Markus J. / Gray, Rob, W(h)ither Ecology? The Triple Bottom Line, the Global Reporting Initiative, and Corporate Sustainability Reporting, in: Journal of Business Ethics 118.1/2013, S. 13-29.

Morsing, Mette / Schultz, Majken, Corporate social responsibility communication: stakeholder information, response and involvement strategies, in: Business Ethics: A European Review 15/4/2006, S. 323-338.

Müller-Arnack, Alfred, Wirtschaftsordnung und Wirtschaftspolitik, Studien und Konzepte zur Sozialen Marktwirtschaft und zur Europäischen Integration, Bern 1976.

Münch, Philip Alexander, Die globale Finanzkrise als Kumulation von Dilemmastrukturen, Plädoyer für eine Ethik mit ökonomischer Methode, Peter Löscher-Stiftungslehrstuhl für Wirtschaftsethik, Technische Universität München, München 2012.

Neumann, John von / Morgenstern, Oskar, Theory of Games and Economic Behavior, Princeton, NJ 1944.

Palenberg, Markus / Reinicke, Wolfgang / Witte, Jan Martin, Trends in non-financial reporting, Paper prepared for the United Nations Environment Programme, Division of Technology, Industry and Ecnomomics (DTIE), global public policy institute (GPPi), Berlin 2006.

Perrini, Francesco / Tencati, Antonio, Sustainability and Stakeholder Management: the Need for New Corporate Performance Evaluation and Reporting Systems, in: Business Strategy and Environment 15/2006, S. 296-308.

Pfaff, Tobias, Das „Bruttonationalglück“ als Leitlinie der Politik in Bhutan - eine ordnungspolitische Analyse, in: ORDO, Jahrbuch für die Ordnung von Wirtschaft und Gesellschaft 62/2011, S. 365-385.

Pieper, Annemarie, Einführung in die Ethik, 6. Aufl., Basel 2007.

Pieroth, Elmar, Sozialbilanzen in der Bundesrepublik Deutschland, Düsseldorf-Wien 1978.

Polanyi, Karl, Aristotle Discovers the Economy, in: George Dalton (Hg.), Primitive, Archaic and Modern Economies, Essays of Karl Polanyi, New York 1968.

Powelson John P., Social Accounting, in: The Accounting Review 30.4/1955, S. 651-659.

Riegler, Josef, Antworten für die Zukunft. Ökosoziale Marktwirtschaft. Politische Akademie der Österreichischen Volkspartei, Wien 1990.

Roos, Johan / Roos, Goran / Dragonetti, Nicola Carlo / Edvinsson, Leif, Intellectual Capital. Navigating the New Business Landscape, New York 1997. 
Roslender, Robin, Accounting for Human Resources Revisited, Insights from the Intellectual Capital Field, in: Magdy G. Abdel-Kader (Hg.), Review of Management Accounting Research, London 2011, S. 85-110.

Schaffhauser-Linzatti, Michaela, Rechnungswesen Schritt für Schritt, 4. Aufl., Wien 2019. Schaffhauser-Linzatti, Michaela / Kirchschläger, Peter G., Sustainability and ethics in financial reporting: an empirical study of German, Austrian, and Swiss groups, in: Adam Lindgreen / Christine Vallaster / Shumaila Yousafzai / Bernhard Hirsch (Hg.), Measuring and Controlling Sustainability: Spanning Theory, London-New York 2018, S. 269-283.

Schaffhauser-Linzatti, Michaela, Welchen Beitrag kann die unternehmerische Rechnungslegung zu einer Ethik der Nachhaltigkeit leisten?, in: Ingeborg Gabriel / Peter G. Kirchschläger / Richard Sturn (Hg.), Eine Wirtschaft, die Leben fördert, Ostfildern 2017, S. 319-336.

Schaffhauser-Linzatti, Michaela, Bilden die traditionelle Rechnungslegung oder alternative Bilanzen Gemeinwohl und Glück ab?, Vortrag im Rahmen der Konferenz „Wirtschaft - Gemeinwohl - Glück. Interdisziplinäre Zugänge zur Wirtschaftsethik“, 9.-11. April 2015, Universität Wien, vgl. https://se-ktf.univie.ac.at/veranstaltungen/ta gung-wirtschaft-gemeinwohl-glueck/ (letzter Zugriff: 25.07.2019).

Schaffhauser-Linzatti, Michaela / Kirchschläger, Peter G., Ethik in Integrated Reports, Transparente Kommunikation von Corporate Social Responsibility und Nachhaltigkeit-Aktivitäten von Unternehmen, in: Linard Nadig / Ulrich Egle (Hg.), CARF Luzern 2016 Controlling. Accounting. Risiko. Finanzen, IFZ - Hochschule Luzern, Luzern 2016, S. 263-282.

Schaffhauser-Linzatti, Michaela, Die Wissensbilanz als Innovatives Managementinstrument im öffentlichen Bereich, Aktuelle Entwicklungen der Wissensbilanzierung als Controllinginstrument in öffentlichen Verwaltungen, insbesondere im Hochschulwesen an der Johannes Kepler Universität Linz, Wien 2010.

Schaffhauser-Linzatti, Michaela, Wissensbilanzierung als Instrument der Unternehmensbewertung, Jahresforum 2004, Wien 2004.

Schaffhauser-Linzatti, Michaela / Moritsch, Hans, Human Resource Accounting, A Real Options Approach, working paper, 2003.

Schulte, Heinz, Die Sozialbilanz der STEAG Aktiengesellschaft, in: Betriebswirtschaftliche Forschung und Praxis 26.4/1974, S. 277-294.

Seers Dudley, Social Accounting, in: Economic Record - The Economic Society of Australia 22.1/1946, S. 117-132.

Sieber, Tom / Weißenberger, Barbara E. / Oberdörster, Tatjana / Baetge, Jörg, Let's talk strategy: the impact of voluntary strategy disclosure on the cost of equity capital, in: Business Research 7/2014, S. 263-312.

Smith, Adam, Der Wohlstand der Nationen: Eine Untersuchung seiner Natur und seiner Ursachen, 8.Aufl., München 1999.

Smith, Adam, The Theory of Moral Sentiments, Düsseldorf 1759.

Social Accountability Accreditation Service (SAAS), vgl. http://www.saasaccreditation. org/ (letzter Zugriff: 17.06.2019).

Srnka, Katharina J., Marketing. Ethik \& Kultur, Wirtschafts- und Unternehmensethik 12, München 2005.

Steinman, Jim / Kunze Michael, Tanz der Vampire, Die unstillbare Gier, Musical, 1997. 
Stewart, Thomas A., Der vierte Produktionsfaktor, Wachstum und Wettbewerbsvorteile durch Wissensmanagement, München 1998.

Stone, Richard, The Accounts of Society, in: Nobel Memorial Lecture, Journal of Applied Econometrics 1986, S. 5-28.

Sveiby, Karl Erik, The Intangible Assets Monitor, vgl. https:/www.sveiby.com/files/pdf/ the-intangible-assets-monitor.pdf (letzter Zugriff: 17.06.2019).

Szejnwald Brown, Halina / de Jong, Martin / Levy, David L., Building institutions based on information disclosure: lessons from GRI's sustainability reporting, in: Journal of Cleaner Production 17/2009, S. 571-580.

Vallentin, Steen, Pensionsinvestering, etik og offentlighed: en systemteoretisk analyse af offentlig meningsdannelse, Samfungslitteratur, København 2001.

Veltri, Stefania / Mastroleo, Giovanni / Schaffhauser-Linzatti, Michaela, The Development of a Corporate Intellectual Capital Index in the Austrian University Sector Using a Fuzzy Logic Approach, 5th European Institute for Advanced Studies in Management (EIASM), Workshop on Visualizing, Measuring, and Managing Intangibles \& Intellectual Capital, 2009.

Vogl, Joseph, Das Gespenst des Kapitals (minima oeconomica), 3. Aufl., Zürich 2010.

Weber, Max, Soziologische Grundbegriffe, 6. Aufl., Tübingen 1984.

Wettstein, Florian, Waiting for the Mountain to Move: The Role of Multinational Corporations in the Quest for Global Justice, in: notizie di POLITEIA XXIX 111/2013, S. 13-21.

Wiemeyer, Joachim, Unternehmensethik aus christlich-sozialethischer Sicht, in: Katholische Sozialwissenschaftliche Zentralstelle (Hg.), Kirche und Gesellschaft 403/2013.

Zadeh, Lofti A., Fuzzy Sets, Information and Control Department of Electrical Engineering and Electronics Research Laboratory 8, Berkeley 1965. 


\section{Bernhard Leubolt (Wien) / Magdalena Holztrattner (Wien) / Markus Schlagnitweit (Wien)}

\section{Zur Erneuerung des Sozialstaats: Soziale Innovation und katholische Soziallehre}

\section{Einleitung}

Seit vielen Jahren identifizieren zahlreiche prominente BeobachterInnen Krisenerscheinungen des Sozialstaats. Nach der Expansion zwischen den 1950er und 1970er Jahren wurde vielerorts „Erschöpfung“, „Bürokratisierung“, „Überhitzung“ und ähnliches diagnostiziert. Der konservative Autor Murray ${ }^{1}$ ging in seiner Kritik so weit, den bürokratischen Wohlfahrtsstaat für die Entstehung der Unterschicht („underclass“) verantwortlich zu machen. Durch bürokratische Gängelung und fehlende Anreize würden Menschen dem Arbeitsmarkt ferngehalten und zu Abhängigen des Wohlfahrtsstaats. Linke KritikerInnen $^{2}$ stellten auf die Stabilisierung des Staats im krisengeschüttelten Kapitalismus mittels wohlfahrtsstaatlicher, bürokratisch gesteuerter Interventionen ab. Feministische KritikerInnen ${ }^{3}$ diagnostizierten eine Dominanz des Modells des „männlichen Familienernährers“, durch die auch Wohlfahrtsstaaten die Ungleichheiten zwischen den Geschlechtern reproduzierten.

Trotz deutlicher regionaler Unterschiede ${ }^{4}$ zeigt sich seit den 1980er bzw. 1990er Jahren ein Trend in Richtung neoliberaler Reformen des Wohlfahrtsstaats: Eine weitere Expansion wurde weitgehend gestoppt. Stattdessen wurden manche Leistungen wieder privatisiert und andere umstrukturiert. ${ }^{5}$ „Aktivierende Sozialpolitik“ wurde zu einem wichtigen Schlagwort. ${ }^{6}$ Menschen sollten nicht mehr primär „versorgt“, sondern stattdessen vordergründig „aktiviert“

1 Charles Murray, Losing Ground: American Social Policy, 1950-1980, New York 1984.

2 Z.B. Claus Offe, Contradictions of the Welfare State, London 1984.

3 Z.B. Jane Lewis, Gender and the Development of Welfare Regimes, in: Journal of European Social Policy 2/3/1992, S. 159-173.

4 Vgl. Stephen Haggard / Robert R. Kaufman, Development, Democracy, and Welfare States: Latin America, East Asia, and Eastern Europe, Princeton-Oxford 2008.

5 Francis G. Castles, The Disappearing State? Retrenchment Realities in an Age of Globalisation, Cheltenham 2007.

6 Stephan Lessenich, Die Neuerfindung des Sozialen: Der Sozialstaat im flexiblen Kapitalismus, Bielefeld 2008. 
werden, um möglichst dauerhaft mittels Erwerbsarbeit ihren Lebensunterhalt individuell und ohne Rückgriff auf die Solidargemeinschaft bestreiten zu können. ${ }^{7}$ Die Finanzkrise ab 2007/08 und der damit verbundene sprunghafte Anstieg der Staatsverschuldung zur Begleichung von Krisenverlusten ${ }^{8}$ führten im Zuge der darauf folgenden „Sparpolitik“ dazu, dass Sozialausgaben weiter reduziert wurden oder reduziert werden sollen.

Vor diesem Hintergrund wurde „soziale Innovation“ in den letzten Jahren zu einem wichtigen Schlagwort. ${ }^{9}$ Gemeint sind damit zumeist soziale Unternehmen bzw. engagierte BürgerInnen, die angesichts drückender sozialer Forderungen und Prozessen sozialen Zusammenlebens neue Lösungen für Probleme finden, die der Staat nicht lösen konnte. Die Europäische Kommission propagiert das Konzept besonders für Wohlfahrtsstaaten in finanziellen Nöten, aber auch darüber hinaus.

Dieser Beitrag gibt eine Einführung und beschäftigt sich mit den Möglichkeiten und Grenzen sozialer Innovation zur Förderung sozialer Gerechtigkeit. Abschließend diskutieren wir das Konzept der sozialstaatlichen Erneuerung unter Maßgabe von Grundsätzen der katholischen Soziallehre. Ähnlich wie beim Umgang mit dieser zeigen sich auch im Hinblick auf soziale Innovation Ambivalenzen. Neben einigen kritischen Aspekten geben viele Projekte sozialer Innovation auch Hoffnung, dass eine solidarische und gemeinwohlorientierte Erneuerung des Wohlfahrtsstaats möglich und machbar ist.

\section{Soziale Innovation als offenes „Quasi-Konzept“}

Inspiriert vom österreichischen Ökonomen Joseph Schumpeter ${ }^{10}$ und dem renommierten Management-Denker Peter Drucker ${ }^{11}$ wurde Innovation seit den 1980er Jahren als wichtiges Konzept wiederentdeckt, um der wirtschaftlichen Krise erfolgreich begegnen zu können. Der wirtschaftliche Übergang von der Fließbandproduktion zu deutlich flexibleren Technologien und der neue Fokus

7 Margit Appel, Von sozialen Rechten zur Sozialinvestition? Sozialstaat im Umbau, in: ksoe blog, 2019, vgl. https://blog.ksoe.at/von-sozialen-rechten-zur-sozialinvestition-sozialstaatim-umbau/ (letzter Zugriff: 21.06.2019).

8 Wolfgang Streeck, Gekaufte Zeit: Die vertagte Krise des demokratischen Kapitalismus, Frankfurt 2013.

9 Katharina Meichenitsch / Michaela Neumayr / Martin Schenk (Hg.), Neu! Besser! Billiger! Soziale Innovation als leeres Versprechen, Wien 2016.

10 Joseph Schumpeter, Theorie der wirtschaftlichen Entwicklung. Eine Untersuchung über Unternehmergewinn, Kapital, Kredit, Zins und den Konjunkturzyklus, München-Leipzig 1931.

11 Peter Drucker, Innovation and Entrepreneurship, New York 1985. 
auf Entrepreneurship ${ }^{12}$ machten Innovationen noch wichtiger, um am globalisierten Weltmarkt bestehen zu können. In diesem Kontext etablierte sich ein spezielles Konzept der Innovation: Soziale Innovation wurde quasi eine Art komplementärer Gegenpart zur ,Business-Innovation'. Unter geschichtlicher Betrachtung bis mindestens ins 19. Jahrhundert zurückreichend ${ }^{13}$, wurde soziale Innovation seit den 1990er Jahren zu einem zunehmend bedeutsamen Konzept. ${ }^{14}$

Soziale Innovation betont die soziale Seite von Innovation. VerfechterInnen in Wissenschaft und Politik konnten sich bisher nicht auf eine trennscharfe Definition einigen, sondern hielten das Konzept bisher sehr offen. Die einflussreiche britische Young Foundation geht beispielsweise davon aus, dass

„soziale Innovation keine Grenzen hat: Sie geschieht in allen Sektoren, öffentlich, non-profit und privat. Die kreativsten Taten geschehen an den Grenzen der Sektoren, in so unterschiedlichen Feldern wie Fair Trade, Fern-Bildung, Hospize, urbane Landwirtschaft, Abfallreduktion und Vergangenheitsbewältigung“. ${ }^{15}$

Auch die EU-Kommission hat keine trennscharfe Definition, sondern sieht soziale Innovation als

„Entwicklung und Einführung neuer Ideen (Produkte, Dienstleistungen und Modelle), um soziale Bedürfnisse zu befriedigen und neue soziale Beziehungen und Kooperationen zu kreieren. Soziale Innovation steht für neue Antworten auf drückende soziale Forderungen, die den Prozess sozialen Zusammenlebens beeinflussen. Sie zielt ab auf verbesserte gesellschaftliche Wohlfahrt. Soziale Innovationen sind sozial sowohl in ihren Zielsetzungen als auch in ihren Mitteln. Es sind Innovationen, die nicht nur gut für die Gesellschaft sind, sondern auch die individuelle Handlungsfähigkeit verbessern. “16

Auch das stärker wissenschaftlich orientierte „International Handbook on Social Innovation “17 bietet keine trennscharfe und vereinheitlichende Defini-

12 Klaus Dörre / Bernd Röttger (Hg.), Das neue Marktregime: Konturen eines nachfordistischen Produktionsmodells, Hamburg 2003.

13 Frank Moulaert / Abid Mehmoud / Diana MacCallum / Bernhard Leubolt, Social Innovation as a Trigger for Transformations; The Role of Research, Policy Review for EC, Brussels 2017, vgl. https://ec.europa.eu/research/social-sciences/pdf/policy_reviews/social_innovation_ trigger_for_transformations.pdf, S. 16f. (letzter Zugriff: 06.06.2019).

14 Frank Moulaert / Diana MacCallum, Advanced Introduction to Social Innovation, Cheltenham 2019.

15 Robin Murray / Julie Caulier-Grice / Geoff Mulgan, The Open Book of Social Innovation, London 2010,vgl.https://media.nesta.org.uk/documents/the_open_book_of_social_innova tion.pdf, S. 3 (letzter Zugriff: 06.06.2019).

16 European Commission, Guide to Social Innovation. Brussels 2013, vgl. https://publications. europa.eu/en/publication-detail/-/publication/12d044fe-617a-4131-93c2-5e0a951a095c, S. 6 (letzter Zugriff: 06.06.2019).

17 Frank Moulaert / Diana MacCallum / Abid Mehmood / Abdelillah Hamdouch (Hg.), The International Handbook on Social Innovation: Collective Action, Social Learning and Transdisciplinary Research, Cheltenham 2013. 
tion an, sondern betont vielmehr die Vielgestaltigkeit des Konzeptes und seiner Anwendungsbereiche in zivilgesellschaftlichen Tätigkeiten, Politik, sozialen Bewegungen und Protesten sowie in philosophischen, ethischen und sozialwissenschaftlichen Debatten. Für das 20. Jahrhundert heben Moulaert, MacCallum und Hillier vor allem die Bedeutung der sozialen Proteste im Europa der späten 1960er Jahre hervor, in denen soziale Innovation zu einem wichtigen Schlagwort wurde. In dieser Zeit ging es vordergründig um die soziale Erneuerung des bürokratischen Wohlfahrtsstaats und gesellschaftlicher Verhältnisse. ${ }^{18}$ Diese Impulse bereicherten dann in den 1980er und 1990er Jahren Strategien von Stadt- und Regionalentwicklung - besonders im Kontext von Restrukturierungen im Zuge der De-Industrialisierung von Städten. Im Verlauf der 2000er Jahre fand die Idee dann auch Einzug in neoliberale Überlegungen zur Umstrukturierung des Wohlfahrtsstaats. ${ }^{19}$

Moulaert u. a. betonen im Vergleich zur Europäischen Kommission und der Young Foundation stärker die Zusammenarbeit von Zivilgesellschaft und Staat und den Faktor des „Empowerment" von bis dahin benachteiligten Gruppen. Ihnen zu Folge hat gelungene soziale Innovation stets drei Dimensionen ${ }^{20}$ :

- Inhaltliche Dimension: Befriedigung menschlicher Bedürfnisse, die aktuell von Markt und Staat entweder noch nicht oder nicht mehr als wichtig betrachtet werden.

- Prozess-Dimension: Veränderung sozialer Beziehungen zur Förderung von Partizipation, vor allem von benachteiligten Bevölkerungsgruppen.

- Empowerment-Dimension: Verbesserung der sozialen und politischen Fähigkeiten und des Zugangs zu Ressourcen, um Rechte auf Bedürfnis-Befriedigung und Partizipation geltend machen zu können. Empowerment ist demnach zugleich Verbindung und Erweiterung von inhaltlicher und Prozess-Dimension.

Das Team um Frank Moulaert betont besonders den ermöglichenden Aspekt der sozialen Innovation. Die wichtige Gemeinsamkeit mit dem Zugang der Europäischen Kommission besteht in der Betonung der Bedeutung neuer Wege der Zusammenarbeit von staatlichen und nicht-staatlichen AkteurInnen (Zivilgesellschaft und Unternehmen).

18 Frank Moulaert / Diana MacCallum / Jean Hillier, Social innovation: intuition, precept, concept, theory and practice, in: Moulaert / MacCallum / Mehmood / Hamdouch (Hg.), International Handbook, S. 13-24.

19 Moulaert / Mehmoud / MacCallum / Leubolt, Social Innovation, S. $18 \mathrm{ff}$.

20 Frank Moulaert / Flavia Martinelli / Erik Swyngedouw / Sara González, Towards Alternative Model(s) of Local Innovation, in: Urban Studies 42/11/2005, S. 1969-1990. 


\section{Ambivalenzen sozialer Innovation}

Die Interpretation dieses erneuerten Zusammenspiels von Staat, Zivilgesellschaft und Unternehmen ist ebenso wenig einheitlich wie die Definition sozialer Innovation. Das auf EU-Ebene sehr einflussreiche Bureau of European Policy Advisors sieht es z.B. „im aktuellen ökonomischen Klima als notwendig an, Mehr mit Weniger zu tun und es besser zu tun “21. In dieser Lesart ist soziale Innovation eine „ideale“ Antwort auf die aktuellen Erfordernisse der vorherrschenden Austeritätspolitik: Zivilgesellschaft oder Unternehmen übernähmen vormals staatliche Aufgaben deutlich unbürokratischer und sorgten damit für einen verbesserten Wohlfahrtsstaat trotz Sparpolitik - so die These.

Diese Sichtweise auf Reformen des Sozialstaats ist nicht neu. Schon für das Österreich der 2000er Jahre gab es entsprechende Ideen der Etablierung einer „Bürgergesellschaft“. Margit Appel, Luise Gubitzer und Birgit Sauer ${ }^{22}$ zeigten indes schon damals auf, dass die aktivere Beteiligung von BürgerInnen zwar mit großen Potenzialen verbunden ist, gleichzeitig aber auch Kehrseiten hat: So führe der Ausbau ehrenamtlicher Tätigkeiten oft zur Verdrängung von Frauen aus dem bezahlten Arbeitsmarkt in den Bereich unbezahlter Tätigkeiten. Während bürokratische Regelungen im Wohlfahrtsstaat oftmals zu rigide wären, erwiesen sich manche der privaten Dienstleistungen als intransparent und untergrüben soziale Rechte. Erik Swyngedouw ${ }^{23}$ kam in seiner Analyse von „Governance jenseits des Staats“ zu ähnlich kritischen Erkenntnissen und betonte die „Janus-Köpfigkeit“, d.h., dass den positiven Potenzialen viele Gefahren gegenüber ständen. Guy Peters und Jon Pierre diagnostizierten einen „Faust'schen Handel $^{\text {“24 }}$ : Effizienz werde in vielen neuen Arrangements auf Kosten demokratischer Legitimität und Nachvollziehbarkeit (Accountability) gewonnen.

Auch aktuelle Forschungsergebnisse bestätigen, dass der Versuch einer aktiveren Einbeziehung der Zivilgesellschaft Kehrseiten hat: Besonders ambitioniert war diesbezüglich die „Big Society“-Initiative in Großbritannien. Forschungsarbeiten zu den Auswirkungen auf ehrenamtliches Engagement ${ }^{25}$ sowie

21 Bureau of European Policy Advisors, Social Innovation: A Decade of Changes, Brussels 2014, vgl. http://espas.eu/orbis/sites/default/files/generated/document/en/social_innovation_de cade_of_changes.pdf (letzter Zugriff: 06.06.2019).

22 Margit Appel / Luise Gubitzer / Birgit Sauer (Hg.), Zivilgesellschaft - ein Konzept für Frauen?, Frankfurt 2013.

23 Erik Swyngedouw, Governance Innovation and the Citizen. The Janus Face of Governance-beyond-the-state, in: Urban Studies 42/11/2005, S. 1991-2006.

24 Guy Peters / Jon Pierre, Multi-level Governance and Democracy. A Faustian Bargain?, in: Ian Bache / Matthew Flinders (Hg.), Multi-level Governance, Oxford 2004, S. 75-89.

25 Annette Zimmer / Benedikt Pahl, TSI Comparative Report. Learning from Europe, Third Sector Impact: Comparative report 1/2016, vgl. http://thirdsectorimpact.eu/site/assets/uplo 
soziale Innovation ${ }^{26}$ zeigten sogar auf, dass der Versuch, zivilgesellschaftliches Engagement politisch zu fördern, in der Praxis das Gegenteil bewirken kann. Wenn die Durchführung sozialer Dienstleistungen ausgeschrieben wird, kann die Konkurrenz durch private Profit-orientierte Unternehmen dazu führen, dass nicht-gewinn-orientierte Organisationen (NGOs) und ehrenamtliche Vereine und Organisationen ins Hintertreffen geraten. NGOs und Ehrenamtliche operieren oft mit höheren Standards und sind weniger auf die Erfordernisse öffentlicher Ausschreibungen eingerichtet als Profit-orientierte Unternehmen. Diese kritischen Erkenntnisse sind besonders wichtig, wenn es um den Umgang mit „Social Entrepreneurship“ geht, der oftmals als vielversprechender neuer Ansatz sozialer Innovationen gesehen wird. ${ }^{27}$

Trotz vielfältiger Kritik gibt es auch die andere Seite des „Janus-Kopfes“ sozialer Innovation - besonders dann, wenn die drei Dimensionen Inhalt, Prozess und Empowerment verwirklicht werden können. Unzählige Beispiele zeigen, dass die aktive Beteiligung benachteiligter Gruppen einen deutlich größeren Wohlfahrtseffekt hat, als die bloße Bedürfnisbefriedigung. ${ }^{28}$ Für die positiven Wirkungen stellte sich als wichtig heraus, dass eine dynamische Balance zwischen zivilgesellschaftlichen „bottom-up“- und staatlichen „top-down“-Prozessen gefunden wurde. ${ }^{29}$ Öffnende und demokratische Aspekte von „bottom-up“-Initiativen konnten so mit den Vorzügen staatlicher „top-down“-Vorgehensweisen kombiniert werden. Bei guter Balance wurden solche Prozesse als „bottom-linked“ beschrieben. ${ }^{30}$ Sie offenbarten sich in sehr unterschiedlichen Bereichen wie z. B. Solidarökonomie, Initiativen zur Weiterbildung, Beschäftigungsprojekten, Integration von MigrantInnen und Minderheiten, partizipati-

ads/documentations/comparative-report-learning-europe/TSI-comparative-report-No.-1. pdf (letzter Zugriff: 06.06.2016).

26 Pieter Cools, Looking for a Mutually Supporting Relationship between Local Social Innovation and Welfare Reform. The Case of Re-use Non-profits in the UK, in: Journal für Entwicklungspolitik 33/2/2017, S. 13-35.

27 Jürgen Howaldt / Christoph Kaletka / Antonius Schröder, Social Entrepreneurs: Important Actors within an Ecosystem of Social Innovation, in: European Public \& Social Innovation Review 1/2/2016, S. 95-110.

28 Vgl. z. B. die Case Studies des FP7-Forschungsprojekts, ImPRovE', vgl. http://improve-rese arch.eu/?page_id=2507 (letzter Zugriff: 06.06.2019).

29 Flavia Martinelli, Learning from case studies of social innovation in the field of social services: creatively balancing top-down universalism with bottom up democracy, in: Moulaert / MacCallum / Mehmood / Hamdouch (Hg.), International Handbook, S. 346-360.

30 Marisol Garcia / Marc Pradel / Santiago Eizaguierre, Theorizing multi-level governance in social innovation dynamics, in: Moulaert / MacCallum / Mehmood / Hamdouch (Hg.), International Handbook, S. 155-168. 
ver Stadtplanung, gemeinschaftlichen Wohnprojekten, Kulturprojekten, Initiativen eines Grundeinkommens oder auch partizipativer Budgeterstellung ${ }^{31}$.

In den letzten Jahren erlangten soziale Innovationen größere Bedeutung, die sich mit der Verwirklichung ganzheitlicher Nachhaltigkeit (sozial, ökonomisch und ökologisch) auseinandersetzen. ${ }^{32}$ Im Folgenden will ein exemplarischer Fall einer sozialen Innovation aus Brasilien die Potenziale, aber auch die Ambivalenzen sozialer Innovation verdeutlichen:

\section{Recycling von verwertbarem Material als Beitrag zur sozial-ökologischen Transformation}

In Brasilien entstanden zwischen den späten 1980er und den 2010er Jahren einige soziale Innovationen. Besonders prominent wurde international die partizipative Budgeterstellung in Porto Alegre ${ }^{33}$ - ein Modell, das als Prototyp für „bottom-linked governance“ dienen könnte. Während der Zeit der Demokratisierung in den 1980er Jahren wurden auch für andere wichtige Beispiele sozialer Innovation die Grundsteine gelegt.

Ein solches Beispiel sind die SammlerInnen von verwertbarem Material. ${ }^{34}$ In Brasilien wird diese Tätigkeit seit vielen Jahre von Obdachlosen und anderen sozial benachteiligten Menschen verrichtet. Sie sammeln das recyclingfähige Material von der Straße auf und verkaufen es dann gesammelt an ZwischenhändlerInnen. Sie verrichten diesen Dienst, um ihren Lebensunterhalt zu sichern, und bekommen für diese ökologisch wertvolle Tätigkeit oft nur einen sehr niedrigen Lohn. Schon während der 1980er Jahre erkannten soziale NGOs diesen Sachverhalt. In São Paulo initiierte die christliche NGO „Organização de Auxilio Fraterno“ („Organisation für Geschwisterliche Hilfestellung“), ein Projekt mit den MaterialsammlerInnen, um sie bei der Gründung einer Kooperative zu unterstützen. So entstand 1989 die erste brasilianische Kooperative von MaterialsammlerInnen - Coopamare. ${ }^{35}$

31 Vgl. z. B. die Beispiele des FP7-Forschungsprojekts ,ImPRovE‘ oder in Moulaert / MacCallum / Mehmood / Hamdouch (Hg.), International Handbook.

32 Adina Dumitru / Giuseppe Carrus, How to support transitions towards more sustainable lifestyles? GLAMURS Policy Brief 1/2016, vgl. http://glamurs.eu/wp-content/uploads/2016/ 01/GLAMURS-PB1_final.pdf (letzter Zugriff: 06.06.2019).

33 Bernhard Leubolt, Staat als Gemeinwesen: Das Partizipative Budget in Rio Grande do Sul und Porto Alegre, Wien 2006.

34 Bernhard Leubolt / Wagner de Melo Romão, Socio-Ecological Innovation in Brazil: The Collective Survival Strategy of the Collectors of Recyclable Material, in: Journal für Entwicklungspolitik 33/2/2017, S. 36-57.

35 Bernhard Leubolt / Wagner de Melo Romão, Solidarity Economy in Brazil. Good Practice Example. Collectors of Recyclable Material, Wien 2016, vgl. http://at.solidarityeconomy.eu/fi 
Durch die Gründung der Kooperative gelang es, einige Probleme der MaterialsammlerInnen erfolgreich zu bekämpfen: Die gemeinschaftliche Organisation verhalf ihnen relativ schnell dazu, ein höheres Einkommen erzielen zu können. Der Verkauf in größeren Mengen verbesserte die Verhandlungsbasis der MaterialsammlerInnen gegenüber den ZwischenhändlerInnen. Die gemeinschaftliche Anschaffung einer Lastenwaage konnte ihre Position zusätzlich verbessern. Gleichzeitig erlernten sie als Mitglieder der Kooperative das gleichberechtigte Ausdiskutieren und Treffen gemeinsamer Entscheidungen. Diese Prozesse trugen mittel- bis langfristig auch dazu bei, dass die MaterialsammlerInnen in ihrem Selbstvertrauen und ihrer Menschenwürde gestärkt wurden. $^{36}$

Während der 1990er Jahre wurden in Brasilien zusehends mehr Kooperativen von MaterialsammlerInnen gegründet. Das war ein sehr wichtiger Impuls für weitere soziale Innovationen. Ende der 1990er fanden erstmals bundesweite Treffen der MaterialsammlerInnen statt. 2001 mündete das in die Gründung der „Nationalen Bewegung der SammlerInnen von Recyclingfähigem Material“ (Movimento Nacional dos Catadores de Máterial Reciclável - MNCR), einer eigenständigen berufsständischen Vertretung, die sich als soziale Bewegung versteht und organisiert. In ihr organisieren sich die MaterialsammlerInnen nicht länger als „Arme“, sondern mit positivem Bezug auf ihren Beruf. Damit erreichten sie schon 2001 die offizielle rechtliche Anerkennung in der brasilianischen Arbeitsgesetzgebung.

Im Laufe der 2000er Jahre konnten sie weitere wichtige Schritte setzen: Sie wurden in die partizipativen Planungen von Aktionen zur Hunger- und Armutsbekämpfung einbezogen. Ab 2010 waren die organisierten MaterialsammlerInnen besonders wichtige TeilnehmerInnen am Prozess der partizipativen Erstellung neuer bundesweiter Umweltgesetze. Der Umgang mit den Abfällen wurde von der Bundesregierung als eines der wichtigsten Umweltprobleme erkannt und die MaterialsammlerInnen als wichtige Gruppe von ExpertInnen in die Entscheidungen mit einbezogen. Zusätzlich entstanden staatliche Förderprogramme, die SammlerInnen von verwertbarem Material unterstützen, technische Geräte (z. B. Müllautos, Waagen, Fließbänder etc.) anzuschaffen.

Trotz der Unterstützung kämpften die MaterialsammlerInnen auch stets mit Problemen. Ihre Bezahlung konnten sie zwar verbessern, dennoch blieb sie deutlich unter dem brasilianischen Durchschnittsniveau. Sie konnten zwar ihre rechtliche Stellung deutlich heben, schafften aber den Aufstieg als exklusiv zu-

leadmin/Media/at.solidarityeconomy.eu/Good_practice_Report_Brazil.pdf, (letzter Zugriff: 06.06.2019).

36 Vgl. das online-Video „Coopamare“, vgl. https://youtu.be/Ng5dF8iOPLk (letzter Zugriff: 06.06.2019). 
ständige Gruppe für die urbane Abfallproblematik nicht vollständig. Stattdessen blieben sie abhängig vom Verkauf der verwertbaren Materialien an ZwischenhändlerInnen.

Mit Hilfe der bundesweiten Organisation MNCR und in engagierter Zusammenarbeit mit lokal tätigen NGOs und Kommunalregierungen konnten sich die MaterialsammlerInnen aber auch in die Weiterbildung der Bevölkerung zur Abfallthematik einbringen. Dafür organisieren sie ein internes Aus- und Weiterbildungsprogramm, das neben dem Beitrag zur sozialen und ökologischen Nachhaltigkeit auch auf politische Weiterbildung der SammlerInnen setzt. Es gelang über die Jahre, einerseits das Selbstvertrauen der Beteiligten zu stärken und andererseits das gesellschaftliche Bild von MaterialsammlerInnen zu verändern. Diese werden zunehmend nicht mehr als obdachlose Hilfsbedürftige (oder gar „Störenfriede“) wahrgenommen, sondern ihre Dienste für den Umweltschutz als positiver Beitrag zur Gesellschaft registriert.

Soziale Innovation verband im Fall der SammlerInnen von recyclingfähigem Material die inhaltliche Dimension der Verbesserung der Lebensumstände - seitens gesellschaftlich Benachteiligter und seitens der Gesellschaft - mit der Prozessdimension des Etablierens von Demokratie. Dadurch kam es zu Ermächtigung (Empowerment). Das Beispiel zeigt aber auch die Prozesshaftigkeit sozialer Innovation, da die Veränderungen nicht von heute auf morgen, sondern über einen längeren Zeitraum vonstattengingen. Ursprünglich initiiert von christlichen NGOs und später auch von staatlicher Seite begleitet und unterstützt, konnten die Betroffenen Strukturen gemeinschaftlicher Selbst-Organisation etablieren.

\section{Soziale Innovation und Katholische Soziallehre}

Soziale Innovation als komplementäre Antwort der Zivilgesellschaft auf drängende soziale Probleme, die der (Sozial)Staat nicht oder nur ungenügend beantwortet, behält ihre Ambivalenzen. Trotzdem können in einer quasi archäologischen Vorgehensweise anhand des beschriebenen Projekts der MaterialsammlerInnen Linien sichtbar gemacht werden, die den Grundprinzipien der Katholischen Soziallehre entsprechen. Auffallend ist, dass viele sozial innovative Projekte ihren Ursprung in christlichen Organisationen bzw. kirchlichen Wirkungsfelder haben. Insofern die Katholische Soziallehre - in ihrer Korrektiv-Funktion - immer Antworten auf die drängenden sozialen und gesellschaftspolitischen Fragen ihrer Zeit sucht, wird viel Übersetzungsarbeit der Soziallehre in die Sozial-Praxis der Kirche in engagierten (Pfarr)Gemeinden und christlich inspirierten Organisationen geleistet. Besonders die im vorgestellten Projekt deutliche Dimension des Empowerment soll hervorgehoben werden: aus 
dem Zusammenschluss in eine Kooperative erwächst den MaterialsammlerInnen die Freiheit, ihre Rechte einzufordern und ihren Bedürfnissen Ausdruck zu geben. Diese Erfahrung der gemeinschaftlichen Stärke wird als verlässlicher Halt erlebt, als eine Kraft, die sozialethisches Handeln in persönlicher wie gesellschaftlicher Verantwortung ermöglicht. ${ }^{37}$

Dass es den MaterialsammlerInnen gelungen ist, ihre Forderungen auf staatlicher Ebene zur rechtlich verbrieften Geltung zu bringen, verweist auf einen wesentlichen Punkt einer sozialethisch geprägten Gemeinschaft: Solidarität drückt sich nicht aus als individuelle Zuwendung, sondern als rechtlich verbriefte Sicherheit, die bei individuellen Krisen schützt. Soziale Innovationen können den menschlichen Zusammenhalt besonders unter ihren AkteurInnen stärken, v.a. wenn sie in die nachhaltige Gründung von Organisationen und Interessensvertretungen münden: Soziale Innovationen stellen so in der Regel besonders auf subsidiäre Hilfe zur Selbsthilfe ab und verstehen sich als Gegenentwurf zu staatlichem Paternalismus und Bürokratismus. Ohne den Staat von seiner Hilfspflicht zu entbinden, weswegen der Gang durch die Institutionen bis zur nationalen Gesetzgebung beachtenswert ist.

Die Würde der Menschen ist - in seiner Gott-Ebenbildlichkeit begründet der Dreh- und Angelpunkt der Katholischen Soziallehre. Allerdings wird auch in Brasilien in der aktuellen politischen Situation Individualisierung im Rahmen der makro-ökonomischen Tendenzen gestärkt, Probleme werden ihrer strukturellen Dimension entkleidet und politisch durch sprachliche Abwertung der Betroffenen gefärbt. Innovative Wege der sozialen Förderung können - im Sinne der Personalität - zur besseren Anerkennung und Entfaltung der Personenwürde der von sprachlich oder strukturellen Abwertung betroffenen Gruppen führen. Viele soziale Innovationen verbessern zudem die (Möglichkeits-)Bedingungen für menschlichen Einsatz für soziale Gerechtigkeit und generieren einen gesamtgesellschaftlichen Mehrwert, der eine Orientierung am Gemeinwohl im Blick hat.

Mit dem Empowerment dieser von Elend betroffenen Bevölkerungsgruppe wird eine wesentliche Dimension der vorrangigen Option für die Armen als eine Dimension sozialer Gerechtigkeit deutlich: Benachteiligte Menschen werden selbst zu aktiven Subjekten sozialer Innovation und der Verbesserung ihrer sozialen Lage. Soziale Innovationen können so eine inspirierende Kraft entwickeln für politische, soziale und wirtschaftliche Teilhabe der bisher politisch Marginalisierten und sozial Abgewerteten. Soziale Innovationen können, wie

37 Vgl. Markus Schlagnitweit, Bedarfsorientierte Grundsicherung - bedingungsloses Grundeinkommen. Sozialethische Anmerkungen zur Sozialreformdebatte, in: Andreas Kohl / Günther Ofner / Günther Burkert-Dottolo / Stefan Karner (Hg.), Österreichisches Jahrbuch für Politik, Wien 2006, S. 435-451, hier: S. 451. 
sichtbar geworden ist, auch als Katalysatoren wirken für partizipative Prozesse wirtschaftlicher, sozialer und politischer Reformen. Zudem ist mit der Arbeit der MaterialsammlerInnen eine ökologische Zielsetzung impliziert, die die Perspektive auf nachhaltigen Umgang mit Ressourcen wie der Frage der Sorge um die organische Mitwelt eröffnet und in den politischen Diskurs einbringt.

\section{Schlussfolgerungen}

Die Katholische Soziallehre ist gut mit sozialer Innovation vereinbar bzw. werden dadurch die sozialethischen Grundwerte potenziell gefördert. Die vorangehenden Ausführungen würdigen das hohe Potential sozialer Innovationen zur qualitativen Verbesserung des Sozialstaates und zur Stärkung des sozialen $\mathrm{Zu}$ sammenhalts innerhalb einer Gesellschaft. Dieses kann v.a. gehoben und wirksam werden bei einer entsprechenden institutionellen Absicherung, Einbettung und Förderung von Projekten sozialer Innovation seitens staatlicher Sozialpolitik im Sinne des beschriebenen „bottom-linked“-Ansatzes.

Wenn das Konzept sozialer Innovation dagegen als Argument für die Entlassung der öffentlichen Hand aus ihrer sozialpolitischen Agenda verstanden wird, drohen zahlreiche Gefahren, das positive Potential sozialer Innovation im Sinne der Katholischen Soziallehre zu neutralisieren oder gar ins Gegenteil zu verkehren: Als Beispiel sei die mit einer Privatisierung sozialer Dienstleistungen im Sinne des sozialen Unternehmertums einhergehende Gefahr des Absenkens von Leistungsstandards unter ökonomischem Konkurrenz- bzw. Kostendruck genannt. Wenn unter sozialer Innovation die Auslagerung sozialstaatlicher Leistungen auf soziale Dienstleistungsunternehmen verstanden wird und dies zur Zurückdrängung des sozialen NPO-Sektors führt, verliert das in der Katholischen Soziallehre an Gewicht gewinnende Prinzip der Geschenkhaftigkeit und Unentgeltlichkeit sozialer und wirtschaftlicher Leistungen ${ }^{38}$ zugunsten einer wachsenden Ökonomisierung menschlicher und gesellschaftlicher Interaktion. Schließlich darf die (auch symbolische) Rolle des Sozialstaats als politisch „organisierte und institutionalisierte Solidarität ${ }^{\text {“39 }}$ für den gesellschaftlichen Zusammenhalt nicht unterschätzt werden. Wenn soziale Innovation einfach als Chance zum Rückbau des traditionellen Sozialstaats (miss-)verstanden wird, droht die Gefahr eines weiteren Zerfalls der großen gesamtgesellschaftlichen Solidarität in viele, einander u. U. sogar konkurrierende oder gar be-

38 Vgl. Benedikt XVI., Caritas in veritate, Art. 38.

39 Katholische Sozialakademie Österreichs (ksoe), Solidarisch ausgestalten. Zur Aktualisierung des Sozialstaats, ksoe Dossier 06/2015, vgl. https://www.ksoe.at/dl/uLtsJmoJKMMJqx4 KJKJKJKkomLm/Dossier_2015_06.pdf (letzter Zugriff 21.06.2019). 
kämpfende Gruppen- bzw. „Teil-Solidaritäten“ - zum Schaden des gesamtgesellschaftlichen Zusammenhalts.

Bei produktiver Berücksichtigung dieser Gefahren können soziale Innovationen dennoch einen wichtigen Beitrag zur gesellschaftlichen Wohlfahrt leisten

- v. a. dann, wenn sie als komplementäre, zivilgesellschaftliche Ergänzung und qualitative Verbesserung (im Sinne des Abbaus von Paternalismus und Bürokratismus) staatlicher Sozialpolitik Förderung und Ausbau erfahren.

\section{Quellen}

Appel, Margit, Von sozialen Rechten zur Sozialinvestition? Sozialstaat im Umbau, ksoe blog, 2019, vgl. https://blog.ksoe.at/von-sozialen-rechten-zur-sozialinvestition-sozial staat-im-umbau/ (letzter Zugriff: 21.06.2019).

Appel, Margit / Gubitzer, Luise / Sauer, Birgit (Hg.), Zivilgesellschaft - ein Konzept für Frauen?, Frankfurt 2013.

Benedikt XVI., Caritas in veritate, Vatikan 2009, vgl. http://w2.vatican.va/content/bene dict-xvi/de/encyclicals/documents/hf_ben-xvi_enc_20090629_caritas-in-veritate. html (letzter Zugriff 21.06.2019).

Bureau of European Policy Advisors, Social Innovation, A Decade of Changes, Brussels 2014, vgl. http://espas.eu/orbis/sites/default/files/generated/document/en/social_inno vation_decade_of_changes.pdf (letzter Zugriff: 06.06.2019).

Castles, Francis G., The Disappearing State? Retrenchment Realities in an Age of Globalisation, Cheltenham 2007.

Cools, Pieter, Looking for a Mutually Supporting Relationship between Local Social Innovation and Welfare Reform. The Case of Re-use Non-profits in the UK, in: Journal für Entwicklungspolitik 33/2/2017, S. 13-35.

Coopamare, vgl. https://youtu.be/Ng5dF8iOPLk (letzter Zugriff: 06. 06.2019).

Dörre, Klaus / Röttger, Bernd (Hg.), Das neue Marktregime: Konturen eines nachfordistischen Produktionsmodells, Hamburg 2003.

Drucker, Peter, Innovation and Entrepreneurship, New York 1985.

Dumitru, Adina / Carrus, Giuseppe, How to support transitions towards more sustainable lifestyles? GLAMURS Policy Brief 1/2016, vgl. http://glamurs.eu/wp-content/uploads/ 2016/01/GLAMURS-PB1_final.pdf (letzter Zugriff: 06.06.2019).

European Commission, Guide to Social Innovation. Brussels 2013, vgl. https://publicati ons.europa.eu/en/publication-detail/-/publication/12d044 fe-617a-4131-93c2-5e0a951 a095c, S. 6 (letzter Zugriff: 06.06.2019).

FP7-Forschungsprojekt ,ImPRovE', vgl. http://improve-research.eu/?page_id=2507 (letzter Zugriff: 06.06.2019).

Garcia, Marisol / Pradel, Marc / Eizaguierre, Santiago, Theorizing multi-level governance in social innovation dynamics, in: Frank Moulaert / Diana MacCallum / Abid Mehmood / Abdelillah Hamdouch (Hg.), The International Handbook on Social Innovation: Collective Action, Social Learning and Transdisciplinary Research, Cheltenham 2013, S. 155-168. 
Haggard, Stephen / Kaufman, Robert R., Development, Democracy, and Welfare States: Latin America, East Asia, and Eastern Europe, Princeton-Oxford 2008.

Howaldt, Jürgen / Kaletka, Christoph / Schröder, Antonius, Social Entrepreneurs: Important Actors within an Ecosystem of Social Innovation, in: European Public \& Social Innovation Review 1/2/2016, S. 95-110.

ksoe, Katholische Sozialakademie Österreichs, Solidarisch ausgestalten. Zur Aktualisierung des Sozialstaats, ksoe Dossier 06/2015, vgl. https://www.ksoe.at/dl/uLtsJmoJKMM Jqx4KJKJKJKkomLm/Dossier_2015_06.pdf (letzter Zugriff 21.06.2019).

Lessenich, Stephan, Die Neuerfindung des Sozialen: Der Sozialstaat im flexiblen Kapitalismus, Bielefeld 2008.

Leubolt, Bernhard / Romão, Wagner de Melo, Socio-Ecological Innovation in Brazil: The Collective Survival Strategy of the Collectors of Recyclable Material, in: Journal für Entwicklungspolitik 33/2/2017, S. 36-57.

Leubolt, Bernhard / Romão, Wagner de Melo, Solidarity Economy in Brazil. Good Practice Example. Collectors of Recyclable Material, Wien 2016, vgl. http://at.solidarityeco nomy.eu/fileadmin/Media/at.solidarityeconomy.eu/Good_practice_Report_Brazil.pdf (letzter Zugriff: 06.06.2019).

Leubolt, Bernhard, Staat als Gemeinwesen: Das Partizipative Budget in Rio Grande do Sul und Porto Alegre, Wien 2006.

Lewis, Jane, Gender and the Development of Welfare Regimes, in: Journal of European Social Policy 2/3/1992, S. 159-173.

Martinelli, Flavia, Learning from case studies of social innovation in the field of social services: creatively balancing top-down universalism with bottom up democracy, in: Frank Moulaert / Diana MacCallum / Abid Mehmood / Abdelillah Hamdouch (Hg.), The International Handbook on Social Innovation: Collective Action, Social Learning and Transdisciplinary Research, Cheltenham 2013, S. 346-360.

Meichenitsch, Katharina / Neumayr, Michaela / Schenk, Martin (Hg.), Neu! Besser! Billiger! Soziale Innovation als leeres Versprechen, Wien 2016.

Moulaert, Frank / MacCallum, Diana, Advanced Introduction to Social Innovation, Cheltenham 2019.

Moulaert, Frank / Mehmoud, Abid / MacCallum, Diana / Leubolt, Bernhard, Social Innovation as a Trigger for Transformations; The Role of Research, Policy Review for EC, Brussels 2017, vgl. https://ec.europa.eu/research/social-sciences/pdf/policy_reviews/ social_innovation_trigger_for_transformations.pdf (letzter Zugriff: 06. 06.2019).

Moulaert, Frank / MacCallum, Diana / Hillier, Jean, Social innovation: intuition, precept, concept, theory and practice, in: Frank Moulaert / Diana MacCallum / Abid Mehmood / Abdelillah Hamdouch (Hg.), The International Handbook on Social Innovation: Collective Action, Social Learning and Transdisciplinary Research, Cheltenham 2013, S. 13-24.

Moulaert, Frank / MacCallum, Diana / Mehmood, Abid / Hamdouch, Abdelillah (Hg.), The International Handbook on Social Innovation: Collective Action, Social Learning and Transdisciplinary Research, Cheltenham 2013.

Moulaert, Frank / Martinelli, Flavia / Swyngedouw, Erik / González, Sara, Towards Alternative Model(s) of Local Innovation, in: Urban Studies 42/11/2005, S. 1969-1990. 
Murray, Robin / Caulier-Grice, Julie / Mulgan Geoff, The Open Book of Social Innovation. London 2010, vgl. https://media.nesta.org.uk/documents/the_open_book_of_social_ innovation.pdf (letzter Zugriff: 06.06.2019).

Murray, Charles, Losing Ground: American Social Policy, 1950-1980, New York 1984.

Offe, Claus, Contradictions of the Welfare State, London 1984.

Peters, Guy / Pierre, Jon, Multi-level Governance and Democracy. A Faustian Bargain?, in: Ian Bache / Matthew Flinders (Hg.), Multi-level Governance, Oxford 2004, S. 75-89.

Schlagnitweit, Markus, Bedarfsorientierte Grundsicherung - bedingungsloses Grundeinkommen. Sozialethische Anmerkungen zur Sozialreformdebatte, in: Andreas Kohl / Günther Ofner / Günther Burkert-Dottolo / Stefan Karner (Hg.), Österreichisches Jahrbuch für Politik, Wien 2006, S. 435-451.

Schumpeter, Joseph, Theorie der wirtschaftlichen Entwicklung. Eine Untersuchung über Unternehmergewinn, Kapital, Kredit, Zins und den Konjunkturzyklus, MünchenLeipzig 1931.

Streeck, Wolfgang, Gekaufte Zeit: Die vertagte Krise des demokratischen Kapitalismus, Frankfurt 2013.

Swyngedouw, Erik, Governance Innovation and the Citizen. The Janus Face of Governance-beyond-the-state, in: Urban Studies 42/11/2005, S. 1991-2006.

Zimmer, Annette / Pahl, Benedikt, TSI Comparative Report. Learning from Europe, Third Sector Impact: Comparative report 1/2016, vgl. http://thirdsectorimpact.eu/site/as sets/uploads/documentations/comparative-report-learning-europe/TSI-comparativereport-No.-1.pdf (letzter Zugriff: 06.06.2016). 


\section{Das Richtige vor dem Rentablen. Zur Entwicklung und zu den aktuellen wirtschaftsethischen Herausforderungen der ethisch-nachhaltigen Geldanlage}

\section{Einleitung: die ethisch-nachhaltige Geldanlage auf dem Weg zur Normalität}

Als ich mich Mitte der 1990er-Jahre zum ersten Mal mit dem Thema der ethischen und nachhaltigen Geldanlage beschäftigte, gab es zu dieser Thematik nur wenig wissenschaftliche Literatur und noch kaum praktische Anwendungsfälle. Obwohl vielen klar war, dass bereits bei der Finanzierung wirtschaftlicher Aktivitäten die Weichen für soziale Verantwortung und ökologische Zukunftsfähigkeit gestellt werden, beschäftigten sich nur wenige Menschen mit dieser Frage. Der Zeitgeist schien in eine andere Richtung zu weisen: Geld ist ein neutrales Mittel, das automatisch dorthin fließt, wo die größten Renditen möglich sind. Mit Moral habe das nichts zu tun.

Seither wurde dem Thema eine bemerkenswerte Aufwertung in Theorie und Praxis zuteil und heute, mehr als zwanzig Jahre später, kann man durchaus behaupten, dass die ethisch-nachhaltige Geldanlage drauf und dran ist, aus der Nische in den Mainstream zu wechseln. Einerseits werden von der Finanzwirtschaft fast flächendeckend Produkte und Dienstleistungen zu Ethik- und Nachhaltigkeitsaspekte offeriert, andererseits fragen sowohl institutionell als auch privat Investierende verstärkt derartige Möglichkeiten nach. Darüber hinaus hat das Thema auch eine politisch-praktische Dimension erreicht. Die Europäische Kommission, die Organe der Finanzaufsicht oder auch politischen Parteien und Regierungen haben die nachhaltige Geldanlage auf ihre Agenda gesetzt und treiben das Thema energisch voran. All das sind Anzeichen dafür, dass die Integration von Ethik und Nachhaltigkeit in die Geldanlage bald zum New Normal avancieren kann.

Gleichzeitig steigen aber damit auch die Herausforderungen: gerade darüber, was „ethisch“ und „nachhaltig“ im Kontext einer Geldanlage nun konkret ist, wird leidenschaftlich diskutiert. Mit dem Trend zum Mainstream steigt auch die Gefahr der Verwässerung und wer seine individuellen Werthaltungen realisiert 
wissen will kommt nicht umhin, tief in die Materie einzutauchen, um besser zu verstehen, inwieweit ein jeweiliger Ansatz oder ein entsprechendes Finanzprodukt auch wirklich dem entspricht, was man selbst von einer ethisch-nachhaltigen Geldanlage erwartet.

In meinem Beitrag möchte ich die bisherige Entwicklung der ethisch-nachhaltigen Geldanlage kurz beschreiben und die gängigsten Strategien erläutern, mit denen soziale und ökologische Kriterien bei der Geldanlage berücksichtigt werden. Des Weiteren möchte ich dann auf die unterschiedlichen Motive von Investierenden eingehen und insbesondere am Konzept der finanziellen Materialität deutlich machen, dass eine rein auf Risikomanagement fokussierte Herangehensweise alleine nicht ausreichen wird, um die vielfältigen gesellschaftlichen Herausforderungen zu bewältigen.

\section{Geschichte und Entwicklung der ethisch-nachhaltigen Geldanlage}

Wann und wo zum ersten Mal von einer ethischen oder nachhaltigen Geldanlage gesprochen wurde, lässt sich vermutlich nicht mehr mit Bestimmtheit feststellen. Als breiteres gesellschaftliches Phänomen zum ersten Mal aufgetaucht ist die ethische Geldanlage im frühen 20. Jahrhundert, als religiös motivierte Menschen in den Vereinigten Staaten - vor allem waren das Quäker und Methodisten Investitionen in so genannte Sin-Stocks ablehnten. Damit waren die Aktien von solchen Unternehmen gemeint, denen eine schädliche Wirkung auf Mensch und Gesellschaft angelastet wurde. Das waren zum Beispiel Unternehmen der Alkohol- und Tabakbranche, des Glückspiels oder der Waffenproduktion. Das Ziel war ein zweifaches: einerseits ging es darum, diese Tätigkeiten nicht durch Kapitalbereitstellung zu ermöglichen und andererseits wollte man vermeiden, davon zu profitieren, dass der Gewinn zum Schaden anderer oder der Umwelt erwirtschaftet wurde. Der 1928 gegründete Pioneer Fund wird rückblickend als erster Ethik-Investmentfonds bezeichnet. Dieser berücksichtige sogenannte Ausschlusskriterien zu gesellschaftlich kontroversen Wirtschaftspraktiken. Weitere Investmentfonds folgten und vor allem die Proteste gegen den Vietnamkrieg und gegen die Apartheidpolitik Südafrikas führten dazu, dass sich zahlreiche Investoren aus Unternehmen zurückzogen, die Waffen produzierten oder mit dem Apartheidregime in Geschäftsverbindung standen. Solche Investoren-Boykotte, die von Kirchen ebenso wie von Pensionsfonds mitgetragen wurden, waren zwar nicht die alleinige Ursache, aber sicherlich ein wichtiger Faktor dafür, dass politische Veränderungen möglich wurden. In der Folge entstanden immer mehr Anlageprodukte, die nicht mehr vorbehaltlos in alle 
möglichen Unternehmen investierten, sondern einen so genannten Ethik- oder Nachhaltigkeitsfilter einbauten. Diese durch Vermeidung gekennzeichnete Geldanlage-Strategie will nicht nur Kapitalströme lenken, sondern auch öffentliches Bewusstsein erzeugen und damit Druck auf Unternehmen ausüben. Tatsächlich gibt es auch zahlreiche Beispiele dafür, wie Unternehmen den Forderungen ethisch orientierter Investorinnen und Investoren nachgekommen sind, kritisierte Produkte aus dem Programm genommen oder unverantwortliche Produktionsmethoden beendet haben.

Mit der ab den 1970er-Jahren einsetzenden Umweltdebatte entwickelte und etablierte sich ein weiterer Anlagestil, dessen Fokus auf der Förderung ökologisch zukunftsfähiger Produkte und Technologien lag. Hier standen zu Beginn vor allem ökologische Themen im Vordergrund, wie etwa der sparsame Umgang mit endlichen Ressourcen oder die Entwicklung erneuerbarer Energieformen. Umwelttechnologie- und Ökoeffizienzfonds, aber auch Direktbeteiligungsmodelle in Windparks oder Fotovoltaik-Projekte entstanden und trugen wesentlich dazu bei, dass die Realisierung derartiger Ideen und Initiativen überhaupt möglich wurde. Im Zentrum dieser fördernden Geldanlage stehen dabei nicht mehr Ausschluss- oder Negativkriterien, sondern Positivkriterien, die nicht nur ökologische Themen, sondern ebenso die soziale und kulturelle Dimension einer nachhaltigen Entwicklung umfassen. In weiterer Folge spielte spätestens ab den 1980er Jahren das Konzept der nachhaltigen Entwicklung eine entscheidende Rolle. Nachhaltigkeit basiert auf den drei Säulen der Ökologie, der Ökonomie und des Sozialen, die gleichberechtigt zu berücksichtigen sind, um eine zukunftsfähige gesellschaftliche Entwicklung zu ermöglichen. In Zentrum steht dabei die Suche nach ökonomischen Konzepten und Praktiken, welche sozial verantwortlich und ökologisch zukunftsfähig sind und dazu beitragen, gesellschaftlichen Wohlstand bei gleichzeitiger Achtung der biosphärischen Grenzen zu gewährleisten.

Im englischen Sprachraum werden ethische und nachhaltige Geldanlagen oft als Socially Responsible Investments (SRI) bezeichnet. In dieser Bezeichnung schwingt noch die auf soziale Themen fokussierte Entstehungsgeschichte ethischer Geldanlagen in den USA mit, wenngleich ökologische Themen mittlerweile einen ebenso großen Stellenwert bei SRI haben. In den letzten Jahren hat sich auch das Kürzel ESG durchgesetzt: gemeint sind die drei Bereiche Ökologie (environment), Sozial-Gesellschaftliches (social) und Unternehmensführung (governance). Im Kontext der Geldanlage werden ESG-Kriterien vor allem angewendet, um die sich aus diesen Themenfeldern ergebende Chancen und Risiken für Unternehmen zu identifizieren.

Mitunter lösen die unterschiedlichen Bezeichnungen Verwirrung aus. Noch größer wird diese Verwirrung, wenn man sich die hinter diesen Zuschreibungen stehenden Anlageprodukte im Detail anschaut. Dann stellt man nämlich fest, 
dass eine klare inhaltliche Unterscheidung alleine aufgrund der Bezeichnung kaum noch möglich ist, weil Begriffe wie SRI, ESG, Nachhaltigkeit, Ethik oder Impact uneinheitlich und oft auch willkürlich verwendet werden. Kirchliche Investoren in Deutschland bedienen sich nun zunehmend des Begriffs der ethisch-nachhaltigen Geldanlage. ${ }^{1}$ Sowohl die evangelische Kirche Deutschlands als auch die katholische Deutsche Bischofskonferenz verwenden diesen Begriff in ihren jüngsten Publikationen, um deutlich zu machen, dass es darauf ankommt, die drei Säulen der Nachhaltigkeit möglichst gleichrangig, in Konfliktfällen aber im Kontext einer am guten Leben für alle orientierten Güterabwägung, in die Geldanlage zu integrieren. Diese Güterabwägung ist ein ethischer Reflexionsprozess und orientiert sich an den Werthaltungen und moralischen Standards der Investierenden. Was im konkreten Anwendungsfall also „nachhaltig“ ist, erschließt sich erst in einem Reflexionsverfahren, bei dem die unterschiedlichen und sich womöglich widersprechenden ökonomischen, ökologischen und sozialen Ziele einer verantwortlichen Geldanlage identifiziert und abgewogen werden. ${ }^{2}$ Je nachdem, welche Werthaltungen vertreten und welche Prioritäten gesetzt werden, kann Nachhaltigkeit unterschiedlich umgesetzt werden. Damit wird deutlich, dass das, was im Kontext der Geldanlage letztlich als nachhaltig bezeichnet und umgesetzt wird, oft einen Kompromiss darstellt. Dass es nicht das eine, für alle gültige Verständnis von Nachhaltigkeit gibt, sondern vielmehr unterschiedliche Verstehensweisen darüber existieren, was denn nun nachhaltig ist, macht die Sache freilich nicht einfacher. Gleichwohl: angesichts der Komplexität gesellschaftlicher und ökologischer Herausforderungen erweist sich Nachhaltigkeit als ein Such- und Lernprozess, als ein Ringen nach bestmöglichen Lösungen. Dass also unterschiedliche Verstehens- und Zugehensweisen in der nachhaltigen Geldanlage existieren, ist unter diesem Gesichtspunkt zuerst einmal nicht negativ, sondern positiv zu bewerten. Letztlich kommt es jedoch darauf an, welche Ansätze am besten den Werthaltungen der jeweiligen Investoren entsprechen. Hier kommt die Ethik ins Spiel: welches Verständnis von Nachhaltigkeit moralisch vertretbar bzw. geboten ist, erweist sich erst im Zuge eines Reflexionsprozesses vor dem Hintergrund der jeweiligen moralischen Überzeugungen. Die dabei getroffenen Entscheidungen - oftmals

1 Der „Leitfaden für ethisch-nachhaltige Geldanlagen in der evangelischen Kirche“ sowie die „Orientierungshilfe ,Ethisch-nachhaltig investieren“" der Deutschen Bischofskonferenz und des Zentralkomitees der deutschen Katholiken bieten jeweils eine umfangreiche Hilfestellung zu Fragen der ethisch-nachhaltigen Geldanlage an. Die österreichische Bischofskonferenz ist bei ihrer im Herbst 2017 beschlossenen und am 01.01.2018 im Amtsblatt Nr. 74 der Österreichischen Bischofskonferenz veröffentlichten Richtlinie Ethische Geldanlagen beim Begriff der „ethischen Geldanlage“ geblieben.

2 Aus ethisch-theologischer Sicht wurde das Thema der Nachhaltigkeit von Markus Vogt ausführlich behandelt: Markus Vogt, Prinzip Nachhaltigkeit. Ein Entwurf aus theologisch-ethischer Perspektive, München 2009. 
auch Kompromisse - müssen einerseits gut begründet werden, andererseits aber auch offen für neue Erkenntnisse und Argumente bleiben. Solche Verfahren können langwierig und mühsam sein, bleiben Investierenden jedoch nicht erspart, wenn sie ihrer Verantwortung gerecht werden wollen. ${ }^{3}$

Trotz dieser Schwierigkeiten lässt sich aber zeigen, dass die ethisch-nachhaltige Geldanlage stark an Bedeutung gewinnt. Nicht nur kirchliche Investoren, auch Stiftungen, Vorsorgeeinrichtungen oder Unternehmen legen ihr Geld zunehmend unter Anwendung ökologischer und sozialer Kriterien an. Nicht zuletzt zeigt sich der Bedeutungszuwachs ethisch-nachhaltiger Geldanlagen im immer breiter werdenden Angebot entsprechender Finanzprodukte: selbst große, dieser Thematik gegenüber sonst eher unverdächtige konventionelle Finanzunternehmen haben begonnen, ihre Produktpalette um nachhaltige Geldanlageprodukte zu ergänzen. Wie kommt das?

\section{Gründe für die zunehmende Bedeutung nachhaltiger Geldanlagen}

Ein erster Grund liegt in der Erkenntnis, dass die gesellschaftlichen und ökologischen Zustände auf unserem Globus keine bloßen Naturereignisse, sondern vor allem das Ergebnis sozialer und wirtschaftlicher Prozesse sind. Dem Geld kommt dabei eine besondere Bedeutung zu, weil es eine unverzichtbare Basis für wirtschaftliche Aktivitäten ist. Die Art und Weise, wie wir Geld einsetzen, hat etwas zu tun mit dem Zustand unserer Welt. Mit einer bewussten Geldanlageentscheidung können wir einen Beitrag leisten, damit sich nachhaltige und faire Wirtschaftsweisen durchsetzen. Dazu braucht es vor allem verantwortlich handelnde Investorinnen und Investoren. In der Vergangenheit waren es vor allem kirchliche Einrichtungen und philanthropisch orientierte Akteure, die Pionierarbeit geleistet haben - heute wird das nachhaltige Investment von Pensionskassen und Versicherungen ebenso betrieben wie von einer stetig wachsenden Anzahl von Finanzdienstleistern. Sie alle folgen der Einsicht, dass die Geldanlage eine Auswirkung auf den Zustand der Welt hat, in der wir leben.

Ein zweiter Grund für die zunehmende Bedeutung nachhaltiger Geldanlagen liegt wohl darin, dass vor dem Hintergrund der globalen gesellschaftlichen, kulturellen, ökologischen und sozialen Herausforderungen ein stärkeres Bewusstsein dafür entstand, dass für deren Bewältigung enorme finanzielle An-

3 Gemeinsam mit Markus Schlagnitweit habe ich versucht, diesen ethischen Reflexionsprozess im Kontext der ethisch-nachhaltigen Geldanlage zu skizzieren: Klaus Gabriel / Markus Schlagnitweit, Das gute Geld. Ethisches Investment - Hintergründe und Möglichkeiten, Innsbruck 2009. 
strengungen notwendig sind, welche wiederum die Beteiligung privater Kapitalgeber erforderlich machen. Die Europäische Kommission schätzt, dass zur Erreichung der europäischen Klimaziele für 2030 pro Jahr 180 Milliarden Euro zusätzlich investiert werden müssen. ${ }^{4}$ Die im Jahr 2015 von den Vereinten Nationen veröffentlichten 17 nachhaltigen Entwicklungsziele (Sustainable Development Goals - SDGs) bedeuten eine grundlegende Transformation der globalen Lebens- und Wirtschaftsstile, für deren Gelingen enorme Investitionen erforderlich sein werden. Bis zum Jahr 2030 - so der Zeitplan - sollen beispielsweise Hunger und Armut nicht mehr existieren und sich nachhaltige Wirtschaftsweisen durchgesetzt haben. Das setzt voraus, dass es zu einer Neuausrichtung der globalen Finanzströme kommt, um den Ursachen für soziale und ökologische Missstände die Kapitalbasis zu entziehen bzw. eine nachhaltige Entwicklung zu finanzieren. Dafür müssen auch die Rahmenbedingungen an den Kapitalmärkten verändert werden. Und tatsächlich lassen sich diesbezüglich seit einigen Jahren erste Schritte beobachten: Das Thema sustainable finance findet sich auf der Agenda der größten Industrienationen (G20), erhält zunehmendes Gewicht auf europäischer Ebene und wird auf nationaler und regionaler Ebene immer konkreter. Die Vereinten Nationen entwickelten bereits im Jahr 2006 die Principles for Responsible Investment und die Europäische Kommission hat im März 2018 einen Aktionsplan zur Finanzierung nachhaltigen Wachstums vorgelegt, der zum Ziel hat, die Rahmenbedingungen für nachhaltige Geldanlagen zu schaffen und so die Finanzierung nachhaltiger Projekte gegen den Klimawandel zu ermöglichen. In ersten Regionen und Städten - wie zum Beispiel dem Land Berlin oder der Stadt Stuttgart - gibt es mittlerweile konkrete Vorgaben, um die Geldanlage der öffentlichen Hand sozial verantwortlich und ökologisch zukunftsfähig zu gestalten. Die nachhaltige Geldanlage ist somit in der Politik angekommen.

Als einen dritten Grund für das Erstarken nachhaltiger Geldanlagen kann man anführen, dass Bedenken bezüglich einer generellen Unvereinbarkeit von nachhaltigen Wirtschaftsweisen einerseits und ökonomischem Erfolg andererseits widerlegt werden konnten. Wie die bisherigen Erfahrungen mit ethischen und nachhaltigen Geldanlagen sowie eine ganze Reihe von wissenschaftlichen Studien belegen, bedeutet die Berücksichtigung von Ethik und Nachhaltigkeit nicht, dass damit automatisch Ertragseinbußen einhergehen müssen. Mehr noch: es gibt Hinweise, dass Risiken reduziert und neue Chancen genutzt werden können. Dies ist auch der Grund, warum gerade konventionelle Finanzakteure vermehrt Nachhaltigkeitsaspekte in ihre Investitionsentscheidungen einfließen

4 Mitteilung der Kommission vom 8.3.2018/COM/2018/97 - Aktionsplan: Finanzierung nachhaltigen Wachstums, vgl. https://eur-lex.europa.eu/legal-content/DE/TXT/PDF/?uri=CELEX:52 018DC0097\& from=EN (letzter Zugriff: 17.05.2019). 
lassen: weil das dazu beitragen kann, das Risiko-Rendite-Verhältnis einer Geldanlage zu optimieren, es also ökonomisch vernünftig ist.

Zudem fällt auf, dass Investoren heute auf verschiedene Strategien zurückgreifen können, um ihr Geld nachhaltig anzulegen. Dazu kommt, dass Investoren oft unterschiedliche Motive haben, um soziale und ökologische Kriterien in ihre Geldanlage zu integrieren. Beides soll im Nachfolgenden kurz beleuchtet werden.

\section{Anlagestrategien einer ethisch-nachhaltigen Geldanlage}

Wer die Geldanlage nach ethisch-nachhaltigen Kriterien ausrichten möchte, kann heute auf mehrere Strategien zurückgreifen und diese auch kombinieren. ${ }^{5}$ Am bekanntesten ist dabei die Anwendung von Ausschlusskriterien. Hier werden Geschäftsfelder und Geschäftspraktiken definiert, in die man nicht investieren möchte. Atomenergie, Menschenrechtsverletzungen und Waffen zählen hierbei zu den am häufigsten angewendeten Ausschlusskriterien im deutschsprachigen Raum. Welche Ausschlusskriterien angewendet werden, obliegt den Investierenden: sie können Unternehmen mit einem besonders hohen CO2-Fußabdruck ausschließen oder auf Unternehmen verzichten, die in moralisch kontroversen Bereichen tätig sind, wie z.B. Gentechnik oder Rüstung. In der praktischen Umsetzung erweisen sich Ausschlusskriterien jedoch oft als schwierig: viele Unternehmen sind in mehreren Geschäftsfeldern tätig und bieten nicht nur moralisch abzulehnende, sondern gleichzeitig oft auch moralisch wünschenswerte Produkte und Dienstleistungen an. Und häufig kann ein und dasselbe Produkt sowohl in moralisch unbedenklicher als auch in moralisch abzulehnender Weise eingesetzt werden. Wie beurteilt man zum Beispiel einen Hersteller von Technologien, die sowohl im medizinischen als auch im militärischen Bereich eingesetzt werden? Bedeutsam in diesem Zusammenhang ist die Divest-Bewegung, die auf einen Zusammenschluss von Investoren abzielt, um bestimmte Geschäftsfelder - wie zum Beispiel die Kohleförderung - zu boykottieren. ${ }^{6}$ Der Vorteil von Ausschlusskriterien liegt darin, dass man sich nicht

5 Vgl. hierzu ausführlicher: Klaus Gabriel, Verantwortlich Investierende: Motive, Maßstäbe und Handlungsoptionen von Kapitalanlegern, in: Manfred Stüttgen (Hg.), Ethik von Banken und Finanzen, Zürich 2017, S. 57-75.

6 Die Fossil Free-Bewegung setzt auf eine Energiewende und ruft dazu auf, nicht mehr in Unternehmen zu investieren, die fossile Energieträger fördern. Zahlreiche große institutionelle Investoren - wie z.B. die Allianz, der norwegische Staatsfonds oder die Rockefeller Stiftung - verzichten auf Kohleinvestments bzw. schränken diese ein. Die katholische Kirche in Österreich hat im Frühjahr 2019 beschlossen, in den kommenden fünf Jahren aus allen Unternehmen auszusteigen, die fossile Brennstoffe fördern oder produzieren. 
vorwerfen lassen muss, mit der Geldanlage nicht-nachhaltige oder unmoralische Wirtschaftsweisen zu unterstützen. Indem man öffentlich erklärt, dass man derartige Aktivitäten nicht finanzieren will, trägt man dazu bei, das Problem bewusster zu machen und eine öffentliche Debatte darüber zu führen, warum eine bestimmte wirtschaftliche Aktivität generell unterlassen werden sollte. Und wenn Unternehmen die Finanzierung entzogen wird, können sie ungleich schwerer ihr Geschäftsmodell aufrechterhalten. Es ist allerdings zu berücksichtigen, dass in der Praxis ein kompletter Boykott nicht-nachhaltig agierender Unternehmen nur schwer durchzusetzen ist. Kritiker wenden ein, dass Ausschlusskriterien nur der Gewissensberuhigung dienen und sich am Verhalten der Unternehmen nichts ändert, weil den Unternehmen in der Regel ja kein Kapital entzogen wird, sondern die Unternehmensanteile an einen anderen Investor weiterverkauft werden. Wer nicht in Rüstungsunternehmen investiert, verhindert damit in der Regel noch nicht, dass weniger geächtete Waffen produziert und in Umlauf gebracht werden. Erst wenn es einen weitgehenden oder zumindest von einer kritischen Masse der Investoren mitgetragenen Boykott gibt, kann das Auswirkungen auf die Finanzierungskosten von Unternehmen haben. Auch wenn Ausschlusskriterien nicht immer eine direkte (Finanz-)Wirkung entfalten können, sollte man die indirekte Wirkung von Ausschlusskriterien nicht unterschätzen: weniger Nachfrage führt für gewöhnlich zu sinkenden Aktienkursen und ein öffentlich kommunizierter Ausschluss kann dem Image von Unternehmen Schaden zufügen. Ausschlusskriterien sind auch ein Statement gegen soziale und ökologische Missstände und tragen damit zu jenem Kulturwandel bei, den es für nachhaltige Wirtschaftsweisen braucht.

Viele Investierende setzen auf Positivkriterien. Dabei steht nicht die Vermeidung von, sondern die Unterstützung für bestimmte Unternehmen im Vordergrund. Abgezielt wird dabei auf jene Unternehmen, die einen besonderen Beitrag für eine nachhaltige Entwicklung leisten. Mit dem Best in Class-Ansatz können dabei auch noch jene Unternehmen bevorzugt werden, die im Vergleich zu ihren Mitbewerbern aus Nachhaltigkeitssicht die Nase vorn haben. Damit soll ein Wettbewerb für mehr Nachhaltigkeit unter den Unternehmen initiiert werden. Der Vorteil von Positivkriterien liegt auf der Hand: die Finanzströme werden in Richtung nachhaltiger Wirtschaftsweisen gelenkt. Der Best in Class-Ansatz kann für Unternehmen Anreize liefern, ihre Nachhaltigkeitsperformance stetig zu verbessern - zumal das auch zu einem besseren Image beitragen kann. Viele Investoren stellt der Best in Class-Ansatz aber vor das Problem, dass sie zwar in die besten Unternehmen einer Branche investieren, nicht alle Branchen aber per se als nachhaltig bezeichnet werden können. Um zu vermeiden, dass man in die „nachhaltigsten “ Rüstungskonzerne investiert, wird der Best in Class-Ansatz in der Praxis mit Ausschlusskriterien kombiniert. 
Eine relativ neue Anlagestrategie ist das Engagement. ${ }^{7}$ Darunter werden kommunikative Verfahren verstanden, bei denen die Investoren versuchen, die Unternehmen zu mehr Verantwortung und Nachhaltigkeit zu motivieren - oder zu drängen. Aktionäre haben etwa die Möglichkeit, ihr Stimm- und Rederecht auf Hauptversammlungen von Unternehmen auszuüben. Engagement vollzieht sich aber auch abseits der Hauptversammlung, nämlich im Dialog zwischen Investoren und Unternehmensvertretern. Dabei können konkrete Missstände angesprochen und Strategien für deren Behebung diskutiert werden. Immer mehr Investierende sehen im Engagement ein wirksames Instrument, um die Nachhaltigkeit von Unternehmen zu verbessern. Tatsächlich lassen sich immer mehr Beispiele anführen, bei denen Engagement-Aktivitäten zu Verbesserungen in sozialer und ökologischer Sicht geführt haben.

In den letzten Jahren hat sich über diese Strategien hinaus noch ein weiterer Ansatz etabliert, der im angelsächsischen Raum recht verbreitet, im deutschsprachigen Raum jedoch erst vereinzelt anzutreffen ist: Das Impact Investment. Zwar ist das Erzielen eines Impacts, also einer Wirkung, das erklärte Ziel aller hier erwähnten Anlagestrategien, mit der Bezeichnung Impact Investment will man aber noch deutlicher herausstellen, dass die Wirkung an erster Stelle steht und Impact-Investoren auch bereit sind, höhere Risiken einzugehen. Impact Investments können bei der Finanzierung von sozialen und ökologischen Projekten, die mit einem hohen finanziellen Risiko verbunden sind, eine wichtige Rolle spielen. ${ }^{8}$

Seit einigen Jahren mehren sich die Hinweise, dass die Einbeziehung von Ethik und Nachhaltigkeit in die Beurteilung von Investitionsmöglichkeiten auch ökonomisch relevant sein kann - und zwar im positiven Sinne. Was schon lange vermutet wurde, kann nun durch wissenschaftliche Studien bestätigt werden: Nachhaltigkeit kann sich auszahlen. Das ist auch der Grund dafür, dass immer mehr Investoren Ethik- und Nachhaltigkeitskriterien nutzen, ohne dabei eine explizit moralische Zielsetzung zu verfolgen. Diesem als Integration bezeichneten Ansatz liegen also gar keine moralischen Überzeugungen oder Motive zugrunde, sondern das Kalkül, dass die Berücksichtigung ethischer Normen und Nachhaltigkeitsstandards ökonomisch durchaus vernünftig sein kann. Der we-

7 Engagement (engl. ausgesprochen) wird in den USA, Großbritannien und in Skandinavien mittlerweile umfassend betrieben, in Kontinentaleuropa wird Engagement zunehmend angewendet.

8 Eine gelungene Zusammenfassung des aktuellen Standes bei Impact Investment hat das FERI Cognitive Finance Institute in Kooperation mit dem Institut für Wirtschaftsethik der Universität St. Gallen verfasst: Impact Investing: Konzepte, Spannungsfelder und Zukunftsperspektiven. Eine Orientierung für private und institutionelle Investoren. Die Studie ist erhältlich unter https://fa-se.de/static/fa_se_de/uploads/2019/02/FERI-CFI-Impact-2019.pdf (letzter Zugriff 17.05.2019). 
sentliche Vorteil dieses Ansatzes besteht darin, dass er höchst anschlussfähig an die Logik der konventionellen Finanzwirtschaft ist. Wenn Nachhaltigkeit für Investoren keine ökonomischen Nachteile bedeutet und es sogar Hinweise gibt, dass Nachhaltigkeit ökonomisch vernünftig ist, gibt es selbst für hartgesottene Profit-Maximierer wohl keinen Grund mehr, Nachhaltigkeit zu negieren. Diese finanzielle Materialität der Nachhaltigkeit kann also einen wichtigen Anreiz darstellen, soziale und ökologische Kriterien bei der Geldanlage zu berücksichtigen. Kritisch ist aber zu sehen, dass ein ausschließlicher Fokus auf finanzielle Materialität auch dazu führen kann, dass jene Nachhaltigkeitsaspekte, die eben keinen unmittelbaren ökonomisch-finanziellen Beitrag zu leisten in der Lage sind, die aber für die Bewältigung drängender gesellschaftlicher Herausforderungen von zentraler Bedeutung sind, aus dem Blickfeld geraten. Auf die Problematik der finanziellen Materialität wird weiter unten noch eingegangen.

Welcher Strategie nun das größte Wirkungspotential zugeschrieben werden kann, lässt sich nicht generell beantworten. Vielmehr kommt es auf die jeweilige Situation an: es gibt Fälle, in denen ein Dialog mit Unternehmen mehr bewirken kann als ein Ausschluss oder der Best in Class-Ansatz. Umgekehrt gibt es Fälle, bei denen Gespräche keine Wirkung zeigen und ein Ausschluss des Unternehmens aus dem Investmentuniversum die einzig mögliche Konsequenz für verantwortlich Investierende darstellt. Die eine Strategie gegen eine andere auszuspielen kann also keine Lösung sein. Vielmehr sollte es darum gehen, die verfügbaren Strategien als Werkzeuge zu betrachten, die es den jeweiligen Umständen entsprechend anzuwenden gilt. Wer also verantwortlich investieren will, beurteilt jeweils im Einzelfall, welche Strategie oder Kombination von Strategien am erfolgversprechendsten erscheint bzw. am ehesten in der Lage ist, nachhaltige Wirtschaftsweisen zu fördern.

\section{Warum ethisch-nachhaltig investieren?}

Welche Motive haben Investierende, wenn sie sich mit der ethisch-nachhaltigen Geldanlage beschäftigen? Die Motive von Investorinnen und Investoren werden oft zu wenig berücksichtigt. Es überrascht deshalb auch nicht, dass es zwar viele Definitionen dafür gibt, was ein nachhaltiges Anlageprodukt ausmacht, aber kaum Erklärungen dafür existieren, was einen nachhaltigen Investor oder eine nachhaltige Investorin letztlich auszeichnet. Zwischen dem Investment-Objekt und dem Investment-Subjekt zu unterscheiden ist aber von Bedeutung, weil Investierende in der Regel sehr unterschiedlich Ausgangsituationen und Umsetzungsmöglichkeiten haben und ein bestimmtes Anlageprodukt oder eine jeweilige Anlagestrategie für die eine Investorin passend, für den anderen Investor aber unpassend sein kann. Eine kirchliche Einrichtung etwa hat bezüglich 
der Nachhaltigkeit ihrer Geldanlage andere Präferenzen und Möglichkeiten als ein Versicherungskonzern. Dementsprechend gibt es auch Unterschiede, wie die Einbeziehung sozialer und ökologischer Kriterien konkret erfolgen kann. Von daher macht es durchaus Sinn, sich einmal grundlegend mit den unterschiedlichen Motiven und Möglichkeiten der einzelnen Investoren zu beschäftigen. ${ }^{9}$

Wie bereits weiter oben ausgeführt, entstand die ethisch-nachhaltige Geldanlage als Reaktion auf soziale und ökologische Missstände. Investoren sehen dabei die Geldanlage als Möglichkeit, über die Erzielung einer Finanzrendite hinaus einen Beitrag für soziale Gerechtigkeit und ökologische Zukunftsfähigkeit zu leisten. Dabei können - wie ebenfalls schon ausgeführt wurde - Motive des Vermeidens und des Förderns unterschieden, gleichzeitig aber unter der Bezeichnung moralische Motive zusammengefasst werden. Diesen moralischen Motiven ist gemein, dass sie auf die Gestaltung gesellschaftlicher und wirtschaftlicher Bereiche abzielen. Daneben hat sich in den letzten Jahren noch eine andere Gruppe von Investoren etabliert, welche Ethik und Nachhaltigkeit auf der Basis von außer-moralischen Motiven bzw. ausschließlich auf der Grundlage finanzieller Überlegungen berücksichtigt. Im Rahmen dieses Ansatzes werden Nachhaltigkeitsinformationen in die Finanzanalyse von Unternehmen und Projekten integriert, um zusätzliche Informationen über die Chancen und Risiken einer Geldanlage zu erhalten - technisch ausgedrückt geht es dabei um die Optimierung des Risiko-Rendite-Verhältnisses. Dieser Ansatz hat in den letzten Jahren massiv an Bedeutung gewonnen. Dieser ökonomisch motivierte Trend bei nachhaltigen Geldanlagen lässt sich auch international beobachten.

Bei diesem Ansatz wird also untersucht, welche Auswirkungen bestimmte soziale und ökologische Themen auf den Gewinn der Unternehmen haben. Welche ökonomischen Chancen und Risiken ergeben sich für Unternehmen hinsichtlich konkreter gesellschaftlicher, ökologischer und sozialer Herausforderungen? Wie kann ich als Investor auf Grundlage sozialer und ökologischer Indikatoren die finanziellen Chancen und Risiken einer Geldanlage besser einschätzen? Im Vordergrund steht dabei in erster Linie also die Ertragssituation des Unternehmens. Das Erreichen bestimmter, für Gesellschaft und Umwelt zentraler Nachhaltigkeitsziele kann damit einhergehen, ist dem finanziellen Ziel im Ernstfall aber nachgereiht.

9 Eine ausführliche Darstellung von Investorentypen bzw. investorenspezifischer Herausforderungen kann hier aus Platzgründen nicht erfolgen. Kevin Schaefers hat z.B. zwischen ökonomistisch, konventionell und supererogatorisch Investierenden unterschieden, vgl. Kevin Schaefers, Nachhaltiges Investieren - ein wirtschaftsethisches Beratungskonzept, St. Gallener Beiträge zur Wirtschaftsethik 46, Bern 2014, S. 204-217. 


\section{Der Vorrang des Richtigen vor dem Rentablen: eine Herausforderung für die Wirtschaftsethik}

Diese Differenzierung ist bedeutsam und folgenreich: Oft können finanzielle und gesellschaftliche Motive Hand in Hand gehen, manchmal aber schließen sie einander aus. Wenn dies der Fall ist, können soziale und ökologische Anliegen auf der Strecke bleiben - wenn sich zum Beispiel herausstellt, dass eine moralisch abzulehnende Praxis wie Korruption in einem konkreten Fall mehr finanzielle Chancen bietet als Risiken enthält oder die Kommerzialisierung öffentlicher Güter - wie Bildung und Wasser - für die Gesellschaft zwar problematisch, für Unternehmen aber rentabel ist. Natürlich ist es nicht verwerflich, Nachhaltigkeitsaspekte auch vor dem Hintergrund ökonomischer Rentabilität zu betrachten - im Gegenteil: es gibt gute Gründe dafür, dass sich nachhaltiges Wirtschaften auch ökonomisch bezahlt machen kann und soll. Aber verantwortliches Investieren meint mehr, nämlich den Vorrang des Richtigen vor dem Rentablen - auch und gerade dann, wenn das Ertragschancen einschränkt.

Die Unterscheidung zwischen moralischer Motivation und finanzieller Materialität ist letztlich zentral für das Verständnis ethisch-nachhaltiger Geldanlagen. Es ist zu begrüßen, dass konventionelle Investoren soziale und ökologische Kriterien in ihre Investment-Prozesse einfließen lassen, auch wenn das „nur“ ökonomischen Überlegungen geschuldet ist. Eine solche Vorgehensweise im Sinne einer finanziellen Materialität ist aber noch kein ethisch-nachhaltiges Investment im engeren Sinne. Verantwortung bei der Geldanlage kann in Konfliktfällen nämlich bedeuten, auf Ertragsmöglichkeiten verzichten zu müssen. Denn letztlich geht es für verantwortlich Investierende nicht nur darum, die sich aus Nachhaltigkeitssicht ergebenden Veränderungsprozesse ökonomisch erfolgreich zu nutzen, sondern auch und vor allem darum, die notwendige Transformation unseres Wirtschaftssystems mit ihrem Anlageverhalten überhaupt erst zu ermöglichen.

Um es deutlich zu machen: eine moralisch motivierte und an der Transformation wirtschaftlicher Prozesse ausgerichtete Geldanlage zielt darauf ab, einen Beitrag zur Bewältigung sozialer und ökologischer Herausforderungen zu leisten - auch wenn das bedeuten kann, auf Renditemöglichkeiten zu verzichten. Demgegenüber geht es einer Geldanlage, bei der die finanzielle Materialität im Vordergrund steht, um die Optimierung des Risiko-Rendite-Verhältnisses - mit der möglichen Konsequenz, dass solche Nachhaltigkeitsaspekte unberücksichtigt bleiben, die keine finanziellen Vorteile bieten. Damit besteht die Gefahr, dass das transformative Element ethisch-nachhaltiger Geldanlagen verloren geht und Nachhaltigkeit zu einer Form von Renditeoptimierung verkommt. Die Idee der ethisch-nachhaltigen Geldanlage, nämlich das Einwirken auf die wirtschaftliche 
Praxis und das Ermöglichen einer nachhaltigen Entwicklung, würde damit letztlich in ihr Gegenteil verkehrt werden. ${ }^{10}$ Damit ist auch die aktuelle investmentethische Herausforderung für die Wirtschaftsethik skizziert: ist eine Ethik, die sich nur noch auf die Vermeidung von Risiken und auf die Optimierung von Renditechancen bezieht, überhaupt noch eine Ethik?

\section{Zusammenfassung und Fazit}

Die Bekanntheit und das Umfeld der nachhaltigen Geldanlage haben sich in den letzten Jahren nicht zuletzt aufgrund der veränderten gesellschaftspolitischen Rahmenbedingungen und der zunehmenden Professionalisierung deutlich verbessert. Mittlerweile stehen Investoren verschiedene Möglichkeiten zur Verfügung, um soziale und ökologische Verantwortung bei der Geldanlage wahrzunehmen. Verschiedene Anlagestrategien wie Ausschlusskriterien, Best in Class-Ansatz oder Engagement können so kombiniert werden, dass Investierende eine speziell auf ihre Voraussetzungen abgestimmt Anlagestrategie festlegen können. Von zentraler Bedeutung ist es, die unterschiedlichen Motive der Investierenden zu beachten. Dass die Berücksichtigung von Ethik und Nachhaltigkeit auch ökonomisch vernünftig ist und dazu führen kann, das Rendite-Risiko-Verhältnis zu optimieren, ist ein wesentlicher Grund für das anhaltende Interesse an ethisch-nachhaltigen Geldanlagen.

Diese „finanzielle Materialität“ ist aber ein zweischneidiges Schwert und kann dazu führen, dass es $\mathrm{zu}$ einer folgenschweren Akzentverschiebung bei ethisch-nachhaltigen Geldanlagen kommt. Für die weitere Entwicklung der ethisch-nachhaltigen Geldanlage wird es deshalb wichtig sein, die Qualität von Anlagestilen und -produkten vor dem Hintergrund der Debatte um finanzielle Materialität kritisch zu diskutieren. Für Investierende ist es deshalb wichtig, sich genau über das hinter einem Anlageprodukt stehende Materialitätsverständnis zu informieren. Die Wirtschaftsethik ist vor diesem Hintergrund gefordert und kann einen wichtigen Beitrag leisten, um das transformative Element der ethisch-nachhaltigen Geldanlage zu stärken.

10 Siehe hierzu auch: Klaus Gabriel, Primat der Ethik. Die kirchliche Geldanlage vor dem Hintergrund der Cooperatio ad malum-Debatte, in: Michael Rosenberger / Walter Schaupp (Hg.), Ein Pakt mit dem Bösen? Die moraltheologische Lehre von der,Cooperatio ad malum ‘ und ihre Bedeutung heute, Münster 2015, S. 201-210. 


\section{Quellen}

Deutsche Bischofskonferenz / Zentralkomitee der deutschen Katholiken, Ethisch-nachhaltig investieren. Eine Orientierungshilfe für Finanzverantwortliche katholischer Einrichtungen in Deutschland, 2015.

Europäische Kommission, Aktionsplan: Finanzierung nachhaltigen Wachstums, Mitteilung der Kommission vom 08.03.2018/COM/2018/97, vgl. https://eur-lex.europa.eu/le gal-content/DE/TXT/PDF/?uri=CELEX:52018DC0097\& from=EN (letzter Zugriff 17.05.2019).

FERI Cognitive Finance Institute, Impact Investing: Konzepte, Spannungsfelder und Zukunftsperspektiven. Eine Orientierung für private und institutionelle Investoren, vgl. https://fa-se.de/static/fa_se_de/uploads/2019/02/FERI-CFI-Impact-2019.pdf (letzter Zugriff 17.05.2019).

Gabriel, Klaus, Verantwortlich Investierende: Motive, Maßstäbe und Handlungsoptionen von Kapitalanlegern, in: Manfred Stüttgen (Hg.), Ethik von Banken und Finanzen, Zürich 2017, S. 57-75.

Gabriel, Klaus, Primat der Ethik. Die kirchliche Geldanlage vor dem Hintergrund der Cooperatio ad malum-Debatte, in: Michael Rosenberger / Walter Schaupp (Hg.), Ein Pakt mit dem Bösen? Die moraltheologische Lehre von der, Cooperatio ad malum' und ihre Bedeutung heute, Münster 2015, S. 201-210.

Gabriel, Klaus / Schlagnitweit, Markus, Das gute Geld. Ethisches Investment - Hintergründe und Möglichkeiten, Innsbruck 2009.

Kirchenamt der Evangelischen Kirche in Deutschland (EKD) (Hg.), Leitfaden für ethisch nachhaltige Geldanlage in der evangelischen Kirche, EKD-Text 113, aktualisierte Fassung in der vierten Auflage 2019.

Österreichische Bischofskonferenz, Finanzanlagen als Kooperation. Richtlinie Ethische Geldanlagen der Österreichischen Bischofskonferenz und der Ordensgemeinschaften Österreichs (Kurzname FinAnKo), veröffentlicht im Amtsblatt Nr. 74 der Österreichischen Bischofskonferenz am 01.01.2018.

Schaefers, Kevin, Nachhaltiges Investieren - ein wirtschaftsethisches Beratungskonzept, St. Gallener Beiträge zur Wirtschaftsethik 46, Bern 2014.

Vogt, Markus, Prinzip Nachhaltigkeit. Ein Entwurf aus theologisch-ethischer Perspektive, München 2009. 


\section{Georges Enderle (University of Notre Dame, USA)}

\section{Unternehmensverantwortung für weniger Einkommensungleichheit}

\section{Einführung}

In ihrer Einleitung zum Buch Eine Wirtschaft, die Leben fördert (2017) weist Ingeborg Gabriel ${ }^{1}$ darauf hin, dass Papst Franziskus in seiner Antrittsenzyklika Evangelii Gaudium die soziale Ungleichheit als zentrale Wunde des gegenwärtigen Systems der Weltwirtschaft kritisiert. Soziale Ungleichheit muss zu Gewalt und Radikalisierung in einer jungen, vom Wohlstand ausgeschlossenen Bevölkerung führen, mit all den negativen gesellschaftlichen Folgen, die dies notwendig nach sich zieht. Eine entscheidende Dimension dieser sozialen Ungleichheit ist die extreme und skandalöse Ungleichheit der Einkommens- und Vermögensverteilung in vielen Ländern. Sie hat seit der Finanzkrise von 2007-2008 und der Großen Rezession viele öffentliche Debatten und wissenschaftliche Diskussionen ausgelöst. Dabei stellte sich heraus, dass die zunehmende Ungleichheit schon seit den 1980er Jahren eingesetzt hatte. Diese Entwicklungen sind nun in zahlreichen Veröffentlichungen dokumentiert. ${ }^{2}$

Es ist bemerkenswert, dass viel weniger Literatur zur Einkommensungleichheit in Organisationen im Allgemeinen und Unternehmen im Besonderen $\mathrm{zu}$ finden ist. Zudem gibt es nur wenige jüngere Arbeiten zur ebenso wichtigen

1 Ingeborg Gabriel / Peter G. Kirchschläger / Richard Sturn (Hg.), Eine Wirtschaft, die Leben fördert. Wirtschafts- und unternehmensethische Reflexionen im Anschluss an Papst Franziskus, Mainz 2017, hier: S. 14-15.

2 Zum Beispiel: Robert H. Frank, Falling Behind. How Rising Inequality Harms the Middle Class, Berkeley 2007; Richard Wilkinson / Kate Pickett, The Spirit Level. Why Greater Equality Makes Societies Stronger, New York 2010; Thomas Piketty, Capital in the Twenty-First Century, Cambridge, MA 2014; Ders., The Economics of Inequality, Cambridge, MA 2015; Martin Wolf, The Shifts and the Shocks, London 2014; Anthony B. Atkinson, Inequality. What Can Be Done?, Cambridge, MA 2015; Joseph E. Stiglitz, The Great Divide: Unequal Societies and What We Can Do About Them, New York 2015; Inequality: What Causes It. Why It Matters. What Can Be Done, Foreign Affairs 2016; Mervyn A. King, The End of Alchemy. Money, Banking and the Future of the Global Economy, London 2016; Heather Boushey / Bradford DeLong / Marshall Steinbaum, After Picketty: The Agenda for Economics and Inequality, Cambridge, MA 2017. 
Frage, wie sich die Einkommensungleichheit in Organisationen auf die Einkommensungleichheit in Ländern und weltweit tatsächlich auswirkt und auswirken sollte. Der folgende Beitrag behandelt die erste Frage nach der Unternehmensverantwortung für weniger Einkommensungleichheit in wirtschaftlichen Organisationen, während für die zweite Frage auf den längeren Artikel des Autors $^{3}$ verwiesen werden muss.

\section{Unternehmensverantwortung für weniger Einkommensungleichheit in wirtschaftlichen Organisationen}

\subsection{Einige grundlegende Bemerkungen}

Bevor ich auf die Fragen der Ungleichheit eingehe, möchte ich kurz den Begriff der Unternehmensverantwortung erläutern, wie er in diesem Beitrag verstanden und auch von den Leitprinzipien für Wirtschaft und Menschenrechte der Vereinten Nationen ${ }^{4}$ gebraucht wird. Eine solche Klärung scheint angezeigt zu sein, da der Begriff in vielen Diskussionen zur „Corporate Social Responsibility“ oder CSR unreflektiert und nachlässig verwendet wird. ${ }^{5}$ Natürlich erklären diese Bemerkungen nur einige wesentliche Aspekte, die weiterhin kontrovers diskutiert werden.

Der Begriff der Verantwortung ist zu einem Schlüsselbegriff der zeitgemäßen Ethik geworden - sowohl im praktischen Leben wie auch in den Wissenschaften - und drückt die moralische Verpflichtung eines Akteurs aus. ${ }^{6}$ Nach Walter $S_{\text {chulz }}^{7}$ enthält der Verantwortungsbegriff eine spannungsvolle Polarität, die Max Webers Antithese von Gesinnungsethik und Verantwortungsethik überwindet. ${ }^{8}$ Auf der einen Seite hebt der innere Pol die Relevanz der innerlichen Entscheidung hervor, das heißt, Ethik als „Selbsteinsatz aus Freiheit“. Auf der anderen Seite hat der Selbsteinsatz aus Freiheit seinen Ausgangs- und Zielpunkt in einem „welthaften Bezug“(dem äußeren Pol). Verantwortung als relationaler

3 Georges Enderle, Corporate Responsibility for Less Income Inequality, in: Review of Social Economy 76/4/2018, S. 399-421.

4 Vereinte Nationen, Hochkommissariat für Menschenrechte, Leitprinzipien für Wirtschaft und Menschenrechte. Umsetzung des Rahmens der Vereinten Nationen „Schutz, Achtung und Abhilfe", New York-Genf 2011.

5 Siehe Georges Enderle, Clarifying the Terms of Business Ethics and Corporate Social Responsibility, in: Business Ethics Quarterly 20/4/2010, S. 730-732.

6 Georges Enderle, Handlungsorientierte Wirtschaftsethik. Grundlagen und Anwendungen, Bern 1993, S. 145-153.

7 Walter Schulz, Philosophie in der veränderten Welt, Pfullingen 1972, hier: S. 632.

8 Siehe Georges Enderle, The Ethics of Conviction Versus the Ethics of Responsibility: A False Antithesis for Business Ethics, in: Journal of Human Values 13/2/2007, S. 83-94. 
Begriff ist immer in einem oder mehreren Akteuren „verankert“ (wer ist verantwortlich?), bezieht sich auf eine Instanz, vor der man verantwortlich ist (zum Beispiel gegenüber Anspruchsgruppen, Gerichten, einem Lebenspartner oder dem Gewissen) und betrifft eine sehr konkrete Sache, für die man verantwortlich ist.

Dieser dreigliedrige Begriff kann die wesentlichen Komponenten der Unternehmensverantwortung klären. Erstens, Verantwortung ist nicht ein freistehendes ethisches Prinzip (wie zum Beispiel „Füge keinen Schaden zu!“), sondern muss auf einen Akteur bezogen sein. Wie die VN-Leitprinzipien schließen wir als Akteure alle wirtschaftlichen Unternehmen ein: von gigantischen globalen Konzernen und großen Firmen mit beschränkter Haftung zu Staatsbetrieben, Familienunternehmen, mittleren, kleinen und kleinsten Unternehmen. Die Welt der wirtschaftlichen Unternehmen ist unübersehbar. Nicht nur verfolgen die Unternehmen eine enorme Vielfalt von Tätigkeiten; sie weisen auch gewaltige Unterschiede in der Größe, Struktur, rechtlichen Form und Unternehmensführung auf. Darum erhebt sich die Frage: Ist es sinnvoll - und wenn ja, wie - die Unternehmen als ethisch verantwortliche Akteure zu konzipieren und von Unternehmensverantwortung im eigentlichen Sinn zu sprechen?

Die Frage wurde über Jahrzehnte debattiert und brachte eine umfangreiche Literatur hervor, auf die hier nicht eingegangen werden kann. ${ }^{9}$ Ich schlage vor, das Unternehmen als „moralischen Akteur“ zu verstehen, insofern es eine relativ freistehende formale Struktur im Sinn von James Coleman besitzt: Es hat Kontrolle über Ressourcen und Ereignisse, Interessen in Ressourcen und Ereignisse und die Fähigkeit, Taten zu setzen, um diese Interessen unter seiner Kontrolle zu verwirklichen. ${ }^{10}$ Unternehmen als moralische Akteure sind weder „moralische Personen“, die ein Gewissen haben und Ziele in sich selbst sind, noch „amoralische Akteure“ ohne die Fähigkeit, Taten zu setzen. Sie bilden kollektive Organe, die verschieden, aber nicht getrennt von Personen sind, einen gewissen Handlungsfreiraum besitzen, mit Absicht handeln (oder wenigstens

9 Siehe: Denis Arnold, Corporate Moral Agency, in: Midwest Studies in Philosophy XXX/2006, S. 279-291; Richard T. De George, Business Ethics, 7.Aufl., Boston 2010; Peter A. French, The Corporation as a Moral Person, in: Midwest Studies in Philosophy 30/1/1979, S. 279-291; Milton Friedman, The Social Responsibility of Business Is to Increase Its Profit, in: The New York Times Sunday Magazin, September $13^{\text {th }}$ 1970; Kendy M. Hess, (Book of:) The Fallacy of Corporate Moral Agency, by David Rönnegard, Dordrecht 2015, in: Business Ethics Quarterly 26/4/2016, S. 557-560; Seumas Miller, Collective Moral Responsibility: An Individualist Accout, in: Midwest Studies in Philosophy XXX/2006, S. 176-193; Lynn S. Paine, Value Shift. Why Companies Must Merge Social and Financial Imperatives to Achieve Superior Performance, New York 2003, Chapter 4; David Rönnegard, The Fallacy of Corporate Moral Agency, Dordrecht 2015; Patricia H. Werhane, Corporate Moral Agency and the Responsibility to Respect Human Rights in the UN Guiding Principles: Do Corporations Have Moral Rights?, in: Business and Human Rights Journal 1/1/2016, S. 5-20.

10 James S. Coleman, Foundations of Social Theory, Cambridge, MA 1990, hier: S. 542. 
absichtliches Verhalten anzeigen), um ihre Ziele zu erreichen, und Auswirkungen auf Menschen und Natur haben. Als moralische Akteure tragen sie „Unternehmensverantwortung" und können für ihr Verhalten zur Verantwortung gezogen werden. Sie sind Akteure auf der Meso-Ebene - im Unterschied zur Makro- (oder systemischen) und Mikro- (oder individuellen) Ebene. Wenn jedoch Unternehmen (von geringer Größe) keine korporativen und deshalb auch keine moralischen Akteure sind, sind die Träger der Unternehmensverantwortung Personen und Gruppen (das heißt, auf der Mikro-Ebene).

Der zweipolige Begriff der Unternehmensverantwortung umfasst eine „innere“ und eine „äußere“ Seite. Der Einsatz des Unternehmens in seinem Handlungsfreiraum muss in der Unternehmenskultur und -strategie verkörpert sein, und der welthafte Bezug des Unternehmensverhaltens muss sich in seinen Auswirkungen auf Menschen, Gesellschaften und Natur ausdrücken.

\subsection{Verantwortlich für was: Wieviel weniger Einkommensungleichheit?}

Nachdem der Träger der Unternehmensverantwortung genauer bestimmt ist, wird nun nach dem Inhalt der Unternehmensverantwortung gefragt, das heißt, um wieviel die Einkommensungleichheit im Unternehmen reduziert werden sollte. Diese inhaltliche Frage enthält zwei Aspekte: (1) Was ist die Grundlage der Ungleichheit? Und (2) was bedeutet „weniger" Einkommensungleichheit?

Die Grundlage der Ungleichheit in diesem Beitrag ist das Einkommen oder der monetäre und nicht-monetäre Verdienst, den die Personen in einem Unternehmen für ihre Arbeit erhalten, seien es Arbeiterinnen, Arbeiter, Angestellte oder Führungskräfte. Diese Zahlungen des Arbeitgebers umfassen monetäre Leistungen (zum Beispiel Löhne, Prämien für Pensionskassen, Aktien) und Sachleistungen (zum Beispiel Kindergeld); sie sind also nicht Leistungen, die von andern Quellen außerhalb des Arbeitgebers (wie Lebensmittelmarken der Regierung und Spendenbeiträge von philanthropischen Organisationen) erbracht werden. Ein Einkommen verdienen heißt einen Arbeitsplatz und einen Anspruch haben, was verschieden ist vom Konsumieren von Gütern und Dienstleistungen. ${ }^{11}$

Im Zusammenhang mit dem Einkommen als Grundlage steht die Frage nach der Einheit, für die das Einkommen verdient wird. Ist es die individuelle Person, die tatsächlich im Unternehmen arbeitet? Oder ist es die Familie, die den andern Elternteil und Kinder einschließt? Oder ist es der (größere) Haushalt, der zusätzliche Glieder wie erwachsene Kinder und andere Verwandte oder Freunde umfasst? Diese Frage der Untersuchungseinheit ist besonders wichtig für

11 Siehe Atkinson, Inequality, hier: S. 35. 
Niedrig-Einkommen-Verdiener und die Definition des Minimal- und existenzsichernden Lohns (siehe unten).

Der zweite Aspekt der inhaltlichen Frage der Unternehmensverantwortung betrifft das Ausmaß der Ungleichheit: Was wird mit „weniger“ Einkommensungleichheit gemeint? Wohlverstanden, die Frage zielt nicht auf eine absolute Gleichheit für alle, sondern sucht eine Antwort in der Richtung auf weniger Einkommensungleichheit. Dies kann auf verschiedene Weisen erfolgen. „Weniger" kann sich auf die ganze Einkommensverteilung im Unternehmen beziehen und mit verschiedenen Koeffizienten (zum Beispiel dem Gini-Koeffizient) gemessen werden. ${ }^{12}$ Eine andere Art der Messung unterscheidet verschiedene Segmente (zum Beispiel unterstes und oberstes Quintil) und misst deren Verhältnis (zum Beispiel 1:20). In diesem Beitrag wird vorgeschlagen, die Ungleichheit der Einkommen als Verhältnis von existenzsicherndem Lohn („living wage“) und (höchstem) Entschädigungspaket („compensation package“) des Geschäftsführers („Chief Executive Officer“) zu erfassen. Mit diesem Indikator können nicht nur relative (zum Beispiel 20mal größer), sondern auch absolute Größen erfasst werden. Zudem gibt er konkretere wirtschaftliche und außerwirtschaftliche Vergleichspunkte innerhalb und zwischen den Unternehmen und in der Gesellschaft.

Mit Hilfe dieser begrifflichen Klärungen wird der Inhalt der Unternehmensverantwortung für weniger Einkommensungleichheit als „ein angemessener, wohl begründeter und ausführbarer Vorschlag" unterbreitet, der die Ziele des existenzsichernden Lohns am unteren Ende und das „annehmbare“ oberste Einkommen am oberen Ende der Verteilung festlegt. Für beide Fixpunkte werden ethische und wirtschaftliche Argumente geltend gemacht.

\subsection{Unternehmensverantwortung für die Zahlung von wenigstens existenzsichernden Löhnen}

Als erste Annäherung kann der existenzsichernde Lohn („living wage“) definiert werden als „der Geldbetrag, den ein vollzeitlicher Arbeitnehmer benötigt, um entweder die Grundbedürfnisse im Leben zu decken oder die Armutsgrenze zu übersteigen. Er gründet auf dem Prinzip, dass Menschen, die vollzeitig arbeiten, genug Geld machen können, um ihre Familien finanziell zu unterstützen. ${ }^{\text {"13 }}$ Der existenzsichernde Lohn ist eine alte Forderung und hat unzählige Kontroversen

12 Siehe Ambros Lüthi, Messung wirtschaftlicher Ungleichheit, Berlin 1980.

13 Denis Collins, Living Wage, in: Robert W. Kolb (Hg.), Encyclopedia of Business Ethics and Society, 2. Aufl., Thousand Oaks 2018, S. 2102-2105 (übersetzt von G.E.). 
bis zum heutigen Tag hervorgerufen, auf die hier nicht eingegangen werden kann. $^{14}$

Für die Forderung, dass die Unternehmen allen Arbeitnehmerinnen und Arbeitnehmern wenigstens einen existenzsichernden Lohn zahlen, sprechen nach meiner Auffassung folgende ethischen und wirtschaftlichen Gründe. Im Gegensatz zum deterministischen Gesetz von Angebot und Nachfrage des Arbeitsmarktes wird hier als empirische Tatsache angenommen, dass Wirtschaftsunternehmen und ihre Führungskräfte im Wirtschaftssystem des freien Unternehmertums einen gewissen Handlungsfreiraum und Macht haben, Entscheidungen über die niedrigen Löhne der Arbeitnehmerinnen und Arbeitnehmer zu treffen. Diese Handlungsfreiheit schließt ethische Verantwortung für ihre Entscheidungen ein - gemäß dem Grundsatz: Mit (viel) Macht kommt (viel) Verantwortung.

Diese Unternehmensverantwortung besteht darin, das Menschenrecht zu achten, das im Artikel 23.3 der Allgemeinen Erklärung der Menschenrechte festgehalten ist: „Jeder Mensch, der arbeitet, hat das Recht auf angemessene und befriedigende Entlohnung, die ihm und seiner Familie eine der menschlichen Würde entsprechende Existenz sichert (... “. ${ }^{15}$ Zur Rechtfertigung dieses Anspruchs machen die VN-Leitprinzipien für Wirtschaft und Menschenrechte geltend, dass die Unternehmen für ihre direkten negativen Auswirkungen auf Menschenrechte verantwortlich sind:

Die Verantwortung, die Menschenrechte $\mathrm{zu}$ achten, erfordert, dass Wirtschaftsunternehmen

(a) es vermeiden, durch ihre eigene Tätigkeit nachteilige Auswirkungen auf die Menschenrechte zu verursachen oder dazu beizutragen, und diesen Auswirkungen begegnen, wenn sie auftreten;

(b) bemüht sind, negative Auswirkungen auf die Menschenrechte zu verhüten oder zu vermindern, die auf Grund einer Geschäftsbeziehung mit ihrer Geschäftstätigkeit, ihren Produkten oder Dienstleistungen unmittelbar verbunden sind, selbst wenn sie nicht zu diesen Auswirkungen beitragen. ${ }^{16}$

Weil Unternehmen mit ihrer Lohnpolitik eine direkte Auswirkung auf jede Arbeitnehmerin und jeden Arbeitnehmer haben, sind sie ethisch verantwortlich, eine angemessene und befriedigende Entlohnung zu zahlen, die ihnen und ihren Familien eine menschenwürdige Existenz sichert. Zudem, mit moralischem Einfallsreichtum und unternehmerischem Geist, haben die meisten Unterneh-

14 Siehe Enderle, Corporate Responsibility.

15 Allgemeine Erklärung der Menschenrechte Art.23(3), vgl. https://www.menschenrechtserk laerung.de/die-allgemeine-erklaerung-der-menschenrechte-3157/ (letzter Zugriff: 13.04. 2020).

16 Vereinte Nationen, Leitprinzipien, \#13. 
men auch die Fähigkeit, dieses Recht zu achten, wenn nicht unmittelbar, so wenigstens längerfristig. Innovation kann die Qualität der Arbeitsplätze verbessern, ohne die Quantität zu verringern. Kurz gesagt, Unternehmensverantwortung ist Selbsteinsatz aus Freiheit in der konkreten Herausforderung, existenzsichernde Löhne zu zahlen.

Das Recht auf einen existenzsichernden Lohn gründet in der persönlichen Würde der Arbeitenden und in ihrem Recht auf ein menschenwürdiges Existenzminimum als Bürgerinnen und Bürger und nicht bloß als Arbeitskräfte. Persönliche Würde heißt fähig zu sein, ein würdiges Leben zu führen und die Mittel für einen angemessenen Lebensunterhalt $\mathrm{zu}$ haben, nicht nur für sich, sondern auch für die Familie mit ein oder mehreren Kindern, bis sie erwachsen sind. Der existenzsichernde Lohn ist definiert in Bezug auf die sozioökonomischen Standards der Gemeinde, in der die Arbeitenden leben, und notwendigerweise variiert je nach Zeit und Raum. Obschon es nicht leicht ist, einen genauen existenzsichernden Lohn zu definieren, ist es möglich, ihn innerhalb einer gewissen Bandbreite der Unschärfe zu bestimmen. ${ }^{17}$ Zudem muss er aus ethischen und wirtschaftlichen Gründen auch festgelegt werden.

Zusätzlich zu den ethischen Argumenten gibt es auch starke mikro- und makro-ökonomische Argumente, die für existenzsichernde Löhne sprechen. Nach Donald Stabile ${ }^{18}$ können sie in drei Gruppen eingeteilt werden. (1) Nachhaltigkeit als langfristige Perspektive über Generationen verlangt, dass die Arbeitskraft nicht aufgebraucht, sondern erneuert und gestärkt wird. Parasitäre Branchen und Unternehmen, die keine existenzsichernden Löhne zahlen, nehmen von der Natur, den Menschen und der Gesellschaft mehr weg, als sie zurückgeben. (2) Das Fähigkeitsargument nimmt die Arbeitenden nicht nur als Produktivkräfte, sondern auch als Menschen ernst. Löhne sollen sie motivieren, ihre Fähigkeiten als Mitglieder sowohl der Unternehmen als auch der Gesellschaft zu verbessern. Insoweit Löhne mit Arbeitsproduktivität positiv korreliert sind, zahlen sich höhere Löhne durch höhere Produktivität aus. ${ }^{19}$ (3) Das Externalitätenargument besagt, dass das Nichtzahlen von existenzsichernden Löhnen netto negative Externalitäten verursacht, indem es Drittparteien schadet, die nicht in Angebot und Nachfrage von Löhnen involviert sind. Ähnlich zum Nachhaltigkeitsargument kann man geltend machen, dass diejenigen, die weniger als den existenzsichernden Lohn erhalten, die notwendigen Ressourcen für einen angemessenen Lebensunterhalt nicht bekommen. Wenn dieser Mangel

17 Siehe zum Beispiel den ALICE Report 2018, Indiana, vgl. https://www.iuw.org/alice (letzter Zugriff: 13.04.2020).

18 Donald R. Stabile, The Living Wage. Lessons from the History of Economic Thought, Cheltenham, UK 2008.

19 George A. Akerlof / Janet Yellen, Fairness and Unemployment, in: American Economic Review 78/1988, S. 44-49. 
an Ressourcen nicht der arbeitenden Person schadet, muss die Unterstützung von anderen Personen (zum Beispiel Familienangehörigen) oder Institutionen (zum Beispiel Regierung oder Wohltätigkeitsorganisationen) erfolgen und kann die Form von privaten und/oder öffentlichen Gütern annehmen. Auf jeden Fall ist es nicht der Arbeitgeber, der diese Kosten trägt.

Gegen all diese Gründe zugunsten eines existenzsichernden Lohns mag man einwenden, dass dieser Vorschlag, obschon er angemessen und wohl begründet ist, nicht ausgeführt werden kann. Für die Unternehmen sei es zu teuer, die sehr tiefen Löhne auf das Niveau der existenzsichernden Löhne zu heben. Falls das Gesetz es erfordern sollte, müssten die Unternehmen Leute entlassen, die dann von der Regierung oder wohltätigen Organisationen unterstützt werden müssten.

Um auf diese Schwierigkeiten zu antworten, sollten folgende Überlegungen beachtet werden: (1) Die meisten Unternehmen haben einen hinreichend großen Handlungsfreiraum, um eine solche Lohnerhöhung zu verkraften. (2) Die Kosten einer solchen Lohnerhöhung sind normalerweise nicht übermäßig groß im Verhältnis zur Unternehmensbilanz, wenn moralischer Einfallsreichtum verwendet wird. $^{20}$ (3) Wenn die Lohnerhöhung eine schwere Last für das Unternehmen bedeutet, kann sie stufenweise und über eine längere Zeitdauer eingeführt werden. (4) Um die Kosten dieser steigenden Löhne zu decken, kann eine Umverteilung innerhalb des Unternehmens stattfinden, das heißt, indem die obersten Gehälter auf ein „ethisch annehmbares“ Niveau reduziert werden (siehe nächster Abschnitt).

Abschließend sei festgehalten, dass sich die Diskussion der Unternehmensverantwortung für wenigstens existenzsichernde Löhne auf wirtschaftlich entwickelte Länder konzentriert hat. Selbstverständlich ist der existenzsichernde Lohn nicht nur eine Herausforderung für diese Länder. Mit der wachsenden wirtschaftlichen und politischen Verflechtung über die nationalen Grenzen hinaus ist der Kampf für existenzsichernde Löhne eine dringliche Angelegenheit in der globalen Wirtschaft im Allgemeinen und in den globalen Lieferketten im Besondern geworden. ${ }^{21}$ Deshalb bleibt sehr viel für existenzsichernde Löhne in der internationalen Wirtschaft zu tun, sowohl in der Forschung als auch in der Praxis.

20 Siehe zum Beispiel: Joanne B. Ciulla, Drops in the Pond: Leaders, Morality, and Imagination, in: Georges Enderle / Patrick E. Murphy (Hg.), Ethical Innovation in Business and the Economy, Cheltenham, UK 2015, S. 119-136.

21 Siehe Oxfam, Steps Towards a Living Wage in Global Supply Chains, in: Oxfam Issue Briefing, December 2014; Georges Enderle, How Can Universities Promote Corporate Responsibility in Their Supply Chains? The Experience of the University of Notre Dame, in: Joanne B. Ciulla I Tobey Scharding (Hg.), Ethical Business Leadership in Troubling Times, Cheltenham, UK 2019, S. 159-186. 


\subsection{Unternehmensverantwortung für ethisch annehmbare oberste Einkommen}

Nachdem der existenzsichernde Lohn als erforderliche untere Grenze der Einkommensverteilung im Unternehmen behandelt wurde, wird nun die schwierigere Frage untersucht, wie eine ethisch annehmbare obere Grenze der höchsten Einkommen (das heißt hier des obersten Geschäftsführers) identifiziert und gerechtfertigt werden kann. Diese zweite Bezugsgröße ist notwendig, wenn auf eine Reduzierung der Einkommensverteilung im Unternehmen abgezielt werden soll. Wenn nämlich eine obere Grenze nicht festgelegt wird, ist es möglich, dass die Ungleichheit zunimmt, selbst wenn die untere Grenze fixiert ist. Die obersten Einkommen können weiterhin wachsen, auch wenn existenzsichernde Löhne bezahlt werden.

Wie Randall Thomas und Jennifer Hill ${ }^{22}$ feststellen, sind die Gehälter der obersten Führungskräfte wieder ein zentrales Thema der öffentlichen Diskussion und der staatlichen Regulierung geworden, insbesondere wegen Unternehmensskandalen und wirtschaftlichen Krisen, einschließlich der globalen Finanzkrise. Außerdem bemerkt Atkinson, dass:

„die Explosion von sehr hohen Gehältern zwar in einigen entwickelten Ländern stattgefunden hat, aber nicht in anderen. Dies legt nahe, dass institutionelle Unterschiede zwischen den Ländern eine zentrale Rolle gespielt haben und nicht allgemeine und a priori universelle Ursachen wie technologische Entwicklung. ${ }^{\text {"23 }}$

Als konkretes Beispiel kann die Entwicklung der höchsten Gehälter in den Vereinigten Staaten dienen. Das Entschädigungspaket des obersten Geschäftsführers (CEO) umfasst das Basis-Gehalt, Boni, Aktienoptionen und andere Zahlungen $^{24}$ :

„In Bezug auf alle [S\& P 500] Unternehmen war das durchschnittliche Gehalt des CEOs \$13.8 Millionen per Jahr [2014], das durchschnittliche mediane Einkommen des Arbeiters war ungefähr $\$ 77,800$ und das durchschnittliche Verhältnis des CEO-Gehalts zum medianen Arbeitereinkommen war 204. In andern Worten, CEOs verdienen im Durchschnitt etwa $204 \mathrm{mal}$ mehr als sein oder ihr Arbeiter verdient. ${ }^{\star 25}$

22 Randall S. Thomas / Jennifer G. Hill (Hg.), Research Handbook on Executive Pay, Cheltenham, UK 2012, hier: S. 1.

23 Atkinson, Inequality, hier: S. 315 (übersetzt von G.E.).

24 Siehe Robert W. Kolb, Too Much Is Not Enough: Incentivess in Executive Compensation, New York 2012; Robert C. Posen / S.P. Kothari, Decoding CEO Pay: The Truth Is Burried in the Fine Print - and That's a Problem, in: Harvard Business Review 95/4/2017, S. 78-84.

25 Andrew Chamberlain, vgl. www.glassdoor.com/research/ceo-pay-ratio (2015) (übersetzt von G.E.), (letzter Zugriff: 16.05.2019). 
David Zaslav, 2014 CEO von Discovery Communications, rangiert mit $\$ 156,077,914$ an erster Stelle (Medianeinkommen des Arbeiters: \$80,000; Verhältnis: 1,951). Im Gegensatz dazu verdiente, zum Beispiel W. Craig Jelinek, CEO von Costco Wholesale, \$5.6 Millionen (Medianeinkommen des Arbeiters: $\$ 30,555$; Verhältnis: 184), und viele CEOs von kleinen und mittleren Unternehmen verdienten weniger als \$1 Million.

Für eine drastische Reduzierung der extrem hohen CEO-Gehälter können zahlreiche ethische und wirtschaftliche Argumente angeführt werden, wobei offenbleibt, wieviel in absoluten und relativen Zahlen diese Reduzierung sein soll. Jeffrey Moriarty vertritt die gleiche Ansicht aus philosophischer Perspektive und verweist auf reichhaltige Literatur. ${ }^{26}$

Eine erste ethische Überlegung betrifft das Verständnis des Unternehmens. Wenn es als eine Gemeinschaft von Personen verstanden wird, ${ }^{27}$ bestehen - direkte oder indirekte - menschliche Beziehungen zwischen Personen. Dann entstehen Erwartungen der Solidarität und der gegenseitigen Achtung, und - wenn sie erfüllt werden - sind sie eine starke Motivation, zusammenzuarbeiten und „sich im gleichen Boot zu fühlen“. Das ist nicht der Fall, wenn das Unternehmen als ein Stück Eigentum, eine Produktionsfunktion oder eine Verbindung von Verträgen konzipiert wird.

Wenn die Einkommen im Unternehmen außerordentlich weit verteilt sind, treibt ein Sinn für Fairness einen zu der Frage, wie die verschiedenen Anspruchsgruppen, besonders die Angestellten und Aktionäre, im Verhältnis zu ihren jeweiligen Beiträgen zum Unternehmenserfolg entlohnt werden sollen. ${ }^{28}$ Wie im vorhergehenden Abschnitt gezeigt wurde, erfordert Fairness auch, dass jede Arbeitnehmerin und jeder Arbeitnehmer wenigstens einen existenzsichernden Lohn verdient. Wenn die Einkommen der Arbeiterschaft und der Aktionäre beschränkt sind, sind unbeschränkte CEO-Gehälter ethisch nicht vertretbar.

Es stellt sich deshalb die Frage, auf welcher Grundlage die CEO-Gehälter berechtigterweise begrenzt werden können und wer die Autorität hat, diese Begrenzungen aufzuerlegen. Die Standardargumente in der Literatur sind die Ausübung von Macht, die Kräfte des Marktes und die Entlohnung der verdienten

26 Jeffrey Moriarty, Do CEOs Get Paid Too Much?, in: Business Ethics Quarterly 15/2/2005, S. 257-281; Jeffrey Moriarty, How Much Compensation Can CEOs Permissibly Accept?, in: Business Ethics Quarterly 19/2/2009, S. 235-250.

27 Wie dies Papst Johannes Paul II. in seiner Enzyklika Centesimus Annus (Nr. 25) postuliert: www.vatican.va/content/leo-xiii/pt/encyclicals/documents/hf_l-xiii_enc_15051891_rerumnovarum.html (letzter Zugriff: 13.04.2020).

28 Siehe auch Sumantra Ghoshal, Bad Management Theories Are Destroying Good Management Practices, in: Academy of Management Learning \& Education 4/1/2005, S. 75-91. 
Leistung. ${ }^{29}$ Das Machtargument besagt, dass die amerikanischen CEOs so mächtig sind, dass ihre Entlohnung nur durch sie selber (und nicht durch den Vorstand oder andere Instanzen) begrenzt werden kann. Das zweite Argument basiert auf der Agency-Theorie, die auf den Informations- und Transaktionskosten und der rechtlichen und regulatorischen Rahmenordnung aufbaut und die CEO-Gehälter und deren Begrenzung mit optimalen Verträgen erklärt. Insofern die Agency-Theorie theoretisch begründet ist, die Kosten genau ermittelt werden können und die Rahmenordnung die Präferenzen der Bürgerinnen und Bürger widerspiegelt, ist das CEO-Gehalt gerechtfertigt, auf welchem Niveau es auch immer festgesetzt wird. Das dritte Argument besagt, dass das Entschädigungspaket auf der Leistung des Unternehmens beruhen muss. Wenn die Leistung im vorigen Jahr gewachsen ist, soll der Geschäftsführer ein entsprechend höheres Gehalt bekommen; und wenn sie nachgelassen hat, soll der Gehalt entsprechend reduziert werden. Dabei wird die Unternehmensleistung gewöhnlich mit dem Aktienkurs gemessen und die Entlohnung der Führungskräfte teilweise mit Aktienoptionen (als Anreiz, im Unternehmensinteresse zu handeln) ausbezahlt.

Diese drei Argumente können bis zu einem gewissen Grad die gegenwärtige Situation der Gehälter der obersten Führungskräfte in den USA erklären und sind deshalb hilfreich, wirksame Maßnahmen zur Begrenzung übermäßiger Gehälter zu treffen. Sie haben jedoch auch schwerwiegende theoretische Mängel und sind nicht von empirischen Studien bestätigt. ${ }^{30}$ Das Machtargument kann nicht in sich selbst gelten, sondern benötigt Legitimität und Rechtfertigung. Wenn die obersten Führungskräfte, Aufsichtsräte, Aktionäre oder andere Anspruchsgruppen nicht fähig oder willens sind, die Explosion der hohen Gehälter einzudämmen, ist es die Rolle der Regierung, einzugreifen und Begrenzungen zu setzen. Die Agency-Theorie hat sich als mangelhaft, wenn nicht gefährlich, in der globalen Finanzkrise erwiesen. Und was die Belohnung für Leistung betrifft, gründet sie weder theoretisch noch praktisch auf soliden Verdiensten der Führungskräfte, und, wenn sie vorgeschlagen wird, sollte sie konsistent sowohl beim Aufschwung wie auch beim Abschwung angewendet werden. Empirische Untersuchungen haben jedoch gezeigt, dass keine Korrelation zwischen dem

29 Siehe Thomas / Hill, Research Handbook, Introduction.

30 Siehe Anne S. Tsui / Kaifeng Jiang / Georges Enderle, Income Inequality in Organizations. Paper presented at the ,A Global Compact for Sustainable Development Conference,' University of Notre Dame, 4 April 2016; Anne S. Tsui / Georges Enderle / Kaifeng Jiang, Income Inequality in the United States: Reflections on the Role of Corporations, in: Academy of Management Review 43/1/2018, S. 156-168; Anne S. Tsui / Georges Enderle / Kaifeng Jiang, On Addressing the Puzzle of Extreme Income Inequality: A Response to Agarwal and Holmes, in: Academy of Management Review 44/2/2019, S. 1-4. 
CEO-Gehalt und der Unternehmensleistung besteht. ${ }^{31}$ Überdies haben in 1980 bis 2010 die Gehälter der obersten Führungskräfte um das Vierfache zugenommen, während die Unternehmensgewinne leicht abgenommen haben. ${ }^{32}$

Zusammenfassend kann festgehalten werden, das eine drastische Reduzierung der Gehälter der obersten Führungskräfte in den USA gerechtfertigt ist. Diese These gründet auf der unbestreitbaren Tatsache, dass diese Führungskräfte einen relativ großen Handlungsfreiraum in ihren Entscheidungen haben. Sie können ihn ausnützen und sind für ihre Handlungen ethisch verantwortlich. Die Argumente für den Status-quo sind nicht überzeugend, während die ethischen Überlegungen eine solche Reduzierung stark befürworten. Was mit diesen Kürzungen gewonnen wird, kann für manche Zwecke verwendet werden: für die interne Einkommensumverteilung im Unternehmen, Forschungsprojekte für Innovation, Ausbildungsprogramme der Belegschaft und andere Aktionen zur Stärkung der Motivation. Weit davon entfernt, dem Unternehmen zu schaden, sind diese und andere Maßnahmen sehr wirksam, seine Produktivität zu steigern.

Nachdem die Dringlichkeit einer drastischen Reduzierung der Gehälter der obersten Führungskräfte herausgestellt ist, bleibt immer noch die Frage, um wieviel in absoluten und relativen Größen sie reduziert werden sollen. Bei der gegenwärtigen Situation der Literatur bleibt diese Frage leider unbeantwortet. Auch ich kann keine Antwort anbieten, selbst wenn kein genauer Dollar-Betrag gesucht wird und nur eine gewisse Bandbreite von Gehältern als obere Grenze (zum Beispiel \$5-7 Millionen) festgelegt wird. Gleichwohl können verschiedene Empfehlungen helfen, praktische Lösungen anzusteuern ${ }^{33}$ : (1) Die Transparenz der obersten Einkommen in Unternehmen kann gestärkt und erweitert werden (was bereits mit der Dodd-Frank Gesetzgebung begonnen wurde). (2) Die Aktionäre können ein Mitspracherecht bei der Bestimmung der obersten Gehälter bekommen. (3) Freiwillige Gehälter-Kodizes können eingeführt werden. (4) Im öffentlichem Sektor kann eine obere Grenze der Gehälter festgelegt werden. (5) „Ein landesweiter Dialog“ kann gefördert werden, der die Verteilung der Einkommen, die Verteilung der Gewinne von einer wachsenden Wirtschaft und das Ausmaß untersucht, in dem Menschen in der Mitte und darunter zurückgelassen werden.

31 Lucian A. Bebchuk / Jesse M. Fried, Pay Without Performance: Overview of the Issue, in: Academy of Management Perspectives 20/1/2006, S. 5-24; Ric Marshall / Linda-Eling Lee, Are CEOs Paid for Performance? Evaluating the Effectiveness of Equity Incentives. MSCI ESG Research Inc., July 2016, S. 1-23; Roger L. Martin, Fixing the Game: Bubbles, Crashes, and What Capitalism Can Learn from the NFL, Cambridge, MA 2011.

32 Siehe Martin, Fixing the Game.

33 Siehe Atkinson, Inequality, hier: S. 133-154, S. 179-204. 


\section{Schlussbemerkung}

Soziale Ungleichheit im Allgemeinen und Einkommensungleichheit im Besondern sind zentrale Herausforderungen unserer Zeit, denen wir ausgesetzt sind, ob wir es wollen oder nicht. Sie provozieren manchmal leidenschaftliche Ausbrüche von Wut und Hilflosigkeit und manchmal eindringliche Forderungen nach durchgreifenden Gesetzen. Leider sind diese Probleme außerordentlich komplex, die nicht mit einigen einfachen Maßnahmen und ohne das Engagement vieler sozialer Akteure, einschließlich Unternehmen, gelöst werden können.

Der obige Beitrag konzentriert sich auf die Unternehmensverantwortung für weniger Einkommensungleichheit innerhalb der Organisation. Aufgrund ethischer und wirtschaftlicher Argumente können und sollen Unternehmen existenzsichernde Löhne bezahlen und die extremen Gehälter der obersten Führungskräfte drastisch reduzieren. Damit erfüllen sie eine wichtige Verantwortung in ihrem eigenen „Haus“. Sie tragen damit auch - in einem ersten Schritt dazu bei, das Problem der Einkommensungleichheit in der Gesellschaft anzugehen. Aber weitere Schritte zur gesellschaftlichen Verantwortung sind notwendig. Ohne weitere Verzögerungen können viele Initiativen ergriffen und faszinierende Forschungsperspektiven untersucht werden. Und schließlich wird es früher oder später unvermeidbar sein, existenzsichernde Löhne und „ethisch annehmbare“ Einkommensbeschränkungen gesetzlich zu verankern.

\section{Quellen}

Allgemeine Erklärung der Menschenrechte Art.23(3), vgl. https://www.menschenrecht serklaerung.de/die-allgemeine-erklaerung-der-menschenrechte-3157/ (letzter Zugriff: 13.04.2020).

Akerlof, George A. / Yellen, Janet, Fairness and unemployment, in: American Economic Review, 78/1988, S. 44-49.

Alice Report 2018, Indiana, vgl. https://www.iuw.org/alice (letzter Zugriff: 13.04.2020). Arnold, Denis, Corporate moral agency, in: Midwest Studies in Philosophy XXX/2006, S. 279-291.

Atkinson, Anthony B, Inequality. What can be done?, Cambridge, MA 2015.

Bebchuk, Lucian A. / Fried, Jesse M., Pay without performance: Overview of the issue, in: Academy of Management Perspectives, February 2006, S. 5-24.

Boushey, Heather / DeLong, Bradford / Steinbaum, Marshall, After Picketty: The Agenda for Economics and Inequality, Cambridge, MA 2017.

Ciulla, Joanne B., Drops in the pond: Leaders, morality, an imagination, in: Georges Enderle / Patrick E. Murphy (Hg.), Ethical innovation in business and the economy, Cheltenham, UK 2015, S. 119-136. 
Chamberlain, Andrew (2015), vgl. www.glassdoor.com/research/ceo-pay-ratio (letzter Zugriff: 16.05.2019).

Collins, Denis, Living wage, in: Robert Kolb (Hg.), Encyclopedia of business ethics and society, 2. Auf., Thousand Oaks 2018, Sp.2102-2105.

Coleman, James S., Foundations of social theory, Cambridge, MA. 1990.

De George, Richard T., Business ethics, 7. Aufl., Boston 2010.

Dodd-Frank, Wall Street Reform and Consumer Protection Act. 2015, vgl. https://www. sec.gov/answers/about-lawsshtml.html\#df2010 (letzter Zugriff: 13.04.2020).

Enderle, Georges, How can universities promote corporate responsibility in their supply chains? The experience of the University of Notre Dame, in: Joanne B. Ciulla / Tobey Scharding (Hg.), Ethical Business Leadership in Troubling Times, Cheltenham, UK 2019, S. 159-186.

Enderle, Georges, Corporate responsibility for less income inequality, in: Review of Social Economy 76/4/2018, S. 399-421.

Enderle, Georges, Clarifying the terms of business ethics and corporate social responsibility, in: Business Ethics Quarterly 20/4/2010, S. 730-732.

Enderle, Georges, The Ethics of conviction versus the ethics of responsibility: A false antithesis for business ethics, in: Journal of Human Values 13/2/2007, S. 83-94.

Enderle, Georges, Handlungsorientierte Wirtschaftsethik. Grundlagen und Anwendungen, Bern 1993.

Frank, Robert H., Falling behind. How rising inequality harms the middle class, Berkeley 2007.

French, Peter A., The Corporation as a Moral Person, in: Midwest Studies in Philosophy 30/1/1979, S. 279-291.

Friedman, Milton, The Social Responsibility of Business Is to Increase Its Profit, in: The New York Times Sunday Magazin, September $13^{\text {th }} 1970$.

Gabriel, Ingeborg / Kirchschläger, Peter G. / Sturn, Richard (Hg.), Eine Wirtschaft, die Leben fördert. Wirtschafts- und unternehmensethische Reflexionen im Anschluss an Papst Franziskus, Mainz 2017.

Ghoshal, Sumantra, Bad management theories are destroying good management practices, in: Academy of Management Learning \& Education 4/1/2005, S. 75-91.

Hess, Kendy M., (Book of:) The fallacy of corporate moral agency, by David Rönnegard, Dordrecht 2015, in: Business Ethics Quarterly 26/4/2016, S. 557-560.

Inequality. What causes it. Why it matters. What can be done, Foreign Affairs 95/1/2016, S. 1-44.

Johannes Paul II., Centesimus annus (1991), vgl. http://w2.vatican.va/content/john-paulii/de/encyclicals/documents/hf_jp-ii_enc_01051991_centesimus-annus.html (letzter Zugriff: 13.04.2020).

King, Mervyn, The end of alchemy. Money, banking and the future of the global economy, London 2016.

Kolb, Robert W., Too much is not enough: Incentivess in executive compensation. New York 2012.

Lüthi, Ambros P., Messung wirtschaftlicher Ungleichheit, Berlin 1980.

Marshall, Ric / Lee, Linda-Eling, Are CEOs paid for performance? Evaluating the effectiveness of equity incentives, MSCI ESG Research Inc., July 2016, S. 1-23. 
Martin. Roger L., Fixing the game: Bubbles, crashes, and what capitalism can learn from the NFL, Cambridge, MA 2011.

Miller, Seumas, Collective moral responsibility: An individualist account, in: Midwest Studies in Philosophy XXX/2006, S. 176-193.

Moriarty, Jeffrey, How much compensation can CEOs permissibly accept?, in: Business Ethics Quarterly 19/2/2009, S. 235-250.

Moriarty, Jeffrey, Do CEOs get paid too much?, in: Business Ethics Quarterly 15/2/2005, S. $257-281$.

Oxfam, Steps towards a living wage in global supply chains, in: Oxfam Issue Briefing, December 2014 vgl. https://www.oxfam.org/en/research/steps-towards-living-wageglobal-supply-chains (letzter Zugriff: 13.04.2020).

Paine, Lynn S., Value shift. Why companies must merge social and financial imperatives to achieve superior performance, New York 2003.

Piketty, Thomas, The economics of inequality, Cambridge, MA 2015.

Piketty, Thomas, Capital in the twenty-first century, Cambridge, MA 2014.

Posen, Robert C. / Kothari, S.P., Decoding CEO pay: The truth is burried in the fine print and that's a problem, in: Harvard Business Review 95/4/2017, S. 78-84.

Rönnegard, David, The fallacy of corporate moral agency, Dordrecht 2015.

Schulz, Walter, Philosophie der veränderten Welt, Pfullingen 1972.

Stabile, Donald R., The living wage. Lessons from the history of economic thought, Cheltenham, UK 2008.

Stiglitz, Joseph, The great divide: Unequal societies and what we can do about them, New York 2015.

Thomas, Randal S. / Hill, Jennifer G. (Hg.), Research handbook on executive pay, Cheltenham, UK 2012.

Tsui, Anne S. / Enderle, Georges / Jiang, Kaifeng, On Addressing the Puzzle of Extreme Income Inequality: A Response to Agarwal and Holmes, in: Academy of Management Review 44/2/2019, S. 1-4.

Tsui, Anne S. / Enderle, Georges / Jiang, Kaifeng, Income inequality in the United States: Reflections on the role of corporations, in: Academy of Management Review 43/1/2018, S. $156-168$.

Tsui, Anne S. / Jiang, Kaifeng / Enderle, Georges, Income inequality in organizations. Paper presented at the „A Global Compact for Sustainable Development Conference“, University of Notre Dame, Indiana, April 4, 2016.

Vereinte Nationen, Hochkommissariat für Menschenrechte (VN), Leitprinzipien für Wirtschaft und Menschenrechte. Umsetzung des Rahmens der Vereinten Nationen „Schutz, Achtung und Abhilfe“, New York-Genf 2011.

Werhane, Patricia H., Corporate moral agency and the responsibility to respect human rights in the UN Guiding Principles: Do corporations have moral rights?, in: Business and Human Rights Journal 1/1/2016, S. 5-20.

Wilkinson, Richard / Pickett, Kate, The spirit level: Why greater equality makes societies stronger, New York 2010.

Wolf, Martin, The shifts and the shocks, London 2014. 
Open-Access-Publikation im Sinne der CC-Lizenz BY 4.0

(C) 2020, Vandenhoeck \& Ruprecht $\mathrm{GmbH} \&$ Co. KG, Göttingen ISBN Print: 9783847111658 - ISBN E-Lib: 9783737011655 


\section{Wirtschaftsordnung - Wertschöpfung - Schöpfungsverantwortung. Zu den Chancen ökosozialer Ordnungspolitik in der Globalisierung}

Das Wirtschaftsmodell der westlichen Gesellschaften befindet sich trotz seiner unbestreitbaren Erfolge in einer manifesten Legitimationskrise. Grundsätzliche Kritik kommt nicht nur von Seiten traditioneller ideologischer Gegner marktwirtschaftlicher Ordnungen, sondern auch aus der Mitte des Systems. Ein entscheidender Grund dafür liegt in der Vernachlässigung der gedanklichen und konzeptionellen Weiterentwicklung sozial-marktwirtschaftlicher Modelle als Alternative zu einer überwiegend marktfundamentalistisch („neoliberal“) geprägten Globalisierung.

In der folgenden Gedankenskizze werden deshalb in Anknüpfung an ordoliberale Denkweisen die Potentiale von sozial-marktwirtschaftlichen Systemen aufgezeigt, auch unter den Bedingungen der Globalisierung den erforderlichen Ausgleich zwischen einzelwirtschaftlicher und gesamtgesellschaftlicher Wertschöpfung zu leisten. Zugleich soll deutlich werden, dass die Wirtschaftseliten in der sozialethischen Verantwortung stehen, an der Neugestaltung der Rahmenbedingungen einer gerechteren, lebensfreundlichen Wirtschaftsordnung mitzuwirken. Der sich zuspitzende politische Diskurs zur richtigen Ausgestaltung unseres Wirtschaftssystems fokussiert meist auf Fragen der Verteilungsgerechtigkeit, Unsicherheiten über die Zukunft des klassischen Erwerbsmodells im Zeitalter der Digitalisierung und an Schärfe zunehmende handelspolitische Auseinandersetzungen. Dazu kommen die Nachwirkungen der bei weitem noch nicht vollständig aufgearbeiteten Finanzkrise $2008^{1}$ und eine durch Migrationsund Fluchtkrisen verdunkelte Globalisierungs-Perspektive.

Die um sich greifende ordnungspolitische Verunsicherung mag zu einem guten Teil der Tatsache geschuldet sein, dass die wirtschaftspolitische Handlungssouveränität nicht mehr am Nationalstaat allein festzumachen ist. So ist etwa die Europäische Union aufgrund ihrer unvollendeten Staatlichkeit nach wie

1 Stadler Wilfried, 10 Jahre nach Lehman - eine Zwischenbilanz; Beitrag für INARA BoardNews, September 2018, vgl. https://www.wilfried-stadler.com/zehn-jahre-nach-lehman-neu (letzter Zugriff: 24.04.2019). 
vor von Spannungen zwischen Mitgliedsstaaten mit höchst unterschiedlichen wirtschafts- und sozialpolitischen Ausgangsvoraussetzungen geprägt.

Dass Sozialstaatlichkeit national definiert bleibt, während der globale Wettbewerb um die besten Standortbedingungen überstaatlich ausgetragen wird, ist nur eines von mehreren Spannungsfeldern, die eindeutige wirtschafts- und sozialpolitische Positionierungen erschweren.

Dies gilt umso mehr in einer zunehmend globalisierten Wettbewerbswirtschaft, deren Regelwerk stark von Unternehmensinteressen beeinflusst wird, während eine adäquate Mitwirkung der politisch eigentlich verantwortlichen Regelsetzer im Sinn eines Primats der Politik oft unterbleibt. Harvard-Ökonom Dani Rodrik sieht in der Kluft zwischen einer meist national begrenzten politischen Verantwortlichkeit und der globalen Ausrichtung der Märkte für Güter, Kapital und Dienstleistungen eine ordnungspolitische Lücke, die Marktversagen, Instabilität und Krisen zur Folge hat. Zugleich führt eine institutionell oft unausgegorene Verlagerung der Regelsetzung auf übernationale Einrichtungen zu Demokratiedefiziten und schwächt die Legitimität des Systems. ${ }^{2}$

Immer häufiger ist von „Globalisierungsverlierern“ die Rede, denen im Unterschied zu einer verhältnismäßig kleinen Gruppe von Globalisierungs-Pionieren die Schaffung eines größeren Wettbewerbs-Spielfeldes nur wenig Vorteile verschafft. Die Wanderungsfreiheit von Arbeitskräften aus Niedriglohnländern sowie die digital unterstützte Auslagerungsmöglichkeit von Arbeit in Staaten mit extrem günstigen Kostenstrukturen setzt viele Arbeitnehmer einem „race to the bottom " aus, das frühere Träume von Chancengleichheit und Aufstiegschancen immer schwerer erfüllbar macht. ${ }^{3}$

Die genannten Entwicklungen tragen seit geraumer Zeit zur Stärkung fundamentalistischer und nationalistischer Bewegungen am äußeren linken und rechten Rand des politischen Spektrums bei, die auf Kosten der klassischen ehemaligen Großparteien der politischen Mitte in ihrer sozialdemokratischen wie christdemokratisch-liberalen Ausprägung anwachsen.

Darüber hinaus wird die Transformation des politischen Spektrums von dem durch die Klima-Diskussion angestoßenen Diskurs um die ökologische Verträglichkeit unseres Wirtschaftsstils mit beeinflusst, an den sich unterschied-

2 Dani Rodrik, Der Druck globaler Bürger, Gastkommentar, Wirtschaftsblatt am 20.03.2013, sowie „A New Deal on Labour Mobility“ in „The Crisis of Globalisation“, in: Social Europe Dossier März 2019, S. $88 \mathrm{ff}$.

3 Das Financial Times Lexikon beschreibt den mit der Globalisierung beschleunigten Wettbewerb, welcher zunehmend die Form eines „Race to the bottom“ annimmt, so: „Companies and countries try to compete with each other by cutting wages and living standards for workers, and the production of goods is moved to the place where the wages are lowest and the workers have the fewest rights.“, vgl. http://lexicon.ft.com/Term?term=race-to-the-bottom (letzter Zugriff: 24.04.2019). 
lichste Entwürfe für alternative Systeme einer Post-Wachstums-Ökonomie knüpfen. Wohl noch nie, seit wir das Zeitalter der Ideologien hinter uns gelassen haben, war die Suche nach dem ganz anderen Entwurf „richtigen“Wirtschaftens so ausgeprägt wie heute.

\section{Die verloren gegangene Zentralperspektive}

Über einen längeren Zeitraum hinweg herrschte nach der so genannten „Ostöffnung" eine deutlich optimistischere Sicht auf kommende globale Entwicklungen. Das Ende des Systemdualismus von Markt- und Planwirtschaft schien tatsächlich ein von Francis Fukuyama postuliertes „Ende der Geschichte“ im Sinne einer weltgeschichtlichen Entscheidung für die dauerhafte Überlegenheit des Marktmodells und die mit ihm verbundenen demokratisch-zivilisatorischen Standards einzuläuten. ${ }^{4}$

Drei Jahrzehnte später zeigen sich wesentlich nüchternere, höchst fragmentierte Bilder eines Geschehens, das sich - einer Beobachtung Peter Sloterdijks folgend - nicht mehr in eine globale Zentralperspektive fügen will. ${ }^{5}$ Anstelle eines konvergierenden Weltbildes nehmen wir gewissermaßen ein Wimmelbild der Welt wahr, das sich aus höchst unterschiedlichen Szenen und Entwicklungsstufen zusammenfügt, die noch dazu einer disruptiven Veränderungsdynamik unterliegen.

So verlockend es war, die Welt-Ökonomie nach dem Zusammenbruch der kommunistischen Planwirtschaften über einen einzigen System-Leisten zu schlagen, so wenig entspricht diese Wunschvorstellung der heutigen Realität.

- In Europa stehen beeindruckenden Wachstumserfolgen und dem Wohlstandszuwachs in vielen der mittlerweile der EU beigetretenen Staaten Mittelund Osteuropas deutliche Defizite in der erhofften sozialen Konvergenz gegenüber. Die Binnenglobalisierung als zentrale Folge der Wirtschafts- und Währungsunion zeitigt auch nachteilige Folgen auf den Arbeitsmärkten für den traditionellen Mittelstand.

- In den nach wie vor unter russischem Einfluss stehenden Nachfolgestaaten der ehemaligen Sowjetunion zeigen sich massive Folgeprobleme einer ungeordneten Systemkonversion. Oligarchische Strukturen, mangelnde Durchsetzbarkeit individueller Rechte, demokratiepolitische Defizite und mediale Monopole mit begrenzter Meinungsfreiheit behindern vielfach die Entwicklung hin zu breite-

4 Francis Fukuyama, The End of History and the last Man, London 1992.

5 Peter Sloterdijk im Gespräch mit Martin Walser, in: Cicero 11/2013, S. $126 \mathrm{f}$. 
rem Wohlstand. Zudem stehen massive Rückschläge in der sich um die Jahrhundertwende abzeichnenden Annäherung zwischen der Europäischen Union und Russland spätestens seit der Ukraine-Krise der Herausbildung einer gemeinsamen Friedens- und Wachstumszone entgegen.

- Im Nahen und mittleren Osten wie in der Arabischen Welt haben die Entwicklungen seit dem Anschlag auf das World Trade Center und den nachfolgenden Verhärtungen und verheerenden kriegerischen Auseinandersetzungen gedeihliche wirtschaftliche Entwicklungen weitgehend verhindert. Diese geopolitische Problemzone grenzt an den nicht weniger schwierigen afrikanischen Raum, in dem es in einer Mehrzahl der Länder an grundlegenden Voraussetzungen für wirtschaftliches und soziales Wohlergehen fehlt. Spätfolgen der Kolonialisierung sowie massive außenpolitische Versäumnisse des "Westens“ auch nach dem Ende der Kolonialzeit tragen das ihre dazu bei, dass das westliche Wirtschafts- und Gesellschaftsmodell zwar gleich einem Abziehbild möglichen Wohlstands wahrgenommen, nicht aber verstanden und übernommen wird. Migration oder fundamentalistischer Antimodernismus sind die häufige Folge.

- Ganz anders die Entwicklung in China und einigen der angrenzenden asiatischen Staaten. Die Öffnung Chinas für marktwirtschaftliche Dynamik hat auf der Grundlage eines gut entwickelten Bildungssystems und massiver zentraler Impulse ein Wachstum ermöglicht, das in sehr kurzer Zeit ein großer Teil der Bevölkerung aus der Armut geführt hat. Zugleich gelang es zahlreichen chinesischen Unternehmen, vom Imitator zum Innovator zu werden und insbesondere in den digitalen Technologien und der Informationstechnik bereits im direkten Wettbewerb um die globale Führungsrolle mit den führenden Konkurrenten aus den USA zu stehen.

Galt bis zum Fall des Eisernen Vorhangs die Dichotomie von Markt- und Planwirtschaft als das maßgebliche Paradigma, ist mit China nun ein wirkungsmächtiges drittes Modell hinzugetreten, dessen befriedigende politisch-ökonomische Einordnung wohl vor allem deshalb noch aussteht, weil die ökonomisch erfolgreiche Entwicklung eines Marktsystems innerhalb einer Einparteien-Diktatur allen historischen Erfahrungen zuwiderläuft.

Thomas Friedman beschrieb schon vor gut einem Jahrzehnt in The world is flat, wie das globale Wettbewerbs-Spielfeld zeitgleich von verschiedensten Teams nach ganz unterschiedlichen Regeln bespielt wird. ${ }^{6}$ Bildhaft ausgedrückt: Freistilringer-Gruppen aus Staaten ohne verbindliche soziale und ökologische Mindeststandards treten gegen extrem regelgebundene Unternehmens-Teams aus sozialen und ökologischen Best-Practice-Staaten an. In einer ohnehin kon-

6 Thomas Friedman, The world is flat. A brief history of the twenty-first century, New York 2005. 
junkturell belasteten Situation, die sich durch wachsende geopolitische Risiken derzeit weiter eintrübt, nehmen dadurch die Beschäftigungsprobleme in den etablierten Marktwirtschaften zu. Am untersten Ende der Lohnskala, aber auch im klassischen Mittelstand wachsen die Abstiegsängste. Auch innereuropäisch bringt die Binnen-Globalisierung trotz unbestreitbarer Erfolge für die meisten Beitrittsländer problematische Reibungsverluste mit sich, wie die aus zahlreichen EU-Staaten bekannten Auseinandersetzungen zu Fragen der Mindestlöhne und einer ausdifferenzierten Sozialpolitik zeigen.

\section{Die "unsichtbare Hand" und das Primat der Politik}

Die „unsichtbare Hand“, das von Adam Smith zu Beginn der industriellen Revolution geschaffene Symbol jener sozialen Transformation, mit der aus millionenfacher eigennütziger Aktivität von Bürgern Wertschöpfung und zugleich gesamtwirtschaftliche Nutzenstiftung entsteht, hat nichts von ihrer Faszination verloren. Denn eine Versöhnung von Eigennutz und Gemeinnutz kann in einer arbeitsteiligen Gesellschaft gerade deshalb gelingen, weil die aus effizienter Herstellung und Verteilung von Gütern und Dienstleistungen erwachsende Wertschöpfung über den Umweg der Alimentierung zentraler Staatsfunktionen im Wege des Steuer- und Sozialsystems der Allgemeinheit zu Gute kommt.

Darüber hinaus trägt die Revolution der Informationstechnologien die Chancen der Informationsgesellschaft in die entlegensten Weltgegenden. Die Gleichheit der Zugangsmöglichkeiten zu Informationen befreit von traditionalistischen Fesseln und gibt konkrete, persönliche Aufstiegsmöglichkeiten selbst in starren Standesgesellschaften - wie etwa jener Indiens, wo jungen Computerspezialisten der soziale Aufstieg gelingt, weil sie zur neuen „Kaste“ der leistungsbereiten, mobilen Informationsdienstleister gehören.

Länder, die sich nach lähmenden Jahrzehnten der Planwirtschaft oder Jahrhunderten in feudalen Herrschaftssystemen der Unternehmerwirtschaft öffnen und am internationalen Austausch von Gütern und Dienstleistungen teilnehmen, benötigen jedoch als Orientierungshilfe ein realistisches Bild von reifen, erfahrenen Marktwirtschaften und deren Wirkungs-Voraussetzungen. Denn eine funktionierende Wettbewerbswirtschaft baut nun einmal - vom Rechtssystem („rule of law“) über die Bildungs- und Sozialpolitik bis zu einer tragfähigen Infrastruktur - auf essentielle institutionelle Voraussetzungen, ohne die ihr gesellschaftspolitisches, emanzipatorisches Potential nicht freigesetzt werden kann. ${ }^{7}$

7 Daron Acemoglu / James A. Robinson, Why Nations Fail - The Origins of Power, Prosperity and Poverty, New York 2012. 
Globale Marktfreiheit allein ist trotz damit verbundener Chancen für bisher benachteiligte Länder kein ausreichendes wirtschaftspolitisches Programm. Gerade Staaten, die ganz am Beginn der Marktöffnung stehen und noch keinen breiten, mittelständischen Marktsektor haben, können nämlich an der übereilten Konfrontation mit dem Wettbewerb der höchst entwickelten Marktwirtschaften erkranken. Ohne ausreichende zivilgesellschaftliche Grundlagen bauen sie Abhängigkeiten auf und werden $\mathrm{zu}$ - langfristig politisch schwer integrierbaren - Wirtschaftskolonien. Weltweiter Freihandel wirkt nur dann in die gewünschte Richtung, wenn seine Regeln die Voraussetzung für eine gemeinsame, gleichrangige Weiterentwicklung von Wirtschaftswachstum, Demokratie und sozialer Gerechtigkeit schaffen. Ohne Berücksichtigung dieses ordnungspolitischen Prärogativs droht ein Rückfall in gesellschaftliche Spaltung und autoritäre Traditionen.

Vorbildhaft und prägend kann das Marktmodell daher nur dann sein, wenn es neben der Ermöglichung von Wettbewerb qualitative Charakteristika aufweist, die ihm das Potential zuschreiben, „Wohlstand für Alle“ zu bewirken. ${ }^{8}$ Die „unsichtbare Hand“ bedarf, um in der gewünschten Weise wirksam zu sein, der geeigneten, politisch gesetzten Rahmenbedingungen. Ein klares Primat der Politik ist daher unverzichtbar.

\section{Gesucht: ein ordnungspolitisches Leitbild}

Der Versuch, Handlungsperspektiven für ein Wirtschaftssystem zu entwickeln, das der Gesellschaft als Ganzer dient, wird durch eine vielfach feststellbare begriffliche Verengung des politischen Diskurses erschwert. Die „Textbuch-Ökonomie“ des universitären Alltags, in der überwiegend modellhaft-mechanistisch gearbeitet wird, dominiert längst auch eine plakativ verkürzte mediale Diskussion um das „richtige“ Wirtschaften. Werte-Bezüge bleiben meist ebenso ausgeklammert wie der geschichtliche, geisteswissenschaftliche und politischökonomische Bezugsrahmen wirtschaftlichen Handelns.

Die Unterscheidung zwischen ausgeprägt unterschiedlichen Wirtschaftsstilen marktwirtschaftlich-demokratischer Ordnungen wird in der Regel vernachlässigt. So dient meist der Sammelbegriff „Kapitalismus“ vereinfachend als übergeordnete Bezeichnung für marktwirtschaftliche Systeme. Daneben verblasst die zur Zeit ihrer Gründung als durchaus eigenständiger Gegenentwurf zum gescheiterten Laissez-Faire-Liberalismus konzipierte „Soziale Marktwirtschaft“ zur bloßen Sonderform kapitalistischen Wirtschaftens.

8 Die Konzeption der Sozialen Marktwirtschaft wurde erstmals populärwissenschaftlich niedergelegt in: Ludwig Erhard, Wohlstand für Alle, Düsseldorf 1957. 
Der mit solch marktfundamentalistischer Engführung assoziierte „Neoliberalismus" wurde zur Feindbild-Schablone kritischer Beobachter und brachte es spätestens seit der Finanzkrise zum wohl meist verwendeten Begriff der Systemskeptiker. Manche von ihnen zeigen sich nicht selten bereit, gleich das Marktsystem - eben den „Kapitalismus“ - als Gesamtes durch etwas ganz Anderes ersetzen zu wollen, ohne dieses näher zu benennen. Andere hoffen durch die Verfolgung von aus idealistischen Zielsetzungen hergeleiteten Alternativkonzepten - von der Gemeinwohlökonomie über Zero-Growth-Ansätze bis zum Vollgeld und bedingungslosen Grundeinkommen - auf eine Überwindung des Kapitalismus.

Thomas Sedlacek, Verfasser des Buches Die Ökonomie von Gut und Böse, beschreibt die oft paradoxe Hassliebe der wohlhabenden Gesellschaften zu ihrem Wirtschaftssystem so: „Der Grund dafür, dass der Kapitalismus so unbeliebt geworden ist, ist nicht, dass er nicht gehalten hätte, was er versprochen hat, sondern dass er es gehalten hat. [...] Kein anderes System hat uns so reich gemacht. Aber nun wissen wir nicht, was wir uns noch wünschen sollen als einfach nur mehr von allem. “9

Die Befürworter einer sozial-marktwirtschaftlichen Ordnung haben verabsäumt, deren erfolgreiche Geschichte weiter zu erzählen und trugen damit maßgeblich zur Unübersichtlichkeit des aktuellen System-Diskurses bei. Seit dem Ende der Systemkonkurrenz zwischen Markt und Plan wurde jedenfalls nur wenig unternommen, um den wohlstands- wie sozialpolitisch höchst erfolgreichen, europäischen Weg der „Sozialen Marktwirtschaft“ inhaltlich und begrifflich fortzuschreiben. Im Zuge der Vergrößerung der Union und der Schaffung einer Gemeinschaftswährung waren die Träger der politischen und wirtschaftlichen Verantwortung vor allem damit beschäftigt, zur vermeintlich besseren Absicherung der internationalen Wettbewerbsfähigkeit eine weitgehende Angleichung der bilanz- und finanzpolitischen Spielregeln an jene der USA voranzutreiben. Obwohl die Finanzkrise den Nachweis lieferte, dass diese unkritische Adaptierung mit fatalen Folgewirkungen für die Finanzmarktstabilität und die Verfasstheit von „Euro-Land“verbunden war, blieben Konsequenzen für eine Neuformulierung des Leitbildes aus.

Über die Zielsetzungen und Qualitäten einer zu erneuernden Wirtschaftsordnung herrschen auch innerhalb der Wirtschaftseliten keine einheitlichen Auffassungen. Das jeweilige Leitbild weist je nach dem vorherrschenden Wirtschaftsstil starke Unterschiede auf. So mag es etwa von einer kapitalmarktorientierten Wirtschaftskultur wie jener der USA geprägt sein oder von einer für Kontinentaleuropa typischen Orientierung an den Bedürfnissen einer über-

9 Thomas Sedlacek, Kapitalismus wird völlig überbewertet, Interview in: Die Presse am 29.02. 2016. 
wiegend von Familienunternehmen geprägten Realwirtschaft. Dementsprechend wird die zunehmende Finanzialisierung der Ökonomie - im Sinn einer fortschreitenden Entkoppelung der Finanzwirtschaft von der Realwirtschaft - in den USA als wesentlich weniger problematisch angesehen als in Europa. Ebenso tiefgreifende Unterschiede zeigen sich in der Sichtweise der Rolle des Staates etwa im Gesundheitssystem, im Bildungssystem oder in der Pensionsvorsorge.

\section{Die Mitverantwortung der Wirtschaftseliten}

In den letzten Jahren wächst auch in den Führungsetagen großer Unternehmen die Sorge um eine ausreichende gesellschaftliche Akzeptanz des Wirtschaftssystems, in dem sie agieren. So erregte anlässlich der Hauptversammlung der Siemens AG im Jänner 2019 Konzernchef Joe Kaeser erhöhte Aufmerksamkeit, als er abseits der Erläuterung des Zahlenwerkes und aktueller Geschäftsstrategien seines Unternehmens auch auf Wertefragen zu sprechen kam. Angesichts der zunehmenden Spaltung der Gesellschaften berge der reine Shareholder-Value-Ansatz Gefahren, weil er einseitig auf vermögende Kapitalgeber fokussiert ist und die Schwächen aus dem Blick verliert. Die Ungleichgewichte hätten ein nicht mehr hinzunehmendes Maß erreicht. Es wäre deshalb an der Zeit, sich mit einem ,inklusiven Kapitalismus" auseinanderzusetzen und sich der Frage zu stellen, wie eine „Soziale Marktwirtschaft 2.0“ aussehen könnte. ${ }^{10}$

Noch ist es eine Minderheit von Unternehmensverantwortlichen, die ihre Mitverantwortung deutlich weiter fasst, als um die bloße Einhaltung immer umfangreicherer „Corporate Social Responsibility“-Regelwerke bemüht zu sein. Es beginnt sich jedoch - auch unter dem Druck einer kritischen Öffentlichkeit die Erkenntnis durchzusetzen, dass Unternehmen durch die Qualität ihres Handelns Einfluss auf das soziale Ganze nehmen. Ob es um Fragen der Ausbildung geht, um Maßnahmen im Gesundheitsbereich oder um die Arbeitsbedingungen in strukturarmen Gebieten von Entwicklungsstaaten: auf all diesen Gebieten sind Großunternehmen längst zu Repräsentanten einer „Fünften Gewalt" geworden, die neben den drei verfassungsmäßigen Gewalten und den Medien maßgeblichen Einfluss auf den Gang der Politik und die konkrete Ausprägung eines Wirtschafts- und Gesellschaftssystems nimmt. ${ }^{11}$

Die Schweizer „Konzernverantwortungsinitiative“ ist hier Vorreiter eines über die nationale Rechtssphäre hinausreichenden Verständnisses von unter-

10 Joe Kaeser zitiert in Handelsblatt am 29.01.2019, „Ein neuer Kapitalismus“.

11 Wilfried Stadler, Wirtschaftsethik - Schönwetterdisziplin oder Grundlage unserer Wirtschaftsordnung?, Vortragsmanuskript zur Tagung des Friedrich von Weizsäcker Instituts am 08.04.2016, vgl. https://www.wilfried-stadler.com/wirtschaftsethik-schnwetterdisziplinoder-grundlage-unserer-wirtschaftsordnung (letzter Zugriff: 24.04.2019). 
nehmerischer Verpflichtung. ${ }^{12}$ Ihrem Einfluss sind konkrete Gesetzesvorhaben zu verdanken, auf Grund derer Unternehmen künftig für ihre soziale und ökologische Mitverantwortung entlang der gesamten Lieferkette haftbar gemacht werden sollen.

Die Verantwortung von Unternehmen endet jedoch nicht bei den von ihnen direkt beeinflussbaren Geschäftsprozessen und Wertschöpfungsketten. Sie erschöpft sich auch nicht in klassischer Lobbyarbeit zur Durchsetzung des gebräuchlichen Katalogs interessenspolitischer Anliegen auf allen politischen Ebenen, vom Bemühen um geringere Auflagen, Ausnahmebestimmungen oder längere Übergangsfristen bis zur Geltung neuer Grenzwerte oder Förderungen. Gefordert ist vielmehr ihre Mitwirkung am ordnungspolitischen Agenda-Setting und der Weiterentwicklung der Rahmenbedingungen des Wirtschaftens auf gesamtgesellschaftlicher Ebene. Im politischen Raum, dort, wo die jeweiligen Spielregeln um- und neugestaltet werden, liegt der eigentliche Ort ihrer sozialethischen Bewährung.

In einer von weitgehend ungebremstem „Corporate Capitalism“ geprägten politischen Wirklichkeit, in der die Einflussnahme finanzstarker Gruppierungen den Kampf „Wall Street versus Main Street“ immer einseitiger bestimmt, wird die Wahrnehmung unternehmerische Mitverantwortung für eine dem Ganzen verpflichtete Ausgestaltung der Rahmenbedingungen - auch wenn sie kurzfristig Brancheninteressen widersprechen mag - zu einer demokratiepolitisch unverzichtbaren Übung.

\section{Kapitalismus versus Soziale Marktwirtschaft}

Nach den Verheerungen des zweiten Weltkrieges diente das Konzept der „Sozialen Marktwirtschaft" als Grundlage des erfolgreichen Wiederaufbaus in Deutschland, getragen vom Konsens der christdemokratisch-liberalen wie sozialdemokratischen Volksparteien. Verwandte Ausprägungen von Marktwirtschaften „mit Vorzeichen “13 prägten praktisch alle Länder des freien Europa, mit eigenen Akzentsetzungen in den Wohlfahrtsstaaten Skandinaviens oder der für Frankreich typischen „Planification“. Mit der Ostöffnung und der nachfolgenden Erweiterung der Europäischen Union wurde daraus das zunächst bestim-

12 Vgl. Peter G. Kirchschläger, Wirtschaft und Menschenrechte, in: Ingeborg Gabriel / Peter G. Kirchschläger / Richard Sturn (Hg.), Eine Wirtschaft, die Leben fördert, Wirtschafts- und unternehmensethische Reflexionen im Anschluss an Papst Franziskus, Ostfildern 2017, S. 241-264.

13 Klaus Vaclav, Präsident Tschechiens von 2003 bis 2013, prägte den Begriff einer „Marktwirtschaft ohne Vorzeichen“ als Zeichen seiner Präferenz für das kapitalmarktorientierte, angloamerikanische Wirtschaftsmodell. 
mende Leitbild des Europäischen Projektes. Im Zuge der Erweiterung der Europäischen Union zeigte sich allerdings, dass neu hinzukommende Staaten Mittel- und Osteuropas nach Befreiung von der Enge planwirtschaftlicher Regime wenig Ambition hatten, sich mit sozial-marktwirtschaftlichen Gedankenmodellen auseinanderzusetzen. Zu eng erschien ihnen die begriffliche Nähe zum soeben überwundenen Sozialismus. ${ }^{14}$

Um auch heute wieder als Kohärenz-stiftendes Narrativ wirken zu können, bedarf das europäische Modell schon aus diesem Grund einer Weiterentwicklung, die sich nicht in einer Wiederbelebung allzu lange vernachlässigter Begriffe erschöpfen kann. Es gilt deshalb, bei der Wiederaufnahme des Erzählfadens auch jene neueren Diskussionsstränge mit zu berücksichtigen, die gewissermaßen interimistisch die Fahne einer dezidiert wertorientierten Ordnungspolitik hochgehalten haben. So sieht sich etwa die „Postwachstumsökonomie“ als potentieller Nachfolger des Ordoliberalismus. ${ }^{15}$ Ebenso enthält die „Gemeinwohlökonomie“ wertvolle Denkanstöße hinsichtlich nachhaltiger, sozial und ökologisch verträglicher Produktionsweisen sowie gelebter unternehmensethischer Praxis. $^{16}$

Unter Zugrundelegung gemeinsamer Werte-Ziele besteht durchaus wieder die Chance auf einen konzeptionellen Neubeginn jener weltanschaulichen Gruppierungen, deren größter gemeinsamer Nenner in der Einsicht liegt, dass Ordnungspolitik nur im Rahmen einer Werte-Ordnung gelingen kann. Entscheidend für das Gelingen einer derartigen, in der Folge auch politisch wirksamen Erneuerung sozial-marktwirtschaftlicher Programmatik ist die inhaltliche Festlegung auf das gemeinsame Ziel einer inklusiven Marktwirtschaft, in der Bildungschancen, Chancengleichheit und vertikale Mobilität ebenso hoch gehalten werden wie ein ausgeprägtes Gesundheits- und Pensionssystem sowie sozialer Ausgleich gegenüber benachteiligten Gruppen.

Angesichts der aktuellen politischen und sozialen Lage in den USA lassen sich die Konturen eines solchen europäischen Modells deutlicher benennen als in früheren Jahren. Denn im ehemaligen Land der unbegrenzten Möglichkeiten ist die soziale Durchlässigkeit im Vergleich zu Europa zuletzt deutlich zurückgegangen. Während das Durchschnittseinkommen der unteren Hälfte der Ein-

14 Zur Entwicklung des Diskurses zur Sozialen Marktwirtschaft vgl. Wilfried Stadler, Die offene Gesellschaft und ihre Werte, Thesen zur Erneuerung der Ökosozialen Marktwirtschaft, in: Thomas Köhler / Christian Mertens / Michael Spindelegger (Hg.), Stromaufwärts, Christdemokratie in der Postmoderne des 21. Jahrhunderts, Wien 2003, S. 182-192, hier: S.183ff.

15 André Reichel, Jenseits des Wachstumszwangs: Postwachstumsökonomie als Wirtschaft der Freiheit, Beitrag zum Tagungsband der GLOBART-Academy 2017, „(UN)ORDNUNG - Was die Welt zusammenhält", München 2019, S. 59-67.

16 Ein umfassender Überblick dazu findet sich in: Reinhard Fischer, Mit Werten wirtschaften Praxismodell Gemeinwohlökonomie, Reihe Wirtschaftswissenschaften 89, Baden-Baden 2019. 
kommensempfänger zwischen 1980 und Ende 2017 in realer Kaufkraft gemessen weitgehend unverändert blieb, hat sich das Vorsteuer-Einkommen des obersten Prozents im selben Zeitraum verdreifacht und jenes des obersten Promilles sogar versiebenfacht. Die Lebenserwartung der untersten Einkommensschichten liegt um 15 Jahre hinter jener der Top-Verdiener und nimmt insgesamt ab, während der Drogenkonsum stark im Steigen begriffen ist.

Auch zeigt sich immer klarer, dass öffentliche Güter etwa im Bildungs- und Gesundheitswesen sowie in der Infrastruktur nicht durch noch so großzügige private Initiativen substituiert werden können. Die Stiftungen der Superreichen mögen eine wünschenswerte Ergänzung bilden, können jedoch die Leistungen eines demokratischen Regeln folgenden, gut organisierten öffentlichen Sektors keinesfalls ersetzen. Dennoch wird dessen Aktionsradius gerade durch die unzureichende Besteuerung der großen Einkommen und Vermögen zusehends eingeschränkt, wodurch sich die Einflussmacht der privaten Donatoren laufend erhöht.

Die sozial-ökonomische Grund-Konfiguration einer inklusiven Marktwirtschaft wäre jedoch unvollständig ohne Einbindung des ökologischen Nachhaltigkeitsziels. ${ }^{17}$ Nur wenn auch diese gelingt, kann sich eine „Soziale Marktwirtschaft 2.0" im politischen und medialen Diskurs als ein anderen Alternativen überlegenes System etablieren. Die zukunftsgerechte Kombination lautet Wohlstand für möglichst Viele, sozialer Ausgleich für die Schwächeren und ein auf Nachhaltigkeit angelegter Umgang mit Ressourcen und Umwelt. Erfolge in dieser Königsdisziplin können nur als Ergebnis einer klugen Gewaltenteilung zwischen Ökonomie und Politik gelingen, die sich von der Dominanz der am Shareholder-Value anstelle des Gesamtwohls orientierten Großunternehmen emanzipiert hat.

Es liegt im aufgeklärten Eigeninteresse der Wirtschaftseliten, sich dieses Verständnis zu eigen $\mathrm{zu}$ machen. Andernfalls riskieren sie weitere Legitimationsverluste eines Systems, das in demokratisch verfassten Gesellschaften auf breiten gesellschaftlichen Konsens angewiesen ist.

\section{Neue Rahmenbedingungen einer globalisierten Ökonomie}

Vorausschauende, nicht von ad-hoc-Maßnahmen dominierte Wirtschaftspolitik setzt eine Standortbestimmung voraus, in der die jeweiligen Kriterien für die Schaffung kluger Rahmenbedingungen für die Entfaltung von Wettbewerb, er-

17 Ingeborg Gabriel, Zur Einführung - Ökologie als Gerechtigkeitsfrage der Gegenwart, in: Ingeborg Gabriel / Petra Steinmair-Pösel (Hg.), Gerechtigkeit in einer endlichen Welt: Ökologie - Wirtschaft - Ethik, Stuttgart 2013, S. 9-31. 
höhte Wertschöpfung und Sicherstellung öffentlicher Güter geklärt werden. Der Bogen reicht von der Bildungs- und Innovationspolitik zur Infrastrukturpolitik, von der Steuerpolitik bis zur Sozialpolitik, von der Kapitalmarkt- bis zur Wettbewerbspolitik. Mit der Schaffung des Binnenmarktes stellen sich all diese Aufgaben neben der nationalen auch auf europäischer Ebene.

Dabei zeigen sich in wichtigen Bereichen innereuropäische Spannungsfelder:

- Der gemeinsame Währungsraum geht mit zentraler Geldpolitik und zugleich dezentraler Budgetpolitik der Mitgliedsstaaten einher. Diese sind durch das Regelwerk von Maastricht sowie des Wachstums- und Stabilitätspaktes an ein haushaltspolitisches Korsett gebunden, das den jeweiligen nationalen Handlungsspielraum stark einschränkt.

- Da die nationalen Steueraufkommen für die Aufrechterhaltung bestehender Sozialkontrakte der Mitgliedsstaaten entscheidend sind, besteht innerhalb des gemeinsamen Binnenmarktes eine intensive Standortkonkurrenz.

- Mit dem Binnenmarkt wurden neue, größere Spielflächen für alle Industrien und Dienstleistungen, aber auch für Bereiche wie Energiewirtschaft, Telekommunikation und Medien geschaffen. Die Globalisierung des Wettbewerbs stellt nun das Instrumentarium herkömmlicher Wettbewerbspolitik in Frage. Daraus abgeleitete gesamteuropäische Konzeptionen geraten leicht in Widerspruch zu nationalen Interessen von Mitgliedsstaaten. ${ }^{18}$

- Hohe Unterschiede in den Ausgangsniveaus der Einkommen und Kaufkraftverhältnisse erschweren die innereuropäische Konvergenz sowie eine langfristig angestrebte Absicherung sozialer Mindeststandards. ${ }^{19}$

Neben diesen laufend zu bewältigenden innereuropäischen Fragestellungen ergibt sich in globalisierten Märkten eine übergeordnete, zusätzliche ordnungspolitische Handlungsebene für die Schaffung von Rahmenbedingungen, unter denen der Markt nun auch global in die gewünschte Richtung sozialer und ökologischer Nachhaltigkeit wirken soll. Ob es um Wettbewerbspolitik und Handelsabkommen geht, Fragen der Finanzmärkte und adäquater Besteuerung oder Einigung auf durchsetzbare soziale wie ökologische Mindeststandards überall ist der Komplexitätsgrad gegenüber nationalen oder europäischen Lösungsansätzen noch einmal deutlich erhöht.

So sehr internationale Zusammenarbeit im Bereich der Handelspolitik und zu Themen der Währungs- und Entwicklungspolitik auf durchaus bewährte Tra-

18 Die Untersagung einer intendierten Fusion der Eisenbahntechnik von Siemens und Alstom stellt ein aktuelles Beispiel für die Schwierigkeit ausgewogener wettbewerbspolitischer Entscheidungen dar.

19 Vgl. beispielhaft die strittige Entscheidung der österreichischen Bundesregierung, Kinderbeihilfen an im Ausland lebende Kinder von in Österreich beschäftigten EU-BürgerInnen abgestuft je nach Kaufkraft des Herkunftslandes zu bemessen. 
ditionen bauen kann, wurden die darüber hinaus gehenden ordnungspolitischen Herausforderungen von supranationalen Organisationen erst in den letzten Jahren von supranationalen Organisationen aufgegriffen, die sich verstärkt darum bemühen, einen einvernehmlichen Referenzrahmen für den Umgang mit den entscheidenden globalen Fragen zu schaffen. ${ }^{20}$

Während es zu Fragen der Umweltökonomie seit dem legendären Bericht des Club of Rome über „Die Grenzen des Wachstums“ ${ }^{\text {“21 }}$ schon verhältnismäßig früh zur Herausbildung eines Bewusstseins gemeinsamer Verantwortung für das „Raumschiff Erde“ kam, folgten umfangreichere konzeptionelle Anstrengungen zum richtigen Umgang mit Fragen der globalen Wirtschaftsordnung erst deutlich später nach.

Zum maßgeblichen Auslöser wieder vermehrter Kooperation in Grundsatzfragen des Wirtschaftens wurde die Finanzkrise des Jahres 2008, in deren Folge sich die gegenseitige Abstimmung der maßgeblichen Wirtschaftsnationen im Club der G20 intensivierte. Über Initiative ihres Generalsekretärs Angel Gurría entwickelte die OECD als Organisation der entwickelten Industriestaaten in der Folge eine ganzheitliche Agenda für „Inklusive Marktwirtschaft“. ${ }^{22}$

Unabhängig davon entwickelten die Vereinten Nationen unter Federführung von Harvard-Ökonom Jeffrey Sachs mit den "Sustainable Development Goals“ $(\mathrm{SDGs})^{23}$ erstmals einen wirklich umfassenden globalen, ordnungspolitischen Referenzrahmen. Dieser zeigt 17 Handlungsfelder auf, die allesamt auch in operationell fassbaren Teilzielen präzisiert werden. Mit dem Jahr 2030 wurde ein zeitlicher Rahmen abgesteckt, innerhalb dessen die entscheidenden globalen Ziele erfüllbar sein sollen - entsprechenden Einsatz von Ressourcen und politischem Willen vorausgesetzt.

Ein nicht $\mathrm{zu}$ unterschätzender praktischer Wert dieser neu geschaffenen Rahmenentwürfe für globales politisches Handeln liegt vor allem darin, dass sie durch Außerstreitstellung grundlegender Fakten und das Aufzeigen konkreter Ziele im Rahmen einer Gesamtordnung einen Bezugsrahmen sowohl für multilaterales als auch nationales politisches Handelns darstellen. Sie schaffen damit eine Verbindlichkeit, die die Arbeit von politischen Kräften, die sich um Implementierung einer inklusiven Wirtschaftsordnung bemühen, entscheidend erleichtert.

20 Vgl. Ingeborg Gabriel / Ludwig Schwarz (Hg.), Weltordnungspolitik in der Krise - Perspektiven internationaler Gerechtigkeit, Paderborn 2011.

21 Die Studie des Club of Rome von Denis und Donella Meadows u. a. wurde 1972 veröffentlicht

22 Näheres zu den „New Approaches to Economic Challenges“ der OECD siehe http://www. oecd.org/naec/ (letzter Zugriff: 24.04.2019).

23 Näheres zu den Sustainable Development Goals und ihrer Implementierung: Jeffrey Sachs, The Age of Sustainable Development, New York 2015. 


\section{Schöpfungsverantwortung jenseits des Shareholder-Value}

Es ist eine viel zu oft vernachlässigte Voraussetzung für den nachhaltigen Erfolg marktwirtschaftlicher Systeme, dass sie neben der materiellen Wertschöpfung auch immaterielle Werte schöpfen, dass sie „Sinn machen“ und demgemäß als gesamtgesellschaftlich wertvoll angesehen werden. Fehlt dieses Element, droht der gesellschaftliche Zusammenhalt - das was Ralf Dahrendorf "Ligaturen“ nannte $^{24}$ - verloren $\mathrm{zu}$ gehen. Ein auf Kurzfrist-Maximierung getrimmter Shareholder-Value zerstört, wenn er aus politischer Selbstvergessenheit zum Werte-Fetisch erhoben wird, letztlich die Bindung der Bürger an ihr Wirtschaftssystem - oder lässt solche Bindungen dort nicht aufkommen, wo Marktwirtschaft erst etabliert werden muss.

Es gehört in diesem Sinn zur Verantwortung von Politikern, Führungskräften und Ökonomen, an der ständigen Weiterentwicklung angemessener Rahmenbedingungen für eine Wettbewerbsordnung zu arbeiten, die den alten Zielkonflikt von Effizienz und Gerechtigkeit zu entschärfen hilft.

Aus christlich-humanistischer Perspektive liegt in diesem Auftrag ein Stück jener Schöpfungsverantwortung, aus der die Chance erwächst, an einem Wirtschaftssystem mitzuwirken, das Freiheit in Verbindung mit Entfaltungs- und Lebenschancen für alle Menschen ermöglicht.

\section{Quellen}

Acemoglu, Daron / Robinson, James A., Why nations fail - The origins of power, prosperity and poverty, New York 2012.

Dahrendorf, Ralf, Lebenschancen - Anläufe zur sozialen und politischen Theorie, Frankfurt 1979.

Erhard, Ludwig, Wohlstand für Alle, Düsseldorf 1957.

Financial Times Lexikon, Race to bottom, vgl. http://lexicon.ft.com/Term?term=race-tothe-bottom (letzter Zugriff: 24. 04.2019).

Fischer, Reinhard, Mit Werten wirtschaften - Praxismodell Gemeinwohlökonomie, Reihe Wirtschaftswissenschaften 89, Baden-Baden 2019.

Friedman, Thomas, The world is flat. A brief history of the twenty-first century, New York 2005.

Fukuyama, Francis, The end of history and the last man, London 1992.

Gabriel, Ingeborg, Zur Einführung - Ökologie als Gerechtigkeitsfrage der Gegenwart, in: Ingeborg Gabriel / Petra Steinmair-Pösel (Hg.), Gerechtigkeit in einer endlichen Welt: Ökologie -Wirtschaft - Ethik, Stuttgart 2013, S. 9-31.

24 Zum Begriff der „Ligaturen“: Ralf Dahrendorf, Lebenschancen - Anläufe zur sozialen und politischen Theorie, Frankfurt 1979, S. 24 f. 
Gabriel, Ingeborg / Schwarz, Ludwig (Hg.), Weltordnungspolitik in der Krise - Perspektiven internationaler Gerechtigkeit, Paderborn 2011.

Kirchschläger, Peter G., Wirtschaft und Menschenrechte, in: Ingeborg Gabriel / Peter G. Kirchschläger / Richard Sturn (Hg.), Eine Wirtschaft, die Leben fördert, Wirtschaftsund unternehmensethische Reflexionen im Anschluss an Papst Franziskus, Ostfildern 2017, S. 241-264.

Reichel, André, Jenseits des Wachstumszwangs: Postwachstumsökonomie als Wirtschaft der Freiheit, Beitrag zum Tagungsband der GLOBART-Academy 2017, „(UN)ORDNUNG - Was die Welt zusammenhält", München 2019, S. 59-67.

Rodrik, Dani, „A New Deal on Labour Mobility“ in „The Crisis of Globalisation“, in: Social Europe Dossier März 2019.

Rodrik, Dani, Der Druck globaler Bürger, Gastkommentar, in: Wirtschaftsblatt am 20.03. 2013.

Sachs, Jeffrey, The Age of Sustainable Development, New York 2015.

Sedlacek, Thomas, Kapitalismus wird völlig überbewertet, Interview in: Die Presse am 29.02.2016.

Stadler, Wilfried, 10 Jahre nach Lehman - eine Zwischenbilanz; Beitrag für INARA BoardNews, September 2018, vgl. https://www.wilfried-stadler.com/zehn-jahre-nach-leh man-neu (letzter Zugriff: 24.04.2019).

Stadler, Wilfried, Wirtschaftsethik - Schönwetterdisziplin oder Grundlage unserer Wirtschaftsordnung? Vortragsmanuskript zur Tagung des Friedrich von Weizsäcker Instituts am 08.04.2016, vgl. https://www.wilfried-stadler.com/wirtschaftsethik-schnwet terdisziplin-oder-grundlage-unserer-wirtschaftsordnung (letzter Zugriff: 24.04. 2019).

Stadler, Wilfried, Die offene Gesellschaft und ihre Werte, Thesen zur Erneuerung der Ökosozialen Marktwirtschaft, in: Thomas Köhler / Christian Mertens / Michael Spindelegger (Hg.), Stromaufwärts, Christdemokratie in der Postmoderne des 21. Jahrhunderts, Wien 2003, S. 182-192.

Weiters:

Peter Sloterdijk im Gespräch mit Martin Walser, in: Cicero 11/2013, S. $126 \mathrm{f}$. Joe Kaeser zitiert in Handelsblatt am 29.01.2019, „Ein neuer Kapitalismus“. 
Open-Access-Publikation im Sinne der CC-Lizenz BY 4.0

(C) 2020, Vandenhoeck \& Ruprecht $\mathrm{GmbH} \&$ Co. KG, Göttingen ISBN Print: 9783847111658 - ISBN E-Lib: 9783737011655 
Franz Gassner (Macau, S.A.R. China)

\section{Resources for Future in a Caring Economy}

The current global model of politics and economy is in urgent need of a fundamental paradigm shift, as Prof. Ingeborg Gabriel writes: "An economy in its original sense of meaning of a well ruled house-management calls for a new orientation in its relation to ecology, in view of the necessary balance of available resources and their economic use on a national and global level". ${ }^{1}$ There are calls for a basic "structural transformation"2 and "fundamental and profound reform of our economic and societal model" ${ }^{\prime \prime}$ in view of a better care for the people and the earth with its ecosystem and resources, as the "Friday for Future" movement among others justly demand. Our societies and economies have to give up throwaway thinking and unsustainable locked-in structures and move towards a much more responsible use of resources and way of satisfying needs and wants. ${ }^{4}$ "Goals for conserving and sustainably using nature and achieving sustainability cannot be met by current trajectories, and goals for 2030 and beyond may only be achieved through transformative changes across economic, social, political and technological factors." ${ }^{\prime 5}$ The present contribution pleads for the need of a re-

1 Ingeborg Gabriel, Zur Einführung - Ökologie als Gerechtigkeitsfrage der Gegenwart, in: Ingeborg Gabriel / Petra Steinmair-Pösel (ed.), Gerechtigkeit in einer endlichen Welt: Ökologie - Wirtschaft - Ethik, Ostfildern 2014, pp. 9-31, here: p. 16. (tr. F.G.).

2 Alfred Endres, 2.4.5. Wirtschaft im ökologisch-systemaren Zusammenhang, in: Wilhelm Korff / Alois Baumgartner (u. a.) (ed.), Handbuch der Wirtschaftsethik 2: Ethik wirtschaftlicher Ordnungen, Gütersloh 1999, pp. 350-372, here: p. 371. Endres writes of an environmentally-sensible structural change of the economy ("umweltsparenden Strukturwandel der Wirtschaft").

3 Othmar Edenhofer, Das Klima und die Kirche, in: Zur Debatte: Themen der Katholischen Akademie in Bayern 01/2020, pp. 1-5, here: p. 4.

4 Ingeborg Gabriel / Peter G. Kirchschläger / Richard Sturn (ed.), Eine Wirtschaft, die Leben fördert: Wirtschafts- und unternehmensethische Reflexionen im Anschluss an Papst Franziskus, Ostfildern 2017; see also: Gabriel / Steinmair-Posel (ed.), Gerechtigkeit in einer endlichen Welt.

5 Sandra Díaz / Josef Settele / Eduardo Brondízio, et al., Summary for Policymakers of the Global Assessment Report on Biodiversity and Ecosystem Services of the Intergovernmental SciencePolicy Platform on Biodiversity and Ecosystem Services, 6 May 2019, p. 5, see: https://www. 
source sensible economy within our globalized societies. The setting up of a "green fence" by China in 2018 revealed the unjust and shameless inconsistencies of the global ruling ecopolitical elite and their practical resource and waste regime. Countries throughout Asia are shipping waste back to their countries of origin in Canada, the US, and Europe. "Indonesian customs officers examine one of 65 containers full of imported plastic rubbish, at the Batu Ampar port in Batam. Indonesia returned five other containers of rubbish to the United States and will not become a 'dumping ground', officials said." ${ }^{\text {"Something got }}$ fundamentally wrong in economic and political thinking and policies, for instance, how resources are understood and handled, locally and globally. "Very large quantities of plastic waste leak into the environment from sources both on land and at sea, generating significant economic and environmental damage. Globally, 5 to 13 million tonnes of plastics -1.5 to $4 \%$ of global plastics production - end up in the oceans every year. It is estimated that plastic accounts for over $80 \%$ of marine litter." ${ }^{7}$ Indeed, a thoroughly new economic and political approach in dealing with resources is needed and a termination of an embarrassing shallow throw-away mentality of shipping waste over $1000 \mathrm{~s}$ of $\mathrm{kms}$ to other countries' backyards, not to mention how much of it end up in the oceans. The aim must be to transform a careless and unsustainable economy that kills into a consistent and sustainable economy, sensible for people and natural resources, a primary concern of research and teaching of Prof. Ingeborg Gabriel as economist and theologian.

\section{From Planetary Guard Rails towards Resource Ethics}

Societies and economies have to learn to live strictly within "planetary boundaries and guard rails" ${ }^{8}$. The COP21 Paris Agreement 2015 sets the upper limit of $1.5^{\circ} \mathrm{C}\left(2^{\circ} \mathrm{C}\right)$ for anthropogenic atmospheric warming. For reducing emissions, circular economies and zero waste models are indispensable requirements. For instance, precious rare earth materials are limited and need to be shared with present and future generations. However, at the moment, they are still wasted with increasing pace and on a grand scale. The current economic logic of design,

ipbes.net/sites/default/files/downloads/spm_unedited_advance_for_posting_htn.pdf (accessed on August $27^{\text {th }}$ 2019).

6 China Daily, Hong Kong Edition, Tuesday June $18^{\text {th }} 2019$, p. 12.

7 European Commission, A European Strategy for Plastics in a Circular Economy, Brussels 2018, p. 7.

8 WBGU [= German Advisory Council on Global Change], Human Progress within Planetary Guard Rails: A Contribution to the SDG Debate, Berlin 2014; Tim Jackson, Prosperity without Growth: Economics for a Finite Planet, London-Washington, DC 2009. 
production, and consumption is still based on a linear "throwaway culture" (LS, sec.22) and feeds mainly the well-offs. "The consumption decision and lifestyles of the middle and upper classes are currently making the biggest contribution to the causes of global environmental problems." According to research at the Potsdam Institute of Climate Impact, "the poor are responsible for a tiny share of global emissions, yet they have to bear the greatest consequences. Contrary to what some have claimed, it is not the mass of poor people that destroys the planet, but the consumption of the rich. Global warming is the consequence of this development of a few and will affect everyone, but brings devastation especially to the weakest in society." ${ }^{10}$ Research on household consumption in Finland mapping a vision for 2050 demands to cut the use of material resources by a factor of five, from currently 40 to 8 tons per person a year. ${ }^{11}$ The authors admit that there is an "enormous transformation task" and a "long way to go" in view of reducing prevailing patterns of material use. The total consumption of resources in Germany per person in 2004 was $74.000 \mathrm{~kg}$ or 74 metric tons. ${ }^{12}$ WEEE (Waste Electrical and Electronic Equipment, or e-waste) is globally the fastest growing waste stream. The year 2016 saw 44.7 million tons (Mt) of e-waste worldwide, with only 20 percent $(8.9 \mathrm{Mt})$ of it being collected and recycled properly, resulting in 80 percent $(35.8 \mathrm{Mt})$ of it being unaccounted for. ${ }^{13}$ This entails enormous environmental, social and political implications, as scarce so-called conflict materials are crucial for the production especially of electronic equipment. "The total value of all raw materials present in e-waste is estimated at approximately 55 billion euros in 2016, which is more than the 2016 Gross Domestic Product of most countries in the world." ${ }^{14}$ Robertson affirms that:

9 WBGU, Human Progress within Planetary Guard Rails, p. 3.

10 Hans Joachim Schellnhuber, Common Ground: The Papal Encyclical, Science and the Protection of Planet Earth, Potsdam Institute for Climate Impact Research, Germany; Santa Fe Institute for Complex Systems Research, USA, Rome, June $18^{\text {th }} 2015$, p. 2.

11 Michael Lettenmeier / Christa Liedtke / Holger Rohn, Eight Tons of Material Footprint Suggestion for a Resource Cap for Household Consumption in Finland, in: Resources 3/2014, p. 3, see: www.mdpi.com/journal/resources (accessed on February $20^{\text {th }} 2018$ ). See also: Stefan Bringezu, Possible Target Corridor for Sustainable Use of Global Material Resources, in: Resources 4/2015, see: https://www.mdpi.com/2079-9276/4/1/25 (accessed on June $21^{\text {st }}$ 2019).

12 Cf. Gerd Scholl et al., Konsumenten- und kundennahe Ansätze zur Ressourceneffizienzsteigerung. Zusammenfassung der Ergebnisse des Arbeitspakets 12 des Projekts "Materialeffizienz und Ressourcenschonung" (MaRess), Wuppertal, July 2010, p. 3, see: www.ressourcen.wupperinst.org (accessed on August $28^{\text {th }} 2019$ ).

13 C. P. Baldé et al., The Global E-waste Monitor - 2017, United Nations University (UNU), International Telecommunication Union (ITU) \& International Solid Waste Association (ISWA), Bonn-Geneva-Vienna, 2016, pp. 4-6.

14 Ibid., p. 7. 
"Up to 80 percent of America's electronic waste is exported to developing countries, where environmental and worker protection laws and enforcement are less strict. (...) Low-wage workers without protective gear, including children, burn components, soak them in acid baths to separate small amounts of resalable materials, breathe dioxinfilled smoke, and disassemble lead- and mercury-laden parts with their hands. Contaminated water is poured into lakes and rivers and contaminated solid waste is dumped in huge piles near villages, where toxins continue to leak into the soil and water supply." 15

Pope Francis' Encyclical Letter Laudato si' (2015) warns strongly of the injustice involved in the export of "solid waste and toxic liquids to developing countries" (LS 51). Francis calls for a radical turnaround, a "cultural revolution" based on ecological conversion, in fact a "change of humanity" (LS 9 \& 13), of both policies and lifestyles, from unsustainable to "prophetic" and sustainable forms (LS 222). How can such a Copernican revolution get momentum?

\section{On Circular Economy and Waste (Resource) Hierarchy}

Currently prevailing methods of resource, energy, and waste management are still driven by linear end-of-pipe systems of production and consumption, through which energy and resources are wasted inconsistently and unjustly. One reason for this is that goods and services are delivered with a lack of proper accounting for the true costs of their social and ecological consequences (externalisation). To set out on a sensible and sustainable path of resource and energy use, the concept of "waste hierarchy" is necessary to follow. Waste hierarchy as normative principle prioritises and protects the resources and human work inherent in resource streams.

"The waste hierarchy establishes a priority order from prevention, preparation for reuse, recycling and energy recovery through to disposal, such as landfilling. This principle aims to encourage the options that deliver the best overall environmental outcome. The way we collect and manage our waste can lead either to high rates of recycling and to valuable materials finding their way back into the economy, or to an inefficient system where most recyclable waste ends in landfills or is incinerated, with potentially harmful environmental impacts and significant economic losses. To achieve high levels of material recovery, it is essential to send long-term signals to public authorities, businesses and investors (...)"16

15 Margaret Robertson, Sustainability: Principles and Practice, London-New York 2014, pp. 276-277.

16 EU Commission, Closing the Loop: An EU Action Plan for the Circular Economy, Communication from the Commission to the European Parliament, The Council, The European Economic and Social Committee and the Committee of the Regions, Brussels December $2^{\text {nd }}$ 2015, p. 8. 
Within the Waste (Resource) Hierarchy, "No Waste" or "Waste Prevention" ("Refuse!") comes in first, as Zero Waste Movements globally affirm. Zero Waste does not mean that there will be no waste at all, but that waste is radically reduced in the best ways possible, at best down to Zero. This needs a fundamental change in the Design of Products and Services (DfE). ${ }^{17}$ Planned Obsolescence must become a serious socio-ecological crime, as it is in fact. Within the Waste Hierarchy, second comes in "Re-Use", of which Deposit Return systems and Repair are important practical examples. Policies have to promote "reparability, upgradability, durability, and recyclability of products by developing product requirements relevant to the circular economy." ${ }^{\prime 18}$ This also needs proper incentives and the use of "economic instruments, such as taxation, to ensure that product prices better reflect environmental costs." ${ }^{19}$ Reusing has priority before Recycling, as the latter can demand "lengthy transport with additional energy consumption and greenhouse gas emissions. While there are energy savings in recycling, it still consumes more energy than either reusing a product or not producing it in the first place" ${ }^{20}$ An uncritical focus on recycling alone can lead to a higher resource use and can even inhibit necessary systemic changes in view of prevention or reuse, which are on a higher level within the Waste (resource) Hierarchy:

"Recycling often has the effect of encouraging even greater consumption, known as the rebound effect. Consumers seeing the recycling symbol on a plastic container may assume that consuming the product is without environmental costs and may feel that consuming and discarding are environmentally-responsible actions. Recycling may point us in the wrong direction and distract us from more efficient and fundamental changes." 21

Nevertheless, in specific cases, such as aluminium cans, recycling is a must. "Virgin aluminium contains an extremely large amount of embodied energy; recycled aluminium can save 75 to 96 percent of that energy". ${ }^{22}$ The energy required for "aluminium's primary manufacture is locked inside the metal, only a fraction, just $5 \%$, of that original power is needed to drive the recycling process. It is as if the energy is 'banked' for the future." ${ }^{23}$ The recycling rate of aluminium in construction and automobile sector in Europe is about $90 \%$ and in packaging about $60 \%$. The recycling rate of the Aluminium Beverage Can within

$17 \mathrm{DfE}=$ Design for the Environment.

18 EU Commission, Closing the Loop, p. 4.

19 Ibid., p. 6.

20 Robertson, Sustainability, p. 275.

21 Ibid., pp. 275-276.

22 Ibid., p. 277.

23 European Aluminium, Recycling Aluminium: A Pathway to a Sustainable Economy, Brussels September 2015, p. 5. 
the European Union, Switzerland, Norway, and Iceland increased end of 2015 to $74 \% .{ }^{24}$ "Despite such a strong record, the amount of aluminium collected and sorted needs to be increased. Growing demand for scrap makes it challenging for the European industry to access this valuable raw material." ${ }^{25}$ Despite its limits, one of the greatest benefits of recycling is raising ecological awareness:

"Using recycled materials in manufacturing almost always uses less water and energy, releases less pollution, and emits less carbon dioxide than manufacturing with virgin materials. In addition, perhaps one of the greatest benefits of recycling has been its effect on public awareness of environmental issues. Recycling is the first contact many people have with issues of planetary health and the connection between their own actions and the environment." ${ }^{26}$

The next step within the waste or resource hierarchy is Energy Recovery (WtE, Waste to Energy) through incineration, which can be - if properly done - a better option than mere disposal of waste on landfills. In general, waste incineration and landfilling are at the lowest level of the Waste Hierarchy and thus the least choice and should be widely phased out in the long run. Robertson affirms that in "addition to having concerns about health risks, some organizations object on the basis of environmental justice since incinerators are usually built in lowincome communities" ${ }^{27}$. When waste cannot be prevented or its resources not recycled, "recovering its energy content is in most cases preferable to landfilling it, in both environmental and economic terms." ${ }^{28}$ But WtE must strictly be chosen and implemented based on the Principle of the Waste (Resource) Hierarchy. The implementation of the Waste Hierarchy Principle in societies requires consistent policies and incentives and the raising of awareness and education among all stakeholders. "Rather than a single monthly fee, users are charged based on the volume they discard, an approach sometimes known as pay-as-youthrow. Some regions have taken money that would have been spent on landfills or incinerators and instead have invested in infrastructure that supports reuse." 29 Overall, a profound change of mentality and thinking, and a fundamental transformation of social-economic structures is crucial towards implementing consistent circular and zero-waste systems:

"Zero Waste involves rethinking the entire production and wasting system. This approach considers the entire life cycle of a product when analyzing its costs. It stresses

24 European Aluminium, Press Release "Aluminium Beverage Can Recycling Rate at $74 \%$ : Aluminium beverage cans already well above the future EU Circular Economy recycling targets.", Brussels June $12^{\text {th }} 2018$.

25 European Aluminium, Recycling Aluminium, p. 10.

26 Robertson, Sustainability, p. 275.

27 Ibid., p. 272.

28 EU Commission 2015, Closing the Loop, p. 10.

29 Robertson, Sustainability, p. 281. 
prevention, recognizing that it is more efficient and healthier to prevent waste formation in the first place than to treat waste after it has formed. At its core, Zero Waste acknowledges that humans are part of the natural world. It aims for cradle-to-cradle, closed-loop cycling of non-toxic matter that will allow the biosphere in which we are embedded to continue intact into the future." ${ }^{30}$

Pope Francis supports in the strongest terms in Laudato si' the urgent need for resource responsibility, waste prevention (LS $22 \& 113$ ), reuse, repairing and recycling (LS $192 \&$ 211). As Archbishop of Buenos Aires he encouraged cartoneros and recicladores in their recycling efforts, "because what is leftover is rich". ${ }^{31}$ For him, the proper dealing with resources is also deeply connected with the appreciation of human work. In general, the exploitation of resources of our common home "has exceeded unacceptable limits" (LS 11). Thus, we have to overcome the culture of discarding in "wasteful cities" (LS 44). Francis vehemently calls for "less waste" (LS 129) and a termination of the throwaway culture violating the dignity of humans and of the resources of our common home.

\section{The Strategies Efficiency-Consistency-Sufficiency and Sustainable Resource Use}

The strategies efficiency, consistency, and sufficiency as elements of a resource ethics help to navigate the journey towards a more sustainable development path. ${ }^{32}$ Efficiency means to save resources and energy mainly through technological innovation. However, higher efficiency is not enough for sustainable development because of direct and indirect rebound or "boomerang effects" of consumption patterns. Rebound effects eat up efficiency gains by more (direct rebound) and new (indirect rebound) forms of consumption. For instance, the fuel efficiency of cars increased in the US by 40 percent from 1980 to 2011, but fuel consumption per vehicle "remained constant since 1980 due to more driving and more (and larger) vehicles." ${ }^{\prime 3}$ An example for an indirect rebound effect is to use efficiency gains and respective monetary savings to switch to new forms of

30 Ibid., pp. 281-282.

31 Francis, Pope's Video Message to Recycling Workers of Argentina, Vatican City, December $20^{\text {th }}$ 2013, see: http://www.zenit.org/en/articles/pope-s-video-message-to-recycling-work ers-of-argentina (accessed on December $21^{\text {st }} 2013$ ).

32 Secretariat of the German Bishops' Conference, Committed to God's Creation, Suggestions for a Sustainable Approach to Energy, Bonn 2011; Sascha Samadi / Marie-Christine Gröne / Uwe Schneidewind / Hans-Jochen Luhmann / Johannes Venjakob / Benjamin Best, Sufficiency in energy scenario studies: Taking the potential benefits of lifestyle changes into account, in: Technological Forecasting and Social Change 124/2017, pp. 126-134.

33 Juliet Schor, True Wealth: How and Why Millions of Americans Are Creating a Time-Rich, Ecologically Light, Small-Scale, High-Satisfaction Economy, New York 2011, p. 90. 
mobility consumption such as increased air travelling with higher emissions. Pope Francis agrees that technology alone (e.g., higher efficiency) does not bring humanity towards a sustainable path (LS 20). In addition, radical changes in how we structure our societies (consistency, LS 219) and personal life style (sufficiency) are necessary. Consistency means the creation of innovative systems of living together, e.g., the establishment of a shared and effective public transport system (LS 58 and 153) or of using car-sharing systems instead of running private vehicles in cities that waste precious space, cause air and noice pollution and hinder the development of efficient public mobility. Smart cities eliminate private vehicles from their territories, so that they do not occupy the precious resource city-space and prevent the birth of efficient and sustainable mobility systems (e.g., providing convenient Park \& Ride Facilities outside of the cities). Another example for consistency is to switch to deposit return systems instead of current socially and ecologically harmful one-way throwaway systems. Consistency favors a circular economy based on zero-waste policies that internalise external costs (e.g., carbon tax; plastic bag levy; see also LS 36). Already Pope Benedict XVI called for a strict implementation of the True-Cost-Principle (German: Kostenwahrheit) when he writes:

"To make every effort to ensure that the economic and social costs of using up shared environmental resources are recognized with transparency and fully borne by those who incur them, not by other peoples or future generations" (CiV 50). ${ }^{34}$

The sending of plastic waste from the US, Canada, or Europe to Asia reveals the inconsistent and unjust logic of a "killing economy". Such inconsistent externalizing practices ("others should pay or bear the burden") have to be overcome. This applies to all levels of consumption and trade, on the micro, meso, and macro level. The User-or Thrower-Pays-Principle has to be promoted, such as through policies promoting the Extended Producer Responsibility (EPR), as well as Take-Back regulations by governments that require shops and retailers to take back batteries and toxic printer cartridges, and to create and feed funds for circular systems of resource use:

"Resources are often used inefficiently because the information about the true costs to society of consuming them is not available, with the result that businesses and individuals cannot adapt their behavior accordingly. Policy measures to improve resource efficiency and overall economic competitiveness must place greater emphasis on 'getting prices right' and making them transparent to consumers, for instance in transport, energy and water usage, so that prices reflect the full costs of resource use to society (e. g. in terms of environment and health), and do not create perverse incentives.

34 Benedict XVI., Caritas in veritate, Vatican 2009, sec. 50. 
In this respect, information and communication technologies can play a decisive role through, for instance, smart metering."35

However indispensable, higher efficiency backed by more consistent systems is not enough to reach a sustainable development path. Sustainability research argues of the need for sufficiency in combination to higher efficiency and better consistency. ${ }^{36}$ Sufficiency refers to changes in life-style and accepting and living within life-giving limits; for example, reducing food loss and waste - on the institutional and personal level - or observing at least one meatless day a week. "Due to rebound effects, technical (and to some extent social) innovations, as engineered, do not inevitably save resources and energy. Strategies focussing solely on efficiency of products cannot be successful unless they are accompanied by strategies that enhance social innovations that foster a paradigm shift in consumption patterns." ${ }^{37}$ "Sufficiency and changes in lifestyle should rather be embedded, discussed and quantified independently of technology decisions." 38 The three principles efficiency, consistency, and sufficiency are deeply interrelated, which is for instance relevant in view of DfE:

"A sustainable design of products and services requires the integration of productionorientated (efficiency and consistency) and consumption-orientated (sufficiency) strategies. [...] The goal is not to design sustainable products but rather to design systems that manage to foster sustainable lifestyles." ${ }^{\text {"9 }}$

Sufficiency requires a change of mindsets and new orientation, a "voluntary self-limitation" 40 , which has to be nourished by spiritual values (LS 222), including the cultivation of a "capacity for contemplation and reverence" (LS 127 $\& 237)$. A core message of Laudato si' is that spiritual values like mindfulness, thankfulness, tenderness, and respect are crucial in overcoming the throw-away mentality and implementing a sensible use of resources that aims at a sustainable

35 EU-Commission, Resource-efficient Europe - Flagship initiative under the Europe 2020 Strategy, Communication from the Commission to the European Parliament, the Council, the European Economic and Social Committee and the Committee of the Regions, Brussels 2011, p. 7.

36 Thomas Princen, The Logic of Sufficiency, Cambridge 2005; Samadi (et al.), Sufficiency in energy scenario studies, pp. 126-134.

37 Christa Liedtke / Johannes Buhl / Najine Ameli, Designing value through less by integrating sustainability strategies into lifestyles, Wuppertal: Wuppertal Institute for Climate, Environment and Energy: Research Group 'Sustainable Production and Consumption', Wuppertal 2013, p. 12.

38 Samadi (et al.), Sufficiency in energy scenario studies, p. 132.

39 Liedtke / Buhl / Ameli, Designing value through less by integrating sustainability strategies into lifestyles, p. 1.

40 Gabriel, Zur Einführung - Ökologie als Gerechtigkeitsfrage der Gegenwart, p. 10. 
development path. This is fully in line with research on sustainability and ethics of consumption. ${ }^{41}$

\section{Wanted: Spirituality nourishing Sufficiency and Sustainable Life-styles}

Many in the scientific community acknowledge the enormous and epochal transformation and transition ahead, and that religious and spiritual resources are needed to reach a sustainable development path. ${ }^{42}$ Spiritualities deepen awareness, respect, and care, and the ability to live a life within "life-giving limits". Spiritual values can feed a cultural revolution to build a socially and ecologically caring economy. A "spirituality of interconnectedness", as promoted by Pope Francis in Laudato si', is one helpful element. A sound spirituality can open minds to see and appreciate interconnectedness in our common oikos or home, which is crucial to protect the Biodiversity on our planet. Goal 15 of the United Nations SDGs of 2015 demands the halting of losses in biodiversity (BD), so crucial for stability in nature and societies as well as the future of indigenous populations. The current dramatic loss of $\mathrm{BD}$ is due to a failure to respect interconnectedness, resulting in a lack of coherent policies to set and live appropriate limits. Humans have to see and learn to respect the interdependencies of everything with everything (LS 70; $137 \mathrm{ff}$.) and implement coherent policies, systems, and practices. Laudato si' puts a strong focus on biodiversity (LS $32 \mathrm{ff}$.) and emphasises the "mutual connections in an ordered system" with everything "dependent on one another" (LS 42). Social life, ecology, and economy are deeply intertwined. For Francis the "Cry of the Poor" and the "Cry of the Earth", the social and ecological dimension, are deeply interwoven. Indigenous cultural communities live at the precarious place where biological and cultural diversity meet and often at the same place where precious mineral resources are waiting to be exploited by the powerful and wasteful. Also the cultural riches of peoples,

41 David Crocker, Consumption, Well-Being and Capability, in: David Crocker / Toby Linden (ed.), Ethics of Consumption: The Good Life, Justice, and Global Stewardship, LanhamMaryland 1998, pp. 366-390; Lucy Reisch, Sustainable consumption as a consumer policy issue, in: Lucy Reisch / Inge Ropke (ed.), The Ecological Economics of Consumption, Cheltenham-Norhampton 2004, pp. 175-189.

42 Gary Gardner, Engaging Religions To Shape Worldviews, in: Worldwatch Institute (ed.), State of the World: Transforming Cultures from Consumerism to Sustainability, London 2010, pp. 23-29; Dieter Gerten / Sigurd Bergmann, Religion in Environmental and Climate Change: Suffering, Values, Lifestyles, London-New York 2012; Gerhard Banse / Nelson L. Gordon / Oliver Parodi (ed.), Sustainable Development: The Cultural Perspective: Concepts Aspects - Examples, Berlin 2011; Lyn Thomas (ed.), Religion, Consumerism, and Sustainability. Paradise Lost?, London 2011. 
"their art and poetry, their interior life and spirituality" needs to be protected and preserved (LS 62f.) as the "disappearance of a culture can be just as serious, or even more serious, than the disappearance of a species of plant or animal. The imposition of a dominant lifestyle linked to a single form of production can be just as harmful as the altering of ecosystems" (LS 145). Francis condemns any system of exclusion and waste that marginalises the poor and Mother Earth through persistent structures of indifference. Prevention of food waste is of highest priority. "Whenever food is thrown out it is as if it were stolen from the table of the poor" (LS 50). Indeed, globally, "roughly one third of the food produced in the world for human consumption every year - approximately 1.3 billion tons - gets lost or wasted." ${ }^{43}$ Food loss and waste is a burning question of resource and ecological ethics. If food waste were measured as if it were a country on its own, it would be the third largest emitter of $\mathrm{CO}_{2}$ equivalents after China and the USA. ${ }^{44}$ In 2011, Hong Kong produced 3,600 tons of food waste per day, coming from supermarkets, restaurants, hotels, and households, amounting to 40 percent of the city's solid waste (MSW). When food is wasted, the land, water, fertilizer and labour - that is needed to grow that food - are also lost and wasted. ${ }^{45}$ The Campaign Foodwise Hong Kong is a laudable initiative to raise awareness on various societal levels to be more responsible with food and resources. However, this issue needs systemic and structural answers, and thus, besides a change of mindset and thinking, proper political answers. The experience in Hong Kong confirms this: despite 7 years Foodwise Campaign, Foodwaste is still on the same level: 3600 tonnes per day. ${ }^{46}$ Many countries have developed food banks so that supermarkets and hotels can donate surplus food for poor and needy communities. However, such initiatives require proper legislation and institutions. ${ }^{47}$

The Friday for Future Movement calls for drastic changes of our global system. How can we be such a change? A few generations ago, wasting of food was unthinkable, and on Fridays there was no meat on the plate, following an old

43 FAO, Food Wastage Footprint: Impacts on Natural Resources, Rome 2013.

44 Mervyn Jones, Foodwaste Generation and Prevention Strategy: Workshop on Food Waste Management, Prevention and Treatment Technology. Power Point Presentation at the International Conference on Solid Waste 2015: Knowledge Transfer for Sustainable Resource Management, Hong Kong SAR, P.R. China, 19-23 May 2015, Hong Kong, $19^{\text {th }}$ May 2015.

45 Environmental Protection Bureau/Hong Kong Government, Foodwise Hong Kong Campaign: Invitation to Sign Food Wise Charter, Hong Kong 2013, see: http://www.foodwisehk. gov.hk/en/ (accessed on Feb. 20 ${ }^{\text {th }}$ 2018).

46 See: https://www.opark.gov.hk/en/index.php (accessed on April 25 ${ }^{\text {th }} 2020$ ).

47 Felicitas Schneider, The Evolution of Food Donation with Respect to Waste Prevention. Waste Management 33/2013, pp. 755-763, see: https://doi.org/10.1016/j.wasman.2012.10.025 (accessed on $21^{\text {th }}$ 2019). The "Food Recovery Hierarchy" of the EPA (Environmental Protection Agency) in the US tries to translate the issue of resources into the food system. 
Catholic tradition. To take up and revive this practice, globally among 1.2 Billion Catholics, can be a powerful and effective way to reduce emissions significantly and to promote a more sustainable life-style, creating butterfly effects and bridging ecology, economy, and spirituality, as Norma Wirzba describes:

"Feasting and fasting are two primary ways we enact relationships. How we eat, what we
eat, and how much, demonstrate what we think our responsibilities to each other and
the world should be. People who fast, learn food is a gift and is not to be taken for
granted or exploited. [...] When we fast we learn that too much of the time personal life
is marked by an aggressive or rapacious disposition (which is why we might develop a
gentler ego and a calmer gait). When we fast, we learn that in many of our actions we
presume that the world's gifts exist for our own exclusive enjoyment (hence the need to
tame the greed and develop the restraint that are at the basis of all just relationships).
Fasting, in other words, leads us to a realization about the responsibilities of life
together. When we refrain from eating, we not only demonstrate solidarity with those
who do not have food to eat but we also demonstrate that food is the precious gift of a
self-giving God. [...] Fasting, in its most fundamental aspiration, is about developing a
sacrificial, self-offering life that addresses and nurtures the needs of others." 48

We have to be thankful to the young people and their insistent wakeup call in their Friday for Future Initiative. There are many other valuable movements, ushering in fundamental changes in our societies, like the Zero-Waste-Movements, or the Slow-Food-Movement of Carlo Petrini, promoting clean, healthy, and just food, preserving local families, cultures, natural landscapes, and saving fruit variety and tastes in its "Arc of Taste" ${ }^{49}$ Let us embark on their saving "Arc" and support practical applications of a much more resource sensible world. Our Fridays will truly serve a sustainable future if we heed the call of scientists for mitigating climate change by our dietary choices, ${ }^{50}$ refraining from meat and food waste and loss as crucial steps towards a spiritual and cultural revolution in

48 Norma Wirzba, Food and Faith: A Theology of Eating, Cambridge (et al.) 2014, p. $141 \mathrm{ff}$. 49 www.slowfood.com (accessed on August $28^{\text {th }} 2019$ ).

50 "Balanced diets, featuring plant-based foods, such as those based on coarse grains, legumes, fruits and vegetables, nuts and seeds, and animal-sourced food produced in resilient, sustainable and low-GHG emission systems, present major opportunities for adaptation and mitigation while generating significant co-benefits in terms of human health (high confidence). By 2050, dietary changes could free several Mkm2 (medium confidence) of land and provide a technical mitigation potential of 0.7 to $8.0 \mathrm{GtCO} 2 \mathrm{e}$ yr- 1 , relative to business as usual projections (high confidence). Transitions towards low-GHG emission diets may be influenced by local production practices, technical and financial barriers and associated livelihoods and cultural habits.", IPCC Special Report on Climate Change, Desertification, Land Degradation, Sustainable Land Management, Food Security, and Greenhouse gas fluxes in Terrestrial Ecosystems, Summary for Policymakers, Geneva August $7^{\text {th }} 2019$, p. 26, also p. 20 and 21; see: https://www.ipcc.ch/report/srccl/ (accessed on August $27^{\text {th }} 2019$ ). 
view of just and sustainable life-styles and societies, where people, ecology and economy have a future in our common home. ${ }^{51}$

\section{Sources}

Baldé, C. P. et al., The Global E-waste Monitor - 2017, United Nations University (UNU), International Telecommunication Union (ITU) \& International Solid Waste Association (ISWA), Bonn-Geneva-Vienna 2016.

Banse, Gerhard / Gordon, L. Nelson / Parodi, Oliver (ed.), Sustainable Development: The Cultural Perspective: Concepts - Aspects - Examples, Berlin 2011.

Benedict XVI., Caritas in Veritate, Vatican 2009, see: http://w2.vatican.va/content/bene dict-xvi/en/encyclicals/documents/hf_ben-xvi_enc_20090629_caritas-in-veritate. html (accessed on June $21^{\text {st }} 2019$ ).

Bringezu, Stefan, Possible Target Corridor for Sustainable Use of Global Material Resources, in: Resources 4/2015, pp. 25-54, see: https://www.mdpi.com/2079-9276/4/1/ 25 (accessed on June $21^{\text {st }} 2019$ ).

China Daily, Hong Kong Edition, Tuesday June $18^{\text {th }} 2019$, p. 12.

Crocker, David, Consumption, Well-Being and Capability, in: David Crocker / Toby Linden (ed.), Ethics of Consumption: The Good Life, Justice, and Global Stewardship, LanhamMaryland 1998, pp. 366-390.

Díaz, Sandra / Settele, Josef / Brondízio, Eduardo, et al., Summary for Policymakers of the Global Assessment Report on Biodiversity and Ecosystem Services of the Intergovernmental Science-Policy Platform on Biodiversity and Ecosystem Services, 6 May 2019, p. 5, see: https://www.ipbes.net/sites/default/files/downloads/spm_unedited_ad vance_for_posting_htn.pdf (accessed on August $27^{\text {th }}$ 2019).

Edenhofer, Othmar. Das Klima und die Kirche, in: Zur Debatte: Themen der Katholischen Akademie in Bayern 01/2020, pp. 1-5.

Endres, Alfred, 2.4.5. Wirtschaft im ökologisch-systemaren Zusammenhang, in: Wilhelm Korff / Alois Baumgartner (u. a.) (ed.), Handbuch der Wirtschaftsethik 2: Ethik wirtschaftlicher Ordnungen, Gütersloh 1999, pp. 350-372.

51 Univ.-Prof. Dr. Ingeborg Gabriel organized on January $14^{\text {th }} 2011$ the Research Conference "How Much Meat Is Enough? Ecological, social, and spiritual Aspects of Meat Consumption" [Studientag "Wie viel Fleisch ist genug? Ökologische, soziale und spirituelle Aspekte des Fleischkonsums", Institut für Sozialethik, Universität Wien/Iustitia et Pax.] This Research Workshop took place at the Dean's Office of the Faculty of Catholic Theology at the University of Vienna. Besides Prof. Ingeborg Gabriel, contributions were given by: Ao. Univ.-Prof. KarlMichael Brunner (Ernährungssoziologe, Institut für Soziologie und Empirische Sozialforschung der Wirtschaftsuniversität Wien); o. Univ.-Prof. Dr. em. Univ.-Prof. Dr. Gerhard Glatzel (Universität für Bodenkultur - Department für Wald und Bodenwissenschaften; ÖAW); em. Univ.-Prof. Dr. Hans-Peter Lang (Universität für Bodenkultur); Dr. med. Eduard Pesina (Chirurg, Ernährungsmediziner, Fastenarzt, Präsident der Österreichischen Gesellschaft für Gesundheitsförderung); Abt Michael Prohazka (Stift Geras); Dipl. Josef Riegler (Vizekanzler a.D., Ökosoziales Forum Österreich). 
Environmental Protection Bureau/Hong Kong Government, Foodwise Hong Kong Campaign: Invitation to Sign Food Wise Charter, Hong Kong 2013, see: http://www.food wisehk.gov.hk/en/ (accessed on Feb. $20^{\text {th }}$ 2018).

EU-Commission, Resource-efficient Europe - Flagship Initiative under the Europe 2020 Strategy, Communication from the Commission to the European Parliament, the Council, the European Economic and Social Committee and the Committee of the Regions, Brussels 2011.

EU Commission, Closing the Loop: An EU Action Plan for the Circular Economy, Communication from the Commission to the European Parliament, The Council, The European Economic and Social Committee and the Committee of the Regions, Brussels December $2^{\text {nd }} 2015$.

European Aluminium, Recycling Aluminium: A Pathway to a Sustainable Economy, Brussels September 2015.

European Aluminium, Press Release "Aluminium Beverage Can Recycling Rate at 74 \%: Aluminium beverage cans already well above the future EU Circular Economy recycling targets.", Brussels June $12^{\text {th }} 2018$.

European Commission, A European Strategy for Plastics in a Circular Economy, Brussels 2018.

FAO, Food Wastage Footprint: Impacts on Natural Resources, Rome 2013.

Francis, Pope's Video Message to Recycling Workers of Argentina, Vatican City December $20^{\text {th }}$ 2013, see: http://www.zenit.org/en/articles/pope-s-video-message-to-recyclingworkers-of-argentina (accessed on December $21^{\text {st }} 2013$ ).

Francis, Laudato si': Care for Our Common Home, Vatican 2015, see: http://w2.vatican.va/ content/francesco/en/encyclicals/documents/papa-francesco_20150524_enciclica-lau dato-si.html (accessed on June $21^{\text {st }} 2019$ ).

Gabriel, Ingeborg / Kirchschläger Peter G. / Sturn, Richard (ed.), Eine Wirtschaft, die Leben fördert: Wirtschafts- und unternehmensethische Reflexionen im Anschluss an Papst Franziskus, Ostfildern 2017.

Gabriel, Ingeborg, Zur Einführung - Ökologie als Gerechtigkeitsfrage der Gegenwart, in: Ingeborg Gabriel / Petra Steinmair-Pösel (ed.), Gerechtigkeit in einer endlichen Welt: Ökologie - Wirtschaft - Ethik, Ostfildern 2014, pp. 9-31.

Gabriel, Ingeborg / Steinmair-Pösel, Petra (ed.), Gerechtigkeit in einer endlichen Welt: Ökologie - Wirtschaft - Ethik, Ostfildern 2014.

Gardner, Gary, Engaging Religions To Shape Worldviews, in: Worldwatch Institute (ed.), State of the World: Transforming Cultures from Consumerism to Sustainability, London 2011, pp. 23-29.

Gerten, Dieter / Bergmann, Sigurd, Religion in Environmental and Climate Change: Suffering, Values, Lifestyles, London-New York 2012.

IPCC Special Report on Climate Change, Desertification, Land Degradation, Sustainable Land Management, Food Security, and Greenhouse gas fluxes in Terrestrial Ecosystems, Summary for Policymakers, Geneva August $7^{\text {th }} 2019$.

Jackson, Tim, Prosperity without Growth: Economics for a Finite Planet, London-Washington, DC 2009.

Jones, Mervyn, Foodwaste Generation and Prevention Strategy: Workshop on Food Waste Management, Prevention and Treatment Technology. Power Point Presentation at the International Conference on Solid Waste 2015, Knowledge Transfer for Sustainable 
Resource Management, Hong Kong SAR, P.R. China, 19-23 May 2015, Hong Kong $19^{\text {th }}$ May 2015.

Lettenmeier, Michael / Liedtke, Christa / Rohn, Holger, Eight Tons of Material Footprint Suggestion for a Resource Cap for Household Consumption in Finland, in: Resources 3/ 2014, see: www.mdpi.com/journal/resources (accessed on February $20^{\text {th }} 2018$ ).

Liedtke, Christa / Buhl, Johannes / Ameli, Najine, Designing value through less by integrating sustainability strategies into lifestyles, Wuppertal: Wuppertal Institute for Climate, Environment and Energy, Research Group "Sustainable Production and Consumption", Wuppertal 2013.

Princen, Thomas, The Logic of Sufficiency, Cambridge 2005.

Reisch, Lucy, Sustainable consumption as a consumer policy issue, in: Lucy Reisch / Inge Ropke (ed.), The Ecological Economics of Consumption, Cheltenham-Norhampton 2004, pp. 175-189.

Robertson, Margaret, Sustainability: Principles and Practice, London-New York 2014.

Samadi, Sascha / Gröne, Marie-Christine / Schneidewind, Uwe / Luhmann, Hans-Jochen / Venjakob, Johannes / Best, Benjamin, Sufficiency in energy scenario studies: Taking the potential benefits of lifestyle changes into account, in: Technological Forecasting and Social Change 124/2017, pp. 126-134.

Schellnhuber, Hans Joachim, Common Ground. The Papal Encyclical, Science and the Protection of Planet Earth, Statement, Rome-Vatican 2015.

Schneider, Felicitas, The Evolution of Food Donation with Respect to Waste Prevention, in: Waste Management 33/2013, pp. 755-763, see: https://doi.org/10.1016/j.wasman.2012. 10.025 (accessed on June $21^{\text {st }} 2019$ ).

Scholl, Gerd (et al.), Konsumenten- und kundennahe Ansätze zur Ressourceneffizienzsteigerung, Zusammenfassung der Ergebnisse des Arbeitspakets 12 des Projects "Materialeffizienz und Ressourcenschonung" (MaRess), Wuppertal 2010, see: https:// epub.wupperinst.org/files/3373/MaRess_AP12_1A.pdf (accessed on June 21 ${ }^{\text {st }} 2019$ ).

Schor, Juliet, True Wealth. How and Why Millions of Americans Are Creating a Time-Rich, Ecologically Light, Small-Scale, High-Satisfaction Economy, New York 2011.

Secretariat of the German Bishops' Conference, Committed to God's Creation: Suggestions for a Sustainable Approach to Energy, Bonn 2011.

Thomas, Lyn (ed.), Religion, Consumerism, and Sustainability. Paradise Lost?, London 2011.

$\mathrm{WBGU}=$ German Advisory Council on Global Change, Humanity on the Move: Unlocking the Transformative Power of Cities, Berlin 2016.

$\mathrm{WBGU}=$ German Advisory Council on Global Change, Human Progress within Planetary Guard Rails: A Contribution to the SDG Debate, Berlin 2014.

Wirzba, Norma, Food and Faith: A Theology of Eating, Cambridge (et al.) 2014. https://www.opark.gov.hk/en/index.php (accessed on April $25^{\text {th }} 2020$ ). 
Open-Access-Publikation im Sinne der CC-Lizenz BY 4.0

(C) 2020, Vandenhoeck \& Ruprecht $\mathrm{GmbH} \&$ Co. KG, Göttingen ISBN Print: 9783847111658 - ISBN E-Lib: 9783737011655 


\section{Anhang}

Open-Access-Publikation im Sinne der CC-Lizenz BY 4.0

(c) 2020, Vandenhoeck \& Ruprecht GmbH \& Co. KG, Göttingen 
Open-Access-Publikation im Sinne der CC-Lizenz BY 4.0

(C) 2020, Vandenhoeck \& Ruprecht $\mathrm{GmbH} \&$ Co. KG, Göttingen ISBN Print: 9783847111658 - ISBN E-Lib: 9783737011655 


\section{Curriculum vitae \\ o. Univ. Prof. MMag. Dr. Ingeborg Gabriel}

geboren in Wels, Oberösterreich

seit 1997 Ordinaria für Christliche Gesellschaftslehre / 1997-2020 Leiterin des Fachbereichs Sozialethik (bis 2016 Institut für Sozialethik) der KatholischTheologischen Fakultät der Universität Wien

1995-1997 Assistenzprofessorin und Leiterin der Abteilung für Internationale Ethik

1982-1995 Universitätsassistentin am Institut für Ethik und Sozialwissenschaften der Katholisch-Theologischen Fakultät der Universität Wien

1980-1989 Studium der Fachtheologie an der Katholisch-Theologischen Fakultät, Wien (Abschluss Mag.theol. 1986; Dr. theol. 1989)

1980-1981 freie Mitarbeiterin beim ORF

1976-1980 Internationale Beamtin bei den Vereinten Nationen (UNDP) in New York (Referentin der Personalabteilung); Katmandu, Nepal (Verantwortliche des Relief Systems) und Ulan Bator, VR Mongolei (Vice-Resident Representative)

1974-1976 Post-graduate Studium in internationalen Beziehungen an der Diplomatischen Akademie, Wien

1970-1974 Studium der Handelswissenschaften und Volkswirtschaftslehre, Hochschule für Welthandel und Universität Wien (Mag rer.soc. et oec.), daneben Studium der Geschichte, Germanistik und Slawistik

1968/69 Stipendiatin des American Field Service (Long Beach, Kalifornien) 
Funktionen und Mitgliedschaften (eine Auswahl)

Universitäre Funktionen

- Leiterin des Fachbereichs Sozialethik (seit 2016-2020)

- Institutsvorstand des Instituts für Sozialethik (1997-2016)

- Vizedekanin der Katholisch-Theologischen Fakultät der Universität Wien (2010-2012)

- Mitglied des Senates der Universität Wien (1997-2006; 2010-2013)

- Mitglied der Ethikkommission der Universität Wien (2011-2014)

Außeruniversitäre Funktionen

- Sonderbeauftragte der OSZE (Organisation für Sicherheit und Zusammenarbeit in Europa) im Kampf gegen Rassismus, Xenophobie und Diskriminierung, auch fokussierend auf Intoleranz und Diskriminierung gegenüber Christen und anderen Religionen (seit 2017)

- Direktorin der „Justitia et pax“-Kommission der Österreichischen Bischofskonferenz (2008-2016)

- Jurymitglied der Stiftung Centesimus Annus - Pro Pontifice zur Verleihung des International Award „Economy and Society“ (2015)

- Vizepräsidentin von „Justitia et pax“-Europa (2013-2019)

- Vizepräsidentin des Vereins der Stiftung Pro Oriente, Wien

- Mitglied des Kuratoriums des Leopold-Kunschak-Preises

- Mitglied des Wissenschaftlichen Beirats der Edith-Stein-Gesellschaft

- Mitglied des Kuratoriums des Afro-Asiatischen Instituts (1997-2007)

- Mitglied des Kuratoriums der Katholischen Sozialakademie Österreichs (2004-2007)

Sprachen: Englisch, Französisch, Russisch, passiv Spanisch 


\section{Publikationen \\ o. Univ. Prof. MMag. Dr. Ingeborg Gabriel}

\section{Bücher}

Ingeborg Gabriel, Ethik des Politischen. Grundlagen - Prinzipien - Konkretionen, Echter 2020.

Ingeborg Gabriel / Peter G. Kirchschläger / Richard Sturn (Hg.), Eine Wirtschaft, die Leben fördert. Wirtschafts- und unternehmensethische Reflexionen im Anschluss an Papst Franziskus, Ostfildern 2017.

Ingeborg Gabriel gemeinsam mit Kristina Stoeckl / Aristotle Papanikolaou (Hg.), Political Theologies in Orthodox Christianity. Common Challenges - Divergent Positions, London 2017.

Ingeborg Gabriel / Petra Steinmair-Pösel (Hg.), Gerechtigkeit in einer endlichen Welt. Ökologie - Wirtschaft - Ethik, 2. Aufl., Ostfildern 2014.

Ingeborg Gabriel / Petra Steinmair-Pösel (Hg.), Gerechtigkeit in einer endlichen Welt. Ökologie - Wirtschaft - Ethik, Ostfildern 2013.

Ingeborg Gabriel / Alexandros K. Papaderos / Ulrich H. J. Körtner (ed.), Trilogy of Social Ethics: Orthodox - Catholic - Protestant, Philadelphia 2012.

Ingeborg Gabriel / Helmut Renöckl (Hg.), Solidarität in der Krise. Auf der Suche nach neuen Wegen, Würzburg 2012.

Ingeborg Gabriel / Ludwig Schwarz (Hg.), Weltordnungspolitik in der Krise. Perspektiven internationaler Gerechtigkeit, Paderborn 2011.

Ingeborg Gabriel / Cornelia Bystricky (Hg.), Kommunismus im Rückblick. Ökumenische Perspektiven aus Ost und West (1989-2009), Ostfildern 2010.

Ingeborg Gabriel (Hg.), Politik und Theologie in Europa. Perspektiven ökumenischer Sozialethik, Ostfildern 2008.

Ingeborg Gabriel / Franz Gassner (Hg.), Solidarität und Gerechtigkeit. Ökumenische Perspektiven, Ostfildern 2007.

Ingeborg Gabriel / Alexandros K. Papaderos / Ulrich H. J. Körtner (Hg.), Perspektiven ökumenischer Sozialethik. Der Auftrag der Kirchen im größeren Europa, 2. überarb. Aufl., Mainz 2006.

Ingeborg Gabriel / Alexandros K. Papaderos / Ulrich H. J. Körtner (Hg.), Perspektiven ökumenischer Sozialethik. Der Auftrag der Kirchen im größeren Europa, Mainz 2005. 
Ingeborg Gabriel / Christa Schnabl / Paul M. Zulehner (Hg.), Einmischungen. Zur politischen Relevanz der Theologie, Ostfildern 2001.

Ingeborg Gabriel (Hg.), Demokratie als Herausforderung. Christliche Perspektiven mit Schwerpunkt Mittel- und Osteuropa, Wien 1997.

Ingeborg Gabriel, Gewalt in Europa. Ursachen - Hintergründe - Auswege, Regensburg 1995.

Ingeborg Gabriel (Hg.), Freiheit und Verantwortung der Kirche in der Gesellschaft, Wien 1995.

Ingeborg Gabriel (Hg.), Minderheiten und nationale Frage. Die Entwicklung in Mittel- und Südosteuropa im Lichte der katholischen Soziallehre, Wien 1993.

Ingeborg Gabriel, Friede über Israel: Eine Untersuchung zur Friedenstheologie in Chronik I 10 - II 36, Klosterneuburg 1990.

\section{Wissenschaftliche Artikel (eine Auswahl)}

Ingeborg Gabriel, Dialogue on (religious) ethics: a forgotten dimension in interreligious dialogue, in: Asian Horizons 13/4/Dezember 2019, S. 655-672.

Ingeborg Gabriel, Il Credo Umanistico Del Vaticano II e La Sua Reinterpretazione Da Parte Di Papa Francesco. Da Gaudium et Spes a Evangelii Gaudium e Laudato Si', in: Kurt Appel / Jakob Helmut Deibl (Hg.), Misericordia e Tenerezza. Il programma teologico di papa Francesco, Mailand 2019, S. 137-150.

Ingeborg Gabriel, Menschenrechte. Perspektiven christlicher Ethik, in: Staatslexikon. Recht - Wirtschaft - Gesellschaft 3: Herrschaft - Migration, hrsg. von Görres-Gesellschaft und Herder Verlag, 8. völlig neu bearb. Aufl., Freiburg im Breisgau 2019, Sp. 1547-1552.

Ingeborg Gabriel, Antigone war nicht nur hier. Die Achsenzeittheorie als kulturgeschichtliche Fundierung der Menschenrechte, in: Patricia Hladschick / Fiona Steinert (Hg.), Menschenrechten Gestalt und Wirksamkeit verleihen - Making human rights work. Festschrift für Manfred Nowak und Hannes Tretter, Wien-Graz 2019, S. 719-730.

Ingeborg Gabriel, Europa - quo vadis?. Wirtschaft und Politik aus sozialethischer Sicht, in: Zur Debatte. Themen der Katholischen Akademie in Bayern, 1/2019, S. 45-48.

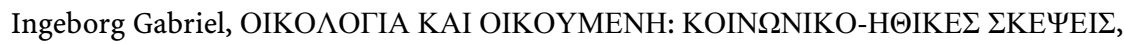
KA $\Theta \Omega \Sigma$ KAI MI $\Lambda \Sigma$ YNHГOPIA (deutsch: Ökologie und Ökumene. Überlegungen aus

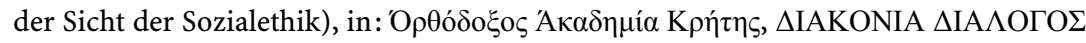

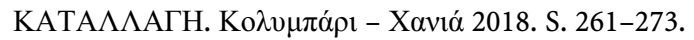

Ingeborg Gabriel, Ist das Gemeinwohl überholt?, Zur hohen politischen Aktualität eines Prinzips der katholischen Soziallehre, in: Bartosz Rydlinski / Slawomir Sowinski / Radoslaw Zenderowski (Red.), Wolność. Wieczne wyzwanie, Warschau 2018, S. 461479.

Ingeborg Gabriel, Time to renew the Church's commitment to women, in: Catholic Theological Ethics in the World Church (Webveröffentlichung), 01. 10.2018.

Ingeborg Gabriel, Ein Glaube, der Hoffnung weckt, in: Johannes Röser (Hg.), Gott? Die religiöse Frage heute, Freiburg im Breisgau 2018, S. 239-242. 
Ingeborg Gabriel, Erosion der Demokratie? Eine Problemanzeige, in: Forum Schulstiftung. Zeitschrift für die Katholischen Freien Schulen der Erzdiözese Freiburg 28/2018, S. 8-22.

Ingeborg Gabriel, Das Kreuz im Widerstreit, in: Christ in der Gegenwart 24/2018, S. 269-270.

Ingeborg Gabriel, Ein Gott, „der den Armen erhöht, der im Schmutz liegt...“ (1 Sam 2,8). Gottes Option für die Armen als (sozial)ethische Herausforderung, in: geist.voll. spirituell orientierend praktisch, 1/2018, S. 10-13.

Ingeborg Gabriel, Ekologie jako otázka „nového cloveka“. Antropologické a sociálneetické uvahy, in: Salve. Revue pro teologii a duchovni zivot, 4/2017, S. 65-85.

Ingeborg Gabriel, Menschenrechte und Religionen - Verbündete oder Gegner?, in: Peter G. Kirchschläger (Hg.), Die Verantwortung von nichtstaatlichen Akteuren gegenüber den Menschenrechten. Religionsrechtliche Studien 4, Zürich 2017, S. 33-52.

Ingeborg Gabriel / Peter G. Kirchschläger / Richard Sturn, Einleitung, in: Ingeborg Gabriel / Peter G. Kirchschläger / Richard Sturn (Hg.), Eine Wirtschaft, die Leben fördert. Wirtschats- und unternehmensethische Reflexionen im Anschluss an Papst Franziskus, Ostfildern 2017, S. 9-22.

Ingeborg Gabriel, Ökonomik - Theologie - Sozialethik, in: Ingeborg Gabriel / Peter G. Kirchschläger / Richard Sturn (Hg.), Eine Wirtschaft, die Leben fördert. Wirtschatsund unternehmensethische Reflexionen im Anschluss an Papst Franziskus, Ostfildern 2017, S. 23-50.

Ingeborg Gabriel, „So sorry!“ Reflections on the moral importance of an everyday word, in: Catholic Theological Ethics in the World Church (Webveröffentlichung), August 2017.

Ingeborg Gabriel, Truth in Earthen Vessels. Catholic Reflections on Contextualization, in: Journal of Eastern Christian Studies 69/1-4/2017, S. 357-372.

Ingeborg Gabriel, All Life Is Encounter: Reflections on Interreligious Dialogue and Concrete Initiatives, in: Religious Education. The official journal of the Religious Education Association (Webveröffentlichung), 28.07.2017.

Ingeborg Gabriel / Kristina Stoeckl / Aristotle Papanikolaou, Introduction, in: Ingeborg Gabriel / Kristina Stoeckl / Aristotle Papanikolaou (Hg.), Political Theologies in Orthodox Christianity. Common Challenges - Divergent Positions, London 2017, S. 1-11.

Ingeborg Gabriel, Political Theology under the conditions of modernity: A catholic perspective, in: Ingeborg Gabriel / Kristina Stoeckl / Aristotle Papanikolaou (Hg.), Political Theologies in Orthodox Christianity. Common Challenges - Divergent Positions, London 2017, S. 55-74.

Ingeborg Gabriel, Wohlstand für alle durch Marktwirtschaft? - Eine Antwort auf Martin Rhonheimer, in: Gesellschaft \& Politik: Zeitschrift für soziales und wirtschaftliches Engagement 53/1/2017: Wohlstand für alle durch Marktwirtschaft - Illusion oder Wirklichkeit?, S. 39-43.

Ingeborg Gabriel, Die Schöpfung mit neuen Augen sehen. Aufruf zu einer ökologischen Reformation, in: inspiration: Zeitschrift für christliche Spiritualität und Lebensgestaltung 43/2/2017, S. 2-7. 
Ingeborg Gabriel, Das tägliche Brot für alle. Welternährung als Gerechtigkeitsfrage der Gegenwart, in: Internationale Katholische Zeitschrift Communio 46./Januar-Februar/ 2017, S. 52-65.

Ingeborg Gabriel, It's the morals, stupid! On the Importance of Ethics in the Post-Truth Age, in: Catholic Theological Ethics in the World Church (Webveröffentlichung), Februar 2017.

Ingeborg Gabriel, Rechtspopulismus und neuer Nationalismus, in: ksoe, 8/2016, S. 1-3. Ingeborg Gabriel, Das humanistische Credo des Zweiten Vatikanums und seine Neuinterpretation durch Papst Franziskus. Von Gaudium et Spes zu Evangelii Gaudium und Laudato Si', in: Kurt Appel / Jakob Deibl (Hg.), Barmherzigkeit und zärtliche Liebe. Das theologische Programm von Papst Franziskus, Freiburg i. Br. 2016, S. 128-140.

Ingeborg Gabriel, Een mijlpaal in de verkondiging van de sociale leer. De encycliek Laudato si', in: Communio. Internationaal Katholiek Tijdschrift 3-4/2016, S. 169-178.

Ingeborg Gabriel, „Die Klage der Erde und der Armen hören“ (LS 49). Öko-soziale Perspektiven aus der Enzyklika Laudato si', in: Verein der Freunde der Theologischen Kurse, Theologische Kurse. Manuskripte 36, Wien 2016, S. 3-17.

Ingeborg Gabriel, Spannende Zeiten, in: Konrad Hilpert (Hg.), Theologische Ethiker im Spiegel ihrer Biografie. Stationen und Kontexte, Paderborn 2016, S. 165-184.

Ingeborg Gabriel, Anerkennung und Theologie der Menschenrechte in der Katholischen Kirche, in: Erfurter Studien zur Kulturgeschichte des orthodoxen Christentums. Christentum und Menschenrechte in Europa. Perspektiven und Debatten in Ost und West 11, Frankfurt a. M. 2016, S. 149-164.

Ingeborg Gabriel, Ukraine at the Crossroads: Political and ethical reflections, in: Catholic Theological Ethics in the World Church (Webveröffentlichung), Oktober 2015.

Ingeborg Gabriel, Nächstenliebe - Feindesliebe: Private und soziale Perspektiven, in: geist.voll spirituell. orientierend. praktisch, 4/2015, S. 7-9.

Ingeborg Gabriel, Die Enzyklika „Laudato Si“. Ein Meilenstein in der lehramtlichen Sozialverkündigung, in: Internationale Katholische Zeitschrift Communio 44/NovemberDezember/2015, S. 639-646.

Ingeborg Gabriel, Die europäische Grundrechtecharta. Überlegungen zu Konkretisierung durch die Kirchen, in: Peter Klasvogt / Stefan Klug (Hg.), Europa - Wertegemeinschaft oder Wirtschaftsunion? Zur Prägekraft des Katholizismus in Mitteleuropa, Paderborn 2015, S. 65-89.

Ingeborg Gabriel, Communio und Synchoresis. Zur ökumenischen Dimension christlicher Ethik im heutigen Europa, in: Ekeyos eis timen. Festschrift zum 25-jährigen Jubiläum der Bischofsweihe und 20-jährigen Jubiläum der Inthronisation zum Metropoliten von Austria und Exarchen von Ungarn und Mitteleuropa Dr. Michael Staikos, Athen 2011 (erschienen 2014), S. 269-284.

Ingeborg Gabriel, Verantwortung in der Zeit. Das Ökumenische Sozialwort als Impuls zum Engagement, in: Severin J. Lederhilger (Hg.), Wer ist mein Nächster? Das Soziale in der Ego-Gesellschaft, 15. Ökumenische Sommerakademie, Linzer Philosophisch-Theologische Beiträge 29, Frankfurt a. M. 2014, S. 127-147. 
Ingeborg Gabriel, Perspektiven europäischer Solidarität. Aus Sicht der katholischen Sozialethik, in: Amos International Gesellschaft gerecht gestalten: Internationale Zeitschrift für christliche Sozialethik 8/2/2014, S. 10-16.

Ingeborg Gabriel, Menschenrechte und Religionen: Kann der Brückenschlag gelingen? Theologische Stolpersteine und Ressourcen, in: Brigitte Schinkele / René Kuppe / Stefan Schima (u.a.) (Hg.), Recht Religion Kultur, Festschrift für Richard Potz zum 70. Geburtstag, Wien 2014, S. 87-101.

Ingeborg Gabriel, Zur Einführung - Ökologie als Gerechtigkeitsfrage der Gegenwart, in: Ingeborg Gabriel / Petra Steinmair-Pösel (Hg.), Gerechtigkeit in einer endlichen Welt. Ökologie - Wirtschaft -Ethik, 2. Aufl., Ostfildern 2014, S. 9-31.

Ingeborg Gabriel, Perspektiven katholischer Sozialethik für eine soziale Gestaltung Europas, in: Hermann Schoenauer (Hg.), Sozialethische Dimensionen in Europa. Von einer Wirtschaftsunion zu einer Wertegemeinschaft, Stuttgart 2014, S. 33-52.

Ingeborg Gabriel, Im Spannungsfeld zwischen universitärer Freiheit und kirchlicher Bindung, in: Zenon Kard. Grocholewski / Friedrich Bechina / Ludger Müller / Martin Krutzler (Hg.), Katholisch-Theologische Fakultäten zwischen „Autonomie“ der Universität und kirchlicher Bindung, Heiligenkreuz 2013, S. 101-105.

Ingeborg Gabriel, Zur Zukunft der Demokratie unter Globalisierungsbedingungen. Eine sozialethische Problemanzeige, in: Marianne Heimbach-Steins (Hg.), Demokratie, Jahrbuch für Christliche Sozialwissenschaften 54, Münster 2013, S. 83-104.

Ingeborg Gabriel, Religions and Religious Freedom: Bridging the Gap, The Position and Experience of the Roman Catholic Church, in: Stefan Hammer / Fatimah Husein (ed.), Religious Pluralism and Religious Freedom. Religions, Society and the State in Dialogue. Contributions to the Austrian-Indonesian Dialogue, Department of Legal Philosophy, Law of Religion and Culture, University of Vienna [et al.], Vienna-Yogyakarta 2013, S. 94-114.

Ingeborg Gabriel, Religious Pluralism, Freedom of Religion, and Responsibilities of State, Society, and Religious Communities, in: Stefan Hammer / Fatimah Husein (ed.), Religious Pluralism and Religious Freedom. Religions, Society and the State in Dialogue. Contributions to the Austrian-Indonesian Dialogue, Department of Legal Philosophy, Law of Religion and Culture, University of Vienna [et al.], Vienna-Yogyakarta 2013, S. 213-218.

Ingeborg Gabriel, Weltpastoralkonstitution. Zukunftsweisende Orientierungen aus Gaudium et spes, in: Philipp Thull (Hg.), Ermutigung zum Aufbruch. Eine kritische Bilanz des Zweiten Vatikanischen Konzils, Darmstadt 2013, S. 59-66.

Ingeborg Gabriel, Christliche Sozialethik in der Moderne. Der kaum rezipierte Ansatz von Gaudium et spes, in: Tück, Jan-Heiner (Hg.), Erinnerung an die Zukunft. Das Zweite Vatikanische Konzil, 2. Aufl., Freiburg i. Br.-Wien (u. a.) 2013, S. 605-621.

Ingeborg Gabriel / Irene Klissenbauer, Klagen gegen Blasphemie? Zum schwierigen Verhältnis von Religions- und Meinungsfreiheit, in: Thomas Weißer (Hg.), Kann man Gott beleidigen? Zur aktuellen Blasphemie-Debatte, Theologie kontrovers, Freiburg 2013, S. 179-191.

Ingeborg Gabriel, Artikel Freiheit, in: Bertram Stubenrauch / Erzpriester Andrej Lorgus (Hg.), Handwörterbuch Theologische Anthropologie. Römisch-katholisch - Russisch-orthodox. Eine Gegenüberstellung, Freiburg 2013, S. 249-256. 
Ingeborg Gabriel, Artikel Gesellschaft / Gesellschaftslehre, in: Bertram Stubenrauch / Erzpriester Andrej Lorgus (Hg.), Handwörterbuch Theologische Anthropologie. Römisch-katholisch - Russisch-orthodox. Eine Gegenüberstellung, Freiburg 2013, S. 314-319.

Ingeborg Gabriel, Artikel Persönlichkeit, in: Bertram Stubenrauch / Andrej Lorgus (Hg.), Handwörterbuch Theologische Anthropologie. Römisch-katholisch - Russisch-orthodox. Eine Gegenüberstellung, Freiburg 2013, S. 61-66.

Ingeborg Gabriel, Artikel Litschnost, in: Andrej Lorgus (Hg.), Bogoslowskaja antropologija: russko-prawoslawnij / rimsko-katolitscheskij slowar, Moskva 2013, S. 72-78.

Ingeborg Gabriel, Artikel Obschtschestwo, in: Andrej Lorgus (Hg.), Bogoslowskaja antropologija: russko-prawoslawnij / rimsko-katolitscheskij slowar, Moskva 2013, S. 358365.

Ingeborg Gabriel, Artikel Swoboda, in: Andrej Lorgus (Hg.), Bogoslowskaja antropologija: russko-prawoslawnij / rimsko-katolitscheskij slowar, Moskva 2013, S. 437-445.

Ingeborg Gabriel, Autonomie der irdischen Wirklichkeiten. Reflexionen zu einer komplexen Konzilsmetapher, in: Mariano Delgado / Michael Sievernich (Hg.), Die großen Metaphern des Zweiten Vatikanischen Konzils, Freiburg (u. a.) 2013, S. 267-286.

Ingeborg Gabriel, Beitrag zu „Konservative heute: Ja oder Nein, hic salta“, in: Markus Porsche-Ludwig / Jürgen Bellers (Hg.), Was ist konservativ? Eine Spurensuche in Politik, Philosophie, Wissenschaft, Literatur, Nordhausen 2013, S. 75-76.

Ingeborg Gabriel gemeinsam mit Markus Vogt / Arnd Küppers (u.a.), Theologie in der Sozialethik - Eine Einführung, in: Markus Vogt (Hg.), Theologie der Sozialethik, Freiburg (u. a.) 2013, S. 7-22.

Ingeborg Gabriel, Naturrecht, Menschenrechte und die theologische Fundierung der Sozialethik, in: Markus Vogt (Hg.), Theologie der Sozialethik, Freiburg (u.a.) 2013, S. 229-251.

Ingeborg Gabriel, Where Difference Matters: Social Ethics in the Contemporary World, in: Journal of Ecumenical Studies 48/1/2013, S. 97-106.

Ingeborg Gabriel, Zur Einführung - Ökologie als Gerechtigkeitsfrage der Gegenwart, in: Ingeborg Gabriel / Petra Steinmair-Pösel (Hg.), Gerechtigkeit in einer endlichen Welt. Ökologie - Wirtschaft -Ethik, Ostfildern 2013, S. 9-31.

Ingeborg Gabriel, Politische Umbrüche: Impulsreferat, in: Andreas Pawlitschek (Hg.), Krise fordert Kreativität: Auslandskulturarbeit in Zeiten des Umbruchs / Auslandskulturtagung 2011, Bundesministerium für Europäische und Internationale Angelegenheiten, Wien 2012, S. 36-45.

Ingeborg Gabriel, Klagen gegen Blasphemie? Wie sollen die Christen reagieren, wenn das, was ihnen heilig ist, verunglimpft wird?, in: Christ in der Gegenwart 64/48/2012, S. 537.

Ingeborg Gabriel, Erosion der Demokratie? Eine Problemanzeige, in: Katholische Sozialwissenschaftliche Zentralstelle Mönchengladbach (Hg.), Kirche und Gesellschaft 394/2012, S. 3-16.

Ingeborg Gabriel, Giving Meaning to Work: The Spiritual Challenge of Our Time, in: Bartholomew C. Okonkwo (ed.), Finding Meaning in Business, Theology, Ethics, and Vocation, New York 2012, S. 3-11. 
Ingeborg Gabriel, Human Rights from a Theological Perspective, in: Manfred Nowak / Karolina M. Januszewski / Tina Hofstätter (ed.), All Human Rights for All. Vienna Manual on Human Rights, Wien 2012, S. 33-35.

Ingeborg Gabriel, Freedom of Religion, in: Manfred Nowak / Karolina M. Januszewski / Tina Hofstätter (ed.), All Human Rights for All. Vienna Manual on Human Rights, Wien 2012, S. 392-396.

Ingeborg Gabriel, Human Rights and Religion - From Monologue to Dialogue, in: Manfred Nowak / Karolina M. Januszewski / Tina Hofstätter (ed.), All Human Rights for All. Vienna Manual on Human Rights, Wien 2012, S. 591-596.

Ingeborg Gabriel, Characteristics and Positions of Catholic Social Ethics, in: Ingeborg Gabriel / Alexandros K. Papaderos / Ulrich H. J. Körtner (ed.), Trilogy of Social Ethics. Orthodox - Catholic - Protestant, Philadelphia 2012, S. 133-238.

Ingeborg Gabriel, Introduction. Why this book was written, in: Ingeborg Gabriel / Alexandros K. Papaderos / Ulrich H. J. Körtner (ed.), Trilogy of Social Ethics. Orthodox Catholic - Protestant, Philadelphia 2012, S. 5-20.

Ingeborg Gabriel, „In der Welt, aber nicht von der Welt“. Die katholische Kirche im öffentlichen Raum, in: Alojz Ivanišević (Hg.), Re-Sakralisierung des öffentlichen Raums in Südosteuropa nach der Wende 1989?, Pro Oriente. Schriftenreihe der Kommission für südosteuropäische Geschichte 5., Frankfurt a. M. 2012, S. 17-34.

Ingeborg Gabriel, Christliche Sozialethik in der Moderne. Der kaum rezipierte Ansatz von Gaudium et spes, in: Jan-Heiner Tück (Hg.), Erinnerung an die Zukunft. Das Zweite Vatikanische Konzil, Freiburg 2012, S. 537-553.

Ingeborg Gabriel, Über Solidarität. Zur Einleitung, in: Ingeborg Gabriel / Helmut Renöckl (Hg.), Solidarität in der Krise. Auf der Suche nach neuen Wegen, Würzburg 2012, S. 9-22.

Ingeborg Gabriel, Kommunismus als die „barbarische Rückseite des Spiegels der Moderne“, in: Perekroctki 1-2/2011, S. 56-78 (russisch).

Ingeborg Gabriel, Zur Bedeutung der Sozialethik für die Ökumene. Ein Plädoyer, in: Una Sancta. Zeitschrift für ökumenische Begegnung 66/3/2011, S. 171-179.

Ingeborg Gabriel, Der Beitrag der Kirchen: eine Provokation für die Ökonomie?, in: Severin Lederhilger (Hg.), Gerechtigkeit will ich. Christliche Provokation für die Ökonomie, Frankfurt 2011, S. 133-152.

Ingeborg Gabriel, Gerechtigkeit von Globalisierung, die katholische Kirche und die Religionen, in: Ingeborg Gabriel / Ludwig Schwarz (Hg.), Weltordnungspolitik in der Krise. Perspektiven internationaler Gerechtigkeit, Paderborn 2011, S. 9-30.

Ingeborg Gabriel, Globalisierung und Demokratie. Überlegungen zu einer zentralen weltordnungsethischen Frage, in: Ingeborg Gabriel / Ludwig Schwarz (Hg.), Weltordnungspolitik in der Krise. Perspektiven internationaler Gerechtigkeit, Paderborn 2011, S. 91-110.

Ingeborg Gabriel, Wozu taugt die Tugend? Überlegungen zur Aktualität der Tugendethik, in: Karl Baier / Markus Riedenauer (Hg.), Die Spannweite des Daseins: Philosophie, Theologie, Psychotherapie und Religionswissenschaft im Gespräch, FS für Augustinus Wucherer-Huldenfeld zum 80. Geburtstag, Wien 2011, S. 199-219.

Ingeborg Gabriel, Islam in Austria: Facts and Perspectives, Al-Liqa Journal June 2011, S. 1-15. 
Ingeborg Gabriel, Vorwort und Einleitung, in: Ingeborg Gabriel / Cornelia Bystricky (Hg.), Kommunismus im Rückblick. Ökumenische Perspektiven aus Ost und West (19892009), Ostfildern 2010, S. 8-22.

Ingeborg Gabriel, Why Religions Should Opt for Emancipation, in: Richard Potz / Sabine Kroissenbrunner / Astrid Hafner (ed.), State, Law and Religion in Pluralistic Societies Austrian and Indonesian Perspectives, Göttingen 2010, S. 157-163.

Ingeborg Gabriel, The Role of Religions in the Public Square: Elements of Transformation Process, in: Richard Potz / Sabine Kroissenbrunner / Astrid Hafner (ed.), State, Law and Religion in Pluralistic Societies, Göttingen 2010, S. 179-190.

Ingeborg Gabriel, Die Faszination von Herrschaft. Die dunkle Seite der Moderne, ihre ökologischen Folgen und der ethische und spirituelle Umgang mit ihnen, in: Geiko Müller-Fahrenholz (Hg.), Friede mit der Erde. Wie überwinden wir unsere Gewalt gegen die Natur?, Frankfurt 2010, S. 83-112.

Ingeborg Gabriel, Transformationen. Europa zwanzig Jahre nach der Wende, in: Peter Klasvogt / Andreas Fisch (Hg.), „Was trägt, wenn die Welt aus den Fugen gerät“: Christliche Weltverantwortung im Horizont der Globalisierung, Paderborn 2010, S. 319-327.

Ingeborg Gabriel, Christianity in an Age of Uncertainty. A Catholic Perspective, in: Peter L. Berger (ed.), Between Relativism and Fundamentalism, Religious Resources for a Middle Position, Grand Rapids 2010, S. 124-151.

Ingeborg Gabriel, Like Rosewater. Reflections on Interreligious Dialogue, in: Journal of Ecumenical Studies 45/1/2010, S. 1-23.

Ingeborg Gabriel, Der Kommunismus als die „barbarische Rückseite des Spiegels der Moderne" und der ethische Umgang mit der Geschichte, in: Ingeborg Gabriel / Cornelia Bystricky (Hg.), Kommunismus im Rückblick. Ökumenische Perspektiven aus Ost und West (1989-2009), Ostfildern 2010, S. 42-62.

Ingeborg Gabriel, Der Glaube und die Menschenrechte. Ein Dokument der Russisch-Orthodoxen Kirche sorgt für Diskussionsstoff, in: Herder Korrespondenz 64/2010, S. 29 34 .

Ingeborg Gabriel, Westlicher Lebensstil in der Krise. Wie wir leben und wie wir leben sollten, in: Helmut Renöckl / Stephan Baloban (Hg.), Jetzt die Zukunft gestalten. Sozialethische Perspektiven, Wien 2010, S. 197-226.

Ingeborg Gabriel, Hermeneutik im Spannungsfeld von positiver Offenbarung und Naturrecht (gem. m. Karl-Heinz Peschke), in: Andreas Bsteh / Seyed A. Mirdamadi (Hg.), Hermeneutik - Thema der 4. Iranisch-Österreichischen Konferenz: Referate - Anfragen - Gesprächsbeiträge, Mödling 2010, S. 37-52 (auch in Farsi und Arabisch publiziert).

Ingeborg Gabriel, Paradigmenwechsel in der Sozialethik, in: Johann Reikerstorfer / Martin Jäggle (Hg.), Vorwärtserinnerungen. 625 Jahre Katholisch-Theologische Fakultät der Universität Wien, Göttingen 2009, S. 145-171.

Ingeborg Gabriel, Transformationen. Europa zwanzig Jahre nach der Wende, in: Amos. Internationale Zeitschrift für christliche Sozialethik 3/4/2009, S. 3-13. 
Ingeborg Gabriel, Fascinated with Domination: The Dark Side of Modernity. Its ecological consequences and how to deal with them ethically and spiritually, in: Geiko MüllerFahrenholz (ed.), Peace on Earth, Peace with the Earth, Geneva 2008, S. 113-134.

Ingeborg Gabriel, Auf dem Weg zu einer ökumenischen Sozialethik, in: Amos. Internationale Zeitschrift für christliche Sozialethik 2/2/2008, S. 48-50.

Ingeborg Gabriel, Einleitung, in: Ingeborg Gabriel (Hg.), Politik und Theologie in Europa. Perspektiven ökumenischer Sozialethik, Ostfildern 2008, S. 11-38.

Ingeborg Gabriel, Unteilbarkeit und Schutz der Menschenrechte. Die Rede Papst Benedikts XVI. vor der UNO, in: Amos. Internationale Zeitschrift für christliche Sozialethik 2/2/ 2008, S. 36-39.

Ingeborg Gabriel, Wie viel christliche Ethik verträgt die Politik? Standortbestimmungen und Desiderate im Blick auf Österreich, in: Mariano Delgado / David Neuhold (Hg.), Politik aus christlicher Verantwortung. Ein Ländervergleich Österreich - Schweiz, Innsbruck-Wien 2008, S. 137-155.

Ingeborg Gabriel, Weltethos in Bewegung: Zwischen religiöser und säkularer Ethik, in: Erwin Bader (Hg.), Weltethos und Globalisierung, Münster 2008, S. 149-163.

Ingeborg Gabriel, The European Union and Cultural Integration. A Challenge for the Churches, in: UTCP Bulletin VII/2007, S. 53-61.

Ingeborg Gabriel, Perspektiven der Sozial- und Wirtschaftsethik. Überlegungen zur Russisch-Orthodoxen Sozialkonzeption aus Sicht der katholischen Soziallehre, in: Pro Oriente (Hg.), Die Sozialkonzeption der Russisch-Orthodoxen Kirche. Ein Dokument der sozialen Verantwortung, Wien 2007, S. 132-159 (in Deutsch und Russisch).

Ingeborg Gabriel, Gerechtigkeit lernen, in: Andreas Bsteh / Tahir Mahmood (Hg.), Erziehung zu Gleichberechtigung. Eine Antwort auf Ungerechtigkeit und Intoleranz, Mödling 2007, S. 137-146 (auch in Englisch, Arabisch und Urdu publiziert).

Ingeborg Gabriel, Ist die Re-Theologisierung der Politik ein Übel? Eine Antwort auf Rudolf Burger, in: Friedrich Gleißner / Hanspeter Ruedl (u. a.) (Hg.), Religionen im öffentlichen Raum. Religiöse Freiheit im neuen Europa, Wien 2007, S. 115-131.

Ingeborg Gabriel, Interreligiöse Dialoge - ein Weg zu Frieden und Verständigung, in: Gerald Faschingeder / Clemens Six (Hg.), Religion und Entwicklung. Wechselwirkungen in Staat und Gesellschaft, Wien 2007, S. 205-235.

Ingeborg Gabriel, Grundzüge und Positionen katholischer Sozialethik, in: Ingeborg Gabriel / Alexandros K. Papaderos / Ulrich H. J. Körtner (Hg.), Perspektiven ökumenischer Sozialethik. Der Auftrag der Kirchen im größeren Europa, 2. überarb. Aufl., Mainz 2006, S. 127-226.

Ingeborg Gabriel, Die verschiedenen Gesichter der Armut, in: Andreas Bsteh / Tahir Mahmood (Hg.), Armut und Ungerechtigkeit - Krisenzeichen der gegenwärtigen Gesellschaftsordnung weltweit, Mödling 2006, S. 27-37 (auch in Englisch und Arabisch publiziert).

Ingeborg Gabriel, Die Menschenrechte als Grundlage der politischen Kultur Europas, in: Helmut Renöckl / Alzbeta Dufferova / Alfred Rammer (Hg.), Rudern auf stürmischer See. Sozialethische Perspektiven in Mitteleuropa, Wien 2006, S. 152-162. 
Ingeborg Gabriel, Christliche Identität im europäischen Kontext, in: Facultatae de Teologie Ortodoxa de Universitatijy Alba Iulia (ed.), Identitate crestina si dialog in noul context European, Alba Iulia 2006, S. 19-36.

Ingeborg Gabriel, Der lange Schatten der Geschichte: Konflikt und Versöhnung in den christlich-muslimischen Beziehungen, in: Andreas Bsteh / Seyed A. Akrami / Seyed A. Mirdamadi (Hg.), Friede, Gerechtigkeit und ihre Bedrohungen in der heutigen Welt, Mödling 2005, S. 31-56 (auch in Farsi und Arabisch publiziert).

Ingeborg Gabriel, Gibt es einen fundamentalistischen Imperativ? Die Moderne zwischen Säkularisierung und Fundamentalismus, (Webveröffentlichung), Wien 2005.

Ingeborg Gabriel, Humanität und Heiligkeit. Spiritualität und Ethik als „Zeichen der Zeit“ und als Anfrage an die christlichen Kirchen, in: Paul M. Zulehner (Hg.), Spiritualität mehr als ein Megatrend? Gedenkschrift für Kardinal Franz König, Ostfildern 2004, S. 95-107.

Ingeborg Gabriel, Ordensleben unter den Bedingungen der Globalisierung, in: Ordenskorrespondenz 45/2004, S. 334-358.

Ingeborg Gabriel, Das Sozialwort der christlichen Kirchen in Österreich, in: Herbert Pribyl / Helmut Renöckl (Hg.), Was macht Europa zukunftsfähig? Sozialethische Perspektiven, Wien 2004, S. 272-275.

Ingeborg Gabriel, Geschlechterrollen und -positionen in Gesellschaft und Kirche, in: Herbert Pribyl / Helmut Renöckl (Hg.), Was macht Europa zukunftsfähig? Sozialethische Perspektiven, Wien 2004, S. 173-186.

Ingeborg Gabriel, Gewalt als Menschheitsverhängnis. Ethische und theologische Überlegungen aus christlicher Sicht, in: Andreas Bsteh / Tahir Mahmood (Hg.), Intoleranz und Gewalt. Erscheinungsformen - Gründe - Zugänge, Mödling 2004, S. 159-173 (auch in Englisch und Arabisch publiziert).

Ingeborg Gabriel, Die Sozialkonzeption der russisch-orthodoxen Kirche: Ein Beitrag zur christlichen Sozialethik, in: Zbigniew Sarelo (Red.), Zyc godnie w zmieniajacym sie swiecie. Ksiega pamiatkowa ku czci ks. Prof. dra hab. Jana Pryszmonta, Zabki 2004, S. 349-367.

Ingeborg Gabriel, Gerechtigkeit als zentrale Herausforderung für das 21. Jahrhundert, in: Andreas Bsteh / Tahir Mahmood (Hg.), Um unsere Zeit zu bedenken. Christen und Muslime vor den Herausforderungen der Gegenwart, Mödling 2003, S. 19-29 (auch in Englisch, Arabisch und Urdu publiziert).

Ingeborg Gabriel, Die christlichen Kirchen in Europa. Auf dem Weg zu einer ökumenischen Sozialethik, in: Österreichisches Archiv für Recht \& Religion 50/2-3/2003, S. 201-212.

Ingeborg Gabriel, Religion und Wirtschaftsstil, in: Wirtschaftspolitische Blätter 50/2003, S. 22-28.

Ingeborg Gabriel, Arbeit und Sinn. Gedanken zu Max Weber und Teilhard de Chardin, in: Erwin Bader (Hg.), Die Macht des Geistes. FS für Norbert Leser zum 70. Geburtstag, Frankfurt 2003, S. 84-95.

Ingeborg Gabriel, Moral in Zeiten der Globalisierung: Zwischen Säkularität und Religion, in: Ralf Elm (Hg.), Ethik, Politik und Kulturen im Globalisierungsprozess. Eine interdisziplinäre Zusammenführung, Studium Generale 13, Bochum 2003, S. 47-64. 
Ingeborg Gabriel, Demokratie in Zeiten der Globalisierung. Aktuelle Herausforderungen, in: Günter Virt (Hg.), Der Globalisierungsprozess. Facetten einer Dynamik aus ethischer und theologischer Perspektive, Freiburg 2002, S. 115-130.

Ingeborg Gabriel, Erinnerung und Versöhnung. Zur politischen Renaissance eines theologischen Konzepts, in: Ingeborg Gabriel / Christa Schnabl / Paul M. Zulehner (Hg.), Einmischungen. Zur politischen Relevanz der Theologie, Ostfildern 2001, S. 25-47.

Ingeborg Gabriel, Das ethische Element in der ökonomischen Doktrin und die Katholische Soziallehre, in: Andreas Bsteh / Seyed A. Mirdamadi (Hg.), Werte - Rechte - Pflichten. Grundfragen einer gerechten Ordnung des Zusammenlebens in christlicher und islamischer Sicht, Mödling 2001, S. 321-343 (auch in Englisch, Farsi und Arabisch publiziert).

Ingeborg Gabriel, Der alte und der neue Mensch: Metamorphosen des Heils, in: Werk Christliche Innerlichkeit (Hg.), Christliche Innerlichkeit 3, Wien 2001, S. 76-82.

Ingeborg Gabriel, Johannes Schasching, in: Lexikon für Theologie und Kirche 9, 3. Aufl., Freiburg 2000, S. 11.

Ingeborg Gabriel, Arbeit und menschliche Würde, in: Karl Klein / Matthias Tschirf / Helmut Wohnout (Hg.), Was bleibt an sozialer Gerechtigkeit? Gesellschaft und Katholische Soziallehre im neuen Jahrtausend, Wien 2000, S. 69-85.

Ingeborg Gabriel, Giving Meaning to Work: the Spiritual Challenge of our Time, in: Rethinking the Spiritual and Social Life within Business, Conference Papers for the Third International Symposium on Catholic Social Thought and Management Education, Goa 1999, S. 1-15.

Ingeborg Gabriel, Einige Überlegungen zum Thema Kultur, in: Petrus Bsteh (Hg.), Welt in Begegnung, Welt in Bewegung. FS 40 Jahre Afro-Asiatisches Institut in Wien, Wien 1999, S. 37-49.

Ingeborg Gabriel, Der böse Andere. Vorurteile, Feinbilder, Gewalt - Analyse und Möglichkeiten ihrer Überwindung, in: Theologie und Seelsorge 19/1999, S. 226-242.

Ingeborg Gabriel, Aktuelle soziale Entwicklungen als Herausforderungen für die christliche Ethik, in: Walter Krieger / Balthasar Sieberer (Hg.), Caritas - Dienst an Mensch und Gesellschaft, Würzburg 1999, S. 9-22.

Ingeborg Gabriel, Is the right to property sacred? The debate on property rights in Catholic Social Teaching, in: Nová evanjelizácia. Zborník symposia s medzinárodnou účast’ou. VII. ročník, Bratislava 1998, S. 73-88.

Ingeborg Gabriel, Der Beitrag der Religionen zum Weltethos, in: Adel T. Khoury / Gottfried Vanoni (Hg.), „Geglaubt habe ich alles, deshalb habe ich geredet“. FS für Andreas Bsteh zum 65. Geburtstag, Würzburg 1998, S. 107-124.

Ingeborg Gabriel, Gerechtigkeit aus christlicher Sicht, in: Andreas Bsteh / Seyed A. Mirdamadi (Hg.), Gerechtigkeit in den internationalen und interreligiösen Beziehungen in islamischer und christlicher Perspektive, Mödling 1997, S. 51-72 (auch in Englisch, Farsi und Arabisch publiziert). 
Ingeborg Gabriel, Warum macht Ökonomie Angst? Eine Problemanzeige aus christlicher Sicht, in: Ulrike M. Ernst / Luise Gubitzer / A. Schmidt (Hg.), Ökonomie M(m)acht Angst, Wien 1997, S. 175-187.

Ingeborg Gabriel, Freiheit und gesellschaftlicher Auftrag der Kirchen in einer demokratischen Gesellschaft, in: Ingeborg Gabriel (Hg.), Freiheit und Verantwortung der Kirche in der Gesellschaft, Wien 1995, S. 55-66.

Ingeborg Gabriel, Eigeninteresse und Moral. Der geschichtliche und kulturell-religiöse Begriffshorizont als Anfrage an die christliche Ethik, in: Wolfgang Schmitz / Rudolf Weiler (Hg.), Interesse und Moral: Gegenpole oder Bundesgenossen?, Berlin 1994, S. 105-122.

Ingeborg Gabriel, „When I was a stranger and you took me into your home“ (Matt 25:35). Elements of a Theology of Migration, in: People on the move 66/1994, S. 9-22.

Ingeborg Gabriel, Kirche und Kultur. Überlegungen zum Thema Inkulturation, in: Wolfgang Freistetter / Rudolf Weiler (Hg.), Die Einheit der Kulturethik in vielen Ethosformen, Berlin 1993, S. 127-144.

Ingeborg Gabriel, Eigentum im Dienste des Menschen. Die Lehre zum Eigentum in den päpstlichen Enzykliken von Rerum novarum bis Centesimus annus und die Entwicklung in Österreich im Überblick, in: Herbert Schambeck / Rudolf Weiler (Hg.), Der Mensch ist der Weg der Kirche. FS für Johannes Schasching, Berlin 1992, S. 17-33.

$\mathrm{Zu}$ erwähnen sind darüber hinaus Ingeborg Gabriels vielfältigen Vorträge, Interviews und Expertengespräche, Beiträge zu Podiumsdiskussionen, Panels, (u.a.m.) in Radio, Fernsehen, bei Tagungen und anderen wissenschaftlichen sowie zivilgesellschaftlichen Veranstaltungen, die jedoch aufgrund ihrer Fülle hier nicht im Einzelnen angeführt werden können. 


\section{Zu den AutorInnen}

\section{Appel, Kurt}

Professor für Theologische Grundlagenforschung an der Katholisch-Theologischen Fakultät der Universität Wien, Leiter des Forschungszentrums „Religion and Transformation in Contemporary Society"

\section{Bielefeldt, Heiner}

Inhaber des Lehrstuhls für Menschenrechte und Menschenrechtspolitik der Friedrich-Alexander-Universität Erlangen-Nürnberg, 2010-2016 UN-Sonderberichterstatter über Religions- und Weltanschauungsfreiheit

\section{Bogner, Daniel}

Professor für Moraltheologie und Ethik an der Universität Fribourg/CH

\section{Braulik, Georg}

Professor em. für Alttestamentliche Bibelwissenschaft an der KatholischTheologischen Fakultät der Universität Wien

Deibl, Jakob

Assistenzprofessor für Religion und Ästhetik an der Katholisch-Theologischen Fakultät der Universität Wien, Wissenschaftlicher Manager des Forschungszentrums „Religion and Transformation in Contemporary Society“

Delikostantis, Konstantinos

Professor em. für Philosophie und Systematische Theologie an der Theologischen Fakultät der Universität Athen

Enderle, Georges

John T. Ryan Jr. Professor of International Business Ethics am Mendoza College of Business sowie Professor an der Keough School of Global Affairs der University of Notre Dame (USA) 
Fel, Stanislaw

Professor für Soziologie und Sozialethik an der John Paul II Catholic University of Lublin

Figl, Johann

Professor em. für Religionswissenschaft an der Katholisch-Theologischen Fakultät der Universität Wien

Gabriel, Klaus

Unternehmensberater, Lehrbeauftragter (u. a. Executive Academy Wirtschaftsuniversität Wien und Gastprofessor für Wirtschafts- und Unternehmensethik von 2017-2018 Universität Kassel), Geschäftsführer (CRIC e.V.) und Gutachter

Gassner, Franz

Associate Professor, Coordinator of the Department of Catholic Theology, University of Saint Joseph, Macau, S.A.R. China

Hammer, Stefan

ao. Prof. für Rechtsphilosophie und Öffentliches Recht an der Rechtswissenschaftlichen Fakultät der Universität Wien

Heimbach-Steins, Marianne

Professorin für Christliche Sozialwissenschaften und sozialethische Genderforschung sowie Direktorin des Instituts für Christliche Sozialwissenschaften an der WWU Münster

Hilpert, Konrad

Professor em. für Moraltheologie an der Katholisch-Theologischen Fakultät der Ludwig-Maximilians-Universität München, 2016-2017 Gastprofessur an der Universität Luzern

Hödl, Hans Gerald

a.o. Professor für Religionswissenschaft an der Katholisch-Theologischen Fakultät der Universität Wien

Hogan, Linda

Professorin für Ökumene am Trinity College, Dublin

Holztrattner, Magdalena

Direktorin der Katholischen Sozialakademie Österreichs 
Kirchschläger, Peter G.

Ordinarius für Theologische Ethik und Leiter des Instituts für Sozialethik ISE an der Theologischen Fakultät der Universität Luzern

Klasvogt, Peter

Direktor des Sozialinstituts Kommende Dortmund und der Katholischen Akademie Schwerte. Mitherausgeber von Amosinternational, Zeitschrift für Christliche Ethik. Gründer des europäischen Jugendnetzwerks socioMovens. Träger des Konstanzer Konzilspreises 2017.

Klissenbauer, Irene

Universitätsassistentin (post-doc) am Fachbereich Sozialethik des Instituts für Systematische Theologie und Ethik an der Katholisch-Theologischen Fakultät der Universität Wien

Körtner, Ulrich H.J.

Professor für Systematische Theologie an der Evangelisch-Theologischen Fakultät und Vorstand des Instituts für Ethik und Recht in der Medizin der Universität Wien

Leubolt, Bernhard

Wissenschaftlicher Mitarbeiter der Katholischen Sozialakademie Österreichs

Lohlker, Rüdiger

Professor für Islamwissenschaften am Institut für Orientalistik an der philologisch-kulturwissenschaftlichen Fakultät der Universität Wien

Loretan, Adrian

Professor für Kirchenrecht und Staatskirchenrecht der Theologischen Fakultät der Universität Luzern, Co-Direktor des Zentrums für Religionsverfassungsrecht; Herausgeber der Reihen „ReligionsRecht im Dialog“, „Religionsverfassungsrechtliche Studien“"

Marksteiner-Ungureanu, Cezar

Universitätsassistent (prae-doc) am Fachbereich Sozialethik des Instituts für Systematische Theologie und Ethik an der Katholisch-Theologischen Fakultät der Universität Wien

Neuhold, Leopold

Professor für Ethik und Gesellschaftslehre an der Katholisch-Theologischen Fakultät der Universität Graz 
Nowak, Manfred

Generalsekretär des Global Campus of Human Rights in Venedig, Professor für Menschenrechte an der Universität Wien und UNO-Experte für die Global Study on Children Deprived of Liberty

Palaver, Wolfgang

Professor für Christliche Gesellschaftslehre an der Katholisch-Theologischen Fakultät der Universität Innsbruck

Pock, Johann

Professor für Pastoraltheologie am Institut für Praktische Theologie und Dekan der Katholisch-Theologischen Fakultät der Universität Wien

Potz, Richard

Professor em. für Religionsrecht am Institut für Rechtsphilosophie der Universität Wien

Schaffhauser-Linzatti, Michaela

a.o. Professorin für Externes Rechnungswesen an der Fakultät für Wirtschaftswissenschaften der Universität Wien

Schipka, Peter

Generalsekretär der Österreichischen Bischofskonferenz

Schlagnitweit, Markus

Kooperationspartner (2005-2009 Direktor) der Katholischen Sozialakademie Österreichs

Spieß, Christian

Professor für Christliche Sozialwissenschaften und Leiter des Johannes Schasching-Instituts an der Katholischen Privat-Universität Linz

Stadler, Wilfried

bis 2009 Führungsfunktionen im Bankwesen, Honorarprofessor an der WU Wien, Lektor an der Universität Salzburg, Vorsitzender des Industriewissenschaftlichen Instituts (IWI), Mit-Herausgeber der Wochenzeitung DIE FURCHE

Steiner, Anna-Maria

persönliche Assistentin des Generalsekretärs, Global Campus of Human Rights 
Steinmair-Pösel, Petra

Leiterin des Instituts für Religionspädagogische Bildung Feldkirch der KPH Edith Stein

Stöckl, Kristina

Professorin für Soziologie an der Universität Innsbruck

Stückelberger, Christoph

Professor em. für Ethik an der Universität Basel, Gründer und Präsident von Globethics.net, Gastprofessor an Universitäten in Großbritannien, Nigeria, China, Russland

Sturn, Richard

Richard Joseph A Schumpeter Professor; Leiter des Instituts für Finanzwissenschaft und Öffentliche Wirtschaft sowie des Graz Schumpeter Centres der Universität Graz, Vorsitzender des Ausschusses Wirtschaft und Ethik im Verein für Socialpolitik, Geschäftsführender Herausgeber des European Journals of the History of Economic Thought

Tobler, Stefan

Professor für Systematische Theologie an der Universität Lucian Blaga Sibiu und Co-Direktor des Instituts für Ökumenische Forschung Hermannstadt/Sibiu

Tück, Jan Heiner

Professor für Dogmatik und Dogmengeschichte an der Katholisch-Theologischen Fakultät der Universität Wien

Turkson, Peter Kodwo Appiah

Kurienkardinal der römisch-katholischen Kirche; Präfekt des Dikasteriums für den Dienst zugunsten der ganzheitlichen Entwicklung des Menschen

Virt, Günter

Professor em. für Moraltheologie an der Katholisch-Theologischen Fakultät der Universität Wien

Vogt, Markus

Professor für Christliche Sozialethik an der Ludwig-Maximilians-Universität in München 
Open-Access-Publikation im Sinne der CC-Lizenz BY 4.0

(C) 2020, Vandenhoeck \& Ruprecht $\mathrm{GmbH} \&$ Co. KG, Göttingen ISBN Print: 9783847111658 - ISBN E-Lib: 9783737011655 